\title{
The detention of asylum seekers in the European Union and Australia
}

Citation for published version (APA):

Provera, M. A. (2013). The detention of asylum seekers in the European Union and Australia. [Doctoral Thesis, Maastricht University]. Wolf Legal Publishers. https://doi.org/10.26481/dis.20130516mp

Document status and date:

Published: 01/01/2013

DOI:

10.26481/dis.20130516mp

Document Version:

Publisher's PDF, also known as Version of record

\section{Please check the document version of this publication:}

- A submitted manuscript is the version of the article upon submission and before peer-review. There can be important differences between the submitted version and the official published version of record.

People interested in the research are advised to contact the author for the final version of the publication, or visit the DOI to the publisher's website.

- The final author version and the galley proof are versions of the publication after peer review.

- The final published version features the final layout of the paper including the volume, issue and page numbers.

Link to publication

\footnotetext{
General rights rights.

- You may freely distribute the URL identifying the publication in the public portal. please follow below link for the End User Agreement:

www.umlib.nl/taverne-license

Take down policy

If you believe that this document breaches copyright please contact us at:

repository@maastrichtuniversity.nl

providing details and we will investigate your claim.
}

Copyright and moral rights for the publications made accessible in the public portal are retained by the authors and/or other copyright owners and it is a condition of accessing publications that users recognise and abide by the legal requirements associated with these

- Users may download and print one copy of any publication from the public portal for the purpose of private study or research.

- You may not further distribute the material or use it for any profit-making activity or commercial gain

If the publication is distributed under the terms of Article $25 \mathrm{fa}$ of the Dutch Copyright Act, indicated by the "Taverne" license above, 
THE Detention OF ASYlum SEEKERS IN THE EUROPEAN UNION AND AUSTRALIA

A COMPARATIVE ANALYSIS

Mark Provera 
The Detention of Asylum Seekers in the European Union and Australia

A Comparative Analysis

M. A. Provera

Cover photo: Catherine Street, Lilyfield (C) 2010 M. A. Provera

This publication was produced by

ฟolf Legal Publishers (WLP)

PO Box 313

5060 AH Oisterwijk

The Netherlands

E-Mail: info@wolfpublishers.nl

www.wolfpublishers.com

(C) 2013 M. A. Provera 


\title{
THE DETENTION OF ASYLUM SEEKERS IN THE EUROPEAN UNION AND AUSTRALIA
}

\section{A Comparative ANALYSIS}

\author{
DISSERTATION \\ to obtain the degree of Doctor \\ at Maastricht University, \\ on the authority of the Rector Magnificus, \\ Prof. Dr. L.L.G. Soete \\ in accordance with the decision of the Board of Deans, \\ to be defended in public \\ on Thursday 16 May 2013, at 10.00 hours \\ by
}

Mark Angelo Provera 


\section{Supervisors}

Prof. dr. G.-R. de Groot

Prof. dr. H.E.G. Schneider

\section{Assessment Committee}

Prof. Dr. A.P.M. Coomans (chair)

Dr. S. Carrera Nuñez

Prof. Dr. G. de Jonge

Prof. Dr. J. McAdam (University of New South Wales)

Prof. Dr. B.E.F.M. de Witte 


\section{Acknowledgments}

The journey to the Bouillonstraat in Maastricht has been a far from solitary one - indeed, it would not have been possible at all without the assistance, love, support and encouragement of so many people. A friend wisely advised me that a $\mathrm{PhD}$ thesis is not one's life's work but, rather, it is the springboard from which to commence that work. For those that have helped me reach the stage where I'm poised to take my leap of faith, it's time for me to give thanks.

I would like to thank Hildegard Schneider for her wonderful gift of making one believe that anything is possible and for investing her belief in me. This work is a result of that belief. I am grateful to her for giving me the opportunity to teach at Maastricht University where I was able to continue my research and writing. I would like to thank René de Groot for his insights into statelessness, nationality, comparative legal theory and the European Convention on the Exercise of Children's Rights.

I would also like to thank the members of my assessment committee, Fons Coomans, Sergio Carrera Nuñez, Bruno de Witte, Gerard de Jonge and Jane McAdam, for taking the time and care to read my thesis and for providing such insightful suggestions as to how it may be improved.

I am deeply indebted to my paranympfs, Michael Phoon and Louis Sartor, who travelled from Australia to take part in my defence. I'm so honoured to have friends such as these who have witnessed, and walked beside me through, the rigours of $\mathrm{PhD}$ writing stretched across two continents.

I am very grateful to Graham Thom for giving me the opportunity to have worked face-to-face with asylum seekers as a refugee caseworker with Amnesty International Australia, where I gained so much of the insight that I was able to incorporate in this book.

There is a core group of people to whom I'm extremely grateful: Debra and Craig Keller (my 'replacement parents'); Eric Bruinsma and Henk Busink (my 'Dutch parents' whose journey to Australia commenced my journey to Maastricht); Aloysia Brooks (for her outstanding support, for always barracking from the sidelines and for her generosity of heart and mind); Sophie Sirtes (for provoking me to take this course in life); Carina Bertram (for her gentle motivation throughout this experience); Kathrin Hamenstädt (for the joy of her company and for indulging me with long conversations about, inter alia, the principle of proportionality over tea and Ragusa); Elise Muir (whose intellectual passion and nurturing is a source of inspiration); Mark Dawson (whose amazing intellect shone light on dark corners); Alexander Hoogenboom (for generously sharing his razor-sharp knowledge of European 
Union case law) and Lisa Webley (whose empathetic insights were a great source of personal and professional solace). I appreciate the generosity of Tamara Wood for assisting with difficult-to-source books whilst I was researching and writing in Australia, as well as the kind assistance of Sophia de Groot with the translation of the samenvatting.

My parents, through their lifetimes' work, have made this work possible and I deeply appreciate the things they denied themselves in order that I might not be denied. To Rosemary, my cousin, who raised my awareness of the path before me and answered my uncertainty about where to start by always responding, "Start with the compassion" - I dedicate this book to you. 


\section{Outline Contents}

Table of Contents

Abbreviations

Chapter 1

Introduction

Chapter 2

The European Union - "Citizens without a constitution"

Chapter 3

Australia - A Constitution Without Citizenship

Chapter 4

Definitions, Territorial and Jurisdictional Scope

Chapter 5

Circumstances in which the Detention of an Asylum Seeker May Occur or be Prolonged

Chapter 6

Review Mechanisms for Detention

Chapter 7

Conditions of Detention

Chapter 8

The Principle of Proportionality and Alternatives to Detention

Chapter 9

Conclusions

Epilogue

Samenvatting

Bibliography

Resumé 



\section{Table of Contents}

Abbreviations

Chapter 1 - Introduction

Chapter 2 - The European Union - "Citizens without a constitution"

2.1 European Immigration and Notions of Citizenship

2.2 Union Law, the Council of Europe, the ECHR and ECtHR case law 32

2.2.1 Inter-relationship between the EU Charter and the ECHR 37

$\begin{array}{ll}\text { 2.2.2 EU Accession to the ECHR } & 38\end{array}$

2.3 Europe and Asylum $\quad 44$

2.3.1 From Tampere to Stockholm 48

2.3.2 Recent Developments - challenges to the concepts of Mutual Trust and

Solidarity $\quad 57$

2.4 Current EU Legal Basis $\quad 60$

2.4.1 Current European Union Legislative Framework $\quad 62$

2.4.1.1 The Eurodac and the Implementation of the Eurodac 64

2.4.1.2 The Temporary Protection Directive $\quad 65$

2.4.1.3 The Reception Conditions Directive $\quad 66$

2.4.1.4 The Dublin II Regulation $\quad 66$

$\begin{array}{ll}\text { 2.4.1.5 The Qualification Directives } & 67\end{array}$

$\begin{array}{ll}\text { 2.4.1.6 The Procedures Directive } & 70\end{array}$

$\begin{array}{ll}\text { 2.4.1.7 The Returns Directive } & 71\end{array}$

$\begin{array}{ll}\text { 2.4.2 Forthcoming Legislation } & 73\end{array}$

2.4.2.1 Proposed Amendments to the Reception Conditions Directive 73

2.4.2.2 Proposed Amendments to the Dublin II Regulation 75

2.4.2.3 Proposed Amendments to the Procedures Directive 77

$\begin{array}{lr}2.5 \text { Statistical Overview } & 80\end{array}$

Chapter 3 - Australia - A Constitution Without Citizenship 83

3.1 Australian Immigration and Notions of Citizenship 83

$\begin{array}{lr}3.2 \text { Australia and Asylum Seekers } & 102\end{array}$

3.2.1 1930-1973 - Early responses to refugees and asylum seekers 103

3.2.2 1973-1996 - The Whitlam, Fraser, and Hawke/Keating Governments 106

3.2.2.1 1973-1976 The Whitlam Government 106

3.2.2.2 1976-1983 The Fraser Government 106

3.2.2.3 1983-1991 The Hawke Government and the
1991-1996 Keating Government

3.2.3 1996-2007 - The Howard Government 114

3.2.4 2007 - present - The Rudd/Gillard Governments 124

$\begin{array}{ll}3.3 \text { Legislative Framework } & 134\end{array}$

$\begin{array}{ll}\text { 3.4 Statistical Overview } & 137\end{array}$ 


\section{Chapter 4 - Definitions, Territorial and Jurisdictional Scope}

4.1 Asylum Seeker

Special categories of asylum seeker:

4.1.2 Family Members

4.1.3 Minors and Unaccompanied Minors $\quad 161$

4.1.4 Vulnerable Persons 169

4.1.5 Stateless Persons 173

4.2 Detention 179

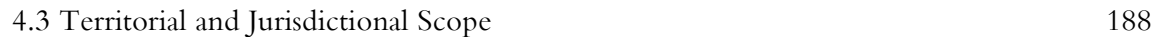

Chapter 5 - Circumstances In Which The Detention Of An Asylum Seeker May Occur Or Be Prolonged

5.1 Introduction

5.1.1 International 202

5.1.1.1 Physical and Lawful Presence 202

5.1.1.2 Physical Presence - Non-refoulement and Entry to the Territory 202

5.1.1.3 Physical Presence - Non-penalisation 203

5.1.1.4 Lawful Presence - Right to Remain 204

5.1.1.5 Lawful Presence - Detention and the Right to Free Movement 206

5.1.2 Council of Europe, EU Charter \& General Principles of European Union Law

5.1.2.2 EU Charter and General Principles of European Union Law 217

$\begin{array}{ll}\text { 5.1.3 Special Categories of Asylum Seeker } & 218\end{array}$

5.1.3.1 Minors and Unaccompanied Minors 218

$\begin{array}{ll}\text { 5.1.3.1.1 International } & 218\end{array}$

5.1.3.1.2 Council of Europe $\quad 222$

5.1.3.1.3 EU Charter $\quad 224$

5.1.3.2 Family Members $\quad 224$

$\begin{array}{ll}\text { 5.1.3.2.1 International } & 225\end{array}$

5.1.3.2.2 Council of Europe 228

$\begin{array}{ll}5.1 .3 .2 .3 \text { EU Charter } & 229\end{array}$

5.1.3.3 Vulnerable Persons 229

5.1.3.3.1 International 229

5.1.3.3.2 Council of Europe 231

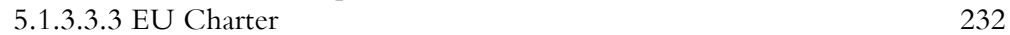

5.1.3.4 Stateless Persons $\quad 232$

5.1.3.4.1 International 232

5.1.3.4.2 Council of Europe $\quad 234$

5.2 European Union Secondary Legislation 236

5.2.1 At the External Borders $\quad 236$

5.2.2 Interrelationship of European Union Secondary Legislation Contemplating Detention

$\begin{array}{ll}\text { 5.2.3 Right to Remain } & 238 \\ \text { 5.2.3.1 Regular Procedure } & 240\end{array}$

5.2.3.1.1 Proposed Legislation 242

5.2.3.2 Border Procedure 246

$\begin{array}{ll}\text { 5.2.3.2.1 Proposed Legislation } & 247\end{array}$

$\begin{array}{ll}\text { 5.2.4 Right to Liberty } & 248\end{array}$

5.2.4.1 Regular Procedure $\quad 248$

5.2.4.1.1 Proposed Legislation $\quad 250$

5.2.4.2 Border Procedure 250 
5.2.4.2.2 Proposed Legislation 250

5.2.5 Grounds for Detention if the Right to Remain Exists 251

5.2.5.1 Regular Procedure 251

5.2.5.1.1 The Commission's 2011 Proposed Reception Conditions

Directive

5.2.5.1.2 The Council's Amended Proposed Reception Conditions

Directive

5.2.5.1.3 The Commission's Proposed Procedures Directive 260

5.2.5.2.Border Procedure 260

5.2.5.2.1 The Proposed Legislation 261

5.2.6 Grounds for Detention if the Right to Remain is Lost 262

5.2.6.1 Regular Procedure $\quad 262$

5.2.6.1.1 Proposed Legislation $\quad 262$

5.2.6.1.2 The Returns Directive $\quad 262$

$\begin{array}{ll}\text { 5.2.6.2 Border Procedure } & 267\end{array}$

5.2.6.2.1 Proposed Legislation 268

5.2.7 Grounds for Detention if an Asylum Seeker is in a Member State Other

Than That of First Entry or Asylum 268

$\begin{array}{ll}\text { 5.2.7.1 Proposed Legislation } & 268\end{array}$

$\begin{array}{ll}5.3 \text { Australia } & 272\end{array}$

5.3.1 Overview of the Australian system 272

5.3.2 At the External Borders (and even before reaching them) 273

5.3.3 Right to Remain 276

5.3.3.1 Asylum seeker as a Lawful Non-Citizen 276

$\begin{array}{ll}\text { 5.3.3.2 Asylum seeker as an Unlawful Non-Citizen } & 278\end{array}$

5.3.4 Right to Liberty 283

5.3.4.1 Asylum Seeker as a Lawful Non-Citizen $\quad 283$

5.3.4.2 Asylum Seeker as a Unlawful Non-Citizen $\quad 284$

5.3.4.2.1 Migration Zone $\quad 284$

$\begin{array}{ll}\text { 5.3.4.2.1.1 Minors } & 284\end{array}$

5.3.4.2.1.2 Guardianship of Minors 286

5.3.4.2.1.3 Guardianship of Minors - conflicts of interest 287

$\begin{array}{ll}\text { 5.3.4.2.1.4 Families } & 288\end{array}$

5.3.4.2.1.5 Vulnerable Persons 288

$\begin{array}{ll}\text { 5.3.4.2.1.6 Stateless Persons } & 289\end{array}$

5.3.4.2.1.7 Establishing Liberty $\quad 289$

$\begin{array}{ll}\text { 5.3.4.2.2 Excised Offshore Places } & 290\end{array}$

5.3.5 Circumstances in Which Detention May Occur
Asylum seeker as a Lawful Non-Citizen

$\begin{array}{ll}\text { 5.3.5.1 Questioning Detention } & 293\end{array}$

$\begin{array}{ll}\text { 5.3.5.2 Section } 501 \text { Migration Act } & 294\end{array}$

5.3.6 Circumstances in Which Detention May be Prolonged
Asylum seeker as an Unlawful Non-Citizen

5.3.7 Assessment of Key Immigration Detention Values 307

5.3.8 Lapsed Proposed Amendments 308

$\begin{array}{ll}\text { 5.4 Conclusions } & 312\end{array}$ 
Chapter 6 - Review Mechanisms for Detention 319

$\begin{array}{lr}\text { 6.1 Provision of Reasons for Detention } & 320\end{array}$

$\begin{array}{ll}6.1 .1 \text { International } & 320\end{array}$

6.1.2 Council of Europe $\quad 321$

6.1.3 European Union 323

6.1.3.1 General Principles of European Union Law 323

6.1.3.2 European Union Secondary Legislation 324

6.1.3.2.1 Detention where the Right to Remain Exists 324

Current Legislation $\quad 324$

Proposed Legislation 324

6.1.3.2.2 Detention where the Right to Remain is Lost 324

Current Legislation $\quad 324$

Proposed Legislation $\quad 324$

Returns Directive 325

6.1.3.2.3 If an Asylum Seeker is in a Member State Other Than That of

First Entry or Asylum 326

Current Legislation $\quad 326$

\begin{tabular}{lr} 
& Proposed Legislation \\
6.1.4 Australia & 326 \\
\hline & 326
\end{tabular}

$\begin{array}{ll}\text { 6.1.5 Conclusions } & 328\end{array}$

6.2 Access to, and communication with, lawyers and the provision of legal assistance

$\begin{array}{lr}\text { 6.2.1 International } & 329\end{array}$

6.2.1.1 Minors 331

6.2.1.2 Vulnerable Persons $\quad 332$

6.2.2 Council of Europe 333

6.2.3 European Union 335

6.2.3.1 EU Charter and General Principles of European Union Law 335

6.2.3.2 European Union Secondary Legislation 336

6.2.3.2.1 Detention where the Right to Remain Exists 336

Current legislation 336

Access to, and communication with, lawyers 336

Legal Assistance $\quad 336$

Proposed Legislation $\quad 337$

Access to, and communication with, lawyers $\quad 337$

Legal Assistance 338

6.2.3.2.2 Detention where the Right to Remain is Lost 341

Current Legislation $\quad 341$

Access to, and communication with, lawyers 341

Legal Assistance $\quad 341$

Proposed Legislation $\quad 342$

Access to, and communication with, lawyers \& Legal
Assistance

Returns Directive 343

6.2.3.2.3 Detention in a Member State Other Than That of First Entry or Asylum 344

Current Legislation $\quad 344$

Proposed Legislation $\quad 344$

Access to, and communication with, lawyers $\quad 344$

Legal Assistance $\quad 344$

$\begin{array}{ll}\text { 6.2.4 Australia } & 344\end{array}$

6.2.4.1 Access to, and communication with, lawyers 344 
6.2.4.2 Legal Assistance $\quad 347$

6.2.5 Conclusions 351

Access and communication 351

Legal Assistance $\quad 352$

Limiting the Provision of Legal Services 353

6.3 Review and Challenge of the Detention Decision 354

$\begin{array}{ll}\text { 6.3.1 International } & 354\end{array}$

6.3.1.1 Minors 356

6.3.1.2 Vulnerable Persons $\quad 357$

$\begin{array}{ll}\text { 6.3.2 Council of Europe } & 357\end{array}$

$\begin{array}{ll}\text { 6.3.2.1 'Speedily' } & 358\end{array}$

6.3.2.2 'Court' 360

6.3.2.3 Scope of Review 361

6.3.2.4 Security-Related Detention 362

6.3.2.5 Interim Measures 363

6.3.2.6 Committee of Ministers $\quad 364$

$\begin{array}{ll}\text { 6.3.2.7 CPT } & 364\end{array}$

6.3.2.8 European Convention on the Exercise of Children's Rights 364

6.3.3 European Union 365

6.3.3.1 EU Charter \& General Principles of EU Law 365

6.3.3.2 Security-Related Evidence 367

6.3.3.3 Public Access to European Parliament, Council \& Commission
Documents

6.3.3.4 Court of Justice of the European Union - Jurisdiction 372

6.3.3.5 General Court of the European Union - Jurisdiction 373

$\begin{array}{ll}\text { 6.3.3.6 Interim Measures } & 374\end{array}$

6.3.3.7 European Union Secondary Legislation 375

6.3.3.7.1 Detention where the Right to Remain Exists $\quad 375$

$\begin{array}{ll}\text { Current Legislation } & 375\end{array}$

Proposed Legislation $\quad 376$

6.3.3.7.2 Detention where the Right to Remain is Lost 377

$\begin{array}{ll}\text { Current Legislation } & 377\end{array}$

Proposed Legislation $\quad 377$

Returns Directive 377

6.3.3.7.3 Detention in a Member State Other Than That of First Entry or
Asylum

$\begin{array}{ll}\text { Current Legislation } & 378\end{array}$

Proposed Legislation $\quad 378$

6.3.3.7.4 Security-related Information \& Detention $\quad 380$

$\begin{array}{ll}\text { Current Legislation } & 380\end{array}$

Proposed Legislation $\quad 381$

$\begin{array}{ll}\text { 6.3.4 Australia } & 382\end{array}$

6.3.4.1 Challenges to prolonged detention - Security Assessments 386

$\begin{array}{ll}\text { 6.3.4.2 Internal review by DIAC } & 389\end{array}$

$\begin{array}{ll}\text { 6.3.5 Conclusions } & 390\end{array}$

6.4 External Communication, Access and Oversight 392

6.4.1 External Communication and Access 392

6.4.1.1 International 392

6.4.1.2 Council of Europe 393

$\begin{array}{ll}\text { 6.4.2 External Oversight } & 394\end{array}$

$\begin{array}{ll}\text { 6.4.2.1 International } & 394\end{array}$

6.4.2.2 Council of Europe $\quad 394$ 
6.4.3 European Union $\quad 395$

6.4.3.1 External Communication \& Access 395

6.4.3.1.1 Detention where the Right to Remain Exists 395

Current Legislation $\quad 395$

Proposed Legislation $\quad 396$

6.4.3.1.2 If the Right to Remain is Lost 397

Current Legislation 397

Proposed Legislation $\quad 398$

Returns Directive 398

6.4.3.1.3 Detention in a Member State Other Than That of First Entry or
Asylum

Current Legislation 399

Proposed Legislation 399

6.4.3.2 External Oversight 399

$\begin{array}{ll}\text { 6.4.4 Australia } & 401\end{array}$

6.4.4.1 Commonwealth Ombudsman 401

6.4.4.2 Australian Human Rights Commission (“AHRC”) 403

6.4.4.3 Council for Immigration Services and Status Resolution ("CISSR”) 405

6.4.5 Conclusions 405

Chapter 7 - Conditions of Detention 407

$\begin{array}{ll}\text { 7.1.1 General Standards } & 408\end{array}$

7.1.1.1 International 408

$\begin{array}{ll}\text { 7.1.1.2 Council of Europe } & 415\end{array}$

7.1.1.3 EU Charter \& General Principles of EU Law 419

$\begin{array}{ll}\text { 7.1.2 Special Categories of Asylum Seeker } & 420\end{array}$

$\begin{array}{ll}\text { 7.1.2.1 Minors } & 420\end{array}$

International $\quad 420$

Council of Europe $\quad 425$

EU Charter 426

7.1.2.2 Families $\quad 427$

International $\quad 427$

Council of Europe $\quad 428$

EU Charter $\quad 430$

7.1.2.3 Vulnerable Persons $\quad 430$

International $\quad 430$

Council of Europe $\quad 432$

EU Charter 433

7.2 European Union Secondary Legislation 433

7.2.1 Detention where the Right to Remain Exists 433

7.2.1.1 Current Legislation $\quad 433$

Border Applicants 435

Minors and Families $\quad 436$

Vulnerable Persons 437

$\begin{array}{ll}\text { 7.2.1.2 Proposed Legislation } & 437\end{array}$

Border Applicants $\quad 440$

Minors and Families $\quad 441$

Vulnerable Persons 443

7.2.2 Detention where the Right to Remain is Lost 443

7.2.2.1 Current Legislation $\quad 443$

7.2.2.2 Proposed Legislation $\quad 444$

7.2.2.3 Returns Directive $\quad 444$

Minors and Families $\quad 445$ 
Vulnerable Persons

7.2.3 If Detained in a Member State Other Than That of First Entry or Asylum

7.2.3.1 Current Legislation

7.2.3.2 Proposed Legislation

7.2.4 Legal Liability for Detention Conditions - Outsourcing the Management of Detention Centres

7.3.2 Legal Liability for Detention Conditions and Scope of the Duty of Care

7.3.2.2 Unaccompanied Minors

7.3.2.3 Education of Minors

7.3.3 Review of Decisions Taken in Detention Relating to the Treatment of Asylum Seekers

\section{Chapter 8 - The Principle of Proportionality \& Alternatives to} Detention

8.1 Introduction

8.1.1 The Principle - Origins and Elements

8.1.2 Alexy's Principle Theory

8.1.3 Why Proportionality and Detention?

8.1.4 Contexts in which the Principle of Proportionality may operate

8.1.6 The Principle of Proportionality - Application and Qualifications

8.3 Council of Europe $\quad 492$

8.4 European Union $\quad 496$

8.4.1 Legislative stage $\quad 496$

8.4.2 Implementation or Judicial Review stage 497

8.4.2.1 Review of Union Measures 498

8.4.2.1.1 Comparison - Detention of Union Citizens and Asylum Seekers - 'Manifestly Disproportionate'?

Union Citizens and Family Members - Right of Entry and

Residence, Right to Liberty, Grounds for Expulsion

Asylum seekers - Right to Remain, Right to Liberty

Union Citizens - Restrictions on Liberty

Union Citizens - Deprivation of Liberty

8.4.2.2 Review of Member State Measures Implementing Union Law

8.4.2.2.1 Current Legislation 
8.5.2.2 The Dividing Line - Alternative 'forms of detention and alternatives

'to' detention

Community Detention $\quad 535$

Bridging Visas 536

8.5.2.3 Eligibility for a Bridging Visa $\quad 537$

Offshore Entry Persons and Transitory Persons 537

Applicants within the Migration Zone 538

"Eligible non-citizens" 538

8.5.2.4 Classes of Bridging Visa 540

8.5.2.4.1 Bridging Visa E - Subclass 050 - General Class $\quad 542$

General Eligibility $\quad 542$

Particular Requirements $\quad 542$

No-work Condition 543

8.5.2.4.2 Bridging Visa E - Subclass 051 - Protection Visa Applicants 544

General Eligibility $\quad 544$

Work Rights $\quad 545$

8.5.2.4.3 Bridging Visa R $\quad 545$

8.5.2.4.4 "Compelling Need to Work" 546

$\begin{array}{ll}\text { 8.5.2.4.5 Medicare } & 549\end{array}$

8.5.2.5 Other conditions which may be imposed on Bridging Visa holders $\quad 549$

Security Bonds $\quad 550$

Reporting and Residence Conditions 551

8.5.2.6 Assistance for Asylum Seekers on Bridging Visas $\quad 551$

Community Assistance Support Program ("CAS”) 552

Asylum Seekers Assistance Scheme ("ASAS") 553

$\begin{array}{lr}\text { Chapter 9-Conclusions } & 561\end{array}$

$\begin{array}{ll}\text { Epilogue } & 571\end{array}$

$\begin{array}{lr}\text { Samenvatting } & 575\end{array}$

$\begin{array}{ll}\text { Bibliography } & 577\end{array}$

$\begin{array}{ll}\text { Resumé } & 645\end{array}$ 


\section{Abbreviations}

ACP African, Caribbean and Pacific countries

AHRC Australian Human Rights Commission (formerly HREOC)

ANAO Australian National Audit Office

APOD Alternative Places of Detention

ASAS Asylum Seeker Assistance Scheme

ASIO Australian Security and Intelligence Organisation

ATV Air Transit Visas

CAT Convention Against Torture and Other Cruel, Inhuman or

Degrading Treatment or Punishment

CAS Community Assistance Support Program

CCP Community Care Pilot Program

CEAS Common European Asylum System

CERD International Convention on the Elimination of All Forms of Racial Discrimination

CFI Court of First Instance

CJEU Court of Justice of the European Union

CPA Comprehensive Plan of Action

CPT European Convention for the Prevention of Torture and Inhuman or Degrading Treatment

CRD Citizens' Rights Directive (Directive 2004/38/EC)

CROC Convention on the Rights of the Child

CRPD Convention on the Rights of Persons with Disabilities

CteeERD Committee on the Elimination of Racial Discrimination

CteePT European Committee for the Prevention of Torture and Inhuman or Degrading Treatment or Punishment

CteeRC Committee on the Rights of the Child

Cth Commonwealth (of Australia)

DIAC Department of Immigration and Citizenship

DIMIA Department of Immigration, Multicultural and Indigenous Affairs (later DIAC)

EASO European Asylum Support Office

EC European Community

ECECR European Convention on the Exercise of Children's Rights

ECHR European Convention on Human Rights

ECmHR European Commission on Human Rights

ECJ European Court of Justice

ECRE European Council on Refugees and Exiles

ECtHR European Court of Human Rights

EEA European Economic Area

ELENA European Legal Network on Asylum

EU European Union

HRC United Nations Human Rights Committee 
HREOC Human Rights and Equal Opportunity Commission (now the Australian Human Rights Commission - AHRC)

ICCPR International Covenant on Civil and Political Rights

ICESCR International Covenant on Economic, Social and Cultural Rights

ICJ International Court of Justice

IDC Immigration Detention Centre

ILO Immigration Liaison Officers

IMA Irregular Maritime Arrival

IMR Independent Merits Review

IRH Immigration Residential Housing

IRO International Refugee Organisation

ITA Immigration Transit Accommodation

ITOA International Treaty Obligations Assessment

JHA Justice and Home Affairs

MRT Migration Review Tribunal

MSI Ministerial Series Instruction

NSW New South Wales

OHCHR Office of the High Commissioner for Human Rights

OPCAT Optional Protocol to the Convention Against Torture and Other Cruel, Inhuman or Degrading Treatment or Punishment

PIC Public Interest Criteria

POD Protection Obligation Determination

QMV Qualified Majority Voting

RRT Refugee Review Tribunal

RSA Refugee Status Assessment

SBC Schengen Borders Code

SEA Single European Act

SHP Special Humanitarian Programme

TCN Third Country National

TEU Treaty on the European Union

TFEU Treaty on the Functioning of the European Union

TPV Temporary Protection Visa

UDHR Universal Declaration on Human Rights

UAMS Unaccompanied Minors

UN United Nations

UNHCHR United Nations High Commissioner for Human Rights

UNHCR United Nations High Commissioner for Refugees

UNRAA United Nations Relief and Rehabilitation Administration 


\section{Chapter 1 Introduction}

The Woomera Prohibited Area is an area of 127,000 square kilometres ${ }^{1}$ (about three times the size of the Netherlands) in the central Australian desert in the state of South Australia. From 1947 to 1980, it was used in a joint operation with the United Kingdom for the testing of long-range missiles and rockets at a facility near the purpose-built town of Woomera itself. ${ }^{2}$

In 1999, the Australian Government opened an immigration detention centre in Woomera to process 'irregular' arrivals - including asylum seekers. ${ }^{3}$ It became host to riots, lip-sewing, and harsh conditions of detention. ${ }^{4}$ The retired Chief Justice of India, Prafullachandra Bhagawati, visited the Woomera detention centre over May-June 2002 at the request of the United Nations High Commissioner for Human Rights and concluded that the human rights situation he found there "could, in many ways, be considered inhuman and degrading". 5

In January 2001, two boys, Alamdar and Muntazar Bakhtiari, accompanied their mother and three other siblings by boat to seek asylum in Australia where their father had already been granted a Temporary Protection Visa (on the basis that he was a Hazara from Afghanistan but which was later cancelled by the Department of Immigration who claimed that he was from Pakistan ${ }^{6}$ ). The boys and their mother were detained in the Woomera detention centre having been refused a Protection Visa and were pending deportation. In June 2002, Alamdar and Muntazar escaped from the detention centre and, with the assistance of refugee advocates and lawyers, sought asylum at the British Consulate in Melbourne (some $1200 \mathrm{~km}$ away in the state of Victoria). The boys based their claim on the Convention on the Rights of the Child ("CROC") and their mental health from being in the detention centre.

\footnotetext{
${ }^{1}$ Australian Government, Department of Defence, http://www.defence.gov.au/woomera/ about.htm (last accessed 12 July 2012)

2 Morton, P, Fire Across the Desert, 1989, AGPS, Canberra

${ }^{3}$ Human Rights and Equal Opportunity Commission ("HREOC") (now the Australian Human Rights Commission (“AHRC”)), A last resort? National Inquiry into Children in Immigration Detention, April 2004, Sydney, P.59

${ }^{4}$ HREOC, A last resort? National Inquiry into Children in Immigration Detention, April 2004, Sydney, Pp.300-310; 408-410; 751-756

${ }^{5}$ Bhagawati, Justice P N, Regional Advisor for Asia and the Pacific of the United Nations High Commissioner for Human Rights, Mission to Australia, 24 May to 2 June 2002, Human Rights and Immigration Detention in Australia, http://www.unhchr.ch/huricane/huricane.nsf/424e6fc8b8e55fa6802566b0004083d9/bc4c 8230f96684c8 c1256c070032f5f1/\$FILE/Report.doc (last accessed 12 July 2012), para 62

${ }^{6}$ Sydney Morning Herald, Mrs Bakhtiari is one of ours, say Afghan, 28 September 2005, http://www.smh.com.au/news/world/mrs-bakhtiari-is-one-of-ours-say-afghan/2005/09/ 27/1127804478530.html (last accessed 12 July 2012)
} 
Within the day, the British Consulate rejected their applications, and the boys were subsequently returned to the Woomera detention centre. ${ }^{7}$ In October 2003, the Human Rights Committee ("HRC"), upon receipt of a Communication from the Bakhtiaris, expressed their View that Article 9(1) and (4) of the International Covenant on Civil and Political Rights ("ICCPR") had been breached by Australia in relation to Mrs Bakhtiari and her children. ${ }^{8}$ In October 2004, an appeal by the Bakhtiaris to the United Kingdom Court of Appeal on the basis that the United Kingdom breached its obligations under Article 3 of the European Convention for the Protection of Human Rights and Fundamental Freedoms ("ECHR") by refusing the boys asylum at the consulate was ultimately unsuccessful - the Court so ruling inter alia because:

"Australia is a country which observes the rule of law and where diplomatic officials would not expect the authorities knowingly to impose or permit a regime where children were exposed to inhuman and degrading treatment". ${ }^{9}$

In essence, the Court was not satisfied that the minimum level of severity was reached, but the quotation reveals more - it conveys disbelief. In December 2004, the entire family was deported from Australia. ${ }^{10}$

Even ten years after the consular incident, and notwithstanding that the Woomera detention centre was closed in April 2003, ${ }^{11}$ the story of the Bakhtiaris is remarkable on a number of levels. Firstly, their pursuit of legal avenues for assistance and redress brought two legal systems, from opposite sides of the globe, within striking distance of one another. Secondly, their circumstances gave rise to a View by the HRC identifying breaches of the ICCPR by Australia. In these senses, the real-life experiences of the Bakhtiaris touched upon the jurisdictions that this book now considers.

But there is at least one further element that the journey of the Bakhtiaris highlights - disbelief that such treatment could possibly occur in Australia. Exchanges with European academics and lawyers about the laws regarding the

\footnotetext{
7 O'Neil, M, Blind Conscience, 2008, UNSW Press, University of New South Wales, Pp.104-118

8 United Nations, Human Rights Committee, Bakhtiyariv Australia, Communication No. 1069/2002, 29 October 2003, CCPR/C/79/D/1069/2002, paras 9.3-9.5; also note the breach of Article 24(1) ICCPR and potential breaches of Articles 17(1) and 23(1) ICCPR see paras 9.6, 9.7 and 10

9 The Queen on the Application of "B" \& Ors $v$ Secretary of State for the Foreign \& Commonwealth Office [2004] EWCA Civ 1344, at para 95

${ }^{10}$ Banham, C, and Debelle, P, Bakhtiari family deported under cover of darkness, Sydney Morning Herald, 31 December 2004, http://www.smh.com.au/news/National/Bakhtiarifamily-deported-under-cover-of-darkness/2004/12/30/1104344932116.html (last accessed 12 July 2012)

${ }^{11}$ HREOC, A last resort? National Inquiry into Children in Immigration Detention, April 2004, Sydney, P.59
} 
detention of asylum seekers meets with furrowed brows and disbelief that such a state of affairs can possibly co-exist with that very welcoming, generous and beneficent image that Australia projects. But the disbelief is, at times, also mutual. Exchanges with Australian lawyers and academics, who look toward Europe for guidance and inspiration and admire its over-arching human rights protection, appear confused when reports of conditions in Greece, ${ }^{12}$ or Italy pushing back boats from north Africa, ${ }^{13}$ are revealed. Indeed, mutual trust that human rights standards are upheld even within the European Union has been shown as something not to be assumed. ${ }^{14}$

These disbeliefs represent the nub of the question.

The belief that another State will act in accordance with international human rights conventions is predicated on the notion that the human rights identified in those conventions are universal and that they will be respected and protected by State parties. Accordingly, a State's subscription to international human rights conventions has resulted in the 'mutual trust' amongst State parties that they will respect and protect the human rights contained therein and, until recently, it is arguable that that trust is based on not much more than a State's subscription to the relevant conventions themselves. That sentiment can be seen in the above-quoted judgment of the United Kingdom Court of Appeal in relation to Australia. It is also manifest in the safe countries of origin concept in the European Union Common European Asylum System ("CEAS") whereby Member States are deemed safe countries of origin. Until recent challenge, the approach also formed the bedrock basis for the operation of the Dublin Regulation (that is, an asylum seeker could be returned to a Member State of first entry or asylum because it could be presumed that the receiving Member State would comply with fundamental rights obligations). ${ }^{15}$ Further, States that have subscribed to international human rights obligations have also 'trusted' States that have not so subscribed to provide protection to asylum seekers - for example, in the case of the Malaysia 'swap deal' in which 800 asylum seekers arriving 'irregularly' in Australia were to be taken to Malaysia in return for Australia receiving 4,000 refugees from Malaysia (which is not a signatory to the Geneva Convention ${ }^{16}$ or the ICCPR).

12 MSS v Belgium \& Greece, No. 30696/09, Judgment, Grand Chamber, 21 January 2011

13 Hirsi Jamaa and Others $v$ Italy, No. 27765/09, 23 February 2012, Judgment, Grand Chamber

${ }^{14}$ MSS v Belgium \& Greece, No. 30696/09, Judgment, Grand Chamber, 21 January 2011 (ECtHR); Cases C-411/10 and C-493/10 N.S. v Secretary of State for the Home Department and M. E. and Others $v$ Refugee Applications Commissioner and Minister for Justice, Equality and Law Reform, 21 December 2011, Judgment Grand Chamber (CJEU)

15 See Cases C-411/10 and C-493/10 N.S. v Secretary of State for the Home Department and M. E. and Others $v$ Refugee Applications Commissioner and Minister for Justice, Equality and Law Reform, 21 December 2011, Judgment Grand Chamber (CJEU), para 80

16 Throughout this book, the term "Geneva Convention" will refer to the Convention Relating to the Status of Refugees (1951) and the Protocol Relating to the Status of Refugees (1967) unless otherwise specified. The terminology "Geneva Convention" is 
Recently, however, the concept of mutual trust even amongst States that are purportedly 'on the same page' has been under increasing challenge from the human rights reality within those States. In MSS, the European Court of Human Rights ("ECtHR") held that an asylum seeker must not be transferred to a Member State of the European Union (under the Dublin Regulation) if doing so would result in a breach of Article 3 ECHR. ${ }^{17}$ The Court of Justice of the European Union ("CJEU") delivered a comparable decision in NS holding that an asylum seeker must not be transferred to a Member State (under the Dublin Regulation) if it resulted in a breach of Article 4 of the Charter of Fundamental Rights of the European Union ("EU Charter"). Further, the CJEU held that there was a rebuttable presumption that the Member State would comply with fundamental rights. ${ }^{18}$ However, it would appear that mutual trust is more likely to be asserted by the Member State that benefits from that assertion, which can prove toxic to the human rights of asylum seekers as well as a legal system ${ }^{19}$ and an asylum system ${ }^{20}$ based on the concept of solidarity - a recent example being the grandstanding between Italy and France in 2011 resulting in the shuffling of boat arrivals between the two countries. In the Australian context, there is a growing body of Human Rights Committee jurisprudence relating to Australia's non-compliance with ICCPR standards in relation to immigration detention. ${ }^{21}$ Further, in 2011, the High Court of Australia in its $M 70$ decision quashed the proposed plan to send asylum seekers that reached Australian shores to Malaysia as part of the "Swap Deal" after finding that the Minister for Immigration's declaration (based on human rights protections and the ability to have their claims processed) that Malaysia was a country to which asylum seekers could be sent was invalid (the Court noting that the declaration was based on purported practice not on legal

adopted in the European Union primary and secondary legislation and, for the sake of clarity and consistency, is adopted here

17 MSS v Belgium \& Greece, No. 30696/09, Judgment, Grand Chamber, 21 January 2011

18 Cases C-411/10 and C-493/10 N.S. v Secretary of State for the Home Department and M. E. and Others $v$ Refugee Applications Commissioner and Minister for Justice, Equality and Law Reform, 21 December 2011, Judgment Grand Chamber (CJEU), para 104

19 Article 4(3) Treaty on European Union (“TEU”)

20 Articles 67(2) and 80 Treaty on the Functioning of the European Union ("TFEU”)

$21 A v$ Australia UNHRC Communication No. 560/1993, UN Doc. CCPR/C/59/D/560/1993, 30 April 1997; C v Australia, UNHRC, Communication 90/1999, UN Doc CCPR/C/76/D/900/1999, 28 October 2002; Baban v Australia, UNHRC Communication No. 1014/2001, UN Doc. CCPR/C/78/D/1014/2001, 6 August 2003; Bakhtiyiari v Australia, UNHRC Communication No. 1069/2002, UN Doc. CCPR/C/D/1069/2002, 12 August 2003; Madafferi v Australia, UNHRC Communication No. 1011/2001, UN Doc. CCPR/C/81/D/1011/2001, 26 August 2004; D and E v Australia, UNHRC Communication No. 1050/2002, UN Doc. CCPR/C/87/D/1050/2002, 11 July 2006; Shafiq v Australia, UNHRC, Communication No. 1324/2004, UN Doc. CCPR/C/88/D/1324/2004, 13 November 2006; Shams et al v Australia, UNHRC, Communication Nos. 1255, 1256, 1259, 1260, 1268, 1270 , 1288/2004, UN Doc CCPR/C/90/D/1255, 1256, 1259, 1260, 1266, 1268, $1270 \&$ 1288/2004, 11 September 2007. 
safeguards for asylum seekers within Malaysia). ${ }^{22}$ One cannot help but wonder, 'Is the trust that States place in one another misplaced?'.

These events have highlighted the tensions that exist firstly, between legal orders, for example: between international and national, between supranational and national (such as the EU and Member States); between supranational and international (such as the EU and the Geneva Convention and human rights conventions), and even between supranational legal orders (such as the ECHR and EU). Secondly, recent events have also highlighted the tensions between institutions within legal orders (such as between the executive through the legislature to act, but checked by the courts).

If subscription to international human rights conventions, which themselves are predicated on the notion of the universality of human rights, is the basis for the concept of mutual trust amongst States, and if international law has a potentially harmonising role to play, ${ }^{23}$ then one might expect to see a positive convergence of laws in each jurisdiction as it relates to the detention of asylum seekers (that is, a convergence towards positive treatment and outcomes for asylum seekers). However, these challenges to the concept of mutual trust are an irritant to that theory. If international norms and obligations have the potential to foster convergence of laws in subsidiary legal systems, the research question that emerges is: to what extent do the laws regarding the detention of asylum seekers in the European Union and Australia converge (or otherwise)?

In each jurisdiction, the issue of the detention of asylum seekers has been of increasing significance. Although an intergovernmental approach in relation to migration matters can be traced back to the formation of the Trevi Group in 1975, the European Union (then having distinct and separate legal personality from the European Community) has had involvement in asylum matters since 1992 following the Treaty of Maastricht, then passing to the European Community in the inter-governmental 'Third Pillar' since the Treaty of Amsterdam in 1997. However, the impetus for the CEAS and the reaffirmation of the right to seek asylum followed the Tampere European Council in 1999 and, although taking some time to materialise, resulted in secondary legislation relating to asylum that contemplated detention but with a high degree of discretion given to Member States and with Member State competence largely unfettered. Further, that secondary legislation only contemplated "minimum standards" due to the legislative competence granted under the then EC Treaty. Following the entry into force of the Lisbon Treaty in 2009, the European Union (now with singular legal personality) has enhanced competence to formulate legislation beyond minimum standards. Following the Commission's 2007 Green Paper on the Future of the

22 Plaintiff M70/2011 v Minister for Immigration and Citizenship; Plaintiff M106 of $2011 v$ Minister for Immigration and Citizenship [2011] HCA 32

${ }_{23}^{3}$ Menski, W, Comparative Law in a Global Context - The Legal Systems of Asia and Africa, (2ed), 2006, CUP, Cambridge, Pp.38-45 particularly at Pp.41-44 
Common European Asylum System, ${ }^{24}$ a reform of the CEAS was mooted and which provided the initiative for the second generation of secondary legislation whose enactment is anticipated shortly. However, in 2009, the Stockholm Programme, under the Swedish Presidency, set the future agenda for European Union migration and asylum with an emphasis on "mutual trust" and "solidarity". ${ }^{25}$ The importance of detention in this context is that the proposed secondary legislation contains much more prescriptive and extensive provisions relating to detention - moving away from the large amount of discretion that was given to Member States under the first generation of legislation. Additionally, it will also apply to those seeking complementary protection. This comes at a time of increasing demands for international protection in the Mediterranean and frontier Member States, and in circumstances where mutual trust and solidarity are at their lowest ebb. The challenge for Member States in the European Union is ensuring adequate protection for asylum seekers as detention becomes the subject of seeming harmonisation.

In Australia mandatory detention has, since 1992, been an integral part of Australia's response to asylum seekers. The period from the late 1980s to 2007 has evidenced some of the most drastic measures taken in response to asylum seekers - in addition to mandatory detention other measures included the interdiction of boats, offshore processing in third countries, the 'excision' of territory from the Migration Zone precluding the making of any application for a visa (including a Protection Visa), the use of Temporary Protection Visas, and harsh conditions of detention for protracted periods. This was achieved through legislation that, in some instances, vested a significant degree of personal, non-compellable discretion in the Minister for Immigration. ${ }^{26}$ The period also witnessed decisions by the High Court of Australia that upheld the legality of indefinite detention of those whose removal was not reasonably practicable ${ }^{27}$ the legality of detention even where the conditions were so harsh they might otherwise constitute punishment; ${ }^{28}$ and the legality of the mandatory detention of children who were "unlawful non-citizens". ${ }^{29}$ In 2007-2008 began a discernible shift in policy, which has brought about a greater use of community detention and alternatives to detention ${ }^{30}$ and, most

\footnotetext{
${ }^{24}$ COM (2007) 301 final

25 Presidency, Council of the European Union, The Stockholm Programme - An open and secure Europe serving and protecting the citizens, 17024/09, 2 December 2009

${ }^{26}$ See, for example, sections 46A, 197AE, 197AF, 195A of the Migration Act 1958 (Cth)

27 Al-Kateb v Godwin [2004] HCA 37

${ }_{28}$ Behrooz $v$ Secretary of the Department of Immigration and Multicultural and Indigenous Affairs (2004) 219 CLR 486

${ }^{29}$ Re Woolley; Ex parte Applicants M276/2003 [2004] HCA 49

30 See, for example, Australian Government, Department of Immigration and Citizenship, Fact Sheet 65 - Onshore Processing for Irregular Maritime Arrivals, http://www.immi.gov.au/media/fact-sheets/65onshore-processing-irregular-maritimearrivals.htm (last accessed 13 July 2012)
} 
recently, the legislative embodiment of complementary protection. ${ }^{31}$ The High Court of Australia has, in recent times, also handed down two significant decisions that have appreciably benefited asylum seekers in Australia. ${ }^{32}$ Following the announcement of the end of offshore processing in third countries in 2008, the succeeding years have also seen directionless and reactive policy emerge: firstly, adopting onshore processing on Christmas Island (in Australia's excision zone), followed by an attempt to send asylum seekers to Malaysia as part of a 'swap deal', then followed by a commitment to onshore processing and now a parliamentary stalemate as a return to offshore processing is sought. ${ }^{33}$ However, despite policy changes, the legislation has remained unchanged in relation to detention. Concerns are held over the prolonged and indefinite detention of those asylum seekers who have been granted refugee status but have failed security clearances. Judicial review and oversight of those in detention remains a serious shortcoming, and the outsourcing of the management of immigration detention contracts raises questions about accountability. As the numbers arriving by boat has recently increased, ${ }^{34}$ mandatory detention is still at the heart of Australia's response to those asylum seekers that arrive "unlawfully" (that is without a valid visa). ${ }^{35}$

There is also a confluence of events in recent times that present an apt opportunity to explore comparatively the detention of asylum seekers in both jurisdictions. 2011 saw the sixtieth anniversary of the Geneva Convention, and the ten years since first sending asylum seekers from Australia for offshore processing in Nauru (and, subsequently, Papua New Guinea). 2012 represents twenty years since the Australian introduction of a policy for the mandatory detention of all 'irregular' arrivals (including asylum seekers) and, in the European Union, the twentieth anniversary since the Treaty of Maastricht and the entry of the European Union into asylum matters. 2012 also marks five years since the Commission's Green Paper on the Future Common European

\footnotetext{
31 Migration (Amendment Complementary Protection) Act 2011 (Cth)

32 Plaintiff M61/2010E v Commonwealth of Australia; Plaintiff M69 of 2010 v Commonwealth of Australia [2010] HCA 41 and Plaintiff M70/2011 v Minister for Immigration and Citizenship; Plaintiff M106 of 2011 v Minister for Immigration and Citizenship [2011] HCA 32

33 On recent developments in Parliament to secure 'offshore processing' in third countries see Coorey, P, Paralysis in Parliament, Sydney Morning Herald, 28 June 2012, http://www.smh.com.au/opinion/political-news/paralysis-in-parliament-20120627212ye.html (last accessed 12 July 2012)

${ }^{34}$ Phillips, J, and Spinks, H, Boat arrivals in Australia since 1976, Parliament of Australia, Department of Parliamentary Sevices, Parliamentary Library, updated 5 January 2011, statistics updated 9 July 2012, http://parlinfo.aph.gov.au/parlInfo/download/library/ $\mathrm{prspub} / 5 \mathrm{P} 1 \mathrm{X} 6 /$ upload_binary $/ 5 \mathrm{P} 1 \mathrm{X} 6 . \mathrm{pdf} ;$ fileType $=$ application $/ \mathrm{pdf} \#$ search $=\% 22 \mathrm{boat} \% 20 \mathrm{a}$ rrivals\%20in\%20Australia\%20since\%22, P.19; Vasek, L, Boat arrivals up more than eightfold on a year ago, The Australian, 29 June 2012, http://www.theaustralian.com.au/nationalaffairs/immigration/boat-arrivals-up-more-than-eightfold-on-a-year-ago/story-fn $9 \mathrm{hm} 1 \mathrm{gu}$ 1226411567024 (last accessed 13 July 2012)

35 Australian Government, Department of Immigration and Citizenship, Key Immigration Detention Values, http://www.immi.gov.au/managing-australias-borders/detention/about/ key-values.htm (last accessed 13 July 2012), Value 1
} 
Asylum System (which precipitated the current proposed secondary legislation)..$^{36} 2013$ represents the $65^{\text {th }}$ anniversary of the Universal Declaration of Human Rights, which provided the modern genesis of an individual's right to seek and enjoy asylum in another country, and the right not to be subject to arbitrary detention. 2013 will also see ten years since the introduction of the EU Reception Conditions Directive (which contemplates detention) and the Dublin II Regulation (where detention of asylum seekers has been used to give effect to the transfer provisions of the Regulation). In the Australian context, 2013 will see the fifth anniversary of the Australian Government's Key Immigration Detention Values that marked the discernible shift in the policy surrounding the detention of asylum seekers.

On the face of it, the European Union and Australia bear little resemblance when one considers the disparity in numbers seeking asylum in each territory. In 2011, the 27 Member States of the European Union received a total of 277,370 asylum applications, representing $63 \%$ of asylum claims in 44 industrialised countries and 0.6 claims per 1,000 inhabitants. ${ }^{37}$ Australia, on the other hand, received 11,510 claims for asylum representing 3\% of all claims lodged in 44 industrialised countries and representing 0.5 claims lodged per 1,000 inhabitants. ${ }^{38}$ Statistically, Australia is closest to The Netherlands in terms of asylum claims lodged and the share of all claims lodged in 44 industrialised countries $(11,590$ claims lodged in The Netherlands representing $3 \%$ respectively for 2011). On the basis of claims lodged per 1,000 inhabitants, Australia, Australia is comparable to that of the United Kingdom ( 0.4 claims per 1,000 inhabitants) or Germany (0.6 claims per 1,000 inhabitants). ${ }^{39}$ In 2011, the top-3 nationalities of asylum seekers in Australia were Iran, Afghanistan and China, ${ }^{40}$ whereas the top-3 origins of those seeking asylum in the EU-27 countries were Afghanistan, Serbia and Russia. ${ }^{41}$

A further significant difference between the two jurisdictions is the fact that the European Union shares its external borders with multiple countries, presenting an additional challenge to frontier Member States (and, at times, to the concept of solidarity amongst Member States), whereas Australia does not share a border with any other country.

\footnotetext{
36 COM (2007)301 final

37 UNHCR, Asylum Levels and Trends in Industrialized Countries 2011, 27 March 2012, http://www.unhcr.org/4e9beaa19.html (last accessed 15 May 2012), Table 1, P.20

38 UNHCR, Asylum Levels and Trends in Industrialized Countries 2011, 27 March 2012, http://www.unhcr.org/4e9beaa19.html (last accessed 3 May 2012), Table 1, P.20

${ }^{39}$ UNHCR, Asylum Levels and Trends in Industrialized Countries 2011, 27 March 2012, http://www.unhcr.org/4e9beaa19.html (last accessed 15 May 2012), Table 1, P.20

40 UNHCR, Asylum Levels and Trends in Industrialized Countries 2011, 27 March 2012, http://www.unhcr.org/4e9beaa19.html (last accessed 3 May 2012), Table 23, P.44

${ }^{41}$ UNHCR, Asylum Levels and Trends in Industrialized Countries 2011, 27 March 2012, http://www.unhcr.org/4e9beaa19.html (last accessed 3 May 2012), Table 5, P.24
} 
In a legal context, there are also differences that should be borne in mind throughout the course of this book. Firstly, the European Union is a supranational legal order covering 27 Member States, whereas Australia is a single State. Secondly, the European Union is underpinned by the EU Charter and each Member State's accession to the ECHR (and soon the EU's accession to the ECHR), whereas Australia does not have a constitutional bill of rights. Secondly, the nature of the European Union secondary legislation both in asylum and return contexts is cast in a more normative style, allowing for Member State discretion as regards mode of implementation (where appropriate) and focussed on the objective to be achieved. The Australian Migration Act 1958 (Cth) ("the Migration Act"), on the other hand, is highly prescriptive, complex and almost code-like in the exhaustiveness of its provisions.

Notwithstanding these differences, both jurisdictions have adopted measures whereby access to the territory is made extremely difficult for those seeking asylum. Asylum seekers are increasingly faced with tough border control measures, carrier sanctions, interdiction, the notion of 'safe third countries', and cooperation with countries of transit or source. The aim of this comparative research between the two jurisdictions, then, is to fulfil one of the classic aims of comparative legal analysis - to be (mutually) illuminative to legislators $^{42}$ and thereby hopefully lead to better outcomes in the treatment of asylum seekers. In an increasingly globalised age, it is no surprise to find Australian law assisting in the interpretation of United Kingdom asylum law ${ }^{43}$ or the provisions of the ECHR. ${ }^{44}$ Nor should it be any surprise that the European conceptualisation of the principle of proportionality be considered to help define what 'proportionality' means (or does not mean) in the Australian constitutional law landscape, ${ }^{45}$ or a consideration of the Qualification Directive in relation to "internal protection". ${ }^{46}$ Particularly in

\footnotetext{
42 Zweigert, K, and Kötz, H, An Introduction to Comparative Law, (3ed), 1998, OUP, Oxford, Pp.16-17

${ }^{43}$ See R v Immigration Appeal Tribunal, Ex parte Shah [1999] 2 AC 629; Fornah v Secretary of State for the Home Department [2006] UKHL 46; $R v$ Secretary of State for the Home Department, Ex parte Adan [2001] AC 477 cited in Bingham, T, Widening Horizons - The Influence of Comparative Law and International Law on Domestic Law, 2010, CUP, Cambridge, Pp.37-41

${ }^{44}$ See, for example, in relation to Article 8 ECHR, the consideration of the Australian position concerning the recognition of a person's assigned sex in Goodwin $v$ The United Kingdom, No. 28957/95, Judgment Grand Chamber, 11 July 2002 at paras 56, 82 and 84; or the prohibition on refoulement even if a State is acting extra-territorially in the concurring opinion of Judge Pinto de Albuquerque in the recent decision of Hirsi Jamaa and Others $v$ Italy, No. 27765/09, Judgment, Grand Chamber, 23 February 2012

${ }^{45}$ See Chapter 8, 8.5.1

46 SZATV v Minister for Immigration and Citizenship [2007] HCA 40 at para 14 per Gummow, Hayne and Crennan JJ; at para 48, n.48 per Kirby J
} 
the interpretation of international conventions, comparative legal analysis can be an extremely useful tool for the judiciary. ${ }^{47}$

Accordingly, it is hoped that this comparative research will bridge the gap in knowledge about the two jurisdictions' approach.

\section{Scope}

The distinction between asylum seekers and other types of forced migrants is not always clear, particularly when the degree of human suffering is comparable and distinctions seemingly difficult to justify. ${ }^{48}$ Spheres may often overlap. Indeed, an emerging issue is those forced to flee their countries due to climate-induced circumstances. ${ }^{49}$ However, the focus of this research is on the detention of those outside their country of origin seeking international protection under the Geneva Convention as a refugee or seeking a form of complementary protection by engaging obligations under one of the other international instruments (such as the ICCPR or the Convention Against Torture and Other Cruel, Inhuman or Degrading Treatment or Punishment ("CAT")). The common obligation towards asylum seekers amongst states is not to refoule them. But the blanket term of art of 'asylum seekers' does not always reveal the distinct needs of particular persons in need of international protection. For this reason, the position of children, families, vulnerable persons and stateless persons will also be explored where possible.

Because liberty is such a fundamental right and which must be capable of justiciability and protection, the research focuses solely on the applicable laws in the two jurisdictions. The importance of this focus is more demonstrable in the Australian scheme where policy changes can result in better outcomes for asylum seekers, but which remain unbacked by legislative change. Rather, by keeping such measures in the realm of policy, enforceability is undermined and complete discretion at the hands of the executive is maintained. There are three further reasons for limiting the research, at this stage, to the law applicable in both jurisdictions: firstly, the European Union's CEAS is dependent on Member State implementation and does not have the usual attributes of policy or practice that a nation-state might otherwise have from ground-level implementation. In that regard, Member State implementation of European Union law and the resulting practice would be essential to provide the most direct comparison with the policies and practices of Australia. Secondly, although one of the most pressing research questions might be how Member States implement the CEAS in both law and practice, practical constraints at this time prevent an exploration into this area. It is hoped that

\footnotetext{
47 Zweigert, K, and Kötz, H, An Introduction to Comparative Law, (3ed), 1998, OUP, Oxford, Pp.18-21

48 See Turton, D, Who is a Forced Migrant? in de Wet, C, (ed) Development-induced Displacement, 2006, Berghahn Books, New York, Pp.14-36

49 See McAdam, J, Climate change, forced migration, and international law, 2012, OUP, Oxford
} 
this study might provide the basis for further research in that direction. Thirdly, exploring the Australian policy and practice without undergoing a similar exploration on the European Union side may result in a distortion of the findings - that is, the Australian policies and practices may well result in the European Union presenting more favourably, if only because a direct comparison has not been furnished. However, the Australian experiences, as borne out in the case law and particularly in relation to children, do provide a very ample warning of what, in some instances, should be legislatively proscribed. Accordingly, practice and policy are not entirely disregarded - in the Australian sphere, this will be highlighted from time to time where there is disjunction between the policy or practice and the underlying legal reality; in the European sphere, the facts of particular cases can illuminate the disjunction between legal and factual realities.

In referring to the European Union (and, formerly, the European Community) ('Brussels'), the distinction must be made between that entity and the Council of Europe ('Strasbourg'). As will be explored and explained in Chapter 2, there has traditionally been a triangulated relationship between the European Union, the Member States of the European Union and the Council of Europe. In the sphere of human rights, that relationship has chiefly (though not solely) materialised through each Member State's accession to the ECHR and its supervision by the ECtHR. Indeed, the European Union itself will soon accede to the ECHR. In many respects, the ECHR provides parallel human rights protection to that of the European Union, and has been the traditional guardian of such rights. Accordingly, the analysis includes references to the Council of Europe, the ECHR and the decisions of the ECtHR to the extent that they apply to the Union legal order.

\section{Methodology}

The research adopts a comparative law methodology with a human rightsbased approach concordant with the rule of law. The perspective of the individual (as opposed to the State) is of more immediate concern. The laws considered will be international human rights law, the ECHR with its associated jurisprudence, European Union law and Australian law. Given the tensions that arise between jurisdictions as to the application of human rights norms, the aim is to establish the highest international norm in each topic area (which may also act as points of reference in the comparison), and then for the European Union and Australian jurisdictions to be compared to each other. Accordingly, the process adopted in each chapter is: the international standard is established, followed by the regional standard set by the ECHR, followed by European Union standards contained in the Charter of Fundamental Rights of the European Union ("the EU Charter") ${ }^{50}$ or as General Principles of European Union law. Once these elements are established, the European

50 OJ 2010 C $83 / 02$ 
Union secondary legislation and the Australian provisions are explored, before coming to a conclusion as regards a comparison between the two.

Within Chapters 4 to 8 , a jurisdictional approach is adopted rather than a thematic one - that is, each jurisdiction's standards are dealt with as a discrete analysis. This process was adopted due to the subtle (and, at times, not so subtle) differences in the standards between the different jurisdictions that require precise and clear identification as well as to highlight the tensions between the different legal orders. This is particularly important in the European Union context whose secondary legislation must be seen against the backdrop of ECHR standards. Accordingly, the process of comparison is facilitated and, hopefully, enhanced by exploring each jurisdiction separately before coming to a conclusion.

Within the discussion of international human rights law, standards such as the UNHCR Revised Guidelines on the Detention of Asylum Seekers ("the UNHCR Revised Guidelines"), ${ }^{51}$ the United Nations Standard Minimum Rules for the Treatment of Prisoners ${ }^{52}$ and the Body of Principles for the Protection of All Persons under Any Form of Detention or Imprisonment ${ }^{53}$ will be included as they are, at the least, reflective of international human rights standards and persuasive for state parties, particularly if reports are to be furnished regarding their implementation in State reports. Reference will also be made to the United Nations Treaty Bodies such as the HRC, through their Views and General Comments, and whose jurisprudence, although not legally binding on states, may be considered persuasive and illuminative of expected State practice.

The discussion of the ECHR and its jurisprudence from the ECtHR also includes Recommendations and Guidelines from the Council of Europe's Committee of Ministers, and makes reference to the Guidelines of the Committee for the Prevention of Torture ("CteePT"). Again, these Recommendations and Guidelines are not legally binding on States, but are indicative of the provisions that States should make in their laws. As will be discussed in Chapter 2, the ECHR will bear an even greater significance given the Union's proposed accession to the ECHR.

Given the heightened status of the EU Charter as having the same legal value as the Treaties itself, ${ }^{54}$ and given that the ECHR provides the minimum

\footnotetext{
${ }^{51}$ UNHCR, UNHCR Revised Guidelines on Applicable Criteria and Standards relating to the Detention of Asylum Seekers, February 1999

52 Adopted by the First United Nations Congress on the Prevention of Crime and the Treatment of Offenders, held at Geneva in 1955, and approved by the Economic and Social Council by its resolutions 663 C (XXIV) of 31 July 1957 and 2076 (LXII) of 13 May 1977

53 Adopted by General Assembly Resolution 43/173 of 9 December 1988

${ }^{54}$ Article 6(1) of the Treaty on the European Union, OJ 2010 C83/01
} 
standard between the two, ${ }^{55}$ the provisions of the EU Charter will be identified, together with any general principles of Union law which might also be applicable. The focus of the examination is, however, on the CEAS secondary legislation itself. A critical analysis of the current secondary legislation, as well as the proposed secondary legislation, will be made. At the time of writing the proposed secondary legislation is in an advanced state of negotiation. Further proposals by the Commission and multiple amended versions by the Council (resulting from the negotiations with the European Parliament) led to a conscious decision to limit the comparison to specific Commission proposals and further amended Council proposals. These are identified in Chapter 2. To have included an exhaustive analysis of prior proposals (although reference is made to these when necessary) and all subsequent amendments would have resulted in a cumbersome discourse and, it was felt, would not have aided the accuracy or directness of the comparison.

In the Australian sphere, the Migration Act is the main object of analysis, together with the Migration Regulations 1994 (Cth) and the relevant case law. However, other relevant legislation and common law will also be explored when necessary. As mentioned earlier, it should be borne in mind that Australia does not have a constitutional bill of rights and extraction of comparable rights as might be found in modern constitutions or human rights conventions is achieved through a process of deduction from legislation, the common law and case law in relation to the Australian Constitution itself.

\section{Structure}

Chapters 2 and 3 provide an introduction into the notions of citizenship and migration, as well as asylum law and policy, of each jurisdiction, before providing an overview of the legislative framework. The purpose of these introductory chapters is to provide sufficient background and history of each jurisdiction (particularly for those unfamiliar with one or both jurisdictions) so that the reader can more easily navigate the substantive comparison and be cognisant of the legislative choices that have been made. Both chapters invite the reader to consider how 'the other' is conceptualised in each jurisdiction. A statistical overview is also provided.

In Chapter 4, the terms "asylum seeker" (together with the four subcategories of "families", "minors", "vulnerable persons" and "stateless persons") and "detention" will be explored. Both jurisdictions have complexities as regards their territorial and jurisdictional scope - the European Union with its 27 Member States in addition to its EEA and Schengen agreements with third countries on the one hand, and Australia with its "excised offshore areas" on the other. Accordingly, Chapter 4 will also set the limits of the territorial and jurisdictional scope of the analysis.

${ }^{55}$ Article 52(3) of the EU Charter 
The research question itself is broken up into four discrete topics and follows the compartmentalisation adopted by Vohra. ${ }^{56}$ The approach consists of exploring firstly, circumstances in which detention might occur or be prolonged (Chapter 5); secondly, review mechanisms for detention (Chapter 6); thirdly, conditions of detention (Chapter 7); and lastly, proportionality and alternatives to detention (Chapter 8 ). This approach was adopted in order to give the most comprehensive analysis possible by dealing with all elements that are pertinent to the detention of asylum seekers. It also provided a framework within which to deal with each of those elements (and sub-elements - for example, in relation to security-related detention) discretely. By compartmentalising the study in such a way, the 'hard points' of the comparison have surfaced more readily, thereby facilitating and hopefully enhancing the accuracy of the comparison.

Chapter 5 explores the circumstances in which detention may occur or be prolonged. The chapter takes a holistic approach to the legal factors that may bear upon detention. Because physical access and the ability to remain on the territory of asylum are necessary precursors to any discussion of a right to liberty and grounds for detention, the chapter follows a sequence concordant with the accretion of rights contemplated in the Geneva Convention based on physical presence and lawful presence on the territory of asylum, as advanced by Hathaway. ${ }^{57}$ The advantages of adopting such an approach are, firstly, that it highlights instances in the law of where de facto detention can occur; and secondly, it highlights how the very procedure in seeking asylum can influence circumstances in which liberty might be restricted or deprived. Additionally, following the enactment of the European Union proposed secondary legislation, detention provisions in both jurisdictions will apply, in particular circumstances, irrespective of whether refugee status or complementary protection is sought. It is, however, acknowledged that the Geneva Convention deals specifically with refugees. The ongoing academic debate about the place of the Geneva Convention in relation to those seeking complementary protection is also acknowledged, ${ }^{58}$ but this book makes no express contribution in that regard.

Chapter 6 also adopts a holistic approach to the review of detention decisions. The access to effective remedies to review and challenge detention decisions can be affected by the presence or absence of reasons for detention and the provision of legal assistance. Indeed, adequate communication with

56 Vohra, S, Detention of Irregular Migrants and Asylum Seekers in Cholewinski, R, Perruchoud, R, MacDonald, E, (eds), International Migration Law: Developing Paradigms and Key Challenges, 2007, TMC Asser Press, The Hague, Pp.49-69

${ }^{57}$ Hathaway, J, The Rights of Refugees Under International Law, 2011, CUP, Cambridge

58 See McAdam, J, Complementary Protection in International Refugee Law, 2007, OUP, Oxford, Pp.17-18 and Hathaway, J, Leveraging Asylum [2009] University of Melbourne Law School Research Series 6 
the outside world, physical access by persons, professionals and organisations together with oversight mechanisms act as a complementary safeguard for the rights of those detained and will be examined in both jurisdictions.

Chapter 7 inquires as to the standards applicable in law relating to the conditions of detention for asylum seekers. The chapter also focuses on the legal liability for detention conditions and for decisions made in detention facilities that have been outsourced by the state to private contractors.

Chapter 8 explores the principle of proportionality and alternatives to detention as a facet of the 'least restrictive means' element of the principle. The chapter makes a conceptual distinction between alternatives to detention and alternatives forms of detention, and advocates that the least restrictive means of detention should be adopted both before and after a detention decision is made, consistent with an application of the principle. In the European Union context, an analysis compares the grounds for detention for both Union citizens and asylum seekers, in addition to analysing the current and proposed secondary legislation. In the Australian context, the legislative framework of Bridging Visas as an alternative to detention will be considered in detail.

Chapter 9 explores the overall themes and draws together the conclusions of the substantive comparison. It considers to what extent there is convergence in the laws of the European Union and Australia as they relate to the detention of asylum seekers. The chapter highlights the difficulties inherent in comparative research, and identifies that two key areas highlight divergence in each jurisdiction: judicial review of detention decisions and the principle of proportionality. In answer to the research question, it is submitted that there is no overall positive convergence between the two jurisdictions such as to form a basis for the mutual trust between States that asylum seekers will be treated in accordance with international human rights obligations. 


\section{Chapter 2 \\ Europe - "Citizens without a constitution",59}

\subsection{European Immigration and Notions of Citizenship}

The genesis of the European Union is a market, not a society.

As emphasised by Guild, ${ }^{60}$ the aims of the Community (as it then was) as stated in Article 2 of the EC Treaty, were to "establish[] a common market and an economic and monetary union" (now encapsulated, post Lisbon Treaty, in Article 3 of the Treaty on the European Union ("TEU”)). The way that goal was to be achieved was by the free movement of goods, capital, services and people as between the territories of the Member States. ${ }^{61}$ Initially, provided that the person was a national of a Member State and was economically active (being a worker, ${ }^{62}$ self employed ${ }^{63}$ or a provider of services ${ }^{64}$ ), that person could enter and reside in the territory of a Member State of which he or she was not a national. The rationale behind this approach was to facilitate the "factors of production" - that is, workers would move from where an oversupply of labour existed to fulfil a demand where it was needed ${ }^{65}$ - and was underpinned by principles of non-discrimination. ${ }^{66}$ As noted by Kadelbach, "this concept [being the "market citizen", a "reduced functionalist concept of an individual"] describes the individual as the holder of economic freedoms, the judicial enforcement of which serves to realise the Common market". ${ }^{67}$ However, unlike a product which, having entered the customs union from a third country, is otherwise free to circulate in Member States, ${ }^{68}$ third country nationals (which include refugees and asylum seekers) present an exception to the free movement of persons enshrined in the Treaty on the Functioning of the European Union ("TFEU"). In this sense, it is also arguable that they presented an exception based on the economic model pursued by the Union. In any event, the Member States were compelled to

\footnotetext{
59 This phrase was coined by Elspeth Guild in her article Citizens Without a Constitution, Borders Without a State: EU Free Movement of Person, in Baldaccini, A, Guild, E, and Toner, $\mathrm{H}$, (eds), Whose Freedom, Security and Justice - EU Immigration and Asylum Law and Policy, 2007, Oxford, Hart Publishing, Pp. 25-56.

${ }^{60}$ Guild, E, The Europeanisation of Europe's Asylum Policy, (2006) 18(3-4) International Journal of Refugee Law 630, P. 633.

${ }^{61}$ See Article 3(c) of the EC Treaty

62 Articles 45-48 TFEU

63 Articles 49-55 TFEU

64 Articles 56-62 TFEU

65 Barnard, C, The Substantive Law of the EU - The Four Freedoms, 2010, 3ed, Oxford, OUP, P.224

66 Articles 18, 45(2), 49, and 57 TFEU

${ }^{67}$ Kadelbach, S, Union Citizenship, Jean Monet Working Paper 9/03, Max Planck Institute for Comparative Public Law and International Law, Heidelberg, 24-27 February 2003, P. 5 68 Articles 28(2) and 29 TFEU
} 
relinquish a degree of sovereignty in relation to the free movement of persons (that is, persons from other Member States) into and from their territories in order to achieve the aims set out in the (then) EC Treaty. ${ }^{69}$

Accordingly, there is an internal and external dimension to European migration. In relation to the internal dimension, the concept of European citizenship as introduced in the Treaty of Maastricht ${ }^{70}$ further emphasised the free movement rights of nationals of the Member States as contemplated in the EC Treaty (now the TFEU). The Court of Justice of the European Union (hereinafter referred to as the "CJEU") played an active and pivotal role in expanding the notion of European Citizenship beyond merely an economic, market-based rationale to become "a fundamental status of nationals of the Member States" 71 (later reflected in Community legislation ${ }^{72}$ ) and simultaneously eroding Member States' sovereignty. Indeed, as was noted by Advocate-General Mazák in Förster,

\begin{abstract}
"It is thus fair to say that the concept of Union citizenship, as developed by the case-law of the Court, marks a process of emancipation of Community rights from their economic paradigm. That is in fact the objective invoked by the statement of the Court that Union citizenship is destined to become the 'fundamental status of nationals of the Member States'. Community law rights - in particular the right not to be subjected to unjustified discrimination - are no longer bestowed upon citizens solely when they make use of the economic freedoms and assume a corresponding status (worker, provider of services etc.), but directly by virtue of their status as a citizen of the Union. [...])
\end{abstract}

Thus, whereas rights to social benefits were originally linked to the pursuit of economic activities (in particular in the form of paid employment, which underpins the concept of a worker), they may now also be available to economically inactive citizens on the basis of the principle of non-discrimination. Whereas a Member State was previously required to assume full social responsibility and provide welfare for those who had already entered its employment market ([...]) and who thus made some contribution to its economy, such financial solidarity is now in principle to be extended to all Union citizens lawfully resident on its territory." 73

${ }^{69}$ Guild, E, The Europeanisation of Europe's Asylum Policy, (2006) 18(3-4) International Journal of Refugee Law 630, P.632

70 Articles 20(1) and 21 TFEU

${ }^{71}$ Case C-184/99 Grzelczyk v Centre public d'aide sociale d'Ottignies-Louvain-la-Neuve, 20 September 2001, Judgment, para 31. For an account of the ECJ's role in the expansion of European Citizenship, see Kostakopoulos, D, Ideas, Norms, and European Citizenship: Explaining Institutional Change, 2005, Modern Law Review, Volume 68, No. 2, Pp.233267. For a comprehensive overview of law, policy and academic discussion relating to European Citizenship, see Carrera, S, and Merlino, M, State of the Art on The European Court of Justice and Enacting Citizenship, April 2009, Centre for European Policy Studies Special Report

72 Recital 3 of Directive 2004/38 of 29 April 2004 on the right of citizens and the Union and their family members to move and reside freely within the territory of the Member States.

${ }_{73}$ Case C-158/07, Jacqueline Förster v Hoofdirectie van de Informatie Beheer Groep, 10 July 2008, A-G Opinion, paras 54-55. 
However, three aspects must be noted. Firstly, as noted by Besson and Utzinger, "The rise of EU citizenship depends indeed on the existence of a cross-border element; EU citizens may only benefit from their rights when they have used their freedom of movement". ${ }^{74}$ Indeed, as Guild has observed, the right to free movement and the concordant rights of European citizenship have helped to foster a European identity ${ }^{75}$ and which seems to be supported in a Eurobarometer Report. ${ }^{76}$ The essentiality of a cross-border element to enliven European citizenship rights has been blurred by two recent decisions of the CJEU: In Rottman, notwithstanding that Mr Rottman had not exercised his free movement rights, the prospect of him losing his fraudulently acquired German citizenship (thereby becoming stateless) and, consequently, his European citizenship was sufficient for the Court to declare the matter "within the ambit of European Union law". 77 Although the lack of comprehensive reasoning is unfortunate, the CJEU in Zambrano ${ }^{78}$ implied a right of residence for the third country national parents of dependant minor European citizens (Belgian) who, by themselves, were unable to - and indeed did not - exercise their free movement rights. A degree of clarity resumed with two subsequent decisions of the CJEU: in McCarthy the Court took a very conventional line concerning a dual United Kingdom and Irish citizen who had not exercised her right of free movement from the United Kingdom, holding that her right of free movement was not precluded by the refusal of the United Kingdom to grant her third country national husband residency. ${ }^{79}$ Further, in Dereci the CJEU appears to have distinguished Zambrano by reason of the dependency of the EU citizens (as minors, in that case) on their third country national family members and their otherwise need to leave the entire territory of the Union with their third country national parents. The CJEU held in Dereci that the refusal of Austrian authorities to grant residency to the third country national spouses of Austrian citizens who had never exercised their free movement rights did not hinder those Union citizens' rights of free movement. ${ }^{80}$

\footnotetext{
74 Besson, S, and Utzinger, A, Introduction, Future Challenges of European Citizenship - Facing a Wide-Open Pandora's Box (2007) 13(5) European Law Journal 573, P.583.

75 Guild, E, Legal Elements of European Identity, 2004, Kluwer Law International, The Hague.

${ }^{76}$ European Commission (2006), The European Citizens and the Future of Europe - Qualitative Study in the 25 Member States, Eurobarometer, Optem, DG Communication, P.20

77 Case C-135/08 Janko Rottman v Freistaat Bayern, 2 March 2010, Judgment, Grand Chamber, at para 42

78 Case C-34/09 Gerardo Ruiz Zambrano v Office national de l'emploi, 8 March 2011, Judgment, Grand Chamber. The disappointment at the lack of detailed reasoning in the Grand Chamber judgment is amplified when juxtaposed against the thorough and assertive Opinion of Advocate-General Sharpston of 30 September 2010 in the matter - paragraph 86 and footnote 71 sit amongst many gems in the Opinion.

79 Case C 434/09 Shirley McCarthy v Secretary of State for the Home Department, 5 May 2011, Judgment

80 Case C-256/11 Murat Dereci and Others v Bundesministerium für Inneres, 15 November 2011, Judgment, Grand Chamber, noting para 65
} 
The second aspect is that European citizenship has not been decoupled from the nationality of one of the Member States. Originally European citizenship was to "complement and not replace national citizenship" ${ }^{81}$ but even this conceptualisation has evolved into "shall be additional to and not replace national citizenship" 82 in light of the Lisbon Treaty. The subtlety of that change has not been lost on de Waele, who suggests that that amendment may, in the future, form the basis of European citizenship independent of nationality of a Member State. ${ }^{83}$ In any event, European citizenship, may be described as somewhat unorthodox in comparison to traditional models of citizenship, ${ }^{84}$ and which has led Kostakopoulou to explore EU citizenship as a form of "cosmopolitan citizenship" consisting of both national and transnational elements. ${ }^{85}$

Thirdly, the term "European citizen" or "citizen of the Union" cloaks the reality that nationals of one Member State who have entered and are staying (be it residing, visiting, studying or receiving or providing goods and/or services) in another Member State are, essentially, migrants. With the progressive dissolution of the internal obstacles (both actual and legal) to the free movement of persons within the Union but outside the Member State of their nationality, there has been a corresponding reinforcement of the external borders of the Union ${ }^{86}$ and a re-conceptualisation of who represents "the other" - for "the other" is no longer a national of another Member State, but a national from outside the Union.

When exploring "the other" in a Union context, the external element of European migration may be seen to consist of four categories: firstly, migration from outside the Union may be facilitated by being a family member of an EU national; secondly, a position largely akin to being an Union citizen may be derived from one of the nationality-based bilateral or the EEA agreements for those countries in close geographic proximity to the European Union; thirdly, special provisions are made for certain nationals are made under agreements between the Union and certain states under various Partnership, Association, and Stabilization Agreements; fourthly, Union secondary legislation exists which provides for third country national migration on a non-national basis. What emerges is a hierarchy of migration rights with the first three categories being 'privileged third country nationals',

\footnotetext{
81 Article 17(1) of the EC Treaty.

82 Article 20(1) TFEU

83 de Waele, H, EU Citizenship: Revisiting its Meaning, Place and Potential, (2010) 12 European Journal of Migration and Law 319, Pp.322-323 and 332-334.

${ }^{84}$ For a discussion on the possible models of European citizenship, see Kostakopoulos, D, Ideas, Norms, and European Citizenship: Explaining Institutional Change (2005) 68(2) Modern Law Review 233, Pp.238-243.

85 Kostakopoulou, D, European Union Citizenship: Writing the Future (2007) 13(5) European Law Journal 623, Pp.628-633.

${ }^{86}$ Kostakopoulou, D, European Union Citizenship: Writing the Future (2007) 13(5) European Law Journal 623, P.634.
} 
and the latter using a basis other than nationality to determine rights relating to entry and residence in the Union.

Third country national family members of EU nationals represent the crossover point for the internal and external European migration paradigms. This was contemplated as early as 1961 by Regulation 5/61 and later in 1968 in (the now superseded) Articles 10 and 11 of Regulation 1612/68. It was not, however, until the Treaty of Amsterdam ${ }^{87}$ in 1997 that the Community was given shared competence with Member States in the field of, inter alia, immigration by the insertion of Title IV into the EC Treaty. ${ }^{88}$ As is currently the case, ${ }^{89}$ the United Kingdom, Ireland and Denmark were not bound by the new Title IV. ${ }^{90}$ In 1999 the Tampere European Council called for the fair treatment of legally-resident third country nationals and, importantly, "the legal status of third country nationals should be approximated to that of Member States' own nationals". ${ }^{91}$ Subsequently, in 2000, the Lisbon European Council set the goal of the Union for the next decade "to become the most competitive and dynamic knowledge-based economy in the world capable of sustainable economic growth with more and better jobs and greater social cohesion". ${ }^{92}$ At that time, in March 2000, the United Nations published a report which identified the demographic consequences of a declining and ageing population within Europe and suggested legal migration as a possible remedy. ${ }^{93}$ That report influenced the Commission's position on legal migration. The Commission acknowledged the demographic consequences of a "zero" immigration policy and indicated that avenues for legal migration for third country nationals should be established. ${ }^{94}$

\footnotetext{
87 OJ C 340, 10 November 1997

${ }^{88}$ More specifically, see Articles 63(3)(a) and 64 of the EC Treaty

89 See Protocols 20 and 21 to the Treaty on the position of Ireland, the United Kingdom and Denmark on the application of Title V, Chapter 3 of the TFEU, and the Declaration by Ireland on Article 3 of the Protocol on the position of the United Kingdom and Ireland in respect of the area of freedom, security and justice.

${ }^{90}$ By the Protocol to the Treaty on the position of Ireland and the United Kingdom, both countries were able to opt-out of the application of Title IV, but with the ability to opt-in at a later time in accordance with Article 3(1) of the Protocol. Denmark, by the Protocol relating to its position, completely opt-outed out of the application of Title IV, but did not retain the ability to opt-in at a later time.

91 Tampere European Council 15 and 16 October 1999, Presidency Conclusions, paragraph 21, http://www.europarl.europa.eu/summits/tam_en.htm (last accessed 26 April 2011)

92 Lisbon European Council 23 and 24 March 2000, Presidency Conclusions, Paragraph 5, http://www.europarl.europa.eu/summits/lis1_en.htm (last accessed 26 April 2011)

93 Population Division, Department of Economic and Social Affairs, United Nations Secretariat, Replacement migration: is it a solution to declining and ageing populations, 21 March 2000, http://www.un.org/esa/population/publications/migration/migration.htm (last accessed 26 April 2011)

94 Communication from the Commission to the Council and the European Parliament on a Community Immigration Policy, COM(2000)757 final, 22 November 2000.
} 
The corresponding relationship between internal and external European migration is more recently evidenced in the provisions of Directive 2004/38 on Union Citizens' Free Movement Rights. Third country national family members of Union Citizens are contemplated by the Directive, ${ }^{95}$ providing them a right of entry, ${ }^{96}$ residence, ${ }^{97}$ employment or self-employment, ${ }^{98}$ equal treatment, ${ }^{99}$ procedural safeguards ${ }^{100}$ as well as the right (in certain circumstances) to retain their right of residence notwithstanding the death or departure of the Union Citizen or in the event of divorce, annulment of marriage or termination of registered partnership with the Union Citizen. ${ }^{101}$

Concurrent with the erosion of the economic rationale behind Union Citizens' free movement rights ${ }^{102}$ has there also been a more expansive and activist judicial approach to accompanying third-country national family members that manifested itself in Metock. ${ }^{103}$ The significance of Metock is that it provided that third country national family members (as contemplated by Articles 2(2) and 3(1) of Directive 2004/38) do not need to be formerly legally resident in another Member State before the Union Citizen exercised his/her free movement rights, without distinction as to whether such family members entered the Member State before or after the Union Citizen or before or after those persons became the Union Citizen's family Members. ${ }^{104}$ That decision represented a significant shift from Baumbast and $R^{105}$ where the Court identified the children's Union Citizenship and the right to complete their education under Article 12 of Regulation 1612/68 in order to facilitate the stay of third-country national mothers who were either divorced from the Union citizen husband (as in the case of $R$ ) or where the Union Citizen husband was working abroad (as in the case of Baumbast). Metock also represented a clear shift away from Akrich ${ }^{106}$ where the Court had held that a

\footnotetext{
95 Article 2(2) and Article 3(1) of Directive 2004/38

${ }_{96}$ Article 5(1) and (2) of Directive 2004/38

97 Article 7(2) of Directive 2004/38

98 Article 23 of Directive 2004/38

99 Article 24(1) of Directive 2004/38

100 Articles 30 and 31 of Directive 2004/38

101 Articles 12 and 13 of Directive 2004/38
}

102 See Case C-291/05 Minister voor Vreemdelingenzaken en Integratie $v$ R N G Eind, Judgment Grand Chamber, 11 December 2007. See also, Bierbach, J. B., European Citizens' Third Country Family Members and Community Law (2008) 4 European Constitutional Law Review 344

103 See Case C-127/08 Blaise Baheten Metock and others v Minister for Justice, Equality and Law Reform, Grand Chamber of the European Court of Justice, 25 July 2008. See also Fahey, E, Going Back to Basics: Re-embracing the Fundamentals of the Free Movement of Persons in Metock (2009) 36(1) Legal Issues of Economic Integration 83

104 C-127/08 Blaise Baheten Metock and others v Minister for Justice, Equality and Law Reform, Judgment Grand Chamber, 25 July 2008 at paras 58 and 93.

105 Case C-413/99 Baumbast and R $v$ Secretary of State for the Home Department, Judgment, 17 September 2002.

106 Case C-109/01 Secretary of State for the Home Department v Hacene Akrich, Judgment, 23 September 2003. 
third country national spouse needed to be lawfully resident in a Member State prior to the exercise of the Union Citizen's free movement rights as contemplated in Article 10 of Regulation 1612/68.

The category most akin to Union citizens in terms of free movement and residence rights applies to those Norwegian, Icelandic, and Lichtenstein citizens on the basis of the EEA Agreement. ${ }^{107}$ The Agreement creates identical rights for those citizens as for Union citizens contemplated in the TFEU, being entry and residence for workers and self-employed persons ${ }^{108}$ (underpinned by non-discrimination ${ }^{109}$ ), freedom of establishment ${ }^{110}$ and freedom to provide services. ${ }^{111}$ Indeed, the Agreement also provides identical derogations as apply to Union citizens under the TFEU such as nationality requirements for the exercise of official authority or the public service, or on the grounds of public policy, public security and public health. ${ }^{112}$ Indeed, by virtue of the Agreement on the Free Movement of Persons with the European Community, a mostly identical status as that enjoyed by Union citizens is also afforded to Swiss citizens. ${ }^{113}$

After EEA and Swiss nationals, Turkish nationals enjoy the highest degree of migration rights of third country nationals by virtue of the EC-Turkey Agreement, ${ }^{114}$ the Protocol thereto, ${ }^{115}$ and the consequent Decisions of the Association Council. ${ }^{116}$ There are, however, important differences between Turkish nationals and Union, EEA and Swiss citizens. ${ }^{117}$ Firstly, Member States are entirely at liberty to control the entry of Turkish nationals into their territory and to their labour market, and consequently, independent of any

\footnotetext{
107 Agreement on the European Economic Area, OJ L1, 3 January 1994, P.3

108 Article 28 of the Agreement on the European Economic Area, OJ L1/3, 3 January 1994

109 Article 28(2) of the Agreement on the European Economic Area, OJ L1/3, 3 January 1994

110 Artcle 31 of the Agreement on the European Economic Area, OJ L1/3, 3 January 1994

111 Article 36 of the Agreement on the European Economic Area, OJ L1/3, 3 January 1994

112 Articles 28(3) and (4), 32, 33 and 39 of the Agreement on the European Economic Area, OJ L1/3, 3 January 1994

113 Agreement between the European Community and its Member States, of the one part, and the Swiss Confederation, of the other, on the free movement of persons, OJ L114, 30 April 2002, P.6, See Articles 3, 4, 5 and 6; Articles 2 and 7(a) in relation to nondiscrimination and equal treatment; Article 16 (application of Community law); see further, Peers, S, The EC-Switzerland Agreement on Free Movement of Persons: Overview and Analysis (2000) 2(2) European Journal of Migraion and Law 127

114 Association Agreement between Turkey-EEC, 12 September 1963

115 Additional Protocol to the Association Agreement signed on 2 September 1963, 23 November 1970

116 Decisions of the Association Council 2/76, 1/80 and 3/80

117 See further, Theele, T, Rights of Turkish Workers on the Basis of the EEC/Turkey Agreement, in Schneider, H, (ed), Migration, Integration and Citizenship - A Challenge for Europe's Future, Vol II, 2005, Forum Maastricht, Maastricht, Pp.139-165; Wiesbrock, A, Legal Migration to the European Union - Ten Years After Tampere, 2009, Wolf Legal Publishers, Nijmegen, Pp.102-108
} 
other Union secondary legislation, Turkish nationals do not have a right to free movement as do Union, EEA and Swiss citizens. ${ }^{118}$ Secondly, rights of Turkish nationals accrue by virtue of the level of attachment contemplated in Article 6(1) of Decision 1/80, with a right of residence not granted expressly but rather by implication, ${ }^{119}$ and with a right of unrestricted access to the labour market after four years' legal employment. However, several important safeguards apply to Turkish national workers: firstly, a right of equal treatement and prohibition of discrimination based on nationality; ${ }^{120}$ secondly, the prohibition on the imposition of any further restrictive substantive or procedural rules that were applicable to Turkish workers at the time of entry into force of Decision $1 / 80$ or $1 / 76$ by virtue of standstill clauses ${ }^{121}$ (a similar prohibition on further restrictions after the date of the Additional Protocol for those established or providing services in a Member State ${ }^{122}$ ); thirdly, the provisions of Article 6(1) of Decision 1/80 can be relied upon directly. ${ }^{123}$

In a not dissimilar position to Turkish nationals, Russian nationals legally working in a Member State may not also be discriminated against on account of their nationality in relation to working conditions, remuneration or dismissal flowing from the Partnership and Cooperation Agreement between the European Communities and Russia. ${ }^{124}$ The Union has also entered into not dissimilar agreements with other Eastern European, Southern Caucasus, and Central Asian states. ${ }^{125}$ The entry into the Member State of a national the

118 See, for example, Case C-36/96 Günaydin v Freistaat Bayern, 30 September 1997, Judgment, para 23

119 Case C-36/96 Günaydin v Freistaat Bayern, 30 September 1997, Judgment, para 26; Case C-192/89 Sevince v Staatsecretaris van Justitie, 20 September 1990, Judgment, para 29; Case C-237/91 Kus v Landeshauptstadt v Wiesbaden, 16 December 1992, Judgment, paras 29-30, Case C-434/93 Bozkurt v Staatsecretaris van Justitie, 6 June 1995, Judgment, para 28

120 Article 10(1) of Decision 1/80; Case C-171/01 Wählegruppe Gemeinsam, 8 May 2003, Judgment, para 94

121 Article 13 of Decision 1/80; Article 7 of Decision 1/76; However, in Case C-242/06 Minister voor Vreemdelingenzaken en Integratie v Sahin, 17 September 2009, Judgment, new conditions may be imposed on Turkish nationals provided that they are also applied equally to Union citizens, paras 67-70;

122 See Articles 13 and 14 of the Association Agreement, Article 41(1) of the Additional Protocol; Case C-37/98 The Queen $v$ Secretary of State for the Home Department, ex parte Abdulnasir Savas, 11 May 2000, Judgment, paras 46-54, 70

123 Case C-192/89 Sevince v Staatsecretaris van Justitie, 20 September 1990, Judgment, paras 14-15; Case C-36/96 Günaydin v Freistaat Bayern, 30 September 1997, Judgment, para 24

124 Article 23(1), OJ L 327, 28 November 1997, P.3. Article 23(1) may be relied upon directly in a national court by a Russian national: Case C-265/03 Simutenkov v Ministerio de Educación y Cultura and Real Federación Española de Fútbol, 12 April 2005, Judgment Grand Chamber, paras 23 and 29

125 Armenia, OJ L 239, 9 September 1999; Azerbaijan, OJ L 246, 17 September 1999; Georgia, OJ L 205, 4 August 1999; Kazakhstan, OJ L 196, 28 July 1999; Kyrgyz Republic, OJ L 196 of 28 July 1999; Republic of Moldova, OJ L 181, 24 June 1998; Ukraine, OJ L 327, 19 February 1998; Republic of Uzbekistan, OJ L 229, 31 August 1999; Tajikstan, OJ L 350, 29 December 2009 
subject of an Agreement remains entirely within the sovereignty of the Member State of the Union.

The last group of Agreements represent the lower end of the hierarchy of nationality-based agreements with the Union for migration - these consist of the Euro-Mediterranean Association Agreements, ${ }^{126}$ the Cotonou Agreement with African, Caribbean and Pacific Countries ("ACP"), ${ }^{127}$ the Association Agreement with Chile, ${ }^{128}$ and the Stabilization and Association Agreements with a number of Balkan states. ${ }^{129}$ The Euro-Mediterranean, Cotonou and Stablization and Association Agreements (for example, with Albania) have common elements: firstly, they do not regulate the entry of third country nationals to a Member State's territory; and secondly, they are all underpinned by equal treatment provisions as regards working conditions, remuneration and dismissal. ${ }^{130}$ In relation to the Euro-Mediterranean Association Agreements and, by analogy, the Cotonou Agreement, the right to remain in the territory is not regulated as such by the Agreement (unlike in the EECTurkey Agreement where such a right of residence is implied) but the nondiscrimination provisions must not be used in such a way as to nullify the effectiveness of the Agreement. ${ }^{131}$

Independently of European Citizens' free movement rights, provisions have also been implemented at the Union level for third country nationals concerning family reunification, ${ }^{132}$ long-term residents, ${ }^{133}$ students, ${ }^{134}$

${ }^{126}$ Lebanese Republic, OJ L 143, 30 May 2006; People's Democratic Republic of Algeria, OJ L 265, 10 October 2005; Arab Republic of Egypt, OJ L 304, 30 September 2004; Hashemite Kingdom of Jordan, OJ L 129, 15 May 2002; State of Israel, OJ L 147, 21 June 2000; Kingdom of Morocco; OJ L 138, 9 June 2000; Republic of Tunisia; OJ L 9730 March 1998

127 Cotonou Agreement signed 23 June 2000, OJ L 317, 15 December 2000

128 EC-Chile Association Agreement, OJ L 352, 30 December 2002

${ }^{129}$ For example, see Croatia, OJ L 26, 28 January 2005; Albania, OJ L 239, 1 September 2009; note also in relation to Bosnia and Herzogovina, Macedonia, Montenegro: http://europa.eu/legislation_summaries/enlargement/western_balkans/r18003_en.htm (last accessed 11 May 2012)

130 See Article 64 in relation to the Euro-Mediterranean Agreements and Case C-97/05 Gattoussi v Stadt Rüsselsheim, 14 December 2006, Judgment; Article 13(1), (2) and (3) of the Cotonou Agreement; Article 46 of the Stablization and Association Agreement with Albania

131 Case C-97/05 Gattoussi v Stadt Rüsselsheim, 14 December 2006, Judgment, paras 3536, 38-40; in relation to the analagous application to the Cotonou Agreement, see Wiesbrock, A, Legal Migration to the European Union - Ten Years After Tampere, 2009, Wolf Legal Publishers, Nijmegen, Pp.110-111

132 Directive 2003/86/EC of 22 September 2003 on the right to family reunification

133 Directive 2003/109/EC of 25 November 2003 concerning the status of third country nationals who are long-term residents.

${ }^{134}$ Directive 2004/114/EC of 13 December 2004 on the conditions of admission of third country nationals for the purposes of studies, pupil exchange, unremunerated training or voluntary service. 
researchers ${ }^{135}$ and a single permit procedure for the admission of third country nationals. ${ }^{136}$ Recently, the Blue Card Directive ${ }^{137}$ has been adopted, providing a combined entry and residence permit for highly skilled workers so as to attract workers otherwise destined for traditional immigration countries such as the United States of America, Canada, Australia and New Zealand. However, as noted by Wiesbrock, it remains doubtful whether the Directive provides an effective tool to attract such migrants when decoupled from citizenship and long-term residence rights. ${ }^{138}$ But, given the increasingly temporary nature of labour migration movements in "this new era of mobility", ${ }^{139}$ and indeed the express emphasis on circular migration in the Directive itself, ${ }^{140}$ it may well transpire that the Directive's decoupling of migration from citizenship and long term resident rights will not, of itself, be fatal to the success of the Directive. Indeed, in that respect, Peers identifies other shortcomings and short-sightedness of the Directive which may have the cumulative effect of rendering the Directive somewhat less attractive than other highly skilled migration schemes in traditional countries of immigration or, indeed, of such schemes operated in parallel by Member States themselves. ${ }^{141}$

In relation to access to the territory of the Union itself, the Union does not operate a universal visa regime (for example, as Australia does). Rather, the Union identifies two groups: firstly, nationals of countries in which visas are required for entry; and secondly, nationals of countries which are exempt from the requirement of a visa for entry. ${ }^{142}$ However, this still has the practical effect of targeting nationals of those countries from which asylum seekers and refugees are known to have originated. Indeed, even for those persons who

\footnotetext{
135 Directive 2005/71/EC of 12 October 2005 on a specific procedure for admitting third country nationals for the purposes of scientific research.

136 Directive 2011/98/EU of 13 December 2011 on a single application procedure for a single permit for third country nationals to reside and work in the territory of a Member State and on a common set of rights for third-country workers legally residing in the territory of a Member State

137 Directive 2009/50/EC of 25 May 2009 on the conditions of entry and residence of third country nationals for the purposes of highly qualified employment

138 Wiesbrock, A, Legal Migration to the European Union - Ten Years After Tampere, 2009, Wolf Legal Publishers, Nijmegen, Pp.449-452.

139 United Nations General Assembly, International Migration and Development - Report of the Secretary-General, 18 May 2006, Doc A/60/871, P.5

140 Recital 21, Directive 2009/50/EC of 25 May 2009 on the conditions of entry and residence of third country nationals for the purposes of highly qualified employment

${ }^{141}$ Peers, S, Legislative Update: EC Immigration and Asylum Law Attracting and Deterring Labour Migration: The Blue Card and Employer Sanctions Directive (2009) 11 European Journal of Migration and Law 387, Pp.407-410. See also Gümüs, Y. K., The EU Blue Card Scheme: The Right Step in the Right Direction, (2010) 12 European Journal of Migration and Law 435 142 Council Regulation (EC) 539/2001 of 15 March 2001 listing the third countries whose nationals must be in possession of visas when crossing the external borders and those whose nationals are exempt from that requirement - note further amendments to this Regulation in which both lists of countries is updated
} 
are transiting through airports of Member States, Air Transit Visas ("ATVs") are required for certain nationals which have the practical effect of further vetting potential applicants in the event that they may seek asylum whilst in transit in a Member State. ${ }^{143}$ Indeed, Union involvement has also extended to the stationing of immigration liaison officers ("ILOs") in countries beyond the Union through the establishment of the immigration liaison officers network, ${ }^{144}$ the imposition of carrier sanctions, ${ }^{145}$ and the creation of the agency for the operational cooperation of the Union's external borders, FRONTEX. ${ }^{146}$

Distinctions of treatment based on nationality in the Union sit somewhat uneasily with the general provisions relating to non-discrimination found in Article 19(1) TFEU (which provides a legal basis for the Union to combat discrimination based on sex, racial or ethnic origin, religion, disability, age or sexual orientation), as well as the provisions of the EU Charter, and the prohibition against discrimination based on nationality under Article 18 TFEU (but which has been assumed to apply only to EU citizens ${ }^{147}$ ). Indeed, both the Race Equality Directive and the General Framework for the Equal Treatment in Employment and Occupation although prima facie apply to third country nationals, but do include express exemptions for distinctions based on nationality and are without prejudice to provisions relating to entry and residence, and employment and occupation. ${ }^{148}$ What fails to be appreciated in

\footnotetext{
143 See Articles 2 and 3, and Annex to 96/197/JHA: Joint Action of 4 March 1996 adopted by the Council on the basis of Article K.3 of the Treaty on the European Union on air transit arrangements, OJ L063/9 13 March 1996 - including nationals of Afghanistan, Ethiopia, Eritrea, Ghana, Iraq, Iran, Nigeria, Somalia, Sri Lanka and Zaire. See also Council, Common Consular Instructions on Visas for the Diplomatic Missions and Consular Posts OJ C 326/01, 22 December 2005

${ }^{144}$ Regulation 493/2011 of the European Parliament and of the Council of 5 April 2011 amending Council Regulation (EC) No 377/2004 on the creation of an immigration liaison officers network. See further, Peers, S, EU Justice and Home Affairs Law, 3ed, 2011, OUP, Oxford, Pp.544-546

145 Council Directive 2001/51/EC of 28 June 2001 supplementing the provisions of Article 26 of the Convention Implementing the Schengen Agreement of 14 June 1985.

146 Council Regulation (EC) 2007/2004 of 26 October establishing a European Agency for the Management of Operation Cooperation at the External Borders of the Member States of the European Union; see further, Carrera, S, The EU Border Management Strategy FRONTEX and the Challenges of Irregular Immigration in the Canary Islands, CEPS Working Document No. 261, March 2007, http://aei.pitt.edu/7385/1/1482.pdf (last accessed 16 May 2012); Baldaccini, A, Extraterritorial Border Controls in the EU: The Role of Frontex in Operations at Sea, in Ryan, B, and Mitsilegas, V, (eds) Extraterritorial Immigration Control Legal Challenges, 2010, Brill, Pp.229-256

147 For a fascinating discussion on the possible scope of Article 18 TFEU including third country nationals, see Lahuerta, S. B., Race Equality and TCNs, or How to Fight Discrimination with A Discriminatory Law (2009) 15(6) European Law Journal 738, Pp.751754

148 See Recital 13 and Article 3(2) of Directive 2000/43/EC of 29 June 2000 implementing the principle of equal treatment between persons irrespective of racial or ethnic origin; and
} 
the Union legislature is that distinction based on nationality may have the indirect (but perhaps, in some instances, the intentional) effect of discriminating on other grounds (such as racial or ethnic origin or religion) ${ }^{149}$ and appears to be an exception to the otherwise sensitive nature of the Union to indirect discrimination (such as 'measures having equivalent effect' in relation to the free movement of goods within the internal market).

The Union has also been involved in more sophisticated ways of discerning its "other", particularly in relation to its involvement in the policy surrounding integration requirements for third country nationals - for example, knowledge of a Member State's language, history or institutions - even, in some circumstances, before departure. ${ }^{150}$ Indeed, what is so blatantly distasteful about the 'integration abroad' tests is that Member States are at liberty to subject nationals of certain countries to, or exempt nationals of certain countries from, such requirements. For example, the Netherlands exempts nationals from Australia, Canada, Monaco, Japan, Switzerland, New Zealand, South Korea, the United States and the Holy See (that is, 'Western countries') from integration abroad requirements. ${ }^{151}$ Such requirements, especially at the pre-departure stage, have a tinge of the 'dictation test' employed in pursuit of the White Australia Policy (discussed in Chapter 3).

Indeed provisions introduced at the Union level have seen "the other" discerned by the exclusion of third country nationals from the scope of some fields of EU legal migration. Refugees, holders of subsidiary protection status and asylum seekers are excluded from the scope of the Blue Card Directive ${ }^{152}$ and had been, until very recently, excluded from the scope of the Long Term

Recital 12 and Article 3(2) of Directive 2000/78/EC of 27 November 2000 establishing a general framework for equal treatment in employment and occupation

149 Lahuerta, S. B., Race Equality and TCNs, or How to Fight Discrimination with A Discriminatory Law (2009) 15(6) European Law Journal 738, P.750

150 See Carrera Nuñez, S, In Search of the Perfect Citizen - the intersection between integration, immigration and nationality in the EU, 2008, Wolf Legal Publishers, Nijmegen; Wiesbrock, A, Legal Migration to the European Union - Ten Years After Tampere, 2009, Wolf Legal Publishers, Nijmegen, Ch.8; Carrera, S, and Wiesbrock, A, Civic Integration of Third-Country Nationals Nationalism versus Europeanisation in the Common EU Immigration Policy, October 2009, Centre for European Policy Studies, http://aei.pitt.edu/15100/1/ENACT_report_on_ integrating_TCNs_e\%2Dversion_final.pdf (last accessed 15 May 2012)

151 Human Rights Watch, The Netherlands: Discrimination in the Name of Integration Migrants Rights Under the Integration Abroad Act, May 2008, http://www.hrw.org/sites/default/files/reports/netherlands0508.pdf (last accessed 15 May 2012); see further Bonjour, S, Between Integration Provision and Selection Mechanism. Party Politics, Judicial Constraints, and the Making of French and Dutch Policies of Civic Integration Abroad (2010) 12 European Journal of Migration and Law 299

152 Articles 3(2)(b) and (c) Directive 2009/50/EC of 25 May 2009 on the conditions of entry and residence of third country nationals for the purposes of highly qualified employment 
Residents Directive. ${ }^{153}$ Asylum seekers and holders of subsidiary protection status are excluded from the scope of the Family Reunification Directive, ${ }^{154}$ the Students Directive ${ }^{155}$ and the Researchers Directive. ${ }^{156}$ Although expressly contemplated in the Family Reunification Directive, ${ }^{157}$ it would appear that refugees are included in the scope of the Students Directive and the Researchers Directive.

Further, in June 2009 the Employer Sanctions Directive ${ }^{158}$ was introduced which targets the employers of illegally staying third country nationals by prohibiting the employment of illegally staying third country nationals. ${ }^{159}$ The responsibility rests clearly with employers, ${ }^{160}$ with the prospect of financial sanctions, ${ }^{161}$ the requirement to make back-payments to illegally employed third country nationals, ${ }^{162}$ and other sanctions including the exclusion of the employer from some or all public benefits, aids or subsidies for up to five years. ${ }^{163}$ Member States are required to introduce criminal offences and "effective, proportionate and dissuasive" criminal penalties when the offence is intentionally committed. ${ }^{164}$ Peers acknowledges the economic rationale for the introduction of the Directive, but questions the accuracy of the assumptions: firstly, businesses resorting to irregular migrants suggests that employing persons below the minimum wage is essential to those businesses' survival;

153 Articles 3(2)(c) and (d) Directive 2003/109/EC of 25 November 2003 concerning the status of third country nationals who are long-term residents. The Council has recently announced that refugees and beneficiaries of international protection will be now within the scope of the Long Term Residents' Directive: Council of the European Union, EU long term residents' directive extended to refugees and other beneficiaries of international protection, 11 April 2012, http://www.consilium.europa.eu/uedocs/cms_data/docs/pressdata/en/jha/ 121451.pdf (last accesed 11 May 2012)

154 Articles 3(2)(a) and (c) Directive 2003/86/EC of 22 September 2003 on the right to family reunification

155 Article 3(2)(a) Directive 2004/114/EC of 13 December 2004 on the conditions of admission of third country nationals for the purposes of studies, pupil exchange, unremunerated training or voluntary service.

156 Article 3(2)(a) Directive 2005/71/EC of 12 October 2005 on a specific procedure for admitting third country nationals for the purposes of scientific research.

157 See Chapter V Directive 2003/86/EC of 22 September 2003 on the right to family reunification

158 Directive 2009/52/EC of the European Parliament and the Council of 18 June 2009 providing for minimum standards on sanctions and measures against employers of illegally staying third-country nationals ("the Employer Sanctions Directive")

159 Articles 3, 2(a) and (b) of the Employer Sanctions Directive. In this respect, Peers notes that the Directive "does not apply to legal migrants who take up employment which is unauthorised" - Peers, S, Legislative Update: EC Immigration and Asylum Law Attracting and Deterring Labour Migration: The Blue Card and Employer Sanctions Directive (2009) 11 European Journal of Migration and Law 387, P.412

160 Article 4 of the Employer Sanctions Directive

161 Article 5 of the Employer Sanctions Directive

162 Article 6 of the Employer Sanctions Directive

163 Article 7(1) of the Employer Sanctions Directive

164 Articles 9 and 10 of the Employer Sanctions Directive 
secondly, there is an insufficient assessment of the benefits of employing irregular migrants (not only to the migrant but also to the Member State and the Union); thirdly, the option of regularisation was not meaningfully explored; and fourthly, justifying the Directive on the basis of inconsistent enforcement by Member States of sanctions against illegal employment overlooked a possible reality that the uptake of such labour might be a result of economic necessity of the Member State concerned. ${ }^{165}$

An emerging aspect of European migration policy is the integration of development issues into external relations and development policy, particularly with regard to remittances, the management of diasporas, mitigating the effects of 'brain drain' and the promotion of circular migration. ${ }^{166}$ The concept is to incorporate legal migration opportunities into external relations policy in order to develop a "balanced partnership" with third countries. ${ }^{167}$ The approach of using "mobility partnerships" is essentially to facilitate cooperation with third countries on illegal migration in return for Community and Member States' commitments, inter alia, to improve opportunities for legal migration, to help to develop third countries' capacities to manage legal migration, to address 'brain drain' and promote circular migration, and to facilitate the issuance of short term visas. ${ }^{168}$ Currently, mobility partnerships have been entered into with Cape Verde, Moldova and Georgia (with Armenia and Ghana proposed). ${ }^{169}$ However, the overriding emphasis is on the return of the third country national.

\footnotetext{
165 Peers, S, Legislative Update: EC Immigration and Asylum Law Attracting and Deterring Labour Migration: The Blue Card and Employer Sanctions Directive (2009) 11 European Journal of Migration and Law 387, Pp.422-424

166 Commission Communication Migration and Development: Some Concrete Orientations $\operatorname{COM}(2005) 390$ final. For an overview of the integration of migration into the EU's external affairs, see Wiesbrock, A, Legal Migration to the European Union - Ten Years After Tampere, 2009, Wolf Legal Publishers, Nijmegen, at Pp. 126-132. Wiesbrock and Schneider note that the measures essential to promoting circular migration are firstly, securing the portability of pension requirements; secondly, giving migrants who return to their home country the possibility to return to their host country (that is, to use multiple entry visas (for example) to overcome migrants' reluctance to leave their host country if they feel they would not be permitted to return to their host country); and thirdly, to maintain personal and civic connections with the migrant's home country by facilitating dual citizenship and retainin voting rights in the migrant's home country - Wiesbrock, A, and Schneider, H, Circular Migration and Mobility Partnerships, Briefing Paper, European Parliament, D-G Internal Policies of the Union, Policy Department C, Citizens' Rights and Constitutional Affairs, February 2009, Pp.4-6

167 Commission Communication Circular Migration and Mobility Partnerships between the EU and third countries $\operatorname{COM}(2007) 248$ final

168 See Commission Communication Global Approach to Migration One Year On: Towards a Comprehensive European Migration Policy COM(2006) 73 final

169 Council of the European Union, High Level Working Group on Immigration and Asylum, Outome of Proceedings, 27 July 2011, Document No. 12589/11, P.2
} 
Beyond EU parlance, mobility partnerships arguably veil a more utilitarian policy reality. Carrera and Sagrera take the view that mobility partnerships are less about mobility, and more about security partnerships - that is, their purpose is to safeguard the Union's own security with regard to utilitarian labour requirements. Indeed the learned authors suggest that the agreements create insecurity amongst third country nationals in that firstly, they are really an elaborate form of circular migration with individuals conceptualised in economic terms rather than as "human right holders"; secondly, as the agreements are soft law (that is, as joint declarations) and are not legally binding there is a lack of legal certainty and security for third country nationals contemplated by them; thirdly, there is a high degree of selectivity about the countries with whom agreements are entered into with the consequent discrimination based on nationality undermining notions of universality of human rights and labour standards; fourthly, the learned authors argue that the partnerships undermine a common EU migration policy and are, in essence, an elaborate form of external governance. ${ }^{170}$ Indeed, in 2004, the Commission noted that most Member States "did not see a link between the introduction of bilateral schemes and a reduction in illegal migration flows." ${ }^{171}$ The Commission acknowledged that the motivation of illegal migrants was dependent on a range of factors and which are not limited to purely economic ones and the Commission's attempts to establish a profile of 'illegal' residents were laughably vague. ${ }^{172}$

What is evident from this overview of European Union migration law is that the internal element of European migration had its roots in economic rationalism, but which has later evolved into a more robust form of citizenship independent of economic activity due largely to the judicial activism of the CJEU. The discernment of "the other" is much less immediately obvious in an EU internal migration context. However, it should not be forgotten that EU citizens, when exercising their right of free movement, are still migrants. Unlike in Australia where migration law has hugely influenced notions of citizenship, the notion of Union citizenship has greatly influenced Union migration law.

In relation to the external element of European Union migration, the discernment of "the other" follows the gradation of privilege that comes with

\footnotetext{
170 Carrera, S and Sagrera, R. H., The externalisation of the EU's Labour Immigration Policy Towards Mobility or Insecurity Partnerships?, CEPS Working Document No. 321/October 2009, http://www.ceps.eu/system/files/book/2009/10/WD321\%20Carrera\%20and\% 20Sagrera\%20e-version\%20final.pdf (last accessed 27 April 2011) at Pp. 1-4

${ }^{171}$ European Commission, Communication from the Commission to the Council, the European Parliament, the European Economic and Social Committee and the Committee of the Regions Study on the links between legal and illegal migration, 4 June 2004, COM(2004) 412 final, P.12 172 European Commission, Communication from the Commission to the Council, the European Parliament, the European Economic and Social Committee and the Committee of the Regions Study on the links between legal and illegal migration, 4 June 2004, COM(2004) 412 final, P.11 - identified as "males between the ages of 20 and 30 , who are young, mobile and willing to take risks."
} 
being either a family member of a Union citzen or through the various bilateral agreements. Accordingly, some third country nationals have almost identical status to EU citizens and with the all important right of entry into the Union, followed by others who have no right of entry per se but a right to remain, followed by those whose stay in the territory of a Member State is underpinned by non-discrimination as regards working conditions, pay and dismissal but who otherwise may not have a right to enter or remain independent of Member State discretion. Lastly, there is the Union secondary legislation which implements a non-nationality based mode of entry and stay for particular third country nationals and their family members.

But the discernment of "the other" becomes a little clearer when one considers the means adopted to thwart attempts to access the territory of the Union. The seemingly wilful blindness of the Union legislature to the issue of indirect discrimination based on nationality when considering whom the Union simultaneously subjects to, and exempts from, visa requirements as well as the implementation by Member States of integration measures (with not-sotacit Union involvement). Further, the discernment of "the other" is also revealed in the anxiety of the Union to facilitate the return of certain nationals, again by the use of bilateral agreements, joint declarations, the Returns Directive (discussed below) and the growing barnacle of irregular migration management that has affixed itself to Union external governance and relations.

Accordingly, "the other" in the European Union is a much more multifaceted and a much less binary conceptualisation than, for example, in Australia. What emerges is a gradation of "the other" which tracks the hierarchy of rights afforded to migrants in both the internal and external dimension of Union migration. The 'winners' and 'losers' of the passport lottery find varying degrees of comfort, awkwardness and unwelcomeness within the Union.

\subsection{Union Law, the Council of Europe, the ECHR and the ECtHR case law}

As indicated earlier, there is a triangulated relationship between the EU, the Member States of the EU and the Council of Europe. All Member States of the European Union are members of the Council of Europe and, consequently, signatories to the ECHR. The European Union and the European Community were not signatories to the ECHR but the European Union (in its now single legal capacity) will accede to that Convention, as required by Article 6(2) TEU.

The Council of Europe, as a distinct entity from the European Union, has been the traditional guardian of human rights in Europe. Article 1(a) of the 
Statute of the Council of Europe (established by treaty signed on 5 May $1949)^{173}$ states that its aim is to "achieve a greater unity between its members for the purposes of safeguarding and realising the ideals and principles which are their common heritage and facilitating their economic and social progress". That aim was, and still is, to be achieved "through the organs of the Council by discussion of questions of common concern and by agreements and common action in economic, social, cultural, scientific, legal and administrative matters and in the maintenance and further realisation of human rights and fundamental freedoms". ${ }^{174}$

In relation to the relationship of the EU and the Council of Europe with each other, Article 1(c) of the Statute of the Council of Europe provides that "participation in the Council of Europe shall not affect the collaboration of its members in the work of the United Nations and of other international organisations or unions to which they are parties". This clause has been described as a "general non-interference clause". ${ }^{175}$ On the Union's part, Article 220TFEU provides that "the Union shall establish all appropriate forms of co-operation with [...] the Council of Europe...". The combined reading of these two provisions indicates very much a complementary relationship between the two entities, particularly in the area of human rights protection. ${ }^{176}$ The Memorandum of Understanding between the Council of Europe and the European Union reflects that relationship on the basis of "enhanced partnership and complementarity". ${ }^{177}$ The relationship between the two entities is to be developed in "areas of common interest", ${ }^{178}$ including human rights and fundamental freedoms.

One of the chief ways human rights are guarded by the Council of Europe is through the ECHR with its adjudication by the ECtHR and the supervision of the court's judgments and decisions by the Committee of Ministers. However, the Committee of Ministers may also make recommendations to the governments of members and seek information regarding the

\footnotetext{
173 Council of Europe, $A$ short history of the Council of Europe, http://portal.coe.ge/index.php?lan=en\&id=million\&sub=1 (last accessed 27 April 2011)

${ }_{174}$ Article 1(b) of the Statute of the Council of Europe

175 Schneider, H, Claessens, S, and Garben S, The Recognition of Diplomas, Accreditation Procedures and the Free Movement of Professionals in the European Union: Obstacles and Solutions, undated, part of learning materials for the Substantive European Union Law course, Maastricht University, 2011, at P.76.

176 Schneider, H, Claessens, S, and Garben S, The Recognition of Diplomas, Accreditation Procedures and the Free Movement of Professionals in the European Union: Obstacles and Solutions, undated, part of learning materials for the Substantive European Union Law course, Maastricht University, 2011, at P.76.

177 Memorandum of Understanding between the Council of Europe and the European Union, 23 May 2007, para 11

178 Memorandum of Understanding between the Council of Europe and the European Union, 23 May 2007, para 9
} 
implementation of such recommendations. ${ }^{179}$ Further protection additional to that afforded under ECHR is given by the European Convention for the Prevention of Torture and Inhuman and Degrading Treatment of Punishment. Under that Convention, an inspection of a state signatory's detention facilities is carried out by the Committee for the Prevention of Torture (CPT), and a confidential report is issued to the state (which is commonly made public with the consent of the state party). ${ }^{180}$

From the perspective of the European Union, the Council of Europe and the EHCR has had a considerable influence on the integration of human rights into (then) Community law beyond mere internal market concerns. In the (then) Community sphere, this interaction commenced with Internationale Handelsgesellschaft in which the ECJ stated, inter alia,

"In fact, respect for fundamental rights forms an integral part of the general principles of Community law protected by the Court of Justice. The protection of such rights, whilst inspired by the constitutional traditions common to the Member States, must be ensured within the framework of the structure and objectives of the Community." 181

That position was extended to include international treaties in Nold, where the ECJ held:

"In safeguarding these rights, the Court is bound to draw inspiration from
constitutional traditions common to the Member States, and it cannot therefore
uphold measures which are incompatible with fundamental rights recognised and
protected by the Constitutions of those states.

Similarly, international treaties for the protection of human rights on which the Member States have collaborated or which they are signatories, can supply guidelines which should be followed within the framework of Community law"182

A recent example of that continuing influence can be seen in European Parliament $v$ the Council of the European Union where the ECJ held that the Court considered the application of Article 8 of the ECHR in the context of the Family Reunification Directive. The Court held that it "still draws inspiration from the constitutional traditions common to the Member States and from the guidelines supplied by the international instruments for the protection of human rights". ${ }^{183}$

\footnotetext{
179 Article 15(b) of the Statute of the Council of Europe

180 Council of Europe, Human Rights: protection, promotion and prevention http://portal.coe.ge/index.php?lan=en\&id=million\&sub=7 (last accessed 27 April 2011)

181 Case 11/70 Internationale Handelsgesellschaft $v$ Einfuhr- und Vorrastelle für Getreide und Futtermittel, 17 December 1970, Judgment, para 4

182 Case 4/73 Nold v Commission, 14 May 1974, Judgment, para 13.

183 Case C-540/03, European Parliament v Council of the European Union, 27 June 2006, Judgment, at para 35
} 
It is also relevant to consider the perspective of the ECtHR's position on the review of Union acts. Notwithstanding that the European Union and the European Community had not acceded to the ECHR, the ECtHR has indirectly reviewed Union acts. ${ }^{184}$ In Matthews, ${ }^{185}$ the ECtHR held that the United Kingdom was not discharged from its responsibility of securing rights under the Convention (in that case, voting rights in Gibraltar) notwithstanding that the violation stemmed from a primary piece of Community (now Union) law. In considering the United Kingdom's responsibility to secure the relevant right under the Convention, the ECtHR looked to the United Kingdom having voluntarily entered into its treaty commitments as well as the United Kingdom's choice to apply large parts of EC legislation to Gibraltar. ${ }^{186}$

Further, the decision in Bosphorous ${ }^{187}$ also bears relevance on Member States' implementation of Community measures where the Member State has discretion in its implementation. A Member State will comply with its obligations under the ECHR when the Union offers equivalent protection (which is taken to mean "comparable"). ${ }^{188}$ That protection is presumed to exist when the Member State does no more than implement its Union obligations (that is, when it has no discretion). ${ }^{189}$ The presumption of equivalent protection may be rebutted where the protection of ECHR rights is "manifestly deficient". 190

The years subsequent to the Bosphorous decision have highlighted some unresolved areas. Among them are, firstly, at what point is the EU's protection of ECHR rights "manifestly deficient" and to what extent will this be scrutinised by the Court? In this regard, Lock has expressed the view that, although the ECtHR has not shied away from a detailed discussion of manifest deficiency, the review of the case law "reveals a mixed picture". ${ }^{191}$ Secondly,

184 Craig, P, and de Burca, G, EU Law - Text Cases and Materials, 2011, 5ed, Oxford University Press, Oxford, Pp.400-404

185 Matthews v United Kingdom, No. 24833/94, Judgment, Grand Chamber, 18 February 1999

186 Matthews v United Kingdom, No. 24833/9418, Judgment, Grand Chamber, February 1999 at paras 34-35.

187 Bosphorus Hava Yollari Turizm Ve Ticaret Anonim Sirketi v Ireland, No. 45036/98, Judgment, Grand Chamber, 30 June 2005, particularly paras 154-156. See also Costello, C, The Bosphorus Ruling of the European Court of Human Rights: Fundamental Rights and Blurred Boundaries in Europe (2006) 6(1) Human Rights Law Review 87

188 Bosphorus Hava Yollari Turizm Ve Ticaret Anonim Sirketi v Ireland, No. 45036/98, Judgment, Grand Chamber, 30 June 2005 at para 155.

189 Bosphorus Hava Yollari Turizm Ve Ticaret Anonim Sirketi v Ireland, No. 45036/98, Judgment, Grand Chamber, 30 June 2005 at para 156

190 Bosphorus Hava Yollari Turizm Ve Ticaret Anonim Sirketi v Ireland, No. 45036/98, Judgment, Grand Chamber, 30 June 2005 at para 156

${ }^{191}$ Lock, T, Beyond Bosphorous: The European Court of Human Rights' Case Law on the Responsibility of Member States of International Organisations under the European Convention of Human Rights (2010) 10(3) Human Rights Law Review 529, P.543 (see generally Pp.540543) 
what is the amount of discretion necessary before an EU Member State can no longer rely on the presumption of equivalent protection by the EU? For example, is the mere fact that the EU measure is a Directive rather than a Regulation determinative of discretion, or is a precise consideration of the terms of the legislation itself necessary? Lock's review of the case law has revealed that this aspect remains unclear. ${ }^{192}$ Thirdly, the case law subsequent to Bosphorous has been both distinguished and applied in a somewhat inconsistent and unforeseeable manner. ${ }^{193}$

As Guild identifies, the common features of the ECJ and the ECtHR are their supranational character; their ability to adjudicate over natural persons; and their unappellable supremacy over national courts' decisions. ${ }^{194}$ The ECtHR does, however, have the advantage of an individual right of petition ${ }^{195}$ (even if it does require the prior exhaustion of domestic remedies), ${ }^{196}$ as opposed to the ECJ's receipt of a reference from a national court under Article 267 TFEU.

It is beyond the scope of this book to explore in detail the impact of ECtHR case law on immigration matters. However, as noted by Guild, the ECtHR, particularly in its interpretation and application of Article $8 \mathrm{ECHR}$ (right to family life), has had considerable influence in immigration matters. Guild identifies the following categories of cases as: ${ }^{197}$ ensuring family life between children and parents (Berrehab $v$ the Netherlands ${ }^{198}$ and Rodrigues da Silva and Hoogkamer $v$ the Netherlands ${ }^{199}$ ); the expulsion of foreigners involved in criminal activity ("the unsatisfactory young men") (Moustaquim v Belgium, ${ }^{200}$ and Beldjoudi v France $\left.{ }^{201}\right)$; the wives of expelled men where those wives remain in the host state (for example, Boultif v Switzerland, ${ }^{202}$ and Yildiz v Austria ${ }^{203}$ ); children from abroad reunifying with the family (Gül $v$ Switzerland, ${ }^{204}$ Ahmut

\footnotetext{
192 Lock, T, Beyond Bosphorous: The European Court of Human Rights' Case Law on the Responsibility of Member States of International Organisations under the European Convention of Human Rights (2010) 10(3) Human Rights Law Review 529, P.544 (see generally Pp.543544)

193 Lock, T, Beyond Bosphorous: The European Court of Human Rights' Case Law on the Responsibility of Member States of International Organisations under the European Convention of Human Rights (2010) 10(3) Human Rights Law Review 529, Pp. 531-540

194 Guild, E, The Legal Elements of European Identity - EU Citizenship and Migration Law, 2004, The Hague, Kluwer Law International at P.131.

195 Article 34 ECHR

196 Article 35 ECHR

197 Guild, E, The Legal Elements of European Identity - EU Citizenship and Migration Law, 2004, The Hague, Kluwer Law International at Pp.138-142

198 Berrehab v The Netherlands, No. 10730/84, Judgment, 21 June 1988

199 Rodrigues da Silva and Hoogkamer $v$ The Netherlands, 50435/99, Judgment, 31 January 2006.

200 Moustaquim v Belgium, No. 12313/86, Judgment, 18 February 1991

201 Beldjoudi v France, No. 12083/86, Judgment, 26 March 1992

202 Boultifv Switzerland, No. 54273/00, Judgment, 2 August 2001

203 Yildiz v Austria, No. 37295/97, Judgment 31 October 2002

204 Gül v Switzerland, No. 23218/94, Judgment, 19 February 1996
} 
$v$ the Netherlands, ${ }^{205}$, and Sen $v$ the Netherlands $\left.{ }^{206}\right)$. To that list can also be added the category of spousal reunification (such as Abdulaziz, Cabales and Balkandali $v$ the United Kingdom ${ }^{207}$ ). Guild also identifies the impact of the Court's interpretation of Article 3 (prohibition against inhuman or degrading treatment or punishment) on immigration matters in cases involving ${ }^{208}$ asylum seekers (Soering $v$ the United Kingdom ${ }^{209}$ and Chahal $v$ the United Kingdom ${ }^{210}$ ) and the terminally ill $\left(D v\right.$ the United Kingdom $\left.{ }^{211}\right)$.

\subsubsection{Inter-relationship between the EU Charter and the ECHR}

In light of the accession of the EU to the ECHR, it is worth briefly contemplating the inter-relationship between the EU Charter and the ECHR. The accession of the EU to the ECHR would render the ECtHR the ultimate arbiter of Union law. The practical effect of Article 52(3) of the EU Charter is that the ECHR provides the minimum standard of protection with the EU Charter able to provide more extensive protection than the ECHR. In the event that the EU Charter contains a corresponding right to the ECHR, but is based on a right derived from the EU or EC Treaty, Lenaerts and de Smijter observe:

"On the basis of a combined reading of Article 52(2) and (3) and Article 53 of the Charter we may thus conclude that the EU or EC Treaty as well as the ECHR (in fact, the norm offering the highest protection) serve as a reference to determine the minimal content of those fundamental rights contained in the Charter that are based on the EU or EC Treaty and correspond to a right guaranteed by the ECHR"212

However, as noted by van der Velde, the EU Charter ${ }^{213}$ also seeks to limit the impact of the ECtHR's application of its concept of positive obligations. ${ }^{214}$ To that end, Article 51(2) of the EU Charter provides that the Charter "does not

205 Ahmut $v$ the Netherlands, No. 21702/93, Judgment, 28 November 1996

206 Sen $v$ the Netherlands, No. 31465/96, Judgment, 21 December 2001

207 Abdulaziz, Cabales and Balkandali v the United Kingdom, Nos. 9214/80, 9473/81, and 9474/81, Judgment, 28 May 1985

208 Guild, E, The Legal Elements of European Identity - EU Citizenship and Migration Law, 2004, The Hague, Kluwer Law International at Pp.143-146.

209 Soering $v$ the United Kingdom, No. 14038/88, Judgment, 7 July 1989

210 Chahal $v$ the United Kingdom, No. 22414/93, Judgment, Grand Chamber, 15 November 1996

${ }^{211} D v$ the United Kingdom, No. 30240/96, Judgment, 2 May 1997

212 Lenaerts, K and de Smijter, E, The Charter and the Role of the European Courts (2001) 8(1) Maastricht Journal of European and Comparative Law 90, P.98. See also van der Velde, J, The protection of fundamental rights within the European Union - A historical approach, undated, part of course materials for European Human Rights course towards degree of Magister Iuris Communis, Maastricht University, 2009 (copy held on file by author).

213 At the time, the 2007 version (2007 OJ C 303/01), which is identical to the version to which legal effect was given by the Lisbon Treaty, being the Charter of Fundamental Rights of the European Union, 2010/C 83/02, 30 March 2010, OJ C 83/389

${ }^{214}$ Van der Velde, J, The protection of fundamental rights within the European Union - A historical approach, undated, part of course materials for European Human Rights course towards degree of Magister Iuris Communis, Maastricht University, 2009, Pp.11-12 
extend the field of application of Union law beyond the powers of the Union or establish any new power or task for the Union, or modify powers and tasks as defined in the Treaties". Van der Velde also notes the attempts to limit the ECtHR's application of its dynamic (evolutive) approach to interpretation by the insertion of Article 52(4) (rights to be interpreted in harmony with the constitutional traditions common to the Member States), Article 52(6) (full account to be taken of national laws and practices specified in the Charter), and Article 52(7) (courts of the Union and of the Member States to give due regard to guidelines on the interpretation of the Charter) thus rendering the EU Charter's interpretation to an historical approach consistent with specified guidelines. ${ }^{215}$

In relation to parts of the Charter which contain principles (as opposed to "rights" and "freedoms"), Article 52(5) provides that they "may [emphasis added] be implemented by legislative and executive acts taken by institutions, bodies, offices and agencies of the Union, and by acts of Member States when they are implementing Union law" and which may have a consequent extraterritorial effect (discussed in Chapter 4). Additionally, those principles are only justiciable when interpreting those acts and in the ruling of them. However, Weiß has observed that the accession of the EU to the ECHR brings to a head, inter alia, two issues: firstly, the status of the ECHR is above the Union secondary law but below Union primary law in light of Article 216(2) TFEU; and secondly, that the notion of primacy and direct effect of Union law would also apply to ECHR standards when applied in the scope of Union law or as a Member State implementing Union law. ${ }^{216}$

\subsubsection{EU Accession to the ECHR}

By Article 6(2)TEU the Union is required to accede to the ECHR. However, the accession is under the constraints of particular parameters imposed by the Lisbon Treaty. Firstly, Article 6(2)TEU provides that such accession is to be without affecting "the Union's competences as defined in the Treaties", and was emphasised in Protocol $8(2)^{217}$ to the Lisbon Treaty. Secondly, in Declaration $2^{218}$ on Article 6(2)TEU, the agreement to accede to the ECHR "should be arranged in such a way as to preserve the specific features of Union law", noting the regular dialogue between the CJEU and the ECtHR which "could be reinforced" when the Union accedes to the ECHR. Thirdly, the

215 Van der Velde, J, The protection of fundamental rights within the European Union - A historical approach, undated, part of course materials for European Human Rights course towards degree of Magister Iuris Communis, Maastricht University, 2009, Pp.13-14.

216 Weiß, W, Human Rights in the EU: Rethinking the Role of the European Convention on Human Rights After Lisbon (2011) 7 European Constitutional Law Review 64, Pp.72, 88-91 217 Protocol 8 relating to Article 6(2) of the Treaty on European Union on the accession of the Union to the European Convention on the Protection of Human Rights and Fundamental Freedoms, 30 March 2010, OJ C 83/201 at 273

218 Declarations annexed to the final act of the Intergovernmental Conference which adopted the Treaty of Lisbon signed 13 December 2007, 30 March 2010, OJ C 83/335 at 337 
Protocol directs that accession is not to affect the situation of the Member States in relation to the ECHR, particularly in the context of the Protocols to the Convention, derogations in times of emergency, ${ }^{219}$ and any reservations made by Member States to the Convention. ${ }^{220}$ Fourthly, "the specific characteristics of the Union and Union law" are to be provided for in the accession agreement. Fifthly, the agreement is not to affect the undertaking by Member States "not to submit a dispute concerning the interpretation or application of the Treaties to any method of settlement" other than those provided for in the Treaties. ${ }^{221}$ It would appear a Houdini-like forensic task to achieve an agreement amongst those constraints, compounded by the requirement for unanimity in the Council. ${ }^{222}$

Following preliminary informal discussions, the Presidency of the Council of the European Union identified five key areas that presented issues in relation to the EU accession to the ECHR. Firstly, the scope of the accession (that is, would the EU accede to which or all of the Protocols to the ECHR); secondly, compliance with the requirements of the Treaties and their Protocols (as outlined above), including "the preservation of the monopoly of the Court of Justice of the EU in the interpretation of European Union law"; thirdly, ensuring that the EU is a co-defendant with a Member State in particular appropriate cases before the ECtHR; fourthly, the representation of the EU in the Council of Europe - particularly in relation to the appointment of judges (Parliamentary Assembly) and the supervision of the execution of judgments (Council of Ministers); and fifthly, relations between the CJEU and the ECtHR. ${ }^{223}$ Following the subsequent conference held by the Spanish Presidency of the EU and the EU's Fundamental Rights Agency on 2-3 February 2010, ${ }^{224}$ the Spanish Presidency's conclusions largely echoed the Presidency of the Council of the European Union's five identified issues, adding that the relationship between the case law of the CJEU and the ECtHR must be clearly set out. ${ }^{225}$

After protracted delays by the Russian Federation to ratify Protocol 14 to the ECHR (the chief object of which is to improve the organisational efficiency

219 Article 15 ECHR

220 Article 57 ECHR

221 Article 344 TFEU

222 Article 218(8) TEU

${ }^{223}$ Note from the Presidency, Council of the European Union to CATS/Coreper/Council dated 8 February 2010, document 6180/10, Pp.2-3

${ }^{224}$ European Union Agency for Fundamental Rights, Seminar on Fundamental rights in the $E U$ in view of the accession of the Union to the European Convention on Human Rights (02/02/2010), http://fra.europa.eu/fraWebsite/news_and_events/infocus10_0202_en.htm (last accessed 29 April 2011)

225 Note from the General Secretariat of the Council to Coreper/Conseil dated 21 May 2010 on the Conclusions of the seminars organised by the Spanish Presidency in the area of Justice, Pp.7-9 
of the ECtHR ${ }^{226}$ ), the Protocol came into effect on 1 June $2010 .^{227}$ Accordingly, the EU's accession to the ECHR is made possible by Article 59(2) of the ECHR.

Accession talks commenced from 7 July 2010 between the Commission and the Council of Europe's Steering Committee for Human Rights. ${ }^{228}$

The two chief areas of interest over the accession agreement have been firstly, the adoption of a co-respondent mechanism whereby the Union would become a co-respondent to proceedings brought by a complainant against an EU Member State (and thus a Contracting Party) and secondly, a procedure whereby the CJEU would have the ability to give a preliminary ruling on a matter referred to the ECtHR (whereby the CJEU is essentially given "the first bite of the cherry").

In relation to the co-respondent procedure, the latest version of the draft accession agreement proposes to amend Article $36 \mathrm{ECHR}$ and contemplates the EU (or a Member State of the EU) to become a co-respondent to proceedings. ${ }^{229}$

The draft accession agreement further elaborates on that procedure. If an application is brought against a Member State, the EU may become a corespondent if the compatability of Convention rights is in issue in relation to the alleged vioation and "where that violation could have been avoided only by disregarding an obligation under European Union law". ${ }^{230}$ The choice of language of "disregarding an obligation" suggests the corollary of the principle in Bosphorous whereby an EU Member State is taken not to have breached the ECHR provided that the Union offers equivalent protection. As indicated earlier, that protection is presumed to exist when the Member State did no

\footnotetext{
226 See generally on this aspect: Caflisch, L, The Reform of the European Court of Human Rights: Protocol No.14 and Beyond (2006) 6(2) Human Rights Law Review 403; and Hioureas, C. G., Behind the Scenes of Protocol No. 14: Politics in Reforming the European Court of Human Rights (2006) 24 Berkley Journal of International Law 718

227 Council of Europe, Reform of European Court of Human Rights: Protocol 14 enters into force, 31 May 2010, https://wcd.coe.int/wcd/ViewDoc.jsp?Ref=PR437(2010)\&Language= lanEnglish $\& \mathrm{Ver}=$ original $\&$ BackColorInternet $=\mathrm{F} 5 \mathrm{CA} 75 \&$ BackColorIntranet $=\mathrm{F} 5 \mathrm{CA} 75 \& \mathrm{Ba}$ ckColorLogged=A9BACE (last accessed 28 April 2011)

228 Council of Europe, Joint talks on EU's accession to Convention on Human Rights begins, http://human-rights-convention.org/2010/07/07/joint-talks-on-eus-accession-to-

convention-on-human-rights-begin/ (last accessed 29 April 2011)

229 Proposed Article 36(4) of the ECHR, Council of Europe, Meeting Report, $8^{\text {th }}$ Working Meeting of the CDDH Informal Working Group on the Accession of the European Union to the European Convention on Human Rights (CDDH-UE) with the European Commission, 19 July 2011, Document CDDH-EU(2011)16, P.4

230 Proposed Article 3(2) of the Accession Agreement, Council of Europe, Meeting Report, $8^{\text {th }}$ Working Meeting of the CDDH Informal Working Group on the Accession of the European Union to the European Convention on Human Rights (CDDH-UE) with the European Commission, 19 July 2011, Document CDDH-EU(2011)16, P.4
} 
more than implement the EU measure (that is, it did not have any discretion) and is rebuttable only where the protection of ECHR rights is "manifestly deficient".

In the alternative, if an application is brought against the EU, then EU Member States may become co-respondents firstly, if the alleged violation "calls into question the compatability with the Convention rights" of a provision of the TFEU, TEU "or other provision have the same legal value pursuant to those instruments", and secondly, "where that violation could have been avoided only be disregarding an obligation under those instruments". 231

If the situation arises where an application is made against both an EU Member State(s) and the EU then, provided that the conditions as outlined above are met (that is, in proposed Article 3(2) or 3(3)), the status of any of the respondents may be changed to co-respondent. ${ }^{232}$

Lastly, the Draft Accession Agreement provides that a High Contracting Party may only become a co-respondent at its own request and by decision of the Court, and further, that the Court must be satisfied that "it is plausible" that the conditions set out in Articles 3(2) or 3(3) of the Accession Agreement are met. ${ }^{233}$ Indeed, the inducement for the Union to become a co-respondent to proceedings is the ability of the CJEU to assess the matter if it has not already done so (discussed below).

In relation to the preliminary ruling procedure, the respective Presidents of the ECtHR (Costa) and CJEU (Skouris) issued a joint communication resulting from their discussions on 17 January 2011 about the accession. ${ }^{234}$ Three points are to be noted. Firstly, the Presidents noted the rapid ascension of the EU Charter in the Union's legal sphere and the necessity for coherence

\footnotetext{
231 Proposed Article 3(3) of the Accession Agreement, Council of Europe, Meeting Report, $8^{\text {th }}$ Working Meeting of the CDDH Informal Working Group on the Accession of the European Union to the European Convention on Human Rights (CDDH-UE) with the European Commission, 19 July 2011, Document CDDH-EU(2011)16, P.4

232 Proposed Article 3(4) of the Accession Agreement, Council of Europe, Meeting Report, $8^{\text {th }}$ Working Meeting of the CDDH Informal Working Group on the Accession of the European Union to the European Convention on Human Rights (CDDH-UE) with the European Commission, 19 July 2011, Document CDDH-EU(2011)16, P.4

233 Proposed Article 3(5) of the Accession Agreement, Council of Europe, Meeting Report, $8^{\text {th }}$ Working Meeting of the CDDH Informal Working Group on the Accession of the European Union to the European Convention on Human Rights (CDDH-UE) with the European Commission, 19 July 2011, Document CDDH-EU(2011)16, P.4

${ }^{234}$ Council of Europe, Draft Meeting Report, $5^{\text {th }}$ Working Meeting of the CDDH Informal Working Group on the Accession of the European Union to the European Convention on Human Rights (CDDH-UE) with the European Commission, 28 January 2011, Document CDDH-EU(2011)03
} 
between the EU Charter and the ECHR in light of Article 52(3) of the EU Charter.

Secondly, the Presidents identified a situation where actions by the EU institutions would need to be brought before the CJEU before a matter would be admissible before the ECtHR (that is, the requirement of exhaustion of domestic remedies). ${ }^{235}$ However, notwithstanding the amendment to exArticle 230(4)EC by the Lisbon Treaty, a non-privileged applicant still faces considerable constraints to bring an action under Article 263(4)TFEU ${ }^{236}$ and it remains to be seen whether the ECtHR makes any comment on this aspect when considering admissibility decisions. ${ }^{237}$

Thirdly, the Presidents identified a situation whereby acts of Member State authorities resulting from EU law would have to be brought before national courts. In that last instance, it is not obligatory for a court of a Member State to make a reference to the CJEU unless, in particular circumstances, it is necessary. ${ }^{238}$ Essentially, the Presidents acknowledged the lack of an individual right to petition the CJEU. ${ }^{239}$ It is in those circumstances that the CJEU would be given the opportunity to review the matter after an application is made to the ECtHR. The purpose of that referral to the CJEU, as enunciated by the Presidents, would be for the CJEU "to carry out an internal review before the ECHR carries out an external review". ${ }^{240}$ In that regard, it may be

\footnotetext{
235 Article 35(1) ECHR
}

236 See Craig, P. and de Búrca, G, EU Law - Text, Cases, and Materials, 2011, 5ed, OUP, Oxford, Pp.490-500 and Pp.502-510, noting that the amendment brought about by the the Lisbon Treaty only provides for the removal of the individual concern requirement for "regulatory acts" which do "not entail implementing measures" but that other "EU laws, framework laws, decisions or implementing acts" would still be required to demonstrate both direct and individual concern and thus, satisfy the notoriously difficult Plaumann test (Case 25/62 Plaumann \& Co v Commission, 16 July 1963, Judgment) on individual concern - see Pp.493-499. See also, Türk, A. H., Judicial Review in EU Law, 2009, Edward Elgar Publishing, Cheltenham, UK; Northampton, MA, at Pp.166-169

237 Indeed as Craig and de Búrca point out, the myth of a "complete system of legal protection" in the European Union by operation of Articles 263(4) and 267 TFEU as put forward by the ECJ in Case C-50/00 P Unión de Pequeños Agricultores v Council, 25 July 2002, Judgment, at paras 37-45 ("UPA") and Case C-263/02 P Commission v Jégo Quéré \& Cie. SA, 1 April 2004, Judgment, at paras 29-39 ("Jégo-Quére"), is to be seriously questioned in the face of practical reality, as A-G Jacobs did in his Opinion in UPA - see Craig, P. and de Búrca, G, EU Law - Text, Cases, and Materials, 2011, 5ed, OUP, Oxford, at Pp.502-508

238 That is, if the matter is before a court or tribunal against whose decision there is no judicial remedy under national law - Article 267TFEU

239 Council of Europe, Draft Meeting Report, $5^{\text {th }}$ Working Meeting of the CDDH Informal Working Group on the Accession of the European Union to the European Convention on Human Rights (CDDH-UE) with the European Commission, 28 January 2011, Document CDDH-EU(2011)03, Appendix III at P.13

240 Council of Europe, Draft Meeting Report, $5^{\text {th }}$ Working Meeting of the CDDH Informal Working Group on the Accession of the European Union to the European Convention on 
inferred that the scope of the internal review the Presidents had in mind may include an assessment of whether the law was consistent with the fundamental rights guaranteed by the Charter. ${ }^{241}$

The views of the Presidents have been largely reflected in the latest draft accession agreement which provides that the CJEU is to be given the opportunity to assess "the compatability with Convention rights at issue of the provision of European Union law" if it has not already done so. ${ }^{242}$ It is important to note that such a mechanism is only contemplated where the Union is a co-respondent.

Leaving the desire to retain the CJEU's monopoly on Union matters to one side, if the purpose of the preliminary ruling procedure as contemplated by the Presidents (in the third instance identified) is for the Union to assess consistency with the EU Charter then such an approach may have merit. That is, if the practical effect of Article 52(3) of the EU Charter is that the ECHR represents the minimum standard of rights protection then, by use of the preliminary ruling procedure contemplated, the plaintiff may have the benefit of a higher standard of rights protection by having his/her matter assessed in light of the EU Charter. An example of this may be seen in both Courts' application of Article 8 ECHR (of which a corresponding provision can be found in Article 7 of the EU Charter). Traditionally, the ECtHR has taken a somewhat restrictive approach to Article 8 in immigration matters, and the CJEU has taken a much more expansive interpretation of that provision. ${ }^{243}$ Accordingly, the opportunity for assessment in accordance with the EU Charter might potentially heighten the standard of rights protection. However, Weiß has identified a numer of cases (pre-Lisbon Treaty) in which the CJEU has adopted ECHR standards (established via ECtHR case law) to a

Human Rights (CDDH-UE) with the European Commission, 28 January 2011, Document CDDH-EU(2011)03, Appendix III at P.13

${ }^{241}$ Council of Europe, Draft Meeting Report, $5^{\text {th }}$ Working Meeting of the CDDH Informal Working Group on the Accession of the European Union to the European Convention on Human Rights (CDDH-UE) with the European Commission, 28 January 2011, Document CDDH-EU(2011)03, Appendix III at P.12 where the Presidents expressed concern that without such a preliminary ruling having taking place " $[\mathrm{t}]$ he ECHR [sic] would be required to adjudicate on an application calling into question provisions of EU law without the CJEU having the opportunity to review the consistency of that law with the fundamental rights guaranteed by the Charter."

${ }^{242}$ Proposed Article 3(6) of the Accession Agreement, Council of Europe, Meeting Report, $8^{\text {th }}$ Working Meeting of the CDDH Informal Working Group on the Accession of the European Union to the European Convention on Human Rights (CDDH-UE) with the European Commission, 19 July 2011, Document CDDH-EU(2011)16, P.4

243 For example, compare the ECtHR's approach in Abdulaziz, Cabales and Balkandali $v$ the United Kingdom, Nos. 9214/80, 9473/81, and 9474/81, Judgment, 28 May 1985, to the CJEU's (then ECJ's) approach in Case C-540/03, European Parliament $v$ Council of the European Union, 27 June 2006, Judgment. 
somewhat lax standard ${ }^{244}$ - perhaps the preliminary ruling procedure contemplated in the Accession Agreement will provide greater incentive for the CJEU to heighten the normative standard.

However, the contemplated preliminary ruling procedure is also presumably designed to ensure the adjudication of any assessment is kept tightly in line with Articles 52(1), (4), (6) and (7) of the EU Charter.

The factors that will shape the ECtHR's future jurisprudence are threefold: firstly, the terms of the Accession Agreement - more specifically the use of the co-respondent mechanism and the post-ECtHR application CJEU preliminary ruling mechanism. Secondly, the principles in Bosphorous (and the amalgam of subsequent case law) will need to be adapted to reflect the accession reality of the EU if ECHR rights are to be protected effectively (particularly in relation to acts of the Union itself or its institutions). ${ }^{245}$ Thirdly, the constraints imposed by the Lisbon Treaty's accession requirements and the issues identified in the subsequent Spanish EU Presidency seem to embody requirements at times conflicting with a wholehearted accession to the ECHR.

\subsection{Europe and Asylum}

The involvement at the Community level in the field of asylum is a relatively recent one, and had formerly remained exclusively in the domaine réservé of the Member States. The impetus for action at the Community level in the field of migration emerged, inter alia, from two key developments within the Community: firstly, the completion of the internal market and secondly, the conclusion of the Schengen agreements.

The integration of the single internal market was, however, far from a fait accompli or, by the 1980s, far from complete. The lack of political momentum during the 1970s had spurred the activism of the ECJ in dismantling intracommunity trading obstacles in cases such as Cassis de Dijon. ${ }^{246}$ Following the Commission's White Paper $^{247}$ calling for measures to remove the physical, technical and fiscal barriers to the internal market, and its subsequent endorsement by the European Council, the Single European Act (hereinafter referred to as "the SEA") came into force on 1 July 1987 which provided

\footnotetext{
${ }^{244} \mathrm{Wei}, \mathrm{W}$, Human Rights in the EU: Rethinking the Role of the European Convention on Human Rights After Lisbon (2011) 7 European Constitutional Law Review 64, Pp.77-80

${ }^{245}$ For this insight, I am particularly grateful for the comments of (now Professor) Mark Dawson at the lunchtime seminar of the Department of International and European Law at Maastricht University held on 20 April 2011.

${ }^{246}$ Case C-120/78 Rewe-Zentrale AG v Bundesmonoplverwaltung für Branntwein, 20 February 1979, Judgment

${ }^{247}$ European Commission, Completing the Internal Market, COM (85)310, 14 June 1985.
} 
legislative mechanisms to enable the Community to complete the internal market by 31 December 1992. By Article 14(2) of the SEA, the "internal market" was defined as "an area without internal frontiers in which the free movement of goods, persons, services and capital is ensured in accordance with the provisions of the Treaty". Accordingly, this envisaged the abolition of internal border controls. Bigo notes that the White Paper gave birth to "the distinction between an internal and external border". 248

Concurrent with the concept of the completion of the internal market, there were three significant developments - firstly, the Schengen agreements; secondly, the intergovernmental workings of the Trevi Group; and thirdly, the negotiation and adoption of the Dublin Convention. ${ }^{249}$

The Schengen acquis commenced its development in 1984 with the Saarbrucken Agreement between France and Germany to progressively abolish controls at their common borders. Subsequently, with the Benelux countries also joining the scheme, the Schengen Accord was signed in 1985, identifying measures to be taken to remove internal borders amongst the signatory states. Ultimately, the Schengen Convention (implementing the Schengen Accord) was adopted by France, Germany and Benelux on 19 June $1990^{250}$ and came into effect in 1995.

The completion of the single market and the consequences of the Schengen Convention presented obvious challenges to the Member States regarding the control of entry into, and stay on, their territory of third country nationals and asylum seekers in particular. The response was a range of inter-governmental initiatives.

Inter-governmental initiatives in the field of immigration were not new. Although outside the Community institutional structure, the ad hoc intergovernmental "Trevi Group" was established at the European Council in Rome in 1975 by the then 12 EC Member States with a view to countering terrorism and co-ordinating policing. ${ }^{251}$ The group consisted of three levels:

\footnotetext{
248 Bigo, D, Criminalisation of "Migrants": The side effect of the will to control the frontiers and the sovereign illusion in Bogusz, B, Cholewinski, R, Cygnan, A, and Szyszczak, E, (eds) Irregular Migration and Human Rights: Theoretical, European and International Perspectives, 2004, Martinus Nijhoff Publishers, Leiden/Boston, Pp.61-91 at P.72

249 OJ C 254/1, 19 August 1997, Pp.1-12

250 Niessen, J, in Guild, E, The Developing Immigration and Asylum Policies of the European Union: adopted conventions, resolutions, recommendations, decisions and conclusions, 1996, Kluwer Law International, Boston, MA, accessed via Google Books http://books.google.com/books?id=_xigcFKAG4AC\&printsec $=$ frontcover\&source $=$ gbs_v 2_summary_r\&cad $=0 \# \mathrm{v}=$ onepage $\& \mathrm{q}=\& \mathrm{f}=$ false (last accessed 3 May 2011), P.27

251 Occhipinti, J D, The Politics of EU Police Cooperation: Toward a European FBI?, 2003, Lynne Rienner, Boulder, Colorado, accessed via Google Books http://books.google.com/books?id=U8TXXHD_kqEC\&printsec $=$ frontcover\&source $=\mathrm{gbs}$ _v2_summary_r\&cad $=0 \# \mathrm{v}=$ onepage $\& \mathrm{q}=\& \mathrm{f}=$ false, (last accessed 3 May 2011), Pp.31-32
} 
Ministers, Senior Officials, and Working Parties and was structured in five working groups. Working group 3 commenced in 1985 with the purpose of combating transnational organised crime, to which immigration matters were subsequently added. ${ }^{252}$ The informal and intergovernmental nature of the Trevi Group was indicative of the reluctance of Member States to relinquish sovereignty in this area. ${ }^{253}$ The inter-governmental identification of, and response to, such challenges were also seen in the formulation of the Palma Document ${ }^{254}$ in 1989, with contributions from the Ad-hoc Working Group on Immigration (established in 1986 under the British Presidency of the Community) ${ }^{255}$ and as well as the Trevi Group.

A significant product of intergovernmental cooperation (in addition to the Schengen agreements) was the Convention determining the state responsible for examining applications for asylum lodged in one of the Member States of the European Communities ("the Dublin Convention") was adopted on 15 June 1990. ${ }^{256}$ That Convention provided for determining which Member State was responsible for processing an asylum seeker's application. The aim of the Convention was to prevent multiple applications being made throughout the Member States and to reduce the incidence of "refugees in orbit" whereby applicants would be sent from one State to another for the processing of their claim. The Convention also subsequently replaced Chapter 7 of the Schengen Convention, which had, until that Chapter's replacement, made provision for the procedures for dealing with asylum claims. ${ }^{257}$

252 Bunyan, T, Trevi, Europol and the European State, Statewatch, http://www.statewatch.org/news/handbook-trevi.pdf (last accessed 3 May 2011), Pp.2-3. ${ }^{253} \mathrm{Da}$ Lomba, S, The Right to seek Refugee Status in the European Union, 2004, Intersentia, Antwerp, P.13.

254 The Palma Document identified ad intra and ad extra facets to be considered in light of the SEA. The ad extra facets included the tightening of controls at external frontiers with such effectiveness that they could be relied upon by all Member States. To that end, two areas were identified. The first area was in relation to the harmonisation of treatment for all third-country nationals by establishing a common visa list and a common list of persons inadmissible for entry; harmonising visa requirements; and the creation of a European visa. The second area was in relation to asylum by the establishment of a common policy in line with the Geneva Convention and its Protocol with the focus on creating identical international commitments; determining the state responsible for the asylum determination; creating a streamlined procedure for unfounded requests; determining under what conditions an applicant may move between Member States; and suggesting further research into the financing and economic consequences of the policy. Further, the Palma Document states that the tightening of controls at external borders "should not go beyond what it strictly necessary for safeguarding law and order in the Member States".

255 Niessen, J, in Guild, E, The Developing Immigration and Asylum Policies of the European Union: adopted conventions, resolutions, recommendations, decisions and conclusions, 1996, Kluwer Law International, Boston, MA, accessed via Google Books http://books.google.com/books?id=_xigcFKAG4AC\&printsec $=$ frontcover\&source $=$ gbs_v 2_summary_r\&cad $=0 \# \mathrm{v}=$ onepage $\& \mathrm{q}=\& \mathrm{f}=$ false (last accessed 3 May 2011), P.33 256 OJ C 254/1, 19 August 1997, Pp.1-12

257 Article 1, Protocol on the consequences of the Dublin Agreement coming into effect for some regulations on the Schengen Supplementary Agreement of 26 April 1994 ("the Bonn 
The institutionalisation of Community involvement in the field of immigration and asylum came about with Treaty of Maastricht ${ }^{258}$ in 1992, under the title "Cooperation in the Fields of Justice and Home Affairs". The intergovernmental approach in this field was retained by the creation of a "third pillar" for immigration and asylum matters ${ }^{259}$ and was characterised by the requirement of unanimity for the taking of decisions by the Council, minimal judicial control and an absence of parliamentary involvement. ${ }^{260}$ It is interesting to note that no distinction was made between the fields of migration on the one hand and cooperation in criminal and judicial matters on the other. ${ }^{261}$ The Council shared initiative for measures relating to, inter alia, immigration and asylum matters, with any Member State and the Commission. $^{262}$

The Treaty of Amsterdam ${ }^{263}$ made significant changes in the area of asylum and immigration by the creation of an Area of Freedom, Security and Justice, effectively removing matters of immigration and asylum from the Third Pillar under Title VI of the EU Treaty and integrating them (together with visas) into the First Pillar under a new Title IV of Part III of the EC Treaty. The significance of that change was underscored by the Community's ability to enact law which is both supranational in character and has direct effect. Article 62 circumscribed the competencies of the Community with regard to external borders and visas. Article 63 granted competence to the Community in the field of asylum. However, the intergovernmental approach was not entirely abandoned. Article 67 provided that, for a transitional period of five years, the Council had to act unanimously on a proposal from the Commission or on

Protocol"), see also Da Lomba at P.25. Title II of the Schengen Convention provided for the coordination of visa policies of the signatory states, with Chapter 7 of that Title dealing with the responsibility of signatory states in the assessment of asylum claims. Article 30 provided the bases for a signatory state to determine an asylum claim, with the exception under Article 29(4) which provided that a signatory state may determine the claim notwithstanding that it fell under the responsibility of another state under the Schengen Convention. Further, under Article 35, family members' claims had to be assessed by the State that granted refugee status to the alien.

258 OJ C 191, 29 July 1992

259 Under Article K.1 of the Treaty, asylum policy, inter alia, was to be regarded as a matter of "common interest" in achieving the objectives of the Union.

260 Guild, E, The Europeanisation of Europe's Asylum Policy (2006) 18(3-4) International Journal of Refugee Law 630 at P.640, see also, generally, Niessen, J, in Guild, E, The Developing Immigration and Asylum Policies of the European Union: adopted conventions, resolutions, recommendations, decisions and conclusions, 1996, Kluwer Law International, Boston, MA, http://books.google.com/books?id=_xigcFKAG4AC\&printsec $=$ frontcover\&source $=$ gbs_v2_summary_r $\&$ cad $=0 \#_{\mathrm{v}}=$ onepage $\& \mathrm{q}=\& \mathrm{f}=$ false (last accessed 3 May 2011), P.33

261 Cholewinski, R, The Criminalisation of Migration in EU Law and Policy in Baldaccini, A, Guild, E, and Toner, H, (eds), Whose Freedom, Security and Justice - EU Immigration and Asylum Law and Policy, 2007, Hart Publishing, Oxford, P.303

262 Article K.3(2) of the Treaty

263 OJ C 340, 10 November 1997 
the initiative of a Member State, and that the European Parliament merely had to be consulted.

Five further points should be noted in relation to the Treaty of Amsterdam. Firstly, the (then) ECJ's ability to judicially review measures was severely limited by Article 68(1) $)^{264}$ and, as noted by Wiesbrock, stood in contradiction to the regular review procedure under Article $234 .{ }^{265}$ Secondly, as Gondek notes, Title IV (and Article 63 in particular) provided no directly enforceable set of rights but rather a programme of legislative action to be taken in prescribed areas, and with an emphasis on determining minimum standards. ${ }^{266}$ Thirdly, the special position of the United Kingdom, Ireland and Denmark under the Treaty should be noted. By the Protocol to the Treaty on the position of Ireland and the United Kingdom, both countries were able to optout of the application of Title IV, but with the ability to opt-in at a later time in accordance with Article 3(1) of the Protocol. Denmark, by the Protocol relating to its position, completely opt-outed out of the application of Title IV, but did not retain the ability to opt-in at a later time. The combined effect of those two Protocols was to undermine the uniformity of application of Community enacted asylum measures. Fourthly, the Schengen acquis ${ }^{267}$ was incorporated into the European Union framework by a Protocol to the Amsterdam Treaty (it had, up until that time, evolved independently from the Community institutional structure). Fifthly, a Protocol on asylum for nationals of Member States of the European Union deemed Member States to be "safe countries of origin in respect of each other" in asylum matters.

\subsubsection{From Tampere to Stockholm}

Following the adoption of the Vienna Action Plan ${ }^{268}$ in December 1998, the EU heads of state and governments met in Tampere, Finland, at a Special Summit of the European Council on 15-16 October 1999 to determine a five

\footnotetext{
264 The role of the CJEU in the judicial review of asylum matters will be dealt with in more detail later in this book

265 Wiesbrock, A, Legal Migration to the European Union - Ten Years After Tampere, 2009, Wolf Legal Publishers, Nijmegen, Pp.113-114.

266 Gondek, M, The Emerging European Asylum Law: between Protection and Rejection in Schneider, H, Migration, Integration and Citizenship: A Challenge for Europe's Future, 2005, Forum Maastricht, Maastricht, Pp.187-228, at P.191-192

267 See Council, The Schengen Acquis as referred to in Article 1(2) of Council Decision 1999/435/EC of 20 May 1999, 22 September 2000, OJ L 176/1; and the subsequent addition of the Schengen Borders Code - Regulation 562/2006 of 15 March 2006 establishing a Community Code on the rules governing the movement of persons across borders (Schengen Borders Code) (plus amendments thereto)

268 Presidency Conclusions, Vienna European Council, 11 and 12 December 1998, http://www.consilium.europa.eu/ueDocs/cms_Data/docs/pressData/en/ec/00300R1.EN8.htm (last accessed 3 May 2011)
} 
year action plan. ${ }^{269}$ The Presidency Conclusions (frequently referred to as "the Tampere Conclusions") called for "an open and secure European Union, fully committed to the obligations of the Geneva Refugee Convention and other relevant human rights instruments, and able to respond to humanitarian needs on the basis of solidarity". ${ }^{270}$ In particular, a common EU asylum and migration policy was to be developed comprising firstly, of partnerships with countries of origin; secondly, a common European asylum system; thirdly, the fair treatment of third country nationals; and fourthly, the management of migration flows.

Importantly, the European Council, in the Tampere Conclusions, reaffirmed the right to seek asylum, and the development of a Common European Asylum System ("CEAS") based on the "full and inclusive application of the Geneva Convention" in order to maintain the principle of non-refoulement. ${ }^{271}$ The European Council envisaged, in the long term, a common asylum procedure and uniform status "valid throughout the Union" (in this regard, the Commission was asked to prepare a Communication, which it did on 22 November $2000^{272}$ ). In that Communication, the Commission proposed a range of tools for achieving a common asylum procedure and a uniform status throughout the Union. The Commission emphasised that, by doing so, it did not advocate a Community institution making positive or negative decisions to recognise a person's protection status, but rather that this would be left to individual Member States in accordance with the principle of subsidiarity. ${ }^{273}$ The Commission acknowledged that a two-stage approach was necessary firstly, a shorter-term procedure that would allow a minimum level of harmonisation and a second stage that would involve a tightening of procedures. ${ }^{274}$ It is in relation to the reflection on the first stage and a contemplation of the second stage that the Commission's 2007 Green Paper was primarily concerned (which is discussed below). ${ }^{275}$ The November 2000 Communication, inter alia, also looked at the establishment of a single procedure, common approaches to visas and external border control, the need to harmonise reception conditions, a replacement for the Dublin

\footnotetext{
${ }^{269}$ For a summary of the business of the Summit, see Bunyan, T, The Story of Tampere, September 2003, Statewatch Briefing, http://www.statewatch.org/news/ 2003/sep/tampere.doc (last accessed 3 May 2011)

270 Paragraph 4 of the Tampere Conclusions

271 Paragraph 13 of the Tampere Conclusions

272 Commission Communication, Towards a common asylum procedure and a uniform status for those granted asylum valid throughout the Union $\operatorname{COM}(2000) 755$ final.

273 Commission Communication, Towards a common asylum procedure and a uniform status for those granted asylum valid throughout the Union $\operatorname{COM}(2000) 755$ final, at 1.3, P.7

274 Commission Communication, Towards a common asylum procedure and a uniform status for those granted asylum valid throughout the Union $\operatorname{COM}(2000) 755$ final, at 2.1, P.8

275 Commission of the European Communities, Green Paper on the Future Common European Asylum System, 6 June 2007, COM(2007) 301 final, P.2.
} 
Convention $^{276}$ and a removal and returns policy. The Communication also identified the need for a common interpretation of refugee status, as well as consequent rights of residence and access to employment, integration and access to nationality.

In the Tampere Conclusions, in the shorter term (that is, by May 2004), the European Council envisaged for the CEAS "a clear and workable determination of the State responsible for the examination of an asylum application, common standards for a fair and efficient asylum procedure, common minimum conditions of reception of asylum seekers, and the approximation of rules on the recognition and content of the refugee status". ${ }^{277}$ Consultation with the UNHCR and other international organisations was also stressed. The European Council also urged the Council to complete its work on the system for identifying asylum seekers (that is, Eurodac). ${ }^{278}$ Finally, it should also be noted that the Tampere Conclusions included a call for the introduction of a programme of measures to implement the principle of mutual recognition amongst the Member States. ${ }^{279}$

The subsequent legislation adopted amounted to firstly, the Decision establishing the European Refugee Fund; ${ }^{280}$ secondly, the Eurodac Regulation; ${ }^{281}$ and thirdly, the Council Directive on the mutual recognition of

\footnotetext{
276 In this regard, see also Commission of the European Communities, Commission Staff Working Paper - Evaluation of the Dublin Convention, 13 June 2001, SEC(2001) 756 http://www.statewatch.org/semdoc/assets/files/commission/SEC-2001-756.pdf (last accessed 1 Feburary 13), and Commission of the European Communities, Commission Staff Working Paper SEC (2000) 522 http://www.statewatch.org/semdoc/assets/files/ commission/SEC-2000-522.pdf (last accessed 1 February 2013). Both documents highlight the shortcoming of the operation of the Dublin Convention in practice. The latter document notes that "flanking measures" were necessary to reduce secondary movements of asylum seekers as the area without internal frontiers was realized. Further, the enlargement of the EU and the development of Eurodac system were seen as significant developments since the implementation of the Dublin Convention (para 11)

277 Paragraph 14 of the Tampere Conclusions

278 Paragraph 17 of the Tampere Conclusions

279 Paragraph 37 of the Tampere Conclusions. Guild has criticised the Tampere Conclusions' inclusion of the principle of mutual recognition of state acts on the basis that Member States are no longer motivated to investigate the merits of another State's expulsion decision (which, in relation to asylum seekers, may have profound effects) and, if Member States choose so to do, there is a perception that a Member State is challenging "the trust and confidence that is the objective of the exercise". Accordingly, Guild argues that international standards have been waylaid to pursue the objective of mutual trust and confidence - see Guild, E, The Europeanisation of Europe's Asylum Policy, (2006) 18(3-4) International Journal of Refugee Law 630, Pp.642-643.

280 Council Decision 2000/596EC of 28 September 2000 establishing the European Refugee Fund

281 Council Regulation 2725/2000 of 11 December 2000 concerning the establishment of "Eurodac" for the comparison of fingerprints for the effective application of the Dublin Convention
} 
decisions on the expulsion of third country nationals; ${ }^{282}$ and fourthly, the Temporary Protection Directive. ${ }^{283}$

However, the fight against 'illegal' immigration was never far from asylum matters. ${ }^{284}$ This was particularly so with regard to accessing the territory of Member States. On 28 June 2001, Council Directive 2001/51/EC ${ }^{285}$ was adopted supplementing Article 26 of the Schengen Agreement of 1985. The Directive supplemented the Schengen Agreement's provisions relating to carrier sanctions and liability for third country-nationals refused entry or who do not possess the necessary travel documents.

The lofty goals of Tampere were not, however, entirely met and the timetables contemplated by Article 63 of the EC Treaty (as inserted by the Treaty of Amsterdam) and by the Tampere Programme were steadily approaching their conclusion. The tone of the Seville European Council of 21-22 June 2002 marked the turn from a liberal-sounding discourse surrounding immigration and asylum to a tone of security, the fight against illegal immigration and the criminalisation of illegal immigration in the aftermath of the 11 September 2001 attacks in New York. In the area of asylum and immigration, that tone was echoed in the Presidency Conclusions $^{286}$ which urged "measures to combat illegal immigration", ${ }^{287}$ "the gradual introduction of the coordinated, integrated management of borders", ${ }^{288}$ "the integration of immigration policy into the European Union's relations with third countries", ${ }^{289}$ and the "speeding up [of the then] current

\footnotetext{
282 Council Directive 2001/40/EC of 28 May 2001 on the mutual recognition of decisions on the expulsion of third country nationals

283 Council Directive 2001/55/EC of 20 July 2001 on minimum standards for giving temporary protection in the event of a mass influx of displaced persons and on measures promoting a balance of efforts between Member States in receiving such persons and bearing the consequences thereof

${ }^{284}$ For further discussion on the relationship between irregular migration and asylum in the EU context, see van de Klaauw, Irregular Migration and Asylum-seeking: Forced Marriage or Reason for Divorce in Bogusz, B, Cholewinski, R, Cygnan, A, and Szyszczak, E, (eds) Irregular Migration and Human Rights: Theoretical, European and International Perspectives, 2004, Martinus Nijhoff Publishers, Leiden/Boston, Pp.115-135 and Cholewinksi, R, European Union Policy on Irregular Migration: Human Rights Lost? in Bogusz, B, Cholewinski, R, Cygnan, A, and Szyszczak, E, (eds) Irregular Migration and Human Rights: Theoretical, European and International Perspectives, 2004, Martinus Nijhoff Publishers, Leiden/Boston, Pp.159-192

285 Council Directive 2001/51/EC of 28 June 2001 supplementing the provisions of Article 26 of the Convention Implementing the Schengen Agreement of 14 June 1985.

286 Council of the European Union, Seville European Council, 21 and 22 June 2002, Presidency Conclusions, 24 October 2001, Document 13463/02, http://www.consilium.europa.eu/ueDocs/cms_Data/docs/pressData/en/ec/72638.pdf (last accessed 3 May 2011)

287 Paragraph 30 of the Seville Conclusions

288 Paragraphs 31-32 of the Seville Conclusions

289 Paragraphs 33-36 of the Seville Conclusions
} 
legislative work on the framing of a common policy on asylum and immigration". ${ }^{290}$ In relation to that last matter, the European Council urged the adoption of: the Dublin II Regulation by December 2002; the minimum standards for the qualification for refugee status and the content of refugee status (as well as provisions on family reunification and the status of long-term permanent residents) by June 2003; and the common standards for asylum procedures by the end of 2003 .

Subsequently, the Directive for minimum standards for reception of asylum seekers $^{291}$ was adopted on 27 January 2003 and the Dublin II Regulation ${ }^{292}$ was adopted on 18 February 2003. The ANEAS Directive (to establish a programme for financial and technical assistance to third countries in the areas of migration and asylum as contemplated in Seville) ${ }^{293}$ was adopted on 10 March 2004. Further, the Directive on minimum standards for the qualification for refugee and subsidiary protection statuses and their content (“the Qualification Directive") ${ }^{294}$ was adopted on 29 April 2004.

The tenor of security, further amplified by the bombings in Madrid on 11 March 2003, also resonated within the Hague Programme, ${ }^{295}$ which was adopted by the European Council on 4-5 November 2004. To that end, it was stated:

"The citizens of Europe rightly expect the European Union, while guaranteeing respect for fundamental freedoms and rights, to take a more effective, joint approach to cross-border problems such as illegal migration and trafficking in and smuggling of human beings, as well as to terrorism and organised crime." 296

\footnotetext{
290 Paragraphs 37-39 of the Seville Conclusions

${ }^{291}$ Council Directive 2003/9/EC of 27 January 2003 laying down minimum standards for the reception of asylum seekers

292 Consisting of both Council Regulation 343/2003 of 18 February 2003 establishing the criteria and mechanisms for determining the Member State responsible for examining an asylum application lodged in one of the Member States by a third-country national, and Commission Regulation 1560/2003 of 2 September 2003 laying down detailed rules for the application of Council Regulation (EC) No 343/2003 establishing the criteria and mechanisms for determining the Member State responsible for examining an asylum application lodged in one of the Member States by a third-country national

${ }^{293}$ Regulation 491/2004 of the European Parliament and of the Council of 10 March 2004 establishing a programme for financial and technical assistance to third countries in the areas of migration and asylum.

294 Council Directive 2004/83/EC of 29 April 2004 on minimum standards for the qualification and status of third country nationals or stateless persons as refugees or as persons who otherwise need international protection and the content of the protection granted

295 Annex I to the Presidency Conclusions of the Brussels European Council http://www.europol.europa.eu/jit/hague_programme_en.pdf (last accessed 3 May 2011)

296 Paragraph 14 of the Presidency Conclusions of the Brussels European Council http://www.consilium.europa.eu/uedocs/cmsUpload/14292-r1.en04.pdf (last accessed 3 May 2011)
} 
Regarding the internal dimension in the area of asylum, the European Council urged the adoption the Asylum Procedures Directive as soon as possible, ${ }^{297}$ and called for a uniform status for those granted asylum or subsidiary protection. ${ }^{298}$ The creation of a European Support Office was also called for, ${ }^{299}$ as well as the further harmonisation of legislation and, importantly, "a fair sharing of responsibility". ${ }^{300}$ A separate study into joint processing of asylum applications outside the EU was also mooted. ${ }^{301}$ Further, the establishment of a new European Refugee Fund for the period 2005-2010 was welcomed. ${ }^{302}$ Regarding the external dimension in the area of asylum, emphasis was placed on cooperation with third countries as well as countries and regions of origin and transit ${ }^{303}$ together with a call for a European return and re-admission policy for those staying illegally in the territory of the EU. ${ }^{304}$ There was also an emphasis on tougher external border controls to combat illegal immigration, together with a more integrated approach to biometric information. ${ }^{305}$ Guild notes that a striking feature of the Hague Conclusions is the shift of responsibility for asylum claims to outside the territory of the EU. ${ }^{306}$

Subsequently, the Procedures Directive ${ }^{307}$ (which sets minimum standards to be applied in the granting and withdrawal of refugee status) was finally adopted on 1 December 2005.

Following on from the Hague Programme's emphasis on combating illegal immigration, the Commission issued a Communication on illegal immigration 308 as part of a "comprehensive approach towards effective migration management". ${ }^{309}$ The Communication acknowledged that "illegal immigration" includes not only those illegally entering the territory of a

\footnotetext{
297 P.18 of the Annex I to the Presidency Conclusions of the Brussels European Council 298 P.17 of the Annex I to the Presidency Conclusions of the Brussels European Council 299 P.18 of the Annex I to the Presidency Conclusions of the Brussels European Council 300 P.17 of the Annex I to the Presidency Conclusions of the Brussels European Council 301 P. 18 of the Annex I to the Presidency Conclusions of the Brussels European Council 302 P.18 of the Annex I to the Presidency Conclusions of the Brussels European Council ${ }^{303}$ Pp.20-22 of the Annex I to the Presidency Conclusions of the Brussels European Council

304 Pp.22-23 of the Annex I to the Presidency Conclusions of the Brussels European Council

${ }^{305}$ Pp.23-26 of the Annex I to the Presidency Conclusions of the Brussels European Council

306 Guild, E, The Europeanisation of Europe's Asylum Policy (2006) 18(3-4) International Journal of Refugee Law 630, Pp. 645-646

307 Council Directive 2005/85/EC of 1 December 2005 on minimum standards on procedures in Member States for granting and withdrawing refugee status.

308 European Commission, 19 July 2006, Communication from the Commission on Policy priorities in the fight against illegal immigration of third-country nationals COM (2006) 402 final

309 European Commission, 19 July 2006, Communication from the Commission on Policy priorities in the fight against illegal immigration of third-country nationals COM (2006) 402 final, Para 1,
} 
Member State, but also those that 'overstay' their initially legal basis for staying, as well as asylum seekers whose claims have been rejected. ${ }^{310}$ The Commission identified nine policy priorities, including a return policy for illegally staying third-country nationals. ${ }^{311}$ Subsequently, on 16 December 2008, the Returns Directive ${ }^{312}$ was adopted which provides minimum standards and procedures for the return of illegally staying third-country nationals.

In 2007 the Commission issued a Green Paper on the Future Common European Asylum System ${ }^{313}$ inviting submissions for the improvement of the CEAS. ${ }^{314}$ Notably, the Commission acknowledged the need for a "higher common standard of protection and greater equality in protection across the EU and to ensure a higher degree of solidarity between EU Member States". 315 This has led to a discussion on the reform of the CEAS (namely, the Reception Conditions Directive, the Asylum Procedures Directive, the Qualification Directive and the Dublin System) as contemplated by the Commission's Policy Plan on Asylum ${ }^{316}$ (the contents of which will be discussed in more detail as they relate to the issue of detention).

Under the French Presidency in the second half of 2008, a European Pact on Immigration and Asylum was adopted in September 2008. ${ }^{317}$ Although a political statement rather than a legally binding document, at the time it provided the sharpest insight into what direction was to be expected under the then forthcoming Swedish Presidency in the field of immigration and asylum. ${ }^{318}$ The document referred to the construction of "A Europe of Asylum" and acknowledged the disparities in Member State practice in the

310 European Commission, 19 July 2006, Communication from the Commission on Policy priorities in the fight against illegal immigration of third-country nationals COM (2006) 402 final, para 3

311 European Commission, 19 July 2006, Communication from the Commission on Policy priorities in the fight against illegal immigration of third-country nationals COM (2006) 402 final, paras 42-48

312 Directive 2008/115/EC of 16 December 2008 on common standards and procedures in Member States for returning illegally staying third-country nationals.

313 COM (2007)301 final

${ }^{314}$ See, for example, the submission by ECRE, Submission from the European Council on Refugees and Exiles in response to the Commission's Green Paper on the Future Common European Asylum System (COM (2007) 301), September 2007, AD5/9/2007/Ext/RW.

315 COM (2007) 301 final, P.3

316 European Commission, 17 June 2008, Policy Plan on Asylum - An Integrated Approach to Protection Across the EU COM (2008) 360 final

317 Council of the European Union, European Pact on Immigration and Asylum, 24 September 2008, http://register.consilium.europa.eu/pdf/en/08/st13/st13440.en08.pdf (last accessed 3 May 2011)

318 See Carrera, S and Guild, E, The French Presidency's European Pact on Immigration and Asylum: Intergovernmentalism vs Europeanisation? Security vs Rights? September 2008, CEPS Policy Brief, No. 170, http://www.libertysecurity.org/IMG/pdf_The_French_ Presidency_s_European_Pact_on_Immigration_and_Asylum.pdf (last accessed 3 May 2011) 
implementation of the CEAS. ${ }^{319}$ In the Pact, the Council agreed to: the establishment of a European Asylum Support Office; invite the Commission to present a proposal for a single asylum procedure by 2012; strengthen cooperation with the UNHCR with regard to resettlement programmes; establish procedures in the event of crisis or mass influx of asylum-seekers; and provide better training in international rights protection for border guards of Member States with external borders. ${ }^{320}$

A Commission proposal for the establishment of a European Asylum Support Office ("EASO") was subsequently made on 18 February 2009. ${ }^{321}$ On 19 May 2010, the EASO Regulation was adopted. ${ }^{322}$ The function of the EASO is not to determine asylum claims but to provide practical support to Member States (including as regards country of origin information). ${ }^{323}$

In the second half of 2009, under the Swedish Presidency (and representing ten and five years since the Tampere and Hague Programmes, respectively), the Stockholm Programme referred to "access to Europe" for, inter alia, "persons in need of international protection and others having a legitimate interest to access EU territory" [emphasis added]. ${ }^{324}$ Overall, the Presidency maintained an emphasis on security and combating "illegal" migration, whilst furthering "a common area of protection and solidarity" 325 by overcoming divergences in Member State practices (including a final acknowledgment that differences exist between national provisions how those provisions are actually applied), ${ }^{326}$ increasing mutual trust, and promoting "solidarity within the

319 Council of the European Union, European Pact on Immigration and Asylum, 24 September 2008, http://register.consilium.europa.eu/pdf/en/08/st13/st13440.en08.pdf (last accessed 3 May 2011), P.11

320 Council of the European Union, European Pact on Immigration and Asylum, 24 September 2008, http://register.consilium.europa.eu/pdf/en/08/st13/st13440.en08.pdf (last accessed 3 May 2011), Pp.11-12

321 European Commission, Proposal for a Regulation of the European Parliament and of the Council establishing a European Asylum Support Office COM (2009) 66 final. See the comments of ECRE, Comments from the European Council on Refugees and Exiles on the Proposal for a Regulation of the European Parliament and of the Council establishing a European Asylum Support Office, April 2009, http://www.ecre.org/files/ECRE_Response _to_Proposal_establishing_EASO_2009.pdf (last accessed 3 May 2011)

322 Regulation (EU) No 439/2010 of the European Parliament and of the Council of 19 May 2010 establishing a European Asylum Support Office. See Comte, F, A New Agency Is Born in the European Union: The European Asylum Support Office, 2010, European Journal of Migration and Law 12, Pp.373-405.

323 See further, Comte, F, A New Agency is Born in the European Union: The European Asylum Support Office (2010) 12 European Journal of Migration and Law 373

324 Presidency, Council of the European Union, The Stockholm Programme - An open and secure Europe serving and protecting the citizens, 17024/09, 2 December 2009, para 1.1, P. 4

325 Presidency, Council of the European Union, The Stockholm Programme - An open and secure Europe serving and protecting the citizens, 17024/09, 2 December 2009, para 6.2, P.69

326 Presidency, Council of the European Union, The Stockholm Programme - An open and secure Europe serving and protecting the citizens, 17024/09, 2 December 2009, para 6.2.1, P.69. Indeed, the Commission acknowledged this obvious and long-troubling aspect in 
EU". ${ }^{327}$ Importantly, the Stockholm Programme advocated the development of the CEAS "based on a full and inclusive application of the Geneva Convention" (and floated the prospect of accession by the EU to the Geneva Convention and its 1967 Protocol) as well as "other relevant international treaties". 328

The main themes - solidarity, mutual trust and creating a common (that is, uniform) area - are further elaborated on and are to be achieved with the assistance of the EASO and by remaining faithful to the Dublin System as the mechanism for asylum claim distribution. ${ }^{329}$ However, an exploration of " $[\mathrm{m}]$ echanisms for the voluntary and coordinated sharing of responsibility between the Member States" 330 as well as Member States assisting each other with capacity-building were also touted. However, although solidarity within the EU was emphasised, the concept of solidarity was also extended to countries outside the EU "in order to promote and help building capacity to handle migratory flows and protracted refugee situations in these countries". 331 One cannot help but wonder if this is an oblique allusion to the creation of a regional processing scheme or an extra-territorial processing arrangement. It is perhaps telling that the Presidency's discussion on asylum matters is bookended by a preceding discussion entitled "Effective policies to combat illegal migration" and "Unaccompanied minors" on the one hand, and succeeded by the discussion entitled "A reinforced external dimension" on the other.

The emphasis on solidarity, mutual trust ${ }^{332}$ and "a genuine common

Communication from the Commission to the European Parliament and the Council, An area of freedom security and justice serving the citizen $\operatorname{COM}(2009) 262 / 4$ when it identified the means by which it would implement the next multi-annual programme:

"ii) To narrow the wide gap between the rules and policies approved at European level and their implementation at national level, greater attention should be paid to national implementation. Beyond strict legal transposal, implementation should be followed up with practical support measures (such as an upgrading of professional networks).

(iii) Priority must also be given to improving the quality of European legislation..."

327 Presidency, Council of the European Union, The Stockholm Programme - An open and secure Europe serving and protecting the citizens, 17024/09, 2 December 2009, para 6.2.1, P.69 328 Presidency, Council of the European Union, The Stockholm Programme - An open and secure Europe serving and protecting the citizens, 17024/09, 2 December 2009, para 6.2.1, P.69 329 Presidency, Council of the European Union, The Stockholm Programme - An open and secure Europe serving and protecting the citizens, 17024/09, 2 December 2009, para 6.2.1, P.70 330 Presidency, Council of the European Union, The Stockholm Programme - An open and secure Europe serving and protecting the citizens, 17024/09, 2 December 2009, para 6.2.2, P.71 331 Presidency, Council of the European Union, The Stockholm Programme - An open and secure Europe serving and protecting the citizens, 17024/09, 2 December 2009, para 6.2.3, P.72 332 Including for the European judicial area where the Commission called for mutual trust amongst "judges, legal professionals, businesses and citizens" - see Communication from the Commission to the European Parliament, the Council, the European Economic and Social Committee and the Committee of the Regions, Delivering an area of freedom, security and justice for Europe's citizens - Action Plan Implementing the Stockholm Programme COM(2010) 171 Final, 20 April 2010, P.4 
immigration and asylum policy"333 were also predictably common themes in the Commission's Action Plan Implementing the Stockholm Programme. In relation to the legislation expected from the Action Plan, proposals were anticipated on amending the Schengen Borders Code (Regulation 562/2006) in 2010-2011 and the establishment of an Entry Exit System (ESS) in 2011. Under the umbrella of "A common area of protection" there were few terribly immediate plans with the exception of developing "a common educational platform for national asylum officials" through the EASO in 2011. In the area of "Sharing of responsibilities and solidarity between Member States" a 2011 date was envisaged for devising a way of reviewing Member States' national asylum systems and to develop Member State to Member State capacity building, as well as issuing a "Communication on intra-EU solidarity". The external dimension of asylum sees priority given to a strategic partnership with the UNHCR in 2011, followed by an evaluation and proposal of EU re-settlement programmes (2012 and 2014 respectively), and a Communication on the targeting of main transit countries in relation to access to asylum procedures (2013).

Although the Commission's agenda on the asylum front is relatively quiet (also due, in part, to the Commission's existing asylum proposals for the second stage of the CEAS pending as part of the co-decision procedure), the emphasis focuses more on the securing of the external borders and a rationalisation and reorganisation of internal processing (that is, through the EASO, solidarity in the form of "burden sharing" and Member State capacity-building, and the review of Member State asylum procedures). However, it has been noted that the rights of undocumented arrivals have gone largely unnoticed by the Stockholm Programme ${ }^{334}$ when that issue is gaining considerable weight by the increasing arrival of undocumented persons in Italy, Malta and Greece. This relative silence is of considerable consequence to those asylum seekers who are either stateless or who are without documents - they are particularly vulnerable to detention - a scenario which the CJEU faced not so long ago in Kadzoev. ${ }^{335}$

2.3.2 Recent Developments - challenges to the concepts of Mutual Trust and Solidarity Indeed, the fragility of the concept of mutual trust and solidarity have recently been exposed by three recent extraordinary developments. The first is the

333 Communication from the Commission to the European Parliament, the Council, the European Economic and Social Committee and the Committee of the Regions, Delivering an area of freedom, security and justice for Europe's citizens - Action Plan Implementing the Stockholm Programme COM(2010) 171 Final, 20 April 2010, P.7

334 See Carrera, S, and Guild, E, Undocumented Migrants and the Stockholm Programme in Carrera, S, and Merlino, M, (eds) Assessing EU Policy on Irregular Migration under the Stockholm Programme, October 2010, Centre for European Policy Studies, at Pp.1-9

335 Case C-357/09 PPU Said Shamilovich Kadzoev (Hucbarov), 30 November 2009, Judgment 
ECtHR's judgment in MSS $v$ Belgium and Greece ${ }^{336}$ in which not only Greece was found to have breached Articles 3 and 13 ECHR but that Belgium had done similarly by sending an asylum seeker back to Greece when it had (at least constructive) knowledge of the situation in Greece (both in terms of inhuman or degrading treatment and the risk of refoulement) and when it had the possibility of assessing the applicant's claim itself under the sovereignty clause of the Dublin II Regulation. ${ }^{337}$ The judgment presents a rather hellish vision of how the CEAS works in practice - frontier Member States overburdened in part due to the Dublin II Regulation's inclination to return asylum seekers to the Member State of first entry or application; appalling conditions of detention; divergences between the laws and practices of Member States; a lack of motivation (or obligation) for other Member States to assist by way of solidarity; and the veil of mutual trust in decision-making behind which Member States invariably hide based on guarantees of particular standards or treatment which form part of the CEAS, but which are somewhat intangible in practice. In early December 2011, the Commission released its Communication on Mutual Trust, aimed at furthering four chief areas: "practical cooperation and technical assistance, financial solidarity, allocation of responsibilities, and improving tools for governance of the asylum system" reform of the Dublin System and the situation of Greece appear to weigh heavily on the Commission's mind. ${ }^{338}$

The second was the judgment of the CJEU in NS in the latter part of December 2011 which dealt with almost identical issues to MSS and in which the Court held that a Member State cannot transfer an asylum seeker if a breach of Article 4 of the EU Charter were to occur, ${ }^{339}$ and that a presumption that asylum seekers will be treated in accordance with fundamental rights in the Member State to which they will be transferred is rebuttable. ${ }^{340}$ The decision represented a significant blow to the concept of mutual trust (this time by an institution within the Union legal order) which had underpinned the operation of the Dublin system.

\footnotetext{
336 Application 30696/09, M.S.S. v Belgium and Greece, 21 January 2011, Judgment, Grand Chamber

337 Article 3(2) of Council Regulation (EC) 343/2003 of 18 February 2003 establishing the criteria and mechanisms for determining the Member State responsible for examining an asylum application lodged in one of the Member States by a third-country national

338 European Commission, Communication from the Commission to the European Parliament, the Council, The European Economic and Social Committee and the Committee of the Regions, 2 December 2011, COM(2011) 845 final, Pp.2, 6, 10-11

339 C-411/10 and C-493/10 N.S. $v$ Secretary of State for the Home Department and M. E. and Others $v$ Refugee Applications Commissioner and Minister for Justice, Equality and Law Reform, 21 December 2011, Judgment Grand Chamber, particularly paras 106-108

340 C-411/10 and C-493/10 N.S. $v$ Secretary of State for the Home Department and M. E. and Others $v$ Refugee Applications Commissioner and Minister for Justice, Equality and Law Reform, 21 December 2011, Judgment Grand Chamber, particularly para 104
} 
The third development has centred around Italy's frustration at a lack of solidarity from other Member States and a lack of interest at the EU level to assist with the reallocation of recent large numbers of boat arrivals from North Africa. ${ }^{341}$ Indeed, due to cultural and family reasons, many of those who made their way to Italy (that is, mainly those from Tunisia) wished to make way for France - a course of action to which France responded by sending them back to Italy. ${ }^{342}$ In a moment of political grandstanding, the Italian authorities issued temporary residence permits to the migrants which enabled travel throughout the Union's Schengen Area. ${ }^{343}$ Germany rebuked Italy for its action and threatened the re-instatement of border controls. ${ }^{344}$ France responded with the extraordinary reaction of stopping (on the Italian-French border) a train carrying the migrants to whom the Italians had issued the residence permits, refusing them entry into France on account of having insufficient resources, and returning them back to Italy. ${ }^{345}$ Leaving aside the questions of the legality and proportionality of these actions, ${ }^{346}$ the principles of mutual trust and solidarity within the Union could not be more vanquished in relation to the CEAS. Indeed, the Commission's response was to announce the preparation for Southern Mediterranean Partnership Agreements ${ }^{347}$ and, subsequently,

${ }^{341}$ Levitz, D, Italy warns of an immigration 'emergency' due to North Africa Unrest, Deutsche Welle, 11 February 2011, http://www.dw-world.de/dw/article/0,,14837362,00.html (last accessed 4 May 2011); Mara, D, EU, Italy at odds over Tunisian asylum surge, Deutsche Welle, 14 February 2011 http://www.dw-world.de/dw/article/0,,14842235,00.html (last accessed 4 May 2011); Dannenberg, N, Bolsolver, C, Connor, R, EU grants Italy emergency funds to deal with migrant influx, Deutsche Welle, 16 February 2011, http://www.dwworld.de/dw/article/0,,14843170,00.html (last accessed 4 May 2011); Shahrigian, S, EU ministers reject Italian request for help with feared Libyan 'exodus', Deutsche Welle, 24 February 2011, http://www.dw-world.de/dw/article/0,,14872918,00.html (last accessed 4 May 2011)

342 Connor, R, Berlusconi visits Lampedusa, promises to remove migrants, Deutsche Welle, 30 March 2011, http://www.dw-world.de/dw/article/0,,14956449,00.html (last accessed 4 May 2011)

343 Connor, R, Hopes fade in shipwreck search, Italy issues refugees permits, Deutsche Welle, 7 April 2011, http://www.dw-world.de/dw/article/0,,14974274,00.html (last accessed 4 May 2011)

344 Mara, D, Germany tells Italy to 'solve its own problems' in Tunisian refugee row, Deutsche Welle, 10 April 2011, http://www.dw-world.de/dw/article/0,14980272,00.html (last accessed 4 May 2011)

345 Benzow, G, Italy protests after France blocks trains in migrant spat, Deutsche Welle, 18 April 2011, http://www.dw-world.de/dw/article/0,,14996064,00.html (last accessed 4 May 2011); see also The Guardian, Another Project in Trouble, 30 April - 6 May 2011, P.30.

346 See Carrera, S, Guild, E, Merlino, M, Parkin, J, A Race against Solidarity - The Schengen Regime and the Franco-Italian affair, Centre for European Policy Studies, April 2011.

347 European Commission, Southern Mediterranean: towards a new era of dialogue and partnership, 24 May 2011, Memo/11/330, http://europa.eu/rapid/pressReleasesAction. do? reference $=\mathrm{MEMO} / 11 / 330$ (last accessed 12 May 2012); see Martin, M, " $A$ radically changing political landscape in the Southern Mediterranean"? The Dialogue for Migration, Mobility and Security with the Southern Mediterranean countries, July 2011, Statewatch Analysis, http://www.statewatch.org/analyses/no-136-southern-med.pdf (last accessed 12 May 2012) 
negotiations have taken place for readmission agreements between Italy, the EU and Egypt, Tunisia and Libya. ${ }^{348}$ Although the Commission later conceded that France and Italy took measures that were within the law in relation to the crossing of their borders, the Commission indicated that they "acted against the 'spirit' of the EU border laws". ${ }^{349}$ The Council has recently presented a proposal for the amendment of rules relating to the temporary introduction of border controls at internal borders. ${ }^{350}$ Indeed, the human cost of those trying to enter the Union is becoming ever more tragic, with a need for greater accountability. ${ }^{351}$ To this end, the ECtHR has recently condemned Italy's 'push back' of Somalian and Eritrean nationals. ${ }^{352}$

Indeed, given that the principle of solidarity (and "fair sharing of responsibility", including financial implications) is to govern the formation of policy and its implementation as required by Article 80 TFEU, an interesting and emerging aspect is how that Article is to be implemented in practice. ${ }^{353}$

\subsection{Current EU Legal Basis}

In the wake of the rejection of the Constitutional Treaty by French and Dutch voters in $2005,{ }^{354}$ the changes brought about by the Treaty of Lisbon provided clear bases for EU action in asylum matters by virtue of Article 78

\footnotetext{
348 Maccanico, Y, The EU's self-interested response to unrest in north Africa: the meaning of treaties and readmission agreements between Italy and north African states, http://www.statewatch.org/analyses/no-165-eu-north-africa.pdf (last accessed 12 May 2012)

349 Pop, V, France and Italy acted against 'spirit' of EU border laws, EUobserver, 25 July 2011, http://euobserver.com/22/32657 (last accessed 12 May 2012)

350 Presidency, European Council, Proposal for a Regulation of the European Parliament and of the Council amending Regulation (EC) No 562/2006 in order to provide for common rules on the temporary introduction of border control at internal borders in exceptional circumstances, 27 March 2012, Doc No 6161/1/12 Rev 1

351 Council of Europe, Parliamentary Assembly, Lives lost in the Mediterranean Sea: who is responsible? 29 March 2012, http://assembly.coe.int/CommitteeDocs/2012/20120329 _mig_RPT.EN.pdf (last accessed 12 May 2012); Martin, M, The Arab Spring and the death toll in the Mediterranean: the true face of Fortress Europe, Statewatch, Analysis, http://www.statewatch.org/analyses/no-167-arab-spring-med.pdf (last accessed 12 May 2012)

352 Hirsi Jamaa and Others v Italy, No. 27765/09, 23 February 2012, Judgment, Grand Chamber

${ }^{353}$ European Parliament, Directorate-General for Internal Policies, Policy Department C, Citizens' Rights and Constitutional Affairs, The Implementation of Article 80 TFEU on the principle of solidarity and fair sharing of responsibility, including its financial implications, between Member States in the field of border checks, asylum and immigration, 2011, http://www.europarl.europa.eu/committees/en/studiesdownload.html?languageDocument $=\mathrm{EN} \&$ file $=35591$ (last accessed 26 February 2013)

354 See de Búrca, G, Reflections on the EU's Path from the Constitutional Treaty to the Lisbon Treaty, June 2008, Fordham University School of Law Research Paper, http://papers.ssrn.com/sol3/Delivery.cfm/SSRN_ID1148448_code339387.pdf?abstractid= 1124586\&mirid=3 (last accessed 3 May 2011)
} 
under its Title V TFEU signed by the Heads of State or Government on 13 December 2007. Following the approval of the Treaty of Lisbon by the Irish referendum held on 2 October 2009, the ratification by Poland on 10 October 2009, and the concessions made to the Czech Republic, ${ }^{355}$ the entry into force of the Treaty occurred on 1 December 2009.

Article 78 TFEU provides a clear and imperative legal basis for the development of a common policy on asylum, subsidiary protection and temporary protection. Article 78(1) states that the policy "must" be in accordance with the Geneva Convention and its 1967 Protocol, "and other relevant treaties". In pursuance of that aim, Article 78(2) provides that a common European asylum system shall comprise of the following measures:

“(a) a uniform status of asylum for nationals of third countries, valid throughout the Union;

(b) a uniform status of subsidiary protection for nationals of third countries who, without obtaining European asylum, are in need of international protection;

(c) a common system of temporary protection for displaced persons in the event of a massive inflow;

(d) common procedures for the granting and withdrawing of uniform asylum or subsidiary protection status;

(e) criteria and mechanisms for determining which Member State is responsible for considering an application for asylum or subsidiary status;

(f) standards concerning the conditions for the reception of applicants for asylum or subsidiary protection;

(g) partnership and cooperation with third countries for the purpose of managing inflows of people applying for asylum or subsidiary or temporary protection."

The introduction of Article 78 TFEU represented a significant departure from Article $63 \mathrm{EC}$, firstly, in that it went beyond a mere timetable for the adoption of measures and, secondly, that the reference to "minimum standards" in Article 63 EC was dropped in favour of the concepts of (inter alia) "uniform status", "a common system" and "commons procedures" under Article 78 TFEU. Those changes provide a degree of optimism for the heightening of standards beyond a bare minimum and, as Peers notes, the potential for full harmonisation, if desired. ${ }^{356}$

It is important to note that the legal basis for the Returns Directive (which is strictly not asylum legislation but has a profound effect on the lives of asylum seekers and rejected asylum seekers) is Article 79 TFEU, specifically provides legislative competence to deal with "illegal immigration, unauthorised

355 Deutsche Welle, European leaders agree to Czech demands over Lisbon Treaty, 29 October 2009, http://www.dw-world.de/dw/article/0,,4839060,00.html (last accessed 3 May 2011) 356 Peers, S, Statewatch Analysis - Changing the institutional framework for EU Justice and Home Affairs law without the Lisbon Treaty, July 2008, http://www.statewatch.org/news/2008/jul/sw-analysis-jha-transfer-july-2008.pdf (last accessed 3 May 2011), P.3 
residence, including removal and repatriation of persons residing without authorisation." 357

There are several other important innovations that were contained in the Lisbon Treaty for the Area of Freedom Security and Justice. Firstly, the codecision procedure under Article 251 EC became the "ordinary legislative procedure" under the TFEU (and expressly contemplated in Article 78(2) TFEU), which gave the Parliament a much greater role and power in matters relating to asylum and subsidiary protection and effectively ended the exclusively intergovernmental nature in relation to asylum matters. ${ }^{358}$ Secondly, the ECJ was finally granted full jurisdiction in the Area of Freedom, Security and Justice with the exception of reviewing the validity or proportionality of operations carried out by police or other law-enforcement services or the responsibilities of maintaining law and order and the safeguarding of internal security (in relation to judicial cooperation in criminal matters and police cooperation under Chapters 4 and 5 of Part V respectively). ${ }^{359}$ Thirdly, the Union (in its envisaged singular legal capacity replacing and succeeding the European Community ${ }^{360}$ ) is required to accede to the European Convention on Human Rights (ECHR) ${ }^{361}$ (as outlined earlier) and full legal recognition has been granted to the EU Charter. ${ }^{362}$

\subsubsection{Current European Union Legislative Framework}

As outlined above, Community (now, Union) competence in the field of asylum was formerly granted under Title IV EC, and now under Title $\mathrm{V}$ TFEU.

Union legislation in relation to asylum is not contained in a single, comprehensive act, but rather in a series of individual pieces of Union secondary legislation aimed to deal with specific areas of the asylum process.

Although the CEAS consists of an extensive and inter-related framework of Union secondary legislation (and indeed, should be viewed in the context of the Union's overall migration legislation and policy), the following legislation represents the most visible and workable unit of the CEAS: firstly, the Eurodac $^{363}$ (Regulation 2725/2000); secondly, the Temporary Protection

\footnotetext{
357 Article 79(2)(c) TFEU, see further, Peers, S, Legislative Update: EU Immigration and Asylum Competence and Decision-Making in the Treaty of Lisbon, (2008) 10 European Journal of Migration and Law 219, Pp. 238-246

358 See Articles 294 and 78(2) TFEU

359 Article 276 TFEU

360 Article 1, third allinea, TEU

361 Article 6(2) TEU

362 Article 6(1) TEU

363 Council Regulation (EC) 2725/2000 of 11 December 2000 concerning the establishment of 'Eurodac' for the comparison of finger prints for the effective application of the Dublin Convention
} 
Directive $^{364}$ (Directive 2001/55/EC); thirdly, the Implementation of the Eurodac $^{365}$ (Regulation 407/2002); fourthly, the Reception Conditions Directive $^{366}$ (Regulation 2003/9/EC); fifthly, the Dublin II Regulation ${ }^{367}$ (Regulation 343/2003); sixthly, the Qualification I Directive ${ }^{368}$ (Directive 2004/83/EC) (for the United Kingdom and Ireland); seventhly, the Qualification II Directive $^{369}$ (Directive 2011/95/EU) (replacing, for the most part, the Qualification I Directive - see below and Chapter 4); eighthly, the Procedures Directive ${ }^{370}$ (Directive 2005/85/EC); and ninethly the Returns Directive $^{371}$ (Directive 2008/115/EC).

Of that secondary legislation, three pieces contemplate the detention of asylum seekers in the European Union:

- the Reception Conditions Directive (Directive 2003/9/EC);

- the Procedures Directive (Directive 2005/85/EC); and

- the Dublin II Regulation (Regulation 343/2003).

The Dublin II Regulation refers to detention only in the context that an extract from a detention centre may prove residence in a member state of at least five months ${ }^{372}$ and in the context that a Member State may require an urgent reply where the asylum seeker is in detention. ${ }^{373}$ The Regulation is otherwise silent on the issue of detention notwithstanding that detention is

\footnotetext{
364 Council Directive 2001/55/EC of 20 July 2001 on minimum standards for giving temporary protection in the event of mass influx of displaced persons and on measures promoting a balance of efforts between Member States in receiving such persons and bearing the consequences thereof

365 Council Regulation 407/2002 of 28 February 2002 laying down certain rules to implement Regulation (EC) No 2725/2000 concerning the establishment of 'Eurodac' for the comparison of fingerprints for the effective application of the Dublin Convention

366 Council Directive 2003/9/EC of 27 January 2003 laying down minimum standards for the reception of asylum seekers

367 Council Regulation (EC) 343/2003 of 18 February 2003 establishing the criteria and mechanisms for determining the Member State responsible for examining an asylum application lodged in one of the Member States by a third-country national

368 Council Directive 2004/83/EC of 29 April 2004 on minimum standards for the qualification and status of third country nationals or stateless persons as refugees or as persons who otherwise need international protection and the content of the protection granted

369 Directive 2011/95/EU of the European Parliament and of the Council of 13 December 2011 on standards for the qualification of third-country nationals or stateless persons as beneficiaries of international protection, for a uniform status for refugees or for persons eligible for subsidiary protection, and for the content of the protection granted

370 Council Directive 205/85/EC of 1 December 2005 on minimum standards on procedures in Member States for granting and withdrawing refugee status

371 Directive 2008/115/EC of the European Parliament and of the Council of 16 December 2008 on common standards and procedures in Member States for returning illegally staying third-country nationals

372 Annex II of the Dublin II Regulation

373 Article 17(2) of the Dublin II Regulation
} 
commonly used to facilitate transfers of asylum seekers between Member States. ${ }^{374}$

Although not strictly dealing with asylum seekers, the Returns Directive (Directive 2008/115/EC) contemplates the detention of illegally staying third country nationals. An examination of the Returns Directive is important because its operation can result in the detention of persons whose applications for asylum have been rejected or implicitly or explicitly withdrawn and, as will be shown in subsequent chapters, those persons who seek asylum but are not screened-in, and/or who otherwise do not fall within the scope of the Procedures Directive or Reception Conditions Directive.

The remaining secondary legislation that forms part of the CEAS is still relevant when analysing the detention of asylum seekers, even if they are silent on the issue.

\subsubsection{The Eurodac and the Implementation of the Eurodac}

The United Kingdom and Ireland participate the application and adoption of the Eurodac. ${ }^{375}$ Its purpose is to assist in determining the Member State responsible for an asylum application under the Dublin II Regulation (which is discussed below). ${ }^{376}$ The procedures play an integral role in determining whether a third country national has made an asylum claim in another Member State, with a consequent 'hit' preceding the hierarchical assessment of the Member State responsible for determining the asylum application under the Dublin II Regulation. The Eurodac identifies three classes of persons for whom finger prints are taken: firstly, asylum seekers over the age of 14 years; ${ }^{377}$ secondly, third country nationals of at least 14 years of age who irregularly cross the border of a Member State; $;{ }^{378}$ and thirdly, an "illegally present alien". ${ }^{379}$ In relation to the first two categories, Member States are obliged to take fingerprints and transmit the data to the Central Unit. Only in relation to illegally present aliens are Member States given a discretion to take fingerprints and transmit data. Data use, protection and liability area also provided for, including rights of the data subject. ${ }^{380}$ The Implementation of

\footnotetext{
374 Jesuit Refugee Service, Detention in the Context of the Dublin II Regulation, http://www.detention-in-europe.org/index.php?option=com_content\&view=article\&id $=175 \&$ Itemid $=209$ (last accessed 4 May 2011); see also the judgment of the ECtHR in Muskhadzhiyeva v Belgium, No. 41442/07, Judgment, 19 January 2010, in relation to a Chechen family which was detained in a closed reception centre in Belgium pending a Dublin transfer to Poland.

375 Council Regulation (EC) 2725/2000 of 11 December 2000 concerning the establishment of 'Eurodac' for the comparison of finger prints for the effective application of the Dublin Convention ("the Eurodac Regulation”)

376 Article 1 of the Eurodac Regulation

377 Article 4 of the Eurodac Regulation

378 Article 8 of the Eurodac Regulation

379 Article 11 of the Eurodac Regulation

380 Chapter VI of the Eurodac Regulation
} 
the Eurodac provides for the transmission of data, ${ }^{381}$ the carrying out of comparisons and transmitting results, ${ }^{382}$ and the communication between Member States and the Central Unit. ${ }^{383}$

\subsubsection{The Temporary Protection Directive}

The purpose of the Directive is to provide minimum standards for giving temporary protection in the event of a mass influx of displaced persons from third countries. ${ }^{384}$ "Mass influx" can only be established by way of a Council Decision subject to qualified majority voting - it is not a state established unilaterally by a Member State - but a Member State may request the Commission to submit a proposal for such to the Council. ${ }^{385}$ The period of temporary protection is for one year, extendable in six-monthly increments to a maximum of one year or, where conditions persist, the Council may decide by qualified majority voting on a Commission proposal to extend protection for up to one year. ${ }^{386}$ Once the temporary protection has ended (either by the effluxion of time or by the Council deciding by qualified majority voting on a Commission proposal), ${ }^{387}$ persons may be returned voluntarily ${ }^{388}$ or through enforced return. ${ }^{389}$ Importantly, the granting of temporary protection is not to prejudice recognition of a person's refugee status under the Geneva Convention. ${ }^{390}$ Further, persons enjoying temporary protection must be able to lodge an application for asylum at any time. ${ }^{391}$ However, Member States are given the discretion to provide that the status of temporary protection and asylum seeker may not be enjoyed concurrently whilst an asylum application is being considered. ${ }^{392}$ To that end, it is clear that the Directive does not equate the recipient of temporary protection to that of asylum seeker.

\footnotetext{
381 Article 2 Council Regulation 407/2002 of 28 February 2002 laying down certain rules to implement Regulation (EC) No 2725/2000 concerning the establishment of 'Eurodac' for the comparison of fingerprints for the effective application of the Dublin Convention ("the Implementation of the Eurodac")

382 Article 3 of the Implementation of the Eurodac

383 Article 4 of the Implementation of the Eurodac

384 Article 1 Council Directive 2001/55/EC of 20 July 2001 on minimum standards for giving temporary protection in the event of mass influx of displaced persons and on measures promoting a balance of efforts between Member States in receiving such persons and bearing the consequences thereof ("the Temporary Protection Directive")

385 Article 5 of the the Temporary Protection Directive

386 Article 4 of the Temporary Protection Directive

387 Article 6 of the Temporary Protection Directive

388 Article 21 of the Temporary Protection Directive

389 Article 22 of the Temporary Protection Directive

390 Article 2 of the Temporary Protection Directive

391 Article 17(1) of the Temporary Protection Directive

392 Article 19(1) the Temporary Protection Directive
} 


\subsubsection{The Reception Conditions Directive}

The Reception Conditions Directive lays down minimum standards for the reception of asylum seekers in Member States ${ }^{393}$ - that is, it is chiefly responsible for the material modalities that asylum seekers are to receive having lodged their application for asylum in a Member State. The Directive applies to the United Kingdom, ${ }^{394}$ but not to Ireland or Denmark. ${ }^{395}$ The scope of the Directive includes asylum seekers who make an application for asylum and their family members. ${ }^{396}$ However, the definition of family is quite narrow as it contemplates the family "as already existed in the country of origin" and who are present in the same Member State, including minor, unmarried, dependent children of the couple. ${ }^{397}$ The Directive does not apply when the provisions of the Temporary Protection Directive are applied. ${ }^{398}$ Member States have the discretion to apply the Directive when deciding on applications for "protection other than that emanating from the Geneva Convention for third country nationals or stateless persons who are not refugees" (that is, for forms of subsidiary protection). ${ }^{399}$ In general terms, provision is also made for education of minors, ${ }^{400}$ employment and vocational training, ${ }^{401}$ material reception conditions, ${ }^{402}$ and for the reduction or withdrawal of reception conditions, including procedural safeguards. ${ }^{403}$ Provision is also made for persons with special needs. ${ }^{404}$

\subsubsection{The Dublin II Regulation}

Also applying to the United Kingdom and Ireland (but not Denmark), ${ }^{405}$ the purpose of the Regulation is to set out the criteria and mechanisms for determining the Member State responsible for the determination of an application for asylum lodged by a third country national. ${ }^{406}$ Essentially this situation arises where an asylum seeker has lodged an application in one Member State and lodges a subsequent application in another Member State. The Regulation aims to achieve its purpose by setting out a hierarchy of

\footnotetext{
393 Article 1 Council Directive 2003/9/EC of 27 January 2003 laying down minimum standards for the reception of asylum seekers ("the Reception Conditions Directive")

${ }^{394}$ Recital 19 to the Reception Conditions Directive

395 Recitals 20 and 21 to Reception Conditions Directive

396 Article 3(1) the Reception Conditions Directive

397 Article 2(d) the Reception Conditions Directive

398 Article 3(3) the Reception Conditions Directive

399 Article 3(4) the Reception Conditions Directive

400 Article 10 the Reception Conditions Directive

401 Articles 11 and 12 the Reception Conditions Directive

402 Articles 13-15 of the Reception Conditions Directive

403 Article 16 of the Reception Conditions Directive

404 Articles 17-20 of the Reception Conditions Directive

405 Recital 17 and 18 Council Regulation (EC) 343/2003 of 18 February 2003 establishing the criteria and mechanisms for determining the Member State responsible for examining an asylum application lodged in one of the Member States by a third-country national ("the Dublin II Regulation")

406 Article 1 of the Dublin II Regulation
} 
criteria for determining which is the responsible Member State. ${ }^{407}$ However, the result of following that criteria tends to lead to the outcome that the Member State where the asylum claim was first lodged, or where the asylum seeker first entered, is deemed responsible for the assessment of the application, thus disproportionately affecting frontier Member States. Notably, a Member State retains the right to send an asylum seeker to a third country. ${ }^{408}$ A Member State has the discretion to utilise the "sovereignty clause" to determine the asylum claim even if another Member State is responsible under the criteria. ${ }^{409}$ In the event of several family members submitting an application simultaneously, a "tie-break" clause has been inserted whereby the Member State responsible is the one which the criteria indicates has the responsibility for taking charge of the largest number of family members or where the criteria indicates that the Member State is responsible for examining the application of the oldest member of the family. ${ }^{410}$ Further, a "humanitarian clause" provides that a Member State may bring family members together, notwithstanding that it is not responsible for assessing the application under the criteria - this is particularly important for dependent relatives who do not fall within the definition of "family member" under the Regulation as well as for unaccompanied minors. "411 "Family member" is narrowly defined under the Regulation and does not contemplate horizontal or sibling relationships. ${ }^{412}$ Member States responsible for examining the asylum claim are to take charge and to take back the applicant having followed certain procedures and within particular timeframes. ${ }^{413}$

\subsubsection{The Qualification Directives}

Given the recent coming into force of the Qualification II Directive, in which the United Kingdom, Ireland and Denmark do not participate, ${ }^{414}$ it is necessary to make clear that the Qualification I Directive still applies to the

\footnotetext{
407 Articles 5 to 13 of the Dublin II Regulation

408 Article 3(1) of the Dublin II Regulation

409 Article 3(2) of the Dublin II Regulation

410 Article 14 of the Dublin II Regulation

411 Article 15 of the Dublin II Regulation

412 Article 2(i) of the Dublin II Regulation

413 Articles 16-20 of the Dublin II Regulation. However, it is important to note the impact of Case C-19/08 Migrationsverket v Edgar Petrosian and Others, Judgment, 29 January 2009 in which the CJEU held that the "suspensive effect" of a decision on appeal or review contemplated in Article 20(1)(d) of the Regulation (and where provided for in national law), and in light of Article 20(2), should be interpreted to mean that the six month time limit for the transfer of an asylum seeker to be carried out runs "from the time the judicial decision which rules on the merits of the procedure and which is no longer as to prevent its implementation" (at Para 46) - that is, the six month period does for the transfer to be carried out does not run from the provisional judgment which suspends the transfer.

${ }^{414}$ Recitals 50 and 51 of the Qualification II Directive
} 
United Kingdom and Ireland (discussed in further detail in Chapter 4). ${ }^{415}$ Accordingly, it is necessary to discuss both Directives.

\section{The Qualification I Directive}

The purpose of the Directive is to provide minimum standards for the qualification of third country nationals or stateless persons as refugees or who otherwise need international protection ${ }^{416}$ - that is, the Directive governs the qualifying criteria for applications both under the 1951 Geneva Convention and its Protocol as well as subsidiary protection. ${ }^{417}$ The United Kingdom and Ireland take part in the adoption and application of the Directive, ${ }^{418}$ but Denmark does not. ${ }^{419}$ Chapter II provides for the assessment of facts and circumstances in relation to both refugee and subsidiary protection applications. ${ }^{420}$ Chapter III provides for the qualification for refugee status, with the nexus between acts of persecution and reasons for persecution. ${ }^{421}$ That Chapter also contemplates the cessation ${ }^{422}$ and exclusion ${ }^{423}$ of refugee status.

415 See further, Peers, S, The revised directive on Refugee and Subsidiary Protection status, Statewatch Analysis, July 2011, http://www.statewatch.org/analyses/no-141-qaulificationsdirective.pdf (last accessed 13 May 2012)

416 Article 1 of the Qualification I Directive

417 In Cases C-57/09 and C101-09 Bundesrepublik Deutschland v B \& D, Judgment, Grand Chamber, 9 November 2010, the CJEU confirmed that Member States were free to introduce more favourable provisions and that any national protection status on a "discretionary and good will basis or for humanitarian reasons" did not fall within the scope of the Directive (that is, for reasons other than international protection) (paras 113-121)

418 Recital 38 and 39 to the Qualification I Directive

419 Recital 40 to of the Qualification I Directive

${ }^{420}$ In relation to internal protection (that is, where an applicant might reasonably be expected to stay in a safe part of his or her country of origin) under Article 8 of the Directive, the ECtHR has held in Salah Sheekh $v$ the Netherlands, No. 1948/04, Judgment, 11 January 2007, that, in relation to Article 3 ECtHR, the time for determining whether the conditions of the country are safe is at the time of the decision, not historically (para 136) and that persons who are returned to an area from where they are noticeably not may be subject to a real risk of treatment in violation of Article 3 ECHR (paras 138-140) For the internal flight alternative to be relied upon, the Court held that the person expelled to such an area must be able to travel there, "gain admittance and settle there" in the absence of which a breach of Article 3 ECHR may occur, compounded if the person expelled "end[s] up in a part of the country of origin where he or she may be subjected to illtreatment" (at para 141).

421 Article 9(3) of the Qualification I Directive; In relation to "acts of persecution" see also Opinion of Bot A-G in Cases C-71/11 and C-99/11 Federal Republic of Germany $v$ Y and Z, 19 April 2012, Opinion.

422 Article 11 of the Qualification I Directive. In regard to the assessment of when refugee status ceases to exist, the standard of probability used and the evidentiary weight to be attached to previous acts of persecution, see Cases C-175/08, C-176/08, C-178/08 and 179/08 Aydin Salahadin Abdulla \& Ors v Bundesrepublik Deutschland, 2 March 2010.

${ }^{423}$ Article 12 of the Qualification I Directive. In Case C-31/09 Nawras Bolbol v Bevándorlási és Állampolgársárgi Hivatal, 17 June 2010, Judgment, Grand Chamber, involved a stateless Palestinian originating from Lebanon, which fell under the mandate of the UNRWA. The question arose as to whether the applicant had not sought protection or assistance from the UNRWA as contemplated under Article 1D of the 1951 Geneva Contention and in light 
Chapter V provides for the qualification for subsidiary protection, including the comprising elements of "serious harm", ${ }^{424}$ and the circumstances in which a person ceases to eligible for, or is excluded from being eligible from, subsidiary protection status. Chapter VI deals with the granting, revocation, ending of or refusal to renew a person's subsidiary protection status. Chapter VII contains the rights derived from having received international protection, including protection from refoulement. ${ }^{425}$ However, there is a clear distinction between the content of rights for those granted refugee status and those granted subsidiary protection status - in that sense, there is a rights hierarchy. For example, although family unity must be maintained by Member States for both statuses, ${ }^{426}$ non-refugee status family members are entitled to equivalent rights as the refugee, whereas non-subsidiary protection status family members of a person granted subsidiary protection are not (which, inter alia, excludes family members from access to education); ${ }^{427}$ refugees are entitled to a residence permit of at least three years, but only one year for those granted subsidiary protection; ${ }^{428}$ refugees have a right to travel documents, whereas subsidiary protection holders only do so if they are unable to obtain a national passport; ${ }^{429}$ refugees have immediate access to employment but such access may be subject to labour market tests for those granted subsidiary

of Article 12(1)(a) of the Directive. The Court held "only those persons who have actually availed themselves of the assistance provided by the UNRWA come within the clause excluding refugee status set out therein, which must as such, be construed narrowly, and cannot therefore also cover persons who are or have been eligible to receive protection or assistance from that agency" (at Para 51) and, accordingly, such persons can only be excluded by operation of Article 12(1)(a) of the Directive when such persons have "actually availed [themselves] of that protection or assistance" [emphasis added] (at Para 53). In Cases C-57/09 and C101-09 Bundesrepublik Deutschland v B \& D, 9 November 2010, Judgment, Grand Chamber, the CJEU considered that "serious non-political crime" and "acts contrary to the purposes and principles of the United Nations" as contemplated in Article $12(2)$ (b) or (c) still required "a full investigation into all the circumstances of each individual case" and membership of a terrorist organisation, by itself, was not sufficient to exclude the applicant from refugee status (paras 88-99). Further, the court held that exclusion from refugee status under Articles 12(2)(b) or (c) was not conditional upon the applicant presenting a danger to the Member State (paras 100-105). The court held that there was no need to carry out an assessment of proportionality under Articles 12(b) or (c) (paras 106111).

${ }^{424}$ Article 15 of the Qualification I Directive. In C-465/07 Meki Elgafaji and Noor Elgafaji v Staatssecretaris van Justitie, 17 February 2009, Judgment, Grand Chamber, the CJEU held that individual exposure to violence (that is, being "specifically targeted by reason of factors particular to his personal circumstances" - at para 43) is not required in light of the competing wording of Article 15(c) of the Directive which contemplates a "serious and individual threat" by reason of "indiscriminate violence". Further an interpretation independent of Article 3 ECHR is required of Article 15(c) but retaining "due regard for fundamental rights as they are guaranteed under the ECHR" (at para 28).

425 Article 21 of the Qualification I Directive

426 Article 23(1) of the Qualification I Directive

${ }^{427}$ Article 23(2) of the Qualification I Directive

428 Article 24 of the Qualification I Directive

${ }^{429}$ Article 25 of the Qualification I Directive 
protection; ${ }^{430}$ refugees are entitled to access to social welfare and health care as provided to nationals of the Member State, but these rights may be limited to core benefits for those granted subsidiary protection status; ${ }^{431}$ finally, a distinction between the two status holders also applies to access to integration facilities. ${ }^{432}$ To persons granted either status, access to education (for minor children, under the same conditions as nationals of the Member State, for adults under the same conditions as legally resident third country nationals) as well as access to accommodation (under equivalent conditions to legally resident third country nationals) is provided for. As has been elaborated earlier, in the face of comparable human suffering, it is questionable why it is necessary to draw a distinction in the content of rights between the two statuses.

\section{The Qualification II Directive}

Although the entry into force of the Qualification II Directive occurs in the usual way (20 days following its publication in the Official Journal), the vast bulk of the Directive does not come into force until 22 December 2013. ${ }^{433}$ Accordingly, the Qualification I Directive will still have relevance for the CEAS for the present time. It is important to note that the overall structure of the Directive remains largely unchanged and the most significant changes for the purpose of this book include the expansion of the definition of family members (discussed in detail in Chapter 4), ${ }^{434}$ and equal treatment of those holders of refugee and subsidiary protection status in relation to family members, ${ }^{435}$ employment and training, ${ }^{436}$ health care, ${ }^{437}$ and integration schemes. ${ }^{438}$ However, distinctions between the two statuses still exist for the validity period of residence permits (three years for refugee status, at least one year for subsidiary protection status, and on renewal, for at least 2 years) ${ }^{439}$ and the discretion of Member States to limit social welfare to subsidiary protection holders to "core benefits". ${ }^{440}$

\subsubsection{The Procedures Directive}

The purpose of the Directive is to provide minimum standards on the procedures for granting and withdrawing refugee status in Member States

\footnotetext{
430 Article 26 of the Qualification I Directive

431 Articles 28 and 29 of the Qualification I Directive

432 Article 33 of the Qualification I Directive

433 Article 41 of the Qualification II Directive

434 Article 2(j) of the Qualification II Directive

435 Article 23(2) of the Qualification II Directive

436 Article 26 of the Qualification II Directive

437 Article 29 of the Qualification II Directive

438 Article 34 of the Qualification II Directive

439 Article 24 of the Qualification II Directive

${ }^{440}$ Article 29(2) of the Qualification II Directive
} 
under the 1951 Geneva Convention and its Protocol. ${ }^{441}$ The United Kingdom and Ireland take part in the adoption and application of the Directive, ${ }^{442}$ but Denmark does not. ${ }^{443}$ The Directive provides for the basic principles and guarantees when assessing asylum claims, ${ }^{444}$ including the requirements for the examination of applications, ${ }^{445}$ certain guarantees for applicants in relation to decisions by the determining authority, ${ }^{446}$ and procedural guarantees. ${ }^{447}$ Although an applicant may be given the opportunity of a personal interview, it may be restricted in certain cases, including where the authority considers the application unfounded. ${ }^{448}$ Similarly, Chapter III sets out the procedures to be followed at asylum applications of first instance, including the acceleration or prioritisation of the examination procedure. ${ }^{449}$ Although the "safe third country of origin" concept has been introduced into the Directive, ${ }^{450}$ the minimum common list of third countries regarded as safe third countries of origin has been annulled by the CJEU. ${ }^{451}$ The Directive provides a right for the applicant to remain in the Member State, for the sole purpose of the procedure, until a decision has been made by the determining authority. ${ }^{452}$ Provision is also made for the explicit and implicit withdrawal, as well as abandonment, of an application. ${ }^{453}$

\subsubsection{The Returns Directive}

The Returns Directive is applicable to the circumstances of asylum seekers not only in the event that their asylum application fails, but also (as will be explored later) in the event that their application is explicitly or implicitly withdrawn or abandoned under the Procedures Directive. Notwithstanding

441 Articles 1 and 3 Council Directive 2005/85/EC of 1 December 2005 on minimum standards on procedures in Member States for granting and withdrawing refugee status ("the Procedures Directive")

442 Recitals 32 and 33 to the Procedures Directive

443 Recital 34 to the Procedures Directive

${ }^{444}$ Chapter III of the Procedures Directive

445 Article 8 of the Procedures Directive

446 Article 9 of the Procedures Directive

447 Article 10 of the Procedures Directive

448 Article 12 generally, and see Article 12(2)(c) of the Procedures Directive in which one of the circumstances in which an interview may be omitted is where inter alia, under Article $23(4)(\mathrm{g})$, the applicant has made "inconsistent, contradictory, improbable or insufficient representations" which, in practice, are not uncommon given a person's trauma or circumstances and, in the case of "improbable representations" the ignorance of determining authorities about particular circumstances in an applicant's country of origin. See also, in relation to the accelerated procedure, including Article 39 of the Procedures Directive, Case C-69/10 Brahim Samba Diouf v Ministre du Travail, de l'Emploi et de l'Immigration, 28 July 2011, Judgment (discussed in subsequent chapters)

449 Articles 23(3) and 23(4) of the Procedures Directive - see preceeding note regarding Article 23(4)(g)

450 Article 27 of the Procedures Directive

451 See Article 29 of the Procedures Directive and Case 133/06 European Parliament $v$ Council of the European Union, 6 May 2008, Judgment

452 Article 7(1) of the Procedures Directive

453 Articles 19 and 20 of the Procedures Directive 
these issues, the Directive ostensibly sets out the minimum standards and procedures for returning illegally staying third country nationals ${ }^{454}$ - that is, this Directive may become applicable when the person's status has changed from an asylum seeker to an illegally staying third country national. The United Kingdom, Ireland and Denmark do not take part in the application of the Directive. ${ }^{455}$ The issuing of a return decision is mandatory ${ }^{456}$ subject to the exceptions including (but not limited to) compassionate or humanitarian reasons ${ }^{457}$ or because the person is subject to a pending procedure for a renewal of his/her residence permit. ${ }^{458} \mathrm{~A}$ voluntary departure of between seven and 30 days is to be provided for, ${ }^{459}$ with the consequences that an entry ban for a maximum period of five years may be imposed if there is no compliance within the period of voluntary departure ${ }^{460}$ together with forced removal. ${ }^{461}$ In El Dridi, the CJEU recently held that a custodial sentence (in that case, for 12 months) on the sole ground that a person remains illegally on the territory of a Member State is subject to the principle of proportionality and effectiveness and that a custodial sentence for failure to comply with a removal order undermines the objective of the Directive (that is, removal from the Member State) and its consequent effectiveness. ${ }^{462}$ Accordingly, it is improper for a Member State to issue an order to leave the territory within a certain period, but then issue a custodial sentence which effectively undermines that order. Removal must be postponed where it would violate the principle of non-refoulement and where a competent authority has granted suspensory effect. ${ }^{463}$ Member States are required to take into account the best interests of the child, family life and the state of health of the third country national. ${ }^{464}$ Procedural safeguards are contemplated in Chapter III, including being afforded an effective remedy before a competent judicial or administrative authority or a competent impartial and independent body. ${ }^{465}$

\footnotetext{
454 Article 1 of the Procedures Directive

455 Recitals 25, 26 and 27 to Directive 2008/115/EC of the European Parliament and of the Council of 16 December 2008 on common standards and procedures in Member States for returning illegally staying third-country nationals ("the Returns Directive")

456 Article 6 of the Returns Directive

457 Article 6(4) of the Returns Directive

458 Article 6(5) of the Returns Directive

459 Article 7 of the Returns Directive

460 Article 11 of the Returns Directive; see also Council of the European Union, Note to Working Party on Integration, Migration and Expulsion/Mixed Committee, Questionnaire on defining the conditions under which an entry ban can be imposed and the means by which Member States can have rapid access to information on an entry ban, 21 June 2011, Document 11905/11 461 Article 8 of the Returns Directive

462 Case C-61/11 PPU Hassen El Dridi (alias Soufi Karim), Judgment, 28 April 2011, paras 52-62. In relation to detention, see also Case C-357/09 PPU Said Shamilovich Kadzoev (Huchbarov), 30 November 2009, Judgment, Grand Chamber (discussed in subsequent chapters)

463 Article 9 of the Returns Directive

464 Article 5 of the Returns Directive

465 Article 13 of the Returns Directive
} 


\subsubsection{Forthcoming Legislation}

Of the four pieces of secondary legislation that contemplate detention, three are currently the subject of proposed amendments by the Commission.

In the Commission Communication entitled "Policy Plan on Asylum an Integrated Approach to Protection Across the EU", the Commission identified divergent results amongst the Member States as a "critical flaw" in the current CEAS. ${ }^{466}$ Further, the Commission also identified the growing use of subsidiary protection based on national law rather than on the 1951 Geneva Convention. ${ }^{467}$ The Communication foreshadowed reform to the CEAS, namely to the Reception Conditions Directive, the Procedures Directive, the Qualification Directive and the Dublin system. At that time, the Commission proposed (in the course of 2009) to amend the Procedures Directive to tighten procedures, to establish obligatory procedural safeguards, to contemplate mixed arrivals and to improve gender equality throughout the asylum process and introduce further safeguards to vulnerable persons. ${ }^{468}$

Accordingly, proposals are currently before the European Parliament and the Council (as part of the co-decision procedure) for amendments to the Reception Conditions Directive, ${ }^{469}$ the Dublin Regulation, ${ }^{470}$ and the Procedures Directive. ${ }^{471}$ This book will consider those three proposals in detail to the extent that their provisions relate to the detention of asylum seekers.

\subsubsection{Proposed Amendments to the Reception Conditions Directive}

The proposed Reception Conditions Directive has been the subject of two proposals by the Commission in 2008 and 2011 . $^{472}$

466 Communication from the Commission to the European Parliament, the Council, the European Economic and Social Committee and the Committee of the Regions, Policy Plan on Asylum - an Integrated Approach to Protection Across the EU COM(2008) 360 final, P.3

467 Ibid, P.3

468 Ibid, P.5

469 European Commission, Proposal for a Directive of the European Parliament and of the Council laying down minimum standards for the reception of asylum seekers 3 December 2008, $\operatorname{COM}(2008) 815$ final; and European Commission, Amended proposal for a Directive of the European Parliament and of the Council laying down standards for the reception of asylum seekers, 1 June 2011, COM(2011) 320 final

${ }^{470}$ European Commission, Proposal for a Regulation of the European Parliament and of the Council establishing the criteria and mechanisms for determining the Member State responsible for examining an application for international protection lodged in one of the Member States by a thirdcountry national or a stateless person, 3 December 2008, COM(2008) 820 final

${ }^{471}$ European Commission, Proposal for a Directive of the European Parliament and of the Council on minimum standards on procedures in Member States for granting and withdrawing international protection, 21 October 2009, COM(2009) 554 final; and European Commission, Directive of the European Parliament and of the Council on common procedures for granting and withdrawing international protection status (Recast), 1 June 2011, COM(2011) 319 final

472 European Commission, Proposal for a Directive of the European Parliament and of the Council laying down minimum standards for the reception of asylum seekers 3 December 2008, $\operatorname{COM}(2008) 815$ final ("the Commission's Proposed 2008 Reception Conditions 
The Commission's 2008 proposed Directive contained a number of amendments that substantially upgraded the rights of asylum seekers. As noted by ECRE, ${ }^{473}$ these positive developments included the application of the Directive to all circumstances where applicants for international protection are hosted for as long as they are permitted to remain on the territory of the Member State as asylum seekers; ${ }^{474}$ the obligation on Member States to allow asylum seekers access to their labour market within six months of the lodging of an application for international protection; ${ }^{475}$ improved protection for children, particularly the clearer enunciation of the best interest principle; ${ }^{476}$ greater reporting requirements for Member States; ${ }^{477}$ and greater clarity regarding the circumstances and conditions of detention. ${ }^{478}$ However, ECRE also expressed concern regarding the broad grounds under which asylum seekers may be detained. ${ }^{479}$

The Commission's 2011 Proposed Reception Conditions Directive saw a significant downgrading of rights for detained asylum seekers (including the possibility of detention being ordered by administrative authorities, ${ }^{480}$ (incredibly) the removal of the prohibition of the detention of minors, ${ }^{481}$ the altering of rights in relation to the provision of legal assistance with respect to challenging the detention order, ${ }^{482}$ derogations concerning the provision of

Directive"); and European Commission, Amended proposal for a Directive of the European Parliament and of the Council laying down standards for the reception of asylum seekers, 1 June 2011, COM(2011) 320 final ("the Commission's Proposed 2011 Reception Conditions Directive")

473 European Council on Refugees and Exiles, Comments from the European Council on Refugees and Exiles on the European Commission Proposal to recast the Reception Conditions Directive, April 2009, http://www.ecre.org/files/ECRE_Comments_on_Reception _Conditions_Directive_recast_2009.pdf (last accessed 5 May 2011), P.3

474 Recital 8 and Article 3 of the Commission's 2008 Proposed Reception Conditions Directive

475 Article 15 of the Commission's 2008 Proposed Reception Conditions Directive

476 Article 22 of the Commission's 2008 Proposed Reception Conditions Directive

477 Article 22 of, and Annexure I to, the Commission's 2008 Proposed Reception Conditions Directive

478 Articles 8, 9, 10 and 11 of the Commission's 2008 Proposed Reception Conditions Directive

479 Under Articles Article 8(2)(b) and (c) of the Commission's 2008 Proposed Reception Conditions Directive - see European Council on Refugees and Exiles, Comments from the European Council on Refugees and Exiles on the European Commission Proposal to recast the Reception Conditions Directive, April 2009, http://www.ecre.org/files/ECRE_Comments _on_Reception_Conditions_Directive_recast_2009.pdf (last accessed 5 May 2011), Pp. 4 and 6-7

480 Article 9(2) of the Commission's 2011 Proposed Reception Conditions Directive

481 Compare proposed Article 11 of the Commission's 2008 and 2011 Proposed Reception Conditions Directive

482 Article 9(5) of the Commission's 2011 Proposed Reception Conditions Directive 
information, ${ }^{483}$ and the possibility for Member States to use prisons for detention accommodation when detention facilities were temporarily not available). ${ }^{484}$

The Commission's 2011 Proposed Reception Conditions Directive was followed by a stern urging from Germany, France and the United Kingdom that the Reception Conditions Directive "should not make claiming asylum more attractive or increase costs on Member States" (including the urging that work rights should not occur within six months of an application, but after 12 months). 485 The Commission's 2011 Reception Conditions Directive proposed to give Member States the discretion to extend the time period in which access to the labour market was to be given by a further six months (that is, up to 12 months' wait in total).

The proposed Directive has also been the subject of quite intense negotiations between the Council and the Parliament, which have resulted in at least five subsequent amended proposals by the Council (of 22 July 2011, 12 September 2011 and 13 December 2011, 27 January 2012 and 20 February 2012). ${ }^{486}$ Given the rapidity of change, the number of versions and the centrality of this Directive to the upcoming CEAS detention regime, the Council's amended proposal of 12 September 2011 will be considered in addition to the Commission's 2011 proposal ("the Council's Amended Proposed Reception Conditions Directive").

\subsubsection{Proposed Amendments to the Dublin II Regulation}

The fundamental mechanism for determining which Member State is responsible for the determination of an asylum claim remains largely intact in the Commission's proposals. Although the Commission believes that "the underlying principles of the Dublin system are worth upholding", ${ }^{487}$ and

483 Article 10(5) and 10(6)(b) of the Commission's 2011 Proposed Reception Conditions Directive

484 Article 10(6)(a) of the Commission's 2011 Proposed Reception Conditions Directive

485 Council of the European Union, Note from the German, French and United Kingdom delegations, Joint contribution of the German, French and United Kingdom delegations regarding the proposals for a directive laying down standards for the reception of asylum seekers and for asylum procedures, 27 June 2011, Document No. 12168/11, P.3

486 Council of the European Union, Outcome of Proceedings of the Asylum Working Party on 6 July 2011, 22 July 2011, Document No. 12580/11; Council of the European Union, Note from Presidency to Asylum Working Party of 26 September 2011, 12 September 2011, Document No. 13102/11; Council of the European Union, Outcome of Proceedings of Asylum Working Party of 6 December 2011, 13 December 2011, Document No. 17832/11; Council of the European Union, Outcome of Proceedings of JHA Counsellors on 23 January 2012, 27 January 2012, Document No. 5515/12; Council of the European Union, Revised Note from Presidency to Permanent Representatives Committee on 22 February 2012, 20 February 2012, Document No. 6394/1/12 Rev 1.

487 Communication from the Commission to the European Parliament, the Council, the European Economic and Social Committee and the Committee of the Regions, Policy Plan 
notwithstanding the Stockholm Programme's commitment to the system, one cannot help but wonder whether the Union must thoroughly reconsider this position in light of the ECtHR decision in MSS $v$ Belgium and Greece, ${ }^{488}$ and the CJEU decision in $N S^{489}$ together with the seeming fragility of the principles of mutual trust and solidarity. ECRE is of the view that the effects of the application of the Dublin system are such that its complete replacement with a "system based on integration and solidarity" 490 is warranted, and that its harmful effects cannot be overcome by completing and perfecting the CEAS. $^{491}$

The proposed Regulation contains a number of amendments including the right to information; ${ }^{492}$ the opportunity afforded to applicants of a personal interview (as a means of increasing efficiency); ${ }^{493}$ certain guarantees for minors; ${ }^{494}$ provisions regarding detention for the purpose of transfer; ${ }^{495}$ and provisions relating to the exchange of relevant information before transfers are carried out. ${ }^{496}$ The proposal contemplates Member States being able to request the temporary suspension of a transfer where its reception capacities are faced with an exceptionally heavy burden. That request is addressed to the Commission who can make a decision to suspend all transfers to the Member State, but the Council may subsequently make a contrary decision. The suspension may only be in place for six months, with a possible further extension of six months. ${ }^{497}$

As with the Reception Conditions Directive, the Proposed Dublin Regulation has been the subject of Council amendments. ${ }^{498}$ As noted by

on Asylum - an Integrated Approach to Protection Across the EU COM(2008) 360 final, ("the Commission's Proposed Dublin Regulation"), P.7

488 M.S.S. v Belgium and Greece, No. 30696/09, Judgment, Grand Chamber, 21 January 2011

489 C-411/10 and C-493/10 N.S. $v$ Secretary of State for the Home Department and M. E. and Others $v$ Refugee Applications Commissioner and Minister for Justice, Equality and Law Reform, 21 December 2011, Judgment Grand Chamber,

490 European Council on Refugees and Exiles, Comments from the European Council on Refugees and Exiles on the European Commission Proposal to recast the Dublin Regulation, April 2009, http://www.ecre.org/files/ECRE_Response_to_Recast_Dublin_Regulation_2009 .pdf (last accessed 15 May 2012), P.3

491 European Council on Refugees and Exiles, Comments from the European Council on Refugees and Exiles on the European Commission Proposal to recast the Dublin Regulation, April 2009, http://www.ecre.org/files/ECRE_Response_to_Recast_Dublin_Regulation_2009 .pdf (last accessed 15 May 2012), Pp.3-5

492 Article 4 of the Commission's Proposed Dublin Regulation

493 Article 5 of the Commission's Proposed Dublin Regulation

494 Article 6 of the Commission's Proposed Dublin Regulation

495 Article 27 of the Commission's Proposed Dublin Regulation

496 Article 30 of the Commission's Proposed Dublin Regulation

497 Article 31 of the Commission's Proposed Dublin Regulation

498 Council of the European Union, Outcome of Proceedings of Asylum Working Party on 23 June 2011, 18 July 2011, Document No. 12069/11 
Peers, the Council's amendments (particularly of Recital 8 of the Commission's Proposed Dublin Regulation) have further muddied the understanding of whether the Reception Conditions Directive is applicable to those in a Dublin situation. ${ }^{499}$ Given the recent developments brought to a head by MSS (which preceded the Council's amendments) and NS (which succeeded the Council's amendments), the pending case before the CJEU on the applicability of the Reception Conditions Directive ${ }^{500}$ and the already multiple versions of the Proposed Reception Conditions Directive, only the Commission's 2008 Proposed Dublin Regulation will be considered in this book so as to establish a baseline. Further developments have included the proposal by the Council for an "early warning system" whereby Member States are constantly monitored as to the state of their asylum systems, with a leading role to be taken by EASO and preventative or crisis management to be taken if necessary. ${ }^{501}$ The Meijers Committee recently expressed its scepticism of the proposal - indicating that firstly, the provision of statistics by Member States do not necessarily reveal the true extent of compliance with international human rights obligations; and secondly, the Committee questioned whether the shortcomings of the system were not a result of the numbers of asylum seekers entering the Union, but rather from individual Member States' shortcomings as regards reception conditions or decisionmaking and called for the Commission's temporary suspension of transfer mechanism as set out in its original 2008 Proposal (outlined above) ${ }^{502}$

\subsubsection{Proposed Amendments to the Procedures Directive}

As with the other proposals, the proposed Procedures Directive has been the subject of two proposals by the Commission ${ }^{503}$ and various proposed

\footnotetext{
499 Peers, S, The revised 'Dublin' rules on responsibility for asylum-seekers: The Council's failure to fix a broken system, April 2012, http://www.statewatch.org/analyses/no-173-dublin-III.pdf (last accessed 14 May 2012)

500 Case C-179/11 CIMADE, Groupe d'information et de soutien des immigrés (GISTI) v Ministre de l'Intérieur, de l'Outre-Mer, des Collectivités Territoriales et de l'Immigration, Reference for Preliminary Ruling lodged 18 April 2011

501 Council of the European Union, Note from Presidency to Strategic Committee on Immigration, Frontiers and Asylum (SCIFA) on 10 October 2011, 5 October 2011, Document No. $15055 / 11$

502 Meijers Committee, Letter dated 26 March 2012 to European Parliament Civil Liberties, Justice and Home Affairs Committee, http://www.statewatch.org/news /2012/mar/meijers-cttee-letter-EP-dublin.pdf (last accessed 15 May 2012)

503 European Commission, Proposal for a Directive of the European Parliament and of the Council on minimum standards on procedures in Member States for granting and withdrawing international protection, 21 October 2009, COM(2009) 554 final ("the Commission's 2009 Proposed Reception Conditions Directive"); and European Commission, Amended Proposal for a Directive of the European Parliament and of the Council on common procedures for granting and withdrawing international protection status (Recast), 1 June 2011, COM(2011) 319 final ("the Commission's 2011 Proposed Procedures Directive")
} 
amendments by the Council during the course of its negotiations with the Parliament. ${ }^{504}$

The Commission's 2009 Proposed Directive introduced new provisions regarding the training of the personnel of Member States' authorities ${ }^{505}$ and the provision of information and counselling at border crossing points and detention facilities. ${ }^{506}$ The provision relating to omit a personal interview on the basis of an application being unfounded was removed. ${ }^{507}$ New provisions were inserted requiring the Member States to make a transcript of every personal interview. ${ }^{508}$ The Proposal provided for applicants to request undergoing a medical examination to verify their statements in relation to having suffered persecution or past harm, ${ }^{509}$ and Member States were then required to take all appropriate measures to ensure that applicants with special needs are given the ability to present elements of their application "as completely as possible and with all available evidence." ${ }^{510}$ Importantly, the Proposal required Member States to ensure that applications for international protection are concluded within six months after the applicant has lodged their application, with that time limit only extendable by a further six months in cases of complex issues fact and law. ${ }^{511}$ However the aspirations of that provision are somewhat undermined by the fact that Member States can determine the consequences of a failure to adhere to those time limits "in accordance with national law", potentially rendering the limits of limited utility. ${ }^{512} \mathrm{~A}$ new distinction arose between prioritising applications and accelerating applications. Applications may be prioritised in cases which are well-founded or the applicant has special need. ${ }^{513}$ Applications may be accelerated if essentially the applicant's behaviour is regarded as being in bad faith or if an unmarried minor makes a subsequent application after his parent or parents' substantive application has been rejected and no new circumstances are raised. ${ }^{514}$ Grounds for an accelerated application that have been removed include making inconsistent, contradictory, improbable or insufficient

\footnotetext{
504 Council of the European Union, Outcome of Proceedings of Asylum Working Party on 28 June, 5 and 20 July and 27 September 2011, 3 October 2011, Document No. 12579/11; Council of the European Union, Outcome of Proceedings of Asylum Working Party on 5 October 2011, 19 October 2011, Document No. 15381/11; Council of the European Union, Outcome of Proceedings of Asylum Working Party on 6 December 2011, 13 December 2011, Document No. 17831/11; Council of the European Union, Outcome of Proceedings of Asylum Working Party on 5 January 2012, 12 January 2012, Document No. 5168/12 505 Article 6(8) of the Commission's 2011 Proposed Procedures Directive 506 Article 7 of the Commission's 2011 Proposed Procedures Directive 507 Article 13(2) of the Commission's 2011 Proposed Procedures Directive 508 Article 16 of the Commission's 2011 Proposed Procedures Directive 509 Article 17 of the Commission's 2011 Proposed Procedures Directive 510 Article 20 of the Commission's 2011 Proposed Procedures Directive 511 Article 27(3) of the Commission's 2011 Proposed Procedures Directive 512 Article 27(4) of the Commission's 2011 Proposed Procedures Directive 513 Article 27(5) of the Commission's 2011 Proposed Procedures Directive 514 Article 27(6) and 27(6)(e) of the Commission's 2011 Proposed Procedures Directive
} 
representations. Applications can only be considered unfounded if it has been established by the determining authority that the applicant does not qualify for international protection in accordance with the Qualification Directive ${ }^{515}$ that is, a seemingly more in-depth assessment must be made rather than just a prima facie assessment. An application can only be declared "manifestly unfounded" as a result of "an adequate and complete procedure". ${ }^{516}$ Irregular entry, of itself, is expressly no automatic ground for an accelerated examination procedure. ${ }^{517}$ In circumstances where the applicant's application may be considered inadmissible, ${ }^{518}$ the applicant is given the opportunity to have an interview prior to an admissibility decision being made. ${ }^{519}$

The Commission's 2011 Proposed Procedures Directive makes a number of changes to the 2009 Proposal, including, inter alia, the introduction of a "tangible prospects of success" threshold for the provision of free legal assistance at the appellate stage ${ }^{520}$ the possibility of Member States to derogate from the 72 hour period in which applicants are registered after making their application by extending the period by up to seven days, ${ }^{521}$ the reintroduction of the ability for Member States to reject (as opposed solely to discontinue) an applicant's application in the case of implicit withdrawal or abandonment of his or her application; ${ }^{522}$ the conduct of an accelerated procedure at the border, ${ }^{523}$ and the reintroduction of two existing, but modified, grounds for ordering the accelerated procedure. ${ }^{524}$

Given the number of versions of the Council's proposed amendments, only the Commission's 2011 Proposed Procedures Directive will be considered for the purposes of this book.

\footnotetext{
515 Article 28 of the Commission's 2011 Proposed Procedures Directive 516 Article 27(7) of the Commission's 2011 Proposed Procedures Directive 517 Article 27(9) of the Commission's 2011 Proposed Procedures Directive 518 Article 29 of the Commission's 2011 Proposed Procedures Directive 519 Article 30 of the Commission's 2011 Proposed Procedures Directive 520 Article 20(3) of the Commission's 2011 Proposed Procedures Directive 521 Article 6(4) of the Commission's 2011 Proposed Procedures Directive 522 Article 28(1) of the Commission's 2011 Proposed Procedures Directive 523 Articles 31(6) and 43 of the Commission's 2011 Proposed Procedures Directive 524 Articles 31(6)(e) of the Commission's 2011 Proposed Procedures Directive compared to Article 24(1)(g) of the current Procedures Directive (applicant has made improbable representation contradicting country of origin information); and Article 31(6)(g) of the Commission's 2011 Proposed Procedures Directive and Article 23(4)(m) of the current Procedures Directive (applicant as danger to national security)
} 


\subsection{Statistical Overview}

In 2011, the EU-27 countries received a total of 277,370 asylum applications, representing $63 \%$ of asylum claims in 44 industrialised countries and 0.6 claims per 1,000 inhabitants. ${ }^{525}$

The top-10 origin of asylum claims lodged in the EU-27 in 2011 was as follows:

\begin{tabular}{|l|r|}
\hline Origin & $\mathbf{2 0 1 1}$ \\
\hline Afghanistan & 26,159 \\
\hline Serbia (and Kosovo) & 19,072 \\
\hline Russian Federation & 15,045 \\
\hline Pakistan & 14,386 \\
\hline Iraq & 13,623 \\
\hline Islamic Republic of Iran & 10,789 \\
\hline Somalia & 10,656 \\
\hline Nigeria & 7,824 \\
\hline Bangladesh & 6,787 \\
\hline Syrian Arab Republic & 6,725 \\
\hline
\end{tabular}

Source: UNHCR 526

In 2010 (the full year's data for 2011 was not yet available), 222,105 first instance decisions were made. $75.19 \%$ of first instance decisions $(167,010)$ resulted in rejection, $12.18 \%(27,045)$ resulted in a grant of refugee status, $9.18 \%(20,400)$ resulted in a grant of subsidiary protection status, and $3.44 \%$ $(7,645)$ received permission to stay on humanitarian grounds. ${ }^{527}$

525 UNHCR, Asylum Levels and Trends in Industrialized Countries 2011, 27 March 2012, http://www.unhcr.org/4e9beaa19.html (last accessed 15 May 2012), Table 1, P.20

526 UNHCR, Asylum Levels and Trends in Industrialized Countries 2011, 27 March 2012, http://www.unhcr.org/4e9beaa19.html (last accessed 3 May 2012), Table 5, P.24

527 Eurostat, Asylum applicants and first instance decisions on asylum applications in 2010, 5/2011, 21 March 2011, P.10, Table 6a http://epp.eurostat.ec.europa.eu/cache/I TY_OFFPUB/KS-QA-11-005/EN/KS-QA-11-005-EN.PDF (last accessed 15 May 2012) 
Of the EU-27 countries, the top-10 countries for number of asylum claims lodged were as follows:

\begin{tabular}{|l|r|r|}
\hline Country & $\begin{array}{c}\text { Number of } \\
\text { asylum } \\
\text { claims } \\
\text { lodged }\end{array}$ & $\begin{array}{c}\text { Share of } \\
\text { claims } \\
\text { amongst } 44 \\
\text { industrialised } \\
\text { countries }\end{array}$ \\
\hline France & 51,910 & $12 \%$ \\
\hline Germany & 45,740 & $10 \%$ \\
\hline Italy & 34,120 & $8 \%$ \\
\hline Sweden & 29,650 & $6 \%$ \\
\hline Belgium & 25,980 & $6 \%$ \\
\hline United Kingdom & 25,420 & $3 \%$ \\
\hline Austria & 14,430 & $2 \%$ \\
\hline The Netherlands & 11,590 & $1 \%$ \\
\hline Greece & 9,310 & \\
\hline Poland & 5,190 & \\
\hline Source: UNHCR
\end{tabular}

Source: UNHCR ${ }^{528}$

However, of the EU-27 countries, the top 10 countries for the number of claims lodged per 1,000 people were as follows:

\begin{tabular}{|l|r|}
\hline Country & $\begin{array}{c}\text { Number of } \\
\text { asylum claims } \\
\text { per 1,000 } \\
\text { inhabitants }\end{array}$ \\
\hline Malta & 4.4 \\
\hline Luxembourg & 4.3 \\
\hline Sweden & 3.2 \\
\hline Belgium & 2.4 \\
\hline Austria & 1.7 \\
\hline Cyprus & 1.6 \\
\hline France & 0.8 \\
\hline Greece & 0.8 \\
\hline The Netherlands & 0.7 \\
\hline Denmark & 0.7 \\
\hline
\end{tabular}

Source: $\mathrm{UNHCR}^{529}$

528 UNHCR, Asylum Levels and Trends in Industrialized Countries 2011, 27 March 2012, http://www.unhcr.org/4e9beaa19.html (last accessed 15 May 2012), Table 1, P.20

529 UNHCR, Asylum Levels and Trends in Industrialized Countries 2011, 27 March 2012, http://www.unhcr.org/4e9beaa19.html (last accessed 15 May 2012), Table 1, P.20) 


\section{Chapter 3}

\section{Australia - A Constitution Without Citizenship}

\subsection{Australian Immigration and Notions of Citizenship}

Australia has had a somewhat tortured relationship with itself when it comes to the formation of its own identity - it has been wracked between competing notions of inclusion and exclusion. Indeed, the very premise of colonisation upon which modern Australia is built is cause for anxiety in itself. Before the commencement of European settlement in 1788, the Aboriginal and Torres Strait Islander peoples had continuously inhabited the island continent for at least 40,000 years. The legal fiction of terra nullius, which provided the legal basis of European settlement, was finally debunked in the landmark ruling of the High Court of Australia in $M a b o^{530}$ in 1992. Two points flow from this: firstly, modern non-Indigenous Australia is a nation of immigrants; and secondly, notions of sovereignty in the context of immigration may arguably be cast in a different light.

Indeed, modern Australia's anxiety about the make-up of its citizenship together with fears of being overrun by 'hordes from the north' may well stem from the fact that, as with anything in life, it is difficult to deal with an object with any degree of comfort, certainty or legitimacy that was not rightfully yours in the first place. In modern Australia's case, it determines who may enter and remain on a territory that was taken from its rightful owners territory which is integral to the culture and way of life of an ancient peoples.

Concurrent with the birth of the Commonwealth of Australia by a federation of the colonies in 1901, the Australian Constitution was, and still remains, silent on the matter of Australian citizenship, but provided powers for naturalisation and aliens, ${ }^{531}$ and immigration and emigration ${ }^{532}$ and quarantine. ${ }^{533}$ The silence of the Australian Constitution on the issue of Australian citizenship is profound - not only is there an absence of a description, but also its substance remains constitutionally undefined. However, this was by no means an accident rather, it was a conscious choice of the drafters resulting from seemingly

\footnotetext{
530 Mabo \& Others $v$ Queensland (No.2) [1992] HCA 23, per Brennan J at para 56

531 Section 51(xix) of the Australian Constitution

532 Section 51(xxvii) of the Australian Constitution

533 Section 51(ix) of the Australian Constitution - indeed, the quarantine power may also be a basis for controlling non-citizens (and, indeed, citizens) - see Bashford, A, and Strange, C, Asylum-Seekers and National Histories of Detention (2002) 48(4) Australian Journal of Politics and History 509, Pp.515-517
} 
insurmountable conceptual obstacles which led to Australian citizenship being "a mere legal inference". 534

There are two important points to note. Firstly, Australia did not become an independent nation at the time of Federation. ${ }^{535}$ Secondly, persons with the status of "subject of the Queen" extended to all those from colonies or dependencies under the British Empire, such that "no subject of the Queen was an alien in any part of Her Majesty's dominions". ${ }^{536}$ Rubenstein identifies three types of 'citizenship' at this time - firstly, British subjects resident in Australia; secondly, British subjects temporarily in Australia; and thirdly, nonBritish subjects and thus aliens. ${ }^{537}$ However, without a constitutional substantiation of citizenship, how was immigration to, and membership of, the Australian community to be governed? Indeed one of the driving forces towards Australian Federation was for the colonies to collectively resolve the issue of excluding Asian immigration (mainly Chinese), as well as excluding those from within the British Empire (such as Hong Kong Chinese and Indians) and the nearby Pacific Islanders ${ }^{538}$ as a way of protecting the Australian labour market and promoting racial homogeneity, the latter which was then particularly seen as essential to the future success of the country. ${ }^{539}$ What emanated from that conceptualisation for Australia was known as the White Australia Policy - a view that Australia should remain white and British.

One of the very first pieces of legislation enacted by the new Federal Parliament (and based on the White Australia Policy) ${ }^{540}$ was the Immigration Restriction Act of 1901. ${ }^{541}$ As Joppke notes, the White Australia Policy was "the

534 Rubenstein, K, Citizenship and the Constitutional Convention Debates: A Mere Legal Inference (1997) 25 Federal Law Review 295, Pp. 298-308; see also Crock, M, Defining Strangers: The Foundations for a Just Society (2007) 31 Melbourne University Law Review 1

535 Nolan v Minister for Immigration and Ethnic Affairs (1988) 165 CLR 178 at 183 per Mason CJ, Wilson, Brennan, Deane, Dawson and Toohey JJ.

536 Nolan v Minister for Immigration and Ethnic Affairs (1988) 165 CLR 178 at 184 per Mason CJ, Wilson, Brennan, Deane, Dawson and Toohey JJ

537 Rubenstein, K, Citizenship And The Centenary - Inclusion And Exclusion In 20th Century Australia (2000) 24 MULR 576, P.582

538 The obtaining and use of Kanaka indentured labour in the Queensland canefields is a horrific tale of abuse which Willard documents, Willard, M, History of the White Australia Policy to 1920, 1974, Melbourne University Press, Victoria, Pp.135-176, and which did not end until 1904, P.183.

539 Willard, M, History of the White Australia Policy to 1920, 1974, Melbourne University Press, Victoria, P.201; Hawkins, F, Critical Years in Immigration: Canada and Australia Compared, 2ed, 1991, McGill-Queens's University Press, P.12

540 Willard, M, History of the White Australia Policy to 1920, 1974, Melbourne University Press, Victoria, P.120

541 Indeed, the Immigration Restriction Act was preceded by the enactment of the Pacific Islander Labourers Act which provided for the deportation of Pacific Islanders, most notably some 10,000 working in Queensland and New South Wales. See National Archives of Australia, Documenting Democracy, Pacific Islanders Labourers Act 1901 (Cth) http://www.foundingdocs.gov.au/item.asp?dID=15, last accessed 5 August 2009, and also 
very fulcrum of Australian nation building and self-definition". ${ }^{542}$ In the absence of a founding myth or an enunciation of Australian citizenship ${ }^{543}$ in the Australian Constitution, Australia sought to define itself by who it kept out - namely Asians - fearing an invasion from its northernmost neighbours and drawing upon fears extending back to the arrival of Chinese immigrants on Australian gold fields in the mid-19 ${ }^{\text {th }}$ Century. ${ }^{544}$ However, it should also be noted the great reliance that Australia placed upon Britain for trade and (particularly naval) security, and in whose prestige (but not its class structure) in which it undoubtedly sought to bask. ${ }^{545}$

The key mechanism of the Act was contained in the infamous section 3(a), an Australianised version of the Natal Test ${ }^{546}$ adopted in South Africa. A person was a "prohibited immigrant" if, when asked to do so by an officer, "fails to write out at dictation and sign in the presence of an officer a passage of fifty words in an European language directed by the officer". "An European language" rather than "English" was chosen in the text of the Act so as not to dissuade European immigration ${ }^{547}$ nor to advantage Japanese immigrants. ${ }^{548}$ In 1905, the Act was amended to change the reference from an European language to a "prescribed language" to avoid further offence to the Japanese. ${ }^{549}$ Essentially, upon sight of the person seeking to enter Australia, a test in a language which the immigrant would surely not understand ${ }^{550}$ was

Hawkins, F, Critical Years in Immigration: Canada and Australia Compared, 2ed, 1991, McGillQueens's University Press, Pp.13-14.

542 Joppke, C, Selecting by Origin: Ethnic Migration in the Liberal State, 2005, Harvard University Press, Cambridge, MA, at P.43.

543 Indeed, "Australian citizenship" did not exist until the introduction of the Nationality and Citizenship Act 1948 (Cth) which only then theoretically included Aboriginals and Torres Strait Islander people (see Cameron, K, Aboriginal People Struggle for Citizenship Rights, http://www.abc.net.au/civics/democracy/struggle.htm last accessed 14 August 2009). Up until that time, a person was a "British subject", subsequently contemplated in the Nationality Act 1920 (Cth).

544 Hawkins, F, Critical Years in Immigration: Canada and Australia Compared, 2ed, 1991, McGill-Queens's University Press, P.11. See also generally, Willard, M, History of the White Australia Policy to 1920, (2ed) 1967, Melbourne University Press, Melbourne.

545 Hawkins, F, Critical Years in Immigration: Canada and Australia Compared, 2ed, 1991, McGill-Queens's University Press, P.23

546 Natal Act 1897, No.1, section 3

547 Yarwood, A. T., The Dictation Test - Historical Survey (1958) 30(2) Australian Quarterly 19, P.24

548 National Archives of Australia, Documenting Democracy, Immigration Restriction Act 1901 (Cth) http://www.foundingdocs.gov.au/item.asp?dID=16 last accessed 5 August 2009

549 Hawkins, F, Critical Years in Immigration: Canada and Australia Compared, 2ed, 1991, McGill-Queens's University Press, P.15. See also Yarwood, A. T., The Dictation Test Historical Survey (1958) 30(2) Australian Quarterly 19, P.26; Willard, M, History of the White Australia Policy to 1920, 1974, Melbourne University Press, Victoria, Pp.122-126.

550 Indeed as noted by Yarwood, if there was any doubt that the language was not to be known by the immigrant, then it was confirmed when the Senate rejected a motion 22:3 that the immigrant should know the language in which he or she would be tested - 
administered by the immigration officer, resulting in a failure of the test and with the consequence that the immigrant would be deemed a "prohibited immigrant". ${ }^{551}$ The White Australia Policy was notoriously effective - after 1909 no-one to whom the test was administered successfully passed. ${ }^{552}$

The Immigration Restriction Act also contained provisions for exemption certificates to be issued on the deposit of $£ 100$ but which could be cancelled by the Minister at any time, thereby rendering the person a prohibited immigrant. ${ }^{553}$ The Act also prohibited certain classes of persons, including potential "charges on the public" "idiots", "insane" persons, carriers of "infectious or dangerous diseases" or prostitutes. ${ }^{554}$

The Naturalisation Act 1903 (Cth) also buttressed the Immigration Restriction Act by excluding applications for naturalisation from those without British subject status who were "an aboriginal native of Asia, Africa, or the Islands of the Pacific" (but excluding New Zealand). ${ }^{555}$ That Act remained in force until it was replaced by the Commonwealth Nationality Act 1920 (Cth). Although the latter Act made no express references to the ethnic origins of applicants, it was perhaps unnecessary to do so given the largely impermeable fortress established by the Immigration Restriction Act as a 'first line of defence'. Indeed, the position towards Aboriginal and Torres Strait Islander peoples was also exclusionary. Although entitled to vote in all States except Queensland and Western Australia (and thus, by section 41 of the Australian Constitution, ${ }^{556}$ entitled to vote at the very first Federal election in 1901), the subsequent Commonwealth Franchise Act 1902 (Cth) expressly excluded "aboriginal native[s] of Australia" from voting unless entitled under section 41 of the Australian Constitution. ${ }^{557}$ However, a narrow interpretation of section 41 effectively meant that voting was restricted to those Aboriginal and Torres Strait Islander people who were enrolled to vote before 1902 - thereby resulting in gradual disenfranchisement. ${ }^{558}$

Yarwood, A. T., The Dictation Test - Historical Survey (1958) 30(2) Australian Quarterly 19, P.24

551 Joppke, C, Selecting by Origin: Ethnic Migration in the Liberal State, 2005, Harvard University Press, Cambridge, MA, at P.46.

552 National Archives of Australia, Documenting Democracy, Immigration Restriction Act 1901

(Cth) http://www.foundingdocs.gov.au/item.asp?dID=16 (last accessed 3 May 2012)

553 Sections 3(a), 4 and 6(a) Immigration Restriction Act 1901 (Cth)

554 Sections 3(b), (c), (d) and (f) Immigration Restriction Act 1901 (Cth)

555 Section 5, Naturalisation Act 1903 (Cth)

556 Section 41, Australian Constitution - "No adult person who has or acquires a right to vote at elections for the more numerous House of Parliament of a State shall, while the right continues, be prevented by any law of the Commonwealth from voting at elections for either House of the Parliament of the Commonwealth."

557 Section 4, Commonwealth Franchise Act 1902 (Cth)

558 Blackshield, T, and Williams, G, Australian Constitutional Law and Theory - Commentary and Materials, 2010, 5ed, Federation Press, Sydney, Pp.153-154 citing Stretton, P, and Finnimore, C, Black Fellow Citizens: Aborigines and the Commonwealth Franchise (1993) 25 Australian Historical Studies 521 
Notwithstanding that the application of the Immigration Restriction Act (later renamed the Immigration Act - but by no means any less restrictive) was primarily aimed at Asian and 'coloured' immigrants, it was also applied to Europeans. ${ }^{559}$ Indeed, one of the most vexing questions the High Court of Australia had to consider was whether (and, if so, to what extent) the Immigration Act applied to British subjects. ${ }^{560}$ In this sense, the High Court of Australia has played a determinative and pivotal role in the formation of Australian citizenship. ${ }^{561}$

The Immigration Restriction Act was the genesis of many features of Australian immigration policy that bear their mark even today. Firstly, as already noted, it played a pivotal role in attempting to define a national identity by a policy of exclusion and selectivity. Secondly, it embodied that immigration to Australia could be entirely controlled. ${ }^{562}$ Australia has the kind of "perfect storm" for immigration control - it is geographically remote and shares no common borders with any other country (notwithstanding its once common borders formerly with the Dutch, and latterly Indonesian, controlled West Papua when Papua and New Guinea was an Australian Territory). Accordingly, it is relatively easy to control migration flows and "pull factors" can be targeted to

559 See $R v$ Wilson, Ex parte Kisch (1934) 52 CLR 234; $R v$ Davey, ex parte Freer (1936) 56 CLR 381 - Mrs Freer was also a British subject - see Robertson, K (with Hohmann, J, and Stewart, I), Dictating to One of "Us": The Migration of Mrs Freer (2005) 5 MacqLJ 241, particularly at Pp.268-271. Indeed, Australians wishing to leave Australia or travel to particular parts of the world (such as Communist countries) also faced restrictions on the issue or cancellation of passports - for a fascinating account of this history, see, Doulman, $\mathrm{J}$, and Lee, D, Every Assistance and Protection - A History of the Australian Passport, 2008, Federation Press, Leichhardt.

560 See Potter $v$ Minahan (1908) 7 CLR 277 in which it was held that Minahan (born in Victoria, a British subject, of a seemingly British mother and a Chinese father who sought re-entry into Australia having left at the age of five years to join his father in China) was not an "immigrant" for the purposes of the Immigration Restriction Act because essentially he was 'retuning home'. Accordingly, the Act could apply to British subjects who were not 'returning home', including visitors, as in the case of $R v$ Macfarlane; Ex parte O'Flanagan and O'Kelly (Irish Envoys' Case) (1923) 32 CLR 518 per Isaacs J at 552-562. In Ex parte Walsh and Johnson; In re Yates (1925) 37 CLR 36, the "immigration" power did not apply to Johnson (having been born in Holland in 1895, migrating to New South Wales in 1910 and then having been naturalised in 1913) on account of him already being "a member of the Australian community".

561 See Rubenstein, K, Australian Citizenship Law in Context, 2002, Lawbook Co., Pyrmont, Chapter 5 and Pp.48-61; and Rubenstein, K, The High Court And The Shaping of Australian Citizenship, Paper presented to Individual, Community, Nation: 50 Years of Australian Citizen Conference, University of Melbourne, 21-23 July 1999, unpublished (copy held on file by author)

562 "The history of this country and its development has been and must inevitably be, largely the story of its policy with respect to population from abroad. That naturally involves the perfect control of the subject of immigration, both as to encouragement and restrictions with all their incidents. This control, I hold, the Commonwealth Parliament possesses in amplitude." [emphasis added] - $R$ v Macfarlane; Ex parte O'Flanagan and O'Kelly (Irish Envoys' Case) (1923) 32 CLR 518 per Isaacs J at 557 
specific (desired) groups. ${ }^{563}$ Thirdly, it instilled the notion of discretion into immigration - initially with the immigration officer and also with the Minister (a facet which still remains today) ${ }^{564}$ - thus keeping certain aspects of immigration closer to the heart of politics than to that of law. Fourthly, as Ang has noted, "while the legal and formal-political structures of the White Australia policy itself are no longer in place, the mentality it nurtured is still part of the deep structure of Australian culture." 565

In the period 1906 to 1914 saw 393,048 British migrants arrive in Australia, with just under half of those on assisted passage schemes. ${ }^{566}$ In the inter-war years, Hawkins notes immigration from Italy, Greece, Malta, Yugoslavia and other European countries and the at times antagonistic way in which they were received. ${ }^{567}$ Although Britain had assisted with emigration to its dominions since 1919 for its ex-servicemen, Hawkins attributes the British Empire Settlement Act of 1922 as the more generalised means by which Britain co-operated with dominion governments by way of assisted settlement schemes - resulting in 282,000 British migrants arriving in Australia with 212,000 the subject of assistance under the Empire Settlement Act. ${ }^{568}$

The events of WWII in the Pacific, and particularly Britain's inability to defend Australia (both during and after the war), dictated a new approach to Australian immigration that centred around a dramatic increase in population with security and economic objectives in mind. Within the context of the White Australia Policy, a program of planned immigration (with the goal of an annual increase in population of 1 per cent per annum) began under the slogan of "Populate or Perish". A combination of both "pull factors" and exclusionary elements were used. Initially it was envisaged that the bulk of immigration to Australia would be British (10 Britons to each 'foreigner'), ${ }^{569}$ and which was facilitated by generous assisted passage schemes. However, when numbers of Britons proved unforthcoming (due to shipping and labour shortages), 170,000 displaced Europeans were admitted between 1947 and

\footnotetext{
563 See Joppke, C, Selecting by Origin: Ethnic Migration in the Liberal State, 2005, Harvard University Press, Cambridge, MA, at P.47.

564 See Joppke, C, Selecting by Origin: Ethnic Migration in the Liberal State, 2005, Cambridge, MA, Harvard University Press at P.46

565 Ang, I, From White Australia to Fortress Australia: the anxious nation in the new century in Jayasuriya, L, Walker, D, and Gothard, J (eds), Legacies of White Australia: Race Culture and Nation, 2003, University of Western Australia Press, Crawley, P.52

566 Hawkins, F, Critical Years in Immigration: Canada and Australia Compared, 2ed, 1991, McGill-Queens's University Press, Pp.15-16

567 Hawkins, F, Critical Years in Immigration: Canada and Australia Compared, 2ed, 1991, McGill-Queens's University Press, P.26

568 Hawkins, F, Critical Years in Immigration: Canada and Australia Compared, 2ed, 1991, McGill-Queens's University Press, Pp.26-27

569 McMaster, D, Asylum Seekers - Australia's Response to Refugees, 2002, Melbourne University Press, Melbourne, P.43, citing Australian Prime Minister Arthur Calwell in November 1946.
} 
1952. Further, bilateral migration arrangements were signed with several European countries from the late 1950s, and assisted passage schemes extended to Europeans from the $1960 s .{ }^{570}$ During this time, Hawkins also notes the emphasis on "distinguished and highly qualified" migration for those of a nonEuropean background, ${ }^{571}$ a policy that McMaster describes as "explicitly selective". ${ }^{572}$ Throughout this period, an assimilationist policy (based on Anglo-Saxon norms) was pursued. ${ }^{573}$

The first legislative conceptualisation of Australian citizenship did not occur until the passing of the Nationality \& Citizenship Act 1948 (Cth). The Act essentially contemplated three categories of person: firstly, an alien (that is, "a person who is not a British subject, an Irish citizen or a protected person") ${ }^{574}$ secondly, a British subject; and thirdly, an Australian citizen. An Australian citizen (or a citizen of other prescribed countries ${ }^{575}$ was also a British subject. ${ }^{576}$ Australian citizenship was conferred by birth in Australia (ius soli), ${ }^{577}$ by descent, ${ }^{578}$ by registration (for British subjects) ${ }^{579}$ or by naturalisation (for aliens) ${ }^{580}$ Although a residence period of five years was applicable to both British subjects and aliens, the Minister, in the case of British subjects, was able (on application) to dispense with that residence requirement and citizenship could be granted to British subjects after 12 months' residence. ${ }^{581}$ Accordingly, the Act confirmed the preference for Britons over Europeans and nonEuropeans - the ability to confer Australian citizenship to British subjects represented one of the "pull factors" in the Government's armoury to draw Britons to Australia. Effectively, due to the residence requirements under the

\footnotetext{
570 Hawkins, F, Critical Years in Immigration: Canada and Australia Compared, 2ed, 1991, McGill-Queens's University Press, Pp.32-35; see also Jupp, J, From White Australia to Woomera - The Story of Australian Immigration, 2ed, 2007, Cambridge University Press, Melbourne, Pp.11-18

${ }^{571}$ Hawkins, F, Critical Years in Immigration: Canada and Australia Compared, 2ed, 1991, McGill-Queens's University Press, P.33

572 McMaster, D, Asylum Seekers - Australia's Response to Refugees, 2002, Melbourne University Press, Melbourne, P.48

573 Jupp, J, From White Australia to Woomera - The Story of Australian Immigration, 2ed, 2007, Cambridge University Press, Melbourne, Pp.11-18; McMaster, D, Asylum Seekers Australia's Response to Refugees, 2002, Melbourne University Press, Melbourne, Pp.46-47

574 Section 5(1), Nationality \& Citizenship Act 1948 (Cth)

575 United Kingdom and Colonies, Canada, New Zealand, the Union of South Africa, Newfoundland, India, Pakistan, Southern Rhodesia and Ceylon - section 7(2) Nationality and Citizenship Act 1948 (Cth)

576 Section 7, Nationality \& Citizenship Act 1948 (Cth)

577 Section 10, Nationality \& Citizenship Act 1948 (Cth) but note that the ius soli provision was changed in 1986 to those who were born in Australia to an Australian parent in response to Kioa $v$ West (1985) 159 CLR 550 - see Rubenstein, K, Citizenship And The Centenary - Inclusion and Exclusion In 20th Century Australia (2000) 24 MULR 576

578 Section 11, Nationality \& Citizenship Act 1948 (Cth)

579 Sections 12 and 13, Nationality \& Citizenship Act 1948 (Cth)

580 Sections 14 to 16, Nationality \& Citizenship Act 1948 (Cth)

${ }^{581}$ Section 12(1)(b), Nationality \& Citizenship Act 1948 (Cth)
} 
Act together with the effect of the Immigration Act, Australian citizenship was selectively applied and reflected an exclusionary policy consistent with the White Australia Policy. As Rubenstein notes, the Act was silent on the substantive rights, benefits and obligations of Australian citizenship which were (and remain) contained under individual pieces of legislation and the common law. ${ }^{582}$

Despite the lack of any express reference, Aboriginal and Torres Strait Islander people were theoretically included in the application of the Nationality $\&$ Citizenship Act. Notwithstanding changes introduced in the Commonwealth Electoral Act 1949 (Cth) which allowed all Aboriginal and Torres Strait Islander peoples entitled to vote at State elections to vote at Federal elections, ${ }^{583}$ it was not until the Commonwealth Electoral Act 1962 (Cth) that all Aboriginal and Torres Strait Islander people of voting age were given the right to vote. By the 1967 referendum, the exclusionary references to Aboriginal people were removed from the Australian Constitution. ${ }^{584}$

For Aboriginal and Torres Strait Islander people, the exclusion was not just in the suffrage. For most of the twentieth century up until the early 1970's both Commonwealth and State governments had pursued a policy of forced removal of Aboriginal children of mixed descent on the premise that they should be "merged" or "absorbed" into the white community or, after 1940, that they should be "assimilated" (more frequently referred to as "the Stolen Generations"). ${ }^{585}$ This had many tragic consequences for the Aboriginal children, families and communities. ${ }^{586}$ Following HREOC's 1997 report Bringing Them Home, the policy was revealed to consist of four major components: firstly, deprivations of liberty; secondly, abolition of parental rights; thirdly, abuses of power in the removal process; and fourthly, the breach of guardianship obligations. ${ }^{587}$ HREOC had no difficulty in concluding

582 Rubenstein, K, Citizenship And The Centenary - Inclusion and Exclusion In 20th Century Australia (2000) 24 MULR 576

583 Section 39(5)(aa) of the Commonwealth Electoral Act 1949 (Cth)

584 That is, the effect of the referendum was to remove the words "other than the Aboriginal race in any State" from section 51(xxvi) and to repeal section 127 of the Australian Constitution which excluded Aboriginal and Torres Strait Islander People from any census (that is, they were not, until 1967, counted as part of the population) - see Blackshield, T, and Williams, G, Australian Constitutional Law and Theory - Commentary and Materials, 2010, 5ed, Federation Press, Sydney, P.154

585 HREOC, National Inquiry into the Separation of Aboriginal and Torres Strait Islander Children from Their Families, Bringing Them Home, 1997, P.22-130. The Report notes that "[w]hereas 'merging' was essentially a passive process of pushing Indigenous people into the non-Indigenous community and denying them assistance, assimilation was a highly intensive process necessitating constant surveillance of people's lives, judged according to non-Indigenous standards": P.27

586 HREOC, National Inquiry into the Separation of Aboriginal and Torres Strait Islander Children from Their Families, Bringing Them Home, 1997,Part 3, Pp.131-214

587 HREOC, National Inquiry into the Separation of Aboriginal and Torres Strait Islander Children from Their Families, Bringing Them Home, 1997, P.218 
that the measures amounted to genocide and that the policy and legislation amounted to a crime against humanity. ${ }^{588}$

Although the frequently amended Immigration Restriction Act and the dictation test were replaced in 1958 with the current Migration Act and ministerial discretion respectively, the White Australia Policy remained applicable until 1973 when the Whitlam (Labor) government finally abandoned it in favour of a non-discriminatory policy and embraced multiculturalism, following their election to government in 1972. ${ }^{589}$

The embrace of multiculturalism was also, in some way, an attempt to forge a new national identity. In addition to the domestic pressures to end the policy, by the 1960s the White Australia policy became increasingly untenable as Australia became more economically integrated with Asia ${ }^{590}$ and was also the cause of a degree of international embarrassment, particularly amongst Australia's Asian neighbours. ${ }^{591}$ The untenability of the White Australia Policy was made conspicuous, as Joppke notes, by the abundance of European immigration (to the exclusion of Asian immigration) after WWII. ${ }^{592}$ Indeed, multiculturalism acknowledged the reality of the diverse make up of Australia's migration population. ${ }^{593}$

Having adopted the term from Canada, the Australian brand of multiculturalism was originally conceived by the then Minister for Immigration, Al Grasby, as "the family of the nation". As McMaster notes:

"This [cultural pluralism] included the preservation of ethnic traditions and languages, and their perpetuation into an indefinite future. 'Multiculturalism' was a term for a policy that sought restitution for the wrongs that immigrants had suffered, and it also applied to diversity in cultural attributes such as films, food and customs" 594

\footnotetext{
588 HREOC, National Inquiry into the Separation of Aboriginal and Torres Strait Islander Children from Their Families, Bringing Them Home, 1997, Pp.234-239

589 Jupp, J, From White Australia to Woomera - The Story of Australian Immigration, 2ed, 2007, Cambridge University Press, Melbourne, Pp.37-38; see also Hawkins, F, Critical Years in Immigration: Canada and Australia Compared, 1989, New South Wales University Press, Kensington, Pp.94-103

590 McMaster, D, Asylum Seekers - Australia's Response to Refugees, 2002, Melbourne University Press, Melbourne, P.47

591 Whitlam, G, The Whitlam Government 1972-1975, 1985, Penguin Books, Ringwood, Pp.494-495

592 See Joppke, C, Selecting by Origin: Ethnic Migration in the Liberal State, 2005, Harvard University Press, Cambridge, MA, at Pp.62-63

593 Jupp, J, From White Australia to Woomera - The Story of Australian Immigration, 2ed, 2007, Cambridge University Press, Melbourne; and Whitlam, G, The Whitlam Government 19721975, 1985, Penguin Books, Ringwood, P.495

594 McMaster, D, Asylum Seekers - Australia's Response to Refugees, 2002, Melbourne University Press, Melbourne, P.49
} 
Jupp characterised the Australian brand of multiculturalism as "an aspect of immigrant settlement policy". ${ }^{595} \mathrm{He}$ distinguished it from other countries' experiences by identifying that multiculturalism in Australia put:

"far less emphasis on civil rights and constitutional protections than does the American variety. It puts less emphasis on cultural maintenance than in the Canadian case. It does not endorse distinct cultural development, as in South Africa." 596

Among the legislative changes that the Whitlam government introduced included the introduction of the Racial Discrimination Act 1975 (Cth). However, the overall immigration intake was reduced. ${ }^{597}$ Whitlam also abolished the Department of Immigration, sending its various functions to other existing departments. ${ }^{598}$

Although commenced by the Whitlam government, the Fraser (Liberal/National Party ("LNP" or "Coalition")) government (1975-1983) is credited with multiculturalism's fruition in Australia. ${ }^{599}$ Multiculturalism was to occur around existing democratic structures, with due regard for existing social rights and obligations. ${ }^{600}$. It was to be inclusive of Anglo-Australians as much as the ethnic groups who were its principal aim. ${ }^{601}$ However, multiculturalism was not institutionally inclusive of Aboriginal and Torres Strait Islander peoples until 1989 and, even after that time, the inclusion of Aboriginal and Torres Strait Islander people into multiculturalism has been institutionally less than wholehearted. ${ }^{602}$

Immigration under the Fraser government (after re-establishing the Department) ${ }^{603}$ could be best described as progressive and liberal. It is

\footnotetext{
595 Jupp, J, From White Australia to Woomera - The Story of Australian Immigration, 2ed, 2007, Cambridge University Press, Melbourne, P.90

596 Jupp, J, From White Australia to Woomera - The Story of Australian Immigration, 2ed, 2007, Cambridge University Press, Melbourne, P.81

597 McMaster, D, Asylum Seekers - Australia's Response to Refugees, 2002, Melbourne University Press, Melbourne, Pp.49-50

598 Jupp, J, From White Australia to Woomera - The Story of Australian Immigration, 2ed, 2007, Cambridge University Press, Melbourne, Pp.37-38

599 Tavan, G, The long, slow death of White Australia, 2005, Scribe Publications, Carlton North, P.216

${ }^{600}$ Australian Population and Immigration Council and Australian Ethnic Affairs Council, Multiculturalism and its Implications for Immigration Policy (Canberra: Australian Government Printing Service, 1979) cited in Hawkins, F, Critical Years in Immigration: Canada and Australia Compared, 1989, New South Wales University Press, Kensington, P.233

${ }^{601}$ Hawkins, F, Critical Years in Immigration: Canada and Australia Compared, 1989, New South Wales University Press, Kensington, P.233

${ }^{602}$ Jupp, J, From White Australia to Woomera - The Story of Australian Immigration, 2ed, 2007, Cambridge University Press, Melbourne, Pp.95-97

${ }^{603}$ Hawkins, F, Critical Years in Immigration: Canada and Australia Compared, 1989, New South Wales University Press, Kensington, Pp.119-125
} 
characterised by the establishment of multicultural institutions and a "humane approach to refugees", ${ }^{604}$ as well as the institution of the NUMAS Numerical Multifactor Assessment System as a basis for immigration selection (a development that had partial genesis in the Whitlam government). ${ }^{605}$ McMaster notes that immigration policy remained distinct from refugee policy on account of "human need". ${ }^{606}$ It is during Fraser's Prime Ministership that Asian immigration significantly increased as a result of the arrival of Indochinese refugees (which will be discussed later). In the period 1975-1982, 68,877 Indochinese refugees arrived in Australia, including 2,059 that arrived by boat. ${ }^{607}$ The dearth of stated immigration policy and objectives as well as non-compliance (effectively the Department's largely unfettered discretion) met with the introduction of the Administrative Decisions (Judicial Review) Act 1977 (Cth) and the Freedom of Information Act 1982 (Cth), ${ }^{608}$ combined with the establishment of the Commonwealth Ombudsman in $1976 .{ }^{609}$ Fraser's government went some way to acknowledging and addressing problems concerning the operation of the Migration Act through a Joint Management Review report presented in July 1978 (which also drew attention to the lack of appeal procedures), ${ }^{610}$ and the immigration policy overall in the Green Paper entitled Immigration Policies and Australia's Population. ${ }^{611}$ Aboriginal and Torres Strait Islander people could also have their claims for title to traditional land recognised through the operation of the Aboriginal Land Rights (Northern Territory) Act 1976 (Cth) also passed under the Fraser Prime Ministership. ${ }^{612}$

Under the Hawke (1983-1993) and Keating (1993-1996) Labor governments, multiculturalism was still embraced. However, the Australian Institute of Multicultural Affairs was closed and the Office of Multicultural Affairs ("OMA") was established and placed within the Department of the Prime

\footnotetext{
${ }^{604}$ Jupp, J, From White Australia to Woomera - The Story of Australian Immigration, 2ed, 2007, Cambridge University Press, Melbourne, P.39

${ }^{605}$ Hawkins, F, Critical Years in Immigration: Canada and Australia Compared, 1989, New South Wales University Press, Kensington, Pp.140-146

606 McMaster, D, Asylum Seekers - Australia's Response to Refugees, 2002, Melbourne University Press, Melbourne, P.51

607 Viviani, N, The Long Journey, 1984, Melbourne University Press, Carlton, P.85

${ }^{608}$ Crock, M, and Berg, L, Immigration, Refugees and Forced Migration - Law, Policy and Practice in Australia, 2011, Federation Press, Leichhardt, Pp.115-117

${ }^{609}$ Ombudsman Act 1976 (Cth); see Hawkins, F, Critical Years in Immigration: Canada and Australia Compared, 1989, New South Wales University Press, Kensington, P.133; Crock, $\mathrm{M}$, and Berg, L, Immigration, Refugees and Forced Migration - Law, Policy and Practice in Australia, 2011, Federation Press, Leichhardt, P.116

${ }^{610}$ Crock, M, and Berg, L, Immigration, Refugees and Forced Migration - Law, Policy and Practice in Australia, 2011, Federation Press, Leichhardt, P.115-116; Hawkins, F, Critical Years in Immigration: Canada and Australia Compared, 1989, New South Wales University Press, Kensington, Pp.122-125, 133

${ }^{611}$ Hawkins, F, Critical Years in Immigration: Canada and Australia Compared, 1989, New South Wales University Press, Kensington, Pp.125-134

${ }^{612}$ See further, O’Neill, N, Rice, S, and Douglas, R, Retreat from Injustice - Human Rights Law in Australia, 2004, Federation Press, Leichhardt, Pp.610-620
} 
Minister and Cabinet. ${ }^{613}$ Multiculturalism was slightly qualified after the release of the Fitzgerald Report, which advocated a shift of emphasis towards skilled migration rather than family reunion or humanitarian streams. ${ }^{614} \mathrm{Jupp}$ notes the shift towards an economically rationalist immigration policy (that would later come to fruition under the subsequent Howard (1996-2007) LNP government). ${ }^{615}$ Debate also centred around the extent of immigration, particularly from Asia, with among the most conspicuous comments coming from historian Geoffrey Blainey ${ }^{616}$ and John Howard who lost his leadership of the Liberal Party as a result of, inter alia, calls for the reduction of Asian immigration. The era also saw a move towards a rule-based immigration system which removed discretion from the Minister but led to a multiplicity of visa categories, ${ }^{617}$ and also witnessed the establishment of appeals mechanisms such as the Immigration Review Tribunal in 1989 and the Refugee Review Tribunal in 1993. ${ }^{618}$ Mandatory detention was introduced in 1992. ${ }^{619}$ In response to Chinese nationals present in Australia after the Tiananmen Square Massacre, Temporary Protection Visas ("TPVs") were introduced. ${ }^{62}$ TPVs ended in 1993 but the Howard government later re-

613 Hawkins, F, Critical Years in Immigration: Canada and Australia Compared, 1989, New South Wales University Press, Kensington, P.239

614 McMaster, D, Asylum Seekers - Australia's Response to Refugees, 2002, Melbourne University Press, Melbourne, P.56; Jupp, J, From White Australia to Woomera - The Story of Australian Immigration, 2ed, 2007, Cambridge University Press, Melbourne, P.44, Pp.142145

615 Jupp, J, From White Australia to Woomera - The Story of Australian Immigration, 2ed, 2007, Cambridge University Press, Melbourne, Pp.44-46, 55-56

616 Castles, S, The Australian Model of Immigration and Multiculturalism: Is It Applicable to Europe? (1992) 26(2) International Migration Review 549 at P.555; Castles, S, and Vasta, E, New Conflicts Around Old Dilemmas in Cornelius, W.A., Tsuda, T, Martin, P.L., and Hollfield, J.F. (eds), Controlling Immigration - A Global Perspective, 2ed, 2004, Stanford University Press, Stanford, CA, Pp.141-177, via Google Books at http://books.google.com/books? id=i0d10wbGkWEC\&printsec $=$ frontcover\&source $=\mathrm{gbs} \_\mathrm{v}$ 2_summary_r\&cad $=0 \# \mathrm{v}=$ onepage $\& \mathrm{q}=\& \mathrm{f}=$ false $($ last accessed 5 April 2012), P.143; McMaster, D, Asylum Seekers - Australia's Response to Refugees, 2002, Melbourne University Press, Melbourne, P.56, Pp.146-152; Jupp, J, From White Australia to Woomera - The Story of Australian Immigration, 2ed, 2007, Cambridge University Press, Melbourne, Pp.109-110

617 Crock, M, and Berg, L, Immigration, Refugees and Forced Migration - Law, Policy and Practice in Australia, 2011, Federation Press, Leichhardt, Pp.121-123

618 Jupp, J, From White Australia to Woomera - The Story of Australian Immigration, 2ed, 2007, Cambridge University Press, Melbourne, P.45. For a history of these institutions, see Crock, M, and Berg, L, Immigration, Refugees and Forced Migration - Law, Policy and Practice in Australia, 2011, Federation Press, Leichhardt, Pp.564-570

619 North AM, Justice, and Decle, P., Courts and immigration detention: The Australian experience (2002) 10 AJ Admin L 5, P.12

${ }^{620}$ Jupp, J, From White Australia to Woomera - The Story of Australian Immigration, 2ed, 2007, Cambridge University Press, Melbourne, P.48 
introduced them. ${ }^{621}$ Significant changes were made to the Migration Regulations in 1989 and 1993, culminating in their present format in $1994 .^{622}$

A discrete but profound amendment to the Migration Act occurred in 1984 with the coming into force of the Migration Amendment Act 1983 (Cth) which removed references to "aliens" and "immigrants" under the Act and introduced the statutory term and definition of "non-citizen". ${ }^{623}$ Bailey observes that this had a significant impact on the common law in relation to aliens which was effectively replaced by the legislative introduction of "noncitizen" together with the later insertion of the (now) section 4 of the Migration Act in $1992^{624}$ whose object, inter alia, is to "cover the field" in relation to the treatment of non-citizens in furtherance of "the national interest". ${ }^{625}$ Accordingly, this legislative demarcation between citizens and non-citizens meant that the rights of non-citizens were then dealt with as contemplated by the Act and by the executive. ${ }^{626}$ Cancellation of visas by the Minister on the grounds of failing 'the character test' were also introduced in 1992, which would later play a significant role in the deportation of long-term residents. $^{627}$

In relation to Australian Indigenous affairs, the historic $M a b o{ }^{628}$ decision (referred to at the beginning of this Chapter) by the High Court of Australia debunked the common law legal fiction of terra nullius and recognised the claims to native title at common law of the Meriam people. Having been introduced into Parliament by Prime Minister Keating, the Native Title Act 1993 (Cth) was subsequently passed to protect and recognise native title interests in land. ${ }^{629}$

The election of the Howard government in 1996 marked a clear shift from the policies not only of the preceding Labor government under Hawke and Keating, but also from that of the Fraser government. Firstly, although not

${ }^{621}$ Jupp, J, From White Australia to Woomera - The Story of Australian Immigration, 2ed, 2007, Cambridge University Press, Melbourne, P.48

${ }^{622}$ Crock, M, and Berg, L, Immigration, Refugees and Forced Migration - Law, Policy and Practice in Australia, 2011, Federation Press, Leichhardt, Pp.123-126

${ }^{623}$ See section 4 of the Migration Amendment Act 1983 (Cth) which removed the terms "alien" and "immigrant" and inserted the definition "non-citizen"

${ }^{624}$ See section 3 of the Migration Reform Act 1992 (Cth)

${ }^{625}$ Bailey, P, The Human Rights Enterprise in Australia and Internationally, 2009, Butterworths, P.790

${ }^{626}$ Bailey, P, The Human Rights Enterprise in Australia and Internationally, 2009, Butterworths, Pp.790-791. Bailey charts the consequences of this approach including on citizenship and British subjects from Pp.791-797.

${ }^{627}$ Foster, M, An "Alien" by the barest of threads - the legality of the deportation of long-term residents from Australia, (2009) 33(2) MULR 483, Pp.507-511

${ }^{628}$ Mabo \& Others $v$ Queensland (No.2) [1992] HCA 23

629 O'Neill, N, Rice, S, and Douglas, R, Retreat from Injustice - Human Rights Law in Australia, 2004, Federation Press Leichhardt, Pp.642-655; Bailey, P, The Human Rights Enterprise in Australia and Internationally, 2009, Butterworths, Pp.728-740 
dispensing with multiculturalism altogether, ${ }^{630}$ the Howard government "cracked the institutional bones of multicultural reforms". ${ }^{631}$ The OMA was transferred from the Department of Prime Minister and Cabinet to the Department of Immigration (which subsequently became the Department of Immigration and Multicultural Affairs) but, as McMaster notes, the OMA was effectively killed off due to no additional funding being provided for it. ${ }^{632}$ Later, in 2001, the Department also encompassed Indigenous affairs to become the Department of Immigration Multicultural and Indigenous Affairs. Jupp pointedly notes that a "ministry of other people" had been created. ${ }^{633}$ Secondly, there was a step back towards assimilationist policies with an emphasis on English language skills tests ${ }^{634}$ and the introduction of a citizenship test in $2006 .{ }^{635}$ Thirdly, in terms of overall policy, there was an increased focus on skilled migration and a reduction in family reunion migration and the capping of the humanitarian intake. ${ }^{636}$

However, it was the entry into Parliament in 1996 and the subsequent rise of Pauline Hanson that would set Howard and immigration policy on a course from which Australia has not fully retreated. Hanson ran for the seat of Oxley, originally as a Liberal candidate but comments she made about Aboriginal people before the election resulted in the revocation of her Liberal party endorsement. ${ }^{637}$ She ran as an independent and won her seat. In her maiden parliamentary speech, she stated, inter alia:

"Immigration and multiculturalism are issues that this government is trying to address, but for far too long ordinary Australians have been kept out of any debate by the major parties. I and most Australians want out immigration policy radically reviewed and that of multiculturalism abolished. Between 1984 and 1995, 40\% of

${ }^{630}$ Baringshorst, S, Policies of Backlash: Recent Shifts in Australian Migration Policy (2004) 6(2) Journal of Comparative Policy Analysis: Research and Practice 131, Pp.143-144

631 Baringshorst, S, Policies of Backlash: Recent Shifts in Australian Migration Policy (2004) 6(2) Journal of Comparative Policy Analysis: Research and Practice 131, P.142

${ }^{632}$ McMaster, D, Asylum Seekers - Australia's Response to Refugees, 2002, Melbourne University Press, Melbourne, P.62

633 Jupp, J, From White Australia to Woomera - The Story of Australian Immigration, 2ed, 2007, Cambridge University Press, Melbourne, P.96; See also Crock, M, and Berg, L, Immigration, Refugees and Forced Migration - Law, Policy and Practice in Australia, 2011, Federation Press, Leichhardt, P.49

${ }^{634}$ McMaster, D, Asylum Seekers - Australia's Response to Refugees, 2002, Melbourne University Press, Melbourne, P.62

${ }^{635}$ See Tavan G, Chapter 7 - Testing Times in Tavan, G, and Neumann, K (eds) Does History Matter - Making and debating citizenship, immigration and refugee policy in Australian and New Zealand, 2009, Australian National University E-Press, Canberra, http://epress.anu.edu.au/anzsog/immigration/html/frames.php (last accessed 5 April 2012); Jupp, J, From White Australia to Woomera - The Story of Australian Immigration, 2ed, 2007, Cambridge University Press, Melbourne, P.199

636 McMaster, D, Asylum Seekers - Australia's Response to Refugees, 2002, Melbourne University Press, Melbourne, P.61

${ }^{637}$ Jupp, J, From White Australia to Woomera - The Story of Australian Immigration, 2ed, 2007, Cambridge University Press, Melbourne, P.125 
all migrants coming into this country were of Asian origin. They have their own culture and religion, form ghettos and do not assimilate". 638

In her view, Hanson saw multiculturalism, immigration and programmes for Aboriginal people as divisive and discriminatory against the white AngloSaxon population. Howard's initial response to her was silence - he did not come out and speak against Hanson until 8 May 1997 - almost eight months after her maiden speech. ${ }^{639}$ That silence meant that Howard did not distance himself from Hanson's rhetoric and thereby did not also potentially alienate voters sympathetic to her views. Hanson's rise and her subsequent popularity (she later formed the One Nation party - attracting support away from the coalition Government) gave space and oxygen to prejudices and fears within the Australian community ${ }^{640}$ - a facet that was recognised and utilised by Howard in his subsequent reaction to asylum seekers in the lead up to the 2001 election. The handling of the Tampa crisis and its utility in the 2001 Federal election (discussed later) led Marr and Wilkinson to observe:

“Pauline Hanson's One Nation Party completely disintegrated. John Howard had carried off perhaps the most remarkable tactical feat of his career: destroying her party without alienating her supporters. Their votes cemented his victory." 641

Indeed, it was this very approach that allowed Howard to both eliminate an undermining political force and at the same time ensure that those voters returned to support the Liberal/National Party. As we shall see below, this had profound effects on asylum seekers who metamorphosed into the means to Howard's political end. It is a legacy and discourse that, notwithstanding a change of government in 2007 and the passing of more than ten years since Tampa, remains a difficult one to shake. Joppke notes that Hanson's stance did not have any significant effect on immigration policy as Howard ultimately confirmed his government's commitment to a non-discriminatory immigration policy. ${ }^{642}$ But that observation does not reveal the full picture. That Howard did not return to a racially discriminatory legal migration policy is true, but Hanson's impact would be felt more strongly in relation to irregular migration and asylum seekers.

${ }^{638}$ Hanson, Pauline, Maiden Speech, 10 September 1996, Hansard, 38 th Parliament, First Session, First Period, http://www.aph.gov.au/Hansard/reps/dailys/dr100996.pdf (last accessed 5 April 2012), Pp.3860-3863 at P.3862,

639 McMaster, D, Asylum Seekers - Australia's Response to Refugees, 2002, Melbourne University Press, Melbourne, P.154

${ }^{640}$ Jupp, J, From White Australia to Woomera - The Story of Australian Immigration, 2ed, 2007, Cambridge University Press, Melbourne, P.134-135

${ }^{641}$ Marr, D, and Wilkinson, M, Dark Victory, (2ed), 2004, Allen \& Unwin, Crows Nest, P. 381

642 Joppke, C, Selecting by Origin: Ethnic Migration in the Liberal State, 2005, Harvard University Press, Cambridge, MA, P.88; see also Baringshorst, S, Policies of Backlash: Recent Shifts in Australian Migration Policy (2004) 6(2) Journal of Comparative Policy Analysis: Research and Practice 131, Pp.143-144 
In 1998 the character test provisions of the Migration Act were enhanced in favour of the Minister. Those provisions were the subject of some notoriety under the Howard government (and, indeed, continue to be) given their use to cancel the visas of long-term residents, resulting in their deportation. ${ }^{643}$ Cancellations of visas on this ground have also resulted in the detention of former visa holders.

In the last year of the Howard government, the Australian Citizenship Act 2007 (Cth) was introduced (with the chief parts effective from 1 July 2007) ${ }^{644}$ which replaced the Australian Citizenship Act 1948 (Cth). Citizenship could now be conferred firstly, if the parent is an Australian citizen or permanent resident at the time of birth, or the child has been ordinarily resident in Australia for 10 years from birth; ${ }^{645}$ secondly, if the person is adopted $;{ }^{646}$ thirdly, if the child is abandoned; ${ }^{647}$ fourthly, by way of territory being incorporated into Australia; ${ }^{648}$ and lastly, by application and conferral. ${ }^{649}$ Provision was also made for the resumption of Australian citizenship ${ }^{650}$ and the citizenship test. ${ }^{651}$ Generally, permanent residency is a requirement for eligibility for citizenship by conferral. ${ }^{652}$

In relation to Indigenous affairs, some of the provisions of the Native Title Act 1993 (Cth) introduced by the Keating government had been pared back following the High Court decision in $W i k^{653}$ which held that pastoral leases did not necessarily extinguish native title. ${ }^{654}$ Other aspects of indigenous policy included the dismantling of the Aboriginal and Torres Strait Islander Commission ("ATSIC"), the refusal of Howard to apologise on behalf of the government for previous governments' policies which saw the forced removal of Aboriginal children from their families. ${ }^{655}$ Howard's emphasis on "practical reconciliation" was considered by some as an assimilation policy in disguise. ${ }^{656}$

${ }^{643}$ Foster, M, An "Alien" by the barest of threads - the legality of the deportation of long-term residents from Australia, (2009) 33(2) MULR 483, Pp.509-514

${ }^{644}$ Section 2 of the Australian Citizenship Act 2007 (Cth)

645 Section 12 of the Australian Citizenship Act 2007 (Cth)

646 Section 13 of the Australian Citizenship Act 2007 (Cth)

647 Section 14 of the Australian Citizenship Act 2007 (Cth)

648 Section 15 of the Australian Citizenship Act 2007 (Cth)

${ }^{649}$ Sections 19G-28 of the Australian Citizenship Act 2007 (Cth)

${ }^{650}$ Sections 28A-32 of the Australian Citizenship Act 2007 (Cth)

${ }^{651}$ Section 23A of the Australian Citizenship Act 2007 (Cth)

${ }^{652}$ Section 21 of the Australian Citizenship Act 2007 (Cth)

${ }^{653}$ Wik Peoples $v$ Queensland [1996] HCA 40

${ }^{654}$ Bailey, P, The Human Rights Enterprise in Australia and Internationally, 2009, Butterworths, Chatswood, Pp.737-738

655 Robbins, J, The Howard Government and Indigenous Rights: An Imposed National Unity? (2007) 42(2) AJPS 315; see also Ryan, N, A decade of social policy under John Howard: social policy in Australia (2005) 33(3) Policy and Politics 451; Howard-Wagner, D, Legislating away Indigenous Rights (2008) 12 Law Text Culture 45

656 Short, D, Reconciliation, Assimilation and the Indigenous Peoples of Australia (2003) 24(4) International Political Science Review 491, P.503 
Pauline Hanson's view that Aboriginal people were somehow 'privileged' over the Anglo-saxon population seemed to resonate in some of the measures adopted under the Howard government. ${ }^{657}$ Late in Howard's Prime Ministership, the government reacted by a military intervention in the Northern Territory following the Little Children are Sacred report which outlined the abuse of children in Aboriginal communities. ${ }^{658}$ The Northern Territory Emergency Response Act 2007 (Cth) was passed - legislation of extraordinary reach and impact which, Bailey notes, made no reference to the term "child", "minor" or "children" in the Act, but provided for such measures including the suspension of the Racial Discrimination Act 1975 (Cth), the compulsory acquisition of Aboriginal land, income management restrictions and the imposition of controls on the sale of alcohol. ${ }^{659}$ The measures were the subject of sharp criticism by the UN Special Rapporteur on the situation of human rights and fundamental freedoms of indigenous people. ${ }^{660}$ Following the election of the Rudd Labor government (discussed below), the suspension of the Racial Discrimination Act was repealed, but the income management measures are now applied on a 'non-discriminatory' basis within "selected locations" 661 (such as the trial about to be undertaken in Bankstown, in Sydney's west, ${ }^{662}$ where a large Middle-Eastern community

657 Howard-Wagner, D, Legislating away Indigenous Rights (2008) 12 Law Text Culture 45 658 Northern Territory Government, Board of Inquiry into the Protection of Aboriginal Children from Sexual Abuse, Ampe Akelyernemane Meke Mekarle - Little Children are Sacred, 2007, http://www.inquirysaac.nt.gov.au/pdf/bipacsa_final_report.pdf (last accessed 8 April 2012); Bailey, P, The Human Rights Enterprise in Australia and Internationally, 2009, Butterworths, Chatswood, Pp769-774

659 Bailey, P, The Human Rights Enterprise in Australia and Internationally, 2009, Butterworths, Chatswood, Pp.769-774; see also Howard-Wagner, D, Restoring Social Order through Tackling 'Passive Welfare': The Statutory Intent of the Northern Territory and National Emergency Response Act 2007 (Cth) and Social Security and Other Legislation Amendment (Welfare Payment Reform) Act 2007 (Cth) (2007-2008) 19 Current Issues in Criminal Justice 243

660 United Nations, High Commissioner for Human Rights, Special Rapporteur on the situation of human rights and fundamental freedoms of indigenous people, James Anaya, Statement of the Special Rapporteur on the situation of human rights and fundamental freedoms of indigenous people, James Anaya, as he concludes his visit to Australia, 27 August 2009, http://www.unhchr.ch/huricane/huricane.nsf/view01/313713727C084992C125761F0044 3D60?opendocument (last accessed 5 May 2012)

661 Australian Government, Parliament of Australia, Department of Parliamentary Services, Parliamentary Library, Buckmaster, L, Spooner, D, and Magarey, K, Income Management and the Racial Discrimination Act, 20 March 2012, http://parlinfo.aph.gov.au/parlInfo/ download/library/prspub/1511200/upload_binary/1511200.pdf;fileType=application/pdf (last accessed 5 May 2012), particularly at P.14

662 Australian Government, Parliament of Australia, Department of Parliamentary Services, Parliamentary Library, Buckmaster, L, Spooner, D, and Magarey, K, Income Management and the Racial Discrimination Act, 20 March 2012, http://parlinfo.aph.gov.au/parlInfo/ download/library/prspub/1511200/upload_binary/1511200.pdf;fileType=application/pdf (last accessed 5 May 2012), P.5; see also Australian Government, Department of Families, Housing, Community Services and Indigenous Affairs, Place Based Income Management in 
resides). However, the measures raise serious issues of indirect discrimination. ${ }^{663}$

With the election of Kevin Rudd's Labor government (2007-2010), followed by Julia Gillard (who defeated Kevin Rudd in an internal leadership contest in 2010 before holding a general election in which her government was returned to office) (2010-present), differences from the previous Howard government's policies included an emphasis on sponsored skilled migration (that is, employment was preferred over independent migration), a de-coupling of student migration from permanent migration (as migrants were shown to be coming to Australia for permanent migration rather than predominantly educational or vocational purposes, as well as in response to the mushrooming of educational institutions incentivising permanent migration at the expense of the quality of the qualifications on offer), and a broadening of qualities seen as priorities for migrants to have (such as English language qualifications and work and skills experience). ${ }^{664}$ The policy marks a shift from an emphasis on permanent migration to temporary skilled migration, with employer sponsorship as the keystone rather than the points-based test. ${ }^{665}$ The Pacific Seasonal Workers Scheme was also introduced in 2008, which enables nationals from Pacific countries (Kiribati, Papua New Guinea, Tonga, Vanuatu, later expanded to Nauru, Solomon Islands, and Tuvalu in 2011) to work as seasonal workers (not dissimilar to the former German guest worker

Bankstown, http://www.families.fahcsia.gov.au/sites/default/files/documents/income_mgt_ bankstown.pdf (last accessed 5 May 2012)

${ }_{663}$ Australian Human Rights Commission, Stronger Futures in the Northern Territory Bill 2011 and two related Bills - Australian Human Rights Commission - Submission to the Senate Community Affairs Legislation Committee, 6 February 2012, http://www.hreoc.gov.au/legal/submissions/2012/20120206_stronger.pdf (last accessed 5 May 2012), P.31

${ }^{664}$ Crock, M, and Berg, L, Immigration, Refugees and Forced Migration - Law, Policy and Practice in Australia, 2011, Federation Press, Leichhardt, Pp.240-241; 314-318; Crock, M, First Term Blues: Labor, Refugees and Immigration Reform, May 2010, Sydney Law School Legal Studies Research Paper 10/43, P.11. For the policy rationales and outcomes concerning the linking of educating foreign students in Australia and permanent migration, see Markus, A, Jupp, J, and McDonald, P, Australia's Immigration Revolution, 2009, Allen \& Unwin, Crows Nest, Pp.11-13

665 Armitage, C, Australia a world leader in skilled migration, Sydney Morning Herald, 9 April 2012, http://www.smh.com.au/opinion/political-news/australia-a-world-leader-in-skilledmigration-20120408-1wjm0.html (last accessed 9 April 2012) 
programme). ${ }^{666}$ The program has recently been extended to Australia's horticultural industries. ${ }^{667}$

In relation to Indigenous affairs, Prime Minister Rudd on 13 February 2008 delivered an apology in Parliament to the Aboriginal and Torres Strait Islander peoples for past government policies, particularly in relation to the forced removal of Aboriginal children from their families ("the Stolen Generations"). ${ }^{668}$ However, the Northern Territory intervention that commenced under the Howard Government, appears set to continue in modified form if the Stronger Futures in the Northern Territory Bill 2011 (Cth) and related Bills are passed by Parliament. In addition to the concerns of outlined earlier, the AHRC has expressed its further concerns about these measures in its submission to the Senate Community Affairs Legislation Committee, particularly in relation to the inadequacies of consultation with Aboriginal communities. ${ }^{669}$ The Committee delivered its report on 14 March $2012 .{ }^{670}$

Accordingly, as Crock points out, Australian citizenship (both legally and notionally) has inter alia "been shaped in large measure by migration law". 671 Indeed, Australian citizenship has been the negative imprint left behind from, inter alia, the die of migration law. Australia has adopted some brutal means to

666 Australian Government, Department of Immigration and Citizenship, Pacific Seasonal Workers Scheme, http://www.immi.gov.au/skilled/pacific-seasonal-worker/ (last accessed 7 April 2012); Australian Government, Department of Immigration and Citizenship, Pacific Seasonal Workers Scheme - What's New, http://www.immi.gov.au/skilled/pacificseasonal-worker/whats-new.htm (last accessed 7 April 2012). In relation to the challenges faced under this scheme, see Ball, R, Beacroft, L, and Lindley, J, Australia's pacific seasonal worker pilot scheme: managing vulnerabilities to exploitation, November 2011, Australian Institute of Criminology, Trends and Issues in Crime and Criminal Justice, No.432, P.1

667 Australian Government, Department of Immigration and Citizenship, Pacific Seasonal Workers Scheme, Program Announcement for Pacific Seasonal Workers, http://www.immi.gov.au/skilled/pacific-seasonal-worker/papsw.htm (last accessed 7 April 2012)

${ }^{668}$ A full transcript of the then Prime Minister's speech can be found at the Parliament of Australia website, http://parlinfo.aph.gov.au/parlInfo/search/display/display.w3p;query=Id\%3A\%22chamber \%2Fhansardr\%2F2008-02-13\%2F0003\%22 (last accessed 8 April 2012)

669 Australian Human Rights Commission, Stronger Futures in the Northern Territory Bill 2011 and two related Bills - Australian Human Rights Commission - Submission to the Senate Community Affairs Legislation Committee, 6 February 2012, http://www.hreoc.gov.au/legal/ submissions/2012/20120206_stronger.pdf (last accessed 7 April 2012)

670 Parliament of Australia, Senate Community Affairs Legislations Committee, Stronger Futures in the Northern Territory Bill 2011 and two related bills, http://www.aph.gov.au/ Parliamentary_Business/Committees/Senate_Committees?url=clac_ctte/strong_future_nt_ 11/report/index.htm (last accessed 7 April 2012)

${ }_{671}$ Crock, M and Berg, L, Immigration, Refugees and Forced Migration - Law, Policy and Practice in Australia, 2011, Federation Press, Leichhardt, P.39. See also in relation to the legal and social notions of Australian citizenship: Rubenstein, K, Citizenship in Australia: Unscrambling its meaning (1995) 20 MULR 503 
develop its own notion of citizenship including exclusion from entry and expulsion on racial grounds, an exclusionary attitude towards its Indigenous people that, in relation to the Stolen Generation, HREOC (now AHRC) has identified as genocide, and the deportation of long-term residents on character grounds. We shall see that asylum seekers and their detention also forms part of this matrix of exclusion. Australia has, in a legal context, sought to define its notion of citizenship by who it was not. Migration law has played a significant role as an exclusionary device and even today, the conceptualisation of "citizen" and "non-citizen" in the Migration Act is reflective of that philosophy. It is perhaps that binary conceptualisation, combined with the over-arching objectives of the Migration Act, that institutionalises a kind of paranoia and anxiety that leaves little room for empathy. Due to the legislative (as opposed to constitutional) basis of citizenship, Crock has rightly described Australian citizenship as being fragile. ${ }^{672}$ As Foster observes "in Australian constitutional law we ask not 'who is the citizen?', but rather 'who is the citizen's Other?", ${ }^{673}$ The flipside to exclusion, of course, is selectivity. Australia has also used the law to attract and select those it considers desirable to form part of its community through the use of assisted passage schemes, favourable or preferential terms for permanent residency and a path towards citizenship and, more recently, an emphasis on students and skilled migration. However, the underpinning of exclusionary and selective devices is predicated, in the Australian migration context, on complete control. As we shall see, this is quite dramatically highlighted in the case of asylum seekers.

\subsection{Australia and Asylum Seekers}

As with the notion of Australian citizenship, there is no over-arching asylum mythology in Australia that has guided the nation's policy in relation to refugees and asylum seekers. ${ }^{674}$ This has, at times, led to reactionary and ad hoc responses. But, more significantly, it has meant that asylum seekers have been forced into the matrix of immigration objectives (as opposed to humanitarian ones) and control.

In Australia, humanitarian concerns have been subordinated to immigration objectives - objectives set with the national self-interest in mind. Accordingly,

672 Crock, M, Defining Strangers: Human Rights, Immigrants and the Foundations for a Just Society (2007) 31 MULR 1, Pp.4-9

${ }^{673}$ Foster, M, An "Alien" by the barest of threads - the legality of the deportation of long-term residents from Australia, (2009) 33(2) MULR 483, Pp.490-491 referencing Macklin, A, Who is the Citizen's Other? Considering the Heft of Citizenship (2007) 8 Theoretical Inquiries in Law 333, P.335

${ }^{674}$ Cronin, K, A culture of control: an overview of immigration policy-making, in Jupp, J and Kabala, M, (eds), The Politics of Australian Immigration, 1993, Bureau of Immigration Research, Australian Government Printing Service, Canberra, P.87 
national self-interest has been the guiding principle in asylum matters which has manifested itself, inter alia, by selectivity, furthering international relations (as opposed to international standing), fluctuations in numbers depending on the suitability to Australia: Neumann's extensive research has identified these (and other factors) as the dominant elements of Australia's attitudes towards refugees from 1930 to 1973 - the learned author notes that humanitarian concerns per se were not a significant factor in measures taken by Australia. ${ }^{675}$ Those findings also present a useful prism through which to analyse more recent periods.

In order to realise immigration objectives, control over the entry and stay of non-nationals has been seen as essential. In the Australian immigration context, control policy may consist of two elements: firstly, there must be stringent control over non-nationals entering and remaining in Australia; and secondly, immigration must be "uncontroversial" or the public must be assured of the integrity of the system so as to assuage any fears that the country will be overrun. ${ }^{676}$ In this sense, Australia views asylum seekers as a "control failure $^{, 677}$ - they may arrive outside of formal control devices by which their intentions are assessed and vetted (namely visas) or, if entering on a valid visa, their intentions to stay permanently by subsequently seeking asylum represent 'a fly in the ointment' of planned immigration control.

Australia's response to refugees and asylum seekers may be broken up into five periods: from 1930-1973 (1973 marking the end of the White Australia Policy); from 1973-1996 (Fraser and Hawke/Keating governments); from 1996-2007 (Howard government) and from 2007 until the present (Rudd/Gillard government). Due to Neumann's already comprehensive treatment of the period from 1930-1945, that period will be dealt with by providing a summary of the learned author's work and chief findings, with a slightly more chronological approach adopted for the remaining periods.

\subsubsection{0-1973 - Early responses to refugees and asylum seekers}

Australia's response to asylum seekers and refugees was subsidiary to its overall immigration objectives throughout this period and is particularly demonstrated by post-WWII immigration to Australia. Although initially rejecting an offer by the UNRRA for 30,000 displaced persons in 1947, Australia later drew

\footnotetext{
${ }^{675}$ Neumann, K, Refuge Australia - Australia's Humanitarian Record, 2004, UNSW Press, Sydney, Pp.110-112

${ }^{676}$ Nicholls, G, Unsettling Admissions: Asylum Seekers in Australia (1998) 11(1) Journal of Refugee Studies 61, P.64 also citing Cronin, K, A culture of control: an overview of immigration policy-making, in Jupp, J and Kabala, M, (eds), The Politics of Australian Immigration, 1993, Bureau of Immigration Research, Australian Government Printing Service, Canberra, P.83104

${ }^{677}$ Cronin, K, A culture of control: an overview of immigration policy-making, in Jupp, J and Kabala, M, (eds), The Politics of Australian Immigration, 1993, Bureau of Immigration Research, Australian Government Printing Service, Canberra, P.86
} 
upon the mass of displaced persons in Europe when it was unable to meet its objectives of dramatically increasing its population by Britons resettling to Australia. Australia was not concerned with the well of suffering experienced by people in camps in Europe, but rather to seize (and competitively so) the opportunity to advance Australia by increasing its population. Between 1947 and 1954, 170,000 displaced persons were admitted for residence in Australia. Following the Hungarian Uprising in 1956, Hungarians were given residence in Australia initially as part of the regular migration programme, in order to make up a shortfall in the regular migration intake with the number of Hungarians being later extended by 5,000 places. Between 1952 and 1961, Yugoslavs, Italians departing Yugoslavia, White Russians, Dutch, Germans and Hungarians made up part of the 70,000 refugees that were resettled. ${ }^{678}$

Neumann's account of the period from 1930-1973 reveals eight major themes in relation to how Australia responded to refugees and asylum seekers during that period. Firstly, selectivity was applied (through the continued application of the White Australia Policy with exceptions only made on account of a person's usefulness and perceived ability to assimilate into Australia; the choice of persons from the Baltic countries due to their physical attractiveness; the imposition of strict age, health, family and gender guidelines; ${ }^{679}$ and the general disinterest in resettling "hard core" refugees or those with disabilities or medical problems). Secondly, as a complement to selectivity, the application of policies of exclusion (such as the initial reluctance to take Jews and the imposition of a quota in relation to their numbers, later withdrawn by the Menzies government; ${ }^{680}$ the discrimination faced by Sephardic Jews on account of being non-European; ${ }^{681}$ the willingness to assist Europeans as Dutch and British colonial rule came to an end in Africa and South East Asia but the anxiety surrounding Asian Kenyans and Asian Ugandans and the extremely limited numbers of Asian Ugandans allowed to resettle in Australia $^{622}$ ). Thirdly, seeing those asylum seekers outside its migration program

678 McMaster, D, Asylum Seekers - Australia's Response to Refugees, 2002, Melbourne University Press, Melbourne, Pp. 29, 33-36, 44

${ }^{679}$ McMaster notes that Australia preferred single men in good health before families, the elderly or the disabled which was later said to lead to isolation, loneliness and alcoholism for many such men in Australia: McMaster, D, Asylum Seekers - Australia's Response to Refugees, 2002, Melbourne University Press, Melbourne, P.46. Neumann notes that to be selected, one had to be under the age of 45 (single men, married couples with children) or under 40 for single women or married couples without children. Those with families were to consist of no more than two parents, and two children under the age of 14 with no health problems - see Neumann (2004) P.32

680 Although Neumann notes that some Jews entered Australia in the late 1930's on tourist visas, and some German Jews being permitted to stay on account of a flexible application of the White Australia Policy: see P.55. Erwin Kisch, a Czech anti-fascist, was prohibited from landing in Australia: see $R v$ Carter; Ex parte Kisch [1934] HCA 50

681 See also Gale, N, A case of double rejection: the immigration of Sephardim to Australia (1994) 20(2) Journal of Ethnic and Migration Studies 269

682 See also Neumann, K, "Our Interests Must Come First" - Australia's response to the expulsion of Asians from Uganda (2006) 3(1) History Australia 10.1 
in light of what advantage they could bring to Australia (noting the Petrov Affair; ${ }^{683}$ the anticipation of "defectors" who were of intelligence value and "refugees" who were perceived to only hold propaganda value in the preparation for the 1956 Melbourne Olympic Games). Fourthly, the furtherance of its international relations (particularly in relation to Indonesia after the end of Dutch colonial rule and the issue of West Papuans desire for independence and also seeking refuge in the Australian Territory of Papua and New Guinea ${ }^{684}$ and later by boat in the Torres Strait; and in relation to the United Kingdom in relation to Portuguese asylum seekers on account of the United Kingdom not wanting to upset its good relations with Portugal). Fifthly, Australia's lack of concern at its international standing (evidenced as outlined above in relation to its response to the expulsion of Asians from Uganda, particularly by Australia being unmoved by the United Kingdom's requests for assistance in that regard; and the evasion of the serious concerns of the UNHCR about West Papuans in the Australian Territory of Papua and New Guinea ${ }^{685}$ ). Sixthly, in relation to the exercise of control, Australia was concerned about the potential impact of the Geneva Convention on the ability to manage its own immigration program ${ }^{686}$ (and given the universal/non-European definition of refugee brought about in the 1967 Protocol sat in contradistinction to the White Australia Policy $\left.{ }^{687}\right)$. Seventhly, the use of deportation as an element of control to act as a deterrent and to remove persons "whose continued presence was regarded as a liability" ${ }^{6} 8$ (seen in the attempts after WWII to remove from Australia non-European wartime refugees and evacuees from Asia and the Pacific who were previously granted permissions to enter and remain for the duration of the war). Eighthly, the management of public concerns by taking an approach which was the least

${ }^{683}$ Neumann attributes the Petrovs as the first political refugees to be granted asylum in Australia due to their lack of a right to remain in the country: P.54

${ }^{684}$ See also Neumann, K, Been there, done that? in Lusher, D, and Haslam, N (eds) Yearning to Breathe Free: seeking asylum in Australia, 2007, The Federation Press, Annandale, Pp.21-32 at Pp. 26-27; Palmer, D, Between a Rock and a Hard Place: the Case of Papuan Asylum-Seekers (2006) 52(4) Australian Journal of Politics and History 576

${ }^{685}$ See also Neumann, K. Hush-hushing the whole matter: the UNHCR, Australia, and West Papuan Refugees (2006) 23(1) Refuge 69

686 Australia's concerns in relation to the application of the Geneva Convention (as identified by Neumann) were: firstly, the definition of "refugee" (that is, the prospect of non-European refugees); secondly, the non-discrimination obligation (as Australia had bonded refugees brought to Australia through the IRO to two years' employment, unlike for other residents); thirdly, provisions relating to non-punishment for unlawful entry; and fourthly, the provisions relating to deportation only on account of national security or public order: Pp.81-83

${ }^{687}$ For an alternative viewpoint on Australia's accession to the Geneva Convention and its Protocol, see Palmer, D, The quest for 'wriggle room': Australia and the Refugees Convention, 1951-1973 (2009) 63(2) Australian Journal of International Affairs 290 who challenges Neumann's interpretation at P.303

${ }^{688}$ Neumann, K, Refuge Australia - Australia's Humanitarian Record, 2004, UNSW Press, Sydney, P.103; see also Neumann, K, Asylum seekers, Willy Wong, and the uses of history: From 2010 to 1962, and back, (2011) 42 Australian Historical Studies 126 
likely to cause public concern on the one hand, but be unmoved by public opinion on the other. Neumann concluded that the Australian Government was, on the whole, less likely to shift its policies due to public opinion and, in contrast to more recent times, did not incite public opinion against refugees and asylum seekers. ${ }^{689}$

However, Neumann's most significant conclusion is that humanitarian concerns were not a major factor in dealing with refugees and asylum seekers during this period. ${ }^{60}$

\subsubsection{3-1996 The Whitlam, Fraser, and Hawke/Keating Governments}

\subsubsection{The Whitlam Government 1973-1976}

The Whitlam government's ending of the White Australia policy in immigration, generally, also coincided with 2500 East Timorese boat arrivals over August and September 1975 (who were given a temporary status to remain) and coincided with the fall of Saigon in April 1975. ${ }^{691}$ Whitlam was not particularly minded to facilitate the resettlement of Vietnamese refugees to Australia, ${ }^{692}$ believing that it was ultimately a United States responsibility and accordingly set very restrictive criteria for their entry, predominantly based on pre-existing links to Australia with the result that only 542 applications were approved out of 5629 applications. ${ }^{693}$ Further limited numbers arrived after an urgent UNHCR request. ${ }^{694}$

\subsubsection{The Fraser Government 1976-1983}

The succeeding Fraser government eventually oversaw a comprehensive strategy to resettle Indo-Chinese refugees in Australia. Immediately after taking office, admitted numbers increased. ${ }^{695}$ Although the independent arrival of asylum seekers by boat was not unprecedented (see above), Indo-Chinese refugees began arriving by boat on Australia's shores in April 1976. 51 boats carrying 2011 refugees had arrived by June 1979 with most being granted

\footnotetext{
689 Neumann, K, Refuge Australia - Australia's Humanitarian Record, 2004, UNSW Press, Sydney

${ }^{690}$ Neumann, K, Refuge Australia - Australia's Humanitarian Record, 2004, UNSW Press, Sydney, P.112

${ }^{691}$ Hawkins, F, Critical Years in Immigration: Canada and Australia Compared, 1989, New South Wales University Press, Kensington, Pp.170-171

692 Tavan, G, The long, slow death of White Australia, 2005, Scribe Publications, Carlton North, P.205. Whitlam was infamously quoted as saying that he "was not having hundreds of fucking Vietnamese Balts coming into this country with their religious and political hatreds against us" - see Tavan, P.205 n.48 citing Cameron, C, China, Communism and Coca-Cola, 1980, Hill of Content, Melbourne, P.230

${ }^{693}$ Hawkins, F, Critical Years in Immigration: Canada and Australia Compared, 1989, New South Wales University Press, Kensington, P.171

${ }^{694}$ Hawkins, F, Critical Years in Immigration: Canada and Australia Compared, 1989, New South Wales University Press, Kensington, P.172

${ }^{695}$ Hawkins, F, Critical Years in Immigration: Canada and Australia Compared, 1989, New South Wales University Press, Kensington, Pp.171
} 
refugee status courtesy of the Determination of Refugee Status (DORS) committee established by the Fraser government in $1977 .{ }^{696}$ However, the non-statutorily-based DORS committee merely provided non-binding recommendations for the exercise of the Minister's broad discretion, with no appeal or review rights and whose composition and function, in Schloenhardt's view, supports the contention that "refugees were just another, more difficult, class of immigrants, and not a humanitarian exception." "697

A Senate Standing Committee on Foreign Affairs and Defence published a report in 1976 indicating that guidelines should be adopted to enable the government to respond to refugee crises as they occur. It does not appear that Committee suggested that the guidelines would be outside the realm of the overall immigration program, but that they should be "identifiable". ${ }^{698}$ As the Migration Act at the time vested large amounts of discretion in the Minister, in 1977 a policy (as opposed to law) was formulated with four principles identified: the first was that Australia recognised "its humanitarian commitment and responsibility to admit refugees for resettlement"; the second, "[t]he decision to accept refugees must always remain with the Government of Australia", suggests that the humanitarian program was integrated within the sphere of immigration (albeit as a discernible component) rather than as an element which stood outside it. ${ }^{699}$

Following the 1979 Geneva Conference, the Orderly Departure Program ${ }^{700}$ was instituted which significantly reduced the number of refugee boats leaving Vietnam. ${ }^{701}$ However, that program was bookended in Australia by tougher legislation dealing with unauthorised entry into, and presence in, Australia, ${ }^{702}$

696 Hawkins, F, Critical Years in Immigration: Canada and Australia Compared, 1989, New South Wales University Press, Kensington, P.173; McMaster, D, Asylum Seekers Australia's Response to Refugees, 2002, Melbourne University Press, Melbourne, P.52; Schloenhardt, A, Australia and the Boat-People: 25 Years of Unauthorised Arrivals 2000 23(3) UNSWLJ 33, P.36

697 Schloenhardt, A, Australia and the Boat-People: 25 Years of Unauthorised Arrivals 2000 23(3) UNSWLJ 33, P.36-37

698 Hawkins, F, Critical Years in Immigration: Canada and Australia Compared, 1989, New South Wales University Press, Kensington, Pp.177

699 Parliament of Australia, House of Representatives, The Hon M. MacKellar, Minister for Immigration and Ethnic Affairs, Refugee Policy and Mechanisms, 24 May 1977; the remaining two elements were "3. Special assistance will often need to be provided for the movement of refugees in designated situations or for their resettlement in Australia. 4. It may not be in the interest of some refugees to settle in Australia. Their interests may be better served by resettlement elsewhere. The Australian government makes an annual contribution to the UNHCR which is the main body associated with such resettlement."

700 Kumin, J, Orderly Departure From Vietnam: Cold War Anomaly or Humanitarian Innovation? (2008) 27(1) RSQ 104

701 Hawkins, F, Critical Years in Immigration: Canada and Australia Compared, 1989, New South Wales University Press, Kensington, P.180-182

702 Schloenhardt, A, Australia and the Boat-People: 25 Years of Unauthorised Arrivals 2000 23(3) UNSWLJ 33, Pp.37-39 
including the Immigration (Unauthorised Arrivals) Act 1980 (Cth) which severely penalised $(\$ 100,000)$ or jailed (10 years imprisonment) non-citizens who brought more than five unauthorised arrivals to Australia. ${ }^{703}$ What is revealing is the then Minister Macphee's second reading speech in relation to the then Bill. The Minister noted the establishment of the refugee resettlement program with Vietnam, and that the Act was "not intended to have a deleterious effect on innocent passengers". However, the Minister stated:

\begin{abstract}
"Genuine refugees have nothing to fear in seeking Australian Government assistance. That is not to say that we will always be in a position to accept without question large numbers of refugees who push their claims for resettlement ahead of their compatriates who wait patiently in camps overseas. The Convention provides that we should offer asylum to genuine refugees presenting themselves here. That does not mean that Australia is bound to resettle them here. We must retain the right to make satisfactory arrangements in appropriate cases for refugees who should be resettled elsewhere. [emphasis added]"704
\end{abstract}

What we begin to see, therefore, is the emergence of the characterisation of "good" refugees (that wait) and "bad" refugees (that arrive outside the resettlement program and without valid visas). The Act was an attempt to plug the gap in the control dam - indeed, the Minister stated that the Bill was seen by the Government as "an essential part of maintaining immigration controls and believes that it will provide an effective deterrent to the operators of vessels who may consider bringing unauthorised persons to Australia". ${ }^{705}$ This emerging characterisation was to resonate more loudly in the years to come.

In 1981 the Global Special Humanitarian Program was introduced which oversaw the admittance of persons who may not fit under the Geneva Convention definition but who were the subject of serious human rights abuses. ${ }^{706}$ Nicholson notes that the effect of this was not to initiate a broader

703 Sections 5 to 9 of the Immigration (Unauthorised Arrivals) Act 1980 (Cth); see Hawkins, F, Critical Years in Immigration: Canada and Australia Compared, 1989, New South Wales University Press, Kensington, P.202 (incorrectly cited as the Immigration (Unauthorised Arrivals) Amendment Bill 1980 (Cth) which was later passed to extend the operation of the principal Act to Christmas Island).

${ }^{704}$ Parliament of Australia, House of Representatives, The Hon Ian Macphee, Minister For Immigration and Ethnic Affairs, Second Reading Speech, Immigration (Unauthorised Arrivals) Bill 1980, 1 May 1980, http://parlinfo.aph.gov.au/parlInfo/search/display/display.w3p;adv $=$ yes;orderBy $=$ customrank;page $=0 ;$ query $=$ AuthorSpeakerReporter\%3Amacphee\%20Datase t \%3Ahansardr,hansardr80\%20Decade $\% 3 \mathrm{~A} \% 221980 \mathrm{~s} \% 22 \% 20$ Year $\% 3 \mathrm{~A} \% 221980 \% 22 ;$ rec $=14$; resCount $=$ Default (last accessed 18 April 2012)

${ }^{705}$ Parliament of Australian, House of Representatives, The Hon Ian Macphee, Minister For Immigration and Ethnic Affairs, Second Reading Speech, Immigration (Unauthorised Arrivals) Bill 1980, 1 May 1980; see also Smit, J H, Malcolm Fraser's response to 'commercial' refugee voyages (2010) 8(2) Journal of International Relations (Dhaka University, Bangladesh) 76 (also available at http://ro.ecu.edu.au/ecuworks/6218/ (last accessed 10 July 2012))

706 Jupp, J, From White Australia to Woomera - The Story of Australian Immigration, (2ed), 2007, Pp.182.183; McMaster, D, Asylum Seekers - Australia's Response to Refugees, 2002, Melbourne University Press, Melbourne, Pp.54-55; Hawkins, F, Critical Years in 
category of eligible persons under the Geneva Convention definition in a domestic legal context (as had been done in Canada and the United States), but to create distinct eligibility criteria applicable offshore. ${ }^{707}$ This appears to have had the effect of maintaining control by instituting a voluntary program offshore rather than supplementing the Geneva Convention definition domestically so that international obligations would not arise if such similarly eligible persons were to apply for asylum onshore in Australia. ${ }^{708}$ Further, the eligibility criteria was predicated on pre-existing ties to Australia. ${ }^{709}$

Viviani's account of the eligibility criteria adopted in response to the IndoChinese refugees over the period 1975-1982 reveals a three-pronged basis in addition to falling under the "blanket" application of the definition of refugee (that is, for those unsettled Indo-Chinese outside Vietnam): firstly, family reunion; secondly, the ability to settle well in Australia; and thirdly, for humanitarian reasons. ${ }^{710}$ From 1979, the objective was set to accept 10 per cent of persons on humanitarian grounds. ${ }^{711}$ The inference to be drawn is that the remainder were chosen on family reunion and suitability for settlement grounds. Under the suitability for settlement category, emphasis was initially placed on the applicant's "association with Australia" and, when this proved difficult to satisfy, resort was had to fulfilling migration criteria as a way of establishing suitability to settle, followed by the applicant's personal characteristics and qualifications. ${ }^{712}$ Selectors placed emphasis on the perceived ability of the applicant to get a job in Australia, which indirectly placed importance on having skills and qualifications, with consequences for the demographic of those accepted (young men and married couples without children preferred over large families, single women, the aged and the illiterate) and which the government strove to redress. ${ }^{713}$ Skill-based selection was thought to lead to an expansion of the middle class. ${ }^{714}$ Indeed, the conclusion that one draws is that Australia's national self-interest was, at the very least, an important consideration.

\footnotetext{
Immigration: Canada and Australia Compared, 1989, New South Wales University Press, Kensington, P.188

707 Nicholls, G, Unsettling admissions: asylum seekers in Australia (1998) 11(1) Journal of Refugee Studies 62 Pp.68-69

708 Nicholls, G, Unsettling admissions: asylum seekers in Australia (1998) 11(1) Journal of Refugee Studies 62, P.69, gives the example of domestic violence to women which would not otherwise have been a ground for the recognition of protection obligations onshore ${ }^{709}$ Hawkins, F, Critical Years in Immigration: Canada and Australia Compared, 1989, New South Wales University Press, Kensington, P.188; Nicholls, G, Unsettling admissions: asylum seekers in Australia (1998) 11(1) Journal of Refugee Studies 62, Pp.72-73

710 Viviani, N, The Long Journey, 1984, Melbourne University Press, Carlton, Pp.116-118

711 Viviani, N, The Long Journey, 1984, Melbourne University Press, Carlton, P.125

712 Viviani, N, The Long Journey, 1984, Melbourne University Press, Carlton, P.120

713 Viviani, N, The Long Journey, 1984, Melbourne University Press, Carlton, Pp.121-122

714 Viviani, N, The Long Journey, 1984, Melbourne University Press, Carlton, P.124
} 
As Australia's focus began shifting towards deterring economic migrants, the approach from 1982 onwards resulted in more stringent, individually-based criteria being applied to the determination of refugee status for Indo-Chinese refugees, rather than the more generalised UNHCR approach that had been adopted up to that time. ${ }^{715}$

The period also saw the resettlement of more than 12,000 Lebanese refugees. ${ }^{716}$ In the period 1975-1985, Australia had resettled 96,262 IndoChinese refugees. ${ }^{717}$ In the period 1975-1991 a relatively small number of Vietnamese and Cambodians (2,500) arrived by boat in Australia. ${ }^{718}$ From 1981 to 1989, no further Indo-Chinese refugees arrived by boat in Australia. ${ }^{719}$

\subsubsection{1991-1996 The Hawke Government and the 1991-1996 Keating Government}

The Hawke government was characterised by six changes of Ministers for Immigration which had a resulting impact on discerning a coherent policy during this time. ${ }^{720}$ As discussed above, the focus during the Hawke government moved from refugee and family reunion intake, to a more economically rationalist focus, further emphasised by the FitzGerald Report of 1988, which recommended reducing humanitarian intakes. Both the Hawke and Keating governments are characterised by the genesis of seemingly extreme lengths taken to ensure government control over immigration generally, as well as selectivity in the treatment various humanitarian groups.

After no boat arrivals of asylum seekers since 1981, in late 1989 Cambodian asylum seekers began arriving by boat in Australia, with a further group arriving in the first half of 1990. The government response was to detain the asylum seekers (some for as long as four years ${ }^{721}$ ) and to deny their claims for

715 McMaster, D, Asylum Seekers - Australia's Response to Refugees, 2002, Melbourne University Press, Melbourne, Pp.53-54; Nicholls, G, Unsettling admissions: asylum seekers in Australia (1998) 11(1) Journal of Refugee Studies 62, P.68; Viviani, N, The Long Journey, 1984, Melbourne University Press, Carlton, P.127

716 Hawkins, F, Critical Years in Immigration: Canada and Australia Compared, 1989, New South Wales University Press, Kensington, P.172

717 Hawkins, F, Critical Years in Immigration: Canada and Australia Compared, 1989, New South Wales University Press, Kensington, P.176

718 McMaster, D, Asylum Seekers - Australia's Response to Refugees, 2002, Melbourne University Press, Melbourne, P.54

719 Australian Government, Department of Immigration and Citizenship, Submission to the Joint Select Committee on Australia's Immigration Detention Network, September 2011, http://www.immi.gov.au/media/publications/pdf/2011/diac-jscaidn-submission-

sept11.pdf (last accessed 7 August 2012), P. 166

720 Jupp, J, From White Australia to Woomera - The Story of Australian Immigration, (2ed), 2007, Pp.42-43

$721 A v$ Australia UNHRC Communication No. 560/1993, UN Doc. CCPR/C/59/D/560/1993, 30 April 1997 
asylum. ${ }^{722}$ Their arrival marked the beginning of the mandatory detention policy in Australia. Foreign Minister Gareth Evans (who played a significant role in the Cambodian Peace $\mathrm{Plan}^{723}$ ) and Prime Minister Hawke dubbed them "economic migrants", ${ }^{724}$ Legislation was hastily passed which deemed the arrivals "designated persons", made their detention mandatory (initially limited to 273 days, or until they departed Australia or were given permission to enter Australia), ${ }^{725}$ and precluded a Court from ordering their release. ${ }^{726}$ After being detained for two years, the High Court challenge in Chu Kheng Lim v Minister for Immigration Local Government and Ethnic Affairs confirmed the legality of their detention but held as invalid the legislation's purported ousting of its jurisdiction to review detention. ${ }^{727}$ However, the law only tells half the story. The government reaction was also influenced by the significance of Australia's role in brokering the Cambodian Peace Plan in Paris in early 1990 with one of the objectives being to deal with the refugee situation. ${ }^{728}$ For Australia to have recognised the refugee status of the Cambodian asylum seekers would have seriously compromised the negotiations with Cambodia. ${ }^{729}$ Nicholls notes that the Cambodian Peace Plan "led to attempts to supress any asylum caseload from that country." ${ }^{, 730}$ Eventually, in 1993, arrangements were made for the return of the detained persons to Cambodia where, after 12 months, they could apply for sponsored entry into Australia - those remaining

722 McMaster, D, Asylum Seekers - Australia's Response to Refugees, 2002, Melbourne University Press, Melbourne, P.73

${ }_{723}$ Scott, K, Gareth Evans, 1999, Allen \& Unwin, St Leonards, Pp.262-273

${ }^{724}$ Crock, M, Saul, B, and Dastyari, A, Future Seekers II, 2006, Federation Press, Leichhardt, Pp.36

${ }^{725}$ However, the 273 day time limit was subject to exceptions under section $54 \mathrm{Q}$ of the Migration Act, as Crock notes "such as the hearing of court or tribunal actions, or time taken by a person outside the control of the Department to furnish information": Crock, M, Climbing Jacob's Ladder: the High Court and the Administrative Detention of Asylum Seekers in Australia, (1993) 15 Sydney Law Review 338, P.347

726 Then section 54R, a provision which still exists as section 183 of the Migration Act 1958 (Cth) (discussed below); see Crock, M, and Berg, L, Immigration, Refugees and Forced Migration - Law, Policy and Practice in Australia, 2011, Federation Press, Leichhardt, P.60

${ }_{727}$ Chu Kheng Lim v Minister for Immigration Local Government and Ethnic Affairs (1992) 176 CLR 1 at 35-37. Crock notes that the survival of section 54R into the current section 183 results from the High Court's narrow reading of that provision such that it does not preclude a Court ordering the release of an unlawfully detained person: see Crock (2011), P.66, n.87, see also Crock, M, Climbing Jacob's Ladder: the High Court and the Administrative Detention of Asylum Seekers in Australia, (1993) 15 Sydney Law Review 338, Pp.350-351; Kneebone, S, The Australian Story: Asylum Seekers Outside the Rule of Law in Kneebone, S, (ed), Refugees, Asylum Seekers and the Rule of Law, 2009, CUP, Cambridge, Pp.185-189

728 McMaster, D, Asylum Seekers - Australia's Response to Refugees, 2002, Melbourne University Press, Melbourne, P.75; see also Crock, M, Saul, B, and Dastyari, A, Future Seekers II, 2006, Federation Press, Leichhardt, Pp.36

729 McMaster, D, Asylum Seekers - Australia's Response to Refugees, 2002, Melbourne University Press, Melbourne, Pp.75-76 citing Crock, M, in Selby, H, (ed) Tomorrow's Law, 1995, Federation Press, Leichhardt, P.35

${ }^{730}$ Nicholls, G, Unsettling admissions: asylum seekers in Australia (1998) 11(1) Journal of Refugee Studies 62, P.75 
in Australia at the end of 1995 were granted entry on humanitarian grounds. ${ }^{731}$ The approach that Australia detain unauthorised arrivals (including throughout the determination of the refugee process) was confirmed in a report by the Joint Standing Committee on Migration in $1994 .{ }^{732}$

The treatment of the Cambodian asylum seekers can be juxtaposed against the wholesale sanctuary offered to around 20,000 Chinese students in Australia following the Tiananmen Square Massacre. ${ }^{733}$ It was in response to that announcement by Prime Minister Hawke that Temporary Protection Visas ("TPVs") of four years' duration were introduced in 1990 but, owing to the relative unattractiveness of TPVs to potential employers, ${ }^{734}$ and the uncertainty it caused to its holders, ${ }^{735}$ were withdrawn at the end of 1993.

Refugees and asylum seekers were subordinated to the pursuit of national interest in the views of the National Population Council's Refugee Review in 1991. In this sense, it became clear that the National Population Council considered refugees and asylum seekers as another form of migrant, rather than a humanitarian exception. ${ }^{736}$

In 1992 the Global Special Humanitarian Program continued augmented by the Special Assistance Category. ${ }^{737}$ However, the program drew criticism for excluding persons of Asian origin, ${ }^{738}$ whilst benefitting persons from, inter alia, the former Yugoslavia and Bosnia. ${ }^{739}$ Colic-Peisker has argued that the government's preference for former Yugoslavs and Bosnians throughout the 1990s (that is spanning both Hawke/Keating and Howard governments) was

\footnotetext{
731 McMaster, D, Asylum Seekers - Australia's Response to Refugees, 2002, Melbourne University Press, Melbourne, P,88-89; see also Nicholls, G, Unsettling admissions: asylum seekers in Australia (1998) 11(1) Journal of Refugee Studies 62, P.67

732 Parliament of Australia, Joint Standing Committee on Migration, Asylum Border Control and Detention, 1994, Australian Government Printing Service, Canberra paras 4.152-4.153, Pp.148-149. Note, however, the dissenting report of Senator Christabel Chamarette.

733 Nicholls, G, Unsettling admissions: asylum seekers in Australia (1998) 11(1) Journal of Refugee Studies 62, P.63

${ }^{734}$ Jupp, J, From White Australia to Woomera - The Story of Australian Immigration, (2ed), 2007, Pp.187, 48

735 Schloenhardt, A, Australia and the Boat-People: 25 Years of Unauthorised Arrivals 2000 23(3) UNSWLJ 33

736 National Population Council (Australia), The National Population Council's refugee review, 1991, Australian Government Printing Service, Canberra, Pp. 12-14; 37-39, noting Recommendation 3; also noting P.41, Recommendation 33; P.51, Recommendation 42; and Pp.51-52, Recommendation 43

737 Jupp, J, From White Australia to Woomera - The Story of Australian Immigration, (2ed), 2007, Pp.182; Nicholls, G, Unsettling admissions: asylum seekers in Australia (1998) 11(1) Journal of Refugee Studies 62, P.69

738 McMaster, D, Asylum Seekers - Australia's Response to Refugees, 2002, Melbourne University Press, Melbourne, P-.58-59

739 Jupp, J, From White Australia to Woomera - The Story of Australian Immigration, (2ed), 2007, P.183;
} 
on account of their perceived assimilability (particularly within existing such communities in Australia), but which overlooked the significant barriers faced by persons after arrival (particularly language) such that their social and economic integration was never as extensive as first contemplated. ${ }^{740}$

The international resettlement (Orderly Departure) program for Indo-Chinese refugees first commenced under the Fraser government in 1979 was internationally re-affirmed as the Comprehensive Plan of Action ("CPA") in 1989 as numbers of Indo-Chinese refugees entering refugee camps in South East Asia began to increase after a largely successful international resettlement program between 1980-1986. ${ }^{741}$ Those Vietnamese that had been resettled in China, however, began to arrive independently by boat in Australia in 1994 stemming from their displacement due to the Chinese government's plans for land redevelopment, ${ }^{742}$ as well as others remaining in camps throughout South East Asia. ${ }^{743}$ The government's response was to amend the Migration Act in 1994 to prevent persons covered by the CPA (and which presumably included those screened out by the $\mathrm{CPA}^{744}$ ) from making an application for asylum in Australia or who resided in a "safe third country" - for those Indo-Chinese (and, from early 1995, other Chinese nationals ${ }^{75}$ ), China was declared a "safe third country", ${ }^{746}$ and were subsequently removed back to China. ${ }^{747}$

In addition to the introduction of mandatory detention in 1992, other legislative amendments for those seeking asylum in Australia where introduced in three phases, some of which proved highly restrictive. Indeed, as will be explored later in this book, many of these elements exist in identical or more restrictive forms today. Firstly, in 1989, changes included the introduction of mandatory removal of an unauthorised arrival after a period of 28 days, strict control provisions relating to documentation, wider search and arrest powers of immigration officials, and the creation of the Migration Internal Review Organisation (MIRO) and the Immigration Review Tribunal (IRT) (but

\footnotetext{
740 Colic-Peisker, V, 'At Least You're the Right Colour': Identity and Social Inclusion of Bosnian Refugees in Australia (2005) 31(4) Journal of Ethnic and Migration Studies 615

${ }^{741}$ Robinson, W. C., The Comprehensive Plan of Action for Indochinese Refugees, 1989-1997: Sharing the Burden and Passing the Buck (2004) 17(3) Journal of Refugee Studies 319, P.320

${ }^{742}$ Schloenhardt, A, Migrant Smuggling: Illegal Migration and Organised Crime in Australia and the Asia Pacific Region, 2003, Brill, Leiden, P.77

${ }^{743}$ Schloenhardt, A, Australia and the Boat-People: 25 Years of Unauthorised Arrivals 2000 23(3) UNSWLJ 33, P.48

${ }^{744}$ Taylor, S, Australia's 'Safe Third Country' Provisions - Their Impact on Australia's Fulfillment of Its Non-Refoulement Obligations (1996) 15(2) University of Tasmania Law Review 196 at 211-212

745 Schloenhardt, A, Australia and the Boat-People: 25 Years of Unauthorised Arrivals 2000 23(3) UNSWLJ 33, P.50

746 Crock, M, in Selby, H, (ed) Tomorrow's Law, 1995, Federation Press, Leichhardt, Pp.4244

${ }^{747}$ Schloenhardt, A, Migrant Smuggling: Illegal Migration and Organised Crime in Australia and the Asia Pacific Region, 2003, Brill, Leiden, P.77
} 
which provided very limited means to appeal asylum decisions); secondly, between 1991-1993, the Protection Visa class was created with express reference to the Geneva Convention and its Protocol (initially as a temporary visa, then as a permanent visa), and the creation of the Refugee Review Tribunal (RRT) to review administrative decisions in relation to claims for asylum (with some avenues for judicial review); thirdly, from 1994, augmenting the "safe third country" concept, the Migration Act provided that further applications for protection visas could not be made once an application had been refused (which still exists as section 48A and 48B of the Act); fourthly, the Act was also amended so that any obligation to provide legal advice to a person in detention only arose when the person expressly asked for it (which still remains as section 256 of the Act). ${ }^{748}$

\subsubsection{6-2007 The Howard Government}

The Howard government's response to asylum seekers arguably represents one of the darkest chapters in Australia's humanitarian history. The measures adopted in response to asylum seekers were hard-hearted and, at times, extraordinary. What is often lost in analyses of the measures taken in this era was that a number of them were not without precedent and had their genesis under previous governments.

Although much focus has been placed on the Tampa incident in 2001 and the resulting legislation, a number of measures were taken before this time which made it increasingly difficult for asylum seekers. Tampa "galvanised, rather than generated"749 Australia's sweeping response to asylum seekers. Following the Howard government's election in 1996, the Special Assistance Category launched in 1992 was abolished. ${ }^{750}$ Further, the linking of 'places' between offshore and onshore asylum seekers was made - that is, for each onshore refugee accepted, the total available 'places' available for offshore resettlement was reduced by a corresponding number. ${ }^{751}$ This further cemented the conceptualisation of "good" and "bad" refugees that had its genesis under the Fraser government, and is again a measure indicative of attempts to control and cap immigration numbers.

In 1999 a series of six key legislative measures were taken. Firstly, criminal provisions were made for those that knowingly brought a group of five persons or more to Australia who would be unlawful non-citizens upon entry (including punishment by a 20 year prison sentence) and offences relating to

\footnotetext{
748 Schloenhardt, A, Australia and the Boat-People: 25 Years of Unauthorised Arrivals 2000 23(3) UNSWLJ 33, P.43-52

749 Grewcock, M, Shooting the passenger: Australia's war on illicit migrants, in Lee, M, (ed), Human Trafficking, 2007, Willan Publishing, Devon, Pp.178-209, P.187

750 Jupp, J, The Pacific Solution, (2002) 21 Dialogue 10, P.11

751 Nicholls, G, Unsettling admissions: asylum seekers in Australia (1998) 11(1) Journal of Refugee Studies 62, P.75; Schloenhardt, A, To Deter, Detain and Deny: Protection of Onshore Asylum Seekers in Australia (2002) 14 IJRL 302, Pp.304-305.
} 
the provision of false documentation in relation to a group of five persons or more, as well as increased penalties for other related offences. ${ }^{752}$ Secondly, in addition to legal advice only being facilitated when requested by persons in immigration detention, amendments to the Migration Act similarly now included the provision of visa application forms only when requested by the person in detention. ${ }^{753}$ Thirdly, the Border Protection Legislation Act 1999 (Cth) was passed which gave extensive powers for inter alia the pursuit, boarding, search and moving of Australian and foreign vessels and aircraft. ${ }^{754}$ The Act amended the Migration $A c t^{755}$ to authorise the detention of a ship and bringing it to a particular place ${ }^{756}$ and the detention of persons on board. ${ }^{757}$ Provisions also included boarding on the high seas in certain circumstances. ${ }^{758}$ Fourthly, in a move initially advocated by Pauline Hanson, ${ }^{759}$ Temporary Protection Visas (TPVs) were reintroduced, which denied permanent residency to successful onshore Protection Visa applicants and limited their lawful stay in Australia to three years, at the end of which they could only apply for a Protection Visa. ${ }^{760}$ TPVs denied rights to family reunion or the ability to reenter Australia - effectively marooning successful applicants in Australia away from family. ${ }^{761}$ Fifthly, in a similar fashion, Temporary Safe Haven Visas were introduced and adopted in relation to Kosovar and East Timor refugees. ${ }^{762}$ Sixthly, amendments to the Migration Act deemed Australia not to have protection obligations to those who did not avail themselves of any right they had to enter or reside (temporarily or permanently) in any country apart from Australia, or to those who were able to seek protection in another country having resided there for a period of at least seven days. ${ }^{763}$

\footnotetext{
752 Migration Legislation Amendment Act (No.1) 1999 (Cth), No. 89 of 1999

753 Migration Legislation Amendment Act (No.1) 1999 (Cth), No. 89 of 1999, now section 256 of the Migration Act 1958 (Cth)

${ }^{754}$ See further Crock, M, Saul, B, and Dastyari, A, Future Seekers II, 2006, Federation Press, Leichhardt, Pp.109-110

755 In addition to the Customs Act 1901 (Cth) and the Fisheries Management Act 1991 (Cth) which were also subject to amendments

756 Section $245 \mathrm{~F}(8)$ of the Migration Act 1958 (Cth)

757 Section 245F(9) of the Migration Act 1958 (Cth)

758 Section $245 \mathrm{G}$ of the Migration Act 1958 (Cth)

759 Jupp, J, The Pacific Solution, (2002) 21 Dialogue 10, P.14; Jupp, J, From White Australia to Woomera - The Story of Australian Immigration, (2ed), 2007, Pp.128,186-187

${ }^{760}$ Migration Amendment Regulations 1999 (No.12) (Cth), No. 243 of 1999; see further Schloenhardt, A, To Deter, Detain and Deny: Protection of Onshore Asylum Seekers in Australia (2002) 14 IJRL 302, P.309

${ }^{761}$ See further in relation to this and the 2001 amendments (discussed later) in Human Rights Watch, "By Invitation Only:" Australia's Asylum Policy, December 2002, Volume 14, No. 10 at Pp.81-90.

762 Migration Amendment Regulations 1999 (No.2) 1999 (Cth) No. 58 of 1999; see Crock, M, Saul, B, and Dastyari, A, Future Seekers II, 2006, Federation Press, Leichhardt, Pp.135-137; Jupp, J, From White Australia to Woomera - The Story of Australian Immigration, (2ed), 2007, P.187

${ }^{763}$ Schedule 1, Part 6, Border Protection Legislation Amendment Act 1999 (Cth); see sections 36(3) and $91(\mathrm{~N})$ of the Migration Act 1958 (Cth)
} 
On 26 August 2001, at the request of the Australian government, Captain Arne Rinnan of the Norwegian cargo vessel, the Tampa, rescued 433 persons (amongst which were Afghans, Sri Lankans, Pakistanis and Iraqis) from a sinking boat in international waters between Australia and Indonesia. ${ }^{764}$ In defiance of orders by the Australian government not to enter Australian waters, Rinnan did so with the wellbeing of those rescued and his crew in mind, taking the Tampa to the coast just off Christmas Island. The Tampa was subsequently boarded by armed SAS soldiers to ensure those rescued would not disembark. The asylum seekers never disembarked onto Australian land. They were subsequently taken to New Zealand, Papua New Guinea and, more controversially, to the tiny and financially-destitute state of Nauru after an aid package was quickly put together. ${ }^{765}$ The events of 11 September 2001 , merely within a few weeks of this incident, subsequently saw the issue of terrorism fused with the issue of asylum seekers. ${ }^{766}$ Upon challenge by a writ of habeas corpus by a concerned commercial lawyer from Melbourne, the Full Federal Court held (by a 2:1 majority) that the government (that is, the executive) had acted lawfully (indeed, extraordinarily, that the asylum seekers were not being detained). ${ }^{767}$

In later unfolding events, the government asserted that a group of Iraqi asylum seekers attempting to reach Australia by boat a month after the Tampa incident, and having been intercepted by the Australian navy, had thrown their children overboard as a way of demanding that their claims for asylum be processed in Australia - a claim which, after the 2001 election, was found to be false and that the government had been informed of the veracity of the

\footnotetext{
${ }^{764}$ For a compelling, detailed and dramatic account of the Tampa affair, see Marr, D, and Wilkinson, M, Dark Victory, (2ed), 2004, Allen \& Unwin, Sydney. See also Magner, T, A Less than Pacific Solution for Asylum Seekers in Australia (2004) 16(1) International Journal of Refugee Law 53

765 Magner, T, A Less than Pacific Solution for Asylum Seekers in Australia (2004) 16(1) IJRL 53, Pp.53-55; Maley, W, Asylum-seekers in Australia's International Relations (2003) 57(1) Australian Journal of International Affairs 187, P.187

766 Marr, D, and Wilkinson, M, Dark Victory, (2ed), 2004, Allen \& Unwin, Sydney, Pp.370-371; Taylor, S, Reconciling Australia's International Protection Obligations with the War on Terrorism (2002) 14(2) Pacfica Review 121, P.121, 125-126; see also Grewcock, M, Shooting the passenger: Australia's war on illicit migrants, in Lee, M, (ed), Human Trafficking, 2007, Willan Publishing, Devon, Pp.178-209, P.188 citing Senate Select Legal and Constitutional References Committee (2002) Migration Zone Excision: An examination of the Migration Legislation Amendment (Further Border Protection Measures) Bill 2002, Canberra, Pp.291-292

767 The matter was heard at first instance by North J in Victorian Council for Civil Liberties Incorporated v Minister for Immigration [2001] FCA 1297, later overturned on appeal in the Full Federal Court in Ruddock v Vadarlis [2001] FCA 1329; for a discussion on the somewhat extraordinary judgments of French and Beaumont JJ, in the Full Federal Court decision, see Crock, M, In the wake of the Tampa: Conflicting Visions of International Refugee Law in the Management of Refugee Flows (2002) 12(1) Pacific Rim Law and Policy Journal 49, Pp.63-69
} 
situation by the then Acting Defence Force Chief, Air Marshall Angus Houston, before the 2001 election. ${ }^{768}$

The Tampa incident witnessed the politicisation of asylum seekers by Howard during the 2001 Federal election, culminating in his electoral victory. At the launch of the Liberal Party's Federal election campaign, Howard famously declared, "we will decide who comes to this country and the circumstances in which they come". ${ }^{769}$ But the influence of Pauline Hanson and her One Nation Party had also been a significant factor. After the 1998 Federal elections, Pauline Hanson's One Nation Party had attracted a very significant one million votes. ${ }^{770}$ Jupp reflects on the influence of One Nation and its effect on the 2001 election as follows:

"The worst effect of One Nation was that it gave legitimacy to those who had always opposed the changes of the past thirty years. Its message was spread by the media to the entire population. It created the belief that there was a large constituency of 'Aussie battlers' whose prejudices had to be treated seriously. It encouraged anti-intellectualism, like all populist parties. This meant that much that had been creative in national development since the 1960s had to be argued for again. By failing to do so, the Howard government consolidated its own electoral position in 2001 and legitimised the whole agenda which he and his colleagues had been developing since the early 1980s." 771

As Lawrence put it, "Howard knew he was tapping into a rich vein of prejudice". ${ }^{772}$ Howard's electoral success was achieved by using the issue of national security to draw upon Australia's invasion anxiety, community ambivalence about race, and the coupling (within Australian minds) of Asian and Muslim immigration to crime. ${ }^{773}$

\footnotetext{
768 Marr, D, and Wilkinson, M, Dark Victory, (2ed), 2004, Allen \& Unwin, Sydney, Pp.247-248, 257-278, 332-351, 382-383; Magner, T, A Less than Pacific Solution for Asylum Seekers in Australia (2004) 16(1) IJRL 53, P.60

${ }^{769}$ Marr, D, and Wilkinson, M, Dark Victory, (2ed), 2004, Allen \& Unwin, Sydney, P.323

770 Jupp, J, From White Australia to Woomera - The Story of Australian Immigration, (2ed), 2007, P.130

771 Jupp, J, From White Australia to Woomera - The Story of Australian Immigration, (2ed), 2007, P.135, citing Markus, A, Race: John Howard and the Remaking of Australia, 2001, Allen \& Unwin, Sydney and Solomon, D, (ed), Howard's Race, 2002, HarperCollins, Sydney; see also Marr, D, and Wilkinson, M, Dark Victory, (2ed), 2004, Allen \& Unwin, Sydney, P.375 772 Lawrence, C, Those People, in Lusher, D, and Haslam, N (eds) Yearning to Breathe Free: seeking asylum in Australia, 2007, The Federation Press, Annandale, Pp.173-182 at P.177

773 McCulloch, J, National (in)security politics in Australia: fear and the federal election, http://www.statewatch.org/analyses/no-30-jude-mccullogh.pdf (last accessed 24 April 2012), Pp. 5-7, citing, inter alia, at n.28, Marr, D, and Wilkinson, M, Dark Victory, 2003, Allen \& Unwin, Sydney, at P.93
} 
Several consequences befell the Tampa affair. The "Pacific Solution" ${ }^{, 774}$ emerged - a policy designed to deter. ${ }^{775}$ The first element of that policy consisted of what Maley describes as a "bizarre exercise in national self-mutilation",776 whereby parts of Australian territory were excised from the "Migration Zone" by virtue of the Migration Amendment (Excision from Migration Zone) Act 2001 (Cth) (a measure which Jupp credits Pauline Hanson for suggesting on 31 August 2001 - merely a week after the Tampa incident). ${ }^{777}$ The effect of that legislation was to deem persons "offshore entry persons" and administratively preclude them from making an application for a visa of any kind, including a Protection Visa (the effect of which will be discussed in more detail later in this book). Over the period 2001-2005, a total of 4,891 islands were excised from Australia's Migration Zone. ${ }^{778}$

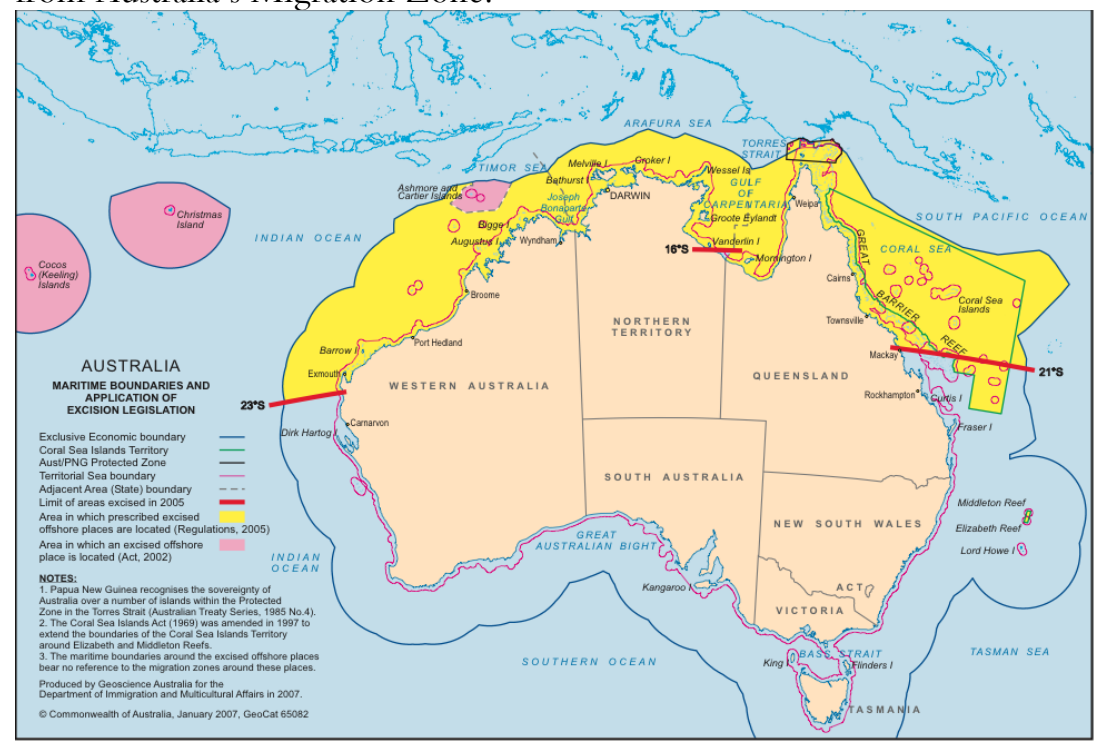

Fig.1 Map of Australian Excision and Migration Zones

Source: Department of Immigration and Citizenship 779

${ }^{774}$ Later renamed the "Pacific Strategy" as, noted by Crock et al, the phrase had "disturbing references to Hitler's "Final Solution"”, Crock, M, Saul, B, and Dastyari, A, Future Seekers II, 2006, Federation Press, Leichhardt, P.117.

775 Gordon, M, The 'Pacific Solution', in Lusher, D, and Haslam, N, Yearning to Breathe Free, 2007, The Federation Press, Leichhardt, Pp.75-99; Pickering, S, The New Criminals: Refugees and Asylum Seekers, in Anthony, T, Cuneen, C, The Critical Criminology Companion, 2008, Hawkins Press, Annandale, Pp.169-179 at P.173-175

776 Maley, W, Asylum-seekers in Australia's International Relations (2003) 57(1) Australian Journal of International Affairs 187, P.195

777 Jupp, J, From White Australia to Woomera - The Story of Australian Immigration, (2ed), 2007, P.190

778 Crock, M, Saul, B, and Dastyari, A, Future Seekers II, 2006, Federation Press, Leichhardt, P.118

779 Australian Government, Department of Immigration and Citizenship, http://www.immi.gov.au/media/fact-sheets/81-excision-places-map.pdf (last accessed 24 April 2012) 
The second element of the Pacific Solution was the introduction of tough border measures contained in the Border Protection (Validation and Enforcement Powers) Act 2001 (Cth) which, inter alia, not only retrospectively validated the actions taken by the government in relation to the Tampa affair, but also provided further search, removal and detention powers to federal officers boarding ships. ${ }^{780}$ As Crock et al note, there are several further significant and disturbing amendments to the 1999 Border Protection Legislation Act: firstly, the 2001 amendments now gave power to prevent persons rescued at sea from being taken to mainland Australia; secondly, section 7A of the Migration Act now meant that executive power could also extend beyond legislative authority; and thirdly, that persons could be expelled from Australia's borders that is, that provision makes no distinction between citizens and noncitizens. $^{781}$

The third element was the interdiction of asylum seekers (that is, interception at sea by coastal or air patrols, including the towing back or escorting of boats from Australian to Indonesian waters) in an operation known as "Operation Relex". ${ }^{782}$ As noted by Crock et al, the change in policy is believed by some to have resulted in the loss of life of 353 people when a boat sank en route from Indonesia to Australia in an incident known as "SIEV-X" - although aware of its departure, officially Australia was said to have no knowledge of its whereabouts at the time of it sinking. ${ }^{783}$

The fourth element, related to the issue of interdiction, was the removal of asylum seekers and their processing extra-territorially, both in Papua New Guinea and in Nauru. ${ }^{784}$ The IOM managed the camps in Papua New Guinea

780 Crock, M, Saul, B, and Dastyari, A, Future Seekers II, 2006, Federation Press, Leichhardt, P.115-117

781 Crock, M, and Berg, L, Immigration Refugees and Forced Migration - Law Policy and Practice in Australia, 2011, Federation Press, Leichhardt, Pp. 146-147; see also Crock, M, Saul, B, and Dastyari, A, Future Seekers II, 2006, Federation Press, Leichhardt, P.116

782 Crock, M, and Berg, L, Immigration Refugees and Forced Migration - Law Policy and Practice in Australia, 2011, Federation Press, Leichhardt, P.98; see also Crock, M, Saul, B, and Dastyari, A, Future Seekers II, 2006, Federation Press, Leichhardt, P.120; Kneebone, S, Controlling Migration by Sea: The Australian Case, in Ryan, B and Mitsilegas, V, (eds) Extraterritorial Immigration Control, 2010, Brill, Leiden, Pp.347-374, at P.354; Howard, J, To Deter and Deny: Australia and the Interdiction of Asylum Seekers (2003) 21(4) Refuge 35, Pp.35-41

783 SIEV is an acronym for "suspected illegal entry vessel", see Crock, M, Saul, B, and Dastyari, A, Future Seekers II, 2006, Federation Press, Leichhardt, Pp.46-48. See also Grewcock, M, Shooting the passenger: Australia's war on illicit migrants, in Lee, M, (ed), Human Trafficking, 2007, Willan Publishing, Devon, Pp.178-209, P.190-194; see also www.sievx.com (last accessed 21 April 2012)

784 Grewcock, M, Shooting the passenger: Australia's war on illicit migrants, in Lee, M, (ed), Human Trafficking, 2007, Willan Publishing, Devon, Pp.178-209, Pp.188-189; Crock, M, Saul, B, and Dastyari, A, Future Seekers II, 2006, Federation Press, Leichhardt, Pp.123-125; see also Burnside, J, Watching Brief, 2007, Scribe Publications, Melbourne, Pp.83-90; 
and Nauru, with the processing of asylum seekers' claims conducted by the UNHCR in Nauru (only for those brought from the Tampa and the Aceng vessels) but the Australian Department of Immigration processed those the UNHCR did not assess in Nauru as well as those taken to Papua New Guinea. ${ }^{785}$ The processing of asylum seekers in Papua New Guinea and in Nauru was clearly an effort to keep asylum seekers outside the reach of Australian law and procedures. ${ }^{786}$ Extraordinarily, Nauru was not a party to the Geneva Convention at the time (only acceding on 28 June 2011 to the Convention and its Protocol), and although Papua New Guinea is a party to the Convention, it retains extensive reservations. ${ }^{787}$

The fifth element was an emboldening of the TPV scheme. In addition to the TPV regime established in 1999, TPVs also became applicable to those asylum seekers who, having resided in a country for at least seven days, were able to seek and obtain effective protection either from that country or from the UNHCR offices in that country ("the seven-day rule"). One of the most formidable features of those subjected to the seven-day rule (bearing in mind Australia's geographic location) was that they would only ever be able to apply for a further TPV when their TPV expired (unless Ministerial discretion was exercised) ${ }^{788}$ Additionally, A TPV of three years' duration was applicable to offshore entry persons (that is, inclusive of those processed in Papua New Guinea and Nauru) (subclass 447), and a TPV of five years' duration was applicable to non-offshore entry persons who were outside of Australia and who sought protection (subclass 451) ${ }^{789}$ Both holders were not able to hold a substantive visa other than a protection visa.

It was also during the period of the Howard government, with particular impetus after the Tampa incident, that greater efforts were made at a regional level to combat the irregular movement of people. The Regional Cooperation Model initiated with Indonesia in 2000 resulted in the interception and arrest

Crock, M, and Berg, L, Immigration Refugees and Forced Migration - Law Policy and Practice in Australia, 2011, Federation Press, Leichhardt, Pp.101-104; For a first hand account of the circumstances in the Nauru and Papua New Guinea camps see Metcalfe, S, The Pacific Solution, 2010, Australian Scholarly Publishing, North Melbourne.

785 Human Rights Watch, "By Invitation Only:" Australia's Asylum Policy, December 2002, Volume 14, No. 10 at Pp. 64-66

${ }^{786}$ Human Rights Watch, "By Invitation Only:” Australia's Asylum Policy, December 2002, Volume 14, No. 10 at Pp. 65, 71

787 Papua New Guinea's reservations are in relation to Articles 17(1) (wage earning employment), 21 (housing), 22(1) (public education), 31 (penalties on account of unlawful presence), 32 (expulsion) and 34 (naturalisation) of the Convention

788 Crock, M, Saul, B, and Dastyari, A, Future Seekers II, 2006, Federation Press, Leichhardt, P.140

789 Schedule 1 Migration Amendment (Excision from Migration Zone) (Consequential Provisions) Act 2001 (Cth) No.128 of 2001; see further, Vrachnas, J, Dimopoulos, P, Boyd, K, Bagaric, M, Migration and Refugee Law: Principles and Practice in Australia, 2008, 2ed, Cambridge University Press, Port Melbourne, Pp.183-184; Human Rights Watch, "By Invitation Only:” Australia's Asylum Policy, December 2002, Volume 14, No. 10, Pp. 82-83 
of irregular migrants in Indonesia, with a focus on those intending or preparing to depart for Australia and resulting in a degree of close cooperation between Australian and Indonesian agencies. ${ }^{790}$ Subsequently, the Australian government, together with Indonesia, initiated the Bali Process on People Smuggling, Trafficking in Persons and Related Transnational Crime in $2002,{ }^{791}$ furthered the goal of closer management of irregular migration by the fusion of irregular migration with the combatting of terrorism. ${ }^{792}$ Arrangements also exist for those intercepted between the IOM, Indonesia and Australia for their maintenance ${ }^{793}$ - including the funding of detention centres in Indonesia by Australia. ${ }^{794}$ However, with Indonesia not being a party to the Geneva Convention, the issue of refoulement remains live. The delicateness of Australia-Indonesian relations emerged with 43 West Papuans seeking asylum on the Australian mainland in 2006 (indeed, as it had with East Timorese seeking asylum in 1999). ${ }^{795}$ When Australia granted TPVs to 42 of the 43 West Papuans, Indonesia withdrew its ambassador in response. ${ }^{796}$ Howard then sought to introduce legislation that would have directed all onshore asylum seekers to have been processed offshore ${ }^{797}-$ a bill that was ultimately withdrawn after its defeat was imminent, with the Opposition claiming that the Government was being a 'soft touch' to Indonesian pressures. ${ }^{798}$ Australia made significant efforts to export a high level of immigration control (including technical assistance) throughout the region to neighbouring countries which were either a transit or source for irregular

790 Howard, J, To Deter and Deny: Australia and the Interdiction of Asylum Seekers (2003) 21(4)

Refuge 35, Pp.41-45

791 http://www.baliprocess.net/ (last accessed 25 April 2012)

792 Wesley, M, The Howard Paradox - Australian Diplomacy in Asia 1996-2006, 2007, ABC Books, Sydney, Pp.180-200

793 Kneebone, S, Controlling Migration by Sea: The Australian Case, in Ryan, B and Mitsilegas, V, (eds) Extraterritorial Immigration Control, 2010, Brill, Leiden, Pp.347-374, at P.355; see also in relation to similar arrangements in Papua New Guinea, East Timor, and Cambodia: Taylor, S, Australia's Border Control and Refugee Protection Capacity-Building Activities in the Asia-Pacific Region in Babacan, A, and Briskman, L, (eds) Asylum Seekers: International Perspectives on Interdiction and Deterrence, 2008, Cambridge Scholars Publishing, Pp.73-75

794 Taylor, J, Behind Australian Doors: Examining the Conditions of Detention of Asylum Seekers in Indonesia, 3 November 2009, http://www.law.monash.edu.au/castancentre/news/ behind-australian-doors-report.pdf (last accessed 25 April 2012); Taylor, S, Australian Funded Care and Maintenance of Asylum Seekers in Indonesia and Papua New Guinea: All Care But No Responsibility? (2010) 33(2) UNSWLJ 337; Taylor, S, and Rafferty-Brown, B, Waiting for Life to Begin: the Plight of Asylum Seekers Caught by Australia's Indonesian Solution (2010) 22(4) IJRL 558

795 Crock, M, Saul, B, and Dastyari, A, Future Seeeker's II, 2006, Federation Press, Leichhardt, Pp.38-39

796 Kneebone, S, Controlling Migration by Sea: The Australian Case, in Ryan, B and Mitsilegas, V, Extraterritorial Immigration Control, 2010, Brill, Leiden, Pp.347-374, at P.367

797 Migration Amendment (Designated Unauthorised Arrivals) Bill 2006 (Cth)

798 Wesley, M, The Howard Paradox - Australian Diplomacy in Asia 1996-2006, 2007, ABC Books, Pp.206-209 
migration to Australia. ${ }^{799}$ However, in (Savitri) Taylor's view, "Australia is choosing to exert its influence beyond its own territory in pursuit of its border control objective without taking a commensurate degree of responsibility for the safeguarding the rights of those affected by its actions". 800

Two further significant events mark this era. They involved the detention of a German citizen and Australian permanent resident, Cornelia Rau, in 2004$2005,{ }^{801}$ and the detention and removal to the Philippines of an Australian citizen, Vivian Alvarez in 2001 (she being discovered in 2005) ${ }^{802}$ Rau had been living in Australia since migrating from Germany with her parents as a young child. She suffered from mental illness (including bipolar disorder and schizophrenia) and had disappeared from Manly Hospital (in Sydney) in March 2004 and travelled to far northern Queensland. After being brought to the attention of Queensland Police by a publican and having given various names but being unable to prove her identity with supporting documents, she was detained by Queensland Police on the suspicion of being an unlawful non-citizen. She claimed that she had no family in Australia. After spending six months in a State prison, and attempts by the German consulate to identify her being hampered by a lack of information, she ended up in the notorious Baxter Immigration Detention Centre where her mental state severely deteriorated - later ending up in the Red One isolation unit. It was only through the publication of a newspaper article about her circumstances that her parents recognised her and she was released. She was detained for 10 months in total. ${ }^{803}$

\footnotetext{
799 Taylor, S, Australia's Border Control and Refugee Protection Capacity-Building Activities in the Asia-Pacific Region in Babacan, A, and Briskman, L, Asylum Seekers: International Perspectives on Interdiction and Deterrence, 2008, Cambridge Scholars Publishing, Pp.63-81

800 Taylor, S, Australia's Border Control and Refugee Protection Capacity-Building Activities in the Asia-Pacific Region in Babacan, A, and Briskman, L, Asylum Seekers: International Perspectives on Interdiction and Deterrence, 2008, Cambridge Scholars Publishing, P.76

801 See Marr, D, Cornelia Rau: the verdict, Sydney Morning Herald, 18 July 2005 http://www.smh.com.au/news/national/cornelia-rau-the-

verdict/2005/07/17/1121538868891.html and Marr, D, Purgatory in Baxter, Sydney Morning Herald, 19 July 2005, http://www.smh.com.au/news/national/purgatory-inbaxter/2005/07/18/1121538922305.html (last accessed 25 April 2012), see also Whitmont, D, Anna's Story, Australian Broadcasting Corporation, 4 April 2005, Transcript, http://www.abc.net.au/4corners/content/2005/s1338239.htm (last accessed 25 April 2012). See also, Freckleton, I, Editorial: Madness Migration and Misfortune: The Challenge of the Bleak Tale of Cornelia Rau (2005) 12(1) Psychiatry, Pschology and Law 1

802 Sydney Morning Herald, The lies that kept Vivian Alvarez hidden for years, 20 August 2005 http://www.smh.com.au/news/national/the-lies-that-kept-vivian-alvarez-hidden-foryears/2005/08/19/1124435144969.html (last accessed 25 April 2012).

803 Palmer, M, Inquiry into the Circumstances of the Detention of Cornelia Rau, July 2005, Commonwealth of Australia, Canberra http://www.immi.gov.au/media/publications/pdf/ palmer-report.pdf (last accessed 25 April 2012); Tippet, G, The missing months of Cornelia Rau, The Age, 12 February 2005, http://www.theage.com.au/news/National/Themissing-months-of-Cornelia-Rau/2005/02/11/1108061868901.html (last accessed 25 April 2012)
} 
Vivian Alvarez had come to Australia from the Philippines in 1984 having married an Australian citizen, and herself became an Australian citizen in 1986. After having divorced her husband in 1993, she developed a paranoid psychotic illness. She came to the attention of a passer-by in a park in Lismore, New South Wales, on 30 March 2001. After she was admitted to Lismore Base Hospital's psychiatric unit, a social worker from the psychiatric unit contacted the Department of Immigration. A spinal lesion was diagnosed for which Alvarez was sent to Sydney for treatment. Following her return to Lismore Base Hospital and interviews by the Department of Immigration, it was assumed that she was a "sex slave". Despite being quite incapacitated and walking with a four-wheeled walker, she was detained, declared fit to travel, and removed to the Philippines on 20 July 2001. Despite numerous contacts by Queensland Police with the Department of Immigration in order to locate Alvarez as a missing person, and the persistence of her former husband flagging that an Australian citizen has been unlawfully deported, it took until April 2005 to establish what had happened. She was located in destitute circumstances in the Philippines in May 2005. ${ }^{804}$

Both matters were the subject of an inquiry conducted by Mick Palmer (former Australian Federal Police Commissioner) having been referred by the Minister for Immigration and Multicultural and Indigenous Affairs ("DIMIA", as it was then called), Senator Amanda Vanstone. ${ }^{805}$ The report was damning in its criticism of how DIMIA handled both matters. In the case of Alvarez, a further report by Neil Comrie, under the Commonwealth Ombudsman's Office, reinforced those findings. ${ }^{806}$ Subsequently, 201 such similar cases were referred to the Palmer Inquiry ${ }^{807}$ and taken over by the Commonwealth Ombudsman. ${ }^{808}$

804 Commonwealth Ombudsman, Inquiry into the Circumstances of the Vivian Alvarez matter, Report under the Ombudsman Act 1976 by the Commonwealth Ombudsman Prof. John McMillan, of an inquiry undertaken by Mr Neil Comrie AO APM, 26 September 2005, Report 03/2005. http://www.immi.gov.au/media/publications/pdf/alvarez_report03.pdf (last accessed 25 April 2012), Pp.9-23

805 Palmer, M, Inquiry into the Circumstances of the Detention of Cornelia Rau, July 2005, Commonwealth of Australia, Canberra http://www.immi.gov.au/media/publications/pdf/ palmer-report.pdf (last accessed 25 April 2012)

806 Commonwealth Ombudsman, Inquiry into the Circumstances of the Vivian Alvarez matter, Report under the Ombudsman Act 1976 by the Commonwealth Ombudsman Prof. John McMillan, of an inquiry undertaken by Mr Neil Comrie AO APM, 26 September 2005, Report 03/2005. http://www.immi.gov.au/media/publications/pdf/alvarez_report03.pdf (last accessed 25 April 2012)

807 ABC News Online, Detention Probe handed 200 cases, 25 May 2005, http://www.abc.net.au/news/newsitems/200505/s1376464.htm (last accessed 25 April 2012).

808 Commonwealth Ombudsman, Department of Immigration and Multicultural Affairs - Report on referred immigration cases: $M r$ T, March 2006, Report under the Ombudsman Act 1976 by the Commonwealth Ombudsman Prof. John McMillan, Report 04/2006 
The significance of these 201 such cases, but particularly those of Rau and Alvarez, is that it blurred the distinction in treatment based on immigration status in Australia - that is, the treatment usually reserved for unlawful noncitizens on the one hand had, in these cases, been extended to lawful noncitizens and, more shockingly, citizens, on the other. The actions that were taken against Rau and Alvarez were deplorable - but one cannot help but think that those actions were considered even more so because they effectively happened to 'one of us' (Marr reports that Rau even "sounded Australian" - that is, those measures were not solely inflicted on "the other". Where "the other" does emerge in these cases is the demeaning assumption that Alvarez, a once Philippine national, was a "sex slave". What has failed to materialise in the debate on the detention of asylum seekers in Australia subsequently is that those actions were so heinous not on account of a person's status as a 'lawful non-citizen', 'citizen' or 'unlawful non-citizen', but merely on account of their membership of humanity generally. The Alvarez case (and to an extent, the Rau case) also highlighted the almost blind determination to enforce the mandatory removal provisions of the Migration Act. ${ }^{810}$ Given that context, it raises serious questions for the well-being, safety and refoulement of rejected asylum seekers and persons previously holding TPVs. ${ }^{811}$

\subsubsection{7 - present - The Rudd (2007-2010) and Gillard (2010-present) Governments}

With the election of the Rudd (Labor) Government on 24 November 2007, there appeared to be a discernible shift in asylum policy. This shift metamorphosed into policy-on-the-run under the Gillard (Labor) Government, partly through reactions to two significant decisions of the High Court of Australia during recent times. Both Rudd and Gillard Governments used policy extensively (usually through the exercise of non-compellable ministerial discretion) rather than law to implement changes. What is important to note is that the harsh legislative skeleton implemented under the Hawke/Keating and Howard governments remains almost entirely intact. Accordingly, in the context of asserting and enforcing rights by asylum seekers (particularly in relation to liberty), the use of policy (implemented by discretion) and the lack of justiciability remains a significant problem. Subject to anything the High Court of Australia has to say (and has said), there would

http://www.ombudsman.gov.au/commonwealth/publish.nsf/AttachmentsByTitle/reports_ 2006_04.pdf/\$FILE/MrT_immigration_mar2006.pdf (last accessed 25 April 2012), P.1

809 Marr, D, Cornelia Rau: the verdict, Sydney Morning Herald, 18 July 2005 http://www.smh.com.au/news/national/cornelia-rau-the-

verdict/2005/07/17/1121538868891.html (last accessed 26 April 2012)

810 Marr, D, Cornelia Rau: the verdict, Sydney Morning Herald, 18 July 2005 http://www.smh.com.au/news/national/cornelia-rau-the-

verdict/2005/07/17/1121538868891.html (last accessed 26 April 2012)

811 For example, see Corlett, D, Following them home - the fate of the returned asylum seekers, 2005, Black Ink, Melbourne 
be nothing to stop a return to the more harsh ways of old should the political or governmental winds of change blow through the Parliament.

Shortly after coming to office, the Rudd government finally announced the end of the Pacific Solution in February 2008 when the last of those refugees detained on Nauru reached the Australian mainland. ${ }^{812}$ However, the end of the Pacific Solution was not followed up by a repeal of the legislation which authorised the offshore processing measures, nor was the legislation which implemented the excision of Australian territory from the Migration Zone. Accordingly, processing of 'unauthorised arrivals' (that is, including asylum seekers) was undertaken on Christmas Island ${ }^{813}$ with the practical effect that asylum seekers were unable to make a valid application for any visa, including a Protection Visa, unless the Minister exercised his non-compellable discretion to 'lift the bar'. ${ }^{814}$ It was thought that, by adopting such a system of 'nonstatutory' processing on Christmas Island that asylum seekers would be outside the scope of the Migration Act, with procedural safeguards not needing to comply with Australian administrative law and with judicial review by the High Court only protected by virtue of section $75(\mathrm{v})$ of the Constitution. That process would later come to be successfully challenged in the High Court of Australia (discussed below).

The second major change that the Rudd government made was to abolish the TPV scheme, allowing for all people who attain refugee status to be granted permanent residence in Australia. ${ }^{815}$

The third significant change made by the Rudd government was in relation to immigration detention. A set of 'key values' were announced by the then Minister for Immigration Senator Chris Evans in his "New Directions in Detention" address on 29 July 2008. The government's seven Key Immigration Detention Values are:

812 Maley, P, Pacific Solution Sinks Quietly, The Australian, 9 February 2009, http://www.theaustralian.news.com.au/story/0,25197,23183785-5013404,00.html (last accessed 27 April 2012); See also Francis, A, Bringing Protection Home: Healing the Schism Between International Obligations and National Safeguards Created by Extraterritorial Processing (2008) 20 IJRL 273, P.309ff

813 Australian Government Media Release, Last Refugees leave Nauru, 8 February 2008, http://www.minister.immi.gov.au/media/media-releases/2008/ce08014.htm (last accessed 27 April 2012)

814 Section 46 A of the Migration Act 1958 (Cth)

815 Australian Government Media Release, Budget 2008-09 - Rudd Government scraps Temporary Protection visas http://www.minister.immi.gov.au/media/mediareleases/2008/ce05-buget-08.htm (last accessed 27 April 2012); Australian Government, Department of Immigration and Citizenship, Fact Sheet 68 - Abolition of the Temporary Protection visa (TPV) and Temporary Humanitarian visas (THVs), http://www.immi.gov.au/media/fact-sheets/68tpv_further.htm (last accessed 27 April 2012) 
"1. Mandatory detention is an essential component of strong border control.

2. To support the integrity of Australia's immigration program three groups will be subject to mandatory detention:

a. all unauthorised arrivals, for management of health, identity and security risks to the community

b. unlawful non-citizens who present unacceptable risks to the community and

c. unlawful non-citizens who have repeatedly refused to comply with their visa conditions

3. Children, including juvenile foreign fishers and, where possible, their families, will not be detained in an immigration detention centre.

4. Detention that is indefinite or otherwise arbitrary is not acceptable and the length and conditions of detention, including the appropriateness of both the accommodation and the services provided, would be subject to regular review.

5. Detention in immigration detention centres is only to be used as a last resort and for the shortest practicable time.

6. People in detention will be treated fairly and reasonably within the law.

7. Conditions of detention will ensure the inherent dignity of the human person." 816

The Australian provisions in relation to the detention of asylum seekers will be assessed in light of those values throughout this book. As will be shown, what has failed to materialise is the embodiment of those values into justiciable rights. An attempt to incorporate the values into law was made with the introduction of the Migration Amendment (Immigration Detention Reform) Bill 2009 (Cth) ${ }^{817}$ but the Bill lapsed with the dissolution of Parliament at the 2010 Federal elections and, indeed, reservations were expressed by the AHRC about the extent to which the Key Immigration Detention Values would have been implemented in any event. ${ }^{818}$ At a fundamental level, the Key Immigration Detention Values manifest a logical and legal inconsistency "mandatory detention" is being touted "as a last resort".

A few months prior to the announcement of the seven Key Immigration Detention values, the Joint Standing Committee on Migration began an inquiry into the immigration detention in Australia, having been requested to do so by Senator Evans on 29 May 2008. Three reports were released by the

\footnotetext{
816 Evans, Senator the Honourable Chris, Minister for Immigration and Citizenship, speech to the Australian National University in Canberra, 29 July 2008, New Directions in Detention - Restoring Integrity to Australia's Immigration System.

http://www.nswbar.asn.au/circulars/july/evans2.pdf (last accessed 27 April 2012); Australian Government, Department of Immigration and Citizenship, Key Immigration Detention Values, http://www.immi.gov.au/managing-australias-borders/detention/ about/key-values.htm (last accessed 27 April 2012)

817 Parliament of Australia, Migration Amendment (Immigration Detention Reform) Bill 2009, Explanatory Memorandum, http://parlinfo.aph.gov.au/parlInfo/search/display/display.w3p ;query=Id\%3A\%22legislation\%2Fems\%2Fs720_ems_1284af8e-e006-4320-b4f3cbcc9d8ded94\%22;rec $=0$ (last accessed 27 April 2012)

818 Australian Human Rights Commission, Migration Amendment (Immigration Detention Reform) Bill 2009, Submission to the Senate Standing Committee on Legal and Constitutional Affairs, 31 July 2009, Sydney, http://www.humanrights.gov.au/legal/submissions /2009/20090731_migration.pdf (last accessed 27 April 2012).
} 
Joint Standing Committee and which will be explored in more detail throughout this book: firstly, Immigration Detention in Australia: A new beginning - criteria for release from detention on 1 December $2008 ;{ }^{819}$ secondly, Immigration Detention in Australia: Community-based alternatives to detention on 25 May $2009,{ }^{820}$ and thirdly, Immigration Detention in Australia: Facilities, services and transparency on 18 August 2009. ${ }^{821}$ All three reports provide an extensive insight into the Australian immigration detention system. A Joint Select Committee on Australia's Immigration Detention Network was established in June 2011. ${ }^{822}$ Its report was published on 30 March 2012. ${ }^{823}$ Although submissions to the Joint Standing Committee will be referred to in this book, the timing of the report's publication has meant that its substance will not be incorporated herein. However, an epilogue will provide an overview of its contents.

In October 2009, 78 asylum seekers were held on board the Australian Customs ship The Oceanic Viking after being rescued at sea. Following appeals by the Australian government to Indonesia, ${ }^{824}$ those rescued were to taken to the Australian-funded Tanjung Pinang detention centre on Indonesia's Bintan Island. ${ }^{825}$ Detention facilities in Indonesia have been described as "third world jails", but the government refused to take responsibility for what may occur in

819 Parliament of Australia, Joint Standing Committee on Migration, Immigration Detention in Australia: A new beginning - criteria for release from detention, 2008, Canberra, http://www.aph.gov.au/house/committee/mig/detention/report/fullreport.pdf (last accessed 27 April 2012)

820 Parliament of Australia, Joint Standing Committee on Migration, Immigration Detention in Australia: Community-based alternatives to detention, 2009, Canberra, http://www.aph.gov.au/house/committee/mig/detention/report2/fullreport.pdf (last accessed 27 April 2012)

821 Parliament of Australia, Joint Standing Committee on Migration, Immigration Detention in Australia: Facilities, services and transparency, 2009, Canberra, http://www.aph.gov.au/house/committee/mig/detention/report3/fullreport.pdf (last accessed 25 August 2011)

822 Parliament of Australia, Joint Select Committee on Australia's Immigration Detention Network, http://www.aph.gov.au/Parliamentary_Business/Committees/Senate_ Committees?url=immigration_detention_ctte/immigration_detention/index.htm_(last accessed 27 April 2012)

823 Parliament of Australia, Joint Select Committee on Australia's Immigration Detention Network - Final Report, March 2012, http://www.aph.gov.au/Parliamentary_Business/ Committees/Senate_Committees?url=immigration_detention_ctte/immigration_detention /report/report.pdf (last accessed 27 April 2012)

824 Australian Broadcasting Corporation, Sri Lankans won't set foot in Australia, 28 October 2009, http://www.abc.net.au/news/stories/2009/10/28/2726181.htm (last accessed 27 April 2012)

825 Australian Broadcasting Corporation, Oceanic Viking stand-off ends, 17 November 2009, http://www.abc.net.au/news/stories/2009/11/17/2745239.htm (last accessed 27 April 2012); Australian Broadcasting Corporation, Oceanic Viking leaves Indonesia after four week stalemate, 19 November 2009, http://www.abc.net.au/am/content/2009/s2747054.htm (last accessed 27 April 2012) 
Indonesia. ${ }^{826}$ In December 2009, two of the 78 were resettled in Australia. ${ }^{827}$ However, five of those rescued on the Oceanic Viking were also taken to Australia and placed in immigration detention pending the resolution of their status - and who are now the subject of a Communication to the HRC regarding their indefinite detention due to an adverse security assessment by ASIO. ${ }^{828}$

Between 9 April 2010 and 6 July 2010, the Government suspended the processing of all claims for asylum made by Sri Lankan nationals and, similarly, from 9 April 2010 to 30 September 2010, asylum claims made by those from Afghanistan were also suspended in light of "evolving circumstances in these two countries". ${ }^{829}$ The decision to suspend claims was the subject of serious concerns held by both the AHRC and the UNHCR. ${ }^{830}$

A move was made to adopt community detention for children and vulnerable family groups in October $2010,{ }^{831}$ followed by an extension of the programme

826 Australian Broadcasting Corporation, Detention centres branded third world jails, 27 October 2009, http://www.abc.net.au/news/stories/2009/10/27/2725761.htm (last accessed 27 April 2012). In relation to Australia's international obligations in these circumstances, see Taylor, S, Australian Funded Care and Maintenance of Asylum Seekers in Indonesia and Papua New Guinea: All Care But No Responsibility? (2010) 33(2) UNSWLJ 337

827 Metherell, M, First of Oceanic Viking's asylum seekers arrive, Sydney Morning Herald, 21 December 2009, http://www.smh.com.au/national/first-of-oceanic-vikings-asylumseekers-arrive-20091220-17iw.html (last accessed 27 April 2012)

${ }^{828}$ Saul, B, Submission to Joint Select Committee on Immigration Detention dated 31 August 2011, together with annexed Communication to the UN Human Rights Committee dated 28 August 2011 https://senate.aph.gov.au/submissions/comittees/ viewdocument.aspx?id=e82994a0-5a90-44c9-80f0-a96aafb95948, https://senate.aph.gov .au/submissions/comittees/viewdocument.aspx?id=229128ab-d97b-4dab-9b97-

bcf31229b81c (both last accessed 27 April 2012)

829 Evans, The Honourable Senator Chris, Minister for Immigration and Citizenship, Smith, The Honourable Stephen, Minister for Foreign Affairs, and O'Connor, The Honourable Brendan, Minister for Home Affairs, Changes to Australia's Immigration Processing System, 9 April 2010, http://www.minister.immi.gov.au/media/mediareleases/2010/ce10029.htm (last accessed 27 April 2012); Gillard, The Honourable Prime Minister Julia, Moving Australia Forward, 6 July 2010, Lowy Institute, Sydney, http://www.lowyinstitute.org/Publication.asp?pid=1328 (last accessed 27 April 2012) P.9; Bowen, The Honourable Chris, Minister for Immigration and Citizenship, Media Release, Suspension of processing of Afghan asylum seeker claims to be lifted, 30 September 2010, http://www.minister.immi.gov.au/media/cb/2010/cb155332.htm (last accessed 27 April 2012)

830 AHRC, Suspension of processing asylum seekers raises serious concerns, 9 April 2010, http://www.hreoc.gov.au/about/media/media_releases/2010/29_10.html (last accessed 27 April 2012); UNHCR, Safeguards needed as Australia's suspension of claims by Sri Lankans and Afghans comes into force, 16 April 2010, http://unhcr.org.au/pdfs/100416_aulpress.pdf (last accessed 27 April 2012)

831 Bowen, The Honourable Chris, Minister for Immigration and Citizenship, Government to move children and vulnerable families into community-based accommodation - Joint Media Release with the Prime Minister, 18 October 2010, http://www.minister.immi.gov.au /media/cb/2010/cb155484.htm (last accessed 27 April 2012) 
in March 2011. ${ }^{832}$ As will be explored later, no legislative change was enacted to facilitate this outcome, but rather it was given effect by an exercise of the Minister's personal and non-compellable discretion under the Migration Act. ${ }^{833}$

In November 2010, the High Court of Australia in its M61/M69 judgment, ${ }^{834}$ held that the Migration Act and administrative law did apply to those asylum seekers processed on Christmas Island. The decision was of great significance as it exploded the forensic wilful blindness that had been exercised up to that point by the Government - namely, that because the Minister had not exercised his non-compellable discretion to 'lift the bar' and allow an application for a Protection (or any other) Visa to be made, the Migration Act and administrative law did not apply. The High Court held that, by commencing investigations into whether he should exercise his discretion, the decisions made in those stages were subject to the Migration Act and administrative law. The government responded by establishing the Protection Obligation Determination ("POD") process for those asylum seekers processed on Christmas Island (formerly the Refugee Status Assessment ("RSA") and Independent Merits Review ("IMR”) processes). ${ }^{835}$ Notwithstanding an attempt to somewhat equalise the process between those on Christmas Island and those within the Migration Zone, the Christmas Island process is still one that operates entirely at the discretion of the Minister. ${ }^{836}$ Further, the geographical remoteness of Christmas Island greatly hampers access to asylum seekers by lawyers and other advisors.

However, the desire for a regional processing centre (or, more accurately, offshore processing) was never far from the agenda. Even before the M61/M69 decision, Prime Minister Gillard had announced in July 2010 the prospect of a regional processing centre in East Timor. ${ }^{837}$ Subsequent to that announcement, discussions were held with Indonesia, Malaysia and East

832 Bowen, The Honourable Chris, Minister for Immigration and Citizenship, Moving asylum seeker children into the community - Statement by the Minister for Immigration and Citizenship, the Hon Chris Bowen, MP, 1 March 2011, http://www.minister.immi.gov.au/media/cb/2011/cb159599.htm (last accessed 27 April 2012)

833 Section $197 \mathrm{AB}$ of the Migration Act 1958 (Cth)

834 Plaintiff M61/2010E v Commonwealth of Australia; Plaintiff M69 of 2010 v Commonwealth of Australia [2010] HCA 41

835 Bowen, The Honourable Chris, Minister for Immigration and Citizenship, Government announces faster, fairer refugee assessment process, 7 January 2011, http://www.minister.immi.gov.au/media/cb/2011/cb157059.htm (last accessed 27 April 2012); see also Francis, A, and Caton, S, Access to Protection for 'Offshore Entry Persons' aka asylum seekers (2011) 36(3) AltLJ 172

836 See further, Foster, M and Pobjoy, J, A Failed Case of Legal Exceptionalism? Refugee Status Determination in Australia's 'Excised' Territory (2011) 23(4) IJRL 583, P.617

837 Gillard, The Honourable Prime Minister Julia, Moving Australia Forward, 6 July 2010, Lowy Institute, Sydney, http://www.lowyinstitute.org/Publication.asp?pid=1328 (last accessed 27 April 2012), Pp7-8 
Timor. ${ }^{838}$ What emerged was a deal with Malaysia (a non-signatory to the Geneva Convention) announced in May 2011 and formalised in July 2011 whereby 800 asylum seekers would be sent from Australia to Malaysia in return for 4,000 refugees from Malaysia. ${ }^{839}$ A Memorandum of Understanding with Papua New Guinea regarding an assessment centre on Manus Island (where a former detention centre had been located as part of the Pacific Solution under the Howard Government) was also signed. ${ }^{840}$ The proposed removal of asylum seekers to Malaysia was to be under section 198A of the Migration Act which, inter alia, requires the Minister to make a declaration about the country to which asylum seekers would be sent (namely, on human rights protections and the ability for an asylum seeker's claim to be processed). ${ }^{841}$ In its $M 70$ decision, the High Court of Australia (in a 6:1 majority decision) held that the Minister's declaration was a jurisdictional fact which had not been satisfied and was therefore invalid. ${ }^{842}$ The government, irritated at the High Court's scuppering of its plans, ${ }^{843}$ proposed the Migration Legislation Amendment (Offshore Processing and Other Measures) Bill 2011 (Cth) to remove some of the safeguards contained in the Migration Act seen as being determinative of the High Court's decision. However, given that Gillard was

838 Bowen, The Honourable Chris, Minister for Immigration and Citizenship, Minister Bowen to engage with regional partners on border protection and people smuggling, 8 October 2010, http://www.minister.immi.gov.au/media/cb/2010/cb155444.htm (last accessed 27 April 2012)

839 Gillard, The Honourable Julia, Prime Minister, Joint Statement with the Prime Minister of Malaysia, 7 May 2011, http://www.pm.gov.au/press-office/joint-statement-primeminister-malaysia (last accessed 27 April 2012); Arrangement between the Government of Australia and the Government of Malaysia on Transfer and Resettlement, 25 July 2011 http://www.minister.immi.gov.au/media/media-releases/_pdf/20110725-arrangementmalaysia-aust.pdf (last accessed 27 April 2012); Annex A - Operational Guidelines to support transfers and resettlement, http://www.immi.gov.au/managing-australias-borders/bordersecurity/_pdf/operational-guidelines-transfers-resettlement.pdf (last accessed 27 April 2012) 840 Memorandum of Understanding between the Government of the Independent State of Papua New Guinea and the Government of Australia, Relating to the Transfer to and Assessment of Persons in Papua New Guinea, and Related Issues, http://www.minister.immi.gov.au/media/mediareleases/_pdf/20110819-aust-png-mou.pdf (last accessed 27 April 2012); Bowen, the Honourable Chris, Minister for Immigration and Citizenship, Australia and Papua New Guinea Sign MoU, 19 August 2011, http://www.minister.immi.gov.au/ media/cb/2011/cb170699.htm (last accessed 27 April 2012)

${ }^{841}$ See Instrument of Declaration of Malaysia as a Declared Country under Subsection 198A(3) of the Migration Act 1958, declared 25 July 2011, Registered 18 August 2011, http://www.comlaw.gov.au/Details/F2011L01685 (last accessed 27 April 2012)

842 Plaintiff M70/2011 v Minister for Immigration and Citizenship; Plaintiff M106 of $2011 v$ Minister for Immigration and Citizenship [2011] HCA 32; for further detail on the Malaysia Deal and the implications of the M70 decision, see Wood, T, and McAdam, J, Australian Asylum Policy All At Sea: An Analysis of Plaintiff M70/2011 v Minister for Immigration and Citizenship and the Australia-Malaysia Arrangement (2012) 61 ICLQ 274

${ }^{843}$ Gillard, The Honourable Julia, Prime Minister, Transcript of joint press conference, Brisbane, 1 September 2011, http://www.pm.gov.au/press-office/transcript-joint-press-conferencebrisbane-1 (last accessed 27 April 2012) 
leading a minority government, and sufficient support could not be garnered for its passing in the House of Representatives, the Bill was not pursued. ${ }^{844}$

The two decisions of the High Court, and the failure to pass the Offshore Processing Bill, left the Government with very few options other than to announce its commitment to onshore processing. ${ }^{845}$ Indeed, looking back at the trail of policy left in the wake of that announcement, the government looked entirely adrift and highly reactionary - it had ended offshore processing by abolishing the Pacific Solution, it then moved to a separate determination system for those on Christmas Island, then to the implementation of a new determination system for those asylum seekers as a result of the High Court's decision in $M 61 / M 69$, then to a somewhat desperate search for an offshore processing solution using the legislative framework established for the Pacific Solution it had itself ended, and then finally to resigning itself to onshore processing following the High Court's decision in $M 70$. If ever evidence were required to support the assertion that there is an absence of any overarching mythology in relation to asylum seekers in Australia, the measures of the last five years have well and truly furnished it in abundance.

However, there were still further developments - the Government moved towards a single protection visa determination system for both 'unauthorised' arrivals (that is, those on Christmas Island or in other excised offshore areas) and air arrivals (that is, those arriving in the Migration Zone) as well as the use of Bridging Visas to release 'unauthorised' arrivals from detention. ${ }^{846}$ The single processing of air and boat arrivals became effective from 24 March 2012. ${ }^{847}$ Notably, there has been no legislative change to implement this new

${ }^{844}$ Franklin, M, and Kelly, J, Offshore processing backdown will bring boats: Julia Gillard, The Australian, 14 October 2011, http://www.theaustralian.com.au/nationalaffairs/immigration/offshore-processing-backdown-will-bring-boats-julia-gillard/storyfn9hm1gu-1226166277194 (last accessed 27 April 2012); Johnston, M, and Hudson, P, Julia Gillard abandons offshore processing following death of Malaysia deal, Herald Sun, 13 October 2011, http://www.heraldsun.com.au/news/more-news/nationals-mp-tony-crook-maysink-vote-on-malaysia-swap-deal/story-fn7x8me2-1226165520491 (last accessed 27 April 2012)

845 Bowen, The Honourable Chris, Minister for Immigration and Citizenship, Joint Press Conference Canberra with Julia Gillard - Prime Minister of Australia and Chris Bowen MP Minister for Immigration and Citizenship, 13 October 2011, http://www.minister.immi.gov.au/media/cb/2011/cb179299.htm (last accessed 27 April 2012)

846 Bowen, The Honourable Chris, Minister for Immigration and Citizenship, Bridging visas to be issue for boat arrivals, 25 November 2011, http://www.minister.immi.gov.au/ media/cb/2011/cb180599.htm (last accessed 27 April 2012); Needham, K, Boat refugees will be assessed as air arrivals, Sydney Morning Herald, 20 March 2012, http://www.smh.com.au/opinion/political-news/boat-refugees-will-be-assessed-as-airarrivals-20120319-1vfrn.html (last accessed 27 April 2012)

847 Australian Government, Department of Immigration and Citizenship, Onshore Protection, http://www.immi.gov.au/visas/humanitarian/onshore/ (last accessed 27 April 2012) 
policy - indeed, the excision legislation remains entirely intact. The change in processing is given effect by the Minister exercising his personal and noncompellable discretion under section 46A of the Migration Act. ${ }^{848}$ Finally, the Migration Amendment (Complementary Protection) Act 2011 also now provides for Protection Visa applicants to seek complementary protection from 24 March 2012 (which will be discussed in more detail subsequently). ${ }^{849}$

Accordingly, when we look back at the period from 1973 to the present we see that Australia has attempted to create a highly managed and controlled migration scheme. Notwithstanding the significant efforts at the resettlement of Indo-Chinese refugees commenced by the Fraser government, a closer inspection reveals that, notwithstanding its humanitarian focus, it had strong control and immigration elements. The Hawke/Keating Governments' policies were an extension of the Fraser Government's emphasis on resettlement and offshore selection. That approach seems to be reflected in the introduction of some of the most harsh measures, including mandatory detention and TPVs, and which were used extensively by the subsequent Howard government. Indeed, the inherited policy inertia across governments is also seen with the Rudd/Gillard Governments who initially abolished the Pacific Solution, only later to use the very legislation which the Howard Government introduced to seek a similar outcome. That very legislative framework still exists to this day.

Further, when we compare this period to that examined by Neumann (1930 1973), we see the same elements re-emerging - the subordination of refugees and asylum seekers to overarching immigration objectives that pursue the national self-interest; a high level of selectivity (even amongst refugees or displaced persons, and the dominance of offshore resettlement programs); the strong influence of international relations in the formulation of asylum policy (particularly in relation to Indonesia, but also evident in the Cambodian Peace Plan negotiations, and now with a growing regional focus); a disinterest with the nation's international standing (evident most clearly in the Tampa incident and, as will be discussed throughout this book, Communications to the HRC); and a high degree of actual control. The most significant difference, as flagged by Neumann himself, is that more recent governments have been extremely sensitive to popular and populist opinion and, rather than be unmoved by public opinion and minimising public concern, have incited sentiment against asylum seekers.

\footnotetext{
848 Australian Government, Department of Immigration and Citizenship, Implementation of a single process for Irregular Maritime Arrivals (Questions and Answers), http://www.immi.gov.au/visas/humanitarian/_pdf/implementation_single_process_ima.pd f (last accessed 27 April 2012)

849 Australian Government, Department of Immigration and Citizenship, Implementation of Complementary Protection (Questions and Answers) http://www.immi.gov.au/visas/ humanitarian/_pdf/implementation_of_cp_qa.pdf (last accessed 27 April 2012)
} 
Looked at holistically, the responses to asylum seekers from 1973 to the present appear ad hoc and reactionary. For Australia, a good asylum policy is one that is a resettlement policy conducted off its shores with people it could select. The measures taken against asylum seekers during this period are consistent with the perception of an asylum seeker as an affront to a carefully planned and managed immigration policy and to international relations within the region. It is the notion of "the queue" that has so fixated the Australian approach to asylum seekers.

But this notion of "the queue", purportedly existing orderly and offshore, which pervades the Australian policy on asylum seekers, is ripe for debunking. As Nicholls pointedly notes, "the queue" isn't really a queue with each person assessed and accepted on a 'first-come, first-served basis': other factors play a very significant part in the acceptance of persons for resettlement irrespective of their place in the queue - such as pre-existing links to Australia, state of health, or sponsorship from within Australia. ${ }^{850}$ Describing the offshore resettlement program as a "quasi migration program", ${ }^{851}$ Skulan cites the following exchange between Maley and a senior official from the UNHCR:

\begin{abstract}
"He was approached in Africa by an Australian bureaucrat who wished to discuss 'refugee resettlement'. Over tea, the Australian looked at him and said: 'You and I speak the same language. What we want are English-speaking engineers.' 'There's a problem here', replied the UNHCR staffer. 'I can give you some non-literate women who've been raped." 852
\end{abstract}

Of course, the inference drawn from asylum seekers characterised as "queue jumpers" is that they are "bad", that they are 'less genuine' or less worthy than the "good" ones that wait. ${ }^{853}$ Although this has its origins that extend back to the Fraser Government's measures, it is a conceptualisation concretised under the Howard Government's decision to reduce the number of places in the Humanitarian Program by the number of onshore asylum recipients.

What begins to emerge, then, is that Australia's treatment of asylum seekers most notably mandatory detention - is not punishment for 'unlawful' entry per $s e$, it is punishment for defying immigration policy and disrupting international relations. These are measures designed to deter. The approach to asylum

\footnotetext{
850 Nicholls, G, Unsettling admissions: asylum seekers in Australia (1998) 11(1) Journal of Refugee Studies 62, P.76

${ }^{851}$ Skulan, C, Australia's Mandatory Detention of Unauthorised Asylum Seekers: History, Politics, and Analysis, under International Law, (2006) 21(1) Georgetown Immigration Law Journal 61 at P.81

852 Skulan, C, Australia's Mandatory Detention of Unauthorised Asylum Seekers: History, Politics, and Analysis, under International Law, (2006) 21(1) Georgetown Immigration Law Journal 61 at P.82 citing Maley, W, Refugee Policy: Towards a Liberal Framework, Policy, Vol.18, No. 3, Pp. $37-40$ at P.38

853 Crock, M, Saul, B, and Dastyari, A, Future Seekers II, 2006, Federation Press, Leichhardt, P.18
} 
seekers is not consistent with being a true humanitarian exception to an entirely controlled and planned immigration (that is, one that responds to the needs of people rather than the demands of the host State).

If an asylum policy is to be formulated, then it must be flexible to accommodate those greatest in need, responsive to their needs and to be so at times when needed. A resettlement programme with capped numbers and nationally self-interested selection criteria sit uneasily with the flexibility and responsiveness that is required to address human suffering.

\subsection{Current Australian Legislative Framework}

Under the Australian Constitution, the Federal Parliament has power to make laws with respect to, inter alia, naturalisation and aliens, ${ }^{854}$ and immigration and emigration. ${ }^{855}$ Executive power is also expressly conferred by section 61 of the Australian Constitution. ${ }^{856}$

The legislative mechanism for controlling migration to Australia is the Migration Act 1958 (Cth). The Act works in combination with subordinate legislation, the Migration Regulations 1994 (Cth). The Regulations set out the specific eligibility requirements and conditions. Under the Regulations, four schedules to the Regulations are of particular importance: firstly, Schedule 1 prescribes the classes of visas; secondly, Schedule 2 prescribes the subclasses of visas and sets out the criteria required for fulfilling eligibility requirements, as well as when the visa is effective and any conditions that may or must be imposed; thirdly, Schedule 4 sets out the public interest criteria which must be met for the grant of a particular visa (for example, health requirements and "the character test"); and fourthly, Schedule 8 decodes the four-digit codes prescribed in Schedule 2 that may or must be imposed on visas (for example, an 8101 condition prohibits the visa holder from working in Australia).

Although not legislation or subordinate legislation, Ministerial Series Instructions (MSIs) may be made under section 499 of the Migration Act and subsequently form part of the Department of Immigration's Procedural Advice Manual ("PAM3") which sets out instructions for immigration officials on how to apply government policy. PAM3 is not, however, legally binding on a

\footnotetext{
${ }^{854}$ Section 51 (xix) of the Constitution

855 Section 51(xxvii) of the Constitution

856 See further Winterton, G, The Relationship Between Commonwealth Legislative and Executive Power (2004) 25(1) Adelaide Law Review 21; Crock, M, and Berg, L, Immigration, Refugees and Forced Migration - Law, Policy and Practice in Australia, 2011, Federation Press, Leichhardt, Ch.3; Blackshield, T, and Williams, G, Australian Constitutional Law and Theory, (5ed) 2010, Federation Press, Leichhardt, Ch.11
} 
decision maker nor is it a substitution for compliance with the law. ${ }^{857}$ For this reason, the substantive focus of this book is concerned with justiciable rights and will not include references to the PAM3 manual except to the extent that it reveals a discrepancy between the law and actual or aspirational practice.

Australia has adopted a universal visa system by virtue of the Migration Act 1958 (Cth). As noted by Murphy, ${ }^{858}$ the Migration Act essentially recognises three types of persons in Australia: (1) citizens; (2) lawful non-citizens; ${ }^{859}$ and (3) unlawful non-citizens. ${ }^{860} \mathrm{~A}$ person is a lawful non-citizen if they hold a visa, the class and subclass of which is determined by the Migration Regulations 1994. A non-citizen must not travel to Australia without a visa that is in effect. ${ }^{861}$ If a visa has been cancelled and is not immediately succeeded by one that is in effect, then a lawful non-citizen is or becomes an unlawful noncitizen. $^{862}$ The main exception ${ }^{863}$ to persons required to hold a visa prior to entering Australia and/or to remain in Australia are New Zealand citizens, who are subject to the 1973 Trans-Tasman Travel Arrangement. A Special Category Visa is issued to New Zealand citizens upon presentation of their passport to Australian immigration officials upon arrival in Australia. ${ }^{864}$

Migration to Australia is matched against Australia's interests (including the grant of Protection Visas). ${ }^{865}$ Permanent migration is only possible in four ways ${ }^{866}$ - firstly, the Skilled stream; ${ }^{867}$ secondly, the Family stream; $;{ }^{86}$ thirdly, the Special Eligibility scheme ${ }^{869}$ and fourthly, the Humanitarian programme.

857 Minister for Immigration, Local Government and Ethnic Affairs v Gray [1994] FCA 1052 per French and Drummond JJ at para 25; El Ess $v$ Minister for Immigration, Multicultural and Indigenous Affairs [2004] FCA 1038 para 45

858 Murphy, K, The SIEV 36 Incident, recording of presentation at the College of Law, Australian National University, 5 June 2009, ABC Fora, (recording held by author having been downloaded from http://mpegmedia.abc.net.au/tv/fora/anu_siev36_full.mp4 (at 2:33) on 23 September 2009 (link no longer available)

859 Sections 5 and 13 Migration Act 1958 (Cth)

860 Section 14 Migration Act 1958 (Cth)

861 Section 42 Migration Act 1958 (Cth)

862 Section 15 Migration Act 1958 (Cth)

863 There are other limited circumstances in which a non-citizen may travel to Australia without a valid visa set out in section 42 of the Migration Act 1958 (Cth) including those who have been removed from Australia and refused entry by the country to which he or she has been removed, and "transitory persons" who have been sent to another country for offshore processing and are brought back to Australia (see section 42(2A)(ca), (d) and (e)) ${ }^{864}$ Regulation 5.15A of the Migration Regulations 1994 (Cth), section 42(2)(a) Migration Act 1958 (Cth) see also, Australian Government, Department of Immigration and Citizenship, Fact Sheet 17, http://www.immi.gov.au/media/fact-sheets/17nz.htm (last accessed 3 May 2012)

865 See section 4(1) of the Migration Act 1958 (Cth)

866 Australian Government, Department of Immigration and Citizenship, Fact Sheet 1 http://www.immi.gov.au/media/fact-sheets/01backgd.htm (last accessed 3 May 2012)

867 For further detail on the Skilled stream see Crock, M, and Berg, L, Immigration Refugees and Forced Migration - Law, Policy and Practice in Australia, 2011, Federation Press, Leichhardt, Pp.232-268; Vrachnas, J, Dimopoulos, P, Boyd, K, Bagaric, M, Migration and 
The Humanitarian programme is divided into two categories. Firstly, there is a refugee category; and secondly, there is the Special Humanitarian Category. Under the 2011-2012 programme, 13,750 places are reserved under the Humanitarian programme $-6,000$ places are allocated to offshore refugees, and 7,750 places are reserved for the Special Humanitarian Programme (SHP) (for those offshore applicants outside their home country who face substantial discrimination amounting to a gross violation of human rights inside their home country), and to the onshore humanitarian programme. ${ }^{870}$ Accordingly, as pointed out earlier, the linking of onshore grants of asylum and the offshore SHP has resulted in the number of offshore applicants taken under the SHP being reduced by the number of onshore applicants granted Protection Visas.

Accordingly, the capped amount of places consists of an offshore and onshore humanitarian component. The offshore humanitarian programme is conducted with the assistance, but not under the control, of the UNHCR ${ }^{871}$ In 2010 , Australia $(8,500)$ ranked third behind the United States $(71,400)$ and Canada $(12,100)$ in numbers of persons admitted under the resettlement programme. ${ }^{872}$ In 2009 , the Australian resettlement program was described by the High Commissioner for Refugees, António Gueterres, as "one of the best refugee settlement programmes in the world". ${ }^{873}$

Refugee Law: Principles and Practice in Australia, (2ed) 2008, Cambridge University Press, Port Melbourne, Pp.101-116

${ }^{868}$ For further detail on the Family stream see Crock, M, and Berg, L, Immigration Refugees and Forced Migration - Law, Policy and Practice in Australia, 2011, Federation Press, Leichhardt, Pp.176-229; Vrachnas, J, Dimopoulos, P, Boyd, K, Bagaric, M, Migration and Refugee Law: Principles and Practice in Australia, (2ed) 2008, Cambridge University Press, Port Melbourne, Pp.51-81

869 This scheme "covers former residents who had not acquired Australian citizenship and are seeking to return to Australia as permanent residents" see Australian Government, Department of Immigration and Citizenship, Fact Sheet 1 http://www.immi.gov.au/media/fact-sheets/01backgd.htm (last accessed 3 May 2012); Australian Government, Department of Immigration and Citizenship, Fact Sheet 40, http://www.immi.gov.au/media/fact-sheets/40special.htm (last accessed 3 May 2012)

870 Department of Immigration and Citizenship, Australia's Humanitarian Program 20122013 and beyond, December 2011, http://www.immi.gov.au/about/contracts-tenderssubmissions/_pdf/2012-13-humanitarian-program-information-paper.pdf (last accessed 3 May 2012), P.14; Department of Immigration and Citizenship, Fact Sheet 60, http://www.immi.gov.au/media/fact-sheets/60refugee.htm (last accessed 3 May 2012)

${ }^{871}$ UNHCR Regional Office - Australia, New Zealand, Papua New Guinea and the Pacific, Resettlement, http://unhcr.org.au/unhcr/index.php?option=com_content\&view $=$ article\&id $=139 \&$ Itemid $=60$ (last accessed 3 May 2012)

872 United Nations High Commissioner for Refugees, UNHCR 2010 Statistical Yearbook Trends in Displacement Protection and Solutions, http://www.unhcr.org/static/statistical_ yearbook/2010/2011-SYB10-all-chapters.zip (last accessed 3 May 2012), P.38

873 UNHCR, UNHCR chief praises Australia's refugee resettlement services, 25 February 2009, http://www.unhcr.org/49a55ff32.html (last accessed 3 May 2012) 


\subsection{Statistical Overview}

To complete the overview of the Australian Humanitarian Program, the following statistics may be of assistance. In 2011, Australia received 11,510 claims for asylum, representing 3\% of all claims lodged in 44 industrialised countries, and representing 0.5 claims lodged per 1,000 inhabitants. ${ }^{874}$

Humanitarian Program outcomes: visas granted 2010-2011875

\begin{tabular}{|l|r|}
\hline Category & $\mathbf{2 0 1 0 - 2 0 1 1}$ \\
\hline Offshore & 5,211 \\
\hline Refugee & 26 \\
\hline In-country Special Humanitarian & 2,973 \\
\hline Global Special Humanitarian & 2 \\
\hline Emergency Rescue & 759 \\
\hline Woman at Risk & $\mathbf{8 , 9 7 1}$ \\
\hline Total Offshore & 4,818 \\
\hline Onshore & 2 \\
\hline Protection (Refugee) & 8 \\
\hline Resolution of Status (former TPV holders) & \\
\hline $\begin{array}{l}\text { Global Special Humanitarian } \\
\text { (Ministerial Intervention) }\end{array}$ & $\mathbf{4 , 8 2 8}$ \\
\hline Total Onshore & $\mathbf{1 3 , 7 9 9}$ \\
\hline Total Grants & \\
\hline
\end{tabular}

Source: Department of Immigration and Citizenship 876

Offshore humanitarian visa grants by country of birth 2010-2011

\begin{tabular}{|l|r|}
\hline Country of Birth & $\mathbf{2 0 1 0 - 2 0 1 1}$ \\
\hline Iraq & 2,151 \\
\hline Burma & 1,443 \\
\hline Afghanistan & 1,027 \\
\hline Bhutan & 1,001 \\
\hline Congo (DRC) & 565 \\
\hline Ethiopia & 381 \\
\hline Sri Lanka & 289 \\
\hline Iran & 271 \\
\hline Sudan & 243 \\
\hline Somalia & 190 \\
\hline Others & 1,410 \\
\hline Total & $\mathbf{8 , 9 7 1}$ \\
\hline
\end{tabular}

Source: Department of Immigration and Citizenship 877

874 UNHCR, Asylum Levels and Trends in Industrialized Countries 2011, 27 March 2012, http://www.unhcr.org/4e9beaa19.html (last accessed 3 May 2012), Table 1, P.20

875 The year 2010-2011 represents the Australian financial year which runs from 1 July to 30 June

876 Australian Government, Department of Immigration and Citizenship, Trends in Migration: Australia 2010-2011, http://www.immi.gov.au/media/publications/ statistics/trends-in-migration/trends-in-migration-2010-11.pdf (last accessed 3 May 2012), P.52 
Onshore initial Protection visa applications by citizenship 2010-2011

\begin{tabular}{|c|c|c|c|}
\hline Citizenship & $\begin{array}{c}\text { Non-Irregular } \\
\text { Maritime } \\
\text { Arrivals }^{878}\end{array}$ & Citizenship & $\begin{array}{l}\text { Irregular } \\
\text { Maritime } \\
\text { Arrivals }{ }^{879}\end{array}$ \\
\hline PRC & 1,122 & Afghanistan & 1,612 \\
\hline India & 555 & Iran & 1,549 \\
\hline Pakistan & 547 & Stateless & 895 \\
\hline Egypt & 427 & Iraq & 542 \\
\hline Iran & 384 & Sri Lanka & 362 \\
\hline Fiji & 329 & & \\
\hline Nepal & 226 & & \\
\hline Iraq & 220 & & \\
\hline India & 212 & & \\
\hline Malaysia & 195 & & \\
\hline Other & 2,099 & Other & 215 \\
\hline Total & 6,316 & Total & 5,175 \\
\hline
\end{tabular}

Source: Department of Immigration and Citizenship ${ }^{880}$

Onshore Protection Visa grants by citizenship 2010-2011

\begin{tabular}{|c|c|c|c|}
\hline Citizenship & $\begin{array}{c}\text { Non-Irregular } \\
\text { Maritime Arrivals }\end{array}$ & Citizenship & $\begin{array}{c}\text { Irregular } \\
\text { Maritime Arrivals }\end{array}$ \\
\hline Iran & 369 & Afghanistan & 1,335 \\
\hline PRC & 315 & Stateless & 481 \\
\hline Pakistan & 208 & Iran & 333 \\
\hline Zimbabwe & 172 & Iraq & 239 \\
\hline Egypt & 142 & Sri Lanka & 236 \\
\hline Sri Lanka & 117 & & \\
\hline Iraq & 113 & & \\
\hline Fiji & 87 & & \\
\hline Lebanon & 64 & & \\
\hline Afghanistan & 59 & & \\
\hline Other & 455 & Other & 72 \\
\hline Total & 2,101 & Total & 2,696 \\
\hline
\end{tabular}

Source: Department of Immigration and Citizenship 881

877 Australian Government, Department of Immigration and Citizenship, 2010-2011 Humanitarian Program, http://www.immi.gov.au/media/statistics/pdf/humanitarianprogram-outcomes-2010-11.pdf (last accessed 3 May 2012), P.2

878 This denotes those that have entered the country 'lawfully' (that is, with a valid visa)

879 This denotes those that have entered the country 'unlawfully' (that is, without a valid visa, by boat) and who are processed on Christmas Island

880 Australian Government, Department of Immigration and Citizenship, Department of Immigration and Citizenship Annual Report 2010-2011, http://www.immi.gov.au/about/ reports/annual/2010-11/pdf/report-on-performance.pdf (last accessed 3 May 2012) Pp.120-121

881 Australian Government, Department of Immigration and Citizenship, Department of Immigration and Citizenship Annual Report 2010-2011, http://www.immi.gov.au/about /reports/annual/2010-11/pdf/report-on-performance.pdf (last accessed 3 May 2012) Pp.121-122 
To provide comparable data, in 2011 the top-10 nationalities of asylum seekers by country of origin in Australia were as follows:

\begin{tabular}{|l|r|}
\hline Country of Origin & $\begin{array}{c}\text { Number of } \\
\text { applications }\end{array}$ \\
\hline Iran & 2,156 \\
\hline Afghanistan & 1.721 \\
\hline China & 1,188 \\
\hline Pakistan & 817 \\
\hline India & 765 \\
\hline Stateless & 530 \\
\hline Iraq & 491 \\
\hline Egypt & 417 \\
\hline Sri Lanka & 370 \\
\hline Fiji & 276 \\
\hline Soure:
\end{tabular}

Source: UNHCR 882

882 UNHCR, Asylum Levels and Trends in Industrialized Countries 2011, 27 March 2012, http://www.unhcr.org/4e9beaa19.html (last accessed 3 May 2012), Table 23, P.44 


\section{Chapter 4 \\ Definitions, Territorial and Jurisdictional Scope}

Firstly, it is necessary to identify as precisely as possible what is meant by the term "asylum seeker" with a brief exploration of the distinctions between an asylum seeker and a refugee. It is also necessary to identify different subcategories of asylum seeker and to identify the presence of those terms in each jurisdiction's relevant legislation. This is important as different subcategories of asylum seekers will be entitled to differing rights and considerations in the context of detention, and which may have a consequent effect on any analysis of proportionality. In the Union context, the importance of precisely identifying who is an asylum seeker is one of the central elements of falling within the personal scope of the secondary legislation.

Secondly, the term "detention" will be analysed the importance of which becomes more evident when trying to distinguish between alternatives to detention and alternative forms of detention. ${ }^{883}$

Thirdly, the territorial and jurisdictional scope of each jurisdiction's provisions will be analysed. This is particularly important in the Union sphere where certain Member States have decided not to opt-in to parts of the CEAS secondary legislation. Accordingly, the territorial scope of the Union's CEAS secondary legislation does not necessarily follow the geographical bounds of the Union.

\subsection{Asylum Seeker}

\subsubsection{1 "Asylum seeker" - International}

At the international level, there is no definition of "asylum-seeker" per se in the major international treaties. ${ }^{884}$ This is notwithstanding the fact that Article 14 UDHR provides that "Everyone has the right to seek and enjoy in other countries asylum from persecution". Although the term "asylum seeker" may

\footnotetext{
${ }^{883}$ Indeed, this distinction was made by the Joint Standing Committee's Report which separately considered alternatives to immigration detention centres and alternatives to immigration detention per se: see Parliament of Australia, Joint Standing Committee on Migration, Immigration Detention in Australia: Community-based alternatives to detention, 2009, Canberra, http://www.aph.gov.au/house/committee/mig/detention/report2/fullreport .pdf (last accessed 27 April 2012) Pp.24-25, para 2.37. See also, Field, O, with Edwards, A, Alternatives to Detention of Asylum Seekers and Refugees, United Nations High Commissioner for Refugees, Division of International Protection Services, April 2006, POLAS/2006/03 at para 13

884 Weisbrott, D, The Human Rights of Non-Citizens, 2008, Oxford University Press, Oxford, P.111
} 
be characterised more as a term of art than of law in an international legal sense, it has emerged as a term of law in the Union secondary legislation. Further, it is a term widely used in the Australian context, even if it lacks an express legal grounding.

The key to understanding what is meant by the term "asylum seeker" is to understand the nature of the asylum sought. An asylum seeker may be seeking refugee status under the Geneva Convention in accordance with the definition of Article 1A(2). The UNHCR identifies the term "asylum seeker" to generally mean a person that has "left their country of origin, has applied for recognition as a refugee in another country, and is awaiting a decision on their application". ${ }^{885}$ It should be noted that a person is said to be a refugee as a question of fact whenever he or she meets the definition in Article 1A(2) of the Geneva Convention. ${ }^{886}$ That is, a person is a refugee regardless of, and prior to, the conferral of refugee status by a State. Indeed, Goodwin-Gill and McAdam describe the conferral of refugee status as "declaratory, rather than constitutive". ${ }^{887}$ Asylum seekers may be considered "presumptive refugees" for the purposes of the Geneva Convention. ${ }^{888}$ Accordingly, a refugee is, at some point in their plight to obtain refugee status, an asylum seeker. ${ }^{889}$

However, not all asylum seekers are refugees. Where the person does not fulfil the definition of a refugee and is not eligible for refugee status, but still has international protection needs, an asylum seeker may seek to rely on complementary protection ${ }^{890}$ (that is, international protection resulting from international conventions other than the Geneva Convention such as CAT,

885 See, for example, UNHCR, UNHCR - About Us - About Refugees http://unhcr.org.au/unhcr/index.php?option $=$ com_content\&view $=$ article\&id=179\&Itemi $\mathrm{d}=54$ (last accessed 20 May 2011)

886 UNHCR, Handbook on Procedures and Criteria for Determining Refugee Status, 1979, 1992 re-ed, para 28; Goodwin-Gill, G, and McAdam, J, The Refugee in International Law, 2007, OUP, Oxford, P.51; Hathaway, J C, The Rights of Refugees under International Law, 2005, Cambridge University Press, Cambridge, Pp. 158 and 278; Lauterpacht, E, and Bethlehem, $\mathrm{D}$, The scope and content of the principle of non-refoulement: Opinion in Feller, E, Türk, V, and Nicholson, F, Refugee Protection in International Law, 2003, Cambridge University Press, Cambridge, P.116 para 90.

887 Goodwin-Gill, G, and McAdam, J, The Refugee in International Law, 2007, OUP, Oxford, P.51

888 Goodwin-Gill, G, Article 31 of the 1951 Refugee Convention Relating to the Status of Refugees, in Feller, E, Türk, V, and Nicholson, F, Refugee Protection in International Law, 2003, Cambridge University Press, Cambridge, P.193

889 UNHCR, Note on International Protection, 31 August 1993, A/AC.96/815 http://www.unhcr.org/refworld/docid/3ae68d5d10.html (last accessed 7 September 2011), para 11

890 See Mandal, R, Protection Mechanisms Outside of the 1951 Geneva Convention ("Complementary Protection"), UNHCR Legal and Protection Policy Research Series, June 2005, PPLA/2005/02, para 4 
ICCPR, CROC ${ }^{891}$ or on "general humanitarian principles" 892 ). Notably, these Conventions contain other sources of non-refoulement obligations (such as Article 3 CAT, Article 7 ICCPR or, regionally, Article 3 ECHR $^{893}$ ) which are not in identical terms to Article 33 of the Geneva Convention, but which may provide comparable protection. The importance of protection against refoulement for those falling outside the definition of the Geneva Convention was acknowledged by the UNHCR in its 2005 EXCOM conclusion on complementary protection. ${ }^{894}$ Goodwin-Gill and McAdam describe complementary protection as "a shorthand term for the widened scope of nonrefoulement under international law". 895

Complementary protection does, however, have its limitations. As noted by Goodwin-Gill and McAdam, it is an entirely different basis for which a State may permit the stay of a person on its territory than, say for "compassionate" reasons ${ }^{896}$ (such as age, or health conditions or family relationships with no nexus to international protection) ${ }^{897}$ or for "practical reasons" 898 (such as the lack of travel documents). ${ }^{899}$ It is also to be distinguished from temporary

891 McAdam, J, Seeking Asylum under the Convention on the Rights of the Child: A case for Complementary Protection (2006) 15 International Journal of Children's Rights 251

892 McAdam, J, Complementary Protection in International Refugee Law, 2007, OUP, Oxford, P.21

893 See den Heijer, M, Whose Rights and Which Rights? The Continuing Story of NonRefoulement under the European Convention on Human Human Rights (2008) 10 EJML 277; and Battjes, H, The Soering Threshold: Why Only Fundamental Values Prohibit Refoulement in ECHR Case Law (2009) 11 EJML 205 - both authors suggest that non-refoulement under the ECHR has developed beyond Articles 2 and 3 ECHR only in cases of "flagrant" violation of other provisions of the Convention.

894 "Acknowledging that in many countries a number of administrative or legislative mechanisms are in place for regularizing, on a variety of grounds, the stay of persons, including those who may not be eligible for refugee protection but who may be in need of international protection" (Recital) and "Encourages the use of complementary forms of protection for individuals in need of international protection who do not meet the refugee definition under the 1951 Convention or the 1967 Protocol" (para (i)), UNHCR, Executive Committee Conclusion No. 103 (LVI), Conclusion on the Provision of International Protection Including Through Complementary Forms of Protection, 7 October 2005.

895 Goodwin-Gill, G, and McAdam, J, The Refugee in International Law, 2007, OUP, Oxford, P.285; Note however, Hathaway's views on the questionable status of nonrefoulement as customary international law - Hathaway, J C, The Rights of Refugees under International Law, 2005, Cambridge University Press, Cambridge, Pp.363-370

896 UNHCR, Executive Committee Conclusion No. 103 (LVI), Conclusion on the Provision of International Protection Including Through Complementary Forms of Protection, 7 October 2005, para (j)

897 Goodwin-Gill, G, and McAdam, J, The Refugee in International Law, 2007, OUP, Oxford, P.286

898 UNHCR, Executive Committee Conclusion No. 103 (LVI), Conclusion on the Provision of International Protection Including Through Complementary Forms of Protection, 7 October 2005, para (j)

899 Goodwin-Gill, G, and McAdam, J, The Refugee in International Law, 2007, OUP, Oxford, P.286 
protection in the event of a mass-influx of asylum seekers. ${ }^{900}$ The main difference between protection afforded under the Geneva Convention and that of complementary protection is that of status - as McAdam notes, recipients of complementary protection do not, as a rule, hold a particular status (as refugees under the Geneva Convention do and with consequent substantive accretive rights) resulting in protection gaps and legal uncertainty from the reliance of general human rights principles being implemented domestically. ${ }^{901}$

Although it is beyond the scope of this book to explore the motivations for asylum seekers to seek international protection, it is worth noting two points. Firstly, McAdam notes that the Geneva Convention is inclusive of previous broader definitions of persecution, including armed conflict and generalised violence. ${ }^{902}$ Secondly, socio-economic persecution should not necessarily be dismissed as falling outside the scope of the Geneva Convention. ${ }^{903}$ Indeed, when the degree of human suffering is comparable, it is questionable to maintain a distinction between the form of the persecution. In the detention context, a misguided approach by authorities to socio-economic persecution may result in such claims being deemed manifestly unfounded, ${ }^{904}$ resulting in accelerated assessment procedures, systematic detention, or detention pending removal.

\subsubsection{2 "Asylum seeker" - Council of Europe}

The Committee of Ministers of the Council of Europe in their Recommendation 2003(5) (which pre-dates the EU Qualification I Directive) have not expressly defined what is meant by an asylum seeker, notwithstanding that the preamble to the Recommendation recalls the Geneva Convention and its Protocol, as well the ECHR, the case law of the ECtHR, the UDHR, the ICCPR, the ESCR and CROC. The preamble also contemplates "those who are in need of international protection". Accordingly, it is arguable that the term "asylum seeker" contained in the Recommendation is sufficiently broad to contemplate those persons seeking

\footnotetext{
900 UNHCR, Executive Committee Conclusion No. 103 (LVI), Conclusion on the Provision of International Protection Including Through Complementary Forms of Protection, 7 October 2005, para (l)

901 McAdam, J, Complementary Protection in International Refugee Law, 2007, OUP, Oxford, Pp.197-208

902 McAdam, J, Complementary Protection in International Refugee Law, 2007, OUP, Oxford, P.34

903 Foster, M, International Refugee Law and Socio-Economic Rights, 2007, CUP, New York

904 The UNHCR has characterised "clearly abusive" or "manifestly unfounded" claims as "those which are clearly fraudulent or not related to the criteria for the granting of refugee status laid down in the 1951 United Nations Convention relating to the Status of Refugees nor to any other criteria justifying the granting of asylum", UNHCR, The Problem of Manifestly Unfounded or Abusive Applications for Refugee Status or Asylum, 20 October 1983, no. 30 (XXXIV) http://www.unhcr.org/refworld/docid/3ae68c6118.html (last accessed 13 September 2011)
} 
either refugee or subsidiary protection status. The Recommendation expressly does not apply to those asylum seekers who are criminally detained or to those whose applications have been rejected and are detained pending removal. ${ }^{905}$

Further, the Committee of Ministers of the Council of Europe, in its 20 Guidelines on Forced Return, has not expressly set out who is included within the scope of its guidelines - notwithstanding that its preamble refers to "aliens" and "illegal residents" within the territories of the Member States. 906

\subsubsection{3 "Asylum seeker" - European Union - EU Charter}

In the Union sphere, Article 18 of the EU Charter provides a right to asylum but only the Geneva Convention and its Protocol are contemplated. That right is further qualified by the addition of the words "and in accordance with the Treaty on European Union and the Treaty on the Functioning of the European Union".

\subsubsection{1 "Asylum seeker" - EU Secondary Legislation}

As the pieces of Union secondary legislation that contemplate detention are currently the subject of proposed amendments, precisely to whom that secondary legislation applies is in a somewhat transitory state. Accordingly, there is a distinction between the classical understanding of an "asylum seeker" as being one who seeks refugee status under the 1951 Geneva Convention on the one hand and, on the other hand, a broader definition of an "applicant for international protection" which incorporates applicants for either refugee status or for subsidiary protection status.

Currently, the classical understanding of an asylum seeker as a person seeking refugee status is contained in the Reception Conditions Directive, the Dublin II Regulation and the Procedures Directive. ${ }^{907}$ However, inconsistencies in the terminology may be subtle but prevent an immediately amalgamated discussion on any common personal scope of the legislation. ${ }^{908}$

\footnotetext{
905 Committee of Ministers, Council of Europe, Recommendation Rec(2003)5 of the Committee of Ministers to member states on measures of detention to asylum seekers, paragraph 2

906 Committee of Ministers, Council of Europe, Twenty Guidelines on Forced Return, CM(2005)40 Addendum final, Strasbourg, 20 May 2005.

907 Article 2(c) of the Reception Conditions Directive; Article 2(d) of the Dublin II Regulation; and Article 2(c) of the Procedures Directive

908 The inconsistencies arise in both the precise terms used, as well as in the personal scope in each of those three pieces of legislation. Firstly, Article 2(c) of the Reception Conditions Directive and Article 2(d) of the Dublin II Regulation, adopt the terms "applicant" or "asylum seeker", whereas Article 2(c) of the Procedures Directive uses the terms "applicant" or "applicant for asylum". Secondly, Article 2(d) of the Dublin II Regulation does not contemplate stateless persons in its definition, whereas Article 2(c) of the Reception Conditions Directive and Article 2(c) of the Procedures Directives do (in addition to third country nationals).
} 
Notwithstanding those inconsistencies, the essential elements of commonality between those three pieces of legislation that contemplate detention are firstly, that EU citizens are excluded ${ }^{909}$ (that is, the personal scope is restricted at least to third country nationals and, in the case of the Reception Conditions Directive and Procedures Directive, to stateless persons as well); secondly, that the application sought by those persons is under the Geneva Convention (that is, for refugee status only - subsidiary protection is not included) $;{ }^{910}$ and that, thirdly, the status of an asylum seeker is only retained until a final decision on that asylum application is made. ${ }^{911}$

Although "final decision" is only defined in the Procedures Directive, ${ }^{912}$ it may be that a person may be considered an asylum seeker up until the point at which all appeals contemplated in Chapter V of the Directive have been exhausted. ${ }^{913}$ The practical effect of appeals under Chapter V of the Directive on the retention of status of an asylum seeker will be discussed in a subsequent chapter.

${ }^{909}$ In relation to the Dublin II Regulation, Icelandic, Norwegian and Swiss nationals are also excluded by virtue of the relevant Dublin association agreements (see Chapter 2): see Hermann, M in Hailbronner, K, (ed) EU Immigration and Asylum Law - Commentary on EU Regulations and Directives, 2010, Beck, München, Pp.1351-1488 at 1391. In relation to the Reception Conditions Directive, it is questionable whether candidate countries to the Union are excluded from the scope of the Directive: Peek, M, in Hailbronner, K, (ed) EU Immigration and Asylum Law - Commentary on EU Regulations and Directives, 2010, Beck, München, Pp.871-984 at P.896

910 That understanding is also consistent with the provisions of the Eurodac and the Implementation of the Eurodac. The Eurodac Regulation (Regulation 2725/2000) does not define "asylum seeker" as such, but rather refers to an "applicant for asylum" which is defined as "an alien who has made an application for asylum or on whose behalf such an application has been made" (Article 2(1)(b) of the Eurodac, Regulation 2725/2000). Understandably, that definition also bears relevance to the Implementation of the Eurodac (Regulation 407/2002) which also includes references to an "applicant for asylum". However, it is also worth nothing that the Temporary Protection Directive (Directive 2001/55/EC) whilst providing no definition of "asylum seeker" does not necessarily equate "displaced persons" with asylum seekers. Rather, it refers to displaced persons, inter alia, as third-country nationals or stateless persons "who may [emphasis added] fall within the scope of Article $1 \mathrm{~A}$ of the Geneva Convention or other international or national instruments giving international protection" (Article 2(c) of Directive 2001/55/EC).Further, the Reception Conditions Directive does not apply with the Temporary Protection Directive (Directive 2001/55/EC) applies - Article 3(3) of the Reception Conditions Directive (Directive 2003/9/EC).

911 Article 2(c) of the Reception Conditions Directive; Article 2(c) of the Procedures Directive and Article 2(d) of the Dublin II Regulation

912 Article 2(d) of the Procedures Directive

913 Particular attention should also be paid to Annexure III to the Procedures Directive which, provides that, in the determination of "final decision", Spain may equate the term 'recurrente' in its legislation with an "applicant" or an "applicant for asylum" under the Procedures Directive for the purposes of Chapter V of the Directive. 
In relation to those asylum seekers who no longer have a right to remain (that is, under the CEAS or in the absence of another substantive right to remain or who have been refused entry), the Returns Directive predictably does not refer to asylum seekers but rather to illegally staying third-country nationals. An "illegal stay" is defined as the stay on the territory of a Member State where the person "does not fulfil the conditions set out in Article 5 of the Schengen Borders Code" (that is, the entry requirements discussed in Chapters 2 and 5 of this book) ${ }^{914}$ or, importantly, "other conditions for entry, stay or residence in that Member State." "915 "Stateless persons are not expressly contemplated - only "third country nationals", who are defined as any person who is not an EU citizen and "not enjoying the Community right of free movement, as defined in Article 2(5) of the Schengen Borders Code."916

Under the Qualification I Directive (which does not contemplate detention) reference is simply made to the undefined (but self-evident) term "applicants" but its definition of "application for international protection" firstly, contemplates both refugee and subsidiary protection statuses; and secondly, applies only to third country nationals and stateless persons to the exclusion of Union Citizens, ${ }^{917}$ but not necessarily Swiss, Icelandic or Norwegian nationals. ${ }^{918}$ The refugee and subsidiary protection statuses are said to be independent of one another, ${ }^{919}$ and subsidiary protection status may be described as truly complementary given that eligibility for that status is

\footnotetext{
914 Regulation 562/2006 of the European Parliament and of the Council of 15 March 2006 establishing a Community Code on the rules governing the movement of persons across borders (Schengen Borders Code) - discussed in Chapter 2

915 Article 3(2) of the Returns Directive

916 Article 3(1) of the Returns Directive. Note that this would include third country national family members of EU citizens (resulting from Directive 2004/38) and Swiss, Icelandic, Norwegian and Liechtenstein nationals as a result of the EU-Swtizerland Agreement and the other respective EEA Association Agreements (see Chapter 2): Schieffer, M, Chapter V-Termination of Residence in Hailbronner, K, (ed), EU Immigration and Asylum Law - Commentary on EU Regulations and Directives, 2010, Beck, München, Pp.1489-1552 at $1513-1514$

917 Article 2(g) of Directive 2004/83/EC. Consistent with that provision and in relation to the exclusion of Union citizens from applications for asylum, see Protocol (No 24) on asylum for nationals of Member States of the European Union (initially attached to the EC Treaty by the Treaty of Amsterdam) which, inter alia, deems other Member States as "safe countries of origin" and only allows consideration or admissibility of processing of claims of a national of another Member State in limited circumstances. Peers notes that the Protocol arose to stop Belgium processing claims for asylum of alleged terrorists who were wanted for trial in Spain. Peers describes the Protocol as "an extradition measure in disguise" and doubts its validity in light of Article 3 of the Geneva Convention: Peers, S, EU Justice and Home Affairs Law, 2011, 3ed, OUP, Oxford Pp.324-326.

918 On the basis that the Protocol only applies to Member States of the European Union: Peers, S, EU Justice and Home Affairs Law, 2011, 3ed, OUP, Oxford, P.314

919 Cases C-175/08, C-176/08, C-178/08 and 179/08 Aydin Salahadin Abdulla \& Ors $v$ Bundesrepublik Deutschland, 2 March 2010, Judgment, paras 79-80
} 
predicated on not qualifying as a refugee. ${ }^{920}$ However, from a procedural point of view, the Procedures Directive only allows for a single procedure for refugee or subsidiary protection statuses if Member States choose so to do, otherwise the Directive contemplates two separate procedures. ${ }^{921}$

Under the Qualification II Directive, the term "applicant" is now defined as "a third country national or stateless person who has made an application for international protection in respect of which a final decision has not been taken." "922 In all other relevant respects the definition for an "application for international protection" (as set out above) remains the same as the current Qualification Directive (that is, it contemplates both refugee and subsidiary protection statuses). ${ }^{923}$

\subsubsection{2 "Asylum seeker" - European Union - The Proposed Legislation}

The cumulative effect of the Proposals is to provide a greater degree of integration of terms between the secondary legislation. At the core of these changes is the reference to the Qualification Directive to set the personal scope of the satellite secondary legislation that contemplates detention. The combined upshot of those proposals is that the understanding of who constitutes an asylum seeker has been extended beyond the classical (and current) understanding of a person seeking protection under the Geneva Convention to incorporate those seeking subsidiary protection status.

The Commission's 2011 Proposed Procedures Directive would appear to settle the hierarchy between refugee and subsidiary protection status by requiring Member States to first determine applications for refugee status and, if that application is unsuccessful, to then determine whether the person would be eligible for subsidiary protection status. ${ }^{924}$

Each of the Commission's 2008 and 2011 Proposed Reception Conditions Directives (maintained in the Council amendments), ${ }^{925} 2009$ and 2011

\footnotetext{
920 See definition of "person eligible for subsidiary protection" under Article 1(e) of the Qualification I Directive

921 Article 3(3) of the Procedures Directive. See Spijkerboer, T, and Arbaoui, Y, in Hailbronner, K, (ed), EU Immigration and Asylum Law - Commentary on EU Regulations and Directives, 2010, Beck, München, Pp.1227-1350 at P.1261

922 Proposed Article 2(i) of the Qualification II Directive

923 Proposed Article 2(h) and (a) of the Qualification II Directive

924 Article 10(2) of the Commission's 2011 Proposed Procedures Directive. See Peers' comments on Article 9(2) of the first Proposed Procedures Directive which was identical in substance (albeit the wording has been modified): Peers, S, EU Justice and Home Affairs Law, 2011, 3ed, OUP, Oxford, P. 356

925 Article 2(b) and (a) of the Commission's 2008 Proposed Reception Conditions Directive, Article 2(b) and (a) of the Commission's 2011 Proposed Reception Conditions Directive, Article 2(b) and (a) of the Council's Amended Proposed Reception Conditions Directive
} 
Proposed Procedures Directive ${ }^{926}$ and Proposed Dublin Regulation ${ }^{927}$ contemplate both refugee and subsidiary protection statuses with reference to the Qualification Directive. The Proposed Dublin Regulation now expressly includes stateless persons in addition to third country nationals. ${ }^{928}$ Accordingly, the exclusion of Union citizens from the scope of the legislation is still maintained.

The status of an asylum seeker (now inclusive of subsidiary protection applicants) is again temporally limited to a "final decision" as defined in both of the Commission's 2009 and 2011 Proposed Procedures Directives, arguably being an exhaustion of appeal remedies under Chapter V thereof. ${ }^{929}$

Accordingly, if the Proposals are adopted, the category of persons to whom the secondary legislation applies will be extended from those seeking refugee status to include those seeking subsidiary protection status (that is, under the umbrella term of "international protection").

\subsubsection{4 "Asylum seeker" - Australia}

In the Australian context, the term "asylum seeker" although frequently used by the government and the media in Australia, does not have a definitional basis under the Migration Act. ${ }^{930}$ Accordingly, Australian law does not make a distinction based on status between asylum seekers and other non-citizens (either lawful or unlawful). Given the duality of refugee status determination regimes in Australia (that is "onshore" applicants who have made their application within the Migration Zone, and "offshore entry persons" "931 who have entered Australia at an "excised offshore place") 932 and the recent

926 Articles 2(c), (b) and (i) of the Commission's 2009 Proposed Procedures Directive and maintained in Articles 2(c), (b) and (i) of the Commission's 2011 Proposed Procedures Directive

927 Articles 2(b) and (c) of the Commission's Proposed Dublin Regulation. Note however that Article 2(b) refers to Article 2(g) of the current Qualification Directive (2004/83/EC) which will require future amendment to reflect the changes to the Commission's Proposed Qualification Directive (that is, by referring to Article 2(h) of the Commission's Proposed Qualification Directive).

928 Article 2(c) the Commission's Proposed Dublin Regulation

${ }_{929}$ Article 2(e) of the Commission's 2009 Proposed Procedures Directive and Article 2(e) of the Commission's 2011 Proposed Procedures Directive

930 Indeed, dertivatives of the term only appear in four places under the Act: sections 198A, 91C, 91D and 228B but are undefined under the Act

931 Section 5 of the Migration Act 1958 (Cth) defines an "offshore entry person" as a person who (a) entered Australia at an excised offshore place after the excision time for that offshore place; and (b) became an unlawful non citizen because of that entry.

932 Section 5 of the Migration Act 1958 (Cth) which includes

(a) the Territory of Christmas Island;

(b) the Territory of Ashmore and Cartier Islands;

(c) the Territory of Cocos (Keeling) Islands;

(d) any other external Territory that is prescribed by regulations for the purposes of this paragraph; 
announcement to subject offshore entry persons to the regular, onshore procedure, it is necessary to look at the terminology under the two systems.

\subsubsection{1 "Asylum seeker" - Australia - Applications made within the Migration Zone}

For applications made within the Migration Zone, three categories of applicants can be characterised as asylum seekers.

Firstly, the term is broadly inclusive of an application by a non-citizen who seeks a protection visa ${ }^{933}$ - that is, either a non-citizen to whom Australia has protection obligations under the 1951 Geneva Convention and its Protocol ${ }^{934}$ (that is, an applicant for refugee status) or, since 24 March 2012, a non-citizen to whom Australia has protection obligations "because the Minister has substantial grounds for believing that, as a necessary and foreseeable consequence of the non-citizen being removed from Australia to a receiving country, there is a real risk that the non-citizen will suffer significant harm" (that is, an applicant for complementary protection). ${ }^{935}$ It is understood that the procedure will involve a single procedure for a Protection Visa, firstly assessing the person for refugee status, and then, if that is not applicable, for complementary protection. ${ }^{936}$ Notably, unlike for refugee status, the Act does not expressly reference the international treaties upon which the protection obligations are said to arise, thus keeping the complementary protection obligations constrained to domestically developed jurisprudence. Further, both statuses are not to the fulfilment of an objective standard, but are 'to the Minister's satisfaction' which rather weights the evidential burden in favour of the Minister.

(e) any island that forms part of a State or Territory and is prescribed for the purposes of this paragraph;

(f) an Australian sea installation;

(g) an Australian resources installation.

933 A Protection visa subclass 866

934 Section 36(2) of the Migration Act 1958 (Cth) and Migration Regulations 1994, Schedule 2, Clause 866.

935 Section 36(2)(aa) of the Migration Act 1958 (Cth). "Significant harm" is defined in section 36(2A) of the Migration Act 1958 (Cth) as "(a) the non-citizen will be arbitrarily deprived of his or her life; or (b) the death penalty will be carried out on the non-citizen; or (c) the non-citizen will be subjected to torture; or (d) the non-citizen will be subjected to cruel or inhuman treatment or punishment; or (e) the non-citizen will be subjected to degrading treatment or punishment". Note the definitions of "torture", "cruel or inhuman or degrading treatment or punishment" and "degrading treatment or punishment" in section 5(1) of the Act

936 Australian Government, Department of Immigration and Citizenship, Implementation of Complementary Protection (Question and Answers), http://www.immi.gov.au/visas/ humanitarian/_pdf/implementation_of_cp_qa.pdf (last accessed 18 May 2012); Australian Government, Department of Immigration and Citizenship, Seminar held on 14 May 2012, delivered by $\mathrm{Mr}$ Wayne Jenkins, Implementing Complementary Protection (CP) provisions into the protection assessment process (slide handouts held on file by author). 
Secondly, the term "asylum seeker" may apply to a non-citizen who seeks that the Minister exercises his discretion under section 417 of the Migration Act. Before the institution of Australia's complementary protection system, the only way a person could seek complementary protection was by the discretionary process by which the Minister can exercise his or her discretion under section 417 of the Act (including for humanitarian or compassionate reasons). An applicant seeking an exercise of the Minister's discretion has first been the subject of a negative decision by the Refugee Review Tribunal ("RRT"). Before the institution of the complementary protection system, even if an applicant was aware that his/her application for refugee status will fail because he/she seeks another type of international protection, it was necessary for the applicant to exhaust that process by receiving an initial negative decision followed by a negative RRT decision before a request for ministerial intervention under section 417 could be made. The exercise of the Minister's discretion is to substitute a decision of the Tribunal for one that is "more favourable to the applicant", but the exercise of the Minister's discretion is non-compellable, ${ }^{937}$ non-reviewable, ${ }^{938}$ and non-delegable. ${ }^{939}$ The exercise of the Minister's discretion is guided by the "public interest" "940 and non-binding Ministerial Guidelines. ${ }^{941}$ Applicants seeking protection under this section may also be characterised as asylum seekers, with the exception of those seeking a more favourable decision on compassionate or practical grounds (consistent with the international understanding of the substance of complementary protection).

\footnotetext{
937 Section 417(7) of the Migration Act 1958 (Cth)

938 Section 474 relates to "privative clause" decisions which are final and non-reviewable. The Federal Court of Australia, in QAAE of 2002 v Minister for Immigration and Multicultural and Indigenous Affairs [2002] FCA 1213 per Cooper J at 48 held that section 417 decisions are privative clause decisions that are precluded from review unless the Hickman principles apply. Further, Cooper J held that a section 417 decision would constitute a "primary decision" and would be precluded from review by section 476(2) (now relating to the Federal Magistrates Court). By extension, a section 417 decision would not be reviewable by the Federal Court by virtue of the limited grounds available under section 476A of the Migration Act. See additionally Re Minister for Immigration and Multicultural and Indigenous Affairs [2003] HCA 1.

939 Section 417(3) of the Migration Act 1958 (Cth), although the practice of administrative staff deciding which cases to refer to the Minister for intervention has continued notwithstanding the failed challenge to that practice in Ozmanian $v$ Minister for Immigration, Local Government and Ethnic Affairs \& Anor [1996] FCA 1467 particularly at para 108

940 As required by section 417(1) of the Migration Act 1958 (Cth) and contemplated in the PAM3: Act - Ministerial powers - Minister's guidelines on ministerial powers at para 9: "The public interest may be served through the Australian Government responding with care and compassion where an individual's situation involves unique or exceptional circumstances" which are further elaborated on in para 11 to include circumstances involving the Geneva Convention, CAT, ICCPR or CROC. However, those considerations remain discretionary and not obligatory.

941 PAM3: Act - Ministerial powers - Minister's guidelines on ministerial powers. For further background on this issue, see Parliament of Australia - Senate, Senate Select Committee on Ministerial Discretion in Migration Matters, 31 April 2004 http://www.aph.gov.au/s enate_minmig/index.htm (last accessed 8 September 2011)
} 
Thirdly, the term "asylum seeker" may apply to a non-citizen who has been refused an application for a Protection Visa (and who is thereby prohibited from making another such application $)^{942}$ and who seeks that the Minister exercise his discretion under section $48 \mathrm{~B}$ of the Act to allow the non-citizen to make a further Protection Visa application. Before the institution of the complementary protection provisions, it was not uncommon for applicants to make concurrent section $48 \mathrm{~B}$ and section 417 applications (it remains to be seen how the new system will affect the nature of these applications in practice although it is anticipated that it will significantly reduce such applications). There is no limit on the number of times a person can make such an application. However, the Minister may, if he wishes, only consider new information in any subsequent Protection Visa application, and may have regard and take as correct his earlier decision about (or based on) the information in the earlier application. ${ }^{943}$ Accordingly, a subsequent Protection Visa application does not necessarily result in a de novo review.

\subsubsection{2 "Asylum Seeker" - Australia - Those arriving at "Excised Offshore Places" - Australia}

In the case of persons who arrive at an "excised offshore place", that person is consequently defined as an "offshore entry person" who cannot make an application for any visa (Protection or otherwise) by virtue of section 46A of the Migration Act 1958 (Cth). A key feature of section 46A is that the Minister may 'lift the bar' to allow an offshore entry person to make a visa application but that discretion is non-compellable. ${ }^{944}$

As outlined in Chapter 3, up until the High Court of Australia's decision in M61/M69, DIAC (through private contractors, "Wizard People Pty Limited") did make an assessment of those who seek asylum by what was called a "Refugee Status Assessment" (or "RSA") 945 and if, at the outcome of the RSA, it was considered that Australia had protection obligations to that person, a recommendation was sent to the Minister that he "lift the bar" of section 46A to allow the applicant to make an application for a Protection Visa. ${ }^{946}$ If the RSA was negative, the applicant could have appealed to have had his or her application re-considered at an "Independent Merits Review" (or "IMR"). ${ }^{947}$ If the outcome of the IMR was in favour of the applicant, then a recommendation was also sent to the Minister that he or she "lift the bar" of section 46A to allow the applicant to make a Protection Visa application. ${ }^{948}$ Following the M61/M69 decision, DIAC instituted a modified

\footnotetext{
942 Section 48A(1) of the Migration Act 1958 (Cth)

943 Section 50 of the Migration Act 1958 (Cth)

944 Section 46A(7) of the Migration Act 1958 (Cth)

945 M61/2010 \& M69/2010 v Commonwealth of Australia [2010] HCA 41 at para 3

946 M61/2010 \& M69/2010 v Commonwealth of Australia [2010] HCA 41 at para 44

947 M61/2010 \& M69/2010 v Commonwealth of Australia [2010] HCA 41 at para 44

${ }_{948}$ M61/2010 \& M69/2010 v Commonwealth of Australia [2010] HCA 41 at para 49
} 
process for offshore entry persons called "Protection Obligation Determinations" ("PODs") 949 and complementary protection claims were assessed through an "International Treaties Obligation Assessment ("ITOA"). ${ }^{950}$ Following the quashing of the 'Malaysia Solution' by the High Court of Australia in $M 70,{ }^{951}$ the Government announced a single Protection Visa determination procedure for both offshore entry persons ('unauthorised arrivals') and those that arrived in the Migration Zone. ${ }^{952}$ What is essential to bear in mind is that this apparent 'equalisation' of the two procedures by admitting offshore entry persons to the Migration Zone process occurs by way of an exercise of non-compellable Ministerial discretion under section 46A(2). Accordingly, there is still no right an asylum seeker (as an offshore entry person) can assert to make an application for a Protection Visa - it occurs only because the Minister has 'lifted the bar' and permitted such an application to be made.

In light of the Australian government's previous negotiations with East Timor and Papua New Guinea concerning the offshore processing of asylum seekers, and the quashing of the Malaysia 'swap deal' by the High Court of Australia, ${ }^{953}$ it is worth noting the position of those asylum seekers who may be subject to offshore processing. These situations contemplate those asylum seekers who have arrived 'unlawfully'. The Act contemplates those taken firstly, for the purpose of being taken to a "declared country" and secondly, to "transitory persons". In the case of those taken to a declared country under section 198A of the Act, notwithstanding that that declared country may provide protection and access to effective procedures to assess an applicant's claim for

949 Bowen, The Honourable Chris, Minister for Immigration and Citizenship, Government announces faster, fairer refugee assessment process, 7 January 2011, http://www.minister.immi.gov.au/media/cb/2011/cb157059.htm (last accessed 27 April 2012); Foster, M and Pobjoy, J, A Failed Case of Legal Exceptionalism? Refugee Status Determination in Australia's 'Excised' Territory (2011) 23(4) IJRL 583, Pp.616-617; Francis, A, and Caton, S, Access to Protection for 'Offshore Entry Persons' aka asylum seekers (2011) 36(3) AltLJ 172

950 Australian Government, Department of Immigration and Citizenship, Implementation of Complementary Protection (Question and Answers), http://www.immi.gov.au/visas/ humanitarian/_pdf/implementation_of_cp_qa.pdf (last accessed 18 May 2012)

951 M70/2011 v Minister for Immigration and Citizenship; M106/2011 v Minister for Immigration and Citizenship [2011] HCA 32; Wood, T, and McAdam, J, Australian Asylum Policy All At Sea: An Analysis of Plaintiff M70/2011 v Minister for Immigration and Citizenship and the Australia-Malaysia Arrangement (2012) 61 ICLQ 274

952 Bowen, The Honourable Chris, Minister for Immigration and Citizenship, Bridging visas to be issue for boat arrivals, 25 November 2011, http://www.minister.immi.gov.au/media/cb /2011/cb180599.htm (last accessed 27 April 2012); Needham, K, Boat refugees will be assessed as air arrivals, Sydney Morning Herald, 20 March 2012, http://www.smh.com.au/opinion/ political-news/boat-refugees-will-be-assessed-as-air-arrivals-20120319-1vfrn.html (last accessed 27 April 2012)

953 M70/2011 v Minister for Immigration and Citizenship; M106/2011 v Minister for Immigration and Citizenship [2011] HCA 32 
protection $^{954}$ (which may well be by virtue of an Australian government assessment on that country's territory in any event), it is appropriate to consider these applicants as falling within the ambit of asylum seekers at least whilst on Australian territory. In the case of "transitory persons" (that is, inclusive of persons who have been taken to another country under section 198A), ${ }^{955}$ this refers to persons who are brought to Australia for a "temporary purpose" 956 but who are precluded from making an application for a visa and may only make a request to the RRT to be assessed as a refugee (that is, it would appear to exclude being assessed for complementary protection) until after they have remained in Australia for a continuous period of six months. ${ }^{957}$ Accordingly, those persons who form the intention to seek asylum in Australia upon being brought to Australia as transitory persons, also appropriately fall within the ambit of an asylum seeker ${ }^{958}$ (notwithstanding that they may have intended to seek asylum firstly, as an offshore entry person but were precluded from making such an application by the operation of section 46A of the Act and, secondly, that they may have sought asylum in the "declared country" to which they had been taken).

\subsubsection{5 "Asylum seeker" - Conclusions}

The term "asylum seeker" in the international legal sense is more a term of art than that of law. However, in the European Union sphere, it is a term of law that currently refers to those persons seeking refugee status, but future amendments will contemplate those seeking subsidiary (that is, complementary) protection status. The importance of understanding who is an asylum seeker lies with the term going to the very heart of the scope of the Union secondary legislation which contemplates detention. The combined effect of the Commission's proposals are to presume that each applicant seeks refugee status, failing which an assessment for subsidiary protection will then be made. Given (on one view) the accretion of rights of the Geneva Convention, the assumption of that status has significant consequences in international law with regard to detention (which will be explored in subsequent chapters). Where the European legislation departs substantially from the international understanding of an asylum seeker is when one considers that the definitions under all considered secondary legislation (both current and proposed) specifically contemplate only third-country nationals and/or stateless persons - that is, at least Union citizens (and, in certain

\footnotetext{
954 Section 198A, particularly subsection (3), of the Migration Act 1958 (Cth)

955 Section 5 of the Migration Act 1958 (Cth)

956 Section 198B of the Migration Act 1958 (Cth)

957 Sections 46B and 198C of the Migration Act 1958 (Cth). The combined effect of those provisions is to maintain the bar on making a visa application initiated by the operation of section 46A of the Migration Act 1958 (Cth) as it applies to offshore entry persons.

958 In relation to these types of actions see, Applicants WAIV $v$ Minister for Immigration Multicultural and Indigenous Affairs [2002] FCA 1186, WAJC v Minister for Immigration Multicultural and Indigenous Affairs [2002] FCA 1631, and Sadiqi v Commonwealth of Australia (No 2) [2009] FCA 1117
} 
circumstances, Swiss and EEA nationals) are specifically excluded from the scope of the secondary legislation. That exclusion represents an unjustified restriction on the 1951 Geneva Convention.

In comparison, the term "asylum seeker" carries very limited legal consequences in the Australian context, unlike in the European Union. The term can be used to cover a multitude of legislative persons and situations embedded in the Migration Act: those who arrive lawfully as "lawful noncitizens"; those who arrive "unlawfully' as "unlawful non-citizens"; those that arrive at an "excised offshore place" as "offshore entry persons"; those that are taken to a "declared country" for offshore processing; or to those "transitory persons" returning temporarily to Australia having been taken to a declared country for offshore processing. In relation to the nature of asylum sought, the term is inclusive of those who seek both refugee status and complementary forms of protection. The recent introduction of the complementary protection provisions in Australia places Australia in a comparable procedural position to the proposed provisions in European Union (that is, there is first an examination of whether the applicant qualifies for refugee status before examining eligibility for subsidiary (complementary) protection status as part of a single procedure). The primary characterisation of those who seek asylum but who have arrived 'unlawfully' overlooks that persons may be refugees as a question of fact, and may serve to deny or undermine the accretive rights that the Geneva Convention bestows pending the conferral of refugee status. In that respect, the administrative preclusion of an "offshore entry person" from seeking asylum in Australia is problematic in that it denies the applicant the ability to regularise his or her status, with consequences for the accretive rights that flow from the Geneva Convention. Offshore entry persons are only submitted to the Migration Zone procedure by virtue of non-compellable Ministerial discretion. Accordingly, the Australian provisions make little (if any) distinction between irregular migrants and asylum seekers - indeed the Australian position is more pre-occupied with the mode of entry than the nature of the protection sought.

What is interesting, not as a question of law, but as an indication of perceived agency, ${ }^{959}$ is the terminology used in both jurisdictions. In Australia, the terminology centres on whether Australia has "protection obligations" to a person. That may suggest a very passive role for the asylum seeker and infers that the asylum seeker is completely without agency or the capacity for selfdetermination. Further, 'obligation' tends to suggest a rather grudging, huffing, 'only if we have to' measure rather than one of beneficence or mutuality (that is, the recognition of an asserted right). The European Union terms of "applicant for international protection" or the use of the term "asylum seeker", suggests a much more assertive role for the asylum seeker

959 See Turton, D, Who is a Forced Migrant? in de Wet, C, Development-induced Displacement - Problems, Policies and People, 2006, Berghahn Books, New York/Oxford, Pp.13-37 
and, by their seeking of asylum are the active participant in their own destiny and self-determination.

\section{Special Categories of Asylum Seeker}

\subsubsection{Family Members}

It is important to consider the status of family members of an asylum seeker who might accompany the asylum seeker but who are otherwise not making an individual application for international protection. The importance stems from whether any provisions relating to detention also apply to those family members notwithstanding that they do not have the status of an asylum seeker per se. This is particularly important in the European Union context where the characterisation of family members as asylum seekers may be determinative of whether they fall within the scope of the secondary legislation. Accordingly, the detention of an asylum seeker has the potential to separate the applicant from his or her family members otherwise together and present in the same jurisdiction.

\subsubsection{Family Members - International}

At the international level, although the Geneva Convention is silent on the status of family members of applicants for refugee status, the Conference did recommend that family unity be maintained where the applicant "has fulfilled the necessary conditions for admission to a particular country" . ${ }^{960}$ According to the UNHCR Handbook, "[i]f the head of a family meets the criteria of the definition, his dependants are normally granted refugee status according to the principle of family unity". ${ }^{961}$ However, this is subject to exclusion of family members on other grounds such as on account of enjoying another country's protection or if falling within one of the exclusion clauses. ${ }^{962}$ Accordingly, it would appear that family members may not technically be "asylum seekers" purely by virtue of their relationship to the applicant (that is, family members may not be asylum seekers per se unless they have an individual basis for claiming so ${ }^{963}$ but may be granted protection after the primary applicant has attained refugee status or another form of complementary protection), but that family unity is to be maintained nonetheless. ${ }^{964}$ Although the reality is that

\footnotetext{
960 Recommendation B, Final Act of the United Nations Conference of Plenipotentiaries on the Status of Refugees and Stateless Persons, 28 July 1951.

961 UNHCR, Handbook on Procedures and Criteria for Determining Refugee Status under the 1951 Convention and the 1967 Protocol relating to the Status of Refugees, para 184.

962 UNHCR, Handbook on Procedures and Criteria for Determining Refugee Status under the 1951 Convention and the 1967 Protocol relating to the Status of Refugees, paras 184 and 188

963 Which may include being a member of a particular social group on account of being a family member: Foster, M, International Refugee Law and Socio-Economic Rights, 2007, CUP, New York at P.323 fn 141. See also section 91S of the Migration Act 1958 (Cth)

964 See Hathaway, J, The Rights of Refugees under International Law, 2005, CUP, Cambridge, Pp.540-560; and Goodwin-Gill, G, and McAdam, J, The Refugee in International Law, 2007, OUP, Oxford, Pp.130-131; See also Articles 17, 23 and 24 ICCPR, and United Nations,
} 
family members may remain in the country of origin or elsewhere whilst another seeks asylum, for the purpose of this book, the evaluation will proceed on the basis of family members who are physically present in the same jurisdiction (that is, either in the territory of the European Union or Australia) as the applicant. ${ }^{965}$

\subsubsection{Family Members - Council of Europe}

The ECHR protects the right to family life by virtue of Article 8(1). However, that Article cannot be invoked to compel family reunification and the choice of State in which it is to take place, ${ }^{966}$ but is nonetheless an important consideration in Dublin transfers where family members may be in several Member States, particularly so if minors are involved. ${ }^{967}$

The Committee of Ministers of the Council of Europe, in their Recommendation 2003(5), has considered the "family unit" but does not necessarily elevate family members to the status of asylum seekers merely on account of their familial relationship with the applicant. ${ }^{968}$ The Committee of Ministers of the Council of Europe in their 20 Guidelines on Forced Return call for an accommodation of the principle of family unity for those detained pending removal, as well as any interference with family and/or private life as a result of removal order being "proportionate and in pursuance of a legitimate aim". 969

\subsubsection{Family Members - European Union - EU Charter}

In the Union sphere, Article 7 of the EU Charter provides a comparable right for the respect of private and family life to that of Article 8(1) of the ECHR. The development of the jurisprudence surrounding this Article in light of Dublin transfers will be of considerable interest.

\subsection{Family Members - EU Secondary Legislation}

In the Union secondary legislation, the distinction between an applicant for asylum and family members is maintained. The Reception Conditions Directive, Procedures Directive, Dublin II Regulation and Qualification

\footnotetext{
Human Rights Committee, General Comment 19 - Protection of the family, the right to marriage and equality of the spouses - Article 23, 27 July 1990, paras 1 (interference with family life) and 2 (inability to define 'family'); Note also Article 9(1) CROC

965 In relation to family reunification of refugees under international law see Jastram, K, and Newland, K, Family unity and refugee protection, in Feller, E, Türk, V, and Nicholson, F, (eds), Refugee Protection in International Law, 2003, CUP, Cambridge, Pp.505-603

966 Abdulaziz, Cabales and Balkandali $v$ the United Kingdom, No. 9214/80, 9473/81, and 9474/81, Judgment, 28 May 1985, paras 67-68

967 Hermann, M, in Hailbronner, K, (ed), EU Immigration and Asylum Law - Commentary on EU Regulations and Directives, 2010, Beck, München, Pp.1351-1488 at 1380

968 Committee of Ministers, Council of Europe, Recommendation Rec(2003)5 of the Committee of Ministers to member states on measures of detention to asylum seekers, paragraph 14

969 Guidelines 10(4) and 2(2), Committee of Ministers, Council of Europe, Twenty Guidelines on Forced Return, CM(2005)40 Addendum final, Strasbourg, 20 May 2005.
} 
Directives all envisage an individual application for asylum and that status does not appear to be conferred to family members on account of their familial relationship to the applicant. ${ }^{970}$ Under the Procedures Directive, Member States are given the discretion to provide for an applicant to make an application on behalf of his/her dependants, ${ }^{971}$ yet even that application would appear to require an individual basis for a claim for protection.

The Qualification II Directive expands the definition of "family member" by removing the requirement for dependency of children on their parents ${ }^{973}$ and additionally providing for the father, mother or other responsible adult where the minor is unmarried. ${ }^{974}$

There are variances in the definitions of "family member" across the Union secondary legislation that contemplate detention. The Returns Directive (which provides for the detention of families) and the Procedures Directive do not define "family members". The Reception Conditions Directive and the Dublin II Regulation have almost identical definitions, except that the Reception Conditions Directive only contemplates descending vertical relationships (that is, that the father, mother or guardian of a minor applicant is not provided for, as those persons are in the Dublin II Regulation ${ }^{975}$ ) nor are horizontal (sibling) relationships provided for. ${ }^{976}$

However, notwithstanding the non-equation of family members to the status of asylum seekers, there are some instances of near equation consistent with the principle of maintaining family unity. Firstly, the Reception Conditions Directive applies to family members of asylum seekers "if they are covered by

970 See Article 3(1) of the Reception Conditions Directive (but noting those family members covered by national legislation - see below); Article 3(1) of the Procedures Directive; Article 1 of the Qualification I Directive (and noting Recital 27 which notes that, on account of their relationship to the applicant, family members may be "vulnerable to acts of persecution" that could give rise to refugee status); and Article 1 of, and Recitals 18 and 36 to, the Qualification II Directive

971 Article 6(3) of the Procedures Directive

972 Which was the subject of resistance by the German, French and United Kingdom delegations to the Council of the European Union on account that an expanded definition "would lead to excessive costs" - Council of the European Union, Note from the German, French and United Kingdom delegations, Joint contribution of the German, French and United Kingdom delegations regarding the proposals for a directive laying down standards for the reception of asylum seekers and for asylum procedures, 27 June 2011, Document No. 12168/11, P.3

973 Article 2(j) second indent of the Qualification II Directive

974 Article 2(j) third indent of the Qualification II Directive, note also Recital 19 which states "It is necessary to broaden the notion of family members, taking into account the different particular circumstances of dependency and the special attention to be paid to the best interests of the child"

975 Article 2(i)(iii) of the Dublin II Regulation

976 Article 2(d) of the Reception Conditions Directive and Article 2(i) of the Dublin II Regulation 
such application for asylum according to national law". ${ }^{977}$ Secondly, in the context of the Dublin II Regulation, minor family members and newborns born into the Member State territory are "indissociable" from their parents (and with the minor then becoming a matter for the Member State responsible for determining the parent or guardian's application for asylum) even if the minor family member is not making an individual claim for asylum. ${ }^{978}$ Thirdly, the benefits of the Qualification I Directive are to be extended to family members who do not individually qualify for protection status (with a discretion for Member States to define the conditions of benefits to family members of a subsidiary status holder $)^{979}$ and may be extended to other dependent relatives from the country of origin. The Qualification II Directive extends these benefits without distinction as to refugee or subsidiary protection status. ${ }^{980}$ Notwithstanding these near equations of status to family members of applicants, the de jure status of a family member is not equated to an asylum seeker, refugee or subsidiary protection holder in the absence of an individual application for international protection. In relation to accommodation under the Reception Conditions Directive, "family unity" is to be maintained as far as possible for those family members on the territory of the Member State. ${ }^{981}$ The Qualification Directives also require Member States to ensure family unity. ${ }^{982}$ The notion of family unity is also expressed in the preamble to the Dublin II Regulation, as is the joint processing of applications of family members for reasons of thoroughness and consistency. ${ }^{983}$

\subsection{Family Members - European Union - The Proposed Legislation}

The Commission's proposals maintain the distinction between those seeking asylum and their family members. ${ }^{984}$ The Proposed Procedures Directive maintains the Member State discretion to allow an applicant to make a claim on behalf of his/her dependants. ${ }^{985}$

The Commission's 2011 Proposed Reception Conditions Directive and the Proposed Dublin Regulation significantly expand the definition of family members ${ }^{986}$ and, although not in identical terms, now include both horizontal

\footnotetext{
977 Article 3(1) of the Reception Conditions Directive

978 Article 4(3) of the Dublin II Regulation

979 Article 23(2) of the Qualification Directive

980 Article 23(2) of the Qualification II Directive

981 Article 8 of the Reception Conditions Directive

982 Article 23(1) of the Qualification I Directive and Article 23(1) of the Qualification II Directive

983 Recitals 6 and 7 of the Dublin II Regulation

984 See Article 3(1) of the Commission's 2011 Proposed Reception Conditions Directive; Article 3(1) of the Commission's 2011 Proposed Procedures Directive, Article 1 of the Commission's Proposed Dublin Regulation

985 Article 7(2) of the Commission's 2011 Proposed Procedures Directive

986 Which was the subject of resistance by the German, French and United Kingdom delegations to the Council of the European Union on account that an expanded definition "would lead to excessive costs" - Council of the European Union, Note from the German,
} 
and vertical family relations. ${ }^{987}$ The Council's Amended Proposed Reception Conditions Directive scales back the definition to that under the Qualification II Directive. ${ }^{988}$ The Commission's 2011 Proposed Procedures Directive remains silent on any definition of "family member".

The instances of near equation of family members to that of asylum seekers (as identified in the current legislation above) is also maintained in the proposals. The Commission's 2011 Proposed Reception Conditions Directive still foreshadows its application to family members provided their application is covered according to national law ${ }^{989}$ (and maintained in the Council amendments ${ }^{990}$ ); the "indissociability" provisions are maintained in the Proposed Dublin II Regulation; "991 The maintenance of "family unity" provision is also carried over in the Commission's 2011 Proposed Reception Conditions Directive ${ }^{992}$ (and maintained in the Council Amendments). ${ }^{993}$

\subsubsection{Family Members - Australia}

In the Australian sphere, family members ${ }^{994}$ of an asylum seeker are not asylum seekers themselves (unless, of course, they make an individual application ${ }^{995}$ ) as the criteria for the grant of a protection visa to such family members is dependent on their non-citizen family member holding a protection visa

French and United Kingdom delegations, Joint contribution of the German, French and United Kingdom delegations regarding the proposals for a directive laying down standards for the reception of asylum seekers and for asylum procedures, 27 June 2011, Document No. 12168/11, P.3

987 See Article 2(c) of the Commission's 2011 Proposed Reception Conditions Directive and Article 2(i) of the Proposed Dublin Regulation

988 Article 2(c) of the Council's Amended Proposed Reception Conditions Directive

989 Article 3(1) of the Commission's 2011 Proposed Reception Conditions Directive

990 Article 3(1) of the Council's Amended Proposed Reception Conditions Directive

991 Article 20(3) of the Commission's Proposed Dublin Regulation

992 Article 12 of the Commission's 2011 Proposed Reception Conditions Directive

993 Article 12 of the Council's Amended Proposed Reception Conditions Directive

994 Under section 5 of the Migration Act 1958 (Cth) "member of the same family unit" is torturously defined as "one person is a member of the family unit as another if either is a member of the family unit of the other or each is a member of the family unit of a third person. "Member of the family unit" is defined by reference to the Clause 1.12 of the Migration Regulations to mean:

(a) a spouse or partner of the family head; or

(b) a dependent child of the family head or of a spouse or de facto partner of the family head; or

(c) a dependant child of a dependant child of the family head or of a spouse or de facto partner of the family head; or

(e) [sic] a relative of the family head or of a spouse or de facto partner of the family head who:

(i) does not have a spouse or de facto partner; and

(ii) is usually resident in the family head's household; and

(iii) is dependent on the family head.

995 And which may, in itself, be a ground for obtaining refugee status - see section $91 \mathrm{~S}$ of the Migration Act 1958 (Cth) 
(noting that it contemplates both refugee and complementary protection bases for the holding of a Protection Visa). ${ }^{996}$

\subsubsection{Family Members - Conclusions}

In both jurisdictions, family members are not deemed to be applicants for asylum, which is consistent with the international position in relation to family members. The concept of family unity is expressly provided for during the determination process in the European Union whereas in the Australian context, there is no express provision regarding that aspect, and respect for the concept of family unity is only adhered to after a Protection Visa has been granted. In the European Union sphere, the centrality of "asylum seeker" as an element to be satisfied in order to fall within the scope of the Union secondary legislation does leave family members in a somewhat ambiguous position - if a legalistic view is taken, family members may not technically fall within the scope of the secondary legislation unless they are applicants themselves. Rather, they rely on the principle of the preservation of family unity in the secondary legislation to ensure that family members are kept together.

\subsubsection{Minors and Unaccompanied Minors}

The status and situation of minors and unaccompanied minors is of grave importance in a detention context. Minors may well fall within the ambit of family members of an asylum seeker (as alluded to above), but also (together with unaccompanied minors) fall within the ambit of vulnerable persons. Several issues befall minor and unaccompanied minors as asylum seekers. Inter alia, the first issue is who may be considered a minor; the second is what general principles apply to actions concerning minors; and the third issue is a minor's capacity to make a claim for asylum independent of a family relationship to another applicant. The issue of capacity to make a claim for asylum is important in the minor's ability to regularise his or her presence on the territory in which he/she seeks asylum.

\subsubsection{Minors \& Unaccompanied Minors - International}

Although the precise content of international standards concerning minors and unaccompanied minors will be discussed in subsequent chapters as it relates to detention, CROC provides that a child is a person under the age of 18 years unless majority is reached earlier under the applicable law. ${ }^{997}$ The overarching norm remains that the best interests of the child shall be a primary

\footnotetext{
996 Section 36(2)(b) and (c) of the Migration Act 1958 (Cth)

997 Article 1 CROC - in this sense the term "child" and "minor" will be used interchangeably. The understanding as regards the age of 18 is also reflected in Guideline 6, UNHCR, UNHCR Revised Guidelines on Applicable Criteria and Standards relating to the Detention of Asylum Seekers, February 1999
} 
consideration of all actions concerning children. ${ }^{998}$ Indeed, McAdam suggests that that consideration contained in CROC may be sufficient of itself to provide a basis for the complementary protection of children. ${ }^{999}$ Central to the effectiveness of that principle is the implementation of that general principle at all levels of government. ${ }^{1000}$

In relation to the making of an application for asylum by a minor or unaccompanied minor, the Geneva Convention itself is silent. However, the Conference did recommend their protection with "special reference to guardianship and adoption". ${ }^{1001}$ Under Article 22 CROC, although not dealing with the issue of legal capacity to bring an asylum application per se, State Parties are required to take appropriate measures to ensure that children (whether accompanied or not) seeking refugee status "receive appropriate protection". ${ }^{1002}$ However, Goodwin-Gill and McAdam also lament that the UNHCR Handbook, which pre-dates CROC, places emphasis on the status of refugee rather than on the best interests of the child and is thus misguided in its considerations of "mental development and maturity" in determining whether the minor has a well founded fear of persecution. ${ }^{1003}$

\subsubsection{Minors \& Unaccompanied Minors - Council of Europe}

The ECHR does not include an express provision on the rights of the child as expressed in CROC. However, the ECtHR has expressly referred to CROC (particularly in the context of Article 22) ${ }^{1004}$ and the general principle contained in Article 3 CROC. ${ }^{1005}$ There is no inhibition to minors bringing proceedings in the ECtHR in their own capacity. ${ }^{1006}$

The Council of Europe Recommendation (2003)5 by the Committee of Ministers recalls CROC in its preamble. Similarly, in relation to detention of

998 Article 3(1) CROC. See also Bakhtiyari v Australia, UN Human Rights Committee Communication No 1069/2002, CCPR/C/79/D/1069/2002, 29 October 2003, paras 3.5 and 9.7

999 McAdam, J, Seeking Asylum under the Convention on the Rights of the Child: A case for Complementary Protection (2006) 15 International Journal of Children's Rights 251

1000 United Nations, Committee on the Rights of the Child, General Comment No. 5 (2003) - General measures of implementation of the Convention on the Rights of the Child (arts. 4, 42 and 44, para 6), 27 November 2003, paras 3, 45-47

1001 Recommendation B(2), Final Act of the United Nations Conference of Plenipotentiaries on the Status of Refugees and Stateless Persons, 28 July 1951

1002 Article 22(1) CROC

1003 Goodwin-Gill, G, and McAdam, J, The Refugee in International Law, 2007, OUP, Oxford, Pp.130-131

1004 Muskhadzhiyeva \& ors v Belgium, No. 41442/07, Judgment, 19 January 2010, para 62

1005 Mubilanzila Mayeka and Kaniki Mitunga v Belgium, No. 13178/03, Judgment, 12 October 2006, at para 83

1006 See for example, $A v$ United Kingdom, No. 25599/94, Judgment, 23 September 1998; see also, Berro-Lefevre, I, Children's Access to the European Court of Human Rights, http://www.coe.int/t/dg3/children/JusticeSpeeches/berro_en.asp (last accessed 21 May 2012) 
children pending removal, the Committee of Ministers of the Council of Europe provides that the best interests of the child shall be a primary consideration. $^{1007}$

\subsubsection{Minors \& Unaccompanied Minors - European Union - EU Charter}

In the Union sphere, Article 18 of the EU Charter makes no distinction as to the majority or minority of applicants in relation to the right to asylum. Article 24(2) of the EU Charter provides for the best interests of the child in all actions relating to children, irrespective of whether they are undertaken by public or private institutions.

\subsection{Minors \& Unaccompanied Minors - EU Secondary Legislation}

The Union secondary legislation all makes provision for minors, ${ }^{1008}$ but no definition is given with the exception of the Qualification II Directive. ${ }^{1009}$ Further, the secondary legislation provides for the best interests of the child as a primary consideration, ${ }^{1010}$ with the exception of the Procedures Directive (which only provides for the best interests of the child as a primary consideration in the context of unaccompanied minors $)^{1011}$ and the Dublin II Regulation (which makes no provision at all for that standard).

In relation to unaccompanied minors, the secondary legislation also makes provision for them in some way ${ }^{1012}$ and, although differences exist, the legislation contains definitions (with the exception of the Returns Directive) that are inclusive of a minor who is below the age of 18, arrives on the territory of the Member States unaccompanied by an adult responsible for them (either by law or by custom), for as long as they are not effectively taken into the care of such a person, and includes "minors who are left

1007 Guideline 11(4), Committee of Ministers, Council of Europe, Twenty Guidelines on Forced Return, CM(2005)40 Addendum final, Strasbourg, 20 May 2005.

1008 See, for example, Article 18 of the Reception Conditions Directive (Minors); Article 6(4)(a) of the Procedures Directive (circumstances in which a minor can make an application on his/her own behalf is left to the Member States); Article 4(3) of the Dublin Regulation (indissociability of minors and newborns - as referred above); Recital 20 (child specific forms of persecution) and Article 2(h) (definition of family member) of the Qualification I Directive; Recital 28 (child specific forms of persecution), Recital 19 (broader definition of family members), Article 2(j) (definition of family member), Article 9(f) (child-specific forms of persecution) of the Qualification II Directive; and Article 17 (detention of minors and families) of the Returns Directive

1009 Article 2(k) of the Qualification II Directive

1010 Article 17 of the Reception Conditions Directive; Article 20(5) and Recital 12 of the Qualification I Directive; Recitals 18, 19, 38 and Article 20(5) of the Qualification II Directive; and Recital 22 and Article 5(a) of the Returns Directive

1011 Recital 14 and Article 17(6) of the Procedures Directive

1012 See, for example, Article 19 of the Reception Conditions Directive; Article 17 of the Procedures Directive; Articles 6 and 15(3) of the Dublin II Regulation; Article 30 of the Qualification I Directive; Article 31(4) and (5) of the Qualification II Directive; and Articles 10 and 17 of the Returns Directive. 
unaccompanied after they have entered the territory of Member States."1013 The Dublin II Regulation makes one further qualification - that is, that the unaccompanied minor is to be unmarried. ${ }^{1014}$

Further, minors and unaccompanied minors are considered as part of the category of vulnerable persons in the Reception Conditions Directive, ${ }^{1015}$ the Qualification Directives ${ }^{1016}$ and the Returns Directive. ${ }^{1017}$

The capacity of a minor to make an application for asylum is provided for in Article 6 of the Procedures Directive. Although a right to make a claim for asylum is to be ensured for all adults having full legal capacity, ${ }^{1018}$ discretion is given to the Member States in four key areas which may, or do, involve minors or unaccompanied minors: firstly, in relation to the dependants of an applicant for asylum; ${ }^{1019}$ secondly, in relation to which a minor, on his or her own behalf, can make an application; ${ }^{1020}$ thirdly, the lodgement of an application by a representative of an unaccompanied minor; ${ }^{1021}$ and fourthly where the application for asylum "is deemed to constitute also the lodging of an application for asylum for any unmarried minor". ${ }^{1022}$

\subsection{Minors \& Unaccompanied Minors - European Union - The Proposed Legislation}

Predictably, the provisions relating to minors remain in the Commission's Proposals. ${ }^{1023}$ However, the Proposals benefit from the introduction of the definition of "minor" as "a third-country national or stateless person below the age of 18 years". ${ }^{1024}$ The best interests of the child as a primary

1013 Compare Article 2(h) of the Reception Conditions Directive; Article 2(h) of the Procedures Directive; Article 2(i) of the Qualification I Directive; and Article 2(l) of the Qualification II Directive

1014 Article 2(h) of the Dublin II Regulation

1015 Article 17 of the Reception Conditions Directive

1016 Article 20(3) of the Qualification I Directive; Article 20(3) of the Qualification II Directive

1017 Article 3(9) of the Returns Directive

1018 Article 6(2) of the Procedures Directive

1019 Article 6(3) of the Procedures Directive

1020 Article 6(4)(a) of the Procedures Directive

1021 Article 6(4)(b) of the Procedures Directive

1022 Article 6(4)(c) of the Procedures Directive.

1023 See, for example, Article 23 of the Commission's 2011 Proposed Reception Conditions Directive; Article 23 of the Council's Amended Proposed Reception Conditions Directive; Article 7(3) of the Commission's 2011 Proposed Procedures Directive; and Article 6 of the Proposed Dublin Regulation

1024 Article 2(l) of the Commission's 2011 Proposed Reception Conditions Directive; Article 2(d) of the Council's Amended Proposed Reception Conditions Directive; Article 2(l) of the Commission's 2011 Proposed Procedures Directive; Article 2(g) of the Proposed Dublin Regulation 
consideration now forms part of the Proposals. ${ }^{1025}$ However, in relation to the Proposed Procedures Directive, notwithstanding that the best interests of the child as a primary consideration has been incorporated into the preamble to the Proposed Directive, ${ }^{1026}$ the consideration remains applicable only to implementing the Article on unaccompanied minors. ${ }^{1027}$

Unaccompanied minors remain provided for in the Commission's Proposals. ${ }^{1028}$ The essential elements of the definition of an unaccompanied minor remain unchanged, ${ }^{1029}$ but the precise formulation differs amongst the Proposals and, in the case of the Proposed Reception Conditions Directive, the "custom" by which an adult may be considered otherwise responsible for a minor has been amended to "the national practice of the Member State concerned". ${ }^{1030}$ The Proposed Dublin Regulation no longer requires that the unaccompanied minor be unmarried. ${ }^{1031}$

Minors and unaccompanied minors are contemplated as a class of vulnerable persons in the Proposed Reception Conditions Directive ${ }^{1032}$ (maintained in the Council's amendments) ${ }^{1033}$ and may be an "applicant in need of special procedural guarantees" on account of their age as provided in the Proposed Procedures Directive. ${ }^{1034}$

The capacity of a minor to make an application for asylum is dealt with under Article 7 of the Commission's 2011 Proposed Procedures Directive. The Proposal provides that Member States are to ensure that a minor is able to make an application firstly, on his or her own behalf "if he/she has the legal capacity to act in procedures according to the national law of the Member State concerned"; secondly, through parents, adult family members or another adult responsible for the minor (with that responsibility arising "by law or by

1025 Article 23(1) and (2) of the Commission's 2011 Proposed Reception Conditions Directive; Article 23(1) and (2) of the Council's Amended Proposed Reception Conditions Directive; Recital 10 and Article 6 of the Proposed Dublin Regulation; and Recitals 17 and 18 and Article 20(5) of the Proposed Qualification Directive

1026 Recital 26 of the Commission's 2011 Proposed Procedures Directive

1027 Article 25(7) of the Commission's 2011 Proposed Procedures Directive

1028 Article 24 of the Commission's 2011 Proposed Reception Conditions Directive; Article 24 of the Council's Amended Proposed Reception Conditions Directive; Article 25 of the Commission's 2011 Proposed Procedures Directive; Article 8 of the Proposed Dublin Regulation

1029 Compare Article 2(f) of the Proposed Reception Conditions Directive; Article 2(f) of the Council's Amended Proposed Reception Conditions Directive; Article 2(m) of the Commission's 2011 Proposed Procedures Directive (which refers to Article 2(l) of the Qualification Directive); and Article 2(h) of the Proposed Dublin Regulation.

1030 Article 2(f) of the Commission's 2011 Proposed Reception Conditions Directive; Article 2(e) of the Council's Amended Proposed Reception Conditions Directive 1031 Article 2(h) of the Proposed Dublin Regulation

1032 Article 21 of the Commission's 2011 Proposed Reception Conditions Directive

1033 Article 21 of the Council's Amended Proposed Reception Conditions Directive

1034 Article 2(d) of the Commission's 2011 Proposed Procedures Directive 
national practice of the Member State concerned"); or thirdly, through a representative. ${ }^{1035}$ An application for international protection may also be made on behalf of the child by authorities under Article 10 of the Returns Directive "if those bodies are of the opinion that the minor may have protection needs pursuant" to the Qualification Directive. ${ }^{1036}$

The discretion of Member States remains substantially unchanged in relation to the dependants of an applicant for asylum; ${ }^{1037}$ the circumstances in which a minor, on his or her own behalf, can make an application; ${ }^{1038}$ the lodgement of an application by a representative of an unaccompanied minor; ${ }^{1039}$ in which circumstances the application for international protection "is deemed to constitute also the lodging of an application for international protection for any unmarried minor". ${ }^{1040}$

\subsubsection{Minors \& Unaccompanied Minors - Australia}

In Australia, the Migration Act provides that a minor is a person who is less than 18 years old. ${ }^{1041}$ The Act makes no distinction as to the majority or minority of a non-citizen to whom Australia owes protection obligations. ${ }^{1042}$ The term "non-citizen" in the Act (whether "lawful" or "unlawful", accompanied or unaccompanied, or relating to detention or otherwise) has been held to make no distinction between minors and adults. ${ }^{1043}$

Some additional insight is, however, given in relation to unaccompanied minors under the Immigration (Guardianship of Children) Act 1946 (Cth) ("IGOC Act"), which appoints the Minister for immigration as the legal guardian of certain unaccompanied minors. ${ }^{1044}$ Although the provisions of this Act and its relationship to the Migration Act will be dealt with in later chapters, the IGOC Act defines "non-citizen child" as a "(a) a child who has not turned 18; and (b) enters Australia as a non-citizen; and (c) intends, or is intended, to become a permanent resident of Australia." 1045 However, children who enter Australia under the charge of or for the purposes of living in Australia under the care of a parent, a relative of the child who has turned 21, or an intending adoptive relative of the child, ${ }^{1046}$ or are under a prescribed adoption class visa, are excluded from the earlier definition. ${ }^{1047}$

\footnotetext{
1035 Article 7(3) of the Commission's 2011 Proposed Procedures Directive

1036 Article 7(4) of the Commission's 2011 Proposed Procedures Directive

1037 Article 7(2) of the Commission's 2011 Proposed Procedures Directive

1038 Article 6(5)(a) of the Commission's 2011 Proposed Procedures Directive

1039 Article 6(5)(b) of the Commission's 2011 Proposed Procedures Directive

1040 Article 6(5)(c) of the Commission's 2011 Proposed Procedures Directive

1041 Section 5(1) of the Migration Act 1958 (Cth)

1042 Section 36 of the Migration Act 1958 (Cth)

1043 Re Woolley; Ex parte Applicants M276/2003 [2004] HCA 49 per Gleeson CJ at para 7

1044 Section 6 of the Immigration (Guardianship of Children) Act 1946 (Cth)

1045 Section 4AAA(1) of the Immigration (Guardianship of Children) Act 1946 (Cth)

1046 Section 4AAA(2) Immigration (Guardianship of Children) Act 1946 (Cth)

1047 Section 4AAA(3) Immigration (Guardianship of Children) Act 1946 (Cth)
} 
Although Australia is a party to CROC, it has not "been given the force of domestic law in Australia". ${ }^{1048}$ It was at one time arguable that CROC (and indeed, any international convention which Australia has ratified, but had not yet incorporated into national law) gave rise to a "legitimate expectation" that "administrative decision makers will act in conformity with the Convention". ${ }^{1049}$ However, that proposition came under strong criticism in Lam, ${ }^{1050}$ but otherwise still stands. Accordingly, it is questionable to what extent CROC is applicable, particularly in relation to Article $3 .{ }^{1051}$ It would appear that, in the absence of ambiguity, a Court is not compelled to interpret the provisions of the Migration Act in light of the Convention. ${ }^{1052}$ O'Neill et al note the uncertainty of the applicability of CROC in Australia. ${ }^{1053}$ In 2005, the CteeRC expressed its concern that "while the Convention may be considered and taken into account in order to assist courts to resolve uncertainties or ambiguities in the law, it cannot be used by the judiciary to override inconsistent provisions of domestic law." 1054

Notwithstanding the preclusion from making an application for a visa for those minors or unaccompanied minors arriving at an "excised offshore place", ${ }^{1055}$ it would appear that there is no bar to a child applying for a visa (including a protection visa) under the Act. ${ }^{1056}$ However, as pointed out by Taylor, the validity of the visa application may come into question where the requirements of the form (Form 866 for a Protection (Class XA) visa) are that

1048 X v Minister for Immigration and Multicultural Affairs [1999] FCA 995 at para 42

1049 Minister of State for Immigration E Ethnic Affairs $v$ Teoh [1995] HCA 20 per Mason CJ and Deane $J$ at para 34

1050 Re Minister for Immigration and Multicultural Affairs; Ex parte Lam [2003] HCA 6 per McHugh and Gummow JJ at paras 81-83 and particularly at paras 95-102, per Hayne J at 122 and per Callinan $\mathrm{J}$ at $139-141$

1051 McAdam, however, is of the view that there is sufficient obiter dicta in Teoh "to suggest that the reasoning may apply to any decision contemplated by article 3, namely on by 'courts of law, administrative authorities or legislative bodies'." McAdam, J, Complementary Protection in International Refugee Law, 2007, OUP, Oxford, P.190. For further commentary, see Lacey, W, A Prelude to the Demise of Teoh: The High Court Decision in Re Minister for Immigration and Multicultural Affairs; Ex parte Lam (2004) 26(1) Sydney Law Review 131; and Ruddle, L, and Nicholes, S, B \& B and Minister for Immigration and Multicultural and Indigenous Affairs: Can International Treaties Release Children from Immigration Detention Centres? (2004) 5(1) Melbourne Journal of International Law 256

1052 Plaintiff S157/2002 v Commonwealth [2003] HCA 2 per Gleeson CJ at para 29, Coleman $v$ Power [2004] HCA 39 at 225 per Kirby J; ${ }^{1052}$ Re Woolley; Ex parte Applicants M276/2003 [2004] HCA 49 per Gleeson CJ at para 11, per Kirby J at para 201.

1053 O'Neill, N, Rice, S, and Douglas, R, Retreat from Injustice, (2ed), 2004, Federation Press, Leichhardt, Pp.182-184

1054 United Nations, Committee on the Rights of the Child, Consideration of Reports Submitted by States Parties under Article 44 of the Convention - Concluding Observations: Australia, 20 October 2005, CRC/C/15/Add.268, para 9

1055 That is, by operation of section 46A of the Migration Act 1958 (Cth)

1056 Al Raied v Minister for Immigration and Multicultural Affairs [2001] FCA 313 at para 39; Jaffari v Minister for Immigration \& Multicultural Affairs [2001] FCA 985 at paras 17-18. 
the application be signed by a parent or guardian, if the applicant is under a certain age or lacks legal capacity. ${ }^{1057}$ The current Form 866 requires the form to be signed by a parent or guardian if the child is under the age of 15 years or lacks legal capacity, but unaccompanied minors may sign the form on their own behalf. ${ }^{1058}$

\subsubsection{Minors \& Unaccompanied Minors - Conclusions}

Both jurisdictions share the same view of who is a minor - that is, a person under the age of 18 years, although the European Union secondary legislation provides additional and varying qualifications regarding unaccompanied minors, which is further regularised in the proposed legislation. In the Australian context, the Migration Act does not make any distinction between minors and adults within the terminology of "lawful" or "unlawful" "noncitizens". The European Union makes express reference to the best interests of the child throughout the secondary legislation with the exceptions of the qualifications in Procedures Directive and the absence of such considerations in the Dublin II Regulation. The Proposals provide greater consistency in that regard, but the shortcomings in the Commission's 2011 Proposed Procedures Directive still remain. Australia has questionable applicability of the principle of "the best interests of the child" and CROC generally in relation to the operation of the Migration Act. The European Union expressly contemplates minors as asylum seekers in its secondary legislation, whereas, in Australia, the Migration Act does not. The European Union provides for minors to make an application on their own behalf but there is a degree of ambiguity and Member State discretion regarding the precise circumstances and age that such an application can occur. Australia does not preclude a minor making an application for a Protection Visa, and there appear to be no restrictions on unaccompanied minors from doing so, but the question of validity of the visa application may arise if the application is made by a minor under the age of 15 or who otherwise lacks capacity (and is accompanied).

1057 Taylor, J, Guardianship of Child Asylum Seekers (2006) 34 Federal Law Review 185 at Pp. 195-196 in which the author discusses the case of Minister for Immigration and Multicultural Affairs $v$ WAIK [2003] FCAFC 307 where the issue of an applicant under the age of 18 signed the application 866 form for a Protection (Class XA) visa when that form required that a parent or guardian sign the form if the applicant was under the age of 18 . The court noted the application of regulation 2.07 of the Migration Regulations. See $W A I K$ at paras 19-31.

1058 Australian Government, Department of Immigration and Citizenship, Form 866 Application for a Protection (Class XA) visa, Part B, P.10 http://www.immi.gov.au/allforms/pdf/866.pdf (last accessed 21 May 2012); Note also Form 866D - Application for a Protection (Class XA) visa-Application for a member of the family unit http://www.immi.gov.au/allforms/pdf/866d.pdf (last accessed 21 May 2012) for family members who do not have their own claims for protection 


\subsubsection{Vulnerable Persons}

\subsubsection{Vulnerable Persons - International}

At the international level, the UNHCR Revised Guidelines include as vulnerable persons "single women, children, unaccompanied minors and those with special medical or psychological needs"1059 as well as "unaccompanied elderly persons", "torture or trauma victims" or "persons with a mental or physical disability". ${ }^{1060}$ The Convention on the Rights of Persons with Disabilities ("CRPD") notes that "disability is an evolving concept" and accordingly, the focus of the Convention is on the environment in which a person with disabilities is interacting (both in an "attitudinal and environmental" sense). ${ }^{1061}$ As a consequence, a non-exhaustive definition of "persons with disabilities" is set out which includes "those who have longterm physical, mental, intellectual or sensory impairments which in interaction with various barriers may hinder their full and effective participation in society on an equal basis with others". ${ }^{1062}$

\subsubsection{Vulnerable Persons - Council of Europe}

The ECtHR has attributed an autonomous meaning of "vulnerable persons" to include those groups covered by Article 5(1)(e) ECHR, including vagrants, the mentally ill, alcoholics and those suffering from infectious disease. ${ }^{1063}$ However, most recently, in MSS, the ECtHR characterised asylum seekers generally as being a "particularly underprivileged and vulnerable population group in need of special protection" "1064 which, in light of the ECtHR's prior jurisprudence on the term "vulnerable persons", drew criticism in the partly concurring and partly dissenting judgment of Judge Sajó.

The Committee of Ministers of the Council of Europe, in their Recommendation (2003)5, identified those with "special needs" as "minors, pregnant women, elderly people, persons with physical or mental disabilities and people who have been severely traumatised, including torture victims". The Committee of Ministers' 20 Guidelines on Forced Returns does not make express provision for vulnerable persons or those with special needs.

\footnotetext{
1059 UNHCR, UNHCR Revised Guidelines on Applicable Criteria and Standards relating to the Detention of Asylum Seekers, February 1999 - Introduction 1060 Guideline 7, UNHCR, UNHCR Revised Guidelines on Applicable Criteria and Standards relating to the Detention of Asylum Seekers, February 1999.

1061 Recital (e) to the Convention on the Rights of Persons with Disabilities 2006 ("CRPD")

1062 Article 1, second paragraph, CRPD

${ }^{1063}$ See generally, Ovey, C, and White, R.C.A., The European Convention on Human Rights, (4ed) 2006, OUP, Oxford, Pp.144-148, particularly at P.147

1064 MSS v Belgium \& Greece, No. 30696/09, Judgment, 21 January 2011, para 251
} 
4.1.4.3 Vulnerable Persons - European Union - EU CharterIn the Union sphere, Article 26 of the EU Charter provides for the right of persons with disabilities to be integrated within the community. The Charter does not elaborate on the nature of the disabilities that a person may have.

\subsection{Vulnerable Persons - EU Secondary Legislation}

The Union secondary legislation makes express provision for vulnerable persons, ${ }^{1065}$ with the exception of the Dublin II Regulation. However, there is no entirely comparable definition. The Procedures Directive does not define "vulnerable persons" and only refers to "vulnerability". ${ }^{1066}$ The Reception Conditions Directive and the Qualification Directives provides an inclusive definition (indicated by the use of the words "such as"), ${ }^{1067}$ whereas the Returns Directive provides an exhaustive definition (indicated by the use of the word "means"). ${ }^{1068}$ All three definitions contemplate minors, unaccompanied minors, disable people, elderly people, pregnant women, single parents with minor children and persons who have been subject to torture, rape or other serious forms of sexual violence. ${ }^{1069}$ The Qualification I Directive and the Returns Directive provide a slightly more extensive definition than the Reception Conditions Directive by also including persons who have been subjected to other forms of psychological or physical violence. ${ }^{1070}$ Victims of human trafficking and persons with mental disorders have been included in the Qualification II Directive. ${ }^{1071}$

\subsection{Vulnerable Persons - European Union - The Proposed Legislation}

The Commission's Proposals all provide for more extensive definitions of vulnerable persons but, surprisingly, the terminology and the categories of persons have diverged in their consistency. Table 4.1 (below) shows the diversity of terms and their applicability. Although such variations in the terminology may be justified on the basis of the purpose of the legislation, it is difficult to see why a consistent and coherent description of this category of asylum seekers cannot be made, and why discrimination is made on the basis of the element of the asylum process that the asylum seeker finds him or herself in.

1065 Article 17 of the Reception Conditions Directive; Article 13(3)(a) of the Procedures Directive; Article 20(3) and (4) of the Qualification I Directive; Article 20(3) and (4) of the Qualification II Directive; and Articles 4(4)(a) and 16(3) of the Returns Directive.

1066 Article 13(3)(a) of the Procedures Directive

1067 Article 17(1) of the Reception Conditions Directive and Article 20(3) of the Qualification I Directive; Article 20(3) of the Qualification II Directive

1068 Article 3(9) of the Returns Directive

1069 Article 17(1) of the Reception Conditions Directive; Article 20(3) of the Qualification I Directive; Article 20(3) of the Qualification II Directive and Article 3(9) of the Returns Directive

1070 Article 20(3) of the Qualification I Directive; and Article 3(9) of the Returns Directive 1071 Article 20(3) of the Qualification II Directive 
Table 4.1 - Definitions of "Vulnerable Persons" in the European Union proposed legislation

\begin{tabular}{|c|c|c|c|c|c|}
\hline & & $\begin{array}{c}\text { Commission's } \\
\text { 2011 Proposed } \\
\text { Reception } \\
\text { Condition } \\
\text { Directive }\end{array}$ & $\begin{array}{l}\text { Council's } \\
\text { Amended } \\
\text { Proposed } \\
\text { Reception } \\
\text { Condition } \\
\text { Directive }\end{array}$ & $\begin{array}{l}\text { Commission's } \\
2011 \text { Proposed } \\
\text { Procedures } \\
\text { Directive }\end{array}$ & $\begin{array}{l}\text { Commission's } \\
\text { Proposed Dublin } \\
\text { Regulation }\end{array}$ \\
\hline Category & $\begin{array}{l}\text { Sub- } \\
\text { category }\end{array}$ & $\begin{array}{c}\text { Applicant with } \\
\text { special reception } \\
\text { needs (Article 2(k)) } \\
\text { and 'vulnerable } \\
\text { persons' (Article } \\
\text { 21) }\end{array}$ & $\begin{array}{c}\text { Applicant with } \\
\text { special reception } \\
\text { needs (Article 2(k)) } \\
\text { and 'vulnerable } \\
\text { persons' (Article } \\
\text { 21) }\end{array}$ & $\begin{array}{l}\text { 'Applicant in need } \\
\text { of special } \\
\text { procedural } \\
\text { guarantees' } \\
\text { (Article } 2(\mathrm{~d})) \text { due } \\
\text { to: }\end{array}$ & $\begin{array}{l}\text { No global term } \\
\text { (Article 30(4)) }\end{array}$ \\
\hline Minors & & $\checkmark$ & $\checkmark$ & & $\checkmark$ \\
\hline $\begin{array}{l}\text { Unaccompanied } \\
\text { Minors }\end{array}$ & & $\checkmark$ & $\checkmark$ & & \\
\hline Disabled People & & $\checkmark$ & $\checkmark$ & & \\
\hline Disabled Persons & & & & & $\checkmark$ \\
\hline Disability & & & & $\checkmark$ & \\
\hline Elderly people & & $\checkmark$ & $\checkmark$ & & $\checkmark$ \\
\hline Pregnant women & & $\checkmark$ & $\checkmark$ & & $\checkmark$ \\
\hline $\begin{array}{l}\text { Single parents with } \\
\text { minor children }\end{array}$ & & $\checkmark$ & $\checkmark$ & & \\
\hline $\begin{array}{l}\text { Victims of } \\
\text { trafficking }\end{array}$ & & $\checkmark$ & $\checkmark$ & & \\
\hline \multicolumn{6}{|l|}{$\begin{array}{l}\text { Persons with } \\
\text { serious }\end{array}$} \\
\hline & $\begin{array}{l}\text { physical } \\
\text { illnesses }\end{array}$ & $\checkmark$ & $\checkmark$ & & \\
\hline & $\begin{array}{l}\text { mental } \\
\text { illnesses }\end{array}$ & $\checkmark$ & & & \\
\hline & $\begin{array}{l}\text { post- } \\
\text { traumatic } \\
\text { disorders } \\
\end{array}$ & $\checkmark$ & & & \\
\hline $\begin{array}{l}\text { Persons with } \\
\text { mental disorders }\end{array}$ & & & $\checkmark$ & & \\
\hline $\begin{array}{l}\text { Serious physical } \\
\text { illness }\end{array}$ & & & & $\checkmark$ & \\
\hline Mental illness & & & & $\checkmark$ & \\
\hline $\begin{array}{l}\text { Post traumatic } \\
\text { stress disorders }\end{array}$ & & & & $\checkmark$ & \\
\hline \multicolumn{6}{|l|}{$\begin{array}{l}\text { Persons who have } \\
\text { been subject to: }\end{array}$} \\
\hline & torture & $\checkmark$ & $\checkmark$ & $\checkmark$ & $\checkmark$ \\
\hline & rape & $\checkmark$ & $\checkmark$ & $\checkmark$ & $\checkmark$ \\
\hline & $\begin{array}{l}\text { or other } \\
\text { serious forms } \\
\text { of sexual } \\
\text { violence }\end{array}$ & $\checkmark$ & $\checkmark$ & $\checkmark$ & $\checkmark$ \\
\hline & $\begin{array}{l}\text { Or other } \\
\text { forms of } \\
\text { psychologica } \\
\text { l physical [..] } \\
\text { violence }\end{array}$ & & $\checkmark$ & $\checkmark$ & $\checkmark$ \\
\hline Age & & & & $\checkmark$ & \\
\hline Gender & & & & $\checkmark$ & \\
\hline Sexual orientation & & & & $\checkmark$ & \\
\hline Gender identity & & & & $\checkmark$ & \\
\hline Indicative & & $\checkmark$ & $\checkmark$ & & $\checkmark$ \\
\hline Exhaustive & & & & $\checkmark$ & \\
\hline Qualifications & & $\begin{array}{l}\text { "in the national } \\
\text { legislation } \\
\text { implementing this } \\
\text { Directive" }\end{array}$ & $\begin{array}{l}\text { "in the national } \\
\text { legislation } \\
\text { implementing this } \\
\text { Directive" }\end{array}$ & & \\
\hline
\end{tabular}




\subsubsection{Vulnerable Persons - Australia}

In the Australian context, as with minors, the Migration Act does not make an explicit distinction between categories of non-citizens based on vulnerability. However, the Act and Regulations do make an indirect provision for vulnerability in the context of Bridging Visas as an alternative to detention.

Although a more detailed exploration of Bridging Visas will be made in subsequent chapters, vulnerability is contemplated in one of the three categories of "eligible non-citizens" (which is the first juridical hurdle in becoming eligible for a Bridging Visa) as a "prescribed" category (that is, by reference to the Migration Regulations 1994 (Cth)). ${ }^{1072}$ Inter alia, vulnerability can be evidenced in the Regulations by the reference to those detained who are under the age of 18 years where it has inter alia been certified by State or Territory child welfare authorities that it is in the minor's best interest to be released. ${ }^{1073}$ Similarly, it may be evidenced by protection visa applicants that have bypassed or been refused immigration clearance and come to the attention of the Department of Immigration within 45 days, this includes minors,${ }^{1074}$ those older than 75 years of age,${ }^{1075}$ those who have "special needs" on account of health, trauma or torture. ${ }^{1076}$ Vulnerability is also reflected in the category of Bridging Visa offered - particularly Bridging Visa E, Subclass 051 - which contemplates, inter alia, Protection Visa applicants who have been refused or bypassed immigration clearance and are: (1) aged less than 18 or more than 75 years of age; or (2) have been certified by a DIAC appointed medical specialist that the person "cannot properly be cared for in a detention environment" by virtue of having a "special need (based on health or previous experience of torture or trauma)[emphasis added]"). ${ }^{1077}$

Although outside the legislative scheme, reference to vulnerability is also made in the two assistance schemes for those asylum seekers on Bridging Visas (which will be discussed in more detail in subsequent chapters). Firstly, under the Community Assistance Support Program ("CAS")(formerly the Community Care Pilot program ("CCP")), part of the eligibility requirements include being under a particular vulnerability identified as: (1) "a diagnosed mental health condition"; (2) "significant disability or serious health issue"; (3) being a minor at risk, unaccompanied minor or elderly person; (4) "suffering the effects of torture and trauma"; (5) "suffering domestic abuse or violence"; or (6) suffering a mental or physical impairment. ${ }^{1078}$ Secondly, vulnerability

\footnotetext{
1072 Section 72(1)(b) of the Migration Act 1958 (Cth)

1073 Regulation 2.20(5) of the Migration Regulations 1994 (Cth)

1074 Regulation 2.20(7) of the Migration Regulations 1994 (Cth)

1075 Regulation 2.20(8) of the Migration Regulations 1994 (Cth)

1076 Regulation 2.20(9) of the Migration Regulations 1994 (Cth)

1077 Clause 051.212 of Schedule 2 to the Migration Regulations 1994 (Cth)

1078 Australian Government, Department of Immigration and Citizenship, Fact Sheet $64-$ Community Assistance Support Program, http://www.immi.gov.au/media/factsheets/64community-assistance.htm (last accessed 23 March 2012); see also Parliament of
} 
may act as an exemption to some of the bars to eligibility for assistance under the Asylum Seeker Assistance Scheme ("ASAS") which are identified as being: an unaccompanied minor; unable to work due to illness, disability or care responsibilities, or as a result of torture or trauma; or in financial hardship "resulting from a change in circumstances since arriving in Australia". Families with minors are also exempted from the regular eligibility criteria. ${ }^{1079}$

\subsubsection{Vulnerable Persons - Conclusions}

The European Union secondary legislation makes reasonably extensive provisions expressly contemplating vulnerable persons as a category of asylum seeker throughout almost all elements of the asylum stage - reception, procedures and return/removal - but not transfer to another Member State. However, the terminology is not entirely consistent throughout the current legislation - a facet that is agonisingly amplified in the proposed legislation. In the Australian context, there is no express legislative distinction between different categories of non-citizens. However, they are indirectly contemplated in the Act and Regulations as a category of prescribed persons eligible for Bridging Visas (in certain circumstances) and, outside the legislative scheme, under the two assistance schemes for those asylum seekers in the community. Both jurisdictions contemplate, in a broad sense, similar categories of vulnerable persons, but the upper age threshold of 75 years in the Australian context is a considerably high juridical hurdle that may exclude those who are less than 75 years of age but still experience vulnerability on account of their age.

\subsubsection{Stateless Persons}

Although the various issues in relation to stateless asylum seekers will be explored at various stages throughout this book as they relate to detention, it is useful to identify what provision has been made for stateless persons at the international level as well as in the Union and Australian contexts.

\subsubsection{Stateless Persons - International}

At the international level, the Nottebohm Case defined nationality as:

"a legal bond having as its basis a social fact of attachment, a genuine connection of existence, interest and sentiments, together with the existence of reciprocal rights and duties"1080

\footnotetext{
Australia, Joint Standing Committee on Migration, Immigration detention in Australia: Community-based alternatives to detention, May 2009, Canberra, http://www.aph.gov.au/ house/committee/mig/detention/report2/fullreport.pdf (last accessed 21 March 2012), P. 37 para 2.73

1079 Australian Government, Department of Immigration and Citizenship, Fact Sheet 64 Community Assistance Support Program, http://www.immi.gov.au/media/factsheets/64community-assistance.htm (last accessed 23 March 2012)

1080 Nottebohm Case (Liechtenstein v Guatemala), Second Phase, Judgment of 6 April 1955: ICJ Reports 1955, P.4 at P.23
} 
Additionally, the right to a nationality and the non-arbitrary deprivation of nationality are reflected in the major international human rights treaties. ${ }^{1081}$

The 1954 Convention relating to the Status of Stateless Persons identifies "stateless persons" as "a person who is not considered as a national by any State under the operation of its law". ${ }^{1082}$ However, the Convention does not apply:

“(i) To persons who are at present receiving from organs or agencies of the United Nations other than the United Nations High Commissioner for Refugees protection or assistance so long as they are receiving such protection or assistance;

(ii) To persons who are recognized by the competent authorities of the country in which they have taken residence as having the rights and obligations which are attached to the possession of the nationality of that country;

(iii) To persons with respect to whom there are serious reasons for considering that:

(a) They have committed a crime against peace, a war crime, or a crime against humanity, as defined in the international instruments drawn up to make provisions in respect of such crimes;

(b) They have committed a serious non-political crime outside the country of their residence prior to their admission to that country;

(c) They have been guilty of acts contrary to the purposes and principles of the United Nations." 1083

Article 26 of the 1954 Convention provides that stateless persons lawfully within the territory of the Contracting State have the right to choose their place of residence and to move freely within its territory, subject to any regulations applicable to aliens generally in the same circumstances ("in the same circumstances" is further defined by Article 6).

Accordingly, there are three points to note from the 1954 Convention definition of statelessness: firstly, the Convention definition only contemplates de jure statelessness - de facto statelessness is not provided for; secondly, the definition is cast in negative terms - that is, in order to fall within the scope of the definition of statelessness, the person must establish that he or she is not considered to be a national under its laws; thirdly, there is an inherent difficulty in regularising the presence of stateless persons who may be lacking documentation and who, notwithstanding their long connection with the territory concerned, be treated no better than aliens "in the same circumstances".

In relation to de facto statelessness, this refers to those who persons who have no "effective nationality". Although the conceptualisation of de facto

1081 Article 15 UDHR; Article 24(1) ICCPR; Article 5(d)(iii) CERD; Article 9 CEDAW; Articles 7 and 8 CROC

1082 Article 1(1) Convention relating to the Status of Stateless Persons 1954

1083 Article 1(2) Convention relating to the Status of Stateless Persons 1954 
statelessness has developed since the UN's 1949 Study of Statelessness, ${ }^{1084}$ the UN has more recently defined de facto statelessness as a person who is "unable to demonstrate that he/she is de jure stateless, yet/he she has no effective nationality and does not enjoy national protection". ${ }^{1085}$ In attempting to circumscribe what is meant by the ambiguous term "effective nationality", the UNHCR background paper entitled UNHCR and De Facto Statelessness suggested identifying de facto statelessness as non-inclusive of those who are within the country of their nationality:

"De facto stateless persons are persons outside their country of their nationality who are unable or, for valid reasons, unwilling to avail themselves of the protection of that country.

Persons who have more than one nationality are de facto stateless only if they are outside all the countries of their nationality and are unable or, for valid reasons, unwilling to avail themselves of the protection of any of those countries." 1086

Following the Prato Expert Sessions in May 2010, the UNHCR published its Summary Conclusions on the Concept of Stateless Persons under International Law. ${ }^{1087}$ The Summary Conclusions maintain the distinction between statelessness and ineffective nationality. ${ }^{1088}$ The definition of de facto statelessness (as identified in the first paragraph cited above in the April 2010 UNHCR background paper) was augmented in the summary conclusions by:

"Protection in this sense refers to the right of diplomatic protection exercised by a State of nationality in order to remedy an internationally wrongful act against one of its nationals, as well as diplomatic and consular protection and assistance generally, including in relation to return to the State of nationality" 1089

1084 United Nations, A Study of Statelessness, August 1949, Lake Success, New York, E/112-E/1112/Add.1 http://www.unhcr.org/3ae68c2d0.pdf (last accessed 12 September 2011) - see UNHCR, Massey, H, UNHCR and De Facto Statelessness, April 2010, LPPR/2010/01, http://www.unhcr.org/refworld/docid/4bbf387d2.html (last accessed 12 Septmber 2011), P.1 - 26, particularly P.5ff

1085 UNHCR, Nationality and Statelessness. A Handbook for Parliamentarians, 20 October 2005, http://www.unhcr.org/refworld/docid/436608b24.html (last accessed 12 September 2011), P.11,

1086 UNHCR, Massey, H, UNHCR and De Facto Statelessness, April 2010, LPPR/2010/01, http://www.unhcr.org/refworld/docid/4bbf387d2.html (last accessed 12 Septmber 2011), P.61

1087 UNHCR, Expert Meeting - The Concept of Stateless Persons under International Law Summary Conclusions, Expert meeting organised by the Office of the United Nations High Commissioner for Refugees, Prato, Italy, 27-28 May 2010

1088 UNHCR, Expert Meeting - The Concept of Stateless Persons under International Law Summary Conclusions, Expert meeting organised by the Office of the United Nations High Commissioner for Refugees, Prato, Italy, 27-28 May 2010, para 3

1089 UNHCR, Expert Meeting - The Concept of Stateless Persons under International Law Summary Conclusions, Expert meeting organised by the Office of the United Nations High Commissioner for Refugees, Prato, Italy, 27-28 May 2010, P.6, para 2; see also Open Society Justice Initiative, De Jure Statelessness in the Real World: Applying the Prato Summary 
Additionally, following the Geneva Expert Sessions in December 2010, the UNHCR published its Summary Conclusions on Statelessness Determination Procedures and the Status of Stateless Persons, ${ }^{1090}$ which formed the basis of the UNHCR's Guidelines on Statelessness No. 2. ${ }^{1091}$

The Equal Rights Trust has critiqued and criticised the distinction between de jure and de facto statelessness and concluded:

\begin{abstract}
"Instead of attempting such a categorisation, the stateless population can be perceived as a broad spectrum ranging from those whose statelessness has minimal negative impact on their lives, to those whose statelessness is both cause and consequence of acute discrimination, vulnerability and persecution. This spectrum is insensitive to the categorisation of de facto and de jure, being shaped instead by the realities faced by the stateless in their daily lives." 1092
\end{abstract}

Further, the Equal Rights Trust has advocated the "ineffective nationality" test be applied indiscriminately of de jure or de facto statelessness. ${ }^{1093}$

The UNHCR's Revised Guidelines expressly contemplate stateless persons. ${ }^{1094}$

\title{
4.1.5.2 Stateless Persons - Council of Europe
}

In the European sphere, the Council of Europe, in its European Convention on Nationality, defines nationality as "the legal bond between a person and a State and does not indicate the person's ethnic origin". ${ }^{109}$ Further, the Convention on the avoidance of statelessness in relation to State succession, defined statelessness as "the situation where a person is not considered a national by any State under the operation of its internal law". ${ }^{1096}$

Conclusions, 2011, New York, http://www.soros.org/sites/default/files/prato-statelessness20110303.pdf (last accessed 11 June 2012)

1090 UNHCR, Expert Meeting - Statelessness Determination Procedures and the Status of Stateless Persons - Summary Conclusions, Expert meeting convened by the Office of the United Nations High Commissioner for Refugees and the Open Society Justice Initiative, Geneva, Switzerland, 6-7 December 2010

1091 UNHCR, Guidelines on Statelessness No. 2: Procedures for Determining whether an Individual is a Stateless Person, HCR/GS/12/02, 5 April 2012

1092 The Equal Rights Trust, Unravelling Anomaly - Detention, Discrimination and the Protection Needs of Stateless Persons, July 2010, Equal Rights Trust, London, P.78

1093 The Equal Rights Trust, Unravelling Anomaly - Detention, Discrimination and the Protection Needs of Stateless Persons, July 2010, Equal Rights Trust, London, P.80

${ }^{1094}$ UNHCR, UNHCR Revised Guidelines on Applicable Criteria and Standards relating to the Detention of Asylum Seekers, February 1999, Guideline 9. See further, UNHCR, Executive Committee Conclusion No. 78 (XLVI), Prevention and Reduction of Statelessness and Protection of Stateless Persons, 1995; UNHCR, Executive Committee Conclusion No. 106 (LVII), Identification, Prevention and Reduction of Statelessness and Protection of Stateless Persons, 2006 1095 Article 2(a) European Convention on Nationality, Strasbourg, 6 November 1997

1096 Article 1(c) Convention on the avoidance of statelessness in relation to State succession, Strasbourg, 19 May 2006 


\subsection{Stateless Persons - EU Secondary Legislation}

In the Union secondary legislation, the Reception Conditions Directive, ${ }^{1097}$ the Procedures Directive ${ }^{1098}$ and the Qualification Directives ${ }^{1099}$ expressly contemplate stateless persons within the personal scope of the secondary legislation, but that term is otherwise undefined. The Dublin II Regulation ${ }^{1100}$ and the Returns Directive ${ }^{1101}$ make no references to stateless persons.

\subsection{Stateless Persons - European Union - The Proposed Legislation}

The proposed Reception Conditions Directive (including the Council's Amended Proposal) and Procedures Directive maintain their references (albeit undefined) to stateless persons. Further, the Proposed Dublin Regulation is now inclusive of stateless persons. ${ }^{1102}$

\subsubsection{Stateless Persons - Australia}

Australia acceded to the 1954 Statelessness Convention on 13 December $1973^{1103}$ and its primary service has been within the application of the Australian Citizenship Act 2007 (Cth). The Migation Act, however, makes no distinction between stateless and other types of lawful or unlawful noncitizens. Accordingly, there is no legislative definition to which to refer. Although a more detailed discussion of the High Court of Australia's decision in Al-Kateb $v$ Godwin, ${ }^{1104}$ in relation to a stateless Palestinian detained in Australia, will be discussed in later chapters, it is worth noting some aspects in relation to how the Court viewed "stateless" in light of the Migration Act.

The majority judgment consisted of McHugh, Hayne, Callinan and Heydon JJ (who agreed with Hayne J), with the dissenting judgments being delivered by Glesson CJ, Gummow and Kirby JJ. The overall consensus was that stateless persons were included within the definition of "non-citizen" for the purposes of the Migration Act, and that they were indistinguishable from other "noncitizens" on account of their statelessness.

McHugh J's judgment proceeded on the basis that the appellant was an alien. ${ }^{1105}$ Hayne J did not make any distinction between the appellant's statelessness and his status as a non-citizen under the Act, ${ }^{1106}$ further pointing out that if it was otherwise constitutionally valid to detain a non-citizen, then

\footnotetext{
1097 Articles 3(1) and 2(b) of the Reception Conditions Directive

1098 Articles 3(3) and 2(c) of the Procedures Directive

1099 Article 1 of the Qualification I Directive; Article 1 of the Qualification II Directive

1100 Article 1 of the Dublin II Regulation

1101 Article 2(1) of the Returns Directive

1102 Article 2(b), (c) and (f) of the Commission's Proposed Dublin Regulation

1103 UN Treaty Collection http://treaties.un.org/pages/ViewDetailsII.aspx?\&src= TREATY\&mtdsg_no $=\mathrm{V} \sim 3 \&$ chapter $=5 \& \mathrm{Temp}=\operatorname{mtdsg} 2 \& l a n g=$ en $\quad$ (last accessed 12 September 2011)

1104 Al-Kateb v Godwin [2004] HCA 37

1105 Al-Kateb v Godwin [2004] HCA 37 per McHugh J at 31-75

1106 Al-Kateb v Godwin [2004] HCA 37 per Hayne J at 227
} 
it "does not necessarily entail that a law requiring detention of aliens in other circumstances, or for other purposes, is beyond power." 1107 Accordingly, the circumstances of a non-citizen (be they stateless or otherwise) does not affect the constitutional power to detain. Indeed, Callinan J held:

\begin{abstract}
"Under the Migration Act there are not two classes of illegal entrants, those who can be readily and promptly removed from this country because another state is willing to receive them, and others who, on account of statelessness or otherwise, may not so readily be found another country of residence. Whether statelessness calls for a different treatment, as it may well do for practical and humanitarian reasons, is a matter for the legislature and not for the courts. Nor should the appellant be accorded any special advantages because he has managed illegally to penetrate the borders of this country of those who have sought to, but have been stopped because they could do so." 1108
\end{abstract}

Gleeson CJ was of the view that "[f]or the present purposes, unlawful noncitizens are aliens who have entered Australia without permission, or whose permission to remain in Australia has come to an end. In this context, alien includes a stateless person, such as the appellant." 1109

Whilst finding that the appellant was and is an unlawful non-citizen under the Migration Act, ${ }^{1110}$ Gummow J gave the most nuanced evaluation of whether a stateless person can be considered an alien as regards the Australian constitution. Although finding no need to immediately answer the question, Gummow J, after identifying that an alien is one who is a citizen of another country or owes allegiance to another State, asked, "[b]ut the appellant here is destitute of any nationality. Does that condition deny him the character of a constitutional 'alien'?" 1111 As with Gummow J, Kirby J saw no need to consider whether a stateless person was an "alien". 1112

\title{
4.1.5.5 Stateless Persons - Conclusions
}

The European Union secondary legislation expressly contemplates stateless persons as falling within its scope, with the exception of the Dublin II Regulation and the Returns Directive. The Commission's Proposed Dublin Regulation is inclusive of stateless persons. As there is no definition of "stateless" in the current or proposed secondary legislation, it is unclear, however, whether de facto or de jure statelessness is contemplated. Further, statelessness is only referred to with respect to the personal scope of the secondary legislation - it remains to be seen in later chapters whether there are sufficient safeguards for stateless asylum seekers subject to detention. In the Australian context, stateless persons are indistinguishable from other non-

\footnotetext{
1107 Al-Kateb v Godwin [2004] HCA 37 per Hayne J at 247

1108 Al-Kateb v Godwin [2004] HCA 37 per Callinan J at 301

1109 Al-Kateb v Godwin [2004] HCA 37 per Gleeson CJ at 1

1110 Al-Kateb v Godwin [2004] HCA 37 per Gummow J at 82 and 90

1111 Al-Kateb v Godwin [2004] HCA 37 per Gummow J at 85

1112 Al-Kateb v Godwin [2004] HCA 37 per Kirby J at 144
} 
citizens under the Migration Act and are considered as constitutional aliens. There is no legislative definition of a stateless person in the Australian context.

\subsection{Detention}

\subsection{1 "Detention" - International}

At the international level the UNHCR's 1999 Revised Guidelines provide a source for defining what is meant by detention in the context of asylum seekers. Notwithstanding that those Guidelines are not binding on States, the UNHCR considers that detention constitutes:

"confinement within a narrowly bounded or restricted location, including prisons, closed camps, detention facilities or airport transit zones, where freedom of movement is substantially curtailed, and where the only opportunity to leave this limited area is to leave the territory" 1113

The Guidelines also provide that "persons who are subject to limitations on domicile and residency are not generally considered to be in detention". 1114 The Guidelines further urge that a cumulative approach of the restrictions (together with the degree and intensity thereof) imposed on an asylum seeker should be undertaken when assessing whether a person is in detention. ${ }^{1115}$

The United Nations Commission on Human Rights Working Group on Arbitrary Detention has indicated that a restriction on liberty may differ from a deprivation of liberty, and identified distinctions between categories of premises. ${ }^{1116}$ The Commission on Human Rights Working Group on Arbitrary Detention subsequently indicated:

"The places of deprivation of liberty concerned by the present principles may be places of custody situated in border areas, on police premises, premises under the authority of a prison administration, ad hoc centres (centres de rétention), so called international or transit zones in ports or international airports, gathering centres or certain hospital premises." 1117

\footnotetext{
1113 UNHCR Revised Guidelines on applicable criteria and standards relating to the detention of asylum seekers, February 1999, Guideline 1

1114 UNHCR Revised Guidelines on applicable criteria and standards relating to the detention of asylum seekers, February 1999, Guideline 1

1115 UNHCR Revised Guidelines on applicable criteria and standards relating to the detention of asylum seekers, February 1999, Guideline 1

1116 United Nations Commission on Human Rights, Working Group on Arbitrary Detention, Question of the Human Rights of all Persons Subjected to Any Form of Detention or Imprisonment, Situation Regarding Immigrants and Asylum Seekers, UN Doc. E/CN.4/1998/44, 19 December 1997, Paras 40-41

1117 United Nations Commission on Human Rights, Working Group on Arbitrary Detention, Body of Principles for the Protection of All Persons under Any Form of Detention or Imprisonment regarding the situation of immigrants and asylum seekers, Deliberation No. 5, UN Doc. E/CN.4/2000/4/Annex 2, 28 December 1999, P.29
} 
The Optional Protocol to CAT (OPCAT) refers to places "where persons are or may be deprived of their liberty, either by virtue of an order given by a public authority or at its instigation or with its consent or acquiescence (hereinafter referred to as places of detention)."1118 "Deprivation of liberty" is further defined as:

"any form of detention or imprisonment or the placement of a person in a public or private custodial setting which that person is not permitted to leave at will by order of any judicial, administrative or other authority." 1119

\subsection{2 "Detention" - Council of Europe}

The nature of detention has been considered by the ECtHR in the context of Article 5 ECHR. In Guzzardi, ${ }^{1120}$ the applicant was considered to be a Mafiosi, and taken to Asinara, a small island off Sardinia, where he was restricted to staying within an area of compulsory residence of approximately 2.5 square kilometres. His family could live with him, if they chose, although the buildings were said to be in a state of dilapidation. He was able to go out between $7 \mathrm{am}$ and $10 \mathrm{pm}$ and had to report twice daily to authorities. There were limited opportunities for work. He had to seek permission to make or receive a phone call. The Court held that a deprivation of liberty occurred as contemplated by Article 5 ECHR, noting, firstly, that "the difference between deprivation of and restriction upon liberty is nonetheless merely one of degree or intensity, and not one of nature or substance". ${ }^{1121}$ Secondly, the court looked to the cumulative effects of the restrictions under which the applicant was placed. ${ }^{1122}$

In relation to being held in an international zone, the ECtHR held in Amuur $^{1123}$ that a deprivation of liberty may occur in circumstances where the only option open to asylum seekers was to leave the territory of the Contracting Party (in this case, France: the asylum seekers having been kept in a transit zone which incorporated an hotel and an airport lounge). Importantly, the argument that the asylum seekers could end their detention by voluntarily choosing to leave France was expressly rejected and the Court held that a restriction on liberty could not be guaranteed by the existence of that possibility. ${ }^{1124}$ The Court held that being held in an international zone did amount to a "restriction on liberty" but which could escalate to a "deprivation of liberty" where the holding of the person was "prolonged excessively". ${ }^{1125}$ The Court also forewarned that, in any event, the asylum-seekers' right to "effective access" [emphasis added] to asylum procedures should not be

\footnotetext{
1118 Article 4(1) OPCAT

1119 Article 4(2) OPCAT

${ }_{1120}$ Guzzardi v Italy, No. 7367/76, 6 November 1980, Judgment, Plenary Chamber.

1121 Ibid at para 93

1122 Ibid at para 95

1123 Amuur v France, No. 19776/92, Judgment, 25 June 1996,

${ }^{1124}$ Ibid at para 48

1125 Ibid at para 43
} 
deprived on account of their confinement. ${ }^{1126}$

The Committee of Ministers of the Council of Europe has indicated in its Recommendation (2003)5 that, "'measures of detention of asylum seekers' means any confinement of asylum seekers within a narrowly bounded or restricted location, where they are deprived of liberty. Persons who are subject to restrictions on domicile or residence are not generally considered to be subject to detention measures." 1127 In relation to forced returns, the Committee of Ministers in its Twenty Guidelines on Forced Returns has adopted the notion of "deprivation of liberty, ${ }^{1128}$ consistent with Article 5 ECHR and the ECtHR's reasoning in cases involving that Article.

\subsection{3 "Detention" - European Union}

Under the Union secondary legislation, a definition of detention is quite obscure and much discretion is given to the Member States. This is particularly the case in the Reception Conditions Directive. "Detention" is defined under the Directive as "confinement of an asylum seeker by a Member State within a particular place, where the applicant is deprived of his or her freedom of movement". ${ }^{1129}$ "Accommodation centre" is defined as "any place used for collective housing of asylum seekers". ${ }^{1130}$ It remains a question of fact on a case-by-case basis to ascertain what distinction there is between "collective housing" and "detention".

If one looks at the scheme that appears to be established by Article 7 of the Reception Conditions Directive, there appears to be a gradation of liberty without any discernable boundaries as to when liberty becomes a 'restriction on liberty' and, most severely, a 'deprivation of liberty'. The scheme starts with a vapid right of free movement - that is, free movement at first within the territory of the Member State unless the Member State has determined an "assigned area" in which case there would appear to be free movement within that assigned area. ${ }^{1131}$ The Article then refers to "residence", ${ }^{1132}$ and finally to

\footnotetext{
1126 Ibid

1127 Committee of Ministers, Council of Europe, Recommendation Rec(2003)5 of the Committee of Ministers to member states on measures of detention to asylum seekers, paragraph 1.

1128 Guideline 6(1), Committee of Ministers, Council of Europe, Twenty Guidelines on Forced Return, CM(2005)40 Addendum final, Strasbourg, 20 May 2005.

${ }_{1129}$ Article 2(k) of the Reception Conditions Directive

1130 Article 2(l) of the Reception Conditions Directive; see also the reference to "collective accommodation" in Guideline 4(iv), "Open Centres", of the UNHCR Revised Guidelines on applicable criteria and standards relating to the detention of asylum seekers, February 1999. The UNHCR has indicated "Open Centres" as an alternative to detention. It is unclear whether the Reception Conditions Directive is mimicking the language used by the UNHCR in that regard and, consequently, considers "collective accommodation" to be an alternative to detention. Again, much will turn on the practical realities of how that accommodation is used rather than solely on terminology.

1131 Article 7(1) of the Reception Conditions Directive

1132 Article 7(2) of the Reception Conditions Directive
} 
confinement "to a particular place". ${ }^{1133}$

The multiplicity of terms under Article 7 to deal with "residence and free movement" does not advance the understanding of what constitutes detention. Indeed, the word "detention" is not used within the Article itself. In relation to the first qualification on the right to free movement, the "assigned area" must not "affect the unalienable sphere of private life". ${ }^{1134}$ In relation to the second qualification of the right to free movement, the somewhat neutral term "residence" is used. ${ }^{1135}$ Further, the reception conditions may be "subject to actual residence by the applicants in a specific place, to be determined by the Member States". ${ }^{1136}$ It is very unclear whether "actual residence" at that "specific place" referred to in Article 7(4) may, in fact, constitute detention. The third qualification to free movement confinement "to a particular place" - is to be in accordance with Member States' national law. ${ }^{1137}$ Ambiguity is also seen in Article 14, which sets out the modalities for material reception conditions. Under that Article, different types of housing are identified, but it is unclear what the relationship to detention is and whether "accommodation centres" can constitute detention or be a detention facility. The Commission's 2011 Proposed Reception Conditions Directive maintains the four gradations of liberty in the current Reception Conditions Directive, as well as the definition of detention, ${ }^{1138}$ but makes a clearer distinction between detention and other forms of accommodation firstly, through its use of the word "detention", secondly, by setting apart the detention provisions in a separate Article; thirdly through the removal of the reference to confinement "to a particular place" as provided for under the current Article 7(3); and finally by the adoption of a mechanism for detention under the proposed Articles 8 and 9. However, the boundaries between what constitutes detention and other restrictions on liberty (including deprivation of liberty at the most severe end of the spectrum) still turn on a question of fact. As Edwards warns, "[1]abels can be misleading". ${ }^{1139}$

Ambiguity also pervades Article 18 of the Procedures Directive, which merely refers to "detention" and is otherwise undefined. The Commission's 2011 Proposed Procedures Directive does not advance its own distinct definition, but refers to the Reception Conditions Directive as regards grounds and

\footnotetext{
1133 Article 7(3) of the Reception Conditions Directive

1134 Article 7(1) of the Reception Conditions Directive

1135 Article 7(2) of the Reception Conditions Directive

1136 Article 7(4) of the Reception Conditions Directive

1137 Article 7(3) of the Reception Conditions Directive

1138 Article 2(h) of the Commission's 2011 Proposed Reception Conditions Directive; maintained in Article 2(h) of the Council's Amended Proposed Reception Conditions Directive

1139 Edwards, A, Back to Basics: The Right to Liberty and Security of Person and 'Alternatives to Detention' of Refugees, Asylum-Seekers, Stateless Persons and Other Migrants, UNHCR, April 2011, PPLA/2011/01.Rev.1, P.9
} 
conditions (and, presumably, the definition) of detention ${ }^{1140}$ as well as making an additional reference to "detention facilities" which is undefined. ${ }^{1141}$

Although the current Dublin II Regulation is silent on detention, the Commission's Proposed Dublin Regulation includes new provisions for detention. ${ }^{1142}$ Reference is made in the preamble to the circumstances and conditions provided for under the Reception Conditions Directive. ${ }^{1143}$ However, detention otherwise remains undefined in the Proposed Regulation.

Chapter IV of the Returns Directive deals with detention. Recital 17 of the Directive provides minimal guidance on what constitutes detention, stating that detention "as a general rule, should [emphasis added] take place in specialised detention facilities". Article 16(1) states more imperatively that "[d]etention shall take place as a rule in specialised detention facilities" but the qualification "as a rule" and provision for Member States resorting to prison accommodation in the event of not being able to provide accommodation in specialised detention facilities somewhat undermines the imperative aspirations of that Article.

\subsection{4 "Detention" - Australia}

Groves ${ }^{1144}$ explains that Australian immigration detention principles have developed largely in isolation from correctional (penal) detention. This has occurred because there is no federal prison system in Australia. The states are compelled to take persons "accused or convicted of offences" against federal law into their prison system by virtue of section 120 of the Australian Constitution. However, the clear enunciation of "accused or convicted" under section 120 means that immigration detainees (who do not commit a crime, but are merely "unlawful non-citizens") fall outside the scope of this transmission between the federal and the state governments. ${ }^{1145}$

Under section 5 of the Migration Act 1958 (Cth), "detain" is defined as being

\footnotetext{
1140 Article 26 of the Commission's 2011 Proposed Procedures Directive

1141 Articles 8 and 23(2) of the Commission's 2011 Proposed Procedures Directive. See also the proposed Articles 6(8), 7 and 19(2) the Commission's 2009 Proposed Procedures Directive

1142 Article 27 of the Commission's Proposed Dublin Regulation

1143 Recital 18 of the Commission's Proposed Dublin Regulation. Note, however, the pending case of Case C-179/11 CIMADE, Groupe d'information et de soutien des immigrés (GISTI) v Ministre de l'Intérieur, de l'Outre-Mer, des Collectivités Territoriales et de l'Immigration, Reference for Preliminary Ruling lodged 18 April 2011 as regards the applicability of the current Reception Conditions Directive to those falling under the scope of the Dublin II Regulation

1144 Groves, M, Immigration Detention vs Imprisonment: Differences explored (2004) 29(5) Alternative Law Journal 228, P.228

1145 Groves, M, Immigration Detention vs Imprisonment: Differences explored, (2004) 29(5) Alternative Law Journal 228, P.228
} 
"taken into immigration detention" or "keep, or cause to be kept, in immigration detention; and includes taking such action and using such force as are reasonably necessary to do so". "Immigration detention" is defined under section 5 as:

"(a) being in the company of, and restrained by:

(i) an officer; or

(ii) in relation to a particular detainee--another person directed by the Secretary to accompany and restrain the detainee; or

(b) being held by, or on behalf of, an officer:

(i) in a detention centre established under this Act; or

(ii) in a prison or remand centre of the Commonwealth, a State or a Territory; or

(iii) in a police station or watch house; or

(iv) in relation to a non citizen who is prevented, under section 249 , from leaving a vessel--on that vessel; or

(v) in another place approved by the Minister in writing;

but does not include being restrained as described in subsection $245 \mathrm{~F}(8 \mathrm{~A})$, or being dealt with under paragraph $245 \mathrm{~F}(9)(\mathrm{b}) . "$

"Officer" is defined under section 5(1) to include particular categories of persons and, under sections $198 \mathrm{~A}(5)$ and 198B(3) (in relation to the offshore entry persons being taken to another country or to transitory persons being brought to Australia) to include a member of the Australian Defence Force. That definition may prove significant in circumstances when an officer has, for example, boarded a vessel or in circumstances where the purported "officer" in fact does not fall within the statutory definition.

The Minister is given power under section 273 of the Act to establish and maintain detention centres.

It is also important to note that, under the definition of "detain" in section 5 , a person is still considered to be "detained" even if the Minister makes a "residence determination" under section $197 \mathrm{AB}$ of the Act whereby a person may reside at a specified place, with specified conditions, instead of being detained at a place covered by the definition of "immigration detention". Currently, the Minister must make, vary or revoke a residence determination personally ${ }^{1146}$ - a somewhat cumbersome and inflexible procedure which

1146 Section 197AF, Migration Act 1958 (Cth). Clause 13, Schedule 1 of the Migration Amendment (Immigration Detention Reform) Bill 2009 had proposed to abolish that requirement, allowing the Minister to delegate his powers to an appropriate officer, thereby providing greater responsiveness and flexibility to those who have applied for a residence determination - see Australian Human Rights Commission, Migration Amendment (Immigration Detention Reform) Bill 2009, Submission to the Senate Standing Committee on Legal and Constitutional Affairs, 31 July 2009, Sydney, http://www.humanrights.gov.au/legal/submissions/2009/20090731_migration.pdf (last accessed 21 May 2011) at paras 105-111. Other proposed amendments contained in the Bill amended the definition of "immigration detention" under section 5 to include temporary 
reduces the responsiveness of decision-making to the circumstances of the detained person. Further, children who are the subject of a residence determination are deemed not to be detained. ${ }^{1147}$

For offshore entry persons taken to another country under section 198A of the Act, the Act deems those persons not to be in "immigration detention" (that is, "immigration detention" as defined under section 5 of the Act). ${ }^{1148}$ As alluded to in Chapter 3, the majority of the Full Federal Court in Ruddock $v$ Vardarlis (per French J with Beaumont J agreeing) came to the extraordinary conclusion that those being held in relation to the Tampa incident (that is, prior to their removal to Nauru and New Zealand) were not being detained because they could voluntarily choose to leave Australia. ${ }^{1149}$ In 2011, French CJ (as Chief Justice of the High Court of Australia), when interpreting section 198A in the M70 decision (which quashed the Malaysia 'swap' deal) appeared to have retreated from his earlier position somewhat by stating:

"According to the Explanatory Memorandum for the 2001 Excision Consequential
Provisions Bill those words mean that a person is not in "immigration detention'...
merely because the person is being dealt with under section 198A." They plainly
do not and cannot bear that meaning. They explicitly exclude a person who is
being dealt with under s 198A from being in immigration detention for any other
purposes under the Act." 1150

No comparable deeming provision is made for those transitory persons brought to Australia under section $198 \mathrm{~B}$ of the Act. ${ }^{1151}$

Groves observes that it was noted by all judges except Kirby $\mathrm{J}$ in the High Court of Australia case of Behrooz $z^{1152}$ that the Migration Act did not define what is meant by "immigration detention". ${ }^{1153}$ Nor did the Act indicate whether its

community access permission (see Clauses 4 and 5, Schedule 1 of the Bill) in line with the then proposed introduction of temporary community access permission provisions introduced by the then proposed new sections 194A and 194B to the Migration Act (see Clause 12, Schedule 1 of the Bill). However, with lapsing of that Bill, and in the absence of any re-introduction of it, the proposed changes never came into effect - nor will they for the foreseeable future.

1147 Section 4AA(2) of the Migration Act 1958 (Cth)

1148 Section 198A(4) of the Migration Act 1958 (Cth)

1149 Ruddock $v$ Vadarlis [2001] FCA 1329 at paras 206-215, particularly at 206, 212-213 per French J; contra Black CJ at paras 65-89 who expressly referred to Amuur at para 73; see further Crock, M, In the wake of the Tampa: Conflicting Visions of International Refugee Law in the Management of Refugee Flows (2002) 12(1) Pacific Rim Law and Policy Journal 49, Pp.63-69

1150 M70/2011 v Minister for Immigration and Citizenship; M106/2011 v Minister for Immigration and Citizenship [2011] HCA 32 at 11 per French CJ

${ }^{1151}$ Section 198C of the Migration Act 1958 (Cth)

1152 Behrooz v Secretary, Department of Immigration and Multicultural and Indigenous Affairs [2004] HCA 36

1153 Groves, M, Immigration Detention vs Imprisonment: Differences explored (2004) 29(5) Alternative Law Journal 228, P.230 
character is punitive or otherwise. Ultimately the Court held that that deficiency did not affect the lawfulness of detention. ${ }^{1154}$ Groves notes that the current legislative definition of detention makes it virtually impossible to prove that a particular place is not an immigration detention centre. ${ }^{1155}$ As will be explored in Chapter 8 on proportionality, the line of authority from the High Court of Australia is that the purpose (as opposed to any actual or purported effect) of immigration detention is not punitive because its purpose is to exclude and deport aliens (that is, it is an administrative form of executive detention incidental to the aliens power of the Australian Constitution). ${ }^{1156}$

Although the Migration Act makes no distinction as to the form of immigration detention, different types of immigration detention do exist in Australia. In December 2008, the Joint Standing Committee on Migration identified these different types to include: (1) immigration detention centres (most secure); (2) immigration detention housing (low risk, less institutional housing); (3) immigration transit accommodation (low security, flight and health risk hostel style accommodation); (4) community detention (by virtue of a section 197AB residence determination referred to above); and (5) alternative temporary detention (within the community, such as a hotel to permit hospital treatment). ${ }^{1157}$ The Department of Immigration and Citizenship makes a slightly different characterisation being: Immigration Detention Centres ("IDC"); ${ }^{1158}$ Immigration Residential Housing ("IRH”); ${ }^{1159}$ Immigration

1154 Behrooz v Secretary, Department of Immigration and Multicultural and Indigenous Affairs [2004] HCA 36, Gleeson CJ at 21, McHugh, Gummow and Heydon JJ at 53, and Callinan $\mathrm{J}$ at 223. See also Head, M, High Court Sanctions Indefinite Detention of Asylum Seekers, [2004] University of Western Sydney Law Review 7.

1155 Groves, M, Immigration Detention vs Imprisonment: Differences explored (2004) 29(5) Alternative Law Journal 228, P.230

1156 See particularly, Behrooz v Secretary, Department of Immigration and Multicultural and Indigenous Affairs [2004] HCA 36 per Gleeson CJ at para 21; Re Woolley; Ex parte Applicants M276/2003 [2004] HCA 49 at paras 81-82, 88, and 115 per McHugh J. See also, Zagor, M, Uncertainty and Exclusion: Detention and Aliens and the High Court (2006) 34 Federal Law Review 127

1157 Parliament of Australia, Joint Standing Committee on Migration, Immigration Detention in Australia: A new beginning - criteria for release from detention, 2008, Canberra, http://www.aph.gov.au/house/committee/mig/detention/report/fullreport.pdf (last accessed 27 April 2012), Appendix E, Pp.155-158

1158 To "accommodate a range of unlawful non-citizens, mainly people who have overstayed their visa, people in breach of their visa conditions, or people who were refused entry at Australia's international airports." Australian Government, Department of Immigration and Citizenship, Managing Australia's Borders, Detention Services, Facilities, About the Facilities, About Immigration Detention Facilities, http://www.immi.gov.au/managing-australias-borders/detention/facilities/about/ immigration-detention-facilities.htm (last accessed 21 May 2011)

1159 "Immigration residential housing provides an option for accommodating people in independent family-style housing in a community setting while still formally being detained. This type of facility is one of several types of alternative residential accommodation for detained people, subject to them meeting eligibility criteria.

People in immigration detention accommodated in immigration residential 
Transit Accommodation ("ITA"); ${ }^{1160}$ and Alternative Places of Detention (“APOD”). ${ }^{1161}$

\subsection{5 "Detention" - Conclusions}

Accordingly, the international guidelines as to what constitutes detention provide a very broad definition and require a case-by-case analysis to determine the cumulative effect upon an individual. In the case of the European Union, much discretion has been given to the Member States and the nature and meaning of detention is left very much undefined, potentially leading to variations amongst the Member States. Currently the distinction between detention and other forms of accommodation or residence is not so clear and will depend largely on a case-by-case analysis of the cumulative effects of any conditions imposed upon the accommodation or residence of the asylum seeker. This distinction is important in two respects: firstly, whether a person is in detention in both a legal and factual sense will significantly impact on the rights to which that person is entitled; secondly, when considering alternatives to detention - that is, are they alternatives to detention, or alternative forms of detention. Further, the nature of detention is not consistently (or, in some circumstances, at all) conceptualised throughout the current relevant secondary legislation, but a higher degree of integration (and less of a 'silo effect') is evident in the forthcoming proposed legislation. The Proposed Reception Conditions Directives, however, still retain the 'onion ring' gradation of liberty found in the current Reception Conditions Directive, albeit with a mechanism in place for detention. The Australian position provides a much higher level of legal certainty than the European legislation, but in a somewhat binary way - either an asylum seeker is in "immigration detention" or they are not. Further, the broad definition of "immigration detention" does not give any insight into its meaning or character. The legal fiction under section $198 \mathrm{~A}(5)$ that an offshore entry person who is to be taken to another country is not in immigration detention

housing live in a more domestic environment which permits a greater degree of autonomy. Participation is voluntary. Those who participate are provided with the opportunity to live a more self-sufficient lifestyle in housing within a community setting. They are able to cook their own food and undertake regular trips to other locations for shopping and recreation under the supervision of the Detention Service Provider." Australian Government, Department of Immigration and Citizenship, Managing Australia's Borders, Detention Services, Facilities, About the Facilities, About Immigration Residential Housing (IRH), http://www.immi.gov.au/managing-australias-borders/detention/facilities/about/rhcs.htm (last accessed 21 May 2011).

1160 "Facilities for short term, low flight risk detainees." Australian Government, Department of Immigration and Citizenship, Managing Australia's Borders, Detention Services, Facilities, About the Facilities, http://www.immi.gov.au/managing-australiasborders/detention/facilities/about/ (last accessed 21 May 2011)

1161 Australian Government, Department of Immigration and Citizenship, Managing Australia's Borders, Detention Services, Facilities, About the Facilities, About Immigration Detention Facilities, http://www.immi.gov.au/managing-australias-borders/detention/ facilities/about/immigration-detention-facilities.htm (last accessed 21 May 2011). 
for the purposes of the Act does not reflect the reality that such persons will invariably be detained.

Both the EU and Australia have different characterisations of detention that are inadequately reflected in the law. In the Australian sphere, the transfer of a detainee to a different type of detention facility does not automatically result in any alteration of the legal status of being in "immigration detention" for the purposes of the Migration Act. The significance of the terminology becomes important in any discussion about alternatives to detention. For example, any policy or other commitment to release children or others from immigration detention centres does not reflect a possible reality that, for the purposes of the Migration Act, such children are still detained in law albeit in another type of facility. Further, the lack of legislative embodiment results in a lack of enforceability to a less restrictive form of detention. Accordingly, there can easily be a disjunction in the legal and factual reality - that is, is an alternative to detention really just another form of detention? The significance of this is underscored due to the jurisprudence's primary focus on whether a person is in immigration detention for the purposes of the Migration Act - the international and European conception of detention as a factual continuum has not been reflected in the Australian case law. Further, any disjunction in law and fact may obscure any potential test for proportionality.

\subsection{Territorial \& Jurisdictional Scope}

Although it is beyond the scope of this book to explore all aspects of the territorial application of the Geneva Convention (indeed, measures and provisions relating to the Law of the Sea fall outside the scope of this book $^{1162}$ ), it is necessary to look at some aspects for three reasons: firstly, an asylum seeker will seek asylum by their physical presence on the territory of a State Party to the Convention (or by attempting to enter the territory of a State Party) which can be indicative of the State Party's jurisdiction over the asylum seeker and any application for his/her protection; secondly, such physical presence on the territory of a State Party commences a gradual accretion of rights for asylum seekers under the Geneva Convention based on his/her degree of attachment to the territory of the State Party; and thirdly, regularisation of such physical presence is made by access to the asylum procedures. Further, the territorial scope of other international human rights instruments may be relevant when considering those who fall outside the

1162 In this regard, see Goodwin-Gill, G, and McAdam, J, The Refugee in International Law, (3ed), 2007, OUP, Oxord, Pp.267-284; Mallia, P, Migrant Smuggling by Sea - Combatting a Current Threat to Maritime Security through the Creation of a Cooperative Framework, 2010, Martius Nijhoff, Leiden/Boston; Mathew, P, International Association of Refugee Law Judges Conference - Address - Legal Issues Concerning Interception, (2003) 17 Georgetown Immigration Law Journal 221 
scope of the Geneva Convention. Territoriality, though indicative of an exercise of jurisdiction by a State, is not necessarily the sole determinant jurisdiction may also be asserted extra-territorially. In the context of detention, the territorial and jurisdictional scope of the Geneva Convention and other international human rights instruments affecting asylum seekers plays an important part in the assessment of the rights of detained asylum seekers.

Identifying the territorial and jurisdictional scope is important in the European Union context where the application of European Union asylum legislation does not follow the geographical confines of the Union - for example, the United Kingdom and Ireland's ability to opt in/opt out; the Danish opt out; and the engagement of Association States (such as Norway and Iceland) and Switzerland. Further, Australia takes a bifurcated approach, creating the "migration zone" and "excised offshore places" under the Migration Act. Accordingly, these two geographic areas (although in Australian territory) afford different rights and treatment of asylum seekers.

\subsubsection{Territorial \& Jurisdictional Scope - International}

At the international level, the Geneva Convention applies when an asylum seeker is at least physically present on a State Party's territory but, in circumstances where a State is acting extra-territorially, some rights may be able to accrue to asylum seekers notwithstanding that they are not physically present on a State Party's territory. ${ }^{1163}$ For all practical purposes, Hathaway identifies the right to non-refoulement (Article 33) and non-discrimination amongst refugees (Article 3) as "two core refugee rights" that would be of applicability to a State Party acting extra-territorially. ${ }^{1164}$

In relation to other human rights instruments that may form the basis of complementary protection, attention must turn to the text of the treaties themselves. Although Article 2(1) CAT provides that State Parties are to "prevent acts of torture in any territory under its jurisdiction", it is the prohibition of refoulement under Article 3 that is most relevant in the context of asylum seekers, and which is silent on the issue of whether the person concerned is within or outside the territory of the State Party but who must, in any event, be under the jurisdiction (and hence, the responsibility) of the State Party. Under CROC, Article 2(1) provides that its rights are to be ensured "to each child within their jurisdiction".

${ }^{1163}$ For example, Hathaway identifies, property rights (Article 13), tax equity rights (Article 29), access to the courts (Article 16(1)), education (Article 22), and access to rationing systems (Article 20) as accruing even if the refugee is not physically present but where the State Party is asserting jurisdiction over them. Hathaway also identifies a more limited circumstance not requiring physical presence - being the naturalization provision - as more advisory than obligatory: Hathaway, J, The Rights of Refugees under International Law, 2011, CUP, Cambridge, Pp.160-164

${ }^{1164}$ Hathaway, J, The Rights of Refugees under International Law, 2011, CUP, Cambridge, P.163 
Article 2(1) ICCPR provides that the Covenant is applicable "to all individuals within its territory and subject to its jurisdiction". The Human Rights Committee, in its General Comment 31, emphasised that Article 2(1) applies to all those within a State Party's territory or subject to its jurisdiction "regardless of nationality or statelessness, such as asylum seekers, [and] refugees", stating further that that "principle also applies to those within the power or effective control of the forces of a State Party acting outside its territory, regardless of the circumstances in which such power or effective control was obtained, such as forces constituting a national contingent of a State Party assigned to an international peace-keeping or peace-enforcement operation." 1165

In the ICJ's Advisory Opinion on the Legal Consequences of the Construction of a Wall in the Occupied Palestinian Territory, the Court held that, consistent with the Human Rights Committee's interpretation, the ICCPR was applicable to acts undertaken by a State but outside its own territory. ${ }^{1166}$ Further, in relation to the ICESCR, whose rights the Court described as "essentially territorial", it was held that "it is not to be excluded that it applies both to territories over which a State party has sovereignty and to those over which that State exercises territorial jurisdiction". 1167 Although those findings relate to the applicability of the ICCPR and ICESCR, its guidance on the applicability of obligations when a State is acting extra-territorially is also of particular analogous relevance to other international conventions, including the Geneva Convention which consists of both territorial and not-necessarily-territorial rights.

One of the Human Rights Committee's views cited with approval by the ICJ in its opinion on the Palestinian Wall ${ }^{1168}$ was López Burgos $v$ Uruguay (concerning Mr López' arrest and detention by Uruguayan agents in Argentina) in which the Committee emphasised that, in relation to its jurisdiction to hear the Communication, it was not the "place where the violation occurred, but rather to the relationship between the individual and

1165 United Nations, Human Rights Committee, General Comment 31 - Nature of the General Legal Obligation Imposed on State Parties to the Covenant, 26 May 2004, para 10. See also Tomuschat, C, Human Rights - Between Idealism and Realism, 2008, (2ed), OUP, Oxford, Pp.129-132.

1166 Advisory Opinion on the Legal Consequences of the Construction of a Wall in the Occupied Palestinian Territory, General List No. 131 [2004] ICJ 2, at 108-111

1167 Advisory Opinion on the Legal Consequences of the Construction of a Wall in the Occupied Palestinian Territory, General List No. 131 [2004] ICJ 2 at 112

1168 Other views cited with approval included case No. 56/79, Lilian Celiberti de Casariego v. Uruguay and case No. 106/81, Montero v. Uruguay - Advisory Opinion on the Legal Consequences of the Construction of a Wall in the Occupied Palestinian Territory, General List No. 131 [2004] ICJ 2 at 109 
the State" 1169 concerning the subject Convention rights being violated. Further, The Committee held the view that Article 2(1) ICCPR did "not imply that the State party concerned cannot be held accountable for violations of rights under the Covenant which its agents commit upon the territory of another states, whether with the acquiescence of the Government of that State or in opposition to it". ${ }^{1170}$ The Committee concluded that:

“...it would be unconscionable to so interpret the responsibility under article 2 of the Covenant as to permit a State party to perpetrate violations of the Covenant on the territory of another State, which violations it could not perpetrate on its own territory." 1171

\subsubsection{Territorial \& Jurisdictional Scope - Council of Europe}

The ECtHR held in Loizidou that jurisdiction under the ECHR was not territorially restricted. ${ }^{1172}$ The Court identified that a High Contracting Party's jurisdiction may arise by the exercise of "effective control of an area outside its territory" via military action (regardless of whether it is lawful or unlawful) and that such effective control can be "exercised directly, through its armed forces, or through a subordinate local administration". ${ }^{1173}$ Further, the Court also identified extradition or expulsion decisions giving rise to ECHR obligations, as could acts of authorities regardless of where they took place and "which produce effects outside their own territory". ${ }^{1174}$

In Bankovic the Court held that jurisdiction under the ECHR was "essentially territorial" 1175 and other jurisdictional bases were "exceptional and requiring special justification in the particular circumstances of each case". ${ }^{1176}$ Those other jurisdictional bases included "the effective control of the relevant territory and its inhabitants abroad as a consequence of military occupation or through the consent, invitation or acquiescence of the Government of that territory, exercises all or some of the public powers normally to be exercised by that Government"1177 or "the activities of its diplomatic or consular agents

1169 López Burgos v Uruguay, Communication No.52/1979, CCPR/C/13/D/1979, 29 July 1981, para 12.2

1170 López Burgos v Uruguay, Communication No.52/1979, CCPR/C/13/D/1979, 29 July 1981, para 12.3

1171 López Burgos v Uruguay, Communication No.52/1979, CCPR/C/13/D/1979, 29 July 1981, para 12.3

1172 Loizidou v Turkey, No. 15318/89, Judgment, Grand Chamber, 23 March 1995, para 62

1173 Loizidou v Turkey, No. 15318/89, Judgment, Grand Chamber, 23 March 1995, para 62

1174 Loizidou v Turkey, No. 15318/89, Judgment, Grand Chamber, 23 March 1995, para 62

1175 Bankovic et al. v Belgium et al., No. 52207/99, Decision, Grand Chamber, 12 December 2001, para 61

1176 Bankovic et al. v Belgium et al., No. 52207/99, Decision, Grand Chamber, 12 December 2001, para 61

1177 Bankovic et al. v Belgium et al., No. 52207/99, Decision, Grand Chamber, 12 December 2001, para 71 
abroad and on board craft and vessels registered in, or flying the flag of, that State". ${ }^{1178}$

Although the Court in Bankovic rejected a "cause-and-effect" approach as a jurisdictional basis ${ }^{1179}$ and emphasised that the ECHR was a regional instrument not to be applied to the world at large,${ }^{1180}$ the analysis of the basis of its jurisdiction is illuminating in the interpretation of the jurisdictional bases of other international treaties as the Court construed Article 1 ECHR in line with general principles of public international law. ${ }^{1181}$ Hathaway notes the criticism of that construction which may be seen as narrower than the interpretation generally afforded to human rights instruments. ${ }^{1182}$ Tomuschat also laments that the Court in Bankovic did not fully appreciate the engagement of the ECHR in situations where fighters are detained by European forces, noting that "[c]ustody entails both jurisdiction and responsibility". ${ }^{1183}$ In that respect, it is important to note that extraterritorial jurisdiction is to be distinguished from state responsibility as contemplated by the International Law Commission but also that, notwithstanding that distinction, a nexus exists between extraterritorial jurisdiction and state responsibility in the sense that if an individual's rights have been violated by reason of coming within the jurisdiction of a State Party, then responsibility can be attributed to the State for the violation of those rights. ${ }^{1184}$

The overall approach to the jurisdictional bases identified in Loizidou and Bankovic was confirmed in Ilaşcu, ${ }^{1185}$ but the issue in Ilaşcu turned on the engagement of ECHR obligations in a separatist part of Moldova. Although jurisdiction was presumed to be territorial, the Court indicated that "military occupation", "acts of war or rebellion, the acts of a foreign State supporting the installation of a separatist State within the territory of the State concerned"

1178 Bankovic et al. v Belgium et al., No. 52207/99, Decision, Grand Chamber, 12 December 2001, para 73

1179 Bankovic et al. v Belgium et al., No. 52207/99, Decision, Grand Chamber, 12 December 2001, para 75

1180 Bankovic et al. v Belgium et al., No. 52207/99, Decision, Grand Chamber, 12 December 2001, para 80

1181 Bankovic et al. v Belgium et al., No. 52207/99, Decision, Grand Chamber, 12 December 2001, para 59-61

1182 Hathaway, J, The Rights of Refugees under International Law, 2011, CUP, Cambridge, P.167 and fn 70 .

1183 Tomuschat, C, Human Rights - Between Idealism and Realism, 2008, (2ed), OUP, Oxford, Pp.128-129

1184 McGoldrick, D, Extraterritorial application of the International Covenant on Civil and Political Rights in Coomans, F, and Kamminga, M, (eds), Extraterritorial Application of Human Rights Treaties, 2004, Insentia, Oxford at Pp.42-43; see also Hathaway, J, The Rights of Refugees under International Law, 2011, CUP, Cambridge, P165-166, fn 59.

1185 Ilaşcu et al. v Moldova and Russia, No. 48787/99, Judgment, Grand Chamber, 8 July 2004 
could limit that presumption. ${ }^{1186}$ However, a State in those circumstances was held to have a positive obligation to ensure that EHCR rights were being respected throughout its territory. ${ }^{1187}$

In relation to extra-territorial acts, the Court indicated that jurisdiction may arise firstly, by "acts of the local administration which survives there by virtue of its military and other support"; ${ }^{1188}$ secondly, where the acts have "sufficiently proximate repercussions" on ECHR rights even where the breach of those rights may occur outside the national territory (for example, in the case of extradition resulting in torture or inhuman and degrading treatment); ${ }^{1189}$ thirdly, if an individual's ECHR rights have been breached by a private party with the "acquiescence or connivance" of a Contracting Party; ${ }^{1190}$ and fourthly, even where a Contracting Party's agents have acted ultra vires. ${ }^{1191}$

In Amuur, the Court held that "an international zone does not have extraterritorial status" and asylum seekers thus held were subject to French law. ${ }^{1192}$ The Court emphasised earlier in its judgment that detention in an international zone should not preclude asylum seekers from "effective access" to determination procedures under the Geneva Convention. ${ }^{1193}$ Indeed, the ECtHR recently held that Italy's actions on board vessels under its flag on the high seas was a sufficient exercise of its jurisdiction such as to fall within the scope of Article 1 ECHR. ${ }^{1194}$

\subsubsection{Territorial \& Jurisdictional Scope - European Union}

In the Union sphere, it is important to note that under 51(1) of the EU Charter, the Charter is addressed to "the institutions, bodies, offices and agencies of the Union" as well as to Member States "only when they are implementing Union law." Accordingly, the scope of the Charter is not

1186 Ilaşcu et al. v Moldova and Russia, No. 48787/99, Judgment, Grand Chamber, 8 July 2004, para 312

1187 Ilaşcu et al. v Moldova and Russia, No. 48787/99, Judgment, Grand Chamber, 8 July 2004, paras 313 and 331

1188 Ilaşcu et al. v Moldova and Russia, No. 48787/99, Judgment, Grand Chamber, 8 July 2004, para 316

1189 Ilaşcu et al. v Moldova and Russia, No. 48787/99, Judgment, Grand Chamber, 8 July 2004, para 317

1190 Ilaşcu et al. v Moldova and Russia, No. 48787/99, Judgment, Grand Chamber, 8 July 2004, para 318

${ }_{1191}$ Ilaşcu et al. v Moldova and Russia, No. 48787/99, Judgment, Grand Chamber, 8 July 2004. para 319

1192 Amuur v France, No. 19776/92, Judgment, 25 June 1996, para 52

1193 Amuur v France, No. 19776/92, Judgment, 25 June 1996, para 43

1194 Hirsi Jamaa and Others $v$ Italy, No. 27765/09, 23 February 2012, Judgment, Grand Chamber, paras 76-82; see also Medvedyev and Others $v$ France, No. 3394/03, 29 March 2010, Judgment, Grand Chamber, paras 62-67 
territorially limited and may apply extra-territorially. ${ }^{1195}$ This may have particular ramifications for front-line European Union agencies such as FRONTEX.

However, Protocol 30 to the Lisbon Treaty ${ }^{1196}$ in relation to the application of the EU Charter to United Kingdom and Poland should be noted. Article 1(1) exempts the ability of the CJEU or any national court to find inconsistencies by the UK or Poland (in law, regulations, administrative provisions or practices or actions) with fundamental rights contained in the EU Charter. Article 1(2) provides that no justiciable rights arise with respect Title IV of the Charter (that is, social and economic rights). Advocate-General Trstenjak expressed the view in N.S. that Article 1(1) of the Protocol does not create a general opt-out by the United Kingdom and Poland but merely affirms the content of Article 51 of the EU Charter. ${ }^{1197}$ As the matter did not deal with social and economic rights, no detailed consideration was given to the application of Article 1(2) of the Protocol. ${ }^{1198}$ Both those positions in the Advocate General's Opinion were confirmed by the CJEU in its subsequent judgment. ${ }^{1199}$

It was recently argued by the European Parliament that the geographical scope of the Schengen Borders Code (as regards surveillance measures) could not be extended to the high seas. ${ }^{1200}$ Although Advocate General Mengozzi did not rule squarely on that argument (indicating that the contested measure created powers to do so which were "essential in nature" to the SBC basic instrument and were thus, in his opinion, invalid), ${ }^{1201}$ the Advocate General did indicate that the contested measure created options for FRONTEX to use which were likely to affect the personal freedoms and fundamental rights of persons and

1195 Directorate-General for Internal Policies, Policy Department C, Citizens' Rights and Constitutional Affairs, Implementation of the EU Charter of Fundamental Rights and its Impact on EU Home Affairs Agencies, 2011, http://www.europarl.europa.eu/committees/en/libe/ studiesdownload.html?languageDocument $=E N \& f i l e=48349$ (last accessed 22 May 2012), P.48

1196 Protocol on the application of the Charter of Fundamental Rights of the European Union to Poland and to the United Kingdom, OJ C 306/156-157, 17 December 2007

1197 Case C-411/10 N.S. v Secretary of State for the Home Department, 22 September 2011, Opinion, paras 167-171

1198 Case C-411/10 N.S. v Secretary of State for the Home Department, 22 September 2011, Opinion, para 174

1199 Cases C-411/10 and C-493/10 N.S. $v$ Secretary of State for the Home Department and M. E. and Others $v$ Refugee Applications Commissioner and Minister for Justice, Equality and Law Reform, 21 December 2011, Judgment Grand Chamber, paras 118-120 (in relation to Article 1(1) of the Protocol) and para 121 (in relation to Article 1(2) of the Protocol

1200 Case C-355/10 European Parliament v Council of the European Union, Opinion, 17 April 2012, para 48

1201 Case C-355/10 European Parliament v Council of the European Union, Opinion, 17 April 2012, para 62 
their opportunity to seek protection in the European Union. ${ }^{1202}$ Accordingly, there appeared to have been recognition from the Advocate General that, if the contested measure had been allowed to stand, jurisdiction could be exercised by FRONTEX through the SBC over individuals in such circumstances (that is, extra-territorially).

\subsubsection{Territorial \& Jurisdictional Scope - EU Secondary Legislation}

The scope of the Reception Conditions Directive provides for asylum applications made at the border or in the territory of a Member State. The United Kingdom takes part in the application of the Directive, ${ }^{1203}$ but Ireland $^{1204}$ and Denmark ${ }^{1205}$ do not.

The scope of the Procedures Directive also includes asylum applications made in the territory of a Member State, including at the border or in the transit zones of a Member State. The United Kingdom and Ireland take part in the application of the Directive, ${ }^{1206}$ but Denmark does not participate. ${ }^{1207}$

The Dublin II Regulation compels Member States to examine an application for asylum made at the border or in the territory of a Member State. The United Kingdom and Ireland ${ }^{1208}$ take part in the application of the Dublin II Regulation as do Denmark, ${ }^{1209}$ Iceland, Norway, ${ }^{1210}$ and Switzerland ${ }^{1211}$ (including the application of the Eurodac).

1202 Case C-355/10 European Parliament v Council of the European Union, Opinion, 17 April 2012, para 61. See further, Statewatch, ECJ General Advocate's opinion on sea surveillance and the Schengen Borders Code: reasserting the Parliament's legislative role, reopening the Frontex debate? http://www.statewatch.org/news/2012/may/ecj-schengen-borders.pdf (last accessed 11 June 2012

1203 Recital 19 Reception Conditions Directive

1204 Recital 20 Reception Conditions Directive

1205 Recital 21 Reception Conditions Directive

1206 Recitals 32 and 33 Procedures Directive

1207 Recital 34 Procedures Directive

1208 Recital 17 Dublin II Regulation

1209 2006/188/EC Council Decision of 21 February 2006 on the conclusion of the Agreement between the European Community and the Kingdom of Denmark extending to Denmark the provisions of Council Regulation (EC) No 343/2003 establishing the criteria and mechanisms for determining the Member State responsible for examining an asylum application lodged in one of the Member States by a third-country national and Council Regulation (EC) No 2725/2000 concerning the establishment of Eurodac for the comparison of fingerprints for the effective application of the Dublin Convention, [2006] OJ L $66 / 37$

1210 2001/258/EC Council Decision of 15 March 2001 concerning the conclusion of an Agreement between the European Community and the Republic of Iceland and the Kingdom of Norway concerning the criteria and mechanisms for establishing the State responsible for examining a request for asylum lodged in a Member State or Iceland or Norway [2001] OJ L 93/38

1211 Agreement between the European Community and the Swiss Confederation concerning the criteria and mechanisms for establishing the State responsible for examining a request for asylum lodged in a Member State or in Switzerland - Final Act - Declarations 
The Qualification I Directive is silent on its precise territorial application, but may be presumed to be territorial. The United Kingdom and Ireland take part in the application of the Directive, ${ }^{1212}$ but not so Denmark. ${ }^{1213}$ Following the coming into force of the Qualification II Directive, the United Kingdom Ireland and Denmark are not participating in the application of the Directive. ${ }^{1214}$

In relation to the secondary legislation which the United Kingdom and Ireland have opted into and which are subject to further Commission proposals, Peers has highlighted the issue of what legislation will remain in force (or be replaced, as the case may be) in those Member States which have opted-in to the first phase asylum legislation, but not participated in the second phase asylum legislation. ${ }^{1215}$ Article $4 \mathrm{a}$ of the Protocol relating to the United Kingdom and Ireland contemplates proposed or adopted measures amending legislation to which the United Kingdom and Ireland are already bound (but it is questionable whether the second phase legislation is more accurately characterised as a repeal and replacement than an amendment as such $\left.^{1216}\right)$. In those circumstances, it is possible that, where the Council determines that the non-participation of the United Kingdom and Ireland would render the application of the measure "inoperable" for the other Member States, the Council may (by QMV) determine that the existing measure no longer be binding on the United Kingdom or Ireland. ${ }^{1217}$ Peers notes the Council legal service advice both in relation to the Proposed European Investigation Order ${ }^{1218}$ and, more specifically, in relation to the then Proposed Qualification Directive - the latter advice being that secondary

[2008] OJ L 53/5 and Information relating to the entry into force of the Agreement between the European Union, the European Community and the Swiss Confederation on the Swiss Confederation's association with the implementation, application and development of the Schengen acquis, as well as of the Agreement between the European Community and the Swiss Confederation concerning the criteria and mechanisms for establishing the State responsible for examining a request for asylum lodged in a Member State in Switzerland [2008] OJ L 53/18 (regarding the date that the treaty enters into force). 1212 Recitals 38 and 39 to the Qualification Directive

1213 Recital 40 to the Qualification I Directive

1214 Recitals 50 and 51 to the Qualification II Directive

1215 Peers, S, Statewatch Analysis - The revised directive on Refugee and Subsidiary Protection status, July 2011, http://www.statewatch.org/analyses/no-141-qaulifications-directive.pdf (last accessed 21 September 2011)

1216 Peers, S, Statewatch Analysis - The revised directive on Refugee and Subsidiary Protection status, July 2011, http://www.statewatch.org/analyses/no-141-qaulifications-directive.pdf (last accessed 21 September 2011), P.2

1217 Article 4a(2) of Protocol (No 21) on the position of the United Kingdom and Ireland in respect of the Area of Freedom, Security and Justice

1218 Peers, S, Statewatch Analysis - Update - The Proposed European Investigation Order, 24 November 2010, http://www.statewatch.org/analyses/no-112-eu-eio-update.pdf (last accessed 21 September 2011), Pp.1-5 
legislation of only those participating Member States be repealed. ${ }^{1219}$ Accordingly, the upshot of that advice has been that the Qualification I Directive will still apply to the United Kingdom and Ireland. ${ }^{1220}$

The Returns Directive predictably uses physical presence on the territory as the means by which to enliven its jurisdiction. ${ }^{1221}$ Iceland, Norway, Switzerland and Lichtenstein participate in its application, ${ }^{1222}$ whereas Denmark, the United Kingdom and Ireland do not. ${ }^{1223}$

\subsubsection{Territorial \& Jurisdictional Scope - European Union - the Proposed Legislation}

The Commission's 2011 Proposed Reception Conditions Directive expands its current application to include applications for international protection made "in the territorial waters or in the transit zones of a Member State". ${ }^{1224}$ The United Kingdom, Ireland and Denmark are not adopting the Directive nor are bound to it. ${ }^{1225}$ The Council's amendments made no changes in either matter. ${ }^{1226}$

The Commission's 2011 Proposed Procedures Directive has also included applications made "in the territorial waters" of Member States to expand the scope of its application. The United Kingdom and Ireland are not bound by the proposed Directive, nor does Denmark take part in its application. ${ }^{1227}$

The Proposed Dublin Regulation has clarified the scope of its application by requiring Member States to examine claims for international protection made in transit zones. ${ }^{1228}$ Notably, "territorial waters" has not been included in the scope of the proposed Regulation, but it is arguable that the Regulation would apply in territorial waters in any event. The Proposed Regulation is presently silent about any Member States excluded from its application, and it would be anticipated that the United Kingdom, Ireland, Norway, Iceland,

\footnotetext{
1219 Peers, S, Statewatch Analysis - The revised directive on Refugee and Subsidiary Protection status, July 2011, http://www.statewatch.org/analyses/no-141-qaulifications-directive.pdf (last accessed 21 September 2011), P.3

1220 Peers, S, Statewatch Analysis - The revised directive on Refugee and Subsidiary Protection status, July 2011, http://www.statewatch.org/analyses/no-141-qaulifications-directive.pdf (last accessed 21 September 2011), P.3

1221 See Articles 3(2) and 6 of the Returns Directive

1222 Recitals 28, 29 and 30 to the Returns Directive. See further, Peers, S, EU Justice and Home Affairs Law, (3ed), 2011, OUP, Oxford, P.511

1223 Recitals 25, 26 and 27 to the Returns Directive

1224 Article 3(1) of the Commission's 2011 Proposed Reception Conditions Directive

1225 Recitals 28, 29 and 30 of the Commission's 2011 Proposed Reception Conditions Directive

1226 Article 3(1) and Recitals 28, 29 and 30 of the Council's Amended Proposed Reception Conditions Directive

1227 Recitals 45 and 46 of the Commission's 2011 Proposed Procedures Directive

1228 Article 3(1) of the Proposed Dublin Regulation
} 
Denmark and Switzerland would continue to take part in the application of the Dublin system.

\subsubsection{Territorial \& Jurisdictional Scope - Australia}

As discussed earlier, Australian territory is divided into two zones for the purposes of the Migration Act - the "migration zone" and "excised offshore places" (see Chapter 3, Fig.1).

The "migration zone" is defined as:

"the area consisting of the States, the Territories, Australian resource installations and Australian sea installations and, to avoid doubt, includes:

(a) land that is part of a State or Territory at mean low water; and

(b) sea within the limits of both a State or a Territory and a port; and

(c) piers, or similar structures, any part of which is connected to such land or to ground under such sea; ${ }^{1229}$

but does not include sea within the limits of a State or Territory but not in a port." 1230

An "excised offshore place" is defined as:

"(a) the Territory of Christmas Island;

(b) the Territory of Ashmore and Cartier Islands

(c) the Territory of Cocos (Keeling) Islands

(d) any other external Territory that is prescribed by the regulations for the purposes of this paragraph;

(e) any island that forms part of a State or Territory and is prescribed for the purposes of this paragraph;

(f) an Australian sea installation;

(g) an Australian resources installation." 1231

These zones came into existence in 2001 after the passing of legislation ${ }^{1232}$ in response to the Tampa incident and the establishment of the "Pacific Solution". The scope of the excision was further expanded in $2005^{1233}$ resulting in a combined exclusion of 4,891 islands from the operation of the Migration Act. Those that arrive at an "excised offshore place" are termed

\footnotetext{
1229 Section 5(1) of the Migration Act 1958 (Cth)

1230 Section 5(1) of the Migration Act 1958 (Cth)

1231 Section 5(1) of the Migration Act 1958 (Cth). Note that the definitions of migration zone and excised offshore place are subject to further defined terms: "Territory", "prescribed", "installations", "Australian sea installation", "Australian resources installation" and "port" as set out in section 5(1) of the Act.

1232 Border Protection (Validation and Enforcement Powers) Act 2001 (Cth); Migration Amendment (Excision from Migration Zone) Act 2001; Migration Amendment (Excision from Migration Zone) (Consequential Provisions) Act 2001 (Cth); Migration Legislation Amendment Act (No 1) 2001 (Cth); Migration Legislation Amendment Act (No 5) 2001 (Cth); Migration Legislation Amendment Act (No 6) 2001 (Cth)

1233 Regulation 5.15C of the Migration Regulations 1994 (Cth)
} 
"offshore entry persons" (see earlier in this chapter). The practical effect of those amendments to the Migration Act is to administratively preclude offshore entry persons from making an application for any visa, including a protection visa, ${ }^{1234}$ and to act as a precondition for persons to be sent to a declared country (including for offshore processing). ${ }^{1235}$ Accordingly, a dual international protection framework has emerged on Australian territory. The High Court of Australia held in M61 that Australian law (including as it relates to procedural fairness) applied to the assessments of whether the Minister would "lift the bar" to allow an offshore entry person to make a visa application. ${ }^{1236}$ However, the excision provisions do not territorially restrict Australia's obligations under the Geneva Convention solely to the Migration Zone. ${ }^{1237}$

Further, the Migration Act makes a distinction between physical presence on the territory of Australia, and entering Australia. To "enter Australia" means to "enter the migration zone". ${ }^{1238}$ Accordingly, asylum seekers who are physically present in an excised offshore place have technically not 'entered' Australia for the purposes of the Act.

There are also aspects of the Migration Act that may have extraterritorial reach. ${ }^{1239}$ This arises from the provisions set out under Part 2, Division 12A of the Act which contemplate the chasing and request to board both foreign and Australian ships, including, in certain circumstances, on the high seas. ${ }^{1240}$ Power to board ships is also provided for, together with provisions for the searching of the vessel and persons on board, and the detention of persons. ${ }^{1241}$

Indeed, given the legislative provisions (which still remain) that facilitated and authorised offshore processing in a third country (such as Nauru and Papua New Guinea under the Pacific Solution), an interesting point arises as to

\footnotetext{
1234 Section 46A of the Migration Act 1958 (Cth)

1235 Section 198A of the Migration Act 1958 (Cth)

1236 M61/2010E v Commonwealth of Australia; M69/2010 v Commonwealth of Australia [2010] HCA 41 at para 78

1237 Foster, M, and Pobjoy, J, A Failed Case of Legal Exceptionalism? Refugee Status Determination in Australia's 'Excised' Territory (2011) 23(4) International Journal of Refugee Law 583, Pp.622-624

1238 Section 5(1) of the Migration Act 1958 (Cth). However, note section 6 of the Act in relation to the interpretation of the definitions of "enter Australia", "leave Australia" and "remain in Australia", particularly section 6(b) which makes expressly clear that the Act still extends to parts of Australia outside the migration zone.

1239 See further, White, M. W. D., Australian Offshore Laws, 2009, Federation Press, Annandale, Ch.6

1240 Sections 245A, 245B, 245B, 245C and 245D of the Migration Act 1958 (Cth)

${ }^{1241}$ Sections $245 \mathrm{~F}$ and $245 \mathrm{FA}$. It would appear that the power to board and search under section $245 \mathrm{~F}$ can only occur on the high seas if the officer "is satisfied [...] that the ship is an Australian ship" - see subsection (1) of section 245F
} 
whether, and to what extent, Australia exercises extra-territorial jurisdiction and responsibility for persons taken to and/or processed in third countries. ${ }^{1242}$

\subsubsection{Territorial \& Jurisdictional Scope - Conclusions}

Accordingly, what can be seen is that the Union secondary legislation applies within the territory of the Member States of the European Union, but there are exceptions for those Member States who do not participate in various pieces of secondary legislation. Further, that position is also more complicated by the concurrent application of the Qualification Directives in light of the position of the United Kingdom and the other participating Member States. The European secondary legislation may also have extraterritorial effect in that, for example, the Dublin II Regulation is applied by certain countries outside the Union (that is, Iceland, Norway and Switzerland). The scope of human rights protection provided by the ECHR and the EU Charter may also have extraterritorial application. In Australia, the division of the country into the Migration Zone and Excised Offshore Places creates a somewhat curious anomaly to the territorial notion of jurisdiction but it does not restrict obligations Geneva Convention or other international human rights instruments merely to the Migration Zone. Further, the Migration Act can, in some circumstances, have extraterritorial application, particularly as regards requests to board, chasing and boarding of vessels to Australia (in some circumstances on the high seas), and the detention and taking of persons to a third country.

\footnotetext{
${ }^{1242}$ See further, Taylor, S, Australian Funded Care and Maintenance of Asylum Seekers in Indonesia and Papua New Guinea: All Care But No Responsibility? (2010) 33(2) UNSWLJ 337; Foster, M, Protection Elsewhere: The Legal Implications of Requiring Refugees to Seek Protection in Another State (2007) 28 Michigan Journal of International Law 223; Francis, A, Bringing Protection Home: Healing the Schism Between International Obligations and National Safeguards Created by Extraterritorial Processing (2008) 20 International Journal of Refugee Law 273
} 


\section{Chapter 5 \\ Circumstances in which the detention of an asylum seeker may occur or be prolonged}

\subsection{Introduction}

The circumstances in which the detention of asylum seekers may occur can be seen in the context of any right to enter and remain in, and the right to freedom of internal movement within, the territory of the State of asylum. Further, those rights are also to be seen in light of the accretion of rights granted to asylum seekers through the Geneva Convention by the progressive attachment of the asylum seeker to the State of asylum. Hathaway has characterised the rights flowing under the Convention into four levels of attachment to the territory of State of asylum (in addition to the very real possibility of an exercise of extra-territorial jurisdiction by a State): firstly, physical presence; secondly, lawful presence; thirdly, lawful stay; and fourthly, durable residence. ${ }^{1243}$ It is the first two levels of attachment that are of significance for this exploration. At the very least, this characterisation provides a useful, and perhaps holistic, prism through which to view and compare the rights of asylum seekers and measures relating to their treatment.

After exploring the international law surrounding the physical and lawful presence and the accruing rights (as outlined above), the chapter will then examine comparable standards in the Council of Europe sphere as well as the EU Charter and General Principles of European Union Law. Because the rights of asylum seekers can also be affected by any special category they may belong to, the chapter will then investigate the international, Council of Europe and EU Charter positions of minors and unaccompanied minors, family members, vulnerable persons and stateless persons.

After that point, the analysis turns to the European Union secondary legislation and the laws of Australia. The analyses consider the entire course that an asylum seeker may take - that is, from presentation at the border (or even before), to presence on the territory of the State of asylum, to pending removal from the territory of the State of asylum in the case of rejection or abandonment of the claim or not being screened-in. In both jurisdictions (and following the logic of the Geneva Convention set out previously), three elements are chiefly examined: firstly, the right to remain; secondly, the right to liberty; and thirdly, grounds for which, or circumstances in which, detention may be ordered, arise or be prolonged. Under the European Union secondary legislation, much hinges on two critical factors: firstly, whether the

1243 Hathaway, J C, The Rights of Refugees under International Law, 2005, Cambridge University Press, Cambridge 
asylum seeker is screened-in and has a right to remain; and secondly, whether the regular procedure or the border procedure is adopted. In Australia, much hinges on whether the asylum seeker is an "unlawful non-citizen" or a "lawful non-citizen" and the person's geographic location on Australian territory (that is, within the Migration Zone or in an Excised Offshore Place).

\subsubsection{International}

\subsubsection{Physical and Lawful Presence}

For the purposes of this discussion, the contemplated rights accruing to refugees under the Geneva Convention as a result of physical presence include Articles 31 (prohibition on penalties for illegal entry or presence; no restrictions other than necessary) and 33 (prohibition against refoulement), whilst lawful presence is required for Articles 26 (freedom of movement within the territory) and 32 (non-expulsion except on national security or public order grounds).

\subsubsection{Physical Presence - Non-refoulement and Entry to the Territory}

The prohibition against non-refoulement contained in Article 33 of the Geneva Convention does not necessarily provide a right of entry per se. What that Article obliges states to do is not to expel or return refugees to territories (that is, not just states or countries) "in any manner whatsoever" such that their life or freedom might be threatened. At the frontier, states are not at liberty to reject asylum seekers, but must act consistently with the obligation not to refoule. ${ }^{1244}$ Admission to the State's territory is one option open to states - the couching of non-refoulement obligations in the terms of Article 33 has seen states utilise other methods of non-entrée, including sending asylum seekers to third countries, as well as adopting restrictive visa requirements and carrier sanctions which prevent access to the territory itself. Hathaway describes Article 33 as a "de facto duty to admit" where admission to the territory is the only way to obviate the risk to the life or freedom to which an asylum seeker would otherwise be subjected. ${ }^{1245}$ Goodwin-Gill and McAdam note that "[s]tate practice in fact attributes little weight to the precise nature of admission, but far more to the necessity for non-refoulement through time, pending the obtaining of durable solutions." 1246 The UNHCR's Executive Committee has expressed its deep preoccupation at asylum seekers and

\footnotetext{
1244 Lauterpacht, E, and Bethlehem, D, The scope and principle of the non-refoulement obligation: Opinion, in Feller, E, Türk, V, and Nicholson, F, (eds), Refugee Protection in International Law, 2003, CUP, Cambridge, paras-76-86

1245 Hathaway, J C, The Rights of Refugees under International Law, 2005, Cambridge University Press, Cambridge, P.301

1246 Goodwin-Gill, G. S., \& McAdam, J, The Refugee in International Law, 2007, OUP, Oxford Pp.209-210.
} 
refugees being rejected at the border without their applications being examined or "safeguards to prevent refoulement". ${ }^{1247}$

\subsubsection{Physical Presence - Non-penalisation}

In any event, prior authorisation for entry into a State by a refugee is not necessary. ${ }^{1248}$ This is reflected in Article 31(1) which prohibits penalties on account of illegal entry provided that the terms of that Article are met (they are, firstly, that refugees come "directly from a territory where their life or freedom was threatened"; secondly, that "they present themselves without delay to the authorities"; and thirdly, that they "show good cause for their illegal entry or presence"). Although the Geneva Convention remains silent on the definition of "penalties" and that differences exist between the French text (which arguably contemplates criminal sanctions) and the English text (which can arguably accommodate a wider interpretation) of the Convention, Goodwin-Gill has concluded that, in light of the object and purpose of the treaty, "penalties" may include detention [a]nd that an overly formal or restrictive approach to defining this term will not be appropriate, for otherwise the fundamental protection intended may be circumvented and the refugee's rights withdrawn at discretion". ${ }^{1249}$ That conclusion is supported by reference to the HRC's interpretation of "penalty" in Article 15(1) ICCPR which was considered in light of its object and purpose and which is said to have an autonomous meaning (that is, removed from, and above, national law). ${ }^{1250}$ In understanding what is meant by "penalty", one element of penalisation is deterrence. ${ }^{1251}$ In that sense, not only may detention constitute a penalty, but also the administrative exclusion from applying for refugee status determination on account of illegal entry or presence - particularly, if submission to such a determination procedure is a step towards the presence of the asylum seeker being regularised and, consequently, lawful, thus affecting the accretion of rights to which an asylum seeker may be entitled under the

1247 UNHCR, Executive Committee Conclusion No 108 (LIX) - Refugees and others of concern with disabilities, 2008

1248 Goodwin-Gill, G. S., \& McAdam, J, The Refugee in International Law, 2007, OUP, Oxford, P.264; Hathaway, J C, The Rights of Refugees under International Law, 2005, Cambridge University Press, Cambridge, Pp.302-303

1249 Goodwin-Gill, G S, Article 31 of the 1951 Convention Relating to the Status of Refugees: non-penalization, detention, and protection in Feller, E, Türk, V, and Nicholson, F, (eds), Refugee Protection in International Law, 2003, CUP, Cambridge, Pp.194-195.

1250 Van Duzen v Canada, Communication No. 50, CCPR/C/15/D/1979, 7 April 1982, para 10.2

1251 "Specifically deterrence raises familiar elements of the criminal justice system as a rationale for punishment: guilt, incarceration and exclusion. It rests on the logic that the action targeted is to be discouraged, and can be discouraged. Deterrence also facilitates the response to refugees shifting from a 'difficult to understand international legal obligation' to a 'domestically controlled and knowable criminal problem'." Pickering, S, The New Criminals: Refugees and Asylum Seekers, in Anthony, T, and Cunneen, C, (eds) The Critical Criminology Companion, 2008, Hawkins Press, Leichhardt, P.173 
Geneva Convention. ${ }^{1252}$ The presumption against penalisation for illegal entry or presence of asylum seekers is also reflected in the United Nations Protocol Against the Smuggling of Migrants by Land, Sea and Air. ${ }^{1253}$

\subsubsection{Lawful Presence - Right to Remain}

Being "lawfully present", may occur in three ways: firstly, if the State admits the person to its territory for a finite period; secondly, if the person has submitted to the refugee assessment procedure (including the exhaustion of appeals); and thirdly, if the State does not carry out a refugee determination procedure but otherwise recognises and grants rights under the Convention to which a person is entitled by reason that he or she is a refugee as a question of fact. ${ }^{1254}$ Further, "regularization" (as contemplated in Article 31(2)) occurs not when formal refugee status has been conferred but rather when "a refugee has met the host state's requirements to have his or her entitlement to protection evaluated". ${ }^{1255}$

Indeed, lawfulness in a State's territory is also contemplated in the right to free movement enshrined in Article 12 ICCPR. In relation to whether the author's presence in the territory was lawful for the purposes of Article 12(1) ICCPR, the Human Rights Committee stated in Celepliv Sweden:

"The Committee notes that the author's expulsion was ordered on 10 December 1984, but that this order was not enforced and that the author was allowed to stay in Sweden, subject to restrictions on his freedom of movement. The Committee is of the view that following the expulsion order, the author was lawfully in the territory of Sweden, for purposes of article 12, paragraph 1, of the Covenant, only under the restrictions placed upon him by the State party." 1256

Once a refugee's presence is lawful (that is, once he or she has applied for refugee status determination), expulsion is only possible on grounds of national security or public order under Article 32(1) and to which consideration of

\footnotetext{
1252 And which may arguably contravene the good faith implementation of the Geneva Convention as required by Article 26 of the 1969 Vienna Convention on the Law of Treaties

1253 Article 5, United Nations Protocol Against the Smuggling of Migrants by Land, Sea and Air, Supplementing the United Nations Convention Against Organised Transnational Crime

1254 Hathaway, J C, The Rights of Refugees under International Law, 2005, Cambridge University Press, Cambridge, Pp.173-186. Recalling that a person is a refugee as a question of fact and that the conferral of refugee status is merely a declaration of that fact - see Chapter 4

1255 Hathaway, J C, The Rights of Refugees under International Law, 2005, Cambridge University Press, Cambridge at P.417

1256 Celepli v Sweden, Communication No. 456/1991, CCPR/C/51/D/456/1991, 2 August 1994 http://www.unhchr.ch/tbs/doc.nsf/(Symbol)/c42b12d2b65629ff8025672700 5a00fe? Opendocument (last accessed 23 September 2011), para 9.2
} 
non-refoulement obligations under Article 33 must be given. ${ }^{1257}$ Article 32(2) provides that expulsion can only be by way of a "decision reached in accordance with due process of law"[emphasis added], with the right (except "where compelling reasons of national security otherwise require") "to submit evidence to clear himself, and to appeal and to be represented" for that purpose. Hathaway notes that the due process requirement under Article 32(2) provides both procedural and substantive protection against expulsion. ${ }^{1258}$ Article 32 is also buttressed by the operation of Article 13 ICCPR, which provides that those lawfully in a State's territory may only be expelled by a decision reached "in accordance with law", but which offers less comprehensive protection than Article $32(2)$ as Article 13 ICCPR is concerned with procedural safeguards. ${ }^{1259}$ Accordingly, it is arguable that a right to remain pending the outcome of the refugee status procedure may be implied into the terms of Article $32(1) .{ }^{1260}$ Naturally, that right to remain is terminated once a negative decision has been reached. However, whether that right endures in circumstances of implicit withdrawal from, or implicit abandonment of, the refugee determination procedure is unclear and may turn on the facts of the case at hand. It is arguable that the right to remain should logically be extended to include appeals of a first instance negative decision (or, to express the proposition alternately, an appeal of a first instance negative decision should have suspensive effect on the liability for removal from the State). ${ }^{1261}$ To restrict the right to remain to only the outcome of a first instance negative decision would result in a disjunction of protection where a person is liable more than just to be removed from the territory where asylum is sought, but to be actually or potentially refouled and would, accordingly, serve to defeat the object and purpose of the Convention. Indeed, consistent with the Geneva Convention's contemplated accretion of rights based on attachment to the host asylum State, if a State's determination procedure provides for an appeal of a negative decision, then the rights which flow to asylum seekers

1257 Hathaway, J C, The Rights of Refugees under International Law, 2005, Cambridge University Press, Cambridge, Pp.691-692

1258 Hathaway, J C, The Rights of Refugees under International Law, 2005, Cambridge University Press, Cambridge, Pp.674 and 677

1259 United Nations Human Rights Committee, General Comment No. 15 - The position of aliens under the Covenant, 11 April 1986, para 10; see also Hathaway, J C, The Rights of Refugees under International Law, 2005, Cambridge University Press, Cambridge, P.677

1260 Indeed, Hathaway opines that, once the person has submitted to the determination procedure, it "seems very much a matter of basic fairness" to allow them to remain in the host asylum country and that "it would be unnecessarily harsh to force him or her away before a final answer is given" - Hathaway, J C, The Rights of Refugees under International Law, 2005, Cambridge University Press, Cambridge, Pp.666-668, see also Pp.677-678

1261 As also advocated in the UNHCR Handbook on Procedures and Criteria for Determining Refugee Status under the 1951 Convention and the 1967 Protocol relating to the Status of Refugees, 1979, reedited January 1992, HCR/IP/4/ENG/Rev.1, Geneva, para 192 (vi) and (vii); see also UNHCR, Executive Committee Conclusion No. 8 (XXVIII) - Determination of Refugee Status, 1977, para (e)(vi) and (vii) forming part of UNHCR, Addendum to the Report of the United Nations High Commissioner for Refugees, 31 October 1977, A/32/12/Add.1, at para 53(6)(e)(vi) and (vii) 
(and buttressed by Article 3 CAT and Article 7 ICCPR) should remain as a result of that continued attachment through what is essentially an extended submission to the State's refugee determination procedure. That attachment, through an appeal, or the time period within which to lodge an appeal, would leave an unbroken right to remain. Although outside the scope of this book, much, then, may turn on the quality of decision-making and the grounds for appeal that are permitted.

\subsubsection{Lawful Presence - Detention and the Right to Free Movement}

Hathaway's analysis of the combined reading of Articles 26 and 31(2) the Geneva Convention and the relevant travaux preparatoires has led him to the conclusion that an asylum seeker may be detained until his/her status is "regularized". ${ }^{1262}$ Again, that regularisation occurs not when formal refugee status has been conferred, but when "a refugee has met the host state's requirements to have his or her entitlement to protection evaluated". ${ }^{1263}$ Further, Hathaway's combined reading of the two Articles shows that an asylum seeker is "lawfully" in the territory of a host State (for the purposes of Article 26) when he or she has submitted to the refugee determination procedure. ${ }^{1264}$ Accordingly, an asylum seeker who has unlawfully entered is liable to detention up to the point that he/she applies for protection, after which time the asylum seeker can only be detained if "necessary" 1265 and Article 26 would also then apply (that is, free movement within the host State's territory on the same terms as other aliens generally in the same condition). ${ }^{1266}$ This initial period of detention was said to allow for identification checks and security assessments, and in the event of a mass influx. ${ }^{1267}$ Goodwin-Gill and McAdam also arrive at a similar, if not so definitive, conclusion. ${ }^{1268}$

1262 Hathaway, J C, The Rights of Refugees under International Law, 2005, Cambridge University Press, Cambridge at Pp.706-708

1263 Hathaway, J C, The Rights of Refugees under International Law, 2005, Cambridge University Press, Cambridge at P.417

1264 Hathaway, J C, The Rights of Refugees under International Law, 2005, Cambridge University Press, Cambridge at P.417

1265 Hathaway, J C, The Rights of Refugees under International Law, 2005, Cambridge University Press, Cambridge at P.419; see also Goodwin-Gill, G, and McAdam, J, The Refugee in International Law, 2007, Oxford University Press, Oxford, P.462

1266 As Hathaway notes, "aliens generally in the same circumstances" was included to allow a degree of administrative flexibility towards refugees who were unable to comply with all formal requirements due to the situation in which they found themselves. Accordingly, its purpose is to ameliorate what may otherwise be rules strictly and routinely applied to other non-nationals: Hathaway, J C, The Rights of Refugees under International Law, 2005, Cambridge University Press, Cambridge, P.713

1267 Hathaway, J C, The Rights of Refugees under International Law, 2005, Cambridge University Press, Cambridge Pp.420-421

1268 Goodwin-Gill, G, and McAdam, J, The Refugee in International Law, 2007, Oxford University Press, Oxford, at P.462-465 
The right to free movement within the territory as contemplated by Article 26 of the Geneva Convention is also secured for those lawfully within a State's territory by Article 12 ICCPR. Drawing upon its earlier Celepli jurisprudence, the HRC, in its General Comment 27, stated:

\begin{abstract}
"Everyone lawfully within the territory of a State enjoys, within that territory, the right to move freely and to choose his or her place of residence. In principle, citizens of a State are always lawfully within the territory of that State. The question whether an alien is "lawfully" within the territory of a State is a matter governed by domestic law, which may subject the entry of an alien to the territory of a State to restrictions, provided they are in compliance with the State's international obligations. In that connection, the Committee has held that an alien who entered the State illegally, but whose status has been regularized, must be considered to be lawfully within the territory for the purposes of article 12 [reference to Celepli para 9.2 in original text]. Once a person is lawfully within a State, any restrictions on his or her rights guaranteed by article 12, paragraphs 1 and 2, as well as any treatment different from that accorded to nationals, have to be justified under the rules provided for by article 12, paragraph 3 [reference to General Comment No. 15, para 8 , in original text]." 1269
\end{abstract}

Accordingly, what may be gleaned from that General Comment is firstly, that the entry and presence of aliens generally may be subject to conditions but which must, in any event, be consistent with a State's international obligations; secondly, that regularisation is equated to lawful stay for the purposes of Article $12 \mathrm{ICCPR}$; and thirdly, that justification is necessary for any restrictions on freedom different to those imposed on a State's own nationals.

Article 12(3) ICCPR provides limited and exhaustive grounds for the qualification of the right to liberty of movement. Provided that the restrictions are provided by law, ${ }^{1270}$ are consistent with the other rights in the $\mathrm{ICCPR}^{1271}$ and are necessary, ${ }^{1272}$ the only permissible grounds are the protection of public

\footnotetext{
1269 United Nations Human Rights Committee, General Comment No. 27: Freedom of Movement (Art. 12), CCPR/C/21/Rev.1/Add.9, 2 November 1999 http://www.unhchr.ch/tbs/doc.nsf/(Symbol)/6c76e1b8ee1710e380256824005a10a9?Ope ndocument (last accessed 23 September 2011), para 4

${ }^{1270}$ See further, United Nations Human Rights Committee, General Comment No. 27: Freedom of Movement (Art. 12), CCPR/C/21/Rev.1/Add.9, 2 November 1999 http://www.unhchr.ch/tbs/doc.nsf/(Symbol)/6c76e1b8ee1710e380256824005a10a9?Ope ndocument (last accessed 23 September 2011), para 12

1271 See further, United Nations Human Rights Committee, General Comment No. 27: Freedom of Movement (Art. 12), CCPR/C/21/Rev.1/Add.9, 2 November 1999, http://www.unhchr.ch/tbs/doc.nsf/(Symbol)/6c76e1b8ee1710e380256824005a10a9?Ope ndocument (last accessed 23 September 2011), para 18

1272 That is, proportionate as well: see further, United Nations Human Rights Committee, General Comment No. 27: Freedom of Movement (Art. 12), CCPR/C/21/Rev.1/Add.9, 2 November 1999 http://www.unhchr.ch/tbs/doc.nsf/(Symbol)/6c76e1b8ee1710e3802568 24005a10a9? Opendocument (last accessed 23 September 2011), paras 14-15
} 
order (ordre public), public health or morals or the rights and freedoms of others.

In its Conclusions, the UNHCR's Executive Committee indicated that, although detention "should normally be avoided":

"[i]f necessary, detention may be resorted to only on grounds prescribed by law to verify identity; to determine elements on which the claim to refugee status or asylum is based; to deal with cases where refugees or asylum-seekers have destroyed their travel and/or identity documents or have used fraudulent documents in order to mislead the authorities of the State in which they intend to claim asylum; or to protect national security or public order" 1273 [emphasis added]

That view was adopted and clarified in the UNHCR's Revised Guidelines. ${ }^{1274}$ Under Guideline 3, a presumption against detention was advocated, whilst making clear that detention in the context of determining the elements on which the claim for refugee or asylum is based should be limited to the purposes of conducting a preliminary interview. In relation to the destruction of identity documents or the use of forged identity documents, Guideline 3 emphasises that detention is only justifiable where there was an intention to mislead the authorities of the host State.

The detention of asylum seekers, for whatever reason, should not be arbitrary. As invariable subjects of immigration control measures, asylum seekers fall under the scope of protection contemplated by Article 9(1) ICCPR ${ }^{1275}$ which provides:

"Everyone has the right to liberty and security of person. No one shall be subjected to arbitrary arrest or detention. No one shall be deprived of his liberty except on such grounds and in accordance with such procedure as are established by law."

Indeed, in Van Alphen $v$ the Netherlands the HRC indicated that arbitrariness:

"...is not to be equated with "against the law", but must be interpreted more broadly to include elements of inappropriateness, injustice and lack of predictability. This means that remand in custody pursuant to lawful arrest must not only be lawful but be reasonable in all the circumstances. Further remand in custody must be necessary in all the circumstances, for example, to prevent flight, interference with evidence or the recurrence of crime." [emphasis added] ${ }^{1276}$

1273 UNHCR, Executive Committee Conclusion No. 44 (XXXVII) - Detention of Refugees and Asylum-Seekers, 1986, para (b).

1274 UNHCR Revised Guidelines on applicable criteria and standards relating to the detention of asylum seekers, February 1999.

1275 United Nations Human Rights Committee, General Comment No. 8: Right to liberty and security of persons (Art. 9), 30 June 1982 http://www.unhchr.ch/tbs/doc.nsf/(Symbol) /f4253f9572cd4700c12563ed00483bec?Opendocument (last accessed 27 September 2011), para 1

1276 van Alphen $v$ The Netherlands, Communication No. 305/1988, CCPR/C/39/D/ 305/1988, 15 August 1990, para 5.8 
In relation to Article $9 \mathrm{ICCPR}$, the HRC in $A v$ Australia ${ }^{1277}$ held that the detention must be proportionate when it stated:

"remand in custody could be considered arbitrary if it is not necessary in all the circumstances of the case, for example to prevent flight or interference with evidence: the element of proportionality becomes relevant in this context." 1278

The HRC pointed out that without factors pertinent to the individual, such as the need to investigate or the likelihood of absconding or lack of cooperation, detention on the basis of illegal entry of itself may constitute arbitrary detention. ${ }^{1279}$

The justification of detention on the basis of a State's policy grounds was also rejected by the HRC in C v Australia. ${ }^{1280}$ The policy grounds advocated by Australia were: ensuring the integrity of the migration system; the prevention of entry of persons who do not have prior authorisation to enter; the processing of asylum claims without delay; the facilitation of removal if the claims proved unwarranted; State sovereignty; and the detection, monitoring and apprehension of illegal immigrants in the community. ${ }^{1281}$

In relation to any prolongation of detention, the HRC stated that "[d]etention should not continue beyond the period for which the State can provide appropriate justification". ${ }^{1282}$ Indeed, the HRC has also expressed the view that, notwithstanding an initially lawful basis for detention, detention may become arbitrary when a "reasonable prospect" of expelling a person no longer exists. ${ }^{1283}$

1277 A v Australia, Communication No. 560/1993, CCPR/C/59/D/1993, 30 April 1997

1278 A v Australia, Communication No. 560/1993, CCPR/C/59/D/1993, 30 April 1997, at para 9.2

1279 A v Australia, Communication No. 560/1993, CCPR/C/59/D/1993, 30 April 1997, at para 9.4

1280 C v Australia, Communication No. 900/1999, CCPR/C/76/D/900/1999, 28 October 2002

1281 C v Australia, Communication No. 900/1999, CCPR/C/76/D/900/1999, 28 October 2002, at para 4.26

1282 A v Australia, Communication No. 560/1993, CCPR/C/59/D/1993, 30 April 1997, at para 9.4

1283 Jalloh $v$ The Netherlands, Communication No. 794/1998, CCPR/C/74/D/794/1988, 15 April 2002, at para 8.2 


\subsubsection{Council of Europe, EU Charter \& General Principles of European Union Law}

\subsubsection{Council of Europe ECHR}

Article 13 ECHR provides the right to an effective remedy for a violation of any of the rights and freedoms provided for in the Convention. The right to remain pending the determination of an asylum claim may be inferred by the operation of Articles 3 and 13 ECHR. ${ }^{1284}$ Given the "potentially irreversible" 1285 effects of removal from the territory, particularly on account of refoulement, the ECtHR has held that "it is inconsistent with Article 13 for such measures to be executed before the national authorities have examined whether they are compatible with the Convention". ${ }^{1286}$ Accordingly, where a person has "substantial grounds" to believe that their removal to a country will subject them to harm contemplated by Article 3 ECHR, Article 13 has been interpreted to ensure that the remedy sought has automatic suspensive effect. ${ }^{1287}$ The nature of suspensive effect "take[s] the form of a guarantee and not of a mere statement of intent or a practical arrangement. That is one of the consequences of the rule of law, one of the fundamental principles of a democratic society, which is inherent in all the Articles of the Convention". ${ }^{1288}$ In MSS, the ECtHR confirmed its previous case law that "close and rigorous scrutiny" was to be applied in the examination of whether Article 3 might be breached by the removal of a person to a country. ${ }^{1289}$ In light of MSS, it should not be assumed that EU Member States are immune from being a destination country where a person might suffer from a breach of Article 3. Further, the ECtHR, recalling MSS, recently held that a breach of Article 13 had occurred by an asylum seeker being subjected to an accelerated asylum determination procedure at the very first instance. ${ }^{1290}$ However, the jurisprudence of the Court otherwise suggests that removal to a country where a breach of Article 3 would not occur (that is, a 'safe' third country) is possible.

\footnotetext{
${ }^{1284}$ For commentary, see Spijkerboer, T, Subsidiarity and 'Arguability': the European Court of Human Rights' Case Law on Judicial Review in Asylum Cases, International Journal of Refugee Law, 2009, Volume 21, Pp.48-74 at Pp.69-73

1285 Jabari v Turkey, No. 40035/98, Judgment, 11 July 2000, para 50; Čnka v Belgium, No. 51564/99, Judgment, 5 February 2002, para 79

1286 Čnka v Belgium, No. 51564/99, Judgment, 5 February 2002, para 79

1287 Gebremedhin v France, No. 25389/05, Judgment, 26 April 2007, para 66; see also NAv the United Kingdom, No. 25904/07, Judgment, 17 July 2008, para 90; Sultani v France, No. 45223/05, Judgment, 20 September 2007, paras 50-52 (French text); KRS $v$ the United Kingdom, No. 32733/08, Admissibility Decision, 2 December 2008, p.15.

1288 Čnka $v$ Belgium, No. 51564/99, Judgment, 5 February 2002, para 83

1289 MSS v Belgium and Greece, No. 30696/09, Judgment Grand Chamber, 21 January 2011, at para 387

${ }^{1290}$ I.M. v France, No. 9152/09, Judgment, 2 February 2012, paras 136-160, recalling the general principles and MSS in particular at paras 127-135.
} 
Further, augmenting the Court's jurisprudence in relation to Articles 3 and 13 ECHR, Article 4 of the Fourth Protocol to the ECHR prohibits the collective expulsion of aliens. In Čnka the ECtHR held that expulsion of a group may only take place on "a reasonable and objective examination" of each individual's case in that particular group. ${ }^{1291}$ In legal reasoning with overtones of 'measures having equivalent effect' under European Union free movement of goods jurisprudence, the fact that procedures prima facie have been carried out on an individual basis, may still result in a breach of Article 4 of the Fourth Protocol if the circumstances of the measures give rise to the expulsion being collective in effect (such as the cumulative factors ${ }^{1292}$ of the identical origin of the group being expelled; the public announcement and implementation of the measures by the authorities; the compelled mass attendance at a police station; the identical terms of the expulsion orders; the difficulties in communicating with lawyers; and the asylum process not being concluded). ${ }^{1293}$

The right to liberty and security of a person is secured by Article 5 ECHR. The ECtHR has held that all deprivations of liberty contemplated under Article 5(1) ECHR are both exhaustive and subject to a narrow interpretation "consistent with the aim of that provision, to ensure that no-one is arbitrarily deprived of his liberty". ${ }^{1294}$

Article 5(1) requires that any deprivation of liberty is both "lawful" and "in accordance with a procedure prescribed by law". Accordingly, any deprivation of liberty must conform to national law in both a procedural and substantive sense. ${ }^{1295}$ Additionally, the domestic laws are to be of a certain quality namely, sufficiently accessible and precise as well as foreseeable. ${ }^{1296}$ Indeed, the quality of the law has been said to be of "fundamental importance" with regard to asylum seekers. ${ }^{1297}$ However, mere compliance with national law

\footnotetext{
1291 Čonka $v$ Belgium, No. 51564/99, Judgment, 5 February 2002, para 59

1292 In Sultani v France, No. 45223/05, Judgment, 20 September 2007, para 81, the Court noted that "the fact that a number of aliens are subject to similar decisions does not in itself lead to the conclusion that there is a collective expulsion if each person concerned has been given the opportunity to put arguments against his expulsion to the competent authorities on an individual basis".

1293 Čnka v Belgium, No. 51564/99, Judgment, 5 February 2002, paras 61-62

1294 Vasileva v Denmark, No. 52792/99, Judgment, 25 December 2003, at para 33

1295 Amuur v France, No. 19776/92, Judgment, 25 June 1996, para 50

1296 Sadaykov v Bulgaria, No. 75157/01, Judgment, 22 May 2008, para 23; Longa Yonkeu v Latvia, No. 57229/09, Judgment, 15 November 2011, paras 120, 133-144; Shamsa v Poland, No. 45355/99 and 45357/99, 27 November 2003, para 49; Baranowski v Poland, No. 28358/95, Judgment, 28 March 2000, para 52; Amuur v France, No. 19776/92, Judgment, 25 June 1996, para 50;

1297 Rashed v Czech Republic, No. 298/07, Judgment, 27 November 2008, para 73: "La Cour note à cet régard que la qualité de la loi revêt une importance fondamentale dans le domaine des demandeurs d'asile dans les aéroports, compte tenu notamment de la nécessité de concilier la protection des droits fondamentaux et les impératifs de la politique de l'immigration des Etat."; Amuur v France, No. 19776/92, Judgment, 25 June 1996, para 50
} 
may not be sufficient to satisfy Article 5(1) - the detention measure must also be consistent with the protective purpose of Article 5(1) (that is, protection from arbitrariness):

\begin{abstract}
"Where the "lawfulness" of detention is in issue, including the question whether "a procedure prescribed by law" has been followed, the Convention refers essentially to national law and lays down the obligation to conform to the substantive and procedural rules of national law. Compliance with national law is not, however, sufficient: Article 5(1) requires in addition that any deprivation of liberty should be in keeping with the purpose of protecting the individual from arbitrariness. It is a fundamental principle that no detention which is arbitrary can be compatible with Article 5(1) and the notion of "arbitrariness" in Article 5(1) extends beyond lack of conformity with national law, so that a deprivation of liberty may be lawful in terms of domestic law but still arbitrary and thus contrary to the Convention." ${ }^{1298}$
\end{abstract}

Article 5(1)(f) of the ECHR provides that detention of a person is permissible in accordance with a procedure prescribed by law "to prevent his effecting an unauthorized entry into the country or of a person against whom action is being taken with a view to deportation or extradition".

Contrary to the case law under the other circumstances set out in Article 5(1) ECHR, the ECtHR has, in immigration cases under Article 5(1)(f) ECHR, not required that the detention be reasonably necessary ${ }^{1299}$ or, as in the case of an asylum seeker who presented no risk of absconding or any risk to public order, that the detention be proportionate. ${ }^{1300}$ The result in Saadi was that asylum seekers' detention is justifiable because they are not "authorised" to be on the territory ${ }^{1301}$ in accordance with a strict reading of the text of the ECHR. The administrative convenience of processing the applicant's claim was sufficient justification for his detention. In Chahal, the Court held that deportation proceedings are required to be prosecuted with "due diligence" in order for the detention to be permissible under Article 5(1)(f) ECHR. ${ }^{1302}$ In Saadi, the Court cited the proposition in Chahal that the detention need not be reasonably necessary and stated that it should also apply to those detained

\footnotetext{
1298 Saadi v United Kingdom, No. 13229/03, Judgment, Grand Chamber, 29 January 2008, at para 67

1299 Chahal v United Kingdom, No. 22414/93, Judgment, Grand Chamber, 15 November 1996 at para 112.

1300 Saadi v United Kingdom, No. 13229/03, Judgment, Grand Chamber, 29 January 2008, at para 73 .

1301 Saadi v United Kingdom, No. 13229/03, Judgment, Grand Chamber, 29 January 2008 at para 65-66.

1302 Chahal v United Kingdom, No. 22414/93, Judgment, Grand Chamber, 15 November 1996 at para 113. See also Singh $v$ Czech Republic, No. 60538/00, Judgment, 25 January 2005, paras 61-68; Raza v Bulgaria, No. 31465/08, Judgment, 11 February 2010, paras 7175; $M$ and Others v Bulgaria, No. 41416/08, Judgment 26 July 2011, paras 61-77; Auad v Bulgaria, No. 46390/10, Judgment, 11 October 2011, paras 127-135
} 
for the prevention of their unauthorised entry into the country. ${ }^{1303}$ The Court stated that the detention should not be arbitrary:

\begin{abstract}
"To avoid being branded as arbitrary, therefore, such detention must be carried out in good faith; it must be closely connected to the purpose of preventing unauthorised entry of the person to the country; the place and conditions of detention should be appropriate, bearing in mind that "the measure is applicable not to those who have committed criminal offences but to aliens who, often fearing for their lives, have fled from their own country";... and the length of the detention should not exceed that reasonably required for the purpose pursued"1304
\end{abstract}

In three key areas, the judgment in Saadi sits uneasily with the international standards contemplated by the Geneva Convention and the ICCPR, particularly in relation to the lawfulness of the stay of an asylum seeker.

Firstly, the majority judgment did not ascribe sufficient weight to the fact that the applicant was an asylum seeker who had lodged an application for asylum. The Court noted:

"It does not accept that, as soon as an asylum seeker has surrendered himself to the immigration authorities, he is seeking to effect an "authorised" entry, with the result that detention cannot be justified under the first limb of Article $5 \mathbb{S} 1$ (f)" 1305

1303 Saadi v United Kingdom, No. 13229/03, Judgment, Grand Chamber, 29 January 2008, at paras $72-73$.

1304 Saadi v United Kingdom, No. 13229/03, Judgment, Grand Chamber, 29 January 2008, at para 74; see also Lokpo and Touré v Hungary, No. 10816/10, Judgment, 20 September 2011, a case involving asylum seekers in Hungary where detention occurs up until the "merits" phase of the application after which time release is possible only on the initiative of the alien administration authority. In this case, the authority did not order the release and the detention continued. The Court stated at para 24: "The reasons underlying the applicants' detention may well be those referred to by the Government, that is to comply with European Union standards and at the same time to counter abuses of the asylum procedure; however, for the Court the fact remains that the applicants were deprived of their liberty by virtue of the mere silence of an authority - a procedure which in the Court's view verges on arbitrariness. In this connection the Court would reiterate that the absence of elaborate reasoning for an applicant's deprivation of liberty renders that measure incompatible with the requirement of lawfulness inherent in Article 5 of the Convention [emphasis added]". See also, O'Nions, H, No Right to Liberty: The Detention of Asylum Seekers for Administrative Convenience (2008) 10 European Journal of Migration and Law 149, and, in relation to the Chamber Decision in Saadi, see Wilsher, D, Immigration Detention and the Common European Asylum Policy, in Baldaccini, A, Guild, E, and Toner, H, Whose Freedom Security and Justice? EU Immigration and Asylum Law and Policy, 2007, Hart Publishing, Portland, Oregon, P.395-426; Hermann, M, in Hailbronner, K, (ed) EU Immigration and Asylum Law Commentary on EU Regulations and Directives, 2010, Beck, München, Pp.1351-1488 at Pp.1388-1389; Peers, S, EU Justice and Home Affairs Law, 2011, 3ed, OUP, Oxford Pp.518519

1305 Saadi v United Kingdom, No. 13229/03, Judgment, Grand Chamber, 29 January 2008, at para 65 
Although the Court's characterisation of "surrendered himself" (a somewhat passive characterisation) is ambiguous in that it does not necessarily contemplate an application for asylum being lodged by an asylum seeker (that is, an active measure by the asylum seeker), it is illuminative of the approach taken by the Court. That is, contrary to the regularisation and, thus, lawfulness of stay contemplated under the Geneva Convention by way of submission to a State's refugee determination procedure, and the jurisprudence of the HRC in relation to Article 12 ICCPR (as discussed earlier), the Court did not find that the applicant's submission to the refugee determination procedure provided a lawful basis for being within a State's territory. Indeed, the facts reveal that the applicant did not arrive unauthorised and, in any event, gained physical presence on the territory of the State of asylum whereby he immediately claimed asylum before he was detained (indeed, he had even been given "temporary admission" after making his claim for asylum and before his detention). ${ }^{1306}$ The fact that he had sought asylum, in the absence of any other factors rendering it necessary to detain the applicant, would otherwise be sufficient to have regularised the applicant's stay and thus take the grounds of his detention outside the scope of Article 5(1)(f). Rather, the requirement for necessity was obviated by the Court.

Secondly, as a consequence, the Court (as noted in the dissenting opinion), ${ }^{1307}$ did not make any distinction between asylum seekers and irregular migrants. ${ }^{1308}$

Thirdly, policy reasons of detention to facilitate more efficient processing of asylum claims was accepted as indicia of acting in good faith (that is, in relation to one of the elements which may contra-indicate arbitrariness), when such a policy ground for detention was expressly rejected by the HRC in $C v$ Australia. With somewhat torturous logic, the Court justified the purpose of detention:

"Moreover, since the purpose of the deprivation of liberty was to enable the authorities to quickly and efficiently to determine the applicant's claim to asylum, his detention was closely connected to the purpose of preventing unauthorised entry"1309

Perhaps the inference to be drawn from such a statement is that the Court is of the view that lawful entry to the territory was only possible after a positive determination of an applicant's asylum claim and rather suggests that detention

1306 Saadi v United Kingdom, No. 13229/03, Judgment, Grand Chamber, 29 January 2008, at para 10

1307 Saadi v United Kingdom, No. 13229/03, Judgment, Grand Chamber, 29 January 2008, joint partly dissenting opinion

1308 Saadi v United Kingdom, No. 13229/03, Judgment, Grand Chamber, 29 January 2008, at paras 64-65

1309 Saadi v United Kingdom, No. 13229/03, Judgment, Grand Chamber, 29 January 2008, at para 77 
of an asylum seeker may be justified until such a determination has been made (subject to any factors which may render it arbitrary as indicated in para 74 of the judgment). That inference is entirely at odds with the understanding of 'lawful presence' contemplated by the Geneva Convention and the HRC jurisprudence in relation to Article 12 ICCPR. As noted by Wilsher, the Court's reasoning would appear to permit the use of mandatory detention. ${ }^{1310}$

Accordingly, there is a significant disjunction between the reasoning of the Court in Saadi (and, indeed with the ECHR) and the understanding of the lawful entry and presence of an asylum seeker on the territory of a State as contemplated by the Geneva Convention and the HRC jurisprudence in relation to Article 12 ICCPR.

However, the requirement for necessity must be considered where this is provided for in national law and the authorities did not so comply. ${ }^{1311}$ Further, in a removal context, a detained person's non-cooperation with the host State authorities does not provide a basis for continued or prolonged detention, even if the initial ground for detention was lawful. ${ }^{1312}$

\section{Committee of Ministers' Recommendation Rec(2003)5}

In its Recommendation $\operatorname{Rec}(2003) 5$, the Committee of Ministers has expressly indicated that the aim of detention is not to penalise asylum seekers. The Recommendation outlines that detention should only occur in specific limited circumstances:

\footnotetext{
"- when their identity, including nationality, has in case of doubt to be verified, in particular when asylum seekers have destroyed their travel or identity documents or used fraudulent documents in order to mislead the authorities of the host state;

- when elements on which the asylum claim is based have to be determined which, in the absence of detention, could not be obtained;

- when a decision needs to be taken on their right to enter the territory of the state concerned, or

- when protection of national security and public order so requires." 1313
}

The Recommendation differs slightly from UNHCR's Revised Guidelines in three key respects. Firstly, there is no express general principle that asylum seekers should not be detained. Secondly, in permitting detention to determine the elements of the claim, its scope is broader the UNHCR's

\footnotetext{
1310 Wilsher, D, The Administrative Detention of Non-Nationals Pursuant to Immigration Control: International and Constitutional Law Perspectives, (2004) 53 ICLQ 897, Pp.906 and 909

1311 Rusu v Austria, No. 34082/02, Judgment, 2 October 2008, paras 54-60

1312 Mikolenko v Estonia, No. 10664/05, Judgment, 8 October 2009, Government's submission at paras 51 and 53, Court's assessment at paras 64-65, note dissenting judgment of Judge Maruste at paras 3-4. Contrast with Kolompar v Belgium, No.11613/85, Judgment, 24 September 1992, paras 37-43

1313 Committee of Ministers, Council of Europe, Recommendation Rec(2003)5 of the Committee of Ministers to member states on measures of detention to asylum seekers, paragraph 3.
} 
Revised Guidelines in that detention may be justified not just for a preliminary interview (as contemplated in the UNHCR's Revised Guidelines) but for a period which may extend for as long as the elements of the asylum claim "could not be obtained". Thirdly, the Recommendation permits detention pending the decision of the right to enter the State concerned - a ground not contemplated by the UNHCR's Revised Guidelines but which is more consistent with the ECtHR's jurisprudence on Article 5(1)(f). In that regard, it is questionable whether that Guideline is compatible with the HRC's rejection of the policy ground of the prevention of entry for those without prior authorisation to enter. ${ }^{1314}$

The Recommendation provides:

"Measures of detention of asylum seekers should be applied only after a careful examination of their necessity in each individual case. These measures should be specific, temporary and non-arbitrary and should be applied for the shortest possible time. Such measures are to be implemented as prescribed by law and in conformity with standards established by the relevant international instruments and by the case-law of the European Court of Human Rights."[emphasis added] ${ }^{1315}$

The Recommendation also provides that detention should not be an obstacle to submitting and pursuing an asylum application. ${ }^{1316}$

\section{Committee of Ministers' Twenty Guidelines on Forced Return}

In relation to forced returns, the Committee of Ministers in their Twenty Guidelines on Forced Return has indicated that a deprivation of liberty may only occur:

\footnotetext{
"with a view to ensuring that a removal order will be executed, if this is in accordance with a procedure prescribed by law and if, after an individual and careful examination of the necessity of the deprivation of liberty where the authorities of the host state have concluded that compliance with the removal order cannot be ensured as effectively by resorting to non-custodial measures such as supervision systems, the requirement to report regularly to the authorities, bail or other guarantee systems". [emphasis added] ${ }^{1317}$
}

Further, consistent with the ECtHR's emphasis on due diligence in the context of immigration detention (see below), the Committee of Ministers have also indicated that:

${ }^{1314}$ See C v Australia, Communication No. 900/1999, CCPR/C/76/D/900/1999, 28 October 2002, para 4.26

1315 Committee of Ministers, Council of Europe, Recommendation Rec(2003)5 of the Committee of Ministers to member states on measures of detention to asylum seekers, paragraph 4

1316 Committee of Ministers, Council of Europe, Recommendation Rec(2003)5 of the Committee of Ministers to member states on measures of detention to asylum seekers, paragraph 7 1317 Guideline 6(1) Committee of Ministers, Council of Europe, Twenty Guidelines on Forced Return, CM(2005)40 Addendum final, Strasbourg, 20 May 2005. 
"Detention pending removal shall be justified only for as long as removal arrangements are in progress. If such arrangements are not executed with due diligence the detention will cease to be permissible." 1318

\title{
5.1.2.2 EU Charter and General Principles of European Union Law
}

In light of the heightened status of the EU Charter since the entry into force of the Lisbon Treaty, it is worth noting that Article 47 of the EU Charter provides that any violation of the rights and freedoms protected by Union law are to be subject to an effective remedy before a tribunal. In a an analogous (but not identical) way to Articles 3 and 13 ECHR (although usually cited in the case law of the CJEU as analogous to Articles 6 and 13 ECHR), Article 47 of the EU Charter together with the principle of effectiveness ${ }^{1319}$ may provide a basis for an asylum seeker to remain on the territory of the Member State of asylum pending the determination of his or her application for asylum. ${ }^{1320}$ Further, Article 19(1) of the EU Charter provides a comparable prohibition on the collective expulsion of aliens as Article 4 of the Fourth Protocol to the ECHR, with Article 19(2) of the EU Charter prohibiting removal, expulsion or extradition where "there is a serious risk that he or she would be subjected to the death penalty, torture or other inhuman or degrading treatment or punishment".

The CJEU has recently held in relation to accelerated procedures under the current Procedures Directive, and with express reference in the judgment to Article 47 of the EU Charter:

\begin{abstract}
"The objective of Directive 2005/85 is to establish a common system of safeguards serving to ensure that the Geneva Convention and the fundamental rights are fully complied with. The right to an effective remedy is a fundamental principle of EU law. In order for that right to be exercised effectively, the national court must be able to review the merits of the reasons which led the competent administrative authority to hold the application for international protection to be unfounded or made in bad faith, there being no irrebuttable presumption as to the legality of those reasons. It is also within the framework of that remedy that the national court hearing the case must establish whether the decision to examine an application for asylum under an accelerated procedure was taken in compliance with the procedures and basic guarantees laid down in Chapter II of Directive 2005/85, as provided for in Article 23(4) of the directive." 1321
\end{abstract}

Article 6 of the EU Charter provides that "Everyone has the right to liberty

1318 Guideline 7, Committee of Ministers, Council of Europe, Twenty Guidelines on Forced Return, CM(2005)40 Addendum final, Strasbourg, 20 May 2005.

1319 On the principle of effectiveness in EU law generally, see Tridimas, T, The General Principles of EU Law, 2ed, 2006, OUP, Oxford, Pp. 418-476

${ }^{1320}$ Reneman, M, An EU Right to Interim Protection during Appeal Proceedings in Asylum Cases? (2010) 12 European Journal of Migration and Law 407

1321 Case C-69/10, Brahim Samba Dioufv Ministre du Travail, de l'Emploi et de l'Immigration, Judgment, 28 July 2011, para 61. 
and security of person". Further, Article 18 provides for a right to asylum in accordance with the 1951 Geneva Convention and its Protocol and the TEU and TFEU, ${ }^{1322}$ but is silent on the issue of any right to subsidiary protection. That latter provision, and particularly its express reference to the Geneva Convention, was given considerable weight in Advocate General Trstenjak's opinion in N.S. $v$ Secretary of State for the Home Department. ${ }^{1323}$ The CJEU emphasised the "full and inclusive" application of the Geneva Convention as the basis of the CEAS in it judgment in N.S. ${ }^{1324}$

Further, it should also be emphasised that, in relation to Dublin transfers and the right to remain in a Member State other than that of first entry or asylum, the CJEU held in N.S. that a rebuttable presumption exists that an asylum seeker will be treated in accordance with fundamental rights in the Member State to which he or she will be transferred ${ }^{1325}$ and that a transfer cannot occur if Article 4 of the EU Charter will be breached, ${ }^{1326}$

\subsubsection{Special Categories of Asylum Seeker}

\subsubsection{Minors \& Unaccompanied Minors}

The detention of minors is a particularly egregious situation that warrants consideration of the particular legal obligations that states face when dealing with asylum seekers who are minors or minors who are accompanying asylum seekers as part of the asylum seeker's family. The detention of minors raises particular concerns regarding the detention of families and who may also be considered a subcategory of vulnerable persons.

\subsection{Minors \& Unaccompanied Minors - International}

The UNHCR Revised Guidelines provide that minors should not be detained, and that unaccompanied minors "should not, as a general rule, be detained". ${ }^{1327}$ The UNHCR Revised Guidelines expressly refer to the

\footnotetext{
1322 See further, Gil-Bazo, M. T., The Charter of Fundamental Rights of the European Union and the Right to be Granted Asylum in the Union's Law, (2008) 27(3) Refugee Survey Quarterly 33

1323 Case C-411/10 N.S. v Secretary of State for the Home Department, Opinion, AG Trstenjak, paras 114 and 154

1324 C-411/10 and C-493/10 N.S. $v$ Secretary of State for the Home Department and M. E. and Others $v$ Refugee Applications Commissioner and Minister for Justice, Equality and Law Reform, 21 December 2011, Judgment Grand Chamber, para 75

1325 C-411/10 and C-493/10 N.S. $v$ Secretary of State for the Home Department and M. E. and Others v Refugee Applications Commissioner and Minister for Justice, Equality and Law Reform, 21 December 2011, Judgment Grand Chamber, particularly para 104

1326 C-411/10 and C-493/10 N.S. $v$ Secretary of State for the Home Department and M. E. and Others $v$ Refugee Applications Commissioner and Minister for Justice, Equality and Law Reform, 21 December 2011, Judgment Grand Chamber, particularly paras 106-108

1327 Guideline 6, UNHCR Revised Guidelines on applicable criteria and standards relating to the detention of asylum seekers, February 1999.
} 
provisions of CROC. EXCOM, in its Conclusions, has urged states to refrain from detaining minors on account of their vulnerability, ${ }^{1328}$ as well as condemning the arbitrary detention of minors, ${ }^{1329}$ and calling upon states to respect children's and adolescents' rights to liberty and security of person. ${ }^{1330}$

As a general proposition in addition to the specific rights identified in CROC (as discussed below) Article 24(1) ICCPR provides that:

"Every child shall have, without any discrimination as to race, colour, sex, language, religion, national or social origin, property or birth, the right to such measures of protection as are required by his status as a minor, on the part of his family, society and the State."

The purpose of that provision is to ensure that children benefit from all rights provided for in the ICCPR as well as to provide the possibility of restrictions of certain ICCPR rights where warranted and in the interests of the child (the HRC gives the example of the publication of a criminal judgment provided for in Article 14(1) where a minor is involved). ${ }^{1331}$ The HRC has indicated that States are to include how its laws and practices ensure protection by the removal of discrimination "particularly as between children who are nationals and children who are aliens". ${ }^{1332}$

In Bakhtiyari $v$ Australia the HRC held that, where a breach of Article 9(1) occurred due to the arbitrary detention of minors and, in circumstances where those minors "suffered demonstrable, documented and on-going adverse effects of detention", a breach of Article 24(1) occurred by the State's failure to provide such measures of protection as required by their status as minors. ${ }^{1333}$

As discussed in Chapter 4, CROC provides that the best interests of a child is the primary consideration in all actions concerning children - whether these be "public or private social welfare institutions, courts of law, administrative authorities or legislative bodies". ${ }^{1334}$ As also discussed in Chapter 4, minors may or may not be asylum seekers depending on firstly, whether they fall within the definition of the Geneva Convention or have another basis for

1328 UNHCR, Executive Committee Conclusion No. 107 (LVIII) - Children at Risk, 2007, para (b) (xi) ;

${ }^{1329}$ UNHCR, Executive Committee Conclusion No. 47 (XXXVIII) - Refugee Children, 1987, para (e)

1330 UNHCR, Executive Committee Conclusion No. 84 (XLVIII) - Conclusion on Refugee Children and Adolescents, 1997, para (a)(ii)

1331 United Nations Human Rights Committee, General Comment No. 17 - Rights of the child (Art. 24), 7 April 1989, para 2

1332 United Nations Human Rights Committee, General Comment No. 17 - Rights of the child (Art. 24), 7 April 1989, para 5

${ }_{1333}$ Bakhtiyari v Australia, UN Human Rights Committee Communication No 1069/2002, CCPR/C/79/D/1069/2002, 29 October 2003, para 9.7

1334 Article 3(1) CROC 
seeking asylum (that is, whether or not they have an independent basis for seeking asylum other than by reason that they are a family member of a person who is seeking asylum); and secondly, whether they have the legal capacity to submit to a State's asylum determination process, thereby enabling their physical presence on a State's territory to be regularised. In any event, Article 22(1) CROC requires states to take appropriate measures to ensure that refugee minors or minors seeking refugee status receive "appropriate protection and humanitarian assistance in the enjoyment of the applicable rights" contained in CROC and other international human rights or humanitarian instruments to which a State might be party. Indeed, the Committee on the Rights of the Child has emphasised that minors should have access to asylum procedures, regardless of age and inclusive of complementary protection. ${ }^{1335}$ Although Article 22(1) CROC expressly confirms as applicable to minors the rights to which adult asylum seekers might be entitled (which might, by extension, include the right to remain and the right to liberty) and expresses this as a positive obligation, it does not expressly contemplate the situation of minors who merely accompany asylum seekers. The rights of those minors are best explored in the other provisions of CROC.

Minors have the right not to be deprived of their liberty "unlawfully or arbitrarily". ${ }^{1336}$ The arrest, detention or imprisonment of a minor must firstly, "be in conformity with the law"; secondly; "be used only as a measure of last resort"; and thirdly, be "for the shortest appropriate period of time". 1337 Those principles are also reflected in the United Nations Rules for the Protection of Juveniles Deprived of their Liberty, ${ }^{1338}$ the UNHCR Refugee Children Guidelines on Protection and Care ${ }^{1339}$ and, in cases where the minor has committed an act of delinquency (that is, a criminal act), the United Nations Standard Minimum Rules for the Administration of Juvenile Justice. ${ }^{1340}$ Recently, the Human Rights

1335 Committee on the Rights of the Child, General Comment No. 6 - Treatment of Unaccompanied and Separated Children Outside their Country of Origin, 1 September 2005, paras 66 and $77-78$

1336 Article 37(b) CROC

1337 Article 37(b) CROC

1338 Rules 1 and 2, United Nations Rules for the Protection of Juveniles Deprived of their Liberty, 14 December 1990, A/RES/45/113, http://www.un.org/documents/ga/res/ 45/a45r113.htm (last accessed 7 October 2011).

${ }^{1339}$ Chapter 7, particularly section IV, UNHCR Refugee Children Guidelines on Protection and Care, 1994, http://www.unhcr.org/3b84c6c67.html (last accessed 7 October 2011)

1340 Rules 17(b) and (c), United Nations Standard Minimum Rules for the Administration of Juvenile Justice ("The Beijing Rules"), 29 November 1985, A/RES/40/33, http://www.un.org/documents/ga/res/40/a40r033.htm (last accessed 7 October 2011) noting that the scope of these rules contemplate punishments for offences by a juvenile as contemplated under a State's laws (see Rule 2). By reference to these rules, it is not conceded that entry into a territory by a minor asylum seeker is "illegal", but acknowledges that some states will impose criminal sanctions for illegal entry and presence onto their State territory. Distinctions must be made between administrative and criminal sanctions under a State's laws. It would appear that these rules are applicable if the minor has committed an 
Council has also stated:

"The detention of minors, particularly of unaccompanied minors, requires even further justification. Given the availability of alternatives to detention, it is difficult to conceive of a situation in which the detention of an unaccompanied minor would comply with the requirements stipulated in article 37 (b), clause 2, of the Convention on the Rights of the Child, according to which detention can be used only as a last resort." 1341

The CteeRC has also indicated that, in accordance with Article 37, "[d]etention cannot be justified solely on the basis of the child being unaccompanied or separated, or on their migratory or residence status, or lack thereof." 1342 In furtherance of that line of reasoning, a minor's rights under CROC must be respected and ensured without discrimination on the basis of the child or the child's parent or legal guardian's, inter alia, "national", "birth" or "other status". ${ }^{1343}$ Similarly, where detention may be characterised as punishment for illegal entry or presence in a State's territory, a State is obliged to protect a minor (including an accompanied minor) from "all forms of discrimination or punishment" based on, inter alia, "the status" or "activities" of the child's parents, legal guardians or family members. ${ }^{1344}$ Accordingly, the immigration or other status of minors or of their parents or legal guardians provides no basis for discriminating against the rights of asylum seeking minors under CROC. Rather minors must be protected from such discrimination or punishment as the beneficiaries of a positive obligation.

Where detention (of either the minor or of one of the parents of the minor) would result in the separation of a child from his or her parents, Article 9(1) CROC provides that this must not occur against the will of the parents or the combined will of the parents and child. ${ }^{1345}$ Indeed, it may only occur firstly, "when competent authorities subject to judicial review determine"; secondly, it must be "in accordance with applicable law and procedures"; and thirdly, "that such separation is necessary for the best interests of the child". Minors so capable of forming a view have "the right to express those views freely in all matters affecting the child", with due weight being given to those views "in

act of "delinquency" other than his or her entry and presence in the territory of the State in which he or she seeks asylum - see Chapter 7, particularly section IV, last paragraph, UNHCR Refugee Children Guidelines on Protection and Care, 1994, http://www.unhcr.org/3b84c6c67.html (last accessed 7 October 2011)

1341 United Nations Human Rights Council, Report of the Working Group on Arbitrary Detention, 18 January 2010, A/HRC/13/30, at para 60

1342 Committee on the Rights of the Child, General Comment No. 6 - Treatment of Unaccompanied and Separated Children Outside their Country of Origin, 1 September 2005, para 61

1343 Article 2(1) CROC

1344 Article 2(2) CROC

1345 Regarding the interpretation of "their" in Article 9(1) CROC, see UNICEF, Implementation Handbook for the Convention on the Rights of the Child, (3 ed), 2007, P.122 
accordance with the age and maturity of the child. ${ }^{1346}$ The matters upon which the child may express its views include immigration and asylum matters ${ }^{1347}$ and which should be "elicited and taken into account". ${ }^{1348}$ Further, where a child is temporarily or permanently deprived of their "family environment" (as distinct from his or her parental environment) (say, as an unaccompanied minor or by his or her detention, or the detention of a family member), a minor is to be provided with "special protection and assistance" 1349 and alternative care must be provided for in a State's laws. ${ }^{1350}$ "Special protection and assistance" should include the appointment of a guardian, ${ }^{1351}$ particularly in the context of asylum procedures. ${ }^{1352}$ Guardians whose interests potentially conflict with those of the minor should not be so appointed. ${ }^{1353}$

\subsection{Minors \& Unaccompanied Minors - Council of Europe ECHR}

The ECtHR has indicated that the "extreme vulnerability" of both accompanied and unaccompanied minors is such not only to engage the High Contracting Parties' positive obligations to care for and protect them under Article 3 ECHR, but also "takes precedence over considerations relating to the [minor's] status as an illegal immigrant". ${ }^{1354}$ However, that precedence is not such to exclude a minor from detention under Article 5(1)(f) ECHR such that detention may only be possible under the limited circumstances of Article $5(1)(d)^{1355}$ - rather, the lawfulness of the detention of a minor may be challenged by reference to the conditions of detention (that is, "a link must

\footnotetext{
1346 Article 12(1) CROC

1347 Committee on the Rights of the Child, General Comment No. 12 - The right of the child to be heard, 20 July 2009, paras 123-124; See also UNHCR, Executive Committee Conclusion No 107 (LVIII) - Children at Risk, 2007, para (b)(iv)

1348 Committee on the Rights of the Child, General Comment No. 6 - Treatment of Unaccompanied and Separated Children Outside their Country of Origin, 1 September 2005, para 25.

1349 Article 20(1) CROC

1350 Article 20(2) CROC

1351 Committee on the Rights of the Child, General Comment No. 6 - Treatment of Unaccompanied and Separated Children Outside their Country of Origin, 1 September 2005, para 33

1352 Committee on the Rights of the Child, General Comment No. 6 - Treatment of Unaccompanied and Separated Children Outside their Country of Origin, 1 September 2005, para 36

1353 Committee on the Rights of the Child, General Comment No. 6 - Treatment of Unaccompanied and Separated Children Outside their Country of Origin, 1 September 2005, para 33

1354 Mubilanzila Mayeka and Kaniki Mitunga v Belgium, No. 13178/03, Judgment, 12 October 2006, at para 55; Muskhadzhiyeva \& ors v Belgium, No. 41442/07, Judgment, 19 January 2010, citing paras 53-55 of Mubilanzila with approval at paras 55-58; see also Kanagaratnam \& Others $v$ Belgium, No. 15297/09, Judgment, 13 December 2011

1355 Mubilanzila Mayeka and Kaniki Mitunga v Belgium, No. 13178/03, Judgment, 12 October 2006, at paras 95-105, particularly at 100;
} 
exist between on the one hand, the reason given for the deprivation of liberty permitted and on the other, the place and conditions of detention" ${ }^{1356}$ ), for example, if the detention conditions were only suitable to adults and not to minors. ${ }^{1357}$ Accordingly, the Court did not rule out the possibility of detaining minors or unaccompanied minors provided that the conditions of their detention were appropriate to their status as minors. The positive obligation under Article 3 ECHR enunciated by the Court in light of a minor's "extreme vulnerability" 1358 may, in effect, severely limit the circumstances in which an alien minor may be detained.

Recently, however, there has been a discernible and pro-active shift in the Court's jurisprudence regarding children. In Rahimi, a doubt was raised as to whether authorities had acted in good faith in light of the fact that the best interests of the child were not addressed nor were any less intrusive means explored before resorting to detention in order to secure a child's deportation. In addition to a breach of Article 3 as regards conditions of detention, the Court held that the detention was unlawful under Article 5(1)(f). ${ }^{1359}$ There are also significant consequences for the detention of families with children in light of Kanagaratnam ${ }^{1360}$ and Popov ${ }^{1361}$ (discussed below).

\section{Committee of Ministers' Recommendation Rec(2003)5}

The Committee of Ministers, in their Recommendation Rec(2003)5, have reflected the general position of the UNHCR Revised Guidelines and CROC, namely that:

\footnotetext{
"20. As a rule, minors should not be detained unless as a measure of last resort and for the shortest possible time.

21. Minors should not be separated from their parents against their will, nor from other adults responsible for them whether by law or custom.

$[\ldots]$

23. For unaccompanied minor asylum seekers, alternative an non-custodial care arrangements, such as residential home or foster placements, should be arranged and, where provided for by national legislation, legal guardians should be appointed, within the shortest possible time."1362
}

1356 Mubilanzila Mayeka and Kaniki Mitunga v Belgium, No. 13178/03, Judgment, 12 October 2006, at para 102, cited with approval in Muskhadzhiyeva $\&$ ors v Belgium, No. 41442/07, Judgment, 19 January 2010, at paras 73-75

1357 Mubilanzila Mayeka and Kaniki Mitunga v Belgium, No. 13178/03, Judgment, 12 October 2006, at paras 102-105; Muskhadzhiyeva \& ors v Belgium, No. 41442/07, Judgment, 19 January 2010, citing paras 101-104 of Mubilanzila with approval at paras 73-75.

1358 Affirmed in Kanagaratnam \& Others v Belgium, No. 15297/09, Judgment, 13 December 2011, para 67

1359 Rahimi v Greece, No. 8687/08, Judgment, 5 April 2011, paras 109-110

1360 Kanagaratnam \& Others $v$ Belgium, No. 15297/09, Judgment, 13 December 2011

1361 Popov v France, Nos. 39472 and 39474/07, Judgment, 19 January 2012

1362 Committee of Ministers, Council of Europe, Recommendation Rec(2003)5 of the Committee of Ministers to member states on measures of detention to asylum seekers 
Committee of Ministers' Twenty Guidelines on Forced Return

The Committee of Ministers' Twenty Guidelines on Forced Return partly reflect Article 37(b) CROC in that minors must only be detained "as a measure of last resort and for the shortest appropriate period of time." 1363 Although not expressly prohibiting the detention of unaccompanied minors, the Guidelines urge that "separated children" be accommodated in institutions "provided with the personnel and facilities which take into account the needs of persons of their age". ${ }^{1364}$

Committee of Ministers' Recommendation (2009)13 on the Nationality of Children Although not directly applicable in relation to the CEAS legislation, the Committee of Minister's Recommendation (2009)13 on the nationality of children may provide some comparison as regards access of minors to the asylum procedure. Principle 20 of the Recommendation provides that children should have "the right to file applications for the acquisition or loss of nationality if they are considered by law as having sufficient understanding and are, where necessary, legally represented as required by domestic law". Principle 19 provides that children are to be consulted and their views taken into account "having regard to their maturity". Principle 19 also provides that the age at which a child is said to have attained sufficient understanding is to be prescribed by law, but no older than 14 years. The Recommendation also provides that children may challenge decisions regarding their nationality and be legally represented as required by national law, where necessary. ${ }^{1365}$

\subsection{Minors \& Unaccompanied Minors - EU Charter}

In the Union sphere, minors have the right to "such protection and care as is necessary for their wellbeing" under the EU Charter. ${ }^{1366}$ Further, the views of minors are free to be expressed and are to be taken into consideration in matters that concern them "in accordance with their age and maturity". 1367 Minors have the right to "a personal relationship and direct contact" with the minor's parents, but that right is qualified by "on a regular basis". ${ }^{1368}$

\subsubsection{Family Members}

The importance of family unity in a detention context stems from the possibility to disintegrate otherwise unified families at least physically present in a State's territory by detaining the principal applicant or family members

\footnotetext{
1363 Guideline 11(1), Committee of Ministers, Council of Europe, Twenty Guidelines on Forced Return, CM(2005)40 Addendum final, Strasbourg, 20 May 2005

1364 Guideline 11(4), Committee of Ministers, Council of Europe, Twenty Guidelines on Forced Return, CM(2005)40 Addendum final, Strasbourg, 20 May 2005

1365 Principle 21, Committee of Ministers, Council of Europe, Recommendation (2009)13 of

the Committee of Ministers to member states on the nationality of children, 9 December 2009

1366 Article 24(1) EU Charter

1367 Article 24(1) EU Charter

1368 Article 24(3) EU Charter
} 
thereof and it also raises concerns in relation to the detention of entire families, which is particularly egregious when minor children are involved.

In circumstances where minors form part of the family unit, the principle that minors should be detained as a measure of last resort combined with the principles of the best interests of the child and family unity dictate that the detention of families together, or the detention of one family member which has the effect of disintegrating an otherwise unified family, should occur only in extremely limited circumstances.

\subsection{Family Members - International}

The rights to which asylum seekers physically and lawfully present in a State's territory as provided under the Geneva Convention may not be transmuted to that asylum seeker's family because the definition of "refugee" under the Convention does not contemplate family members. ${ }^{1369}$ However, as discussed in Chapter 4, the Conference did recommend that family unity be maintained "particularly in cases where the head of the family has fulfilled the necessary conditions for admission to a particular country". ${ }^{1370}$ Although that Recommendation is not legally binding, it is indicative of the intent of the drafters to maintain family unity ${ }^{1371}$ and it is arguable that the use of the word "particularly" suggests that family unity should also be maintained at stages of the refugee determination process prior to the formal conferral of refugee status. As a practical (as distinct from a legal) consequence of maintaining family unity, the rights to which an asylum seeker may be entitled under the Geneva Convention may also flow to family members - namely, the right to remain, the right to liberty and the circumstances in which detention may arise.

The UNHCR, in its Executive Committee Conclusions, has repeatedly emphasised the significance of the family ${ }^{1372}$ and of the principle of family unity, ${ }^{1373}$ including:

"Underlin[ing] the need for the unity of the refugee's family to be protected, inter alia by:

(i) measures which ensure respect for the principle of family unity, including, those to reunify family members separated as a result of refugee

\footnotetext{
1369 UNHCR, Handbook on Procedures and Criteria for Determining Refugee Status under the 1951 Convention and the 1967 Protocol relating to the Status of Refugees, para 183

1370 Recommendation B, Final Act of the United Nations Conference of Plenipotentiaries on the Status of Refugees and Stateless Persons, 28 July 1951.

1371 Hathaway, J C, The Rights of Refugees under International Law, 2005, Cambridge University Press, Cambridge at Pp. 540-542

1372 UNHCR, Executive Committee Conclusion No. 84 (XLVIII) - Refugee Children and Adolescents, 1997; UNHCR, Executive Committee Conclusion No. 85 (XLIX) - Conclusion on International Protection, 1998, para (u)

1373 UNHCR, Executive Committee Conclusion No. 22 (XXXII) - Protection of Asylum Seekers in Situations of Mass Influx, 1981, para (II)(B)(2)(i); UNHCR, Executive Committee Conclusion No. 85 (XLIX) - Conclusion on International Protection, 1998, para (v)
} 
flight

$[\ldots]$

(iv) the prioritisation of family unity issues at an early stage in all refugee operations;" 1374

Indeed, the UNHCR has further indicated that the principle of family unity should also be respected throughout the voluntary repatriation process, ${ }^{1375}$ and where complementary protection is granted. ${ }^{1376}$ The UNHCR has also emphasised that family unity includes the family's stay in detention as well as their release from detention together. ${ }^{1377}$

The primacy of the family as "the natural and fundamental group unit of society" which "is entitled to protection by society and the State" is reflected in Article 23(1) ICCPR and Article 10(1) ICESCR. Protection against "arbitrary or unlawful interference" with a person's family is provided for by Article 17(1) ICCPR and, if the family member is a minor, by Article 16 CROC. The right to form a family is recognised by Article 23(2) ICCPR. For minor family members, Article 9(1) CROC provides:

"a child shall not be separated from his or her parents against their will, except when competent authorities subject to judicial review determine, in accordance with applicable law and procedures, that such separation is necessary for the best interests of the child."

In relation to what constitutes "unlawful" and "arbitrary interference" under Article 17 ICCPR, the HRC has indicated:

"3. The term 'unlawful' means that no interference can take place except in cases envisaged by the law. Interference authorized by States can only take place on the basis of law, which itself must comply with the provisions, aims and objectives of the Covenant.

4. The expression 'arbitrary interference' is also relevant to the protection of the right provided for in article 17. In the Committee's view the expression 'arbitrary interference' can also extend to interference provided for under the law. The introduction of the concept of arbitrariness is intended to guarantee that even interference provided for by law should be in accordance with the provisions, aims and objectives of the Covenant and should be, in any event, reasonable in the particular circumstances." [emphasis added] ${ }^{1378}$

\footnotetext{
1374 UNHCR, Executive Committee Conclusion No. 88 (XLX) - Protection of the Refugee's Family, 1999, para (b)

1375 UNHCR, Executive Committee Conclusion No. 101 (LV) - Conclusion on Legal Safety Issues in the Context of Voluntary Repatriation of Refugees, 2004, para (n)

1376 UNHCR, Executive Committee Conclusion No. 103 (LVI) - Conclusion on the Provision of International Protection Including Through Complementary Forms of Protection, 2005, para (n)

1377 Chapter 7, section IV, UNHCR Refugee Children Guidelines on Protection and Care, 1994, http://www.unhcr.org/3b84c6c67.html (last accessed 7 October 2011), P.37

1378 UN Human Rights Committee, General Comment No. 16: The right to respect of privacy, family, home and correspondence, and protection of honour and reputation (Art, 17), 8 April 1988, paras 3-4
} 
In Bakhtiyari $v$ Australia the HRC noted that "to separate a spouse and children arriving in a State from a spouse validly resident in a State may give rise to issues under articles 17 and 23 of the Covenant". ${ }^{1379}$ In circumstances where an asylum seeker was awaiting the outcome of his claim and where his family (having arrived after him) were proposed to be removed from the State, the HRC indicated that a violation of Articles 17(1) and 23(1) ICCPR would occur bearing in mind the particular circumstances of the case. ${ }^{1380}$ Accordingly, it may be inferred from that jurisprudence that family members of an asylum seeker who has submitted to the procedures for determination of his or her claim have a right (albeit not unqualified) to remain in the territory of the State of asylum - that is, where to do otherwise would be contrary to the provisions, aims and objectives of the ICCPR and would be unreasonable in the particular circumstances of the case.

In relation to Article 23(1) ICCPR, the HRC has indicated in its General Comment 19:

"The right to found a family implies, in principle, the possibility to procreate and live together. When States parties adopt family planning policies, they should be compatible with the provisions of the Covenant and should, in particular, not be discriminatory or compulsory. Similarly, the possibility to live together implies the adoption of appropriate measures, both at the internal level and as the case may be, in cooperation with other States, to ensure the unity or reunification of families, particularly when their members are separated for political, economic or similar reasons.[emphasis added]" 1381

The inference to draw from that jurisprudence is that Article 23(1) requires more than just for the family to be in the same State, but that living together is an integral part of family life and which may particularly be the case for asylum seekers who may be separated from their family for the "political, economic or similar reasons" contemplated in the General Comment.

1379 Bakhtiyari v Australia, UN Human Rights Committee Communication No 1069/2002, CCPR/C/79/D/1069/2002, 29 October 2003, para 9.6

1380 Bakhtiyari v Australia, UN Human Rights Committee Communication No 1069/2002, CCPR/C/79/D/1069/2002, 29 October 2003, para 9.6. The particular facts were: "the number and age of the children, including a newborn, the traumatic experiences of Mrs Bakhtiyari and the children in long-term immigration detention in breach of Article 9 of the Covenant, the difficulties that Mrs Bakhtiyari and her children would face if returned to Pakistan without Mr Bakhtiyari and the absence of arguments by the State party to justify removal in these circumstances".

1381 UN Human Rights Committee, General Comment No. 19: Protection of the family, the right to marriage and equality of spouses (Article 23), 1990, http://www.unhchr.ch/tbs/doc.nsf/(Symbol)/6f97648603f69bcdc12563ed004c3881?Open document (last accessed 6 October 2011), para 5 


\subsection{Family Members - Council of Europe}

\section{ECHR}

The ECHR protects the right to family life by virtue of Article 8(1). However, that Article has been more narrowly construed than that under the ICCPR. Although this discussion focuses on family unity as opposed to family re-unification it is worth noting that Article 8 ECHR cannot be invoked to compel family reunification and the choice of State in which it is to take place, ${ }^{1382}$ but is nonetheless an important consideration in Dublin transfers where family members may be in several Member States, particularly so if minors are involved. ${ }^{1383}$

In relation to the nature of family life secured by Article 8 , the Court has indicated that " $[t]$ he mutual enjoyment by parent and child of each other's company constitutes a fundamental element of family life". ${ }^{1384}$ Indeed, a person's disintegration from siblings as well as parents has also been held to be a violation of Article $8 \mathrm{ECHR} .{ }^{1385}$ As indicated in Chapter 2, the CJEU has taken a more expansive interpretation of Article 8 ECHR than the ECtHR. ${ }^{1386}$ However, the ECtHR had formerly indicated that there is no breach of Article $8 \mathrm{ECHR}$ as regards family life or privacy where a family has been detained together, ${ }^{1387}$ but the ECtHR seems to have distanced itself from that jurisprudence in Popov - a case involving the detention of children with their parents. In Popov the ECtHR held a breach of Article 8 had occurred because the best interests of the child had not been taken into account and that the detention of the family in the absence of any risk of absconding was disproportionate. ${ }^{1388}$ The ECtHR has also recently indicated that detention of a mother with her children amounted to arbitrary detention (and thus a breach of Article 5(1)(f)) on account of the length of detention and the unsuitability of the accommodation conditions for families, ${ }^{1389}$ but that no breach of Article 3 occurred by reason of the mother witnessing the distress of her children in

1382 Abdulaziz, Cabales and Balkandali $v$ the United Kingdom, Nos. 9214/80, 9473/81, and 9474/81, 28 May 1985, paras 67-68

1383 Hermann, M, in Hailbronner, K, (ed), EU Immigration and Asylum Law - Commentary on EU Regulations and Directives, 2010, Beck, München, Pp.1351-1488 at 1380

${ }^{1384}$ B. $v$ United Kingdom, No. 9840/82, Judgment, 8 July 1987 at para 60; Olsson v Sweden (No. 1), No. 10465/83, Judgment, 24 March 1988, para 59; Eriksson v Sweden, No. 11373/85, Judgment, 22 June 1989, para 58; Gnahoré v France, No. 40031/98, Judgment, 19 September 2000, para 50; Mubilanzila Mayeka and Kaniki Mitunga v Belgium, No. 13178/03, Judgment, 12 October 2006, at para 75.

1385 Moustaquim v Belgium, No. 12313/86, Judgment, 18 February 1991, paras 36 and 43-47

1386 For example, compare the ECtHR's approach in Applications 9214/80, 9473/81, and 9474/81 Abdulaziz, Cabales and Balkandali $v$ the United Kingdom, 28 May 1985 to the CJEU's (then ECJ's) approach in Case C-540/03, 27 June 2006, European Parliament $v$ Council of the European Union

1387 Muskhadzhiyeva \& ors v Belgium, No. 41442/07, Judgment, 19 January 2010, paras 9799

${ }_{1388}$ Popov v France, Nos. 39472 and 39474/07, Judgment, 19 January 2012, paras 147-148

1389 Kanagaratnam \& Others v Belgium, No. 15297/09, Judgment, 13 December 2011, paras 94-95 
detention. ${ }^{1390}$

The Committee of Ministers' Recommendation Rec(2003)5 \& Twenty Guidelines on Forced Return

The Committee of Ministers of the Council of Europe in their Recommendation $\operatorname{Rec}(2003) 5$ do not exclude the possibility of detaining families as such, but rather calls for persons to be "accommodated together [emphasis added]" when they are part of a family unit. The Recommendation calls for the "the right to a private and family life" to be ensured. ${ }^{1391}$ The Committee of Ministers' Twenty Guidelines on Forced Return calls for an accommodation of the principle of family unity for those detained pending removal, as well as any interference with family and/or private life as a result of removal order being "proportionate and in pursuance of a legitimate aim". ${ }^{1392}$ The Guidelines also expressly contemplate the detention of families pending removal. ${ }^{1393}$

\subsection{Family Members - EU Charter}

In the Union sphere Article 7 of the EU Charter provides that everyone has the right to respect for his or her family life. Article 9 provides the right to marry and found a family "in accordance with the national laws governing the exercise of these rights". Legal, economic, and social protection for the family is also ensured by Article 33 .

\subsubsection{Vulnerable Persons}

\subsection{Vulnerable Persons - International}

As acknowledged in the UNHCR Revised Guidelines, detaining vulnerable persons can have a very serious effect on the psychological ${ }^{1394}$ (and indeed, physical) well-being of vulnerable persons. The UNHCR Revised Guidelines call for an "active consideration of possible alternatives" for vulnerable persons - advising that the detention of vulnerable persons should "only be on the certification of a qualified medical practitioner that detention will not adversely affect their health and well being [emphasis added]". ${ }^{1395}$ In relation to pregnant women "in their final months" and nursing mothers, the UNHCR has indicated that detention should be avoided on account of their special

\footnotetext{
1390 Kanagaratnam \& Others v Belgium, No. 15297/09, Judgment, 13 December 2011, paras $70-72$

1391 Committee of Ministers, Council of Europe, Recommendation Rec(2003)5 of the Committee of Ministers to member states on measures of detention to asylum seekers, para 14

1392 Guidelines 10(4) and 2(2), Committee of Ministers, Council of Europe, Twenty Guidelines on Forced Return, CM(2005)40 Addendum final, Strasbourg, 20 May 2005.

1393 Guideline 11(2), Committee of Ministers, Council of Europe, Twenty Guidelines on Forced Return, CM(2005)40 Addendum final, Strasbourg, 20 May 2005.

1394 Guideline 7, UNHCR Revised Guidelines on applicable criteria and standards relating to the detention of asylum seekers, February 1999

1395 Guideline 7, UNHCR Revised Guidelines on applicable criteria and standards relating to the detention of asylum seekers, February 1999.
} 
needs. ${ }^{1396}$

The UNHCR, through its Executive Committee Conclusions, has underlined the applicability of the 2006 Convention on the Rights of Persons with Disabilities ("CRPD") to the situation of refugees and others of concern to UNHCR. ${ }^{1397}$ The UNHCR has recommended that States identify and register those persons with disabilities swiftly and systematically in order to ensure that their protection and assistance needs are identified. ${ }^{1398}$ States are encouraged to ensure that all "information, procedures, decisions and policies" are understood by those with disabilities, and that refugee determination and other procedures are accessible "and designed to enable persons with disabilities to fully and fairly represent their claims with the necessary support". 1399

The CRPD firstly provides that persons with disabilities enjoy the right to liberty and security of person. ${ }^{1400}$ Further, persons with disabilities are not to be deprived of their liberty unlawfully or arbitrarily - any deprivation of liberty must be in accordance with the law and that a person's disability must "in no case justify a deprivation of liberty". ${ }^{1401}$ If a person with a disability is deprived of their liberty, then they are entitled to guarantees "in accordance with international human rights law", including by being provided "reasonable accommodation". ${ }^{402}$ A person with a disability has a right to liberty of movement, as well as the "freedom to choose their residence". ${ }^{1403}$ Further, States are under an obligation to ensure that persons with disabilities are "not deprived, on the basis of disability, [...] to utilize relevant processes such as immigration proceedings, that may be needed to facilitate the exercise of the right to liberty of movement". ${ }^{1404}$

1396 Guideline 8, UNHCR Revised Guidelines on applicable criteria and standards relating to the detention of asylum seekers, February 1999

1397 UNHCR, Executive Committee Conclusion No 108 (LIX) - Refugees and others of concern with disabilities, 2008, para (i); UNHCR, Executive Committee Conclusion No 110 (LXI) Refugees with disabilities and other persons with disabilities, 2010, recital 4

1398 UNHCR, Executive Committee Conclusion No 110 (LXI) - Refugees with disabilities and other persons with disabilities, 2010, para (c)

1399 UNHCR, Executive Committee Conclusion No 110 (LXI) - Refugees with disabilities and other persons with disabilities, 2010, para (j)

1400 Article 14(1)(a) CRPD

1401 Article 14(1)(b) CRPD

1402 Article 14(2) CRPD; "reasonable accommodation" is defined in Article 2 CRPD as "necessary and appropriate modification and adjustment not imposing a disproportionate or undue burden, where needed in a particular case, to ensure to persons with disabilities the enjoyment or exercise on an equal basis with others of all human rights and fundamental freedoms"

1403 Article 18(1) CRPD

1404 Article 18(1)(b) CRPD 


\subsection{Vulnerable Persons - Council of Europe ECHR}

The ECHR makes express provision for the detention of particular vulnerable persons, namely vagrants, the mentally ill, alcoholics and those suffering from infectious disease under Article 5(1)(e). Accordingly, it may be argued that particularly vulnerable groups of asylum seekers may not be detained unless the requirements of Article 5(1)(e) are met, as opposed to Article 5(1)(f). However, as indicated earlier, the ECtHR has expressly rejected that reasoning in Mubilanzila Mayeka. ${ }^{1405}$ If the line of reasoning in Mubilanzila Mayeka and Muskhadzhiveva cases is extended by analogy to vulnerable groups of asylum seekers, their vulnerability (say by virtue of their having a disability or otherwise) would not exclude them from detention under Article 5(1)(f). However, for that detention to be lawful under Article 5(1)(f), given the "extreme vulnerability" which some asylum seekers may be under, the place and conditions of detention must bear some relationship to the ground of deprivation of liberty. ${ }^{1406}$ Further, the place and conditions of detention may also constitute a breach of the positive obligations under Article 3 ECHR if they inadequately reflect the "extreme vulnerability" that vulnerable groups of asylum seekers experience. ${ }^{1407}$ Indeed, the ECtHR in MSS characterised asylum seekers generally as being a "particularly underprivileged and vulnerable population group in need of special protection" ${ }^{1408}$ which, in light of the ECtHR's prior jurisprudence on the term "vulnerable persons", drew criticism in the partly concurring and partly dissenting judgment of Judge Sajó. It remains to be seen whether asylum seekers are in future considered "vulnerable persons" within the autonomous meaning previously given to that term by the Court.

The Committee of Ministers' Recommendation Rec(2003)5 \& Twenty Guidelines on Forced Return

The Committee of Ministers, in their Recommendation Rec(2003)5, has not ruled out the possibility of detaining vulnerable asylum seekers, nor identified in which circumstances detention may occur, but rather has indicated that the screening of asylum seekers should occur "at the outset of their detention to identify torture victims and traumatised persons among them so that appropriate treatment and conditions can be provided for them." 1409

1405 Mubilanzila Mayeka and Kaniki Mitunga v Belgium, No. 13178/03, Judgment, 12 October 2006, at paras 95-105, particularly at 100;

1406 Mubilanzila Mayeka and Kaniki Mitunga v Belgium, No. 13178/03, Judgment, 12 October 2006, at para 102, cited with approval in Muskhadzhiyeva \& ors v Belgium, No. 41442/07, Judgment, 19 January 2010, at paras 73-75; see also Aerts v Belgium, No, 25357/94, Judgment, 30 July 1998

1407 Mubilanzila Mayeka and Kaniki Mitunga v Belgium, No. 13178/03, Judgment, 12 October 2006, at para 55; Muskhadzhiyeva \& ors v Belgium, No. 41442/07, Judgment, 19 January 2010, citing paras 53-55 of Mubilanzila with approval at paras 55-58

1408 MSS v Belgium \& Greece, No. 30696/09, Judgment, 21 January 2011, para 251

1409 Committee of Ministers, Council of Europe, Recommendation Rec(2003)5 of the Committee of Ministers to member states on measures of detention to asylum seekers, Guideline 12 
Accordingly, the inference to be drawn from that recommendation is that treatment and conditions of detention should meet the particular vulnerability that an asylum seeker may be facing. ${ }^{1410}$ The early identification of vulnerable persons is in line with the UNHCR position (as discussed above). The Committee of Ministers' Twenty Guidelines on Forced Return does not make any special provision for the circumstances in which vulnerable persons are detained (that is, in addition to those provisions relating to the general circumstances in which detention is to occur).

\subsection{Vulnerable Persons - EU Charter}

In the Union sphere, the EU Charter provides for the non-discrimination of any persons based inter alia on the grounds of disability, ${ }^{1411}$ and makes express provision to ensure their "independence, social and occupational integration and participation in the life of the community". ${ }^{1412}$

\subsubsection{Stateless Persons}

The position of stateless persons in an immigration detention context is a particularly precarious one. This stems from the inability of the State of habitual residence to allow the return of a person who is stateless and accordingly, delay any proceedings to remove the person from the country of asylum or to allow readmission into its territory. Those stateless persons who are detained, for example, for further verification of their identity or subject to removal run a serious risk of prolonged or indefinite detention.

\subsection{Stateless Persons - International}

The UNHCR's Revised Guidelines advocates that stateless persons "are to benefit from the same standards of treatment as those in detention generally" and that being stateless "should not lead to indefinite detention" or "be a bar to release". ${ }^{1413}$ Through its Executive Committee conclusions, the UNHCR has expressed its concern at the prolonged detention of stateless persons, ${ }^{1414}$ and has called on states not to detain stateless persons on the sole ground that they are stateless. ${ }^{1415}$

\footnotetext{
1410 And which is also partly reflected in Guideline 13, Committee of Ministers, Council of Europe, Recommendation Rec(2003)5 of the Committee of Ministers to member states on measures of detention to asylum seekers: "Appropriate medical treatment and, where necessary, psychological counselling should be provided. This is particularly relevant for persons with special needs: minors, pregnant women, elderly people, persons with physical or mental disabilities and people who have been seriously traumatised, including torture victims."

1411 Article 21 EU Charter

1412 Article 26 EU Charter

1413 Guideline 9, UNHCR Revised Guidelines on applicable criteria and standards relating to the detention of asylum seekers, February 1999

1414 UNHCR, Executive Committee Conclusion No. 106 (LVII) - Identification, Prevention and Reduction of Statelessness and Protection of Stateless Persons, 2006, Recital 3

1415 UNHCR, Executive Committee Conclusion No. 106 (LVII) - Identification, Prevention and Reduction of Statelessness and Protection of Stateless Persons, 2006, para (x)
} 
Through its Geneva Expert Sessions, UNHCR has indicated that international human rights law is applicable to stateless persons regardless of the legal status of the country in which they are present. ${ }^{1416}$ The UNHCR has called upon the use of "simple and efficient" procedures for determining statelessness ${ }^{1417}$ and, where a stateless person is also a refugee, then the person should be protected according to the higher standard of protection (more likely) being international refugee law "supplemented by international human rights law". 1418

Following the recent publication of its Guidelines on Statelessness No. 2, the UNHCR has acknowledged that statelessness determination procedures are very much dependent on the context in which statelessness arises as an issue (for example, in spheres such as employment, immigration or acquisition of nationality). ${ }^{1419}$ The Guidelines advocate for the centralisation of determination procedures ${ }^{1420}$ and acknowledge that States may place determination procedures, for example, within the purview of immigration authorities, ${ }^{1421}$ as well as considering combining refugee and stateless determination procedures. ${ }^{1422}$ The Guidelines contemplate both a separate and combined determination procedure for statelessness and refugee status, but in the case of separate determination procedures, no contact should be made with the country of origin. ${ }^{1423}$ In the case of a combined determination procedure, the determinations should be conducted together by the person examining. ${ }^{1424}$ Importantly, given the particular practical difficulties that

1416 UNHCR, Expert Meeting - Statelessness Determination Procedures and the Status of Stateless Persons - Summary Conclusions, Expert meeting convened by the Office of the United Nations High Commissioner for Refugees and the Open Society Justice Initiative, Geneva, Switzerland, 6-7 December 2010, para 22

1417 UNHCR, Expert Meeting - Statelessness Determination Procedures and the Status of Stateless Persons - Summary Conclusions, Expert meeting convened by the Office of the United Nations High Commissioner for Refugees and the Open Society Justice Initiative, Geneva, Switzerland, 6-7 December 2010, para 3

1418 UNHCR, Expert Meeting - Statelessness Determination Procedures and the Status of Stateless Persons - Summary Conclusions, Expert meeting convened by the Office of the United Nations High Commissioner for Refugees and the Open Society Justice Initiative, Geneva, Switzerland, 6-7 December 2010, para 29

1419 UNHCR, Guidelines on Statelessness No. 2: Procedures for Determining whether an Individual is a Stateless Person, HCR/GS/12/02, 5 April 2012, para 6

1420 UNHCR, Guidelines on Statelessness No. 2: Procedures for Determining whether an Individual is a Stateless Person, HCR/GS/12/02, 5 April 2012, para 11

1421 UNHCR, Guidelines on Statelessness No. 2: Procedures for Determining whether an Individual is a Stateless Person, HCR/GS/12/02, 5 April 2012, para 13

1422 UNHCR, Guidelines on Statelessness No. 2: Procedures for Determining whether an Individual is a Stateless Person, HCR/GS/12/02, 5 April 2012, para 14

1423 UNHCR, Guidelines on Statelessness No. 2: Procedures for Determining whether an Individual is a Stateless Person, HCR/GS/12/02, 5 April 2012, para 28

1424 UNHCR, Guidelines on Statelessness No. 2: Procedures for Determining whether an Individual is a Stateless Person, HCR/GS/12/02, 5 April 2012, para 29 
stateless persons encounter, the Guidelines advocate the sharing of the burden of proof between the stateless applicant and the State conducting the determination. ${ }^{1425}$ The Guidelines acknowledge the heightened risk of stateless persons to detention and calls for any such detention not to be arbitrary, to be used as a last resort only where less invasive or coercive means are insufficient, and for stateless persons not to be detained with convicted criminals or those on remand. ${ }^{1426}$

As mentioned in Chapter 4, Article 26 of the 1954 Convention on Statelessness provides that stateless persons lawfully within the territory of the Contracting State have the right to choose their place of residence and to move freely within its territory, subject to any regulations applicable to aliens generally in the same circumstances. "In the same circumstances" is further defined by Article 6 of the Convention to mean:

\begin{abstract}
"any requirements (including requirements as to length and conditions of sojourn or residence) which the particular individual would have to fulfil for the enjoyment of the right in question, if he were not a stateless person, must be fulfilled by him, with the exception of requirements which by the nature a stateless person is incapable of fulfilling".
\end{abstract}

However, there is an inherent difficulty in regularising the presence of stateless persons who may be lacking documentation and who, notwithstanding their long connection with the territory concerned, may be treated no better than aliens "in the same circumstances."

In the circumstances where a stateless person is outside his country of habitual residence and is seeking asylum in another country, then his status as a stateless person as a matter of fact should not distinguish him or herself from the rights to which other asylum seekers are entitled both upon physical presence and after regularisation (namely the right to remain and right to liberty after submission to a State's determination procedures).

\title{
5.1.3.4.2 Stateless Persons - Council of Europe ECHR
}

Although no specific provisions exist within the ECHR for the protection of stateless persons, the general provisions already discussed in this chapter are applicable to the situation of stateless persons. For stateless persons arriving with no documentation or identity documents, if enquiries are being made by authorities to establish the identity or verify purported statelessness, then a lack of due diligence in those enquiries can result in an initially lawful ground of

1425 UNHCR, Guidelines on Statelessness No. 2: Procedures for Determining whether an Individual is a Stateless Person, HCR/GS/12/02, 5 April 2012, para 37

1426 UNHCR, Guidelines on Statelessness No. 2: Procedures for Determining whether an Individual is a Stateless Person, HCR/GS/12/02, 5 April 2012, paras 59-62 
detention being rendered unlawful. ${ }^{1427}$

The Committee of Ministers' Recommendation Rec(2003)5 \& Twenty Guidelines on Forced Return

Although the Committee of Ministers' Recommendation Rec(2003)5 is silent on the issue of the detention of stateless asylum seekers, its Twenty Guidelines on Forced Returns makes specific provisions for stateless persons in the removal context. The Guidelines contemplate situations where the person becomes stateless after entry into the host State. The Guidelines provide that the State of origin may not arbitrarily deprive a person of his or her nationality where it would lead to statelessness, nor may the State of origin permit a renunciation of nationality where the resulting statelessness would then prevent the person's return. ${ }^{1428}$ Notwithstanding that that Guideline cannot be seen as coercive on states outside the Council of Europe, the commentary to that Guideline purports that the Guideline is not only consistent with calls upon States to adopt legislation to reduce statelessness ${ }^{1429}$ and international obligations imposed on States to reduce statelessness ${ }^{1430}$ but also aims to prevent any frustration of the right to enter one's own country under Article 12(4) ICCPR. ${ }^{1431}$ From a State-centric perspective, the Guideline arguably also seeks to avoid the frustration of the host State from returning a person who has renounced his or her nationality whilst under its jurisdiction.

If one considers the grounds for detention permissible under the UNHCR's ExCom 44, its Revised Guidelines, as well as the HRC's jurisprudence in relation to Article 9 ICCPR and the jurisprudence of the ECtHR in relation to Article 5(1)(f) ECHR as discussed above, it becomes clear that stateless persons are in a particularly vulnerable situation. In addition to not having a nationality, their vulnerability may also arise from not having identity papers or travel documents. Consequently, their detention may be ordered or prolonged on otherwise legitimate grounds which can easily last for protracted

\footnotetext{
1427 Although not involving a case of a stateless person in detention, analogous principles can be extracted from Mikolenko v Estonia, No. 10664/05, Judgment, 8 October 2009, where an initially lawful ground of detention under Article 5(1)(f) was rendered unlawful by virtue of the lack of due diligence of the authorities in pursuing enquiries with the origin State, thus leading to prolonged detention. On the lack of "due diligence" leading to a breach of Article 5(1)(f) see Singh v Czech Republic, No. 60538/00, Judgment, 25 January 2005, paras 61-68; Raza v Bulgaria, No. 31465/08, Judgment, 11 February 2010, paras 7175

1428 Guideline 14, Committee of Ministers, Council of Europe, Twenty Guidelines on Forced Return, CM(2005)40 Addendum final, Strasbourg, 20 May 2005

1429 United Nations General Assembly Resolution A/RES/50/152, 9 February 1996, http://www.un.org/documents/ga/res/50/ares50-152.htm (last accessed 12 October 2011), para 16 - see also para 15, and recital 9

1430 Such as the 1961 Convention on the Reduction of Statelessness and the 1997 European Convention on nationality

1431 Committee of Ministers, Council of Europe, Twenty Guidelines on Forced Return, CM(2005)40 Addendum final, Strasbourg, 20 May 2005, P.43
} 
or indefinite periods in circumstances outside their control - particularly if there is a lack of cooperation from the State of origin (say, in a return context), or a lack of due diligence in pursuing the purpose of the detention from the host State. Accordingly, it is highly desirable that potentially stateless asylum seekers are subject to an early process to identify them as stateless. The Equal Rights Trust has recommended that, inter alia, any such process be "efficient, effective, fair and accessible", and compliant with UNHCR Guidance, ${ }^{1432}$ before being detained. ${ }^{1433}$ The Equal Rights Trust has indicated that factors such as a State's failure to provide diplomatic or consular protection, "the lack of a practical route of return" or "the inability to guarantee safe return" should be factors that determination procedures should take into account. ${ }^{1434}$ By early and systematic identification, the likelihood of arbitrary detention can be reduced by considering the status of a person as stateless in any evaluation of the proportionality of a decision to detain.

\subsection{European Union Secondary Legislation}

\subsubsection{At the External Borders}

As outlined in Chapter 2, the European Union does not adopt a universal visa regime. However, a third country national wishing to enter a Member State at the external frontiers of the Union is not necessarily guaranteed a right of entry per se on the basis of holding a valid visa (or being exempt from the requirement to hold one). In this regard, the Schengen Borders Code determines that entry into a Member State is based on five conditions (only one of which relates to holding a valid visa) for stays not exceeding three months in a six month period: the person firstly, must hold valid travel documents or documents authorising the crossing of the border; secondly, unless he or she is a national which is exempt from the requirement of holding a visa to cross the external border (as discussed in Chapter $2^{1435}$ ), must hold a valid visa; thirdly, must justify his or her reasons for stay, have sufficient resources for subsistence (for his or her stay and return to the country of origin); fourthly, is not the subject of a Schengen Information System ("SIS") Alert for refusal of entry; fifthly, must not be a threat to "pubic policy, public security, public health or the international relations of any of the Member States". ${ }^{1436}$ The Schengen Borders Code is said to apply without prejudice to

\footnotetext{
1432 Equal Rights Trust, Guidelines on the Detention of Stateless Persons, 2011, Guideline 19

1433 Equal Rights Trust, Guidelines on the Detention of Stateless Persons, 2011, Guideline 22

1434 Equal Rights Trust, Guidelines on the Detention of Stateless Persons, 2011, Guideline 20

1435 Council Regulation (EC) 539/2001 of 15 March 2001 listing the third countries whose nationals must be in possession of visas when crossing the external borders and those whose nationals are exempt from that requirement - note further amendments to this Regulation in which both lists of countries is updated

1436 Article 5(1) of Regulation 562/2006 of 15 March 2006 establishing a Community Code on the rules governing the movement of persons across borders (Schengen Borders
} 
"the rights of refugees and persons requesting international protection, in particular as regards non-refoulement". ${ }^{1437}$

It is possible for a visa to be issued at the border if the person satisfies all of the conditions discussed above (other than having a valid visa). ${ }^{1438}$ Curiously, that authorisation applies "to enter the territories of the Member States" [emphasis added]. A Member State may also authorise a person "to enter its territory [emphasis added] on humanitarian grounds, on grounds of national interest or because of international obligations" if a person does not fulfil one or more of the five conditions outlined above. ${ }^{1439}$ Accordingly, one can see that asylum seekers may be the subject of a number of juridical hurdles: they may be a national of a country who is required to have a visa for the crossing of an external Union border or they may lack travel documents. But even if they do hold such a visa, or have travel documents, their impecuniosity, their (understandable and justified) lack of intention to return to their country of origin or other justification for stay in a Member State may all result in the refusal of entry with only a Member State's discretion allowing them entry. ${ }^{140}$ The consequence of failing to meet the conditions of the Schengen Borders Code is that the person becomes an 'illegally staying third country national' ${ }^{1441}$ and thus subject to a mandatory return decision under the Returns Directive $^{1442}$ (unless the Member State either decides to exercise its discretion for the Directive not to apply to the person ${ }^{1443}$ or another exception to the issue of a return decision under the Directive applies ${ }^{1444}$ ) (discussed below). By falling under the Returns Directive, there is the risk that the person may be detained for the purpose of removal. ${ }^{145}$ Accordingly, the asylum seeker's initial contact with the Member State's officials and screening-in process becomes of vital importance in light of the risk of refoulement.

Code). Note also the non-exhaustive list of documents which may be requested to evidence reasons for stay and subsistence - Article 5(2) and Annexure I to the Schengen Borders Code

1437 Article 3(b) of the Schengen Borders Code

1438 Article 5(4)(b) of the Schengen Borders Code; Regulation 415/2003 of 27 February 2003 on the issue of visas at the border, including the issue of such visas to seamen in transit (in particular, Article 1 thereof)

1439 Article 5(4)(c) Regulation 562/2006 of the Schengen Borders Code; see also Article 6(4) of Directive 2008/115/EC of 16 December 2007 on common standards and procedures in Member States for returning illegally-staying third country nationals ("the Returns Directive")

1440 Article 13 of the Schengen Borders Code

1441 Article 3(2) and 3(1) of the Returns Directive

1442 Article 6(1) of the Returns Directive

1443 Article 2(2) of the Returns Directive

1444 Article 6(2)-(5) of the Returns Directive

1445 Chapter IV of the Returns Directive 


\subsubsection{Inter-relationship between European Union secondary legislation contemplating detention}

It is first necessary to discuss briefly the interrelationship between each of the pieces of Union secondary legislation that contemplate the detention of asylum seekers.

The Procedures Directive is determinative of an asylum seeker's right to remain pending the determination of his or her application for asylum. Where there is a right to remain, the Reception Conditions Directive provides a qualified right to free movement and is largely responsible for determining any restrictions of liberty on asylum seekers. Where the right to remain is lost, the Procedures Directive contemplates detention (but which falls to Member State competence) or, if a negative decision on the asylum application has entered into force, the asylum seeker may be subject to a return decision and possible detention under the Returns Directive (unless the Member State does not apply the Directive to the person or the person falls under an exception of the Directive). Detention has occurred in connection with transfers of those asylum seekers or rejected asylum seekers who are in a Member State other than the one in which they first sought asylum and who are to be removed back to the Member State of first asylum in accordance with the hierarchy set out in the Dublin II Regulation, even if this Regulation is silent on detention.

Accordingly, the (albeit qualified) right to liberty is closely linked with an asylum seeker's right to remain in the territory of the Member State in which he or she sought asylum.

Two procedures are contemplated under the Procedures Directive: the 'regular procedure' and the 'border procedure'. The border procedures can effectively amount to detention at the border with reduced guarantees for asylum seekers. The elements of that procedure will be examined subsequent to any discussion of the regular procedure so as to highlight the possible derogations.

\subsubsection{The Right to Remain}

\section{The Personal Scope of the Procedures Directive}

As the Procedures Directive is determinative of an asylum seeker's right to remain pending the determination of his or her application for asylum, the personal scope of the legislation must first be explored. 
The scope of the Procedures Directive is enlivened by the making of an application for asylum. ${ }^{1446}$ Although that may be seemingly uncontentious, it presents problems in at least two particular instances.

\section{Personal Scope of the Procedures Directive - Consequences for Minors}

Firstly, minors: Member States may decide that minors do not have the ability to make an application on their own behalf, or require a representative (which does not necessarily mean a legal guardian ${ }^{1447}$ ) to do so in the case of unaccompanied minors, or deem the unmarried minors of an asylum seeker to have made an application at the time that the asylum seeker has lodged his or her application. ${ }^{1448}$ In the case of unaccompanied minors, notwithstanding that Member States are required to appoint a representative as soon as possible, ${ }^{1449}$ Member States are also given considerable discretion as to when a representative may be appointed. ${ }^{1450}$ In order to fully embrace the protection provided by Articles 20(1) and 22(1) CROC, as well as the right to asylum enshrined in Article 18 of the EU Charter, it would be advisable if Member States were compelled to provide legal guardianship of unaccompanied minors, as well as ensuring that minors have full access to asylum procedures. Such access is also important for the regularisation of the minor's stay under the EU secondary legislation and consistent with the manner contemplated under the Geneva Convention.

\section{Personal Scope of the Procedures Directive - Consequences for Family Members}

Secondly, family members are not expressly included in the scope of the Directive $^{1451}$ and Member States have the discretion to allow an applicant to make an application on behalf of his or her dependants, ${ }^{1452}$ but it would appear that such dependants should have an individual basis for doing so. ${ }^{1453}$ By not being included within the scope of the Directive, and thus not enjoying the right to remain as does the chief applicant for asylum, there is a significant risk that arbitrary interference with an applicant's family will result (as contemplated by Articles 17(1) and 23(1) ICCPR and the HRC jurisprudence) if accompanying family members are removed from the

\footnotetext{
1446 Article 3(1) and 2(b) of the Procedures Directive

1447 "Representative" is defined as "a person acting on behalf of an organisation, representing an unaccompanied minor as legal guardian, a person acting on behalf of a national organisation which is responsible for the care and well-being of minors, or any other appropriate representation appointed to ensure his or her best interests" - Article 2(i) of the Procedures Directive

1448 Article 6(4)(a), (b) and (c) of the Procedures Directive

1449 Article 17(1)(a) of the Procedures Directive

1450 Article 17(2) of the Procedures Directive

1451 See Article 3(1) and 2(b) of the Procedures Directive

1452 Article 6(3) of the Procedures Directive

1453 As indicated by "failing which [that is, if the dependents do not consent to an application made on their behalf by the applicant] they shall have an opportunity to make an application on their own behalf [emphasis added]", Article 6(3) of the Procedures Directive
} 
territory of asylum and where such a measure would be contrary to the provisions, aims and objectives of the ICCPR and would be unreasonable in the particular circumstances of the case.

\subsubsection{The Right to Remain - The Regular Procedure}

If the asylum seeker falls within the personal scope of the Procedures Directive, then attention must turn to the right to remain provision in Article 7(1) of the Directive:

"1. Applicants shall be allowed to remain in the Member State, for the sole purpose of the procedure, until the determining authority has made a decision in accordance with the procedures at first instance set out in Chapter III. This right to remain shall not constitute a residence permit"

Express exceptions to the right to remain are set out in Article 7(2):

"Member States can make an exception only where, in accordance with Articles 32 and 34, a subsequent application will not be further examined or where they will surrender or extradite, as appropriate, a person either to another Member State pursuant to obligations in accordance with a European arrest warrant or otherwise, or to a third country, or to international criminal courts or tribunals."

"Applicant" is defined as:

"a third country national or stateless person who has made an application for asylum in respect of which a final decision has not yet been taken"1454

"Final decision" is defined as:

"a decision on whether the third country national or stateless person be granted refugee status by virtue of Directive 2004/83/EC and which is no longer subject to a remedy within the framework of Chapter $\mathrm{V}$ of this Directive irrespective of whether such a remedy has the effect of allowing applicants to remain in the Member States concerned pending its outcome, subject to Annex III to this Directive" 1455

"Remain in the Member State" is defined as:

"to remain in the territory, including at the border or in transit zones, of the Member State in which the application for asylum has been made or is being examined" 1456

"Determining authority" is defined as:

1454 Article 2(c) of the Procedures Directive

1455 Article 2(d) of the Procedures Directive

1456 Article 2(k) of the Procedures Directive 
"any quasi-judicial or administrative body in a Member State responsible for examining applications for asylum and competent to take decisions at first instance in such cases, subject to Annex I" 1457

The salient points to note are firstly, that the right to remain is only for the purpose of the determination procedure; secondly, that the right to remain does not constitute a residence permit; and thirdly, notwithstanding that an asylum seeker may still have an application on foot beyond a Chapter III first instance decision (that is, exercising his or her right to an effective remedy under Chapter $\mathrm{V}$ of the Directive), his or her right to remain is only guaranteed until a first instance decision has been made. That position is also reflected in Article 39(3)(a) of the Directive which gives Member States the discretion "in accordance with their international obligations" as to whether an applicant be permitted to remain in its territory pending the outcome of the appeal. Accordingly, it is contemplated that an applicant may be removed from the Member State even when the decision about their appeal has not yet been made.

At the most fundamental level, the truncation of the right to remain after a first instance decision has been made and particularly where a substantive examination of the application has not occurred generates a significant risk of refoulement contrary to Article 33 of the Geneva Convention and Article 3 ECHR. If looked through the prism of the Geneva Convention, the stay of an applicant who appeals a first instance decision, and which can thus be seen as an extended submission to the refugee status determination procedure, is still regular and lawful within the meaning of the Geneva Convention. Accordingly, expulsion from the territory is only possible on the grounds of national security or public order in accordance with Article 32(1) of the Convention, and in accordance with "due process". Similarly, Article 13 ICCPR may also be breached if there is no compliance with the procedural safeguards contemplated in that Article. Further, the removal of an asylum seeker pending the outcome of an appeal of their first instance decision would amount to the denial of an effective remedy by breaching Articles 3 and 13 ECHR, as well as running contrary to the principle of effectiveness and a possible breach of Articles 19(2) and 47 of the EU Charter. ${ }^{1458}$

An ambiguity surrounding the right to remain arises in the event of either an explicit $^{1459}$ or implicit ${ }^{1460}$ withdrawal of the asylum seeker's application. Under Article 7(1), the determining authority is required to make a decision to either

\footnotetext{
1457 Article 2(e) of the Procedures Directive

1458 For an excellent discussion of that proposition, see Reneman, M, An EU Right to Interim Protection during Appeal Proceedings in Asylum Cases? (2010) 12 European Journal of Migration and Law 407

1459 Article 19 of the Procedures Directive

1460 Article 20 of the Procedures Directive
} 
discontinue the examination or reject the application. ${ }^{1461}$ However, it is ambiguous whether the right to remain is extinguished on the making of such a decision, as the decision of the determining authority in the case of explicit or implicit withdrawal of an application is not made in accordance with the procedures at first instance set out in Chapter III of the Directive but, rather, under Chapter II of the Directive. Accordingly, an asylum seeker's implicit or explicit withdrawal of their application places them in a precarious and, at the same time, ambiguous position regarding their right to remain and in circumstances where (in the case of implicit withdrawal) the substance of their application may not have been dealt with.

Under Article 7(2), the exceptions to the right to remain are limited to surrender or extradition - concepts which do not import any discretion of the Member State to send, remove or deport (in a juridical sense) an applicant to a third country. Articles 32 and 34 deal with subsequent applications (including after withdrawal or abandonment ${ }^{1462}$ ) and the procedural rules that are to be followed in those circumstances. Asylum seekers who have made an application in one Member State, but left that Member State and lodged an application in another Member State, but have then been subject to a Dublin transfer back to the first Member State, are in a particularly precarious position - an arguable construction of their behaviour in the context of Article 20 is that their subsequent application in the first Member State will be dealt in accordance with Articles 32 and 34 and, thus, not be entitled to the right to remain. Accordingly, not only do such asylum seekers not enjoy the right to liberty under the Reception Conditions Directive, but they may be liable to removal without the substance of their application having been dealt with by either the first or second Member State. ${ }^{1463}$ Such a measure would be contrary to the obligation in Article 3(1) of the Dublin II Regulation that asylum applications "shall be examined by a single Member State". Indeed, such a measure could potentially amount to refoulement contrary to Article 33 of the Geneva Convention, as well as a denial of an effective remedy in breach of Articles 3 and 13 ECHR. Similarly, such a measure would amount to a breach of the principle of effectiveness and of Articles 19(2) and 47 of the EU Charter.

\subsection{The Right to Remain - The Regular Procedure - The Proposed Legislation}

The Commission's 2011 Proposed Procedures Directive remains, in the suite of proposed secondary legislation, determinative of the right to remain

\footnotetext{
1461 Articles 19(1) and 20(1) of the Procedures Directive

1462 Article $32(2)(\mathrm{a})$ of the Procedures Directive referring to the withdrawal or abandonment of a previous application by virtue of Articles 19 or 20 of the Procedures Directive

1463 See further, ECRE, Information Note on the Council Directive 2005/85/EC of 1 December 2005 on minimum standards on procedures in Member States for granting and withdrawing refugee status, October 2006, IN1/10/2006/EXT/JJ www.ecre.org/component/downloads/ downloads/87.html (last accessed 18 October 2011), Pp. 9-10, 18-20
} 
pending the determination of an application for international protection (formerly, asylum).

The scope of the 2011 Proposal remains largely unchanged from the current Procedures Directive in that it is enlivened by making an application for international protection. ${ }^{1464}$

\section{Scope - Minors}

The position of minors to make an application, and thus fall within the scope of the Directive, has been significantly improved under the Commission's 2011 Proposal. Notwithstanding that Member States still retain the discretion to determine the circumstances in which a minor or an unaccompanied minor may make an application on his/her own behalf, ${ }^{1465}$ Member States are now required to ensure that the minor has a right to make an application - if not through his or her own legal capacity as provided for in national legislation, then either through parents or other adult family members, a responsible adult, or a representative. ${ }^{1466}$ In relation to unaccompanied minors, Member States are still obliged to ensure that a representative is appointed as soon as possible, ${ }^{1467}$ but it is of concern that the reference in the Commission's 2009 Proposal to an "impartial" representative ${ }^{1468}$ has been removed in the 2011 Proposal and which raises a serious concern that the best interests of the child may not be served if the detaining authority (that is, the Member State government or its agencies) is also the legal guardian of the child. Further, a Member State may choose not to appoint a representative where the applicant will most likely reach 18 years of age before a first instance decision is given. ${ }^{1469}$ Although that represents a significant improvement over the current legislation, it would be desirable to remove that discretion entirely to avoid any chance that an unaccompanied minor is denied access to the procedure if he or she is otherwise prevented from making an application - which, if he/she remains outside the scope of the Directive, is not afforded any right to remain in the Member State. Accordingly, those amendments should be made to ensure a full embrace of Articles 20(1) and 22 CROC.

\footnotetext{
1464 Article 3(1) of the Commission's 2011 Proposed Procedures Directive 1465 Article 7(5) of the Commission's 2011 Proposed Procedures Directive 1466 Article 7(3) of the Commission's 2011 Proposed Procedures Directive. "Representative" is defined as "a person or an organisation appointed by the competent bodies to act as a legal guardian in order to assist and represent an unaccompanied minor in procedures provided for in this Directive with a view to ensuring the child's best interests and exercising legal capacity for the minor where necessary. Where an organisation acts as a representative, it shall appoint a person responsible for carrying out the duties of the legal guardian in respect of the minor, in accordance of this Directive": Article 2(n) of the Commission's 2011 Proposed Procedures Directive

1467 Article 25(1)(a) of the Commission's 2011 Proposed Procedures Directive

1468 See Article 21(1)(a) of the Commission's 2011 Procedures Directive I

1469 Article 25(2) of the Commission's 2011 Proposed Procedures Directive
} 
Scope - Family Members

Family members remain outside the scope of the 2011 Proposal $^{1470}$ and Member States retain the discretion to allow an applicant to make an application on behalf of his or her dependants, apparently including that such dependants should still have an individual basis for doing so. ${ }^{1471}$

\section{The Right to Remain - Generally}

The substantive right to remain in a Member State remains unchanged from the current legislation in that it provides that the right to remain up until a first instance decision in accordance with Chapter III has been made, ${ }^{1472}$ as do the express exceptions to the right to remain. ${ }^{1473} \mathrm{~A}$ significant safeguard has been introduced in that Member States may not extradite the applicant to his or her country of origin ${ }^{1474}$ or, in the case of extradition to a third country, "where the competent authorities are satisfied that" it would not result in direct or indirect refoulement of the applicant. ${ }^{1475}$ The absolute nature of the prohibition against refoulement should be strengthened, as ECRE has suggested, by the removal of the words "the competent authorities are satisfied that". ${ }^{1476}$

\section{Exceptions to Right to Remain}

Exceptions to the right to remain also continue to apply to those who have made subsequent applications. ${ }^{1477}$ Member States are given the discretion to make an exception to the right to remain, adopt an accelerated examination procedure, or derogate from normal time limits applicable to admissibility procedures. ${ }^{1478}$ The rejection or inadmissibility of a subsequent application is dealt with in Article 40(5). Article 40(7) provides expressly that the further representations or the subsequent application of a person who has been the subject of a Dublin Transfer (where those further representations or subsequent application has been made in that Member State) in the Member State must be examined by the receiving Member State. However, the linking of the right to remain to such persons by virtue of Article 41 remains ambiguous or possibly doubtful. ${ }^{1479}$

\footnotetext{
1470 See Article 3(1) and 2(b) of the Commission's 2011 Proposed Procedures Directive 1471 Article 7(2) of the Commission's 2011 Proposed Procedures Directive

1472 Article 9(1) together with Articles 2(c), (e), (f), (p) of the Commission's Recast Procedures Directive

1473 Article 9(2) of the Commission's 2011 Proposed Procedures Directive

1474 Article 9(2) of the Commission's 2011 Proposed Procedures Directive

1475 Article 9(3) of the Commission's 2011 Proposed Procedures Directive

1476 ECRE, Comments from the European Council on Refugees and Exiles on the European Commission Proposal to recast the Asylum Procedures Directive, May 2010, Pp.15-16

1477 Articles 9(2) and 41 of the Commission's 2011 Proposed Procedures Directive

1478 Article 41 of the Commission's 2011 Proposed Procedures Directive

${ }^{1479}$ For further commentary see ECRE, Comments from the European Council on Refugees an Exiles on the Amended Commission Proposal to recast the Asylum Procedures Directive (COM(2011) 319 final) at Pp.32-34
} 


\section{The Dual System of Suspensive Effect}

The Commission's 2011 Proposal establishes a dual system for the suspensive effect of an appeal. Firstly, in relation to 'regular' appeals of a first instance decision, the 2011 Proposal gives applicants the right to remain in the territory of a Member State until the time limit for making the appeal has expired. ${ }^{1480}$ If the right to an appeal has been exercised within the time limit, then the applicant has a right to remain pending the outcome of the appeal. ${ }^{1481}$ This is reflective of the right to an effective remedy consistent with both ECHR and CJEU jurisprudence.

The second nature of appeals are if Member State legislation has not provided a right to remain in the case of a decision to consider an application unfounded (as part of accelerated procedures) ${ }^{1482}$ or inadmissible ${ }^{1483}$ then a court or tribunal must have the power to rule upon whether the applicant has the right to remain, either on its own motion or at the applicant's request. ${ }^{1484}$ Accordingly, there is no automatic suspensive effect. The applicant retains the right to remain up until the court or tribunal has determined that request to remain. ${ }^{1485}$ As noted by ECRE, it is of concern that those subject to accelerated procedures are not subject to automatic suspensive effect where the initial review of the matter is concerned only with the right to remain, and where the independent and rigorous scrutiny contemplated in the ECtHR jurisprudence surrounding Articles 3 and 13 ECHR would not be carried out until some later time - with potentially grave consequences if an applicant is subsequently found, upon deeper scrutiny, to require international protection. ${ }^{1486}$ Further, the CJEU in Diouf, made no distinction as to accelerated or 'regular' procedures in holding that a person has a right to an effective remedy. ${ }^{1487}$ In relation to those inadmissible applications, one such circumstance includes those applicants who have already been granted refugee status by another Member State. As noted by ECRE, no mutual recognition of refugee decisions applies within the Union and which, in light of the difficulties of some applicants in exercising the rights ascribed to them in the Qualification Directive, should warrant independent and rigorous scrutiny

\footnotetext{
1480 Article 46(5) of the Commission's 2011 Proposed Procedures Directive

1481 Article 46(5) of the Commission's 2011 Proposed Procedures Directive

1482 Article 31(6)(a) to (g) of the Commission's Recast Proposed Procedures Directive

1483 Article 33(2)(a) to (d) in relation to inadmissible applications

1484 Article 46(6) of the Commission's Recast Proposed Procedures Directive

1485 Article 46(7) of the Commission's Recast Proposed Procedures Directive

1486 ECRE, Comments from the European Council on Refugees and Exiles on the Amended Commission Proposal to Recast the Asylum Procedures Directive COM(2011) 319 final, September 2011, Pp.36-37. See also, in relation to accelerated procedures I.M. $v$ France, No. 9152/09, Judgment, 2 February 2012

1487 Case C-69/10, Brahim Samba Diouf v Ministre du Travail, de l'Emploi et de l'Immigration, Judgment, 28 July 2011, para 61.
} 
before their right to remain is denied on that basis ${ }^{1488}$ - particularly in light of the ECtHR's rulings in $M_{S S}^{1489}$ as well as the CJEU's decision in N.S. ${ }^{1490}$ Accordingly, ECRE has justifiably called for the fusion of the assessment of the right to remain and the substantive assessment of the applicant's appeal. ${ }^{1491}$

\subsubsection{The Right to Remain - The Border Procedure}

The Procedures Directive gives discretion to Member States to apply special procedures for applicants who make a claim for asylum at the border. ${ }^{1492}$ If applied, these special procedures are to ensure the same principles and guarantees as set out in Chapter II of the Directive as they relate to the regular procedure (including, inter alia, the right to remain and the prohibition against detaining a person for the sole reason that a person is an asylum seeker) ${ }^{1493}$ However, Member States are also given the possibility to maintain their own provisions in place as at 1 December 2005 that derogate from the principles and guarantees ensured by Chapter II of the Directive. ${ }^{1494}$ Although certain guarantees are said to be ensured (including the right to remain), ${ }^{1495}$ they are effectively undermined by an express provision for Member States to derogate from them ${ }^{1496}$ - rendering such guarantees worthless. The gravity of that derogation is also underscored by the fact that the specific guarantees to be derogated from are not identified. ${ }^{1497}$ Due to a decision on the substantive application being held at the border or in transit zones, ${ }^{1498}$ it may well be that detention occurs as a question of fact as highlighted by the ECtHR in Amuur.

The provisions on border procedures accordingly affect the right to remain in the territory of the Member State of asylum in at least two ways. Firstly, the right to remain in the territory of the Member State pending the determination of the application is not sacrosanct from derogation. Secondly, the determining authority of the application is not necessarily the responsible authority, ${ }^{1499}$ which effectively means that a border guard may be capable of

\footnotetext{
1488 ECRE, Comments from the European Council on Refugees and Exiles on the Amended Commission Proposal to Recast the Asylum Procedures Directive (COM(2011) 319 final, September 2011, P.36

1489 M.S.S. v Belgium and Greece, No. 30696/09, Judgment, 21 January 2011 at para 393

1490 Cases C-411/10 and C-493/10 N.S. v Secretary of State for the Home Department and M.

E. and Others $v$ Refugee Applications Commissioner and Minister for Justice, Equality and Law Reform, 21 December 2011, Judgment Grand Chamber

1491 ECRE, Comments from the European Council on Refugees and Exiles on the Amended Commission Proposal to Recast the Asylum Procedures Directive (COM(2011) 319 final, September 2011, Pp.37-38

1492 Article 35 of the Procedures Directive

1493 Article 35(1) of the Procedures Directive

1494 Article 35(2) of the Procedures Directive

1495 Article 35(3) of the Procedures Directive

1496 Article 24(1)(b) of the Procedures Directive

1497 See Article 24(1)(b) of the Procedures Directive

1498 Article 35(1) of the Procedures Directive

1499 Article 4(2)(d) and (e) of the Procedures Directive
} 
determining the entire substantive application ${ }^{1500}$ without the guarantees that normally apply to those examining applications such as individual, impartial, objective taking of decisions ${ }^{1501}$ or that such personnel have "the knowledge with respect to relevant standards applicable in the field of asylum and refugee law". ${ }^{1502}$ Accordingly, the cumulative effect of these two elements gives no certainty of a right to remain and a perfunctory or less than rigorous examination of an asylum claim significantly increases the risk of refoulement. As discussed earlier in relation to the regular procedure, the right to an effective remedy after a negative first instance decision does not give rise to automatic suspensive effect, which, particularly for those subject to border procedures, provides inadequate safeguards against refoulement and the possibility of removal from the Member State before a close and rigorous examination of the application has taken place. As border procedures are a matter of Member State competence, it is only the protection afforded by Articles 3 and 13 ECHR and the ICCPR through which an asylum seeker in this situation may draw some comfort.

If a decision on the application is not made within four weeks, the asylum seeker is to be granted entry to the country and to have his or her application determined in accordance with the regular procedure. ${ }^{1503}$ Accordingly, submission to the regular procedure ensures the application of the suite of guarantees provided by Chapter II of the Directive, including the right to remain (as discussed earlier).

\subsection{The Right to Remain - The Border Procedure - The Proposed Legislation}

The Commission's 2011 Proposed Procedures Directive makes a significant change to the current Procedures Directive in that border applicants are, generally, not subject to derogations of guarantees provided for in Chapter II of the Directive ${ }^{1504}$ - so the normal provisions regarding the right to remain would also apply to border applicants. Member States are given the discretion to decide on the admissibility of applications ${ }^{1505}$ and the substance of applications that are subject to an accelerated procedure. ${ }^{1506}$ Again, if a decision has not been made within four weeks, then the applicant is to be granted entry into the territory of the Member State and be subject to the regular procedure. ${ }^{1507}$

\footnotetext{
1500 Spijkerboer, T, and Arbaoui, Y, in Hailbronner, K, (ed), EU Immigration and Asylum Law - Commentary on EU Regulations and Directives, 2010, Beck, München, Pp.1227-1350 at P.1301

1501 Article 8(2)(a) of the Procedures Directive

1502 Article 8(2)(c) of the Procedures Directive

1503 Article 35(4) of the Procedures Directive

1504 Article 43 of the Commission's 2011 Proposed Procedures Directive

1505 Article 43(1)(a) and Article 33 of the Commission's 2011 Proposed Procedures Directive

1506 Article 43(1)(b) of the Commission's Recast 2011 Procedures Directive

1507 Article 43(2) of the Commission's 2011 Proposed Procedures Directive)
} 
However, Member State discretion as to maintaining a distinction between the determining authority and the responsible authority still exists in the Proposed Directive but whose decisions on granting or refusing to enter are now also "on the basis of the opinion of the determining authority." ${ }^{1508}$ As ECRE notes, this still effectively means that the persons deciding such border applications are not subject to the same level of training as the determining authority and that the opinion of the determining authority is not made binding on the decision maker. ${ }^{1509}$

In relation to suspensive effect, the 2011 Proposed Directive gives Member States the discretion to provide for ex officio reviews of decisions subject to border procedures. ${ }^{1510}$ Although no express provision is made for suspensive effect pending that review, it is arguable that suspensive effect occurs in the same way as the regular procedure as Article 46(6) expressly precludes border procedure decisions from the bi-furcated procedure (that is, determining the right to remain and the substantive application separately). Accordingly, it would appear that the right to remain exists up until either the period in which to exercise the right to an effective remedy expires, or up until the outcome of the remedy. ${ }^{1511}$

\subsubsection{The Right to Liberty}

\subsubsection{The Right to Liberty - The Regular Procedure}

The Reception Conditions Directive is largely responsible for determining the right to liberty for those asylum seekers that have the right to remain as asylum seekers.

\section{Personal Scope of the Reception Conditions Directive}

The personal scope of the Directive ${ }^{1512}$ is enlivened (1) by a third country national or stateless person; (2) making an application for asylum ${ }^{1513}$ at the border or in the territory of a Member State; (3) "as long as they are allowed to remain on the territory as asylum seekers". ${ }^{1514}$ The personal scope is also extended to family members ${ }^{1515}$ but "only if they are covered by such

\footnotetext{
1508 Article 4(2)(b) of the Commission's 2011 Proposed Procedures Directive

${ }^{1509}$ ECRE, Comments from the European Council on Refugees and Exiles on the Amended Commission Proposal to recast the Asylum Procedures Directive (COM(2011) 319 final), September 2011, Brussels, Pp.6-8.

1510 Article 46(4) the Commission's 2011 Proposed Procedures Directive

1511 Article 46(5) the Commission's 2011 Proposed Procedures Directive

1512 Article 3(1) of the Reception Conditions Directive

1513 As defined in Article 2(b) of the Reception Conditions Directive

1514 "Asylum seeker" is defined as "a third country national or a stateless person who has made an application for asylum in respect of which a final decision has not yet been taken": Article2(c) of the Reception Conditions Directive

1515 As defined in Article 2(d) of the Reception Conditions Directive
} 
application for asylum according to the national law". ${ }^{1516}$ Accordingly, Member States retain the discretion as to whether family members are included in the applicant's asylum application and that fact will be determinative of whether those family members fall within the scope of the Directive.

Although "allowed to remain on the territory as asylum seekers" is not defined within the Directive, it is arguable that it is referable to the right to remain conferred by the Procedures Directive. It also presents problems for those who have left the Member State of first application and have travelled to a second Member State and made an application for asylum there.

Article 8 of the Reception Conditions Directive provides that Member States are to maintain family unity "as present within their territory, if applicants are provided with housing by the Member State concerned." There are two concerns: firstly, the maintenance of family unity is only possible where Member States have provided housing. Secondly, it is possible that family members who do not have an individual basis for making an application for asylum, and thus do not make such an application under the Procedures Directive (with no consequent right to remain) or that family members who are not covered by the primary applicant's application for asylum under the law of the Member State potentially fall outside the scope of the Reception Conditions Directive. Consequently, such family members are not only not entitled to the material reception conditions provided by the Directive, but also cannot enjoy the right to liberty as provided for by the Directive. Such family members also run the risk of falling within the scope of the Returns Directive (which will be discussed later). Accordingly, bearing in mind the jurisprudence of the HRC in Bakhtiyari, ${ }^{1517}$ scope exists for a possible breach of Articles 17 and 23 ICCPR. It would be preferable for family members of an applicant to fall expressly within the scope of the Directive and that the accommodation of family members is expressly provided for within the Directive.

\section{The Right to Liberty}

As discussed in Chapter 4, Article 7 of the Reception Conditions Directive provides a gradation of liberty - from free movement, to a restriction upon liberty, to a deprivation of liberty. In relation to the right to liberty, Article 7(1) provides:

\footnotetext{
"Asylum seekers may move freely within the territory of the host Member State or within an area assigned to them by that Member State. The assigned area shall not affect the unalienable sphere of private life and shall allow sufficient scope for guaranteeing access to all benefits under this Directive"
}

\footnotetext{
1516 Article 3(1) of the Reception Conditions Directive

1517 Bakhtiyari v Australia, UN Human Rights Committee Communication No 1069/2002, CCPR/C/79/D/1069/2002, 29 October 2003, para 9.6.
} 
Accordingly, the right to liberty may be seen as quite vapid. It is easily qualified by the restriction to "an assigned area". Member States must allow the possibility for granting temporary permission to leave the assigned area, with decisions taken "individually, objectively, and impartially" with reasons given if the decision is negative. ${ }^{1518}$

\subsection{The Right to Liberty - The Regular Procedure - The Proposed Legislation} The right to liberty under the Commission's 2011 Proposed Reception Conditions Directive ${ }^{1519}$ remains essentially unchanged from the current legislation, as it does under the Council's Amended Proposed Reception Conditions Directive. ${ }^{1520}$

\subsubsection{The Right to Liberty - The Border Procedure}

As discussed earlier, it remains within the discretion of the Member State as to whether the right to remain is derogated from in the context of border procedures. It is arguable that, if a Member State has granted a right to remain on its territory pending the determination of an application for asylum made at the border, then the right to liberty granted under the Reception Conditions Directive should also apply as the Reception Conditions Directive makes no distinction between the right to remain emanating from the border procedure and the regular procedures. Indeed the scope of the Reception Conditions Directive expressly contemplates applications made at the border, but unlike the Procedures Directive, it does not include applications made in transit zones. ${ }^{1521}$

However, as indicated earlier, the vague terminology of the right to liberty enunciated in Article 7 of the Reception Conditions Directive makes it very difficult to determine, as a question of law, where liberty changes to restriction on liberty and then to a deprivation of liberty, especially where Article 7(1) refers to Member States' ability to keep asylum seekers in an "assigned area". Accordingly, it is arguable that there is very weak protection for border applicants' right to liberty under the secondary legislation, and where the jurisprudence of the ECtHR surrounding Article 5(1)(f) ECHR (namely, Saadi and Chahal) provides little comfort.

\subsection{The Right to Liberty - The Border Procedure - The Proposed Legislation}

Given that, under the Commission's 2011 Proposed Procedures Directive, the right to remain is no longer able to be derogated from (see above discussion), it still remains arguable that the right to liberty in the Commission's 2011 Proposed Reception Conditions Directive and the Council's Amendments to

\footnotetext{
1518 Article 7(5) of the Reception Conditions Directive

1519 Article 7(1) of the Commission's 2011 Proposed Reception Conditions Directive

1520 Article 7(1) of the Council's Amended Proposed Reception Conditions Directive

${ }^{1521}$ Article 3(1) of the Reception Conditions Directive
} 
the Recast Proposed Reception Conditions Directive should apply to asylum seekers in these circumstances as the scope of both versions of the Proposed Reception Conditions Directive now expressly includes applications made in transit zones as well as at the border. ${ }^{1522}$ However, that right to liberty is again weakened by the vague terminology surrounding the residence and free movement provisions, ${ }^{1523}$ as well as the fact that a ground of detention now exists regarding the right to enter the territory. ${ }^{1524}$

\subsubsection{Grounds for Detention if the Right to Remain exists}

\subsubsection{Grounds for Detention if the Right to Remain exists - The Regular Procedure} If the right to remain exists, then an asylum seeker may be detained under the Reception Conditions Directive. The Procedures Directive may also have some bearing on the grounds of detention.

As discussed in Chapter 4, the restrictions and deprivations of liberty contemplated in the Reception Conditions Directive are vague in their terminology and allow Member States a wide discretion in their interpretation. ${ }^{1525}$ As any deprivation of liberty runs along a continuum of degree and intensity, and whose effects are cumulative, it will remain largely a question of fact as to whether an asylum seeker is deprived of their liberty under the provisions in the Reception Conditions Directive.

The first ground may include restriction to an "assigned area" (as identified in the discussion on the right to liberty). ${ }^{1526}$ In this sense, it is worth recalling that, in Guzzardi, a deprivation of liberty occurred as a result of compulsory residence on an island of 2.5 square kilometres. ${ }^{1527}$

The restriction of an asylum seeker to an assigned area is arguably contrary to Articles 26 and 31(2) of the Geneva Convention in that no restrictions other than those which are "necessary" may be imposed on asylum seekers and who are otherwise entitled to free movement within territory of the State of asylum. The requirement of necessity is also contemplated in Article 12(3) ICCPR. Article $7(1)$ of the Directive provides no requirement that the restriction be necessary, nor sets out grounds upon which an asylum seeker

\footnotetext{
1522 Article 3(1) of the Commission's 2011 Proposed Reception Conditions Directive and Article 3(1) of the Council's Amended Proposed Reception Conditions Directive

1523 See above and Article 7 of both the Commission's 2011 Proposed Reception Conditions Directive and the Council's Amended Proposed Reception Conditions Directive

1524 See below and Article 8(3)(c) of both the Commission's 2011 Proposed Reception Conditions Directive and the Council's Amended Proposed Reception Conditions Directive

1525 Article 7 of the Reception Conditions Directive

1526 Article 7(1) of the Reception Conditions Directive

1527 Guzzardi v Italy, No. 7367/76, 6 November 1980, Judgment, Plenary Chamber
} 
may be restricted to an assigned area. Further, given the HRC jurisprudence in relation to Article 12 ICCPR, an asylum seeker should be entitled to access the entire territory of the Member State of asylum unless any of the grounds identified in Article 12(3) ICCPR (public order (ordre public), public health or morals or the rights and freedoms of others) are met.

The second ground may be for the "residence" of an asylum seeker being decided by a Member State may for (1) reasons of public interest; (2) public order; or (3) "when necessary, for the swift processing and effective monitoring of his or her application". ${ }^{1528}$ If that residence in fact amounts to a deprivation of liberty then, in accordance with the HRC jurisprudence in $C v$ Australia, detention for the purpose of efficient processing of asylum applications is not a justifiable ground for detention.

The third ground, is set out in Article 7(3):

"When it proves necessary, for example for legal reasons or reasons of public order, Member States may confine an applicant to a particular place in accordance with their national law"

Several points are to be noted about this provision. Firstly, it is unclear whether "necessary" can be inclusive of the notion of "necessity" as contemplated by the HRC in its jurisprudence on Article 9 ICCPR, or as, Hailbronner notes, is the necessity test to be dispensed with entirely in accordance with the ECtHR jurisprudence, or does it refer to a "test of arbitrariness" contemplated by the ECtHR jurisprudence? ${ }^{1529}$ Secondly, "legal reasons" is an extremely vague term which does nothing to elucidate a discernible and justifiable ground for detention: as the ECtHR has indicated, even if the detention is in accordance with national law, it may still be unlawful on account of the quality of the law or because it fails to serve the protective purpose of Article 5 ECHR. Thirdly, the confinement "to a particular place" says nothing of the location or conditions of detention, or their suitability to the applicant's needs ${ }^{1530}$ which, if unsuited, may prove that the detention is not lawful. Indeed, the special considerations that are to be given to vulnerable persons (including minors) only relates to "the provisions of Chapter II relating to material reception conditions and health care" which, notwithstanding that the detention provisions fall within Chapter II, is regulated lex specialis by Article 13.

\footnotetext{
1528 Article 7(2) of the Reception Conditions Directive

1529 Hailbronner, K, Detention of Asylum Seekers, (2007) 9 European Journal of Migration and Law 159, P.169.

1530 Only a recital, which is non-binding and more aspirational in nature, indicates that the reception of those in detention "should be specifically designed to meet their needs in that situation" - Recital 10 of the Reception Conditions Directive
} 


\section{Minors}

Although acknowledging the best interests of the child as the primary consideration in the implementation of the Directive, ${ }^{1531}$ the Directive does not rule out the possibility of detaining minors. Indeed, special provisions are to be made for the placement of unaccompanied minors in, inter alia, "accommodation centres" or "other accommodation suitable for minors" 1532 but there is no prohibition of their detention. Further, the Directive does not make a provision consistent with Article 37(b) CROC that detention should be a measure of last resort and for the shortest possible period of time. Although "representation" is to be ensured for unaccompanied minors, it is inclusive of, but does not necessarily result in, legal guardianship, ${ }^{1533}$ which may run counter to Article 20(1) CROC and the related CteeRC jurisprudence. Additionally, no provision has been made which prohibits the detaining authority from acting as legal guardian which, if permitted, would pose a grave conflict of interest that would create a serious risk that the best interests of the child would not be served.

\section{Families}

In relation to families, it is of concern that an asylum seeker who falls within the scope of the Directive may have accompanying family members who do not fall within the scope of the Directive. Accordingly, that asylum seeker may be detained according to the provisions of the Directive which may have the effect of separating the asylum seeker from his family who are also present in the territory. The provision relating to the maintenance of family unity "as far as possible" ${ }^{1534}$ is somewhat futile if the family members themselves do not fall within the scope of the Directive (as discussed above). In those circumstances, the principles of family unity provided for in the ICCPR, CROC and ECHR would be applicable.

\section{Vulnerable \& Stateless Persons}

Although account is to be taken for vulnerable persons as a general principle in the implementation of material reception conditions under Chapter II of the Directive (which includes the free movement and detention provisions), ${ }^{1535}$ the Directive does not make provision for the early and systematic identification of vulnerable and stateless persons, particularly before any detention decision is made and which, accordingly, may increase the risk that those factors are not be taken into consideration in any assessment of the proportionality of a decision to detain.

\footnotetext{
1531 Article 18 of the Reception Conditions Directive 1532 Article 19(2) of the Reception Conditions Directive

1533 Article 19(1) of the Reception Conditions Directive - possibilities other than legal guardianship include "where necessary, representation by an organisation which is responsible for the care and well-being of minors, or by any other appropriate representation".

1534 Article 8 of the Reception Conditions Directive

1535 Article 17(1) of the Procedures Directive
} 


\section{Procedures Directive}

The other piece of secondary legislation that contemplates detention is the Procedures Directive. It is arguable that the Procedures Directive applies in circumstances where either the asylum seeker has the right to remain or has lost the right to remain, as the scope of the Directive itself is not conditional upon the right to remain ${ }^{1536}$ (indeed, the Directive itself, as outlined earlier, is determinative of that right). The Procedures Directive does not provide an identifiable ground for detention, but merely that a person "should not be held in detention for the sole reason that he/she is an applicant for asylum". However, as noted by Gondek, Member States are easily able to circumvent that prohibition as asylum seekers will not be detained solely because they seek protection in the EU, but rather because they will have invariably irregularly crossed the border of a Member State to enter the EU to seek that protection, ${ }^{1537}$ and which is entirely a matter then falling within Member State competence - an outcome which the negotiations surrounding the adoption of the Procedures Directive reveal was entirely intentional. ${ }^{1538}$ Notwithstanding that detention in those circumstances may fall within Member State competence, any detention, as noted by Peers, must then be in accordance with purposes concordant with ECHR and ICCPR standards (even if those two conventions and their respective jurisprudence are not entirely comparable as discussed above). ${ }^{1539}$

\subsection{Grounds for Detention if the Right to Remain Exists - The Regular} Procedure - The Commission's 2011 Proposed Reception Conditions Directive

Personal Scope

As discussed earlier, the personal scope of the Reception Conditions Directive, ${ }^{1540}$ restrictions to an assigned area, ${ }^{1541}$ and the discretion of Member States to determine the residence of asylum seekers ${ }^{1542}$ remain substantially unchanged in the 2011 Proposal. Accordingly, the concerns expressed earlier in relation to those matters remain unchanged.

\section{Grounds for Detention}

The Commission's 2011 Proposed Reception Conditions Directive makes substantial improvements to elucidating the grounds of detention and the circumstances in which they may arise. The ambiguous provision relating to

\footnotetext{
1536 Article 3(1) of the Procedures Directive

1537 Gondek, M, The Emerging European Asylum Law: between Protection and Rejection in Schneider, H, Migration, Integration and Citizenship: A Challenge for Europe's Future, 2005, Forum Maastricht, Maastricht, Pp.187-228 at Pp.217-218.

1538 Wilsher, D, The Liberty of Foreigners - A History, Law and Politics of Immigration Detention, 2008, Wolf Legal Publishers, Nijmegen, Pp.160-162

1539 Peers, S, EU Justice and Home Affairs Law, (3ed), 2011, OUP, Oxford, Pp.352-353

1540 Article 3(1) of the Commission's 2011 Proposed Reception Conditions Directive

1541 Article 7(1) of the Commission's 2011 Proposed Reception Conditions Directive

1542 Article 7(2) of the Commission's 2011 Proposed Reception Conditions Directive
} 
confinement "to a particular place" (currently Article 7(3)) has been removed, and is replaced with a series of provisions particular to detention. ${ }^{1543}$

Firstly, detention cannot occur unless three criteria have first been fulfilled: (1) that the detention "proves necessary"; (2) is based on "an individual assessment of each case"; and (3) "other less coercive measures cannot be applied effectively". ${ }^{1544}$ Member States are required to ensure that rules regarding alternatives to detention are laid down in national law. ${ }^{1545}$ Further, detention is without prejudice to the provisions on vulnerable persons (Article 11) and "to detention in the framework of criminal proceedings" - a most helpful clarification. Accordingly, there appears to be an active consideration of the principle of proportionality and necessity as a pre-requisite to detention.

If that juridical hurdle has been cleared, detention is possible on the following grounds:

“(a) in order to determine or verify his/her identity or nationality;

(b) in order to determine, within the context of a preliminary interview, the elements on which the application for international protection is based which could not be obtained in the absence of detention;

(c) in the context of a procedure, to decide on the right to enter the territory;

(d) when protection of national security or public order so requires." 1546

Article 8(3)(a) is a little wider in scope than the UNHCR Revised Guideline 3 which only identifies the ground of "to verify identity" and provides that "[t]his relates to those cases where identity may be undetermined or in dispute". ${ }^{1547}$ Guideline 3 is silent on the need to "determine" or verify nationality, which would undoubtedly have a significant impact on stateless persons who bear the evidential burden to prove that they are not a national of a State (see Chapter 4) and where the Recast Proposal makes no provision for their early identification. Articles 8(3)(b) and (d) are largely in line with the position set out in UNHCR ExCom 44 and Guideline 3 of the UNHCR Guidelines. However, Article 8(3)(c), although consistent with the ECtHR jurisprudence in relation to Article 5(1)(f) ECHR, is problematic in that it may provide the basis for systematic detention of asylum seekers for considerable periods of time - a concern expressed by the UNHCR ${ }^{1548}$

1543 Articles 8, 9. 10 and 11 of the Commission's 2011 Proposed Reception Conditions Directive

1544 Article 8(3) of the Commission's 2011 Proposed Reception Conditions Directive 1545 Article 8(4) of the Commission's 2011 Proposed Reception Conditions Directive 1546 Article 8(3) of the Commission's 2011 Proposed Reception Conditions Directive 1547 Guideline 3(i), UNHCR Revised Guidelines on applicable criteria and standards relating to the detention of asylum seekers, February 1999.

1548UNHCR, UNHCR Comments on the European Commission's Proposal for a recast of the Directive laying down minimum standards for the reception of asylum seekers (COM(2008)815 final of 3 December 2008, March 2009, http://www.unhcr.org/4a0d6bf86.pdf (last accessed 14 October 2011) at Pp.4-5 
regarding the Commission's 2008 Proposal in identical terms. ${ }^{1549}$ Further, that provision is essentially aimed at border applicants (discussed below) as otherwise it would be internally inconsistent - that is, it is logically inconsistent to have an asylum seeker submit to the asylum determination process under the Procedures Directive, then be entitled to a concomitant right to remain under that Directive, and then deny the asylum seeker the right to enter the territory (on which he or she is physically present and which he or she already clearly had to have entered) by means of detention. In any event, it is a ground for detention not contemplated by the UNHCR Revised Guidelines.

Detention is prohibited on account of the person being an applicant for international protection. ${ }^{1550}$ However, as noted previously in relation to the comparable provisions under the Procedures Directive, that prohibition is easily circumvented by Member States.

\section{Minors and Families}

Unaccompanied minors are to have appointed a representative to act as their legal guardian ${ }^{1551}$ - a significant improvement upon the terms in the current legislation. However, there is still no provision that prohibits the appointment of the detaining authority as the minor's legal guardian. The possibility for unaccompanied minors to be placed, inter alia, in "accommodation centres" or "other accommodation suitable for minors" remains unchanged. ${ }^{1552}$ The detention of unaccompanied minors is not prohibited but may occur "only in particularly exceptional circumstances". ${ }^{1553}$ It is expressly provided that minors must not be detained unless "it is established in an individual case that it in the minor's best interests" by reference to Article 23(2), ${ }^{1554}$ which states:

"In assessing the best interest of the child, Member State shall in particular take due account of the following factors:
(a) family reunification possibilities;
(b) the minor's well-being and social development, taking into particular consideration the minor's ethnic, religious, cultural and linguistic background;
(c) safety and security considerations, in particular where there is a risk of the minor being a victim of trafficking;
(d) the views of the minor in accordance with his/her age and maturity."

\footnotetext{
1549 European Commission, Proposal for a Directive of the European Parliament and of the Council laying down minimum standards for the reception of asylum seekers, 3 December 2008, $\operatorname{COM}(2008) 815$ final

1550 Article 8(3) of the Commission's 2011 Proposed Reception Conditions Directive

1551 Article 24 and 2(j) of the Commission's 2011 Proposed Reception Conditions Directive

1552 Article 24(2) of the Commission's 2011 Proposed Reception Conditions Directive

1553 Article 11(2) of the Commission's 2011 Proposed Reception Conditions Directive

1554 Article 11(2) of the Commission's 2011 Proposed Reception Conditions Directive
} 
It is deeply regrettable that the Commission's 2011 Proposed Reception Conditions Directive removed the prohibition on the detention of unaccompanied minors contained in the Commission's 2008 Proposal. ${ }^{1555}$ As indicated earlier, the detention of minors runs a significant risk of breaching Articles 3 and 5 ECHR, as demonstrated in Mubilanzila Mayeka and Muskhadzhiveya ${ }^{1556}$ (and recently affirmed in Kanagaratnam ${ }^{1557}$ ), particularly where the conditions of detention are not suitable for minors. The 2011 Proposal provides that the detention of minors is to be "a measure of last resort, after having established that other less coercive alternative measures cannot be applied effectively", and that detention is to be "for as short a period as possible". ${ }^{1558}$ Further, Member States are under a positive obligation to make "all efforts to release the detained minors and place them in accommodation suitable for minors". 1559 The use of the term "effectively" does, however, import a degree of discretion to the Member State's considerations of alternative measures. The detention of families under the Recast Proposal is also implicitly permitted. ${ }^{1560}$

\section{Vulnerable Persons}

In relation to vulnerable persons, those asylum seekers must not be detained:

"unless it is established that their health, including their mental health, and well being, will not significantly deteriorate as a result of the detention" 1561

That provision is not as absolute as the UNHCR Revised Guidelines which provide that detention may occur only if a "qualified medical practitioner" has certified "that detention will not adversely affect their health and well being [emphasis added]". ${ }^{1562}$ That is, the UNHCR Revised Guidelines prohibit detention if there is any adverse effect as opposed to a "significant deteriorat[ion]" as contemplated under the Commission's Recast Proposed Reception Conditions Directive. The removal of the requirement for that certification to be carried out by a "qualified professional" in the Commission's 2008 Proposal ${ }^{1563}$ represents a downgrading of protection and may be open for administrative or other decision-makers to make an uneducated or expedient assessment. The identification of vulnerable persons

\footnotetext{
1555 Article 11(1) of the Commission's 2008 Proposed Reception Conditions Directive 1556 Mubilanzila Mayeka and Kaniki Mitunga v Belgium, No. 13178/03, Judgment, 12 October 2006; Muskhadzhiyeva \& ors v Belgium, No. 41442/07, Judgment, 19 January 2010 1557 Kanagaratnam \& Others v Belgium, No. 15297/09, Judgment, 13 December 2011

1558 Article 11(2), second paragraph, of the Commission's 2011 Proposed Reception Conditions Directive

1559 Article 11(2) second paragraph, of the Commission's 2011 Proposed Reception Conditions Directive

1560 Article 11(3) of the Commission's 2011 Proposed Reception Conditions Directive 1561 Article 11(1) of the Commission's 2011 Proposed Reception Conditions Directive 1562 Guideline 7, UNHCR Revised Guidelines on applicable criteria and standards relating to the detention of asylum seekers, February 1999.

1563 See Article 11(5) of the Commission's 2008 Proposed Reception Conditions Directive
} 
is to be initiated "within a reasonable time after an application for international protection is made", ${ }^{1564}$ differs from the Commission's 2008 Proposal which required identification procedure to be initiated "as soon as an application for international protection is lodged". ${ }^{1565}$ There is now a temporal difference in making and lodging an application that is reflected in the 2011 Proposed Procedures Directive. ${ }^{1566}$ Accordingly it would be advisable to amend the provision to read "as soon as an application for international protection is made" to identify such persons as early as possible and to reduce Member State discretion in the interpretation of "reasonable time". The 2011 Proposal also provides for the identification of vulnerable persons during a later stage in the asylum procedures (which would presumably include detention). ${ }^{1567}$

\section{Stateless Persons}

As indicated earlier, the 2011 Proposal remains silent on the early identification of stateless persons and, indeed, under Article 8(3)(a), stateless persons may find themselves subject to prolonged detention in order to determine that, ultimately, they have no nationality (indeed, in circumstances where the evidential burden rests on them to prove that they are stateless - see Chapter 4).

\subsection{Grounds for Detention if the Right to Remain Exists - The Regular} Procedure - the Council's Amended Proposed Reception Conditions Directive

\section{Grounds for Detention}

The chief amendments made by the Council to the Commission's 2011 Proposal relate firstly to two further grounds for detention under Article 8(3), being:

"(d) when he/she is detained in order to prepare the return and/or carry on the removal process and it can reasonably be considered that he/she makes an application for international protection merely in order to delay or frustrate the enforcement of that return or removal process;

$[\ldots]$

(e) in accordance with Regulation (EC) No [.../...] [Dublin Regulation], where a risk exists that the applicant may abscond in order to delay or frustrate his/her transfer, once the take back or take charge request has been sent to the Member State considered to be responsible for examining the application."

The ground contemplated in Article 8(3)(d) appears to be in response to the situation which emerged in Kadzoev where a third country national was

\footnotetext{
1564 Article 22(1) of the Commission's 2011 Proposed Reception Conditions Directive 1565 Article 22(5) of the Commission's 2008 Proposed Reception Conditions Directive 1566 See Article 6 of the Commission's 2011 Proposed Procedures Directive whereby an application is "lodged" after an applicant is registered as having declared their wish to make an application for international protection, such registration occurring as soon as possible but no later than 72 hours after such a declaration

1567 Article 22(1) of the Commission's Recast Receptions Conditions Directive
} 
detained as part of the removal process, but sought asylum during that period of detention. The CJEU indicated that no additional grounds for detention would be read into the Returns Directive and that continuation of detention after an asylum application was not possible under the Returns Directive. ${ }^{1568}$ However, the proposed provision is logically and legally at odds with the prohibition against detaining a person merely on account that they are an applicant for international protection. ${ }^{1569}$ Any such provision should be made by amending the Returns Directive with sufficient safeguards for protection against refoulement.

The ground contemplated in Article 8(3)(e) is problematic from an internal consistency perspective. If the application of that provision is to occur when an applicant is in another Member State, having already made an application for international protection in a first Member State, then the applicant will not be able to fall within the personal scope of the Proposed Procedures Directive as his or her right to remain will only exist in the Member State where he or she made his or her first application, not in the Member State to which he or she now finds him or herself in. Accordingly, the inclusion of that ground of detention would create great uncertainty.

\section{Minors}

In relation to the assessment of the best interest of a child, a minor's ethnic, religious, cultural and linguistic background no longer forms part of the consideration of their well being and social development. ${ }^{1570}$ Most significantly, for unaccompanied minors, the appointment of a representative is now no longer a legal guardian of the minor. ${ }^{1571}$ That amendment is a significantly retrograde measure that represents a lower standard of care than the current legislation. Indeed, there is no requirement that the representative be independent or impartial, nor is there any prohibition against appointment of a representative who is also the detaining authority. It is highly questionable that without the appointment of a legal guardian, compliance with Articles 20(1) and 22(1) CROC as well as the CteeRC jurisprudence can be assured.

\section{Vulnerable Persons}

In relation to vulnerable persons, their "identification" as opposed to a Member State's obligations to "establish mechanisms with a view to identifying" vulnerable persons under the Commission's 2011 Proposed Reception Conditions Directive provides stronger protection for vulnerable persons. ${ }^{1572}$

1568 C-357/09 PPU Kadzoev, 30 November 2009, Judgment Grand Chamber, para 45 1569 Article 8(1) of the Council's Amended Proposed Reception Conditions Directive 1570 Article 23(2)(b) of the Council's Amended Proposed Reception Conditions Directive 1571 Articles 24(1) and Article 2(i) of the Council's Amended Proposed Reception Conditions Directive

1572 Article 22(1) of the Council's Amended Proposed Reception Conditions Directive 
5.2.5.1.3 Grounds for Detention if the Right to Remain Exists - The Regular Procedure - the Commission's 2011 Proposed Procedures Directive

The Recast Proposed Procedures Directive refers to the Reception Conditions Directive as regards grounds and conditions of detention, as well as guarantees to detainees, whilst maintaining that a person should not be detained for the sole reason that he/she is an applicant for international protection. ${ }^{1573}$ The comments addressing the Commission's 2011 Proposed Reception Conditions Directive and the Council's amendments thereto are also applicable in these circumstances.

\subsubsection{Grounds for Detention if the Right to Remain Exists - The Border Procedure}

As noted by ILPA in 2004, the border procedures under the Procedures Directive effectively permit the detention of asylum seekers by deciding their application at the border or in the transit zone. ${ }^{1574}$ Any such detention would be a matter of Member State competence. Given that it is possible for Member States to derogate from the guarantees and principles contained in Chapter II of the Procedures Directive, one of the most essential safeguards that may be lost is the prohibition against detention for the sole reason that a person is an applicant for asylum. ${ }^{1575}$ In any event, even if that protection were to exist, it does not preclude detention at the border on other grounds. An alternative argument may be that if a person subject to border procedures has a right to remain (that is, it has not been the subject of derogation), then the only restrictions on liberty could be those contemplated in the Reception Conditions Directive (see above) as the right to remain would allow the applicant to fall within the scope of the Reception Conditions Directive. However, as discussed above, the ambiguous terminology surrounding detention in Article 7 of the Reception Conditions Directive (and the degree of Member State discretion contained therein) may essentially permit detention (consistent with the ECtHR jurisprudence surrounding Article 5(1)(f) ECHR) of border applicants.

In any event, if a decision on the application for asylum has not been made within four weeks, the asylum seeker is to be granted entry into the Member State and to have his or her application determined by the regular procedure. ${ }^{1576}$

\footnotetext{
1573 Article 26(1) of the Commission's 2011 Proposed Procedures Directive.

1574 Immigration Law Practitioner's Association (“ILPA"), Immigration Law Practitioners' Association (ILPA) Analysis and Critique of Council Directive on minimum standards on procedures in Member States for granting and withdrawing refugee status (30 April 2004), July 2004, http://www.ilpa.org.uk/data/resources/13178/04.07.00-ILPA-Analysis-Critique-EC-

directive-Granting-Withdrawing-Refugee-Status..pdf (last accessed 21 November 2011), Pp.31-32

1575 See Article 18(1) of the Procedures Directive

1576 Article 35(4) of the Procedures Directive
} 


\subsection{Grounds for Detention if the Right to Remain Exists - The Border} Procedure - The Proposed Legislation

The Commission's 2011 Proposed Procedures Directive is now expressly referable to the Reception Conditions Directive as regards grounds, conditions and guarantees of detention (see above). ${ }^{1577}$ As discussed above, Member States still retain the discretion to determine the admissibility of applications and the substance of accelerated procedures at the border or in transit zones. ${ }^{1578}$ Whether this amounts to a de facto ground for detention remains to be seen in practice. At least the general provisions against the detention of persons for the sole reason that they are applicants for international protection now applies regardless of whether a person is subject to the border or regular procedures. ${ }^{1579}$ If an applicant seeks an effective remedy of a first instance decision, it is arguable that the applicant may remain in detention pending the outcome of the effective remedy as Article 46 is silent as to what is to happen to border applicants in that situation.

If reference is made to either of the Proposed Reception Conditions Directives for the purposes of detention, then detention may be ordered "in the context of a procedure, to decide on the right to enter the territory". ${ }^{150}$ Although prima facie that provision is consistent with the ECtHR jurisprudence on Article 5(1)(f) ECHR, that provision (as indicated earlier) may provide the basis for the systematic detention of asylum seekers for considerable periods of time. It is arguable, therefore, that although there may be increased guarantees for asylum seekers under the proposed legislation, the detention situation for border applicants effectively remains unchanged by the introduction of Article 8(3)(c) of the Proposed Reception Conditions Directive (that is, detention pending the determination of the right to enter the territory).

However, it is also arguable that, by reference to the Proposed Reception Conditions Directives as provided for in the Commission's 2011 Proposed Procedures Directive, the prohibition against detention for the sole reason that a person is an applicant for international protection should also apply to border applicants. ${ }^{1581}$ In practice, however, detention may still arise due to the assessment of the right of the person to enter the territory.

1577 Article 26 of the Commission's 2011 Proposed Procedures Directive

1578 Article 43(1)(a) and (b) of the Commission's 2011 Proposed Procedures Directive

1579 That is, by the deletion of the current Article 24(1)(b) of the Procedures Directive

1580 Article 8(3)(c) of both of the Commission's 2011 Proposed Reception Conditions Directive and the Council's Amended Proposed Reception Conditions Directive 1581 Article 8(1) of both of the Commission's 2011 Proposed Reception Conditions Directive and the Council's Amended Proposed Reception Conditions Directive 


\subsubsection{Grounds to Detain if the Right to Remain is Lost}

\subsubsection{Grounds to Detain if the Right to Remain is Lost - The Regular Procedure}

In circumstances where the right to remain is lost, the Procedures Directive is partly applicable in that a person is not to be detained on the sole basis that he or she is an applicant for asylum. However, as indicated above, it would appear that it would then be within Member State competence as regards the detention of an asylum seeker who no longer held the right to remain. ${ }^{1582}$ Accordingly, detention in those circumstances as noted by Peers, must then be in accordance with purposes concordant with ECHR and ICCPR standards ${ }^{1583}$ (even if those two conventions are not entirely comparable as discussed above), as well as the Geneva Convention and the UNHCR Revised Guidelines.

\subsection{Grounds to Detain if the Right to Remain is Lost - The Regular Procedure} - The Proposed Legislation

As indicated earlier, under the Commission's 2011 Proposed Procedures Directive, the grounds for detention are referable to the Reception Conditions Directive. ${ }^{1584}$ Accordingly, it would appear that if that Proposal were to be adopted, the detention of asylum seekers would be a field covered by the Union. However, the Proposed Reception Conditions Directive does nothing to interrupt the Member States' competence as regards any question regarding the right to remain. That gap is left to the Member States to fulfill in accordance with their international obligations - indeed, that gap (as discussed earlier) has significantly shrunk under the 2011 Proposal due to its extension to the period within which to seek an effective remedy or, if sought within time, until that remedy has been decided. It does not, however, affect the cessation of any right to remain which might result from the withdrawal or otherwise of an application for international protection.

5.2.6.1.2 Grounds to detain if the right to remain is lost - The Regular Procedure The Returns Directive - Personal Scope

The Returns Directive is largely determinative of the grounds for detention for those asylum seekers who have either received a negative decision regarding their application or have lost their right to remain. This is reflected in the preamble to the Directive:

“... a third country national who has applied for asylum in a Member State should not be regarded as staying illegally on the territory of that Member State until a

1582 Wilsher, D, The Liberty of Foreigners - A History, Law and Politics of Immigration Detention, 2008, Wolf Legal Publishers, Nijmegen, Pp.160-162

1583 Peers, S, EU Justice and Home Affairs Law, (3ed), 2011, OUP, Oxford, Pp.352-353

1584 Article 26 of the Commission's 2011 Proposed Procedures Directive 
negative decision on the application, or a decision ending his or her right of stay as asylum seeker [sic] has entered into force."1585

The Directive acknowledges that illegally staying third country nationals ("TCNs") may be returned by Member States provided that "fair and efficient asylum systems are in place which fully respect the principle of nonrefoulement". ${ }^{1586}$ The Directive is said to be without prejudice to the obligations under the Geneva Convention. ${ }^{1587}$ Detention is said to be justified "only to prepare the return or carry out the removal process" and only if less coercive measures would be insufficient. ${ }^{1588}$ Respect must be paid to the principle of non-refoulement under the Directive. ${ }^{1589}$

As regards the personal scope of the Returns Directive, it is primarily concerned with illegally staying third country nationals. ${ }^{1590}$ In light of the Schengen Borders Code discussed earlier in this chapter, "Illegal stay" is defined under the Returns Directive as:

"the presence on the territory of a Member State, of a third-country national who does not fulfil, or no longer fulfils the conditions of entry as set out in Article 5 of the Schengen Borders Code or other conditions for entry, stay or residence in that Member State". ${ }^{1591}$

"Third-country national" is defined as:

"any person who is not a citizens of the Union within the meaning of Article 17(1) of the Treaty and who is not a person enjoying the Community right of free movement, as defined in Article 2(5) of the Schengen Borders Code"1592

However, it is important to note that Member States retain the discretion not to apply the Directive to certain third country nationals. Such third country nationals who may be excluded from the Directive's operation include:

(1) those that have been refused entry under Article 13 of the Schengen Borders Code or who are apprehended or intercepted "in connection with" an irregular crossing of an external border of a Member State and "have not subsequently obtained an authorisation or a right to stay in a Member State". ${ }^{1593}$ In this regard, "right to stay" should also contemplate the "right to remain" provided under the Procedures Directive; and

\footnotetext{
1585 Recital 9 to the Returns Directive; see also C-357/09 PPU, Kadzoev, 20 November 2009, Grand Chamber, para 41

1586 Recital 8 to the Returns Directive

1587 Recital 23 to the Returns Directive

1588 Recital 16 to the Returns Directive

1589 Article 5, last paragraph, of the Returns Directive

1590 Article 2(1) of the Returns Directive

1591 Article 3(2) of the Returns Directive

1592 Article 3(1) of the Returns Directive

1593 Article 2(2)(a) of the Returns Directive
} 
(2) those to be returned in connection with a criminal law sanction or by way of extradition; ${ }^{1594}$

Relatedly, it is also important to bear in mind that Member States may refrain from issuing a return decision to those third country nationals:

(1) who are subject to bilateral agreements between the Member State where the third country national is present, and another Member State. However, the Member State to which the third country national is sent must then issue a return decision; 1595

(2) to whom an autonomous residence permit or other right to stay based on "compassionate, humanitarian or other reasons". In this case, any return decision must be withdrawn; 1596

(3) who are in the process of renewing their residence permits "or other authorisation offering a right to stay". ${ }^{1597}$

Grounds to Detain if the Right to Remain is Lost - The Regular Procedure - The Returns Directive - Grounds for Detention

Before a decision to detain is made, a return decision must be made. ${ }^{1598}$ That decision provides for an "appropriate period" to allow the illegally staying TCN to voluntarily depart - a period of between seven and thirty days. ${ }^{1599}$ The period for voluntary departure may be reduced or extinguished in cases where there is a risk of absconding, ${ }^{1600}$ "or if an application for a legal stay has been dismissed as manifestly unfounded or fraudulent" (which would include asylum claims), or on public policy, public security or national security grounds. ${ }^{1601}$ Member States are then free to enforce the return decision if no voluntary period for departure has been given or, if a voluntary period for departure has been given, if it has not been complied with. ${ }^{1602}$ The return decision can only be executed after the voluntary period for departure has expired unless one of the grounds for reducing or extinguishing it has arisen in that time. ${ }^{1603}$ Coercive measures are implicitly permitted, provided that they are "proportionate and do not exceed reasonable force", with respect for

\footnotetext{
1594 Article 2(2)(b) of the Returns Directive

1595 Article 6(3) of the Returns Directive

1596 Article 6(4) of the Returns Directive

1597 Article 6(5) of the Returns Directive

1598 Article 6(1) of the Returns Directive

1599 Article 7(1) of the Returns Directive

1600 Note that "risk of absconding" is defined as "the existence of reasons in an individual case which are based on objective criteria defined by law to believe that a third-country national who is the subject of return procedures may abscond" - Article 3(7) of the Returns Directive. This definition essentially allows Member States to set their own criteria as to what constitutes a risk of absconding.

1601 Article 7(4) of the Returns Directive

1602 Article 8(1) of the Returns Directive

1603 Article 8(2) of the Returns Directive
} 
"fundamental rights and with due respect for the dignity and physical integrity of the third-country national concerned". ${ }^{1604}$

Detention can only be utilised (1) unless " other sufficient but less coercive measures can be applied effectively in a specific case"; (2) the TCN is subject to a return procedure; (3) the purpose of the detention is in order "to prepare the return and/or carry out the removal process". ${ }^{1605}$ Accordingly, it would appear that that provision requires an active consideration of proportionality and necessity. However, "effectively" does import a degree of Member State discretion.

The grounds for detention are either "a risk of absconding"1606 or the TCN "avoids or hampers the preparation of return or the removal process". ${ }^{1607}$ It was initially thought that, by preceding those two grounds with the words "in particular", that the list of grounds was not exhaustive. ${ }^{1608}$ However, the CJEU in Kadzoev was reluctant to (and, indeed, did not) read additional grounds for detention based on public order and public safety once the maximum period of detention has been reached. ${ }^{1609}$

Detention is to be for as short a period as possible and "only maintained as long as removal arrangements are in progress and executed with due diligence", and reflects the language used by the ECtHR in Chahal (cited above). Importantly, if a "reasonable prospect of removal no longer exists", then the detention cannot be further justified, and the person must be released. ${ }^{1610}$ In Kadzoev, the CJEU interpreted that provision to be satisfied "where it appears unlikely that the person concerned will be admitted to a third country, having regard to those periods [those being, under Articles 15(5) and (6)]." 1611 Under Article 15(5) Member States are to provide for a maximum period of detention not exceeding six months, extendable for a further 12 months under Article 15(6), which do not appear to take into account the Court's dicta in Saadi where it was implied that excessive length may result in arbitrary detention. As Peers has rightly noted, the CJEU in Kadzoev was silent on the issue of aggregated periods of detention ${ }^{1612}$ - that is,

\footnotetext{
1604 Article 8(4) of the Returns Directive

1605 Article 15(1) of the Returns Directive

1606 Article 15(1)(a) of the Returns Directive; noting also the definition of "risk of absconding" in Article 3(7) of the Returns Directive and the note supra.

1607 Article 15(1)(b) of the Returns Directive

1608 ECRE, Information Note on the Directive 2008/115/EC of the European Parliament and of the Council of 16 December 2008 on common standards and procedures in Member States for returning illegally staying third-country nationals, 7 January 2009, P.20. See also, generally, Baldaccini, A, The Return and Removal of Irregular Migrants under EU Law: An Analysis of the Returns Directive (2009) 11 European Journal of Migration and Law 1

1609 C-357/09 PPU, Kadzoev, 20 November 2009, Grand Chamber, paras 68-70

1610 Article 15(4) of the Returns Directive

1611 C-357/09 PPU, Kadzoev, 20 November 2009, Grand Chamber, para 67

1612 Peers, S, EU Justice and Home Affairs Law, (3ed), 2011, OUP, Oxford at Pp.573-574
} 
what of the deeply regrettable situation if a Member State were to release a detained person, only to re-detain him or her so that time could run afresh? ${ }^{1613}$ Further, the grounds for the 12-month extension of detention are justified if attributable to the lack of cooperation by the detained person or delays in obtaining necessary documentation from third countries. ${ }^{1614}$ However, a lack of cooperation on the part of the detained person was not considered a justifiable ground for detention by the ECtHR in Mikolenko, ${ }^{1615}$ even if it may have been considered to have been, in individual circumstances, by the HRC in $A v$ Australia. ${ }^{1616}$ In any event, the rights of the detained person should not be subjugated by matters that are indeed outside his or her own control.

\section{Minors}

The Directive contains implicit permission to detain minors. ${ }^{1617}$ The best interests of the child are to be taken due account when implementing the Directive, ${ }^{1618}$ particularly before deciding on a return decision for an unaccompanied minor, ${ }^{1619}$ and must be a primary consideration when minors are to be detained pending removal. ${ }^{1620}$ Prior to any removal from the territory, it must be satisfied that the minor will be "returned to a member of his or her family, a nominated guardian, or adequate reception facilities in the State of return." ${ }^{1621}$ Unaccompanied minors are to be detained as a measure of last resort. ${ }^{1622}$

\section{Families}

The Directive also contains an implicit permission to detain families, ${ }^{1623}$ which, if consisting of a minor or minors, are to be detained as a measure of last resort. ${ }^{1624}$ The Directive contains a general requirement for Member States to take into account family life in the implementation of the Directive (but it is questionable whether this is sufficiently inclusive of family unity). ${ }^{1625}$

1613 However, Schieffer notes that to do so would effectively "undermine the "effet utile" of Article 15(5) and (6): Schieffer, M, M, Chapter V-Termination of Residence, in Hailbronner, $\mathrm{K}$, (ed), EU Immigration and Asylum Law - Commentary on EU Regulations and Directives, 2010, Verlag C. H. Beck oHG, München, Pp.1489-1552 at 1544

1614 Article 15(6)(a) and (b)

1615 Mikolenko v Estonia, No. 10664/05, Judgment, 8 October 2009, Government's submission at paras 51 and 53, Court's assessment at paras 64-65, note dissenting judgment of Judge Maruste at paras 3-4; contra Kolompar v Belgium, No.11613/85, Judgment, 24 September 1992, paras 37-43

1616 A v Australia, Communication No. 560/1993 at para 9.4

1617 Article 17 of the Returns Directive

1618 Article 5(a) of the Returns Directive

1619 Article 10(1) of the Returns Directive

1620 Article 17(5) of the Returns Directive

1621 Article 10(2) of the Returns Directive

1622 Article 17(1) of the Returns Directive

1623 Article 17(2) of the Returns Directive

1624 Article 17(1) of the Returns Directive

1625 Article 5(b) of the Returns Directive 


\section{Vulnerable Persons}

Vulnerable persons are also implicitly permitted to be detained, ${ }^{1626}$ and although there is no general consideration for vulnerable persons in the implementation of the Directive (as provided for the best interest of the child and family life), the state of health of a TCN is to be taken into account. ${ }^{1627}$ It is doubtful whether this provides sufficient safeguards for conditions of detention being suitable to the particular vulnerabilities of a person in light of the ECtHR jurisprudence in Mayeka Mubilanzila and related cases.

\subsubsection{Grounds for Detention where the Right to Remain is Lost or Denied - The} Border Procedure

As indicated earlier, the right to remain is a right that may be subject to derogation under the border procedures provisions of the Procedures Directive. ${ }^{1628}$ Accordingly, that right may be denied to applicants for asylum or may be withdrawn after their application has been negatively determined. Further, the prohibition of detention on the sole basis that an asylum seeker is an applicant for asylum is also a right that may be subject to derogation. ${ }^{1629}$ In those circumstances, detention, as a matter of Member State competence, must be in accordance with ECHR jurisprudence and ICCPR standards.

As indicated above, asylum seekers may only fall within the scope of the Returns Directive once a negative decision as regards their application has entered into force, ${ }^{1630}$ and the mere denial of the right to remain would not appear, without an accompanying negative decision on their application, to be sufficient for a border applicant to fall within the scope of the Returns Directive.

However, being screened-in as an asylum seeker becomes of the highest importance at the border. Given the failure to fulfil the requirements of the conditions for entry of the Schengen Borders Code is contemplated in the definition of "illegal stay" under the Returns Directive, ${ }^{1631}$ it is possible that without successfully persuading an official that an asylum seeker is in need of international protection, the asylum seeker may fall under the scope of the Returns Directive (unless the Member State exercises its discretion to exclude them from the personal scope $\mathrm{e}^{1632}$ ) and thus liable to a return decision (unless excluded from the issue of a return decision as discussed above ${ }^{1633}$ ) and runs

\footnotetext{
1626 Article 17(3) of the Returns Directive

1627 Article 5(c) of the Returns Directive

1628 Article 24(1)(b) of the Procedures Directive

1629 Article 24(1)(b) of the Procedures Directive

1630 Recital 9 to the Returns Directive

1631 Article 3(2) of the Returns Directive, Article 5 of the Schengen Borders Code (supra)

1632 Article 2(2) of the Returns Directive

1633 Article 6(2)-(5) of the Returns Directive
} 
the risk of detention, particularly depending on the criteria for "risk of absconding" set by the Member State in question.

\subsection{Grounds for Detention where the Right to Remain is Lost or Denied - The} Border Procedure - The Proposed Legislation

Under the Commission's 2011 Proposed Procedures Directive, the right to remain can no longer be denied to border applicants separately from a negative determination of their application (either at first instance or appeal) due to the deletion of Article 24(1)(b) of the current Directive. Accordingly, once the right to remain is lost, detention may be referable to the grounds, conditions and guarantees contained in the Reception Conditions Directive, but which should be in accordance with ECHR jurisprudence and ICCPR standards. Further, as discussed above, such a rejected application for asylum (or failure to otherwise fulfil conditions for entry under the Schengen Borders Code) may otherwise bring the rejected applicant within the scope of the Returns Directive and the circumstances in which detention may occur therein.

\subsubsection{Grounds for Detention if an Asylum Seeker is in a Member State Other Than That of First Entry or Asylum}

As indicated in Chapter 4, the Dublin II Regulation is silent on the issue of detention notwithstanding that Member States detain asylum seekers to facilitate transfers to other Member States under the Dublin System. The most concerning aspect of this is that, in the absence of specific provisions in the Regulation, detention for such purposes runs a grave risk of not complying with the requirement in Article 9 ICCPR that any deprivation of liberty be "on such grounds and in accordance with such procedures as are established by law" or Article 5(1) ECHR which requires any deprivation of liberty to be "in accordance with a procedure prescribed by law". ${ }^{1634}$ This is particularly underscored by the fact that this piece of secondary legislation is in the form of a Regulation and therefore capable of direct effect without the requirement for further Member State implementation.

\subsubsection{Grounds for Detention if an Asylum Seeker is in a Member State Other} Than That of First Entry or Asylum - The Proposed Legislation

The Commission's Proposed Dublin Regulation introduces a suite of provisions surrounding the detention of asylum seekers (and asylum seekers whose claims have been rejected) for the purpose of transfer to another Member State. The preamble to the Regulation makes three aspects clear: firstly, asylum seekers should not be detained for the sole reason that they are

1634 See Hermann, $M$ in Hailbronner, K, (ed) EU Immigration and Asylum Law Commentary on EU Regulations and Directives, 2010, Beck, München, Pp.1351-1488 at P.1388, para 58 
seeking international protection; secondly, that detention must be in accordance with Article 31 of the Geneva Convention "and under the clearly defined exceptional circumstances and guarantees" set out in the Reception Conditions Directive; thirdly, detention "should be limited and subject to the principle of proportionality with regard to the means taken and the objective pursued". ${ }^{1635}$

\section{Juridical hurdles before resorting to detention}

The prohibition against the detention of asylum seekers for the sole reason that they seek international protection is expressly provided for in the body of the Regulation, as it has in the other secondary legislation proposed by the Commission. ${ }^{1636}$ Before detention "to a particular place" can occur, certain criteria must be fulfilled: (1) the detention must "prove necessary"; (2) it must be "on the basis of an individual assessment of each case"; (3) "other less coercive measures cannot be applied effectively"; (4) the person must be either an asylum seeker or a person whose application for international protection has been rejected; and (5) the person must be the subject of a transfer decision to the responsible Member State. ${ }^{1637}$ In the assessment of "less coercive measures", Member States must take a non-exhaustive list of alternatives to detention into consideration, including "regular reporting to authorities, the deposit of a financial guarantee, an obligation to stay at a designated place or other measures to prevent the risk of absconding." 1638 However, the use of the word "effectively" when considering less coercive measures does import a degree of discretion into the Member State's considerations.

\section{Grounds for detention - "significant risk of him/her absconding"}

If those juridical hurdles have been cleared, an asylum seeker or an asylum seeker whose application has been rejected may only be detained if there is a "significant risk of him/her absconding". "Risk of absconding" is defined as:

"the existence of reasons in an individual case which are based on objective criteria defined by law, to believe that an applicant or a third-country national or a stateless person who is subject to a transfer decision may abscond"1639

The definition of "risk of absconding", as under Article 3(7) of the Returns Directive, essentially allows Member States to set their own criteria as regards what constitutes a risk of absconding. In that regard, the definition proves inadequate given that one of the aims of the CEAS is to provide for a uniform system, and given that the form of the secondary legislation is that of a Regulation (that is, it may be directly relied upon without further Member State implementation).

\footnotetext{
1635 Recital 18 to the Commission's Proposed Dublin Regulation 1636 Article 27(1) of the Commission's Proposed Dublin Regulation 1637 Article 27(2) of the Commission's Proposed Dublin Regulation 1638 Article 27(3) of the Commission's Proposed Dublin Regulation 1639 Article 2(l) of the Commission's Proposed Dublin Regulation
} 


\section{Limitations on detention}

Detention is to be for the shortest period possible and "shall be no longer than the time reasonably necessary to fulfil the required administrative procedures for carrying out a transfer". ${ }^{1640}$ In any event, the detention may only run from the time a person has been notified of a transfer decision in accordance with Article $25^{1641}$ and ceases when that person has been transferred to the responsible Member State. ${ }^{1642}$

Accordingly, the Proposal does ensure a reasonably active consideration of the principle of proportionality and necessity in considering a decision to detain. However, its weakness is the lack of specificity surrounding the definition of "risk of absconding".

\section{Minors}

Minors are subject to the best interests of the child as a primary consideration involving all procedures under the Regulation. ${ }^{1643}$ Member States are compelled to "closely cooperate" with each other in assessing the best interests of the child. ${ }^{1644}$ The factors to be taken into account when assessing the best interests of the child are identical to those in the Commission's 2011 Proposed Reception Conditions Directive ${ }^{1645}$, namely:

"In assessing the best interest of the child, Member State shall in particular take due account of the following factors:

(a) family reunification possibilities;

(b) the minor's well-being and social development, taking into particular consideration the minor's ethnic, religious, cultural and linguistic background;

(c) safety and security considerations, in particular where there is a risk of the minor being a victim of trafficking;

(d) the views of the minor in accordance with his/her age and maturity."1646

The Proposed Regulation provides that minors are not to be detained unless it is in their best interests as set out in the hierarchy of criteria in Article 7 and "in accordance with an individual examination of their situation" in accordance with Article 11(5) of the Reception Conditions Directive. ${ }^{1647}$

\footnotetext{
1640 Article 27(5) of the Commission's Proposed Dublin Regulation

1641 Article 25 of the Commission's Proposed Dublin Regulation deals with the procedural elements of the notification of a transfer decision - for example, that it be made in writing, in a language which the person is reasonably supposed to understand, within 15 days of the reply from the requested Member State.

1642 Article 27(4) of the Commission's Proposed Dublin Regulation

1643 Recital 10 and Article 6(1) of the Commission's Proposed Dublin Regulation

1644 Article 6(3) of the Commission's Proposed Dublin Regulation

1645 Article 23(2) of the Commission's 2011 Proposed Reception Conditions Directive

1646 Article 6(3) of the Commission's Proposed Dublin Regulation

1647 Which, at the time of the Commission's 2008 Proposed Reception Conditions Directive, read "Persons with special needs shall not be detained unless and individual
} 
The Proposed Regulation prohibits the detention of unaccompanied minors. ${ }^{1648}$ Member States are to ensure that a representative "represents and/or assists" any unaccompanied minors and which may be the same representative appointed under the Reception Conditions Directive. ${ }^{1649}$ Although the term "representative" is undefined, it would be preferable to ensure that the representative is in fact the legal guardian of any unaccompanied minor and that the "/or" is removed to ensure that the representative represents and assists the unaccompanied minor. Further, it would be preferable to ensure that any representative appointed is impartial and independent - that is, the authority determining the decision to transfer and detain the unaccompanied minor should not be the minor's representative in order to avoid any conflict of interest and to ensure that the best interests of the child are pursued.

It is of concern that, in the context of a transfer to another Member State, it is prohibited for an unaccompanied minor to be detained yet if that unaccompanied minor is to be subject to a return decision upon arrival in the responsible Member State, the Returns Directive provides no such prohibition against the detention of unaccompanied minors, thereby discriminating against the minor on account of their status which is prohibited by Article 2(1) CROC. It is difficult to substantiate why detention of an unaccompanied minor should be prohibited in one context, yet permitted in another. In any event, such a prohibition against the detention of unaccompanied minors should be consistent across the secondary legislation to ensure the maximum level of protection for minors.

\section{Vulnerable Persons}

The Proposed Regulation is largely silent on the needs of vulnerable persons in a detention context. The detention of vulnerable persons is implicitly permitted under the Proposed Regulation in two contexts: firstly, Article 27(12) provides:

\footnotetext{
"Member States shall ensure that asylum-seekers detained in accordance with this Article enjoy the same level of reception conditions for detained applicants as those laid down in particular in Articles 10 and 11 of Directive [.../.../EC] [laying down minimum standards for the reception of asylum seekers]" 1650
}

examination of their situation by a qualified professional certifies that their health, including their mental health, and well-being, will not significantly deteriorate as a result of the detention. Where persons with special needs are detained Member States shall ensure regular monitoring and adequate support." - Article 27(10) of the Commission's Proposed Dublin Regulation

1648 Article 27(11) of the Commission's Proposed Dublin Regulation

1649 Article 6(2) of the Commission's Proposed Dublin Regulation

1650 Article 27(12) of the Commission's Proposed Dublin Regulation 
At the time of the Commission's 2008 Proposed Reception Conditions Directive, Article 11 referred to the detention of vulnerable groups and persons with special needs. As discussed above in relation to the Commission's 2011 Proposed Reception Conditions Directive, Article 11(5) of the Proposed Reception Conditions Directive provided a safeguard against the detention of vulnerable persons unless it was certified that their "health, including their mental health and well-being" would not "significantly deteriorate as a result of detention". The drafting of the Article in the Commission's Proposed Dublin Regulation provides inadequate protection to vulnerable persons as, on a narrow reading, it presupposes that detention has already occurred and the Proposed Regulation appears to blindly refer to the Articles contained in the Proposed Reception Conditions Directive with the intention of prescribing the conditions of detention, but without taking into account their content as they relate to vulnerable persons (that is, they provide an extra qualification in relation to whether that class of persons should be detained at all, not just the conditions of their detention). The Proposed Dublin II Regulation should expressly provide for the protection of vulnerable persons in a detention context in an analogous way to that of minors under the Proposed Regulation, as well as has been proposed under the Recast Proposed Reception Conditions Directive to ensure that any decision concerning detention fully takes into account the fact that a person is vulnerable when assessing proportionality and necessity, and also to comply with the requirement of "lawfulness" under Article 5 ECHR on account of the suitability of detention conditions.

The second context in which vulnerable persons are contemplated are in the exchange of information between Member States solely for the purpose of providing care or treatment before a transfer is carried out. ${ }^{1651}$ This provision should be further substantiated by a provision for the special general considerations that should be given to vulnerable persons throughout the procedures in the Proposed Regulation (as indicated above).

\subsection{Australia}

\subsubsection{Overview of the Australian System}

The Australian system provides for the mandatory detention of all unauthorised arrivals that reach its Migration Zone, which includes asylum seekers (that is, "unlawful non-citizens" or "offshore entry persons") and those asylum seeking 'unlawful' arrivals at its excised offshore places. Asylum seekers who come to Australia with a valid visa (that is, "lawful non-citizens") and are immigration cleared remain in the community pending the determination of their claims. If a lawful non-citizen becomes an unlawful non-citizen in the Migration Zone by the expiry or cancellation of their visa, then he or she is

1651 Article 30(4) of the Commission's Proposed Dublin II Regulation 
subject to mandatory detention. An unlawful non-citizen is subject to automatic removal from Australia once their application for a substantive visa has been finally determined.

Detention is for an indefinite period of time - it only ceases when a person is removed, deported or is granted a visa. Accordingly, detention is prolonged in situations including where a person has been recognised as a refugee or in need of complementary protection but is awaiting the outcome of an ASIO security assessment; has failed the character test and where no other country is willing to receive the person; or doesn't meet the Public Interest Criteria (PIC) or ASIO security assessment and no other country is willing to receive the person.

These issues by themselves are particularly grave. However, the situations of children, families, vulnerable persons and stateless persons underscore that gravity.

Notwithstanding policy changes that have seen the increased used of Bridging Visas and community detention arrangements, these changes have not been reflected in the legislation. Accordingly, this has a resulting impact on any right to liberty and the justiciability of any such rights.

\subsubsection{At the External Borders (and even before reaching them)}

As discussed in Chapter 3, Australia adopts a universal visa regime (that is, a visa is necessary for lawful entry and stay in Australia). A visa provides a prima facie right of entry and stay. ${ }^{1652}$

In light of the particular plight of asylum seekers, a person may become an unlawful non-citizen if he or she arrives firstly, without a valid visa or secondly, with a visa but which is cancelled at or prior to "immigration clearance" or thirdly, if the person is not immigration cleared. ${ }^{1653}$ The consequence of not having a valid visa is being deemed an unlawful non-citizen and thus liable to detention. Accordingly, as we shall see, being a lawful non-citizen and immigration cleared allows an asylum seeker to remain at liberty in the community (or to express this another way, seeking asylum at the border without a valid visa or being immigration cleared leads to detention).

Prior to arrival at the border

It should be remembered that persons (that is, not just non-citizens) may, in certain circumstances, be detained by an Australian officer who has boarded a vessel (including whilst on the high seas, if the ship is an Australian ship) and

1652 Section 29 of the Migration Act 1958 (Cth)

1653 "Immigration clearance" is defined under section 173 of the Migration Act 1958 (Cth) 
brought to the Migration Zone or to be taken to a place outside of Australia. ${ }^{1654}$

Power exists for the Minister to cancel a visa prior to the person entering Australia. ${ }^{1655}$ Accordingly, upon arrival in Australia, the person is deemed an unlawful non-citizen. ${ }^{1656}$

\section{Arrival at the border}

For those asylum seekers that arrive in the Migration Zone without a valid visa, then the person is deemed an unlawful non-citizen. ${ }^{1657}$ For those that arrive at an excised offshore place, the person is deemed an "offshore entry person" (see further, Chapter 4). ${ }^{1658}$

Although the holding of a valid visa provides a right of entry and stay in Australia, that right is not entirely unqualified. The right to enter and remain in Australia as provided for by the visa is dependent upon a person being "immigration cleared". ${ }^{169}$ Part of that immigration clearance includes the mandatory provision of information required under the Act or Regulations, a visa that is in effect, the holding of a passport, and any personal identifiers required. ${ }^{1660}$ The failure to be immigration cleared or to provide evidence required during immigration clearance renders the person to be suspected of being an unlawful non-citizen, ${ }^{1661}$ and thus liable to detention. ${ }^{1662}$

There are further obligations upon non-citizens entering Australia. There is a duty on non-citizens to provide correct information ${ }^{1663}$ with regard to visa

\footnotetext{
${ }^{1654}$ Section $249 \mathrm{~F}(9)$ of the Migration Act 1958 (Cth)

1655 Section 128 of the Migration Act 1958 (Cth)

1656 Section 14 read with section 13 and the definitions under section 5(1) of the Migration Act 1958 (Cth)

1657 Section 14 read with section 13 and the definitions under section 5(1) of the Migration Act 1958 (Cth)

1658 Section 5(1) of the Migration Act 1958 (Cth)

1659 Sections 172-174 of the Migration Act 1958 (Cth)

${ }^{1660}$ Section 166 of the Migration Act 1958 (Cth); Regulations 3.03 and 3.03A of the Migration Regulations 1994 (Cth)

1661 Section 190 of the Migration Act 1958 (Cth)

1662 Section 189 of the Migration Act 1958 (Cth)

1663 In relation to "incorrect information" see Sandoval $v$ Minister for Immigration and Multicultural Affairs [2001] FCA 1237 per Gray J at para 50 "I am of the view that the question "Why do you want to visit Australia?" requires an applicant to give a reason, disclosing a purpose, genuinely held by the applicant, falling within the criteria for the visa concerned. It does not require an applicant to set out all of the reasons that he or she may have for wishing to come to Australia. As long as the reason specified in the answer is a genuine one, the answer cannot be said to be incorrect for the purposes of s 101(b) of the Migration Act." Accordingly, "incorrect information" is not constituted by omitted information that the immigration officer considered to be relevant - see Gray J at para 51. See also Singh v Minister for Immigration \& Anor [2006] FMCA 1163, paras 105-110.
} 
applications ${ }^{1664}$ and passenger cards, ${ }^{1665}$ an obligation not to provide bogus documents, ${ }^{1666}$ to notify the Department of changes in circumstances ${ }^{1667}$ and to notify the Department as soon as practicable if incorrect information has been given and to correct that information. ${ }^{1668}$ Those duties are to be discharged regardless of whether the non-citizen knew that the information was incorrect or not. ${ }^{1669}$ Failure to comply with those obligations can lead to visa cancellation at the border and prior to immigration clearance. ${ }^{1670}$ Cancellation may occur notwithstanding that non-compliance with those obligations was deliberate or inadvertent. ${ }^{1671}$ Powers also exist for officers to search a person, his or her belongings and clothing if the person is in detention ${ }^{1672}$ or is in immigration clearance and suspects that there are reasonable grounds for cancelling the person's visa. ${ }^{1673}$

Temporary visas may also be cancelled prior to or during immigration clearance (and indeed, after) as part of the Minister's general discretion to cancel visas. ${ }^{1674}$ In addition to the failure to comply with the provision of information obligations discussed above, such grounds include where: firstly, the circumstances which permitted the grant of the visa no longer exist; secondly, where there has been non-compliance with a visa condition; thirdly, where another person required to comply with the visa condition has not done so; fourthly, if the visa holder is or would be a risk to the "health safety or good order of the Australian community"; fifthly, if the grant of the visa should not have occurred because either the application or the grant contravened the Migration Act or another Commonwealth law; sixthly, if the holder of a student visa is not or not likely to be a genuine student or engage in (or omit) conduct "not contemplated by the visa"; and seventhly, for a ground prescribed by the Regulations for the cancellation. ${ }^{1675}$ The Minister must cancel a visa if the person's presence is or would be "contrary to Australia's foreign policy interests" (but which does not apply to Protection Visa applicants ${ }^{1676}$ ) or if ASIO has assessed the person "to be directly or

\footnotetext{
1664 Section 101 of the Migration Act 1958 (Cth)

1665 Section 102 of the Migration Act 1958 (Cth)

${ }^{1666}$ Section 103 of the Migration Act 1958 (Cth), noting section 97 of the Act for the definition of "bogus documents"

1667 Section 104 of the Migration Act 1958 (Cth)

1668 Section 105 of the Migration Act 1958 (Cth)

1669 Section 100 of the Migration Act 1958 (Cth)

${ }^{1670}$ Sections 109, 116(1)(d) and 117(1)(b) of the Migration Act 1958 (Cth)

1671 Section 111 of the Migration Act 1958 (Cth)

1672 An officer may detain the person for this purpose - section 252(3) of the Migration Act 1958 (Cth)

1673 Section 252 of the Migration Act 1958 (Cth)

1674 Sections 116 and 117 of the Migration Act 1958 (Cth)

1675 Section 116(1) of the Migration Act 1958 (Cth)

1676 See Schedule 2 Clause 866.225(a) of the Migration Regulations 1994
} 
indirectly a risk to security". ${ }^{1677}$

Given the particular difficulties that asylum seekers face as regards documentation and any disjunction between actual and stated intention in order to access the territory of asylum, any evidence in their belongings suggesting a purpose of coming to Australia other than that consistent with the face of their visa, ${ }^{1678}$ asylum seekers may be particularly vulnerable to visa cancellation under these provisions. Visa cancellation leads to being deemed an unlawful non-citizen and mandatory detention. Accordingly, the process of being screened-in as an applicant for asylum (in Australia, an applicant for a Protection Visa) is again of vital importance. Much turns on that initial contact with front line immigration officers and enunciating a request for protection.

\subsubsection{The Right to Remain}

5.3.3.1 The Right to Remain Pending Status Determination - Asylum Seeker as a Lawful Non-Citizen

Those asylum seekers who arrive 'lawfully' (that is, with a valid visa) represents the majority of asylum seekers who arrive in Australia, ${ }^{1679}$ yet in 2009 23.3\% of onshore arrivals successfully obtained refugee status, compared (in 20092010 ) to $73 \%$ of applicants at the RSA stage for offshore entry persons, and a further $44 \%$ of offshore entry persons who appealed the negative outcome of their RSA decision to the IMR. ${ }^{1680}$ Since the beginning of the Pacific Solution in 2001 to 2011 , between 70 to $95 \%$ of offshore asylum seekers have obtained refugee status. ${ }^{1681}$ Accordingly, notwithstanding that the asylum debate in Australia has focussed on the alleged lack of 'genuineness' of irregular arrivals, the above figures reveals that the real focus (in terms of humanitarianism as opposed to an immigration control issue) should be on

\footnotetext{
1677 Section 116(3) of the Migration Act 1958 (Cth) and Regulation 2.43(2) of the Migration Regulations 1994

1678 See, for example, Walton v Phillip Ruddock, The Minister for Immigration \& Multicultural Affairs [2001] FCA 1839; Sandoval v Minister for Immigration and Multicultural Affairs [2001] FCA 1237

1679 Parliament of Australia, Department of Parliamentary Services, Parliamentary Library, Background Note, Asylum seekers and refugees: what are the facts?, 14 January 2011, http://www.aph.gov.au/library/pubs/bn/sp/AsylumFacts.pdf (last accessed 22 May 2011), P.7

1680 Parliament of Australia, Department of Parliamentary Services, Parliamentary Library, Background Note, Asylum seekers and refugees: what are the facts?, 14 January 2011, http://www.aph.gov.au/library/pubs/bn/sp/AsylumFacts.pdf (last accessed 22 May 2011), P.9

1681 Parliament of Australia, Department of Parliamentary Services, Parliamentary Library, Background Note, Asylum seekers and refugees: what are the facts?, 14 January 2011, http://www.aph.gov.au/library/pubs/bn/sp/AsylumFacts.pdf (last accessed 22 May 2011), P.8-9
} 
irregular arrivals.

Those asylum seekers who enter and remain in Australia with a valid visa are characterised as "lawful non-citizens" under the Migration Act, ${ }^{1682}$ they are not subject to the mandatory detention provisions that unlawful non-citizens face. They may make an application for a Protection Visa provided that they are in the Migration Zone. ${ }^{1683}$ However, some applicants are administratively precluded from making an application. ${ }^{1684}$ By the fact that they hold a valid visa, they may remain in the community pending the determination of their Protection Visa application. Lawful non-citizens retain their status as such provided that they hold a valid visa. ${ }^{1685}$

In the event of the cessation of validity of an asylum seeker's visa pending the determination of their application for a Protection Visa (or, in general, if a valid application for a substantive visa is made ${ }^{1686}$ ), a Bridging Visa (a temporary visa) may be applied for so that the person can retain the status of lawful non-citizen and thus remain in the community (provided that they are an "eligible non-citizen"1687).

Although the rights attached to these visas will be explored in more detail in Chapter 8 on alternatives to detention and proportionality, Bridging Visas remain valid until either a specified date or an event occurs ${ }^{1688}$ - for example, if a substantive visa, such as a Protection Visa, comes into effect ${ }^{1689}$ or a specified event occurs. ${ }^{1690}$

Accordingly, the right to remain conferred by Bridging Visas A, B, C, and E (unless otherwise indicated) lasts until:

(1) the substantive visa (the subject of the application) is granted;

(2) the substantive visa currently held (if any) is cancelled (Bridging

1682 Sections 13 and 42 of the Migration Act 1958 (Cth)

1683 Schedule 2, Clause 866.411 of the Migration Regulations 1994 - that is, "in Australia" is defined in Regulation 1.03 as "in the migration zone".

1684 Migration Act 1958 (Cth) - an application for a Protection Visa is not a valid application in respect of those for whom there is a safe third country (section $91 \mathrm{E}(\mathrm{b})$ ), temporary safe haven visa holders (section $91 \mathrm{~K}$ ), and where protection is available from third countries (section 91P(2)).

1685 Section 13(1) of the Migration Act 1958 (Cth)

${ }^{1686}$ Australian Government Department of Immigration and Citizenship, Bridging Visas, Form 1024i, http://www.immi.gov.au/allforms/pdf/1024i.pdf (last accessed 25 October 2011), P.1

1687 Section 72 of the Migration Act 1958 (Cth) - that is, either "immigration cleared" as defined by section 172(1), or as prescribed by the Migration Regulations (namely, Regulation 2.20 of the Migration Regulations 1994), or a person the Minister has determined to be an eligible non-citizen in accordance with section 72(2)-(6). The exercise of the Minister's discretion in that last instance is non-compellable - see section 72(7).

1688 Section 73 of the Migration Act 1958 (Cth)

1689 Section 82(3) of the Migration Act 1958 (Cth)

1690 Section 82(7A) of the Migration Act 1958 (Cth) 
Visas A, B and C);

(3) 28 days after withdrawing the substantive visa application;

(4) 28 days after the notice of refusal of the substantive visa application;

(5) 28 days after the notification of a review decision (judicial or merits review);

(6) 28 days after the notification of the invalidity of a substantive visa application; or

(7) 28 days after the withdrawal of an application for judicial or merits review. ${ }^{1691}$

Only a Bridging Visa B allows the applicant to depart and re-enter Australia. ${ }^{1692}$ A Bridging Visa E may be granted to those seeking Ministerial intervention under sections $48 \mathrm{~B}$ or 417 and who have not previously sought or been the subject of a section 417 or $48 \mathrm{~B}$ determination. ${ }^{1693}$

Accordingly, given the backdrop of mandatory detention and automatic removal which is consequent upon any loss of lawful status, a Bridging Visa may be more accurately characterised as a right not to be removed during its validity, rather than a right to remain per se. For those with lawful non-citizen status, a high degree of suspensive effect applies to their right to remain. As long as a Bridging Visa is in place, their status remains lawful and thus may remain in Australia by not being subject to the automatic removal provisions.

\subsubsection{The Right to Remain - Asylum Seeker as an Unlawful Non-Citizen Migration Zone}

Asylum seekers who have entered the Migration Zone unlawfully and who are in detention can apply for a Protection Visa. ${ }^{1694}$

The ability of an asylum seeker to remain in Australia pending the determination of their application exists until their valid application for a substantive visa has been "finally determined", ${ }^{1695}$ after which time they must

1691 Migration Regulations 1994, Schedule 2, Clauses 010.511 - 010.513 (Bridging Visa A); Clauses 020.511 - 020.513 (Bridging Visa B); Clauses $030.511-030.513$ (Bridging Visa C); Clauses 050.511 - 050.517 (Bridging Visa E); Clauses 051.511 - 051.513 (Bridging Visa E Protection Visa Applicant)

1692 Migration Regulations 1994, Schedule 2, Clauses 020.511(c) and 020.512(c)

1693 Migration Regulations 1994, Schedule 2, Clause 050.212(5B) and (6)

1694 As well as a Bridging Visa within strict time limits - section 195 of the Migration Act 1958 (Cth)

1695 "Finally determined" is defined in section 5(9) of the Act as "For the purposes of this Act, an application under this Act is finally determined when either: (a) a decision that has been made in respect of the application is not, or is no longer, subject to any form of review under Part 5 or 7; or (b) a decision that has been made in respect of the application was subject to some form of review under Part 5 or 7 , but the period within which such a review could be instituted has ended without a review having been instituted as prescribed." 
be removed "as soon as reasonably practicable". ${ }^{1696}$ Accordingly, an asylum seeker has the right to remain pending the outcome of a review by the Migration Review Tribunal or the Refugee Review Tribunal, or until the time within which to lodge an appeal has passed. ${ }^{1697}$ In this sense, it is important to note that it is immaterial whether the decision by the Tribunal was subject to jurisdictional error (in which case it would not constitute a decision at all) but rather, in the words of the statute, the pivotal question is whether the decision is still "subject to any form of review" under Part 5 or Part 7 of the Act. ${ }^{1698}$ It may be inferred from Azemoudeh that removal would be unlawful where an asylum seeker's application for asylum had not been considered. ${ }^{1699}$

Indeed in Tchoylak, ${ }^{1700}$ concerning an asylum seeker who sought an appeal of his protection visa application, was rendered moot by his removal from Australia by DIAC pursuant to section 198 of the Act. The Court noted that the series of events and misunderstandings which led to the removal of the applicant "almost defie[d] credulity". ${ }^{1701}$ The Court issued a stern warning:

\begin{abstract}
"The respondent [Minister for Immigration] must take responsibility for ensuring that no-one is removed from this country while there are proceedings pending in this Court challenging the validity of that removal. We do not accept that any of the various subsections of $s 198$ of the Act, which impose a duty in circumstances there specified to remove a non-citizen "as soon as reasonably practicable" can be invoked by the respondent to justify what occurred in the present case." 1702
\end{abstract}

If a detained asylum seeker makes a request for Ministerial Intervention under sections $48 \mathrm{~B}$ or 417 , they are liable to removal as their request does not constitute an "application for a substantive visa" as contemplated by section 198 of the Migration Act. ${ }^{1703}$ Indeed, the mere fact that a person may be eligible for a substantive visa, but has not applied, does not affect their liability to be

\footnotetext{
1696 Section 198(2) of the Migration Act 1958 (Cth)

1697 See definition of "finally determined" under section 5(9) of the Act, supra

1698 Section 5(9) of the Migration Act 1958 (Cth); SZKUO $v$ Minister for Immigration and Citizenship [2009] FCAFC 167 at 24

1699 Re Masoud Azemoudeh v Minister for Immigration and Ethnic Affairs and Emil Joseph (1985) 8 ALD 281; [1985] FCA 380

1700 Tchoylak v Minister for Immigration and Multicultural Affairs [2001] FCA 872. See further in relation to this and related cases: Taylor, S, The Human Rights of Rejected Asylum Seekers Being Removed From Australia in Kneebone, S, (ed), The Refugee Convention 50 Years On, 2003, Ashgate, Aldershot, Pp.193-232

1701 Tchoylak v Minister for Immigration and Multicultural Affairs [2001] FCA 872 at para 17

1702 Tchoylak $v$ Minister for Immigration and Multicultural Affairs [2001] FCA 872 at para 53 cited with approval by the Full Court of the Federal Court of Australia in SZKUO $v$ Minister for Immigration and Citizenship [2009] FCAFC 167 at 32; see also Kopiev v Minister for Immigration and Multicultural Affairs [2000] FCA 1831

1703 See Masila v Minister for Immigration and Multicultural Affairs [2001] FCA 649 at para 15; not overturned on appeal Masila v Minister for Immigration and Multicultural Affairs [2001] FCA 1611
} 
removed. ${ }^{1704}$ In Bolea, ${ }^{1705}$ such a removal took place pending a section 417 application, rendering moot the application to extend the time to lodge a notice of appeal of judgment for judicial review of an MRT decision refusing the applicant's application for a bridging visa. However, Hill J, conceding that the application was rendered moot by the removal noted:

"14. But that leaves the issue of the unsatisfactory way in which those responsible have proceeded to remove someone who is in detention, in circumstances that inevitably defeated their legal rights, when proceedings are pending in the Court. As the Court said in Tchoylak, there are circumstances where removal, if it is known that the person has an application before the Court, could constitute contempt of court. Ultimately the responsibility lies with the Minister. Indirectly, of course, it lies with those responsible to him.

$[\ldots]$

16. The written judgment in Tchoylak was given ultimately on 10 July 2001 (the events occurred a considerable time before that). Eleven days later, what is effectively the same situation has happened again. Unless within 14 days of today the Minister provides satisfactory evidence of procedures to ensure that this situation is never to be repeated as far as human diligence can ensure and tenders an appropriate apology to the Court, I will consider sending the Court's papers to the Attorney-General with a request that he consider whether to commence proceedings directly against the Minister or those answerable to him for contempt of Court." 1706

In $S Z K U O^{1707}$ the applicant took some six years to bring proceedings seeking judicial review of the Tribunal's decision. The Full Federal Court cited Tchoylak and Bolea with approval, but noted that the obligation for an unlawful non-citizen to be removed "as soon as reasonably practicable" under section 198(2) "is qualified by considerations of practicality which would have to be determined on a case-by-case basis" noting that "[ $t]$ his would include consideration of whether the unlawful non-citizen had regularly commenced proceedings of substance in a court challenging the validity of the Tribunal decision which had not been determined". ${ }^{1708}$

Where judicial review by either the Federal Court or the High Court of Australia is possible, an application must be made within 35 days of the date of the decision. ${ }^{1709}$ However, unlike a Bridging Visa, the making of an application for judicial review for those in detention does not provide an automatic stay order or, to put it another way, does not provide any automatic suspensive effect. ${ }^{1710}$ Rather, a separate stay order has to be sought under section 23 of the Federal Court of Australia Act 1976 (Cth) or an injunction

\footnotetext{
1704 Section 198(3) of the Migration Act 1958 (Cth)

1705 Bolea v Minister for Immigration and Multicultural Affairs [2001] FCA 1129. In relation

1706 Bolea v Minister for Immigration and Multicultural Affairs [2001] FCA 1129 at paras 14 and 16

1707 SZKUO v Minister for Immigration and Citizenship [2009] FCAFC 167

1708 SZKUO v Minister for Immigration and Citizenship [2009] FCAFC 167 at 32

1709 Sections 477A and 486A of the Migration Act 1958 (Cth)

1710 Sections 481 and 486AB of the Migration Act 1958 (Cth)
} 
from the High Court of Australia under its inherent jurisdiction.

\section{Offshore Entry Persons (Excised Offshore Places)}

Offshore Entry Persons are administratively precluded from making an application for any visa, including a Protection Visa by virtue of section 46A of the Act. Following the High Court of Australia's decision in M61/M69, the Court interpreted the decision by the Minister to make enquiries about whether Australia owed protection obligations to Offshore Entry Persons (incidental to sections 46A and 195A) as inclusive of the ability to make a valid application for a substantive visa. ${ }^{1711}$ Accordingly, removal of an Offshore Entry Person "as soon as reasonably practicable" may only occur after the taking of steps to consider whether to 'lift the bar' of section 46A have been concluded (or, in the words of the statute, "finally determined"). The Full Federal Court has recently held that the 35-day time limit within which to lodge proceedings against a negative IMR decision does not apply to offshore applicants. ${ }^{1712}$ Following the Government's recent announcement of a single Protection Visa determination system for both onshore and offshore applicants, ${ }^{1713}$ it is arguable that such offshore entry persons would have a right to remain equivalent to those in the regular onshore process.

In relation to Offshore Entry Persons who are subject to removal to another country for offshore processing, ${ }^{1714}$ the High Court of Australia has recently indicated that the declaration made by the Minister concerning the destination country ${ }^{1715}$ is a question of jurisdictional fact and that, unless those jurisdictional facts are satisfied in respect of the destination country, removal cannot occur. ${ }^{1716}$

More specifically, in relation to that declaration, section $198 \mathrm{~A}(3)$ of the Migration Act provides:

"The Minister may:

(a) declare in writing that a specified country:

1711 M61/2010E v Commonwealth of Australia; M69/2010 v Commonwealth of Australia [2010] HCA 41 at 35 and 71

1712 SZQDZ v Minister for Immigration and Citizenship [2012] FCAFC 26

1713 Bowen, The Honourable Chris, Minister for Immigration and Citizenship, Bridging visas to be issue for boat arrivals, 25 November 2011, http://www.minister.immi.gov.au/media/cb/2011/cb180599.htm (last accessed 27 April 2012); Needham, K, Boat refugees will be assessed as air arrivals, Sydney Morning Herald, 20 March 2012, http://www.smh.com.au/opinion/political-news/boat-refugees-will-beassessed-as-air-arrivals-20120319-1vfrn.html (last accessed 27 April 2012)

1714 Section 198A(1) of the Migration Act 1958 (Cth)

1715 Section 198A(3) of the Migration Act 1958 (Cth)

1716 M70/2011 v Minister for Immigration and Citizenship, M106/2011 v Minister for Immigration and Citizenship [2011] HCA 32; See further, Wood, T, and McAdam, J, Australian Asylum Policy All At Sea: An Analysis of Plaintiff M70/2011 v Minister for Immigration and Citizenship and the Australia-Malaysia Arrangement (2012) 61 ICLQ 274, Pp.282-288 
(i) provides access, for persons seeking asylum, to effective procedures for assessing their need for protection; and

(ii) provides protection for persons seeking asylum, pending determination of their refugee status; and

(iii) provides protection to persons who are given refugee status, pending their voluntary repatriation to their country of origin or resettlement in another country; and

(iv) meets relevant human rights standards in providing that protection; and

(b) in writing, revoke a declaration made under paragraph (a).

The declaration made with respect to Malaysia was found to be deficient having regard to the laws in force in Malaysia which obliged the protection of those asylum seekers (that is, legal obligations to provide protection were the paramount consideration, not solely what occurred in practice). ${ }^{1717}$

In relation to whether section 198 (which is the general removal power) or s198A of the Migration Act applied, the majority of the High Court held that section 198A was the sole source of power for the removal of the asylum seekers. $^{1718}$

In relation to unaccompanied minors who are Offshore Entry Persons, not only are the provisions of section 198A applicable, but also the provisions of the Immigration (Guardianship of Children) Act 1946 (Cth) (the "IGOC Act"). A non-citizen unaccompanied minor cannot leave Australia without ministerial written consent. ${ }^{1719}$ Further, that ministerial consent cannot be refused unless the Minister is "satisfied that the granting of the consent would be prejudicial to the interests of the non-citizen child". ${ }^{1720}$ Although the High Court of Australia did not answer this question squarely in $M 70$, the majority indicated, as obiter dicta, that a generalised determination by the Minister was insufficient for the purposes of the IGOC Act - that is, that only the written consent contemplated by the IGOC Act would be satisfactory. ${ }^{1721}$ Further, such consent should be furnished with reasons and, thus, susceptible to judicial

1717 M70/2011 v Minister for Immigration and Citizenship, M106/2011 v Minister for Immigration and Citizenship [2011] HCA 32 per French CJ at 65, Gummow, Hayne, Crennan, Bell JJ at 125-135, Kiefel J at 244-245. See also Francis, A, and Caton, S, Access to Protection for 'Offshore Entry Persons' aka asylum seekers (2011) 36(3) Alternative Law Journal Volume 172; In relation to obligations when transferring asylum seekers to a third country, see Foster, M, Protection Elsewhere: The Legal Implications of Requiring Refugees to Seek Protection in another State (2007) 28 Michigan Journal of International Law 223

1718 M70/2011 v Minister for Immigration and Citizenship, M106/2011 v Minister for Immigration and Citizenship [2011] HCA 32, per Hummow, Hayne, Crennan and Bell JJ at paras 97-98; per French CJ at paras 54-55; per Kiefel J at para 239

1719 Section 6A(1) of the Immigration (Guardianship of Children) Act 1946 (Cth)

1720 Section 6A(2) of the Immigration (Guardianship of Children) Act 1946 (Cth)

1721 M70/2011 v Minister for Immigration and Citizenship, M106/2011 v Minister for Immigration and Citizenship [2011] HCA 32 per Gummow, Hayne, Crennan and Bell JJ at paras 137-147 with French CJ agreeing at para 69; per Kiefel J at 257 
review. $^{1722}$

\section{Transitory Persons}

Transitory Persons are also administratively precluded from making an application for any visa and are only able to seek an assessment by the RRT that they are a refugee (that is, it does not include complementary forms of protection) once they have remained in Australia for a continuous period of six months. ${ }^{1723}$ They are to be removed as soon as reasonably practicable "after the person no longer needs to be in Australia for that [temporary] purpose (whether or not that purpose has been achieved)". ${ }^{1724} \mathrm{P} 1 / 2003$ involved a transitory person who had arrived in Australia unlawfully, who had then been taken to Nauru and then taken back to Australia to give evidence in a coronial inquest. Whilst in Australia having been brought from Nauru, the applicant sought damages against the Minister for various breaches of duty. French J declined to order an injunction preventing his removal from Australia back to Nauru notwithstanding that litigation was on foot. His Honour stated that "the mandatory terms of the legislation leave no room for transitory persons or unlawful non-citizens to remain in Australia merely for the purpose of pursuing legal proceedings in this country". ${ }^{1725}$ In light of the foregoing case law, and the fact that an appeal was attempted, but never heard, in this matter, ${ }^{1726}$ it is unclear how much weight can be ascribed to that judgment.

\subsubsection{The Right to Liberty}

\subsubsection{The Right to Liberty - Asylum Seeker as a Lawful Non-Citizen}

As indicated earlier, an asylum seeker who has entered Australia lawfully and has subsequently applied for a Protection Visa will be able to remain in the community pending the determination of their application. Accordingly, the right to remain is fused with a right to liberty for those asylum seekers initially through their substantive visa and then through any subsequent Bridging Visa.

Given that mandatory detention and automatic removal are the consequences for becoming an unlawful non-citizen, the right to liberty for those asylum seekers is more accurately described as a negative right - that is, the right not to

1722 M70/2011 v Minister for Immigration and Citizenship, M106/2011 v Minister for Immigration and Citizenship [2011] HCA 32 per Gummow, Hayne, Crennan and Bell JJ at para 146

1723 Sections 46B and 198C of the Migration Act 1958 (Cth)

${ }_{1724}$ Section 198(1A) of the Migration Act 1958 (Cth)

1725 P1/2003 v Minister for Immigration and Multicultural and Indigenous Affairs [2003] FCA 1029 , para 51

1726 P1/2003 v Minister for Immigration and Multicultural and Indigenous Affairs [2003] FCA 1370, a fact noted by Mansfield $\mathrm{J}$ in Mastipour $v$ Secretary, Department of Immigration and Multicultural and Indigenous Affairs [2004] FCA 1571, para 27 
be detained and the right not to be removed.

\subsubsection{The Right to Liberty - Asylum Seeker as an Unlawful Non-Citizen \\ 5.3.4.2.1 Migration Zone}

The current law provides for mandatory detention of all unlawful non-citizens (which includes asylum seekers who have entered Australia "unlawfully"). As discussed earlier, a person is an unlawful non-citizen if he/she does not possess a valid visa to enter and remain in Australia or is not immigration cleared. Under section 189(1) of the Migration Act, an officer must detain a person in the Migration Zone ${ }^{1727}$ (other than on excised offshore place) if the officer knows or reasonably suspects that a person is an unlawful non-citizen. Under section 189(2), an officer must detain a person who is in Australia but outside the Migration Zone if that person is seeking to enter the Migration Zone (other than an excised offshore place) or would be an unlawful non-citizen if in the Migration Zone.

Accordingly, there is no discretion to be exercised in the detention of an unlawful non-citizen in those circumstances. As Hayne J noted in Al-Kateb $v$ Godwin:

\footnotetext{
"True it is that the requirement is made of the Executive: an "officer" must detain. But the provision is mandatory; the legislature requires that persons of the identified class be detained and kept in detention. No discretion must, or even can, be exercised. No judgment is called or. The only disputable question is whether the person is an unlawful non-citizen. And the courts can readily adjudicate any dispute about that. There is, therefore, nothing about the decision-making that must precede detention which bespeaks an exercise of the judicial power. Nor is there any legislative judgment made against a person otherwise entitled to be at liberty in the Australian community. The premise for the debate is that the non-citizen does not have permission to be at liberty in the community." 1728
}

\subsection{Migration Zone - Minors}

As outlined in Chapter 4, the definition of "non-citizen" under the Migration Act makes no distinction between minor and adult non-citizens as regards a decision to detain. Accordingly, for those minors in the Migration Zone, the law makes their detention obligatory and, if in an excised offshore place, equally susceptible, at law, to mandatory detention as with an adult offshore entry person. ${ }^{1729}$

Following the submission of the report by the Human Rights and Equal Opportunity Commission (now the Australian Human Rights Commission)

\footnotetext{
${ }^{1727}$ See earlier discussion on the 'excision' of Australian territory and the explanation of the "Migration Zone" in Chapters 3 and 4

1728 Al-Kateb v Godwin [2004] HCA 37 per Hayne J at para 254

${ }^{1729}$ In relation to the establishment of a prima facie case of unlawful detention of minors see, Plaintiff M168/10 v The Commonwealth \& Ors [2011] HCA 25 in which a prima facie case could not be made out
} 
entitled A Last Resort - The National Inquiry into Children in Immigration Detention, ${ }^{1730}$ section 4AA was inserted into the Migration Act in 2005 which provides, "as a principle that a minor shall only be detained as a measure of last resort". ${ }^{1731}$ As a "principle", this is of very dubious justiciable value. However, unlike for adult detainees, subsection (2) of that section provides that a reference to a minor being detained does not include a minor who is "residing" at a place in accordance with a residence determination granted by the Minister under section 197AB(1) of the Act. As noted by Crock et al, this effectively meant that children were released into "community detention" rather than being held in traditional immigration detention facilities. ${ }^{1732}$ As at 30 April 2012, 9 minors were in Immigration Residential Housing, 454 were in Alternative Places of Detention (158 being on Christmas Island) and 556 were the subject of a Community Residence Determination. ${ }^{1733}$ Although DIAC states that "[n]o children are detained in an immigration detention centre", ${ }^{1734}$ "immigration detention centre" is not defined in the Migration Act and it is possible that, although not "detained" within the meaning ascribed to that word in the Migration Act by virtue of section 4AA(2) (that is, because a residence determination has been made in favour of the minor under section 197AB), detention as a question of fact may still occur depending on the place which has been the subject of a residence determination and the conditions of that placement. In that regard, what constitutes "detention" has, in the past, been known to be more an issue of semantics than of substance. ${ }^{1735}$ Indeed, there have been recent examples of minors' community detention orders

1730 Human Rights and Equal Opportunity Commission, A Last Resort - The National Inquiry into Children in Immigration Detention, April 2004, Sydney http://www.humanrights.gov.au/human_rights/children_detention_report/report/PDF/al r_complete.pdf (last accessed 30 October 2011)

1731 Section 4AA(1) of the Migration Act 1958 (Cth). See also Ozdowski, S, An Absence of Human Rights: Children in Detention, paper delivered at Human Rights Law and Policy Conference, 16-17 June 2008, Melbourne, http://www.ajustaustralia.com/resource.php?act=attache\&id=321 (last accessed 30 October 2011)

1732 Crock, M, Saul, B, and Dastyari, A, Future Seekers II, 2006, Federation Press, Leichhardt, Pp. 164-165

1733 Australian Government, Department of Immigration and Citizenship, Immigration Detention Statistics Summary, 30 April 2012, http://www.immi.gov.au/managing-australiasborders/detention/_pdf/immigration-detention-statistics-20120430.pdf (last accessed 1 June 2012), P.4

1734 Australian Government, Department of Immigration and Citizenship, Immigration Detention Statistics Summary, 30 April 2012, http://www.immi.gov.au/managing-australiasborders/detention/_pdf/immigration-detention-statistics-20120430.pdf (last accessed 1 June 2012), P.7

1735 See Amnesty International, Detention of children on Christmas Island must end, 18 June 2009, http://www.amnesty.org.au/news/comments/21194/ (last accessed 30 October 2011), and Government response to report on immigration detention unacceptable, 19 August 2009, http://www.amnesty.org.au/news/comments/21567/ (last accessed 30 October 2011) 
being revoked. ${ }^{1736}$

\subsection{Guardianship of Minors}

As noted in Chapter 4, the Minister is deemed the guardian of unaccompanied minors by operation of section 6 of the Immigration (Guardianship of Children) Act 1946 (Cth). The appointment of the Minister is not prejudiced by the child's mode of entry into Australia. ${ }^{1737}$ The scope of the guardianship duty is provided for in section 6 which is inclusive of "the same rights, powers, duties, obligations, and liabilities as the natural guardian of the child would have".

Taylor notes that the Minister's responsibilities are inclusive of the duties of guardianship at common law, and the nature of the relationship is a fiduciary one with the best interest of the child at its core. ${ }^{1738}$

The scope of the Minister's responsibility under section 6 was further elaborated upon in the Federal Court in " $X$ " to include:

"The responsibilities of a guardian under s 6 of the Act include the responsibilities which are the subject of the Convention [on the Rights of the Child]. They are responsibilities concerned with according fundamental human rights to children. $[\ldots]$ Once it is recognised that the rights with $\mathrm{s} 6$ is concerned are in the nature of fundamental human rights it becomes clear that Parliament intended that if a noncitizen child were denied any of these fundamental rights, they would have access to the legal system with the minimum of formal hurdles." 1739

Delegation to a State child welfare authority (amongst other possible delegates) is made possible by section 5. However, it would appear that, notwithstanding an effective delegation (which Taylor questions) ultimate legal responsibility remains with the Minister. ${ }^{1740}$ Crock and Berg indicate that, in practice, the appointment of a guardian does not occur until after a "screening in" process has been undertaken (that is, until it has been established that the minor has

1736 Needham, K, Protest as teenage asylum seekers are detained with adults, Sydney Morning Herald, 16 December 2011, http://www.smh.com.au/world/protest-as-teenage-asylumseekers-are-detained-with-adults-20111215-1owyf.html (last accessed 1 June 2012)

1737 M70/2011 v Minister for Immigration and Citizenship; M106/2011 v Minister for Immigration and Citizenship [2011] HCA 32 per Gummow, Hayne, Crennan, and Bell JJ at 141

1738 Taylor, J, Guardianship of Child Asylum Seekers (2006) 34 Federal Law Review 185, P.190

1739 X v Minister for Immigration \& Multicultural Affairs [1999] FCA 995 at para 43

1740 Buti, A, British Child Migration to Australia: History, Senate Inquiry and Responsibilities, (2002) 9(4) E-Law - Murdoch University Electronic Journal of Law http://www.murdoch.edu.au/elaw/issues/v9n4/buti94.html (last accessed 2 November 2011) at para 6, cited in Taylor, J, Guardianship of Child Asylum Seekers (2006) 34 Federal Law Review 185, P.187, n13; see also Crock, M, Seeking Asylum Alone, 2006, Themis Press, Leichhardt, P.106 
some prima facie merit and justification for the grant of a visa). ${ }^{1741}$

\title{
5.3.4.2.1.3 Guardianship of Minors - Conflict of Interests
}

However, as Taylor observes, ${ }^{1742}$ the potential for conflicts of interest of the Minster's simultaneous role as guardian of an unaccompanied minor and administrator of the Migration Act was noted by the Full Federal Court in Odhiambo where the Court observed:

\begin{abstract}
"For example, the Minister may have a policy of detaining all asylum seekers (or all persons falling within a particular class of asylum seekers) pending final determination of their claims to be recognised as refugees. Yet a person acting independently of the Minister might see grounds, in the particular case, for the grant of a bridging visa permitting release of the child from detention during that period.

Similarly, as the person administering the Migration Act, the Minister has an interest in resisting challenges of delegates and decisions of the Tribunal that uphold delegates' decisions. That interest is directly opposed to the interest of an asylum seeker in setting aside a decision unfavourable to him or her and obtaining reconsideration of the application for a protection visa." ${ }^{1743}$
\end{abstract}

The High Court of Australia has noted the tension between the IGOC Act and the Migration Act in $W A C B .{ }^{1744}$ Although the majority indicated (as obiter dicta) that the Minister's responsibilities as guardian do not necessarily take precedence over the Minister's obligations under the Migration Act, the majority expressed the view that the Minister's role as guardian was not clear and the Court did not proceed to determine that issue on the basis that it was "irrelevant to the question raised by this appeal". ${ }^{174}$ As Taylor points out "International law and Australian domestic child welfare laws should inform the Court's interpretation in which the obligation of the Minister to care for the welfare of the child takes precedence over obligations under the Migration Act [citations omitted]."1746

As discussed earlier, an unlawful non-citizen in detention who wishes to seek

\footnotetext{
1741 Crock, M, and Berg, L, Immigration, Refugees and Forced Migration - Law Policy and Practice in Australia, 2011, Federation Press, Leichhardt, P.151 citing at fn.35 Crock, M, Seeking Asylum Alone, 2006, Themis Press, Leichhardt, Pp.119-131

1742 Taylor, J, Guardianship of Child Asylum Seekers (2006) 34 Federal Law Review 185, P.190ff; see also Crock, M, You have to be stronger than razor wire: Legal issues relating to the detention of Refugees and asylum seekers (2002) 10 AJ Admin L 33, Pp.56-60

1743 Odhiambo v Minister for Immigration and Multicultural Affairs [2002] FCAFC 194 at paras 90-91; see also Crock, M, Seeking Asylum Alone, 2006, Themis Press, Leichhardt, P.106 1744 WACB $v$ Minister for Immigration and Multicultural and Indigenous Affairs [2004] HCA 50 1745 WACB v Minister for Immigration and Multicultural and Indigenous Affairs [2004] HCA 50 at para 42; see also Kirby J at para 106; see also M70/2011 v Minister for Immigration and Citizenship; M106/2011 v Minister for Immigration and Citizenship [2011] HCA 32 per Gummow, Hayne, Crennan, and Bell JJ at 145

1746 Taylor, J, Guardianship of Child Asylum Seekers (2006) 34 Federal Law Review 185, P.194
} 
judicial review of an adverse merits decision is not entitled to an automatic stay order (or suspensive effect) upon the commencement of judicial review proceedings. The issue of the conflict of interest of the Minister's roles was manifest in the case of $X^{1747}$ where Crock notes that the Minister argued that the minor children involved should be prevented from lodging their application for judicial review within the prescribed period (indeed, they had already been removed to Singapore in contravention of a Federal Court order and then subsequently brought back to Australia) on the basis that firstly, they lacked legal capacity as minors and, secondly, that the Minister would have a conflict of interest in acting as tutor or guardian ad litem because he had an opposing interest to the minor applicants. ${ }^{1748}$ The Court noted that the substantive right to commence litigation was not affected by their status as minors ${ }^{1749}$ and devolved considerations based firstly, on the age, understanding and capacity of the child; secondly, an assessment of the "nature of the rights asserted and the urgency attending the determination of those rights"; thirdly, "the ease or otherwise of the child finding a tutor to act"; fourthly, whether requiring a tutor to be appointed "would stifle the litigation" and lastly "any undue prejudice" to the opposing party in relation to costs if the minors were unsuccessful. ${ }^{1750}$ The situation for unaccompanied minors is particularly compromised where, notwithstanding the appointment of a guardian, that guardian displays a lack of willingness to act on the child's behalf. ${ }^{1751}$

\subsection{Families}

As with minors (discussed above) and vulnerable persons (discussed below), the Migration Act does not distinguish between families and other groups of unlawful non-citizens (see Chapter 4) as regards a decision to detain. Accordingly, the detention of families (including with minor children) remains possible at law.

\subsection{Vulnerable Persons}

Just as the Migration Act does not distinguish between minors and other noncitizens, nor does the Act make any distinction between vulnerable persons and other non-citizens as regards a decision to detain. The relevant parts of the Disability Discrimination Act 1992 (Cth) (relating to discrimination in work, to other areas including access to premises and accommodation, and to disability standards) do not apply to the Migration Act or any instrument made under (including any permitted or required action taken under either the Act or any

\footnotetext{
1747 X v Minister for Immigration \& Multicultural Affairs [1999] FCA 995

1748 Crock, M, Seeking Asylum Alone, 2006, Themis Press, Leichhardt, P.107

$1749 X v$ Minister for Immigration \& Multicultural Affairs [1999] FCA 995 at paras 54 and 61

1750 X v Minister for Immigration \& Multicultural Affairs [1999] FCA 995 at para 62 also cited in Crock, M, Seeking Asylum Alone, 2006, Themis Press, Leichhardt, P.107

1751 Odhiambo v Minister for Immigration and Multicultural Affairs [2002] FCAFC 194 and commentary thereon in Taylor, J, Guardianship of Child Asylum Seekers (2006) 34 Federal Law Review 185, Pp.196-200
} 
instrument made under it). ${ }^{1752}$ Although the Joint Standing Committee on Migration noted in 2008 that mental health checks were done as part of an initial health screen in practice, ${ }^{1753}$ the law is silent on provisions that are inclusive of a range of vulnerable persons to be identified and for justiciable rights to be ascribed to those persons in relation to any decision to detain them (other than in the context of possible eligibility for a Bridging Visa as discussed below).

\subsection{Stateless Persons}

As discussed in this and the preceding chapter, the High Court of Australia's decision in Al Kateb $v$ Godwin ${ }^{1754}$ held that the indefinite detention of a Palestinian who had no reasonable prospects of removal to another country was lawful. The case highlights the particular vulnerabilities that stateless persons face in the Australian legal landscape. The response to the decision was the creation of the Removal Pending Bridging Visa for those unlawful noncitizens detained where "removal from Australia is not reasonably practicable at that time" (see below and Chapter 8). ${ }^{1755}$ However, a stateless person in this situation may remain in detention indefinitely at the will of the Minister. As noted by the AHRC, Australia does not have a formal stateless identification procedure. ${ }^{1756}$

\subsection{Establishing Liberty}

Other than pursuing a writ for habeas corpus or other relief challenging the lawfulness of the detention itself (if that is, in fact, in issue), and given that a person may only be released from detention by way of removal, deportation, being issued a visa or being an Australian citizen (and given that a Court is expressly prohibited from ordering the release of a person from detention unless the person has been granted a visa), ${ }^{1757}$ liberty for those in detention is usually achieved by way of a Bridging Visa. ${ }^{1758} \mathrm{~A}$ detailed analysis of the Bridging Visa provisions is made in Chapter 8 (as regards proportionality and alternatives to detention) and, for the sake of conciseness, will not be repeated here. What should be borne in mind is that Bridging Visas E (subclasses 050 and 051), F and $\mathrm{R}$ are the only Bridging Visas that may be applied for whilst a person is in immigration detention in the Migration Zone. When one looks at

\footnotetext{
1752 Section 52 of the Disability Discrimination Act 1992 (Cth)

1753 Parliament of Australia, Joint Standing Committee on Migration, Immigration detention in Australia: A new beginning, December 2008, Canberra, P.38, para 2.22

1754 Al Kateb v Godwin [2004] HCA 37

1755 Removal Pending Bridging Visa, subclass 070, and Regulation 2.20(12) of the Migration Regulations

1756 Australian Human Rights Commission, Australian Human Rights Commission Submission to the Joint Select Committee on Australia's Immigration Detention Network, August 2011, http://www.hreoc.gov.au/legal/submissions/2011/201108_immigration.pdf (last accessed 31 October 2011) P.24, para 67

1757 Sections 196(1) - (3) and 191 of the Migration Act 1958 (Cth)

1758 Noting the two day time limit involved for the application of a substantive visa under section 195 of the Migration Act 1958 (Cth) unless it is a Protection or Bridging Visa
} 
the cumulative requirements firstly, to be eligible to apply for a Bridging Visa, then, secondly, the eligibility requirements for the classes of Bridging Visas themselves, what emerges is an extremely constrained class of eligibility. The Bridging Visa regime is not an evaluation of a substantive right to liberty but rather, the matching of highly specific eligibility requirements against the individual circumstances of the applicant.

In very general terms, certain categories of asylum seeker (prescribed under the Migration Regulations) who are not immigration cleared (which may include border applicants) may be eligible for Bridging Visas to release them from detention. ${ }^{1759}$ These categories include minors, those who are at least 75 years old, those who have special needs (torture or trauma victims) or those who are spouses or de facto partners of an Australian citizen. ${ }^{1760}$ For those border applicants that fall outside these prescribed categories, only the Minister personally ${ }^{1761}$ can make a non-compellable ${ }^{1762}$ determination that an asylum seeker is eligible for a Bridging Visa, inter alia, if they have been in detention for at least six months after making their Protection Visa application and a primary decision has not been made in relation to their Protection Visa application. ${ }^{1763} \mathrm{~A}$ further non-compellable, personally exercisable Ministerial discretion exists for the granting of visas for those in detention (whether they have applied or not) under section 195A of the Act.

In response to the decision in Al Kateb (above) the Removal Pending Bridging Visa was established for those unlawful non-citizens detained where "removal from Australia is not reasonably practicable at that time". ${ }^{1764}$ However, a valid application for that Bridging Visa is made only by accepting an invitation from the Minister ${ }^{1765}$ and is then granted by the Minister exercising his or her noncompellable and non-reviewable discretion under section 195A of the Act. Effectively, persons in this situation may remain in indefinite detention at the will of the Minister.

\subsection{Right to Liberty - Asylum Seeker as an Unlawful Non-Citizen - Excised Offshore Places}

Those unlawful non-citizens in excised offshore places are also subject to mandatory detention under section 189(3). A discretion to detain is only given to an officer under section 189(4), if the person is in Australia, but outside the

\footnotetext{
1759 Section 72(1)(b) of the Migration Act 1958 (Cth)

${ }_{1760}$ Regulations 2.20(5) - (11) of the Migration Regulations 1994 (Cth)

${ }_{1761}$ Section 72(3) of the Migration Act 1958 (Cth)

1762 Section 72(7) of the Migration Act 1958 (Cth)

1763 Section 72(2)(c)-(d) of the Migration Act 1958 (Cth)

1764 Removal Pending Bridging Visa, subclass 070, and Regulation 2.20(12) of the Migration Regulations

1765 Section 46(2) of the Migration Act 1958 (Cth); Schedule 2, clause 070.211 of the Migration Regulations; Regulation 2.20A(2) of the Migration Regulations
} 
Migration Zone and is seeking to enter an excised offshore place and would be an unlawful non-citizen if in the Migration Zone. The Australian policy has been to take all unauthorised boat arrivals to Christmas Island for processing and, consequently, detention. ${ }^{1766}$ However, an apparently different approach is taken for other types of offshore entry persons:

\begin{abstract}
"Sometimes overseas visitors on yachts make ports at excised offshore places their first point of entry into Australia yet forgot to obtain visas before arrival. They, too, will be offshore entry persons and barred from applying for visas in Australia. As an alternative to detention in such circumstances, immigration officers may direct the visitors to remain on board their yacht until departure while also giving them the opportunity to replenish low stores and supplies if required." ${ }^{1767}$
\end{abstract}

Indeed, one cannot help but draw the inference from that statement that those who are detained are detained because they are asylum seekers.

As indicated in Chapter 4, asylum seekers who are unlawful non-citizens and who arrive at an excised offshore place are administratively precluded from making an application for a visa (including a protection visa or a bridging visa) by the operation of section 46A of the Migration Act and are thus unable to regularise their stay or be at liberty as they cannot even apply for a Bridging Visa. As mentioned in earlier chapters, the Government's recent announcement to process their Protection Visa claims under the same system as those in the Migration Zone occurs only through ministerial discretion under section 46A of the Act. ${ }^{1768}$ Further, notwithstanding the policy announcement that Bridging Visas would be issued for boat arrivals (including offshore entry persons), ${ }^{1769}$ such a grant still remains a matter of ministerial discretion under either section 46A or section 195A of the Act.

In relation to Offshore Entry Persons who are the subject of removal for

1766 Australian Government, Department of Immigration and Citizenship, Fact Sheet 75 Processing Irregular Maritime Arrivals, http://www.immi.gov.au/media/factsheets/75processing-irregular-maritime-arrivals.htm (last accessed 29 May 2011) and Department of Immigration and Citizenship, Managing Australia's Borders, Detention Services, About Immigration Detention, Key Immigration Detention Values, http://www.immi.gov.au/managing-australias-borders/detention/about/key-values.htm (last accessed 29 May 2011)

1767 Australian Government, Department of Immigration and Citizenship, Fact Sheet 81 Australia's Excised Offshore Places, http://www.immi.gov.au/media/fact-sheets/81excisedoffshore.htm (last accessed 29 May 2011)

1768 Australian Government, Department of Immigration and Citizenship, Implementation of a single process for Irregular Maritime Arrivals (Questions and Answers), http://www.immi.gov.au/visas/humanitarian/_pdf/implementation_single_process_ima.pd f (last accessed 27 April 2012)

1769 Bowen, The Honourable Chris, Minister for Immigration and Citizenship, Bridging visas to be issue for boat arrivals, 25 November 2011, http://www.minister.immi.gov.au/media/cb/2011/cb180599.htm (last accessed 27 April 2012); 
processing in another country, although section 198A(4) deems them not to be in immigration detention, provision has been made under section 198A(2) for coercive powers to be used incidental to their being taken to another country. French CJ observed in $M 70$ :

\begin{abstract}
"According to the Explanatory Memorandum for the 2001 Excision Consequential Provisions Bill those words mean that a person is not in "immigration detention'... merely because the person is being dealt with under section 198A." They plainly do not and cannot bear that meaning. They explicitly exclude a person who is being dealt with under s 198A from being in immigration detention for any other purposes under the Act." 1770
\end{abstract}

But, later in that judgment, the Chief Justice went on to say:

"The plaintiffs pointed to s 198A(4) and the cessation of immigration detention in relation to a person being dealt with under s 198A. They submitted that s 198A(4) is enlivened upon a decision being taken to consider an offshore entry person for removal from Australia under s 198A(1). Although such a person is not in immigration detention as defined in s 5(1), he or she can be detained as an incident of the power to take him or her to another country. The existence of that incidental power is indicated by the specific but non-exhaustive coercive powers conferred by s $198 \mathrm{~A}(2)$. The cessation of immigration detention for persons being dealt with under s 198A(1) is consistent with the discretionary character of their detention as "offshore entry persons" under s 189(3).

The plaintiffs' submissions should be accepted. [...]"1771

Accordingly, on French CJ's construction, the incidental powers contained in section 198A(2) gives the basis for detaining those offshore entry persons considered for removal to another country, and is inherent as part of the exercise of discretion that an officer may exercise in relation to offshore entry persons under section 189(3) of the Act.

A transitory person who has been brought to Australia and who is also an unlawful non-citizen is liable to mandatory detention within the Migration Zone. ${ }^{1772}$ As indicated earlier, transitory persons are also precluded from making a valid application for a visa (including a Protection Visa) in Australia by section $46 \mathrm{~B}(1)$ of the Act, and which the Minister may exercise a noncompellable power to allow such a valid application to be made provided that "it is in the public interest to do so". ${ }^{1773}$ Further, a transitory person may only

1770 M70/2011 v Minister for Immigration and Citizenship; M106/2011 v Minister for Immigration and Citizenship [2011] HCA 32 at para 11

1771 M70/2011 v Minister for Immigration and Citizenship; M106/2011 v Minister for Immigration and Citizenship [2011] HCA 32 at paras 53-54

1772 This issue was considered in Sadiqi v Commonwealth of Australia (No.2) [2009] FCA 1117, paras 278-288 as part of preliminary questions but an answer for which was declined on this issue: maintained also Sadiqi v Commonwealth of Australia (No. 3) [2010] FCA 596 relating to question 13

1773 Section 46B(2) of the Migration Act 1958 (Cth) 
request an assessment by the RRT of whether he or she falls within the definition of refugee provided by the Geneva Convention (that is, not inclusive of complementary protection) if he or she is brought to Australia and remains continuously in Australia for a period of six months. ${ }^{1774}$

\subsubsection{Circumstances in Which Detention May Occur - Asylum Seeker as a Lawful Non-Citizen}

Some of the circumstances ${ }^{1775}$ in which an asylum seeker may have their visa cancelled at or prior to immigration clearance discussed earlier herein (such as the provision of incorrect information or, in the case of temporary visas, cancellation for inter alia, non-compliance) apply equally to those asylum seekers who are lawful non-citizens and have been immigration cleared. Additionally, a lawful non-citizen can become an unlawful non-citizen (and thus liable to detention) at the end of the period of validity or on a particular date of the visa ${ }^{1776}$ or if the visa is cancelled in accordance with the specific provisions relating to that visa (for example, student visas) $;{ }^{1777}$ or if the visa is cancelled because the person fails the character test. ${ }^{1778}$

As compliance with visa conditions not only concerns those seeking asylum, but all non-citizens entering and remaining in Australia, an exhaustive setting out of circumstances which might give rise to the cancellation of a visa will not be set out here. However, there are some aspects that are relevant to those asylum seekers who remain in the community.

\subsubsection{Questioning Detention}

Section 192 of the Migration Act, provides that a non-citizen (which includes an asylum seeker lawfully in the community) may be detained where the officer knows or reasonably suspects that a the non-citizen holds a visa which may be cancelled in accordance with particular parts of the Act (that is, before

\footnotetext{
1774 198C of the Migration Act 1958 (Cth)

1775 Because mandatory detention and removal is the default consequence if a lawful noncitizen becomes an unlawful non-citizen, and because the legislation does not refer to individualised and discernible grounds for detention, it is more accurate to refer to the circumstances in which detention may arise, rather than grounds for detention, per se.

1776 Section 82(7) of the Migration Act 1958 (Cth)

1777 For example, cancelling of business visas - sections 134-137; cancelling student visas sections 137J-137P; cancelling of regional sponsored employment visas - sections 137Q to 137T; cancelling of criminal justice visas - sections 162-164; cancellation of temporary safe have visas - section 500A of the Migration Act 1958 (Cth)

1778 Section 501 of the Migration Act 1958 (Cth). Note that pending visa applications, with the exception of Protection Visa applications, are deemed to be refused by that cancellation - see section 501F. See also Ministerial Direction No. 41 on Visa refusal and cancellation under s501, 3 June 2009, http://www.immi.gov.au/media/fact-sheets/79-ministerialdirection-41.pdf (last accessed 21 May 2011).
} 
the person's visa has actually been cancelled). ${ }^{1779}$ This is known as "questioning detention" (which may also apply to those in immigration clearance). ${ }^{1780}$ However, the non-citizen is not to be detained unless the officer knows or reasonably suspects that, if not detained, the person would attempt to abscond or would not co-operate with inquiries relating to the visa. ${ }^{1781}$ The non-citizen may be questioned about the visa and the matters relevant to the visa. ${ }^{1782}$ The classes of visa cancellation to which that detention provision applies are the failure of the character test, ${ }^{1783}$ business visas, ${ }^{1784}$ the general cancellation powers ${ }^{1785}$ and giving incorrect information ${ }^{1786}$ - if the visa is not one which falls within those categories of cancellation then the citizen must be released from detention. ${ }^{1787}$ There are time limits imposed on the detention of non-citizens under this section - a maximum of four hours ${ }^{1788}$ or, if more than once in a 48-hour period, those periods are effectively aggregated. ${ }^{1789}$ However, there are a number of circumstances which are excluded from the calculation of the four-hour period which suggest that the period of time that the non-citizen is in detention is calculated by reference to the time that the non-citizen is effectively being questioned. ${ }^{1790}$

\subsubsection{Section 501 of the Migration Act}

An area of particular concern relates both to asylum seekers as lawful noncitizens in the community as well as unlawful non-citizens in detention (a discussion about the latter appears later in this chapter). A degree of overlap exists in both the ability to cancel an existing visa or to refuse a visa application (including a Protection Visa). This arises in two ways: firstly, a current visa may be cancelled for having failed the character test under section 501 of the Migration Act; ${ }^{1791}$ secondly, a visa application may be refused for having failed the character test under section $501^{1792}$ or for failing to fulfil the Public Interest Criteria for a Protection Visa ${ }^{1793}$ (that is, in relation to the character test ${ }^{1794}$ or

\footnotetext{
1779 Section 192(1) of the Migration Act 1958 (Cth)

1780 Section 5 of the Migration Act 1958 (Cth)

1781 Section 192(2) of the Migration Act 1958 (Cth)

1782 Section 192(3) of the Migration Act 1958 (Cth) - see also Yusuf $v$ Minister for Immigration and Multicultural Affairs [2002] FCA 1103

1783 Sections 501 and 501A of the Migration Act 1958 (Cth)

1784 Subdivision G of Division 3 of the Migration Act 1958 (Cth)

1785 Subdivision D of Division 3 of the Migration Act 1958 (Cth)

1786 Subdivision C of Division 3 of the Migration Act 1958 (Cth)

1787 Section 192(4) of the Migration Act 1958 (Cth)

1788 Section 192(5) of the Migration Act 1958 (Cth)

1789 Section 192(6) of the Migration Act 1958 (Cth)

${ }^{1790}$ See section 192(7) of the Migration Act 1958 (Cth)

${ }_{1791}$ Section 501(2) and (3) of the Migration Act 1958 (Cth)

1792 Section 501(1) and (3) of the Migration Act 1958 (Cth)

1793 For a subclass 866 Protection Visa, the Public Interest Criteria are 4001, 4002, 4003A and 4019 - Clause 866.225, Schedule 2 to the Migration Regulations.

${ }^{1794}$ Schedule 4 and Regulation 1.03 of the Migration Regulations - Public Interest Criteria 4001 is satisfied when "Either:
}

(a) the person satisfies the Minister that the person passes the character test; or 
the asylum seeker having been assessed by ASIO "to be directly or indirectly a risk to security"). ${ }^{1795}$ The effect of those provisions may result in either the detention, or continued detention, of an asylum seeker.

It is helpful to first discuss the provisions of the character test under section 501 of the Migration Act as they relate to those asylum seekers in the community.

The use of section 501 of the Migration Act mechanism to cancel visas (subsequently resulting in the detention and removal of non-citizens, including permanent residents seemingly contrary to sections 200 and 201 of the Act) has attained a certain degree of notoriety. ${ }^{1796}$

The refusal or cancellation of a visa for having failed the character test consists not only of the provisions of the Migration Act, but also of considerations outlined in Ministerial Direction No. 41, which delegates of the Minister (but not the Minister personally) are obliged to follow. ${ }^{1797}$

(b) the Minister is satisfied, after appropriate inquiries, that there is nothing to indicate that the person would fail to satisfy the Minister that the person passes the character test; or

(c) the Minister has decided not to refuse to grant a visa to the person despite reasonably suspecting that the person does not pass the character test; or

(d) the Minister has decided not to refuse to grant a visa to the person despite not being satisfied that the person passes the character test."

1795 Schedule 4 and Regulation 1.03 of the Migration Regulations - Public Interest Criteria 4002 is satisfied when " $t$ the applicant is not assessed by the Australian Security Intelligence Organisation to be directly or indirectly a risk to security, within the meaning of section 4 of the Australian Security Intelligence Organisation Act 1979."

1796 See the excellent articles by Foster, M, 'An "Alien" by the barest of threads' - the legality of the deportation of long-term residents in Australia (2009) 33(2) MULR 483 and by Taylor, S, Exclusion From Protection of Persons of 'Bad Character': Is Australia Fulfilling Its Treaty-based Non-refoulement Obligations?” (2002) 8(1) Australian Journal of Human Rights 83; In relation to the operation of section 501 combined with the superseded Ministerial Direction 21, see Haneef $v$ Minister for Immigration and Citizenship [2007] FCA 1273; Parliament of Australia, Joint Standing Committee on Migration, Immigration Detention in Australia: A new beginning - Criteria for release from detention, December 2008, Canberra, Pp.47-54; and Kneebone, S, Ruddock and Others $v$ Taylor [2005] Sydney Law Review 6

${ }_{1797}$ Sections 499(2A), 496 (generally) and 496(1A) of the Migration Act 1958 (Cth) and Ministerial Direction No. 41, para 4(1). The Minister is not bound by the Direction, but may use it as a guide: see Halmi v Minister for Immigration and Multicultural Affairs [2000] FCA 113 at para 20; Black v Minister for Immigration and Citizenship [2007] FCA 1249 at para 19; Howells v Minister for Immigration Multicultural and Indigenous Affairs [2004] FCAFC 327 at para 31; Damanik v Minister for Immigration and Multicultural Affairs [2000] FCA 771 at para 10. In relation to the superseded Direction 17, the Full Federal Court of Australia in Howells (infra) held at para 131 that if "the Minister has slavishly adhered to Direction No. 17 without applying an independent mind, then it would be appropriate to find that the exercise of the discretion has miscarried": see also Re Drake and Minister for Immigration and Ethnic Affairs (No.2) (1979) 2 ALD 634 per Brennan J at 640 and Ruhl v Minister for Immigration and Multicultural Affairs [2001] FCA 648 at paras 39-40 citing Brennan J in Drake (infra) at para 34. 
Essentially, there are two aspects to section 501 - the failure of the character test by the non-citizen and the discretion (exercised by the delegate of the Minister or the Minister personally) to cancel the visa. Those distinct stages are also reflected in Ministerial Direction No. 41.

A decision to refuse or cancel a visa can either occur by a delegate of the Minister, or the Minister personally. In the case of refusal, either may refuse to grant a visa if a person fails the character test. ${ }^{1798}$

Additionally, either the Minister or his or her delegate may cancel a visa if they "reasonably suspect[ ] that the person does not pass the character test" and if "the person does not satisfy the Minister [or his or her delegate ${ }^{1799}$ ] that the person does not pass the character test" 1800 - that is, the burden rests on the person to satisfy the Minister or his or her delegate.

The third circumstance contemplates only the Minister personally exercising his discretion to refuse or cancel a visa where he "reasonably suspects that the person does not pass the character test" and if the refusal or cancellation "is in the national interest". ${ }^{1801}$

These distinctions in the identity of the decision maker correspondingly vary the right of review against any decision - if made by a delegate, then an Administrative Appeals Tribunal merits review is possible; ${ }^{1802}$ but not so if made by the Minister personally. If the Minister personally made a decision, a restricted judicial review is possible but only if the grounds of jurisdictional error arise. ${ }^{1803}$

Failure of the character test can occur in six situations: Firstly, if the person has a "substantial criminal record". ${ }^{1804}$ "Substantial criminal record" is taken to mean that the person has been:

1. sentenced to death;

2. sentenced to imprisonment for life;

3. sentenced to a term of imprisonment of 12 months or more;

4. sentenced to two or more terms of imprisonment (whether on one or more occasions) where the total of those terms is two years or more;

\footnotetext{
1798 Section 501(1) of the Migration Act 1958 (Cth)

1799 Section 496 of the Migration Act 1958 (Cth)

1800 Section 501(2) of the Migration Act 1958 (Cth)

1801 Section 501(3) of the Migration Act 1958 (Cth)

1802 Section 500(1)(b) of the Migration Act 1958 (Cth)

1803 Section 474(1) of the Migration Act 1958 (Cth) and S157/2002v Godwin [2003] HCA

2 at paras 74-76; 211 CLR 476 at Pp.505-506.

1804 Section 501(6)(a) of the Migration Act 1958 (Cth)
} 
5. acquitted of an offence on the grounds of unsoundness of mind or insanity resulting in the detention of the person in a facility or institution. ${ }^{1805}$

Secondly, with the coming into force of the Migration Amendment (Strengthening the Character Test and Other Provisions) Act 2011 (Cth), new grounds for failing the character test were introduced which affect those asylum seekers already in detention, namely if

"the person has been convicted of an offence that was committed:

(i) while the person was in immigration detention; or

(ii) during an escape by the person from immigration detention; or

(iii) after the person escaped from immigration detention but before the person was taken into immigration detention again"1806

Thirdly, if the person has been convicted for escape from an immigration detention centre (which was also included with that amendment to section $501(6)$ of the Act). ${ }^{1807}$

Fourthly, "if the person has had an association with someone else, or with a group or organisation, whom the Minister reasonably suspects has been or is involved in criminal conduct." 1808

Fifthly, if the person is "not of good character" 1809 taking into account either

1805 Section 501(7) of the Migration Act 1958 (Cth) but also note that periodic detention is included for the purpose of "sentence" (see section 501(8)), as well as "residential" programs for drug rehabilitation or the mentally ill (see section 501(9)). The "sentence" is not a question of time the person was actually detained, but rather the sentence imposed on the person by the Court: see Minister for Immigration and Indigenous Affairs v Hicks (2004) FCAFC 114 at paras 13, 14 and 18 per Hill J; and Seyfarth $v$ Minister for Immigration Multicultural and Indigenous Affairs [2005] FCAFC 105 at 27.

1806 Section 501(6)(aa) of the Migration Act 1958 (Cth)

1807 Section 501(6)(ab) of the Migration Act 1958 (Cth); section 197A of the Act prohibits the escape from a detention centre with penalty of imprisonment for five years

1808 Section 501(6)(b) of the Migration Act 1958 (Cth). See also para 7.2 of Ministerial Direction No. 41 which directs the decision maker to look to the nature, degree, frequency and duration of the association. The "association must have some negative bearing upon the person's character" and "mere knowledge of the criminality of the associate is not, in itself, sufficient". See also Haneef $v$ Minister for Immigration and Citizenship [2007] FCA 1273 at 230, approved on appeal by the Full Federal Court Minister for Immigration and Citizenship $v$ Haneef [2007] FCAFC 203 at 130

${ }^{1809}$ Section 501(6)(c) of the Migration Act 1958 (Cth). See also Ministerial Direction No. 41, para 7.3(2) which provides that "all the relevant circumstances of the particular case are to be taken into account, including evidence of rehabilitation and any recent good conduct". See Mujedenovski v Minister for Immigration and Citizenship [2009] FCAFC 149 at paras 49-50 where the appropriate question to be answered under section 501(6)(c) is whether the person lacks enduring moral qualities. See also Minister for Immigration and Ethnic Affairs v Baker (1997) 73 FCR 187 at 194-196; Godley v Minister for Immigration and Multicultural and Indigenous Affairs [2004] FCA 774 at 56, approved by the Full Federal 
or both of the person's past and present criminal conduct, ${ }^{1810}$ and/or past and present general conduct. ${ }^{1811}$

Sixthly, the future conduct of the person is considered ${ }^{1812}$ - that is, if there is a "significant risk" 1813 that the person would:

(a) engage in criminal conduct in Australia; ${ }^{1814}$ or

(b) harass, molest, ${ }^{1815}$ intimidate or stalk another person in Australia; ${ }^{1816}$ or

(c) vilify a segment of the Australian community; or

(d) incite discord in the Australian community; or

(e) represent a danger to the community or to a segment of that community, whether by way of being liable to become involved in activities that are disruptive to, or in violence threatening

Court in Minister for Immigration \& Multicultural and Indigenous Affairs $v$ Godley [2005] FCAFC 10 at 34.

1810 Para 7.3.1(1) of Ministerial Direction No. 41 - factors which are considered include "(a) the nature, severity, and frequency of the offence/s; (b) the period since the offence/s were committed; (c) where the offences were committed; (d) the person's record since the offences were committed, including: (i) any evidence of recidivism or continuing association with criminals; (ii) any pattern of similar offences; (iii) any pattern of continued or blatant disregard or contempt for the law; (e) any circumstances surrounding the offending which may explain the conduct such as may be evident from judges' comments, parole reports and similar documents; and ( $\mathrm{f}$ ) any good acts of the person after their criminal conduct are indications that the person's character may have reformed". The Direction requires that "both good and bad conduct must be taken into consideration in obtaining a complete picture of the person's character'.

1811 Para 7.3.2(1) of Ministerial Direction No. 41 - factors which are considered include "(a) whether the person has been involved in activities indicating contempt or disregard for the law or human rights". Oddly it is not necessary that for the convictions to have been recorded or for the person's conduct to have amounted to a crime - see note to paragraph (a). Other factors to consider are "(b) whether the person has been removed or deported from Australia or another country and the circumstances that led to the removal/deportation; or (c) whether the person has been: (i) dishonourably discharged; or (ii) discharged prematurely; from the armed forces of another country as the result of disciplinary action in circumstances, or because of conduct, that in Australia would be regarded as serious." Again, good and bad conduct is to be taken into account to obtain "a complete picture of the person's character" - para 7.3.2(4).

1812 Section 501(6)(d) of the Migration Act 1958 (Cth)

1813 Para 7.4(2) of Ministerial Direction No. 41 states that that ground is "enlivened if there is evidence suggesting that there is more than a minimal or trivial likelihood" that the person would engage in the conduct identified in section 501(6)(d) of the Act. Further, the risk attaches to conduct in the future - past conduct is insufficient - see para 7.4(3) of Ministerial Direction No. 41

1814 See para 7.4.1 of Ministerial Direction No. 41

1815 "[C]onduct may amount to harassment or molestation" even if "it does not involve violence, or threatened violence, to the person" or "it consists only of damage, or threatened damage, to property belonging to, in the possession of, or used by, the person" - section 501(11) of the Migration Act 1958 (Cth)

1816 See para 7.4.2 of Ministerial Direction No. 41 
harm to, that community or segment, or in any other way. ${ }^{1817}$

In relation to the exercise of the discretion to cancel or refuse a visa, a delegate of the Minister (but, as outlined above, not necessarily the Minister exercising his discretion personally), is to take into account both "primary considerations" and "other considerations" under Ministerial Direction No. $41 .{ }^{1818}$

Primary considerations are:

“(a) the protection of the Australian community from serious criminal or other harmful conduct, particularly crimes involving violence;

(b) whether the person was a minor when they began living in Australia;

(c) the length of time that the person has been ordinarily resident in Australia prior to engaging in criminal activity or other relevant conduct; and

(d) relevant international obligations, including but not limited to:

(i) the best interest of the child, as described in the Convention on the Rights of the Child (CROC); and

(ii) the non-refoulement obligations contained in the Convention and the Protocol Relating to the Status of Refugees (the Refugees Convention), the International Covenant on Civil and Political Rights (ICCPR) and the Convention Against Torture and Other Cruel, Inhuman or Degrading Treatment or Punishment (CAT). ${ }^{\prime} 1819$

"Other considerations" include "family ties, the nature and extent of any relationships"; "the person's age"; "the person's health"; "any links to the country to which [the person] would be removed"; "hardship likely to be experienced by the person or their immediate family members lawfully resident in Australia"; the person's "level of education"; and "whether the person has been formally advised in the past" by a DIAC officer about conduct that brought the person within the deportation or character provisions of the Act. ${ }^{1820}$

Considerations (in relation to the discretion to cancel or refuse a visa) for the "Protection of the Australian community", under the heading "The seriousness and nature of the conduct", take into account mitigating factors or whether the offence or conduct is an offence in Australia. But, curiously, the note to that latter consideration states:

1817 See para 7.4.3 of Ministerial Direction No. 41. Note, however, that para 7.4.3(2) of the Ministerial Direction requires that those last three categories be "balanced against Australia's well-established tradition of free expression" such that a person's visa is not denied or cancelled "because they hold and are likely to express unpopular opinions, even if these opinions may attract strong expressions of disagreement and condemnation from some elements of the Australian community."

1818 Para 9 of Ministerial Discretion No. 41

1819 Paragraph 10 of Ministerial Direction No. 41

1820 Paragraph 11 of Ministerial Direction No. 41 


\begin{abstract}
"For example, a person who has been subject to imprisonment in another country as a result of political, religious or ethnic persecution may have a substantial criminal record and fail the character test. However, it may nonetheless be appropriate not to exercise the discretion to refuse or cancel the visa, thus permitting the person to enter or remain." 1821
\end{abstract}

Ministerial Direction No. 41 acknowledges the absolute nature of prohibition from refoulement contained in the ICCPR and CAT (as distinct from the qualification in Article 33(2) of the Geneva Convention):

"The prohibition against refoulement under the ICCPR and CAT is absolute. There is no balancing of other factors if the removal of a person from Australia, including if that removal followed as a consequence of the refusal or cancellation of a visa, would amount to refoulement under the ICCPR or the CAT". ${ }^{1822}$

However, notwithstanding all of those considerations in the exercise of the decision maker's discretion to cancel or refuse a visa, ultimately the national interest and ministerial discretion prevail as Ministerial Direction No. 41 so unambiguously states:

"Notwithstanding international obligations, the power to refuse to grant a visa or
cancel a visa must inherently remain a fundamental exercise of Australian sovereignty. The
responsibility to determine who should be allowed to enter or to remain in
Australia in the interests of the Australian community ultimately lies within the
discretion of the responsible Minister" [emphasis added] ${ }^{1823}$

In relation to those asylum seekers lawfully in the community pending the determination of their Protection Visa application, a cancellation of their visa which permits them to remain in the community (whether that be a substantive or Bridging Visa) raises significant concerns. The significance of these concerns is underscored by the mandatory detention requirements and automatic removal provisions.

Firstly, in the case of an asylum seeker who is in the community on a valid visa, a failure of that person of the character test and an exercise of a discretion to cancel the person's visa means that, by operation of section $501 \mathrm{~F}(2)$ of the Act, all other pending visa applications are deemed refused except if any pending application is for a Protection Visa. If in the Migration Zone, no other visa other than a Protection Visa or a Removal Pending Bridging Visa can be applied for. ${ }^{1824}$ This may lead to the situation where a person who was formerly in the community will be detained whilst their Protection Visa application is being assessed.

1821 Note to para 10.1.1(4)(c) of Ministerial Direction No. 41

1822 Para 10.4.3(1)(c) of Ministerial Direction No. 41

1823 Note to para 10.4 of Ministerial Direction No. 41

1824 Section 501E of the Migration Act 1958 (Cth) and Regulation 2.12AA of the Migration

Regulations 1994 (Cth) 
Secondly, the AHRC has identified significant concerns regarding the application of section 501 and Ministerial Direction No. 41. Whilst noting the provisions of Article 33(1) and (2) of the Geneva Convention, and nothing the primacy given to the considerations of non-refoulement under Ministerial Direction No. 41, the Commission has identified that the scope of the character test provisions contained in section 501 is broader than that contemplated by Article 33(2) of the Convention in at least one instance. The AHRC has stated:

"The exclusion grounds in the Refugee Convention require that a person be a danger to Australia's security or to the Australian community - whereas a person can fail the section 501 character test on grounds as general as being 'not of good character' having regard to their 'past or present general conduct' [that is, in relation to section 501(6)(c)]"1825

The other considerations for exclusion under the Geneva Convention (such as Article $1 \mathrm{~F}$ and Article 33(2)) are said to be construed without the influence of section 501(6). ${ }^{1826}$

It remains to be seen how the exclusion provisions for complementary protection sit within this framework. ${ }^{1827}$

Notwithstanding that non-refoulement obligations are a primary consideration for decision makers under Ministerial Direction 41, it still remains within the discretion of the decision maker to cancel the visa - that is, there is no obligation upon a decision maker to adhere to international obligations.

As noted by the AHRC, ${ }^{1828}$ the Commonwealth Ombudsman has expressed concern at the quality and rigour of assessment of those international

\footnotetext{
1825 Australian Human Rights Commission, Background Paper: Immigration detention and visa cancellation under section 501 of the Migration Act, March 2010, http://www.hreoc.gov.au/ human_rights/immigration/501_migration_2010.pdf (last accessed 24 May 2011), para 8.2(a).

1826 SZLDG v Minister for Immigration and Citizenship [2008] FCA 11 per Lindgren J at paras 76-83. At para 76: "It has been held that Article 1F of the Convention is said "not to be construed under the influence of the character test in s501(6) of the Act, and that Article 1F is an independent exclusion of the application of the Convention Provisions see Applicant NADB of $2001 v$ Minister for Immigration and Multicultural Affairs [2002] FCAFC 326; (2002) 126 FCR 453 at [42] per Merkel J with whom Madgwick and Conti JJ agreed, and at first instance, NADB v Minister for Immigration and Multicultural Affairs [2002] FCA 200; (2002) 189 ALR 293 at [46] and [47] per Hely J."

1827 Section 36(2C) of the Migration Act 1958 (Cth)

1828 Australian Human Rights Commission, Background Paper: Immigration detention and visa cancellation under section 501 of the Migration Act, March 2010, http://www.hreoc.gov.au/ human_rights/immigration/501_migration_2010.pdf (last accessed 24 May 2011), para $8.2(\mathrm{~b})$
} 
obligations in particular cases. ${ }^{1829}$

Thirdly, it is also of concern that the very conduct which may evidence persecution under the Geneva Convention may be used against the asylum seeker resulting in a failure of the character test. ${ }^{1830}$ An asylum seeker in those circumstances is in both an impossible and precarious position - such evidence of persecution in their country of origin is the very basis of their Protection Visa application but curiously also leaves them liable to failure of the character test in Australia. The failure of the test, in those circumstances, is only saved by the decision maker exercising a discretion (as opposed to an obligation) not to cancel the visa taking into account the various considerations, including international obligations resulting from the Geneva Convention, ${ }^{1831}$ ICCPR and CAT.

Fourthly, it is also surprising that, in the second stage of the consideration under section 501 (that is, the exercise of discretion to refuse or cancel a visa), Ministerial Direction No. 41 takes a very selective application of the ICCPR. In that Direction, only the provision relating to refoulement are contemplated that is, a contemplation of circumstances outside Australia. Indeed, the possible prolonged, arbitrary and indefinite detention in Australia resulting from the visa cancellation is not considered in relation to Australia's obligations under Article 9(1) ICCPR to those already within its jurisdiction.

Fifthly, Taylor, in 2002, expressed concern for those asylum seekers in the community who may be at risk of obtaining a "substantial criminal record" (and thus falling foul of section 501) by virtue of the fact that the socioeconomic support provided for them during their stay in the community is inadequate and thus "predisposing individuals to involvement in crime". ${ }^{1832}$ Accordingly, it would also be unjust if the cancellation of a visa resulted from environmental factors which led to a criminal behaviour outcome and thus, resulted in detention and possible subsequent removal.

1829 Commonwealth Ombudsman, Department of Immigration and Multicultural Affairs Administration of $s 501$ of the Migration Act 1958 as it applies to long-term residents, February 2006, Report 01/2006, http://www.ombudsman.gov.au/files/investigation_2006_01.pdf (last accessed 28 October 2011), paras 3.41-3.45

1830 Note to para 10.1.1(4)(c) of Ministerial Direction No. 41

1831 Ministerial Direction No. 41, see para 9(1) - as a "primary consideration", the Geneva Convention must be taken into account "in every case"; para 10.4(2) "non-refoulement obligations, including under the Refugees Convention, must be considered"; and para 10.4.2(1) "In cases where issues of protection pursuant to the Refugees Convention are raised by the person or are clear from the facts of the case, they must be given consideration."

1832 Taylor, S, Exclusion From Protection of Persons of 'Bad Character': Is Australia Fulfilling Its Treaty-based Non-refoulement Obligations?” (2002) 8(1) Australian Journal of Human Rights 83, Pp.10-11 (upon printout from http://www.austlii.edu.au/au/other/ahric/ajhr/ ajhrindex.html/2002/7.html (last accessed 3 June 2012)) 


\subsubsection{Circumstances in Which Detention May be Prolonged - Asylum Seeker as an Unlawful Non-Citizen}

The failure of the character test may result in the refusal of a grant of a visa and, consequently, a prolongation of detention for those already detained.

As noted above, an asylum seeker may fail the character test on account of a conviction for an offence relating to immigration detention or for escaping from immigration detention. ${ }^{1833}$ Indeed, as Taylor has noted, conviction for escape from a detention centre, ${ }^{1834}$ manufacture, possession use or distribution of a weapon by a detained person, ${ }^{1835}$ as well as other "particularly serious crimes" punishable by imprisonment for life, a fixed term of not less than three years, or a maximum term of not less than three years ${ }^{1836}$ is sufficient to exclude an asylum seeker from refugee status on the basis of Article 33(2) of the Geneva Convention and most likely result in the failure of the character test. ${ }^{1837}$ However, it would be unjust if the behaviour that subsequently led to either of the convictions contemplated in section 501(6)(aa) and (ab) were a result of the conditions of detention as was the case in Behrooz ${ }^{1838}$ who submitted that his escape from Woomera detention centre (in central South Australia) was motivated because the conditions of detention were so deplorable that they effectively amounted to punishment. Given the recent outbreaks of violence in the detention system, and the highlighting of the conditions for detention, ${ }^{1839}$ asylum seekers are in a particularly vulnerable situation where the conditions and circumstances of their detention (that is, external environmental factors influencing already quite vulnerable persons) may ultimately lead to behaviour resulting in the refusal of a Protection Visa.

A situation may occur where an asylum seeker may be owed protection obligations by Australia but fails the character test resulting in their detention or the refusal of a grant of a Protection Visa. The AHRC has expressed its

\footnotetext{
1833 Article 501(6)(aa) and (ab) of the Migration Act 1958 (Cth)

1834 Section 197A of the Migration Act 1958 (Cth)

1835 Section 197B of the Migration Act 1958 (Cth)

1836 Section $91 \mathrm{U}$ of the Migration Act 1958 (Cth)

1837 Taylor, S, Exclusion From Protection of Persons of 'Bad Character': Is Australia Fulfilling Its Treaty-based Non-refoulement Obligations?” (2002) 8(1) Australian Journal of Human Rights 83 P.8 (upon printout from http://www.austlii.edu.au/au/other/ahric/ ajhr/ajhrindex.html/2002/7.html (last accessed 3 June 2012))

1838 Behrooz $v$ Secretary of the Department of Immigration and Multicultural and Indigenous Affairs (2004) 219 CLR 486. As noted by Blackshield and Williams, Mr Behrooz pleaded guilty to the offence and was discharged with a good behaviour bond and no conviction was recorded - that sentence remaining unchanged having been appealed to the Supreme Court of South Australia by the prosecution - Blackshield, T, and Williams, G, Australian Constitutional Law and Theory - Commentary and Materials, 5ed, 2010, Federation Press, Leichhardt, P.666

1839 Australian Broadcasting Corporation, Asylum, aired Monday, 24 October 2011, http://www.abc.net.au/4corners/stories/2011/10/20/3344543.htm (last accessed 28 October 2011)
} 
concerns at how detention may be prolonged indefinitely whilst either the decision to challenge the visa cancellation decision is pursued, or whilst an application for a Protection Visa is pending determination. ${ }^{1840}$ Due to the absolute nature of non-refoulement in ICCPR and CAT, that person may be detained for extended periods while arrangements are being made for a third country to take them or, in the even that no other third country is willing to take them, may remain in detention indefinitely. ${ }^{1841}$

Prolonged detention may also occur as a result of a refusal of a Protection Visa for not fulfilling the Public Interest Criteria ("PIC"). As outlined earlier, part of the PIC for the grant of a Protection Visa include, inter alia, both considerations involving the character test as contemplated by section 501 of the Migration Act (PIC 4001) and an assessment by ASIO that the person is not "directly or indirectly a risk to security" (PIC 4002).

The PIC for the grant of a Protection Visa is satisfied when:

"Either:

(a) the person satisfies the Minister that the person passes the character test; or

(b) the Minister is satisfied, after appropriate inquiries, that there is nothing to indicate that the person would fail to satisfy the Minister that the person passes the character test; or

(c) the Minister has decided not to refuse to grant a visa to the person despite reasonably suspecting that the person does not pass the character test; or

(d) the Minister has decided not to refuse to grant a visa to the person despite not being satisfied that the person passes the character test." 1842

Accordingly, a person may still satisfy the PIC if the Minister makes a decision to grant a visa notwithstanding that the Minister reasonably suspects or is not satisfied that the person passes the character test. ${ }^{1843}$ However, some of the grounds for failing the character test, as identified earlier, are broader than that contemplated by Article 33(2) of the Geneva Convention with the consequent issues as discussed above.

\footnotetext{
1840 Australian Human Rights Commission, Background Paper: Immigration detention and visa cancellation under section 501 of the Migration Act, March 2010, http://www.hreoc.gov.au/human_rights/immigration/501_migration_2010.pdf (last accessed 24 May 2011), para 8.5

${ }^{1841}$ Indeed, Poynder believes that CAT would prevent the return of an applicant excluded by Article $1 \mathrm{~F}$ of the Convention in relation to crimes against humanity - Poynder, N, 'Mind the Gap': Seeking Alternative Protection under the Convention Against Torture and the International Covenant on Civil and Political Rights, in Kneebone, S, (ed), The Refugee Convention 50 Years On, 2003, Ashgate, Aldershot, Pp.173-192 at P.188 1842 Schedule 4 and Regulation 1.03 of the Migration Regulations (Cth) 1843 The relationship between section 501 and Public Interest Criteria 4001 has been briefly explored in SZLDG v Minister for Immigration and Citizenship [2008] FCA 11 at 84-91 where Lindgren J noted at 90 "The question of the relationship between PIC 4001 and s501 of the Act is not a simple one susceptible of a straightforward answer."
} 
In relation to the assessment by ASIO, "security" is defined in section 4 of the Australian Security Intelligence Organisation Act 1979 (Cth) as:

“(a) the protection of, and of the people of, the Commonwealth and the several States and Territories from:

(i) espionage;

(ii) sabotage;

(iii) politically motivated violence; 1844

(iv) promotion of communal violence; ${ }^{1845}$

(v) attacks on Australia's defence system; 1846 or

(vi) acts of foreign interference; whether directed from, or committed within, Australia or not; and

(aa) the protection of Australia's territorial and border integrity from serious threats; and

(b) the carrying out of Australia's responsibilities to any foreign country in relation to a matter mentioned in any of the subparagraphs of paragraph (a) or the matter mentioned in paragraph (aa)."

The first issue is that the failure to fulfil either of those two Public Interest Criteria may result in prolonged detention. That is, the failure to fulfil the requirements results in the failure of one of the conditions for the grant of a Protection Visa. ${ }^{1847}$ This is particularly relevant for those "offshore entry persons" who are detained at "excised offshore places" (namely, the Christmas Island Immigration Detention Centre) who are unable to make a valid visa application ${ }^{1848}$ (for example, for a Bridging Visa) ${ }^{1849}$ without which only deportation, removal, being an Australian citizen or the Minister exercising his non-compellable and non-reviewable discretion are the only other means by which release from immigration detention can occur. Accordingly, for those in detention, so long as they otherwise remain unlawful non-citizens, the failure of the PIC may result in the continuation of their status as unlawful non-citizens and, consequently, their continued detention. The practical reality is that, if an asylum seeker has been found to be owed protection obligations by Australia, but fails one of the public interest requirements, then the asylum seeker is stuck in a legal no-man's land - unable to enter the Australian community but who no other country may wish to accept. ${ }^{1850}$

\footnotetext{
1844 "Politically motivated violence" is defined under section 4 of the Australian Security Intelligence Organisation Act 1979 (Cth)

1845 "Promotion of communal violence" is defined under section 4 of the Australian Security Intelligence Organisation Act 1979 (Cth)

1846 "Attacks on Australia's defence system" is defined under section 4 of the Australian Security Intelligence Organisation Act 1979 (Cth)

1847 Together with the application of section 65 of the Migration Act 1958 (Cth) - see also SZLDG v Minister for Immigration and Citizenship [2008] FCA 11

1848 Section 46A of the Migration Act 1958 (Cth),

${ }_{1849}$ Regulation 2.07A of the Migration Regulations 1994 (Cth)

1850 A situation which has sadly eventuated, see Flitton, D, Men waited in hope as asylum bid faltered, Sydney Morning Herald, 2 June 2012, http://www.smh.com.au/national/menwaited-in-hope-as-asylum-bid-faltered-20120601-1znjg.html (last accessed 3 June 2012); Beck, M, The voices of those held in indefinite detention, Sydney Morning Herald, 3 June 2012
} 
Accordingly, an asylum seeker may remain in detention until a third country will accept him or her - with the possibility of indefinite detention if no other country is willing to take him or her (a not unimaginable prospect if the asylum seeker has already received such an assessment from Australia). Understandably, stateless persons are particularly vulnerable in this situation.

The second issue regarding the fulfilment of the PIC is that those in detention who have been found to be owed protection obligations by Australia are kept in detention until a positive security assessment has been made by ASIO. Most significantly, the AHRC has noted that if the assessment by ASIO is not made until after the person is found to be a refugee, then prolonged detention may be the result. ${ }^{1851}$ Further, as noted by the AHRC, there are no requirements in the Migration Act or the Australian Security Intelligence Organisation Act that require those pending security assessments to be held in detention ${ }^{1852}$ and, as there are no provisions for individual assessment of the necessity of detention (in addition to any prolonged detention which may also result), it renders the detention arbitrary in breach of Article 9(1) ICCPR. A number of cases have been the subject of inordinate delays in obtaining those assessments, thereby prolonging the detention of those already in detention and to whom Australia owes protection obligations. ${ }^{1853}$

Currently under the Migration Act there is no specified time limit in which a person will be released from immigration detention (that is, it is indefinite) and a person will only be released from detention if they are removed from Australia, deported from Australia, granted a visa, ${ }^{1854}$ or are an Australian citizen. ${ }^{1855}$ Although discussed further in the chapters on the conditions of detention and proportionality, it is worth noting the unsuccessful judicial challenges in the High Court of Australia to the indefinite detention of unlawful non-citizens. ${ }^{1856}$ Those judgments have confirmed the authority

http://www.smh.com.au/opinion/political-news/the-voices-of-those-held-in-indefinitedetention-20120602-1zoy2.html (last accessed 3 June 2012)

1851 Australian Human Rights Commission, Independent Review of the Intelligence Community, April 2011, P.3

1852 Australian Human Rights Commission, Independent Review of the Intelligence Community, April 2011, P.3

1853 Australian Human Rights Commission, Independent Review of the Intelligence Community, April 2011, Pp.3-4; see also Saul, B, Submission to Joint Select Committee on Immigration Detention dated 31 August 2011, together with annexed Communication to the UN Human Rights Committee dated 28 August 2011 https://senate.aph.gov.au /submissions/comittees/viewdocument.aspx?id=e82994a0-5a90-44c9-80f0-a96aafb95948, https://senate.aph.gov.au/submissions/comittees/viewdocument.aspx?id=229128ab-d97b4dab-9b97-bcf31229b81c (both last accessed 28 October 2011); Needham, K, Without hope, without reason, Sydney Morning Herald, 14 January 2012, http://www.smh.com.au/ national/without-hope-without-reason-20120113-1pzei.html (last accessed 1 June 2012) 1854 Section 196(1) of the Migration Act 1958 (Cth)

${ }^{1855}$ See section 196(2) and 191 of the Migration Act 1958 (Cth)

1856 Al-Kateb v Godwin [2004] HCA 37, Minister for Immigration and Multicultural Affairs v Al Khafaji [2004] HCA 38 
under the Migration Act to detain an unlawful non-citizen indefinitely even where there is no real prospect of the person's removal from Australia. ${ }^{1857}$

\subsubsection{Assessment of Key Immigration Detention Values}

As indicated earlier, on 29 July 2008 the then Minister for Immigration, Senator Chris Evans, indicated seven values that form the basis of Australia's new risk-based approach to immigration detention policy, and which have subsequently been adopted by the Department of Immigration and Citizenship as the "Key Immigration Detention Values". ${ }^{1858}$ Firstly, mandatory detention still remains "an essential component of strong border control". However, mandatory detention is now said to be applicable to unauthorized arrivals "for the management of health, identity and security risks to the community" and for "unlawful non-citizens who present unacceptable risks to the community". Further, the Minister stated that "detention that is indefinite or otherwise arbitrary is not acceptable" and that "detention in immigration detention centres is only to be used as a last resort and for the shortest practicable time". ${ }^{1859}$

Prima facie, at the time, the Minister's seven values evidenced a discernible shift in attitude towards the circumstances in which asylum seekers may be detained. However, the first value remains that immigration detention is "an essential component of strong border control". Indeed, the overall policy is geared towards "supporting the integrity of Australia's immigration program". As noted in C $v$ Australia policy grounds espoused in the absence of individual assessment cannot provide sufficient justification for mandatory detention of unlawful non-citizens.

The detention of all unauthorised arrivals (that is, without individual assessment) for, inter alia, in order to assess "security risks to the community" is inconsistent with other key values of detention, namely "as a last resort and for the shortest possible practicable time" if such security assessments are not carried out until after Australia's protection obligations to an individual have been recognised. The "risk-based approach" adopted is more consistent with a

\footnotetext{
1857 See also Head, M, Detention Without Trial - A Threat to Democratic Rights, 2005, University of Western Sydney Law Review, 3; Curtin, J, 'Never Say Never': Al-Kateb v Godwin [2005] Sydney Law Review 16; and Crock, M, Saul, B, and Dastyari, A, Future Seekers II, 2006, Federation Press, Leichhardt Pp.178-181.

1858 Department of Immigration and Citizenship, Managing Australia's Borders, Detention Services, About Immigration Detention, Key Immigration Detention Values, http://www.immi.gov.au/managing-australias-borders/detention/about/key-values.htm (last accessed 24 May 2011)

1859 Evans, Senator the Honourable Chris, Minister for Immigration and Citizenship, speech to the Australian National University in Canberra, 29 July 2008, New Directions in Detention - Restoring Integrity to Australia's Immigration System http://www.nswbar.asn.au/ circulars/july/evans2.pdf (last accessed 27 April 2012);
} 
policy that aims to eliminate any possible risk that the asylum seeker may pose, rather than use detention as a proportionate and individually assessed means of managing such risks. Accordingly, keeping an individual in detention only until after a positive assessment has been given, and which may result in prolonged detention, may be considered disproportionate. Indeed, no presumption against detention has been embodied into the legislation.

The use of detention to manage "unacceptable risks to the community" contemplates a class of person whose presence in the community would be intolerable for safety or security reasons. However, the operation of section 501 of the Migration Act may result in people who do not pose such risks to the community being detained - particularly those deemed to be "not of good character".

\subsubsection{Lapsed Proposed Amendments}

The Migration Amendment (Immigration Detention Reform) Bill 2009 (now lapsed) had proposed to introduce two sets of principles: firstly, that detention was for the management of risks to the Australian community and to resolve a noncitizen's immigration status (proposed section 4AAA(1)); ${ }^{1860}$ and secondly, that detention was to be used as a last resort and for the shortest practicable time (proposed section 4AAA $(2)){ }^{1861}$

In relation to the first set of principles, it is worth highlighting that the note to proposed section 4AAA(1) considered "resolving a non-citizen's immigration status" as either the granting of a visa to the non-citizen or the removal or deportation of the non-citizen. Further, as the AHRC had identified, it was of concern that both sets of principles referred to "non-citizens" as opposed to the current terminology (and, indeed, the terminology otherwise used in the Bill) of "unlawful non-citizen". ${ }^{1862}$ The first set of principles was given more substance in subsection 189(1B) where it provided that an officer must make "reasonable efforts" to (a) ascertain the person's identity; and (b) identify whether the person is of character concern; and (c) ascertain the health and security risks of the person entering or remaining in Australia; and (d) resolve the person's immigration status. However, three points should be noted: firstly, the requirement of health checks is not a justifiable ground of detention

1860 Proposed section 4AAA(1) of the Migration Act, Clause 1, Schedule 1, Migration Amendment (Immigration Detention Reform) Bill 2009 (Cth).

1861 Proposed section 4AAA(2) of the Migration Act, Clause 1, Schedule 1, Migration Amendment (Immigration Detention Reform) Bill 2009 (Cth).

1862 Australian Human Rights Commission, Migration Amendment (Immigration Detention Reform) Bill 2009, Submission to the Senate Standing Committee on Legal and Constitutional Affairs, 31 July 2009, Sydney, http://www.humanrights.gov.au/legal/submissions/2009 /20090731_migration.pdf (last accessed 1 June 2012) at para 24. 
contemplated by the UNHCR ${ }^{1863}$ and, only then, in extremely limited circumstances. Detention for the management of health risks may well result in detention by another justification. ${ }^{1864}$ Secondly, "reasonable efforts" was a rather neutral term that provided no guarantee of release once the checks had actually been carried out. ${ }^{1865}$ It may well have been that so long as "reasonable efforts" were being carried out that detention could, theoretically, have been justified on an indefinite basis. In that regard, Parliament appeared to have ignored the Joint Standing Committee's recommendation that, where a security assessment is ongoing after 90 days, mechanisms be developed for conditional release from detention, and that release from immigration detention should be granted where there is little indication of a risk to the community. ${ }^{1866}$ Thirdly, the "reasonable efforts" obligation did not extend to those who would have been detained on the basis of presenting an "unacceptable risk".

In relation to the second set of principles, the AHRC recommended that the words "The Parliament affirms as a principle that" in proposed section 4AA(2) (relating to detention as a last resort and for the shortest possible period of time) be removed to have ensured that full force was given to the values espoused by the Minister and to have provided adequate protection for those in immigration detention. ${ }^{1867}$ Otherwise, the inclusion of the words "The Parliament affirms as a principle that" would have rendered the remainder of those sections of very limited (if any) justiciable value for the protection of asylum seekers in detention. The inclusion of the proposed principles in the legislation, although a positive development, would have remained logically inconsistent with the then proposed subsection 189(1) (discussed below) which, for all practical purposes, retained mandatory detention and otherwise introduced a broad discretion to detain.

In relation to the circumstances in which detention arises, the Migration

\footnotetext{
1863 See submissions of the UNHCR cited in Parliament of Australia, Joint Standing Committee on Migration, Inquiry into Immigration Detention in Australia, Immigration Detention in Australia: A New Beginning, December 2008 at Pp.19-20.

1864 See section 4 of the Quarantine Act 1908 (Cth). See also Bashford, A, and Strange, C, Asylum Seekers and National Histories of Detention (2002) 48(4) Australian Journal of Politics and History 509

1865 Australian Human Rights Commission, Migration Amendment (Immigration Detention Reform) Bill 2009, Submission to the Senate Standing Committee on Legal and Constitutional Affairs, 31 July 2009, Sydney, http://www.humanrights.gov.au/legal/submissions/2009 /20090731_migration.pdf (last accessed 1 June 2012) at para 55

1866 Parliament of Australia, Joint Standing Committee on Migration, Inquiry into Immigration Detention in Australia, Immigration Detention in Australia: A New Beginning, December 2008, P.42 para 2.138

1867 Australian Human Rights Commission, Migration Amendment (Immigration Detention Reform) Bill 2009, Submission to the Senate Standing Committee on Legal and Constitutional Affairs, 31 July 2009, Sydney, http://www.humanrights.gov.au/legal/submissions/2009 /20090731_migration.pdf (last accessed 1 June 2012) at paras 19-23.
} 
Amendment (Immigration Detention Reform) Bill 2009 would have repealed subsection 189(1) and replaced it with new provisions. Under the then proposed subsection 189(1), mandatory detention of an unlawful non-citizen in the migration zone (other than an excised offshore place) would still have occurred if the officer knew or reasonably suspected that the person was an unlawful non-citizen and the person either (1) presented an "unacceptable risk to the Australian community", or (2) had "bypassed immigration clearance" or had been refused immigration clearance, or (3) had had their visa cancelled due to his/her production of a false document or providing false information whilst in immigration clearance. Under subsection 189(1A), a person presented an "unacceptable risk to the Australian community" if (1) they would have been refused a visa or had their visa cancelled on national security grounds, or (2) the person overstayed an enforcement visa, or (3) in "circumstances prescribed by the regulations apply in relation to the person". Further under subsection 189(1C), an officer who knew or reasonably suspected a person to have been an unlawful non-citizen would have retained the discretion to detain such a person (in the migration zone and other than an excised offshore place).

Several points are to be noted about the then proposed subsection 189(1). Firstly, although subsection 189(1)(b) would appear to have provided a form of individualised assessment (that is, only certain categories of unlawful noncitizens are to be detained), the comprehensive circumstances enunciated in that subsection mean that its practical effect would have provided a basis for the mandatory detention of asylum seekers who had bypassed or been refused immigration clearance (for example, by arriving by boat on Australian territory). The situation for that category of asylum seekers was unchanged by the proposed legislation. Secondly, it remained to be seen what "circumstances prescribed by the regulations" gave rise to detention. Thirdly, the broad discretion given to an officer under subsection 189(1C) was troubling. It appeared to provide both sufficient justification to detain and insufficient protection against detention without requiring that the person fell into any of the categories identified in subsection 189(1)(b). Fourthly, there was no provision for an individual assessment of a person who presented as an "unacceptable risk". ${ }^{1868}$ Fifthly, no justiciable presumption against detention was proposed. Accordingly, the Bill fell short in the implementation of all of the values espoused by the Minister on 29 July 2008 and insufficient protection for asylum seekers was a key shortcoming. Sixthly, "unacceptable risk to the Australian community" contemplates a narrower class of people than may actually be detained as a result of a cancellation of a visa under section 501 - particularly in relation to those deemed to have failed the

1868 Australian Human Rights Commission, Migration Amendment (Immigration Detention Reform) Bill 2009, Submission to the Senate Standing Committee on Legal and Constitutional Affairs, 31 July 2009, Sydney, http://www.humanrights.gov.au/legal/submissions /2009/20090731_migration.pdf (last accessed 1 June 2012) at paras 56-64. 
character test on account of being "not of good character". 1869

The Migration Amendment (Immigration Detention Reform Bill) 2009 also proposed to provide that where a minor was to be detained as a measure of last resort, the child was not to be detained in an immigration detention centre established under the Migration Act (proposed subsection 4AA(3)). Further, where a minor was to be detained, the best interests of the minor must be the primary consideration when determining where the minor is to be detained (proposed subsection 4AA(4)).

Although a positive development, the AHRC noted that Value 3 of the Minister's 29 July 2009 speech would only be partially implemented - that is, there is no protection against the family members of minors from detention. ${ }^{1870}$ Further the AHRC noted that the best interests of the minor criteria only relates to where the minor is detained, not to the initial decision to detain the minor. ${ }^{1871}$ In that regard, AHRC called for the deletion of the opening words to subsection 4AA(1) “The Parliament affirms as a principle that" to strengthen the protection of minors from detention ${ }^{1872}$ and the application of the best interests criteria to the initial decision to detain. ${ }^{1873}$ The AHRC also urged that section 4AA be amended to provide that if a minor is detained as a measure of last resort that such detention be for the shortest appropriate period of time and with appropriate independent review mechanisms. ${ }^{1874}$

1869 Australian Human Rights Commission, Background Paper: Immigration detention and visa cancellation under section 501 of the Migration Act, March 2010, http://www.hreoc.gov.au/ human_rights/immigration/501_migration_2010.pdf (last accessed 1 June 2012), para 8.5

1870 Australian Human Rights Commission, Migration Amendment (Immigration Detention Reform) Bill 2009, Submission to the Senate Standing Committee on Legal and Constitutional Affairs, 31 July 2009, Sydney, http://www.humanrights.gov.au/legal/ submissions/2009/20090731_migration.pdf (last accessed 1 June 2012) at paras 25-32.

1871 Australian Human Rights Commission, Migration Amendment (Immigration Detention Reform) Bill 2009, Submission to the Senate Standing Committee on Legal and Constitutional Affairs, 31 July 2009, Sydney, http://www.humanrights.gov.au/legal/ submissions/2009/20090731_migration.pdf (last accessed 1 June 2012 at paras 33-44 at 35. 1872 Australian Human Rights Commission, Migration Amendment (Immigration Detention Reform) Bill 2009, Submission to the Senate Standing Committee on Legal and Constitutional Affairs, 31 July 2009, Sydney, http://www.humanrights.gov.au/legal/ submissions/2009/20090731_migration.pdf (last accessed 1 June 2012 at paras 33-44 at 39. 1873 Australian Human Rights Commission, Migration Amendment (Immigration Detention Reform) Bill 2009, Submission to the Senate Standing Committee on Legal and Constitutional Affairs, 31 July 2009, Sydney, http://www.humanrights.gov.au/legal/ submissions/2009/20090731_migration.pdf (last accessed 1 June 2012 at paras 33-44 at 35. 1874 Australian Human Rights Commission, Migration Amendment (Immigration Detention Reform) Bill 2009, Submission to the Senate Standing Committee on Legal and Constitutional Affairs, 31 July 2009, Sydney, http://www.humanrights.gov.au/legal/ submissions/2009/20090731_migration.pdf (last accessed 1 June 2012 at paras 33-44 at 41. 


\subsection{Conclusions}

The European Union does not adopt a universal visa regime on account of providing exemptions for nationals of certain countries. In the Australian sphere, a universal visa regime is adopted. However, in both jurisdictions, the holding of a valid visa (or the exemption from holding one) does not provide an entirely unqualified right of entry. Rather in both jurisdictions persons are under certain positive obligations in addition to holding a visa (if required) in the European Union, certain additional criteria must be met in relation to the person's means and purpose of entering the territory; in Australia, the positive obligation to provide correct information. In both jurisdictions the non-compliance with these positive obligations can result in the refusal of immigration clearance (to adopt the Australian term) and consequently result in detention as a question of fact (in the European Union and possibly by law in light of the Returns Directive and Article 5(1)(f) ECHR) or by compulsory operation of law (as in Australia).

Both jurisdictions adopt a bifurcated approach to asylum seekers. In the European Union this is manifest in the different procedures that exist for border and 'regular' applicants, and the possible derogations by Member States from guarantees in relation to border applicants. In Australia, this is manifest in the difference in treatment at law that is afforded to those firstly, that arrive without a valid visa or do arrive with a valid visa and are not immigration cleared (which results in the person becoming an unlawful non-citizen and subject to detention) and secondly, those who arrive with a valid visa and are immigration cleared (who are lawful non-citizens able to remain at liberty in the community pending the determination of their application). Accordingly, the laws of both jurisdictions express an implicit preference for those asylum seekers that arrive in a regular migratory fashion - that is, both jurisdictions exhibit a preference for those asylum seekers that are immigration cleared and then apply for asylum. The difference in the laws that apply to both groups of asylum seekers does raise questions as regards their compatibility with Article 31 of the Geneva Convention. The discourse that surrounds asylum seekers at the border has often been obfuscated with "illegal immigration", "economic migration" and "queue jumping", inferring that border applicants are somehow lacking in credibility as regards their asylum claims. There is a degree of duplicity on the part of States, then, by adopting a series of laws that, by preferring those that arrive and enter in a regular migratory fashion, effectively compels asylum seekers to establish a purpose other than seeking asylum in the State they wish to enter. Accordingly, given the great difficulties (and often impossibilities) that such an approach poses for asylum seekers, what is revealed is the entirely State-centric purpose - immigration control as opposed to humanitarian object.

The European Union and Australia both have 'excised areas' - that is, both jurisdictions have parts of their territory which result in reduced rights for 
asylum seekers and a greater susceptibility for detention with reduced avenues for liberty. In the European Union's case, the border zone represents a significant downgrading of rights, evidenced by the derogations from the 'regular' procedure discussed herein, and given a degree of imprimatur by the jurisprudence surrounding Article 5(1)(f) ECHR. In Australia, the "excised offshore areas" sees a very significant curtailing of rights by which applicants are not able to apply for any visa (including a Protection Visa or Bridging Visa) other than through the personal and non-compellable discretion of the Minister. Notwithstanding the recent changes to Australian policy in this regard by the announcement of irregular maritime arrivals being granted Bridging Visas, the legislative skeleton remains intact and is only softened by departmental policy and Ministerial discretion.

When one looks at the accretion of rights that is contemplated (on one view) of the Geneva Convention through the gradation of physical presence then regularisation of presence on the territory of asylum, both jurisdictions largely reflect that conceptualisation for those asylum seekers that seek asylum after achieving immigration clearance. However, border applicants in both jurisdictions are exceptionally vulnerable to systematic detention, premature removal, and possible refoulement. The lodging of an application for asylum does not necessarily give rise to regularisation and, therefore, liberty. The ECtHR has indicated that it does not consider submission to the asylum determination procedure as regularising a person's stay such to bring them outside the ambit of Article 5(1)(f) ECHR. In Australia, the lodging of an application for a Protection Visa in detention does not immediately regularise a person's stay (but which may be a condition precedent for eligibility for a Bridging Visa). Indeed, for offshore entry persons in an excised offshore place, they are precluded from making an application for any visa and are unable to regularise their stay by the submission of an application for asylum (unless the Minister exercises his or her personal and non-compellable discretion to do so).

In the European Union the right to remain can be truncated in the case of border applicants and, even in the case of 'regular' applicants, the right to remain is only presently contemplated up until a first instance decision has been made with the subsequent responsibility of the applicant's right to remain falling to the Member State of application. Further reliance may be placed on Articles 3 and 13 ECHR and Articles 19(2) and 47 of the EU Charter. Notwithstanding the express considerations of non-refoulement found in the Returns Directive and the Proposed Procedures Directive, refoulement remains a risk. In the case of the Returns Directive, it is difficult to foresee what attempts would be made (if any) to be satisfied that a person subject to a return decision would not be refouled once the first instance (for example) negative decision had been given. In this sense, for those on Bridging Visas, the Australian system of suspensive effect lasting for 28 days beyond a judicial decision having been made (or for those on a Bridging Visa E who seek 
Ministerial intervention under sections $48 \mathrm{~B}$ or 417 ) represents a more robust right to remain pending a thorough determination of the claim, provided that the person continues to hold such a visa. The same cannot be said for those unlawful non-citizens in detention whose right to remain exists up until their RRT (or, until recently, the IMR decision for those in excised offshore places), after which time a separate stay order is required from the Federal Court or the High Court of Australia to avoid consequent removal pending judicial review. However, even for those in detention, their right to remain bears witness to at least a merits review of their application. The EU Proposals evidence a significant strengthening of the right to remain to include up to the determination of an effective remedy, but there are still gaps through which refoulement is possible, particularly where the decision on the right to remain is not taken with a substantive decision on the merits of the review. Australia is at risk of exposing persons to refoulement through the cancellation of visas (or the refusal of the grant of Protection Visas) by virtue of section 501 of the Migration Act where one of the grounds is potentially broader than that contemplated by the exclusion provisions of the Geneva Convention (noting that it remains to be seen how the exclusion provisions as regards complementary protection will fit within this framework), as well as where environmental factors in Australia (such as the detention environment or a lack of material support in the community) contribute to behaviour which results in the grant of a Protection Visa being refused and where discretion is otherwise exercised to cancel the visa. In those circumstances, the compliance with non-refoulement obligations as a matter of discretion rather than legal obligation (and underpinned by automatic removal provisions) is of concern, especially in circumstances where the consequences can be irreversible and tragic.

In relation to transfers to another country, human rights obligations (in both the ECHR and EU legal orders) by themselves were not enough to satisfy the ECHR in MSS or the CJEU in NS that they would be complied with should an asylum seeker be transferred to another Member State as part of a Dublin transfer. The CJEU enunciated a rebuttable presumption in that regard. In M70, the High Court of Australia paid particular attention to the legal obligations of the destination country to provide protection to transferred asylum seekers (as a question of jurisdictional fact), although not ruling out a consideration of what occurred in practice in such countries, provided that the destination country's practices were not the sole factor considered by the Minister in the making of his or her determination.

The right to liberty for asylum seekers in both jurisdictions is compromised. In both jurisdictions, systematic detention of asylum seekers at the borders is possible at law. In the European Union, the secondary legislation provides a fairly vapid right to liberty for those who have a right to remain. The key, however, is securing the right to remain - which is a possible derogation for border applicants under the current Procedures Directive. The grounds for 
detention under the Reception Conditions Directive are vague. For those border applicants in the European Union, detention may occur as a question of fact by not being authorised to be on the territory of a State (little comfort for which is found in the jurisprudence surrounding Article 5(1)(f) ECHR) or by the vagueness of the terms of Article 7 of the Reception Conditions Directive. The principle of proportionality, as a General Principle of EU law, may provide a higher standard of protection than the ECHR in this regard. Indeed, the proposed secondary legislation would appear to provide a more active and deliberate consideration of the principle of proportionality before a detention decision is made, with grounds for detention much more clearly enunciated. It remains to be seen how well border applicants benefit (if at all) from those proposed provisions - particularly in light of deciding the right to enter the territory as an introduced ground for detention. In the Australian sphere, for those asylum seekers in the community as lawful non-citizens, there is a very strong right to liberty (or perhaps, more accurately, a strong right not to be detained) by virtue of holding either a substantive or Bridging Visa whilst their application is being determined. For those asylum seekers in detention, a right to liberty may be asserted by way of a Bridging Visa. However, as shall be examined in Chapter 8, there are very prescribed and complex grounds for eligibility (both as regards eligibility for making an application for a Bridging Visa and for the class of Bridging Visa in question). For Offshore Entry Persons, due to being precluded from making any application for a visa, their ability to secure liberty in Australia is by way of an exercise of personal and non-compellable ministerial discretion. As with those in the Migration Zone, liberty may only otherwise occur through being removed or deported. The Australian legislation relating to detention makes no assessment of the necessity for detention on an individualised basis nor of the proportionality of the decision to detain. Indeed, in the absence of individualised grounds for detention, it is difficult to elicit the purpose of detention. In the Australian sphere, the right to liberty and to remain are never divorced from the visa status of the person. There is no consideration of the effect, necessity, or proportionality of detention as a consequence of cancellation or non-possession of a valid visa. Indeed, the decision on the merits of the visa should be divorced from the consequences of cancellation (that is, detention).

Circumstances of prolonged detention for those in a return situation remain possible in both jurisdictions. Notwithstanding the 18-month time limit contained in the Returns Directive (which should not be seen as an implicit inducement to detain up to that point), the Directive is sadly silent on aggregate periods of detention under the Directive. In Australia, indefinite detention remains possible and may only be alleviated through a noncompellable and personal exercise of ministerial discretion.

In both jurisdictions, the detention of minors is possible at law with attention on the place or conditions of detention rather than the decision to detain at 
all. Both jurisdictions exhibit severely compromised provisions as regards legal guardianship of unaccompanied minors - chiefly, the concurrency of roles of detaining authority, determining authority, and guardian of the minor. The treatment of minors in the EU secondary legislation is perhaps best described as ambiguous. The challenges for minors under the legislation are threefold: firstly, it is unclear at times whether they fall within the scope of the secondary legislation on account of their ability to access the procedure in their own right, and which consequently may affect their right to remain and right to liberty. Secondly, although there is a general adoption of the best interests of the child as a primary consideration, there is no prohibition against the detention of minors, but there is increasing comfort found in the recent decisions of the ECtHR. Only the Proposed Dublin Regulation contains a prohibition against the detention of unaccompanied minors - a prohibition which has been removed in the Council's Amended Reception Conditions Directive - and, without such a prohibition finding its way into the other future secondary legislation, discriminates against minors on account of their status. Thirdly, the issue of legal guardianship of minors is worrying not only in the sense that Member States are not obliged to provide legal guardianship (and which is removed altogether in the Council's Amended Proposed Reception Conditions Directive), but also that there is no prohibition against the appointment of a guardian or representative that is both the determining authority for international protection status or the detaining authority of the minor. Accordingly, there are significant risks for conflicts of interest and for measures to be taken (or omitted) that are prejudicial to the best interest of the child.

In Australia, notwithstanding the principle contained in the legislation that minors are to be detained as a measure of last resort, that principle is of questionable justiciability. The legislation still permits the detention of minors. The fact that minors as a matter of policy (which is non-justiciable) are detained in alternative forms of detention, as opposed to alternatives to detention, do not provide much comfort. Such policies remain at the whim of the government of the day and should be legislatively embedded as should the protections and prohibitions contemplated in CROC. The automatic appointment of a guardian and the written consent of the Minister for an unaccompanied minor to leave Australia (satisfied that the minor's best interests will not be prejudiced) are very sound measures for the protection of a minor's best interests. However, the appointment of the Minister for Immigration (or, for example, the immigration detention regional manager as the Minister's delegate) as the guardian is far from sound - the trifold conflicts of interest as a result of that appointment in no way ensure that the best interests of the child will be protected. The litigated examples serve as a powerful example to European Union legislators of what should be legislatively proscribed.

It is possible at law in both jurisdictions to detain family members of asylum seekers. In the European Union family members of asylum seekers face an 
ambiguity as to whether they fall within the scope of the secondary legislation. Notwithstanding references to the principle of family unity, leaving Member States the discretion to determine whether the Procedures Directive is applicable (and thus, affect consequent rights under the Reception Conditions Directive) has the potential to gravely undermine that principle. Further, the secondary legislation contains implicit permission to detain families. The ECtHR has considered the detention of families and only recently in Kanagaratnam and Popov is there evidence of a shift to considering the unsuitability of accommodation for families (and, in Kanagaratnam, excessive length of detention) as a ground for rendering detention under Article 5(1)(f) unlawful. Similarly, it is also within the possibilities of the Australian legislation (and with no express reference to the principle of maintenance of family unity) to detain families with minors.

In the European Union, vulnerable persons are expressly contemplated under the current Reception Conditions Directive and receive stronger protection in the Proposed secondary legislation, including when vulnerable persons should be identified, under what circumstances they should be detained and the conditions of their detention. However, the Returns Directive perhaps provides the weakest consideration for vulnerable persons. The ECtHR jurisprudence does, however, compel the conditions of detention to be matched to the vulnerability of the person in order to be lawful. In Australia, the Migration Act does not make any distinction between non-citizens based on their vulnerability or otherwise in relation to a decision to detain. Provision is indirectly made for those vulnerable persons in the Migration Zone in the context of eligibility for a Bridging Visa.

Both the European Union and Australia do not have an early, systematic, and pre-detention identification process for stateless persons contained in their legislation. Stateless persons are particularly vulnerable in Australia given the possibility for indefinite detention. 


\section{Chapter 6 \\ Review Mechanisms for Detention}

This chapter considers review mechanisms for detention, covering both judicial review and oversight by external bodies and agencies. It consists of four parts: (1) the provision of reasons for detention; (2) access to, and communication with, lawyers and the provision of legal assistance; (3) the review and challenge of the detention decision; and (4) external communication, access and oversight. In practical terms, the cumulative effect of those four parts is to ensure that a detained asylum seeker is not impeded from making an effective challenge to his or her detention decision.

Providing an asylum seeker with reasons for detention, as well as legal assistance and access to, and communication with, lawyers can have a direct bearing on his or her ability to effectively challenge a detention decision. The provision of reasons allows a detained asylum seeker to immediately assess whether his or her grounds for detention are invalid or unsubstantiated and to commence action to secure his or her release. In an increasingly complex field such as asylum law and with such a fundamental right as liberty at stake, the ability to access and communicate with a lawyer and for that lawyer to be provided through some form of legal aid (for those detained asylum seekers without means) can prove vital in elucidating, enunciating and navigating a challenge to a detention decision. It is also an important means for ensuring that a detained asylum seeker is not left in 'legal isolation' - that is, unaware of their rights and unable to exercise them such that their agency is severely diminished. Those first two parts of the chapter culminate in the third, the review of the detention decision itself. Because the detention of asylum seekers is often an exercise of administrative law (and executive power), it is submitted that judicial review provides the greatest safeguard against abuse. Included in that examination is how security-related information can create grave obstacles to an asylum seeker's effective challenge of a detention decision and how each jurisdiction addresses (or fails to address) that issue.

The mere existence of human rights safeguards (including procedural safeguards) is insufficient to protect asylum seekers from arbitrary detention and ill treatment if they are not aware of those rights or how to exercise them. External communication with, and access to, asylum seekers as well as external oversight is important for bringing asylum seekers' attention to their rights and to the bodies and organisations that can assist them. In that regard, it is submitted that the rights of access and communication should be expressed as reciprocal rights between the asylum seeker and the body, organisation or other external party so that each has the right to access and communicate with the other. Each can then be aware of the other's existence. In addition to this, the external oversight of detained asylum seekers plays a key role in reducing the risk of torture, cruel, inhuman or degrading treatment as well as providing 
transparency in relation to detention conditions. It is submitted that external scrutiny is best served by being underpinned by compellable action if it is to be truly effective.

\subsection{Provision of Reasons for Detention}

\subsubsection{Provision of Reasons for Detention - International} Article 9(2) ICCPR provides:

"Anyone who is arrested shall be informed, at the time of arrest, of the reasons for his arrest and shall be promptly informed of any charges against him."

The HRC has indicated that part of Article 9(2) is applicable only to those facing criminal detention (that is, concerning any charges laid against the person as well as paragraph 3) with the remainder of Article 9 being applicable to persons facing, or in, detention. ${ }^{1875}$ Accordingly, this includes asylum seekers.

The reasons for detention require a degree of specificity as general reasons will not suffice - that is, it is insufficient to inform the detained person that he or she is being detained merely on "security measures without any indication of the substance of the complaint made against him."1876 The purpose behind such a degree of specificity of reasons is "to enable [the detained person] to take immediate steps to secure his release if he believes that the reasons given are invalid or unfounded". ${ }^{1877}$

It is arguable that the requirement contemplated by Article 9(2) ICCPR is also embraced by Article 14(2) CRPD, which is inclusive of the "guarantees in accordance with international human rights law".

The UNHCR Revised Guidelines provide that as part of the minimum of procedural guarantees, detained asylum seekers are to:

"receive prompt and full communication of any order of detention, together with the reasons for the order, and their rights in connection with the order, in a language and in terms which they understand" 1878

\footnotetext{
1875 United Nations Human Rights Committee, General Comment No. 8: Right to liberty and security of persons (Article 9), 20 June 1982, http://www.unhchr.ch/tbs/doc.nsf/(Symbol)/ f4253f9572cd4700c12563ed00483bec?Opendocument (last accessed 5 November 2011), para 1

1876 Adolfo Drescher Caldas v Uruguay, Communication No. 43/1979, 1990, para 13.2

1877 Adolfo Drescher Caldas v Uruguay, Communication No. 43/1979, 1990, para 13.2

1878 UNHCR Revised Guidelines on applicable criteria and standards relating to the detention of asylum seekers, February 1999, Guideline 5(i)
} 
The UN Body of Principles for the Protection of All Persons under Any Form of Detention or Imprisonment also echo those requirements:

"A detained person and his counsel, if any, shall receive prompt and full communication of any order of detention, together with the reasons therefor [sic]." 1879

Further, the UN Body of Principles also provides that a detained person should be informed of his rights and how to exercise those rights, ${ }^{1880}$ and that that information, together with the reasons for detention should be given in a language the detained person understands. ${ }^{1881}$

The Working Group on Arbitrary Detention has indicated that a person held at the border (which, as has been explored in Chapters 4 and 5, may also amount to detention) must be at least informed orally of the nature and grounds that he or she has been refused entry into the territory, in a language which he or she understands. ${ }^{1882}$ Further, the Working Group on Arbitrary Detention has also indicated that, in relation to detention, the person must be informed in writing setting out firstly, the grounds of detention; and secondly, the conditions for seeking a judicial remedy for a prompt decision on the lawfulness of detention and for an order to release the person, if appropriate. $^{1883}$

\subsubsection{Provision of Reasons for Detention - Council of Europe ECHR}

Article 5(2) ECHR provides that:

"Everyone who is arrested shall be informed promptly, in a language which he understands, of the reasons for his arrest and of any charge against him."

The requirement specified in Article 5(2) ECHR applies to all grounds for detention contemplated under Article $5(1)^{1884}$ (that is, inclusive of Article $\left.5(1)(f)^{1885}\right)$.

\footnotetext{
1879 Principle 11(2), Adopted by General Assembly Resolution 43/173 of 9 December 1988 http://www2.ohchr.org/english/law/bodyprinciples.htm (last accessed 7 November 2011) 1880 Principle 13, Adopted by General Assembly Resolution 43/173 of 9 December 1988 http://www2.ohchr.org/english/law/bodyprinciples.htm (last accessed 7 November 2011) 1881 Principle 14, Adopted by General Assembly Resolution 43/173 of 9 December 1988 http://www2.ohchr.org/english/law/bodyprinciples.htm (last accessed 7 November 2011) 1882 UN Commission on Human Rights, Working Group on Arbitrary Detention, 28 December 1999, E/CN.4/2000/4, Annex II, Deliberation No. 5, Principle 1

1883 UN Commission on Human Rights, Working Group on Arbitrary Detention, 28 December 1999, E/CN.4/2000/4, Annex II, Deliberation No. 5, Principle 8

1884 Kerr v United Kingdom, No. 40451/98, Partial Decision, 7 December 1999 where the Court stated "The Court recalls that paragraph 2 of Article 5 contains the elementary safeguard that any person arrested should know why he is being deprived of his liberty. This provision is an integral part of the scheme of protection afforded by Article 5". See also, Fox, Campbell and Hartley v United Kingdom, Nos. 12446/86, 12245/86 and 12383/86,
} 
As with Article 9(2) ICCPR, the ECtHR has also emphasised that the "essential legal and factual grounds" 1886 for arrest must be given so that the lawfulness of detention may be challenged. Notice of the grounds for detention must be conveyed "in simple, non-technical language that the person detained] can understand." 1887 The timing of the notice need not be at arrest, but must be prompt - in Saadi, 76 hours was held to be in breach of Article 5(2) ECHR. ${ }^{1888}$ In any event, whether the requirements of Article 5(2) have been satisfied will turn on a case-by-case basis. ${ }^{1889}$

\section{Committee of Ministers' Recommendation Rec(2003)5 \& Twenty Guidelines on Forced Returns}

The Committee of Ministers' Recommendation Rec(2003)5 does not make specific reference to the reasons for detention being given to an asylum seeker, but does make a general reference that all measures are to be implemented in accordance with international standards and ECtHR case law. ${ }^{1890}$ In relation to forced returns, the Committee of Ministers in their Twenty Guidelines on Forced Return, generally reflect the position of the ECtHR jurisprudence by requiring the person to be informed of the legal and factual grounds for detention in a language the detained person understands as well as "the possible remedies". ${ }^{1891}$ The Guidelines further indicate that the person should be given the opportunity to contact a lawyer, doctor or other person "to inform that person about his/her situation". ${ }^{1892}$

Judgment, 30 August 1990, para 40; On the failure to provide reasons and its consequent invalidity of Article 5(1) ECHR see Lopko and Touré v Hungary, No. 10816/10, Judgment, 20 September 2011, para 24

1885 Saadi v United Kingdom, No. 13229/03, Judgment, Grand Chamber, 29 January 2008, at paras 81-85 affirming the Chamber's reasoning.

1886 Kerr $v$ United Kingdom, No. 40451/98, Partial Decision, 7 December 1999; see also Abdolhani and Karimnia v Turkey, No. 30471/08, Judgment, 22 September 2009, paras 136138; Rusu v Austria, No. 34082/02, Judgment, 2 October 2008, paras 32-46; Kaboulov v Ukraine, No. 41015/04, Judgment, 19 November 2009, paras 143-148

1887 Kerr v United Kingdom, No. 40451/98, Partial Decision, 7 December 1999; Čonka v Belgium, No. 51564/99, Judgment, 5 February 2002, para 50

1888 Saadi v United Kingdom, No. 13229/03, Judgment, Grand Chamber, 29 January 2008, at paras 81-85 affirming the Chamber's reasoning. Compare Murray v United Kingdom, No. 14310/88, Judgment, Grand Chamber, 28 October 1994, at paras 77-80 where a matter of one hour twenty minutes between arrest and the commencement of the interview (which lasted one hour fifteen minutes) and which the reasons for arrest were said to have become clear during the interview was held not to be lacking in promptness contemplated by Article 5(2).

1889 Kerr v United Kingdom, No. 40451/98, Partial Decision, 7 December 1999; Murray v United Kingdom, No. 14310/88, Judgment, Grand Chamber, 28 October 1994, at para 72

1890 Committee of Ministers, Council of Europe, Recommendation Rec(2003)5 of the Committee of Ministers to member states on measures of detention to asylum seekers, paragraph 3.

1891 Guideline 6(2), Committee of Ministers, Council of Europe, Twenty Guidelines on Forced Return, CM(2005)40 Addendum final, Strasbourg, 20 May 2005

1892 Guideline 6(2), Committee of Ministers, Council of Europe, Twenty Guidelines on Forced Return, CM(2005)40 Addendum final, Strasbourg, 20 May 2005 


\title{
CPT
}

The Committee for the Prevention of Torture ("CteePT") has also indicated that persons detained in immigration detention facilities should be "expressly informed, without delay and in a language they understand, of all their rights and of the procedure applicable to them". ${ }^{1893}$ Although noting that asylum seekers should be subject to higher standards than irregular migrants detained generally, ${ }^{1894}$ the CteePT has urged that "[e]very instance of deprivation of liberty should be covered by a proper individual detention order" that is easily accessible in the place of detention. ${ }^{1895}$

\subsubsection{Provision of Reasons for Detention - European Union \\ 6.1.3.1 General Principles of European Union Law}

Tridimas notes that, as a General Principle of Union law, Member States are required to furnish reasons where a Union right is compromised. ${ }^{1896}$ As Advocate-General Fennelly noted, in Sodemare:

\begin{abstract}
"The obligation to give reasons for national decisions affecting the exercise of Community law rights does not arise from any extension of Article 190 of the Treaty, 1897 but from the general principle of Community law, flowing from the constitutional traditions of the Member States, that judicial remedies should be available to individuals in such cases." 1898
\end{abstract}

The rationale behind this is to allow a judicial challenge to the decision, if necessary. It is arguable that the rights set out in the EU Charter, in particular the right to liberty, and which are not solely addressed to EU citizens, would be denied an effective remedy for their breach if reasons were not provided, especially in circumstances where a Member State is implementing Union law. ${ }^{1899}$

1893 The European Committee for the Prevention of Torture and Inhuman or Degrading Treatment or Punishment, The CPT Standards, October 2006, Strasbourg, CPT/Inf/E (2002) 1 - Rev. 2010, P.55, para 30

1894 The European Committee for the Prevention of Torture and Inhuman or Degrading Treatment or Punishment, The CPT Standards, October 2006, Strasbourg, CPT/Inf/E (2002) 1 - Rev. 2010, P.59, para 78

1895 The European Committee for the Prevention of Torture and Inhuman or Degrading Treatment or Punishment, The CPT Standards, October 2006, Strasbourg, CPT/Inf/E (2002) 1 - Rev. 2010, P.61, para 85

1896 Case 222/86 UNECTEF v Heylens, Judgment, 15 October 1987 at para 15; Case C340/89 Vlassopolou $v$ Ministerium für Justiz, Bundes- und Europaangelenheiten BadenWürttemberg, Judgment, 7 May 1991 at para 22; Case C-19/92 Kraus v Land BadenWürttemberg, Judgment, 31 March 1993 at para 40 - cited in Tridimas, T, The General Principles of EU Law, 2ed, 2006, OUP, Oxford, P.445

1897 Now Article 296 TFEU

1898 Case C-70/95 Sodemare SA et al v Regione Lombardia, Opinion of Fennelly AG, 6 February 1997 at para 17 cited in Tridimas, T, The General Principles of EU Law, 2ed, 2006, OUP, Oxford, P.445; see also Case C-70/95 Sodemare SA et al $v$ Regione Lombardia, Judgment, 17 June 1997.

1899 Indeed, it is to be noted that a right to good administration is provided in Article 41(1) and (2) of the EU Charter which includes the right to be given reasons for a decision by a 


\subsubsection{Provision of Reasons for Detention - European Union Secondary Legislation}

The current Union secondary legislation is silent on the provision of reasons for detention.

\subsection{Detention where the Right to Remain Exists}

If the right to remain exists, and detention occurs under the current Reception Conditions Directive, then that Directive makes no provision for reasons for detention to be given to the detained person.

\section{Detention where the Right to Remain Exists - The Proposed Legislation}

Under the Commission's 2011 Proposed Reception Conditions Directive detention must firstly, be ordered in writing; secondly, the detention order must state the legal and factual reasons for the detention as well as the procedures in national law to challenge the detention decision; thirdly, the order must be in a language the asylum seeker understands "or is reasonably supposed to understand" (which is a lesser standard than that contemplated by the UNHCR Revised Guidelines and the ECtHR jurisprudence surrounding Article 5(2) ECHR); and fourthly, the detention order must be immediately provided to the detained person. ${ }^{1900}$ The Council's amendments to that proposal reformulate the wording of that provision with no discernible change in effect except that the Council's proposal has, regretfully, removed the requirement that the detention order be given to the detained person immediately. ${ }^{1901}$

\subsection{Detention where the Right to Remain is Lost}

If the right to remain is lost and detention has occurred whilst the current Procedures Directive still applies then that Directive is also silent on the reasons for detention being provided to a detained person. As Peers has noted, detention in those circumstances must also be in accordance with the ICCPR and ECtHR ${ }^{1902}$ which both expressly (and through their respective jurisprudence) contemplate grounds for detention being provided.

\section{Detention where the Right to Remain is Lost - The Proposed Legislation}

Under the Commission's 2011 Proposed Procedures Directive, those that would be detained whilst the (proposed) Procedures Directive applies are done so by reference to the Reception Conditions Directive as to grounds, conditions and guarantees. ${ }^{1903}$ Accordingly, the procedural gap will now have been equalised and closed between the two pieces of secondary legislation.

\footnotetext{
Union institution, body, office or agency. However, that right is restricted to Union citizens and further does not expressly contemplate Member States which are implementing Union law

1900 Article 9(3) of the Commission's 2011 Proposed Reception Conditions Directive

1901 Article 9(3) of the Council's Amended Proposed Reception Conditions Directive

1902 Peers, S, EU Justice and Home Affairs Law, (3ed), 2011, OUP, Oxford, Pp.352-353

1903 Article 26(1) of the Commission's 2011 Proposed Procedures Directive
} 


\section{The Returns Directive}

Under the Returns Directive, detention is to be "ordered in writing with reasons being given in fact and in law". ${ }^{1904}$ The Returns Directive makes no express provision as to the timing for the notice to be given, the content (that is, whether procedures for challenging the decision are to be included in the notice of detention), as well as the requirement that the notice be given in a language that the detained person understands "or is reasonably supposed to understand".

As regards notification on the part of the authorities to the detained person about their right to challenge a detention decision, it is arguable that that information would be included in the "rights and obligations" which must be systematically provided to detained persons as required by Article 15(5) of the Returns Directive. The inclusion of that information in the notification is particularly important as an obligation on the part of authorities to inform a detained person of their right to challenge the detention decision is only explicitly made in the case where the decision to detain has been made administratively and automatic speedy judicial review confirming the detention order has not been made. ${ }^{1905}$ However, it would be deeply regrettable if a narrow construction of Article 15(5) were made so that the only rights and obligations required to be informed were those relating to the detention facility (noting, as a question of interpretation, that that Article also includes an immediately preceding obligation to provide a detained person with information "which explains the rules applied in the facility"). Support for a narrow construction might be found in the Proposed Reception Conditions Directive noting: (1) the extremely similar formulation to that under the Returns Directive; ${ }^{1906}$ (2) that the provision under the Proposed Reception Conditions Directive is separate from and in addition to the requirements that the asylum seeker be notified of the procedures for challenging the detention decision in the detention order; ${ }^{1907}$ and (3) that such a notification requirement may the subject of derogation under the Proposal. ${ }^{1908}$ Notwithstanding a general reference to the Council of Europe's Twenty Guidelines on Forced Returns in the recitals to the Directive, ${ }^{1909}$ it would be preferable if there was an express obligation on the part of authorities to inform detained persons of their right to challenge the lawfulness of their detention at any time (whether or not it was instituted by a judicial or administrative authority).

\footnotetext{
1904 Article 15(2), second paragraph, of the Returns Directive 1905 Article 15(2)(b) of the Returns Directive

1906 Article 10(5) of the Commission's 2011 Proposed Reception Conditions Directive and Article 10(5) of the Council's Amended Proposed Reception Conditions Directive 1907 Article 9(3) of the Commission's 2011 Proposed Reception Conditions Directive and Article 9(3) of the Council's Amended Proposed Reception Conditions Directive 1908 Article 10(6)(a) of the Commission's 2011 Proposed Reception Conditions Directive and Article 10(6)(a) of the Council's Amended Proposed Reception Conditions Directive ${ }^{1909}$ Recital 3 of the Returns Directive
} 
6.1.3.2.3 If an Asylum Seeker is in a Member State Other Than That of First Entry or Asylum

As noted previously, the current Dublin II Regulation remains silent on the detention of asylum seekers for the purpose of transfer to the responsible Member State. Accordingly, there are no provisions with respect to the notice to be given to detained persons in those circumstances. It is arguable that the requirements of the ICCPR and ECHR apply in those circumstances (even if, as discussed in Chapter 5, there is a question about whether any such detention is "in accordance with a procedure prescribed by law" as provided for in Article 5(1) ECHR).

\section{If an Asylum Seeker is in a Member State Other Than That of First Entry or Asylum} - The Proposed Legislation

The Commission's Proposed Dublin Regulation, now expressly providing for detention, also stipulates that reasons be provided to the person detained. ${ }^{1910}$ As with the Commission's 2011 Proposed Reception Conditions Directive, reasons in fact and law must be provided to the detained person, inclusive of national legal procedures for challenging the detention order, with the reasons provided immediately. However, there are two additional provisos: firstly, the reasons in fact and law for the detention must "in particular specify[...] the reasons on the basis of which it is considered that there is a significant risk that the person concerned absconding as well as the time period of its duration"; and secondly, the intended duration of the detention. The order is to be in a language that the detained person is "reasonably supposed to understand" and makes no more specific provision that the order be given in language that the detained person does understand. Again, this is of dubious compliance with the UNHCR Revised Guidelines and the ECtHR jurisprudence surrounding Article 5(2) ECHR.

\subsubsection{Provision of Reasons for Detention - Australia}

The Migration Act does not provide for the reasons for detention to be given. Written notice only need be given to those removees or deportees who are in Commonwealth, State or Territory custody otherwise than under the Migration Act. ${ }^{1911}$

At common law, other than a court carrying out its judicial functions, there is no obligation for a decision maker to furnish reasons. ${ }^{1912}$ An avenue for a statutory obligation to give reasons may be found under the Administrative Decisions (Judicial Review) Act 1975 (Cth) (“ADJR Act”) ${ }^{1913}$ but the Act does not apply to privative or purported privative clause decisions under the

\footnotetext{
1910 Article 27(7) of the Commission's Proposed Dublin Regulation

1911 Section 254 of the Migration Act 1958 (Cth)

1912 Public Service Board v Osmond [1986] HCA 7; see further, in relation to the implication of this decision over time: Aronson, M, Dyer, B, and Groves, M, Judicial Review of Administrative Action, 4ed, 2009, Lawbook Co, Pyrmont, Pp.630-637

${ }^{1913}$ Section 13(1) of the ADJR Act
} 
Migration Act, ${ }^{1914}$ which includes decisions to detain under section $189 .{ }^{1915}$ Similarly, provision is made for reasons for a decision to be furnished under the Administrative Appeals Tribunal Act 1975 (Cth), ${ }^{1916}$ but the Migration Act only contemplates referral to the Administrative Appeals Tribunal in limited circumstances, ${ }^{1917}$ which do not include detention decisions.

In light of a mandatory detention policy, it is arguable that the only reasons that could be given consistent with the current legislation is that a person is, or is reasonably suspected of being, an unlawful non-citizen (that is, the reason given relates to their general status in domestic law). For those offshore entry persons, the Migration Act is equally silent.

A revocation of a residence determination (which is still detention at law) can lead to a person being detained in an immigration detention centre and must be made by notice in writing. ${ }^{1918}$ However, as it relates to a revocation of a residence determination (as opposed to a variation ${ }^{1919}$ ), the Act is silent as to the content of that notice.

The only information that a detained person is to be given in relation to their detention is that he or she is to be told of the consequences of their detention: ${ }^{1920}$ firstly, that they may apply for a visa within two working days after having been given notice of the consequences of their detention (extendable to five days if written notice of the detained person's intention to apply is given to an officer within those two working days) ${ }^{1921}$ secondly, that if a visa is not applied for in that time, only a Bridging Visa or Protection Visa may be applied for; ${ }^{1922}$ thirdly, that the duration of detention is to last until either the person is removed, deported of granted a visa (together with the other provisions of section 196). ${ }^{1923}$

However, there is no requirement to give that information to anyone who has bypassed or refused immigration clearance, including offshore entry persons, or persons whose visas have been cancelled under section $501 .{ }^{1924}$ Unless

\footnotetext{
1914 See sections 13 (provision of reasons), 5 ("a decision to which this Act applies"), section 3 (definition of "a decision to which this Act applies") and Schedule 1 (da) and (db) of the ADJR Act

1915 Section 474 of the Migration Act 1958 (Cth); see also Crock, M, Saul, B, and Dastyari, A, Future Seekers II, 2006, Federation Press, P.159

1916 Section 28 of the Administrative Appeals Tribunal Act 1975 (Cth)

1917 See sections 381, 306, 311F, 306AJ, 311M, 443, 500 and 202 of the Migration Act 1958 (Cth)

1918 Section 197AD of the Migration Act 1958 (Cth)

1919 See section 197AD(2) of the Migration Act 1958 (Cth)

1920 Section 194 of the Migration Act 1958 (Cth)

1921 Section 195(1) of the Migration Act 1958 (Cth)

1922 Section 195(2) of the Migration Act 1958 (Cth)

1923 Section 196 of the Migration Act 1958 (Cth)

1924 Section 193(1) of the Migration Act 1958 (Cth)
} 
expressly requested by the person detained, ${ }^{1925}$ the Minister or any officer is expressly absolved from any obligation to give an application form to apply for a visa, advise a person as to whether they may apply for a visa, give an opportunity to apply for a visa or allow access to advice (legal or otherwise) in relation to applying for a visa. ${ }^{1926}$ Further, an officer is under no obligation to inform a detained person of their rights under section 256, as upheld by the Full Federal Court. ${ }^{1927}$

Those offshore entry persons who are detained pending their removal to a third country for offshore processing are deemed not to be in immigration detention, ${ }^{1928}$ and are doubly denied that information. These provisions unfairly prejudice the rights of those asylum seekers who have arrived in Australia without prior authorisation, or whose authorisation to enter has been cancelled or refused at the border.

Accordingly, there is no obligation under the Migration Act to provide substantive reasons for detention with a degree of specificity sufficient to allow an asylum seeker to challenge his or her detention as contemplated by Article 9(2) and consistent with the jurisprudence of the HRC in Drescher. Indeed, even if there were such an obligation, presumably the reasons it contained would only deal with formal compliance with domestic law as opposed to any substantive reasons for detention. The Act discloses no discernible purpose for detention.

\subsubsection{Provision of Reasons for Detention - Conclusions}

With the exception of the Returns Directive (which is, in any event, lacking as to the timing of the notice and is somewhat ambiguous as to its precise content regarding any right to challenge the lawfulness of detention), the current EU secondary legislation is deficient in that it does not expressly provide for the grounds in fact and law for the detention of asylum seekers or for procedures to challenge the lawfulness of the detention decisions. However, it is still arguable that, against the backdrop of the ECHR and General Principles of EU law, information containing the substantive reasons for detention is required to be provided by the Member States (that is, when Member States implement their obligations under the Union secondary legislation). The suite of proposed legislation makes express reference for the provision of grounds in fact and law for the detention decision, and the procedures for challenging the legality of a detention decision, but which are not deficiency-free as regards the language of such notice. In the Australian sphere, the largely legislative silence of notice requirements, together with the inadequacy of what information is required to be given (indeed, and only then

\footnotetext{
1925 Section 256 of the Migration Act 1958 (Cth)

1926 Section 193(2) of the Migration Act 1958 (Cth)

${ }^{1927} W u$ Yu Fang and 117 Others $v$ the Minister for Immigration and Ethnic Affairs and Commonwealth of Australia [1996] FCA 1272 per Nicholson J with whom Jenkinson J agreed 1928 Section 198A(4) of the Migration Act 1958 (Cth)
} 
in circumstances where the Act obliges that information to be given) fails to ensure compliance with Article 9(2) ICCPR, its related jurisprudence and the UNHCR Revised Guidelines.

\subsection{Access to, and communication with, lawyers and the provision of legal assistance}

Access to, and communication with lawyers and the provision of legal assistance for asylum seekers may be instrumental in elucidating and formulating their claim for asylum as well as to guide an asylum seeker through the process and procedure involved. In addition, access to legal assistance is an important safeguard for the rights of detained asylum seekers and their ability to make any challenge to the detention decision. ${ }^{1929}$ Indeed, the denial of access to lawyers for those persons in transit zones is not unknown. ${ }^{1930}$

6.2.1 Access to, and communication with, lawyers and the provision of legal assistance International

Guideline 5(ii) of the UNHCR Revised Guidelines provides that detained asylum seekers are entitled:

"to be informed of the right to legal counsel. Where possible, they should receive free legal assistance".

Article 7 ICCPR provides that "[n]o one shall be subjected to torture or to cruel, inhuman or degrading treatment". Persons may be at increased risk of torture, inhuman or degrading treatment when placed in incommunicado detention. The HRC has indicated that the prevention of torture is best served by obviating incommunicado detention and that an integral part of the safeguards that States are to ensure to that end are prompt and regular access by the detained person to lawyers. ${ }^{1931}$

1929 See, for example, Marques de Morais v Angola, Communication 1128/2002, CCPR/C/83/D/1128/2002, 29 March 2005, para 6.5, where a person who was held in incommunicado detention was unable to challenge his detention by the effective denial of access to a lawyer, resulting in a breach of Article 9(4) ICCPR; see also Machado v Uruguay, Communication 83/1981, CCPR/C/20/D/1981, 4 November 1983, para 13, in relation to how a person being held in incommunicado detention resulting in a breach of Article 10(1) ICCPR was effectively deprived from access to legal assistance, resulting in a breach of Article 14(3)(b) ICCPR (relating to criminal charges)

1930 In the European context, see Statewatch, Court decision overturns government attempt to deny foreigners' access to lawyers in transit zones, 2012, http://www.statewatch.org/news/2012/jan/03fr-anfe.htm (last accessed 13 June 2012); in the Australian context, see Re Masoud Azemoudeh v Minister for Immigration and Ethnic Affairs and Emil Joseph (1985) 8 ALD 281; [1985] FCA 380

1931 UNHRC, General Comment No. 20: Replaces general comment 7 concerning prohibition of torture and cruel treatment or punishment, 10 March 1992, para 11 
Article 10(1) ICCPR provides that those deprived of their liberty "shall be treated with humanity and with respect for the inherent dignity of the human person". The HRC has indicated that this positive obligation on States is complementary to Article 7 ICCPR, ${ }^{1932}$ and is inclusive of "all institutions and establishments within their jurisdiction where persons are held", and expressly includes "detention camps". ${ }^{1933}$ Accordingly, incommunicado detention has been found by the HRC in its Views to breach Article 10(1). ${ }^{1934}$

To that end the HRC has expressly invited States to include in their reports the extent of application of the Standard Minimum Rules on the Treatment of Prisoners and the Body of Principles for the Protection of All Persons under Any Form of Detention or Imprisonment. ${ }^{1935}$

The Standard Minimum Rules for the Treatment of Prisoners provides that civil prisoners are entitled to treatment "not less favourable than that of untried prisoners", ${ }^{1936}$ and specifically contemplates persons arrested or detained without charge, entitling them to the same protection. ${ }^{1937}$ Under the Standard Minimum Rules, untried prisoners "shall be allowed to apply for free legal aid where such aid is available, and to receive such visits from his legal adviser with a view to his defence and to prepare and hand to him confidential instructions." 1938

The Body of Principles for the Protection of All Persons under Any Form of Detention or Imprisonment ${ }^{1939}$ provides, relevantly, in Principle 13:

Any person shall, at the moment of arrest and at the commencement of detention or imprisonment, or promptly thereafter, be provided by the authority responsible

1932 UNHRC, General Comment No. 21: Replaces general comment 9 concerning humane treatment of persons deprived of liberty, 10 April 1992, para 3

1933 UNHRC, General Comment No. 21: Replaces general comment 9 concerning humane treatment of persons deprived of liberty, 10 April 1992, para 2

1934 See, Pietraroia v Uruguay, Communication 44/1979, ICCPR A/36/40 153, 27 March 1981, paras 13.2 and 17; Simones v Uruguay, Communication R 17/70, ICCPR A/37/40 174, April 1982, paras 11.2 and 12; Marais v Madagascar, Communication 49/1979, ICCPR A/38/40 141, 24 March 1983, paras 17.4 and 19; Caldas v Uruguay, Communication 43/1979, ICCPR A/38/40 192, 21 July 1983, paras 13.3 and 14; De Romero v Uruguay, Communication 85/1981, ICCPR A/39/40 159, 29 March 1984, para 13; Muteba v Zaire, Communication 124/1982, ICCPR A/39/40 182, 24 July 1984, para 12; Arzuaga $v$ Uruguay, Communication 147/1983, ICCPR A/41/40 128, 1 November 1985, para 14

1935 UNHRC, General Comment No. 21: Replaces general comment 9 concerning humane treatment of persons deprived of liberty, 10 April 1992, para 5

1936 Rule 94 of the Standard Minimum Rules for the Treatment of Prisoners

1937 Rule 95 of the Standard Minimum Rules for the Treatment of Prisoners

1938 Rule 93 of the Standard Minimum Rules for the Treatment of Prisoners

1939 Adopted by General Assembly Resolution 43/173 of 9 December 1988 http://www2.ohchr.org/english/law/bodyprinciples.htm (last accessed 7 November 2011) 
for his arrest, detention or imprisonment, respectively with information on and an explanation of his rights and how to avail himself of such rights.

Any denial of communication with the outside world including, inter alia, with a lawyer, must not be more than "a matter of days". ${ }^{1940}$

Further, Principle 17 states:

(1) A detained person shall be entitled to have the assistance of a legal counsel. He shall be informed of his right by the competent authority promptly after his arrest and shall be provided with reasonable facilities for exercising it.

(2) If a detained person does not have a legal counsel of his own choice, he shall be entitled to have legal counsel assigned to him by a judicial or other authority in all cases where the interests of justice so require and without payment by him if he does not have sufficient means to pay.

In addition, Principle 18(1) provides a right for a detained person "to communicate and consult with his legal counsel."

The Working Group on Arbitrary Detention Deliberation No 5 also reflects the right of a detained asylum seeker to contact a lawyer. ${ }^{1941}$

6.2.1.1 Access to, and communication with, lawyers and the provision of legal assistance - Minors

In relation to minors, the HRC has expressly invited States, as regards Article 10 ICCPR, to include in their reports whether they are applying the United Nations Standard Minimum Rules for the Administration of Juvenile Justice ("the Beijing Rules"). ${ }^{1942}$ The Beijing Rules confirm the right of a minor to counsel, ${ }^{1943}$ the rights to legal representation and, if available, to apply for free legal aid. ${ }^{1944}$ Importantly, the rights and guarantees contained in the Standard Minimum Rules for the Treatment of Prisoners are also explicitly incorporated into the Beijing Rules (which, as discussed above, sets out rights in relation to access to legal advisors). ${ }^{1945}$

\footnotetext{
${ }^{1940}$ Principle 15 of the Body of Principles for the Protection of All Persons under Any Form of Detention or Imprisonment

1941 UN Commission on Human Rights, Working Group on Arbitrary Detention, 28 December 1999, E/CN.4/2000/4, Annex II, Deliberation No. 5, Principle 1

1942 UNHRC, General Comment No. 21: Replaces general comment 9 concerning humane treatment of persons deprived of liberty, 10 April 1992, para 13

1943 Rule 7.1 of the United Nations Standard Minimum Rules for the Administration of Juvenile Justice

1944 Rule 15.1 of the United Nations Standard Minimum Rules for the Administration of Juvenile Justice

1945 Rules 13.3 and 27 of the United Nations Standard Minimum Rules for the Administration of Juvenile Justice
} 
CROC also provides that "prompt access to legal and other appropriate assistance" be provided to those minors who are deprived of their liberty. ${ }^{1946}$ The CteeRC has indicated that:

"In cases where children are involved in asylum procedures or administrative or judicial proceedings, they should, in addition to the appointment of a guardian, be provided with legal representation."1947

More specifically, in relation to those unaccompanied or separated minors who are detained, the CteeRC has indicated that:

"In order to effectively secure the rights provided by Article $37(\mathrm{~d})$ of the Convention, unaccompanied or separated children deprived of their liberty shall be provided with prompt and free access to legal and other appropriate assistance, including the assignment of a legal representative." ${ }^{1948}$

6.2.1.2 Access to, and communication with, lawyers and the provision of legal assistance - Vulnerable Persons

For those vulnerable asylum seekers who may fall within the scope of the CRPD, Article 15(1) CRPD provides a comparable protection against torture, cruel, inhuman or degrading treatment or punishment as contained in Article 7(1) ICCPR. Similarly, Article 14(2) CRPD are to ensure that those persons with disabilities deprived of their liberty "through any process" are "entitled to guarantees in accordance with international human rights law" which would presumably include at least protection offered by Article 10(1) ICCPR. Accordingly, those directly comparable provisions to the ICCPR discussed above should include access to legal representation and advice and which is particularly underscored by Article 13(1) CRPD which requires States to provide persons with disabilities with "effective access to justice" (emphasis added).

6.2.2 Access to, and communication with, lawyers and the provision of legal assistance - Council of Europe

\section{ECHR}

Article 6(1) ECHR provides for access to the courts. In Airey, where the applicant was unable to secure divorce proceedings in the High Court of Ireland due to her inability to afford a lawyer, the ECtHR held that the rights

1946 Article 37(d) CROC

1947 UN Committee on the Rights of the Child, General Comment No. 6 (2005) - Treatment of unaccompanied and separated children outside their country of origin, 1 September 2005, para 36 1948 UN Committee on the Rights of the Child, General Comment No. 6 (2005) - Treatment of unaccompanied and separated children outside their country of origin, 1 September 2005, para 63; See also Rule 18(a) United Nations Rules for the Protection of Juveniles Deprived of their Liberty, 14 December 1990, A/RES/45/113, http://www.un.org/documents/ga/res/45/ a45r113.htm (last accessed 6 November 2011); Rules 7 and 15.1, United Nations Standard Minimum Rules for the Administration of Juvenile Justice ("The Beijing Rules"), 29 November 1985, A/RES/40/33, http://www.un.org/documents/ga/res/40/a40r033.htm (last accessed 6 November 2011) 
protected by the ECHR are not "theoretical or illusory but rights that are practical and effective". ${ }^{1949}$ The Court bore in mind the complexity of the procedure, the complicated points of law involved and that it was "most improbable that a person in [the applicant's] position [...] can effectively present his or her own case." 1950 Accordingly, the Court held that a Contracting State is under an obligation to provide a lawyer:

"when such assistance proves indispensable for an effective access to court either because legal representation is rendered compulsory, as is done by the domestic law of certain Contracting States for various types of litigation, or by reason of the complexity of the procedure of the case." 1951

Given the complexity of asylum law and the many practical hurdles that asylum seekers may face (such as language, understanding of the system and material support), the principles enunciated in Airey could be analogously applied to the circumstances in which many asylum seekers find themselves.

The case of Zamir concerned a Pakistani national detained after entry into the United Kingdom and whose ability to file affidavit evidence in support of his lawyer's application for habeas corpus resulted from delays in a decision regarding the provision of legal aid. After considering that the applicant was lawfully detained in accordance with Article 5(1)(f) ECHR, the ECmHR noted:

"In proceedings concerning the liberty of the individual Art. 5(4) clearly requires that decisions concerning legal aid be taken speedily where such a decision is a prerequisite for the initiation of the continued conduct of the proceedings. In the opinion of the Commission, it would have been unreasonable to expect the applicant to present his own case in light of the complexity of the procedures involved and his limited command of English." 1952

In Čnka, the ECtHR emphasised the importance of access to lawyers in what can only be described as reproachable circumstances:

"44. In the instant case, the Court identifies a number of factors which undoubtedly affected the accessibility of the remedy which the Government claim was not exercised. These include the fact that the information on the available remedies handed to the applicants on their arrival at the police station was printed in tiny characters and in a language they did not understand; only one interpreter was available to assist the large number of Roma families who attended the police station in understanding the verbal and written communications addressed to them and, although he was present at the police station, he did not stay with them at the closed centre. In those circumstances, the applicants undoubtedly had little prospect of being able to contact a lawyer from the police station with the help of the

\footnotetext{
1949 Airey v Ireland, No. 6289/73, Judgment, 9 October 1979, para 24

1950 Airey v Ireland, No. 6289/73, Judgment, 9 October 1979, para 24

1951 Airey v Ireland, No. 6289/73, Judgment, 9 October 1979, para 27

1952 Zamir v United Kingdom, No. 9174/80, Commission Report, 11 October 1983 at para 
interpreter and, although they could have contacted a lawyer by telephone from the closed transit centre, they would no longer have been able to call upon the interpreter's services; despite those difficulties, the authorities did not offer any form of legal assistance at either the police station or the centre.

45. Whatever the position - and this factor is decisive in the eyes of the Court as the applicants' lawyer explained at the hearing without the Government contesting the point, he was only informed of the events in issue and of his clients' situation at 10.30 p.m. On Friday 1 October 1999, such that any appeal to the committals division would have been pointless because, had he lodged an appeal with the division on 4 October, the case could not have been heard until 6 October, a day after the applicants' expulsion on 5 October. Thus, although he still regarded himself as acting for the applicants (see paragraph 21 above), he was unable to lodge an appeal with the committals division." 1953

Committee of Ministers' Recommendation Rec(2003)5 \& Twenty Guidelines on Forced Returns

The Committee of Ministers of the Council of Europe in their Recommendation $\operatorname{Rec}(2003) 5$ have indicated that "[d]etained asylum seekers should have the right to contact a legal counsellor or a lawyer and to benefit from their assistance". ${ }^{1954}$ The Recommendation is silent as to the provision of legal aid in those circumstances. The Committee of Ministers' Twenty Guidelines on Forced Returns provides the possibility for a detained person to immediately contact, inter alia, a lawyer to inform him or her about his or her situation. ${ }^{1955}$ The Twenty Guidelines also emphasise that any judicial remedy against a detention decision "must be readily accessible and effective and legal aid should be provided in accordance with national legislation."1956

\section{CPT}

The CteePT has indicated in its Guidelines that judicial review of the detention decision should be by way of oral hearing "with legal assistance provided free of charge for persons without sufficient means" and interpretation services if necessary. ${ }^{1957}$ Most importantly, the CteePT has indicated that those detained "should be expressly informed of this legal remedy"1958 - a guarantee without which can seriously prejudice an applicant's circumstances.

1953 Čonka v Belgium, No. 51564/99, Judgment, 5 February 2002, paras 44-45

1954 Committee of Ministers, Council of Europe, Recommendation Rec(2003)5 of the Committee of Ministers to member states on measures of detention to asylum seekers, paragraph 17

1955 Guideline 6(2), Committee of Ministers, Council of Europe, Twenty Guidelines on Forced Return, CM(2005)40 Addendum final, Strasbourg, 20 May 2005

1956 Guideline 9(2), Committee of Ministers, Council of Europe, Twenty Guidelines on Forced Return, CM(2005)40 Addendum final, Strasbourg, 20 May 2005

1957 The European Committee for the Prevention of Torture and Inhuman or Degrading Treatment or Punishment, The CPT Standards, October 2006, Strasbourg, CPT/Inf/E (2002) 1 - Rev. 2010, P.61 para 86

1958 The European Committee for the Prevention of Torture and Inhuman or Degrading Treatment or Punishment, The CPT Standards, October 2006, Strasbourg, CPT/Inf/E (2002) 1 - Rev. 2010, P.61, para 86 
6.2.3 Access to, and communication with, lawyers and the provision of legal assistance - European Union

\subsubsection{EU Charter and General Principles of European Union Law}

In the Union sphere, Article 47(2) of the EU Charter provides a right to legal representation. Tridimas notes that the formulation of Article 47(2) is wider than Article 6(1) ECHR in that that right it is not limited to "civil rights and obligations". ${ }^{1959}$ Article 47(3) provides that legal aid is also to be provided to those who lack sufficient resources and where it is necessary for "effective access to justice". Indeed, the CJEU's Rules of Procedure expressly provide for the grant of legal aid where a party is unable meet their legal costs. ${ }^{1960}$ In $D E B$, the CJEU has considered Article 47 of the EU Charter as it relates to the provision of legal aid by a Member State. Indeed, the question of proportionality also becomes relevant. The Court held:

"59. In the light of all of the foregoing, the answer to the question referred must be that the principle of effective judicial protection, as enshrined in Article 47 of the Charter, must be interpreted as meaning that it is not impossible for legal persons to rely on that principle and that aid granted pursuant to that principle may cover, inter alia, dispensation from advance payment of the costs of proceedings and/or the assistance of a lawyer

60. In that connection, it is for the national court to ascertain whether the conditions for granting legal aid constitute a limitation on the right of access to the courts which undermines the very core of that right; whether they pursue a legitimate aim; and whether there is a reasonable relationship of proportionality between the means employed and the legitimate aim which it is sought to achieve.

61. In making that assessment, the national court must take into consideration the subject-matter of the litigation; whether the applicant has a reasonable prospect of success; the importance of what is at stake for the applicant in the proceedings; the complexity of the applicable law and procedure; and the applicant's capacity to represent himself effectively. In order to assess the proportionality, the national court may also take account of the amount of the costs of the proceedings in respect of which advance payment must be made and whether or not those costs might represent an insurmountable obstacle to access to the courts."'1961

6.2.3.2 Access to, and communication with, lawyers and the provision of legal assistance - European Union Secondary Legislation

\subsection{Detention where the Right to Remain Exists}

Detention where the Right to Remain Exists - Access to, and communication with, lawyers - Current Legislation

1959 Tridimas, T, The General Principles of EU Law, 2ed, 2006, OUP, Oxford, P.456.

1960 Article 75, Rules of Procedure of the Court of Justice of the European Union, amendments up to 24 May 2011 (OJ L 162 of 22 June 2011), P.17

1961 Case C-279/09 DEB Deutsche Energiehandels- und Beratungsgesllschaft mbH $v$ Bundesrepublik Deutschland, Judgment, 22 December 2010, paras 59-61 (and dealing with legal persons at para 62) 
As regards the detention of those with the right to remain, the current Reception Conditions Directive provides that legal advisors or counsellors must be granted access to "accommodation centres and other housing facilities" to assist asylum seekers. ${ }^{1962}$ The right is qualified where such access could jeopardise the security of the centres, of the facilities or of the asylum seekers.

There is also a reciprocal obligation on Member States to ensure that 'housed' persons have the possibility of communicating with their legal advisers. ${ }^{1963}$ Those 'housed' would appear to include border applicants, ${ }^{1964}$ but it is ambiguous in relation to those otherwise in detention.

There are two significant concerns in relation to these provisions. Firstly, they do not expressly relate to those in detention. It is arguable that the provisions may be construed to include detention facilities. Secondly, those provisions may be subject to derogation "for a short as possible" period for border applicants or those in detention. ${ }^{1965}$

Accordingly, the Directive does not provide for an express reciprocal right for a detained asylum seeker to have access to a legal advisor or counsellor.

Detention where the Right to Remain Exists - Legal Assistance - Current Legislation Although a right to legal assistance is not enunciated per se under the Reception Conditions Directive, Member States are required to provide procedures for access to legal assistance in their national law for negative decisions taken under the Directive or those decisions involving residence and freedom of movement under Article 7 (that is, inclusive of measures which may amount to detention). ${ }^{1966}$

A right to legal assistance may be inferred, but it is far from clear the extent of the assistance and the limits of Member State discretion in its implementation.

In any event, it is arguable that Article 6 ECHR and Article 47 of the EU Charter, together with the general principles of EU law, should prevail to ensure access to a lawyer and, where necessary, legal aid. More ideally, those international standards should be clearly and wholeheartedly embraced in the legislation.

Detention where the Right to Remain Exists - Access to, and communication with, lawyers - The Proposed Legislation

\footnotetext{
1962 Article 14(7) of the Reception Conditions Directive

1963 Article 14(2)(b) of the Reception Conditions Directive

1964 Article 14(1)(a) of the Reception Conditions Directive

1965 Article 14(8), fourth subparagraph, of the Reception Conditions Directive

1966 Article 21(2) of the Reception Conditions Directive
} 
The Commission's 2011 Proposed Reception Conditions Directive represents an improvement in relation to lawyers and legal assistance in the context of detention, but shortcomings remain.

In relation to the right of legal advisers and counsellors to communicate with and physically access their clients, this is expressly provided for in a detention context with limitations only where "by virtue of national law, they are objectively necessary for the security, public order or administrative management of the detention facility, provided that access is not thereby severely limited or rendered impossible". ${ }^{1967}$ For those border applicants or those in transit zones, ${ }^{1968}$ the Proposal recognises that applicants have the right to communicate with legal advisors or counsellors and that legal advisors have a right to be granted access to their clients. ${ }^{1969}$ Accordingly, the mutual right to communication and access is contemplated in a border/transit zone situation. Importantly, Member States are no longer able to derogate from the modalities of material reception conditions for those confined to the border or in detention, ${ }^{1970}$ which would tend to suggest that the foregoing provisions regarding access and communication do apply to those in detention but an ambiguity remains. As with the current Directive, such a mutual right is not expressly provided for those otherwise detained.

The Council's amendments also leave unchanged the Commission's 2011 Proposal as regards communication and physical access rights of lawyers and detained persons, ${ }^{1971}$ as well as those 'housed' at the border or in transit zones. ${ }^{1972}$

Detention where the Right to Remain Exists - Legal Assistance - The Proposed Legislation

Under the Commission's 2011 Proposed Reception Conditions Directive, legal representation is specifically contemplated in light of detention. A clearer expression of the right to legal assistance is incorporated - where a detention order is to be reviewed or appealed, Member States are obliged to provide free legal assistance and representation if the asylum seeker cannot afford to do so and "in so far as it is necessary to ensure their effective access to justice". ${ }^{1973}$ Member States retain the discretion to limit the choice of advisers and counsellors to those "specifically designated by national law to assist and

\footnotetext{
1967 Article 10(4) of the Commission's 2011 Proposed Reception Conditions Directive 1968 Article 18(1)(a) of the Commission's 2011 Proposed Reception Conditions Directive 1969 Article 18(2)(b) and (c) of the Commission's 2011 Proposed Reception Conditions Directive

1970 Article 18(8) of the Commission's 2011 Proposed Reception Conditions Directive 1971 Article 10(4) of the Council's Amended Proposed Reception Conditions Directive 1972 Article 18(1)(a), 18(2)(b) and (c), 18(8) of the Council's Amended Proposed Reception Conditions Directive

1973 Article 9(5), subparagraph 1, of the Commission's 2011 Proposed Reception Conditions Directive
} 
represent asylum seekers". ${ }^{1974}$ The extent of the legal representation is to include, as a minimum, "the preparation of the required procedural documents and representation before the judicial authorities". ${ }^{1975}$ Member States are obliged to embody the procedures for access to legal assistance and representation in their national law. ${ }^{1976}$

The Council's Amended Proposed Reception Conditions Directive signifies a retrograde step in the protection of the rights of those detained. The Commission's proposed detention-specific guarantees for access to legal assistance, representation and legal aid have been removed and the general scheme in relation to legal assistance is to prevail. ${ }^{1977}$ The most disturbing aspect of the general scheme is that Member States retain the discretion not to grant free legal assistance and representation "if the applicant's appeal is considered by a court or a tribunal to have no tangible prospects of success [emphasis added]". ${ }^{1978}$ Member States are obliged to ensure that, in those circumstances, legal assistance and representation "is not arbitrarily restricted and that the applicant's effective access to justice is not hindered". ${ }^{1979}$

What is of concern is that there is no requirement as to when the timing of that assessment is to occur - that is, a court or tribunal may make such an assessment on a prima facie basis divorced from the substantive hearing, effectively resulting in summary dismissal without the protection of legal representation. Further, as ECHR jurisprudence requires judicial authorisation or confirmation of detention, it is entirely inappropriate that such appearances and judicial challenges to a detention decision be allowed to proceed with an impecunious litigant unrepresented on account of the prospects of success particularly where the individual circumstances of the person might require investigation and enunciation. It is submitted that, where such a fundamental right, such as liberty, is at stake, the restriction or denial of access to free legal assistance based on the prospects of success of the applicant's appeal is an entirely inappropriate measure to determine the grant of such assistance. This is due to the fact that an asylum seeker, in detention, may have very serious language, evidential, procedural, financial and interpretative obstacles to overcome that may, prima facie and without legal assistance, unfairly warrant

1974 Article 9(5), subparagraph 3, of the Commission's 2011 Proposed Reception Conditions Directive

1975 Article 9(5), subparagraph 2, of the Commission's 2011 Proposed Reception Conditions Directive

1976 Article 9(5), subparagraph 4, of the Commission's 2011 Proposed Reception Conditions Directive

1977 Article 9(5) of the Council's Amended Proposed Reception Conditions Directive

1978 Article 26(2), subparagraph 2, of the Council's Amended Proposed Reception Conditions Directive. This is consistent with the Member State's discretion to restrict free legal assistance to those whose appeals or reviews "are likely to succeed": see Article 15(3)(d) of the current Procedures Directive (discussed below)

1979 Article 26(2), subparagraph 2, of the Council's Amended Proposed Reception Conditions Directive 
the conclusion that such an appeal has 'no tangible prospects of success'. Such a provision unjustly prejudices impecunious detained asylum seekers. Indeed, it is precisely those circumstances, particularly where liberty is at stake and where a speedy remedy is required, which warrant the provision of free legal assistance and representation. Further, the tangibility of prospects of success do not form the basis of the right to access the courts under ECtHR jurisprudence in relation to Article 6, or the right to an effective remedy under Article 47 of the EU Charter - such a provision represents an unjustified restriction on those rights. That provision is also problematic in light of the "particularly underprivileged and vulnerable" status ascribed to those seeking asylum by the ECtHR in MSS. ${ }^{1980}$

The Council's amendments also introduce other provisions of concern, some of which appear to introduce comparable provisions contained in the current Procedures Directive. ${ }^{1981}$

Firstly, Member States are given the discretion to provide legal assistance and representation by NGOs and "government officials, or specialised services of the State". ${ }^{1982}$ It is of concern that the independence of legal advice may be compromised where government officials or State services may be utilised, potentially creating a conflict of interest and, in circumstances where an asylum seeker's experience of persecution at the hands of State officials in their country of origin may result in less than full, frank and fearless co-operation with such representatives, the asylum seeker's appeal may be unfairly compromised as a result (particularly if the 'tangible prospects of success' provision were allowed to stand as it relates to a detention decision).

Secondly, the Council's amendments also give Member States the discretion to impose monetary and time limits for providing free legal assistance and representation (again with the proviso that "such limits do not arbitrarily restrict access to the provision of legal and procedural information and legal assistance and representation"). ${ }^{1983}$

Thirdly, Member States are also given the discretion not to give treatment to asylum seekers that is more favourable than that accorded to their own nationals as regards fees and other costs relating to legal assistance. ${ }^{1984}$ In that regard, it is submitted that the "extreme vulnerability" of asylum seekers,

1980 MSS v Belgium \& Greece, No. 30696/09, Judgment, 21 January 2011, para 251

${ }^{1981}$ See Article 15 of the Procedures Directive - particularly subparagraphs (3)(d), (5)(a), (5)(b) and (6)

1982 Article 26(2), subparagraph 4, of the Council's Amended Proposed Reception Conditions Directive

1983 Article 26(2), subparagraph 6(a), of the Council's Amended Proposed Reception Conditions Directive

1984 Article 26(2), subparagraph 6(b), of the Council's Amended Proposed Reception Conditions Directive 
outside their country of origin, facing procedural, linguistic, evidential and financial obstacles may, at times, warrant more intensive legal and ancillary assistance than that normally provided to nationals (for example, by way of interpreters and document translation which are costs which may not arise nearly as regularly for litigating nationals of the Member State concerned).

Fourthly, the Council's amendments allow Member States to demand reimbursement (wholly or partially) for legal expenses where "the applicant's financial situation has improved considerably or if the decision to grant such benefits was taken on the basis of false information supplied by the applicant." 1985 The time period is unspecified in relation to when an applicant's circumstances may have improved such that reimbursement may be demanded, but it is arguable that that time period would run up until the asylum seeker no longer falls within the scope of the Directive (that is, until the right to remain is lost, international protection has been granted, or the applicant's claim has been rejected). Further, "improved considerably" is an extremely vague term which, in light of the impecuniosity of some asylum seekers, runs the risk of being based on the subjective relativity of the individual concerned. Lastly, there is no requirement that the information supplied be intentionally false as a basis for limiting legal assistance.

In other respects the Council's amendments affirm the right to access and free representation where asylum seekers "lack sufficient resources" ${ }^{1986}$ and in so far as is necessary to ensure their effective access to justice", ${ }^{1987}$ as well as the scope of legal assistance and identity of legal assistance ${ }^{1988}$ and representation ${ }^{1989}$ contemplated in the Commission's 2011 Proposed Reception Conditions Directive.

\subsection{Detention where the Right to Remain is Lost}

Detention where the Right to Remain is Lost - Access to, and communication with, lawyers - Current Legislation

The current Procedures Directive does not make express provision for detention, nor does it provide an express provision for access to legal assistance and representation in relation to detention. The general provisions in relation to access to legal assistance and representation apply to matters "relating to

\footnotetext{
1985 Article 26(2), subparagraph 7, of the Council's Amended Proposed Reception Conditions Directive

1986 The Council's amendments replaced the Commission's formulation "cannot afford the costs involved" with "lack sufficient resources" - suggesting that the basis for determination has shifted from potentially being income based, to being asset or means based

1987 Article 26(2), subparagraph 1, of the Council's Amended Proposed Reception Conditions Directive

1988 Article 26(2), subparagraph 3, of the Council's Amended Proposed Reception Conditions Directive

1989 Article 26(2), subparagraph 5, of the Council's Amended Proposed Reception Conditions Directive
} 
their asylum applications". ${ }^{1990}$ The determination procedure and a decision to detain are arguably more tightly fused in the situation of border applicants.

Legal advisers and counsellors are given a right to access asylum seekers, even in closed areas, detention and transit areas, and which may only be restricted where "objectively necessary for the security, public order or administrative management of the area, or in order to ensure an efficient examination of the application, provided that access by the legal adviser or other counsellor is not thereby severely limited or rendered impossible". ${ }^{1991}$ The "efficient examination of the application" is a dangerously broad term capable of marooning asylum applicants from legal assistance, particularly at the border. Indeed, as discussed in Chapter 5 of this book, border applicants are under a considerable disadvantage as the right to legal assistance and representation falls under Chapter II of the Directive and thus may be subject to derogation. ${ }^{1992}$ It is arguable that, in the absence of specific provisions relating to access to legal assistance and representation in the context of a detention order, the principles and jurisprudence in relation to Article $6 \mathrm{ECHR}$ and Article 47 of the EU Charter should apply.

Detention where the Right to Remain is Lost - Legal Assistance - Current Legislation It is highly questionable whether the right to legal assistance and representation apply to the challenge of a detention decision as the character of Articles 15 and 16 of the Directive tend to suggest that only the asylum determination procedure is contemplated.

Assuming for the moment that the right to legal assistance under the Procedures Directive does contemplate the challenge of a detention decision, then the extent of the assistance is somewhat worrisome. Firstly, the engagement of a legal adviser or counsellor upon the initial application is at the asylum seeker's own cost - it is only after reaching a negative decision that free legal assistance must be granted "upon request". ${ }^{1993}$ Secondly, free legal assistance may be limited to: appeals under Chapter V of the Directive and no further onward appeals; "those who lack sufficient resources"; those legal advisors or counsellors "specifically designated by national law to assist and/or represent applicants for asylum"; and/or in those circumstances where the "appeal or review is likely to succeed (but representation or assistance is not to be arbitrarily restricted)". ${ }^{1994}$ As will be discussed in relation to the Council's

\footnotetext{
1990 Article 15(1) of the Procedures Directive

1991 Article 16(2) of the Procedures Directive

1992 See Articles 24(1)(b) and Article 35 of the Procedures Directive. Article 35(3)(e) expressly provides for a border applicant to consult a legal adviser or counsellor where Member States have procedures derogating from Chapter II guarantees and rely on regulations in force as at 1 December 2005. However, the effect of Article 24(1)(b) gives Member States the discretion to nullify that guarantee and others under Article 35

1993 Article 15(1) and (2) of the Procedures Directive

1994 Article 15(3)(a)-(d) of the Procedures Directive
} 
Amended Proposed Reception Conditions Directive, limiting legal assistance to those matters which are "likely to succeed" represents a grave shortcoming for those asylum seekers who may be under significant linguistic, evidential, health and pecuniary disadvantages and whose prima facie likeliness to succeed may be affected by those factors. The formulation under the Procedures Directive is particularly broad - the identity of the determining authority for the grant of legal assistance is not known nor is the timing of the assessment specified. Accordingly, it may be that an administrative decision is made to refuse legal aid based prima facie on the papers (and divorced from the substantive adjudication) without the person detained having had the benefit of legal advice. Further, if the appeal of a detention decision is likely to succeed, then surely the Member State is better to end the detention or come to an alternate arrangement than opposing the application? Thirdly, as discussed earlier, provision also exists to limit legal assistance based on monetary or time limits (but not to be arbitrarily restricted); ${ }^{1995}$ no more favourable treatment than that of nationals as regards fees and other costs; ${ }^{1996}$ and the discretion to compel reimbursement "when the applicant's financial situation has improved considerably" or if the decision to grant aid was based on "false information supplied by the applicant" (noting that there is no requirement for the information supplied to be intentionally false). ${ }^{1997}$

Detention where the Right to Remain is Lost - Access to, and communication with, lawyers \& Legal Assistance - The Proposed Legislation

Under the Commission's 2011 Proposed Procedures Directive, the detention provisions are referrable to those under the Reception Conditions Directive as regards grounds, conditions and guarantees, which includes access to legal assistance and representation (as outlined above). ${ }^{1998}$ Accordingly, in the future, the Reception Conditions Directive would appear to cover the field as regards detention guarantees. However, in the event that the Council's amendments to the Commission's 2011 Proposed Procedures Directive are carried through, then the same ramifications for detained asylum seekers apply as will be discussed below. Importantly, the 2011 Proposed Procedures Directive provides a right of a legal advisor or other counsellor to have access to an applicant in closed areas such as detention facilities and transit zones for the purposes of consulting with the applicant with express reference to Article 10(4) (access to those in detention) and 18(2)(b) and (c) (access to those in housing) of the Reception Conditions Directive. ${ }^{1999}$

\section{Detention where the Right to Remain is Lost - The Returns Directive}

Where the person falls under the scope of the Returns Directive, thirdcountry nationals are to have the "possibility to obtain legal advice,

\footnotetext{
1995 Article 15(5)(a) of the Procedures Directive

1996 Article 15(5)(b) of the Procedures Directive

1997 Article 15(6) of the Procedures Directive

1998 Article 26 of the Commission's 2011 Proposed Procedures Directive

1999 Article 23(2) of the Commission's 2011 Proposed Procedures Directive
} 
representation and, where necessary, linguistic assistance." 2000 The Directive also provides for "necessary legal assistance and/or representation" on request and free of charge. However, it would appear that those provisions only relate to the procedural safeguards on the review or appeal of decisions relating to the return decision as opposed to any detention decision. ${ }^{2001}$ It is unlikely that those provisions contemplate such a right for those detained pending their return as the provisions on detention (discussed below) represent a lex specialis on the matter. ${ }^{2002}$ In any event, derogations on legal assistance may be made in accordance with Article 15(3) to (6) of the Reception Conditions Directive (discussed above). ${ }^{2003}$

In relation to detention pending return, Article 16(2) of the Returns Directive provides:

"Third country nationals in detention shall be allowed - on request - to establish in due time contact with legal representatives, family members and competent consular authorities"

Firstly, the right to contact a lawyer is at the request of the asylum seeker. The provision may present significant difficulties for asylum seekers (particularly unaccompanied minors or vulnerable persons) who are either unaware or unable to articulate a request to contact a lawyer and a reciprocal right for lawyers and family members to contact a detained person should be incorporated. It would be hoped that the information that is to be systematically provided to detained persons under Article 15(6) of the Returns Directive (which compels Member States to provide detained persons with "information which explains the rules applied in the facility and sets out their rights and obligations") is broadly construed to include informing them about their right to contact a lawyer (see discussion in 6.1 of this Chapter). Secondly, "in due time" is a vague term which does not correspond to the immediacy of the right to contact a lawyer contemplated in Guideline 6(2) of the Committee of Ministers Twenty Guidelines on Forced Return. The Directive is otherwise silent on the provision of legal aid for those detained under the Directive.

\subsection{Detention in a Member State Other Than That of First Entry or Asylum}

In the absence of specific provisions relating to the detention of asylum seekers under the current Dublin II Regulation, it is submitted that the principles and jurisprudence in relation to Article $6 \mathrm{ECHR}$ and Article 47 of the EU Charter

\footnotetext{
2000 Article 13(3) of the Returns Directive

2001 Article 13(4) of the Returns Directive, read together with the remainder of that Article and Article 12 of the Returns Directive

2002 Schieffer, M, Chapter $V$ - Termination of Residence, in Hailbronner, K, (ed), EU Immigration and Asylum Law - Commentary on EU Regulations and Directives, 2010, Verlag C. H. Beck oHG, München, Pp.1489-1552 at P.1538

${ }_{2003}$ Article 13(4) of the Returns Directive
} 
should prevail to ensure access to legal representation and legal aid where necessary.

Detention in a Member State Other Than That of First Entry or Asylum - The Proposed Legislation

Access to, and communication with, lawyers

The Commission's Proposed Dublin Regulation does not make express provision in relation to access to, and communication with, lawyers in a detention context. The Proposal refers to Articles 10 and 11 of the Reception Conditions Directive as regards guarantees for those detained. ${ }^{2004}$ As discussed above, Article 10(4) of the Proposed Reception Conditions Directive provides that legal advisers and counsellors have the possibility to communicate with applicants and have access to detention facilities. Accordingly, there is no reciprocal right of access to, and communication with, lawyers.

\section{Legal Assistance}

The Commission's Proposed Dublin Regulation obliges Member States to provide access to legal assistance and/or representation specifically in relation to detention. ${ }^{2005}$ That assistance and representation is to be "free of charge where the person concerned cannot afford the costs involved". ${ }^{2006}$ Member States are also obliged to provide procedures for access to legal assistance and/or representation in their national laws. ${ }^{2007}$

6.2.4 Access to, and communication with, lawyers and the provision of legal assistance Australia

6.2.4.1 Australia - Access to, and communication with, lawyers

In the Minister's speech on 29 July 2008 he stated:

"Henceforward, asylum seekers will receive publicly funded advice and assistance, access to independent review of unfavourable decisions and external scrutiny by the Immigration Ombudsman." 2008

Section 256 of the Migration Act provides:

"Where a person in in immigration detention under this Act, the person responsible for his or her immigration detention shall, at the request of the person in immigration detention, give to him or her application forms for a visa or afford to him or her all reasonable facilities for making a statutory declaration for the

2004 Article 27(12) of the Commission's Proposed Dublin Regulation

2005 Article 27(9), subparagraph 1, of the Commission's Proposed Dublin Regulation

2006 Article 27(9), subparagraph 1, of the Commission's Proposed Dublin Regulation

2007 Article 27(9), subparagraph 2, of the Commission's Proposed Dublin Regulation

2008 Evans, Senator Chris, Australian Minister for Immigration and Citizenship, speech to the Australian National University in Canberra, 29 July 2008, New Directions in Detention Restoring Integrity to Australia's Immigration System http://www.nswbar.asn.au/circulars/ july/evans2.pdf, (last accessed 7 November 2011) at P.3 
purposes of this Act or for obtaining legal advice or taking legal proceedings in relation to his or her detention."

However, section 256 only compels the provision of "all reasonable facilities" at the request of the detained person. That is, the asylum seeker must ask for legal assistance.

Further, as discussed in Part 1 of this chapter, and subject to section 256, the Minister or an officer is not obliged to allow access to advice (including legal advice) to those detained persons who are not immigration cleared or who are Offshore Entry Persons in connection with applications for visas ${ }^{2009}$ (that is, possibly distinct from their detention - noting that section 256 refers to legal advice and proceedings "in relation to their detention" but also noting that obtaining a visa is one method for being released from detention ${ }^{2010}$ ).

The upshot of these provisions have, in the past, led to the incommunicado detention of asylum seekers as most are unaware of their right to seek legal assistance. ${ }^{2011}$ Further, the fact that an officer is under no obligation to inform a detained person of their rights under section 256 was upheld by the Full Federal Court. ${ }^{2012}$ It also presents significant problems for unaccompanied minors who, it has been noted in the past, not only have to articulate their own claim for asylum, but also a request to access a lawyer. ${ }^{2013}$

It will be recalled from Chapter 3 that, through the Tampa affair, proceedings were brought on behalf of the rescued asylum seekers by a concerned Melbourne commercial solicitor, Eric Vardalis. Throughout the course of those proceedings, it was not possible for Vardarlis to get instructions from any of the persons being held on board the Tampa through various efforts that the Government took to prevent access by lawyers to the asylum seekers and from

2009 Section 193 of the Migration Act 1958 (Cth). See also HREOC (now AHRC), Those who've come across the seas - Detention of unauthorised arrivals, 1998, Sydney, P.196 on the Commission's interpretation of Sections 256 and 193(1) and (2).

2010 Section 196 of the Migration Act 1958 (Cth)

2011 See Poynder, N, The Incommunicado Detention of Boat People: A Recent Development in Australia's Refugee Policy [1997] Australian Journal of Human Rights 2; HREOC (now AHRC), Those who've come across the seas - Detention of unauthorised arrivals, 1998, Sydney, Pp.196-208; Crock, M, Seeking Asylum Alone: a study of Australian law, policy and practice regarding unaccompanied and separated children, 2006, Themis Press, Leichhardt.

${ }^{2012} \mathrm{Wu}$ Yu Fang and 117 Others $v$ the Minister for Immigration and Ethnic Affairs and Commonwealth of Australia [1996] FCA 1272 per Nicholson J with whom Jenkinson J agreed 2013 See Crock, M, Seeking Asylum Alone: a study of Australian law, policy and practice regarding unaccompanied and separated children, 2006, Themis Press, Leichhardt, particularly Chapter 8, Pp.122-123, and Chapter 15.7 where unaccompanied minors were found to be given access to lawyers after their initial screening-in interview with DIAC. Indeed, Taylor considers in light of Bennett v Minister of Community Welfare (1992) 176 CLR 408 that the Minister may be under an obligation to provide independent legal advice for an unaccompanied minor "where the Minister is a decision-maker or respondent in Tribunal and court proceedings" - Taylor, J, Guardianship of Child Asylum-Seekers (2006) FedLR 185, Pp.190-191 
the asylum seekers making contact with anyone not on the vessel. ${ }^{2014}$ The inability to get instructions from an individual on board had consequences in relation to some of the actions brought by Vardarlis - namely that he did not have sufficient standing to pursue some of the actions sought (but he did have standing in relation to the habeas corpus action which can be brought by any individual). ${ }^{2015}$ In Victorian Council for Civil Liberties Incorporated $v$ Minister for Immigration and Multicultural Affairs, North J acknowledged that there was an implied constitutional freedom of communication, which was not disturbed by the Migration Act, but that that 'right' applied to citizens and not aliens. ${ }^{2016}$ Further, North J acknowledged that a lawyer may give immigration advice and assistance as part of that implied freedom of communication, but that 'right' was not such as to require the Government to facilitate communication. ${ }^{2017}$ In relation to measures taken by the Government which prevented Vardarlis communicating with the rescued asylum seekers, such as closing Flying Fish Cove, North J's preliminary view was that Vardarlis had standing to sue,${ }^{2018}$ but did not come to a concluded view on this part of the matter. ${ }^{2019}$ However, on appeal, Black CJ (who was in the minority), noted as an agreed fact that the rescued persons were unable to communicate with anyone off the Tampa and that persons off the Tampa were unable to communicate with them. ${ }^{2020}$ However, his Honour agreed with the appellants that North J probably fell into error when "he found that the Commonwealth had prevented, rather than merely failed to facilitate, communication with the rescued people". ${ }^{2021}$

For those Offshore Entry Persons who are detained for the purpose of being sent to another country for offshore processing, they are, by perverse irony, denied the right to the provision of "all reasonable facilities" for "obtaining legal advice or taking legal proceedings" as they are deemed not to be in "immigration detention" 2022 (notwithstanding that they may be actually detained pursuant to the incidental powers in section 198A(2) - see Chapters 4 and 5 herein). The AHRC has noted that for those detained pending their

\footnotetext{
2014 In this regard, see Marr, D, and Wilkinson, M, Dark Victory, 2ed, 2004, Allen \& Unwin , Crows Nest, Pp146-152, 156-159, 163, 166-167, 194

2015 See Victorian Council for Civil Liberties Incorporated $v$ Minister for Immigration and Multicultural Affairs [2001] FCA 1297, particularly at paras 123-137

2016 Victorian Council for Civil Liberties Incorporated v Minister for Immigration and Multicultural Affairs [2001] FCA 1297, paras 162-164 citing Cunliffe v Commonwealth of Australia (1994) 182 CLR 272 at 335-336 per Brennan J

2017 Victorian Council for Civil Liberties Incorporated v Minister for Immigration and Multicultural Affairs [2001] FCA 1297, paras 165-166

2018 Victorian Council for Civil Liberties Incorporated v Minister for Immigration and Multicultural Affairs [2001] FCA 1297, para 167

2019 Victorian Council for Civil Liberties Incorporated v Minister for Immigration and Multicultural Affairs [2001] FCA 1297, para 168

2020 Ruddock v Vardarlis [2001] FCA 1329 at para 80 per Black CJ

${ }^{2021}$ Ruddock v Vardarlis [2001] FCA 1329 at para 86 per Black CJ

2022 Section 198A(4) of the Migration Act 1958 (Cth)
} 
transfer to Malaysia under the 'Malaysia Swap Deal', access to a telephone was only made if there was a "request to speak to a specific legal representative or with Legal Aid". ${ }^{2023}$

\subsubsection{Australia - Legal Assistance}

The Immigration Advice and Application Assistance Scheme ("IAAAS") provides independent legal advice to Protection Visa applicants in immigration detention, free of charge. The legal service providers are contracted by DIAC to give that advice and assistance. An IAAAS provider is retained up until the application for a Protection Visa has been rejected by a review tribunal (either the IMR for Offshore Entry People or the RRT for those in the Migration Zone). Judicial review and Ministerial intervention are not included within the scope of the retainer for an IAAAS provider. ${ }^{2024}$

If judicial review of a detention decision (as opposed to a Protection Visa application decision) is not within the scope of the IAAAS retainer (but bearing in mind the very narrow grounds for judicial review of a detention decision, discussed below), then a detained asylum seeker must pursue other avenues. ${ }^{2025}$ The McMillan Report into migration litigation identified five avenues for seeking legal assistance which would be open to asylum seekers ${ }^{2026}$ (and which would appear to be appropriate as regards judicial review of a detention decision): firstly, under the Commonwealth Public Interest and Test Cases Scheme. This scheme is for proceedings involving "a substantial point of unresolved Commonwealth law" or "the outcome of the proceeding is likely to affect a large number of disadvantaged people". ${ }^{2027}$ The considerations that are made in relation to a grant include the financial and material circumstances of the person; the prospects of success; the proceedings' costs; the benefits to the person and to the public (or a sector of it); whether funding is available from a legal aid commission; and the scheme's available funds. ${ }^{2028}$

2023 AHRC, Inquiry into Australia's agreement with Malaysia in relation to asylum seekers Australian Human Rights Commission Submission to the Senate Standing Committees on Legal and Constitutional Affairs, 14 September 2011, Sydney, http://www.hreoc.gov.au/legal/ submissions/2011/20110914_asylum_seekers.pdf (last accessed 8 November 2011), P.6 2024 Australian Government, Department of Immigration and Citizenship, Fact Sheet $63-$ Immigration Advice and Application Assistance Scheme, http://www.immi.gov.au/media/factsheets/63advice.htm (last accessed 8 November 2011)

2025 As to such avenues as existed in 2000 (but which are still highly relevant to this discussion), see Taylor, S, Should Unauthorised Arrivals in Australia Have Free Access to Advice and Assistance [2000] Australian Journal of Human Rights 3

2026 McMillan AO, Professor John, Regulating Migration Litigation after Plaintiff M61 - Report to the Minister for Immigration and Citizenship, 2011, http://www.immi.gov.au/media/publications/pdf/2011/mcmillan-review-regulatingmigration-litigation.pdf (last accessed 14 June 2012), Pp. 48-50

2027 Australian Government, Attorney-General's Department, Schemes administered by the Attorney-General's Department, http://www.ag.gov.au/Legalaid/Pages/Schemesadministered bytheAttorneyGeneralsDepartment.aspx (last accessed 14 June 2012)

2028 Australian Government, Attorney-General's Department, The Commonwealth Public Interest and Test Cases Scheme Guidelines and Conditions, October 2011, 
A detained asylum seeker may also seek assistance, secondly, from a community legal centre, some of which offer specialised migration law services; ${ }^{2029}$ thirdly, from the Public Interest Law Clearing House network (a not-for-profit series of organisations which provide pro-bono legal assistance relying on the professional beneficence of members); ${ }^{2030}$ and fourthly, from schemes operated by the legal profession organisations to provide assistance on a pro-bono basis (for example, the New South Wales Law Society ${ }^{2031}$ ) or on a pro-bono or reduced rate basis (for example, the New South Wales Bar Association $^{2032}$ ) (both of which may involve a means and merit test). The fifth avenue for assistance is through Commonwealth Legal Aid Commission funding which is a scheme administered by agreement with the States and Territories through their respective legal aid commissions. ${ }^{2033}$ The McMillan Report noted that migration matters were included in the scheme provided that assistance could not be provided by DIAC and that considerations of special circumstances of the applicant included any "language or literacy problem; or an intellectual, psychiatric or physical disability; or the person being in a remote locality where it is difficult to obtain legal assistance; or where the person would otherwise be at risk of social exclusion."2034 Further, the Report noted that further more specific merit and means tests may be imposed by the State and Territory legal aid commissions. ${ }^{2035}$

http://www.ag.gov.au/Legalaid/Documents/Commonwealth\%20Public\%20Interest $\% 20$ an d\%20Test\%20Scheme\%20Guidelines\%20revised\%20October\%202011.pdf (last accessed 14 June 2012) Pp.8-12

2029 National Association of Community Legal Centres, http://www.naclc.org.au/cb_pages/clcs.php (last accessed 14 June 2012)

2030 See, for example, PILCH NSW, http://www.pilchnsw.org.au/what-we-do/ (last accessed 14 June 2012)

2031 Law Society of New South Wales, Pro Bono Scheme, http://www.lawsociety.com.au/community/findingalawyer/probono/ (last accessed 14 June 2012)

2032 New South Wales Bar Association, Legal Assistance Referral Scheme, http://www.nswbar.asn.au/docs/legal_assist/LARS_130910.pdf (last accessed 14 June 2012)

2033 Australian Government, Attorney-General's Department, Legal Aid Program, http://www.ag.gov.au/Legalaid/Pages/LegalAidProgram.aspx (last accessed 14 June 2012) ${ }^{2034}$ McMillan AO, Professor John, Regulating Migration Litigation after Plaintiff M61 - Report to the Minister for Immigration and Citizenship, 2011, http://www.immi.gov.au/media/publications/pdf/2011/mcmillan-review-regulatingmigration-litigation.pdf (last accessed 14 June 2012), P.50, referring to the National Partnership Agreement on Legal Assistance Services http://www.federalfinancialrelations.gov.au/content/national_partnership_agreements/Oth er/legal_assistance_services/national_partnership.pdf (last accessed 14 June 2012)

2035 McMillan AO, Professor John, Regulating Migration Litigation after Plaintiff M61 - Report to the Minister for Immigration and Citizenship, 2011, http://www.immi.gov.au/media/publications/pdf/2011/mcmillan-review-regulatingmigration-litigation.pdf (last accessed 14 June 2012), P.50. Indeed, this may comprise of a jurisdiction, means, merits and availability of funds test: see Legal Aid New South Wales, 
Two further points should be noted about the situation of lawyers in Australia. Firstly, not all lawyers are at complete liberty to assist asylum seekers. It is an offence punishable by an AUD6,600 fine for a person (including a lawyer) who is not a registered migration agent and is not exempted ${ }^{2036}$ to give "immigration assistance" (which, inter alia, includes preparing or helping to prepare a visa application). ${ }^{2037}$ A lawyer is exempted from the requirement of being a registered migration agent if he or she is giving "immigration legal assistance" (which essentially relates to court work). ${ }^{2038}$ However, a person does not need to be a lawyer in order to become a registered migration agent. Accordingly, in the normal course where a lawyer not registered as a migration agent represents a person challenging the lawfulness of a detention decision, this should not necessarily present a problem, provided that the lawyer does not do anything that could be characterised as "immigration assistance". However, this delineation blurs when one considers that one avenue for release from detention (distinct from challenging the detention decision itself) is through applying for a Bridging Visa (if eligible - see Chapters 5 and 8) and thus potentially falling within the scope of "immigration assistance". ${ }^{2039}$ Further, the definition of "immigration legal assistance" does not include work done in preparation of applications for ministerial intervention under section $417,{ }^{2040}$ or for the minister to exercise his personal and non-compellable discretion under section 195A, or in relation to a residence determination (either to be made by the minister or in relation to its revocation). ${ }^{2041}$

Secondly, the Migration Act prohibits a person (not just a lawyer) from encouraging a person to continue or commence "migration litigation" in a court if it has "no reasonable prospects of success" and if the person either does not give "proper consideration" 2042 to whether the migration litigation has reasonable prospects of success or if the migration litigation has been commenced for a collateral purpose. ${ }^{2043}$ Bizarrely, the migration litigation does

http://lacextra.legalaid.nsw.gov.au/PublicationsResourcesService/PublicationImprints/Files /384.pdf (last accessed 14 June 2012)

2036 Section 280(2) - (6) of the Migration Act 1958 (Cth)

${ }^{2037}$ Sections 280(1) and 276 of the Migration Act 1958 (Cth) and section 4AA of the Crimes Act 1914 (Cth)

2038 Section 280(3) and 277 of the Migration Act 1958 (Cth)

2039 The distinction between "immigration assistance" and "immigration legal assistance" in the context of a lawyer's work was noted in Law Society of New South Wales v Jayawardena [2008] NSWADT 187 at para 142 citing Portale v Law Society of NSW (No.2) (LSD) [2003] NSWADTAP 56, para 153

2040 Section 277(4) of the Migration Act 1958 (Cth)

2041 Section 277(5) of the Migration Act 1958 (Cth)

2042 See SZFDZ v Minister for Immigration and Multicultural Affairs [2006] FCA 1366 at paras 23-28; see paras 21-22 regarding "encourage"

${ }^{2043}$ Section 486E of the Migration Act 1958 (Cth) - "migration litigation" is defined in section 486E of the Migration Act 1958 (Cth) 
not need to be hopeless or bound to fail for it to have no reasonable prospects of success. ${ }^{2044}$ Lawyers are required to certify their belief in writing that the migration litigation has a reasonable prospect of success before filing a document commencing the litigation. ${ }^{2045}$ A court can make cost orders against a person who breaches that prohibition ${ }^{2046}$ and, in relation to lawyers, their fees may be ordered not to be paid by the litigant or, if already paid, repaid by the lawyer to the litigant. ${ }^{2047}$ An application can be made on the court's own motion or by one of the parties (presumably the Minister), ${ }^{2048}$ and the court is to consider whether an order should be made in relation to costs if at the time the substantive decision is made the Court finds the migration litigation had no reasonable prospects of success. ${ }^{2049}$ Stanton, in 2006, made a number of arguments as to the potential effect of these provisions: firstly, that such provisions are not necessary when such ethical duties already exist for lawyers and which rather infers that the real target of the provisions are migration agents; secondly, the provisions may have the effect of hindering the development of the common law through the reluctance to pursue novel points of law or interpretation; thirdly, it may have deleterious effects on probono advocacy which is invariably engaged at the last minute (which, at times, requires the urgent filing of an application within statutory time limits) and which may not have had the immediately preceding benefit of detailed research on the matter, not to mention the costs orders provisions acting as a disincentive to pro-bono lawyers (as well as paid lawyers ${ }^{2050}$ ) to act if they run the risk of being personally liable; fourthly, Stanton opines that the real aim of the legislation is not unmeritorious claims, but "creates a system where there will be more people denied representation, more unmeritorious litigation, and more applications summarily dismissed" - essentially the lack of representation resulting in a swift disposal of cases without concomitant protection. ${ }^{2051}$

\footnotetext{
${ }^{2044}$ Section 486E(2) of the Migration Act 1958 (Cth)

2045 Section 486I of the Migration Act 1958 (Cth): regarding the relationship of this section to sections 486E, 486F, 486G, 486H, and 486J see Uppu v Minister for Immigration and Anor [2012] FMCA 157. Note, however, that in New South Wales, for example, that is a requirement also imposed by section 347(2) of the Legal Profession Act 2004 (NSW). A legal practice is prohibited from acting in matters which have no reasonable prospects of success and costs orders may be made personally against the legal practice concerned - see sections 244-349 of the Legal Profession Act 2004 (NSW) but the formulation in section 345 is different from that contemplated under the Migration Act, namely because the New South Wales legislation refers to a belief on the "basis of provable facts and a reasonably arguable view of the law that the claim or the defence (as appropriate) has reasonable prospects of success" (section 345(1))

2046 Section 486F of the Migration Act 1958 (Cth)

2047 Section 486F(1)(c) of the Migration Act 1958 (Cth)

2048 Section $486 \mathrm{~F}(3)$ of the Migration Act 1958 (Cth)

${ }^{2049}$ Section 486F(2) of the Migration Act 1958 (Cth)

${ }^{2050}$ Corker, J, Funding Litigation: The Challenge [2007] UNSWLRS 2

2051 Stanton, M, Removing Voices from the Voiceless: The Migration Litigation Reform Act 2005 [2006] AltLawJ 8
} 
Indeed, unrepresented litigants face considerable difficulties in this regard. ${ }^{2052}$ The practical effect of these provisions could be the subject of further research.

\subsubsection{Access to, and communication with, lawyers and the provision of legal assistance - Conclusions}

In relation to access and communication between lawyers and detained asylum seekers, what should be ideally expressly contemplated in legislation is a reciprocal right of detained persons and lawyers to access and communicate with one another. Having the right-holder as only one of the parties increases the risk that a detained asylum seeker's rights will not be adequately protected - particularly if a narrow or formalistic view of a detained asylum seeker's rights is taken. The express provision of reciprocal rights builds upon the importance of being informed of the reasons for detention, of the procedures for challenging the detention order, and of the right to contact a lawyer and seek (if necessary) legal assistance - the absence of any one of those elements thereby increasing the risk of inadequately protecting the rights of those detained.

The European Union legislation and the Australian legislation do not provide an express reciprocal right of access and communication between lawyers and detained asylum seekers. The current Reception Conditions Directive is ambiguous in this regard. The Proposed Reception Conditions Directives represent a significant improvement for border applicants and those in transit zones. For those otherwise detained, the ability for lawyers to communicate with and access asylum seekers is expressly provided for under the Proposals but whether that right is in fact mutual is legislatively ambiguous. The Dublin II Regulation is silent on the matter, and the Proposed Dublin Regulation provides a position analogous to the Reception Conditions Directive. The Returns Directive also suffers from a lack of an express mutual right of access and communication - indeed, the Returns Directive shares an eerie similarity with the Australian situation in that the right to contact a lawyer is at the detained person's request. It is arguable that an implied freedom of communication exists for lawyers to give migration advice and assistance in Australia, but the extent with which that 'right' may be interfered requires additional research, and would benefit from express legislative protection in that regard. Those detained in Australia for the purpose of removal to another country are particularly vulnerable because, as they are not in "detention" for the purposes of the Act, their right to request a lawyer is not covered by the legislation. Detained asylum seekers (or third country nationals to be returned) in the European Union may, however, draw some comfort, from Article 6 ECHR and Article 47 of the EU Charter.

2052 SZLHM v Minister for Immigration and Citizenship [2008] FCA 754, paras 41-42, although the Court noted that representation is not always the key to reducing unmeritorious claims 
In relation to legal assistance, it is of considerable importance that a distinction is made between legal assistance for the review or challenge of the lawfulness of a detention decision and legal assistance for other purposes in the asylum or return context (such as the asylum application itself, withdrawing material reception conditions, or the issue of a return decision). It is arguable that thresholds applicable in determining eligibility for legal assistance in relation to an asylum application may possibly hinder access to an effective remedy in relation to challenging the lawfulness of a detention decision. Ideally, separate provision and criteria for legal assistance in relation to challenging the lawfulness of a detention decision should be made.

The Union legislation is ambiguous in relation to legal assistance for those in detention. The current Reception Conditions Directive does not provide an express right in that regard (even if it does compel Member States to provide access to procedures for legal assistance). Similarly, the current Procedures Directive would (on one view) appear to contemplate only legal assistance for the asylum determination procedure. The Commission's 2011 Proposed Reception Conditions Directive represents a significant upgrading of rights in that regard with a clear distinction between legal assistance for the review of a detention decision and for decisions relating to the withdrawal of material reception conditions. Sadly, that distinction was lost in the Council's amendments whereby legal assistance in relation to challenging a detention decision falls under the general scheme. The 2011 Proposed Procedures Directive is now referable to the Reception Conditions Directive as regards guarantees in relation to detention. The current Dublin II Regulation is silent on the matter, but the Proposed Dublin Regulation does expressly provide for legal assistance in a detention context. The Returns Directive is silent on the issue of legal assistance for the review of a detention decision and this would appear to be distinct from legal assistance given in relation to the return decision. The Australian situation would appear to be that an asylum seeker may seek assistance from legal professionals who either provide pro-bono or reduced rate legal services or who may apply under one of the merit and means-based legal aid schemes. The provision of legal assistance, as of right, to challenge the decision to detain (distinct from the cancellation of a visa, for example) would not appear to exist, but which may be otherwise sourced on the detained person's own initiative. This may also largely reflect the futility of challenging the decision to detain given the extremely narrow grounds for doing so (discussed below).

Both jurisdictions do, however, have provisions relating to the qualification of legal assistance (or the payment of legal fees) based on "tangible" or "reasonable" prospects of success. That qualification may well be justified regarding any unmeritorious appeals regarding the substantive application for asylum. However, as regards a review or challenge of a detention decision, it is submitted that such a fundamental right as freedom should not be impeded arbitrarily on account of the denial of legal assistance on that basis - without 
which, such challenges may prima facie seem without prospects. The Council's proposed Reception Conditions Directive, whose provisions on legal assistance now cover both detention decisions and those appeals for the withdrawal of material reception conditions, do not provide sufficient safeguards for ensuring that Member States do not (in the words of the Proposal) result in the person's legal assistance and representation being "arbitrarily restricted" or their "effective access to justice is [...] hindered". Reliance must therefore be placed on Article 6 ECHR and Article 47 of the EU Charter. The Australian provisions at least determine that the time that such a determination is to ultimately take place is at the substantive hearing (but also bearing in mind that legal aid schemes will consider this at the outset and legal professionals themselves are under a statutory professional obligation to certify their belief that the matter has reasonable prospects of success before initiating proceedings). The Union proposed provisions are silent as to the separation of the assessment of whether the matter has tangible prospects of success from a decision on the substantive application. Accordingly, great care should be exercised to avoid prima facie assessments being carried out without appropriate legal representation and assistance - particularly where, as a principle of Union law, the principle of proportionality may require the enunciation of matters particular to the applicant. Where the Australian provisions go further than the Union proposed provisions is the awarding of personal costs orders against representatives.

In limiting the provision of legal services to asylum seekers to particular legal professionals, great care should be exercised. If the aim is to ensure a high standard of specialised legal services in an increasingly complex area such as asylum law, then this should be carefully prescribed so as not to restrict the access to, and the provision of, legal services to emanate from such an extremely small part of the profession such as to practically undermine access to an effective remedy.

In the two jurisdictions there is an emerging convergence. Both the Commission and the Council's proposed Reception Conditions Directive appear to provide a broad discretion to Member States to limit access given to asylum seekers to particular legal professionals. In the Australian sphere, assistance with particular matters (largely in relation to visas) is unable to be given to asylum seekers without being registered as a migration agent. The Australian provisions should not necessarily affect a lawyer's ability to challenge a detention decision (but the line is sometimes not so clear) and the Union provisions in this regard are potentially broader as national law may require specific professionals to be engaged for both the asylum determination procedure, appeals concerning the withdrawal of any material reception conditions, and any review or challenge of the detention decision. One might ask, would a publically minded commercial lawyer like Mr Vardarlis, in a European Union context, be able to challenge the lawfulness of a detention decision? 


\title{
6.3 Review and Challenge of the Detention Decision
}

\subsubsection{Review and Challenge of the Detention Decision - International}

At the international level, a recognised safeguard against arbitrary detention is contained in Article 9(4) ICCPR, which provides for the judicial review of a detention decision:

"Anyone who is deprived of his liberty by arrest or detention shall be entitled to take proceedings before a court, in order that that court may decide without delay on the lawfulness of his detention and order his release if the detention is not lawful"

In $A v$ Australia, the Human Rights Committee held:

\begin{abstract}
"In the Committee's opinion, court review of the lawfulness of detention under article 9, paragraph 4 , which must include the possibility of ordering release, is not limited to mere compliance of the detention with domestic law. While domestic legal systems may institute differing methods for ensuring court review of administrative detention, what is decisive for the purposes of article 9, paragraph 4, is that such review is, in its effects, real and not merely formal. By stipulating that the court must have the power to order release 'if the detention is not lawful', article 9 , paragraph 4 , requires that the court be empowered to order release, if the detention is incompatible with the requirements in article 9, paragraph 1 , or in other provisions of the Covenant." 2053
\end{abstract}

Accordingly, one can discern firstly, that a person in detention must be able to seek the judicial review of the lawfulness of his/her detention (that is, by a court) $;{ }^{2054}$ secondly, that the court must be able to order that detained person be released; thirdly, that the review must not be simply a review of the compliance of the domestic law but of compliance with Article 9(1) ICCPR or other provisions of the Convention - that is, that the review goes beyond formal compliance with domestic law (including immigration status). In that

$2053 A v$ Australia UNHRC Communication No. 560/1993, UN Doc. CCPR/C/59/D/560/1993, 30 April 1997, para 9.5. See also C $v$ Australia, UNHRC, Communication 90/1999, UN Doc CCPR/C/76/D/900/1999, 28 October 2002 at para 7.4; Baban $v$ Australia, UNHRC Communication No. 1014/2001, UN Doc. CCPR/C/78/D/1014/2001, 6 August 2003, para 7.2. See also Shafiq $v$ Australia, UNHRC, Communication No. 1324/2004, UN Doc. CCPR/C/88/D/1324/2004, 13 November 2006, para 7.3; Shams et al v Australia, UNHRC, Communication Nos. 1255, 1256, 1259, 1260, 1268, 1270, 1288/2004, UN Doc CCPR/C/90/D/1255, 1256, 1259, 1260, 1266, 1268, $1270 \& 1288 / 2004,11$ September 2007, para 7.3

2054 In relation to the essentiality of a court for the purposes of review under Article 9(4) ICCPR, see Torres $v$ Finland, UNHRC, Communication No. 291/1988, UN Doc CCPR/C/38/D/291/1988, 5 April 1990 at para 7.2, and Vuolanne $v$ Finland, Communication No. 265/1987, UN Doc CCPR/C?35/D/265/1987, 7 April 1989 at para 9.6 
respect, the HRC has indicated that the depth of review required by Article $9(4)$ is for a court:

"to make a substantive assessment of whether there are substantive grounds justifying detention in the circumstances of the case". 2055

In relation to detention based on security grounds, the HRC in Ahani $v$ Canada ${ }^{2056}$ gave consideration to the procedure in Canada whereby detention results from the Minister for Immigration signing a certificate that reasonable grounds exist for the belief that a person may commit acts of terrorism (and thereby be inadmissible to Canada). The Canadian provisions provide for the judicial review, within seven days and in camera, of the "reasonableness" of that certification together with the statutorily required disclosure of summary redacted information forming the basis of the certification such to allow the applicant to respond. The HRC accepted that a "reasonableness hearing" was sufficient for discharging a State Party's obligations under Article 9(4) ${ }^{2057}$ - that is, the HRC has considered as acceptable a somewhat different standard of review than that contemplated in C $v$ Australia (cited above). ${ }^{2058}$

In relation to the scope of the disclosure made to the applicant and the procedural opportunities afforded to him, in the context of national security, the HRC was satisfied that the applicant was given sufficient information to be "reasonably" informed of the case against him and was able respond appropriately (including his conduct of the hearing, the making of submissions and cross examination of witnesses). ${ }^{2059}$

$2055 C \quad v \quad$ Australia, UNHRC, Communication 90/1999, UN Doc CCPR/C/76/D/900/1999, 28 October 2002 at para 7.4

2056 Ahani $v$ Canada, UNHRC, Communication No. 1051/2002, UN Doc CCPRC/C/80/D/1051/2002, 29 March 2004; see further, Heckman, G, International Decisions - Ahani v Canada, (2005) 99 American Journal of International Law 669.

2057 Ahani $v$ Canada, UNHRC, Communication No. 1051/2002, UN Doc CCPRC/C/80/D/1051/2002, 29 March 2004, para 10.3

2058 Saul submits, "The Committee appears to accept that a full 'merits' review of detention by a court, for instance, to determine its factual 'correctness' as opposed to its legal 'reasonableness', is not necessarily always required.": Saul, B, Submission to Joint Select Committee on Immigration Detention dated 31 August 2011, together with annexed Communication to the UN Human Rights Committee dated 28 August 2011 https://senate.aph.gov.au/submissions/comittees/viewdocument.aspx?id=e82994a0-5a9044c9-80f0-a96aafb95948, https://senate.aph.gov.au/submissions/comittees/viewdocument .aspx?id=229128ab-d97b-4dab-9b97-bcf31229b81c (both last accessed 9 November 2011), para 206. Compare the HRC's views in Ahani with United Nations Human Rights Committee, General Comment No. 8: Right to liberty and security of persons (Article 9), 20 June 1982, http://www.unhchr.ch/tbs/doc.nsf/(Symbol)/f4253f9572cd4700c12563ed00483bec ?Opendocument (last accessed 5 November 2011), para 4, which makes no distinction in treatment for reasons of public security.

2059 Ahani $v$ Canada, UNHRC, Communication No. 1051/2002, UN Doc CCPRC/C/80/D/1051/2002, 29 March 2004, para 10.5 
The UNHCR Revised Guidelines provide that, as part of the minimum procedural guarantees available, detained asylum seekers should have the right:

"(iii) to have the decision subjected to an automatic review before a judicial or
administrative body independent of the detaining authorities. This should be
followed by regular periodic reviews of the necessity for the continuation of
detention, which the asylum-seeker or his representative would have the right to
attend;
(iv) either personally or through a representative, to challenge the necessity of the
deprivation of liberty at the review hearing, and to rebut any findings made. Such a
rights should extend to all aspects of the case and not simply the executive
discretion to detain" 2060

Those guarantees are also largely reflected in the UN Body of Principles for the Protection of All Persons under Any Form of Detention or Imprisonment. ${ }^{2061}$

\subsubsection{Review and Challenge of the Detention Decision - International - Minors}

Article $37(\mathrm{~d})$ CROC provides that a child has the right to "challenge the legality of the deprivation of his or her liberty before a court or other competent, independent and impartial authority, and to a prompt decision on any such action". Although primarily with a juvenile justice context in mind, the HRC has indicated that the legality of the detention of a minor should be examined within 24 hours and that Article 37(d) contemplates not only a right to appeal but also access to a court or other independent and impartial authority or judicial body. ${ }^{2062}$ Any challenge to a detention decision should be made within two weeks of the challenge. ${ }^{2063}$

Article 12 CROC requires that the child's views be taken into account in accordance with the child's age and maturity, particularly in cases of unaccompanied minors. ${ }^{2064}$ Article 25 provides the right for a child "placed for the purpose of care, protection or treatment" to periodic review "of the treatment provided and all other circumstances relevant to his or her

2060 UNHCR Revised Guidelines on applicable criteria and standards relating to the detention of asylum seekers, February 1999, Guideline 5

2061 Principles 4 (judicial authorisation of detention), 9 (detaining authorities subject to judicial authority), 11(1) (no detention without effective opportunity for prompt hearing by judicial or other authority), (3) (judicial or other authority has power to review continuing detention) and 32 (right to challenge lawfulness of detention at any time in order to obtain release without delay) Adopted by General Assembly Resolution 43/173 of 9 December 1988 http://www2.ohchr.org/english/law/bodyprinciples.htm (last accessed 7 November 2011)

2062 United Nations, Committee on the Rights of the Child, General Comment No. 10 Children's rights in juvenile justice, 25 April 2007, paras 83-84

2063 United Nations, Committee on the Rights of the Child, General Comment No. 10 Children's rights in juvenile justice, 25 April 2007, para 84

${ }^{2064}$ United Nations, Committee on the Rights of the Child, General Comment No. 6 Treatment of Unaccompanied and Separated Children Outside Their Country of Origin (2005), 1 September 2005, para 25 
placement". Although detention is not expressly contemplated under that Article, it is arguable that minors (including those minors accompanying parents or other family members) are under the "care and protection" of the State of asylum whilst in detention. ${ }^{2065}$ In addition, the reviewer under Article 25 need not necessarily hold judicial office.

\subsubsection{Review and Challenge of the Detention Decision - International - Vulnerable Persons}

Although no specific provisions in the UNHCR Revised Guidelines refer to the challenge or review of a detention decision of a vulnerable person, Article 14(2) CRPD provides that persons with disabilities are, "on an equal basis with others, entitled to guarantees in accordance with international human rights law". Accordingly, the general international legal position regarding the challenge and review of deprivation of liberty decisions is included within the scope of the CRPD. It is submitted that, due to the difficulty vulnerable persons generally face in articulating their rights, special attention should be paid to ensure that their vulnerabilities do not effectively undermine their right so to do.

\subsubsection{Review and Challenge of the Detention Decision - Council of Europe ECHR}

The lawfulness of detention under Article 5(1)(f) ECHR may be reviewed as provided for in Article 5(4):

"Everyone who is deprived of his liberty by arrest or detention shall be entitled to take proceedings by which the lawfulness of his detention shall be decided speedily by a court and his release ordered if the detention is not lawful"

Dealing with the elements of the Article, seriatim:

\subsubsection{1 'Speedily'}

The concept of "speedily" has been held not to be definable in the abstract, but must "be determined in light of the circumstances of each case", ${ }^{2066}$ and runs from the institution of proceedings to the date that a decision is handed down. ${ }^{2067}$ In comparison to "promptly" under Article 5(3), the Court has indicated:

"The notion of "promptly" (aussitôt) in [Article 5(3)] indicates greater urgency than that of "speedily" (à bref délai) in Article 5(4)"2068

2065 UNICEF, Implementation Handbook for the Convention on the Rights of the Child, (3 ed), 2007, Pp.379-382

2066 Sanchez-Reisse v Switzerland, No. 9862/82, Judgment, 21 October 1986, para 55; see also Ev Norway, No. 11701/85, Judgment, 29 August 1990 para 64.

2067 Singh v Czech Republic, No. 60538/00, Judgment, 25 October 2005, para 74

${ }^{2068}$ E v Norway, No. 11701/85, Judgment, 29 August 1990 para 64 
As noted by Ovey \& White, the genesis of periodic judicial review of a detention decision stems from the approach adopted in cases of the detention of persons of unsound mind where the initial justification for detention may metamorphose or evaporate over time, but such approach is now generally applicable to other categories of deprivation of liberty under Article 5(1) ECHR. ${ }^{2069}$ The ECtHR has held that where a decision to detain is a result of judicial proceedings (for example, resulting in conviction), then the review of the lawfulness of the detention decision is incorporated into that decision similarly, if a decision to detain is made by an administrative body, then a right must be afforded to a person to judicially challenge the detention decision. ${ }^{2070}$ In Amuur, the ECtHR suggested that the prolongation of detention "requires speedy review by the courts, the traditional guardians of personal liberties". ${ }^{2071}$ There is also a corresponding obligation on the Contracting Party to proceed with "special diligence" after the application is made. ${ }^{2072}$ In Kadem, a period of 23 days from the lodgement of a claim (and which remained unresolved due to the applicant being discharged and released) was held not to be "speedy" as contemplated by Article 5(4). ${ }^{2073}$ In Tekdemir, ${ }^{2074}$ seven applications contesting, and consequent determinations affirming, detention over a period of just over 10 months were also held not to be contrary to "speedy" as contemplated by Article 5(4). In Eminbeyli a delay of five months from the institution of proceedings to a final decision was held to be contrary to "speedy" under Article 5(4). ${ }^{2075}$ In Raza a four month period to decide an application for the review of the lawfulness of detention followed by a further year for the judgment to become final was held to breach Article 5(4). ${ }^{2076}$ In $M$ \& Others $v$ Bulgaria a period of two and a half years between the initial challenge to the lawfulness of the decision until a decision handed down in the applicant's favour resulted in a breach of Article 5(4). ${ }^{2077}$

It is also important to note the obiter comments in Shamsa in relation to the detention of foreigners without a basis in Polish law, where the ECtHR stated:

\footnotetext{
2069 Ovey, C, and White, R, The European Convention on Human Rights, 4ed, 2006, OUP, Oxford, Pp.154-155; see Winterwerp $v$ the Netherlands, No. 6301/73, Judgment, 24 October 1979 at para 55; Xv United Kingdom, No. 7215/75, Judgment, 5 November 1981, at para 52; Luberti v Italy, 9019/80, Judgment, 23 February 1984 paras 31-32; Bezicheri v Italy, No. 11400/85, Judgment, 25 October 1989, at para 20.

2070 De Wilde, Ooms and Versyp v Belgium, Nos. 28322/66, 2835/66, 2899/66), Judgment, 18 June 1971, para 76.

2071 Amuur v France, No. 19776/92, Judgment, 25 June 1996, at para 43

2072 Baranowski v Poland, No. 28358/95, Judgment, 28 March 2000, para 73.

2073 Kadem v Malta, No. 55263/00, Judgment, 9 January 2003, para 53

2074 Tekdemir $v$ the Netherlands, No. 46860/99 and 49823/99, Admissibility Decision, 1 October 2002, Pp.21-22

2075 Eminbeyli v Russia, No. 42443/02, Judgment, 26 February 2009, paras 63-69

2076 Raza v Bulgaria, No. 31465/08, Judgment, 11 February 2010, paras 76-79

2077 M \& Others v Bulgaria, No. 41416/08, Judgment, 26 July 2011, paras 80-84
} 
"In this regard, the Court also noted that for the purposes of Article 5(1), the detention for a period of several days and was not ordered by a court or a judge or any other person "entitled (...) to exercise judicial power" can not be considered "lawful" within the meaning of this provision. If this requirement is not explicitly stated in Article 5(1), it can be inferred from Article 5 taken as a whole, particularly the wording of paragraph 1(c) ("to be brought before the competent judicial authority") and paragraph 3 ("shall be brought promptly before a judge or other officer authorised by law to exercise judicial power"). In addition, the guarantee of habeas corpus contained in Article 5(4) also supports the idea that detention extended beyond the initial period envisaged in paragraph 3 calls for the intervention of a "court" as a safeguard against arbitrariness (Baranowski v. Poland, Judgment of 28 March 2000, Reports 2000-III)."2078

Accordingly, as Wilsher insightfully notes, it may be inferred from that reasoning that judicial authorisation of the detention may be necessary for foreigners kept in immigration detention for a period in excess of "several days". ${ }^{2079}$ The innovation in Shamsa is that it suggests that detention be judicially ordered when that requirement does not otherwise exist under the ECHR for those detained under Article 5(1)(f).

\subsubsection{2 'Court'}

In Weeks the ECtHR succinctly summarised the general principles in relation to what constitutes a "court" for the purposes of Article 5(4):

"The "court" referred to in Article 5 para. 4 (art. 5-4) does not necessarily have to
be a court of law of the classic kind integrated within the standard judicial
machinery of the country (see the above-mentioned X v. the United Kingdom
judgment, Series A no. 46, p. 23 , para. 53 ). 2080 The term "court" serves to denote
"bodies which exhibit not only common fundamental features, of which the most
important is independence of the executive and of the parties to the case..., but also
the guarantees" - "appropriate to the kind of deprivation of liberty in question" -
"of a judicial procedure", the forms of which may vary from one domain to
another (see the above-mentioned De Wilde, Ooms and Versyp judgment, Series A

2078 Shamsa v Poland, Nos. 45355/99 and 45357/99, Judgment, 27 November 2003, para 59 (own translation) "A cet égard, la Cour souligne également qu'aux fins de l'article 5 \& la détention qui s'étend sur une période de plusieurs jours et qui n'a pas été ordonnée par un tribunal ou par un juge ou par toute autre personne " habilitée (...) à exercer des fonctions judiciaires " ne saurait passer pour " régulière " au sens de cette disposition. Si cette exigence n'est pas explicitement formulée à l'article $5 \$ 1$, elle peut se déduire de l'article 5 pris dans sa globalité, en particulier du libellé du paragraphe 1 c) (" en vue d'être conduit devant l'autorité judiciaire compétente ») et du paragraphe 3 (" doit être aussitôt traduite devant un juge ou un autre magistrat habilité par la loi à exercer des fonctions judiciaires »). En outre, la garantie d'habeas corpus que contient l'article 5 \$ vient également appuyer l'idée que la détention qui est prolongée au-delà de la période initiale envisagée au paragraphe 3 appelle l'intervention d'un " tribunal " comme garantie contre l'arbitraire (Baranowski c. Pologne, arrêt du 28 mars 2000, Recueil 2000-III)."

2079 Wilsher, D, The Liberty of Foreigners - A History, Law and Politics of Immigration Detention, 2008, Wolf Legal Publishers, Nijmegen, P.126

${ }^{2080}$ X v United Kingdom, No. 7215/75, Judgment, 5 November 1981 
no. 12, pp. 41-42, paras. 76 and 78). ${ }^{2081}$ In addition, as the text of Article 5 para. 4 (art. 5-4) makes clear, the body in question must not have merely advisory functions but must have the competence to "decide" the "lawfulness" of the detention and to order release if the detention is unlawful. There is thus nothing to preclude a specialised body such as the Parole Board being considered as a "court" within the meaning of Article 5 para. 4 (art. 5-4), provided it fulfils the foregoing conditions (see the above-mentioned X v. the United Kingdom judgment, Series A no. 46 , p. 26, para. 61)." 2082

Accordingly, a mayor who gave the initial order to detain, or the prosecutor who prolonged it, were not considered a "court" for the purpose of Article 5(4). ${ }^{2083}$ Nor will Article 5(4) be satisfied where appeals are made to a higher administrative authority, such as a Minister or a delegate thereof. ${ }^{2084}$ Further, as contemplated by Article 5(4) itself, the 'court' must be able to order the release of the person, ${ }^{2085}$ not merely advise so to do. ${ }^{2086}$

Finally, it should be noted that detained minors accompanying their parents should have access to a court to decide the lawfulness of their detention with that right not solely restricted to the parents. ${ }^{2087}$

\subsubsection{Scope of the Review}

The scope of review under Article 5(1)(f) is not identical to the scope of review under the other grounds of Article 5(1). ${ }^{2088}$ The scope is said not to be so wide as to allow a court to substitute its own decision, on all aspects of the case, for that of the decision-making authority but should be wide enough to examine the "essential" conditions for lawful detention. ${ }^{2089}$ Naturally, where there is no possibility for judicial review, Article 5(4) will be breached. ${ }^{2090}$ This

2081 De Wilde, Ooms and Versyp v Belgium, Nos. 28322/66, 2835/66, 2899/66), Judgment, 18 June 1971. In this regard also see Neumeister v Austria, No. 1936/63, Judgment, 27 June 1968 at para 24

2082 Weeks v United Kingdom, No. 9787/82, Judgment, Plenary, 2 March 1987, para 61

2083 Winterwerp $v$ the Netherlands, No. 6301/73, Judgment, 24 October 1979 at para 56

2084 Sadaykov v Bulgaria, No. 75157/01, Judgment, 22 May 2008, para 35

2085 Singh $v$ United Kingdom, No. 23389/94, Judgment, 21 February 1996, para 66, Curley v United Kingdom, No. 32340/96, Judgment, 28 March 2000, para 32; Chahal v United Kingdom, No. 22414/93, Judgment 15 November 1996, paras 130 and 132

2086 Benjamin and Wilson v United Kingdom, No. 28212/95, Judgment, 26 September 2002, para 34; Chahal v United Kingdom, No. 22414/93, Judgment Grand Chamber, 15 November 1996, para 130

${ }^{2087}$ Popov v France, Nos. 39472/07 and 39474/07, Judgment, 19 January 2012, paras 124125

2088 Chahal v United Kingdom, No. 22414/93, Judgment 15 November 1996, para 127

2089 Chahal v United Kingdom, No. 22414/93, Judgment 15 November 1996, para 127

2090 Shchebet v Russia, No. 16074/07, Judgment, 12 June 2008, paras 75-79; Soldatenko $v$ Ukraine, 2440/07, Judgment, 23 October 2008, paras 125-127 (extradition); SD v Greece, No. 53541/07, Judgment, 11 June 2009, paras 70-77 (French version); Dzhurayev v Russia, No. 38124/07, Judgment, 17 December 2009, paras 55-63; Khodzhayev v Russia, No. 
includes where a family with minor children has been detained and although a right to review the lawfulness of detention is open to the parents, no such possibility exists for the detained minor children; ${ }^{2091}$ or where reasons for detention and legal assistance have not been provided; ${ }^{2092}$ or where an appeal court ultimately decides that deportees are not entitled to a review of the lawfulness of their detention. ${ }^{2093}$

In light of the view taken by the ECtHR in Chahal and Saadi where the Court eschewed the requirement of necessity, and all other things being equal, there is a real risk that the review conducted pursuant to Article 5(4) would be limited to whether the decision to detain was in conformity with national law. ${ }^{2094}$ Provided that the reason for detention was to prevent unauthorised entry into the country, and that this had been carried out in accordance with national law, then the decision to detain would be justified. However, the relationship between necessity and arbitrariness becomes problematic when considering the length of detention (which was contemplated by the Grand Chamber in paragraph 74 of Saadi as a ground of arbitrariness). If necessity is not taken into account when reviewing the lawfulness of a decision to detain, then it follows that the length of detention is almost impossible to challenge if the detention is otherwise lawful. For as long as the question of necessity is not evaluated, and for as long as it can be shown that deportation arrangements were underway or unauthorised entry is being prevented, detention can always be justified on the basis of national law. Accordingly, such an interpretation would effectively render pointless any regular review of the lawfulness of detention. Further, that approach sits uneasily (and inconsistently) with the approach advocated by the Human Rights Committee in $A v$ Australia where the reviewing court should determine more than just mere compliance with national law, but with requirements of Article 9(1) and the ICCPR itself.

\subsubsection{Security-related decisions}

In relation to detention in the context of national security, the ECtHR held in Chahal that:

"The Court recognises that the use of confidential material may be unavoidable where national security is at stake. This does not mean, however, that the national

52466/08, Judgment, 12 May 2010, paras 120-131; Khaydarov v Russia, No. 21055/09, Judgment, 20 May 2010, paras 137-142; Kamyshev v Russia, No. 3990/06, Judgment, 20 May 2010, paras 66-68

2091 Popov v France, Nos. 39472/07 and 39474/07, Judgment, 19 January 2012, paras 122125

2092 Abdolkhani v Turkey, No. 30471/08, Judgment, 22 September 2009, paras 139-142

${ }^{2093}$ Raza v Bulgaria, No. 31465/08, Judgment, 11 February 2010, paras 76-79

${ }^{2094}$ See also Ovey, C and White, R, The European Convention on Human Rights, 2006, Oxford University Press, Oxford, Pp.151-152. 
authorities can be free from effective control by the domestic courts whenever they choose to assert that national security and terrorism are involved"2095

Accordingly, as the assertions of national security were unable to be effectively challenged by the detained person (and whilst suggesting that such a challenge may be rendered possible by a system as adopted in Canada), the Court held that a breach of Article 5(4) had occurred. In Al-Nashif the ECtHR held that detention in the context of national security which resulted in the automatic denial of judicial review, which was incapable of curial enquiry, and which resulted from an order which stated no reasons, was held to be incompatible with Article 5(4). ${ }^{2096}$ The Court again referred to other systems where an individual could be afforded "a substantial measure of procedural justice". 2097 In $A \&$ Ors $v$ United Kingdom, where detention in the context of national security occurs and which can lead to the lengthy and indefinite detention, the ECtHR has equated the assessment under Article 5(4) to "substantially the same fair trial guarantees as Article 6(1) in its criminal aspect". ${ }^{2098}$ If the material that formed (or largely formed) the basis of the decision to detain is made available to an applicant, it must be of sufficient specificity to allow the applicant to give instructions to his legal representative - that is, to effectively challenge the assertions. If material made available to the detained person was of a general nature and other material which formed the basis of the detention decision was not disclosed, then Article 5(4) will be breached as the detained person is unable to effectively challenge the assertions. ${ }^{2099}$

\subsubsection{Interim Measures}

Although not expressly provided for in the ECHR itself, the ECtHR may grant interim relief by way of Article 39(1) of its Rules of Court, ${ }^{2100}$ and which are said to bind the Contracting State by virtue of Article 34 ECHR (that is, in light of the undertaking by the High Contracting Parties not to hinder an individual from exercising his or her right to receive an application from a person claiming to be a victim of a breach of a Convention right or

\footnotetext{
2095 Chahal v United Kingdom, No. 22414/93, Judgment 15 November 1996, para 127

2096 Al Nashif v Bulgaria, No. 50963/99, Judgment, 20 June 2002, paras 94-98

2097 Al Nashif v Bulgaria, No. 50963/99, Judgment, 20 June 2002, paras 95-97; see also paras 123-124

2098 A \& Ors v United Kingdom, No. 3455/05, Judgment Grand Chamber, 19 February 2009, para 217; see also Garcia Alva v Germany, No.23541/94, Judgment, 13 February 2001, para 39

2099 A \& Ors v United Kingdom, No. 3455/05, Judgment Grand Chamber, 19 February 2009, para 220

2100 ECtHR, Rules of Court, April 2011, Strasbourg, http://www.echr.coe.int/NR/rdonlyres/6AC1A02E-9A3C-4E06-94EF-E0BD377731DA /0/REGLEMENT_EN_Avril2011.pdf (last accessed 15 November 2011)
} 
rights). ${ }^{2101}$ Recently, given the $4000 \%$ increase in applications for interim measures, on 7 July 2011 the Court issued a new Practice Direction on the procedure for Rule 39 interim measures. ${ }^{2102}$ Accordingly, the Practice Direction makes clear that reasons for seeking interim relief must be furnished to the ECtHR and that the provision of complete documentation (including the date and time of removal and all supporting court documents) together with the application is absolutely essential in order for the Court to consider the application. Further, the application should be made in good time and domestic remedies in relation to achieving suspensive effect should be exhausted before an application to the ECtHR is made. A recent study by ELENA and ECRE has identified significant challenges (both in practice and in law) to asylum applicants and their practitioners in the use of Rule 39 interim measures. ${ }^{2103}$

\subsubsection{Committee of Ministers' Recommendation Rec(2003)5 \& Twenty Guidelines on Forced Return}

The Committee of Ministers of the Council of Europe in its Recommendation $\operatorname{Rec}(2003) 5$ provides that detention should be reviewed regularly by a court in accordance with Article 5(4) ECHR. Where no maximum period of detention has been provided by law, the reviewing court should review the duration of detention as part of its review. ${ }^{2104}$ The Committee of Ministers' Twenty Guidelines on Forced Return almost mimics

${ }^{2101}$ Mamatkulov and Askarov v Turkey, Nos. 46827/99 and 46951/99, Judgment Grand Chamber, 4 February 2005, para 128. See also Öcalan v Turkey, No. 46221/99, Judgment, Grand Chamber, 12 May 2005, para 5. Flowing from analogous reasoning in relation to the (then) Commission and interim measures, it would appear that Article 34 ECHR cannot be relied upon solely as the basis for interim measures (that is, it must be taken in conjunction with Rule 39(1)): see Cruz Varas v Sweden, No. 15576/89, 20 March 1991, Judgment (Plenary), paras 97-103 and paras 52-64 regarding the proceedings before the Commission. See also Soering $v$ United Kingdom, No. 14038/88, 7 July 1989, paras 4 and 77 (compliance by United Kingdom with Commission and Court's indications); I.M. $v$ France, No. 9152/09, Judgment, 2 February 2012, paras 4 and 161-162; See further, Tomuschat, C, Human Rights - Between Idealism and Realism, 2ed, 2008, OUP, Oxford, Pp.249-252

2102 ECtHR, Practice Direction, Requests for Interim Measures, http://www.echr.coe.int/NR/rdonlyres/5F40172B-450F-4107-9514-69D6CBDECF5C /0/INSTRUCTION_PRATIQUE_Demandes_de_mesures_provisoires_juillet_2011_EN. pdf (last accessed 15 November 2011); and ECtHR, Press Release, New statistics and instructions published on request to suspend expulsion of applicants before European Court of Human Rights, 28 July 2011 http://cmiskp.echr.coe.int/tkp197/view.asp? action $=$ open\&documentId $=888948 \&$ portal $=$ hbkm\&source $=$ externalbydocnumber $\&$ table $=$ F69A27FD8FB86142BF01C1166DEA398649 (last accessed 15 November 2011); Statistics in relation to interim measures - http://www.echr.coe.int/NR/rdonlyres/43F2D6A88034-4271-9498-AD9EAC707FB6/0/ART_39_TABLEAU_PAR_PAYS_2011_EN.pdf (last accessed 18 June 2012)

2103 ELENA and ECRE, Research on ECHR Rule 39 Interim Measures - Executive Summary, April 2012, http://www.ecre.org/component/downloads/downloads/476.html (last accessed 18 June 2012)

2104 Committee of Ministers, Council of Europe, Recommendation Rec(2003)5 of the Committee of Ministers to member states on measures of detention to asylum seekers, paragraph 5 
Article 5(4) ECHR. ${ }^{2105}$ However, the Guideline inserts "subject to any appeal" before providing the right to immediate release if the detention is not lawful. Accordingly, it may be inferred that the Guidelines advocate that a person's detention may continue pending any appeal of a successfully challenged detention decision.

\subsubsection{CPT}

The CteePT has noted in its Guidelines that detained irregular migrants (which can include asylum seekers or rejected asylum seekers) have been invariably detained by administrative authorities without the benefit of judicial review or a time limit for their detention. ${ }^{2106}$ The CteePT has indicated that such person should be able to have at their disposal an effective remedy for reviewing the lawfulness of their detention, speedily and judicially. ${ }^{2107}$

\subsubsection{European Convention on the Exercise of Children's Rights}

The European Convention on the Exercise of Children's Rights ("the ECECR") may have some limited application under the CEAS legislation where the detention of a minor or a parent results in the disintegration of a family, but it is briefly discussed here to provide a comparison, particularly in light of access to proceedings in which a minor is involved. The ECECR is limited in scope to proceedings affecting minors before judicial proceedings which are "family proceedings" concerning "in particular those involving the exercise of parental responsibilities such as residence and access to children", ${ }^{2108}$ but States are encouraged to consider extending the provisions of its Articles 3, 4 and 9 (discussed below) to other proceedings involving children. ${ }^{2109}$ Under ECECR the child is given a comprehensive right to information and opportunity to express his her views, namely "to receive all relevant information"; "to be consulted and express his or her views"; and "to be informed of the possible consequences of compliance with these views and the consequences of any decision". ${ }^{2110}$ Further the child has the right to seek (either personally or through other persons or bodies) the appointment of a special representative (only where a conflict of interest exists with the holder of parental responsibilities), with States able to limit that right to children "considered by internal law to have sufficient understanding". ${ }^{2111}$ However, a

2105 Guideline 9(2), Committee of Ministers, Council of Europe, Twenty Guidelines on Forced Return, CM(2005)40 Addendum final, Strasbourg, 20 May 2005

2106 The European Committee for the Prevention of Torture and Inhuman or Degrading Treatment or Punishment, The CPT Standards, October 2006, Strasbourg, CPT/Inf/E (2002) 1 - Rev. 2010, P.60, para 80

2107 The European Committee for the Prevention of Torture and Inhuman or Degrading Treatment or Punishment, The CPT Standards, October 2006, Strasbourg, CPT/Inf/E (2002) 1 - Rev. 2010, P.61, para 86

2108 Article 1(2) and (3) of the European Convention on the Exercise of Children's Rights, concluded at Strasbourg, 25 January 1996

2109 Article 11 of the European Convention on the Exercise of Children's Rights

2110 Article 3 of the European Convention on the Exercise of Children's Rights

2111 Article 4 of the European Convention on the Exercise of Children's Rights 
child's right to exercise "some or all of the rights of the parties to the proceedings" is a matter for State discretion, ${ }^{2112}$ and which is really the nub of the need for appropriate representation. Further, a "special representative" does not necessarily mean a "separate representative" which may include a lawyer. ${ }^{2113}$ A judicial authority is also under an obligation to consider that it has sufficient information to decide in the best interests of the child. ${ }^{2114}$ Where the child has sufficient understanding, a judicial authority must ensure that the child has received all relevant information; consult the child in person (where appropriate); allow the views of the child to be expressed; and "give due weight" to the child's views. ${ }^{2115}$ A judicial authority is also obliged to act speedily; ${ }^{2116}$ must have the power to act on their own motion where a child's welfare is "in serious danger"; ${ }^{2117}$ and must have the power to appoint a "special representative". 2118 Representatives are required to provide information and the explanation of any consequences to the child, and to determine and present the views of the child. ${ }^{2119}$

\subsubsection{Review and Challenge of the Detention Decision - European Union}

\subsubsection{EU Charter and General Principles of EU Law}

In the Union sphere, although the EU Charter does not expressly provide for a deprivation of liberty order to be challenged, Article 47(1) does provide a right to an effective remedy before a tribunal where a person's Union rights and freedoms have been violated. Article 47(2) provides that that challenge is to be before an "independent and impartial tribunal previously established by law". The principle of effectiveness as a General Principle of EU law is said to be embodied in Article 47 of the EU Charter. ${ }^{2120}$ The principle as expressed by the Charter may be invoked subject to the limitations in Articles 51, 52 and 53 of the Charter (see Chapter 2). Tridimas notes, however, that the scope of the right is not as broad as the principle as expressed in the case law of the CJEU because the right as expressed in Article 47 is addressed to Union institutions and Member States when they are implementing Union law, ${ }^{2121}$ as opposed to the general body of case $l_{a w}^{2122}$ where the principle may be

\footnotetext{
2112 Article 5(d) of the European Convention on the Exercise of Children's Rights

2113 Compare Articles 5(b) and 9(2) to Article 4(1) of the European Convention on the Exercise of Children's Rights

2114 Article 6(a) of the European Convention on the Exercise of Children's Rights

2115 Article 6(b) and (c) of the European Convention on the Exercise of Children's Rights

2116 Article 7 of the European Convention on the Exercise of Children's Rights

2117 Article 8 of the European Convention on the Exercise of Children's Rights

2118 Article 9 of the European Convention on the Exercise of Children's Rights

2119 Article 12 of the European Convention on the Exercise of Children's Rights

2120 C-69/10 Diouf v Ministre due Travail, de 'Emploi et de L'Immigration, Judgment, 28 July 2011, para 49;

2121 Article 51(1) of the EU Charter

2122 See, for example, Case C-222/84 Johnston $v$ Chief Constable of the Royal Ulster Constabulary, Judgment, 15 May 1986; Case C-222/86 UNECTEF v Heylens, Judgment, 15 October 1987. See also Tridimas, T, The General Principles of EU Law, 2ed, 2006, OUP, Oxford, Pp.418-476; Gordon, R, EC Law in Judicial Review, 2007, OUP, Oxford, Pp.142-
} 
invoked against Member States whenever they "act within the scope of application of Union law". ${ }^{2123}$ The general body of case law requires Member States to provide effective judicial protection, ${ }^{2124}$ and that Member States adopt such measures to ensure real and effective judicial protection. ${ }^{2125}$ In $N S$, Advocate General Trstenjak expressed the opinion that Member States may introduce a rebuttable presumption of compliance with an asylum seeker's fundamental rights and human rights by another Member State (in that context relating to Dublin transfers) but that the principle of effectiveness must, in any event, be observed. ${ }^{2126}$ Wilsher notes that a degree of ambiguity remains about whether detention falls within the scope of Union law. ${ }^{2127}$ That is an important question to be answered concerning the current suite of secondary legislation. The Court in Kadzoev ${ }^{2128}$ and El Dridi ${ }^{2129}$ did not appear to show any reluctance that detention under the Returns Directive fell within the scope of Union law. ${ }^{2130}$ Further, the more extensive and more prescriptive proposed secondary legislation together with the heightened legal bases under the Lisbon Treaty would arguably place the detention of asylum seekers within the scope of Union law.

\subsubsection{Security-Related Evidence}

Although the CJEU and General Court have not had to deal with the issue of the detention (or prolonged detention) of asylum seekers on a purely securityrelated issue as yet, and although detention in such circumstances will invariably be by a Member State (but which may involve the Union in terms

144; Craig, P. and de Búrca, G, EU Law, 5ed, 2011, OUP, Oxford, Pp.222-237; Wiesbrock, A, Legal Migration to the European Union - Ten Years After Tampere, 2009, Wolf Legal Publishers, Nijmegen, Pp.147-149.

2123 Tridimas, T, The General Principles of EU Law, 2ed, 2006, OUP, Oxford, P.456. See also the Opinion of A-G Sharpston in Case C-34/09 Zambrano $v$ Office national de l'emploi, Opinion, 30 September 2010, para 156

2124 Case C-222/84 Johnston v Chief Constable of the Royal Ulster Constabulary, Judgment, 15 May 1986; UNECTEF v Heylens, Judgment, 15 October 1987

2125 Case C-14/83 Von Colson and Kamann v Land Nordrhein Westfalen, Judgment, 10 April 1984, at paras 18 and 23; as to limitations in an asylum context (effective judicial review of decision for accelerated procedures), see Case C-69/10 Diouf $v$ Ministre due Travail, de 'Emploi et de L'Immigration, Judgment, 28 July 2011, paras 54-56

2126 Case C-411/10 N. S. v Secretary of State for Home Affairs, Opinion of Advocate General Trstenjak, 22 September 2011, at paras 130-136 particularly at para 134; see further on the rebuttable presumption affirmed by the CJEU: Cases C-411/10 and C-493/10 N.S. v Secretary of State for the Home Department and M. E. and Others $v$ Refugee Applications Commissioner and Minister for Justice, Equality and Law Reform, 21 December 2011, Judgment Grand Chamber, para 104

2127 Wilsher, D, Immigration Detention and the Common European Asylum Policy, in Baldaccini, A, Guild, E, and Toner, H, (eds) Whose Freedom Security and Justice? EU Immigration and Asylum Law and Policy, 2007, Hart Publishing, Portland, Oregon, Pp.395-426 at Pp.408416

2128 Case C-357/09 PPU Kadzoev, Judgment, Grand Chamber, 7 September 2009

2129 Case C-61/11 PPU El Dridi, Judgment, 28 April 2011

${ }^{2130}$ Albeit that the Returns Directive falls under Article 79TFEU not Article 78TFEU which is the legal basis for asylum secondary legislation - see Chapter 2 herein 
of agencies such as FRONTEX or measures taken at the Union level under its Common Foreign and Security Policy), some guidance may be found in the line of reasoning that the Court may follow in such circumstances in the $\mathrm{Kadi}^{2131}{ }^{2} \mathrm{OMPI} / \mathrm{PMOI}^{2132}$ and related ${ }^{2133}$ line of cases. These lines of cases are the subjects of a great deal of academic writing ${ }^{2134}$ and it is not proposed to

2131 Case T-315/01 Kadi v Council of the European Union and Commission of the European Communities, 21 September 2005, Judgment and Case T-306/01 Yusuf and Al Barakaat International Foundation $v$ Council of the European Union and Commission of the European Communities, 21 September 2005, Judgment, CFI, which were the subject of a successful appeal to the (then) ECJ in Cases C-402/05 and 415/05 Kadi and Al Barakaat International Foundation $v$ Council of the European Union and Commission of the European Communities, 3 September 2008, Judgment, Grand Chamber ("Kadi I"), following the Opinion of Advocate General Maduro - Cases C-402/05 and 415/05 Kadi and Al Barakaat International Foundation $v$ Council of the European Union and Commission of the European Communities, 23 January 2008, Opinion. Cases following the Kadi I line include: Case T-318/01 Omar Mohammed Othman $v$ Council of the European Union and Commission of the European Communities, 11 June 2009, Judgment, CFI; Cases C-399/06 P and C-403/06 P Faraj Hassan $v$ Council of the European Union and European Commission and Chafiq Ayadi v Council of the European Union, 3 December 2009, Judgment, ECJ; Case T-135/06 - T-138/06 AlBashir Mohammed Al-Faqih and Others v Council of the European Union, 29 September 2010, Judgment, General Court. Kadi I was followed in Case T-85/09 Kadi v European Commission, 30 September 2010, Judgment, General Court ("Kadi II") (appeal pending before CJEU)

2132 Case T-228/02 Organisation de Mohadjedines du peuple d'Iran $v$ Council of the European Union, 12 December 2006, Judgment, CFI (“OMPI”); Case T-47/03 Jose Maria Sison v Council of the European Union, 11 July 2007, Judgment, CFI; Case T-327/03 Stichting AlAqsa $v$ Council of the European Union, 11 July 2007, Judgment, CFI; Case T-253/04 KongraGel and Others $v$ Council of the European Union, 3 April 2008, Judgment, CFI; Case T256/07 People's Mohajedin Organization of Iran v Council of the European Union, 23 October 2008, Judgment, CFI ("PMOI I"); Case T-284/08 People's Mohajedin Organization of Iran v Council of the European Union, 4 December 2008, Judgment, CFI ("PMOI II"); Case T341/07 Jose Maria Sison v Council of the European Union, 30 September 2009, Judgment, CFI; Case T-348/07 Stichting Al-Aqsa v Council of the European Union, 9 September 2010, Judgment (on appeal before General Court); and Case T-341/07 Jose Maria Sison v Council of the European Union, 23 November 2011, Judgment

2133 Case T-390/08 Bank Melli Iran v Council of the European Union, 14 October 2009, Judgment, CFI; and Case T-181/08 Pye Phyo Tay Zav Council of the European Union, 19 May 2010, Judgment (pending appeal)

2134 A small selection includes: Godinho, J, When Worlds Collide: Enforcing United Nations Security Council Asset Freezes in the EU Legal Order (2010) 16(1) ELJ 67; Türküler Isikel, N, Fundamental rights in the EU after Kadi and Al Barakat (2010) 16(5) ELJ 551; Tzanou, M and El Droubi, S, Case T-318/01, Omar Mohammed Othman v. Council of the European Union and Commission of the European Communities, Judgment of the Court of First Instance of 11 June 2009 (Seventh Chamber), not yet reported (2010) 47 CMLRev 1233; Tridimas, T, Terrorism and the ECJ: empowerment and democracy in the EC legal order (2009) 34(1) ELRev 103; Halberstam, D, and Stein, E, The United Nations, the European Union, and the King of Sweden: Economic Sanctions and Individual Rights in a Plural World Order (2009) 46 CMLRev 13; Eckes, C, Judicial Review of European Anti-Terrorism Measures - the Yusuf and Kadi Judgments of the Court of First Instance (2008) 14(1) ELJ 74; Tridimas, T, and Guiterrez-Fons, J. A., EU law, international law, and economic sanctions against terrorism: the judiciary in distress? (2008) 32 Fordham International Law Journal 660; Nettesheim, M, U.N. sanctions against individuals - a challenge to the architecture of European Union governance (2007) 44 CMLRev 
traverse all the issues raised in those cases here. Attention will briefly turn to the disclosure of material to the person affected by the decision and the right to an effective judicial remedy.

The Kadi line of cases were characterised by the applicants' inclusion on a list of terrorist organisations whose assets were to be frozen following a United Nations Security Council resolution which specifically listed those organisations and which the European Union was obliged to implement. The OMPI/PMOI line of cases were also characterised by a United Nations Security Council resolution but which did not specify the organisations or individuals to be targeted - rather, the Union implemented measures and a Council decision were made to include certain groups or individuals based on the decision of a "competent authority" (taken to be a judicial authority) of a Member State. However, although the primary obligation rests on the Member State concerned to make provision for an affected person to express their views on the decision and evidence, the Union is also under an obligation to provide redress where the decision to include a person or organisation on the list was based otherwise than on the decision of the "competent authority" of the Member State. ${ }^{2135}$ The related line of cases represents situations where the Union has taken action directed at third countries and where such measures do not necessarily present avenues for effective judicial review at the Member State level.

In Kadi I, the Court expressly referred to Articles 6 and 13 ECHR and to Article 47 of the EU Charter. ${ }^{2136}$ The Court acknowledged that security considerations may justify the non-disclosure of evidence and related matters and for the person concerned to be heard on them, but the Court was not of the view that review is completely obviated by security-related reasons, expressly citing the ECtHR decision in Chahal. ${ }^{2137}$ The Court did not set out what it considered an appropriate procedure for dealing with security-related evidence but referred generally to:

"techniques which accommodate, on the one hand, legitimate security concerns about the nature and sources of information taken into account in the adoption of

567; Della Cananea, G, Return to the due process of law: the European Union and the fight against terrorism (2007) 32(6) ELR 896

2135 Case T-228/02 Organisation de Mohadjedines du peuple d'Iran v Council of the European Union, 12 December 2006, Judgment, CFI (“OMPI”), para 126

2136 Cases C-402/05 and 415/05 Kadi and Al Barakaat International Foundation v Council of the European Union and Commission of the European Communities, 3 September 2008, Judgment, Grand Chamber ("Kadi I"), para 135

2137 Cases C-402/05 and 415/05 Kadi and Al Barakaat International Foundation v Council of the European Union and Commission of the European Communities, 3 September 2008, Judgment, Grand Chamber ("Kadi I"), paras 342-344 
the act concerned and, on the other, the need to accord the individual a sufficient measure of procedural justice" 2138

The Court also acknowledged the strong relationship between the rights of defence and the rights to an effective judicial remedy - the failure to inform the applicants of the evidence against them had a corresponding and consequential effect on the conduct of any subsequent effective judicial review (that is, the absence of that evidence rendered the judicial review entirely ineffective). ${ }^{2139}$ The applicants' rights to an effective legal remedy was infringed on account of there being no obligation to inform them of any adverse evidence against them or any right to be heard in relation to such evidence. ${ }^{2140}$ Accordingly, the Court held that the rights of defence, particularly the right to be heard and the right to effective judicial protection, were breached, ${ }^{2141}$ and that the measures adopted against Mr Kadi were made "without furnishing any guarantee enabling him to put his case to the competent authorities". ${ }^{2142}$ This position was largely affirmed in Kadi $I I^{2143}$ but, significantly, the Court cited with approval and applied the ECtHR decision in $A v$ United Kingdom regarding the disclosure of security information to enable an effective legal remedy. ${ }^{2144}$

The OMPI/PMOI line of cases deals a little more specifically with securityrelated evidence. In OMPI, the Court noted that there was no need to notify the persons concerned of the evidence against them before the measure was taken (as it would undermine the effectiveness of the measure) ${ }^{2145}$ but that the evidence must be notified to the person at the time of making the decision or as soon as possible thereafter ${ }^{2146}$ and that the disclosure of the reasons at the

2138 Cases C-402/05 and 415/05 Kadi and Al Barakaat International Foundation v Council of the European Union and Commission of the European Communities, 3 September 2008, Judgment, Grand Chamber ("Kadi I"), para 344

2139 Cases C-402/05 and 415/05 Kadi and Al Barakaat International Foundation v Council of the European Union and Commission of the European Communities, 3 September 2008, Judgment, Grand Chamber ("Kadi I"), para 349

${ }_{2140}$ Cases C-402/05 and 415/05 Kadi and Al Barakaat International Foundation v Council of the European Union and Commission of the European Communities, 3 September 2008, Judgment, Grand Chamber ("Kadi I"), para 352

2141 Cases C-402/05 and 415/05 Kadi and Al Barakaat International Foundation v Council of the European Union and Commission of the European Communities, 3 September 2008, Judgment, Grand Chamber ("Kadi I"), para 353

2142 Cases C-402/05 and 415/05 Kadi and Al Barakaat International Foundation v Council of the European Union and Commission of the European Communities, 3 September 2008, Judgment, Grand Chamber ("Kadi I"), para 369

2143 Case T-85/09 Kadi v European Commission, 30 September 2010, Judgment, General Court (“Kadi II"), paras 181-184

2144 Case T-85/09 Kadi v European Commission, 30 September 2010, Judgment, General Court (“Kadi II"), paras 176-177

2145 Case T-228/02 Organisation de Mohadjedines du peuple d'Iran $v$ Council of the European Union, 12 December 2006, Judgment, CFI ("OMPI"), para 128

2146 Case T-228/02 Organisation de Mohadjedines du peuple d'Iran $v$ Council of the European Union, 12 December 2006, Judgment, CFI (“OMPI”), para 129 
hearing will not cure a failure to previously state reasons. ${ }^{2147}$ There is no automatic requirement for a hearing. ${ }^{2148}$ The Court acknowledged that communication of certain evidence, and any hearing related to it, may be excluded on account of security of the Member State, the Community or the maintenance of international relations ${ }^{2149}$ but that such restrictions are consistent with the case law of the ECtHR in relation to Article 6 ECHR (and expressly citing Chahal). ${ }^{2150}$ Such a restriction on the disclosure of such evidence might be justified (including evidence of "the specific grounds for that decision, or even the identity that took it" as well as, in very specific circumstances, "the identification of the Member State or third country in which a competent authority has taken a decision" relating to the person's threat to public security). ${ }^{2151}$ The Court noted the importance of review as the "only safeguard ensuring that a fair balance is struck between the need to combat international terrorism and the protection of fundamental rights." 2152 Significantly, the Court pointed out that in the ECtHR jurisprudence the use of confidential information does not mean that judicial review cannot occur. ${ }^{2153}$ Subsequently, in Sison, the Court expressly chose not to deal with the procedure for access by lawyers to security-related material (citing the ECtHR in Al-Nashiff). ${ }^{2154}$ In PMOI (I) the Court affirmed its position in OMPI that "actual and specific reasons" be given for the measure adopted. ${ }^{2155}$ Later, in PMOI (II), the Court held that the lawfulness of the decision "extends to an assessment of facts and circumstances relied on as justifying

2147 Case T-228/02 Organisation de Mohadjedines du peuple d'Iran v Council of the European Union, 12 December 2006, Judgment, CFI (“OMPI”), para 139

2148 Case T-228/02 Organisation de Mohadjedines du peuple d'Iran $v$ Council of the European Union, 12 December 2006, Judgment, CFI (“OMPI”), para 130

2149 Case T-228/02 Organisation de Mohadjedines du peuple d'Iran v Council of the European Union, 12 December 2006, Judgment, CFI (“OMPI”), paras 133-134

${ }^{2150}$ Case T-228/02 Organisation de Mohadjedines du peuple d'Iran $v$ Council of the European Union, 12 December 2006, Judgment, CFI (“OMPI"), para 135

${ }^{2151}$ Case T-228/02 Organisation de Mohadjedines du peuple d'Iran v Council of the European Union, 12 December 2006, Judgment, CFI (“OMPI"), para 136 and 148

${ }^{2152}$ Case T-228/02 Organisation de Mohadjedines du peuple d'Iran $v$ Council of the European Union, 12 December 2006, Judgment, CFI (“OMPI”), para 155

2153 Case T-228/02 Organisation de Mohadjedines du peuple d'Iran v Council of the European Union, 12 December 2006, Judgment, CFI (“OMPI”), para 156 citing Chahal and Öcalan

2154 Case T-47/03 Jose Maria Sison v Council of the European Union, 11 July 2007, Judgment, CFI, para 205

2155 Case T-256/07 People's Mohajedin Organization of Iran v Council of the European Union, 23 October 2008, Judgment, CFI ("PMOI I") at para 81 citing with approval Case T228/02 Organisation de Mohadjedines du peuple d'Iran $v$ Council of the European Union, 12 December 2006, Judgment, CFI (“OMPI”), paras 143-146 and 151 
it" 2156 and cited with approval the importance attributed to the review by the Court in OMPI. ${ }^{2157}$

Accordingly, what can be seen is that the judgments fiercely defend the right to an effective judicial review but appear to qualify this by the justified nondisclosure of security information in light of possible public security implications. It is only more recently, in Kadi II, that a stronger endorsement of the position taken by the ECtHR in $A v$ United Kingdom has come about. Indeed, in this regard, the ECtHR jurisprudence on this issue still has a vital influencing role to play in the Union sphere.

\subsubsection{Public Access to European Parliament, Council \& Commission Documents}

It is also worth noting that Regulation 1049/2001 regarding public access to European Parliament, Council and Commission documents is limited res personae to Union citizens and any natural or legal person residing or having its registered office in a Member State, with the institutions having a discretion to grant access to documents to those natural or legal persons who do not reside or do not have their registered office in a Member State. ${ }^{2158}$ It will be recalled that the right to remain contained in the Procedures Directive expressly does not constitute an entitlement to a residence permit. ${ }^{2159}$ Accordingly, it is questionable whether asylum seekers have the right to seek access to documents under this Regulation and which may otherwise prove particularly useful in circumstances where a Member State has furnished a Union institution with its documents. ${ }^{2160}$ That obstacle may, however, be circumvented by a Union citizen seeking that information on the asylum seeker's behalf ${ }^{2161}$ as there is no need to state reasons to access documents ${ }^{2162}$ (but noting that specific rules apply as regards access or refusal of access to confidential or sensitive documents ${ }^{2163}$ ).

2156 Case T-284/08 People's Mohajedin Organization of Iran v Council of the European Union, 4 December 2008, Judgment, CFI ("PMOI II") para 74 approving Case T-228/02 Organisation de Mohadjedines du peuple d'Iran $v$ Council of the European Union, 12 December 2006, Judgment, CFI (“OMPI”), para 154

2157 Case T-284/08 People's Mohajedin Organization of Iran v Council of the European Union, 4 December 2008, Judgment, CFI ("PMOI II") para 75 approving Case T-228/02 Organisation de Mohadjedines du peuple d'Iran $v$ Council of the European Union, 12 December 2006, Judgment, CFI (“OMPI”), para 155

2158 Article 2(1) and 2(2) of Regulation 1049/2001 regarding public access to European Parliament, Council and Commission documents. See generally, Craig, P, and de Búrca, G, EU Law, 5ed, 2011, OUP, Oxford, Pp.543-549

2159 Article 7(1) of the Procedures Directive

2160 See, for example, Case C-64/05 P Sweden v Commission of the European Communities and Others, 18 December 2007, Judgment, Grand Chamber

2161 See Peers, S, The New Regulation on Access to Documents: A Critical Analysis, 6/2002, The Queen's Papers on Europeanisation, http://www.qub.ac.uk/schools/SchoolofPolitics InternationalStudiesandPhilosophy/FileStore/EuropeanisationFiles/Filetoupload,38419,en.p df (last accessed 21 June 2012) at n.31-33 and accompanying text

2162 Article 6(1) of Regulation 1049/2001

2163 Article 4 and 9 of Regulation 1049/2001 


\subsubsection{The Court of Justice of the European Union - Jurisdiction}

The Lisbon Treaty removed the restrictions on the jurisdiction of the CJEU in visa, immigration and asylum matters ${ }^{2164}$ (that is, Chapter 2 of Title V TFEU) and would permit any court or tribunal to request the CJEU to give a preliminary ruling where "a decision on that question is necessary to enable it to give judgment" (Article 267 TFEU) as contemplated under the old Article 234 of the EC Treaty.

There is a limit to the Court's jurisdiction under Article 276 TFEU which provides that the Court has no jurisdiction to review the validity or proportionality of operations carried out by a Member State's police or law enforcement services or a Member State's responsibilities with regard to "the maintenance of law and order and the safeguarding of internal security". ${ }^{2165}$ Although Article 276 very specifically relates to Chapters 4 and 5 of Title V of Part Three of the TFEU, there should be vigilance by practitioners to ensure that that provision is not used by Member States to artificially conflate nonscreened-in asylum seekers as a threat to "the maintenance of law and order and the safeguarding of internal security" in order to evade the jurisdiction of the CJEU. Even if such an attempt were made, it is submitted that, at the very least, the ECHR and ECtHR would provide an important safeguard in that respect.

Prior to the coming into force of the Lisbon Treaty, in relation to the review of matters arising under Title IV EC (now Title V TFEU), the practical effect of the jurisdiction of the ECJ (as it was then called) provided a somewhat limited form of protection, which had led Jacobs to question the compatibility of Article 68EC with the ECHR and the EU Charter. ${ }^{2166}$ Even with the changes to the jurisdiction of the CJEU brought about by the Lisbon Treaty, it should be noted that, given the relationship between national courts and the

\footnotetext{
${ }^{2164}$ In relation to the Court's jurisdiction prior to the entry into force of the Lisbon Treaty see Peers, S, The Jurisdiction of the Court of Justice Over EC Immigration and Asylum Law: Time For a Change?, in Baldaccini, A, Guild, E, and Toner, H, (eds), Whose Freedom Security and Justice - EU Immigration and Asylum Law and Policy, 2007, Hart Publishing, Portland, Pp.85103; in relation to the Court's jurisdiction post-Lisbon, see Leczykiewicz, D, "Effective Judicial Protection" of human rights after Lisbon: should national courts be empowered to review EU secondary law? (2010) 35(3) ELRev 326

2165 Article 276 maintains the limitation of the CJEU's jurisdiction previously found in Article 35(5) of the (former) EU Treaty. In relation to Article 35(5) of the (former) EU Treaty, see Peers, S, EU Justice and Home Affairs Law, 3ed, 2011, OUP, Oxford, P.33; Craig, P. and de Búrca, G, EU Law, 4ed, 2008, OUP, Oxford, P.507

${ }^{2166}$ Jacobs, F, Effective Judicial Protection of Individuals in the European Union, Now and in the Future, in Andenas, M, and Usher, J (eds), The Treaty of Nice and Beyond, Enlargement and Constitutional Reform, 2003, Hart Publishing, Oxford, Pp.335-344 at P.343 accessed via Google Books at http://books.google.nl/books?id=Oeu3ZZqpqhIC\&printsec=frontcover $\& \mathrm{hl}=$ en\&source $=$ gbs_ge_summary_r\&cad $=0 \# \mathrm{v}=$ onepage\&q\&f$=$ false (last accessed 7 April 2011).
} 
CJEU, the ultimate power to release an asylum seeker from detention rests with the courts of the Member States. As Craig and de Búrca observe, the nature of the relationship between national courts and the CJEU is characterised as one of reference, not appeal (including no individual right of appeal) - a national court applies Union law after the case referred by it has been received back from the CJEU. ${ }^{2167}$

The CJEU also has at its disposal the urgent preliminary ruling procedure ("PPU"), which came into effect on 1 March $2008^{2168}$ and which is now further buttressed by Article 267 TFEU. The Court's Statute ${ }^{2169}$ and Rules of Procedure $^{2170}$ provide for the PPU procedure. Under Article 267 TFEU, the CJEU is required to act "with the minimum of delay" in cases involving those in custody. So far, in relation to detention under the current suite of secondary legislation considered herein, two cases have been the subject of a ruling under the PPU procedure. ${ }^{2171}$

\subsubsection{General Court of the European Union - Jurisdiction}

It should be noted that the General Court's jurisdiction is granted by Article 256(1) TFEU, and the Court has jurisdiction to hear the following actions: for an annulment; for a failure to act; for damages; those relating to Union employees; and those relating to arbitration clauses contained in a contract concluded by or on behalf of the Union. ${ }^{2172}$ Provision has been made for the General Court to hear preliminary rulings under Article 267 TFEU but no specific areas have yet been laid down in the Statute of the Court of Justice in this regard. ${ }^{2173}$ Appeal is possible from the General Court to the CJEU on

2167 Craig, P, and de Burca, G, EU Law, 2011, 5ed, Oxford University Press, Oxford, P.442. However, Craig \& de Búrca also observe that the original conception of a horizontal and bilateral relationship between national courts and the ECJ has transformed into the present reality of a vertical and multilateral relationship. The authors suggest that the ECJ sits at the top of the Union Law hierarchy, effectively acting as a constitutional court - see Pp. 443 and 482.

2168 The Court's Statute and Rules of Procedures were amended by [2008] OJ L 24, [2008] OJ L 42, [2008] OJ L 39. See also the statement at [2008] OJ L 44 and 2009 Information note on references from national courts for a preliminary ruling, OJ 2009 C 297/01 at paras 37 to 40; see also Barnard, C, The PPU: Is it worth the candle? An early assessment, (2009) 34 ELRev 281

${ }^{2169}$ Article 23a of the Statute of the Court of Justice of the European Union

2170 Article 104(b) of the Rules of Procedure of the Court of Justice

2171 Case C-357/09 PPU Kadzoev, Judgment Grand Chamber, 30 November 2009; Case C-61/11 PPU El Dridi, Judgment, 28 April 2011 both concerning detention under the Returns Directive

2172 Articles 263, 265 (note, however, in relations to matters under Articles 263 and 265 the reservations of particular matters to the CJEU by virtue of Article 51 of the Statute of the Court of Justice of the European Union), 268, 270 and 272 TFEU

2173 Article 256(3) TFEU, see also Craig, P and de Búrca, G, EU Law, OUP, Oxford, Pp.481-482 
points of law. ${ }^{2174}$ The Rules of Procedure of the General Court provide for the prioritisation of a case ${ }^{2175}$ as well as for proceedings to be expedited. ${ }^{2176}$

\subsubsection{Interim Measures}

The legal basis of the CJEU and the General Court to grant interim relief can be found in Articles 278 and 279 TFEU in matters that are raised directly before it. Notwithstanding that the bringing of an action in the Union courts does not result in automatic suspensive effect, the Court has the power so to order under Article 278 TFEU. ${ }^{2177}$ The TFEU provisions are buttressed by the Rules of Procedure of the Court of Justice ${ }^{2178}$ and of the General Court. ${ }^{2179}$ However, the courts of the Member States may also be obliged to order interim relief even where otherwise prohibited by national law, in order to protect Union rights and consistent with ensuring the "effectiveness of Community [now, Union] law". ${ }^{2180}$ Where interim relief is sought against a national measure that implements Union law, various factors are to be taken into account by the national Court in the granting of any interim relief. The conditions for granting interim relief were first set out in Zuckerfabrik ${ }^{2181}$ and later refined in Atlanta ${ }^{2182}$ and T. Port. ${ }^{2183}$ Tridimas helpfully observes that interim relief by a national court against a national measure implementing Union law can only be granted if the following conditions are met:

- "the court entertains serious doubts as to the validity of the Community act, and if the validity of the contested act is not already in issue before the Court of Justice, itself refers the question to the Court of Justice;

\footnotetext{
2174 Article 256(1) TFEU

2175 Article 55 of the Rules of Procedure of the General Court

2176 Article 76a of the Rules of Procedure of the General Court

2177 See generally in relation to interim measures in before the Union courts: Castillo de la Torre, F, Interim Measures in Community Courts: Recent Trends (2007) 44 CMLRev 273

2178 Rules 83-90 of the Rules of Procedure of the Court of Justice

2179 Rules 104-110 of the Rules of Procedure of the General Court, and Article 60 of the Statute of the Court of Justice of the European Union (an appeal to the CJEU does not have suspensory effect)

2180 Case C-213/89 The Queen v Secretary of State for Transport, ex parte Factortame Ltd \& Ors, Judgment, 19 June 1990, ("Factortame I") paras 21-22

2181 Case C-143/88 and C-92/89 Zuckerfabrik Süderdithmarschen AG v Hauptzollamt Itzehoe and Zuckerfabrik Soest GmbH v Hauptzollamt Paderborn, Judgment, 21 February 1991 at paras $23 \mathrm{ff}$

2182 Case C-465/93 Atlanta Fruchtandelsgesellschaft I $v$ Bundesamt für Ernährung und Forstwirtschaft, Judgment, 9 November 1995, paras 36, 37, 44 and 46

2183 Case C-68/95, T. Port GmbH v Bundesanstalt für Lanwirtschaft und Ernährung, Judgment, 26 November 1996. See also Cases C-453/03, C-11/04, C-12/04 and C-194/04 The Queen, on the application of ABNA Ltd and Others $v$ Secretary of State for Health and Food Standards Agency, Fratelli Martini \& C. SpA and Cargill Srl v Ministero delle Politiche Agricole e Forestali and Others, Ferrari Mangimi Srl and Associazione nazionale tra $i$ produttori di alimenti zootecnici (Assalzoo) v Ministero delle Politiche Agricole e Forestali and Others and Nederlandse Vereniging Diervoederindustrie (Nevedi) v Productschap Diervoeder, Judgment Grand Chamber, 6 December 2005 at paras 103-108
} 
- there is urgency, in that the interim relief is necessary to avoid serious and irreparable damage being caused to the party seeking such relief;

- the court takes due account of the Community interest; and

- $\quad$ in its assessment of all those conditions, it respects any decisions of the Court of Justice or the Court of First Instance ruling on the lawfulness of the regulation or on the application for interim measures seeking similar interim relief at the Community level.”2184

Further, national courts are required to grant interim relief irrespective of whether the applicant seeks that a national measure implementing Union law be suspended or "the grant of interim measures settling or regulating the disputed legal positions or relationships for [his or her] benefit". ${ }^{2185}$

\subsubsection{European Union Secondary Legislation}

\subsection{Detention where the Right to Remain Exists - Review \& Challenge of the} Detention Decision - Current Legislation

The current Reception Conditions Directive provides for appeal procedures for decisions taken under Article 7 of the Directive, which includes detention decisions (or "confinement" as it is described in the Directive ${ }^{2186}$ ), provided that the asylum seeker is "individually affected" (that is, that it does not relate to the general or systematic withdrawal of conditions or other decisions made under Article 7). ${ }^{2187}$ Member States are required to ensure that appeal procedures are laid down in national law. Member States are also to ensure that, at least in the last instance, the possibility for review or appeal before a judicial body. Notwithstanding that guarantee, the review or appeal of decisions up to the last instance may be before administrative bodies - nor is there any guarantee that, in those circumstances, the reviewing authority be independent of the detaining authority. Although protection may be afforded by the ECHR and Article 47 of the EU Charter, there is no express provision made for periodic judicial review of the detention decision.

Detention where the Right to Remain Exists - Review \& Challenge of the Detention Decision - The Proposed Legislation

The Commission's 2011 Proposed Reception Conditions Directive

The Commission's 2011 Proposed Reception Conditions Directive makes more express provision for the review of detention decisions and provides for judicial oversight of the detention decision. Detention may be ordered by judicial or administrative authorities ${ }^{2188}$ - a retrograde step from the Commission's 2008 Proposed Reception Conditions Directive which (1)

2184 Tridimas, T, The General Principles of EU Law, 2ed, 2006, OUP, Oxford, P.476; see also Craig, P, and de Burca, G, EU Law, 2008, 4ed, Oxford University Press, Oxford, P.472;

2185 Case C-465/93 Atlanta Fruchtandelsgesellschaft I $v$ Bundesamt für Ernährung und Forstwirtschaft, Judgment, 9 November 1995, para 28

2186 Article 7(3) of the Reception Conditions Directive

2187 Article 21(1) of the Reception Conditions Directive

2188 Article 9(2) of the Commission's 2011 Proposed Reception Conditions Directive 
required that detention be judicially ordered; (2) only provided for ordering by administrative authorities in "urgent cases"; and (3) in those "urgent cases", detention had to be subsequently confirmed by judicial authorities within 72 hours from the beginning of detention. ${ }^{2189}$ Under the Commission's 2011 Proposal, detention must be ordered by judicial authorities within 72 hours where the detention has been ordered by an administrative authority. ${ }^{2190}$ If there is no decision within 72 hours, or the detention is found to be unlawful by the judicial authority, the asylum seeker must be immediately released. ${ }^{2191}$

The Commission's 2011 Proposal also provides for the judicial review of the detention of an asylum seeker "at reasonable intervals of time". ${ }^{2192}$ Such reviews may be done ex officio or at the request of the asylum seeker. ECRE notes that protection for asylum seekers should be enhanced by providing for the review ex officio and at the request of the asylum seeker, rather than be expressed as an alternative in that Proposal. ${ }^{2193}$ The 2011 Proposal also identifies detention of a "prolonged duration" or where "relevant circumstances arise or new information becomes available which may affect the lawfulness of detention" as particular circumstances requiring judicial review. That provision of the Recast Proposal largely reflects the minimum standards imposed by Article 5(4) ECHR.

\section{Council's Amended Proposed Reception Conditions Directive}

There are two significant changes to the provision of review of a detention decision proposed by the Council. Firstly, the requirement of judicial confirmation of the detention decision is not to be within "72 hours" but rather "within 3 working days". That can result in a considerably longer period of detention for those detained on Fridays or on or over public holidays, and does not pay sufficient heed to the obiter comments in Shamsa which referred to detention of "several days" not 'several working days'. The second amendment is indeed a positive one as advocated by ECRE - that is, that judicial review of a detention decision is now both ex officio and on the request of an asylum seeker.

\subsection{Detention where the Right to Remain is Lost - Review \& Challenge of the} Detention Decision - Current Legislation

\footnotetext{
2189 Article 9(2) of the Commission's 2008 Proposed Reception Conditions Directive 2190 Article 9(2) of the Commission's 2011 Proposed Reception Conditions Directive 2191 Article 9(2) of the Commission's 2011 Proposed Reception Conditions Directive 2192 Article 9(4) of the Commission's 2011 Proposed Reception Conditions Directive 2193 ECRE, Comments from the European Council on Refugees and Exiles on the Amended Commission Proposal to recast the Reception Conditions Directive (COM(2011) 320 final), September 2011, Brussels, http://www.ecre.org/component/content/article/57-policypapers/253-ecre-comments-and-recommendations-on-the-amended-commission-proposalto-recast-the-reception-conditions-directive-com2011-320-final.html (last accessed 14 November 2011), P.12
} 
The current Procedures Directive requires Member States to ensure that asylum seekers held in detention have the right to speedy judicial review. ${ }^{2194}$ The language mimics that of Article 5(4) ECHR but the Directive is otherwise silent on making express provisions for the review of detention decisions. Indeed, the right to an effective remedy contemplated in Article 39 of the Directive does not include detention as one of the circumstances giving rise to such a right.

Detention where the Right to Remain is Lost-Review \& Challenge of the Detention Decision - The Proposed Legislation

Commission's Recast Proposed Procedures Directive

As indicated earlier, the Commission's Recast Proposed Procedures Directive refers to the Reception Conditions Directive as regards conditions, grounds, guarantees, ${ }^{2195}$ and speedy judicial review. ${ }^{2196}$ Accordingly, the preceding analysis of the Reception Conditions Directive and its Proposals is relevant in these circumstances.

Detention where the Right to Remain is Lost-Review \& Challenge of the Detention Decision - The Returns Directive

Under the Returns Directive detention can be ordered by either a judicial or administrative authority. ${ }^{2197}$ Where detention is ordered by an administrative authority, Member States must provide the detained person with one of two possibilities: firstly, the asylum seeker is entitled to have "speedy judicial review of the lawfulness of the detention" with the decision "as speedily as possible from the beginning of detention". ${ }^{2198}$ Secondly, and in the alternate, a person can initiate his or her own proceedings for a speedy judicial review of the lawfulness of his or her detention, "to be decided on as speedily as possible" after the initiation of proceedings. ${ }^{2199}$ In that latter circumstance, the Member State must immediately inform the person of their right to take such proceedings. ${ }^{2200}$ If detention is ultimately unlawful, then the person must be released. ${ }^{2201}$ However, there is no safety provision as in the current suite of Proposals, which provides for the release of a detained person if no decision is made within a stipulated time period.

The detained person is entitled to have their detention "reviewed at reasonable intervals of time" either ex officio or on their own application. ${ }^{2202}$ The precise nature of "reviewed" is unclear - that is, whether it is judicial or

\footnotetext{
2194 Article 18(2) of the Procedures Directive

2195 Article 26(1) of the Commission's 2011 Proposed Reception Conditions Directive

2196 Article 26(2) of the Commission's 2011 Proposed Reception Conditions Directive

2197 Article 15(2) of the Returns Directive

2198 Article 15(2)(a) of the Returns Directive

2199 Article 15(2)(b) of the Returns Directive

2200 Article 15(2)(b) of the Returns Directive

${ }^{2201}$ Article 15(2), last paragraph, of the Returns Directive

2202 Article 15(3) of the Returns Directive
} 
administrative. "Prolonged detention periods" are to be subject to judicial review. ${ }^{2203}$ It is unclear from the construction of Article 15(3) whether a distinction is to be made between periodic review generally, and periodic review in the case of prolonged detention, as regards the identity of the reviewer (that is, it is unclear whether judicial review is only reserved in circumstances of prolonged detention). It is arguable that Article 5(4) ECHR and Article 47 of the EU Charter would provide sufficient protection to ensure judicial review in those circumstances, but the rights of detained persons are better protected by express provision on that issue.

What is most disturbing about the Returns Directive is the ability for Member States to derogate from those timeframes in circumstances where "exceptionally large numbers of third-country nationals" are to be returned and place an "unforeseen heavy burden" on detention facilities, administrative or judicial staff. ${ }^{2204}$ It is arguable that emergency situations should not justify a derogation of rights in this way, particularly in light of the ECtHR's judgment in MSS.

\subsection{Detention in a Member State Other Than That of First Entry or Asylum -} Review \& Challenge of the Detention Decision - Current Legislation

As indicated previously, the current Dublin II Regulation is silent on the issue of detention for the purposes of transfer to a responsible Member State. Accordingly, it is arguable that, in those circumstances, Member States are required to provide a level of protection contemplated by Article 5(4) ECHR as well as Article 9(4) ICCPR.

Detention in a Member State Other Than That of First Entry or Asylum - The Proposed Legislation

The Commission's Proposed Dublin II Regulation, in its preamble, does make express reference to Article 47 of the EU Charter as regards "legal safeguards and the right to an effective remedy" in relation to decisions to transfer a person to a responsible Member State. ${ }^{2205}$ Further, the right to "the effective remedy" as contemplated by the ECtHR is also expressly provided for in relation to "the examination of the application of this Regulation and of the legal and factual situation in the Member State to which the applicant is transferred". 2206 The wording of both recitals tends to suggest that only decisions regarding transfers are expressly contemplated by the recitals as being susceptible to an effective remedy in accordance with ECtHR caselaw. Notwithstanding that those recitals are not legally binding, it would be advisable to expressly include detention within the scope of the protection that those recitals seek to ensure.

\footnotetext{
2203 Article 15(3) of the Returns Directive

2204 Article 18(1) of the Returns Directive

2205 Recital 16 of the Commission's Proposed Dublin Regulation

2206 Recital 17 of the Commission's Proposed Dublin Regulation
} 
The substantive provisions concerning the review of detention decisions mimic the Commission's 2008 Proposed Reception Conditions. ${ }^{2207}$ Accordingly, detention must be judicially ordered with ordering by administrative authorities only in "urgent cases". ${ }^{2208}$ Where detention is ordered by administrative authorities, it must be judicially confirmed within 72 hours from the commencement of detention. ${ }^{2209}$ Where detention is found to be unlawful, the detained person is to be immediately released. ${ }^{2210}$

Regarding the periodic review of detention, the Proposed Regulation provides that "continued detention" is to be judicially reviewed "at reasonable periods of time" either ex officio or at the request of the detained person. ${ }^{2211}$ The UNHCR has suggested that the proposed provision be amended (by removing "continued") to reflect its understanding that "continued detention" is inclusive of both "the legality of the detention during the initial period for which detention has been ordered and its prolongation." 2212 Further the UNHCR also suggested that the express provision should be made for the judicial review of a detention decision "whenever new circumstances arise or new information becomes available which affects the lawfulness of the detention", 2213 which an almost identical provision has been adopted in the Proposed Reception Conditions Directive. ${ }^{2214}$ It is worth re-emphasising ECRE's comments regarding the similar provision in the 2011 Proposed Reception Conditions Directive in that protection should be heightened for asylum seekers by providing for judicial review both ex officio and at the request of the asylum seeker. ${ }^{2215}$

\title{
6.3.3.7.4 Security-Related Information \& Detention Current Legislation
}

\begin{abstract}
${ }^{2207}$ See Article 9(2) of the Commission's 2008 Proposed Reception Conditions Directive 2208 Article 27(6) of the Commission's Proposed Dublin Regulation 2209 Article 27(6) of the Commission's Proposed Dublin Regulation 2210 Article 27(6) of the Commission's Proposed Dublin Regulation 2211 Article 27(8) of the Commission's Proposed Dublin Regulation

2212 UNHCR, UNHCR Comments on the European Commission's Proposal for a recast of the Directive laying down minimum standards for the reception of asylum seekers (COM(2008)815 final of 3 December 2008), 13 March 2009, http://www.unhcr.org/refworld /docid/49ba8a192.html (last accessed 14 November 2011) at Pp.18-19

2213 UNHCR, UNHCR Comments on the European Commission's Proposal for a recast of the Directive laying down minimum standards for the reception of asylum seekers (COM(2008)815 final of 3 December 2008), 13 March 2009, http://www.unhcr.org/refworld/ docid/49ba8a192.html (last accessed 14 November 2011) at Pp.18-19

2214 Article 9(4) of the Commission's 2011 Proposed Reception Conditions Directive and Article 9(4) of the Council's Amended Proposed Reception Conditions Directive

2215 ECRE, Comments from the European Council on Refugees and Exiles on the Amended Commission Proposal to recast the Reception Conditions Directive (COM(2011) 320 final), September 2011, Brussels, http://www.ecre.org/component/content/article/57-policypapers/253-ecre-comments-and-recommendations-on-the-amended-commission-proposalto-recast-the-reception-conditions-directive-com2011-320-final.html (last accessed 14 November 2011), P.12
\end{abstract}


The Procedures Directive provides that legal advisers or counsellors are to "enjoy access to such information in the applicant's file as is liable to be examined by the authorities referred to in Chapter $\mathrm{V}$ [that is, a court or tribunal from whom an effective remedy is sought], insofar as the information is relevant to the examination of the application". ${ }^{2216}$ On a narrow construction, it would appear that that right of access to information and sources is limited to the application for asylum, not necessarily for any detention-related decision. That qualification is of concern because securityrelated information or sources directed towards an asylum seeker's application may also be used to support a detention decision based on security grounds.

Legal advisers or counsellors may be refused access to information and sources. Further, although the Directive provides that access to such information or sources must be available to the authorities referred to in Chapter V of the Directive, it is quickly qualified by "except where such access is precluded in cases of national security". 2217

The bases for the non-disclosure of information and sources to legal advisers or counsellors are where: (1) "national security, the security of the organisations or person(s) providing the information or the security of the person(s) to whom the information relates" would be jeopardised; (2) "investigative interests relating to the examination of applications of asylum by the competent authorities of the Member States" would be compromised; or (3) or the international relations of the Member States" would be compromised. ${ }^{2218}$

There are two significant issues to note. Firstly, the provisions would appear to provide a blanket refusal of access to evidence to legal advisers or counsellors such that the right to an effective legal remedy would be practically undermined because the applicant, through his/her legal counsel, would be unable to assess the evidence against him or herself. Indeed, the provisions are not consistent with the jurisprudence of the ECtHR as enunciated in $A v$ United Kingdom (and endorsed by the General Court in Kadi II) or even the CJEU's own dicta in Kadi I concerning the balancing of security interests as against the fundamental rights of the person concerned. Secondly, the provisions would also appear to amount to a blanket denial of security-related information to a court or tribunal wherever national security could be invoked, thus potentially leading to a complete denial of an effective remedy. There is no subtlety in the provisions such as to ensure that the applicant has an effective legal remedy at hand for testing the basis of any security-related assertions. Indeed, the provisions do not provide for security-cleared counsel, or the provision of information to a specialised security court or tribunal such

\footnotetext{
2216 Article 16(1), first paragraph, of the Procedures Directive

2217 Article 16(1), second paragraph, of the Procedures Directive

2218 Article 16(1), second paragraph, of the Procedures Directive
} 
that the basis of the assertions could be effectively tested. Thirdly, due to such security-related information being used in both the substantive application for asylum as well as any detention order for an asylum seeker, the provisions (both the rights to information and the qualification of those rights) would arguably appear to relate only to the application for asylum and are of questionable application in a detention context. Finally, it will be recalled that these provisions fall within the range of procedures from which a Member State may derogate as regards border applicants. ${ }^{2219}$

\section{Security-Related Information \& Detention - The Proposed Legislation}

The Commission's 2011 Procedures Directive represents a significant upgrading of rights as regards access to security-related information and sources.

The bases for the denial of access of security-related information and sources remains substantively the same under the Proposed Procedures Directive as under the current Procedures Directive. ${ }^{2220}$

The first innovation under the Proposed Directive is that security-related information and sources may be provided to security-checked legal advisors or counsellors or "at least, to specialised services of the State that are allowed under national law to represent the applicant for this specific purpose". However, the disclosure of that information would appear to be for the purpose of the asylum application as the ultimate part of the paragraph states "insofar as the information is relevant to the examination of the application or taking a decision to withdraw international protection". That is, those provisions would appear to be excluded from a detention context. ${ }^{221}$

The second innovation is that access to security-related information and sources must be made to the authorities referred to in Chapter V of the Directive without any qualification (that is, the national security exception has been deleted $)^{2222}$ and which would provide a greater safeguard of the right to an effective remedy in combination with the disclosure of such information or sources through the applicant's legal counsel.

In light of security-related information and sources being used both for a substantive application for international protection (or its withdrawal) as well as to support any decision to detain a person on security grounds, it is submitted that the Proposed Procedures Directive be amended such that the provision of security-related information and sources not be confined only to the application for international protection (or its withdrawal) but expressly

\footnotetext{
${ }^{2219}$ See Articles 24(1)(b) and Article 35 of the Procedures Directive and Chapter 5 herein 2220 Article 23(1), second paragraph, of the Commission's 2011 Proposed Procedures Directive

2221 Article 23(1)(a) of the Commission's 2011 Proposed Procedures Directive

2222 Article 23(1)(b) of the Commission's 2011 Proposed Procedures Directive
} 
includes detention as well. Ideally, such provisions should be incorporated expressly in the Reception Conditions Directive. The ECtHR jurisprudence, particularly $A v$ United Kingdom, as well as the Union's own jurisprudence in Kadi I, Kadi II and OMPI/PMOI, cases should be fully embraced to ensure that access to an effective legal remedy is not denied in these circumstances.

\subsubsection{Review \& Challenge of the Detention Decision - Australia}

On 29 July 2009, the then Australian Minister for Immigration and Citizenship, Chris Evans, stated that, as one of the Government's seven key immigration detention values:

"Detention that is indefinite or otherwise arbitrary is not acceptable and the length and conditions of detention, including the appropriateness of both the accommodation and the services provided would be subject to regular review"2223

The prospects for, and scope of, judicial review, however, remain extremely limited.

Under section $75(\mathrm{v})$ of the Australian Constitution, the High Court of Australia has original jurisdiction for judicial review in "all matters [...] in which a writ of mandamus ${ }^{2224}$ or prohibition ${ }^{2225}$ or an injunction ${ }^{2226}$ is sought against an officer of the Commonwealth". Habeas corpus, ${ }^{2227}$ quo warranto, ${ }^{2228}$ and certiorari $^{2229}$ are also writs that may be sought from, and granted by, the

${ }^{2223}$ Evans, Senator Chris, Australian Minister for Immigration and Citizenship, speech to the Australian National University in Canberra, 29 July 2008, New Directions in DetentionRestoring Integrity to Australia's Immigration System http://www.nswbar.asn.au/ circulars/july/evans2.pdf (last accessed 15 November 2011); see also DIAC, Managing Australia's Borders, Detention, About Immigration Detention, Key Immigration Detention Values, http://www.immi.gov.au/managing-australias-borders/detention/about/keyvalues.htm (last accessed 15 November 2011)

2224 Mandamus is a court order to a person or body to carry out a public duty. See further, Aronson, M, Dyer, B, and Groves, M, Judicial Review of Administrative Action, 4ed, 2009, Lawbook Co, Pyrmont, Ch.13

2225 Prohibition is relief restraining a decision-maker from action or continuing action. See further, Aronson, M, Dyer, B, and Groves, M, Judicial Review of Administrative Action, 4ed, 2009, Lawbook Co, Pyrmont, Ch.12 (together with relief in the form of certiorari)

2226 Injunctive relief can be used to judicially restrain or compel certain action. See further, Aronson, M, Dyer, B, and Groves, M, Judicial Review of Administrative Action, 4ed, 2009, Lawbook Co, Pyrmont, Ch.16

2227 Rule 25.09 of the High Court Rules 2004; see further, Aronson, M, Dyer, B, and Groves, M, Judicial Review of Administrative Action, 4ed, 2009, Lawbook Co, Pyrmont, Ch.14

2228 Rule 25.14 of the High Court Rules 2004; which may be used to challenge the authority of a person to decide a matter

2229 Certiorari is relief firstly, to compel the removal of an official record made by an inferior court, tribunal or authority into a superior court for it to review and, secondly, to quash an order. See Aitken, LJW, The High Court's Power to Grant Certiorari - the Unresolved Question, 
High Court. The Federal Magistrate's Court and the Federal Court of Australia also have jurisdiction in relation to certain migration matters as governed by Part 8 of the Migration Act.

The scope of judicial review is for the court not to substitute its decision for that of the primary decision maker (that is, for a full merits review) but rather for the court to ensure that the decision maker has interpreted and applied the law correctly. ${ }^{2230}$

In Crock and Berg's assessment, the widening of avenues for judicial review of administrative (and thus including migration) decisions led to a type of merits review by stealth due to the courts' keenness to accept relevancy and reasonableness as a ground for review. The legislative reaction to that approach was to intensely codify decision-making provisions under the Migration Act, to introduce non-compellable and non-reviewable discretions of the Minister, to curtail migration decisions that otherwise fell under the jurisdiction of the Federal Court (but not the High Court of Australia with its constitutionally entrenched original jurisdiction under section $75(\mathrm{v})$ ), to subjectify decision-making to the satisfaction of the decision maker rather than objectify decision-making by reference to the applicant and, most recently, to introduce the "privative clause". The curial response has been a mixture of deference to the legislature and the protection of judicial review. ${ }^{2231}$

A privative clause decision is deemed final and conclusive, non-justiciable before any court and is not to be subject to other forms of relief (such as prohibition, mandamus, injunction, declaration or certiorari) on any account. ${ }^{2232}$

A decision to detain an unlawful non-citizen is an administrative decision under the Migration Act. A decision under section 189 of the Act is classified as a "privative clause decision". 2233

The constitutional validity of the privative clause was tested in the case of S157 where the High Court of Australia upheld its constitutional validity but also held that the clause did not apply to circumstances where a decision resulted from jurisdictional error (and breach of the principles of natural justice). ${ }^{2234}$ Although the general failure of the purpose of the privative clause

(1986) 16(4) Federal Law Review 370; and Aronson, M, Dyer, B, and Groves, M, Judicial Review of Administrative Action, 4ed, 2009, Lawbook Co, Pyrmont, Ch.12 (with prohibition) 2230 Minister for Aboriginal Affairs v Peko Wallsend Ltd [1986] HCA 40 per Mason J at para $15(\mathrm{~d})$

2231 Crock, M, and Berg, L, Immigration, Refugees and Forced Migration - Law Policy and Practice in Australia, 2011, Federation Press, Leichhardt, Pp.615-645

2232 Section 474 of the Migration Act 1958 (Cth)

2233 See also Crock, M, Saul, B, and Dastyari, A, Future Seekers II, 2006, Federation Press, at P.159

2234 Plaintiff S157/2002 v Commonwealth [2003] HCA 2 per Gaudron, McHugh, Gummow, Kirby and Hayne JJ at paras 76-77 and 83; See further, Beaton-Wells, C, Judicial Review of 
has been acknowledged, ${ }^{2235}$ determining jurisdictional error remains a delicate and complex process. ${ }^{2236}$

Judicial challenges to detention decisions have resulted in a very formalistic approach concerned with whether the detention is in compliance with the Migration Act and the Australian Constitution - that is, a full merits review of the necessity of the detention on an individual basis (distinct from their status as constitutional aliens) or compliance with international standards, has not occurred. Only formal compliance with domestic law is assessed - that is, is the person an unlawful non-citizen or reasonably suspected of being so. Rather, the High Court of Australia has held that indefinite detention is lawful under the Migration Act even where there is no real likelihood of removal to another country, ${ }^{2237}$ where the conditions of detention are so deplorable they arguably amounted to punishment, ${ }^{2238}$ or even regarding the detention of minors. ${ }^{2239}$ Accordingly, an assessment of the proportionality and necessity of detention based on the individual circumstances of the case are not (indeed, cannot be) taken into account. ${ }^{2240}$ Assessments have focussed largely on whether the person was an "unlawful non-citizen". Challenges may also be possible on the basis of whether a "reasonable suspicion" of the person being an unlawful non-citizen was formed by the detaining officer (as contemplated under section 189 of the Act). ${ }^{2241}$

Migration Decisions: Life After S157, (2005) 33 Federal Law Review 141; Beaton-Wells, Australian administrative law: the asylum-seeker legacy, [2005] Public Law 267; Campbell, E, and Groves, M, Privative Clauses and the Australian Constitution (2004) 4 Oxford University Commonwealth Law Review Journal 51

2235 Beaton-Wells, C, Judicial Review of Migration Decisions: Life After S157, (2005) 33 Federal Law Review 141 at 173

2236 Crock, M, and Berg, L, Immigration, Refugees and Forced Migration - Law Policy and Practice in Australia, 2011, Federation Press, Leichhardt, Pp.645-647; for the categories of jurisdictional error see and Aronson, M, Dyer, B, and Groves, M, Judicial Review of Administrative Action, 4ed, 2009, Lawbook Co, Pyrmont, Pp.14-15. See also Kirk, J. K., The Concept of Jurisdictional Error, paper delivered at Continuing Professional Development seminar for the New South Wales Bar Association, 30 May 2012 (copy held on file by author)

2237 Al Kateb v Godwin [2004] HCA 37; Minister for Immigration and Multicultural and Indigenous and Affairs $v$ Al Khafaji $v$ [2004] HCA 38

2238 Behrooz v Secretary, Department of Immigration and Multicultural and Indigenous Affairs [2004] HCA 36

2239 Re Woolley; Ex parte Applicants M276/2003 [2004] HCA 49. The approach in Woolley has been largely subsequently followed by the High Court in M168/2010 By His Litigation Guardian Sister Brigid (Marie) Arthur \& Ors v Commonwealth of Australia \& Anor [2011] HCATrans 1 (19 January 2011) and M168/2010 By His Litigation Guardian Sister Brigid (Marie) Arthur \& Ors v Commonwealth of Australia \& Anor [2011] HCATrans 4 (24 January 2011) before Crennan J

2240 See Al-Kateb $v$ Godwin [2004] HCA 37 per Gleeson CJ at 12, per McHugh J at 41-49

${ }_{2241}$ Goldie v Commonwealth [2002] FCAFC 10; Ruddock v Taylor [2005] HCA 48 at paras $27-28$ 
Those series of decisions compare poorly to the active consideration of international obligations on the construction of the Migration Act in the $A l$ Masri case previously decided Full Court of the Federal Court of Australia. ${ }^{2242}$

Detention is not judicially ordered or reviewed after an officer has detained an unlawful non-citizen. Nor is there any provision for periodic judicial review.

Further, even if the scope of the court's assessment were to embrace the international standard, a court is expressly prohibited from releasing an unlawful non-citizen from detention unless he or she has a visa, ${ }^{2243}$ provided that he or she is otherwise lawfully detained. ${ }^{2244} \mathrm{~A}$ person is unable to be released from detention unless he or she is removed, deported or granted a visa. ${ }^{2245}$ It is arguable that persons can be released temporarily from detention by way of interlocutory orders (that is, pending final judgment), ${ }^{2246}$ but Crock and Berg note that "the circumstances in which release from detention may be sought have been narrowed considerably" since the High Court decisions in Al Kateb, Al Khafaji and Re Woolley. ${ }^{2247}$

Accordingly, the HRC in its Views has regarded the Australian approach to judicial review of a detention decision under the Migration Act as not fulfilling the standards required by Article 9(4) ICCPR. ${ }^{2248}$

For those offshore entry persons destined for offshore processing in another country, they are legislatively precluded from even challenging the legality of their status as an offshore entry person, their detention at all, or any exercise of

2242 Minister for Immigration and Multicultural Affairs v Al Masri [2003]FCAFC 70 at paras 138155

2243 Section 196(3) of the Migration Act 1958 (Cth)

${ }^{2244}$ Lim v Minister for Immigration, Local Government and Ethnic Affairs (1992) 176 CLR 1 at 35-36 per Brennan, Deane and Dawson JJ (Gaudron J in agreement); see also Justice North, AM, and Decle, P., Courts and immigration detention: The Australian experience (2002) 10 AJ Admin L 5, P.14-15

2245 Section 196(1) of the Migration Act 1958 (Cth)

2246 Minister for Immigration and Multicultural and Indigenous Affairs v VFAD of 2002 [2002] FCAFC 390

2247 Crock, M, and Berg, L, Immigration, Refugees and Forced Migration - Law Policy and Practice in Australia, 2011, Federation Press, Leichhardt, P.509

$2248 A v$ Australia UNHRC Communication No. 560/1993, UN Doc. CCPR/C/59/D/560/1993, 30 April 1997, para 9.5; C $v$ Australia, UNHRC, Communication 90/1999, UN Doc CCPR/C/76/D/900/1999, 28 October 2002 at para 7.4; Baban $v$ Australia, UNHRC Communication No. 1014/2001, UN Doc. CCPR/C/78/D/1014/2001, 6 August 2003, para 7.2; Shafiq v Australia, UNHRC, Communication No. 1324/2004, UN Doc. CCPR/C/88/D/1324/2004, 13 November 2006, para 7.4; Shams et al v Australia, UNHRC, Communication Nos. 1255, 1256, 1259 , 1260, 1268, 1270, 1288/2004, UN Doc CCPR/C/90/D/1255, 1256, 1259, 1260, 1266, 1268, 1270 \& 1288/2004, 11 September 2007, para 7.3; see also, Stubbs, M, Arbitrary Detention in Australia: Detention of Unlawful Non-Citizens under the Migration Act 1958 (Cth) (2006) 25 Australian Yearbook of International Law 273 
power to take them to another country in any Court (with the exception of the High Court of Australia due to its original jurisdiction under section 75 of the Constitution). ${ }^{2249}$ Those persons' rights are not only significantly breached, but also are legislatively taken out of the judicial searchlights (save for the High Court of Australia).

\subsubsection{Australia - Challenges to Prolonged Detention - Security Assessments}

As discussed in Chapter 5, notwithstanding that a person is found to be a refugee (and, consequently, that Australia owes protection obligations to that person), that person still needs to satisfy the Public Interest Criteria (PIC) 4002 in order to be granted a Protection Visa.

The Australian Security Intelligence Organisation ("ASIO”) is responsible for conducting those security assessments. ${ }^{2250}$

Although there is no legislative requirement so to do, those asylum seekers who are in detention are detained pending the outcome of their security clearance and whose security assessment is not commenced until after they have been found to be a refugee. ${ }^{2251}$ As indicated in Chapter 5, as there are no legislative time limits imposed for the outcome of an assessment, this has led to prolonged periods of detention pending an assessment. Further, detention has been particularly prolonged where a negative assessment has been given.

In contradistinction to Australian citizens, permanent visa holders, and special category visa holders, asylum seekers (who almost entirely do not fall within those categories) are legislatively excluded from being notified of the grounds of their adverse security assessment ${ }^{2252}$ and from seeking a merits review of their adverse security assessment in the Administrative Appeals Tribunal (“AAT”), ${ }^{2253}$ notwithstanding that a Security Appeal Division already exists as part of the AAT. ${ }^{2254}$ Submissions filed on behalf of the Gilbert + Tobin Centre of Public Law to the Joint Select Committee on Immigration Detention have recommended that the Security Division of the AAT be used for such assessments, to be made possible by amending the ASIO Act to allow

\footnotetext{
${ }^{2249}$ Section 494AA(1) of the Migration Act 1958 (Cth)

2250 ASIO is established under the Australian Security Intelligence Organisation Act 1979 (Cth)

2251 AHRC, Independent Review of the Intelligence Community - Australian Human Rights Commission Submission, April 2011, Sydney, http://www.hreoc.gov.au/legal/submissions /2011/20110431_intelligence.pdf (last accessed 16 November 2011) P.3; see also McLeod, S, Refugees challenge ASIO risk assessment, ABC News, 20 January 2011, http://www.abc.net.au/news/2011-01-20/refugees-challenge-asio-risk-

assessment/1912678 (last accessed 16 November 2011)

2252 Section 36 of the Australian Security Intelligence Organisation Act 1979 (Cth) precludes the grounds of the security assessment normally required to be given under section 37 of the Act

2253 Section 36 of the Australian Security Intelligence Organisation Act 1979 (Cth) precludes the review by the AAT normally provided under section 54 of the Act ${ }^{2254}$ Section 21AA of the Administrative Appeals Tribunal Act 1975 (Cth)
} 
such appeals by asylum seekers. ${ }^{2255}$ The High Court of Australia has reserved its judgment on a challenge by detained asylum seekers who have been granted refugee status but have been given an adverse security assessment by ASIO. ${ }^{2256}$

The absence of furnishing the grounds of an adverse security assessment has three significant consequences: firstly, without any such reasons, it is virtually impossible for an asylum seeker to identify any jurisdictional error for the purpose of judicial review; secondly, even if compelled by an order for discovery, ASIO can refuse to furnish the detained asylum seeker with any information relating to their adverse security assessment on the grounds of public interest immunity; and thirdly, no jurisdictional error stems from the refusal to furnish sensitive security information. Accordingly, as the AHRC has noted in its summary of the current legal position in Australia, there is no effective way to judicially challenge an adverse security assessment, thus resulting in prolonged detention:

"There is very little practical opportunity for substantive judicial review of adverse
security assessments. Although the High Court of Australia has held that ASIO
decisions are subject to judicial review,2257 the ability of ASIO to withhold from an
applicant and the court the information on which it has relied means that
challenging that information is virtually impossible. The case of Parkin $v$ O'Sullivan
is illustrative of this difficulty. 2258 Although an order of discovery was made against
ASIO, production of the relevant documents was refused on the basis that it would
prejudice national security and would be contrary to the public interest. 2259
Accordingly, none of the relevant documents was admitted into evidence for the
substantial hearing. In Sagar $v$ O'Sullivan, Justice Tracey found that 'in some rare
cases, such as the present, no jurisdictional error is made if sensitive security
information is withheld from an applicant and the applicant is not, as a result,
alerted to prejudicial material on which the information has been based'. 2260
Consequently, the practical difficulties in obtaining the necessary evidence and the
restricted scope of procedural fairness in the context of security assessments by

2255 Gilbert + Tobin Centre of Public Law, Faculty of Law, University of New South Wales, submission to the Joint Select Committee on Immigration Detention, Annexure 1, 7 November 2011, https://senate.aph.gov.au/submissions/comittees/viewdocument.aspx ?id=018ca141-39cc-4350-985f-db4dcf3b900a, (last accessed 9 November 2011), Pp.2-3

2256 Plaintiff M47/2012 v Director General of Security \& Ors; Plaintiff S138/2012 v Australian Security and Intelligence Organisation [2012]; Gordon, M, Lawyers disagree over Bowen's role, Sydney Morning Herald, 22 June 2012, http://www.smh.com.au/opinion/politicalnews/lawyers-disagree-over-bowens-role-20120621-20qyr.html (last accessed 25 June 2012)

2257 Church of Scientology Inc v Woodward (1982) 154 CLR 25 [alternative citation [1982] HCA 78 - see particularly para 16 per Brennan J]

2258 Parkin v O'Sullivan [2006] FCA 1413; O'Sullivan v Parkin [2006] FCA 1654; O'Sullivan v Parkin [2007] FCAFC 98; O'Sullivan v Parkin [sic Parkin v O'Sullivan] [2007] FCA 1647; O'Sullivan v Parkin [2008] FCR 283 [sic (2008) 169 FCR 283; [2008] FCAFC 134] ; Parkin $v$ O'Sullivan (2009) 260 ALR 503.

2259 Parkin v O'Sullivan (2009) 260 ALR 503; [2009] FCA 1096

2260 Sagar $v$ O'Sullivan [2011] FCA 182 at 73 
ASIO as interpreted by Australian courts make judicial review an ineffective appeal avenue."2261

A Communication under the First Optional Protocol to the ICCPR has been made to the HRC in relation to those rescued on the MV Oceanic Viking (see Chapter 3) concerning these very issues. The eloquent and erudite submissions of Professor Saul on behalf of the authors also identify that, even if judicial review proceedings were to be commenced, any procedural fairness afforded to the authors is virtually non-existent as identified in the Federal Court of Australia case of Leghaei v Director General of Security ${ }^{2262}$ (having been upheld by the Full Court of the Federal Court on appeal $\left.{ }^{2263}\right) .{ }^{2264}$ Professor Saul's submissions summarise the Australian position as follows (citations included):

“(a) Persons who are not Australian citizens or permanent residents are statutorily precluded from receiving notification of, a statement of reasons for, or a right to review of, or procedural fairness in respect of, the issue of adverse security assessments under the ASIO Act; 2265

(b) The common law still provides a degree of procedural fairness to such persons. However, there is only a duty to afford 'such degree of procedural fairness as the circumstances could bear, consistent with a lack of prejudice to national security';2266

(c) That obligation will be 'discharged by evidence of the fact and content of such genuine consideration by the [ASIO] Director-General personally'. ${ }^{2267}$ Where the ASIO Director-General determines that no disclosure whatsoever is consistent with a lack of prejudice to national security, no disclosure need be made;

(d) The courts lack expertise in evaluating security intelligence ('Courts are illequipped to evaluate intelligence') 2268 and are not in a position to form a contrary view as to the opinion of the ASIO Director General;

(e) In consequence, in a given case, it may be that 'the content of procedural fairness is reduced, in practical terms, to nothingness', 2269 a view confirmed by the full Federal Court on appeal.2270"2271

2261 AHRC, Independent Review of the Intelligence Community - Australian Human Rights Commission Submission, April 2011, Sydney, http://www.hreoc.gov.au/legal/submissions /2011/20110431_intelligence.pdf (last accessed 16 November 2011) P.6-7

2262 Leghaei v Director General of Security [2005] FCA 1576

2263 Leghaei v Director General of Security [2007] FCFCA 37

${ }^{2264}$ Saul, B, Submission to Joint Select Committee on Immigration Detention dated 31 August 2011, together with annexed Communication to the UN Human Rights Committee dated 28 August 2011 https://senate.aph.gov.au/submissions / comittees/viewdocument.aspx?id=e82994a0-5a90-44c9-80f0-a96aafb95948, https://senate.aph.gov.au/submissions/comittees/viewdocument.aspx?id=229128ab-d97b4dab-9b97-bcf31229b81c (both last accessed 9 November 2011), at Pp.44-45; see also Saul, B, The Kafka-esque case of Sheikh Mansour Leghaei: The denial of the international human right to a fair hearing in national security assessments and migration hearings in Australia, (2010) 33(3) UNSWLJ 629

2265 Leghaei v Director General of Security [2005] FCA 1576, paras 70-71

2266 Leghaei v Director General of Security [2005] FCA 1576, para 83

2267 Leghaei v Director General of Security [2005] FCA 1576, para 86

2268 Leghaei v Director General of Security [2005] FCA 1576, paras 84, 87

2269 Leghaei v Director General of Security [2005] FCA 1576, para 88

2270 Leghaei v Director General of Security (2007) 241 ALR 141, at 146-147 
ASIO is overseen by the Inspector-General of Intelligence and Security. ${ }^{2272}$ The Inspector-General's inquiry functions with respect to ASIO are limited to ASIO's compliance with the law and Ministerial directions and guidelines; the propriety of ASIO activities; the effectiveness and appropriateness of ASIO procedures as they relate to the legality of ASIO activities; and any act by ASIO that may be inconsistent with or contrary to any human right or breach of any discrimination legislation. ${ }^{2273}$ Accordingly, as noted by the AHRC, the Inspector-General's powers of inquiry do not extend to a merits review of an adverse ASIO security assessment. ${ }^{274}$

Accordingly, the lack of an effective means to challenge an adverse security assessment does not comply with the requirements of Article 9(4) ICCPR or contemplate the procedures considered acceptable to the HRC in Ahani $v$ Canada.

\subsubsection{Australia - internal review by DIAC}

Together with the announcement on 29 July 2008 of the seven key values for immigration detention, the then Minister for Immigration Senator Chris Evans also indicated a new three-month internal review procedure. He stated:

"In future the department will have to justify why a person should be detained. Once in detention a detainee's case will be reviewed by a senior departmental official every three months to certify that the further detention of the individual is justified."2275

“....in determining the ongoing detention of a person, the onus of proof will be reversed. A departmental decision-maker will have to justify why a person should be detained against these values that presume that that person should be in the community." 2276

2271 Saul, B, Submission to Joint Select Committee on Immigration Detention dated 31 August 2011, together with annexed Communication to the UN Human Rights Committee dated 28 August 2011 https://senate.aph.gov.au/submissions/ comittees/viewdocument.aspx?id=e82994a0-5a90-44c9-80f0-a96aafb95948,

https://senate.aph.gov.au/submissions/comittees/viewdocument.aspx?id=229128ab-d97b4dab-9b97-bcf31229b81c (both last accessed 9 November 2011), at Pp.44-45

2272 That office is established under the Inspector-General of Intelligence and Security Act 1986 (Cth)

2273 Section 8 of the Inspector-General of Intelligence and Security Act 1986 (Cth)

2274 AHRC, Independent Review of the Intelligence Community - Australian Human Rights Commission Submission, April 2011, Sydney, http://www.hreoc.gov.au/legal/submissions/ 2011/20110431_intelligence.pdf(last accessed 16 November 2011), P.7

2275 Evans, Senator Chris, Australian Minister for Immigration and Citizenship, speech to the Australian National University in Canberra, 29 July 2008, New Directions in DetentionRestoring Integrity to Australia's Immigration System http://www.nswbar.asn.au/circulars/ july/evans2.pdf, (last accessed 16 November 2011), P.6.

2276 Evans, Senator Chris, Australian Minister for Immigration and Citizenship, speech to the Australian National University in Canberra, 29 July 2008, New Directions in Detention- 
This internal policy change, although possibly an improvement, does not provide substantive or justiciable rights for asylum seekers in detention. In light of the Palmer and Comrie Inquiries into citizens and other lawful noncitizens being detained stemming from the Cornelia Rau and Vivian AlvarezSolon affairs, it is highly doubtful that internal reviews in the absence of effective judicial review constitute an appropriate and effective safeguard against arbitrary or unlawful detention. At the very least, such a review does not satisfy the independent review requirements advocated by the UNHCR Guidelines and international standards identified above. There is little, if any, prospect for asylum seekers, of their own motion, to effectively challenge or seek a review of their detention under this review procedure.

The now lapsed Migration Amendment (Immigration Detention Reform) Bill 2009 did not propose to make any amendment to the Migration Act to allow for full judicial review of the decision to detain or to continue detention. ${ }^{2277}$

\subsubsection{Review and Challenge of the Detention Decision - Conclusions}

Eventhough the current Union secondary legislation does not always exhaustively provide for all aspects of the judicial review of a detention decision, the protections provided by Article 5(4) ECHR and the principle of effectiveness as developed by the case law of the CJEU and now reflected in Article 47 of the EU Charter provide for the effective judicial challenge to the lawfulness of detention as well as providing for regular judicial review at least at the request of the person concerned. In this regard, given the ECtHR's pronouncement on the necessity requirements under Article 5(1)(f), it is submitted that the EU principle of effectiveness and Article 47 of the EU Charter provide a slightly higher level of protection, but with the ECHR providing at least the minimum standard.

The proposed secondary legislation provides much more comprehensive provisions on the rights to challenge the lawfulness of detention, although the latest proposals have seen a regrettable shift away from the judicial ordering of the initial detention to either judicial or administrative ordering of detention but at least, if administratively ordered, detention is to be judicially ordered within a limited time period. Accordingly, a significant degree of protection against unlawful detention is provided, provided that a decision is reached speedily. The provisions reflect the obiter comments in Shamsa.

\footnotetext{
Restoring Integrity to Australia's Immigration System http://www.nswbar.asn.au/circulars/july/ evans2.pdf, (last accessed 16 November 2011), P.5

2277 See AHRC, Migration Amendment (Immigration Detention Reform) Bill 2009, Submission to the Senate Standing Committee on Legal and Constitutional Affairs, 31 July 2009, Sydney, http://www.humanrights.gov.au/legal/submissions/2009/20090731_migration.pdf (last accessed 18 November 2011), paras 85-91.
} 
Australia does share at least one aspect with the ECHR's approach under Article 5(1)(f) - that is, there appears to be a degree of similarity between the ECtHR's approach in the Saadi decision (that is, eschewing considerations of necessity, detention is justified so long as the person remains unauthorised to enter the country), and the approach adopted by the High Court of Australia in its series of cases (which essentially looked at the compliance of the detention with national law, with no consideration of the necessity of detention in the individual case). Both approaches gave primacy to State sovereignty and a textual reading of the ECHR and the Migration Act respectively. However, there are two significant differences: firstly, despite the unsatisfactory reasoning in Saadi the ECtHR has, at least, expressly warned against arbitrariness (although it remains to be seen how obviating necessity under Article 5(1)(f) is reconciled against the court's warning against arbitrariness); secondly, the obiter comments in Shamsa regarding the eventual judicial authorisation of detention appear to have been taken quite seriously by the EU secondary legislators.

Accordingly, Australia diverges significantly from the European Union as regards judicial protection against arbitrariness, the non-judicial ordering of detention, and the lack of provision for periodic judicial review. Internal departmental reviews are an unsatisfactory safeguard. The lack of effective justiciable safeguards are conspicuous by their absence but are also reflective of the narrow grounds for review.

In relation to detention ordered or prolonged on account of security assessments, the EU has, as a minimum standard, the approach adopted by the ECtHR that requires the sufficient disclosure of material such to allow an effective challenge to the lawfulness of detention. However, the Union secondary legislation is currently inconsistent with the ECtHR jurisprudence (and arguably the Union's own normative standards and jurisprudence) as regards the provision of security-related material to lawyers and to a court or tribunal which may practically undermine access to an effective remedy. In that regard, there are similarities with the Australian position. The proposed secondary legislation represents a significant upgrade of rights in that regard, but whether those provisions relate to detention decisions remains ambiguous. The legislative exclusion of merits review and the practical exclusion of judicial review of such security assessments in Australia is contrary to the standards considered acceptable to the HRC in Ahani $v$ Canada, bears no resemblance to the procedure adopted by the ECtHR under Article 5(4) and is responsible for prolonged and potentially indefinite detention of asylum seekers. It is entirely contrary to Article 9(4) ICCPR.

\subsection{External Communication, Access and Oversight}

6.4.1 External Communication and Access

6.4.1.1 External Communication and Access - International 
Article 35(1) of the Geneva Convention provides that Contracting States are to cooperate with the UNHCR in the exercise of its functions and, in particular, to "facilitate its duty of supervising the application of the provisions" of the Convention.

The UNHCR Revised Guidelines provide that, as a minimum, detained asylum seekers should be entitled:

"to contact and be contacted by the UNHCR Office, available national refugee bodies or other agencies and an advocate. The right to communicate with these representatives in private and the means to make such contact should be made available".2278

The UNHCR, through its ExCom Conclusion 85, has deplored the inadequate access to the UNHCR granted to detained asylum seekers. ${ }^{279}$

The UN Body of Principles for the Protection of All Persons Under Any Form of Detention or Imprisonment provides a general right to communicate with the outside world (subject to "reasonable conditions and restrictions specified by law or lawful regulations"). ${ }^{2280}$

As indicated earlier, the Standard Minimum Rules for the Treatment of Prisoners provides that civil prisoners are entitled to a standard not less favourable than that provided for untried prisoners, ${ }^{2281}$ and for persons detained without charge, the full protection contemplated in the relevant parts of Part I and II of the Rules apply. ${ }^{2282}$ Accordingly, it is arguable that detained asylum seekers who have committed no crime, and are not charged with any crime, fall into either of those two categories. Refugees and stateless persons are expressly contemplated in that they are entitled to be allowed facilities to communicate, inter alia, with "any national or international authority whose task it is to protect such persons," 2283 and which would presumably include the UNHCR.

The UN Standard Minimum Rules for the Administration of Juvenile Justice ("the Beijing Rules") expressly incorporate the UN Standard Minimum Rules

\footnotetext{
2278 UNHCR Revised Guidelines on applicable criteria and standards relating to the detention of asylum seekers, February 1999, Guideline 5(v)

2279 UNHCR, Executive Committee Conclusion 85 (XLIX) - Conclusion on International Protection, 1998, para (dd)

2280 Principle 19, Adopted by General Assembly Resolution 43/173 of 9 December 1988 http://www2.ohchr.org/english/law/bodyprinciples.htm (last accessed 7 November 2011)

${ }^{2281}$ Rule 94 of the Standard Minimum Rules for the Treatment of Prisoners

2282 Rule 95 of the Standard Minimum Rules for the Treatment of Prisoners

2283 Rule 38(2) of the Standard Minimum Rules for the Treatment of Prisoners
} 
for the Treatment of Prisoners. ${ }^{2284}$ The right of detained minors to contact "other persons or representative of reputable outside organizations" and the right to request assistance from "humanitarian groups or others where possible" in order to make a complaint is provided by the UN Rules for the Protection of Juveniles Deprived of their Liberty. ${ }^{2285}$

The Working Group on Arbitrary Detention, through its Deliberation No. 5, has stated that the UNHCR and the ICRC "must be allowed access to the places of custody" where asylum seekers or immigrants are held. ${ }^{2286}$

\subsubsection{External Communication and Access - Council of Europe \\ ECHR}

The importance of access to humanitarian and social assistance was underscored by being one of the contributing factors that led the ECtHR to hold that the detention of persons in a transit zone was unlawful under Article 5(1) ECHR. ${ }^{2287}$

Committee of Ministers' Recommendation Rec(2003)5 \& Twenty Guidelines on Forced Return

The Committee of Ministers Recommendation Rec(2003)5 recommends that detained asylum seekers should have the right to contact a UNHCR office and that the UNHCR should have "unhindered access" to detained asylum seekers. ${ }^{2288}$ Further, contact with the outside world including "nongovernmental organisations active in the field of human rights or in the protection of refugees or asylum seekers" should be allowed. ${ }^{2289}$ The Committee of Ministers' Twenty Guidelines on Forced Return also expressly provides that national authorities ensure access to, inter alia, the UNHCR and NGOs. ${ }^{2290}$

\subsubsection{External Oversight \\ 6.4.2.1 External Oversight - International}

2284 Rule 27 United Nations Standard Minimum Rules for the Administration of Juvenile Justice (“The Beijing Rules”), 29 November 1985, A/RES/40/33, http://www.un.org/ documents/ga/res/40/a40r033.htm (last accessed 6 November 2011)

2285 Rules 59 and 78 United Nations Rules for the Protection of Juveniles Deprived of their Liberty, 14 December 1990, A/RES/45/113, http://www.un.org/documents/ga/res/45/ a45r113.htm (last accessed 6 November 2011)

2286 UN Commission on Human Rights, Working Group on Arbitrary Detention, 28 December 1999, E/CN.4/2000/4, Annex II, Deliberation No. 5, Principle 10

2287 Riad and Idiab v Belgium, No. 29787/03 and 29810/03, Judgment, 24 January 2008, para 77

2288 Committee of Ministers, Council of Europe, Recommendation Rec(2003)5 of the Committee of Ministers to member states on measures of detention to asylum seekers, Paragraph 16

2289 Committee of Ministers, Council of Europe, Recommendation Rec(2003) 5 of the Committee of Ministers to member states on measures of detention to asylum seekers, Paragraph 18 2290 Guideline 10(5) Committee of Ministers, Council of Europe, Twenty Guidelines on Forced Return, CM(2005)40 Addendum final, Strasbourg, 20 May 2005 
The ultimate oversight mechanism for detained asylum seekers may arguably be the Treaty Bodies responsible for overseeing the various international human rights treaties, such as those created by the Optional Protocols to CAT, ${ }^{2291}$ ICCPR and CRPD, together with the Committee on the Rights of the Child under CROC. ${ }^{2292}$

The UN Body of Principles for the Protection of All Forms of Detention or Imprisonment makes express reference for the regular visitation by independent competent authorities for the purpose of "supervising the strict observance of relevant laws and regulations", combined with a corresponding right for a detained person to make communication with such visiting persons. ${ }^{2293}$ Inspection is also contemplated by the Standard Minimum Rules for the Treatment of Prisoners (and, by implication, the UN Standard Minimum Rules for the Administration of Juvenile Justice ("the Beijing Rules”)). ${ }^{2294}$ The UN Rules for the Protection of Juveniles Deprived of their Liberty makes extensive provision for the independent inspection of facilities, and urges the creation of an ombudsman's office for the receipt and investigation of complaints. ${ }^{2295}$

\subsubsection{External Oversight - Council of Europe CPT}

The Council of Europe's Committee for the Prevention of Torture is an important form of oversight of those detained. In this regard, the scope of the European Committee's periodic visits include immigration detention facilities, and the substantive parts of their reports generally reflect the international standards in addition to standards set by the ECHR and adjudicated by the ECtHR. ${ }^{2296}$ An example of the Committee's role and work in this area is its 17 November 2010 report into Greece's detention facilities based on its visit from 17-29 September 2009. ${ }^{2297}$ The Committee can visit any place within a

2291 In this regard, see Edwards' comprehensive discussion in: Edwards, A, The Optional Protocol to the Convention Against Torture and the Detention of Refugees, (2008) 57 ICLQ 789

2292 See generally, Tomuschat, C, Human Rights - Between Idealism and Realism, 2ed, 2008, OUP, Oxford, Pp.193-229

2293 Principle 29, Adopted by General Assembly Resolution 43/173 of 9 December 1988 http://www2.ohchr.org/english/law/bodyprinciples.htm (last accessed 7 November 2011) ${ }_{2294}$ Rule 27, United Nations Standard Minimum Rules for the Administration of Juvenile Justice ("The Beijing Rules"), 29 November 1985, A/RES/40/33, http://www.un.org/documents/ga/res/40/a40r033.htm (last accessed 6 November 2011) 2295 Rules 72-78, United Nations Rules for the Protection of Juveniles Deprived of their Liberty, 14 December 1990, A/RES/45/113, http://www.un.org/documents/ga/res/45/a45r113.htm (last accessed 6 November 2011)

2296 See The European Committee for the Prevention of Torture and Inhuman or Degrading Treatment or Punishment, The CPT Standards, October 2006, Strasbourg, CPT/Inf/E (2002) 1 - Rev. 2006 at Pp. 39-50.

2297 European Committee for the Prevention of Torture and Inhuman or Degrading Treatment, Report to the Government of Greece carried out by the European Committee for the Prevention of Torture and Inhuman or Degrading Treatment from 17 to 29 September 2009, 17 
State's jurisdiction where persons are deprived of their liberty by a public authority, ${ }^{2298}$ and other than periodic visits, can make other visits "as appear to it to be required in the circumstances". ${ }^{2299}$ Although the Convention renders the information, its report and any consultation with the State confidential, ${ }^{2300}$ in practice most States request the publication of the report. ${ }^{2301}$ The Committee may also release a public statement if the State fails to co-operate or "refuses to improve the situation in light of the Committee's recommendation". ${ }^{2302}$

Committee of Ministers' Recommendation Rec(2003)5 \& Twenty Guidelines on Forced Return

Although the Committee of Ministers' Recommendation Rec(2003)5 is silent as regards external oversight of detained asylum seekers, the Committee of Ministers' Twenty Guidelines on Forced Return calls for the monitoring, including by recognised independent monitors, of the functioning of the detention facilities. 2303

\subsubsection{European Union}

\subsubsection{External Communication and Access}

6.4.3.1.1 Detention where the Right to Remain Exists - Current Legislation

In a not dissimilar position to that of lawyers, the Reception Conditions Directive provides that the UNHCR or NGOs "designated" by the UNHCR and "recognised by the Member State concerned" must be granted access to "accommodation centres and other housing facilities" in order to assist asylum seekers. ${ }^{2304}$ Only on the grounds relating to the security of the centres and facilities and to asylum seekers may limitations to access be imposed. ${ }^{2305}$ It is unnecessarily restrictive (and contrary to the broad provisions found in the Committee of Ministers' Recommendation Rec(2003)5) that NGOs need to be "designated" by the UNHCR.

There is also a reciprocal obligation on Member States to ensure that 'housed' persons have the possibility of communicating with representatives of the UNHCR and NGOs "recognised by Member States". ${ }^{2306}$ As with lawyers,

November 2010, CPT/Inf (2010) 33, http://www.cpt.coe.int/documents/grc/2010-33inf-eng.htm (last accessed 7 April 2011).

2298 Article 2 European Convention for the Prevention of Torture

${ }^{2299}$ Article 7(1) European Convention for the Prevention of Torture

2300 Article 11(1) European Convention for the Prevention of Torture

2301 As contemplated in Article 11(2) European Convention for the Prevention of Torture

2302 Article 10(2) European Convention for the Prevention of Torture

2303 Guideline 10(5) Committee of Ministers, Council of Europe, Twenty Guidelines on Forced Return, CM(2005)40 Addendum final, Strasbourg, 20 May 2005

2304 Article 14(7) of the Reception Conditions Directive

2305 Article 14(7) of the Reception Conditions Directive

2306 Article 14(2)(b) of the Reception Conditions Directive 
those 'housed' would appear to include border applicants, ${ }^{2307}$ but the provisions are ambiguous in relation to those otherwise in detention.

Accordingly, there is some ambiguity about whether the Directive provides for reciprocal rights of access between the UNHCR and NGOs and detained asylum seekers.

External Communication \& Access - Detention where the Right to Remain Exists The Proposed Legislation

The Commission's 2011 Proposed Reception Conditions Directive expressly provides that the UNHCR and "organisations working on behalf of the UNHCR pursuant to an agreement with the Member State concerned" must have the possibility to "communicate with applicants and have access to detention facilities". 2308

In other respects, as with lawyers, Member States are to ensure that representatives of "relevant" NGOs have the possibility to communicate with detained asylum seekers and have access to detention facilities. ${ }^{2309}$ That right to access is qualified by limitations by virtue of national law that are "objectively necessary for the security, public order or administrative management of the detention facility" but in any event access is not to be "severely limited or rendered impossible". 2310

For those border applicants or those in transit zones, ${ }^{2311}$ the Proposal recognises that applicants have the right to communicate with persons representing the UNHCR and other relevant national, international and nongovernment organisations and bodies. ${ }^{2312}$ Further, persons representing the UNHCR, relevant NGOs recognised by the Member State concerned have the right to access asylum seekers to assist them. ${ }^{2313}$ Although there would appear to be a mutual right to communication and access as regards the UNHCR and relevant non-government organisations, the right of access by outsiders appears to have neglected the broad formulation of "other relevant national, international and non-government organisations and bodies". The same description of entities should be used in both circumstances to ensure that the rights of access and communication are perfectly mutual, which would otherwise appear to be the case for those in a border/transit zone situation. Importantly, Member States are no longer able to derogate from the modalities of material reception conditions for those confined to the border or

\footnotetext{
2307 Article 14(1)(a) of the Reception Conditions Directive

2308 Article 10(3) of the Commission's 2011 Proposed Reception Conditions Directive

2309 Article 10(4) of the Commission's 2011 Proposed Reception Conditions Directive

2310 Article 10(4) of the Commission's 2011 Proposed Reception Conditions Directive

2311 Article 18(1)(a) of the Commission's 2011 Proposed Reception Conditions Directive

2312 Article 18(2)(b) of the Commission's 2011 Proposed Reception Conditions Directive

2313 Article 18(2)(c) of the Commission's 2011 Proposed Reception Conditions Directive
} 
in detention, ${ }^{2314}$ which would tend to suggest that the foregoing provisions regarding access and communication do apply to those in detention but an ambiguity remains. As with the current Directive, such a mutual right is not expressly provided for those otherwise detained and should be included for the sake of clarity.

The Council's amendments also leave unchanged the Commission's 2011 Proposal as regards communication and access rights of UNHCR and NGOs ${ }^{2315}$ as well as those 'housed' at the border or in transit zones. ${ }^{2316}$

\subsection{External Communication \& Access - Detention where the Right to Remain is Lost-Current Legislation}

The Procedures Directive provides a general permission for the UNHCR (or an organisation working on its behalf pursuant to an agreement with the Member State concerned) to have access to asylum seekers, including those in detention and in airport and transit zones. ${ }^{2317}$ As part of the general guarantees provided throughout the asylum determination procedure, an asylum seeker "shall not be denied" the opportunity to communicate with the UNHCR (or an organisation working on its behalf). ${ }^{2318}$ ECRE has expressed regret that that right is expressed as a negative right and has emphasised that it should be expressed as a positive right, ${ }^{2319}$ and that in both circumstances the right of NGOs to contact and be contacted is qualified by the requirement to work on behalf of the UNHCR. ${ }^{2320}$ For border applicants, as discussed in earlier parts of this book, it would appear that those guarantees may be subject to derogation by Member States. ${ }^{2321}$

External Communication \& Access - detention where the Right to Remain is Lost The Proposed Legislation

The Commission's 2011 Proposed Procedures Directive mimics the formulation of the current Directive as regards access by the UNHCR to applicants for international protection and now expressly includes those at the border as well as those in detention and in transit zones. ${ }^{2322}$ Additionally, as

\footnotetext{
2314 Article 18(8) of the Commission's 2011 Proposed Reception Conditions Directive

2315 Article 10(3) and (4) of the Council's Amended Proposed Reception Conditions Directive

2316 Article 18(1)(a), 18(2)(b) and (c), 18(8) of the Council's Amended Proposed Reception Conditions Directive

2317 Article 21(1)(a) of the Procedures Directive

2318 Article 10(1)(c) of the Procedures Directive

2319 ECRE, Information Note on the Council Directive 2005/85/EC of 1 December 2005 on minimum standards on procedures in Member States for granting and withdrawing refugee status, October 2006, Brussels, IN1/10/2006/EXT/JJ at P.12

2320 ECRE, Information Note on the Council Directive 2005/85/EC of 1 December 2005 on minimum standards on procedures in Member States for granting and withdrawing refugee status, October 2006, Brussels, IN1/10/2006/EXT/JJ at Pp. 12 and 20

2321 Article 24(1)(b) and Article 35 of the Procedures Directive

2322 Article 29(1)(b) of the Commission's 2011 Proposed Procedures Directive
} 
with the current formulation, asylum seekers "shall not be denied the opportunity to communicate with the UNHCR" but the other organisations contemplated are now no longer those working on behalf of the UNHCR but are ones "providing legal advice or counselling to applicants for international protection in accordance with the national law of that Member State". ${ }^{2323}$ Accordingly, there is still no reciprocal positive right for an asylum seeker to make contact with the UNHCR or other organisations; and secondly, the limitation of other organisations which shall not be denied access to asylum seekers seems unnecessarily restricted firstly, to those providing legal advice or "counselling" (which is undefined - it is unclear whether legal counsel is contemplated or whether communication with other persons such as psychologists or social workers is contemplated), and secondly, to those such persons in accordance with the law of the Member State. The deletion of the current Article 24 of the Procedures Directive means that such guarantees are applicable to border applicants without the possibility for Member State derogation.

The Commission's 2011 Proposed Procedures Directive is now also referable to the Reception Conditions Directive as regards grounds, conditions and guarantees for detention ${ }^{2324}$ and the foregoing analysis of the Reception Conditions Directive is relevant.

External Communication \& Access - detention where the Right to Remain is Lostthe Returns Directive

Under the Returns Directive "relevant and competent, national, international and non-governmental organisations and bodies" must have the possibility to visit detention facilities for third country nationals. ${ }^{2325}$ However, Member States may require prior authorisation ${ }^{2326}$ - a condition that ECRE understandably advocates as unnecessary. ${ }^{2327}$ Further, the right holder in this particular circumstance is again not the detained person, but the external party. Detained persons must be given information about contacting competent national, international and non-government organisations and bodies, but this entitlement is qualified by "under national law". ${ }^{232}$ An unambiguous, reciprocal right to make contact and request the presence of such organisations should be provided.

\footnotetext{
2323 Article 12(1)(c) of the Commission's 2011 Proposed Procedures Directive

2324 Article 26 of the Commission's 2011 Proposed Procedures Directive

2325 Article 16(4) of the Returns Directive

2326 Article 16(4) of the Returns Directive

2327 ECRE, ECRE Information note on the Directive 2008/115/EC of the European Parliament and of the Council of 16 December 2008 on common standards and procedures in Member States for returning illegally staying third-country nationals, undated, Brussels, CO7/1/2009/Ext/MDM, Pp.22-23

${ }^{2328}$ Article 16(5) of the Returns Directive
} 
6.4.3.1.3 Detention in a Member State Other Than That of First Entry or Asylum Current Legislation

As discussed in earlier parts of this book, the current Dublin II Regulation does not provide for detention for those asylum seekers in a Dublin circumstance.

Detention in a Member State Other Than That of First Entry or Asylum - The Proposed Legislation

Under the Commission's Proposed Dublin Regulation, the Reception Conditions Directive governs the conditions of detention that deal with access by and communication with the UNHCR and other NGOs, ${ }^{2329}$ and the above discussion is relevant.

\subsubsection{European Union - External Oversight}

One of the Commission's roles is to ensure "the application of the Treaties, and of measures adopted by the institutions pursuant to them". ${ }^{2330}$ In order to carry out that role, the Commission may take infringement proceedings against a Member State under Article 258TFEU for 'failing to fulfil an obligation under the Treaties' which, as Craig and de Búrca identify, may include a breach of the principle of sincere cooperation; ${ }^{2331}$ a Member State failing to adequately implement Union law; ${ }^{2332}$ the failure to provide penalties for the breach of Union law in an analogous way to those breaches for national law and which are not "effective proportionate and dissuasive",2333 the breach of the positive obligation to take effective measures to uphold Union law; ${ }^{2334}$ breaching Union law on a general and persistent basis, ${ }^{2335}$ and also, possibly, breaches of compliance with Union law by national courts. ${ }^{236}$ Given the heightened legal status of the EU Charter as equivalent to the Treaties, ${ }^{2337}$ it may also be possible that the Commission could base its future proceedings on a breach of the EU Charter, yet within the constraints imposed therein. ${ }^{2338}$ Further, it is also possible under Article 7 TEU that a Member State may have their rights derived under the Treaties suspended on

\footnotetext{
${ }^{2329}$ Article 27(12) of the Commission's Proposed Dublin II Regulation

2330 Article 17(1) TEU

2331 Article 4(3) TEU (ex Article 10 EC)

2332 Case C-167/73 Commission v France, Judgment, 4 April 1974

2333 Article 4(3) TEU (ex Article 10EC) and Case C-68/88 Commission v Greece, Judgment 21 September 1989 , para 24

2334 Article 4(3) TEU (ex Article 10 EC) and Case C-265/95 Commission v France, Judgment, 9 December 1997 ("the Spanish Strawberries Case")

2335 Case C-494/01 Commission v Ireland, Judgment Grand Chamber, 26 April 2005, paras $169-171$

2336 See Craig, P. and de Búrca, G, EU Law, 4ed, 2008, OUP, Oxford, Pp.428-429; and generally on the Commission's grounds for infringement action identified by them and highlighted herein at Pp.408-431

2337 Article 6(1) TEU

2338 Articles 51 and 52 of the EU Charter
} 
account of a determination of a "serious and persistent breach" of human rights. ${ }^{2339}$

Although no express provisions on the oversight of detention are included, the Reception Conditions Directive provides that Member States, "with due respect to their constitutional structure", are obliged to ensure that "appropriate guidance, monitoring and control of the level of reception conditions are established". ${ }^{2340}$ Peek notes that this does not create any new rights for asylum seekers nor does it oblige Member States to introduce an additional system if one already exists. ${ }^{2341}$

Under the Commission's 2011 Proposed Reception Conditions Directive (which remain untouched by the Council's Amendments), ${ }^{2342}$ Member States are required to "put in place relevant mechanisms" to ensure the guidance, monitoring and control contemplated in the current Directive. ${ }^{2343}$

The current and Proposed Procedures Directive and the current and Proposed Dublin II Regulation do not make provision for external oversight of those detained under their scope.

As already indicated, the Returns Directive provides for the visitation of international organisations and NGOs, but Member States may require prior authorisation. As noted by Baldaccini, there is no obligation in the Directive to follow up on any recommendations by those organisations, nor was the European Parliament's suggestion to create an "Ombudsman for Returns" to make unannounced inspections taken up in the final version of the Directive. ${ }^{2344}$ Although Baldaccini notes the requirement for prior authorisation may prevent the Council of Europe's Human Rights Commissioner or the European Parliament's LIBE Committee from making unscheduled visits to detention facilities for returnees, ${ }^{2345}$ it is arguable that Member States would be breaching their CPT obligations should they require the CteePT so to request prior authorisation ${ }^{2346}$ or refuse access outside the express terms provided in the CPT. ${ }^{2347}$

${ }^{2339}$ See Tomuschat, C, Human Rights - Between Idealism and Realism, 2ed, 2008, OUP Oxford, Pp. 159-160; note also in relation to the voting procedure, Article 354 TFEU

2340 Article 23 of the Reception Conditions Directive

${ }^{2341}$ Peek, M, in Hailbronner, K, (ed) EU Immigration and Asylum Law - Commentary on EU Regulations and Directives, 2010, Beck, München, Pp.871-984 at P.961

2342 See Article 28(1) of the Council's Amended Proposed Reception Conditions Directive 2343 Article 28(1) of the Commission's 2011 Proposed Reception Conditions Directive 2344 Baldaccini, A, The EU Directive on Returns: Principles and Protests, (2010) 28(4) RSQ 114, P.131-132

2345 Baldaccini, A, The EU Directive on Returns: Principles and Protests, (2010) 28(4) RSQ 114, P.131-132

2346 See Articles 2, 7 and 8 of the CPT

2347 See Article 9 of the CPT 
6.4.4 External Communication, Access \& External Oversight - Australia

Access to detention centres, generally, is governed by section $252 \mathrm{G}$ of the Migration Act and deals with such matters as screening by metal detectors and measures relating to the property of visitors to detention centres.

The Migration Act does not make express provision for the contact of, or access by, the UNHCR to those in immigration detention. However, the DIAC acknowledges that the UNHCR is one of the bodies that scrutinise immigration detention operations. ${ }^{2348}$ Accordingly, it becomes a matter of policy, not a justiciable right, as to whether detained persons are allowed communication and access to the UNHCR and NGOs and accordingly whether the UNHCR and NGOs are allowed access to detained persons.

In the then Minister for Immigration and Citizenship's speech on 29 July 2008 he stated:

"Henceforward, asylum seekers will receive publicly funded advice and assistance, access to independent review of unfavourable decisions and external scrutiny by the Immigration Ombudsman." 2349

External communication, access and external oversight become concurrent issues in the Australian context when considering the functions of the Commonwealth Ombudsman and the AHRC in the immigration detention context. $^{2350}$

\subsubsection{Australia - Commonwealth Ombudsman}

External review independent of DIAC is provided by the Commonwealth Ombudsman ("the Ombudsman").

Persons detained in custody have a right to make a complaint to the Ombudsman orally or in writing. ${ }^{2351}$ The Ombudsman must investigate any complaint brought by a person against an administrative decision, ${ }^{2352}$ but is not authorised to investigate an action taken by a Minister (which places any

\footnotetext{
2348 Australian Government, Department of Immigration and Citizenship, Managing Australia's Borders, Detention, Regulations, External Scrutiny of Immigration Detention Services, http://www.immi.gov.au/managing-australias-borders/detention/regulations/externalscrutiny.htm (last accessed 17 November 2011)

2349 Evans, Senator Chris, Australian Minister for Immigration and Citizenship, speech to the Australian National University in Canberra, 29 July 2008, New Directions in DetentionRestoring Integrity to Australia's Immigration System http://www.nswbar.asn.au/circulars/ july/evans2.pdf (last accessed 18 November 2011), P.3

2350 See also, writing in 2000, Taylor, S, Protecting the Human Rights of Immigration Detainees in Australia: An Evaluation of Current Accountability Mechanisms (2000) 22 SydLR 50

${ }^{2351}$ Section 7(1) - (3)(a) of the Ombudsman Act 1976 (Cth)

2352 Section 5(1)(a) of the Ombudsman Act 1976 (Cth)
} 
matter the subject of Ministerial discretion such as the grant of a visa under section 195A outside the scope of the Ombudsman's investigation). ${ }^{2353}$

Ordinarily, a person detained in custody has the right to receive a sealed envelope from the Ombudsman. ${ }^{2354}$ However, detained asylum seekers are precluded from receiving any such sealed envelope unless they have made a complaint orally or in writing to the Ombudsman. ${ }^{2355}$ Accordingly, the Ombudsman has no right to ensure that initial communication, which may include information about the role and procedures for contacting the Ombudsman in relation to their detention, reaches a detained asylum seeker.

The Ombudsman has the power to enter premises for the purposes of an investigation. $^{2356}$

The Ombudsman has two review functions with regard to immigration detention. The first is statutorily imbedded under Part 8C of the Migration Act. This review, first occurring two years after a person has been in detention, requires the Ombudsman to give a report to the Minister having assessed a person's detention arrangements. ${ }^{2357}$ The Ombudsman may also include a recommendation in that assessment, ${ }^{2358}$ but which is not binding on the Minister. ${ }^{2359}$ The Minister is obliged to table that assessment in Parliament within 15 days of having received it. ${ }^{2360}$

The second review function that the Ombudsman carries out is under his or her own motion power ${ }^{2361}$ every six months that a person has been in detention (that is, six, twelve and eighteen month reviews). ${ }^{2362}$ The Migration Act expressly provides for the continued application of the Ombudsman Act 1976 (Cth) notwithstanding the provisions contained in the Migration Act. ${ }^{2363}$ However, the assessment differs from the two-year reviews in that firstly, they are furnished to the Secretary of DIAC; ${ }^{2364}$ secondly, there is no statutory

\footnotetext{
2353 Section 5(1)(b) of the Ombudsman Act 1976 (Cth)

${ }^{2354}$ Section 7(3)(b) of the Ombudsman Act 1976 (Cth)

2355 Section 195(3)(c) of the Migration Act 1958 (Cth)

2356 Section 14 of the Ombudsman Act 1976 (Cth)

2357 Sections 486L, 486M and 486O of the Migration Act 1958 (Cth)

2358 Section 486(2) and (3) of the Migration Act 1958 (Cth)

2359 Section 486(4) of the Migration Act 1958 (Cth)

${ }^{2360}$ Section 486P of the Migration Act 1958 (Cth)

${ }^{2361}$ Section 5(1)(b) of the Ombudsman Act 1976 (Cth)

2362 Commonwealth Ombudsman, Submission by the Commonwealth and Immigration Ombudsman - Joint Select Committee on Australia's Immigration Detention Network, September 2011, http://www.ombudsman.gov.au/files/Joint_Select_Committee_on_Australias_ Immigration_Detention_Network_September_2011.pdf (last accessed 18 November 2011), Pp.4-5

2363 Section 486Q of the Migration Act 1958 (Cth)

2364 Commonwealth Ombudsman, Submission by the Commonwealth and Immigration Ombudsman - Joint Select Committee on Australia's Immigration Detention Network, September 2011, http://www.ombudsman.gov.au/files/Joint_Select_Committee_on_Australias_
} 
requirement that the assessment be tabled in Parliament; and thirdly, the Ombudsman has taken the approach of not making recommendations as part of those assessments. ${ }^{2365}$

In December 2008, the Joint Standing Committee on Migration recommended that the Ombudsman's six-monthly reviews be tabled in Parliament and that the Minister be compelled to provide a reasoned response within 15 sitting days of receipt of the Ombudsman's review being tabled in Parliament. ${ }^{2366}$ No statutory change has taken place to reflect that recommendation.

Accordingly, although the Ombudsman's reviews provide an important element of the review process and a greater degree of independence than that conducted by DIAC, the non-binding nature of its recommendations in either the six-monthly or two-yearly reviews and the statutory preclusion of a detained person to receive initial contact from the Ombudsman represent significant shortcomings in the use of this mechanism as a safeguard against the arbitrary detention of detained persons. It is certainly no substitute for judicial review.

\subsubsection{Australia - Australian Human Rights Commission ("AHRC")}

External review independent of DIAC is also available by the AHRC.

The AHRC's functions are to inquire into any act or practice that may be inconsistent with, or contrary to, any human right and, if effecting a settlement is not appropriate, to report it to the Minister. ${ }^{2367}$ In relation to that function, the AHRC may be requested by the Minister, on the complaint of a person or on the AHRC's own motion. ${ }^{2368}$

As with the Ombudsman, a person detained in custody normally has the right to make a written complaint to the AHRC in relation to their detention and to receive any sealed envelope from the AHRC. ${ }^{2369}$ However, the Migration Act expressly precludes that right from applying to detained asylum seekers

Immigration_Detention_Network_September_2011.pdf (last accessed 18 November 2011), Pp.4-5

2365 Commonwealth Ombudsman, Submission by the Commonwealth and Immigration Ombudsman - Joint Select Committee on Australia's Immigration Detention Network, September 2011, http://www.ombudsman.gov.au/files/Joint_Select_Committee_on_Australias_ Immigration_Detention_Network_September_2011.pdf (last accessed 18 November 2011), Pp. 4-5

2366 Parliament of Australia, Joint Standing Committee on Migration, Inquiry into Immigration Detention in Australia, Immigration Detention in Australia: A New Beginning, December 2008, Pp.78, para 4.68

${ }^{2367}$ Section 11(1)(f) of the Australian Human Rights Commission Act 1986 (Cth)

2368 Section 20(1) of the Australian Human Rights Commission Act 1986 (Cth)

${ }^{2369}$ Section 20(6)(b) of the Australian Human Rights Commission Act 1986 (Cth) 
unless the detained person has initiated contact with the AHRC. ${ }^{2370}$ Accordingly, as with the Ombudsman, the AHRC is denied the right to initiate contact with asylum seekers, including the provision of information about the AHRC's role and procedures.

The AHRC has no express statutory right to enter premises, but its powers include a general power to do "all things necessary or convenient for or in connection with the performance of its functions", ${ }^{2371}$ as well as powers to obtain documents and information, ${ }^{2372}$ and examine witnesses ${ }^{2373}$ (there are penalties for persons who fail to comply). ${ }^{2374}$ Further, it is an offence to "hinder, obstruct, molest or interfere with" Commission members or persons acting on behalf of the Commission whilst such persons are "participating in an inquiry or examination". 2375

The AHRC also has as its function to intervene in proceedings that involve human rights (with the leave of the court). ${ }^{2376}$ However, this does not create standing to commence litigation on behalf of concerned persons or to initiate enforcement or compliance proceedings - the proceedings must already be on foot before the AHRC can intervene. ${ }^{2377}$

Although the AHRC has undertaken extremely valuable work regarding migration issues and detention in particular (most notably through its reports), it is not, by itself, an institution which can enforce justiciable rights or compel compliance with human rights standards. Its inability to initiate contact with detained asylum seekers is a significant concern where those detained are otherwise unaware of the AHRC's existence or their right to complain, or are unable to effectively articulate their complaint. The CteeAT has expressed its regret that the AHRC "can only make recommendations of an advisory nature". 2378

2370 Section 193(3)(c) of the Migration Act 1958 (Cth) - That provision as it relates to both the AHRC and the Ombudsman was the result of litigation surrounding the provision of information to detained persons in Human Rights and Equal Opportunity Commission $v$ Secretary of the Department for Immigration and Multicultural Affairs [1996] FCA 1538

2371 Section 13(1) of the Australian Human Rights Commission Act 1986 (Cth); the AHRC's functions are set out in section 11(1) of the Australian Human Rights Commission Act 1986 (Cth)

2372 Section 21 of the Australian Human Rights Commission Act 1986 (Cth)

2373 Section 22 of the Australian Human Rights Commission Act 1986 (Cth)

${ }^{2374}$ Section 23 of the Australian Human Rights Commission Act 1986 (Cth). Note, however, the public interest exemption certificates under section 24 of the Australian Human Rights Commission Act 1986 (Cth)

2375 Section 26 of the Australian Human Rights Commission Act 1986 (Cth)

2376 Section 11(1)(o) of the Australian Human Rights Commission Act 1986 (Cth)

2377 Indeed, one cannot help but ponder the apparent irritation of Heydon J at the AHRC's presence in M70/2011 v Minister for Immigration and Citizenship, M106/2011v Minister for Immigration and Citizenship [2011] HCA 32 at 150

${ }^{2378}$ United Nations, Committee Against Torture, Concluding Observations of the Committee Against Torture - Australia, CAT/C/AUS/CO/3, 22 May 2008, para 14 


\subsubsection{Australia - Council for Immigration Services and Status Resolution ("CISSR")}

According to the DIAC website, CISSR was established in 2009 to replace the Immigration Detention Advisory Group (IDAG) ${ }^{2379}$ It is an independent advisory group providing advice to the Minister "on policies, processes, services and programs necessary for the timely fair and effective resolution of immigration status for people seeking migration outcomes in Australia". ${ }^{2380}$ Its terms of reference also include "detention matters including, but not limited to, the suitability of facilities, accommodation and service arrangements." 2381

\subsubsection{External Communication, Access and Oversight - Conclusions}

External access to, and communication with, detained asylum seekers is an essential component in ensuring that asylum seekers are aware of their rights and the existence of bodies who may be able to ensure that those rights are exercisable, as well as providing transparency to ensure that their conditions of treatment in detention are humane. It also serves to reduce the risk of torture, cruel, inhuman or degrading treatment. The knowledge and exercise of rights which asylum seekers have whilst in detention can be rendered nugatory if access by organisations and individuals is unduly restricted. External oversight is an essential component in ensuring that fundamental rights are being afforded.

External oversight is not a substitute for an individual to challenge the legality of his or her detention. External oversight, physical access and communication are important secondary and supporting means of ensuring that authorities comply with the rights of those detained. However, the effectiveness of those measures as safeguards depends on, firstly, the quality of the access and communication; secondly, the existence of reciprocal rights of access and communication for detained persons and external bodies, regardless of who initiates contact; and thirdly, any such embodiment in law of those reciprocal rights should not be a substitute for individuals being able to challenge the

2379 Australian Government, Department of Immigration and Citizenship, Managing Australia's Borders, Detention Services, Council for Immigration Services and Status Resolution (CISSR), http://www.immi.gov.au/managing-australias-borders/detention /regulations/cissr/ (last accessed 18 November 2011)

2380 Australian Government, Department of Immigration and Citizenship, Managing Australia's Borders, Detention Services, Council for Immigration Services and Status Resolution (CISSR), Terms of Reference, http://www.immi.gov.au/managing-australiasborders/detention/regulations/cissr/terms-of-reference.htm (last accessed 18 November 2011)

2381 Australian Government, Department of Immigration and Citizenship, Managing Australia's Borders, Detention Services, Council for Immigration Services and Status Resolution (CISSR), Terms of Reference, http://www.immi.gov.au/managing-australiasborders/detention/regulations/cissr/terms-of-reference.htm (last accessed 18 November 2011) 
lawfulness of their detention. Further, just as there should be reciprocal rights for the detained person and the external party to communicate and have access to one another, so too should there not only be a right for external scrutiny of detained asylum seekers, but also there should be a reciprocal obligation that any recommendations flowing from those inspections are put in place.

The current Union secondary legislation as a general rule makes provision for external access, communication and oversight by the UNHCR and NGOs but can qualify those provisions either by requiring recognition (in the case of NGOs) under national law or designation by the UNHCR. The rights of access and communication regarding these organisations should be expressed in a clear, reciprocal manner. The European Union does have the presence and work of important monitoring bodies for the oversight of those in detention - namely, the European Commission as a guardian of compliance with Union law, and the powerful presence of the CteePT through the CPT (operating outside the Union sphere but whose scrutiny encompasses Member States of the Union).

In the Australian sphere, there is no specific legislative guarantee for access to detention centres in which asylum seekers are being held (other than the general powers to enter premises contained in the Ombudsman Act and the ancillary powers in the $A H R C A c t)$. Although there would appear to be no legislative impediment to an asylum seeker contacting an external body, a detained person must already know the existence of those bodies and must articulate what rights they wish to invoke. Two important external agencies, the Commonwealth Ombudsman and the AHRC, are unable at law to initiate contact to advise detained persons of the existences of those bodies or the rights of the detained persons in relation to those bodies (or otherwise). This situation underscores the importance of creating reciprocal rights of access between detained persons and external bodies.

Notwithstanding the important and valuable work that the Commonwealth Ombudsman and the AHRC undertake, the effectiveness of their scrutiny is hamstrung by the fact that they can only make recommendations (in the case of the two year reviews by the Ombudsman under the Migration Act but which is not presently the case for the six-monthly reviews), which are not bound to be followed by the Minister or the Secretary of the Department. Both agencies cannot compel compliance with domestic or international legal standards. 


\section{Chapter 7 \\ Conditions of Detention}

This chapter explores the legal standards relating to conditions of detention. It focuses on a number of key areas. Firstly, the examination is concerned with the existence of standards relating to material reception conditions. Within that examination, the particular provisions relating to minors, families and vulnerable persons are explored because different legal standards for the detention of those special categories of asylum seeker may apply. This arises because those special categories of asylum seeker are under particular vulnerabilities that heighten their dependence on the State and for which provision must be made whilst under the control of the State in detention.

Secondly, given that detention facilities can be operated or co-operated by private contractors, the legal liability for breaches of standards or duties can be unclear. The ambiguity can arise because there can be difficulties in identifying the proper defendant - that is, were the actions or omissions which have resulted in damage to an asylum seeker in detention a result of the private contractor; or is the private contractor an emanation of the State; or does the State retain ultimate responsibility? Accordingly, this chapter analyses the legal liability for detention conditions in both jurisdictions.

Thirdly, related to the outsourcing of detention facilities to private contractors is the issue of reviewing decisions affecting asylum seekers in detention. This issue arises because there are multiple decisions which can be made affecting the treatment of asylum seekers in detention (for example, placement in isolation or disciplining). Accordingly, it is important to know what are the possible avenues for the review of such decisions.

This chapter firstly examines the general standards in relation to the conditions of detention of asylum seekers in the international, Council of Europe and EU Charter and General Principles of EU Law contexts. The position of minors, family members and vulnerable persons are then separately explored, examining the standards in each of those three previously identified legal contexts.

The analysis then turns to the European Union secondary legislation and Australia.

There are four elements to the analysis of standards relating to detention conditions in the European Union secondary legislation: (1) detention where the right to remain exists; (2) detention where the right to remain is lost; (3) where detention occurs in a Member State other than that of first entry or asylum; and (4) a discussion of the legal liability for detention conditions. Where appropriate, not only the current legislation, but also the proposed 
legislation is analysed, with particular attention on border applicants, minors and families, and vulnerable persons.

The Australian analysis consists of four elements: (1) a discussion regarding the absence of legislative minimum standards for the treatment of detained asylum seekers; (2) the legal liability for detention conditions and the scope of the duty of care owed to detained asylum seekers (with particular attention on the position of minors); (3) the avenues for the review for decisions taken affecting asylum seekers in detention; and (4) a summary of DIAC's policies.

\subsubsection{General Standards}

\subsubsection{International \\ Geneva Convention}

At the international level, the Geneva Convention is silent as regards the conditions of detention of asylum seekers save for Article 22, which in respect of elementary education affords to refugees (regardless of the lawfulness of their presence) the same treatment as nationals. Accordingly, an examination of other international human rights law is necessary.

\section{ICCPR}

Article 10(1) ICCPR provides:

"All persons deprived of their liberty shall be treated with humanity and with respect for the inherent dignity of the human person"

States are under a positive obligation to ensure compliance with Article 10, and which the HRC has indicated is complementary to Article 7 ICCPR (discussed below). ${ }^{2382}$ Although Article 10, by itself, is largely normative (as opposed to prescriptive), the HRC has indicated that States are to address not only the extent of their compliance with, inter alia, the Standard Minimum Rules for the Treatment of Prisoners and the Body of Principles for the Protection of All Persons under Any form of Detention or Imprisonment, ${ }^{2383}$ but also how States monitor the effective application of rules relating to the treatment of those deprived of their liberty. ${ }^{2384}$ Notwithstanding that the remainder of Article 10 relates specifically to criminal proceedings (which the HRC discusses with respect to minors as part of its General Comment 21), the HRC has invited States in their reports to address their application of the

\footnotetext{
2382 UN OHCHR, Human Rights Committee, General Comment 21: Replaces general comment 9 concerning humane treatment of persons deprived of liberty (Art 10), 10 April 1992, para 3; see also UN OHCHR, Human Rights Committee, General Comment 20; Replaces general comment 7 concerning prohibition of torture and cruel treatment or punishment (Art. 7), 10 March 1992, para 2

2383 UN OHCHR, Human Rights Committee, General Comment 21: Replaces general comment 9 concerning humane treatment of persons deprived of liberty (Art 10), 10 April 1992, para 5

${ }^{2384}$ UN OHCHR, Human Rights Committee, General Comment 21: Replaces general comment 9 concerning humane treatment of persons deprived of liberty (Art 10), 10 April 1992, para 6
} 
Standard Minimum Rules for the Administration of Juvenile Justice ("the Beijing Rules") in relation to minors (see discussion below). ${ }^{2385}$

The Standard Minimum Rules for the Treatment of Prisoners" 2386 "set out what is generally accepted as being good principle and practice in the treatment of prisoners and the management of institutions" 2387 and specifically contemplates persons arrested or detained without charge. ${ }^{2388}$ Vohra notes that the Rules were drafted with the intention that they be considered in the interpretation of Article 10 of the ICCPR. ${ }^{2389}$ Equally relevant in light of the application of Article 10 are the Principles for the Protection of all Persons under Any form of Detention or Imprisonment. ${ }^{2390}$ Although both documents are not legally binding in international law, they do constitute persuasive international standards. Further, the Principles for the Protection of all Persons under Any form of Detention or Imprisonment is said to be "declaratory of pre-existing rights, in as much as the main purpose of its provisions is to set forth, and sometimes to develop, principles already recognized under customary law",2391.

In jurisprudence relating to Article 10 ICCPR, the HRC in Madafferi $v$ Australia indicated in its View that Article 10(1) had been breached where, contrary to medical and psychiatric advice, a person was placed in immigration detention "without a proper assessment of the circumstances of the case" and which the HRC viewed as disproportionate, particularly in light of the person's later involuntary admission to a psychiatric hospital following the decline of the person's mental state as a result of his detention. ${ }^{2392}$

2385 UN OHCHR, Human Rights Committee, General Comment 21: Replaces general comment 9 concerning humane treatment of persons deprived of liberty (Art 10), 10 April 1992, para 13

2386 Adopted by the First United Nations Congress on the Prevention of Crime and the Treatment of Offenders, held at Geneva in 1955, and approved by the Economic and Social Council by its resolutions 663 C (XXIV) of 31 July 1957 and 2076 (LXII) of 13 May 1977, http://www2.ohchr.org/english/law/treatmentprisoners.htm (last accessed 13 July 2012)

2387 Paragraph 1 of the Preliminary Observations to the Standard Minimum Rules for the Treatment of Prisoners.

2388 Rule 95 of the Standard Minimum Rules for the Treatment of Prisoners

2389 Vohra, S, Detention of Irregular Migrants and Asylum Seekers in Cholewinski, R, Perruchoud, R, MacDonald, E, (eds), International Migration Law: Developing Paradigms and Key Challenges, 2007, TMC Asser Press, The Hague, Pp.49-69 at P.61. See also Groves, M, International Law and Australian Prisoners [2001] UNSWLJ 11, para 23

2390 Adopted by General Assembly Resolution 43/173 of 9 December 1988 http://www2.ohchr.org/english/law/bodyprinciples.htm (last accessed 13 July 2012)

2391 Commission on Human Rights, 49th Session, Question of the Human Rights of All Persons Subjected to Any Form of Detention or Imprisonment - Report of the Working Group on Arbitrary Detention, UN Doc. E/CN.4/1993/24, 12 January 1993, P.12, para 20.

2392 Madafferi v Australia, CCPR/C/81/D/1011/2001, UN Human Rights Committee (HRC), 26 August 2004, para 9.3 
Article 7 ICCPR provides:

"No one shall be subjected to torture or to cruel, inhuman or degrading treatment or punishment. In particular, no one shall be subjected without his free consent to medical or scientific experimentation".

As indicated earlier, Article 7 ICCPR is complementary to the positive obligations contained in Article 10 ICCPR. A person's "dignity and [his/her] physical and mental integrity" is to be protected by both legislation and other measures notwithstanding that acts may be perpetrated by those acting in an "official capacity, outside their official capacity or in a private capacity." 2393 The HRC considers that punishment, of itself, is insufficient when implementing Article 7 - it extends a State's obligations to prevent torture, cruel, inhuman and degrading treatment through legislative, judicial, administrative and other means. ${ }^{2394}$ Article 7 is to be read in combination with Article 2(3), such that a State is to indicate how their measures are effective in guaranteeing "the immediate termination of all the acts prohibited by Article 7", as well as the recognition in law of the right to lodge complaints (consistent with Article 13 CAT). ${ }^{2395}$ The HRC considers that the systematic review of the treatment and custody arrangements for those in detention is an effective means of prevention (consistent with Article 11 CAT), and has requested States to provide detailed information on those aspects in its reports, particularly as they relate to vulnerable persons. ${ }^{2396}$ In relation to the nature of suffering, Article 7 not only contemplates physical suffering, but also mental suffering. ${ }^{2397}$

\section{$C A T$}

Article 2(1) CAT provides:

"Each party shall take effective legislative, administrative, judicial or other measures to prevent acts of torture in any territory under its jurisdiction"

\footnotetext{
2393 UN OHCHR, Human Rights Committee, General Comment 20; Replaces general comment 7 concerning prohibition of torture and cruel treatment or punishment (Art. 7), 10 March 1992, para 2

2394 UN OHCHR, Human Rights Committee, General Comment 20; Replaces general comment 7 concerning prohibition of torture and cruel treatment or punishment (Art. 7), 10 March 1992, para 8

2395 UN OHCHR, Human Rights Committee, General Comment 20; Replaces general comment 7 concerning prohibition of torture and cruel treatment or punishment (Art. 7), 10 March 1992, para 14

2396 UN OHCHR, Human Rights Committee, General Comment 20; Replaces general comment 7 concerning prohibition of torture and cruel treatment or punishment (Art. 7), 10 March 1992, para 11

2397 UN OHCHR, Human Rights Committee, General Comment 20; Replaces general comment 7 concerning prohibition of torture and cruel treatment or punishment (Art. 7), 10 March 1992, para 5
} 
The prohibition against torture is absolute and non-derogable. ${ }^{2398}$

"Torture" is defined in Article 1(1) CAT as, inter alia, the intentional infliction of severe pain or suffering by, with the consent or acquiescence of, a public official or other person acting in an official capacity. Article 16 obliges States to prevent cruel, inhuman or degrading treatment or punishment. The references to "torture" in CAT are said to be inclusive of references to "cruel, inhuman or degrading treatment or punishment" in relation to a number of Articles "in particular", such as: Article 10 (education of, and information for, those involved, inter alia, with the detention or treatment of detained persons); Article 11 (systematic review of custody arrangements and treatment of those detained); and Article 13 (right to complaints procedure and prompt and impartial examination). ${ }^{2399}$

In the interpretation of Articles 16 and 2 CAT, the CteeAT has indicated that torture, cruel, inhuman and degrading treatment or punishment are "indivisible, interdependent and interrelated", and that the words "in particular" in Article 16(1) do not limit effective protection against cruel, inhuman or degrading treatment or punishment to the Articles identified therein. ${ }^{2400}$ Further, cruel, inhuman or degrading treatment or punishment carries the same non-derogable nature as does. ${ }^{2401}$ Agents and private contractors as perpetrators are also included within the scope of Article 2, as well as "contexts where the failure of the State to intervene encourages and enhances the danger of the privately inflicted harm." ${ }^{2402}$ The CteeAT has contemplated privately run detention centres as falling within the scope of a State's obligations under Article 2(1). ${ }^{2403}$ In relation to State complicity, the CteeAT has indicated that:

"where State authorities or others acting in official capacity or under colour of law,
know or have reasonable grounds to believe that acts of torture or ill-treatment are
being committed by non-State officials or private actors and they fail to exercise
due diligence to prevent, investigate, prosecute and punish such non-State officials
or private actors consistently with the Convention, the State bears responsibility and
its officials should be considered as authors, complicit or otherwise responsible

2398 Article 2(2) CAT; see also UN, Committee Against Torture, General Comment No. 2 Implementation by State Parties, 24 January 2008, para 5

2399 Article 16(1) CAT

${ }^{2400}$ UN, Committee Against Torture, General Comment No. 2 - Implementation by State Parties, 24 January 2008, para 3

2401 UN, Committee Against Torture, General Comment No. 2 - Implementation by State Parties, 24 January 2008, para 3

2402 UN, Committee Against Torture, General Comment No. 2 - Implementation by State Parties, 24 January 2008, para 15

${ }^{2403}$ UN, Committee Against Torture, General Comment No. 2 - Implementation by State Parties, 24 January 2008, para 17 
under the Convention for consenting to or acquiescing in such impermissible acts" 2404

The Convention's prohibition against such treatment applies without discrimination, including to "asylum seekers, refugees, or others under international protection, or any other status or adverse distinction."2405

\section{ICESCR}

Article 12(1) ICESCR provides:

"The States Parties to the present Convention recognize the right of everyone to the enjoyment of the highest attainable standard of physical and mental health".

A State's obligations to respect, protect and fulfil obligations under the ICESCR have been explored already in the CteeESCR's General Comment No. $3,{ }^{2406}$ but were reaffirmed in relation to a right to health under its General Comment No. 14. ${ }^{2407}$ The CteeESCR has indicated that the right to health is to be respected by "inter alia, refraining from denying or limiting equal access for all persons, including prisoners or detainees, asylum seekers and illegal immigrants, to preventative, curative and palliative health services". ${ }^{2408}$

\section{CERD}

Article 2 of CERD obliges States Parties to condemn and eliminate racial discrimination. Racial discrimination is defined in Article 1(1) as:

"any distinction, exclusion, restriction or preference based on race, colour, descent, or national or ethnic origin which has the purpose or effect of nullifying or impairing the recognition, enjoyment or exercise, on an equal footing, of human rights and fundamental freedoms in the political, economic, social, cultural or any other field of public life".

Article 1(2) provides that:

"This Convention shall not apply to distinctions, exclusions, restrictions or preferences made by a State Party to this Convention between citizens and noncitizens."

${ }^{2404}$ UN, Committee Against Torture, General Comment No. 2 - Implementation by State Parties, 24 January 2008, para 18

2405 UN, Committee Against Torture, General Comment No. 2 - Implementation by State Parties, 24 January 2008, para 21

2406 UN, Committee on Economic, Social and Cultural Rights, General Comment No. 3 The nature of States' parties obligations (Art 2, par. 1), 14 December 1990

2407 UN, Committee on Economic, Social and Cultural Rights, General Comment No. 14 The right to the highest attainable standard of health (article 12 of the International Covenant on Economic, Social and Cultural Rights, 11 August 2000, paras 30-33

2408 UN, Committee on Economic, Social and Cultural Rights, General Comment No. 14 The right to the highest attainable standard of health (article 12 of the International Covenant on Economic, Social and Cultural Rights, 11 August 2000, para 34 
Article 1(3) removes the application of CERD from matters of nationality, citizenship or naturalisation.

The CteeERD has indicated that Article 1(2) should not be interpreted so as to "detract" from the rights set out in the UDHR, ICCPR and ICESCR. ${ }^{2409}$ Further the CteeERD has indicated that "differential treatment based on citizenship or immigration status will constitute discrimination if the criteria for such differentiation, judged in the light of the objectives and purposes of the Convention, are not applied pursuant to a legitimate aim, and are not proportional to the achievement of this aim." ${ }^{2410}$ In particular, the CteeERD has called for the security of non-citizens, particularly from arbitrary detention, and for accommodation conditions for refugees and asylum seekers to meet international standards. ${ }^{2411}$ The CteeERD has also largely echoed the comments of the CteeECSR for an adequate standard of physical and mental health for non-citizens. ${ }^{2412}$

\section{Working Group on Arbitrary Detention}

In its Deliberation No. 5, the Working Group on Arbitrary Detention stated that detention should occur in specialised facilities but that if, "for practical reasons" that cannot be done, then an asylum seeker is to be kept separately from those imprisoned by reason of criminal law. ${ }^{2413}$

\section{UNHCR Revised Guidelines \& Executive Committee Conclusions}

The UNHCR Revised Guidelines expressly refer to the Standard Minimum Rules for the Treatment of Prisoners and the Principles for the Protection of all Persons under Any Form of Detention or Imprisonment in the formulation of its Guidelines. Guideline 10 of the UNHCR Revised Guidelines emphasises some key provisions of those documents and provides:

“(i) the initial screening of all asylum seekers at the outset of detention to identify trauma or torture victims, for treatment in accordance with Guideline 7;2414

(ii) the segregation within facilities of men and women; children from adults (unless these are relatives); 2415

(iii) the use of separate detention facilities to accommodate asylum-seekers. The use of prisons should be avoided. If separate detention facilities are not used,

2409 UN, Committee on the Elimination of Racial Discrimination, General Recommendation No. 30 - Discrimination Against Non Citizens, 1 October 2004, para 2

2410 UN, Committee on the Elimination of Racial Discrimination, General Recommendation No. 30 - Discrimination Against Non Citizens, 1 October 2004, para 4

2411 UN, Committee on the Elimination of Racial Discrimination, General Recommendation No. 30 - Discrimination Against Non Citizens, 1 October 2004, para 19

2412 UN, Committee on the Elimination of Racial Discrimination, General Recommendation No. 30 - Discrimination Against Non Citizens, 1 October 2004, para 36

2413 UN Commission on Human Rights, Working Group on Arbitrary Detention, 28

December 1999, E/CN.4/2000/4, Annex II, Deliberation No. 5, Principle 9

2414 See the Standard Minimum Rules for the Treatment of Prisoners, Rule 8

2415 See the Standard Minimum Rules for the Treatment of Prisoners, Rule 8(a) 
asylum-seekers should be accommodated separately from convicted criminals or prisoners on remand. There should be no co-mingling of the two groups; 2416

(iv) the opportunity to make regular contact and receive visits from friends, relatives, religious, social and legal counsel. Facilities should be made available to enable such visits. Where possible such visits should take place in private unless there are compelling reasons to warrant the contrary;2417

(v) the opportunity to receive appropriate medical treatment, and psychological counselling where appropriate; 2418

(vi) the opportunity to conduct some form of physical exercise through daily indoor and outdoor recreational activities; ${ }^{2419}$

(vii) the opportunity to continue further education or vocational training; ${ }^{2420}$

(viii) the opportunity to exercise their religion and to receive a diet in keeping with their religion; 2421

(ix) the opportunity to have access to basic necessities i.e. beds, shower facilities, basic toiletries etc.; 2422

(x) access to a complaints mechanism, (grievance procedures) where complaints may be submitted either directly or confidentially to the detaining authority. Procedures for lodging complaints, including time limits and appeal procedures, should be displayed and made available to detainees in different languages." 2423

Through its Executive Committee Conclusions, the UNHCR has called for humane conditions of detention for refugees and asylum seekers, that they not be detained with common criminals or be placed in areas where their physical safety is endangered. ${ }^{2424}$ Further, the Executive Committee has expressed its deep concern over "physical attacks on refugees and detention under unacceptable conditions". ${ }^{425}$

${ }^{2416}$ See the Standard Minimum Rules for the Treatment of Prisoners, Rule 8(c); Principles for the Protection of all Persons under Any Form of Detention or Imprisonment, Principle 8.

2417 See the Principles for the Protection of all Persons under Any Form of Detention or Imprisonment, Principles 16(1), 18 and 19

${ }^{2418}$ See the Principles for the Protection of all Persons under Any Form of Detention or Imprisonment, Principle 24; Standard Minimum Rules for the Treatment of Prisoners, Rules 22-26

2419 See the Standard Minimum Rules for the Treatment of Prisoners, Rule 21

${ }^{2420}$ See the Principles for the Protection of all Persons under Any Form of Detention or Imprisonment, Principle 28

${ }^{2421}$ See the Standard Minimum Rules for the Treatment of Prisoners, Rules 41-42

2422 See the Standard Minimum Rules for the Treatment of Prisoners, Rules 15-19

${ }^{2423}$ See the Standard Minimum Rules for the Treatment of Prisoners, Rules 35-36; Principles for the Protection of all Persons under Any Form of Detention or Imprisonment, Principle 33

${ }^{2424}$ UNHCR, Executive Committee Conclusion No. 44 (XXXVII) - Detention of Refugees and Asylum-Seekers, 1986, para (f); UNHCR, Executive Committee Conclusion No. 85 (XLIX) Conclusion on International Protection, 1998, para (ee)

2425 UNHCR, Executive Committee Conclusion No. 68 (XLIII) - General Conclusion on International Protection, 1992, para (e) 


\subsubsection{Council of Europe}

ECHR

Article 3 ECHR provides:

"No one shall be subjected to torture or to inhuman or degrading treatment or punishment"

The distinction between torture and inhuman and degrading treatment stems from "the intensity of the suffering inflicted" with torture having a "special stigma to deliberate inhuman treatment causing very serious and cruel suffering." ${ }^{2426}$ Indeed, the force-feeding of a hunger-striking detained person (which was resisted by the detained person) without medical necessity, and with the use of particular restraints (handcuffs, a mouth widener, a special rubber tube inserted into the food pipe) was considered by the ECtHR to amount to torture. ${ }^{2427}$

In MSS $v$ Belgium and Greece, the Court reiterated the general principles in relation to inhuman or degrading treatment. ${ }^{2428}$ In order to fall under the umbrella of protection proffered by Article 3, a minimum level of severity must be reached, which is a relative assessment taking into account all the circumstances of the case, such as "the nature and context of the treatment, the manner and method of its execution, its duration, its physical or mental effects and, in some instances, the sex, age and state of health of the victim". ${ }^{2429}$ The Court will examine the particular circumstances pertinent to the individual, ${ }^{2430}$ but the absolute terms of Article 3 means that any such assessment is not qualified by the conduct of the individual. ${ }^{2431}$

Dealing with the terms of Article 3 itself, "inhuman" treatment is one that is "premeditated, was applied for hours at a stretch and caused either actual bodily injury or intense physical or mental suffering". ${ }^{2432}$ However, a lack of intention is not necessarily fatal to a finding of inhuman treatment. ${ }^{2433}$

\footnotetext{
2426 Ireland v United Kingdom, No. 5310/71, Judgment (Plenary), 18 January 1978, para 167 affirmed in Aksoy v Turkey, No. 21987/93, Judgment, 18 December 1996, para 63. See also Selmouni v France, No. 25803/94, Judgment, 28 July 1999, paras 91-106 at 96 2427 Nevmerzhitsky v Ukraine, No. 54825/00, Judgment, 5 April 2005, paras 93-99 at 98 2428 M.S.S. v Belgium and Greece, No. 30696/09, Judgment Grand Chamber, 21 January 2011, paras 216-222

${ }^{2429}$ Kudla v Poland, No. 30210/96, Judgment Grand Chamber, 26 October 2000, para 91; see also Ireland $v$ United Kingdom, No. 5310/71, Judgment, 18 January 1978 para 162; and Tyrer $v$ United Kingdom, No. 5862/72, Judgment, 25 April 1978 para 30 2430 Riad and Idiab v Belgium, Nos. 29787/03 and 29810/03, Judgment, 24 January 2008, para 100

2431 Labita v Italy, No. 26772/95, Judgment, 6 April 2000, para 119

2432 Kudla $v$ Poland, No. 30210/96, Judgment Grand Chamber, 26 October 2000, para 92

2433 Labita v Italy, No. 26772/95, Judgment, 6 April 2000, para 120; see also V v United Kingdom, No. 24888/94, Judgment, 16 December 1999 para 71
} 
"Degrading treatment" is treatment that debases and humiliates a victim by arousing "feelings of fear, anguish and inferiority". ${ }^{2434}$ The humiliation need not be in the eyes of others - it is sufficient for the victim to view the humiliation through his or her own eyes. ${ }^{2435}$ As with inhuman treatment, the absence of intention is not necessarily fatal to a finding of degrading treatment. ${ }^{2436}$ In relation to those detained under Article 5(1)(f), the ECtHR has not hesitated in finding conditions of detention amounting to degrading treatment in breach of Article 3. ${ }^{2437}$ The Court has held that those deprived of their liberty should also be afforded "requisite medical assistance". 2438

In matters involving either inhuman or degrading treatment, the treatment must not "go beyond that inevitable element of suffering or humiliation connected with a given form of legitimate treatment or punishment". ${ }^{2439}$

Although Ovey and White note that the distinction between "treatment" and "punishment" is not usually made in cases under Article $3^{2440}$ and that "little distinction can be drawn between 'treatment' and 'punishment", ${ }^{2441}$ such a position would appear difficult to maintain in light of the fact that detained asylum seekers are generally subject to administrative detention, not penal incarceration, let alone the fact that they have not been convicted of a crime. $^{2442}$

As discussed in Chapter 5, notwithstanding Article 3, the place and conditions of detention may also have a bearing on the lawfulness of the detention itself

${ }^{2434}$ Kudla v Poland, No. 30210/96, Judgment Grand Chamber, 26 October 2000, para 92; Pretty $v$ United Kingdom, No. 2346/02, Judgment, 29 April 2002, para 52

2435 Tyrer $v$ United Kingdom, No. 5856/72, Judgment, 25 April 1978, para 32; Al-Agha v Romania, No. 40933/02, Judgment, 12 January 2010, para 68

2436 Peers $v$ Greece, No. 28524/95, Judgment, 19 April 2001, para 74

${ }^{2437}$ See, for example, R.U. $v$ Greece, No. 2237/08, Judgment, 7 June 2011, paras 62-64; M.S.S. v Belgium and Greece, No. 30696/09, Judgment Grand Chamber, 21 January 2011, paras 223-234; Al-Agha v Romania, No. 40933/02, Judgment, 12 January 2010, paras 61-69 (French version); S.D. v Greece, No. 53541/07, Judgment, 11 June 2009, paras 49-54 (French version); Tabesh $v$ Greece, No. 8256/07, Judgment, 26 November 2009, paras 3844 (French version); A. A. v Greece, No. 12186/08, Judgment, 22 July 2010, paras 57-65 (French version); Riad and Idiab v Belgium, Nos. 29787/03 and 29810/03, Judgment, 24 January 2008, paras 104-111 (French version); Shchebet v Russia, No. 16074/07, Judgment, 12 June 2008, paras 80-96; Dougoz v Greece, Application 40907/98, Judgment, 6 March 2001, paras 43-49

2438 Mouisel v France, No. 67263/01, Judgment, 14 November 2002, para 40

${ }^{2439} V v$ United Kingdom, No. 24888/94, Judgment, 16 December 1999 para 71; Kudla $v$ Poland, No. 30210/96, Judgment Grand Chamber, 26 October 2000, para 94;

2440 Ovey, C and White, R, The European Convention on Human Rights, 2006, Oxford University Press, Oxford, Pp.83-84

2441 Ovey, C and White, R, The European Convention on Human Rights, 2006, Oxford University Press, Oxford, P.97

${ }^{2442}$ See Saadi v United Kingdom, No. 13229/03, Judgment, Grand Chamber, 29 January 2008 , para 74 
under Article 5(1). ${ }^{2443}$ Indeed, a connection with between Article 5(1) and Article 3 may arise where the "extreme vulnerability" of a minor, for example, might result in a breach of a State's positive obligations under Article 3 if the place and conditions of detention are suitable only for adults and not children. ${ }^{244}$ In those circumstances, a minor's extreme vulnerability may take precedence over their status as an "illegal alien"2445 (but not such to limit the grounds of detention solely to Article 5(1)(d) (see Chapter 5)).

Two further points about positive obligations under Article 3 should also be noted. Firstly, Article 3 imposes a positive procedural obligation to conduct an effective investigation of the treatment complained of which the Court considers essential to avoid impunity and to ensure the effective guarantee of the rights enshrined in Article $3 .{ }^{2446}$ Secondly, the acts of private individuals (and private entities) fall within the scope of Article 3 as States are obliged to ensure the prohibition of the treatment contemplated by Article 3 regardless of whether such treatment was at the hands of the State or private actors. ${ }^{247}$

\section{CPT}

The CPT Standards expressly include immigration detention facilities in the scope of the Committee's inspections. The CPT has made a distinction between irregular migrants and asylum seekers and has called for detained asylum seekers to be "afforded a wide range of safeguards in line with their status, going beyond those applicable to irregular migrants" contemplated in the CPT Standards. ${ }^{2448}$ In relation to general immigration detained persons, the CPT has noted that point of entry holding facilities have been inadequate and that prisons have been used (which the CPT considers "fundamentally flawed" - expressing the view that specially designed accommodation should

2443 Aerts v Belgium, No. 61/2997/845/1051, Judgment, 30 July 1998, para 46; Bizzotto v Greece, No. 22126/93, Judgment, 15 November 1996, para 31; Ashingdane v United Kingdom, No. 8225/78, Judgment, 28 May 1985, para 44

2444 Mubilanzila Mayeka and Kaniki Mitunga v Belgium, No. 13178/03, Judgment, 12 October 2006, at paras 102-105; Muskhadzhiyeva E ors v Belgium, No. 41442/07, Judgment, 19 January 2010, citing paras 101-104 of Mubilanzila with approval at paras 73-75; Popov $v$ France, Nos. 39472/07 and 39474/07, Judgment, 19 January 2012, para 103; Kanagaratnam $v$ Belgium, No. 15297/09, Judgment, 13 December 2011, para 69; Rahimi v Greece, No. 8687/08, Judgment, 5 April 2011, paras 86, 94-95 (unaccompanied minor)

2445 Mubilanzila Mayeka and Kaniki Mitunga v Belgium, No. 13178/03, Judgment, 12 October 2006, at para 55; Muskhadzhiyeva $\mathcal{E}$ ors v Belgium, No. 41442/07, Judgment, 19 January 2010, citing paras 53-55 of Mubilanzila with approval at paras 55-58

2446 Assenov v Bulgaria, 24760/94, Judgment, 28 October 1998; Sevtap Veznedaroğlu v Turkey, No. 32357/96, Judgment, 11 April 2000, paras 32 and 35; Ecli v Turkey, Nos. 23145/93 and 25091/94, Judgment, 13 November 2003, paras 648-649; Shchukin \& Ors v Cyprus, No. 14030/03, Judgment, 29 July 2010, paras 101-108 on the procedural violation of Article 3

2447 Costello-Roberts v United Kingdom, No. 13134/87, Judgment, 25 March 1993; A v United Kingdom, No. 25599/94, Judgment, 23 September 1998

2448 Council of Europe, CteePT, CPT Standards, 2010, CPT/Inf/E (2002) 1 - Rev 2010, P.58, para 76 
be used, with prisons only used in exceptional circumstances of known violence). ${ }^{249}$ The CPT views the dissemination of clear rules regarding the detention facility in a range of languages as important for both detained persons and staff members. ${ }^{2450}$ Understandably, the CPT is of the view that the physical and mental health of detained persons must be catered for and which takes into account pre-existing traumatic experiences. ${ }^{2451}$ The CPT has also expressed its views regarding standards applicable in the event of foreign nationals being deported - particularly on the use of coercive measures, medication, physical restraint, psychological preparation for the person to be removed, proper staff training and managerial and external oversight. ${ }^{2452}$

\section{Committee of Ministers' Recommendation Rec(2003)5}

The Committee of Ministers' Recommendation Rec(2003)5 provides that "measures of detention should be implemented in a humane manner, respecting the inherent dignity of the person and in accordance with applicable norms of international law and international standards." 2453 Supplementing that general standard are more specific recommendations that asylum seekers should: (1) be detained in an appropriate place and that, "in principle", prisons should not be used; ${ }^{2454}$ (2) have their basic needs and requirements should met so as to ensure an adequate standard of living for their health and well-being; ${ }^{2455}$ (3) receive appropriate medical treatment and psychological counselling - particularly for vulnerable persons; ${ }^{2456}$ (4) be accommodated separately according to gender; ${ }^{2457}(5)$ be able to practise their

${ }^{2449}$ Council of Europe, CteePT, CPT Standards, 2010, CPT/Inf/E (2002) 1 - Rev 2010, P. 54

2450 Council of Europe, CteePT, CPT Standards, 2010, CPT/Inf/E (2002) 1 - Rev 2010, P.61

2451 Council of Europe, CteePT, CPT Standards, 2010, CPT/Inf/E (2002) 1 - Rev 2010, P.62

2452 Council of Europe, CteePT, CPT Standards, 2010, CPT/Inf/E (2002) 1 - Rev 2010, Pp.66-71

2453 Council of Europe, Committee of Ministers, Recommendation Rec(2003)5 of the Committee of Ministers to member states on measures of detention of asylum seekers, 16 April 2003, Para 9

2454 Council of Europe, Committee of Ministers, Recommendation Rec(2003)5 of the Committee of Ministers to member states on measures of detention of asylum seekers, 16 April 2003, Para 10

2455 Council of Europe, Committee of Ministers, Recommendation Rec(2003)5 of the Committee of Ministers to member states on measures of detention of asylum seekers, 16 April 2003, Para 11

2456 Council of Europe, Committee of Ministers, Recommendation Rec(2003)5 of the Committee of Ministers to member states on measures of detention of asylum seekers, 16 April 2003, Para 13

2457 Council of Europe, Committee of Ministers, Recommendation Rec(2003)5 of the Committee of Ministers to member states on measures of detention of asylum seekers, 16 April 2003, Para 14 
religion and observe any special religious dietary requirements; ${ }^{2458}$ and (6) be guaranteed access to a complaints mechanism in relation to the conditions of detention. ${ }^{2459}$

\section{Committee of Ministers' Twenty Guidelines on Forced Returns}

Similarly, the Committee of Ministers' Twenty Guidelines on Forced Returns also calls for detained persons to be held in purpose-designed facilities, staffed with qualified personnel, ${ }^{2460}$ and adopting conditions and a regime "appropriate to their legal situation". ${ }^{2461}$ The Guidelines also call for adequate furnishing, cleanliness and for the facilities to be in a good state of repair bearing as little resemblance as possible to a "carcereal" environment. ${ }^{2462}$ As with Recommendation $\operatorname{Rec}(2003) 5$, the Guidelines do not prohibit the use of prisons as detention facilities, merely stating that persons should not "normally be held together with ordinary prisoners" but reflect Recommendation Rec(2003)5's standards regarding the separation of men and women. ${ }^{2463}$ The Guidelines also require that detained persons have the right to file complaints regarding their treatment (including where they have not been protected from ill-treatment by other detained persons). ${ }^{2464}$ Largely echoing the views of the CPT, the Guidelines also recommend (but do not require) the provision of information about rights and procedures of the detention facility and whom they are entitled to contact. ${ }^{2465}$

\subsubsection{EU Charter \& General Principles of EU Law}

In the Union sphere, Article 1 of the EU Charter provides that "Human dignity is inviolable. It must be respected and protected". Further Article 3(1) provides that "Everyone has the right to respect for his or her physical and mental integrity". Prior to the formal legal status granted to the EU Charter,

2458 Council of Europe, Committee of Ministers, Recommendation Rec(2003)5 of the Committee of Ministers to member states on measures of detention of asylum seekers, 16 April 2003, Para 15

2459 Council of Europe, Committee of Ministers, Recommendation Rec(2003)5 of the Committee of Ministers to member states on measures of detention of asylum seekers, 16 April 2003, Para 19

2460 Committee of Ministers, Council of Europe, Twenty Guidelines on Forced Return, CM(2005)40 Addendum final, Strasbourg, 20 May 2005, Guideline 10(3)

2461 Committee of Ministers, Council of Europe, Twenty Guidelines on Forced Return, CM(2005)40 Addendum final, Strasbourg, 20 May 2005, Guideline 10(1)

2462 Committee of Ministers, Council of Europe, Twenty Guidelines on Forced Return, CM(2005)40 Addendum final, Strasbourg, 20 May 2005, Guideline 10(2)

2463 Committee of Ministers, Council of Europe, Twenty Guidelines on Forced Return, CM(2005)40 Addendum final, Strasbourg, 20 May 2005, Guideline 10(4)

2464 Committee of Ministers, Council of Europe, Twenty Guidelines on Forced Return, CM(2005)40 Addendum final, Strasbourg, 20 May 2005, Guideline 10(6)

2465 Committee of Ministers, Council of Europe, Twenty Guidelines on Forced Return, CM(2005)40 Addendum final, Strasbourg, 20 May 2005, Guideline 10(7) 
those rights also formed part of the general principles of Union law as established by the CJEU. ${ }^{2466}$

Further, Article 4 of the EU Charter prohibits torture, inhuman or degrading treatment or punishment. In this regard, it will be recalled that the CJEU in N.S. held that transfer of an asylum seeker to another Member State (that is, in a Dublin situation) must not occur if there is a real risk that the asylum seeker would face inhuman or degrading treatment as contemplated by Article 4 of the EU Charter. ${ }^{2467}$

\subsubsection{Special Categories of Asylum Seeker}

\subsubsection{Minors}

\section{International}

Provisions of CROC are pertinent to minors in detention, as well as minors generally in the territory of State. Three situations involving minors are contemplated: (1) as asylum seekers; (2) as UAMs or separated minors; and (3) as minors accompanying family members who are asylum seekers.

\section{"Best Interests of the Child"}

The overarching standard set forth in CROC is that the best interests of the child shall be the primary consideration. ${ }^{2468}$ The CteeRC has given some insight (albeit, in relation to UAMs and separated minors) as to what needs to be considered as part of an assessment of the best interests of the child:

\footnotetext{
"A determination of what is in the best interests of the child requires a clear and comprehensive assessment of the child's nationality, upbringing, ethnic, cultural and linguistic background, particular vulnerabilities and protection needs." 2469
}

CROC obliges State Parties to take all legislative and administrative measures to ensure a minor's protection as is necessary for his or her well-being. ${ }^{2470}$ Those standards as established by competent authorities must be upheld by all institutions (that is, both public and private) that provide services and facilities for the care and protection of children. ${ }^{2471}$

\footnotetext{
${ }^{2466}$ Case C-36/02 Omega Spielhalen- und Automatenaufstellungs-GmbH v Oberbürgermeistern der Bundesstadt Bonn, Judgment, 14 October 2004, paras 34-35, 39-41; see also Case C377/98 Kingdom of the Netherlands $v$ European Parliament and Council of the European Union, Judgment, 9 October 2001.

2467 Case C-411/10 and C-493/10 N.S. $v$ Secretary of State for the Home Department and M. E. and Others $v$ Refugee Applications Commissioner and Minister for Justice, Equality and Law Reform, 21 December 2011, Judgment Grand Chamber, para 94

2468 Article 3(1) CROC

${ }^{2469}$ UN Committee on the Rights of the Child, General Comment No. 6 (2005) - Treatment of unaccompanied and separated children outside their country of origin, 1 September 2005, para 20 2470 Article 3(2) CROC

2471 Article 3(3) CROC
} 
Minors deprived of their liberty

Dealing specifically with deprivations of liberty, Article 37 CROC provides:

“ (a) no child shall be subjected to torture or other cruel, inhuman or degrading treatment or punishment. Neither capital punishment nor life imprisonment without possibility of release shall be imposed for offences committed by persons below eighteen years of age"

$[\ldots]$

(c) every child deprived of liberty shall be treated with humanity and respect for the inherent dignity of the human person, and in a manner which takes into account the needs of persons of his or her age. In particular, every child deprived of liberty shall be separated from adults unless it is considered in the child's best interests not to do so and shall have the right to maintain contact with his or her family through correspondence and visits, save in exceptional circumstances"

UNICEF has observed that the CteeRC considers the implementation of Article 37 by reference to the United Nations Standard Minimum Rules for the Administration of Juvenile Justice ("the Beijing Rules"), the United Nations Rules for the Protection of Juveniles Deprived of their Liberty, and the United Nations Guidelines for the Prevention of Juvenile Delinquency. ${ }^{2472}$ The HRC has also invited State parties to indicate their application of the Beijing Rules in their reports in relation to Article 10 ICCPR. ${ }^{2473}$

The requirement that children be separated from adults whilst deprived of their liberty is also reflected in Article 10(2)(b) ICCPR $^{2474}$ and Rule 8(d) of the UN Standard Minimum Rules for the Treatment of Prisoners, and inferentially by Article 24 ICCPR. ${ }^{2475}$ Australia has made a reservation in relation to the second sentence of Article 37(c) CROC (in relation to the separation of minors from adults in prisons) in that it will only implement that obligation:

"to the extent that such imprisonment is considered by the responsible authorities to be feasible and consistent with the obligation that children be able to maintain contact with their families, having regard to the geography and demography of Australia".

2472 UNICEF, Implementation Handbook for the Convention on the Rights of the Child, (3 ed), 2007, P.548; see, for example, UN Committee on the Rights of the Child, General Comment No. 10 (2007) - Children's rights in juvenile justice, 25 April 2007, para 88. See also Guideline 6, note 10 and Guideline 10, note 17, of the UNHCR Revised Guidelines which refer to the UN Rules for the Protection of Juveniles Deprived of their Liberty

2473 UN OHCHR, Human Rights Committee, General Comment 21: Replaces general comment 9 concerning humane treatment of persons deprived of liberty (Art 10), 10 April 1992, para 3

2474 See further, UN OHCHR, Human Rights Committee, General Comment 21: Replaces general comment 9 concerning humane treatment of persons deprived of liberty (Art 10), 10 April 1992, para 13

2475 UN OHCHR, Human Rights Committee, General Comment 17 - Rights of the Child (Art 24), 7 April 1989, paras 2 and 5 
In relation to UAMs and separated children, the CteeRC has again emphasised the importance of the separation of children from adults when deprived of their liberty, unless it is not in their best interests to do so. Further the CteeRC stresses that the underlying approach should be "care" and not "detention" - such as, by providing living quarters suitable for children, by not locating the facilities in isolated areas, and by allowing minors to be able to receive visits from friends, relatives, social and legal counsel and their guardian. The CteeRC has indicated that UAMs and separated children deprived of their liberty receive all the basic necessities including appropriate medical treatment and psychological counselling. The CteeRC is of the view that their right to education should ideally take place outside the detention facility in order to facilitate their integration upon release. The CteeRC has also emphasised the right of a minor to recreation and play as provided for in Article 31 CROC. ${ }^{2476}$

From what are minors to be protected?

Physical and/or mental violence resulting from placement or acts within a detention environment can have particularly devastating effects for minors. Article 19 CROC provides that States are always under an obligation to:

\begin{abstract}
"take all appropriate legislative, administrative, social and educational measures to protect the child from all forms of physical and mental violence, injury or abuse, neglect or negligent treatment, maltreatment or exploitation, including sexual abuse, while in the care of parent(s), legal guardian(s) or any other person who has the care of the child."
\end{abstract}

The protection obligations under Article 19 are comprehensive. "Neglect" is said to include physical, psychological or emotional neglect, and may include physical or mental health neglect by the withholding of essential healthcare, educational neglect or neglect by virtue of abandonment. ${ }^{2477}$ "Mental violence" includes that resulting from being placed in humiliating or degrading detention conditions. ${ }^{2478}$ "Physical violence" includes sexual abuse and exploitation, as well as torture, inhuman or degrading treatment or punishment. ${ }^{2479}$ Self-harm is also a contemplated form of violence. ${ }^{2480}$ The "caregivers" contemplated by Article 19 are said to include those with "clear, recognised legal, professional-ethical and/or cultural responsibility for the

2476 UN Committee on the Rights of the Child, General Comment No. 6 (2005) - Treatment of unaccompanied and separated children outside their country of origin, 1 September 2005, CRC/GC/2005/6, para 63

2477 UN Committee on the Rights of the Child, General Comment No. 13 (2011) - The right of the child to freedom from all forms of violence, 18 April 2011, para 20

2478 UN Committee on the Rights of the Child, General Comment No. 13 (2011) - The right of the child to freedom from all forms of violence, 18 April 2011, para 21(f)

2479 UN Committee on the Rights of the Child, General Comment No. 13 (2011) - The right of the child to freedom from all forms of violence, 18 April 2011, para 22ff, especially paras 25-26 ${ }^{2480}$ UN Committee on the Rights of the Child, General Comment No. 13 (2011) - The right of the child to freedom from all forms of violence, 18 April 2011, para 28 
safety, health, development and well-being of the child" - which is inclusive of government or non-government institutional personnel "in the position of caregivers." ${ }^{2481}$ For UAMs, the State is said to be the de facto caregiver, ${ }^{2482}$ consistent with Article 20 CROC. ${ }^{2483}$

States are also obliged to protect children from economic exploitation, ${ }^{2484} \mathrm{drug}$ abuse, ${ }^{2485}$ sexual exploitation and abuse, ${ }^{2486}$ trafficking, ${ }^{2487}$ and any other form of exploitation that prejudices their welfare. ${ }^{2488}$

To render effective the rights for which provision has been made in Article 19, Article 12 provides the right of a minor who is capable of forming his or her own views to express those views freely in all matters affecting him or her. The CteeRC has indicated that compliance with Article 12 also includes the implementation of an independent and child-friendly complaints mechanism. ${ }^{2489}$

What is a minor to be provided?

A minor has the right to a standard of living "adequate for the child's physical, mental, spiritual, moral and social development". ${ }^{2490}$ Although that responsibility primarily rests on parents or others responsible for the child, ${ }^{2491}$ in a detention context, the child's right and the reciprocal parental responsibility can be seriously compromised or nullified. Accordingly States are obliged to assist parents with that right, particularly in relation to "nutrition, clothing and housing" 2492 and consistent with the State's general

2481 UN Committee on the Rights of the Child, General Comment No. 13 (2011) - The right of the child to freedom from all forms of violence, 18 April 2011, para 33

2482 UN Committee on the Rights of the Child, General Comment No. 13 (2011) - The right of the child to freedom from all forms of violence, 18 April 2011, para 33. The CteeRC has indicated that Articles 4 and 20 CROC apply as the lex specialis in place of Article 2(3) ICCPR: see UN Committee on the Rights of the Child, General Comment No. 6 (2005) Treatment of unaccompanied and separated children outside their country of origin, 1 September 2005, para 16

2483 UN Committee on the Rights of the Child, General Comment No. 13 (2011) - The right of the child to freedom from all forms of violence, 18 April 2011, para 35

2484 Article 32 CROC

2485 Article 33 CROC

2486 Article 34 CROC

2487 Article 35 CROC

2488 Article 36 CROC; in relation to Article 34, 35 and 36 CROC, see UN Committee on the Rights of the Child, General Comment No. 6 (2005) - Treatment of unaccompanied and separated children outside their country of origin, 1 September 2005, paras 50-53

2489 UN CteeRC, Concluding Observations of the Committee on the Rights of the Child: St Kitts and Nevis, 24 August 1999, CRC/C/15/Add.104, para 13

2490 Article 27(1) CROC

2491 Article 27(2) CROC

2492 Article 27(3) CROC; see also UN Committee on the Rights of the Child, General Comment No. 6 (2005) - Treatment of unaccompanied and separated children outside their country of origin, 1 September 2005, paras 44-45 
obligation to ensure "to the maximum extent possible the survival and development of the child". ${ }^{2493}$

CROC provides that a minor has a right to "the highest attainable standard of health and to facilities for the treatment of illness and rehabilitation of health". ${ }^{2494}$ States are also under an obligation to provide rehabilitation services to child victims of neglect, exploitation, abuse, torture, cruel, inhuman or degrading treatment or punishment or armed conflicts. ${ }^{2495}$

The right of a minor to an education is secured by Article 28 CROC. ${ }^{2496}$ This is also supported by Guideline 6 of the UNHCR Revised Guidelines that indicates that education should be given to minors notwithstanding their detention, as well as the right to everyone to education enshrined in Article 13 ICESCR. The respect for the cultural identity of a minor or the minor's parents', is to be developed as part of their education (and which may be particularly susceptible to being diminished in a detention context). ${ }^{2497}$

Further, the UNESCO Convention Against Discrimination in Education calls for the elimination and prevention of discrimination in education, ${ }^{2498}$ including access to resident foreign nationals on the same basis as its own nationals. ${ }^{2499}$ The term "discrimination" under the UNESCO Convention is broad - it includes measures which "have the purpose or effect of nullifying or impairing equality of treatment in education" and which include, in particular, denying access to education to any group or person, or limiting education to that of an inferior standard to any group or person. ${ }^{2500}$ Also proscribed are the establishment or maintenance of separate institutions for persons or groups of persons (unless one of the exceptions applies). ${ }^{2501}$ Accordingly, the separate education of children in detention (as opposed to a community context) may arguably contravene the provisions of the UNESCO Convention. ${ }^{2502}$

\footnotetext{
2493 Article 6(2) CROC

2494 Article 24 CROC; see also Article 23 in relation to minors with disabilities

2495 Article 39 CROC; see also see UN Committee on the Rights of the Child, General Comment No. 6 (2005) - Treatment of unaccompanied and separated children outside their country of origin, 1 September 2005, CRC/GC/2005/6, paras 46-49

2496 See also UN Committee on the Rights of the Child, General Comment No. 6 (2005) Treatment of unaccompanied and separated children outside their country of origin, 1 September 2005, paras 41-43. See further, Bourgonje, P, Education for refugee and asylum seeking children in OECD countries, Education International, March 2010, http://download.eiie.org/Docs/WebDepot/EIResearch_Paloma_Eng_final_med.pdf (last accessed 3 July 2012), Pp.27-30

2497 Article 29(1)(c) CROC

2498 Article 3 of the UNESCO Convention Against Discrimination in Education

2499 Article 3(e) of the UNESCO Convention Against Discrimination in Education

2500 Article 1(a) and (b) of the UNESCO Convention Against Discrimination in Education

2501 Article 1(c) of the UNESCO Convention Against Discrimination in Education

2502 It should be noted that Australia has accepted the UNESCO Convention and has made a notification that its territorial application extends to Christmas Island
} 


\section{Minors - Council of Europe \\ ECHR}

Article 3 ECHR is equally applicable to children and, as indicated earlier in this chapter and in Chapter 5, a State may breach its positive obligations under Article 3 if the conditions of detention are not suitable for a minor. ${ }^{2503}$

\section{CPT}

The CteePT has indicated that, although detention of minors "is rarely justified and, in the Committee's view, can certainly not be motivated solely by the absence of residence status", ${ }^{2504}$ minors should be subject to an initial interview to determine their vulnerabilities. ${ }^{2505}$ The Committee takes the view that a social worker and psychologist should be regularly present and make contact with the minor, together with mixed-gender staffing. ${ }^{2506}$ Further, "constructive activities" should be made available to minors with a focus on continuing their education. ${ }^{2507}$ The CteePT takes the view that special living arrangements should be made for minors - including separation from adults unless it is in the best interests of the child. ${ }^{2508}$ These standards are in addition to those the CteePT applies generally in relation to juveniles deprived of their liberty, and which are complementary to CROC, the UN Standard Minimum Rules for the Administration of Juvenile Justice ("the Beijing Rules"), the UN Rules for the Protection of Juveniles Deprived of their Liberty and the UN Guidelines for the Prevention of Juvenile Delinquency. ${ }^{2509}$

\section{Committee of Ministers' Recommendation Rec(2003)5}

The Committee of Ministers' Recommendation Rec(2003)5 makes special provision for the detention of minor asylum seekers. The Recommendation

2503 Mubilanzila Mayeka and Kaniki Mitunga v Belgium, No. 13178/03, Judgment, 12 October 2006, at para 55; Muskhadzhiyeva \& ors v Belgium, No. 41442/07, Judgment, 19 January 2010, citing paras 53-55 of Mubilanzila with approval at paras 55-58; Popov $v$ France, Nos. 39472/07 and 39474/07, Judgment, 19 January 2012, para 103 (Article 3), paras 115121, (Article 5(1)(f)); Kanagaratnam v Belgium, No. 15297/09, Judgment, 13 December 2011, para 69 (Article 3), paras 86-87 (Article 5(1)(f) - children), paras 94-95 (Article 5(1)(f) - mother); Rahimi v Greece, No. 8687/08, Judgment, 5 April 2011, paras 86, 94-95 (Article 3), paras 109-110 (Article 5(1)(f)) (unaccompanied minor)

${ }^{2504}$ Council of Europe, CteePT, CPT Standards, 2010, CPT/Inf/E (2002) 1 - Rev 2010, P.64, para 97

2505 Council of Europe, CteePT, CPT Standards, 2010, CPT/Inf/E (2002) 1 - Rev 2010, P.65, para 98

2506 Council of Europe, CteePT, CPT Standards, 2010, CPT/Inf/E (2002) 1 - Rev 2010, P.65, para 99

2507 Council of Europe, CteePT, CPT Standards, 2010, CPT/Inf/E (2002) 1 - Rev 2010, P.65, para 99

2508 Council of Europe, CteePT, CPT Standards, 2010, CPT/Inf/E (2002) 1 - Rev 2010, P.65, para 100

${ }^{2509}$ Council of Europe, CteePT, CPT Standards, 2010, CPT/Inf/E (2002) 1 - Rev 2010, P.72, para 21 
provides that minors should not be separated from their parents or other responsible adults against their will (reflecting Article 9 CROC), ${ }^{2510}$ and that minors should be separated from adults unless they are members of the same family. ${ }^{2511}$ The Recommendation also provides that minors should not be held under "prison-like conditions" - rather they should be released as quickly as possible and placed in other accommodation or, if otherwise impossible, that "special arrangements" suitable for children and their families should be made. ${ }^{2512}$ UAMs should be placed in alternative and non-custodial arrangements. ${ }^{2513}$

\section{Committee of Ministers' Twenty Guidelines on Forced Returns}

The Committee of Ministers' Twenty Guidelines on Forced Return provide that minors have a right to education and leisure ("including a right to engage in play and recreation activities appropriate to their age") regardless of whether they are in detention or not. ${ }^{2514}$ This largely reflects Articles 28 and 31 CROC. However, unlike CROC, the right to education may be qualified by the length of stay of the minor. ${ }^{2515}$ The Guidelines provide that separated children should be accommodated in institutions "with the personnel and facilities which take into account the needs of persons and their age.",2516

\section{Minors - EU Charter}

In the Union sphere, Article 24(1) of the EU Charter provides:

"Children shall have the right to such protection and care as is necessary for their well-being. They may express their views freely. Such views shall be taken into consideration on matters which concern them in accordance with their age and maturity."

The EU Charter ensures that the best interest of the child principle applies irrespective of whether action in relation to a child is taken by a public

2510 Council of Europe, Committee of Ministers, Recommendation Rec(2003)5 of the Committee of Ministers to member states on measures of detention of asylum seekers, 16 April 2003, Para 21

2511 Council of Europe, Committee of Ministers, Recommendation Rec(2003)5 of the Committee of Ministers to member states on measures of detention of asylum seekers, 16 April 2003, Para 14

2512 Council of Europe, Committee of Ministers, Recommendation Rec(2003)5 of the Committee of Ministers to member states on measures of detention of asylum seekers, 16 April 2003, Para 22

2513 Council of Europe, Committee of Ministers, Recommendation Rec(2003)5 of the Committee of Ministers to member states on measures of detention of asylum seekers, 16 April 2003, Para 23

2514 Committee of Ministers, Council of Europe, Twenty Guidelines on Forced Return, CM(2005)40 Addendum final, Strasbourg, 20 May 2005, Guideline 11(3)

Committee of Ministers, Council of Europe, Twenty Guidelines on Forced Return, CM(2005)40 Addendum final, Strasbourg, 20 May 2005, Guideline 11(3) last sentence

Committee of Ministers, Council of Europe, Twenty Guidelines on Forced Return, CM(2005)40 Addendum final, Strasbourg, 20 May 2005, Guideline 11(4) 
authority or public institution. ${ }^{2517}$ The EU Charter also provides a right to education as well as access to vocational and continuing training, ${ }^{2518}$ inclusive of "the possibility to receive free compulsory education.", 2519

\subsubsection{Families}

\section{International}

The UNHCR Refugee Children Guidelines on Protection and Care emphasise that families should be kept together in humane conditions. ${ }^{2520}$

The circumstances in which asylum seekers and their families may be detained, together with the principle of family unity, have been explored previously in Chapter 5. The primacy of the family is embodied in Article 23(1) ICCPR and Article 10(1) ICESCR where it is described as "the natural and fundamental group unit of society". Article 23(1) provides that the family is "entitled to protection by society and the State", which has been emphasised by the HRC. ${ }^{2521}$ Article 10(1) ICESCR provides that the family should be accorded "the widest possible protection and assistance". Article 17(1) ICCPR provides protection against "arbitrary or unlawful interference" with a person's family.

Accordingly, it is arguable that for those asylum-seeking families in detention, there should be no distinction in their treatment based on their immigration status or otherwise such as to deny them from the "protection by society and the State" from such conditions of detention that would otherwise render their right to family life nugatory. This is consistent with the HRC's comments in relation to Article 17 ICCPR - for example, where conditions of detention (although in accordance with national law) are arbitrary because they do not accord with the aims, provisions and objectives of the ICCPR and are not reasonable in the circumstances. ${ }^{2522}$

Article 17 and 23 ICCPR are buttressed by Article 9(1) CROC which provides that a minor must not be separated from his or her parents (as opposed to his or her family) against the minor's will except firstly, when

\footnotetext{
2517 Article 24(2) EU Charter

2518 Article 14(1) EU Charter

2519 Article 14(2) EU Charter

${ }^{2520}$ Chapter 7, particularly section IV, UNHCR Refugee Children Guidelines on Protection and Care, 1994, http://www.unhcr.org/3b84c6c67.html (last accessed 4 December 2011)

2521 "However the Committee emphasizes that, when a group of persons is regarded as a family under the legislation and practice of a State, it must be given the protection referred to in article 23": UN Human Rights Committee, General Comment No. 19: Protection of the family, the right to marriage and equality of spouses (Article 23), 1990, http://www.unhchr.ch/tbs/doc.nsf/(Symbol)/6f97648603f69bcdc12563ed004c3881?Open document (last accessed 6 October 2011), para 2

2522 UN Human Rights Committee, General Comment No. 16: The right to respect of privacy, family, home and correspondence, and protection of honour and reputation (Art, 17), 8 April 1988, paras 3-4;
} 
"competent authorities subject to judicial review determine"; secondly, where that determination is carried out "in accordance with all applicable law and procedures"; and thirdly, where "the separation is necessary for the best interests of the child." Further Article 16 CROC provides that no child shall be subject to arbitrary and unlawful interference with his or her privacy, family or home, with the protection of law against such interference.

Although CROC emphasises that the primary responsibility for minors rests with parents, ${ }^{2523}$ that relationship structure should not be interpreted restrictively so that, in a detention context where a parent is unable to independently provide for the child's material needs due to the environment in which the family has been involuntarily placed, a State absolves itself, or significantly diminishes, its responsibilities to minors. That is, the mere presence of parents in detention with their children is insufficient justification for States to reduce the level of care and responsibility towards children. To do otherwise would mean that parents would otherwise be unable to effectively discharge their responsibility to care for their children. Accordingly, States have a responsibility to ensure detention conditions are suitable for the care of children in detention notwithstanding the presence of the child's parents. The responsibility of States towards assisting parents for the benefit of their children's standard of living, development and care is reflected in, and compelled by, Articles 18(2) and 27(3) CROC.

In light of the international standards in relation to minors, Penovic and Sifris reflect on the effect of immigration detention on the family, which, although having the Australian context in mind, is of pertinence in any jurisdiction:

"Immigration detention decimates the triangular relationship between children, parents and the state. Parents place their children and themselves at the mercy of the state; submitting them to the perilous journey to Australia in a quest for the recognition and protection of their human rights. Instead of receiving assistance in their parenting role, parents in immigration detention are denuded of autonomy. They have thus experienced a form of de-skilling, and are rendered incapable of making the most basic decisions concerning their children's welfare. These parents and their children are therefore dependent upon the beneficence of the state. Yet the state has adopted a policy which is punitive in its effect and assumes them to be unentitled to protection." 2524

\section{Families - Council of Europe}

ECHR

Article 8 ECHR protects the right to family life. However, the ECtHR has declared manifestly ill-founded an application for a breach of Article 8 ECHR regarding family life or privacy where the family had been detained

${ }^{2523}$ See Articles 3(2), 5, 7, 9, 10, 18(1) and 27(2) CROC

2524 Penovic, T, and Sifris, A, Children's rights through the lens of immigration detention (2006)

20 AJFL 12, P.9, circa n.61 and following text 
together. ${ }^{2525}$ However, recently, in Popov, the Court retreated from that position following the decision in Rahimi (discussed below) and found a breach of Article 8 on account of the best interests of the child not being taken into account and that detention of the family in the absence of evidence of any risk of absconding was disproportionate. ${ }^{2526}$

Further in Kanagaratnam, the ECtHR has indicated that the length of stay and the inappropriateness of the conditions of detention for a family (which, in the case of the children, amounted to a violation of Article 3 ECHR) did amount to arbitrary detention on the part of the accompanying adult mother, and thus a breach of Article 5(1)(f) ${ }^{2527}$ However, in Popov, the ECtHR was willing to find a violation of Article 5(1)(f) on account of the authorities not giving proper consideration as to whether there were alternatives to detaining the children, but the accompanying parents of the children (who were also detained) were not found to have been unlawfully detained. ${ }^{2528}$ It will be recalled that, in the case law of the ECtHR on Article 5(1)(f), a lack of good faith may amount to detention being arbitrary. In Rahimi, the Court held doubts as to whether the authorities acted in good faith in the detention of an unaccompanied minor because they did not address what was in the best interests of the child and did not consider whether there were less intrusive means than detention. ${ }^{2529}$ It would appear that those two factors, and the breach of Article 3 ECHR in relation to the conditions of detention, led the Court to hold a violation of Article 5(1)(f). ${ }^{2530}$ Accordingly, the cumulative effect of those cases may be that we are evidencing a shift by the Court to require States to actively consider alternatives to detention in relation to children which, when combined with a consideration of the best interests of the child, severely limits the circumstances in which families may be detained.

\section{Committee of Ministers' Recommendation Rec(2003)5}

As indicated in Chapter 5, the Committee of Ministers' Recommendation $\operatorname{Rec}(2003) 5$ recommends that families be "accommodated together" and makes express reference to the right to ensuring a private and family life. ${ }^{2531}$ Reflecting Article 9 CROC, the Committee of Ministers recommends that minors not be separated from their parents or other responsible adults against

\footnotetext{
2525 Muskhadzhiyeva \& ors v Belgium, No. 41442/07, Judgment, 19 January 2010, paras 9799

${ }^{2526}$ Popov v France, Nos. 39472 and 39474/07, Judgment, 19 January 2012, paras 147-148

2527 Kanagaratnam \& Others v Belgium, No. 15297/09, Judgment, 13 December 2011, para 94

2528 Popov v France, Nos. 39472 and 39474/07, Judgment, 19 January 2012, paras 119-121

2529 Rahimi v Greece, No. 8687/08, Judgment, 5 April 2011, para 109

${ }_{2530}$ Rahimi v Greece, No. 8687/08, Judgment, 5 April 2011, para 110

2531 Council of Europe, Committee of Ministers, Recommendation Rec(2003)5 of the Committee of Ministers to member states on measures of detention of asylum seekers, 16 April 2003, para 14
} 
their will. ${ }^{2532}$ Further, special accommodation arrangements are to be made for minors and their families if they cannot be placed in other accommodation. ${ }^{2533}$

\section{Committee of Ministers' Twenty Guidelines on Forced Returns}

The Committee of Ministers' Twenty Guidelines on Forced Returns provides that family unity should be maintained, ${ }^{2534}$ and that, if families are detained, "separate accommodation guaranteeing adequate privacy" should be provided. ${ }^{2535}$

\section{Families - EU Charter}

In the Union sphere Article 7 of the EU Charter provides that everyone has the right to respect for his or her family life. In not dissimilar terms from Article 23 ICCPR, the family is entitled to "legal, economic and social protection" by virtue of Article 33 of the EU Charter.

\subsubsection{Vulnerable Persons}

\section{International}

The UNHCR has acknowledged the difficulties facing refugees and other persons with disabilities through its Executive Committee and the applicability of the CRPD ${ }^{.2536}$ The UNHCR has recommended that, as part of a global needs assessment, refugees and other person with disabilities be systematically identified in order to identify their protection and assistance needs. ${ }^{2537}$ The UNHCR Revised Guidelines indicate that vulnerable persons in detention should be subject to "regular follow up and support by a relevant skilled professional". ${ }^{2538}$ The UNHCR Revised Guidelines also indicate that "services, hospitalisation, medication and counselling" should be made accessible if necessary. ${ }^{2539}$ The UNHCR Revised Guidelines also expressly contemplate the situation of women and the risks that they face in detention. The Guidelines recommend that women should be accommodated separately

2532 Council of Europe, Committee of Ministers, Recommendation Rec(2003)5 of the Committee of Ministers to member states on measures of detention of asylum seekers, 16 April 2003, para 21

2533 Council of Europe, Committee of Ministers, Recommendation Rec(2003)5 of the Committee of Ministers to member states on measures of detention of asylum seekers, 16 April 2003, para 22

2534 Committee of Ministers, Council of Europe, Twenty Guidelines on Forced Return, CM(2005)40 Addendum final, Strasbourg, 20 May 2005, Guideline 10(4)

2535 Committee of Ministers, Council of Europe, Twenty Guidelines on Forced Return, CM(2005)40 Addendum final, Strasbourg, 20 May 2005, Guideline 11(2)

2536 UNHCR, Executive Committee Conclusion No 108 (LIX) - Refugees and others of concern with disabilities, 2008, para (i); UNHCR, Executive Committee Conclusion No 110 (LXI) Refugees with disabilities and other persons with disabilities, 2010, recital 4

2537 UNHCR, Executive Committee Conclusion No 110 (LXI) - Refugees with disabilities and other persons with disabilities, 2010, para (c)

2538 UNHCR Revised Guidelines on applicable criteria and standards relating to the detention of asylum seekers, February 1999, Guideline 7

2539 UNHCR Revised Guidelines on applicable criteria and standards relating to the detention of asylum seekers, February 1999, Guideline 7 
from men (unless family), and that services particular to their needs should be provided (particularly gynaecological and obstetrical). ${ }^{2540}$

The CRPD obliges States to take all appropriate steps to ensure the provision of "reasonable accommodation" for persons with disabilities. ${ }^{2541}$ "Reasonable accommodation" is a term that appears throughout the CRPD, ${ }^{2542}$ and is defined as:

"necessary and appropriate modification and adjustments not imposing a disproportionate or undue burden, where needed in a particular case, to ensure to persons with disabilities the enjoyment or exercise on an equal basis with others of all human rights and fundamental freedoms" 2543

"Discrimination on the basis of disability" also includes the denial of reasonable accommodation. ${ }^{2544}$

Persons with disabilities who are deprived of their liberty are entitled to treatment guaranteed by international human rights law and are to be treated "in compliance with the objectives and principles" of the CRPD (which includes being provided reasonable accommodation). ${ }^{2545}$ In a detention context, facilities must be such to allow persons with disabilities to enjoy or exercise their human rights and fundamental freedoms. Accordingly, the detention environment must be appropriate to their circumstances.

Turning to other rights, the CRPD provides that persons with disabilities have the inherent right to life and States are obliged to "take all necessary measures to ensure" that persons with disabilities can enjoy that right on an equal basis with others. ${ }^{2546}$ Reflecting the provisions of ICCPR, CAT and CROC, the CRPD prohibits torture, cruel, inhuman or degrading treatment or punishment. ${ }^{2547}$ Persons with disabilities have the right to be free from exploitation, abuse and violence. ${ }^{2548}$ States are required to take appropriate measures to assist persons with disabilities, ${ }^{2549}$ as well as ensure that facilities and programmes undergo effective monitoring by independent authorities. ${ }^{2550}$

\footnotetext{
${ }^{2540}$ UNHCR Revised Guidelines on applicable criteria and standards relating to the detention of asylum seekers, February 1999, Guideline 8

2541 Article 5(3) CRPD

2542 See Articles 2, 5(3), 14(2), 24(2)(c), 24(5) and 27(1)(i) CRPD

2543 Article 2, para 4, CRPD

2544 Article 2, para 3, CRPD

2545 Article 14(2) CRPD

2546 Article 10 CRPD

2547 Article 15 CRPD

2548 Article 16(1) CRPD

2549 Article 16(2) CRPD

${ }^{2550}$ Article 16(3) CRPD
} 
The CRPD provides that persons with disabilities have the right to physical and mental integrity on an equal basis with others. ${ }^{2551}$

Persons with disabilities have the right to freedom from arbitrary or unlawful interference with his or her privacy, family, home or correspondence and protection from the law against such interference (expressed in an analogous way to Article 17 ICCPR). ${ }^{2552}$

Importantly, Article 28 CRPD provides that persons with disabilities and their families have a right to an adequate standard of living inclusive of "adequate food, clothing, housing, and to the continuous improvement of living conditions".

Recovery, rehabilitation and re-integration are also at the core of measures that States are required to take to assist persons with disabilities. This is particularly the case in relation to the health, ${ }^{253}$ habilitation and rehabilitation of persons with disabilities, ${ }^{2554}$ and those who have been the victims of exploitation, violence or abuse. ${ }^{2555}$ The recovery and reintegration of that latter group is to take place "in an environment that fosters the health, welfare, self-respect, dignity and autonomy of the person and takes into account gender- and age-specific needs." 2556

\section{Vulnerable Persons - Council of Europe ECHR}

As explored in Chapter 5, if the logic of the ECtHR in the Mubilanzila Mayeka and Muskhadzhiveva line of cases is extrapolated to particularly vulnerable asylum seekers, it is arguable that the place and conditions of detention must bear some relationship to the ground of deprivation of liberty (that is, if, for example, a trauma or torture victim were analogous to a child as regards their level of "extreme vulnerability"). ${ }^{2557}$ Further, it may also then be arguable that the place and conditions of detention may constitute a breach of the positive obligations of a State under Article 3 ECHR if those conditions of detention are inadequately reflect the "extreme vulnerability" of particular groups of asylum seekers (for example, victims of torture and trauma). ${ }^{2558}$

\footnotetext{
2551 Article 17 CRPD

2552 Article 22(1) CRPD

2553 Article 25 CRPD

2554 Article 26 CRPD

2555 Article 16(4) CRPD

2556 Article 16(4) CRPD

2557 Mubilanzila Mayeka and Kaniki Mitunga v Belgium, No. 13178/03, Judgment, 12 October 2006, at para 102, cited with approval in Muskhadzhiyeva \& ors v Belgium, No. 41442/07, Judgment, 19 January 2010, at paras 73-75; see also Aerts v Belgium, No, 25357/94, Judgment, 30 July 1998

2558 Mubilanzila Mayeka and Kaniki Mitunga v Belgium, No. 13178/03, Judgment, 12 October 2006, at para 55; Muskhadzhiyeva \& ors v Belgium, No. 41442/07, Judgment, 19 January 2010, citing paras 53-55 of Mubilanzila with approval at paras 55-58
} 


\section{CPT}

The CteePT has called for attention to be paid to the physical and psychological state of irregular migrants generally, particularly those who have been tortured or ill-treated in their countries of origin. ${ }^{2559}$

Committee of Ministers' Recommendation Rec(2003)5 \& Council of Europe's Twenty Guidelines on Forced Returns

The Committee of Ministers' Recommendation Rec(2003)5 provides that appropriate medical treatment and counselling should be provided for detained asylum seekers, particularly for vulnerable persons. ${ }^{2560}$ The Committee of Ministers' Twenty Guidelines on Forced Returns is silent in relation to the conditions of detention for vulnerable asylum seekers.

\section{Vulnerable Persons - EU Charter}

In the Union sphere, the EU Charter provides that persons with disabilities have the right "to benefit from measures designed to ensure their independence, social and occupational integration and participation in the life of the community". ${ }^{2561}$ Further, the Charter recognises the rights of the elderly "to lead a life of dignity and independence". ${ }^{2562}$

\subsection{European Union Secondary Legislation}

\subsubsection{Detention where the Right to Remain Exists}

\subsubsection{Current Legislation}

The preamble of the Reception Conditions Directive provides that "material reception conditions" for asylum seekers should be such that "ensure them a dignified standard of living". 2563

"Material reception conditions" include "housing, food, and clothing, provided in kind, or as financial allowances or in vouchers, and a daily living expense". ${ }^{2564}$ These are distinct from "reception conditions" which are "the full set of measures" that are granted to asylum seekers. ${ }^{2565}$

\footnotetext{
2559 Council of Europe, CteePT, CPT Standards, 2010, CPT/Inf/E (2002) 1 - Rev 2010, P.55, para 31

2560 Council of Europe, Committee of Ministers, Recommendation Rec(2003)5 of the Committee of Ministers to member states on measures of detention of asylum seekers, 16 April 2003, para 13

2561 Article 26 EU Charter

2562 Article 25 EU Charter

2563 Recital 7 of the Reception Conditions Directive

2564 Article 2(j) of the Reception Conditions Directive

2565 Article 2(i) of the Reception Conditions Directive
} 
The Directive provides that "material reception conditions" are to be made available to asylum seekers when they make their application for asylum. ${ }^{2566}$ Member States are obliged to make provisions which "ensure a standard of living adequate for the health of applicants and capable of ensuring their subsistence ${ }^{2567}$ and that standard expressly applies to those in detention. ${ }^{2568}$

There is a degree of ambiguity surrounding the derogation from the modalities of material reception conditions contained in Article 14, which generally deals with housing. Article 14(8) provides that material reception conditions "different from those provided for in this Article" may be made "for a reasonable period which shall be as short as possible" when an asylum seeker is detained or is confined to border posts. In any event, the "basic needs" must be covered. On the one hand, it is arguable that that derogation may apply generally to all material reception conditions, but, on the other hand, Peek makes a persuasive argument for interpreting the scope of that derogation only as it relates to the provision of housing by pointing to the formulation "different from those provided for in this Article" [emphasis added] contained in Article 14(8).

There is also a degree of ambiguity surrounding the applicability of the general reception conditions provided by the Directive to detained asylum seekers. This is largely attributable to the inadequate definition of, and current lack of procedural mechanism surrounding, detention (as discussed in earlier chapters). It is also not helped by the bifurcated definitions of 'material reception conditions' and 'reception conditions'. Hailbronner identifies two interpretative positions: firstly, that detained asylum seekers are only entitled to the reception conditions identified in Article 13(2) of the Directive (adequate standard of living, provision of housing, food, clothing, and daily living expense). The second position is that detained asylum seekers are entitled to the full range of reception conditions other than in the circumstances expressly excluded. ${ }^{2569}$ However, Hailbronner raises the question of "whether detained asylum seekers are entitled to other rights like medical screening, schooling and education of minors, employment and vocational training". ${ }^{2570}$

Hailbronner ultimately forms the opinion that the latter view prevails and that a contextual reading of Article 13(2) with the other provisions of the Directive is needed. ${ }^{2571}$ The problem with such a contextual interpretation is that

\footnotetext{
2566 Article 13(1) of the Reception Conditions Directive

2567 Article 13(2) of the Reception Conditions Directive

2568 Article 13(2) second sentence, of the Reception Conditions Directive

2569 Hailbronner, K, Detention of Asylum Seekers (2007) 9 European Journal of Migration and Law 159, P.170

${ }^{2570}$ Hailbronner, K, Detention of Asylum Seekers (2007) 9 European Journal of Migration and Law 159, P.170

${ }^{2571}$ Hailbronner, K, Detention of Asylum Seekers (2007) 9 European Journal of Migration and Law 159, P.170
} 
although matters such as employment may be more readily understood not to apply to detained asylum seekers, it is difficult to determine whether other provisions such as education and vocational training are to apply. Further, given the seriousness of detention, the rights to which detained asylum seekers are entitled should be clearly enunciated and justiciable. Accordingly, the extent to which detained asylum seekers are entitled to the benefits under the Reception Conditions Directive is far from clear and would benefit from a clearer enunciation or, ideally, from express provisions, in that regard.

If a contextual reading of the Directive is adopted, asylum seekers are to receive "necessary health care" which includes as a minimum "emergency care" and "essential treatment of illness". ${ }^{2572}$ The obligations imposed on Member States in this regard are rather insubstantial. Peek notes that there are variances amongst the different language versions of "essential treatment of illness" which vary between a fairly broad formulation and a formulation that contemplates really only essential treatment. ${ }^{2573}$ Member States retain the discretion to allow asylum seekers access to vocational training (irrespective of whether they have access to the labour market). ${ }^{2574}$

Detention where the Right to Remain Exists - Current Legislation - Border Applicants Express provision is made for the 'housing' of border applicants pending the determination of their application but, for those confined to border posts, derogations are permitted by Article 14(8) on the same terms as discussed above for those in detention. As with those detained, any derogation must at least ensure that basic needs are covered in any event. As border applicants can be subjected to at least de facto detention (that is, resulting from a deprivation of liberty by being kept in the vicinity of border posts), that derogation may result in particularly scant protection of human dignity (save only for the provisions of the ECtHR and ICCPR) and a large degree of discretion that is afforded to Member States. Particularly of concern are border applicants who are unaccompanied minors who suffer from a temporal disjunction in relation to their accommodation rights under the Directive - these applicants can only be placed in an accommodation centre after they have been "admitted to the territory" and not at the time that they have made their application for asylum. ${ }^{2575}$ Accordingly, de facto detention for minors at the border may result.

2572 Article 15(1) of the Reception Conditions Directive

2573 Peek, M, in Hailbronner, K, (ed) EU Immigration and Asylum Law - Commentary on EU Regulations and Directives, 2010, Beck, München, Pp.871-984, at P.942

2574 Article 12(1) of the Reception Conditions Directive

2575 Article 19(2) of the Reception Conditions Directive; see also Peek, M, in Hailbronner, K, (ed) EU Immigration and Asylum Law - Commentary on EU Regulations and Directives, 2010, Beck, München, Pp.871-984, at P.956 
Detention where the Right to Remain Exists - Current Legislation - Minors and Families

As discussed in earlier chapters, the best interests of the child are the primary consideration applicable in the implementation of the Directive. ${ }^{2576}$ The Directive also requires Member States to ensure access to rehabilitation services for children who have been the victims of abuse, neglect, exploitation, torture or cruel, inhuman and degrading treatment or punishment or have suffered from armed conflict. ${ }^{2577}$

Minors generally (that is, non-detained minors) have the right to "access the education system" under "similar conditions" to nationals (as opposed to identical conditions). ${ }^{2578}$ The right to access the education system lasts "for as long as an expulsion measure against them or their parents is not actually enforced" which, inconsistently with the scope of the Directive (see Chapter 5 ), applies even if the right to remain of the minor or his or her parents is lost. One of the main criticisms of the provision on education is that Member States may provide education in accommodation centres ${ }^{2579}$ (which may presumably include detention centres), and which is entirely at odds with the formerly enunciated right of a child to "access the education system" (as opposed to the mere right to "an education"). ${ }^{2580}$ As ECRE has noted, it is arguable that the best interests of the child are served by children attending local schools to avoid the segregation of asylum seekers. ${ }^{2581}$ Further, such segregation may be contrary to the UNESCO Convention Against Discrimination in Education. Access to the education system is to be provided within three months from lodgement of an asylum claim by a minor or his or her parents but which may be extended to one year in the case of "specific education" (such as language) "in order to facilitate access to the education system". 2582 "Other education arrangements" are to be made for those minors whose "specific situation" is such that access to the education system is not possible. ${ }^{2583}$ Peek believes that the "specific situation" mimics the reference to that phrase in Articles 13(2) and 17(1), namely those who have special needs on account of being the victim of trauma or physical injury. ${ }^{2584}$

If a contextual reading of the Directive is given (as advocated by Hailbronner), then those rehabilitative services and access to education should be provided to

\footnotetext{
2576 Article 18(1) of the Reception Conditions Directive

2577 Article 18(2) of the Reception Conditions Directive

2578 Article 10(1) of the Reception Conditions Directive

2579 Article 10(1) of the Reception Conditions Directive

${ }^{2580}$ See Peek, M, in Hailbronner, K, (ed) EU Immigration and Asylum Law - Commentary on

EU Regulations and Directives, 2010, Beck, München, Pp.871-984, at P.922

2581 ECRE, ECRE Information Note on the Council Directive 2003/9/EC of 27 January 2003, June 2003, IN1/06/2003/EXT/HM, P.5

2582 Article 10(2) of the Reception Conditions Directive

2583 Article 10(3) of the Reception Conditions Directive

${ }_{2584}$ Peek, M, in Hailbronner, K, (ed) EU Immigration and Asylum Law - Commentary on EU

Regulations and Directives, 2010, Beck, München, Pp.871-984, at P.925
} 
those detained. The consideration of the needs of children based on their age, as required by Article 37(c) CROC, is not expressly provided for in the Directive.

Although the protection of family life and the lodgement of children with their parents or other responsible adult are contemplated in relation to material reception conditions, ${ }^{2585}$ Article 14(8) of the Directive allows those provisions to be subject to derogation in relation to those in detention or confined to border posts.

\section{Detention where the Right to Remain Exists - Current Legislation - Vulnerable Persons}

The Preamble to the Directive calls for the reception of those in detention to be "specifically designed to meet their needs in that situation". ${ }^{2586}$ The substantive provisions of the Directive provide that the situation of vulnerable persons must be taken into account when implementing Chapter II of the Directive $^{2587}$ (which includes the residence and detention provisions ${ }^{2588}$ ) but only after an "individual evaluation" of the asylum seeker has occurred. ${ }^{2589}$ The Directive makes no provision for the initial screening of asylum seekers to identify torture or trauma victims in light of Guideline 10(i) of the UNHCR Revised Guidelines (see Chapter 5 regarding the timing of assessment of vulnerable persons). The situation of vulnerable persons must also be considered with respect to material reception conditions. ${ }^{2590}$ Victims of torture and violence are entitled to treatment if "necessary", ${ }^{2591}$ and those with "special needs" are entitled to "medical or other assistance". ${ }^{2592}$ If a contextual reading of the Directive is applied, those rights should also apply to those detained but again, it is by no means clear.

\subsubsection{Detention where the Right to Remain Exists - The Proposed Legislation}

The Commission's 2011 Proposed Reception Conditions Directive and the Council's Amended Proposed Reception Conditions Directive

The lack of clarity surrounding the applicability of the reception conditions to detained asylum seekers has been modestly improved in both versions of the Proposed Reception Conditions Directive by the insertion of Recital 8 which provides that the Directive is to apply "during all stages and types of procedures" and "in all locations and facilities holding asylum seekers". However, as a question of interpretation, the body of the Proposed Directive still retains many of the ambiguities of the current Directive. This is due to the

\footnotetext{
2585 Article 14(2)(a) and 14(3) of the Reception Conditions Directive

2586 Recital 10 of the Reception Conditions Directive

2587 Article 17(1) of the Reception Conditions Directive

2588 Article 7 of the Reception Conditions Directive

2589 Article 17(2) of the Reception Conditions Directive

2590 Article 13(2) of the Reception Conditions Directive

2591 Article 20 of the Reception Conditions Directive

${ }^{2592}$ Article 15(2) of the Reception Conditions Directive
} 
detention provisions representing a lex specialis, including the conditions that are to apply to those in detention. Accordingly, it is still a question of context as to which of the material reception conditions and guarantees contained in the Proposed Directive apply to those in detention.

The appropriate overall standard to be ensured by Member States is that of an "adequate standard of living [...] which guarantees their subsistence and protects their physical and mental health". ${ }^{2593}$ It remains that Member States are to ensure that that standard is to be met for those in detention. ${ }^{2594}$

As outlined above, the applicability of the modalities of reception conditions to those in detention is still ambiguous - those provisions are "without prejudice" to the specific detention provisions in the Proposed Directive. ${ }^{2595} \mathrm{It}$ would tend to suggest that those Articles dealing with detention (Articles 10 and 11 of the Proposed Directive) represent a lex specialis on the matter noting that, as identified in Chapter 6, detention facilities are not expressly included in the 'housing' referred to Article 18(1). But, curiously, detainees and those confined to border posts are now no longer subject to derogation from the modalities of material reception conditions ${ }^{2596}$ - which is helpful, if only it was known precisely which material reception conditions under Article 18 (if any) apply to those in detention.

The most significant improvements under the Proposed Directive stem from the setting out of specific conditions of detention, particularly under proposed Article 10. Firstly, detention must only take place in "specialised detention facilities". ${ }^{2597}$ However, that guarantee is completely undermined by a derogation "in duly justified cases" allowing the use of prison accommodation where specialised detention facilities are not available. ${ }^{2598}$ In those circumstances, asylum seekers are to be kept separately from prisoners. Given the stern reminder of the absolute nature of the prohibition against torture or inhuman and degrading treatment or punishment by the ECtHR in MSS $v$ Belgium \& Greece, ${ }^{2599}$ and the relationship between the ground of detention and

2593 Article 17(2) of the Commission's 2011 Proposed Reception Conditions Directive; Article 17(2) the Council's Amended Proposed Reception Conditions Directive

2594 Article 17(2) second sentence, of the Commission's 2011 Proposed Reception Conditions Directive; Article 17(2) the Council's Amended Proposed Reception Conditions Directive

2595 Article 18(2) Commission's 2011 Proposed Reception Conditions Directive; Article 18(2) the Council's Amended Proposed Reception Conditions Directive

2596 That is, by the deletion to those two grounds which currently exist as Article 14(8) of the Reception Conditions Directive.

2597 Article 10(1) of the Commission's 2011 Proposed Reception Conditions Directive; Article 10(1) of the Council's Amended Proposed Reception Conditions Directive 2598 Article 10(6)(a) of the Commission's 2011 Proposed Reception Conditions Directive; Article 10(6)(a) of the Council's Amended Proposed Reception Conditions Directive 2599 M.S.S. $v$ Belgium and Greece, No. 30696/09, Judgment Grand Chamber, 21 January 2011, paras 223-224 
the conditions of detention, ${ }^{2600}$ it is arguable that the use of prison accommodation may well fall foul of Article 3 ECHR (not to mention Article 5 ECHR after the warning given by the ECtHR in Saadi against conditions which may render detention arbitrary ${ }^{2601}$ ).

Secondly, under the Commission's 2011 Proposed Reception Conditions, detained asylum seekers are to be kept separately from other third country nationals who are not asylum seekers, unless it is to ensure family unity. ${ }^{2602}$ Disturbingly, under the Council's Amendments, the insertion of "[i]n the specialised detention facilities" rather suggests that the unsegregated detention of asylum seekers and other third country nationals is acceptable in other nonspecialised detention facilities. ${ }^{2603}$

Thirdly, detained asylum seekers are to have access to open-air spaces. ${ }^{2604}$

Fourthly, detained asylum seekers are to be provided with information on the rules of the detention facility and their rights and obligations "in a language which they are reasonably supposed to understand". ${ }^{2605}$ In order to reduce the risk of abuse and to ensure amenity for both detained persons and staff, it is important that detained asylum seekers are given such notice in a language that they do understand. This provision would appear to relate solely to rights and obligations in the detention facility (as opposed to the detention order itself a similar formulation is used in Article 16(5) of the Returns Directive) as Article 9(3) of the Proposed Directive deals specifically with providing the asylum seeker with the detention order and the procedures in national law which the asylum seeker can use to challenge the detention decision.

The general standard of health care to be provided remains largely unchanged and meagre in the Proposed Reception Conditions Directive. The Commission's 2011 Proposed Reception Conditions Directive now includes express reference to "post traumatic disorders" but this has been amended to

${ }^{2600}$ Mubilanzila Mayeka and Kaniki Mitunga v Belgium, No. 13178/03, Judgment, 12 October 2006, at paras 102-105

2601 Saadi v United Kingdom, No. 13229/03, Judgment, Grand Chamber, 29 January 2008, para 74

2602 Article 10(1), second sentence, of the Commission's 2011 Proposed Reception Conditions Directive

2603 Article 10(1), second sentence, of the Council's Amended Proposed Reception Conditions Directive

2604 Article 10(2) of the Commission's 2011 Proposed Reception Conditions Directive; Article 10(2) of the Council's Amended Proposed Reception Conditions Directive

2605 Article 10(5) of the of the Commission's 2011 Proposed Reception Conditions Directive; Article 10(5) of the Council's Amended Proposed Reception Conditions Directive 
"mental disorders" in the Council's Amendments. ${ }^{2606}$ The provisions on vocational training remain unchanged from the current Directive. ${ }^{2607}$

Detention where the Right to Remain exists - The Proposed Legislation - Border Applicants

The Proposed Directives make a clearer distinction between those applicants 'housed' pending the examination of their application for international protection that they made at the border or in a transit zone; ${ }^{2608}$ and those detained at border posts or in a transit zone. ${ }^{2609}$ The first instance turns on where the application was made; the second instance turns on where the person is detained. In reality, there may be instances where this is little or no distinction between these two scenarios.

\section{'Housing' for applications made at the border or in a transit zone}

The derogations from modalities for material reception conditions have been substantially changed under both versions of the Proposed Directive for 'housed' applicants who have made an application at the border or in transit zones, which is now expressly contemplated. ${ }^{2610}$ As identified above, persons 'housed' in that situation are now no longer subject to derogation from the modalities of material reception conditions. ${ }^{2611}$

Unaccompanied minors are still not able to be placed in accommodation until after they have been admitted to the territory ${ }^{2612}$ (and which may still lead to de facto detention). However, age (as well as gender and vulnerability)-specific concerns are now required to be taken into account if they are housed pending the examination of their application that they made at the border or in a transit zone. ${ }^{2613}$ 'Housed' minors have the right to access "leisure

2606 Article 19(1) of the of the Commission's 2011 Proposed Reception Conditions Directive; Article 19(1) of the Council's Amended Proposed Reception Conditions Directive

2607 Article 16 of the of the Commission's 2011 Proposed Reception Conditions Directive; Article 16 of the Council's Amended Proposed Reception Conditions Directive

2608 Article 18(1)(a) of the Commission's 2011 Proposed Reception Conditions Directive; and Article 18(1)(a) of the Council's Amended Proposed Reception Conditions Directive 2609 Article 11(5) of the Commission's 2011 Proposed Reception Conditions Directive; and Article 11(5) of the Council's Amended Proposed Reception Conditions Directive

2610 Article 18(1)(a) Commission's 2011 Proposed Reception Conditions Directive; Article 18(1)(a) the Council's Amended Proposed Reception Conditions Directive

2611 That is, by the deletion of that possibility which currently exists as Article 14(8) of the Reception Conditions Directive.

2612 Article 24(2) of the Commission's 2011 Proposed Reception Conditions Directive; Article 24(2) of the Council's Amended Proposed Reception Conditions Directive

2613 Articles 18(3) and 18(1)(a) of the Commission's 2011 Proposed Reception Conditions Directive; Article 18(3) and 18(1)(a) of the Council's Amended Proposed Reception Conditions Directive 
activities, including play and recreational activities appropriate to their age" and "to open air activities". ${ }^{2614}$

\section{'Detained' at border posts or in a transit zone}

For those detained under the detention provisions (Articles 9, 10 and 11 of the Proposed Directive), derogations exist for those detained at border posts or in transit zones.

Firstly, such persons are not entitled to receive information on the rules of the detention facility and their rights and obligations with the exception of those subject to Article 43 of the Proposed Procedures Directive (that is, admissibility of applications or those subject to an accelerated procedure).$^{2615}$ Such a derogation seems hardly justifiable, and most likely discriminatory amongst asylum seekers. It is contrary to the views of the CteePT on this matter.

Secondly, other guarantees which normally apply (see below), but which are also subject to the same derogation on account of being detained at a border post or in a transit zone (again, with the exception of those subject to Article 43 of the Proposed Procedures Directive), ${ }^{2616}$ include: the ability for minors to engage in leisure activities; for families to be guaranteed privacy (which applies as a lex specialis over the protection of their "family life" purportedly guaranteed by Article 18(2)(a)); and for females to be accommodated separately from males (unless they are family).

Both sets of derogations may be made "in duly justified cases and for a reasonable period that shall be as short as possible". ${ }^{2617}$

\section{Detention where the Right to Remain Exists - The Proposed Legislation - Minors and Families}

The 'best interests of the child' remains the overarching principle in relation to the implementation of all provisions involving minors. ${ }^{2618}$ As discussed in Chapter 5, the Proposed Directive sets out a series of factors which must be taken into account in assessing what is in the best interests of the child. ${ }^{2619}$ However, the Council's Amended Proposed Reception Conditions Directive

2614 Article 23(3) of the Commission's 2011 Proposed Reception Conditions Directive; Article 23(3) of the Council's Amended Proposed Reception Conditions Directive 2615 Article 10(6)(b) of the Commission's 2011 Proposed Reception Conditions Directive; Article 10(6)(b) of the Council's Amended Proposed Reception Conditions Directive 2616 Article 11(5) of the Commission's 2011 Proposed Reception Conditions Directive; Article 11(5) of the Council's Amended Proposed Reception Conditions Directive 2617 Article 11(5) of the Commission's 2011 Proposed Reception Conditions Directive; Article 11(5) of the Council's Amended Proposed Reception Conditions Directive 2618 Article 23(1) of the Commission's 2011 Proposed Reception Conditions Directive; Article 23(1) of the Council's Amended Proposed Reception Conditions Directive 2619 Article 23(2) of the Commission's 2011 Proposed Reception Conditions Directive; Article 23(2) of the Council's Amended Proposed Reception Conditions Directive 
removes the minor's ethnic, religious, cultural and linguistic background as part of considering the minor's well-being and social development, ${ }^{2620}$ and which takes insufficient heed of the CteeRC's General Comment 6 on this subject (see above).

The Proposed Directive provides that a detained minor has access to "leisureactivities, including play and recreational facilities appropriate to their age" but which is then, startlingly, the subject of derogation for those children detained at border posts or in transit zones (with the exception of those subject to admissibility decisions or accelerated procedures). ${ }^{2621}$ Detained minors are to have access to open-air spaces. ${ }^{2622}$ Unaccompanied minors are to be detained separately from adults. ${ }^{2623}$

Family members are to receive "separate accommodation guaranteeing adequate privacy". ${ }^{2624}$ However, as for minors detained at border posts or in transit zones, that guarantee is subject to derogation. ${ }^{2625}$

If a contextual approach is again adopted in relation to the Proposed Directive, a significant change in relation to the education for minors is the removal of the 12 month delay for the provision "specific education" "in order to facilitate access to the education system". ${ }^{2626}$ The Commission's 2011 Proposed Reception Conditions requires Member States to provide preparatory classes (including language classes) where "it is necessary to facilitate their access and integration to the national education system [emphasis added]". ${ }^{2627}$ The effect of the Council's amendments to that proposed provision is that education provided in accommodation (and, presumably, detention) centres is still entirely contemplated and within Member State discretion (as opposed to the Commission's proposal which should be interpreted to mean a child would be prepared to attend the regular education

2620 Article 23(2)(b) of the Council's Amended Proposed Reception Conditions Directive 2621 Articles 11(2), fourth subparagraph, and 11(5) of the Commission's 2011 Proposed Reception Conditions Directive; Articles 11(2), fourth subparagraph, and 11(5) of the Council's Amended Proposed Reception Conditions Directive

2622 Article 11(2), fifth subparagraph, of the Commission's 2011 Proposed Reception Conditions Directive; Article 11(2), fifth subparagraph, of the Council's Amended Proposed Reception Conditions Directive

${ }^{2623}$ Article 11(2), sixth subparagraph, of the Commission's 2011 Proposed Reception Conditions Directive; Article 11(2), sixth subparagraph, of the Council's Amended Proposed Reception Conditions Directive

${ }^{2624}$ Article 11(3) of the Commission's 2011 Proposed Reception Conditions Directive; Article 11(3) of the Council's Amended Proposed Reception Conditions Directive

2625 Article 11(5) of the Commission's 2011 Proposed Reception Conditions Directive; Article 11(5) of the Council's Amended Proposed Reception Conditions Directive 2626 Article 14(2) of the of the Commission's 2011 Proposed Reception Conditions Directive; Article 14(2) of the Council's Amended Proposed Reception Conditions Directive

2627 Article 14(2) of the of the Commission's 2011 Proposed Reception Conditions Directive 
system outside the accommodation centre) ${ }^{2628}$ Lastly, the alternate education arrangements on account of a minor's "specific situation" 2629 is now to be "in accordance with national law and practices". ${ }^{2630}$

Detention where the Right to Remain Exists - The Proposed Legislation - Vulnerable Persons

Member States must take into account the specific situation of vulnerable persons at a general level in the implementation of the Proposed Directive ${ }^{2631}$ as well as the more specific considerations in relation to material reception conditions, ${ }^{2632}$ and for those 'housed' pending examination of an application made at the border. ${ }^{2633}$ Provision continues to be made for the rehabilitation of torture and trauma victims, with a particular added emphasis on access to services to allow for medical and psychological treatment, and on the training of professionals. ${ }^{2634}$ Health care now includes post-traumatic stress disorders, ${ }^{2635}$ and the provision of mental health care. ${ }^{2636}$ Regrettably, the provision of health care and mental health care specifically for those with special needs is no longer "under the same conditions as nationals" which appeared in the Commission's 2008 Proposed Reception Conditions Directive. ${ }^{2637}$

\subsubsection{Detention where the Right to Remain is Lost}

\subsubsection{Current Legislation}

If the right to remain is lost and the Procedures Directive is putatively applicable, then that Directive is silent as regards conditions of detention. In those circumstances the standards of the ICCPR and ECHR are applicable.

2628 Article 14(2) of the Council's Amended Proposed Reception Conditions Directive 2629 See above section on minors under the current Reception Conditions Directive regarding the interpretation of "specific situation"

2630 Article 14(3) of the of the Commission's 2011 Proposed Reception Conditions Directive; Article 14(3) of the Council's Amended Proposed Reception Conditions Directive

2631 Article 21 of the Commission's 2011 Proposed Reception Conditions Directive; Article 21 of the Council's Amended Proposed Reception Conditions Directive. Note, however, in the latter version that the term "persons with mental disorders" replaces "mental illnesses, or post-traumatic stress disorders"

2632 Article 17(2) of the Commission's 2011 Proposed Reception Conditions Directive; Article 17(2) of the Council's Amended Proposed Reception Conditions Directive 2633 Article 18(3) of the Commission's 2011 Proposed Reception Conditions Directive; Article 18(3) of the Council's Amended Proposed Reception Conditions Directive 2634 Article 25 of the Commission's 2011 Proposed Reception Conditions Directive; Article 25 of the Council's Amended Proposed Reception Conditions Directive

2635 Article 19(1) of the Commission's 2011 Proposed Reception Conditions Directive; Article 19(1) of the Council's Amended Proposed Reception Conditions Directive 2636 Article 19(2) of the Commission's 2011 Proposed Reception Conditions Directive; Article 19(2) of the Council's Amended Proposed Reception Conditions Directive 2637 Article 19(2) of the Commission's 2008 Proposed Reception Conditions Directive 


\subsubsection{Detention where the Right to Remain is Lost - The Proposed Legislation}

Following the suite of proposed secondary legislation, the Proposed Procedures Directive refers to the (Proposed) Reception Conditions Directive regarding conditions (as well as grounds and guarantees) of detention. ${ }^{2638}$ What is not clear is whether the full set of reception conditions as contemplated under that Directive are applicable in those circumstances (which if the right to remain is lost, the personal scope of the Reception Conditions Directive is not fulfilled), or whether only the specific conditions relating to detention are applicable. Accordingly, if the Reception Conditions Directive were not to apply generally to those whose right to remain is lost, then the international standards contemplated in the ICCPR and ECHR would be applicable.

\subsubsection{Detention where the Right to Remain is Lost - The Returns Directive}

If detained pending removal, the Returns Directive provides as a general principle in its preamble that persons should be treated in a "humane and dignified manner with respect for their fundamental rights and in compliance with international and national law". ${ }^{2639}$ Further, "as a rule" detention should take place in specialised detention facilities. ${ }^{2640}$

The imperative aspirations of Article 16 of the Returns Directive whereby detention is to take place in "specialised detention facilities" are somewhat undermined by the qualification "as a rule" and indeed, by Member States being permitted to resort to prison accommodation where specialised detention facilities cannot be provided. In the event of resorting to prison accommodation, Member States are to keep third-country nationals separate from ordinary prisoners. Derogation from those requirements is possible in circumstances where there are (and for as long as there are) "exceptional circumstances" - that is, where there are an "exceptionally large number of third-country nationals to be returned places an unforeseen heavy burden on the capacity of detention facilities of a Member State or on its administrative or judicial staff." ${ }^{2641}$ As discussed above in relation to the use of prison accommodation in the Proposed Reception Conditions Directive, the use of prison facilities under the Returns Directive also runs a significant risk of breaching Article 3 as well as Article 5 ECHR. The same questions of compatibility with the ECHR in light of MSS $v$ Belgium and Greece 2642 remains notwithstanding that the Directive requires Member States not to derogate from their general obligation "to take all appropriate measures" under the Directive. ${ }^{2643}$

\footnotetext{
2638 Article 26(1) of the Commission's 2011 Proposed Reception Conditions Directive

2639 Recital 17 of the Returns Directive

2640 Recital 17 of the Returns Directive

2641 Article 18(1) of Directive 2008/115/EC

${ }^{2642}$ MSS v Belgium \& Greece, No. 30696/09, 21 January 2011, Judgment, Grand Chamber, paras 223-224

2643 Article 18(3) Directive 2008/115/EC
} 
Persons detained are to be "systematically" given information about the facility rules, their rights and obligations. ${ }^{2644}$ (note the discussion earlier herein and in Chapter 6 regarding the scope of the information to be provided). However, no timeframe is given for when this information is to be provided.

\section{The Returns Directive - Minors and Families}

As general principles, the best interests of the child and family life are to be taken into account throughout the implementation of the Directive. ${ }^{2645}$ The principle of the best interest of the child is repeated more specifically in a detention context. ${ }^{2646}$

Minors have the right to leisure activities, including "play and recreational activities appropriate to their age". ${ }^{2647}$ There is a qualified right to education that may depend on the length of the child's stay in detention. ${ }^{2648}$ As discussed in Chapter 5, unaccompanied minors may be detained as the obligation to accommodate them in appropriate institutions is qualified by "as far as possible". That provision does not fully embrace the ECtHR's decision in Rahimi (discussed above) that requires a full and active consideration of the detention of an unaccompanied minor as a last resort. Disturbingly, as was the case with the use of prison accommodation over specialised detention facilities, a detained family's right to adequate privacy may be subject to derogation in the "emergency situation" contemplated in Article 18. ${ }^{2649}$ Those provisions also run the risk of falling foul of the ECtHR's jurisprudence in Mublilanzila Mayeka, Kanagaratnam and Popov, which emphasise that conditions of detention must be suitable for minors.

\section{The Returns Directive - Vulnerable Persons}

As discussed in Chapter 5, there is no consideration of the situation of vulnerable persons as a general principle in the implementation of the Returns Directive as is the case with minors, family life and non-refoulement. ${ }^{2650}$ However, a person's state of health is to be considered as a general principle, ${ }^{2651}$ which may take into account some of the matters which give rise to a person's vulnerability, but may exclude women, the elderly or other persons who may be vulnerable for reasons other than their health. Notwithstanding this somewhat lacking general principle, the Directive expressly requires, in a detention context, the situation of vulnerable persons to be considered, as well as the provision of emergency health care and

\footnotetext{
2644 Article 16(5) of the Returns Directive

2645 Recital 22 and Article 5(a) and (b) of the Returns Directive

2646 Article 17(5) of the Returns Directive

2647 Article 17(3) of the Returns Directive

2648 Article 17(3) of the Returns Directive

2649 Articles 17(2) and 18(1) of the Returns Directive

2650 See Article 5 of the Returns Directive

2651 Article 5(c) of the Returns Directive
} 
essential treatment. ${ }^{2652}$ As with the Reception Conditions Directive, the level of health care treatment appears to be rather minimal - "emergency health care" and "essential treatment" tend to suggest a rather grudgingly minimal standard.

\subsubsection{If Detained in a Member State Other Than That of First Entry or Asylum}

\subsubsection{Current Legislation}

As with grounds and review mechanisms of detention, the current Dublin II Regulation is silent on the conditions of detention. It is arguable that, at the very least, in those circumstances, the international standards contemplated by the ECHR and ICCPR are applicable for those detained pending a transfer to another Member State. Most recently, there has been a reference for a preliminary ruling from the French Conseil d'État to the CJEU regarding the applicability of the Reception Conditions Directive to those subject to a Dublin procedure. ${ }^{2653}$ The UNHCR has issued a comprehensive submission in that regard. ${ }^{2654}$

\subsubsection{The Proposed Legislation}

Recital 9 of the Commission's Proposed Dublin Regulation provides that the Reception Conditions Directive "should apply" to those that fall within the scope of the Proposed Dublin Regulation. This aspiration is also reflected in Recital 8 of the Commission's Recast Proposed Reception Conditions Directive and the Council's Amendments thereto which provides that the Proposed Directive "should apply during all stages and types of procedures concerning applications for international protection and in all locations and facilities hosting asylum seekers", and which would presumably contemplate Dublin procedures. ${ }^{2655}$ However, for those in a detention context, the extent of application of the Proposed Reception Conditions Directive still remains unclear.

\footnotetext{
2652 Article 16(3) of the Returns Directive

2653 Case C-179, CIMADE and GISTIv Ministre de l'Intérieur, de l'Outre-Mer, des Collectivités Territoriales et de l'Immigration, reference for preliminary ruling lodged on 18 April 2011

${ }^{2654}$ UNHCR, UNHCR Statement on the reception conditions of asylum-seekers under the Dublin procedure, 1 August 2011, http://www.unhcr.org/4e3801d09.pdf (last accessed 8 December 2011)

2655 See further, UNHCR, UNHCR comments on the European Commission's Proposal for a recast of the Regulation of the European Parliament and of the Council establishing the criteria and mechanisms for determining the Member State responsible for examining an application for international protection lodged in one of the Member States by a third country national or a stateless person ("Dublin II") (COM(2008) 820, 3 December 2008) and the European Commission's Proposal for a recast of the Regulation of the European Parliament and of the Council concerning the establishment of 'Eurodac' for the comparison of fingerprints for the effective application of [the Dublin II Regulation] (COM(2008) 825, 3 December 2008), 18 March 2009, http://www.unhcr.org/4a0d6a6710.pdf, (last accessed 11 December 2011), P.20. Note, however, that references to Recital 8 in that document should read Recital 13.
} 
The Proposed Dublin Regulation refers to the (Proposed) Reception Conditions Directive as regards conditions of detention and, "in particular", to Article 10 and 11 of that Directive. Again, it is not expressly clear whether the full set of reception conditions contemplated under the Reception Conditions Directive are to apply in relation to those detained under the Proposed Dublin II Regulation - at the very least, it would appear, that the rights provided in Articles 10 and 11 of the Reception Conditions Directive would be applicable. ${ }^{2656}$ The full set of reception conditions under the Reception Conditions Directive should be made expressly applicable in the body of the Proposed Dublin II Regulation to avoid any ambiguity as regards its application and personal scope. The outcome of the preliminary ruling from the CJEU on the extent of applicability (if at all) of the current Reception Conditions Directive is eagerly awaited and will greatly assist in that regard. ${ }^{2657}$

\subsubsection{Legal Liability for Detention Conditions - Outsourcing the Management of Detention Centres}

Given that a number of EU Member States outsource part of their detention facilities to private organisations, ${ }^{2658}$ it is worth briefly exploring the issue of liability in an action by an asylum seeker for non-compliance with a Directive. This issue arises due to the imminence of some of the Proposed Directives to become EU law. It also assists in drawing a comparison with the Australian position.

Regulations and Directives differ as to their legal effect. A Regulation is directly effective and need not be implemented in national law in order to be relied upon provided that it is sufficiently clear, precise and certain. ${ }^{2659} \mathrm{~A}$ Directive, on the other hand, is addressed to the Member States and requires implementation - the methods for which Member States may exercise their discretion. ${ }^{2660}$ The ECJ (as it then was) recognised the direct effect of

2656 See Case C-37/06 and C-58/06 Viamex Agrar Handels GmbH and Zuchtvieh-Kontor GmbH $(Z V K)$ v Hauptzollamt Hamburg-Jonas, 17 January 2008, Judgment, paras 25-29 in relation to how the relationship between the Reception Conditions Directive and the Proposed Dublin II Regulation might be resolved

2657 Case C-179, CIMADE and GISTI v Ministre de l'Intérieur, de l'Outre-Mer, des Collectivités Territoriales et de l'Immigration, reference for preliminary ruling lodged on 18 April 2011

${ }^{2658}$ See European Migration Network, Ad-Hoc Query on facilities for detention of a thirdcountry national who is the subject of return procedures and asylum seekers, 1 June 2011, http://www.emn.fi/files/424/EE_EMN_Ad_Hoc_Query_on_facilities_for_detention_CO MPILATION_open_2_.pdf (last accessed 12 December 2011); and Flynn, M, and Cannon, C, Global Detention Project, The Privatization of Immigration Detention: Towards a Global View, September 2009, http://www.globaldetentionproject.org/fileadmin/docs/GDP_

PrivatizationPaper_Final5.pdf (last accessed 13 December 2011)

2659 Article 288 TFEU; Case C-403/98 Azienda Agricola Monte Arcosu v Regione Automna della Sardegna, 11 January 2001, Judgment; Case C-39/72 Commission v Italy ("the Slaughtered Cow case"), 7 February 1973, Judgment

2660 Article 288 TFEU 
Directives, ${ }^{2661}$ provided that the term of the Directive to be relied upon was sufficiently, clear, precise and unconditional. ${ }^{2662}$ The direct effect of a Directive may be relied upon after the time for implementation has expired ${ }^{2663}$ - but Member States are also obliged not to adopt measures before the implementation time has expired that would undermine the effect of the Directive. ${ }^{2664}$ Importantly, even if the Directive has been implemented correctly, an individual may still rely directly on the Directive itself against the State if the application of measures is inconsistent with the Directive - this is partly because Directives are binding as to the result to be achieved, not only correct implementation. ${ }^{2665}$

One of the main distinctions between Regulations and Directives is that Directives do not have horizontal direct effect and are applicable only vertically (that is, against the State but not an individual or private entity). ${ }^{266}$ Accordingly, much then turns on what is the "State". In determining this question, the ECJ in Foster held that:

"a body, whatever its legal form, which has been made responsible, pursuant to a measure adopted by the State, for providing a public service under the control of the State and has for that purpose special powers beyond those which result from the normal rules applicable in relations between individuals, is included in any event among the bodies against which the provisions of a directive capable of having direct effect may be relied upon."2667

As noted by Craig and de Búrca, ${ }^{2668}$ the resulting case law has seen, for example, a nationalised gas company, ${ }^{2669}$ public hospitals, ${ }^{2670}$ universities $^{2671}$

2661 Case C-41/74 Van Duyn v Home Office, 4 December 1974, Judgment; C-148/78 Pubblico Ministero v Tullio Ratti, 5 April 1979, Judgment

2662 See, for example, Case C-226/07 Flughafen Köln/Bonn GmbH v Hauptzollamt Köln, Judgment, 17 July 2008, para 23

2663 Case C-8/81 Becker v Finanzamt Münster-Innestadt, 19 January 1982, Judgment, paras 18-25; Case C-156/91 Hansa Fleisch Ernst Mundt GmbH \& Co v Landrat des Kreises Schleswig-Flensburg, 10 November 1992, Judgment, para 20; Case C-316/93 Vaneetveld v Le Foyer SA, 3 March 1994, Judgment, paras 18-19; Case C-348/98 Vitor Manuel Mendes Ferreira and Maria Clara Delgado Correia Ferreira v Companhia de Seguros Mundial Confiança SA, 14 September 2000, Judgment, para 33; Case C-246/06 Navarro v Fondo de Garantía Salarial (Fogasa), 17 January 2008, Judgment, paras 25-30

2664 Case C-129/96 Inter-Environment Wallonie ASBL v Région Wallone, 18 December 1997, Judgment; Case C-212/04 Adeneler \& Ors v Ellinikos Organismos Galaktos (ELOG), 4 July 2006, Judgment Grand Chamber, para 121

2665 Case C-62/00 Marks \& Spencer plev Commisoners of Customs and Excise, 11 July 2002, Judgment, paras 22-28

2666 Case C-152/84 Marshall v Southampton and South-West Hampshire Area Health Authority (Teaching), 26 February 1986, Judgment, para 48

2667 Case C-188/89 Foster and others v British Gas plc, 12 July 1990, Judgment, para 20

2668 Craig, P, and de Búrca, G, EU Law, 5ed, 2011, OUP, Oxford, P.198

${ }^{2669}$ Case C-188/89 Foster and others v British Gas plc, 12 July 1990, Judgment, para 20

2670 Case C-180/04 Vasallo v Azienda Ospedaliera San Martino di Genova e Cliniche Universitarie Convenzionate, 7 September 2006, Judgment, para 26; Case C-53/04 Marrosu 
and a motorway operator ${ }^{2672}$ as an emanation of the State. The learned authors describe the test in Foster as an "unusual inverse principle of state or vicarious responsibility". ${ }^{2673}$

The practical effect of the test means that commercial enterprises that are working with a Member State or under some form of its control may be held liable for a Member State's improper implementation of a Directive. ${ }^{2674}$ The test in Foster is broad - it contemplates a public nature ("a public service"), connection to the State via a source ("a measure"), and a relationship ("under the control of the State" and "special powers"). If one looks at the aspects of an enterprise operating or co-operating an immigration detention facility, it is arguable that an enterprise in that position may be not only be liable for improper implementation of a Directive, but also (consistent with Marks $\mathcal{E}$ Spencer) be liable for improper application of a Directive, where it can be shown that it is fulfilling a public service; that it does so by virtue of a measure; that the enterprise has a corresponding relationship with the State in that its actions remain under the control of the State; and that it has "special powers" which may stem from the fact that it has been authorised to exercise power over persons involuntarily deprived of their liberty and upon whom the detained person is now dependant.

Eventhough such a position is arguable, it is worth trying to analogise some of the principles in the existing case law to determine the likely position for detention centre private contractors. The weakest link in the chain may well be what constitutes a "measure". Some assistance might be gleaned from Rieser ${ }^{2675}$ which involved a motorway operator. Rieser is a case in which the Austrian government was the sole shareholder in a company established under private law. The Austrian government had concluded a "licence" with the company "for the construction, planning, operation and financing of Austrian motorways and expressways". ${ }^{2676}$ The Court refers to the company's ability

and Sardino v Azienda Ospedaliera San Martino di Genova e Cliniche Universitarie Convenzionate, Judgment, 7 September 2006, para 29; Case C-6/05 Medipac-Kazantzidis AEv VenizelioPananeio (PE.S.Y. KRITIS), 14 June 2007, Judgment, para 43

2671 Case C-419/92 Scholz v Opera Universitaria di Cagliari, 23 February 1994, Judgment, para 12; Case C-250/09 and 268/09 Georgiev v Tehnicheski universitet - Sofia, filial Plovdiv, 18 November 2010, Judgment, paras 70-71

2672 Case C-157/02 Rieser Internationale Transporte GmbH v Autobahnen- und SchnellstraßenFinanzierungs- $A G$ (Asfinag), 5 February 2004, Judgment, paras 24-29

2673 Craig, P, and de Búrca, G, EU Law, 5ed, 2011, OUP, Oxford, P.198

2674 In this regard, see the comments of Advocate General Jacobs in Case C-316/93 Vaneetveld $v$ Le Foyer SA, 27 January 1994, Opinion, para 31

2675 Case C-157/02 Rieser Internationale Transporte GmbH v Autobahnen- und SchnellstraßenFinanzierungs- $A G$ (Asfinag), 5 February 2004, Judgment

${ }^{2676}$ Case C-157/02 Rieser Internationale Transporte GmbH v Autobahnen- und SchnellstraßenFinanzierungs- $A G$ (Asfinag), 5 February 2004, Judgment, para 12 
"under that contract" to levy tolls to fund such expenses. ${ }^{2677}$ Accordingly, there are two elements to this emanation of the State - firstly, the corporatisation of part of a government function, and secondly the contractual or "licensing" element. What is important is that, for the purposes of a "measure" either the act of corporatisation (with the government as its sole shareholder) and/or the existence of the "licence" or contract appears to have sufficiently constituted a "measure" (that is, private law and contract law appear to have been a sufficient measure in the absence of a legislative act or other instrument to have constituted the "measure"). The Court looked to the fact that the Austrian government could scrutinise the actions of the company and its subsidiaries; the fact that the government could impose its own objectives in relation to organising traffic, safety and construction; and the company's submission to the government annual budgetary plans. ${ }^{2678}$ Further, the Court noted that the company did not fix the amount of the tolls itself, but rather this aspect was determined by law. ${ }^{2679}$ The Court concluded that the company was, "pursuant to an act adopted by public authorities" entrusted with "the performance of a public-interest service".

It follows that the inference to draw from Rieser is that it is indeed arguable that either the corporatisation of detention facility services and/or the entering into a contract by a State with a private entity for the purpose of that entity carrying out the management of those facilities may well be a sufficient "measure" to cast such a service provider as an emanation of the State.

If the emanation of a detention centre service provider as the State is taken one step further, it is then also arguable that that enterprise is bound by the EU Charter as it is "implementing Union law" as contemplated by Article 51(1) of the Charter. ${ }^{2680}$

Even if a detention centre service provider is not found to be an emanation of the State, it is also possible that such enterprises may be affected by the principle of horizontal harmonious interpretation ${ }^{2681}$ and the principle of

2677 Case C-157/02 Rieser Internationale Transporte GmbH v Autobahnen- und SchnellstraßenFinanzierungs-AG (Asfinag), 5 February 2004, Judgment, para 12

2678 Case C-157/02 Rieser Internationale Transporte GmbH v Autobahnen- und SchnellstraßenFinanzierungs-AG (Asfinag), 5 February 2004, Judgment, para 25

2679 Case C-157/02 Rieser Internationale Transporte GmbH v Autobahnen- und SchnellstraßenFinanzierungs-AG (Asfinag), 5 February 2004, Judgment, para 26

2680 I am grateful to Dr Elise Muir, of Maastricht University, who raised this suggestion in e-mail correspondence with me on 13 December 2011 (copy held on file by author)

2681 Case C-14/83 Von Colson and Kanann v Land Nordrhein-Westfalen, 10 April 1984, Judgment, paras 26-28; Case C-106/89 Marleasing SA v La Commercial Internacionale de Alimentacion SA, 13 November 1990, Judgment, paras 7-8; Case C-397-403/01 Pfeiffer and others $v$ Deutsches Rotes Kreuz, Kreisverband Waldshut eV, 5 October 2004, Judgment Grand Chamber, paras 115-118 
incidental horizontal effects. ${ }^{2682}$ Indeed, as detention conditions may well raise fundamental principles of EU law, it is also possible that, consistent with Mangold ${ }^{2683}$ a detention service provider may find itself bound to the contents of a Directive before the time for implementation has expired.

Accordingly, outsourcing of immigration detention operations may divert liability to a private enterprise from a Member State where that Member State has inadequately implemented the Directive or where the Directive is correctly implemented but inappropriately applied in practice. But that diversion does not result in the absence of a defendant. From an asylum seeker's perspective what remains important is that he or she is able to enforce the content of the Directives at least against the corporate defendant and, where the inadequate implementation has resulted in damage, additionally sue the Member State for liability ${ }^{2684}$ as part of an overall forensic strategy. ${ }^{265}$

\subsection{Australia}

In the Australian legal framework surrounding detention conditions, three chief issues arise. Firstly, the lack of justiciable transparent standards; secondly, liability for treatment experienced in detention; and thirdly, the ambiguity surrounding the judicial review of, and remedies against, decisions made by service providers contracted by the Australian Government to run detention facilities and which may, on a day-to-day basis, affect the human rights of detained asylum seekers.

\subsubsection{An Absence of Legislative Minimum Standards}

There are no minimum standards contained in Australian legislation or regulations for the treatment of those detained in immigration detention, including asylum seekers. ${ }^{2686}$ The Migration Act contemplates the making of

2682 Case C-194/94 CIA Security International SA v Signalson SA and Securitel SPRL, 30 April 1996, Judgment; Case C-443/98 Unilever Italia SpA v Central Food SpA, 26 September 2000, Judgment, paras 45-52

2683 Case C-144/04 Mangold v Rüdiger Helm, 22 November 2005, Judgment Grand Chamber, paras 74-77

${ }^{2684}$ Case C-6/90 and C-9/90 Francovich and Bonifaci v Italy, 19 November 1991, Judgment; Cases C-46/93 and C-48/98 Brasserie du Pêcheur SAv Bundesrepublik Deutschland, and The Queen $v$ Secretary of State for Transport, ex parte: Factortame Ltd and others, 5 March 1996, Judgment

${ }^{2685}$ Such a strategy is suggested by Craig and de Búrca see Craig, P, and de Búrca, G, EU Law, 5ed, 2011, OUP, Oxford, P.215

2686 Australian Human Rights Commission, 2008 Immigration Detention Report - Summary of observations following the inspection of Australia's immigration detention facilities, December 2008, http://www.humanrights.gov.au/human_rights/immigration/idc2008.pdf (last accessed 11 December 2011), P.18, para 6.1; see also Parliament of Australia, Joint Standing Committee on Migration, Immigration Detention in Australia - Facilities, services and transparency, August 2009, Canberra, http://www.aph.gov.au/house/committee/mig/detention/report3/ fullreport.pdf (last accessed 11 December 2011) at Pp.87-88 
regulations concerning the "operation and regulation" of detention centres, ${ }^{2687}$ with particular reference to "the conduct and supervision of detainees" 2688 and "the powers of persons performing functions in connection with the supervision of the detainees". ${ }^{268}$ However, notwithstanding that the Act contemplates the carrying out of searches ${ }^{2690}$ or the administration of medical treatment to detainees without consent, ${ }^{2691}$ no such regulations relating to general conditions of detention have been made. The lack of such legislatively embodied standards has not gone without judicial notice, with Selway J in Mastipour noting that:

"[a]s I mentioned in my reasons for judgment in Alsalih"2692 [...] it is usual when powers of detention are conferred for the Parliament to make provision for the manner of the exercise of those powers. There are two reasons for this. The first is to curtail the possible abuse of powers. The second is to protect those who have to exercise them by providing some guidance as to what the powers are."2693

Finn J agreed with Selway J on this point, stating:

"The present legislative vacuum is, in my view, potentially unfair both to those involved in the conduct of detention centres and to the detainees. Selway J has illustrated why this is so. I need hardly add that this state of affairs is not conducive to ordered and principled public administration." 2694

Prior to 1997, management of detention centres was conducted by the Australian Protective Service. ${ }^{269}$ Accordingly, persons who were part of the service fell under the Public Service Act 1999 (Cth), which provides for a Code of Conduct ${ }^{2696}$ and disciplinary action for breaches of the Code. ${ }^{2697}$

In 1997, Immigration detention services were privatised and a set of standards (known as the Immigration Detention Standards or "IDS") were developed and formed part of the contract with the company providing immigration

\footnotetext{
2687 Section 273(2) of the Migration Act 1958 (Cth)

2688 Section 273(3)(a) of the Migration Act 1958 (Cth)

2689 Section 273(3)(b) of the Migration Act 1958 (Cth)

2690 Sections 252AA (power to conduct a screening procedure), 252A (power to conduct a strip search), 252B (rules for conducting a strip search), 252C (possession and retention of objects obtained during a screening procedure or strip search), 252G (powers concerning entry to a detention centre) of the Migration Act 1958 (Cth)

2691 Regulation 5.35 of the Migration Regulations 1994 (Cth)

2692 Alsalih v Manager Baxter Immigration Detention Facility [2004] FCA 352 at paras 47-48

2693 Secretary, Department of Immigration and Multicultural and Indigenous Affairs $v$ Mastipour [2004] FCAFC 93 per Selway J at para 8

2694 Secretary, Department of Immigration and Multicultural and Indigenous Affairs $v$ Mastipour [2004] FCAFC 93 per Finn J at para 2; see also $S v$ Secretary, Department of Immigration and Multicultural and Indigenous Affairs [2005] FCA 549 at para 198

2695 AHRC, Those Who've Sailed Across the Seas - Detention of Unauthorised Arrivals, 1998, Pp.62-63

${ }^{2696}$ Section 13 of the Public Service Act 1999 (Cth)

2697 Section 15 of the Public Service Act 1999 (Cth)
} 
detention services. ${ }^{2698}$ Following evidence of systemic problems in detention centres post-privatisation, the IDS were further developed with input from the AHRC's formulation of its Immigration Detention Guidelines. ${ }^{2699}$ The revised IDS were then used as a standard for measuring service delivery performance at detention facilities, and have subsequently formed part of contracts to provide immigration detention services. ${ }^{2700}$

The Australian National Audit Office (“ANAO”) in its 2004 Audit Report on the Management of Detention Centre Contracts revealed that the use of the IDS was an inadequate basis for the assessment of the performance of these contracts. ${ }^{2701}$ The Report indicated that the IDS "were not clear statements of detention service requirements" which made it "difficult for DIMIA [now DIAC] to effectively monitor [the service provider's] performance against predetermined levels of service delivery". ${ }^{2702}$ This was partly due to the characterisation of the IDS in terms of detainees' rights but without the totality of the IDS being translated into an effective performance measure. ${ }^{2703}$ The ANAO also noted that although the detention contracts included references to Australia's international obligations to inform how detention services were to be delivered, it was unclear how those international obligations impacted on the performance of the contract or how DIMIA [now DIAC] satisfied itself that such obligations were being met by the service provider's performance of the contract. ${ }^{2704}$

Following both the Palmer Report, which emphasised concerns regarding the monitoring of the performance of the detention services contract and referred

2698 Parliament of the Commonwealth of Australia, Joint Standing Committee on Migration, Immigration Detention in Australia - Facilities, services and transparency, August 2009, Canberra, $\quad$ http://www.aph.gov.au/house/committee/mig/detention/report3/ fullreport.pdf (last accessed 11 December 2011) at Pp.62-63

2699 AHRC, Immigration Detention Guidelines, March 2000, http://www.hreoc.gov.au/pdf/ human_rights/asylum_seekers/idc_guidelines.pdf (last accessed 11 December 2011)

2700 Parliament of Australia, Joint Standing Committee on Migration, Immigration Detention in Australia - Facilities, services and transparency, August 2009, Canberra, http://www.aph.gov.au/house/committee/mig/detention/report3/fullreport.pdf (last accessed 11 December 2011) at Pp.63-66

2701 ANAO, Audit Report 54 2003-2004, Performance Audit, Management of the Detention Centre Contracts - Part A, 18 June 2004, http://www.anao.gov.au/ /media/Uploads/ Documents/2003\%2004_audit_report_54.pdf (last accessed 7 August 2012)

2702 ANAO, Audit Report 54 2003-2004, Performance Audit, Management of the Detention Centre Contracts - Part A, 18 June 2004, http://www.anao.gov.au/ /media/Uploads/ Documents/2003\%2004_audit_report_54.pdf (last accessed 7 August 2012), P.16

2703 ANAO, Audit Report 54 2003-2004, Performance Audit, Management of the Detention Centre Contracts - Part A, 18 June 2004, http://www.anao.gov.au/ /media/Uploads/ Documents/2003\%2004_audit_report_54.pdf (last accessed 7 August 2012), Pp.80-81, paras 4.19-4.20

2704 ANAO, Audit Report 54 2003-2004, Performance Audit, Management of the Detention Centre Contracts - Part A, 18 June 2004, http://www.anao.gov.au/ /media/Uploads/ Documents/2003\%2004_audit_report_54.pdf (last accessed 7 August 2012), Pp.88-89 
to findings made in the ANAO's 2004 Report, ${ }^{2705}$ and an independent review of detention services contracts by Mick Roche in 2006, ${ }^{2706}$ the Department of Immigration and Citizenship developed the Service Delivery Model ("SDM"), ${ }^{2707}$ and which was subsequently adopted as the basis for detention services contracts. 2708

As was noted in 2009 in the submissions to the Joint Standing Committee, and noted by the Joint Standing Committee itself, the IDS, although referred to on the Department's website, were not publicly available, nor were copies of the detention services contracts. ${ }^{2709}$ The Joint Standing Committee noted the distinction between the SDM and IDS:

"The SDM is the high level framework that identifies the values and the behaviours required for the detention service providers. The Standards [that is, the IDS] provide details about the quality of services that would be expected in immigration facilities at the delivery level." 2710

Accordingly, the Joint Standing Committee recommended:

"...that the Department of Immigration and Citizenship publish the detention service standards, or the current equivalent, on its website and provide a copy of the detention service standards or the current equivalent, translated into appropriate languages, to all current and future detainees.

The Committee also recommends that the Department of Immigration and

2705 Palmer, M, Department of Immigration and Citizenship, Inquiry into the Circumstances of the Immigration Detention of Cornelia Rau, July 2005, http://www.immi.gov.au/media/ publications/pdf/palmer-report.pdf (last accessed 11 December 2011), Pp.176-178

2706 Roche, M, Department of Immigration and Citizenship, Detention Services Contract Review, February 2006, http://www.immi.gov.au/about/department/perf-progress/dimaimprovements/_pdf/roche/Roche_Report.pdf (last accessed 11 December 2011)

2707 Parliament of Australia, Joint Standing Committee on Migration, Immigration Detention in Australia - Facilities, services and transparency, August 2009, Canberra, http://www.aph.gov.au/house/committee/mig/detention/report3/fullreport.pdf (last accessed 11 December 2011) at Pp.66-69.

2708 Parliament of Australia, Joint Standing Committee on Migration, Immigration Detention in Australia - Facilities, services and transparency, August 2009, Canberra, http://www.aph.gov.au/house/committee/mig/detention/report3/fullreport.pdf (last accessed 11 December 2011) at Pp.70-72

2709 Parliament of Australia, Joint Standing Committee on Migration, Immigration Detention in Australia - Facilities, services and transparency, August 2009, Canberra, http://www.aph.gov.au/house/committee/mig/detention/report3/fullreport.pdf last accessed 26 August 2009 at Pp.87-88, particularly para 3.110 and P.98-99, particularly at paras 3.163-3.164. For a copy of the IDS, see http://www.aph.gov.au/Parliamentary _Business/Committees/House_of_Representatives_Committees?url=jfadt/idcvisits/idcapph .pdf (last accessed 3 July 2012)

2710 Parliament of Australia, Joint Standing Committee on Migration, Immigration Detention in Australia - Facilities, services and transparency, August 2009, Canberra, http://www.aph.gov.au/house/committee/mig/detention/report3/fullreport.pdf last accessed 26 August 2009 at P.99, para 3.167. 
Citizenship should report on the performance of each immigration detention service provider against the immigration detention standards, or the current equivalent, which should be included in the Department's annual report"2711

In any event, Groves noted in 2004 (at a time when the IDS were publicly available) that (at that time) the IDS and the contracts for the provision of detention services did not provide any "mechanism for detainees to directly enforce any of the immigration detention standards". 2712

Indeed that is precisely the very issue. As persons who are not party to the contract, asylum seekers do not have the legal standing to enforce contractual compliance with the IDS due to the doctrine of privity of contract. ${ }^{2713}$ It is unsurprising that, in 2008, the CteeAT recommended as part of its Concluding Observations that the IDS be codified into legislation. ${ }^{2714}$ As discussed in previous chapters, it is extremely distressing that, notwithstanding deplorable conditions of detention that arguably may amount to punishment, the High Court of Australia has held that that does not affect the legality of the detention. ${ }^{2715}$

In November 2011, a journalist requested a copy of the detention services contract with Serco Australia Pty Limited ("Serco") through a Freedom of Information ("FOI") request and published the contract ${ }^{2716}$ ("the Contract") and its schedules on the Internet. ${ }^{2717}$

The Contract provides that Serco must comply with all "Laws and Australian Government Policies of general application" 2718 and "Department Specific Policies", ${ }^{2719}$ both of which are contained in schedule 16 to the Contract.

2711 Parliament of Australia, Joint Standing Committee on Migration, Immigration Detention in Australia - Facilities, services and transparency, August 2009, Canberra, http://www.aph.gov.au/house/committee/mig/detention/report3/fullreport.pdf (last accessed 11 December 2011) at P.100, para 3.170

2712 Groves, M, Immigration Detention vs Imprisonment: Differences explored, October 2004, Alternative Law Journal, Volume 29, Number 5, Pp.228-234 at 233.

2713 On privity of contract, see Willmott, L, Christensen, S, Butler, D, and Dixon, B, Contract Law, 3ed, 2009, OUP, South Melbourne, Pp.408-433; and Paterson, J, Robertson, A, and Duke, A, Principles of Contract Law, 3ed, 2009, Lawbook Co, Pyrmont, Pp.205-222

2714 UN, CteeAT, Concluding Observations of the Committee Against Torture - Australia, 22 May 2008, CAT/C/AUS/CO/3, para 26

2715 Behrooz $v$ Secretary of the Department of Immigration and Multicultural and Indigenous Affairs [2004] HCA 36

2716 Contract dated 29 June 2009 between the Commonwealth of Australia and Serco Australia Pty Limited

2717 Lowenstein, A, Cordell, M, and Farrell, P, Exclusive: Our Contract with Serco, New Matilda, 9 November 2011, http://newmatilda.com/2011/11/09/exclusive-our-contractserco (last accessed 2 July 2012); see also Borrello, E, Media breach 'bigger threat to Serco than depression', ABC News, 10 November 2011, http://www.abc.net.au/news/2011-1110/serco-contract-released/3656214 (last accessed 2 July 2012)

2718 Clause 3.6 of the Contract

2719 Clause 3.7 of the Contract 
However, Schedule 16.3 to the Contract reveals that the IDS are not listed as a General Australian Government Policy or Department Specific Policy with which Serco is obliged under the Contract to comply. Indeed, the contract reveals the centrality of the seven Immigration Detention Values (announced by the then Minister for Immigration on 29 July 2008 - see Chapter 3) to which the service provider "must seek to give effect" and against which performance is measured. ${ }^{2720}$ Indeed, Schedule 4.1, which deals with performance management, makes no mention of the IDS. The Immigration Detention Values (against which the law has been scrutinised in this book) are broad statements of policy that do not comprehensively set out the rights and obligations of those detained. The lack of incorporation of the IDS into the Contract may have significant consequences when it comes to asserting liability for damage caused to persons in detention because although a duty of care is acknowledged, the absence of the IDS makes it more difficult for a plaintiff to establish the precise nature of the duty owed and breached. Much then, depends, on both the policies, procedures and protocols concluded as part the contract as well as those formulated by the service provider itself. An analysis of those provisions may well be the subject of further detailed research.

\subsubsection{Legal Liability for Detention Conditions \& Scope of the Duty of Care}

An asylum seeker's civil rights are not extinguished by virtue of their detention. As Gleeson CJ alluded in Behrooz:

\footnotetext{
"Harsh conditions of detention may violate the civil rights of an alien. An alien does not stand outside the protection of the civil and criminal law. If an officer in a detention centre assaults a detainee, the officer will be liable to prosecution, or damages. If those who manage a detention centre fail to comply with their duty of care, they may be liable in tort." 2721
}

Notwithstanding the privatisation of detention services, the Commonwealth retains, at common law, the ultimate and non-delegable duty of care towards detained asylum seekers as outlined by Finn $\mathrm{J}$ in $S v$ Secretary DIMIA. ${ }^{2722}$ Groves notes that the Commonwealth's acceptance of the non-delegability of its duty of care in $S v$ Secretary was unexpected given that doubt was expressed by the Full Federal Court in Mastipour as to whether the detention service

2720 Clauses 13.1, 10 and 29 of, Recital A and Schedules 18 and 4.1 to, the Contract

${ }^{2721}$ Behrooz v Secretary of the Department of Immigration and Multicultural and Indigenous Affairs [2004] HCA 36 per Gleeson CJ at 21.

2722 S v Secretary, Department of Immigration and Multicultural and Indigenous Affairs [2005] FCA 549 at paras 199 and 207-213. Note also Kondis v State Transport Authority [1984] HCA 61 per Mason J at 33 and Burnie Port Authority $v$ General Jones Pty Ltd [1994] HCA 13 at paras 36-40 in relation to non-delegable duty of care; see Howard v Jarvis [1958] HCA 19 per Dixon CJ, Fullagar and Taylor JJ at para 8 concerning the nature of the relationship between an inmate and gaoler 
provider was detaining the plaintiff, whether the Secretary was the proper defendant and what obligations were owed to the plaintiff and by whom. ${ }^{2723}$

DIAC has acknowledged a duty of care on its website, ${ }^{2724}$ and which has also been acknowledged in the contract between the Commonwealth and Serco. ${ }^{2725}$

However, as alluded to above, identifying the proper defendant where detention arrangements have been outsourced has, at times, proved less than obvious. $^{2726}$

\section{Scope of the Duty of Care}

The standard of care may be akin to an inmate/gaoler relationship. Immigration detention may not be directly comparable to penal incarceration given that the purpose of detention is not to punish (notwithstanding that it may have that effect, or worse, in practice), ${ }^{2727}$ but it does inform about the nature of the relationship between detainee/detainer and the standard of care involved. Finn $\mathrm{J}$ in $S v$ Secretary DIMIA identified the gaoler/prisoner relationship and hospital/patient relationship, noting that immigration detention shared not only elements of control and assumed responsibility with the hospital/patient relationship, but also shared "the exaggerated vulnerability of the class of detainees at significant risk of mental illness". ${ }^{2728}$ Further, his Honour noted that a characteristic of the gaoler/prisoner is the inability of the detainee to provide for his or her own needs, and the dependence on the gaoler for those needs. ${ }^{2729}$ This is particularly the case with those who have special needs, such as those suffering from mental or physical illness. Finn J noted that the duty of care:

"must accommodate that special dependence and the peculiar vulnerability to which detainees known to suffer mental illness are exposed. The duty must also

2723 Secretary, Department of Immigration and Multicultural and Indigenous Affairs $v$ Mastipour [2004] FCAFC 93 per Selway J at paras 17-18 (agreeing with Lander J), per Lander J at pars 33-37; Groves, M, Outsourcing and Non-Delegable Duties (2005) 16 Public Law Review 265, P. 269

${ }^{2724}$ Australian Government, Department of Immigration and Citizenship, Legislation and International Conventions, http://www.immi.gov.au/managing-australias-borders/ detention/regulations/legislation-conventions.htm (last accessed 11 December 2011)

2725 Clause 14(a) and (d) of the Contract

2726 Secretary, Department of Immigration and Multicultural and Indigenous Affairs $v$ Mastipour [2004] FCAFC 93 per Selway J at 18, per Lander J at 35; S v Secretary, Department of Immigration and Multicultural and Indigenous Affairs [2005] FCA 549 at paras 199-203

2727 For an eloquent discussion on this issue, see Groves, M, Immigration Detention vs Imprisonment: Differences explored (2004) 29(5) Alternative Law Journal 228

2728 S v Secretary, Department of Immigration and Multicultural and Indigenous Affairs [2005] FCA 549 at para 209

2729 S v Secretary, Department of Immigration and Multicultural and Indigenous Affairs [2005] FCA 549 at para 210. See also Crowley-Cyr, L, Mental Illness \& Indefinite Detention at the Minister's Pleasure (2004) 9(1) UWSLR 53 
take account of the very distinctive outsourcing arrangements the Commonwealth has been prepared to accept for the provision of health care services". ${ }^{2730}$

As to the standard which is to be provided by the Commonwealth, his Honour held that the Commonwealth is to:

\begin{abstract}
"ensure that reasonable care is taken of the detainees who, by reason of their detention cannot care for themselves: cf Spicer $v$ Williamson 132 SE 291 (1926) at 293. This necessitates that the Commonwealth ensures that a level of medical care is made available which is reasonably designed to meet their health care needs including psychiatric care: see e.g. Brooks v Home Office (1999) 48 BMLR 109 at 114; cf also, although in a setting affected by constitutional considerations, Bowring $v$ Goodwin 551 F 2d 44 (1977) at 47. Where, as here, the Commonwealth contracts out the provision of services to detainees it is obliged to see that "care is taken": cf Kondis, at 686; and that the requisite level of medical care is provided and with reasonable care and skill." 2731
\end{abstract}

Finn $\mathrm{J}$ expressed the view that placing detention facilities in remote areas of Australia (which have poor health services and the placement of detention facilities in such areas is a policy choice made by the Commonwealth) should not diminish the Commonwealth's duty of care to provide adequate conditions of detention, such as the provision of adequate health services. ${ }^{2732}$

If the analogy to prison cases is extrapolated, ${ }^{2733}$ the duty of care may also include the prevention of suicide of detained persons who are known to be at risk of suicide, ${ }^{2734}$ with such duty additionally arising because of the "special danger of people in prison taking their own lives." 2735 This would seem particularly relevant given that asylum seekers are invariably the victims of

${ }^{2730} S$ v Secretary, Department of Immigration and Multicultural and Indigenous Affairs [2005] FCA 549 at para 211

2731 S v Secretary, Department of Immigration and Multicultural and Indigenous Affairs [2005] FCA 549 at para 212 However, Trindade, Cane and Lunney note "liability appears to have been based on the failure of the Commonwealth to perform service audits on its subcontractors, in which case the liability is personal rather than vicarious" Trindade, F, Cane, P and Lunney, M, The Law of Torts in Australia, 4ed, 2007, OUP, South Melbourne, P.777. For an excellent summary on the position of the Commonwealth as regards both non-vicarious liability and non-delegable duty of care, see Mackay, A, Harm suffered by children in immigration detention: Can tort law provide redress? (2006) 14 Tort Law Review 16, Pp.27-31 $2732 S v$ Secretary, Department of Immigration and Multicultural and Indigenous Affairs [2005] FCA 549 at para 213. See further on this case, McSherry, B, The government's duty of care to provide adequate health care to immigration detainees (2006) 13 Journal of Law and Medicine 281, Pp.283-284

2733 For a more comprehensive discussion on comparing prison cases to those in immigration detention, see Mackay, A, Harm suffered by children in immigration detention: Can tort law provide redress? (2006) 14 Tort Law Review 16, Pp.22-27

2734 Reeves $v$ Commissioner of Police of the Metropolis [1999] 3 WLR 363; Kirkham v Chief Constable of the Greater Manchester Police [1989] EWCA Civ 3 - cited in Balkin, R P, and Davis, J L R, Law of Torts, 4ed, 2009, LexisNexis Butterworths, Chatswood, P.209

2735 Reeves $v$ Commissioner of Police of the Metropolis [1999] 3 WLR 363 per Lord Hoffman at Pp.368-369 
torture and trauma whose tendencies might be heightened in a custodial environment for an indefinite period of time combined with deep anxiety about their future. However, McSherry and Dastyari note that the changes to tort law in Australia in recent years mean that detained asylum seekers who have suffered psychological damage as a result of negligence whilst in detention are now under a further triple juridical hurdle: firstly, that the mental health condition that they suffer is recognised; secondly, as a question of causation, such persons will have to show that that the psychological damage that they have suffered is a result of their being detained and the Commonwealth's and the service provider's lack of adequate care; and thirdly, "that it was foreseeable that the inadequate mental health services and psychiatric care would have led a person of normal fortitude to suffer a recognised psychiatric illness [emphasis added]". ${ }^{2736}$ In circumstances where asylum seekers are the invariable victims of torture and violence, it would always be open to a defendant to assert that the cause of the psychological damage is not a result of detention but of previous trauma. Further, any previous trauma may give rise to propensity to develop further psychological damage once in detention but "a person of normal fortitude" is a much higher threshold for an asylum seeker to reach in these circumstances. That is, it may not be reasonably foreseeable that, where a person of "normal fortitude" (namely, a person who has not been tortured or traumatised) has been detained, that the Commonwealth or the service providers' acts or omissions would result in damage.

In a prison context, the duty of care also extends to the prevention of detainees from being assaulted by other detainees. ${ }^{2737}$ The upper limit of the duty of care is not to guarantee the safety of an inmate, but for the authorities to take "reasonable care". 2738

It should also be noted that prison facilities may be used as places of detention. Indeed, it will be recalled from Chapter 3 that Cornelia Rau had spent some time in state prisons before being placed in an immigration detention centre. Further, Groves notes that the use of prisons to hold immigration detained persons had been the subject of an inquiry by the Commonwealth Ombudsman in 2001. ${ }^{2739}$ The Minister's residence determination powers

\footnotetext{
2736 McSherry, B, and Dastyari, A, Providing Mental Health Services and Psychiatric Care to Immigration Detainees: What Tort Law Requires (2007) 14(2) Psychiatry, Psychology and the Law 260, P.269

2737 Oliviera v New South Wales [1995] NSWSC 7; New South Wales v Napier [2002] NSWCA 402 (although Napier involved a manager of a prison factory who suffered nervous shock as a result of treatment by inmates, Mason $\mathrm{P}$ held that such a duty of care should extend to all those within the prison regardless of whether a prisoner or not - see para 76); New South Wales v Zerafa [2005] NSWCA 187.

2738 New South Wales v Bujdoso [2005] HCA 76 - cited in Balkin, R P, and Davis, J L R, Law of Torts, 4ed, 2009, LexisNexis Butterworths, Chatswood, P.209

2739 Groves, M, Immigration Detention vs Imprisonment - Differences Explored (2004) 29(5) AltLawJ 228, P.229
} 
under section $197 \mathrm{AB}$ of the Migration Act would not preclude designating a prison as an alternative place of detention. There is some authority for the proposition that liability may arise for damage resulting from incarcerating prisoners on remand together with convicted prisoners (in that case, in the Northern Territory), ${ }^{2740}$ but recalling that prisons are a matter of State (as opposed to Federal) competence. However, Australia has also lodged a reservation in regards to Article 10(2)(a) ICCPR that segregation is "an objective to be achieved progressively", and that the segregation of minors from adults compelled by Article $10(2)(\mathrm{b})$ is "only to the extent that such segregation is considered by the responsible authorities to be beneficial to the juveniles or adults concerned." 2741

As a general proposition, legislation specifically authorising an act will not be found to be tortious. ${ }^{2742}$ In addition to the search provisions identified above, Regulation 5.35 of the Migration Regulations 1994 (Cth) authorises the administration of medical treatment (including "administration of nourishment and fluids") to a detainee based on medical opinion even if the detained person fails to give consent (but is in any event deemed to have given consent). The use of reasonable force is also expressly included within the authorisation. That situation may be comparable to Schneidas $v$ Corrective Services Commission ${ }^{2743}$ which involved the force-feeding of a hunger-striking prison inmate which was found to have been "medical treatment" within section 16(2) of the Prisons Act 1952 (NSW) due to the grave health condition that the inmate had induced by not eating.

The Commonwealth also retains legal responsibility under the Occupational Health and Safety Act 1991 (Cth) (the "OH\&S Act") as an "employer" as defined in section 5 of the Act, notwithstanding that services may be performed by a Commonwealth contractor. Under section 17 of the OH\&S Act, employers owe duties to third parties "to take all reasonably practicable steps to ensure that persons at or near a workplace under the employer's control who are not the employer's employees or contractors are not exposed

\footnotetext{
${ }^{2740}$ L $v$ the Commonwealth of Australia (1976) 10 ALR 269 - cited in Balkin, R P, and Davis, J L R, Law of Torts, 4ed, 2009, LexisNexis Butterworths, Chatswood, P.209

2741 See United Nations Treaty Collections http://treaties.un.org/Pages/ViewDetails .aspx? $\mathrm{src}=$ TREATY\&mtdsg_no $=\mathrm{IV}-4 \&$ chapter $=4 \&$ lang $=\mathrm{en} \#$ EndDec (last accessed 2 July 2012); see also Cabal v Secretary, Department of Justice (Victoria) [2000] FCA 949 at paras 2528 where Gray J in the Federal Court acknowledged at para 28 that Australia was under no such obligation to segregate prisoners due to the reservation to Article 10 ICCPR. See further, O'Neill, N, Rice, S, and Douglas, R, Retreat from Injustice - Human Rights Law in Australia, 2ed, Federation Press, Leichhardt, Pp. 144 and 243; Groves, M, International Law and Australian Prisoners (2001) 24(1) UNSWLJ 17

2742 McGlone, F, and Stickley, A, Australian Torts Law, 2ed, 2009, LexisNexis Butterworths, Chatswood, Pp.116-117

2743 Schneidas v Corrective Services Commission, NSWSC, Lee J, 8 April 1983, unreported; see Edney, R, Judicial Deference to the Expertise of Correctional Administrators: The Implications for Prisoners' Rights, (2001) 7(1) AJHR 91 at n.46
} 
to risk to their health or safety arising from the conduct of the employer's undertaking". Indeed, a breach of this section may result in either a civil action or criminal prosecution. ${ }^{2744}$ Under Schedule 2 to the OH\&S Act, civil penalties may be imposed for breaches of the Act as well as the institution of criminal proceedings. As to procedural tools at its disposal, Comcare has the ability to seek injunctions. ${ }^{2745}$ The court has the power to issue prohibitory, mandatory or interim injunctions but must not require (the usual) undertakings as to damages. ${ }^{2746}$ The court also has the power to order that the matters that gave rise to the breach be remedied. ${ }^{2747}$ Indeed, Comcare recently conducted an investigation of occupational health and safety standards in immigration detention facilities and found a number of breaches of the Act and Regulations by DIAC (notwithstanding the outsourcing of management of immigration detention facilities), including not taking reasonable steps to ensure the health and safety of detainees in light of the identification and management of their religious, cultural, ethnic origin and individual needs. ${ }^{2748}$

\subsubsection{Scope of the Duty of Care - Minors}

Although an analysis of practice is outside the scope of this book, the circumstances of Shayan Badraie warrant particular consideration to illuminate the existence and extent of a duty of care to minors in detention. Shayan, a five year old Iranian boy, arrived 'unlawfully' (that is, without a visa) with his parents and sister in Australia seeking a protection visa and was detained for a total of almost 17 months from March 2000 to August 2001. During Shayan's time in the Woomera detention centre (in central South Australia), he witnessed a number of disturbing incidents: riots in the detention centre; a man cutting his wrists; an ACM (the private contractor for the detention facilities at the time) guard making masturbating gestures to him and his father and his father being told by the guard to "fuck off out of here" when his father confronted the inappropriateness of the guard's gestures. The family was, at one point, transferred to the Sierra Compound, which was used for punishment. Shayan witnessed his father being restrained by guards upon moving to the compound. Only one other child was in the Sierra Compound. Shayan witnessed a further incident of self-harm. During his time at

\footnotetext{
${ }^{2744}$ Section 17(1) of the Occupational Health and Safety Act 1991 (Cth)

2745 Clause 14(1) Schedule 2 to the Occupational Health and Safety Act 1991 (Cth)

2746 Clause 14(2) - (8) Schedule 2 to the Occupational Health and Safety Act 1991 (Cth)

2747 Clause 15 Schedule 2 to the Occupational Health and Safety Act 1991 (Cth)

2748 Comcare, Investigation Report on National Detention Facilities, Investigation No. EVE00205473, 21 July 2011, http://www.comcare.gov.au/_data/assets/pdf_file/ 0008/95984/A_copy_of_the_Investigation_Report_on_National_Detention_Facilities.pdf (last accessed 11 December 2011); see also Iggulden, T, ABC News, Report scathing of detention centre conditions, 12 August 2011, http://www.abc.net.au/news/2011-0811/comcare-report-scathing-of-detention-centre-conditions/2835820 (last accessed 11 December 2011)
} 
Woomera, Shayan developed panic attacks, became withdrawn, lost his appetite, bed-wet, had nightmares, anorexia and insomnia and was tearful. ${ }^{2749}$

In early March 2001, the family was transferred to Villawood detention centre in Sydney's western suburbs. During this time he witnessed an incident of selfharm, resulting in him stopping speaking, refusing to eat, having nightmares and requiring to be force-fed. He was subsequently admitted to Westmead Hospital and diagnosed with Post Traumatic Stress Disorder ("PTSD") and later returned to Villawood. He was admitted to Westmead a second time on account of his mental state, and upon his return to Villawood, he refused to eat or drink. He was readmitted a further seven times to Westmead Hospital for rehydration. The medical professionals' reports, particularly from his first two times in hospital, note the impact of the detention environment on his state of health. Shayan was separated from his family and placed in foster care on 23 August 2001 whilst his family remained in detention. In early January 2002, Shayan's foster care came to an end and he, his mother and sister were granted a Bridging Visa by Ministerial Discretion under section 417 of the Migration Act. ${ }^{2750}$

Following a complaint by Shayan's father to HREOC (now AHRC), HREOC found a breach of Article 3(1) CROC (no active consideration of the best interests of the child), 37(b) CROC (Shayan's detention not for shortest possible period of time and arbitrary on account of "inappropriate, unjust, unreasonable and disproportionate"); Article 37(c) CROC (failure to treat Shayan "with humanity and respect for dignity of the human person and/or in a manner appropriate to his age"); and Article 9(1) CROC (the separation from Shayan's parents by being placed in foster care was not necessary). HREOC recommended, inter alia, an apology and compensation of AUD70,000. The Government, however, rejected those recommendations. ${ }^{2751}$

Proceedings for damages resulting from a breach of duty were then brought in the Supreme Court of New South Wales. ${ }^{2752}$ McSherry and Dastyari note that

\footnotetext{
2749 HREOC, Report of an inquiry into a complaint by Mr Mohammed Bedraie on behalf of his son Shayan regarding acts or practices of the Commonwealth of Australia (the Department of Immigration, Multicultural and Indigenous Affairs), HREOC Report No.25 http://www.hreoc.gov.au/ legal/humanrightsreports/hrc_25.html (last accessed 4 July 2012)

${ }^{2750}$ HREOC, Report of an inquiry into a complaint by Mr Mohammed Bedraie on behalf of his son Shayan regarding acts or practices of the Commonwealth of Australia (the Department of Immigration, Multicultural and Indigenous Affairs), HREOC Report No.25 http://www.hreoc.gov.au/ legal/humanrightsreports/hrc_25.html (last accessed 4 July 2012)

${ }^{2751}$ HREOC, Report of an inquiry into a complaint by Mr Mohammed Bedraie on behalf of his son Shayan regarding acts or practices of the Commonwealth of Australia (the Department of Immigration, Multicultural and Indigenous Affairs), HREOC Report No.25 http://www.hreoc.gov.au/ legal/humanrightsreports/hrc_25.html (last accessed 4 July 2012)

2752 Shayan Badraie by his tutor Mohammed Saeed Badraie v Commonwealth of Australia and Ors [2005] NSWSC 1195
} 
the Commonwealth conceded that any duty of care it owed was nondelegable concordant with $S v$ Secretary DIMIA $A^{2753}$ and that, in the out-ofcourt settlement reached (AUD400,000), the Commonwealth did not include 'no admissions as to liability' in the terms of settlement (noting, however, that that has no precedential value - indeed the avoidance of any precedent by settling the matter may well have been at the forefront of the Commonwealth's mind - nor is it clear whether the absence of 'no admissions' was a choice on behalf of the Commonwealth or mere oversight). ${ }^{2754}$ Further, it was noted by the Court that the Commonwealth asserted that it did not breach any such duty of care. ${ }^{2755}$

In line with the reasoning of $S v$ Secretary DIMIA discussed earlier (and in light of Shayan Badraie), the logical extension to the dynamic of the detainee/detainer relationship, and the particular vulnerability of the (minor) detainee, is pertinent to the detention of minors and their family members. It may be arguable that even if the child's parents were detained with the child, the inability of the parents to provide for their own needs, let alone that of their child, may not exclude the Commonwealth from liability if its duty of care was not discharged towards a child in detention.

\subsubsection{Scope of the Duty of Care - Unaccompanied Minors}

As discussed in Chapter 5, the obligations towards unaccompanied minors are heightened by the fact that the Minister is their legal guardian "with the same rights, powers, duties, obligations and liabilities as a natural guardian of the child would have". ${ }^{2756}$ The scope of the Minister's role has been held to include "all the usual incidents of guardianship" 2757 and the rights under CROC. ${ }^{2758}$ Taylor helpfully summarises the position at common law:

"Of course, the meaning of guardianship in a statute will depend on the context in which it appears. At common law, the broad notion of guardianship means 'the full range of rights and powers that can be exercised by an adult in respect of the welfare and upbringing of a child'. Guardianship duties have been said to include the duty to protect the child from harm, to provide for maintenance, to educate

\footnotetext{
2753 Shayan Badraie by his tutor Mohammed Saeed Badraie v Commonwealth of Australia and Ors [2005] NSWSC 1195 at para 28

2754 McSherry, B, and Dastyari, A, Providing Mental Health Services and Psychiatric Care to Immigration Detainees: What Tort Law Requires (2007) 14(2) Psychiatry, Psychology and the Law 260, Pp.264-265; see also Penovic, T, and Sifris, A, Children's rights through the lens of immigration detention (2006) 20 AJFL 12, P.14, circa n.113 and following text; Kennedy, R, Duty of Care in Human Services, 2009, CUP, New York, P.112; Hammerton, C, Children in Detention: Shayan's Story [2006] HRightsDef 28

2755 Shayan Badraie by his tutor Mohammed Saeed Badraie $v$ Commonwealth of Australia and Ors [2005] NSWSC 1195 at para 29

2756 Section 6 of the Immigration (Guardianship of Children) Act 1946 (Cth)

2757 Odhiambo v Minister for Immigration and Multicultural Affairs [2002] FCAFC 194 at para 86

2758 X v Minister for Immigration \& Multicultural Affairs [1999] FCA 995 at para 43
} 
and even to show affection and provide emotional support. Like other fiduciary relationships, the guardianship relationship covers matters of a non-economic nature. The relationship is often characterised as fiduciary, and the guardian's rights and powers carry with them the duty to act in the best interests of the child.

It has been said that guardianship denotes 'duties concerning the child ab extra; that is, a warding off; the defence, protection and guarding of the child, or his property, from danger, harm or loss that may ensure from without.' This includes the right to commence legal proceedings on behalf of the child. [citations omitted]"2759

Given the Federal constitutional structure in Australia, there are considerations for the role of State child welfare authorities. Taylor's analysis of the IGOC Act concludes that the Minister retains ultimate responsibility for an unaccompanied minor notwithstanding an effective delegation to State child welfare authorities (the effectiveness of which Taylor questions). ${ }^{2760}$ However, if a delegation to a State child welfare authority were effective, and that authority breaches its duties, Taylor raises the possibility that an unaccompanied minor may be able to initiate proceedings under a State's child welfare legislation. ${ }^{2761}$

Accordingly, it is arguable that the Commonwealth owes a particular duty of care to detained minors, which, in the case of unaccompanied minors, may be accompanied by the Minister's statutory obligations under the IGOC Act and the fiduciary nature of the role of guardianship. Penovic and Sifris point out that there is an inconsistency in treatment at law between unaccompanied minors (who are subject to the considerations under the IGOC Act which might more readily dispose them to placement outside a detention context) and accompanied minors who are not subject to those considerations and are liable at law to be placed in detention as with other unlawful non-citizens however, the learned authors conclude that, given the distinct purposes of both the IGOC Act and the Migration Act, considerations under the IGOC Act for the "vast majority of children" in detention will be "of little or no assistance". 2762

\subsubsection{Scope of the Duty of Care - Education of Minors}

In relation to the educational rights of asylum seeking children, Bourgonje notes that education legislation is dependent on the State or Territory of the detention centre and opines that it is applicable to those in detention up to the

2759 Taylor, J, Guardianship of Child Asylum Seekers (2006) 34 Federal Law Review 185, P.190

2760 Taylor, J, Guardianship of Child Asylum Seekers (2006) 34 Federal Law Review 185, Pp.187-188

2761 Taylor, J, Guardianship of Child Asylum Seekers (2006) 34 Federal Law Review 185, P.188

2762 Penovic, T, and Sifris, A, Children's rights through the lens of immigration detention (2006) 20 AJFL 12, P.15-16, circa n.127 and following text 
age of 15 or 16 depending on the State or Territory in question (and may be contingent upon there being no inconsistency with Federal law in accordance with section 109 of the Australian Constitution). ${ }^{2763}$ In its submission to the Joint Select Committee, the AHRC noted that practice varied in relation to the availability of education to detained children depending on the location. ${ }^{2764}$ It is highly arguable that the ultimate responsibility to arrange for minors to attend school (including appropriate arrangements with State and Territory governments) must rest with the Commonwealth through DIAC. Stern laments that "there is little legal recourse available to children detained on Christmas Island to enforce their educational rights" and calls for legislation that allows asylum seeking children to attend schools in existing communities. ${ }^{2765}$ The AHRC has recommended that "[c]hildren of all ages should be permitted to attend school or participate in other appropriate educational programs outside the detention environment [emphasis added]". ${ }^{2766}$

\subsubsection{Review of Decisions Taken in Detention Relating to Treatment of Asylum Seekers}

Notwithstanding that the duty of care ultimately rests with the Commonwealth as regards the conditions of detention for asylum seekers, a lacuna exists in Australian law as regards the judicial review of decisions made by a private entity but exercising a 'public' power.

This issue is pertinent to the detention of asylum seekers because the management of detention facilities (which includes many day-to-day decisions which affect the lives and rights of asylum seekers in detention) is carried out by private contractors. For example, what if a detained asylum seeker is sent to a "management unit" (that is, placed in isolation)? What is to occur in the case of disciplinary action of a detained person?

Normally, an administrative decision may be subject to judicial review under (1) the Administrative Decisions (Judicial Review) Act 1977 (Cth) ("ADJR Act") or (2) the Judiciary Act 1903 (Cth) or (3) the original jurisdiction of the High Court of Australia under section 75(v) of the Australian Constitution.

\footnotetext{
2763 Bourgonje, P, Education for refugee and asylum seeking children in OECD countries, Education International, March 2010, http://download.ei-ie.org/Docs/WebDepot/ EIResearch_Paloma_Eng_final_med.pdf (last accessed 3 July 2012), P.69

2764 AHRC, Submission - Joint Select Committee on Australia's Immigration Detention Network, August 2011, http://www.hreoc.gov.au/legal/submissions/2011/201108_immigration.pdf (last accessed 3 July 2012), P.56, para 160

2765 Stern, M, The Educational Rights of Asylum Seeking Children - Observing Failure (2010) 5(7) Journal of Law and Social Justice 1, P.11-12

2766 AHRC, Submission - Joint Select Committee on Australia's Immigration Detention Network, August 2011, http://www.hreoc.gov.au/legal/submissions/2011/201108_immigration.pdf (last accessed 3 July 2012), P.56
} 


\section{The ADJR Act}

The ADJR Act requires that, inter alia, in order to be subject to judicial review under the Act, the decision must be made "under an enactment". ${ }^{2767}$ In NEAT Domestic Trading Pty Ltd $v$ AWB Limited, ${ }^{2768}$ AWB was a private entity whose consent to the Wheat Export Authority was necessary before that Authority could give its consent to an entity other than AWB Limited to export bulk wheat from Australia. The High Court ultimately held that that decision by AWB Limited (although arguably exercising a considerable public power) was not subject to judicial review under the Act because the decision was not "under an enactment" (that is, its power to make a decision vetoing the export of bulk wheat by another entity was sourced from the Corporations Law rather than the wheat marketing laws). Accordingly, the focus was not on the public nature of the power, but rather its source. ${ }^{2769}$ After NEAT, in Tang, concerning the termination of a $\mathrm{PhD}$ student's enrolment from a university, the High Court held that

\footnotetext{
"The determination of whether a decision is 'made [...] under an enactment' involves two criteria: first, the decision must be expressly or impliedly required or authorised by the enactment; and secondly, the decision must itself confer, alter or otherwise affect legal rights or obligations, and in that sense the decision must derive from the enactment. A decision will only be 'made [...] under an enactment' if both these criteria are met" [emphasis added].2770
}

Accordingly, as noted by Aronson et al, the rights altered must be derived from the enactment itself. ${ }^{2771}$ The rights affected cannot come from the general law (such as contract law). According to the High Court in Tang, even if the ability to enter into a contract is granted by legislation, the rights and obligations between the parties stem from the contract not from "the enactment" (which merely enabled the entering into of the contract). ${ }^{2772}$ If that logic is extended one step further, then it must also be the case that decisions made under the contract cannot also be "under enactment" but are governed by the contact itself. ${ }^{2773}$ The result is that such decisions under contracts fall

\footnotetext{
${ }^{2767}$ Sections 5(1) and 3(1) of the Administrative Decisions (Judicial Review) Act 1977 (Cth) 2768 NEAT Domestic Trading v AWB Limited [2003] HCA 35

2769 See an excellent explanation and critique of these issues in Allars, M, Public Administration in Private Hands, (2005) 12(2) Australian Journal of Administrative Law 126. See also Arora, N, Not So Neat: Non-Statutory Corporations and the Reach of the Administrative Decisions (Judicial Review) Act 1977 (2004) 32(1) Federal Law Review 141

2770 Griffith University $v$ Tang [2005] HCA 7

2771 Aronson, M, Dyer, B, and Groves, M, Judicial Review of Administrative Action, 4ed, 2009, Lawbook Co., Sydney, P.82

2772 Griffith University $v$ Tang [2005] HCA 7 per Gummow, Callinan and Heydon JJ at para 82; See also JJ Richards \& Sons Ltd v Bowen Shire Council [2008] QCA 16 at para 22 cited in Aronson, M, Dyer, B, and Groves, M, Judicial Review of Administrative Action, 4ed, 2009, Lawbook Co., Sydney, P.82, n.496

2773 Aronson, M, Dyer, B, and Groves, M, Judicial Review of Administrative Action, 4ed, 2009, Lawbook Co., Sydney, P.82
} 
outside the purview of the ADJR Act because they are not decisions "under an enactment".

The High Court of Australia's jurisdiction under section 75(v) of the Australian Constitution

Section 75(v) of the Australian Constitution allows relief to be sought against a "Commonwealth officer." The High Court has steadfastly protected its constitutionally entrenched original jurisdiction from legislative exclusion such as the privative clause inserted into section 474 of the Migration Act. ${ }^{2774}$

The locus classicus is the definition by Isaacs $\mathrm{J}$ that:

"an 'officer' connotes an 'office' of some conceivable tenure, and connotes appointment, and usually a salary" and that a Commonwealth officer is "individually appointed by the Commonwealth."”2775

Aronson et al note the series of cases which have commonly ascribed to the view that bodies corporate are not Commonwealth officers for the purpose of section $75(\mathrm{v}),{ }^{2776}$ and submits that the Commonwealth Parliament "should not [...] be competent to remove its agencies from the reach of $\mathrm{s} 75(\mathrm{v})$ by the simple expedient of corporatising them". ${ }^{2777}$ Indeed, Groves takes this argument a step further in relation to government outsourcing. It might be recalled that private contractors, Wizard People Pty Limited, were used to make an initial assessment of whether Australia owed protection obligations to asylum seekers on Christmas Island in Plaintiff M61. ${ }^{2778}$ Interestingly, as noted by Groves, ${ }^{2779}$ the High Court sidestepped whether those private contractors fell within the scope of section 75(v) of the Australian Constitution as "officers of the Commonwealth". ${ }^{2780}$ Groves takes the view that, having assiduously guarded its jurisdiction in $S 157^{2781}$ and, if analogous reasoning from the recent decision in Kirk were applied, ${ }^{2782}$ the High Court may be unlikely to sanction

\footnotetext{
2774 Plaintiff S157/2002 v Commonwealth [2003] HCA 2

2775 R v Murray and Cormie; Ex parte Commonwealth [1916] HCA 58; (1916) 22 CLR 437 at $452-453$

2776 Aronson, M, Dyer, B, and Groves, M, Judicial Review of Administrative Action, 4ed, 2009, Lawbook Co., Sydney, P.38

2777 Aronson, M, Dyer, B, and Groves, M, Judicial Review of Administrative Action, 4ed, 2009, Lawbook Co., Sydney, P.39

2778 Plaintiff M61/2010E $v$ Commonwealth [2010] HCA 41

2779 Groves, M, Outsourcing and s75(v) of the Constitution, (2011) 22 Public Law Review 3. See also, Groves, M, Outsourcing and Non-Delegable Duties (2005) 16 Public Law Review 265

2780 Plaintiff M61/2010E $v$ Commonwealth [2010] HCA 41 at 51

2781 Plaintiff S157/2002 v Commonwealth [2003] HCA 2

2782 Kirk v Industrial Relations Commission (NSW) [2010] HCA in which the High Court held that the jurisdiction of State Supreme Courts should not be ousted in light of their constitutional function of protecting against jurisdictional error - that is that there "should be no islands of power immune from supervision and restraint" per French CJ, Gummow,
} 
the removal of decisions made by Commonwealth contractors from its purview. However, firstly, it is entirely unknown how and when the High Court will answer this question, and secondly, if the Court did wish to include such contracts within the definition of "Commonwealth officer", how will it re-shuffle its jurisprudence? Groves has suggested that the Court move towards the reasoning in the English case of Datafin ${ }^{2783}$ which looked more to the nature of the power than its source. ${ }^{2784}$

\section{The Jurisdiction of the Federal Court of Australia}

Under the Judiciary Act, the original jurisdiction of the Federal Court is available in any matter "arising under any laws made by the Parliament" 2785 and, like the section $75(\mathrm{v})$ of the Australian Constitution relating to relief sought from the High Court, also contemplates relief against "an officer of the Commonwealth". ${ }^{2786}$ However, an important distinction between the Federal Court and the High Court is that the Federal Court's jurisdiction is conferred by statute, not the by the Australian Constitution (which requires a referendum to alter) and, accordingly, its jurisdiction is always susceptible to legislative limitation. ${ }^{2787}$ Aronson et al best describe the Court's jurisdiction "arising under any laws made by Parliament" if "that law is the source of the relevant right or duty or (if this is different) that law created the relevant subject matter, or if federal law provides the authority for enforcing the right or duty, or if the matter's resolution turns on the federal law's interpretation", ${ }^{2788}$

Accordingly, it can be seen from the discussion of these three avenues for judicial review of decisions that the rights of those affected by contractual arrangements with the Commonwealth are severely affected by jurisdictional hurdles. Although the jurisdiction of the Federal Court and the ability to review decisions under the ADJR Act can always be changed at the stroke of the legislative pen, it is the High Court's original jurisdiction under the Constitution that is most immune from legislative interference. For detained asylum seekers whose rights and lives are affected by the decisions made by

Hayne, Crennan, Kiefel and Bell JJ at para 99, Groves, M, Outsourcing and $s 75(v)$ of the Constitution (2011) 22 Public Law Review 3, Pp.7-8

${ }^{2783}$ R v Panel on Takeovers and Mergers, Ex parte Datafin plc [1987] QB 815

2784 Groves, M, Outsourcing and s75(v) of the Constitution (2011) 22 Public Law Review 3, Pp.8-9; See also the options discussed in Administrative Review Council, Judicial Review in Australia - Consultation Paper, April 2011, http://www.ag.gov.au/agd/WWW/rwpattach. nsf/VAP/(339383A93E59A076831A75961C22D2A2) Consultation+Paper+_+Judicial

+ Review+in+Australia+-+20+April+11+-+Version+2.pdf/\$file/Consultation+Paper+-

+ Judicial+Review + in + Australia+-+20+April+11+-+Version+2.pdf (last accessed 11

December 2011), Pp.66-67

2785 Section 39B of the Judiciary Act 1903 (Cth)

2786 Section 39B(1) of the Judiciary Act 1903 (Cth)

2787 For example, under section 39B(2) of the Judiciary Act 1903 (Cth) or the restrictions placed on the Court's jurisdiction in Part 8 of the Migration Act 1958 (Cth)

2788 Aronson, M, Dyer, B, and Groves, M, Judicial Review of Administrative Action, 4ed, 2009, Lawbook Co., Sydney, P.43 
private detention centre service providers, it is absolutely essential that this lacuna in the law is closed to enable those decisions to be subject to judicial review. If time is of the essence, and a degree of certainty is sought, then legislative change must be made. Alternatively, the responsibility falls upon the High Court who will hopefully not tolerate the removal of such matters from its jurisdiction through the medium of outsourcing, particularly if outsourcing was adopted to achieve precisely that aim.

\subsubsection{DIAC's Policies}

DIAC's policies are identified below. As they do not constitute binding justiciable standards, their analysis sits outside the scope of this book. However, they may give some insight into what DIAC considers its legal obligations.

As indicated earlier, on 29 July 2008 the then Minister for Immigration, Senator Chris Evans, indicated seven values that form the basis of Australia's new risk-based approach to immigration detention policy, and which have subsequently been adopted by the Department of Immigration and Citizenship as the "Key Immigration Detention Values". ${ }^{2789}$ Value 6 provides that "[p]eople in detention will be treated fairly and reasonably within the law" and Value 7 provides that "[c]onditions of detention will ensure the inherent dignity of the human person".

The fitout of the detention facilities are said to be in accordance with the Standards for Design and Fitout of Immigration Detention Facilities developed by DIAC. ${ }^{2790}$

DIAC states that it provides the following services at immigration detention facilities: firstly, education and other facilities (including English language classes); secondly, food (which is "appealing and culturally appropriate"); thirdly, medical (providing an initial medical screening before entering detention, and access to medical services either onsite or in the local community); and fourthly, religious (with facilities for prayer and worship

\footnotetext{
2789 Australian Government, Department of Immigration and Citizenship, Managing Australia's Borders, Detention Services, About Immigration Detention, Key Immigration Detention Values, http://www.immi.gov.au/managing-australias-borders/detention/about/keyvalues.htm (last accessed 24 May 2011)

2790 Australian Government, Department of Immigration and Citizenship, Standards for Design and Fitout of Immigration Detention Facilities, http://www.immi.gov.au/managingaustralias-borders/detention/facilities/standards-for-design-fitout.htm (last accessed 13 December 2011). See also Parliament of the Commonwealth of Australia, Joint Standing Committee on Migration, Immigration Detention in Australia - Facilities, services and transparency, August 2009, Canberra, http://www.aph.gov.au/house/committee/mig/ detention/report3/fullreport.pdf (last accessed 13 December 2011), Pp.13-14
} 
services and access by external clergy). ${ }^{2791}$

In relation to the provision of health services, the Detention Health Advisory Group was established in March 2006 (following the Palmer Report) within the Department of Immigration and Citizenship, ${ }^{2792}$ and which subsequently assisted in the formulation of the Detention Health Framework. ${ }^{2793}$ According to the Department's website, an initial health assessment is made of all persons entering immigration detention, and a discharge assessment is made of persons discharged from immigration detention. ${ }^{2794}$ The standard of health care, according to the Department's website, is "at a standard generally comparable to the health care available to the Australian community". ${ }^{2795}$ A health services manager manages the provision of health services for those in all forms of immigration detention. ${ }^{2796}$ Provision is also made for an "at risk" assessment of mental health problems as part of the initial health assessment when a person goes into detention. ${ }^{2797}$

It will be recalled from Chapter 3 that moves were made by the Government towards community detention for children and vulnerable family groups in

2791 Australian Government, Department of Immigration and Citizenship, Services Provided at Immigration Detention Facilities, http://www.immi.gov.au/managing-australiasborders/detention/services/services-at-facilities.htm (last accessed 13 December 2011).

2792 Australian Government, Department of Immigration and Citizenship, Managing Australia's Borders, Detention Health Advisory Group (DeHAG), http://www.immi.gov.au/ managing-australias-borders/detention/services/dehag.htm (last accessed 13 December 2011).

2793 Australian Government, Department of Immigration and Citizenship, Managing Australia's Borders, Immigration Detention Health Services, http://www.immi.gov.au/ managing-australias-borders/detention/services/health-services.htm last accessed (13 December 2011); and DIAC, Detention Health Framework, http://www.immi.gov.au/ managing-australias-borders/detention/services/health-framework.htm (last accessed 13 December 2011)

2794 Australian Government, Department of Immigration and Citizenship, Managing Australia's Borders, Immigration Detention Health Services, http://www.immi.gov.au/ managing-australias-borders/detention/services/health-services.htm last accessed 13 December 2011).

2795 Australian Government, Department of Immigration and Citizenship, Managing Australia's Borders, Immigration Detention Health Services, http://www.immi.gov.au/ managing-australias-borders/detention/services/health-services.htm (last accessed 13 December 2011).

2796 Parliament of Australia, Joint Standing Committee on Migration, Immigration Detention in Australia - Facilities, services and transparency, August 2009, Canberra, http://www.aph.gov.au/house/committee/mig/detention/report3/fullreport.pdf (last accessed 13 December 2011), Pp.80-84.

2797 Parliament of Australia, Joint Standing Committee on Migration, Immigration Detention in Australia - Facilities, services and transparency, August 2009, Canberra, http://www.aph.gov.au/house/committee/mig/detention/report3/fullreport.pdf (last accessed 13 December 2011), Pp.84-85 
October 2010, ${ }^{2798}$ followed by an extension of the programme in March 2011. ${ }^{2799}$ As a matter of policy, DIAC states that "children will not be held in immigration detention centres". 2800 "Where possible" this is also said to include the child's family. ${ }^{2801}$ The identification of "immigration detention centre" is significant in that it does not rule out detention in other facilities (that is, another form of detention). Further, the stated policy is also dependent upon capacity to accommodate children and families outside an immigration detention centre. ${ }^{2802}$ According to DIAC, detained children are said to have "access to primary and secondary schooling, including English language classes", and NGOs are "contracted to provide care and services" to unaccompanied minors. ${ }^{2803}$

\subsection{Conclusions}

Legislative and regulatory standards and safeguards concerning the conditions of detention is an area in which the two jurisdictions show relative weakness in comparison to the more prescriptive provisions relating to the asylum procedure generally. The two jurisdictions share an ambiguity about the precise nature of the conditions of detention. In the European Union, the secondary legislation is more normative than detailed and still leaves a high degree of discretion to Member States. In the Australian sphere, there is almost an entire absence of legislative standards relating to the conditions of detention - the only exceptions being provisions relating to search powers and medical treatment. The law of tort may provide some redress in terms of a duty of care owed to those detained but it is submitted that this incremental and costly process, with the precise impact of outsourcing arrangements not yet judicially determined, not to mention the practical and forensic difficulties that detained persons have to overcome in bringing such actions, is hardly a substitute for

2798 Bowen, The Honourable Chris, Minister for Immigration and Citizenship, Government to move children and vulnerable families into community-based accommodation - Joint Media Release with the Prime Minister, 18 October 2010, http://www.minister.immi.gov.au/ media/cb/2010/cb155484.htm (last accessed 27 April 2012)

2799 Bowen, The Honourable Chris, Minister for Immigration and Citizenship, Moving asylum seeker children into the community - Statement by the Minister for Immigration and Citizenship, the Hon Chris Bowen, MP, 1 March 2011, http://www.minister.immi.gov.au/ media/cb/2011/cb159599.htm (last accessed 27 April 2012)

2800 Australian Government, Department of Immigration and Citizenship, Families with Children, http://www.immi.gov.au/managing-australias-borders/detention/services/ families-with-children.htm (last accessed 13 December 2011)

2801 Australian Government, Department of Immigration and Citizenship, Accompanied and Unaccompanied Minors, http://www.immi.gov.au/managing-australias-borders/detention/ services/minors.htm (last accessed 13 December 2011)

2802 Stern, M, The Educational Rights of Asylum Seeking Children - Observing Failure (2010) 5(7) Journal of Law and Social Justice 1, P.9

2803 Australian Government, Department of Immigration and Citizenship, Accompanied and Unaccompanied Minors, http://www.immi.gov.au/managing-australias-borders/detention/ services/minors.htm (last accessed 13 December 2011) 
clear, justiciable legislation, regulations and/or standards regarding the conditions of detention.

In some respects the lack of detailed provisions in the European Union is saved by the framework of protection provided by the ECHR and its associated jurisprudence, particularly as regards cruel, inhuman and degrading treatment, which can affect the legality of the detention itself. Particularly important is the requirement that the place and conditions of detention must be suitable - an aspect which is most visible in relation to minors. Where the Union secondary legislation is lacking is ensuring that the material reception conditions that normally apply also apply to those detained - the current secondary legislation is poorly considered and drafted in this aspect. Indeed, even if those material reception conditions were to apply to detained asylum seekers, in areas such as health and education for minors, the obligations of Member States are so meagre as to question how effective they can be in practice. The forthcoming Proposals do represent a modest improvement but interpretative difficulties remain. If uniform treatment across the Union is to be achieved, then this may be greatly assisted by prescriptive and identical rules and standards implemented at the Union level.

The harshness of conditions of detention do not act as any ground to challenge the validity of detention in Australia. The sheer lack of detailed legislative provisions as to the conditions of treatment is staggering and heightens the risk of cruel, inhuman or degrading treatment. The former inclusion of the IDS into detention centre contracts was acknowledged as an insufficient safeguard against that risk, particularly if the method for assessing the implementation of the IDS is inadequate. Further, the lack of standing on the part of asylum seekers to enforce the IDS due to the doctrine of privity of contract undermined the utility of the IDS as a measure for ensuring and enforcing minimum standards of care. However, their recent lack of express inclusion from such contracts is also a cause for concern due to any impact it may have in the assessment of a breach of duty of care by the Commonwealth or its service providers.

Both jurisdictions acknowledge the need for conditions of detention to be suitable to the needs of detained persons. The ECHR and its jurisprudence, particularly as regards children and, by analogy, to other vulnerable persons, has acknowledged that position accompanied by a modest award of damages. As a matter of European Union law, damages may also be payable where an asylum seeker has suffered loss as a result of inadequate implementation of a Directive. In Australia, it is borne out in the law of tort via the common law (subject to any statutory encroachment), which considers the Commonwealth's duty of care in light of vulnerability and dependence on the detained person's part, and the complete control over the detained person by the detainer. 
In relation to legal liability for conditions of detention, the State in both jurisdictions retains ultimate responsibility. In the European sphere, this is accorded (as mentioned above) by the operation of the ECHR and also as a matter of Union law as regards implementation. In Australia, the Commonwealth's duty of care is non-delegable. What is of concern is that legislation can either authorise certain acts that remove them from the realm of tort (with any such legislation taking no account of international standards for treatment) or which may limit the amount of damages payable (which may not act as a sufficient deterrent to the inhumane treatment of detained persons).

The two jurisdictions present interesting differences is in the area of outsourcing of detention services. In the European Union, the principles that apply to determine the emanation of the State may arguably result in Directives being directly effective against the detention service provider. In Australia, as a matter of administrative law for the judicial review of decisions that a private detention services provider might make, no such construction is (as yet) applicable which arguably results in a protection gap. The chief difference between the two jurisdictions in this regard is that, in the European Union, it would appear that a contract or licence (together with the other elements which determine an emanation of the State) is a sufficient measure to extend the emanation of a State to a private entity. In Australia, corporatisation of government agencies or contractual arrangements are insufficient by themselves to overcome the jurisdictional hurdles to relief that require a much more direct connection (by legislation or by the direct appointment of an individual by the Commonwealth) to the rights and obligations of individuals (in this case, asylum seekers). In the European Union, Craig and de Búrca's characterisation of the liability for private enterprises to be directly affected by Directives as an "unusual inverse principle of State or vicarious responsibility" ${ }^{2804}$ represents the polar opposite to the Australian position where such corporatisation or contractual arrangements limits the availability of individuals to seek judicial review of decisions made by such corporations or under such contractual arrangements (notwithstanding that the ultimate liability for any damage resulting from those decisions still rests with the Commonwealth).

The Union secondary legislation makes a distinction in treatment for border applicants by derogating from a number of guarantees available for those applicants who have been admitted into the territory. This is particularly noticeable in the current secondary legislation, but differences in treatment are still evident in the proposed legislation. Of particular concern are unaccompanied minors who cannot be placed in "accommodation" until after they have been admitted to the territory (an element which has been carried over from the current legislation into the Proposals), and whose retention at

2804 Craig, P, and de Búrca, G, EU Law, 5ed, 2011, OUP, Oxford, P.198 
border posts may effectively amount to detention. Australia does not make distinctions in law regarding the material conditions of detention depending on whether an asylum seeker has arrived unlawfully and been detained or has arrived lawfully, subsequently become unlawful, and then detained. ${ }^{2805}$

The use of prisons as places of detention is contemplated in the Proposed secondary legislation where the right to remain exists, as well as in the current Returns Directive when the right to remain is lost. Member States would be advised to be extremely cautious about the use of prisons to detain of asylum seekers given the jurisprudence of the ECtHR on both Articles 3 and 5(1), and particularly the stern warning given by the Court in MSS $v$ Belgium and Greece concerning the non-derogable nature of Article 3. The use of prisons as places of detention is possible in Australia given the wide definition of "immigration detention" under the Act which expressly contemplates prisons, as well as the Minister's ability to approve additional places as a place of "immigration detention" or to make a residence determination.

In relation to the education of children in detention, it is submitted that the attendance of children in schools within the community and outside the detention environment is clearly in the best interests of the child. To avoid any uncertainty, legislative provision should be made at the Union and Federal levels respectively.

\footnotetext{
${ }^{2805}$ However, see Chapter 6 regarding, inter alia, the differences in access to legal advice and information regarding their rights to apply for Bridging Visas for those who are not immigration cleared or arrive at an excised offshore place.
} 


\section{Chapter 8 The Principle of Proportionality \& Alternatives to Detention}

\subsection{Introduction}

This chapter explores the principle of proportionality and alternatives to detention. The two concepts are interlinked - as part of a proportionality analysis, alternatives to detention must be considered before detention is ordered. Alternatively, detention may be considered a disproportionate measure in the context of the circumstances of the individual and the legitimate aim sought to be achieved. An important part of proportionality analysis is that the least restrictive means be adopted to achieve the legitimate aim sought. It is submitted that, in a detention context, the principle of proportionality applies to both alternatives to detention and, if detention is ultimately ordered, extends to adopting the least restrictive means within the detention environment.

Before undertaking the legal analysis, the origin, elements and contexts of the principle of proportionality will be explored. It will be shown that the principle, although an extremely useful tool for forensic analysis and decisionmaking, has shortcomings that must be borne in mind, particularly in a detention context (and which will be highlighted, where appropriate, in the subsequent legal analysis). One of those shortcomings is the weighting to be applied to competing rights and interests. Alternatives to detention, their need and effectiveness, will also be examined in light of recent expert reports. The analysis strives to make the distinction throughout the chapter between alternatives to detention and alternative forms of detention and how that distinction is characterised (or not, as the case may be) in the laws of each jurisdiction.

The preliminary legal analysis analyses the application of the principle of proportionality at the international level - most notably the ICCPR and CROC, as well as the United Nations Standard Minimum Rules for NonCustodial Measures. The analysis then shifts to the Council of Europe sphere where it is submitted that, although there are disparate elements of the principle of proportionality being applied by the ECtHR, the principle is failing to reach its potential as a jurisprudential tool. Recent case law from the ECtHR is, however, pointing to a new and promising direction for the principle as regards the detention of certain categories of asylum seeker.

The chapter then turns to the substantive legal analysis: an examination of the principle of proportionality and alternatives to detention in both the European Union and Australia. In the European Union, both the legislative and 
implementation (or judicial review) stages of the principle are examined. In exploring the implementation/judicial review stage, two aspects are considered: (1) the application of the principle in the context of reviewing Union measures (which contains a comparison between the detention of Union citizens and asylum seekers and proposes that differences in treatment of the two groups of migrants result from the different respective weighting of the right to liberty); and (2) the review of Member State measures implementing Union law (which appraises the current and proposed secondary legislation). Finally, alternatives to detention in the current and proposed legislation are examined and it is submitted that more detailed provisions should be made for alternatives to detention.

In the Australian context, it will be submitted that the principle of proportionality (as understood in international and Union contexts) has failed to flourish in the Australian legal landscape, which has significant consequences for detained asylum seekers. As regards alternatives to detention, it is submitted that Australian law neither reflects the continuum of alternatives to detention that the principle of proportionality demands nor the alternatives that may exist in practice. The Australian practice of 'community detention' and issuing 'Bridging Visas' will be examined. It is submitted that Bridging Visas contain such highly prescriptive and complex criteria for eligibility such that their accessibility by detained asylum seekers is greatly diminished. In the case of those detained pending removal, their detention is effectively entirely at the discretion of the Minister. Additionally, conditions imposed on Bridging Visas will also be explored (such as, 'no-work', security bonds and reporting and residence conditions). Finally, the two support programs for asylum seekers on Bridging Visas will be investigated, with a particular focus on the grounds for eligibility. It is submitted that detained asylum seekers face multiple juridical hurdles for eligibility for Bridging Visas and assistance once in the community.

\subsubsection{The Principle - Origins and Elements}

The principle of proportionality has its genesis in German public law, and is an unwritten principle of German constitutional law ${ }^{2806}$ that rose to prominence following the establishment of the German Basic Law of 1949, which contains a catalogue of rights in its first twenty articles. ${ }^{2807}$ The three elements of the test in the German context evidence an incremental evolution, from suitability, later adding necessity and, after World War II, proportionality stricto sensu (or proportionality "in the narrow sense"). ${ }^{2808}$

2806 Emiliou, N, The Principle of Proportionality in European Law - A Comparative Study, 1996, Kluwer, London, Pp.41-42

2807 Stone Sweet, A, and Mathews, J, Proportionality Balancing and Global Constitutionalism, (2008) 47 Columbia Journal of Transnational Law 73, Pp.98-112, particularly at Pp.104112 regarding the principle's ascension under the Basic Law

2808 Emiliou, N, The Principle of Proportionality in European Law - A Comparative Study, 1996, Kluwer, London, Pp.23-24 
Accordingly, the elements of the principle of proportionality as understood in the German context (and which will be examined herein) are firstly, that the measure must be suitable - that is, that the measure must be suitable to the pursuit of the objective; secondly, that the measure must also be necessary that is, that there are no less restrictive means for achieving the objective, and thirdly, that the measure must be proportionate (or not disproportionate) stricto sensu. $^{2809}$

After finding that a measure is both suitable and necessary, the last step, proportionality stricto sensu, essentially involves a weighing of the individual's right that will be curtailed against the objective to be achieved to ensure that the correct balance is struck. Accordingly, there is a direct correlation between disadvantages suffered by the individual and the importance of the objective to be achieved.

Although their application will be considered in more detail subsequently, those three elements of the principle of proportionality are also evidenced in the European Union context as a general principle of Union law. ${ }^{2810}$ They arise in three ways: firstly, at the legislative stage (in accordance with Article 5(4) TEU); secondly, at the implementation or judicial review stage (that is, involving European Union measures); and thirdly, in the review of Member State measures implementing Union law.

However, there are two important points to note at the outset. Firstly, in relation to Union measures, the CJEU does not always apply the third stage of the test, proportionality stricto sensu, but Craig notes that this does not mean that the CJEU disregards the third element - rather, the learned author persuasively argues that the CJEU considers it an integral part of the principle by reference to the fact that the Court considers that element when raised in argument by one of the parties. ${ }^{2811}$ Craig notes the importance of the third element - if an assessment of proportionality stricto sensu is absent, then it could result in a situation where the measure is legal "even if the burden thereby imposed on the individual might be felt to be disproportionate to the desired objective."2812

Secondly, in matters involving references from a Member State for a preliminary ruling under Article 267 TFEU, the CJEU may give Member States guidance about the principle of proportionality but essentially leave the Member State to carry out the proportionality analysis itself. It will be recalled

\footnotetext{
2809 Schwarze, J, European Administrative Law, Rev 1ed, 2006, Sweet and Maxwell, London, P.687

2810 Schwarze, J, European Administrative Law, Rev 1ed, 2006, Sweet and Maxwell, London, Pp.854-864

${ }^{2811}$ Craig, P, EU Administrative Law, 2006, OUP, Oxford, P.657, and Pp.670-671

2812 Craig, P, EU Administrative Law, 2006, OUP, Oxford, P.657, and P.657
} 
from Chapter 6 that the CJEU is a court of reference, not appeal. Accordingly, both Tridimas and Craig note that the CJEU can leave the application of the principle for the national court to decide (depending on the case at hand), but will give much more detailed guidance where national courts have struggled to assess the principle ${ }^{2813}$ - which is an acknowledgement of the enormous complexity of the task that the principle can present. ${ }^{2814}$ Tridimas notes that in cases involving questions of national security (but relating to restrictions on trade) a wide berth has been given to national courts. ${ }^{2815}$ This is an important factor to bear in mind in a detention context as Member States may be guided by the CJEU but may ultimately have to make their own assessment of proportionality. However, this does not mean that Member States are given an entirely free hand - as Tridimas notes, the CJEU's jurisprudence will be very much weighing in the mind of a national court. ${ }^{2816}$ Accordingly, although the assessment of the principle of proportionality might span both national courts and the CJEU, the elements of the principle remain constant.

\subsubsection{Alexy's Principle Theory}

The principle of proportionality is more than just a balancing exercise in which two conflicting rights are weighed against one another and one prevails. To this extent, Alexy's contribution to the understanding of constitutional rights is enlightening. Although Alexy's theory is based on a study of the German Federal Constitutional Court decisions, ${ }^{2817}$ the theory may be described as having universal applicability given the prevalence of human rights as expressed in modern constitutions. Further, the prominence of the principle of proportionality in the theory reveals some characteristics that may illuminate some of its limitations.

Given the abstract nature in which fundamental rights are expressed, ${ }^{2818}$ Alexy argues that all norms are to be categorised as either rules or principles. ${ }^{2819}$ Principles are not like rules because they are not capable of being fulfilled in a binary way - they "require that something be realized to the greatest extent possible given the legal and factual possibilities" 2820 and which Alexy describes as "optimization requirements" capable of satisfaction to varying degrees given

\footnotetext{
2813 Tridimas, T, The General Principles of EU Law, 2ed, 2006, OUP, Oxford, Pp.238-241; Craig, P, EU Administrative Law, 2006, OUP, Oxford, Pp.711-715; see also in relation to the CJEU's assessment of proportionality stricto sensu Jans, J H, Proportionality Revisited (2000) 27(3) Legal Issues of Economic Integration 239, Pp.248-249

${ }^{2814}$ Craig, P, EU Administrative Law, 2006, OUP, Oxford, Pp.712-713, Tridimas, T, The General Principles of EU Law, 2ed, 2006, OUP, Oxford, P.241

2815 Tridimas, T, The General Principles of EU Law, 2ed, 2006, OUP, Oxford, P.239

2816 Tridimas, T, The General Principles of EU Law, 2ed, 2006, OUP, Oxford, P.241

2817 Alexy, R, A Theory of Constitutional Rights, 2002, OUP, Oxford, Pp.13-14

2818 Alexy, R, A Theory of Constitutional Rights, 2002, OUP, Oxford, P.45; Pp.60-61

2819 Alexy, R, A Theory of Constitutional Rights, 2002, OUP, Oxford, P.47

2820 Alexy, R, A Theory of Constitutional Rights, 2002, OUP, Oxford, P.47
} 
the legal and factual possibilities (a kind of forensic variable geometry) ${ }^{2821}$ This quality is most characteristic of fundamental and human rights in a constitutional context - that is, principles have no precedence as regards one another and which concern as yet unquantifiable acts or behaviour. ${ }^{2822}$ A rule, on the other hand, is capable merely of fulfilment or not. ${ }^{2823}$ A competition between rules results in either one rule invalidating the other or an exception being built into one of the rules. ${ }^{2824}$

According to Alexy, competing principles are resolved by reference to the Law of Competing Principles. ${ }^{2825}$ The principle of proportionality (that is, inclusive of suitability, necessity and proportionality stricto sensu) is deduced from principles themselves (that is, constitutional fundamental rights). ${ }^{2826}$ Given that principles as "optimization requirements" are shaped by law and fact, proportionality stricto sensu is said to deal with what is legally possible, with the suitability and necessity elements directed towards what is factually possible. ${ }^{2827}$ In that sense, the principle of proportionality provides the necessary framework for adjudication. ${ }^{2828}$ Proportionality, stricto sensu, is then governed by the Law of Balancing - that is " $[t]$ he greater the degree of nonsatisfaction of, or detriment to, one principle, the greater must be the importance of satisfying the other."2829

Accordingly, the principle of proportionality has a central and prominent place in Alexy's Principle Theory - it is the engine room of the theory.

However, what the principle of proportionality does not contain is a way to ascribe weight to the various rights or interests in question. ${ }^{2830}$ Indeed, this is the most vulnerable part of the principle. By taking into consideration any number of interests in determining to what extent a particular right is to be qualified (and, correspondingly, another right is to be maximised), it leaves itself open to variability. This will be discussed further, below.

\footnotetext{
2821 Alexy, R, A Theory of Constitutional Rights, 2002, OUP, Oxford, Pp.47-48

2822 Alexy, R, A Theory of Constitutional Rights, 2002, OUP, Oxford, P.54

2823 Alexy, R, A Theory of Constitutional Rights, 2002, OUP, Oxford, P.48

2824 Alexy, R, A Theory of Constitutional Rights, 2002, OUP, Oxford, Pp.49-50

2825 Alexy, R, A Theory of Constitutional Rights, 2002, OUP, Oxford, P.50-51

2826 Alexy, R, A Theory of Constitutional Rights, 2002, OUP, Oxford, P.66

2827 Alexy, R, A Theory of Constitutional Rights, 2002, OUP, Oxford, P.67

2828 Alexy, R, A Theory of Constitutional Rights, 2002, OUP, Oxford, Pp.66-69

2829 Alexy, R, A Theory of Constitutional Rights, 2002, OUP, Oxford, P.102; Alexy, R, On the Structure of Legal Principles, (2000) 13(3) Ratio Juris 294, P.298; see also Stone Sweet, A, and Mathews, J, Proportionality Balancing and Global Constitutionalism, (2008) 47 Columbia Journal of Transnational Law 73, Pp.95-96 for further discussion on this point. For a critical discussion of Alexy's Principle Theory, see Šušnjar, D, Proportionality, Fundamental Rights and Balance of Powers, 2010, Martinus Nijhoff, Leiden, Pp.69-80

${ }^{2830}$ Habermas, J, Between Facts and Norms, 1996, MIT, Cambridge MA, P.259, particularly fn. 38
} 


\subsubsection{Why Proportionality and Detention?}

As discussed in Chapter 4, detention may be seen as a continuum ranging from liberty, to restrictions upon liberty to deprivation upon liberty. The principle of proportionality generally respects that continuum by adopting a jurisprudential framework that may adopt any number of restrictions of liberty along that continuum so long as they are consistent with the individual's circumstances and the legitimate objectives that the restrictions are said to pursue. Of course, those restrictions upon liberty also simultaneously constitute alternatives to detention. In its most optimal application, the principle of proportionality precedes the decision to detain by the consideration of alternatives to detention and also extends beyond the decision to detain to ensure that alternative forms of detention are the least restrictive possible.

The great hope that is contained by applying the principle in a detention context is firstly, that any restriction on, or deprivation of, liberty will be the least intrusive possible and secondly, that a decision to detain may be challenged where the detention is not suitable or necessary or where, if suitable and necessary, the detention measure is disproportionate to the objective sought to be achieved (that is, its impact on the individual outweighs the stated benefit to society).

\subsubsection{Contexts in which the Principle of Proportionality may operate}

The principle of proportionality itself is multifaceted and has multiple and, at times, overlapping spheres of application. It may be relevant in an international legal context in the compliance with international human rights treaties as has already been discussed in relation to the HRC jurisprudence surrounding Article 9(1) ICCPR. ${ }^{2831}$ It may also be relevant in determining, at the national level, the constitutional validity of certain executive or legislative measures where such constitutions contain a catalogue of rights that may be in competition in a particular case (or, indeed, in monist states where international treaties automatically form part of the domestic law). It may also be relevant in an administrative law context where, for example, although a detention decision may be suitable, it may be challenged on the basis that no other less restrictive means were considered. ${ }^{2832}$ The principle of proportionality may also be relevant in a criminal context where the sentence for punishment is to be proportionate to the crime committed. ${ }^{2833}$ However,

2831 A v Australia, Communication No. 560/1993 at para 9.2 (discussed below)

${ }^{2832}$ In this aspect, Alexy's Principle Theory is inclusive of all spheres of government because each sphere is obliged to optimise rights to the greatest extent possible - Stone Sweet, A, and Mathews, J, Proportionality Balancing and Global Constitutionalism, (2008) 47 Columbia Journal of Transnational Law 73, P.95

2833 See Prosecutor $v$ Stevan Todorovic (Sentencing Judgment), IT-95-9/1-S, International Criminal Tribunal for the former Yugoslavia (ICTY), 31 July 2001 where the Court noted at paras 28-29, [28]"At the outset, the Chamber observes that, while the Appeals Chamber of the International Tribunal has held that retribution and deterrence are the main 
proportionality in the criminal sphere may not be directly comparable to its application in the civil sphere because the quantum of blame ascribed to the offender can influence the degree of punishment meted out ${ }^{2834}$ - a consideration not necessarily comparable in the civil sphere.

According to Stone Sweet and Matthews, the rise to prominence of the principle of proportionality tracks the rise of modern constitutionalism - that is, where sovereignty is vested in the people and with constitutions containing a catalogue of abstractly-formulated rights with such rights invariably competing with one other, and whose adjudication is administered by "trustee courts" (that is, courts whose power to adjudicate is entrusted by the constitution itself) with resulting judicial supremacy. ${ }^{2835}$ The inevitable outcome of applying the principle of proportionality is judicial legislation (or which Stone Sweet and Matthews describe the court acting as a "positive lawmaker" with "discretionary lawmaking authority"), ${ }^{2836}$ and which has consequences for the traditional view of the separation of powers. Accordingly, the principle of proportionality may have a much more limited place in states which adhere to parliamentary supremacy or whose constitutions do not contain a bill of rights (such as Australia). The rise to prominence of the principle is also attributable to international treaties (such as in the EU, ECHR and $\mathrm{WTO}^{2837}$ ) in which the forensic phenomenon of competing abstract norms also arises.

The principle of proportionality becomes unstuck, however, when, in a domestic constitutional context, either there is a limited range of rights or the rights are only exercisable by citizens, not aliens. Further, in an international legal context, the principle of proportionality is underpinned by equality and universality of human rights - if these are not implemented or respected in a

principles in sentencing for international crimes, in the Chamber's opinion these purposive considerations merely form the backdrop against which an individual accused's sentence must be determined. [29] The principle of retribution, if it is to be applied at all in the context of sentencing, must be understood as reflecting a fair and balanced approach to the exaction of punishment for wrongdoing. This means that the penalty imposed must be proportionate to the wrongdoing; in other words, that the punishment be made to fit the crime. The Chamber is of the view that this principle is reflected in the account, which the Chamber is obliged by the Statute and the Rules to take, of the gravity of the crime".

2834 Jackson, V, Being Proportional About Proportionality, (2004) 21 Constitutional Commentary 803, Pp.835-836.

2835 Stone Sweet, A, and Mathews, J, Proportionality Balancing and Global Constitutionalism, (2008) 47 Columbia Journal of Transnational Law 73, Pp.85-87

2836 Stone Sweet, A, and Mathews, J, Proportionality Balancing and Global Constitutionalism, (2008) 47 Columbia Journal of Transnational Law 73, P.93

2837 Van den Bossche, P, The Law and Policy of the World Trade Organization, 2ed, 2008, CUP, Cambridge, P. 57; Stone Sweet, A, and Mathews, J, Proportionality Balancing and Global Constitutionalism, (2008) 47 Columbia Journal of Transnational Law 73, Pp.153-160; In relation to remedies associated with WTO disputes and the use of the principle of proportionality see Mitchell, D, Proportionality and Remedies in WTO Disputes, (2007) 17(5) EJIL 985 
national context (or again, are reserved only for citizens), then the principle of proportionality will find very limited utility. In other words, the principle of proportionality will only be effective to the extent that human rights are sufficiently and universally imbedded in a legal system. In this sense, the principle of subsidiarity is an essential complement for the principle of proportionality to function effectively.

\subsubsection{The Principle of Subsidiarity}

The principle of subsidiarity refers to states retaining the choice of method for achieving the international legal obligation to which they have subscribed. In an international legal context in dualist states, that may include the implementation of international human rights treaties into domestic law. In the ECHR context the "margin of appreciation" is an interpretational tool by which to assess whether a State's measure is such that it may be left to its own discretion or subject to ECHR obligations. ${ }^{2838}$ There is a correlation between proportionality analysis and margin of appreciation analysis, with AraiTakahashi noting that a narrow margin of appreciation generally corresponds to an intense proportionality analysis, and a wide margin of appreciation corresponds to a lax proportionality analysis. ${ }^{2839}$ Whether the margin of appreciation is indeed applicable at all to Article 5 ECHR is questionable Schokkenbroek believes that it has no such application to "most elements of Articles 5 and 6" on account of the rights being protected are "not an area where policy choices come into play but rather the traditional domain of the courts" 2840 - in which case, it would be open to the ECtHR to proceed directly to a proportionality analysis (even if it has chosen not to do so in relation to Article 5(1)(f)). In the Union sphere, the principle of subsidiarity is a reasonably well-enunciated principle that is the bright line for which matters are best dealt with by Union intervention and which matters remain within the competence of the Member States. ${ }^{2841}$ If a matter of Union law, then

2838 Mahoney, P, The Doctrine of the Margin of Appreciation under the European Convention on Human Rights: Its Legitimacy in Theory and Application in Practice (1998) 19(1) HRLJ 1; Ovey, C, and White, R, The European Convention on Human Rights, 4ed, 2006, OUP, Oxford, Pp.52-54; Arai-Takahashi, Y, The Margin of Appreciation Doctrine and the Principle of Proportionality in the Jurisprudence of the ECHR, 2002, Intersentia, Oxford, Pp.1-4

2839 Arai-Takahashi, Y, The Margin of Appreciation Doctrine and the Principle of Proportionality in the Jurisprudence of the ECHR, 2002, Intersentia, Oxford, Pp.2 and 14; In relation to factors influencing the scope of the margin of appreciation, see Schokkenbroek, J, The Basis, Nature and Application of the Margin-of-Appreciation Doctrine in the Case-Law of the European Court of Human Rights, (1998) 19(1) HRLJ 30, Pp.34-35; see also see Šušnjar, D, Proportionality, Fundamental Rights and Balance of Powers, 2010, Martinus Nijhoff, Leiden, Pp.88-89, who describes the relationship as "complementary concepts". Although the concepts certainly are complementary, it is arguable that the scope of the margin of appreciation would first need to be determined (if a margin is applicable to the right in question) before a proportionality analysis could be conducted

2840 Schokkenbroek, J, The Basis, Nature and Application of the Margin-of-Appreciation Doctrine in the Case-Law of the European Court of Human Rights, (1998) 19(1) HRLJ 30, P.34

2841 Article 5(3) TEU and Protocol No. 2 on the Application of the Principles of Subsidiarity and Proportionality; Craig, P, and de Búrca G, EU Law, 5ed, 2011, OUP 
measures taken by the Member State in its implementation of Union law must respect (as a General Principle of EU law) the principle of proportionality. ${ }^{2842}$

\title{
8.1.6 The Principle of Proportionality - Application and Qualifications
}

Although the principle of proportionality does not give rise to any substantive right, per se, it may be a useful tool for judicial decision-making that can lead to greater jurisprudential transparency and metamorphose into an obligation on decision makers and legislators to consider the least restrictive means of curtailing the right in question. In Beatty's view:

\begin{abstract}
"The principle of proportionality structures how to make informed and impartial acts of judgment. It is a formal (some say empty) framework of analysis that orients judges on how to organize and evaluate conflicting factual claims that are made about the laws they are asked to review." 2843
\end{abstract}

Contrary to Beatty's view, it may not be the ultimate rule of constitutional determination $^{2844}$ but rather it may sit amongst the other jurisprudential methods for constitutional determination and interpretation, including the specificities of the constitutional text itself. ${ }^{2845}$ In a detention context the application of the principle can mean the difference between incarceration and either full or conditional liberty. Both Wilsher and Cornelisse have advocated its use in an immigration detention context. Wilsher identifies proportionality as "a tool for scrutinizing the practices of states free from baggage of doctrine and assertions of right" and indeed, emphasises the practical utility of the test in a field such as migration. ${ }^{2846}$ Cornelisse describes the test for proportionality as "only one aspect of the prohibition of arbitrariness, but it is a practical and useful criterion for the assessment whether [sic] the actual deprivation of liberty is compatible with the status of the right to liberty as a fundamental right." 2847

However, as Jackson has identified, the principle of proportionality is not entirely free from "baggage". Firstly, in a constitutional context, the principle

Oxford, Pp.94-100, 168-170; de Búrca, G, The Principle of Subsidiarity and the Court of Justice as an Institutional Actor (1998) 36(2) JCMS 217; see more specifically in a migration law context, Wiesbrock, A, Legal Migration to the European Union - Ten Years After Tampere, 2009, Wolf Legal Publishers, Nijmegen, Pp.159-162

2842 Case C-77/81 Zuckerfabrik Franken GmbH v Federal Republic of Germany, Judgment, 18 February 1982, paras 21-22; Cases C-286/94, C-340/95, C-401/95, C-47/96 Garage Molenheide BVBA, Peter Schepens, Bureau Rik Decan-Business Research \& Development NV (BRD) v Belgische Staat, Judgment, 18 December 1997, para 46; see also Article 52(1) of the EU Charter

2843 Beatty, D. M., The Ultimate Rule of Law, 2004, OUP, Oxford, P.98

2844 Beatty, D. M., The Ultimate Rule of Law, 2004, OUP, Oxford, Ch.5

2845 Jackson, V, Being Proportional About Proportionality (2004) 21 Constitutional Commentary 802, Pp.857-858

2846 Wilsher, D, The Liberty of Foreigners - A History, Law and Politics of Immigration Detention, 2008, Wolf Legal Publishers, Nijmegen, P.262

2847 Cornelisse, G, Immigration Detention and Human Rights - Rethinking Territorial Sovereignty, 2010, Martinus Nijhoff Leiden, P.253 
of proportionality is not a jurisprudential tool isolated from the "specific constitutional text" in question, with all the force of "national self expression" that constitutions generally hold. ${ }^{2848}$ Secondly, the weight ascribed to particular rights in the balancing process may be influenced by "the degree and tradition of legal protection accorded to the different individual rights in play and about the institutional roles of nonjudicial decision makers". ${ }^{2849}$ Thirdly, the outcome provided by the principle of proportionality may be influenced by rights that are not directly comparable (Jackson takes issue with Beatty's analysis of the Supreme Court of Israel case Horev $v$ Minister for Transport concerning the right to drive as compared to the observance of quiet on the Sabbath). ${ }^{2850}$

There are, then, some emerging vagaries about a wholehearted adoption of the principle. Firstly, a proportionality analysis places great emphasis on the factual scenario of the competing parties as well as the legitimate aim sought to be achieved - indeed, for the principle to work effectively and for human rights to be minimally impinged, complete honesty and disclosure is required in the identification and justification of the legitimate aim for detention. Accordingly, the principle of proportionality may be open to abuse - it can easily foster a "culture of justification" 2851 for the legitimate objective sought, particularly if there is a fight for institutional supremacy. As we have seen, particularly in Chapter 3, populist views may invariably encourage inflated justifications for the 'legitimate' aims for the detention of asylum seekers. This may distort the weight normally ascribed to particular rights in issue - most notably liberty or the interests of the state at hand - in any proportionality analysis. Secondly, proportionality analysis says nothing of the weight to be ascribed to the particular rights in the absence of the circumstances of the case at hand ${ }^{2852}$ - factors which (as Jackson has identified) may be influenced by constitutional and legal traditions, and the importance historically ascribed to particular rights, and to particular persons (such as aliens). Although the legislature sets the legitimate objective to be pursued, and although that might give democratic legitimacy to the objective and its implementing measure, it does mean that non-citizens will be unable, by virtue of their status as noncitizens, to influence the legislature or be in such minority that their views

\footnotetext{
2848 Jackson, V, Being Proportional About Proportionality (2004) 21 Constitutional Commentary 802, Pp.809-810, 813-819

2849 Jackson, V, Being Proportional About Proportionality (2004) 21 Constitutional Commentary 802, P.821

2850 Jackson, V, Being Proportional About Proportionality (2004) 21 Constitutional Commentary 802, Pp.820-821

2851 Aronson, M, Dyer, B, and Groves, M, Judicial Review of Administrative Action, 4ed, 2009, Thomson Reuters, Pyrmont, P. 380

2852 See, in relation to a thorough response to both Alexy and Beatty's articulation of the principle of proportionality and the problems regarding the ascription of weight to the rights and interests to be balanced: Webber, G C N, Proportionality, Balancing, and the Cult of Constitutional Rights Scholarship (2010) 23(1) Canadian Journal of Law and Jurisprudence 179, particularly at Pp.191-194
} 
may be disregarded. Further, as Harbo has identified, do Courts ascribe more weight to the collective interest merely because the measure emanates from the legislature? ${ }^{2853}$ Thirdly, one of the essential ingredients of proportionality analysis is judicial discretion. If any attempt was made to codify the elements of proportionality analysis (as opposed to merely compelling its application), this may have the effect of fettering judicial discretion to such an extent that the weighting of rights and interests to be balanced is settled permanently in favour of the detaining authority. In the Union secondary legislation we have seen some attempts at codifying the principle of proportionality - for example, the triple juridical hurdle in the Proposed CEAS legislation in relation to detention (that it be "necessary", "on the basis of an individual assessment", and "other less coercive measures cannot be applied effectively" [emphasis added]), as well as in Articles 27 and 28 of the CRD.

\subsubsection{Proportionality and Alternatives to Detention}

As the principle of proportionality dictates that the least restrictive means is to be adopted to any curtailment of the right to liberty, and that it is to be proportionate to the legitimate aim to be achieved, it is appropriate now to consider alternatives to detention.

As regards alternatives to detention themselves, Field and Edwards' comprehensive international study of alternatives to detention (subsequently updated by Edwards in 2011) noted that the main reason cited by States for the detention of asylum seekers is to prevent their absconding. ${ }^{2854}$ The learned authors note that "likelihood of absconding" or "lack of cooperation" were accepted as justification, in individual cases by the HRC in Av Australia. ${ }^{285}$ The learned authors further noted that there is a lack of statistical information regarding the absconding of non-detained asylum-seekers ${ }^{2856}$ (a fact also noted in Wilsher's research ${ }^{2857}$ ) and the degree of restriction placed on an asylum seeker may vary depending on whether the asylum seeker is in their destination state (where less restrictive measures may be imposed) or whether they are in a transit state (where greater restrictions may be imposed). For

2853 Harbo, T-I, The Function of the Proportionality Principle in EU Law (2010) 16(2) ELJ 158, P.170

2854 Field, O, with Edwards, A, Alternatives to Detention of Asylum Seekers and Refugees, United Nations High Commissioner for Refugees, Division of International Protection Services, April 2006, POLAS/2006/03 at para 87

2855 Field, O, with Edwards, A, Alternatives to Detention of Asylum Seekers and Refugees, United Nations High Commissioner for Refugees, Division of International Protection Services, April 2006, POLAS/2006/03 at para 87, referring to $A v$ Australia UNHRC Communication No. 560/1993, UN Doc. CCPR/C/59/D/560/1993, 30 April 1997, para 9.4

2856 Field, O, with Edwards, A, Alternatives to Detention of Asylum Seekers and Refugees, United Nations High Commissioner for Refugees, Division of International Protection Services, April 2006, POLAS/2006/03 at para 89

2857 Wilsher, D, The Liberty of Foreigners - A History, Law and Politics of Immigration Detention, 2008, Wolf Legal Publishers, Nijmegen, P.268 
those asylum seekers in the destination state, the authors conclude that their compliance with non-detention measures is not a significant problem whilst the determination of their claim is pending, given the extreme lengths that asylum seekers may go to achieve their goal and that there is no chief reason to disregard or disobey such requirements ${ }^{2858}$ - that is, it would not be in an asylum seeker's best interests to act contrary to any requirements imposed on them. Field and Edwards noted that evidence suggested that rejected asylum seekers are more likely to abscond, but warned that this should not be "equated with a risk of absconding and hence a need to detain" ${ }^{2859}$ although Edwards (2011) more recently notes that empirical evidence suggests that such an increased likelihood for absconding has not been borne out. ${ }^{2860}$ The International Detention Coalition's There Are Alternatives key findings included that asylum seekers in their destination country rarely abscond and noted some evidence that those in transit countries are less likely to abscond if they can lawfully have their basic needs met, are not in danger of detention or refoulement and retain hope for the future. ${ }^{2861}$ The report also found that those failed asylum seekers are more likely to comply with negative decisions if the refugee status determination process is fair. ${ }^{2862}$

As regards the effectiveness of alternatives to detention, Field and Edwards noted four factors that proved influential:

“(a) providing legal advice;

(b) ensuring that asylum seekers are not only informed of their rights and obligations but also that they understand them, including all conditions for their release and the consequences of failing to appear for a hearing;

(c) providing adequate material support and accommodation throughout the asylum procedure;

(d) screening for either family or community ties or, alternatively, using community groups to 'create' guarantors/sponsors" 2863

2858 Field, O, with Edwards, A, Alternatives to Detention of Asylum Seekers and Refugees, United Nations High Commissioner for Refugees, Division of International Protection Services, April 2006, POLAS/2006/03 at paras 90-91

${ }^{2859}$ Field, O, with Edwards, A, Alternatives to Detention of Asylum Seekers and Refugees, United Nations High Commissioner for Refugees, Division of International Protection Services, April 2006, POLAS/2006/03 at para 144

${ }^{2860}$ UNHCR, Edwards, A, Back to Basics: The Right to Liberty and Security of Person and Alternatives to Detention of Refugees, Asylum-Seekers, Stateless Persons and Other Migrants, April 2011, UN Doc PPLA/1011/01.Rev.1, Pp.84-85

${ }^{2861}$ Sampson, $\mathrm{R}$, and Bowring, L, There are alternatives: A handbook for preventing unnecessary immigration detention, 2011, Immigration Detention Coalition, Melbourne, P.17

2862 Sampson, $\mathrm{R}$, and Bowring, L, There are alternatives: A handbook for preventing unnecessary immigration detention, 2011, Immigration Detention Coalition, Melbourne, P.17

${ }^{2863}$ Field, O, with Edwards, A, Alternatives to Detention of Asylum Seekers and Refugees, United Nations High Commissioner for Refugees, Division of International Protection Services, April 2006, POLAS/2006/03 at para 155 
Those factors were also affirmed and elaborated upon in Edwards' later 2011 report. ${ }^{2864}$ The International Detention Coalition's report also found that compliance with requirements while placed in the community was enhanced if asylum seekers' basic needs could be met. ${ }^{2865}$

The International Detention Coalition's There Are Alternatives report advocated a Community Assessment and Placement model ("CAP model"). It should be noted from the outset that this study of extraordinary depth and breadth takes into account both law as well as policy and practice. ${ }^{2866}$ A degree of caution should be exercised when considering policy and practice as it may not give an accurate snapshot about what is legally enforceable by asylum seekers - an essential consideration with such a fundamental right as liberty. This is particularly the case in the Australian context where the harrowing legislative skeleton of mandatory detention may be softened from time to time by policy or practice (usually in the form of personal and non-compellable ministerial discretion) but which is otherwise legally unenforceable.

The CAP model consists of five elements, which largely reflect the international jurisprudence. Firstly, it is based on a presumption against detention and an obligation on the part of authorities to consider alternatives to detention. The model calls for the strengthening of the presumption against detention by prescribing alternatives in law. ${ }^{2867}$

The second element of the CAP model calls for a screening and assessment to be made in individual cases (including such factors as age, health, vulnerability, stage in the immigration process, security concerns, gender, whether the person is in a transit state or a state of destination, and character attributes). ${ }^{2868}$

Thirdly, the community setting is to be assessed with the adoption of a case management model. ${ }^{2869}$

Fourthly, if necessary, the CAP model provides that conditions may be applied on those individuals remaining in the community as an alternative to detention (such as reporting requirements, bail, bond or surety). ${ }^{2870}$

\footnotetext{
${ }^{2864}$ UNHCR, Edwards, A, Back to Basics: The Right to Liberty and Security of Person and Alternatives to Detention of Refugees, Asylum-Seekers, Stateless Persons and Other Migrants, April 2011, UN Doc PPLA/1011/01.Rev.1, Pp.83-84

2865 Sampson, $\mathrm{R}$, and Bowring, $\mathrm{L}$, There are alternatives: A handbook for preventing unnecessary immigration detention, 2011, Immigration Detention Coalition, Melbourne, P.17

2866 Sampson, R, and Bowring, L, There are alternatives: A handbook for preventing unnecessary immigration detention, 2011, Immigration Detention Coalition, Melbourne, P.14

2867 Sampson, R, and Bowring, L, There are alternatives: A handbook for preventing unnecessary immigration detention, 2011, Immigration Detention Coalition, Melbourne, Pp.20-22

${ }^{2868}$ Sampson, $\mathrm{R}$, and Bowring, L, There are alternatives: A handbook for preventing unnecessary immigration detention, 2011, Immigration Detention Coalition, Melbourne, Pp.22-29

2869 Sampson, R, and Bowring, L, There are alternatives: A handbook for preventing unnecessary immigration detention, 2011, Immigration Detention Coalition, Melbourne, Pp.29-36
} 
Fifthly, and finally, detention should only be resorted to in exceptional cases as a last resort. ${ }^{2871}$

As shall be explored in more detail below, it may be seen that the CAP model largely follows the elements of the principle of proportionality. However, in relation to the fifth element, it would be preferable if the least restrictive form of detention were ensured once in a detention environment - this is particularly important given the isolation and other compounds that may be used in a detention centre, which may be decided upon and carried out by staff of privately run detention facilities. Further it would appear that the report partly conceptualises community placement and detention as "open accommodation" or "closed accommodation". ${ }^{2872}$ Flynn has commented that caution should be exercised about the binary terminology of "open accommodation" or "closed accommodation" on account that they may not accurately reflect the continuum that the principle of proportionality demands based on an individual assessment. ${ }^{2873}$

\section{Legal Analysis}

\subsection{International}

\section{ICCPR}

At the international level, in relation to Article 9 ICCPR, the HRC has indicated in $A v$ Australia that

"Remand in custody could be considered arbitrary if it is not necessary in all the circumstances of the case, for example to prevent flight or interference with evidence: the element of proportionality becomes relevant in this context" 2874

As discussed in Chapter 5, the HRC also emphasised the individual nature of the assessment - that is, that the decision to detain must be based on factors that are pertinent to the individual, in the absence of which, detention may be considered arbitrary:

"In any event, detention should not continue beyond the period for which the State can provide appropriate justification. For example, the fact of illegal entry may

\footnotetext{
${ }^{2870}$ Sampson, R, and Bowring, L, There are alternatives: A handbook for preventing unnecessary immigration detention, 2011, Immigration Detention Coalition, Melbourne, Pp.36-44 2871 Sampson, R, and Bowring, L, There are alternatives: A handbook for preventing unnecessary immigration detention, 2011, Immigration Detention Coalition, Melbourne, Pp.44-50 2872 Sampson, R, and Bowring, L, There are alternatives: A handbook for preventing unnecessary immigration detention, 2011, Immigration Detention Coalition, Melbourne, Pp.2-3, 19-20 ${ }^{2873}$ Flynn, M, Immigration Detention and Proportionality - Global Detention Project Working Paper No. 4, February 2011, Global Detention Project, P.6

2874 A v Australia, Communication No. 560/1993 at para 9.2
} 
indicate a need for investigation and there may be other factors particular to the individual, such as the likelihood of absconding and lack of cooperation, which may justify detention for a period. Without such factors, detention may be considered arbitrary, even if entry was illegal. In the instant case, the State party has not advanced any grounds particular to the author's case, which would justify his continued detention for a period of four years, during which he was shifted around between various detention centres" 2875

Accordingly, the HRC emphasised firstly, the requirement of necessity "in all the circumstances of the case"; secondly, the objective for detaining a person must be based on an individual assessment; thirdly, the HRC appears to appreciate that the length of detention may result in detention becoming disproportionate.

In terms of a requirement to consider less restrictive methods, the HRC stated in $C v$ Australia that "the State party has not demonstrated that, in light of the author's particular circumstances, there were not less invasive means of achieving the same ends". ${ }^{2876}$ Accordingly, States are obliged to actively consider alternatives to detention before a decision to detain is made.

As will be recalled from Chapter 5 , the policy grounds rejected by the HRC in $C v$ Australia $^{2877}$ as forming an objective for mandatory detention were: ensuring the integrity of the migration system; the prevention of entry of persons who do not have prior authorisation to enter; the processing of asylum claims without delay; the facilitation of removal if the claims proved unwarranted; state sovereignty; and the detection, monitoring and apprehension of illegal immigrants in the community. ${ }^{2878}$

As alternatives to detention may still constitute a restriction on liberty, Article 12 ICCPR forms the logical complement to considerations under Article 9 ICCPR. The comprehensive study on alternatives to detention by Field and Edwards commended States' legislation and regulations that "applied alternative measures and decisions to detain as part of one continuum and one procedure" and, accordingly, that emphasised the tests of proportionality and necessity throughout the entire procedure. ${ }^{2879}$ As discussed in Chapter 3, this continuum also reflects the very nature of detention itself - that is, liberty may metamorphose into a restriction upon liberty and then to a deprivation of liberty along one continuum. The HRC has indicated that any restrictions

\footnotetext{
2875 A v Australia, Communication No. 560/1993 at para 9.4

${ }_{2876}$ C v Australia, Communication No. 900/1999, para 8.2; see also D and Ev Australia, 11 July 2006, Communication No. 1050/2002, UN Doc CCPR/C/87/D/1050/2002 at para 7.2

2877 C v Australia, Communication No. 900/1999

${ }^{2878} C$ v Australia, Communication No. 900/1999 at para 4.26

${ }^{2879}$ Field, O, with Edwards, A, Alternatives to Detention of Asylum Seekers and Refugees, United Nations High Commissioner for Refugees, Division of International Protection Services, April 2006, POLAS/2006/03 at para 83
} 
must not only serve permissible purposes (that is, the limited purposes in Article 12(3)) but must also be necessary in achieving those purposes. ${ }^{2880}$ With the necessity assessment, the HRC has indicated the classic proportionality test:

\begin{abstract}
"Restrictive measures must conform to the principle of proportionality; they must be appropriate to achieve their protective function; they must be the least intrusive instrument amongst those which might achieve the desired result; and they must be proportionate to the interest to be protected". 2881
\end{abstract}

Article 12 requires more than just that the principle of proportionality be respected in law, but also in the application of the law by administrative and judicial authorities. ${ }^{282}$ An active consideration is necessary - lip service is insufficient. Further, restrictions on liberty are not to be made in a discriminatory manner, ${ }^{2883}$ which may result from the absence of "a legitimate aim, and [measures which] are not proportional to the achievement of this aim". ${ }^{2884}$ Accordingly, just as Articles 9 and 12 ICCPR complement one another regarding their subject matter, a proportionality assessment in relation to measures under Article 12 ICCPR represents a logical and unbroken extension of the principle which is also required by Article 9 ICCPR.

\title{
CROC
}

The obligation to consider alternatives is also evident in Article 37(b) CROC that requires that detention of minors be "only used as a measure of last resort and for the shortest appropriate period of time". Accordingly, if detention is to be a last resort, other alternatives must be considered before resorting to detention. The CteeRC has urged States to provide for alternatives to custodial measures. ${ }^{2885}$ However, that urging by the CteeRC highlights an important point - alternatives must exist and be made viable.

2880 UN, HRC, General Comment 27: Freedom of movement (Art.12), 2 November 1999, CCPR/C/21/Rev.1/Add.9, General Comment No. 27, para 14

2881 UN, HRC, General Comment 27: Freedom of movement (Art.12), 2 November 1999, CCPR/C/21/Rev.1/Add.9, General Comment No. 27, para 14

2882 UN, HRC, General Comment 27: Freedom of movement (Art.12), 2 November 1999, CCPR/C/21/Rev.1/Add.9, General Comment No. 27, para 15

2883 UN, HRC, General Comment 27: Freedom of movement (Art.12), 2 November 1999, CCPR/C/21/Rev.1/Add.9, General Comment No. 27, para 18

${ }^{2884}$ UN, CteeERD, General Recommendation No. 30: Discrimination Against Non Citizens, 1 October 2004, para 4

2885 UN CteeRC, UN Committee on the Rights of the Child: Concluding Observations: Canada, 27 October 2003, CRC/C/15/Add.215, para 57(d); UN CteeRC, UN Committee on the Rights of the Child: Concluding Observations, Benin, 20 October 2006, CRC/C/BEN/CO/2, para 76(d); UN CteeRC, UN Committee on the Rights of the Child: Concluding Observations, Latvia, 28 June 2006, CRC/C/LVA/CO/2, para 62(d); UN CteeRC, UN Committee on the Rights of the Child: Concluding Observations, Oman, 29 September 2006, $\mathrm{CRC} / \mathrm{C} / \mathrm{OMN} / \mathrm{CO} / 2$, para 68 (c) and (d) cited in UNICEF, Implementation Handbook for the Convention on the Rights of the Child, (3 ed), 2007, P.556 
Indeed, the essential elements of proportionality are also expressed in Guideline 3 of the UNHCR Revised Guidelines. Together with a presumption against detention, the Guidelines provide that alternatives to detention be adopted first, and that detention should only be resorted to where all possible alternatives "have been demonstrated not to have achieved the lawful and legitimate purpose". The Guidelines expressly provide that in the assessment of the necessity of detention "account should be taken of whether it is reasonable to do so and whether it is proportional to the objectives achieved". The element of least intrusive method for implementing that goal is reflected in the recommendation that, if detention is necessary, "it should only be imposed in a non discriminatory manner for a minimal period".

\section{United Nations Standard Minimum Rules for Non-Custodial Measures}

Although instructive only by way of analogy due to their applicability in a criminal detention context, the United Nations Standard Minimum Rules for Non-Custodial Measures ("The Tokyo Rules") 2886 also reflect a proportionate response to the adoption of non-custodial measures based on individual assessment. The balancing exercise indicative of such a proportionate approach is manifest in one of the fundamental aims of the rules by providing a "proper balance between the rights of individual offenders, the rights of victims, and the concern of society for public safety and crime prevention" (rule 1.4) as well as the balancing of the rights of the offender and the needs of society in any conditions imposed (rule 12.1). The necessity and individual assessment elements are apparent by the requirement for a wide range of options to be taken into account given the nature and gravity of the offence and the personality and background of the offender (rules 2.3, 3.2 and 7.1). The least restrictive means element is reflected in rule 2.6, which, as a general principle, calls for non-custodial measures to be used in accordance with the principle of "minimum intervention". At all times the person's dignity is to be respected (rule 3.9). A non-exhaustive list of non-custodial measures is provided with discretion to adopt appropriate combinations of the identified measures and the possibility to adopt any other non-institutional treatment (rule 8.2). If supervision is to occur as a result of a non-custodial measure, then that supervision is to be prescribed by law (rule 10.2). As has been earlier noted in the Field and Edwards, Field (2011), and the Immigration Detention Coalition research, the non-custodial measures must be adequately supported, and the Tokyo Rules reflect this by requiring that appropriate psychological, social and material assistance is provided (rule 10.4).

2886 United Nations Standard Minimum Rules for Non-custodial Measures ("The Tokyo Rules”), G.A. Res 45/110, 14 December 1990 


\subsection{Council of Europe}

As has already been discussed in previous chapters, the ECtHR has eschewed the requirement of necessity ${ }^{2887}$ and proportionality ${ }^{288}$ in relation to detention under Article 5(1)(f). But the power to detain merely on account of not being authorised to be on the territory is not unqualified. It will be recalled that, in Chahal, the Court held that deportation proceedings must be carried out with "due diligence" in order for detention to be permissible under Article 5(1)(f). ${ }^{2889}$ Further, in Saadi, the Court issued a stern warning that detention should not be arbitrary:
"To avoid being branded as arbitrary, therefore, such detention must be carried out in good faith; it must be closely connected to the purpose of preventing unauthorised entry of the person to the country; the place and conditions of detention should be appropriate, bearing in mind that "the measure is applicable not to those who have committed criminal offences but to aliens who, often fearing for their lives, have fled from their own country";... and the length of the detention should not exceed that reasonably required for the purpose pursued"2890

If the principle of proportionality is one facet of the prohibition against arbitrariness, and is a useful prism through which to assess whether fundamental rights have been infringed, then Cornelisse makes a persuasive argument that the ECtHR has, to an extent, applied disparate elements of the proportionality and necessity assessments notwithstanding that it has, prima facie, rejected those notions in a conventional sense. ${ }^{2891}$ Cornelisse demonstrates that the Court has qualified the State's right to detain in several key $\operatorname{areas}^{2892}$ (and which have been discussed in this book): firstly, if a State's own laws provide for the necessity of detention to be demonstrated; ${ }^{2893}$ secondly, that detention should not continue beyond the time reasonably required for the purpose pursued; ${ }^{2894}$ thirdly, the diligence with which the State authorities have acted; ${ }^{2895}$ fourthly, that detention is to be "closely

2887 Chahal v United Kingdom, No. 22414/93, Judgment, Grand Chamber, 15 November 1996 at para 112.

2888 Saadi v United Kingdom, No. 13229/03, Judgment, Grand Chamber, 29 January 2008, at para 73 .

2889 Chahal v United Kingdom, No. 22414/93, Judgment, Grand Chamber, 15 November 1996 at para 113.

2890 Saadi v United Kingdom, No. 13229/03, Judgment, Grand Chamber, 29 January 2008, at para 74; see also Lokpo and Touré v Hungary, No. 10816/10, Judgment, 20 September 2011, at para 24.

2891 Cornelisse, G, Immigration Detention and Human Rights - Rethinking Territorial Sovereignty, 2010, Martinus Nijhoff Leiden, P.296

2892 Cornelisse, G, Immigration Detention and Human Rights - Rethinking Territorial Sovereignty, 2010, Martinus Nijhoff Leiden, Pp.296-300

2893 Rusu v Austria, No. 34082/02, Judgment, 2 October 2008, paras 54-60

2894 Saadi v United Kingdom, No. 13229/03, Judgment, Grand Chamber, 29 January 2008, at para 74

${ }^{2895}$ Chahal v United Kingdom, No. 22414/93, Judgment, Grand Chamber, 15 November 1996 at para 113. 
connected" to the purposes of either preventing unauthorised entry or deportation; ${ }^{2896}$ fifthly, that detention is to be carried out "in good faith"; ${ }^{2897}$ and sixthly, that the place and conditions of detention be appropriate. ${ }^{2898}$

Arai-Takahashi has noted that, generally throughout the ECHR jurisprudence, the principle of proportionality is not enunciated in a way directly comparable to Union law - the learned author notes that there are two proportionality evaluations that Strasbourg may undertake: (1) the striking of a "fair balance" between individual rights and public interests which is inherent throughout the Convention; and (2) the existence of a "reasonable relationship between the means employed, including their severity and duration, and the public objective to be sought". ${ }^{289}$ That last element is said to correspond to the third element of the Union law proportionality test. Although not specifically examining the jurisprudence surrounding Article $5(1)(f)$, the learned author acknowledges that the "necessity" formula is absent from Article 5 (unlike, say, for Articles 8-11) but believes that it should be "inherent" within that Article. ${ }^{2900}$ Further, the underlying basis for the ECtHR's approach in relation to the doctrine of the margin of appreciation is partly predicated on the delicate consent of the State parties to the Convention - the State parties have the primary responsibility in protecting human rights rather than Strasbourg. ${ }^{2901}$ Accordingly, deference to national sovereignty is made through the use of the margin of appreciation. ${ }^{2902}$ Those two characteristics are consistent with the general understanding that the ECHR operates as a "floor" rather than a "ceiling" of human rights

2896 Saadi v United Kingdom, No. 13229/03, Judgment, Grand Chamber, 29 January 2008, at para 74

2897 Saadi v United Kingdom, No. 13229/03, Judgment, Grand Chamber, 29 January 2008, at para 74; Conka v Belgium, No. 51564/99, Judgment, 5 February 2002, paras 40-42

2898 Saadi v United Kingdom, No. 13229/03, Judgment, Grand Chamber, 29 January 2008, at para 74; Mubilanzila Mayeka and Kaniki Mitunga v Belgium, No. 13178/03, Judgment, 12 October 2006, at para 102, cited with approval in Muskhadzhiyeva \& ors v Belgium, No. 41442/07, Judgment, 19 January 2010, at paras 73-75

2899 Arai-Takahashi, Y, The Margin of Appreciation Doctrine and the Principle of Proportionality in the Jurisprudence of the ECHR, 2002, Intersentia, Oxford, P.193

2900 Arai-Takahashi, Y, The Margin of Appreciation Doctrine and the Principle of Proportionality in the Jurisprudence of the ECHR, 2002, Intersentia, Oxford, P.30, noting at n.43, Trechsel, S, Liberty and Security of Person, in Macdonald, R. St. J., Matscher, F. and Petzold, H. (eds), The European System for the Protection of Human Rights, 1993, Martinus Nijhoff, Dordrecht, Ch.13, P.292

2901 Arai-Takahashi, Y, The Margin of Appreciation Doctrine and the Principle of Proportionality in the Jurisprudence of the ECHR, 2002, Intersentia, Oxford, Pp.239-241, particularly P.240; Mahoney, P, The Doctrine of the Margin of Appreciation under the European Convention on Human Rights: Its Legitimacy in Theory and Application in Practice (1998) 19(1) HRLJ 1, Pp.24; see also Schokkenbroek, J, The Basis, Nature and Application of the Margin-of-Appreciation Doctrine in the Case-Law of the European Court of Human Rights, (1998) 19(1) HRLJ 30, P.31 where the author notes that the court's subsidiary role to the State Party for the securing of rights and freedoms is the "fundamental basis for the margin-of-appreciation doctrine".

2902 Mahoney, P, The Doctrine of the Margin of Appreciation under the European Convention on Human Rights: Its Legitimacy in Theory and Application in Practice (1998) 19(1) HRLJ 1, P.3 
protection, now embodied in Article 52(3) of the EU Charter. Arai-Takahashi contrasts this approach with the "bolder and more ambitious policy pursued in European Community law" 2903 - presumably achieved through the forensic tools of the doctrines of direct effect and supremacy of Union law, which more directly integrate Union law into the domestic legal sphere and where the principle of proportionality has a more heightened role to play. Accordingly, Jackson's observations (discussed earlier) that constitutional interpretation (which may also include the use of the principle of proportionality) being influenced by constitutional history and the text itself appears also to be evidenced in ECtHR jurisprudence.

If one of the core benefits that a classical proportionality analysis offers is transparency in judicial decision-making, then the ECtHR jurisprudence on Article 5(1)(f) may be failing to reach the potential that the principle is said to hold. Chipping away at the precedential harshness of Article 5(1)(f) would not appear to advance jurisprudential transparency or foster confidence that a disciplined weighing and qualification of rights has been properly undertaken. Firstly, the 'legitimate aim' of detention under the ECHR still remains an exercise of mostly unqualified State sovereignty based on notions of territoriality. Secondly, the suitability of detention as a measure for achieving that legitimate aim has not been squarely addressed - indeed, it is a given that detention is a suitable measure purely on account of a person's unauthorised status $^{2904}$ or because deportation proceedings are on foot (albeit pursued with due diligence). ${ }^{2905}$ Thirdly, the qualifications only slightly modify the absence of individual assessment as to whether detention is necessary - and then only in relation to conditions and particularly in relation to children or vulnerable persons (and, it would most recently appear, families). For example, even if there is no risk of absconding and in circumstances where detention is clearly not necessary, detention is still justified. ${ }^{2906}$ The jurisprudence does not encourage states to consider alternatives to detention before a decision to detain is made - it merely addresses what occurs after a decision to detain is made (and, at most, may only encourage considerations as to alternative forms of detention). These shortcomings, once aggregated, substantially qualify any obligation on the part of States to consider alternatives to detention.

\footnotetext{
2903 Arai-Takahashi, Y, The Margin of Appreciation Doctrine and the Principle of Proportionality in the Jurisprudence of the ECHR, 2002, Intersentia, Oxford, Pp.239-241, particularly P.240; Mahoney, P, The Doctrine of the Margin of Appreciation under the European Convention on Human Rights: Its Legitimacy in Theory and Application in Practice (1998) 19(1) HRLJ 1, P.237 2904 Saadi v United Kingdom, No 13229/03, Judgment, Grand Chamber 29 January 2008, at paras 65-66;

2905 Chahal v United Kingdom, No. 22414/93, Judgment, Grand Chamber, 15 November 1996 at para 113

2906 Saadi v United Kingdom, No 13229/03, Judgment, Grand Chamber 29 January 2008, at paras $72-73$
} 
Recent developments, however, have seen the ECtHR embrace a new direction in its jurisprudence. In Rahimi, in a case involving an unaccompanied minor, the Court noted that doubts were raised about whether the authorities acted in good faith by reason of the fact that the authorities both did not address the best interests of the child and did not explore whether there were any less intrusive means before at last resorting to detention in order to secure the child's deportation. That fact, combined with a breach of Article 3 as regards conditions of detention, led the Court to hold that a breach of Article 5(1)(f) had taken place. ${ }^{2907}$ Accordingly, one can evidence a shift towards an active consideration of those principles before a detention decision is made and those considerations are significantly more appropriate than a mere adjustment of detention conditions after a detention decision has been made. In Kanagaratnam, involving a minor and her mother who were detained together, the length of detention together with the unsuitability of the detention conditions for a family (which breached Article 3 ) resulted in the detention of the mother (as well as her children) breaching Article 5(1)(f). ${ }^{2908}$ In Popov, in a case involving the detention of minors together with their parents, the Court noted that although the detention centre provided a family wing, the authorities did not consider the particular circumstances of the children and whether the detention of the children was a measure of last resort for which their was no less intrusive measure that could be substituted. ${ }^{2909}$ Further, distinguishing itself from its Mubilanzila Mayeka jurisprudence, the Court held that a breach of Article 8 had occurred on account of the best interests of the child not being taken into account and that detention of the family in the absence of evidence of any risk of absconding was disproportionate. ${ }^{2910}$ However, in relation to Article 5(1), the Court reiterated that, as regards the parents, it was not required that their detention was reasonably necessary. ${ }^{2911}$ The Court's new position in relation to the detention of families and Article 8 effectively means that there is a significant narrowing of circumstances in which families with minor children may be detained and that an active consideration of what is in the best interests of the children of the family, as well as other less restrictive means, must take place before a decision to detain is made.

The Committee of Ministers' Recommendation Rec(2003)5 recommends that feasible alternatives to detention to be considered on an individual basis before resorting to detention. ${ }^{2912}$ Further, a proportionality and necessity

\footnotetext{
2907 Rahimi v Greece, No. 8687/08, Judgment, 5 April 2011, paras 109-110

2908 Kanagaratnam \& Others $v$ Belgium, No. 15297/09, Judgment, 13 December 2011, paras 94-95

${ }^{2909}$ Popov v France, Nos. 39472 and 39474/07, Judgment, 19 January 2012, paras 119 and 121

2910 Popov v France, Nos. 39472 and 39474/07, Judgment, 19 January 2012, paras 147-148

2911 Popov v France, Nos. 39472 and 39474/07, Judgment, 19 January 2012, para 120

2912 Committee of Ministers, Council of Europe, Recommendation Rec(2003)5 of the Committee of Ministers to member states on measures of detention to asylum seekers, para 6
} 
assessment is contemplated in Guideline 6 of the Committee of Ministers' Twenty Guidelines on Forced Returns with a corresponding obligation to consider non-custodial obligations first. ${ }^{2913}$

\subsection{European Union}

In the Union sphere, proportionality forms an integral part of the General Principles of EU law. Learned authors have exhaustively canvassed the principle. ${ }^{2914}$ The principle of proportionality is multifaceted - it has a legislative application and an implementation or judicial review application. In the implementation or judicial review context, it is applicable in determining the validity of both Union measures as well as national measures when implementing Union law.

\subsubsection{Legislative Stage}

The principle of proportionality at the legislative stage is embodied in Article 5(4) TEU and in the Protocol on the Application of the Principles of Subsidiarity and Proportionality. If the principle of subsidiarity determines when Union action is warranted, ${ }^{2915}$ then the principle of proportionality (in this context) is a tool for examining the extent of that action - Emiliou describes the two principles as having a "cumulative effect". ${ }^{2916}$ When the Protocol on the Application of Principles of Subsidiarity and Proportionality is read together with the Protocol on the Role of National Parliaments in the

2913 Guideline 6(1), Committee of Ministers, Council of Europe, Twenty Guidelines on Forced Return, CM(2005)40 Addendum final, Strasbourg, 20 May 2005

2914 Tridimas, T, The General Principles of EU Law, 2ed, 2006, OUP, Oxford; Craig, P, and de Búrca, G, EU Law, 5ed, 2011, OUP, Oxford; Emiliou, N, The Principle of Proportionality in European Law - A Comparative Study, 1996, Kluwer, London; Craig, P, EU Administrative Law, 2006, OUP, Oxford, Chs. 17 and 18; Jans. J. H., Proportionality Revisited (2000) 27(3) Legal Issues of Economic Integration 239; Harbo, T-I, The Function of the Proportionality Principle in EU Law (2010) 16 ELJ 158; Barnard, C, The Substantive Law of the EU, (3ed), 2010, OUP, Oxford, Pp.171-188, 516-518; Carrera, S, In Search of the Perfect Citizen? The Intersection Between Integration, Immigration and Nationality in the EU, 2009, Wolf, Nijmegen, P.276-283; Wiesbrock, A, Legal Migration to the European Union - Ten Years After Tampere, 2009, Wolf, Nijmegen, P.155-159

2915 Article 5(3) TEU and Protocol No. 2 on the Application of the Principles of Subsidiarity and Proportionality; Craig, P, and de Búrca G, EU Law, 5ed, 2011, OUP Oxford, Pp.94-100, 168-170; Emiliou, N, The Principle of Proportionality in European Law A Comparative Study, 1996, Kluwer, London, Pp.139-140; Tridimas, T, The General Principles of EU Law, 2ed, 2006, OUP, Oxford, Ch 4; de Búrca, G, The Principle of Subsidiarity and the Court of Justice as an Institutional Actor (1998) 36(2) JCMS 217; see more specifically in a migration law context, Wiesbrock, A, Legal Migration to the European Union - Ten Years After Tampere, 2009, Wolf Legal Publishers, Nijmegen, Pp.159-162

2916 Emiliou, N, The Principle of Proportionality in European Law - A Comparative Study, 1996, Kluwer, London, P.142 
EU, it evidences a shift away from a top-down approach to Union legislative intervention, to a more consultative approach with Member States. ${ }^{2917}$

\subsubsection{Implementation or Judicial Review Stage}

In the implementation or judicial review context, the principle of proportionality is a product of jurisprudence from the General Court and the CJEU (1) whereby Union measures can be challenged and (2) whereby the actions of Member States which fall within the scope of Union law (that is, either by the implementation of Union legislation or where Member State measures adversely affect a Union right) may be challenged. As noted by Carrera, its genesis in the jurisprudence of the Court dates back to $1956,{ }^{2918}$ but was not fully embraced until fourteen years later in Internationale Handelsgesellschaft. ${ }^{2919}$ The contemporary articulation of the principle is evidenced in Fedesa:

"The Court has consistently held that the principle of proportionality is one of the general principles of Community law. By virtue of that principle, the lawfulness of the prohibition of an economic activity is subject to the condition that the prohibitory measures are appropriate and necessary in order to achieve the objectives legitimately pursued by the legislation in question; when there is a choice between several appropriate measures, recourse must be had to the least onerous, and the disadvantages caused must not be disproportionate to the aims pursued." 2920

Accordingly as can be seen from Fedesa, the principle of proportionality in the Union context follows a three-stage test. Firstly, the measure must be suitable to achieve the desired objective; secondly, the measure must be necessary to achieve the desired objective (that is, there must be no other less restrictive means available to secure the objective); and lastly the measure must be proportionate stricto sensu. Craig has observed that, without the third stage, a measure may be suitable and necessary but entirely disproportionate to the aim to be achieved. ${ }^{2921}$ It follows that the weighing of competing interests is a rather essential element of the test. It has been noted that the CJEU does not always apply the last stage as a separate discernible assessment, but may incorporate it as part of its assessment of the second stage or may maintain it as a separate assessment if it is particularly articulated as such by a party to the

\footnotetext{
2917 Craig, P, and de Búrca G, EU Law, 5ed, 2011, OUP Oxford, Pp.94-97, 167-170

2918 Case C-8-55, Fédération Charbonière de Belgique v High Authority of the European Coal and Steel Community, Judgment, 16 July 1956

2919 Case C-11-70 Internationale Handelsgesellschaft mbH v Einfuhr- und Vorratsstelle für Getreide und Futtermittel, Judgment, 17 December 1970, para 12; see Carrera, S, In Search of the Perfect Citizen? The Intersection Between Integration, Immigration and Nationality in the EU, 2009, Wolf, Nijmegen, Pp.276-277

2920 Case C-331/88 The Queen v Minister of Agriculture, Fisheries and Food and Secretary of State for Health, ex parte: Fedesa and others, Judgment, 13 November 1990, para 13

${ }^{2921}$ Craig, P, EU Administrative Law, 2006, OUP, Oxford, P.657
} 
proceedings. ${ }^{2922}$ As regards the degree of scrutiny, the CJEU tends to more rigorously scrutinise measures by Member States than those of the Union. ${ }^{2923}$

\title{
8.4.2.1 Review of Union Measures
}

In Fedesa the CJEU held that the legality of a Union measure can only be affected "if the measure is manifestly inappropriate having regard to the objective which the competent institution is seeking to pursue". ${ }^{2924}$ Craig notes that the juridical threshold of manifest disproportionality of a Union measure is indeed high. ${ }^{2925}$ The rigorousness of the proportionality review is affected by the nature of the grant of power granted to the legislature under the Treaties. ${ }^{2926}$ In Omega the CJEU held:

\begin{abstract}
"It is also settled case-law, with respect to judicial review of the conditions mentioned in the preceding paragraph [applicability of the principle of proportionality with respect to Community institutions], that the Community legislature has wide legislative powers in the field of the common transport policy as regards the adoption of appropriate common rules.

In reviewing the exercise of such powers, the Court cannot substitute its own assessment for that of the Community legislature, but must confine itself to examining whether that latter assessment contains a manifest error or constitutes a misuse of powers or whether the authority in question clearly exceeds the bounds of its discretion". 2927
\end{abstract}

Further, in such a proportionality assessment which examines whether a Union measure is manifestly inappropriate, a broad discretion is given to the Union legislature if it is dealing with matters which "entail[] political, economic and social choices on its part, and in which it is called upon to make

2922 Craig, P, EU Administrative Law, 2006, OUP, Oxford, P.657, Pp.670-672; Carrera, S, In Search of the Perfect Citizen? The Intersection Between Integration, Immigration and Nationality in the EU, 2009, Wolf, Nijmegen, P.278; Wiesbrock, A, Legal Migration to the European Union - Ten Years After Tampere, 2009, Wolf, Nijmegen, P.157. See also, Tridimas, T, The General Principles of EU Law, 2ed, 2006, OUP, Oxford, P.139

${ }^{2923}$ Craig, P, EU Administrative Law, 2006, OUP, Oxford, Pp.704-706; Craig, P, and de Búrca, G, EU Law, 5ed, 2011, OUP, Oxford, Pp.532-533; However, note that Harbo suggest that the intensity of review on the generalised basis of a horizontal/vertical dichotomy may not be as accurate as a comparison between the cases of infringement on the vertical dimension and cases of "alleged infringements of fundamental rights on the horizontal level": Harbo, T-I, The Function of the Proportionality Principle in EU Law, (2010) 16(2) ELJ 158, P. 173

${ }^{2924}$ Case C-331/88 The Queen v Minister of Agriculture, Fisheries and Food and Secretary of State for Health, ex parte: Fedesa and others, Judgment, 13 November 1990, para 14; Case T13/99 Pfizer Animal Heath SA v Council of the European Union, Judgment, 11 September 2002, paras 411-412

2925 Craig, P, EU Administrative Law, 2006, OUP, Oxford, P.660, n.13

2926 Craig, P, EU Administrative Law, 2006, OUP, Oxford, P.667

2927 Case C-36/02 Omega Spielhallen- und Automatenaufstellungs-GmbH v Oberbürgermeisterin der Bundesstadt Bonn, Judgment, 14 October 2004, paras 63-64 
complex assessments", ${ }^{2928}$ This is said to result in a low level intensity of review by the CJEU. ${ }^{2929}$

If the Union measure impinges on a fundamental right, then the measure will be illegal where it represents a "disproportionate and intolerable interference, impairing the very substance of the rights guaranteed". ${ }^{2930}$ Craig notes that those cases involved rights relating to property, the pursuit of a trade, profession or business, and the learned author questions whether such reasoning would be applicable in cases involving other fundamental rights. ${ }^{2931}$

Finally, the principle of proportionality is also applicable to Union institutions by way of the EU Charter by virtue of Articles 51(1) and 52(1). ${ }^{2932}$

From a practical point of view, as has been discussed in previous chapters, persons affected by such measures are also significantly hamstrung by the fact that (in addition to the complex standing issues discussed earlier in this book) any such challenge to a Union measure (including Union legislation) must be made within two months of its publication in accordance with Article 263(5) TFEU notwithstanding that there may be a limited possibility for an indirect review of the Union action under Article 267 TFEU. ${ }^{2933}$ Given the

2928 Case C-491-01 The Queen v Secretary of State for Health, ex parte British American Tobacco (Investments) Ltd and Imperial Tobacco Ltd, Judgment, 10 December 2002, para 123; cited with approval in Case C-11/00 Commission of the European Communities $v$ European Central Bank, Judgment, 10 July 2003, para 157

2929 Craig, P, EU Administrative Law, 2006, OUP, Oxford, P.667

2930 Case C-491/01 The Queen v Secretary of State for Health, ex parte British American Tobacco (Investments) Ltd and Imperial Tobacco Ltd, Judgment, 10 December 2002, para 149; Case C44/79 Liselotte Hauer $v$ Land Rheinland-Pfalz, Judgment, 13 December 1979, para 23; Cases C-20/00 and C-64/00 Booker Aquaculture Ltd and Hydro Seafood GSP Ltd v The Scottish Ministers, Judgment, 10 July 2003, para 68; Cases C-184/02 and C-223/02 Kingdom of Spain and Republic of Finland $v$ European Parliament and Council of the European Union, Judgment, 9 September 2004, para 52; Cases C-402/05 P and C-415/05 P Yassin Abdullah Kadi and Al Barakaat International Foundation $v$ Council of the European Union and Commission of the European Communities, Judgment, Grand Chamber, 3 September 2008, para 355, note, however, that the restrictions were justified - see paras 363-366

2931 Craig, P, EU Administrative Law, 2006, OUP, Oxford, P.678-679 - note, however, that, at the time of publication, only the CFI decision of Kadi was available to the learned author - Case Case T 315/01 Yassin Abdullah Kadi v Council of the European Union and Commission of the European Communities, Judgmet, 21 September 2005

2932 However, as noted by Craig, the formulation differs from the CJEU jurisprudence of "impairing the very substance of the rights guaranteed" to the obligation to "respect the essence of those rights and freedoms" - Craig, P, EU Administrative Law, 2006, OUP, Oxford, P.680-681

2933 Note, however, that if the applicant knew of the measure within the two month window period in which an action could have been directly brought under Article 267, then he or she may be precluded from bringing an indirect action under Article 267 TFEU - Case C-188/92 TWD Textilwerke Deggendorf GmbH v Germany, 9 March 1994, Judgment, para 24; 
imminence of the CEAS legislation into law, this presents significant challenges for persons potentially affected by the forthcoming legislation.

Šušnjar notes the at times shifting burden of proof in the proportionality analysis when litigating the legality of a Union measure. ${ }^{2934}$ If the legitimate aim of the measure is to be contested (that is, where the aim pursued is said to be other than the official $\operatorname{aim}^{2935}$ ), the learned author notes that the evidential burden falls to the party making that assertion. ${ }^{2936}$ For example, in a detention context, this may arise if the assertion is that the purpose of detention is punitive. In relation to the suitability element, the evidential burden mostly falls to the Union. ${ }^{2937}$ In relation to the necessity requirement, the evidential burden falls to the party that asserts that there were other suitable measures that were less restrictive. ${ }^{2938}$ The learned author notes that proportionality stricto sensu is not dependent on facts per se but they may still be relevant such as in the assessment of the impact of a particular measure. ${ }^{2939}$

Turning to the legal basis of the CEAS itself, Article 78 TFEU provides a broad legislative basis upon which the Union legislature can base its CEAS secondary legislation. Further, Article 79 TFEU as it relates to the legal basis for the Returns Directive, also provides a broad legal basis for that secondary legislation. It is arguable that the subject matter of those two articles does, to an extent, involve political and social choices and complex assessments which

2934 Šušnjar, D, Proportionality, Fundamental Rights and Balance of Powers, 2010, Martinus Nijhoff, Leiden, Pp.188-191

${ }^{2935}$ See Case C-376/98 Federal Republic of Germany v European Parliament and Council of the European Union, Judgment, 5 October 2000, ("Tobacco Advertising") paras 32-35, 105, 114; Case C-491/01 The Queen v Secretary of State for Health, ex parte British American Tobacco (Investments) Ltd and Imperial Tobacco Limited, ("Tobacco Labelling") Judgment, 10 December 2002, para 43; Case C-331/88 The Queen v Minister for Agriculture, Fisheries and Food and Secretary of State for Health, ex parte: Fedesa and others, Judgment, 13 November 1990, para 22; Case C-84/94 United Kingdom of Great Britain and Northern Ireland v Council of the European Union, Judgment, 12 November 1996, para 26 cited by Šušnjar (2010) at P.188, n.1292

2936 Case C-331/88 The Queen v Minister for Agriculture, Fisheries and Food and Secretary of State for Health, ex parte: Fedesa and others, Judgment, 13 November 1990, para 25 cited by Šušnjar (2010) P.188 n.1293

2937 Case C-84/94 United Kingdom of Great Britain and Northern Ireland v Council of the European Union, Judgment, 12 November 1996 but noting Case C-280/93 Federal Republic of Germany $v$ Council of the European Union, Judgment, 5 October 1994, para 95 where the burden of proof was held by the applicants - cited in Šušnjar (2010) P.189

2938 Case C-491/01 The Queen v Secretary of State for Health, ex parte British American Tobacco (Investments) Ltd and Imperial Tobacco Limited, ("Tobacco Labelling") Judgment, 10 December 2002, paras 130, 139; Case C-331/88 The Queen v Minister for Agriculture, Fisheries and Food and Secretary of State for Health, ex parte: Fedesa and others, Judgment, 13 November 1990, paras 15-16; Case C-11-70 Internationale Handelsgesellschaft mbH v Einfuhrund Vorratsstelle für Getreide und Futtermittel, Judgment, 17 December 1970, paras 9-11 cited in Šušnjar (2010) P.190

2939 Šušnjar, D, Proportionality, Fundamental Rights and Balance of Powers, 2010, Martinus Nijhoff, Leiden, Pp.190-191 
would most likely result in the CJEU taking a less intensive proportionality review when assessing whether the detention provisions were manifestly inappropriate.

\subsection{Comparison - Detention of Union Citizens $v$ Asylum Seekers -} 'Manifestly Disproportionate'?

If, however, attention was turned to whether the detention provisions of the forthcoming secondary legislation were assessed for proportionality based on the infringement of the right to liberty, the assessment of whether the grounds for detention were a disproportionate and intolerable interference which impairs the very substance of the right to liberty would be of significant interest.

If we look at the current and proposed grounds for detention of asylum seekers and then turn to comparable case law involving EU citizens and third country national family members of EU citizens, is a different weight ascribed to the right to liberty in the proportionality analysis? Although these cases involve an assessment of the proportionality of national measures as against Union fundamental rights (most notably free movement rights), they may inform the Union legislature by way of a "trickle up" effect ${ }^{2940}$ about what the Union considers acceptable grounds for detention (as manifested in the forthcoming proposed CEAS legislation), what the legitimate aims of detention are, and the different weighing of competing rights of Union citizens and third country national family members of EU citizens as opposed to those of asylum seekers. Indeed, such a phenomenon of the case law later informing the Union legislature has been known, for example, in the formulation of the CRD (Directive 2004/38). ${ }^{2941}$ However, this discussion focuses mainly on the application of the principle of proportionality.

Union Citizens and Family Members - Right of Entry and Residence, Right to Liberty, Grounds for Expulsion

Regardless of the language used or the supranational rights derived, Union citizens in a Member State other than their own are still, in essence, migrants. Union citizens derive their free movement rights within the territory of a Member State directly from Articles 20(2)(a) and 21(1) TFEU. A right of entry and residence is also reflected in the CRD. ${ }^{2942}$ Their family members

\footnotetext{
${ }^{2940}$ Stone Sweet and Matthews discuss the effect of judicial decisions on the formulation of upcoming legislation in Canada as its Parliament aims to satisfy the principle of proportionality in the pre-legislative stage: Stone Sweet, A, and Mathews, J, Proportionality Balancing and Global Constitutionalism, (2008) 47 Columbia Journal of Transnational Law 73, Pp.119-123

2941 For example, compare Case C-459/99 Mouvement contre le racism, l'antisémitisme et la xénophobie ASBL (MRAX) v Belgian State, Judgment, 25 July 2002 with Article 5(4) of Directive 2004/38; compare Case C-413/99 Baumbast and $R v$ Secretary of State for the Home Department, Judgment, 17 September 2002 with Articles 12(3) and 13 of Directive 2004/38 2942 Articles 2(1), 5(1), 6 and 7 of Directive 2004/38
} 
have parasitic rights of entry and residence within the territory of a Member State from the CRD. ${ }^{2943}$ Article 22 CRD provides that the rights of residence and permanent residence cover the entire territory of the Member State with restrictions only able to be imposed if such restrictions apply also to the Member State's own nationals. Article 6 of the EU Charter and Article 5 ECHR provide a right to liberty for both EU citizens and their family members.

The CJEU has previously indicated that restriction or deprivation of liberty of a Union citizen might be justified where expulsion from a Member State is justified (which will be discussed below). The circumstances in which expulsion may take place are largely governed by Articles 27 and 28 of the CRD. Article 27(1) provides that restrictions on freedom of movement and residence for Union citizens and family members can only be on the basis of public policy, public security and public health. Article 27(2) compels compliance with the principle of proportionality based on an individual assessment with prior criminal convictions not being a ground per se for taking such measures. Article 27(2) further provides that the personal conduct must amount to a "genuine, present and sufficiently serious threat affecting one of the fundamental interests of society". The personal factors that must be taken into account before deciding on an expulsion decision include, the length of residence on the territory of the Member State concerned, the age, state of health, family and economic situation, social and cultural integration into the host Member State and the extent of the person's link with his/her country of origin. ${ }^{2944}$ Union citizens and their family members who are permanent residents may not be expelled unless on "serious grounds of public policy or public security" [emphasis added]. ${ }^{2945}$ Union citizens (no mention is made of their family members) may not be expelled unless there are "imperative grounds of public security" [emphasis added] provided that they have resided in the host Member State for the previous ten years or, if a minor, it is in the child's best interests consistent with CROC. ${ }^{2946}$ Article 28 may be seen as an attempt to express the principle of proportionality by taking into account the personal circumstances of the person concerned and the effects such an order might have. ${ }^{2947}$

\section{Asylum Seekers - Right to Remain, Right to Liberty}

Asylum seekers, on the other hand, do not have an express right of entry per se to any Member State unlike Union citizens, nor do they derive their right to liberty expressly from the Treaties themselves. Rather, as has been discussed

\footnotetext{
2943 Articles 2(2), 5(1) and 7(2) of Directive 2004/38

2944 Article 28(1) of Directive 2004/38

2945 Article 28(2) of Directive 2004/38

2946 Article 28(3) of Directive 2004/38

2947 See generally in relation to Articles 27 and 28 of Directive 2004/38 Case C-145/09 Land Baden-Württemburg v Panagiotis Tsakouridis, Judgment, 23 November 2010, paras 3953, particularly at para 53 regarding proportionality
} 
extensively in Chapter 5, asylum seekers who have submitted to the asylum determination process and thus have a right to remain derive their free movement rights based on Article 6 of the EU Charter which has equal legal value as the Treaties ${ }^{2948}$ and, if holding the right to remain, the qualified right to free movement within a Member State as expressed in Article 7 of the Reception Conditions Directive. Those asylum seekers who are border applicants may only rely on Article 6 of the EU Charter for the basis of their liberty (as discussed earlier, Article 5(1)(f) ECHR is of limited utility in this respect until a right to enter has been granted). The right to asylum is expressly conferred by Article 18 of the EU Charter.

Accordingly, both groups derive their right to liberty within a Member State from a higher, abstract norm, followed by more detailed implementing measures. The chief differences between the two groups are firstly, that asylum seekers, unlike Union citizens and their family members, do not have a right to enter and, secondly, although a right to remain might be conferred, this does not constitute an entitlement to a residence permit. ${ }^{2949}$ For Union citizens, there is a right of residence for up to three months, ${ }^{2950}$ and then a right of residence for more than three months subject to fulfilling certain criteria. ${ }^{2951}$ However, once both groups have a right to remain, their right to liberty is shared by the over-arching norm of Article 6 of the EU Charter.

\section{Union Citizens - Restrictions on Liberty}

From as early as 1975, and before the notion of Union citizenship emerged, the Court of Justice had considered that particular measures with restricted free movement within a Member State territory, were disproportionate when applied to EU nationals. In Rutili, ${ }^{2952}$ the applicant was an Italian national who had lived his entire life in France but, due to his involvement in trade union activities and politics, was prohibited from residence in certain départements of the French Republic (including the one of his own habitual residence). The Court held that restrictions under Article 48(3)EC (now 45(3)TFEU) on the basis of public policy could only be imposed on the whole territory of a Member State, not parts of it and only then in circumstances where it would be applicable to its nationals under the same circumstances. ${ }^{2953}$

However, that position was subsequently qualified and distinguished in Olazabal ${ }^{2954}$ which concerned a Basque Spaniard residing in France who had

\footnotetext{
2948 Article 6(1) TFEU

${ }^{2949}$ Article 7(1) of the Procedures Directive (discussed in Chapter 5 above)

2950 Article 6(1) of Directive 2004/38

2951 Article 7(1) of Directive 2004/38

2952 Case C-36/75 Roland Rutili v Ministre de l'intérieur, Judgment, 28 October 1975

2953 Case C-36/75 Roland Rutili v Ministre de l'intérieur, Judgment, 28 October 1975, paras 48-50. See also Article 22 of Directive 2004/38 (discussed earlier)

2954 Case C-100/01 Ministre de l'Intérieur v Aitor Oteiza Olazabal, Judgment, 26 November 2002
} 
been sentenced to 18 months' imprisonment for conspiracy to terror and a four-year residence ban which resulted in him being banned from nine and then thirty-one départements. The applicant wished to move from département Hauts-de-Seine (Ile de France region) to the département of Pyrénées Atlantique (in the Aquitaine region bordering Spain and the Basque region) but was prohibited from leaving the département Hauts-de-Seine. The Court distinguished the present case from Rutili by referring to the fact that Rutili concerned an Italian national residing since birth in France who was subjected to restrictions based on his trade union involvement and political activities, whereas the applicant in the instant case had been convicted to 18 months' imprisonment for conspiracy to commit acts of terror. ${ }^{2955}$ The Court emphasised the need for the principle of proportionality to be respected ${ }^{2956}$ but ultimately formed the view that a restriction of liberty on the grounds of public policy or public security is not inconsistent with Union law if, inter alia, the conduct engaged in by the Union citizen would otherwise result in the prohibition of residence or banishment from the territory. ${ }^{2957}$ In essence, the Court took the view that where deportation would be justified, restriction to a part of a territory of a Member State is an acceptable course of action (that is, restriction to a part of the territory is a less restrictive means than expulsion from the whole territory).

\section{Union Citizens - Deprivation of Liberty}

The issue of detention (and subsequent expulsion) for failing to comply with residence formalities emerged in 1976 in Royer ${ }^{2958}$ which involved a French national who failed to comply with the legal formalities of residence in Belgium (where he accompanied his French wife who was employed there). Royer was detained by police and committed to prison (such committal was not confirmed) and he was served with an expulsion order before being released. The Court held that failure to complete legal formalities for entry and residence do not justify an expulsion decision ${ }^{2959}$ and cannot be justified on account of public policy or public security. ${ }^{2960}$ The Court held that Member States were not prohibited from expelling a national of another Member State on public policy or public security grounds (except for noncompliance with alien control formalities) ${ }^{2961}$ nor did Community law prohibit the imposition of "appropriate sanctions" other than expulsion to ensure compliance with alien control formalities. ${ }^{2962}$ In relation to Royer's detention,

\footnotetext{
2955 Case C-100/01 Ministre de l'Intérieur v Aitor Oteiza Olazabal, Judgment, 26 November 2002, paras 33-37

2956 Case C-100/01 Ministre de l'Intérieur v Aitor Oteiza Olazabal, Judgment, 26 November 2002, para 43

2957 Case C-100/01 Ministre de l'Intérieur v Aitor Oteiza Olazabal, Judgment, 26 November 2002, para 45

2958 Case C-48/75 Jean Noël Royer, Judgment, 8 April 1975

2959 Case C-48/75 Jean Noël Royer, Judgment, 8 April 1975, para 38

2960 Case C-48/75 Jean Noël Royer, Judgment, 8 April 1975, paras 39-40, 47

2961 Case C-48/75 Jean Noël Royer, Judgment, 8 April 1975, para 41

2962 Case C-48/75 Jean Noël Royer, Judgment, 8 April 1975, para 42
} 
the Court held that detention would not be permissible if expulsion from the territory was contrary to the Treaty. ${ }^{2963}$ Where the person was not covered by the Treaty or was liable to expulsion for reasons other than non-compliance with residence formalities, the Court acknowledged that it remained a matter for national law and international obligations to which the Member State had subscribed - the Court expressly noting that (at that time) "Community law as such does not yet impose any specific obligations on Member States in this respect" ${ }^{2964}$ - a position now covered by Chapter VI of the CRD (discussed above in relation to Articles 27 and 28). The case did not, however, deal squarely with deprivation of liberty per se, but rather suggested that detention for the purposes of deportation was justified (that is, where the deportation order was valid and consistent with Union law, detention may be justified).

A stronger statement on the proportionality of sanctions for failing to comply with legal formalities was made by the Court in Watson and Belmann ${ }^{2965}$ which involved a British national who was prosecuted for not making a declaration of residence within three days of her arrival in Italy as required by Italian law. A fine of Lit 80,000 or three months' imprisonment could be imposed under Italian law. The court held that:

\begin{abstract}
"As regards other penalties, such as fines and detention, whilst the national authorities are entitled to impose penalties in respect of a failure to comply with the terms of provisions requiring foreign nationals to notify their presence which are comparable to those attaching to infringements of provisions of equal importance by nationals, they are not justified in imposing a penalty so disproportionate to the gravity of the infringement that it becomes an obstacle to the free movement of persons." 2966
\end{abstract}

That general position was also subsequently adopted in Pieck (involving a Dutch national who was prosecuted for remaining in the United Kingdom beyond the time that the United Kingdom considered he was entitled) ${ }^{2967}$ and in Messner (which involved similar facts to Watson and Belmann but regarding a German national who failed to comply with the Italian declaration of residence requirements). ${ }^{2968}$ However, in Messner, the Court held that the very short time period for making the required declaration (three days) also made any consequent imprisonment or fine unreasonable. ${ }^{2969}$ Nonetheless, the

\footnotetext{
2963 Case C-48/75 Jean Noël Royer, Judgment, 8 April 1975, para 43

${ }_{2964}$ Case C-48/75 Jean Noël Royer, Judgment, 8 April 1975, para 44

2965 Case C-118/75 Lynne Watson and Alessandron Belmann, Judgment, 7 July 1976

2966 Case C-118/75 Lynne Watson and Alessandron Belmann, Judgment, 7 July 1976, para 21

2967 Case C-157/79 Regina v Stanislaus Pieck, Judgment, 3 July 1980, para 19

2968 Case C-265/88 Criminal proceedings against Lothar Messner, Judgment, 12 December 1989, para 14

2969 Case C-265/88 Criminal proceedings against Lothar Messner, Judgment, 12 December 1989 , paras $13-15$
} 
CJEU has consistently called for administrative measures or penalties involving the exercise of Union citizens' free movement rights to be proportionate. ${ }^{2970}$

The Court has also stressed that public policy, public security and public health grounds are not conditions precedent for a Union citizen to exercise their right to entry and residence in the territory of another Member State. ${ }^{2971}$ Further, the threat to public policy and public security must be a present one. ${ }^{2972}$

The strongest statement against the detention of Union citizens for noncompliance with legal formalities occurred in Oulane. ${ }^{2973} \mathrm{Mr}$ Oulane, a French national visiting the Netherlands, was detained on two occasions for not being able to present his identity card to the authorities (Wilsher suspects the authorities' attention may have been drawn by his North African origins ${ }^{2974}$ which invites a comparison with the characterisation of 'the Other' also evident in the case of Vivian Alvarez in the Australian context). On the first occasion, when questioned, $\mathrm{Mr}$ Oulane indicated that he was a French national staying on holidays in the Netherlands for three months. He was then detained by the Dutch authorities for the purpose of deportation on the basis that he would abscond so as to avoid being deported. He was released one week later when he presented his French identity cards four days after being detained. On the second occasion Mr Oulane was detained after being arrested at Rotterdam Railway station in a goods tunnel off-limits to the public. The Dutch authorities again detained him in preparation for deportation on the basis that he would attempt to abscond. Mr Oulane indicated that he had been in the Netherlands for 18 days and wished to return to France, to where he was subsequently deported.

Mr Oulane's right to enter and remain in the Netherlands was characterised by his Union citizen right to receive services in a Member State other than his own - such a right conferred directly by (then) Article 49 EC (now Article 56

2970 Case C-203/80, Criminal proceedings against Guerrino Casati, Judgment, 11 November 1981, para 27; Cases C-482/01 and C-493/01 Georgios Orfranopoulos and Others and Raffaele Oliveri v Land Baden-Württemberg, Judgment, 29 April 2004, para 100; Case C-456/02 Michel Trojani v Centre public d'aide sociale de Bruxelles (CPAS), Judgment Grand Chamber, 7 September 2004, paras 34 and 46; Case C-145/09 Land Baden-Württemberg v Panagiotis Tsakouridis, Judgment Grand Chamber, 23 November 2010, para 53

2971 Case C-157/79 Regina v Stanislaus Pieck, Judgment, 3 July 1980, para 9

2972 Case C-30/77, Régina v Pierre Bouchereau, Judgment, 27 October 1977, para 28; Case C-348/96 Criminal proceedings against Donatella Calfa, Judgment, 19 January 1999, para 24; Cases C-482/01 and C-493/01 Georgios Orfranopoulos and Others and Raffaele Oliveri $v$ Land Baden-Württemberg, Judgment, 29 April 2004, para 100; note that that requirement is now reflected in Article 27(2) of Directive 2004/38 (discussed above)

2973 Case C-215/03 Salah Oulane v Minister voor Vreemdelingenzaken en Integratie, Judgment, 17 February 2005

2974 Wilsher, D, Immigration Detention - Law, History, Politics, 2011, CUP, Cambridge, P.177 
TFEU) and also reflected in Directive 73/148EEC on the abolition of restrictions of movement and residence within the Community for nationals of Member States with regard to the establishment and provision of services. The relevant Dutch law allowed for the detention of aliens who could not provide proof of identity, but no such comparable provision existed for Dutch nationals who could not prove their identity.

Accordingly, the court was able to find that discrimination based on nationality contrary to a Community right had occurred. It noted that Member States were at liberty to impose penalties for failure to present an identity card or passport but "provided that the penalties were comparable to those which apply to similar national infringements and are proportionate". ${ }^{2975}$

Importantly, however, the Court admonished detention for such reasons:

\begin{abstract}
"Moreover, detention and deportation based solely on the failure of the person concerned to comply with legal formalities concerning the monitoring of aliens impair the very substance of the right of residence directly conferred by Community law and are manifestly disproportionate to the seriousness of the infringement. [emphasis added] 2976
\end{abstract}

Further, the Court held that detention can only be based on an express derogating provision "justified on grounds of public policy, public security or public health". ${ }^{2977}$ However, the Court indicated that "failure to comply with legal formalities pertaining to aliens' access, movement and residence does not by itself constitute a threat to public policy or security". ${ }^{2978}$

In relation to measures that can be taken to determine the right to enter a Member State as they relate to third country national family members of Union citizens, the CJEU dealt with questions stemming from the inability of such persons to provide identity documents at the border in $M R A X .^{2979}$ The CJEU held that a Member State cannot send back at the border a Union citizen or his or her family member where they do not have a valid identity card, passport or visa (if necessary) but is otherwise able to prove his or her identity and marital relationship and where no risk to public policy, public

2975 C-215/03 Salah Oulane v Minister voor Vreemdelingenzaken en Integratie, Judgment, 17 February 2005, para 38

2976 C-215/03 Salah Oulane v Minister voor Vreemdelingenzaken en Integratie, Judgment, 17 February 2005, para 40

2977 C-215/03 Salah Oulane v Minister voor Vreemdelingenzaken en Integratie, Judgment, 17 February 2005, para 41

2978 C-215/03 Salah Oulane v Minister voor Vreemdelingenzaken en Integratie, Judgment, 17 February 2005, para 42

2979 C-459/99 Mouvement contre le racism, l'antisémitisme et la xénophobie ASBL (MRAX) v Belgian State, Judgment, 25 July 2002 
security or public health arises. ${ }^{2980}$ As mentioned earlier, that position was subsequently adopted in Article 5(4) of the CRD which provides that Member States must provide third country national family members in those circumstances with "every reasonable assistance to obtain the necessary documents or have them brought to them within a reasonable period of time or to corroborate or prove by other means that they are covered by the right of free movement and residence" before turning them back.

\section{Analysis}

In exploring these issues, it is not possible to have an exhaustive, direct and definitive comparison between Union citizens and their family members on the one hand and asylum seekers on the other due to the differing objectives each seeks to achieve by their movement to a Member State, and the differences between the two groups as regards rights of entry. Indeed, future research may also look at circumstances involving EU Long Term Residents and other Union Association Agreement nationals such as Turkish nationals. However, for the limited scope of this comparison and where grounds may provide some directness of comparison, it can at least be seen that there is a difference in the outcome of a proportionality analysis. This may be attributable to the weight ascribed to the right to liberty based on each group's respective status, and to weight ascribed to the objective to be achieved (such as the right of free movement of Union citizens guaranteed in the Treaties).

In cases on the restriction of liberty the Court has clearly enunciated what it sees as disproportionate measures for Union citizens. The Court has indicated that a restriction on the liberty of Union citizens is disproportionate unless their behaviour has resulted in an otherwise justifiable removal from the territory on the grounds of public policy or public security. Similarly, concerning deprivations of liberty, the Court has clearly enunciated that deprivations of liberty of Union citizens are entirely disproportionate for failing to comply with residence or proof of identity formalities. The quite high threshold of public policy and public security must be resoundingly fulfilled before such a measure could be taken - such non-compliance with formalities in no way coming close to reaching that lofty threshold. The CRD heightens the level of protection against expulsion for Union citizens and their family members by requiring "serious grounds of public policy or public security" 2981 or for Union citizens who have resided in a host Member State for the previous ten years or for minors (when in their best interest in accordance with CROC) only on "imperative grounds of public security". ${ }^{2982}$ Even third country national family members of Union citizens who are unable to evidence their identity or visa validity (if necessary) are not to be automatically turned back at the border but, according to Article 5(4) of the CRD are to be given "every

2980 C-459/99 Mouvement contre le racism, l'antisémitisme et la xénophobie ASBL (MRAX) v Belgian State, Judgment, 25 July 2002, para 62

2981 Article 27(2) of Directive 2004/38

2982 Article 27(3) of Directive 2004/38 
reasonable assistance" in such circumstances. Given the Court's previous statements that a deprivation of liberty of Union citizens is not justified unless deportation is justified, the logical extension of that argument would be that detention of such third country national family members would also be unjustified and disproportionate unless warranted in the same circumstances.

As we have seen in Chapter 5, asylum seekers may be have their liberty restricted to an assigned area within a Member State without express grounds, ${ }^{2983}$ or their residence decided for them on the basis of "public interest, public order or, when necessary, for the swift processing and effective monitoring" of their application. ${ }^{2984}$ With the exception of "public order", the other two grounds for deciding the residence of asylum seekers would appear to represent a much lower threshold to justify a restriction on liberty than that experienced by Union citizens.

If we look to the grounds upon which a deprivation of liberty may occur under the present Reception Conditions Directive ${ }^{2985}$ and the Council's Amended Proposed Reception Conditions Directive, ${ }^{2986}$ there are two areas that provide a reasonably direct comparison. Firstly, there is a marked contrast between the two groups as regards determining or verification of identity or nationality ${ }^{2987}$ or determining the right to enter the territory. ${ }^{2988}$ Detention on those two grounds would be a disproportionate measure at least for a Union citizen and possibly for an accompanying third-country national family member. Secondly, detention on the basis of national security or public order may also represent a comparable ground of detention with EU citizens, ${ }^{2989}$ but the above cases on Union citizens show the generally high threshold that is required to justify measures based on public policy or public security, as well as the heightened protection proffered by the CRD. It will be interesting to observe how the CJEU interprets that provision - will it be weighted in the same way to the generally high threshold set for EU citizens? If, as the case law provides, public policy or public security is considered not to be a condition precedent for Union citizens to enter a Member State, will the Court weight the right to liberty analogously for asylum seekers, such that detention for the purpose of establishing that the asylum seeker is not a threat to public policy or public security would be disproportionate? Further, if that reasoning is further extended, the threat the asylum seeker faces to public policy or public security would also have to be a present one.

\footnotetext{
2983 Article 7(1) of the Reception Conditions Directive

2984 Article 7(2) of the Reception Conditions Directive

2985 Article 7(3) of the Reception Conditions Directive - where an asylum seeker may be confined to a particular place "for legal reasons" or "reasons of public order"

2986 Article 8(3) of the Council's Amended Proposed Reception Conditions Directive

2987 Article 8(3)(a) of the Council's Amended Proposed Reception Conditions Directive

2988 Article 8(3)(b) of the Council's Amended Proposed Reception Conditions Directive

2989 Article 7(3) of the Reception Conditions Directive and Article 8(3)(c) of the Council's Amended Proposed Reception Conditions Directive
} 
The remaining grounds for detention contained in the Council's amendments to the Proposed Reception Conditions Directive (such as, detention in the context of a preliminary interview, ${ }^{2990}$ detention where a risk of absconding in the context of a Dublin transfer, ${ }^{2991}$ or detention in a returns process where an application for asylum is 'reasonably considered' to frustrate or delay the removal process ${ }^{2992}$ ) and the Proposed Dublin Regulation do not have a direct equivalent in a Union citizen context given the particularities of the asylum process itself. It is difficult to come to definitive conclusions about how those grounds (which may affect the weighting of the right to liberty in a proportionality analysis) compare with proportionality of Union citizens in a comparable situation.

Further, the grounds of detention set out in the current and proposed Reception Conditions Directive say nothing of the situation of border applicants. It will be recalled from Chapter 5 that an asylum seeker's right to liberty under the CEAS legislation is predicated on the right to remain which requires the making of an application for asylum. In those circumstances, and leaving aside Article 9(1) ICCPR, an asylum seeker can only on Article 6 of the EU Charter. As we have seen, Article 5(1)(f) ECHR permits detention on account of not being authorised to enter a State Party's territory. This is a scenario now alien to Union citizens given their right to enter the territory of a Member State of which they are not a national - their third-country national family members also enjoying a parasitic right of entry.

It should also be noted that the discourse that surrounds a number of those restriction on, and deprivation of, liberty cases (regarding Union citizens) is based on "punishment" (the imposition of a penalty), not process. That is, the restriction or deprivation of liberty is regarded as a punitive measure rather than one that is inherently part of a process. Only really in Oulane do we see the linking of the detention of the EU national with a risk that the person might abscond pending deportation. This differs considerably from the discourse that surrounds the grounds for detaining asylum seekers which appears more closely meshed with the process of having submitted to the asylum procedure (for example, Article 7(2) and 8(3)(a), (b), (c), (d), and (f) of the Council's Amended Reception Conditions Directive, and the unique situation of detention for the purposes of Dublin transfers). Consider that, for example, detention to verify the identity of one type of migrant (a Union citizen in a Member State other than his or her own) is considered punitive and disproportionate, but for another type of migrant (an asylum seeker) is considered more procedural, not expressly punitive (mindful of Article 31 of the Geneva Convention) and proportionate based on an individual assessment,

\footnotetext{
2990 Article 8(3)(b) of the Council's Amended Proposed Reception Conditions Directive 2991 Article 8(3)(f) of the Council's Amended Proposed Reception Conditions Directive 2992 Article 8(3)(d) of the Council's Amended Proposed Reception Conditions Directive
} 
but that both migrants are protected by the right to liberty and security under the EU Charter. Although it might suggest that we are looking at a Europe of two liberties, what may be emerging is that the weighting of the right to liberty against the objective to be achieved is different for the two groups.

Accordingly, what can be seen are the differences in 'proportionalities' between the two groups. The liberty of the two groups is not so much affected by a proportionality analysis per se, but rather the weight that it is ascribed to the right to liberty as against the objectives to be pursued. As Jackson has identified (discussed earlier), this emerges through the interpretation of the text of the constitutional document itself and the history of the legal protection of the rights in question. It may also be attributable to the implementing legislation that has a bearing on identifying the legitimate aims and the weight ascribed to (and qualification of) the competing rights.

\subsubsection{Review of Member State Measures Implementing Union Law}

The principle of proportionality has played an important role in the negative implementation of Union law by the CJEU and the forging of economic integration throughout the Union. Combined with the teleological approach taken by the Court, the principle was used to restrict the interferences by Member States of the 'Four Freedoms' contained in the then EC Treaty (now TFEU). ${ }^{2993}$ In an economic integrationist context, the principle, and particularly the least restrictive means element, was discernible in such celebrated cases such as Cassis de Dijon ${ }^{2994}$ (following the prohibition of measures having equivalent effect in Dassonville ${ }^{2995}$ and the adoption of the least restrictive means element in de Peijper ${ }^{2996}$ ) and the Beer Purity case. ${ }^{2997}$

One of the legacies of cases such as Cassis de Dijon and the Beer Purity case is that the CJEU, when faced with a proportionality assessment, demonstrates its unwillingness (at times) to accept Member States' submissions as to the unavailability of less restrictive alternatives for achieving the legitimate aim. In Cassis de Dijon, the Court rejected the German government's argument that the prohibition of sale of fruit-based alcoholic beverages that did not meet a minimum alcohol content requirement based on the protection of public health (that is, it may induce alcoholism). ${ }^{2998}$ Rather, the Court suggested that indicating the alcohol content on the label would be a much less restrictive

2993 Stone Sweet, A, and Mathews, J, Proportionality Balancing and Global Constitutionalism, (2008) 47 Columbia Journal of Transnational Law 73, Pp.139-145

2994 Case C-120/78 Rewe-Zentral AG v Bundesmonopoloverwaltung für Branntwein, Judgment, 20 February 1979

2995 Case C-8/74 Procurer du Roi v Benoît and Gustave Dassonville, Judgment, 11 July 1974

2996 Case C-104/75 Adriaan de Peijper, Managing Director of Centrafarm BV, Judgment, 20 May 1976

2997 Case C-178/84 Commission of the European Communities v Federal Republic of Germany, Judgment, 12 March 1987

2998 Case C-120/78 Rewe-Zentral AG v Bundesmonopoloverwaltung für Branntwein, Judgment, 20 February 1979, para 10 
means of achieving the same ends. ${ }^{2999}$ Similarly, the least restrictive means of labelling was also suggested by the Court as an alternative to the prohibition of the sale of beer in Germany containing certain additives in the Beer Purity Case. ${ }^{3000}$ In Heimdienst the Court suggested that it would be more proportionate for rules concerning grocers' vans to be refrigerated (when foodstuffs are sold directly from them) rather than require the grocer to have a shop locally to ensure the safety of food. ${ }^{3001}$ In a detention context, this may point to the Court's unwillingness to easily entertain submissions by Member States that alternatives to detention are unavailable - indeed, it may even result in the Court suggesting alternatives to detention (if none are forthcoming) and ensuring that, if detention is ordered, the least restrictive means possible is adopted.

Indeed, notwithstanding that the CJEU may suggest less restrictive means for achieving a stated objective, it would appear that the evidentiary burden falls to the Member State to justify the appropriateness of its measure and that the least restrictive means has been adopted together with "specific evidence substantiating its arguments", 3002

Given that the asylum secondary legislation is in the form of Directives and a Regulation, it is appropriate to consider the obligations imposed upon Member States for their implementation in accordance with the principle of proportionality. Although Regulations are able to be directly relied upon without implementation, implementation measures may be made necessary by the Regulation itself. ${ }^{3003}$ Member States are obliged to observe the principle of proportionality when faced with a choice of measures for implementation of secondary legislation. Although dealing with the terms of a Regulation, the CJEU held in Azienda Agricola Ettore Ribaldi:

"Nevertheless, when adopting measures to implement Community legislation,
national authorities must exercise their discretion in compliance with the general
rules of Community law, which include the principles of proportionality, legal
certainty and the protection of legitimate expectations"3004

2999 Case C-120/78 Rewe-Zentral AG v Bundesmonopoloverwaltung für Branntwein, Judgment, 20 February 1979, para 13

3000 Case C-178/84 Commission of the European Communities v Federal Republic of Germany, Judgment, 12 March 1987, paras 35-36

3001 Case C-254/98 Schutzverband gegen unlauteren Wettbewerb v TK-Heimdienst Sass GmbH, Judgment, 13 January 2000, para 36

3002 Case C-147/03 Commission v Austria, 7 July 2005, Judgment, para 63; see also Craig, P, EU Administrative Law, 2006, OUP, Oxford, P.692 in relation to workers and persons; de

Burca, G, Proportionality and Wednesbury Unreasonableness: The Influence of European Legal Concepts on UK Law (1997) 3(4) EPL 561, P. 576

3003 Case C-403/98 Azienda Agricola Monte Arcosu Srl v Regione Automna della Sardegna, Organismo Comprensoriale No. 24 della Sardegna and Ente Regionale per l'Assistenza Tecnica in Agricoltura (ERSAT), 11 January 2001, Judgment, paras 26-29

3004 Cases C-480/00, C-481/00, C-482/00, C-484/00, C-489/00, C-490/00, C-491/00, C-497/00, C-498/00 and C-499/00 Azienda Agricola Ettore Ribaldi v Azienda di Stato per gli 
The obligation for Member States to observe the principle of proportionality also extends to the implementation of Directives recalling, as discussed in Chapter 7, that Directives are binding as to the result to be achieved - not necessarily of the content of their provisions. ${ }^{3005}$ In Unilever, the CJEU held that Member States must observe the principle of proportionality in the implementation of a provision of a Directive. ${ }^{3006}$

\title{
8.4.2.2.1 Current Legislation
}

Indeed, the principle of proportionality in relation to the implementation of the detention provisions of the Returns Directive has been the subject of curial discussion in El Dridi. The CJEU was at pains to emphasise the importance of the principle of proportionality in exercising the decision to detain, particularly when less coercive measures were expressly contemplated. The Court noted that the least coercive measures possible must be used to carry out a removal by reference to recital 16 and Article 15(1) of the Directive - it is only in circumstances where the removal itself may be jeopardised that there may be a resort to detention. ${ }^{3007}$ The Court held:

\begin{abstract}
"It follows from the foregoing that the order in which the stages of the return procedure established by Directive 2008/115 are to take place corresponds to a gradation of measures to be taken in order to enforce the return decision, a gradation which goes from the measure which allows the person concerned the most liberty, namely granting a period for his voluntary departure, to measures which restrict that liberty the most, namely detention in a specialised facility; the principle of proportionality must be observed throughout those stages" [emphasis added] 3008
\end{abstract}

The Court particularly noted the reference to the principles of proportionality and effectiveness as regards coercive measures embodied in recital 13 to the

interventi nel mercato agricolo (AIMA) and Ministero del Tesoro, del Bilancio e della Programmazione Economica, and Caseificio Nazionale Novarese Soc. coop. arl and joined cases, 25 March 2004, Judgment, para 43; Case C-313/99 Mulligan and Others v Minister for Agriculture and Food, Ireland and Attorney General, 20 June 2002, Judgment, para 35; Cases C-201 and 202/85 Klensch and others $v$ Secrétaire d'État à l'Agirculture et à la Viticulture, 25 November 1986, Judgment, para 10

3005 Note the reasoning of Mischo AG in his Opinion in Cases C-20/00 and C-64/00 Booker Acquaculture Ltd and Hydro Seafood GSP Ltd v The Scottish Ministers, 20 September 2001, citing de Witte with approval, that Member States' choices of implementation do not extend to "whether or not to violate fundamental rights", at paras 52-53 and 58

3006 Case C-77/97 Österreichische Unilever GmbbH v Smithkline Beecham Markenartikel GmbH, 28 January 1999, Judgment, para 27; Case C-315/92 Verband Sozialer Wettbewerb eV v Clinique Laboratories SNC and Estée Lauder Cosmetics GmbH, 2 February 1994, Judgment, para 16; Case C-382/87, R. Buet and Educational Business Services (EBS) v Ministère public, 16 May 1989, Judgment, para 11; Case C-239/02 Douwe Egberts NV v Westrom Pharma NV and Cristophe Souranis, carrying on business under the commercial name of "Establissements FICS' and Douwe Egberts NV v FICS-World BVBA, 15 July 2004, Judgment, paras 41-44

3007 Case C-61/11 PPU El Dridi, 28 April 2011, Judgment, para 39

3008 Case C-61/11 PPU El Dridi, 28 April 2011, Judgment, para 41 
preamble, ${ }^{3009}$ as well as held that the detention provisions of the Directive were sufficiently clear and unconditional upon which to be directly relied. ${ }^{3010}$

Given that the detention provisions in the Returns Directive are far more precise and prescriptive than in the current Reception Conditions Directive (and especially the current Procedures Directive) it is questionable how much of the reasoning in El Dridi is analogous to detention under either of those two Directives - particularly as the CJEU in Kadzoev noted that detention under the Returns Directive was distinct from detention under the CEAS secondary legislation. ${ }^{3011}$ Firstly, it has been observed by Wilsher that the provisions of the current Reception Conditions Directive and the Procedures Directive contemplating detention were expressly left as a matter of Member State competence. ${ }^{3012}$ Accordingly, it is not entirely clear whether those detention provisions come within the scope of Union law such as to oblige Member States to comply with the principle of proportionality as a matter of Union law. That issue is less pressing under the suite of proposed secondary legislation because the provisions dealing with detention, similar to the Returns Directive, are much more prescriptive in the use of coercive measures before a decision to detain is made. Secondly, the application of the principle of proportionality to the situation of border applicants is also unclear in that any deprivation of liberty that they may be subject to is not expressly contemplated in the current Reception Conditions Directive but, rather, occurs de facto. Further, the procedural guarantees to which border applicants may be entitled can also be the subject of derogation by the Member State (see Chapters 5 and 7).

In the case of detention under the current Reception Conditions Directive, the gradation of liberty from least restrictive to most restrictive is evident in Article 7(1), (2) and (3) (as discussed in Chapters 4 and 5). It may be arguable that, applying the reasoning in El Dridi which considered the gradation of measures available in order to effect a return decision, such a gradation evident in the Reception Conditions Directive also demands that measures relating to a restriction or deprivation of liberty be individually assessed and proportionate. There is certainly sufficient scope for Member State discretion to apply alternatives to detention, even if those alternatives are not identified.

Further, notwithstanding the legislative drafting history of the Reception Conditions Directive and the Procedures Directive, it may well be that the Court views detention of asylum seekers within the scope of Union law. An alternate way of characterising the situation may be that, given the (albeit vapid) right to liberty provided for in Article $7(1)$ of the Reception

\footnotetext{
3009 Case C-61/11 PPU El Dridi, 28 April 2011, Judgment, para 57

3010 Case C-61/11 PPU El Dridi, 28 April 2011, Judgment, para 47

3011 Case C-357/09 PPU Kadzoev, 30 November 2009, Judgment Grand Chamber, para 45

3012 Wilsher, D, The Liberty of Foreigners - A History, Law and Politics of Immigration Detention, 2008, Wolf Legal Publishers, Nijmegen, Pp.160-162
} 
Conditions Directive, the Court may consider the liberty (as opposed to detention) of asylum seekers as implementing Union law. ${ }^{3013}$ Where that characterisation is problematic is that the right to liberty is dependent upon the right to remain under the Procedures Directive (but not forgetting the right to liberty and security provided independently under Article 6 of the EU Charter). However, to give an example of a seemingly large, unfettered Member State discretion, consider the case of $N S .^{3014}$ In that case the CJEU considered whether the sovereignty clause (Article 3(2)) of the Dublin II Regulation implements Union law for the purposes of Article 6 TEU and Article 51(1) of the EU Charter. The sovereignty clause allows Member States to exercise their discretion about whether to examine an asylum claim that, according to the hierarchical criteria in the Regulation, is otherwise the responsibility of another Member State. The commentary in the Commission's original proposal indicated that, as regards Article 3(2) of the then Proposed Regulation, "Member States may sovereignly decide [emphasis added]" on whether to examine an asylum application. ${ }^{3015}$ The Court held that the exercise of such discretion was implementing Union law and thus subject to Article 6 TEU and Article 51(1) of the Charter. ${ }^{3016}$ The Court has previously held that any Member State derogations from EU fundamental rights must be proportionate. ${ }^{3017}$ If the right to liberty under the Reception Conditions Directive is held to be implementing the CEAS and thus Union law, then Article 52(1) of the EU Charter demands that any such limitation on that right must be subject to the principle of proportionality, consistent with the approach taken in Schmidberger. However, it remains to be seen whether the Court would make a distinction between Member State sovereign discretion on the one hand, and what is essentially a matter of Member State competence on the other.

It will be recalled from previous chapters that the current Procedures Directive makes very limited provision as regards detention ${ }^{3018}$ and, accordingly, the applicability of the principle of proportionality for those that fall solely under its scope remains ambiguous. Similarly, the absence of detention provisions in the current Dublin Regulation also creates ambiguities for the application of

\footnotetext{
3013 That is, under Article 6 of the EU Charter

3014 Cases C-411/10 and C-493/10 N.S. v Secretary of State for the Home Department and M. E. and Others $v$ Refugee Applications Commissioner and Minister for Justice, Equality and Law Reform, 21 December 2011, Judgment Grand Chamber

3015 Commission of the European Communities, Proposal for a Council Regulation establishing the criteria and mechanisms for determining the Member State responsible for examining an asylum application lodged in one of the Member States by a third-country national COM(2001) 447 final, P.10

3016 Cases C-411/10 and C-493/10 N.S. v Secretary of State for the Home Department and M. E. and Others $v$ Refugee Applications Commissioner and Minister for Justice, Equality and Law Reform, 21 December 2011, Judgment Grand Chamber, para 69

3017 Case C-112/00 Eugen Schmidberger, Internationale Transporte und Planzüge $v$ Republik Österreich, Judgment, 12 June 2003

3018 See Article 18 of the Procedures Directive
} 
the principle of proportionality for those detained pending transfer to another Member State.

\subsection{The Proposed Legislation}

As alluded to earlier, and discussed in Chapter 5, the proposed suite of secondary legislation provides a much clearer enunciation of the principle of proportionality and a corresponding obligation to consider alternatives. The Proposed Reception Conditions Directive makes an express reference in the preamble to the principle of proportionality with regard to both the manner and the purpose of detention. ${ }^{3019}$ Further, the preamble also makes express reference to the EU Charter and, in particular, the right to liberty under Article 6 of the Charter. ${ }^{3020}$ The triple juridical hurdle that the body of the Directive creates is to ensure that detention can only occur when (1) necessary, (2) after an individual assessment of each case, and (3) if other less coercive alternative measures cannot be applied effectively. ${ }^{3021}$ These provisions are also relevant for the application of the Proposed Procedures Directive (that is, when the right to remain is lost), which refers directly to the Reception Conditions Directive including as regards grounds, guarantees and conditions of detention. ${ }^{3022}$

Similarly, the Proposed Dublin Regulation makes express reference to the principle of proportionality as regards the "means and objective pursued". 3023 The Proposal also makes reference to the EU Charter ${ }^{3024}$ but, oddly, does not include Article 6 of the Charter as one of the provisions it aims to "promote". ${ }^{3025}$ The triple juridical hurdle as formulated in the Proposed Reception Conditions Directive again requires that detention may only occur when necessary, after an individual assessment and after less coercive measures cannot be applied effectively. ${ }^{3026}$ As discussed in Chapter 5, the grounds for detention for the purposes of a Dublin transfer are only if there is a risk of absconding. ${ }^{3027}$

In terms of what factors contribute individual assessment, the proposed secondary legislation might benefit from a comprehensive, but non-exhaustive list of factors analogous to what is currently set out in Article 28(1) of the CRD.

\footnotetext{
3019 Recital 15 to the Commission's 2011 Proposed Reception Conditions Directive; Recital 15 to the Council's Amended Reception Conditions Directive

3020 Recital 31 to the Commission's 2011 Proposed Reception Conditions Directive; Recital 31 to the Council's Amended Reception Conditions Directive

3021 Article 8(2) of the Commission's 2011 Proposed Reception Conditions Directive; and Article 8(2) of the Council's Amended Proposed Reception Conditions Directive 3022 Article 26 of the Commission's 2011 Proposed Procedures Directive

3023 Recital 18 to the Commission's Proposed Dublin Regulation

3024 Recitals 10, 11, 16 and 34 to the Commission's Proposed Dublin Regulation

3025 Recital 34 to the Commission's Proposed Dublin Regulation

3026 Article 27(2) of the Commission's Proposed Dublin Regulation

3027 Article 27(3) of the Commission's Proposed Dublin Regulation
} 
The inclusion of the word "effectively" in the juridical hurdle in the Proposed legislation ${ }^{3028}$ and the current Returns Directive ${ }^{3029}$ is problematic in the proportionality context. It suggests that, if current alternatives are not able to be applied in an effective manner, then detention may be resorted to without further ado. Although there is an obligation to embody alternatives into law (discussed below), the problem with such a formulation is that it undermines any motivation for Member States to devise, or embody into law other particular less restrictive alternatives that may be better suited to individuals and thus detention may become the default measure. In this way, the qualification of "effectively" in the proposed secondary legislation runs the risk of undermining the protective potential of the proportionality test. However, as seen in Cassis de Dijon and the Beer Purity Case, the Court has not been reluctant in suggesting alternatives and the evidential burden will remain on the Member State to demonstrate that no less restrictive means are available. The inclusion of the word "effectively" may, however, have the effect of lowering the evidential threshold.

It will also remain to be seen whether the Court extends the application of the proportionality principle beyond the detention decision to ensure that any such detention is the least restrictive bearing in mind the individual circumstances of the applicant. This is particularly the case where detention centres contain within them gradations of security levels and facilities. In this sense, Flynn's discussion on the proportionality of detention facilities becomes a very relevant consideration. ${ }^{3030}$

\subsubsection{Alternatives to detention}

\subsubsection{Current Legislation}

In terms of the actual alternatives to detention on offer, the current secondary legislation does not prescribe any particular form of alternative to detention, with the exception of the Returns Directive, which refers to the generalised term "less coercive" alternatives (a term subsequently adopted in the proposed suite of legislation). ${ }^{3031}$ In some ways this is entirely predictable, firstly, given that, as Directives (excluding for the moment the Dublin II Regulation), Member States may choose the method of securing the objective sought; and secondly, that the Reception Conditions Directive and the Procedures

\footnotetext{
3028 Article 27(2) of the Commissions Proposed Dublin Regulation; Article 8(2) of the Proposed Reception Conditions Directive (both the Commission and the Council's versions); (by reference to the Reception Conditions Directive) Article 26(1) of the Proposed Procedures Directive

3029 Article 15(1) of the Returns Directive

${ }^{3030}$ Flynn, M, Immigration Detention and Proportionality - Global Detention Project Working Paper No. 4, February 2011, Global Detention Project,

${ }^{3031}$ Article 15(1) of the Returns Directive
} 
Directive were predicated on the basis that detention would remain a matter of Member State competence.

\subsubsection{The Proposed Legislation}

The proposed suite of secondary legislation makes significant inroads in relation to alternatives to detention, but still falling short of prescribing particular alternatives into the secondary legislation itself. It follows the formula initiated by the Returns Directive. Firstly, there is the use of the "less coercive" alternatives/measures. ${ }^{3032}$ The Commission's 2011 Proposed Reception Conditions Directive compels Member States to lay down rules concerning alternatives to detention in national law and cites a non-exhaustive list of alternatives as "regular reporting to authorities, the deposit of a financial guarantee, or an obligation to stay at an assigned place". ${ }^{3033}$ The Council's amendments have inserted the word "any" so as to read "Member States shall ensure that any rules concerning alternatives to detention [emphasis added]" are laid down in national law. ${ }^{3034}$ The insertion of that "any" might be seen as an attempt not to compel Member States to provide such rules but merely that any rules that they do have are laid down in national law. That formulation represents a significant downgrading of protection. The formulation in the Proposed Dublin Regulation is much stronger - it compels states to take alternatives to detention into consideration when assessing the application of less coercive measures. ${ }^{3035}$ Again, it adopts a non-exhaustive list identical to the Proposed Reception Conditions Directives, but adds "or other measures to prevent the risk of absconding", 3036

As will be recalled from earlier chapters, the Proposed Procedures Directive refers to the Reception Conditions Directive as regards detention grounds, conditions and guarantees. ${ }^{3037}$

Although the legislative character of Directives (leaving to one side the Proposed Dublin Regulation) is to provide Member State choice as to the measures to implement the Directives, the lack of a prescriptive definition of "less coercive" alternatives/measures is problematic as alternatives to detention should ideally be prescribed in law to ensure that Member States do actually provide viable alternatives to detention for asylum seekers. Further, if both the Directives and Regulation contain a more prescriptive range of alternatives (whilst still leaving discretion for other suitable measures), then asylum seekers would be entitled to rely directly on that secondary legislation to ensure that

3032 Article 8(2) of the Proposed Reception Conditions Directive (both the Commission's 2011 and the Council versions); Article 27(2) of the Commission's Proposed Dublin Regulation

3033 Article 8(4) of the Commission's 2011 Proposed Reception Conditions Directive

3034 Article 8(4) of the Council's Amended Proposed Reception Conditions Directive

3035 Article 27(3) of the Commission's Proposed Dublin Regulation

3036 Article 27(3) of the Commission's Proposed Dublin Regulation

3037 Article 26 of the Commission's 2011 Proposed Procedures Directive 
they are appropriately and individually considered for those alternatives. Further, such a formulation may represent an important safeguard to ensure that alternatives to detention are being considered rather than alternative forms of detention.

\subsection{Australia}

\subsubsection{Proportionality}

In the Australian context the principle of proportionality, as it is known in the HRC and Union law contexts, does not exist as a basis for constitutional or administrative law challenges. The term "proportionality" or "reasonable proportionality" is not a complete stranger to the Australian constitutional, ${ }^{3038}$ administrative ${ }^{3039}$ and criminal law ${ }^{3040}$ spheres, but the principle and its application in Australia, although at times sharing similarities, are not identical to that contemplated in the international or European spheres.

Allars' comprehensive and detailed analysis of the case law reveals that the Union law understanding of the term, when translated into the Australian legal context, is revealed to be a faux ami - that is, the principle of proportionality as understood in the Union law context has no basis in Australian law and the use of the term "proportionality" in the Australian legal context is not European in its origin. ${ }^{3041}$

Writing in 1993 and 1997 respectively, Fitzgerald and Kirk both come to the view that, although not expressly adopting the strict three-stage formula (as

3038 The Commonwealth $v$ Tasmania ("the Tasmanian Dam case") (1983) 158 CLR 1 per Deane J at 260; Davis $v$ The Commonwealth (1988) 166 CLR 79 at 99-101, 112-113 and 116-117; Castlemaine Tooheys Limited v South Australia (1990) 169 CLR 436 at 473-4; Re Nolan; Ex parte Young (1991) 172 CLR 460; Polyukovich $v$ The Commonwealth (1991) 172 CLR 501; Nationwide News Limited Pty Limited v Wills (1992) 177 CLR 1 per Mason CJ at 30, per Gaudron J at 93-94, per Deane and Toohey JJ at 68-69, per Dawson J at 88; Australian Capital Television Pty Limited v The Commonwealth ("ACTV") (1992) 177 CLR 106 per Brennan J at 157-162; Cunliffe v The Commonwealth (1994) 182 CLR 272 per Mason CJ at 296-297; per Dawson J at 356-357; per Brennan J at 325; per Deane J at 340; Leask v The Commonwealth (1996) 187 CLR 579 per Brennan CJ at 593-594, per Dawson J at 600-605, per McHugh J at 616, per Gummow J at 624, per Toohey J at 613-616, per Kirby J at 635-636

3039 South Australia v Tanner (1989) 166 CLR 161 (notably at 165 and 168); State of New South Wales v Macquarie Bank (1992) 30 NSWLR 307 per Kirby P at 321-325; Minister for State Resources v Dover Fisheries (1993) FCR 565 per Gummow J at 575-577

3040 Bagaric, M, and Edney, R, The Proportionality Thesis in Australia: Application and Analysis (2008) 4(1) IJPS 38; Aronson, M, Dyer, B, and Groves, M, Judicial Review of Administrative Action, 4ed, 2009, Lawbook Co, Pyrmont, P.382

${ }^{3041}$ Allars, M, Proportionality, Tradition and Constitutional Framework: Borrowing Foreign Legal Notions in Australian Public Law in Doeker-Mach, G, and Ziegert, K, Law and Legal Culture in Comparative Perspective, 2004, Franz Steiner Verlag, Stuttgart, Pp.286-312 
might be expressed in the Union and German conceptualisation of the principle), that there are instances where members of the High Court of Australia have in effect used the three stages of the principle (Fitzgerald particularly noting that proportionality stricto sensu would appear to be used in relation to guarantees). ${ }^{3042}$ However, Michaelsen notes that the logic of the three-stage formulation (as conceptualised in Germany and Canada) has not been applied in Australia. ${ }^{3043}$

In a constitutional law context, the term has been used in connection with whether legislation enacted under the purposive powers of the Constitution is constitutionally valid, and in relation to section 92 of the Constitution (relating to freedom of interstate trade) ${ }^{3044}$ Appleby notes that the use of a type of proportionality test (that is, in Australian parlance, "appropriate and adapted") to test for characterisation of legislation (that is, whether legislation can fall under one of the heads of power of the Constitution) did not gain traction in Al-Kateb $v$ Godwin ${ }^{3045}$ (a case in which the High Court confirmed the legality of indefinite detention of a failed Palestinian asylum seeker pending removal from Australia) because the subject matter of the legislation fell squarely within the aliens power of the Constitution, thus obviating any need for it to be "appropriate and adapted". ${ }^{3046}$

Justice Kiefel, of the High Court of Australia (writing extra-judicially) is of the view that the closest comparison to the application of the principle of proportionality as applied by the CJEU is seen in cases adjudicated by the High Court of Australia involving section 92 of the Constitution and that there are similarities in the application by the High Court of Australia of some parts of the three stage analysis, but her Honour does not go so far as to say that the European understanding of the principle of proportionality (particularly proportionality stricto sensu) has been embraced in the Australian context - indeed, its further development in a constitutional sense has been

\footnotetext{
3042 Fitzgerald, B, Proportionality and Australian Constitutionalism (1993) 12(2) University of Tasmania Law Review 263, particularly P.273; Kirk, J, Constitutional guarantees, characterisation and the concept of proportionality (1997) 21 MelbUnivLR 1, particularly Pp.1314,20

3043 Michaelsen, C, The Proportionality Principle, Counter-terrorism Laws and Human Rights: A German-Australian Comparison (2010) 2(1) City University of Hong Kong Law Review 19, P. 34-35

${ }^{3044}$ Lee, H P, Proportionality in Australian Constitutional Adjudication, in Lindell, G, (ed) Future Directions in Australian Constitutional Law: Essays in Honour of Professor Leslie Zines, 1994, Federation Press, Sydney, Chapter 5; Selway QC, B, The Rise and Rise of the Reasonable Proportionality Test in Public Law (1996) 7 PLR 212; Kiefel AC, The Honourable Justice Susan, Proportionality: A rule of reason (2012) 23 PLR 85

3045 Al Kateb v Godwin [2004] HCA 37

3046 Applelby, G J, Proportionality and Federalism: Can Australia learn from the European Community the US and Canada? (2007) 26(1) University of Tasmania Law Review 1, P.17
} 
somewhat halted. ${ }^{3047}$ Her Honour notes that in Australia the principle of proportionality "has never achieved the status of a general legal principle having applications to questions of legislative power". ${ }^{3048}$

In the State and Territory spheres, the Australian Capital Territory and Victoria have adopted statutory bills of rights that contemplate proportionality (the Victorian Act more expressly so). ${ }^{3049}$

There are several reasons why the principle of proportionality has not flourished in the Australian legal context.

Firstly, the Constitution does not contain a Bill of Rights and expresses its conferral of legislative power by way of identifying the subject matter under heads of power. Pre-existing rights are essential for any proportionality analysis to be applied. The Constitution contains very few express rights ${ }^{3050}-$ these are limited to voting rights; ${ }^{3051}$ no civil conscription of medical and dental services, ${ }^{3052}$ the acquisition of property on just terms; ${ }^{3053}$ trial by jury; ${ }^{3054}$ freedom of movement between the states; ${ }^{3055}$ freedom of religion; ${ }^{3056}$ and protection against discrimination based on a person's state of residency. ${ }^{3057}$ Further, the High Court of Australia has only implied the right of freedom of public and political communication ${ }^{3058}$ (which is said not to confer a right on individuals, but rather "preclude the curtailment of the protected freedom by the exercise of legislative or executive power" ${ }^{3059}$ and which does extend to aliens other than through a citizen ${ }^{3060}$ ) and the doctrine of the separation of

3047 Kiefel, The Honourable Justice Susan, Section 92: Markets, Protectionism and Proportionality - Australian and European Perspectives (2010) 36(2) Monash Law Review 1, Pp.13-15

3048 Kiefel AC, The Honourable Justice Susan, Proportionality: A rule of reason (2012) 23 PLR 85, P.86

${ }^{3049}$ See section 28 of the Human Rights Act (2004) (ACT) and section 7(2) of the Charter of Human Rights and Responsibilities Act 2006 (Vic)

${ }^{3050}$ See generally O'Neill, N, Rice, S, and Douglas, R, Retreat from Injustice - Human Rights Law in Australia, 2ed, 2004, Federation Press, Leichhardt, Pp.50-88; Bailey, P, The Human Rights Enterprise in Australia and Internationally, 2009, Lexis Nexis Butterworths, Chatswood, Pp.273-308; Gageler, S and Glass, A, Constitutional Law and Human Rights in Kinley, D (ed), Human Rights in Australian Law, 1998, Federation Press, Leichhardt, Pp.47-62

3051 Sections 41 and 42 of the Australian Constitution

3052 Section 51(xxiiA) of the Australian Constitution

${ }^{3053}$ Section 51(xxxi) of the Australian Constitution

3054 Section 80 of the Australian Constitution

3055 Section 92 of the Australian Constitution

3056 Section 116 of the Australian Constitution

3057 Section 117 of the Australian Constitution

3058 Australian Capital Television Pty Limited v The Commonwealth (1992) 177 CLR 106; Lange v Australian Broadcasting Corporation (1997) 189 CLR 520

3059 Lange v Australian Broadcasting Corporation (1997) 189 CLR 520 at 560

${ }^{3060}$ Cunliffe $v$ The Commonwealth (1994) 182 CLR 272 per Deane J at 336 
powers into the Constitution. ${ }^{3061}$ The absence of human rights and fundamental freedoms in the Constitution was identified by Dawson $\mathrm{J}$ in Cunliffe as a chief difference between the European application of the principle of proportionality and a reason why the principle should not be adopted in the Australian constitutional context:

\begin{abstract}
"The principle of proportionality appears to have its origin in European countries where it exists to a greater or lesser degree as an instrument for the review of administrative and legislative action. See Schwarze, European Administrative Law (1992) Ch 5. So far as administrative law is concerned it exists as part of a larger framework which finds no counterpart in the common law. See Boyron, "Proportionality in English Administrative Law: A Faulty Translation?" (1992) Oxford Journal of Legal Studies 237. In relation to legislation its application largely depends upon the existence of constitutional or quasi-constitutional guarantees which restrict the exercise of legislative power. Thus where, as in this country, fundamental freedoms do not, for the most part, take the form of constitutional guarantees, the doctrine of proportionality finds no ready application as it does in Europe. There it is used as a protection against unnecessary administrative and legislative intrusions upon fundamental freedoms in a way that has not found favour (in the case of administrative law) or which is not possible (in the case of constitutional law) in this country or in the United Kingdom.” [emphasis added] ${ }^{3062}$
\end{abstract}

Subsequently in Leask $k^{3063}$, Dawson J (with whom Brennan CJ and Gummow J agreed $^{3064}$ ) set out how the principle of proportionality is used in the Union context where his Honour observed that legislative powers are expressed in terms of aims and objectives, and stated:

"The inappropriateness of such a concept in Australian constitutional law where legislative power is with few exceptions conferred by reference to subject-matter rather than aims or objectives is immediately apparent."3065

Accordingly, given the particular expression of legislative power in the Constitution and the lack of a bill of rights to enunciate fundamental rights and freedoms, the principle of proportionality has not embedded itself into Australian constitutional law as a test of validity.

Secondly, notwithstanding that the Constitution does not contain an exhaustive catalogue of fundamental rights and freedoms, the Common Law provides insufficient protection of fundamental rights and freedoms such that any such right is so vulnerable to diminution or abrogation that the principle of proportionality cannot effectively operate in that context. For the principle

${ }^{3061}$ R v Kirby; Ex Parte Boilermakers' Society of Australia (Boilermakers' Case) (1956) 94 CLR 254; see also Chu Kheng Lim v Minister for Immigration, Local Government and Ethnic Affairs (1992) 176 CLR 1 per Brennan, Deane and Dawson JJ at 27-28

3062 Cunliffe v The Commonwealth (1994) 182 CLR 272 per Dawson J at 356-357

3063 Leask $v$ The Commonwealth (1996) 187 CLR 579

3064 Leask $v$ The Commonwealth (1996) 187 CLR 579 per Brennan CJ and 624 per Gummow J at 594

3065 Leask v The Commonwealth (1996) 187 CLR 579 per Dawson J at 600 
of proportionality to gain traction (that is, for a proper balancing of rights and the least restrictive means test to be applied), the rights that are competing with one another cannot be subject to abrogation or diminution to the extent that the right is either unrecognisable or ineffective. A proper balancing exercise between rights cannot occur in those circumstances.

The common law is subject to the legislative will of parliament. Firstly, any rights that the common law may contain may at any time be subject to legislative interference due to parliamentary legislative supremacy, ${ }^{3066}$ and secondly, any attempts by the Court to insist on the recognition of a common law right may be subject to legislation reversing the decision of the Court. ${ }^{3067}$

The common law as the protector of fundamental rights and freedoms is predicated upon the common law allowing all freedoms except where the law does not allow. Accordingly, the common law provides for residual rights, ${ }^{3068}$ and which operates in a negative manner (that is, the "right" is not a substantive one, but merely the void between surrounding and intersecting rights in which an individual can operate). ${ }^{3069}$ Accordingly, as Bailey notes, these are more properly characterised as "freedoms" rather than "rights" per se. ${ }^{3070}$ As Barendt points out, that freedom cuts both ways - that is, that freedom does not just apply to individuals but to the government and other authorities as well such that the government is at liberty to do what it likes subject to any law prohibiting its action. ${ }^{3071}$ If the common law does prohibit

\footnotetext{
3066 This, as Kinley has argued, should be distinct from Parliamentary sovereignty which connotes absolute parliamentary legislative supremacy which, in the Australian context, is not entirely accurate - parliamentary sovereignty is bound by the terms of the Australian constitution itself, particularly given the federal nature of government in Australia which dictates the relationship between the States and the Commonwealth: see Kinley, D, Constitutional Brokerage in Australia: Constitutions and the Doctrines of Parliamentary Supremacy and the Rule of Law (1992) 22 Federal Law Review 194

${ }^{3067}$ Lumb, R. D. Australian Constitutionalism, 1983, Butterworths, P.102 cited by Chief Justice RS French, The Common Law and the Protection of Human Rights, Address to the Anglo Australasian Lawyers Society, 4 September 2009, Sydney, http://www.hcourt.gov.au/assets/publications/speeches/current-justices/frenchcj/

frenchcj4sep09.pdf (last accessed 29 February 2012), para 9

3068 Malone v Metropolitan Police Commissioner [1979] Ch 344 per Megarry V-C at 376 "If the tapping of telephones by the Post Office at the request of the police can be carried out without any breach of the law, it does not require any statutory or common law power to justify it: it can lawfully be done simply because there is nothing to make it unlawful" cited in Barendt, E, Dicey and Civil Liberties [1985] Public Law 596, P.606;

3069 O'Neill, N, Rice, S, and Douglas, R, Retreat from Injustice - Human Rights Law in Australia, 2ed, 2004, Federation Press, Leichhardt, P.111; see also Bailey, P, The Human Rights Enterprise in Australia and Internationally, 2009, Lexis Nexis Butterworths, Chatswood, Pp. 18-24.

3070 Bailey, P, The Human Rights Enterprise in Australia and Internationally, 2009, Lexis Nexis Butterworths, Chatswood, Pp. 18-21, 23

3071 See Barendt, E, Dicey and Civil Liberties [1985] Public Law 596, P.606
} 
particular action then, subject to the Constitution, it may legislate its way around such obstacles.

The power of the common law as a protector of "rights" is said to be in its ability to interpret legislation in light of common law rights - that is, the common law uses an interpretative presumption that the legislature did not intend to interfere with or abrogate a common law right. ${ }^{3072}$ However, that presumption only protects such rights if there is no express intention of the legislature so to do. In Potter $v$ Minahan, O’Connor J cited Maxwell on Statutes (4ed):

"It is in the last degree improbable that the legislature would overthrow fundamental principles, infringe rights, or depart from the general system of law, without expressing its intention with irresistible clearness; and to give any such effect to general words, simply because they have that meaning in their widest, or usual, or natural sense, would be to give them a meaning in which they were not really used". 3073

That principle was strongly affirmed in Coco $v$ The Queen. ${ }^{3074}$ Mason CJ, Brennan, Gaudron and McHugh JJ stated:

\begin{abstract}
"The insistence on express authorisation of an abrogation or curtailment of a fundamental right, freedom or immunity must be understood as a requirement for some manifestation or indication that the legislature has not only directed its attention to the question of the abrogation or curtailment of such basic rights, freedoms or immunities but has also determined upon abrogation or curtailment of them. The courts should not impute to the legislature an intention to interfere with fundamental rights. Such an intention must be clearly manifested by unmistakable and unambiguous language. General words will rarely be sufficient for that purpose if they do not specifically deal with the question because, in the context in which they appear, they will often be ambiguous on the aspect of interference with fundamental rights". 3075
\end{abstract}

Al-Kateb $v$ Godwin concerned the removal of a failed Palestinian asylum seeker where his removal to Palestine or any other country was not reasonably foreseeable, the majority of the Court held that indefinite detention was lawful in those circumstances, with the majority considering, inter alia, that the legislature had clearly expressed its intention (under sections 196 and 198 of

3072 Doyle, J and Wells, B, How Far Can the Common Law Go Towards Protecting Human Rights? in Allston, P (ed), Promoting Human Rights Through Bills of Rights: Comparative Perspectives, 1999, OUP, Oxford, Pp.18-74, at Pp.54-61

3073 Potter v Minahan (1908) 7 CLR 277

3074 Coco $v$ The Queen (1994) 179 CLR 427 per Mason CJ, Brennan, Gaudron and McHugh JJ at 436-438; per Deane and Dawson JJ at 446

3075 Coco $v$ The Queen (1994) 179 CLR 427 per Mason, Brennan, Gaudron and McHugh JJ at 437 
the Migration $A c t)$ such that the presumption of non-interference with a fundamental right (liberty) did not operate. ${ }^{3076}$

Accordingly, what can be seen is that common law rights are not sufficiently robust to provide sufficiently fertile soil needed for the principle of proportionality to flourish - that is, a true balance between competing rights may not take place given the legislative supremacy of parliament, the residuary nature of common law 'rights' (freedoms) and where a sufficiently clear intention of parliament's intentions to abrogate such rights is expressed.

Thirdly, because the principle of proportionality is effectively a form of judicial legislation, its application in the Australian context has been hampered by the courts' strict adherence to the doctrine of the separation of powers. Although the Constitution does not expressly provide for a separation of powers, the High Court of Australia has acknowledged the separation of powers in the Constitution. ${ }^{3077}$ This means that a court established under Chapter III of the Constitution cannot exercise legislative power, and a legislative organ cannot exercise judicial power.

Consistent with the common law approach that the judicial assessment of legislation does not involve an assessment of the appropriateness of the legislation, Dawson J said of the principle of proportionality in Cunliffe:

"Even in Europe it is recognized that to extend the field of application of the doctrine of proportionality "presents the danger of giving to the courts a quasi-law making power in the field of fundamental rights" (See Schwarze, op cit at 864)"3078

In Leask, Dawson J (with whom Gummow J agreed ${ }^{3079}$ ) rejected the European approach undertaken by a proportionality analysis as being "essentially political rather than judicial considerations". ${ }^{3080}$ Brennan CJ said that in the Australian constitutional context (referring to "appropriate and adapted"), "proportionality has nothing to say about the appropriateness, necessity or desirability of the law to achieve an effect or purpose or to attract the support of the power". ${ }^{3081}$ Toohey J was of the view that "[i]f reasonable proportionality were to become a general touchstone of constitutional power, the Court would be drawn inexorably into areas of policy and of value judgments." ${ }^{3082}$ McHugh J cited with approval Dawson J's statement in

\footnotetext{
3076 Al-Kateb v Godwin [2004] HCA 37, per McHugh J at paras 33-36, per Hayne J at 241, per Callinan J at 298 and per Heydon J at 303 (who agreed with Hayne J)

3077 R v Kirby; Ex Parte Boilermakers' Society of Australia (Boilermakers' Case) (1956) 94 CLR

254

3078 Cunliffe v The Commonwealth (1994) 182 CLR 272 at 357

3079 Leask $v$ The Commonwealth (1996) 187 CLR 579 at 624

3080 Leask v The Commonwealth (1996) 187 CLR 579 at 601

3081 Leask $v$ The Commonwealth (1996) 187 CLR 579 at 593

3082 Leask v The Commonwealth (1996) 187 CLR 579 at 616
} 
Nationwide ${ }^{3083}$ that proportionality in the Australian context is not one of appropriateness nor is it the Court's role to judge the appropriateness of the law. ${ }^{3084}$ Kirby J stated:

"Consistent with the function of this Court, neither the task of characterisation nor the application of the concept of proportionality affords any authority for judging the desirability of the law or the means employed by the lawmaker. Provided the law is within power, the means adopted will not ordinarily be a matter for the Court. In this regard McHugh J's remarks on an analogous problem are appropriate:

" $[t]$ he fact that the Parliament has chosen to make liability to forfeiture of the fault of the owner does not make [the section impugned] unreasonably disproportionate to the purpose which it seeks to achieve. The section is not invalid because, among a range of reasonable measures to combat breaches of the Act, the Parliament has chosen a particularly drastic one."'[citations omitted] 3085

The separation of powers doctrine and proportionality in the detention context has taken an interesting course in Australia. The High Court of Australia has consistently held that the involuntary detention of citizens which is punitive in character may only take place in accordance by an order of a court (that is, a court established under Chapter III of the Constitution) with the exception of detention for the purposes such as mental illness, infectious disease or the expulsion or removal of aliens. ${ }^{3086}$ As has already been discussed in previous chapters, the High Court has held that detention of an alien for the purposes of removal under the Migration Act is not punitive in character and thus does not breach Chapter III of the Constitution (that is, the Executive has the power to detain a non-national provided that the purpose of the detention is not punitive and notwithstanding that the detention is indefinite). ${ }^{3087}$ In determining whether Commonwealth legislation breaches Chapter III (that is, whether a law concerning detention has a punitive purpose), McHugh J in Re Woolley (concerning the detention of non-citizen minors) indicated that proportionality (though really only the first two stages of the classical test) does not play a role in determining whether a law of the Commonwealth has a punitive purpose for achieving a non-punitive

\footnotetext{
3083 Nationwide News Pty Ltd v Wills (1992) 177 CLR 1 per Dawson J at 88

3084 Leask v The Commonwealth (1996) 187 CLR 579 at 617

3085 Leask v The Commonwealth (1996) 187 CLR 579 at 635-636

3086 Chu Kheng Lim v Minister for Immigration (1992) 176 CLR 1 per Brennan, Deane and Dawson JJ at 27-28; Kruger $v$ The Commonwealth (1997) 190 CLR 1 per Toohey J at 84, per Gaudron J at 109-111 and per Gummow J at 161

3087 Al Kateb v Godwin [2004] HCA 37 per Hayne J at paras 266-269, per McHugh J at paras 44-48, per Callinan J at paras 287-291 and 294, per Heydon J at para 303 (agreeing with Hayne J); see also Behrooz v Secretary of the Department of Immigration and Multicultural and Indigenous Affairs [2004] HCA 36 per Gleeson J at para 21. See further, Zagor, M, Uncertainty and Exclusion: Detention of Aliens and the High Court (2006) 34 FedLRev 127; McDonald, S, Involuntary Detention and the Separation of Judicial Power (2007) 35 FedLRev 25
} 
purpose. ${ }^{3088}$ Indeed, McHugh J noted, "questions of proportionality cannot arise in the context of Ch III". ${ }^{3089}$ Further, it is not the effect of the detention that is determinative of a breach of Chapter III (which, under a classical proportionality analysis may include evidence of the effect of the detention upon the detainee) but rather the purpose of the detention (that is, in a classical proportionality context, the legitimate identified objective). ${ }^{3090}$ Accordingly, great power is vested in the legislature for determining the purpose of the legislation. ${ }^{3091}$

Fourthly, in an administrative law context, because the principle of proportionality essentially involves a merits review of an administrative decision by a court, ${ }^{3092}$ and since under Australian administrative law judicial review by a court must be strictly confined to the legality of a decision as opposed to its merits, ${ }^{3093}$ the principle is not applied in this context.

Consistent with the doctrine of separation of powers, the role of judicial review in Australia is merely to review the legality of a decision, not the merits of the decision itself. ${ }^{3094}$ In Minister for Aboriginal Affairs $v$ Peko Wallsend $L t d$, Mason J stated:

"It is not the function of the court to substitute its own decision for that of the administrator by exercising a discretion which the legislature has vested in the administrator. Its role is to set limits on the exercise of discretion, and a decision made within those boundaries cannot be impugned."3095

Brennan $\mathrm{J}$ has observed in relation to judicial review of policy (which would appear to very closely resemble an application of the principle of proportionality):

Courts have neither the capacity nor the procedures appropriate to the review of policy. In its application to particular cases, policy calls for the balancing of interests of an individual and the interest of the community at large ... The Courts do not have the resources or techniques for assessing the worth of policy and they may be

3088 Re Woolley; Ex parte Applicants M276/2003 [2004] HCA 49 at paras 66-78, 79-80 per McHugh J

3089 Re Woolley; Ex parte Applicants M276/2003 [2004] HCA 49 at para 80 per McHugh J

3090 Re Woolley; Ex parte Applicants M276/2003 [2004] HCA 49 at para 82 per McHugh J

3091 McDonald, S, Involuntary Detention and the Separation of Judicial Power (2007) 35 FedLRev 25, Pp.42-44

3092 Allars, M, Proportionality, Tradition and Constitutional Framework: Borrowing Foreign Legal Notions in Australian Public Law in Doeker-Mach, G, and Ziegert, K, Law and Legal Culture in Comparative Perspective, 2004, Franz Steiner Verlag, Stuttgart, Pp.286-312, P.310

3093 Panetta, R, Wednesdbury Unreasonableness: Judicial or Merits Review (2002) 9 Australian Journal of Administrative Law 191, P.191-192

3094 Aronson, M, Dyer, B, Groves, M, Judicial Review of Administrative Action, 4ed, 2009, Lawbook Co, Pyrmont, P.20, particularly at n.9

3095 Minister for Aboriginal Affairs v Peko Wallsend Ltd (1986) 162 CLR 24 at 40-41 per Mason J 
quite mistaken about the effect of exempting a particular case from the application of a policy. The balancing of individual and community interest is the stuff of the political branches of Government. If policy hardens into law, the courts do not have to balance individual against community interest: the law determines how the balance is to be struck. 3096

Aronson et al note that the legality/merits distinction in judicial review has been repeatedly emphasised by the High Court of Australia. ${ }^{3097}$ The closest relative to the principle of proportionality in an administrative law context is 'Wednesdbury unreasonableness' whereby "a decision on a competent matter is so unreasonable that no reasonable authority could ever have come to it". 3098 But even "unreasonableness" as a ground has been considered suspicious for its potential to be "merits review in drag" (as the New Zealanders put it). ${ }^{3099}$ Crock et al note the use of reasonableness and relevancy as disguised grounds for judicial review of migration decisions in Australia during the 1980's as the courts took a more expansive view as well as the consequent restrictive legislative response to that development. ${ }^{3100}$ Aronson notes that the principle of proportionality provides a much greater degree of scrutiny of administrative decisions than Wednesbury unreasonableness, ${ }^{3101}$ which is highly deferential to the administrative decision maker. ${ }^{3102}$ Craig and de Búrca take the view that even in the case of manifestly inappropriate measures taken by the Union, the application of the proportionality principle in that context is "more exacting" than Wednesbury unreasonableness. ${ }^{3103}$

3096 Brennan, G, The purpose and scope of judicial review in Taggart, M, (ed), Judicial Review of Administrative Action in the 1980s, 1986, OUP in association with the Legal Research Foundation, Melbourne, P.19, cited in Cronin, K, A culture of control: an overview of immigration policy-making, in Jupp, J, and Kabala, M, The Politics of Australian Immigration, 1993, Bureau of Immigration Research, P.99

3097 Aronson, M, Dyer, B, Groves, M, Judicial Review of Administrative Action, 4ed, 2009, Lawbook Co, Pyrmont, Pp.19-20; see also McMillan, J and Williams, Administrative Law and Human Rights in Kinley, D, Human Rights in Australian Law, 1998, Federation Press, Leichhardt, Pp.63-90, P.88-90

3098 Associated Provincial Picture Houses Ltd v Wednesbury Corp [1948] 1 KB 223 at 229-230 per Lord Greene MR; see also Panetta, R, Wednesdbury Unreasonableness: Judicial or Merits Review (2002) 9 Australian Journal of Administrative Law 191

3099 Powerco Ltd v Commerce Commission [2006] NZHC 662 at para 24 cited in Aronson, M, Dyer, B, Groves, M, Judicial Review of Administrative Action, 4ed, 2009, Lawbook Co, Pyrmont, P.368

3100 Crock, M and Berg, L, Immigration, Refugee and Force Migration - Law, Policy and Practice in Australia, 2011, Federation Press, Leichhardt, Pp.629-649

3101 Aronson, M, Dyer, B, Groves, M, Judicial Review of Administrative Action, 4ed, 2009, Lawbook Co, Pyrmont, P.380

3102 Hettiarachi, P, The Sacred and the Profound: Judicial Review and Rights, Proportionality and Deference to Executive Conduct (2007) 29 Australian Bar Review 223, Pp.234-235

3103 Craig, P, and de Búrca, G, EU Law, 4ed, 2011, OUP, Oxford, P.529; see also Tridimas, T, General Principles of EU Law, 2ed, 2006, OUP, Oxford, Pp.140-141; de Búrca, G, Proportionality and Wednesbury Unreasonableness: The Influence of European Concepts on UK Law (1997) 3(4) European Public Law 561; Boyron, S, Proportionality in English Administrative Law: A Faulty Translation?” [1987] PL 368 
Interestingly, Aronson et al note that, for the principle of proportionality to function in an administrative law context, it needs to operate in a sphere where pre-existing rights are to be balanced. ${ }^{3104}$ Accordingly, in the Australian administrative legal sphere, as in the constitutional and general common law sphere as discussed above, the general dearth of such stated rights which are to be balanced (and the consequent utilisation of the least restrictive means possible) has not seen the principle of proportionality flourish.

Fifthly, even though Australia has ratified the ICCPR and other international human rights treaties, the fact that Australia is a dualist state which has not implemented the vast bulk of those international obligations into national law means that the rights contained in those treaties are not established in the Australian legal context and, consequently, any competition between competing rights is not adjudicated by way of the principle of proportionality.

As a dualist state, ${ }^{3105}$ it is necessary for treaties that Australia has ratified (by way of an exercise of executive power) to be implemented into Australian law (through the will of Parliament) before international treaties become a source of law within the domestic legal system. ${ }^{3106}$ O'Neill et al describe Australia's implementation of the provisions of the ICCPR as having "a small and random presence in Australian law" 3107 and whose implementation "can scarcely be described even as piecemeal" 3108 - a fact that has not gone unnoticed in by the HRC in its Concluding Observations of Australia's report under the ICCPR. ${ }^{3109}$ O'Neill et al also lament the "very limited implementation" of CROC. ${ }^{3110}$ Notwithstanding that the ICCPR is scheduled to the Australian Human Rights Commission Act 1986 (Cth), the Full Federal Court of Australia has rejected the notion that the scheduling of the ICCPR (to the then Human Rights and Equal Opportunity Commission Act 1986 (Cth)) has brought about its implementation into Australian law. ${ }^{311}$

\footnotetext{
3104 Aronson, M, Dyer, B, Groves, M, Judicial Review of Administrative Action, 4ed, 2009, Lawbook Co, Pyrmont, Pp.380-381

3105 Feldman, D, Monism, Dualism and Constitutional Legitimacy (1999) 20 Australian Year Book of International Law 105

3106 Brown v Lizars (1905) 2 CLR 837 per Griffith CJ at 851; Kioa v West (1985) 159 CLR 550 per Gibbs CJ at 570; Dietrich v R (1992) 177 CLR 292 per Mason CJ and McHugh J at 305; Toohey J at 359-360; Minister of State for Immigration \& Ethnic Affairs v Teoh (1995) 183 CLR 273 per Mason CJ and Deane J at 286-287; Nulyarimma v Thompson [1999] FCA 1192 per Wilcox $\mathrm{J}$ at paras 20 and 22

3107 O'Neill, N, Rice, S, and Douglas, R, Retreat from Injustice - Human Rights Law in Australia, 2ed, 2004, Federation Press, Leichhardt, P.178

3108 O'Neill, N, Rice, S, and Douglas, R, Retreat from Injustice - Human Rights Law in Australia, 2ed, 2004, Federation Press, Leichhardt, P.179

3109 United Nations Human Rights Committee, Concluding observations of the Human Rights Committee - Australia, 7 May 2009, CCPR/C/AUS/CO/5, para 8

3110 O'Neill, N, Rice, S, and Douglas, R, Retreat from Injustice - Human Rights Law in Australia, 2ed, 2004, Federation Press, Leichhardt, P.182

3111 Minogue $v$ Williams [2000] FCA 125 at paras 21-25
} 
There are two alternate ways in which international human rights treaties might influence the Australian domestic legal order: firstly, there is a legitimate expectation that administrative decision makers will act in conformity with international obligations. ${ }^{3112}$ However, this does not compel the decision maker to act in a particular way such that it becomes a binding rule of law and thus clandestinely implements an unincorporated treaty into law. ${ }^{3113}$ Further, as discussed in Chapter 4, the strength of that proposition has been seriously put into question by the decision in Lam. ${ }^{3114}$ Secondly, where there is an ambiguity in legislation, an interpretation in accordance with international law should prevail. In Plaintiff S157/2002 Gleeson CJ stated:

“...where legislation has been enacted pursuant to, or in contemplation of, the assumption of international obligations under a treaty or international convention, in cases of ambiguity a could should favour a construction which accords with Australia's obligations: Minister for Immigration and Ethnic Affairs $v$ Teoh (1995) 183 CLR 273, 287 (Mason CJ and Deane J); see also Chu Kheng Lim v Minister for Immigration, Local Government and Ethnic Affairs (1992) 176 CLR 1, 38 (Brennan, Deane and Dawson JJ)." 3115

However, both influences do not correspond to an implementation of justiciable substantive rights and, accordingly, do not sufficiently embed those international human rights provisions to such an extent that the principle of proportionality has managed to germinate.

Blackshield and Williams also note the High Court of Australia's reluctance to interpret the Constitution in light of international obligations. ${ }^{3116}$ In judgments involving immigration detention, the High Court has, with the exception of Kirby $\mathrm{J},{ }^{3117}$ been either indifferent or unmoved by international human rights

3112 Minister of State for Immigration \& Ethnic Affairs v Teoh (1995) 183 CLR 273 at 291 per Mason CJ and Deane J

3113 Minister of State for Immigration \& Ethnic Affairs v Teoh (1995) 183 CLR 273 at 291 per Mason CJ and Deane J

3114 Re Minister for Immigration and Multicultural Affairs; Ex parte Lam (2003) 214 CLR 1, particularly at 27-32 per McHugh and Gummow JJ

3115 Plaintiff S157 v The Commonwealth (2003) 211 CLR 476 at 492 per Gleeson CJ; see also Minister of State for Immigration \& Ethnic Affairs $v$ Teoh (1995) 183 CLR 273 at 403 per Gaudron J who concurred with Mason CJ and Deane J; Coleman v Power [2004] HCA 39 per Gleeson CJ at paras 19-24; see also Section $15 \mathrm{AB}(2)(\mathrm{d})$ of the Acts Interpretation Act 1901 (Cth) which permits reference to treaties mentioned in the Act in question. See generally, Pearce, D, and Geddes, R, Statutory Interpretation in Australia, 6ed, 1996, Butterworths, Sydney, Pp.75-87

3116 Blackshield, T, and Williams, G, Australian Constitutional Law and Theory, 5ed, 2010, The Federation Press, Leichhardt, P.872; see particularly the pointed exchange cited by the learned authors from Al Kateb v Godwin (2003) 219 CLR 562 between McHugh J (at 589595 of the judgment) and Kirby J (at 622-630 of the judgment).

3117 Al-Kateb v Godwin [2004] HCA 37 at paras 169-192; Behrooz v Secretary, Department of Immigration and Multicultural and Indigenous Affairs [2004] HCA 36 at paras 125-133; Minister 
law, ${ }^{3118}$ rather taking a formalist approach concerned chiefly with the validity of the relevant provisions of the Migration Act with the Constitution. ${ }^{3119}$

In the landmark 1992 High Court decision of Mabo, Brennan J noted Australia's accession to the Optional Protocol to the ICCPR the previous year and how it brought "to bear on the common law the powerful influence of the Covenant and the international standards it imports". ${ }^{3120}$ Writing initially in 1992 and updating their work in 1999, Doyle and Wells anticipated the positive influence that Australia's accession to the Optional Protocol might have on the Government and judiciary. ${ }^{3121}$ However, as evidenced earlier in this chapter and throughout this book, there have been a number of Communications concerning Australia's obligations under the ICCPR lodged with the HRC relating to immigration detention. ${ }^{3122}$ The Australian

for Immigration and Multicultural and Indigenous Affairs v Al Khafaji [2004] HCA 38 at paras 27-28; Re Woolley [2004] HCA 49 at paras 195-201

3118 In Al-Kateb v Godwin [2004] HCA 37 Gleeson CJ and Gummow J were silent on such matters; McHugh J at paras 62-73 expressly rejecting interpreting the Constitution in light of international obligations; Hayne $\mathrm{J}$ at paras 238-239 considering it unnecessary to consider HRC jurisprudence; Callinan J at 297-298 rejecting an interpretation consistent with Article 9 ICCPR; Heydon J (agreeing with Hayne J] at 303; in Behrooz v Secretary, Department of Immigration and Multicultural and Indigenous Affairs [2004] HCA 36 only Kirby J considered international human rights implications (cited above); in Minister for Immigration and Multicultural and Indigenous Affairs v Al Khafaji [2004] HCA 38 the Court largely followed the approach taken in Al-Kateb with Gummow J's reasons to be read with his reasons in Al-Kateb (para 5) and with Heydon J at 51 agreeing with Hayne J "[s]ubject to reserving any decision about whether section 196 should be interpreted in a manner consistent with treaties to which Australia is a party but which have not been incorporated into Australian law by statutory enactment"; in Re Woolley [2004] HCA 49 Gleeson CJ only mentions the preamble to CROC without further consideration at para 7; Gummow and Callinan $\mathrm{JJ}$ do not expressly consider international human rights law; McHugh $\mathrm{J}$ at paras 107-115 expressly rejects consideration of international human rights law and HRC jurisprudence; Hayne J at paras 221-222 identifies ICCPR and CROC but is of the view, inter alia, that they do not invalidate the relevant legislative provision; Heydon J at para 270 agreed with Hayne J's reasoning, but again "[s]ubject to reserving any decision about whether section 196 should be interpreted in a manner consistent with treaties to which Australia is a party but which have not been incorporated into Australian law by statutory enactment".

${ }^{3119}$ See further Crock, M, and Berg, L, Immigration, Refugees and Forced Migration - Law Policy and Practice in Australia, 2011, Federation Press, Leichhardt, Pp.86-89; Pp. 653-657

3120 Mabo v Queensland (No.2) [1992] HCA 23 at 42 per Brennan J

3121 Doyle, J and Wells, B, How Far Can the Common Law Go Towards Protecting Human Rights? in Allston, P (ed), Promoting Human Rights Through Bills of Rights: Comparative Perspectives, 1999, OUP, Oxford, Pp.18-74, P.23

$3122 A v$ Australia UNHRC Communication No. 560/1993, UN Doc. CCPR/C/59/D/560/1993, 30 April 1997; C v Australia, UNHRC, Communication 90/1999, UN Doc CCPR/C/76/D/900/1999, 28 October 2002; Baban v Australia, UNHRC Communication No. 1014/2001, UN Doc. CCPR/C/78/D/1014/2001, 6 August 2003; Bakhtiyiari v Australia, UNHRC Communication No. 1069/2002, UN Doc. CCPR/C/D/1069/2002, 12 August 2003; Madafferi v Australia, UNHRC Communication No. 1011/2001, UN Doc. CCPR/C/81/D/1011/2001, 26 August 2004; D and E $v$ 
government has been well aware of the issues surrounding immigration detention and compliance with the ICCPR through the Views expressed by the HRC but the legal framework has remained largely unchanged. What is further distressing is that the Australian Government has, in some cases, strongly refuted the Views of the Committee, ${ }^{3123}$ and shown a degree of indifference or belligerence towards the Committee's Views in relation to other Communications. ${ }^{3124}$ Given that the Views of the HRC are nonbinding, ${ }^{3125}$ and given the attitude of the Australian government to the HRC's Views, it is perhaps unsurprising that the importation of the ICCPR standards, and the related principle of proportionality, have not found their way to Australia through the influence of accession to the Optional Protocol to the ICCPR.

Accordingly, it can be seen that the principle of proportionality, as understood in the Union and international legal context has not flourished in Australia. It

Australia, UNHRC Communication No. 1050/2002, UN Doc.
CCPR/C/87/D/1050/2002, 11 July 2006; Shafiq v Australia, UNHRC, Communication No. 1324/2004, UN Doc. CCPR/C/88/D/1324/2004, 13 November 2006; Shams et al v Australia, UNHRC, Communication Nos. 1255, 1256, 1259, 1260, 1268, 1270, 1288/2004, UN Doc CCPR/C/90/D/1255, 1256, 1259, 1260, 1266, 1268, 1270 \& 1288/2004, 11 September 2007.

3123 See: Australian Government, Response of the Australian Government to the Views of the Committee in Communication No. 1324/2004 Shafiq v Australia, http://www.ag.gov.au/ Documents/Human\%20Rights\%20Communications\%20-\%20Government\%20Response\% 20to\%201324\%202004\%20Shafiq\%20v\%20Australia.pdf (last accessed 8 March 2012); Australian Government, Response of the Australian Government to the Views of the Committee in Communication No. 1050/2002 DE E v Australia, http://www.ag.gov.au/Documents/Communication+No+1050-2002+-+Australian+ Government+Response-+PDF+44KB.pdf (last accessed 8 March 2012); Australian Government, Response of the Australian Government to the Views of the Committee in Communications Numbers 1255/2004, 1256/2004, 1259/2004, 1260/2004, 1268/2004, 1270/2004, 1288/2004 Saed Shams, Kooresh Atvan, Shahin Shahrooei, Payam Saadat, Behrouz Ramezani, Behzad Boostani, Meharn Behrooz, Amin Houvedar Sefed, http://www.ag.gov.au/Documents/n8Iranians\%20\%20Communications\%20_\%20Final\%20 Response.pdf (last accessed 8 March 2012), particularly paras 15-18; Australian Government, Response of the Australian Government to the Views of the Committee in Communication No. 1011/2001 Madafferi v Australia http://webcache.googleusercontent.com/search?q=cache:kw44cHSZ6jEJ:www.ag.gov.au/ www/agd/rwpattach.nsf/VAP/(CFD7369FCAE9B8F32F341DBE097801FF) 1011Madaff eri\%252BResponse.pdf/\$file/1011Madafferi\%252BResponse.pdf+australian+government's + reponse + to + the + views + of + the + committee + in + madafferi\&hl $=$ en $\& g l=$ au (last accessed 8 March 2012)

${ }^{3124}$ Charlesworth, H, Human Rights: Australia versus the UN, Democratic Audit of Australia Discussion Paper 22/06, August 2006, http://democratic.audit.anu.edu.au/papers/ 20060809_charlesworth_aust_un.pdf (last accessed 8 March 2012); Hovell, D, The sovereignty stratagem - Australia's response to UN human rights treaty bodies, (2003) 28(6) AltLJ 297

3125 Article 5(4) of the (First) Optional Protocol to the International Covenant on Civil and Political Rights (1966). See further, Tomuschat, C, Human Rights - Between Idealism and Realism, 2008, OUP, Oxford, P.220-221 
is a concept that is not a complete stranger to the Australian legal sphere and, although elements of the principle have surfaced, it has not resulted in a full embrace of the classical understanding of the term. The assertion that immigration detention is non-punitive in its objective (and thus legitimate) has, as yet, not been the subject of successful challenge. The principle's failure to embed within the administrative and constitutional law spheres tracks the absence and abrogation of fundamental human rights in Australia - indeed, it goes some way to explaining the judiciary's inability (and, at times, seeming unwillingness) to overcome the hard-heartedness of parliament in legislating for, and the executive in enforcing, the mandatory, arbitrary and indefinite detention of those who have committed no crime.

\subsubsection{Alternatives to Detention in Australia}

\subsubsection{Mandatory Detention Context}

As has been discussed earlier herein, a discernible policy shift was announced in July 2008 regarding a needs-based approach to immigration detention. The then Minister for Immigration and Citizenship, Senator the Honourable Chris Evans, stated:

"Under Labor's reforms, persons will be detained only if the need is established. The presumption will be that persons will remain in the community while their immigration status is resolved. If a person is complying with immigration processes and is not a risk to the community then detention in a detention centre cannot be justified. The department will have to justify a decision to detain - not presume detention." 3126

The Minister further stated:

"The Government is interested in broadening alternative detention strategies, most particularly community-based options. The work of the federal parliamentary Joint Standing Committee on Migration will be critical in examining alternative pathways and taking forward a reform agenda." 3127

Firstly, at the outset, it is worth reiterating that a mandatory detention system is logically and legally at odds with a policy purporting to exercise a presumption against detention - a presumption that has not, as yet (and which seems ever unlikely to be) materialised into law. Secondly, as has been discussed in this chapter, Australian constitutional and administrative law has not seen the principle of proportionality operate effectively as regards immigration detention and, combined with a mandatory detention legislative

3126 Evans, Senator the Honourable, speech to the Australian National University in Canberra, 29 July 2008, New Directions in Detention - Restoring Integrity to Australia's Immigration System http://www.nswbar.asn.au/circulars/july/evans2.pdf (last accessed 13 March 2012) P.5

3127 Evans, Senator the Honourable, speech to the Australian National University in Canberra, 29 July 2008, New Directions in Detention - Restoring Integrity to Australia's Immigration System http://www.nswbar.asn.au/circulars/july/evans2.pdf (last accessed 13 March 2012) P.7 
framework, alternatives to detention cannot be considered (if at all) until after detention has taken place (unless a Bridging Visa is granted - which the Joint Standing Committee noted that it was the Department's policy to consider such a grant where appropriate and safe to do so). ${ }^{3128}$ Thirdly, the Minister appears to have chosen his words rather carefully. Attention should be drawn to the Minister's speech in which he stated, "If a person is complying with immigration processes and is not a risk to the community then detention in an immigration detention centre cannot be justified [emphasis added]" and to his choice of the words "alternative detention strategies" as opposed to "alternative to detention strategies" or "alternative strategies to detention". As has been discussed in Chapter 4 and which will be emphasised below, alternative forms of detention (that is other than in an immigration detention centre) under Australian law are indistinct from one another and do not amount to alternatives to detention. Indeed, that distinction is reflected in the Joint Standing Committee's Report of which Chapter 2 thereof separately considers alternatives to immigration detention centres and alternatives to immigration detention per se. ${ }^{3129}$ This distinction has been maintained throughout the 2011 announcement of an enhanced community detention scheme (having commenced in 2005), with care largely provided by the Red Cross and other community-based organisations, who are not in an immigration detention centre but still remain in detention for the purposes of the Migration Act. ${ }^{3130}$

\subsubsection{The Dividing Line - Alternative 'forms of' detention and alternatives 'to' detention}

Under the Migration Act, there is a bifurcated approach to detention which sets a clear delineation between detention and liberty - one is either an unlawful citizen, or not; one is either in detention, or not. However the Migration Act does not reflect the full continuum between liberty, restrictions of liberty and deprivations upon liberty. As was discussed in Chapter 4, there are alternative forms of detention that may range from different types of accommodation other than an immigration detention centre (such as immigration transit

\footnotetext{
3128 Parliament of Australia, Joint Standing Committee on Migration, Immigration detention in Australia: Community-based alternatives to detention, May 2009, Canberra, http://www.aph.gov.au/house/committee/mig/detention/report2/fullreport.pdf (last accessed 13 March 2012) P.25, para 2.42

3129 Parliament of Australia, Joint Standing Committee on Migration, Immigration detention in Australia: Community-based alternatives to detention, May 2009, Canberra, http://www.aph.gov.au/house/committee/mig/detention/report2/fullreport.pdf (last accessed 13 March 2012) Pp.24-25 para 2.37, P.144 paras 5.58-5.59

3130 Australian Government, Department of Immigration and Citizenship, Fact Sheet 83aCommunity Detention, http://www.immi.gov.au/media/fact-sheets/83acommunitydetention.htm (last accessed 13 March 2012); Australian Red Cross, Community detention program, http://www.redcross.org.au/community-detention-program.aspx (last accessed 13 March 2012); Parliament of Australia, Joint Standing Committee on Migration, Immigration detention in Australia: Community-based alternatives to detention, May 2009, Canberra, http://www.aph.gov.au/house/committee/mig/detention/report2/fullreport.pdf (last accessed 13 March 2012) Pp.22-24
} 
accommodation and immigration residential housing) as well as community detention by virtue of the Minister's powers under section 197AB of the Migration Act. Although these forms of detention may, in practice, represent part of the liberty/detention continuum (or less restrictive means of detention) that has been advocated in this book, the law makes no distinction between the various forms of immigration detention ${ }^{3131}$ (except for the case of minors who, if subject to a section $197 \mathrm{AB}$ residence determination are deemed not to be in immigration detention ${ }^{3132}$ and, bizarrely, those pending removal for offshore processing ${ }^{3133}$ ). The result is that, once in immigration detention, there is no way of asserting any right to a less restrictive means of detention such placements are a result of Departmental policy, discretion and capacity. ${ }^{3134}$ For example, a residence determination under section $197 \mathrm{AB}$ can only be made, varied or revoked by the Minister personally under section 197AF and is a non-compellable power under section 197AE of the Act.

\section{Community Detention}

Those in community detention are still detained for the purposes of the Migration Act and are so by a residence determination under section 197AB of the Act. ${ }^{3135}$ This should not be confused with those in the community on Bridging Visas (discussed below). The Australian Red Cross has been contracted by DIAC as the chief service provider for those in community detention. ${ }^{3136}$ Accommodation is sourced by either the Australian Red Cross or DIAC. ${ }^{3137}$ The Australian Red Cross then rents that accommodation for the detainees, provides (together with other NGOs) basic furnishing and linen,

\footnotetext{
3131 See Chapter 4 herein and section 5(1) of the Migration Act 1958 (Cth)

3132 Section 4AA(2) of the Migration Act 1958 (Cth)

3133 Section 198A(4) of the Migration Act 1958 (Cth)

3134 For example, note the criteria applicable for eligibility for immigration residential housing - Australian Government, Department of Immigration and Citizenship, Fact Sheet 83 - Immigration Residential Housing http://www.immi.gov.au/media/factsheets/83rhps.htm (last accessed 13 March 2012)

3135 See further, Parliament of Australia, Joint Standing Committee on Migration, Immigration detention in Australia: Community-based alternatives to detention, May 2009, Canberra, $\quad$ http://www.aph.gov.au/house/committee/mig/detention/report2/ fullreport.pdf (last accessed 13 March 2012), P.23, para 2.30

3136 Australian Government, Department of Immigration and Citizenship, Fact Sheet 83aCommunity Detention, http://www.immi.gov.au/media/fact-sheets/83acommunitydetention.htm (last accessed 13 March 2012); Parliament of the Commonwealth of Australia, Joint Standing Committee on Migration, Immigration detention in Australia: Community-based alternatives to detention, May 2009, Canberra, http://www.aph.gov.au/house/committee/mig/detention/report2/fullreport.pdf (last accessed 13 March 2012), P.23, para 2.32

3137 Parliament of Australia, Joint Standing Committee on Migration, Immigration detention in Australia: Community-based alternatives to detention, May 2009, Canberra, http://www.aph.gov.au/house/committee/mig/detention/report2/fullreport.pdf (last accessed 13 March 2012), P.70, para 3.48
} 
and pays a basic living allowance at $89 \%$ of the Centrelink Special Benefit. ${ }^{3138}$ Medical services are provided through the DIAC contractor, IHMS, who in turn provides medical services through third party providers. ${ }^{3139}$ Those in community detention cannot engage in paid work and cannot access Medicare. ${ }^{3140}$ Reporting and residence requirements are imposed as well as other conditions particular to the individual's case. ${ }^{3141}$ As children with families are meant to be detained in community detention (although may be detained in IRH, ITA or alternative temporary detention whilst pending removal, processing or sourcing appropriate accommodation), ${ }^{3142}$ children can access primary and secondary schooling and attend English language classes. ${ }^{3143}$

\section{Bridging Visas}

In terms of genuine alternatives to detention in the Australian context, this is achieved through the use of Bridging Visas - a temporary visa that gives the holder temporary 'lawful' status and thus the ability to remain in the community while their substantive visa application is being determined. However, it is important to note that the use of the Bridging Visa framework does not amount to an assessment of any substantive right to liberty per se - it is primarily based on eligibility. That is, certain very specific criteria need to be fulfilled by the asylum seeker in detention before being eligible for a grant. The Act and Regulations are entirely byzantine in this respect. ${ }^{3144}$ Once the eligibility criteria have been satisfied, certain conditions may be imposed either mandatorily or on a discretionary basis. Even if liberty through the use of a

3138 Parliament of Australia, Joint Standing Committee on Migration, Immigration detention in Australia: Community-based alternatives to detention, May 2009, Canberra, http://www.aph.gov.au/house/committee/mig/detention/report2/fullreport.pdf (last accessed 13 March 2012), P.23, para 2.33; P.57, para 3.8

3139 Parliament of Australia, Joint Standing Committee on Migration, Immigration detention in Australia: Community-based alternatives to detention, May 2009, Canberra, http://www.aph.gov.au/house/committee/mig/detention/report2/fullreport.pdf (last accessed 13 March 2012), Pp.65-66, para 3.31

3140 Parliament of Australia, Joint Standing Committee on Migration, Immigration detention in Australia: Community-based alternatives to detention, May 2009, Canberra, http://www.aph.gov.au/house/committee/mig/detention/report2/fullreport.pdf (last accessed 13 March 2012), P.23 para 2.32; P.61, para 3.19

3141 Parliament of Australia, Joint Standing Committee on Migration, Immigration detention in Australia: Community-based alternatives to detention, May 2009, Canberra, http://www.aph.gov.au/house/committee/mig/detention/report2/fullreport.pdf (last accessed 13 March 2012), P.23, para 2.31

3142 Parliament of Australia, Joint Standing Committee on Migration, Immigration detention in Australia: Community-based alternatives to detention, May 2009, Canberra, http://www.aph.gov.au/house/committee/mig/detention/report2/fullreport.pdf (last accessed 13 March 2012), Pp.81-82, para 3.93

3143 Parliament of Australia, Joint Standing Committee on Migration, Immigration detention in Australia: Community-based alternatives to detention, May 2009, Canberra, http://www.aph.gov.au/house/committee/mig/detention/report2/fullreport.pdf (last accessed 13 March 2012), P. 24, para 2.35

3144 Note the comments of Madgwick J in Mouradian v Migration Review Tribunal [2001] FCA 1413 at para 8 "The density of the delegated legislation would challenge anybody". 
Bridging Visa has been granted, concerns have been expressed that the conditions imposed (particularly the "no work" (8101) condition) have led asylum seekers in the community to a type of forced destitution. For those asylum seekers particularly destitute or vulnerable in the community on Bridging Visas, two particular schemes are designed to provide assistance - the Asylum Seeker Assistance Scheme ("ASAS") and the Community Assistance Support programme ("CAS") (formerly the Community Care Pilot Programme ("CCP")). However, the narrow eligibility criteria to access those schemes have again raised concerns for the ongoing welfare of asylum seekers in the community. The picture that emerges from an analysis of the law is that detained asylum seekers face multiple juridical and practical hurdles - firstly, to be eligible for a Bridging Visa; secondly, the conditions (both mandatory and discretionary) that are imposed on the grant of such visas; and thirdly, once at liberty, and in the face of hardship, the satisfaction of further eligibility criteria in order to access the assistance schemes.

Accordingly, the examination that will take place will firstly look at eligibility criteria for Bridging Visas, secondly, conditions on the grant of the Bridging Visa and lastly access to the assistance schemes. The examination is predicated on the basis of an asylum seeker already being in detention.

\subsubsection{Eligibility for a Bridging Visa}

\section{Offshore Entry Persons and Transitory Persons}

As outlined in previous chapters, there are certain categories of person who are unable to make a valid application for a visa of any kind, including a Bridging Visa. These include offshore entry persons who are detained in an excised offshore place (such as on Christmas Island to where the policy has been to transfer all irregular arrivals), ${ }^{3145}$ and transitory persons ${ }^{3146}$ (who are only able to make an application to the RRT for determination as to whether they are covered by Article $1 \mathrm{~A}$ of the Refugee Convention after being in Australia for six months). ${ }^{3147}$ Persons in those circumstances can only make a valid visa application if the Minister exercises his or her discretion to 'lift the bar'. ${ }^{3148}$ The exercise of that discretion is personal and non-compellable. ${ }^{3149}$

\footnotetext{
3145 Section 46A of the Migration Act 1958 (Cth). See also section 198A(4) of the Migration Act 1958 (Cth) which deems excised offshore entry persons to be sent to another country for offshore processing not to be in immigration detention - see further, the comments of French CJ in M70/2011 v Minister for Immigration and Citizenship; M106/2011 v Minister for Immigration and Citizenship [2011] HCA 32 at 11 where the Chief Justice noted: "According to the Explanatory Memorandum for the 2001 Excision Consequential Provisions Bill those words mean that a person is not in "immigration detention'... merely because the person is being dealt with under section 198A." They plainly do not and cannot bear that meaning. They explicitly exclude a person who is being dealt with under $\mathrm{s}$ 198A from being in immigration detention for any other purposes under the Act."

3146 Section 46B of the Migration Act 1958 (Cth)

3147 Section 198C of the Migration Act 1958 (Cth)

3148 Sections 46A(2) and 46B(2) of the Migration Act 1958 (Cth)

3149 Sections 46A(3) and (7) and 46B(3) and (7) of the Migration Act 1958 (Cth)
} 
The Minister may also exercise a personal and non-compellable discretion to grant a visa whether an application has been made by the person or not. ${ }^{3150}$ Accordingly, for those persons, any alternatives to detention rest entirely within the executive discretion.

It will be recalled from Chapter 3 that the Government announced that its decision to process boat arrivals (that is, those taken to Christmas Island, in the excision zone) under the same system as air arrivals and issue boat arrivals with Bridging Visas with work rights attached as well as access to Medicare. ${ }^{3151}$

\section{Applicants within the Migration Zone}

For those applicants that are not legislatively precluded from making an application for a Bridging Visa, the Act and Regulations govern the criteria for eligibility of Bridging Visas. A person must first be an "eligible non-citizen" in order to make an application for a Bridging Visa.

\section{"Eligible non-citizens"}

Firstly, "eligible non-citizens" includes those that have been "immigration cleared" 3152 - this is inclusive of those that have arrived and entered the migration zone on a valid visa but does not include unlawful arrivals (that is, those that have not entered with a valid visa and are not immigration cleared either because they have avoided or been refused immigration clearance).

Secondly, the term refers to those who have been prescribed in the Migration Regulations as eligible non-citizens. ${ }^{3153}$ Relevantly for asylum seekers, this includes those detained who are under the age of 18 years where it has inter alia been certified by State or Territory child welfare authorities that it is in the minor's best interest to be released ${ }^{3154}$ and those non-citizens who have bypassed immigration clearance and remained undetected by the Department of Immigration for at least 45 days. ${ }^{3155}$ For those protection visa applicants that have bypassed or been refused immigration clearance and come to the

\footnotetext{
3150 Section 195A of the Migration Act 1958 (Cth)

3151 Bowen, The Honourable Chris, Minister for Immigration and Citizenship, Bridging visas to be issue for boat arrivals, 25 November 2011, http://www.minister.immi.gov.au/ media/cb/2011/cb180599.htm (last accessed 27 April 2012); Australian Government, Department of Immigration and Citizenship, Fact Sheet 65 - Onshore processing arrangements for irregular maritime arrivals, http://www.immi.gov.au/media/fact-sheets/65onshoreprocessing-irregular-maritime-arrivals.htm (last accessed 17 July 2012); Needham, K, Boat refugees will be assessed as air arrivals, Sydney Morning Herald, 20 March 2012, http://www.smh.com.au/opinion/political-news/boat-refugees-will-be-assessed-as-airarrivals-20120319-1vfrn.html (last accessed 27 April 2012)

3152 Section 72(1)(a) of the Migration Act 1958 (Cth); see sections 5(1) and 172 for the definition of "immigration clearance"; "enters Australia" means enter the migration zone see section $5(1)$

3153 Section 72(1)(b) of the Migration Act 1958 (Cth)

3154 Regulation 2.20(5) of the Migration Regulations 1994 (Cth)

3155 Regulation 2.20(6) of the Migration Regulations 1994 (Cth)
} 
attention of the Department of Immigration within 45 days, this includes minors,${ }^{3156}$ those older than 75 years of age,${ }^{3157}$ those who have "special needs" on account of health, trauma or torture, ${ }^{3158}$ and those spouses or de facto partners of Australian citizens ${ }^{3159}$ (including members of the same family unit) ${ }^{3160}$ who are awaiting the outcome of their protection visa application or are the subject of an application (either by the applicant or the Minister) for judicial review of a decision to refuse the protection visa. Finally, the Regulations provide that those in detention whose removal from Australia the Minister is satisfied "is not reasonably practicable at that time" (but the Minister must also be satisfied that the non-citizen will do everything possible to facilitate his or her removal from Australia and any visa applications (except for Ministerial intervention under section $48 \mathrm{~B}$ of the Act) have been finally determined). ${ }^{3161}$ However, note that those pending removal must have been given an "invitation in writing" by the Minister to apply for the bridging visa in order for an application for it to be valid. ${ }^{3162}$

Thirdly, a person may be determined by the Minister to be an "eligible noncitizen". ${ }^{3163}$ However, there are several important qualifications on any such determination. The determination is only applicable to those protection visa applicants who have been in detention for six months after making their protection visa application ${ }^{3164}$ and in circumstances where the Minister has not made a primary decision in relation to the protection visa application. ${ }^{3165}$ Further, the determination can only be made by the Minister personally ${ }^{3166}$ with such determinations being non-compellable. ${ }^{3167}$ Lastly, the Minister must consider the determination to be in the "public interest". 3168

Accordingly, what can be gleaned from this first juridical hurdle is that those who have arrived and entered Australia with a valid visa are not subject to the same degree of stringency in the criteria as those who arrive 'unlawfully'. Secondly, the class of prescribed persons is limited essentially to the young, the particularly vulnerable, the elderly, and spouses or partners of Australian citizens (and those within the same family unit). Thirdly, although those whose removal is not reasonably practicable are also prescribed "eligible non-

\footnotetext{
3156 Regulation 2.20(7) of the Migration Regulations 1994 (Cth)

3157 Regulation 2.20(8) of the Migration Regulations 1994 (Cth)

3158 Regulation 2.20(9) of the Migration Regulations 1994 (Cth)

3159 Regulation 2.20(10) of the Migration Regulations 1994 (Cth)

3160 Regulation 2.20(11) of the Migration Regulations 1994 (Cth)

3161 Regulation 2.20(12) of the Migration Regulations 1994 (Cth)

3162 Regulation 2.20A of the Migration Regulations 1994 (Cth)

3163 Section 72(1)(c) of the Migration Act 1958 (Cth)

3164 Section 72(2)(c) of the Migration Act 1958 (Cth)

3165 Section 72(2)(d) of the Migration Act 1958 (Cth)

3166 Section 72(3) of the Migration Act 1958 (Cth)

3167 Section 72(7) of the Migration Act 1958 (Cth)

3168 Section 72(2)(e), (4)-(6) of the Migration Act 1958 (Cth)
} 
citizens", ${ }^{3169}$ the criteria contemplated by the Regulations and the requirement for Ministerial invitation in order for the application to be valid essentially leave those persons' liberty entirely within the discretion of the Minister - the same applies to those who are determined by the Minister to be eligible noncitizens. Fourthly, a number of the criteria for the prescribed eligible noncitizens must be to the Minister's satisfaction - that is, it is not a question of objective fact but rather, by the adoption of that terminology, the fulfilment of the criteria is always weighted in favour of the Minister. ${ }^{3170}$

\subsubsection{Classes of Bridging Visas}

It does not follow that an applicant who falls within the definition of "eligible non-citizen" is entitled to all classes of Bridging Visas. The class of visa ascribes particular criteria and conditions. Accordingly, additional criteria pertinent to the class of visa determines which bridging visa (if any) is applicable to the circumstances of the person concerned.

There are seven classes of bridging visa which are somewhat hierarchical in nature - A, B, C, D, E, F and R. Bridging visas A to D inclusive do not apply to those in immigration detention. ${ }^{3171}$

Each class of Bridging Visa has criteria that must be satisfied by the "eligible non-citizen" in order for a grant to be made for a particular Bridging Visa. ${ }^{3172}$ The type of Bridging Visa granted can be influenced by factors such as whether the person has been immigration cleared, circumstances particular to the applicant, whether he or she held a substantive visa at the time of making the application for a Bridging Visa and the conditions attached to their substantive visa (or previously held Bridging Visa) at the time of applying for a

3169 In response to the High Court decision in Al Kateb (discussed supra) which held that indefinite detention of a person whose removal was not reasonably foreseeable was legal 3170 See for example, Regulation 2.20(5)(d) in relation to minors where the Minister must be satisfied that arrangements for care and welfare have been made between the non-citizen minor and an Australian citizen, permanent resident or eligible New Zealand citizen; that the arrangements must be in the best interests of the non-citizen; and that the rights or interests of any guardian or custodian would not be or not reasonably expected to be prejudiced. Section 73 of the Migration Act 1958 (Cth) is itself couched in terms of "If the Minister is satisfied".

${ }^{3171}$ For Bridging Visa A, see Schedule 1 Item 1301(3)(f) to the Migration Regulations 1994 (Cth); Bridging Visa B, Schedule 1 Item 1302(3)(c) to the Migration Regulations; Bridging Visa C, Schedule 1 Item 1303(3)(e) to the Migration Regulations; Bridging Visa D, Schedule 1 Item 1304(3)(c) to the Migration Regulations.

3172 For Bridging Visa A see Item 1301(3) Schedule 1 and Clause 010.21 Schedule 2 to the Migration Regulations 1994 (Cth); Bridging Visa B Item 1302(3) Schedule 1 and Clause 020.21 Schedule 2; Bridging Visa C Item 1303(3) Schedule 1 and Clause 030.21 Schedule 2; Bridging Visa D Item 1304(3) Schedule 1 and Clauses 040.21 and 041.21 Schedule; Bridging Visa E Item 1305(3) Schedule 1 and Clauses 050.21 and 051.21 Schedule 2; Bridging Visa F Item 1306(3) Schedule 1 and Clauses 060.21 (no criteria applicable at time of application) and 060.22 (criteria applicable at time of decision) Schedule 2; Bridging Visa R Item 1307(3) Schedule 1 and Clause 070.21 Schedule 2 
Bridging Visa (which is a particular consideration in relation to work rights). The type of Bridging Visa granted also carries with it particular conditions that either must be imposed, or are subject to discretion. ${ }^{3173}$ Accordingly, for those asylum seekers that arrive in Australia with a valid visa, the multitude of circumstances in which an asylum seeker may arrive and the number of substantive visas they may putatively hold upon entry, in addition to the complexity of the Bridging Visa criteria and any discretion imposed as regards conditions, means that it is extremely difficult to definitively advise what Bridging Visa will be granted (or indeed, for which Bridging Visa he or she will be eligible) in the absence of the particular facts of the case.

In very general terms, the Bridging Visa classes are as follows: ${ }^{3174}$ Bridging Visa A is for persons who already have a substantive visa when applying for a further substantive visa. The visa does carry work rights if work rights were ascribed to the substantive visa that he or she held. Bridging Visa B is for Bridging Visa A or B holders who need to leave and re-enter Australia whilst their substantive visa is being finally determined.

If the person makes an application for a substantive visa, but does not hold a substantive visa at the time of making that application, and has remained undetected by the DIAC but has subsequently presented him or herself, then a Bridging Visa $\mathrm{C}$ is granted. Work rights are not provided with this visa unless a "compelling need to work" is demonstrated (which will be discussed below).

Bridging Visa D provides two subclasses: subclass 040 is for an unlawful noncitizen or a citizen who will become unlawful within three working days to provide a limited period of time to make a substantive visa application; subclass 041 is to enable those who are unable or not proposing to make a substantive visa application.

3173 For Bridging Visa A see Clause 010.6 Schedule 2 to the Migration Regulations 1994 (Cth); Bridging Visa B Clause 020.6 Schedule 2 to the Migration Regulations; Bridging Visa C Clause 030.4 Schedule 2 to the Migration Regulations; Bridging Visa D Clauses 040.6 and 041.6 Schedule 2 to the Migration Regulations; Bridging Visa E Clauses 050.6 and 051.6 Schedule 2 to the Migration Regulations; Bridging Visa F Clause 060.6 Schedule 2 to the Migration Regulations; Bridging Visa R Clause 070.6 Schedule 2 to the Migration Regulations; see also Schedule 8 to the Migration Regulations which decipher the numeric condition codes attached to particular visas.

3174 Australian Government, Department of Immigration and Citizenship, Bridging Visas Form 1024i, http://www.immi.gov.au/allforms/pdf/1024i.pdf (last accessed 14 March 2012); Crock, M, and Berg, L, Immigration, Refugees and Forced Migration - Law Policy and Practice in Australia, 2011, Federation Press, Leicchardt, Pp.495-500; Vrachnas, J, Boyd, K, Bagaric, M, Dimopoulos, P, Migration and Refugee Law - Principles and Practice in Australia, 2ed, 2008, Pp.141-144; see also Parliament of Australia, Joint Standing Committee on Migration, Immigration detention in Australia: Community-based alternatives to detention, May 2009, Canberra, http://www.aph.gov.au/house/committee/mig/detention/report2/ fullreport.pdf (last accessed 13 March 2012) 
Bridging Visa $\mathrm{E}$ is a general class of bridging visa and is the class most regularly concerned with asylum seekers in detention in the Migration Zone. It consists of a general subclass (050) and a protection visa applicant subclass (051).

Bridging Visa $F$ relates to those who have been the subject of human trafficking.

Bridging Visa $\mathrm{R}$ relates to those detained pending removal from Australia but whose removal is not reasonably practicable at the time.

What is important for the purposes of this analysis is that for those asylum seekers who arrive unlawfully in the Migration Zone and are detained, as well as for those failed asylum seekers who are detained pending their removal from Australia, the relevant Bridging Visas available to them in detention are the Bridging Visa $\mathrm{E}$ and the Bridging Visa $\mathrm{R}$ respectively. ${ }^{3175} \mathrm{It}$ is to those two classes of Bridging Visa that attention will now turn.

\subsection{Bridging Visa E}

Subclass 050 - General Class

\section{General Eligibility}

Bridging Visa E subclass 050 is a general class of Bridging Visa. It is chiefly concerned with unlawful non-citizens (who may or may not be in detention), existing holders of either a Bridging Visa D or E and those Protection Visa applicants who are not covered by subclass 051 (see below - namely, those under the age of 18 or above the age of 75 , those particularly vulnerable on account of health or prior torture and family members thereof). ${ }^{3176}$

\section{Particular Requirements}

In order to be granted a Bridging Visa E, particular requirements must be met. ${ }^{3177}$ Accordingly, there are 17 different sets of requirements, the fulfilment of one may allow an applicant to be eligible for the grant of a Bridging Visa E. Although to reproduce an exhaustive list of the requirements leads to somewhat Kafkaesque results, these include most relevantly for asylum seekers: (1) a person who is making acceptable arrangements to depart Australia; ${ }^{3178}$ (2)

\footnotetext{
3175 Although outside the scope of this book, those persons the victims of human trafficking may also make an application in detention for Bridging Visa F - see Item 1306 Schedule 1 and Clause 060 Schedule 2 to the Migration Regulations 1994 (Cth)

3176 Clauses 050.211 of Schedule 2 to the Migration Regulations 1994 (Cth); see also Australian Government, Department of Immigration and Citizenship, Bridging Visas - Form 1024i, http://www.immi.gov.au/allforms/pdf/1024i.pdf (last accessed 20 March 2012), P.2 3177 Clause 050.212(1) of Schedule 2 to the Migration Regulations 1994 (Cth)

3178 Clause 050.212(2) of Schedule 2 to the Migration Regulations 1994 (Cth). In relation to "acceptable arrangements to depart" see Huang $v$ Minister for Immigration and Multicultural Affairs [2001] FCA 284 paras 11 and 21; Chen v Minister for Immigration and Multicultural Affairs [2001] FCA 285 paras 11 and 21; Smith v Minister for Immigration Multicultural and Indigenous Affairs [2002] FCA 306; Ahmed v Minister for Immigration and Multicultural Affairs [1999] FCA 430 paras $7-8$ (MRT findings a question of fact); Arkan $v$ Minister for
} 
an application for a substantive visa has been made in Australia that has not been finally determined or the person will so apply for a substantive visa within a specified timeframe (this includes Protection Visas) $;^{3179}$ (3) the judicial review of a decision to refuse a substantive visa; ${ }^{3180}$ (4) those seeking initial ministerial intervention under sections $48 \mathrm{~B}^{3181}$ or $417^{3182}$ of the Act; (5) those who are criminally detained; ${ }^{3183}$ (6) those existing Bridging Visa E holders who are Protection Visa applicants subject to a no-work condition and the Minister is satisfied that the person has both a "compelling need to work" and has given acceptable reasons for the delay in making his or her Protection Visa application. $^{3184}$

\section{No-work Condition}

Generally, holders of Bridging Visa Es are not given permission to work. ${ }^{3185}$ Much depends on the conditions imposed on any previously held visa and the circumstances of the applicant. ${ }^{3186}$ Relevantly for protection visa applicants ${ }^{3187}$ granted a Bridging Visa E subclass 050, a mandatory no-work condition (8101) is imposed, ${ }^{3188}$ particularly if the applicant is seeking judicial review or ministerial intervention ${ }^{3189}$ (except where the person was not unlawful between the final determination of the substantive visa and the request for ministerial intervention, then a no-work condition must be imposed if the last visa held imposed a no-work condition ${ }^{3190}$ ). The Joint Standing Committee noted in 2009 that work rights expire for Bridging Visa E holders beyond the merits review stage (that is, once judicial review or ministerial intervention is

\footnotetext{
Immigration and Multicultural Affairs [2000] FCA 1134 para 9 (MRT findings a question of fact)

3179 Clause 050.212(3) of Schedule 2 to the Migration Regulations 1994 (Cth)

3180 Clause 050.212(3A) and (4) of Schedule 2 to the Migration Regulations 1994 (Cth)

3181 Clause 050.212(5B) of Schedule 2 to the Migration Regulations 1994 (Cth)

3182 Clause 050.212(6) of Schedule 2 to the Migration Regulations 1994 (Cth)

3183 Clause 050.212(7) of Schedule 2 to the Migration Regulations 1994 (Cth)

3184 Clause 050.212(8) of Schedule 2 to the Migration Regulations 1994 (Cth)

3185 Crock, M, and Berg, L, Immigration, Refugees and Forced Migration - Law Policy and Practice in Australia, 2011, Federation Press, Leichhardt, P.497

3186 Parliament of the Commonwealth of Australia, Joint Standing Committee on Migration, Immigration detention in Australia: Community-based alternatives to detention, May 2009, Canberra, http://www.aph.gov.au/house/committee/mig/detention/report2/ fullreport.pdf (last accessed 13 March 2012), P.29, para 2.50

3187 That is, Protection Visa applicants who are otherwise eligible for a Bridging Visa subclass 051 are expressly excluded from subclass 050 - see 050.211(2) of Schedule 2 to the Migration Regulations 1994 (Cth)

3188 Clause 050.613A of Schedule 2 to the Migration Regulations 1994 (Cth)

3189 Clauses 050.614 and 050.615A of Schedule 2 to the Migration Regulations 1994 (Cth)

3190 Clause 050.615 of Schedule 2 to the Migration Regulations 1994 (Cth); see also Clause 050.616 of Schedule 2 to the Migration Regulations 1994 (Cth) in relation to those applicants for ministerial intervention who made an initial application before 1 July 2009, held a Bridging Visa before 1 July 2009, have a compelling need to work and where the Minister's decision is still pending.
} 
sought). ${ }^{3191}$ DIAC states that persons are ineligible for work rights if on a Bridging Visa E whilst seeking judicial review or ministerial intervention "except in limited circumstances". ${ }^{3192}$ General residuary discretion is given to impose certain conditions "in any other case" including no-work or limited work conditions. ${ }^{3193}$ From 1 July 2009, the Government removed the requirement that a person must lodge an application for a Protection Visa within 45 days of their arrival in Australia in order to be eligible for work rights under this subclass. ${ }^{3194}$ Note, however, as discussed below, this is still a relevant consideration for those Protection Visa applicants under subclass 051.

In order to have the no-work condition removed (or at least replaced with a limited work (8104) condition), applicants are required to show a "compelling need to work" which will be discussed below.

Bridging Visa E holders are not eligible for income support through Centrelink (social security). ${ }^{3195}$

\subsection{Bridging Visa E}

Subclass 051 - Particular Protection Visa Applicants

General Eligibility

Subclass 051 deals chiefly with those protection visa applicants who have been refused or bypassed immigration clearance and are under a particular

3191 Parliament of Australia, Joint Standing Committee on Migration, Immigration detention in Australia: Community-based alternatives to detention, May 2009, Canberra, http://www.aph.gov.au/house/committee/mig/detention/report2/fullreport.pdf (last accessed 20` March 2012), P.30 para 2.51

3192 Australian Government, Department of Immigration and Citizenship, Bridging Visas Form 1024i, http://www.immi.gov.au/allforms/pdf/1024i.pdf (last accessed 20 March 2012), P.2. See further, Australian Government, Department of Immigration and Citizenship, Bridging Visa E - Primary Processing, Judicial and Merits Review, http://www.immi.gov.au/refugee/permission/e-review.htm (last accessed 20 March 2012); Australian Government, Department of Immigration and Citizenship, Bridging Visa E Ministerial Intervention, http://www.immi.gov.au/refugee/permission/e-ministerial.htm (last accessed 20 March 2012).

3193 Clause 050.617 of Schedule 2 to the Migration Regulations 1994 (Cth)

3194 Australian Government, Department of Immigration and Citizenship, New Permission to Work Arrangements, http://www.immi.gov.au/refugee/permission/ (last accessed $20 \mathrm{March}$ 2012); Bridging Visa E - Primary Processing, Judicial and Merits Review, http://www.immi.gov.au/refugee/permission/e-review.htm (last accessed 20 March 2012); Bridging Visa E - Ministerial Intervention, http://www.immi.gov.au/refugee/permission/eministerial.htm (last accessed 20 March 2012); see also Australian Human Rights Commission, Australian Human Rights Commission welcomes the removal of the 45-day rule for bridging visas and abolition of immigration debt, 9 September 2009, http://www.hreoc.gov.au/about/media/media_releases/2009/84_09.html (last accessed 20 March 2012).

3195 Parliament of Australia, Joint Standing Committee on Migration, Immigration detention in Australia: Community-based alternatives to detention, May 2009, Canberra, http://www.aph.gov.au/house/committee/mig/detention/report2/fullreport.pdf (last accessed 20 March 2012) at P.32 para 2.61, P.33 Table 2.5, P.57 para 3.9 
vulnerability - this means: (1) they are aged less than 18 or more than 75 years of age; or (2) have been certified by a DIAC appointed medical specialist that the person "cannot properly be cared for in a detention environment" by virtue of having a "special need (based on health or previous experience of torture or trauma)[emphasis added]"); or (3) are a spouse or de facto partner of an Australian citizen or permanent resident or of an eligible New Zealand citizen, together with family members thereof or members of the same family unit. $^{3196}$

Importantly, an additional eligibility criterion is that subclass 051 only applies for those persons who have come to the attention of DIAC within 45 days of entering Australia. ${ }^{3197}$

Accordingly, the cumulative effect of the criteria presents a very narrow range of eligibility for Protection Visa applicants.

Further, an additional criterion is that those persons otherwise eligible must sign an undertaking that they will depart Australia or present themselves to DIAC for removal within 28 days after the rejection of their application or the cessation of judicial review of the decision. ${ }^{3198}$ Applicants are still required to meet health and public interest criteria. ${ }^{3199}$

\section{Work Rights}

A mandatory no-work condition is imposed on this subclass of Bridging Visa for those who are granted a visa deemed by the effluxion of time under section 75 of the Act ${ }^{3200}$ and/or those persons who have spent periods of 45 days or more in Australia over the 12-month period preceding the making of the application for a Protection Visa. ${ }^{3201}$ A residuary discretion "in any other case" is given to impose a range of conditions including no-work or limited work conditions. ${ }^{3202}$

\subsection{Bridging Visa $R$}

Bridging Visa $R$ is granted to those in detention whose removal from Australia the Minister is satisfied is "not reasonably practicable at that time". As outlined earlier, the Minister must be satisfied that the person "will do everything possible to facilitate" their removal from Australia and that any visa application (with the exception of a request for ministerial intervention under section 48B of the Act) has been finally determined and who is "taken to have made an

\footnotetext{
3196 Clause 051.212 of Schedule 2 to the Migration Regulations 1994 (Cth)

3197 Clause 051.212 of Schedule 2 and Regulation 2.20 (7), (8), (9), (10), and (11) to the Migration Regulations 1994 (Cth)

3198 Clause 051.212 of Schedule 2 to the Migration Regulations 1994 (Cth)

3199 Clause 051.213 of Schedule 2 to the Migration Regulations 1994 (Cth)

3200 Clause 051.611 of Schedule 2 to the Migration Regulations 1994 (Cth)

3201 Clause 051.611A(1) and (2) of Schedule 2 to the Migration Regulations 1994 (Cth)

3202 Clause 051.612 of Schedule 2 to the Migration Regulations 1994 (Cth)
} 
application" (that is, if the Minister invites the person in writing to make an application for a Bridging Visa $\mathrm{R}$ and the person accepts that invitation within seven days of its receipt). ${ }^{3203}$ The Minister also needs to be satisfied that the person will abide by the visa conditions. ${ }^{3204}$ The public interest criteria also need to be satisfied. ${ }^{3205}$ Accordingly, in effect, this is a visa granted entirely at the discretion of the Minister.

Bridging Visa $\mathrm{R}$ holders are given permission to work and may receive income support from Centrelink (social security). ${ }^{3206}$

\subsubsection{4 "Compelling Need to Work"}

If a Bridging Visa holder is eligible to seek permission to work, then Regulation 1.08 of the Migration Regulations 1994 (Cth) provides that a "compelling need to work" is where a non-citizen is inter alia in "financial hardship". ${ }^{3207}$ According to DIAC, this means that evidence must be provided that the person's cost of "reasonable living expenses exceeds [his or her] ability to pay for them." 3208

In practice, Bridging Visa $\mathrm{E}$ holders who are given a no-work (8101) condition effectively make a fresh application for a new Bridging Visa $\mathrm{E}$ with work rights by submitting Form 1005. ${ }^{3209}$ It will be recalled that those applicants are expressly contemplated as one of the eligibility requirements discussed earlier in relation to Bridging Visa E subclass $050 .{ }^{3210}$ However, in

3203 Clause 070.211 of Schedule 2 to the Migration Regulations 1994 (Cth) which refers to Regulations 2.20(12) and 2.20A of the Migration Regulations 1994 (Cth) for the fulfillment of the criteria for the grant of that visa.

3204 Clause 070.222 of Schedule 2 to the Migration Regulations 1994 (Cth)

3205 Clause 070.223 of Schedule 2 to the Migration Regulations 1994 (Cth)

3206 Parliament of Australia, Joint Standing Committee on Migration, Immigration detention

in Australia: Community-based alternatives to detention, May 2009, Canberra, http://www.aph.gov.au/house/committee/mig/detention/report2/fullreport.pdf (last accessed 20 March 2012) at P.33 Table 2.5, P.57 para 3.9

3207 Further, it may be necessary for Protection Visa applicants who hold Bridging Visa Es and who entered Australia on a substantive visa to demonstrate "an acceptable reason for delay" - namely, why the applicant "(a) did not apply for a Protection visa after [his or her] arrival in Australia whilst [he or she] held a substantive visa; and (b) why [he or she has] now applied for a Protection visa after [his or her] substantive visa has ceased." Australian Government, Department of Immigration and Citizenship, Bridging Visas - Form 1024i, http://www.immi.gov.au/allforms/pdf/1024i.pdf (last accessed 20 March 2012), P.3. This is consistent with the requirement in Clause 050.212(8) of Schedule 2 to the Migration Regulations 1994 (Cth) discussed above.

3208 Australian Government, Department of Immigration and Citizenship, Bridging Visa EPrimary Processing, Judicial and Merits Review, http://www.immi.gov.au/refugee/permission/ e-review.htm (last accessed 20 March 2012)

3209 Australian Government, Department of Immigration and Citizenship, Bridging Visas Form 1024i, http://www.immi.gov.au/allforms/pdf/1024i.pdf (last accessed 20 March 2012), P.2.

3210 Clauses 050.212(8) (eligibility) and 050.613 (conditions) of Schedule 2 to the Migration Regulations 1994 (Cth) 
2006, the Law Council of Australia noted that where an applicant had made an application for a subsequent Bridging Visa $\mathrm{E}$ with work rights, it had been the practice of DIAC to grant a Bridging Visa E with the no-work (8101) condition in place rather than to refuse the grant of the visa outright. ${ }^{3211}$ The consequence of simply re-issuing a Bridging Visa $\mathrm{E}$ with the no-work condition rather than refusing the grant altogether was that applicants were then unable to have the refusal decision subject to merits review before the MRT. Accordingly, applicants were unable to have any recourse for the refusal of their request to be able to work. Unsurprisingly, the Law Council of Australia considered such action by DIAC "not [to be] a bona fide exercise of power". 3212

The imposition of a no-work condition can deliver extremely harsh outcomes for holders of Bridging Visas. This is particularly so if Protection Visa applicants are pursuing judicial review or ministerial intervention as the inability to work can simultaneously dissuade applicants from pursuing those avenues as well as snuff the ability to pay professionals to assist in those processes and hence indirectly prejudice applicants' prospects of success. This is only in addition to the considerable pressure such restrictions place on the well-being of applicants and any dependants they may have. One can only speculate that it may create indirect pressure on applicants to leave Australia after merits review has been undertaken. In 2009, the Joint Standing Committee noted the concerns of many inquiry participants that a lack of work rights without income support was "equivalent to enforced destitution for some people". ${ }^{3213}$ The Joint Standing Committee also heard evidence that the desperation of Bridging Visa holders to seek work can lead to exploitation. $^{3214}$

The unfairness of mandatory restrictions on work rights for some Bridging Visa holders has not gone without judicial notice. In De Silva, ${ }^{3215}$ the applicant

\footnotetext{
3211 Law Council of Australia, Review of Bridging Visas - Submission by the International Law Section of the Law Council of Australia, 7 August 2006 http://www.lawcouncil.asn.au /shadomx/apps/fms/fmsdownload.cfm?file_uuid=8C745FD0-1C23-CACD-22DC92835705A9D9\&siteName =lca (last accessed 21 March 2012), Pp.5-6

3212 Law Council of Australia, Review of Bridging Visas - Submission by the International Law Section of the Law Council of Australia, 7 August 2006 http://www.lawcouncil.asn.au /shadomx/apps/fms/fmsdownload.cfm?file_uuid=8C745FD0-1C23-CACD-22DC92835705A9D9\&siteName $=$ lca (last accessed 21 March 2012), P.5

3213 Parliament of Australia, Joint Standing Committee on Migration, Immigration detention in Australia: Community-based alternatives to detention, May 2009, Canberra, http://www.aph.gov.au/house/committee/mig/detention/report2/fullreport.pdf (last accessed 20 March 2012) at P.61, para 3.21

3214 Parliament of Australia, Joint Standing Committee on Migration, Immigration detention in Australia: Community-based alternatives to detention, May 2009, Canberra, http://www.aph.gov.au/house/committee/mig/detention/report2/fullreport.pdf (last accessed 20 March 2012) at P.65, para 3,29

3215 De Silva v Minister for Immigration and Multicultural Affairs [2001] FCA 962
} 
was the subject of a mandatory no-work condition imposed on his Bridging Visa. He had a wife who was also not permitted to work and a three year-old Australian-born son for whom he was providing by obtaining food vouchers from charities including the Red Cross and begging for food from inter alia McDonalds and KFC. To provide for his family, the applicant worked in breach of his visa conditions for which he was apprehended and made subject to the imposition of an AUD10,000 security bond. He was later again apprehended for working and the bond was increased to AUD50,000. The applicant was incapable of paying the amount and, as a consequence, he was detained. Merkel J noted that the Tribunal (from which his Honour was hearing the appeal) accepted that the applicant had no record of misconduct (other than the breach of the work conditions on his visa), presented no risk to the community or that of flight or absconding. ${ }^{3216}$ Although the matter was resolved by consent of the parties, his Honour endeavoured to draw attention to this "underlying injustice". ${ }^{3217}$ His Honour described the then current legislative regime leading to a "Kafkaesque situation". 3218

\begin{abstract}
"Occasionally cases come before the Court that show that the law can be used as an instrument of injustice. The present is such a case."

$[\ldots]$

"It is a matter of some concern that the current regulatory environment can operate to require that persons employing proper procedures to remain in Australia be required to live off such charity as may be available or to beg to make up the shortfall to enable their subsistence. I doubt that the regime was intended to have that outcome. The problem lies in the fact that under the regime, in certain categories of cases, there is no discretion to allow an applicant to work no matter how compelling the applicant's circumstances and the need to do so. I have set out my concerns in an endeavour to draw the anomalies that have arisen in the present case to the attention of those responsible for the Regulations in the hope that some corrective action might be taken". 3219
\end{abstract}

Indeed, after considering the evidence before it, the Joint Standing Committee concluded in 2009 ,

"Evidence suggests that the limited access to income support or permission to work is resulting in substantial hardship to bridging visa holders and placing unacceptable demands on non-government organisations." 3220

\footnotetext{
3216 De Silva v Minister for Immigration and Multicultural Affairs [2001] FCA 962 at para 8

${ }^{3217}$ De Silva $v$ Minister for Immigration and Multicultural Affairs [2001] FCA 962 at para 11

${ }^{3218}$ De Silva $v$ Minister for Immigration and Multicultural Affairs [2001] FCA 962 at para 5

3219 De Silva v Minister for Immigration and Multicultural Affairs [2001] FCA 962 at paras 1 and 11

3220 Parliament of Australia, Joint Standing Committee on Migration, Immigration detention in Australia: Community-based alternatives to detention, May 2009, Canberra, http://www.aph.gov.au/house/committee/mig/detention/report2/fullreport.pdf (last accessed 20 March 2012), P.65 para 3.30
} 


\subsection{Medicare}

One of the related outcomes of permission to work under a Bridging Visa is access to Medicare. Normally, a temporary visa holder (such as a Bridging Visa) with work rights who has applied for a permanent visa is eligible to receive Medicare benefits under the Health Insurance Act 1973 (Cth). ${ }^{3221}$ Accordingly, the granting of work rights on Bridging Visas is an essential element in order to access Medicare. ${ }^{322}$ Only those otherwise eligible Protection Visa applicants on a temporary visa who also apply for a parent visa are excluded from receiving Medicare benefits. ${ }^{3223}$ For those that are ineligible to receive Medicare benefits, some State and Territory governments have taken inclusive policies by providing full medical care without charge. ${ }^{3224}$ For those on a Bridging Visa R, they are entitled to Medicare benefits on account of the work rights attached to their visa.

In 2009, the Joint Standing Committee concluded:

"Evidence suggests that there is currently limited access to health care for people on bridging visas, where this is used as an alternative to immigration detention, and this places some people at risk of poor or acute health conditions." 3225

\subsubsection{Other conditions which may be imposed on Bridging Visa holders}

DIAC may also impose security bonds and reporting and residence conditions on the Bridging Visas it issues. It is important to note that, in the context of

3221 Section 10(1) of the Health Insurance Act 1973 (Cth), together with the definition of "eligible person" and "Australian resident" contained in section 3(1) of that Act

3222 See the definition of "Australian resident" contained in section $3(1)(\mathrm{f})(\mathrm{v})(\mathrm{B})$ of the Health Insurance Act 1973 (Cth) which requires "an authority to work in Australia is in force"

3223 See the definition of "Australian resident" contained in section 3(1)(f)(iii) of the Health Insurance Act 1973 (Cth). See also Australian Government, Department of Immigration and Citizenship, Bridging Visas - Form 1024i, http://www.immi.gov.au/allforms/pdf/1024i.pdf (last accessed 20 March 2012), P.3; Australian Government, Department of Human Services, Medicare, Eligibility and Enrolment, http://www.medicareaustralia.gov.au/public/register/eligibility.jsp\#N1004E (last accessed 20 March 2012)

3224 See, for example, Victorian Government, Department of Health, Guide to asylum seeker access to health and community services in Victoria, May 2011, http://docs.health.vic.gov.au/docs/doc/DD261ED347439C91CA2578CA007A31FC/\$FI LE/Guide\%20to\%20asylum\%20seeker\%20access\%20to\%20health\%20and\%20community\%2 Oservices\%20in\%20Victoria.pdf (last accessed 20 March 2012); ACT Government, ACT Health, Public Service to Medicare Ineligible Asylum Seekers Policy, 1 May 2011, http://health.act.gov.au/c/health?a=dlpubpoldoc\&document=891 (last accessed $20 \mathrm{March}$ 2012); see also Tasker, B, Push for asylum seeker Medicare cover, Sydney Morning Herald, 14 August 2011, http://www.smh.com.au/national/push-for-asylum-seeker-medicare-cover20110814-1ispm.html (last accessed 20 March 2012)

3225 Parliament of Australia, Joint Standing Committee on Migration, Immigration detention in Australia: Community-based alternatives to detention, May 2009, Canberra, http://www.aph.gov.au/house/committee/mig/detention/report2/fullreport.pdf (last accessed 20 March 2012), P.70 para 3.46 
alternatives to detention, these are conditions that may be additional to, and imposed upon, Bridging Visa holders. They are not used as an alternative to detention per se but rather are an additional requirement that a Bridging Visa holder must meet.

\section{Security Bonds}

The power to impose security bonds is contained in section 269(1) of the Migration Act and is also reflected in Schedule 2 to the Migration Regulations 1994. ${ }^{3226}$ Security bonds may be imposed in an amount of \$AUD5,000 $\$ 50,000$ (approximately EUR 4,000 - 40,000). ${ }^{3227}$ In Tennakoon, the Federal Court indicated the logical steps that must be followed in deciding whether a security bond should be imposed. ${ }^{3228}$ In relation to the calculation of the amount of security required by DIAC, Merkel J in Mitrevski indicated:

"The power to fix a security amount is a decision that affects the liberty of an individual. The fixing of an amount that is oppressive will necessarily result in the involuntary detention of an individual who has not been convicted of any offence. In such circumstances, caution should be exercised to ensure the amount fixed is reasonable in all the circumstances." 3229

In relation to calculating what is a reasonable amount to be fixed, reference must be made to the nature of the conditions imposed upon the visa, the financial circumstances of the applicant and the applicant's record of compliance with the Migration Act. ${ }^{3230}$ Excessive amounts may be construed as punishment rather than to ensure the applicant's compliance. ${ }^{3231}$ However, in $V W E X$ Weinberg $\mathrm{J}$ indicated that an applicant's inability to meet the security amount (say, on account of impecuniosity) and excessive bail are two separate issues - the Court is chiefly concerned with ensuring that bail is not excessive and the fact that an amount is set beyond the applicants means is not, of itself,

3226 See, for example, in relation to Bridging Visa E subclass 050, Clause 050.224 of Schedule 2 to the Migration Regulations 1994 (Cth)

3227 Parliament of Australia, Joint Standing Committee on Migration, Immigration detention in Australia: Community-based alternatives to detention, May 2009, Canberra, http://www.aph.gov.au/house/committee/mig/detention/report2/fullreport.pdf (last accessed 21 March 2012), Pp.45-46, para 2.112. The MRT has the power to review a decision that relates to the requirement of security and any refusal of a visa in relation to that security - section 338(9) of the Migration Act 1958 (Cth) and Regulation 4.02(4)(f) of the Migration Regulations 1994 (Cth)

3228 Tennakoon v Minister for Immigration and Multicultural Affairs [2001] FCA 615 at paras 1821 (appeal unsuccessful, see Tennakoon v Minister for Immigration and Multicultural Affairs [2001] FCA 1685), cited with approval in Applicant VAAN of $2001 v$ Minister for Immigration and Multicultural Affairs [2002] FCA 197 at paras 19 and 22

3229 Mitrevski v Minister for Immigration and Multicultural Affairs [2001] FCA 221 at para 8 cited with approval in Tennakoon v Minister for Immigration and Multicultural Affairs [2001] FCA 615 at para 16

3230 Tennakoon v Minister for Immigration and Multicultural Affairs [2001] FCA 615 at para 20

3231 Applicant VAAN of 2001 v Minister for Immigration and Multicultural Affairs [2002] FCA 197 at para 26 
unlawful. ${ }^{3232}$ Further, the security requirement is directed towards the applicant complying with the other conditions imposed. ${ }^{3233}$

\section{Reporting and Residence Conditions}

Reporting $^{3234}$ and residence conditions may also be imposed on a Bridging Visa. These can be found in Schedule 2 to the Migration Regulations and deciphered by way of Schedule 8 of the Migration Regulations.

In relation to reporting requirements, the formulations that may be imposed include requiring an applicant to report at a particular time and place specified by the Minister; ${ }^{3235}$ or to report within five days of the grant of the visa to an immigration office and then on the first working day of every week thereafter. ${ }^{3236}$

In relation to residence requirements, an applicant may be required to reside at a particular place specified before the grant of the visa. ${ }^{3237}$ Further, the applicant may be required to notify DIAC of any change of address at least two working days in advance. ${ }^{3238}$

\subsubsection{Assistance for Asylum Seekers on Bridging Visas}

Two programmes exist to provide limited assistance to those most vulnerable that are not in immigration detention - that is, these programmes exclude those who are in community detention. Both programmes utilise NGOs (namely, but not limited to, the Australian Red Cross) to provide services.

3232 VWEX v Minister for Immigration and Multicultural and Indigenous Affairs [2004] FCA 460 at para 51

3233 VWEX $v$ Minister for Immigration and Multicultural and Indigenous Affairs [2004] FCA 460 at paras $52-53$

3234 Parliament of the Commonwealth of Australia, Joint Standing Committee on Migration, Immigration detention in Australia: Community-based alternatives to detention, May 2009, Canberra, http://www.aph.gov.au/house/committee/mig/detention/report2/ fullreport.pdf (last accessed 21 March 2012), P.48, paras 2.120 - 2.121

3235 Condition 8401 Schedule 8 to the Migration Regulations 1994 (Cth); see, for example, Clauses $\quad 050.613 \mathrm{~A}(2) ; \quad 050.614(2) ; \quad 050.612(2) ; \quad 050.615 \mathrm{~A}(2) ; \quad 050.616(2) ; \quad 050.617$; 051.611A(3); 051.612; 070.611 of Schedule 2 to the Migration Regulations 1994 (Cth)

3236 Condition 8402 Schedule 8 to the Migration Regulations 1994 (Cth); see, for example, Clauses 050.614(2); 050.617; 050.611; 051.611A(2) of Schedule 2 to the Migration Regulations 1994 (Cth)

3237 Condition 8505 Schedule 8 to the Migration Regulations 1994 (Cth); see, for example, Clauses $\quad 050.613 \mathrm{~A}(2) ; \quad 050.614(2) ; \quad 050.615(2) ; \quad 050.615 \mathrm{~A}(2) ; \quad 050.616(2) ; \quad 050.617$; 051.611A(3); 051.612 of Schedule 2 to the Migration Regulations 1994 (Cth)

3238 Condition 8506 Schedule 8 to the Migration Regulations 1994 (Cth); see, for example, Clauses 050.613A(2); 050.614(2); 050.615(2); 050.615A(2);050.616(2);050.617;051.611; 051.611A(2) and (3); 051.612 of Schedule 2 to the Migration Regulations 1994 (Cth) 
Community Assistance Support Program ("CAS”) (formerly Community Care Pilot program ("CCP")

CAS provides assistance chiefly in the following areas: (1) through the Australian Red Cross, the programme provides community support in the nature of food, clothing, basic living expenses, health care and accommodation; (2) through the International Organisation for Migration (IOM) the programme provides information and counselling; (3) through the IAAAS service providers, the programme provides immigration and legal assistance to vulnerable persons; ${ }^{3239}$ (4) through DIAC case managers, one-off brokerage funds may be provided $;^{3240}$ (5) through the Australian Red Cross, the programme also provides support to those people transitioning from immigration detention. ${ }^{3241}$

To be eligible to access the scheme, a person must not be in detention; must hold a Bridging Visa; be cooperating with DIAC to resolve their unresolved immigration status; "be unable to access adequate support in the community or be unable to support themselves" and be under at least one particular vulnerability. ${ }^{3242}$ Those particular vulnerabilities are (1) "a diagnosed mental health condition"; (2) "significant disability or serious health issue"; (3) being a minor at risk, unaccompanied minor or elderly person; (4) "suffering the effects of torture and trauma"; (5) "suffering domestic abuse or violence"; or (6) suffering a mental or physical impairment. ${ }^{3243}$ The Joint Standing

3239 Parliament of Australia, Joint Standing Committee on Migration, Immigration detention in Australia: Community-based alternatives to detention, May 2009, Canberra, http://www.aph.gov.au/house/committee/mig/detention/report2/fullreport.pdf (last accessed 21 March 2012), P.36, para 2.72

3240 DIAC identify that such circumstances may include "essential healthcare and medical expenses, emergency hospitalization and ambulance expenses, crisis accommodation, and an essential basic living allowance": Australian Government, Department of Immigration and Citizenship, Fact Sheet 64 - Community Assistance Support Program, http://www.immi.gov.au/media/fact-sheets/64community-assistance.htm (last accessed 23 March 2012); see also Parliament of Australia, Joint Standing Committee on Migration, Immigration detention in Australia: Community-based alternatives to detention, May 2009, Canberra, $\quad$ http://www.aph.gov.au/house/committee/mig/detention/report2/ fullreport.pdf (last accessed 21 March 2012), P.37, para 2.72

3241 Australian Government, Department of Immigration and Citizenship, Fact Sheet 64 Community Assistance Support Program, http://www.immi.gov.au/media/factsheets/64community-assistance.htm (last accessed 23 March 2012)

3242 Australian Government, Department of Immigration and Citizenship, Fact Sheet 64 Community Assistance Support Program, http://www.immi.gov.au/media/factsheets/64community-assistance.htm (last accessed 23 March 2012)

3243 Australian Government, Department of Immigration and Citizenship, Fact Sheet 64 Community Assistance Support Program, http://www.immi.gov.au/media/factsheets/64community-assistance.htm (last accessed 23 March 2012); see also Parliament of Australia, Joint Standing Committee on Migration, Immigration detention in Australia: Community-based alternatives to detention, May 2009, Canberra, http://www.aph.gov.au/house/committee/mig/detention/report2/fullreport.pdf (last accessed 21 March 2012), P.37 para 2.73 
Committee noted that destitution without one of the other grounds of vulnerability was not sufficient to be eligible for the programme. ${ }^{3244}$

Although in 2009 when the scheme was in its pilot phase it was regarded as successful, ${ }^{3245}$ the Joint Standing Committee noted the evidence of the narrow eligibility criteria and a lack of transparency about whom the scheme accepted. ${ }^{3246}$

\section{Asylum Seeker Assistance Scheme ("ASAS")}

ASAS is particularly focussed on those persons making a valid application for a Protection Visa, unlike the CAS, which is open to all Bridging Visa holders. Asylum seekers may be eligible under the CAS but are not able to receive assistance under both CAS and ASAS. ${ }^{3247}$ The Joint Standing Committee noted in 2009 that ASAS was not as comprehensive as CAS. ${ }^{3248}$ The scheme is administered by the Australian Red Cross under contract from DIAC. ${ }^{3249}$

The nature of the assistance provided by the scheme is financial assistance, casework services, legal assistance (through IAAAS service providers), and facilitating access to Medicare. ${ }^{3250}$ It is not clear how, in the absence of work rights attached to the Bridging Visa, access to Medicare might be facilitated. The nature of the financial assistance provided is to assist with everyday living expenses (through the Australian Red Cross) and to cover the costs resulting

3244 Parliament of Australia, Joint Standing Committee on Migration, Immigration detention in Australia: Community-based alternatives to detention, May 2009, Canberra, http://www.aph.gov.au/house/committee/mig/detention/report2/fullreport.pdf (last accessed 21 March 2012), Pp.57-58 para 3.10

3245 Parliament of Australia, Joint Standing Committee on Migration, Immigration detention in Australia: Community-based alternatives to detention, May 2009, Canberra, http://www.aph.gov.au/house/committee/mig/detention/report2/fullreport.pdf (last accessed 13 March 2012), P.87-88, para 3.113

3246 Parliament of Australia, Joint Standing Committee on Migration, Immigration detention in Australia: Community-based alternatives to detention, May 2009, Canberra, http://www.aph.gov.au/house/committee/mig/detention/report2/fullreport.pdf (last accessed 13 March 2012), Pp.88-89, paras 3.114 - 3.116

3247 Parliament of Australia, Joint Standing Committee on Migration, Immigration detention in Australia: Community-based alternatives to detention, May 2009, Canberra, http://www.aph.gov.au/house/committee/mig/detention/report2/fullreport.pdf (last accessed 21 March 2012), P.40 para 2.85

3248 Parliament of Australia, Joint Standing Committee on Migration, Immigration detention in Australia: Community-based alternatives to detention, May 2009, Canberra, http://www.aph.gov.au/house/committee/mig/detention/report2/fullreport.pdf (last accessed 21 March 2012), P.38 para 2.78

3249 Australian Government, Department of Immigration and Citizenship, Fact Sheet 64 Community Assistance Support Program, http://www.immi.gov.au/media/factsheets/64community-assistance.htm (last accessed 23 March 2012)

3250 Australian Government, Department of Immigration and Citizenship, Fact Sheet 64 Community Assistance Support Program, http://www.immi.gov.au/media/factsheets/64community-assistance.htm (last accessed 23 March 2012) 
from the processing of a person's Protection Visa application. ${ }^{3251}$ The Joint Standing Committee noted in 2009 that the income support was equivalent to $89 \%$ of the Centrelink Special Benefit (currently maintained ${ }^{3252}$ ), as well as noting that funded basic health care may be provided through medical service providers organised by the Australian Red Cross. ${ }^{3253}$ In relation to pharmaceuticals, the Joint Standing Committee noted that subsidies were provided equivalent to the Pharmaceutical Benefits Scheme ("PBS"). ${ }^{3254}$ Torture and trauma counselling, as well as minor services, were also provided. ${ }^{3255}$

Eligibility to the scheme is based on means testing - such means testing occurring throughout the time the person accesses the scheme ${ }^{3256}$ - and meeting specific criteria. Those criteria are that the person: (1) must be waiting for the first instance outcome of their Protection Visa application for more than six months; (2) is not in detention; (3) holds a visa; (4) is ineligible for income support from the Australian or an overseas government. ${ }^{3257}$ The Joint Standing Committee noted that the person must also not be the spouse, partner or sponsored fiancé of a permanent resident. ${ }^{3258}$

3251 Australian Government, Department of Immigration and Citizenship, Fact Sheet $64-$ Community Assistance Support Program, http://www.immi.gov.au/media/factsheets/64community-assistance.htm (last accessed 23 March 2012)

3252 Australian Red Cross, Fact Sheet - Migrant Support Programs - Asylum Seeker Assistance Scheme, http://www.redcross.org.au/files/20120203_ASAS_Fact_Sheet_.pdf (last accessed 17 July 2012)

3253 Parliament of the Commonwealth of Australia, Joint Standing Committee on Migration, Immigration detention in Australia: Community-based alternatives to detention, May 2009, Canberra, http://www.aph.gov.au/house/committee/mig/detention/report2/ fullreport.pdf (last accessed 21 March 2012), P.39 para 2.82

3254 Parliament of Australia, Joint Standing Committee on Migration, Immigration detention in Australia: Community-based alternatives to detention, May 2009, Canberra, http://www.aph.gov.au/house/committee/mig/detention/report2/fullreport.pdf (last accessed 21 March 2012), P.39 para 2.82

3255 Parliament of the Commonwealth of Australia, Joint Standing Committee on Migration, Immigration detention in Australia: Community-based alternatives to detention, May 2009, Canberra, http://www.aph.gov.au/house/committee/mig/detention/report2/ fullreport.pdf (last accessed 21 March 2012), P.39 para 2.82

3256 Parliament of Australia, Joint Standing Committee on Migration, Immigration detention in Australia: Community-based alternatives to detention, May 2009, Canberra, http://www.aph.gov.au/house/committee/mig/detention/report2/fullreport.pdf (last accessed 21 March 2012), P.38 para 2.79

3257 Australian Government, Department of Immigration and Citizenship, Fact Sheet 64 Community Assistance Support Program, http://www.immi.gov.au/media/factsheets/64community-assistance.htm (last accessed 23 March 2012)

3258 Parliament of Australia, Joint Standing Committee on Migration, Immigration detention in Australia: Community-based alternatives to detention, May 2009, Canberra, http://www.aph.gov.au/house/committee/mig/detention/report2/fullreport.pdf (last accessed 21 March 2012), Pp.38-39 para 2.79; 
Those who seek merits review after an initial refusal of their Protection Visa application by DIAC may still be eligible under the scheme provided that they still meet the exemption criteria (discussed below). ${ }^{3259}$ Accordingly, those that seek judicial review or ministerial intervention are no longer eligible for the scheme and whose support ceases as a result. ${ }^{3260}$ Persons who have waited for less than six months for the initial outcome of their Protection Visa application may be eligible for the scheme based on an exemption. ${ }^{3261}$

A person fulfils the exemption criteria if he or she is an unaccompanied minor; unable to work due to illness, disability or care responsibilities, or as a result of torture or trauma; or is in financial hardship "resulting from a change in circumstances since arriving in Australia". Families with minors are also exempted from the regular eligibility criteria. ${ }^{3262}$

The Joint Standing Committee noted that 95\% of those on the scheme had been waiting for a period of less than six months for the initial outcome of their protection visa application but did so by virtue of the fact that they fell within the exemptions. ${ }^{3263}$ If anything, that figure tends to support the proposition that the vast majority of asylum seekers are under some form of extreme vulnerability. Indeed, in relation to financial circumstances, the Committee noted that asylum seekers on Bridging Visas, unlike others on Bridging Visas such as tourist, business or student visa holders or over-stayers, "may be less likely to have financial resources or assets with which to survive pending a decision on their visa application." 3264

3259 Australian Government, Department of Immigration and Citizenship, Fact Sheet 64 Community Assistance Support Program, http://www.immi.gov.au/media/factsheets/64community-assistance.htm (last accessed 23 March 2012); Parliament of the Commonwealth of Australia, Joint Standing Committee on Migration, Immigration detention in Australia: Community-based alternatives to detention, May 2009, Canberra, http://www.aph.gov.au/house/committee/mig/detention/report2/fullreport.pdf (last accessed 21 March 2012), Pp.39-40 para 2.83

3260 Parliament of Australia, Joint Standing Committee on Migration, Immigration detention in Australia: Community-based alternatives to detention, May 2009, Canberra, http://www.aph.gov.au/house/committee/mig/detention/report2/fullreport.pdf (last accessed 21 March 2012), P.39, para 2.83

3261 Australian Government, Department of Immigration and Citizenship, Fact Sheet $64-$ Community Assistance Support Program, http://www.immi.gov.au/media/factsheets/64community-assistance.htm (last accessed 23 March 2012)

3262 Australian Government, Department of Immigration and Citizenship, Fact Sheet 64 Community Assistance Support Program, http://www.immi.gov.au/media/factsheets/64community-assistance.htm (last accessed 23 March 2012)

3263 Parliament of Australia, Joint Standing Committee on Migration, Immigration detention in Australia: Community-based alternatives to detention, May 2009, Canberra, http://www.aph.gov.au/house/committee/mig/detention/report2/fullreport.pdf (last accessed 21 March 2012), P.39, para 2.81

3264 Parliament of Australia, Joint Standing Committee on Migration, Immigration detention in Australia: Community-based alternatives to detention, May 2009, Canberra, http://www.aph.gov.au/house/committee/mig/detention/report2/fullreport.pdf (last accessed 21 March 2012), P.59, para 3.13 
The Joint Standing Committee welcomed the presence of the two programs, but noted the evidence that "access and eligibility was patchy or periodic". 3265 Indeed, those asylum seekers that fall through the gaps between the two schemes are still left to rely on their own resources and resourcefulness or to continue their existence through the beneficence of other community groups and NGOs - indeed, Edwards (2011) notes the emergence of the Hotham Mission's programme which, although not covered under the formal CAS or ASAS programmes, attempts to meet the needs of those left without other recourse. ${ }^{3266}$

Accordingly, what can be seen is that asylum seekers who reach an excised offshore place have very limited means to secure their liberty by virtue of the fact that they cannot make an application for any visa without the discretion of the Minister being exercised. For those that do reach the Migration Zone, several juridical hurdles are put in their way - for those that remain in detention, there is no legal right to compel their placement in a less restrictive form of immigration detention (for example, IRH or community detention). For those that seek a Bridging Visa they first need to prove their eligibility, then satisfy the criteria for the relevant visa. Significant variations on the class of visa issued and the rights attached to it are made based on such factors including any previous visa held and the rights ascribed to that visa, any prior time spent in Australia and other circumstances particular to the applicant. Even if their release is achieved by this method, conditions may be imposed. One of the most significant of these is a no-work condition that renders the person unable to access Medicare. The imposition of the no-work condition has also been used as a very blunt instrument against those seeking judicial review or ministerial intervention of their Protection Visa application as work rights are withdrawn once those procedures are commenced. Once in the community, Bridging Visa holders receive little support by virtue of holding the visa per se so that they may be compelled to seek assistance under either of the two formal schemes - failing which they must rely on their own resources and resourcefulness or the beneficence of NGOs and others. It is hardly surprising, then, that the Joint Standing Committee in 2009, and others more recently, have noted that such measures may amount to inhuman or degrading treatment under international law. ${ }^{3267}$

3265 Parliament of Australia, Joint Standing Committee on Migration, Immigration detention in Australia: Community-based alternatives to detention, May 2009, Canberra, http://www.aph.gov.au/house/committee/mig/detention/report2/fullreport.pdf (last accessed 21 March 2012), P.58, para 3.11

3266 UNHCR, Edwards, A, Back to Basics: The Right to Liberty and Security of Person and Alternatives to Detention of Refugees, Asylum-Seekers, Stateless Persons and Other Migrants, April 2011, UN Doc PPLA/1011/01.Rev.1, Pp.64-65

3267 Parliament of Australia, Joint Standing Committee on Migration, Immigration detention in Australia: Community-based alternatives to detention, May 2009, Canberra, http://www.aph.gov.au/house/committee/mig/detention/report2/fullreport.pdf (last accessed 21 March 2012), Pp.60-61, para 3.18; Gilbert + Tobin Centre of Public Law, 


\subsection{Conclusions}

In the Union sphere, the principle of proportionality has the potential to act as a significant safeguard for asylum seekers in protecting their right to liberty and for ensuring that any restriction or deprivation of liberty is the least restrictive possible and is proportionate to the objective pursued. The principle exists both as a General Principle of Union law contained in the jurisprudence of the CJEU, and is expressly contemplated in the EU Charter and the proposed secondary legislation. The triple juridical hurdle contained in the proposed legislation would appear to embody the principle. However, some 'interest filters' are evident: firstly, the use of the term "effectively" under the proposed secondary legislation (regarding the imposition of other less restrictive measures) would appear to qualify the right to liberty in favour of the Member State or at least lower the evidential threshold in favour of the Member State; and secondly, the great deal of discretion afforded to Member States in determining "risk of absconding" under the proposed Dublin Regulation. It should also be remembered that the final assessment of the proportionality of a measure may be left to the Member State to determine - accordingly, in this emerging area and with more prescriptive proposed secondary legislation on its way, it is vital for the CJEU to provide Member States with sufficient guidance to both ensure the consistency of Union law across the Member States and to provide adequate protection for the rights of asylum seekers. It will remain to be seen how the CJEU develops its jurisprudence in this regard, and it is submitted that its existing jurisprudence on Union citizens might be of some inspiration.

The principle of proportionality is no stranger to Australia. Indeed, disparate elements of the principle have emerged in the constitutional case law; there are noted similarities in cases involving inter-state trade; and in administrative law 'Wednesbury unreasonableness' shares a resemblance. But the HRC and Union law understanding of the principle has not germinated and flourished as a means for testing the legality of laws in the constitutional sphere, or as a means for challenging measures in the administrative sphere. The understanding of detention under the Migration Act is clear as a question of law, but the blanket definition of "immigration detention" under the Act encompasses a range of less restrictive means of detention that are possible in practice but are unable to be asserted by detained asylum seekers as a question of right. In that sense, the Act does not provide for a right for an asylum seeker to seek a less restrictive means of detention (other than a Bridging Visa, as an alternative to detention, if eligible). In the context of alternatives to detention,

Faculty of Law, University of New South Wales, submission to the Joint Select Committee on Australia's Immigration Detention Network, 10 August 2011, https://senate.aph.gov.au/submissions/comittees/viewdocument.aspx?id=4033d753-221c4278-af91-9fceea7eb41d (last accessed 24 March 2012), P.9-10, citing at n.45 Secretary of State for the Home Department $v$ Limbuela [2004] EWCA Civ 540 and $R v$ Secretary of State for the Home Department, ex parte Adam [2005] UKHL 66. 
the principle of proportionality would almost appear to be the inverse of the position in the Union sphere: mandatory detention without individual assessment is adopted, followed then by the use of highly specific and complex criteria (based on individual assessment against eligibility criteria) to establish liberty through the use of Bridging Visas. Less restrictive means of detention and alternatives to detention in the Australian context do not follow the continuum in law that the principle of proportionality demands. This process may be contrasted with the position in the Union sphere (after an application for asylum has been lodged) where (an albeit weak) right to liberty is assumed. It is arguable, but by no means clear, that restrictions on, or deprivations of, liberty must be justified in specific circumstances after individual assessment (on one construction of the current legislation in light of El Dridi). However, the definition of detention in the European Union (discussed in Chapter 4) makes it difficult to establish in law when detention is occurring. The proposed secondary legislation represents a significant improvement in relation to the process and grounds of detention and the application of the principle of proportionality.

The European Union, with its principle of proportionality as a general principle of Union law, is more easily disposed to reflecting and respecting the continuum from liberty, restrictions upon liberty, to deprivation of liberty. In the Australian sphere, that continuum is not reflected under the Migration Actrather a binary conceptualisation of either liberty or detention exists, which does not reflect a continuum (or fragments of it) that may exist in practice.

The Union secondary legislation is silent as to the viability of alternatives to detention - particularly as regards Member States' obligations to ensure that alternatives are viable. An analysis of Member State practice is regrettably outside the scope of this book bearing in mind the number of Member States implementing the CEAS. If the Australian experience reveals anything in that regard, it is that alternatives must not only need to exist but must be viable for asylum seekers. Without ensuring their material needs, liberty may be no better, or possibly worse, than some forms of detention.

In both jurisdictions, the most vulnerable in terms of accessing alternatives to detention are border applicants. In the European sphere, Union legislation is largely silent as regards border applicants who are left to rely on Article 6 of the EU Charter or Article 9(1) ICCPR to assert their liberty or seek an alternative to detention (and perhaps, in particular circumstances, Article 5(1)(f) ECHR). Further, vulnerability currently extends to those who have lost the right to remain but do not fall within the scope of the Returns Directive and for those detained pending a Dublin transfer. Similarly, in Australia, those Offshore Entry Persons and Transitory Persons are also denied the ability to seek alternatives to detention for the fact that they cannot make a visa application (including a Bridging Visa application) unless the minister exercises his or her personal and non-compellable discretion. 
As regards citizens ${ }^{3268}$ and asylum seekers, there is evidence to suggest a difference in the outcome of a proportionality analysis as regards Union citizens and asylum seekers. In Australia, what would be unlawful detention for citizens or lawful non-citizens (that is, by a breach of the separation of powers) is not so for asylum seekers based on the purpose of the detention (that is, the detention of asylum seekers is not considered punitive and therefore does not breach the separation of powers). Accordingly, both jurisdictions, in their own way, prima facie, appear to have different thresholds for the detention of asylum seekers and their respective citizens. What would be unlawful detention for citizens in one circumstance may be lawful for asylum seekers in another. Further research would yield a more comprehensive understanding of how the weighting of competing rights and interests of the two groups has been carried out in the Union sphere and indeed how it compares to other groups such as Union Long Term Residents ${ }^{3269}$ and other persons covered by Association and Partnership Agreements such as Turkish nationals. ${ }^{3270}$ In the Australian sphere, further research would explore all forms of non-judicially ordered detention. ${ }^{3271}$

Both jurisdictions could benefit from ensuring that sufficient judicial discretion is ensured but at the same time embodying precise (but not necessarily exhaustive) alternatives to detention in the law. This would enable a court to order the least restrictive means appropriate to the circumstances of the individual but also allow sufficient discretion to order other, more innovative and less restrictive, means if necessary. Within the detention environment, the law should ensure that the least restrictive (or least severe) form of detention is used based on an individual assessment. The gradation or continuum from liberty to detention should not cease once an order for detention has been made.

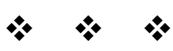

There is little doubt that an entirely proportionate response to the detention of asylum seekers should be adopted. The right to liberty of asylum seekers, as with anyone, should be impinged to the minimum extent necessary provided that the aim is legitimate (indeed, assuming that the aim is legitimate). The

\footnotetext{
3268 In this sense, I conceptualise a Union citizen, as a national of a Member State (not ignoring Swiss or EEA nationals) who is in a Member State of which he or she is not a national (that is, one who has exercised his or her right of free movement)

3269 Under Council Directive 2003/109 of 25 November 2003 concerning the status of third-country nationals who are long-term residents

3270 Under the EEC-Turkey Association Agreement of 12 September 1963

3271 See McDonald, S, Involuntary Detention and the Separation of Judicial Power (2007) 35 FedLRev 25, Pp. 65-77 where the learned author discusses the limits of judicial detention particularly where detention ordered by federal courts is non-punitive and where detention has been ordered by a court where the guilt of a person has not been determined.
} 
principle of proportionality has the potential to be an important safeguard in these circumstances - it has the power to compel States to demonstrate that there are no less restrictive means available before a detention decision is made and that the means are proportionate to the ends. In the Union sphere the CJEU has, in other areas of Union law, not been easily persuaded that no other less restrictive means were available. In the ECtHR sphere, the emerging jurisprudence in relation to children and families is particularly heartening in this respect. Indeed, even beyond a detention decision, an application of the principle should ensure that a person is placed in the least restrictive environment as necessary - a particularly important consideration given isolation and other units that may be used in detention facilities (which may be under private management).

However, the principle of proportionality can also lead to a false sense of forensic security. The principle says nothing for the weight to be ascribed to the rights and interests it is called upon to balance. The misconception that can occur when referring to the principle of proportionality as a response to immigration detention is to assume that the right to liberty (and, indeed, freedom from cruel, inhuman or degrading treatment) is given the same weight for both asylum seekers and citizens alike. In a proportionality analysis, rights can be affected in a number of ways: the applicable legislation; the rules of evidence, burden of proof or other 'evidence filters'; the legitimate aim sought to be upheld; the history of the constitutional text in question and the weight traditionally ascribed to particular rights; the rights traditionally ascribed to non-citizens; judicial discretion; and the rigorousness of judicial assessment. Indeed, in both the European Union and Australia we have seen that the right to liberty is qualified differently for citizens and non-citizens. Further, the legitimate aim will always be cast by the State who will have a forensic advantage in both setting the legitimate aim and evidencing the necessity of its pursuit. As has been demonstrated in Chapter 3, it is not beyond the realms of governments to inflate the necessity for drastic measures. Indeed, one might ask how often, if ever, will the legitimacy of the aim be challenged?

If a truly proportionate and humane response to the detention of asylum seekers is to be pursued, then the weighting of the right to liberty must be as near identical as possible to that of the host country's citizens, and the objective sought by their detention is legitimate, truthful and not overinflated.

History reveals that that presents a most significant challenge for asylum seekers. 


\section{Chapter 9 \\ Conclusions}

The research question that this book sought to explore was the extent that the laws regarding the detention of asylum seekers in the European Union and Australia converged (or otherwise). As the resolution of the research question adopted a comparative law approach, the results are subject to the limitations of comparative legal analysis. Some of those limitations should be borne in mind when considering the overall conclusions.

\subsection{Limitations of Comparative Legal Research}

Throughout the course of this research, it has not been uncommon for the question to be asked of the author, "So, who's worse - the European Union or Australia?". There is no simplistic answer to be given. There is no "winner" and "loser" in this comparative analysis of law. What must be remembered is that the people who are directly affected by the operation of these laws - the asylum seekers themselves - do not "win" because one jurisdiction may be considered (at a theoretical level) to be less bad than the other.

What can be seen from the research conducted, and which is evident from the summary below, is that the degree of convergence is far from absolute or universal in all areas discussed. What the research has shown is that there are significant, multiple and multifaceted areas of divergence and convergence.

Further, it should not be assumed that a convergence in the laws of the two jurisdictions is necessarily indicative of heightened normative standards for the benefit or protection of asylum seekers. In that regard, it is clear from the foregoing research that convergence in some areas is indicative of a downgrading of rights and protection for asylum seekers. Similarly, areas of divergence may not necessarily be indicative of both jurisdictions heading in polar opposite directions, but may evidence that one jurisdiction would appear to offer a higher normative standard than the other in a particular area.

It is also not appropriate to look at the areas of convergence and divergence in a quantitative sense - that is, to look at the number of areas in which there is divergence and the number of areas in which there is convergence and to draw particular conclusions on that basis. Firstly, to do so does not sufficiently take into account and reveal the extent of negative convergence, as outlined above; and secondly, an overall conclusion by quantitative assessment can give a misleading or inaccurate impression of the overall research because it assumes that equal weight is to be ascribed to each identified area. 
The ascription of weight to particular areas is also problematic as it runs the risk of arbitrariness by the imposition of subjective values onto the areas identified and analysed. Accordingly, a qualitative assessment also does not convey the full extent and different facets of the research.

\subsection{Preliminary Views}

Noting that convergence does not necessarily equate to better outcomes for, or treatment of, asylum seekers (that is, that there can be negative convergence), the research nonetheless reveals that the two jurisdictions have not fully converged as regards the detention of asylum seekers. The two most significant areas which preclude a conclusion of full convergence are firstly, the reviewability, generally, of the detention of asylum seekers (including judicial review of the detention decision, review by external agencies to the detention centre and implementation of their reports, and review of and accountability for decisions made by private contractors) and, secondly (and relatedly), to the application of the principle of proportionality in a detention context.

Although it has been shown that the principle of proportionality should be handled with great care, it does have great potential to advance the welfare of asylum seekers. If one of the greatest virtues of the principle of proportionality is its clarity and simplicity as an argumentative framework, then it is submitted that, in argumentation, an appeal is made to the capacity of a decision-maker and legislature for empathy. That is, if one can empathise with the circumstances and needs of the person, to stand in his or her shoes, the discretion that will be exercised (and, thus, the weight ascribed to liberty and to the objective alike) will have the greatest chance of being as indistinguishable as possible from that of any other person. In essence, it is a reminder that humanity does not know these distinctions. It is a submission to uphold universality.

As a general observation, the research also gives some insight into each jurisdiction's attitude towards the agency of an asylum seeker - that is, the extent that the law permits (or denies) the asylum seeker to self-actualise, to have some control, input or choice into his or her own destiny and treatment. This may also include the ability to compel accountability for measures taken by States. Both jurisdictions evidence areas in which their laws diminish the agency of asylum seekers (both within and outside the detention context) and may keep an asylum seeker in a relatively isolated legal space. However, the presence of an overarching human rights structure in the European Union (both by virtue of European Union law and the ECHR) more readily predisposes that jurisdiction to respecting and maintaining the agency of an asylum seeker. In Australia, the lack of such an overarching human rights structure (such as a bill of rights), the mindset of absolute immigration control and the more blatant legal provisions create a legal space far less predisposed to 
maintaining or respecting the agency of an asylum seeker - indeed, in the Australian legal space, the asylum seeker is significantly denuded of their agency. Such an approach is manifest, for example, in the personal and noncompellable discretion of the Minister for Immigration and Citizenship (such as in the inability of offshore entry persons to make an application for a Protection Visa), the limited grounds for judicial review (including the use of the privative clause), the lack of regulatory standards for detention centres, the use of private contractors to manage detention centres, the binary conceptualisation of being either an "unlawful" or "lawful" non-citizen, and the use of offshore processing.

\subsection{Areas of Convergence and Divergence}

A summary of the areas of convergence and divergence are as follows:

\subsubsection{Areas of Convergence}

The jurisdictions evidence an emerging convergence in that, following the passing of the proposed European Union secondary legislation, both refugees and those seeking complementary forms of protection fall within the scope of their detention provisions. Both jurisdictions evidence disjunctions in legal and factual senses of detention.

Both jurisdictions have 'excised areas' which are geographical areas within the territory of both jurisdictions where the rights of asylum seekers are reduced and which evidence a greater susceptibility for detention and reduced avenues for asserting liberty.

The jurisdictions further evidence convergence in that they both adopt a bifurcated approach to asylum seekers - that is, the laws of both jurisdictions reveal an implicit preference for asylum seekers to enter their territories 'lawfully' or 'regularly' and then make an application for asylum. This is arguably consistent with an approach directed towards immigration control. Both jurisdictions share a degree of obfuscation between irregular immigration and the seeking of international protection.

Border applicants in both jurisdictions experience obstacles in submitting to the asylum procedure as a means of regularising their presence and, consequently, ensuring their liberty. Such applicants are also susceptible to systematic detention, premature removal and possible refoulement.

There is partial convergence in that failed asylum seekers may be subjected to prolonged periods of detention in both jurisdictions. The time limits contained in the EU secondary legislation may go some way to alleviating that situation (a maximum period of eighteen months), but the legislation is silent on aggregated periods of detention. The possibility of indefinite detention in Australia clearly represents the more extreme position of the two jurisdictions. 
The detention of minors and families is possible in both jurisdictions. The legislation of both jurisdictions does not prohibit the detention of minors. Where the two jurisdictions take diverging approaches is that Australia as a matter of policy does not detain minors in an immigration detention centre (that is, an alternative form of detention may be used, not necessarily an alternative to detention), whereas the recent jurisprudence of the ECtHR has significantly heightened the threshold in law for the detention of minors and families (by reference to suitability of the detention conditions to a minor and by requiring demonstration that detention is the last resort) such that the circumstances in which a minor may be detained may be very significantly reduced. Both jurisdictions would benefit from clear, express legislative provisions for the education of minors outside a detention environment.

In relation to unaccompanied minors, both jurisdictions are faced with a trifold conflict of interest - that is, where the legal guardian of the unaccompanied minor is also the detaining authority and the authority determining the application for international protection. The Union secondary legislation does not prohibit such conflicts of interest and the Australian experience (where that tri-fold conflict does exist) should serve as a powerful example to the Union legislature about what should be proscribed in that regard. In Australia, the automatic appointment of a guardian to unaccompanied minors entering Australia is a very sound measure and from which the European Union would appear to be diverging. However, the identity of the guardian, as indicated above and as demonstrated in the Australian context, should be entirely independent from any other roles that could result in any conflicts of interest or jeopardise the pursuit of the best interests of the child.

The legislation of both jurisdictions does not contain early, systematic and predetention identification processes for stateless persons.

There is partial convergence in both jurisdictions in that there is legislative silence on the provision of grounds of detention in facts and law to detained asylum seekers. The degree of convergence may be considered partial due to the fact that some reliance may be placed on the jurisprudence of the ECtHR as well as general principles of Union law in that regard. The Australian common law, on the other hand, does not compel the provision of such reasons. If the proposed Union secondary legislation is passed in the forms considered herein, then there will be a significant divergence between the two jurisdictions.

Clear, express reciprocal rights of access and communication as between lawyers and asylum seekers have not been embodied in the legislation of either jurisdiction. The European Union, however, is arguably more pre-disposed to granting such access on account of Article 47 of the EU Charter and Article 6 
ECHR. The Australian position, which requires that the person request a lawyer, arguably represents the lower standard of the two jurisdictions. However, in the EU sphere, the provisions of the Returns Directive bear some similarity to the Australian position in this regard.

The provision of legal assistance in both jurisdictions may be qualified by means and merits assessments and may arguably demonstrate a partial convergence. In the Australian sphere, it is clear when a merit assessment (for the purposes of awarding costs and against whom) is made and by whom. The EU secondary legislation is unclear on the timing of an assessment as regards merit and the identity of the person making the assessment, such that detained asylum seekers' rights may be undermined by having their application for legal assistance dealt with separately from the substantive hearing on the lawfulness of their detention.

There is also an emerging convergence in that both jurisdictions may limit access by asylum seekers to particular legal professionals. In the Australian context (which requires registration as a migration agent for particular matters), this should not normally affect a lawyer's ability to act for a client in challenging a detention decision. In the EU context, the provisions are potentially broader and which could cover the review or challenge of detention decisions as well as the asylum determination procedure and appeals concerning the withdrawal of material reception conditions.

Ultimate legal responsibility for the welfare of asylum seekers in detention rests with the state in both jurisdictions. Both jurisdictions show relative legislative weakness (in comparison to other aspects of their legislation) in respect to the conditions of detention for asylum seekers. In the European Union this is manifested by normative, less prescriptive and, at times, ambiguous legislation (partially saved by ECtHR jurisprudence) and in Australia by the absence of regulatory standards. Both jurisdictions acknowledge the suitability of detention conditions to the needs of persons detained but their approaches on this aspect differ - in the European Union such considerations form part of ECtHR jurisprudence, in Australia it is borne out in the law of tort (subject to any statutory encroachment) and indirectly in the contemplated grounds for eligibility for Bridging Visas. Both jurisdictions have not ruled out the use of prisons to detain asylum seekers, but the possibility of using prison accommodation in the European Union in the future is questionable in light of ECtHR jurisprudence (particularly in relation to Articles 3 and 5(1)(f) ECHR).

The right to liberty for asylum seekers is compromised in both jurisdictions. In the European Union it arises through the vagueness of the secondary legislation. In Australia, it arises due to the narrow and highly technical eligibility requirements for Bridging Visas or, for Offshore Entry Persons, by the preclusion of making any application for a Bridging (or any other) visa. 
Further, both jurisdictions qualify the right to liberty differently as regards asylum seekers and citizens. In the European Union, this arises due to the weights ascribed to rights and competing interests in a proportionality assessment. In Australia, it arises because the detention of asylum seekers does not breach the separation of powers because their detention is not considered punitive.

\subsubsection{Areas of Divergence}

There are two significant areas in which the European Union and Australia demonstrate divergences in their laws regarding the detention of asylum seekers, as well as other areas.

Firstly, the jurisdictions have a prima facie converging approach with regard to the scope of review of detention decisions that is influenced by the grounds for detention themselves. The ECtHR's decision in Saadi in relation to Article $5(1)(f)$ (obviating the needs for necessity and detention being justified on account of a person being unauthorised to enter the territory) and the High Court of Australia's approach in its series of cases (looking essentially at compliance with national law and not considering the circumstances of the individual) both gave primacy to State sovereignty and a textual reading of the ECHR and the Migration Act respectively. Both the ECtHR jurisprudence and the Australian jurisprudence have upheld detention on account of a person being unauthorised to enter the territory of the state.

However, where the two jurisdictions diverge in relation to review matters is that the ECtHR firstly, has at least warned against arbitrariness (which, as was discussed in Chapter 8, has been evidenced by the Court taking into account some of the circumstances personal to the applicant him or herself particularly in relation to children); secondly, the ECtHR has indicated that detention should ultimately be judicially ordered; and thirdly, an effective remedy for challenging the lawfulness of the detention decision is made possible by Article 5(4) ECHR (not forgetting Article 47 of the EU Charter which may have a much more significant role to play when the proposed secondary legislation comes into force).

The divergence of the approaches in relation to judicial review of detention decisions is also seen in relation to security-related detention. Both jurisdictions are similar in that their current legislation may effectively deny access to an effective remedy by precluding lawyers, courts or tribunals from accessing security information that may have formed the basis of a decision to detain or to continue to detain. However, the jurisdictions' approaches diverge when one considers the jurisprudence of the ECtHR and the CJEU has upheld the right to access an effective remedy notwithstanding the existence of security-related material (and by endorsing appropriate mechanisms for its disclosure). The Australian position, on the other hand, is contrary to international standards considered acceptable to the HRC in Ahani 
$v$ Canada, contrary to Article 9(4) ICCPR and results in prolonged and indefinite detention of those who are the subject of such adverse securityrelated material.

Other areas of review and external scrutiny also evidence divergent positions. The European Union has a range of causes of action for a Member State's failure to comply with Union law (including for a "serious and persistent breach" of human rights), and the Commission may have a significant role to play in that regard. The CteePT through the CPT also acts as a powerful means to ensure the appropriateness of detention conditions in the European Union. In Australia, the non-binding nature of the AHRC's and Commonwealth Ombudsman's reports and recommendations substantially compromise the effectiveness (and otherwise great value) of the external scrutiny they provide. Divergences are also seen in the review of decisions taken by private contractors of detention facilities - in the European Union it is highly arguable that such contractors are an emanation of the State such that compliance with the EU secondary legislation can be compelled, whereas in Australia, on one view, the current judicial authorities arguably point to the review of such decisions being impossible or, on the other view, at least ambiguous and in desperate need of curial clarification or legislative amendment. Further, Australia's use of personal and non-compellable ministerial discretion, as well as the use of the privative clause, also evidence a divergence in the approach to reviewability, generally.

The second significant area of divergence is in relation to proportionality and its application in the detention context. The principle of proportionality, as a General Principle of EU law, holds great potential to safeguard the right to liberty of asylum seekers. However, its full potential remains untapped so long as the CJEU has not given clear guidelines to the Member States about how the rights and competing interests are to be weighted and balanced and the ECtHR jurisprudence will remain a significant influence on Member States in that regard. The necessity for the CJEU's guidance is now pressing given the more clearly enunciated grounds for detention in the proposed secondary legislation and the triple juridical hurdle that a Member State will have to satisfy before a detention order is made. The existence of another form of proportionality assessment in relation to ECHR jurisprudence surrounding $5(1)(f)$ (that is, in relation inter alia to the prevention of arbitrariness) has come more to the forefront in recent cases involving children and families. In Australia, where the law provides for mandatory detention, there is no legal obligation to consider the individual circumstances of the case or to use the least restrictive form of detention or to consider alternatives to detention. Indeed, the binary conceptualisation of liberty or detention in the Migration Act does not reflect the continuum of alternative forms of detention or alternatives to detention that may exist in practice and which the principle of proportionality would otherwise demand. It is arguable that the failure of the 
principle of proportionality to germinate in the Australian legal landscape also tracks, to some extent, the absence of an overarching human rights structure.

In other areas, distinctions may be seen in the principles surrounding the transfer of asylum seekers to other countries. Recent jurisprudence from the ECtHR and CJEU has revealed that assumptions about the treatment of asylum seekers flowing from Member States being bound by human rights instruments are rebuttable where, in practice, there is a risk that the asylum seeker would suffer inhuman or degrading treatment if transferred to such a Member State. The recent decision of the High Court of Australia considered that transfers to a third country require at least the existence of a legal protection framework and that merely the practices that occur in the state to which asylum seekers would be transferred (in that case, Malaysia) could not solely be relied upon for providing adequate protection.

In relation to the right to remain, the use of Bridging Visas in Australia provides a very robust right to remain pending the determination of their application for international protection provided that the person remains a lawful non-citizen compared to the provisions of the European Union secondary legislation which only contemplates a right to remain up until a first instance decision has been made. Even as regards those in detention in Australia, the right to remain exists up until a merits review of their initial application which is a higher standard than that contemplated by the current European Union secondary legislation. Both jurisdictions evidence similarities in that judicially ordered interim relief (or "suspensive effect") not to be removed from the territory may be granted on application in certain circumstances.

Distinctions are also seen in that the European Union secondary legislation expressly contemplates vulnerable persons, whereas the Migration Act in Australia does not make a distinction between vulnerable persons and other unlawful non-citizens except indirectly (and in conjunction with the Migration Regulations) in the context of eligibility for a Bridging Visa for those in the Migration Zone.

In relation to a minor's ability to make an application for asylum on their own behalf (and thus fall within the scope of the Procedures Directive), the European Union secondary legislation evidences considerable weakness in that regard and is of serious concern (and is related to the issue of the appointment of a guardian for unaccompanied minors). The Australian position of allowing unaccompanied minors to make an application on their own behalf for a Protection Visa represents a higher standard in that regard but noting that the signature of a parent or guardian is still necessary if the child is under the age of 15 years or lacks legal capacity. 


\subsection{Overall Conclusion}

If subscription to international human rights conventions is the basis for mutual trust amongst States for the treatment of asylum seekers, and if international law can have the effect of harmonising subsidiary legal systems, then one might have expected to see a positive convergence in the laws of both jurisdictions in relation to the detention of asylum seekers. The research, however, reveals that not only is the degree of convergence variable across different areas, but also that there is no overall trend towards positive convergence between the two jurisdictions.

It may be suggested that States embark on an approach that is based not on mutual trust but, rather, on mutual distrust. However, in an area where paranoia has, at times, arguably reached inflated levels, it is submitted that basing State action in relation to the treatment of asylum seekers on mutual distrust amongst States has the potential to add a new element of paranoia. That paranoia can be toxic to solutions to address human suffering based on the solidarity amongst States (that is, mutual distrust amongst States may only see further negative measures directed towards asylum seekers, and increase their isolation, as States become frustrated in their sole attempts to find solutions for asylum seekers and as States pursue their own interests).

Indeed, the approach suggested by the CJEU in N.S. is appealing - that is, an approach based on a rebuttable presumption that a State will act in accordance with its human rights obligations. Such an approach provides a check on misplaced trust amongst States and the misplaced trust that persons under a State's jurisdiction can place in that State. It also respects the agency of an asylum seeker. It is, however, dependent on the implementation of international human rights obligations and the effective access to, and consideration by, the courts. It is regrettable, therefore, that those are two of the very areas where the two jurisdictions show the greatest degree of divergence.

\subsection{Recommendations}

From the foregoing research the author provides the following recommendations to the European Union and the Commonwealth of Australia:

1. Legal guardians should be automatically appointed by operation of law for all unaccompanied minors seeking international protection.

2. Although ideally minors should never be detained, it should be prohibited for a legal guardian of an unaccompanied minor to have any other role which would conflict with the discharge their duties as guardian or with their pursuit of the best interests of the child, namely having any role as the detaining 
authority of the minor or the authority determining the outcome of the minor's application for international protection.

3. The ability at law for a minor to submit an application for international protection on his or her own behalf should be guaranteed.

4. Clear, express and reciprocal rights of access and communication between detained asylum seekers and their lawyers, doctors, family members, international organisations and other organisations and oversight bodies should be legislatively embedded.

5. If detention is to be imposed, it should be subject to maximum time limits but any such time limit must be without prejudice to, and not any substitution for, an assessment of the necessity and proportionality of a decision to detain. Maximum time limits should not be used as mitigation for a mandatory detention policy or to foster a culture where asylum seekers are to "do their time" before attaining their liberty.

6. The legal definition of detention should be sufficiently precise to avoid disjunctions between legal and factual realities.

7. Alternatives to detention should be specifically identified and embedded in law with a concurrent obligation to ensure that those alternatives are viable. Alternatives to detention and alternative forms of detention, as embedded in law, should respect the continuum that the principle of proportionality demands (that is, the principle of proportionality also extends beyond the detention decision to ensure that the least restrictive form of detention should be used).

8. Appropriate mechanisms should be put in place (including the provision of reasons in fact and in law and any material in support) to ensure the lawfulness of detention can be challenged for those detained, most notably for those on security-related grounds.

9. Detailed regulatory standards as to the material reception conditions for asylum seekers in detention should be enacted.

10. States should not use the law to create a legal space that diminishes or extinguishes the agency of asylum seekers. States' human rights obligations should be accessible and enforceable at law to ensure the greatest possible protection for asylum seekers (both those detained and those potentially subject to detention).

11. Alternatives to detention should not just exist as a legal construct, but must be viable in practice. 


\section{Epilogue}

In March 2012, the Joint Select Committee ("the Committee") on Australia's Immigration Detention Network released its final report. ${ }^{3272}$

There are six aspects which are chiefly worth noting.

Firstly, the Committee acknowledged that, although the detention service provider, Serco, had experienced difficulties through an increase in numbers of asylum seekers, the Committee reached the conclusion that, overall, "Serco has not performed to the standard expected" in light of insufficient staffing and training of staff (particularly where in an environment with a high prevalence of persons self harming and with mental health issues), inconsistent visitor procedures, and the lack of activities by which a detained asylum seeker can keep him or self occupied. ${ }^{3273}$

Secondly, the Committee found that the overall standard of medical services for those in detention was "adequate", but noted that improvement was needed for transport services for those in remote areas. The same could not be said for mental health services for those in detention. The Committee noted that mental illness in detention centres was "widespread" and that the provision of mental health services was "severely inadequate" which required "urgent improvement". ${ }^{3274}$ Further the Committee also recommended that outreach services be piloted in detention facilities ${ }^{3275}$ (that is, to avoid reliance solely on persons being treated as a result of an incident or through needing to self-diagnose or identify and come forward to seek assistance).

Thirdly, the Committee recommended that a time limit should be imposed on detention of 90 days with asylum seekers being granted Bridging Visas after initial identity, health, character and security checks. The Committee recommended that DIAC should publish reasons why, on an individual basis, detention extends for more than 90 days. In light of the Key Immigration Detention Value (announced, it will be recalled, in 2008) that "Detention in immigration detention centres is only to be used as a last resort and for the shortest practicable time", ${ }^{3276}$ the Committee recommended that further steps

3272 Parliament of Australia, Joint Select Committee on Australia's Immigration Detention Network - Final Report, March 2012, http://www.aph.gov.au/Parliamentary_Business/Committees /Senate_Committees?url=immigration_detention_ctte/immigration_detention/report/repo rt.pdf (last accessed 8 August 2012) ("Final Report of the Joint Select Committee")

${ }^{3273}$ Final Report of the Joint Select Committee, Pp.77-78

3274 Final Report of the Joint Select Committee, P.101

3275 Final Report of the Joint Select Committee, P.93

3276 Evans, Senator the Honourable Chris, Minister for Immigration and Citizenship, speech to the Australian National University in Canberra, 29 July 2008, New Directions in Detention - Restoring Integrity to Australia's Immigration System http://www.nswbar.asn.au/ 
needed to be taken by the Government to implement that value. ${ }^{3277}$ The Committee made its recommendations after hearing evidence that prolonged detention can lead to an increased risk of detained persons to suicide (with instances noted of persons being returned to immigration detention centres against professional advice) ${ }^{3278}$ and that mental illness was affecting the outcome of an asylum seeker's Protection Visa application. ${ }^{3279}$ The Committee urged that persons with severe mental illness be managed in accordance with medical advice and was concerned that a person's lack of mental health was having an adverse impact on the outcome of their application for protection. ${ }^{3280}$ The Committee also heard evidence that previous trauma suffered by a person could be aggravated by detention. In that regard, the Committee noted that the aggravation caused by detention appeared to be evidenced by (1) indefinite detention; (2) remote facilities, harsh climatic and geographic environments; (3) "an absence of meaningful activity"; and (4) "powerlessness over own fate and perceptions of unfairness". 3281 The Committee also noted that, by suffering harm in detention, further Government action may be required in the future once those persons are granted permanent Protection Visas and that those returned have an "increased vulnerability". 3282

Fourthly, in relation to children, the Committee made several important recommendations. The Committee recommended that guardianship of unaccompanied minors be transferred from the Minister for Immigration and Citizenship as soon as possible; ${ }^{3283}$ that a uniform code of child protection be developed and implemented for all children seeking asylum across the immigration system; ${ }^{3284}$ and that Memoranda of Understandings be adopted between DIAC and the children's commissions or commissioners in all States and Territories as soon as possible. ${ }^{3285}$ The Committee noted that 479 children were still in immigration detention facilities as at 14 March $2012^{3286}$ and was deeply concerned that children also faced indefinite detention on account of adverse security assessments of their parents. ${ }^{3287}$

circulars/july/evans2.pdf (last accessed 27 April 2012); Australian Government, Department of Immigration and Citizenship, Key Immigration Detention Values, http://www.immi.gov.au/managing-australias-borders/detention/about/key-values.htm (last accessed 27 April 2012)

3277 Final Report of the Joint Select Committee, Pp.132-133

3278 Final Report of the Joint Select Committee, Pp.107-109

3279 Final Report of the Joint Select Committee, Pp.109-111

${ }^{3280}$ Final Report of the Joint Select Committee, P.111

3281 Final Report of the Joint Select Committee, Pp.113-122

3282 Final Report of the Joint Select Committee, Pp.122-123

3283 Final Report of the Joint Select Committee, P.126

3284 Final Report of the Joint Select Committee, P.129

3285 Final Report of the Joint Select Committee, P.129

3286 Final Report of the Joint Select Committee, P.128

3287 Final Report of the Joint Select Committee, P.133 
Fifthly, in relation to security assessments, the Committee recommended that the ASIO Act be amended so as to allow the review of ASIO security assessments of asylum seekers and refugees by the Security Division of the Administrative Decisions Tribunal. ${ }^{3288}$ The Committee recommended that internal reviews of adverse security assessments given by ASIO be conducted periodically and commenced as soon as possible. ${ }^{3289}$ Further, community detention was recommended by the Committee whilst an in-depth security assessment was conducted (provided that initial security checks did not raise a "red flag" which might warrant against that course of action). ${ }^{3290}$

Sixthly, in relation to alternatives to detention, the Committee recommended that DIAC "consider publishing criteria for whether asylum seekers are placed in community detention or on bridging visas". ${ }^{3291}$ The Committee expressed the view that the community detention program be expanded, ${ }^{3292}$ and agreed with DIAC's use of community detention for those that cannot cope with being in the community on a Bridging Visa E. ${ }^{3293}$ DIAC's routine monitoring of those in Community detention for Bridging Visas Es was also urged by the Committee to continue. ${ }^{3294}$

The Committee's recommendations particularly regarding children and security assessments represent very sound proposals.

The recommendation of a 90-day time limit on detention is a sound recommendation and, for the purpose of reducing any aggravation of previous trauma by otherwise indefinite detention, it is an important and valuable measure. But its utility, in the absence of legislative amendment (that is, if it is not statutorily embedded, or if mandatory detention remains or, where discretion can be exercised, detention is resorted to as a matter of routine policy), may be undermined - particularly if it is not able to be enforced by a detained asylum seeker. A time limit should not be seen as a substitute for detention on an individual basis and for the application of the principle of proportionality. Indeed, care should be exercised so that time limits do not foster an attitude that an asylum seeker should "do his/her time" before being released into the community. Further, care should be exercised that aggregate periods of 90 days do not result, in effect, to another form of indefinite detention. The recommendation is a positive one but it does not overcome the necessity of a more wholesale review - mechanisms should be in place (including periodic judicial review) to ensure that detention is necessary and proportionate in the individual case.

\footnotetext{
3288 Final Report of the Joint Select Committee, P.175

3289 Final Report of the Joint Select Committee, P.175

${ }^{3290}$ Final Report of the Joint Select Committee, Pp.159-160

3291 Final Report of the Joint Select Committee, P.180

3292 Final Report of the Joint Select Committee, Pp.187 and 198

${ }^{3293}$ Final Report of the Joint Select Committee, P.187

${ }^{3294}$ Final Report of the Joint Select Committee, P.187
} 
In relation to alternatives to detention, the recommendation that community detention be used in circumstances where the individual might not be able to cope on a less materially supported basis if on a Bridging Visa E should perhaps be viewed as a sign that further material support (assessed on an individual basis) should be provided for those on Bridging Visa Es. Further, the lack of published criteria as to the eligibility for community detention or Bridging Visa Es is again consistent with an approach which places the liberty of those detained somewhat beyond the reach of enforcement. The asylum seeker is again in a somewhat passive position. In that regard, and consistent with what has been advocated in this book, liberty should be justiciable and the resort to detention only where necessary and proportionate. 


\section{Samenvatting}

Dit proefschrift heeft als onderwerp de detentie van asielzoekers in de Europese Unie en in Australië. Het heeft tot doel zowel het internationale recht rond de problematiek van de detentie van asielzoekers als het recht in de Europese Unie en Australië in kaart te brengen. Het recht in de Europese Unie en in Australië wordt gedetailleerd met elkaar vergeleken.

Uitgangspunt voor de internationale en de nationale rechtsregimes met betrekking tot asielzoekers is het 'wederzijds vertrouwen' tussen Staten gebaseerd op de toetreding van die Staten tot de internationale verdragen inzake mensenrechten. Recente gebeurtenissen hebben dit vertrouwen echter aan het wankelen gebracht daar aan het licht gekomen is dat de realiteit van de mensenrechtenbescherming in die Staten soms achterblijft bij de idealen vervat in en beschermd door de verdragen. Als de internationale rechtsorde de macht heeft om nationale rechtssystemen te beïnvloeden en te harmoniseren, zou men verwachten dat een vergelijkend onderzoek van het recht van de diverse jurisdicties een positieve convergentie betreffende de detentie van asielzoekers laat zien. Om te kunnen concluderen of het concept van wederzijds vertrouwen tussen de Staten op basis hiervan gerechtvaardigd is, werd onderzocht in welke mate de wetten betreffende de problematiek van detentie van asielzoekers in de Europese Unie en Australië al dan niet convergeren.

$\mathrm{Nu}$ detentie van asielzoekers in de wetten van zowel de Europese Unie als Australië is uitgegroeid tot een zeer belangrijk middel om de asielzoekerstroom te beheersen en te controleren, zijn tegelijkertijd de spanningen tussen rechtssystemen en -instellingen toegenomen. Daarom beschrijft het onderzoek allereerst de internationale normen rond de detentie van asielzoekers, gevolgd door de regionale normen (Europees Verdrag voor de Rechten van de Mens en Handvest van de Grondrechten van de Europese Unie) en besteedt vervolgens aandacht aan de bepalingen van de secundaire wetgeving van de Europese Unie alsmede aan de Australische wetgeving.

De inhoudelijke vergelijking van het onderzoek betreft vier hoofdgebieden: (1) omstandigheden waarin detentie kan voorkomen of worden verlengd, (2) de toetsingsmechanismen ten aanzien van het besluit tot oplegging van detentie, (3) de voorwaarden betreffende de detentie, en (4) het evenredigheidsbeginsel, alsmede alternatieven voor detentie.

Wanneer we kijken naar de vier onderzochte gebieden, dan blijkt de mate van convergentie tussen de twee bestudeerde rechtssystemen verre van absoluut of uniform te zijn. Het onderzoek toont aan dat er vele belangrijke, complexe en multidimensionale gebieden van divergentie en convergentie zijn.

De twee belangrijkste gebieden waarin deze twee rechtssystemen van elkaar verschillen, zijn, ten eerste, de toetsing van detentiebeslissingen (waaronder de 
rechterlijke toetsing van het besluit tot detentie, de toetsing door externe bureaus van de omstandigheden van detentie in detentiecentra en de implementatie van hun rapporten en de toetsing van en verantwoordelijkheid voor beslissingen genomen door "private contractors") en ten tweede, de toepassing van het evenredigheidsbeginsel in de context van detentie.

Uitgaande van een maatstaf waarbij respect voor de internationale normen zou moeten leiden tot een betere behandeling van en resultaten voor asielzoekers in detentie, blijkt uit het onderzoek over het geheel genomen geen algemene tendens naar zulke positieve convergentie, waardoor het onderliggende concept van wederzijds vertrouwen tussen de staten nog maar moeilijk te rechtvaardigen is.

Hoewel zou kunnen worden gesuggereerd dat Staten hierdoor lijken te kiezen voor een aanpak gebaseerd op wederzijds wantrouwen, wordt geopperd dat die benadering desastreuze effecten zou kunnen hebben voor het vinden van oplossingen teneinde het menselijk lijden op basis van solidariteit tussen Staten aan te pakken. Wederzijds wantrouwen tussen Staten zou slechts leiden tot verdere negatieve maatregelen gericht op asielzoekers en zou hun isolement vergroten. Staten die gefrustreerd worden in hun eigen pogingen om oplossingen te vinden voor asielzoekers, zullen hun eigen belangen nastreven.

Een benadering die onlangs door het Europese Hof van Justitie is voorgestaan ware te overwegen. Het is een aanpak op basis van een weerlegbaar vermoeden dat een Staat zal handelen in overeenstemming met zijn verplichtingen inzake mensenrechten. Een dergelijke aanpak voorziet in een mogelijkheid tot toetsing en controle van misplaatst vertrouwen tussen Staten en het misplaatste vertrouwen dat mensen onderworpen aan de jurisdictie van een Staat kunnen hebben in die Staat. Het respecteert ook het recht van asielzoekers om het heft in eigen handen te nemen door zelf in actie te komen teneinde hun lot te beïnvloeden. Het is echter afhankelijk van de juiste uitvoering van internationale mensenrechtenverplichtingen en de effectieve toegang tot, en zorgvuldige controle door, rechters. Het is echter betreurenswaardig dat dit nu juist de twee gebieden zijn waar de twee rechtssystemen het sterkst verschillen. 


\section{Bibliography}

\section{International Instruments}

1948 Universal Declaration of Human Rights (adopted 10 December 1948 UNGA Res $217 \mathrm{~A}(\mathrm{III}))$

1951 Convention Relating to the Status of Refugees (adopted 28 July 1951, 189 UNTS 137) and the 1967 Protocol Relating to the Status of Refugees (adopted 31 January 1967, 606 UNTS 267)

1954 Convention relating to the Status of Stateless Persons (adopted 28 December 1954 360 UNTS 117)

1960 UN Educational Scientific and Cultural Organisation ("UNESCO”), Convention Against Discrimination in Education (adopted Paris, 14 December 1960)

1961 Convention on the Reduction of Statelessness (adopted 30 August 1961, 989 UNTS 175)

1966 International Convention on the Elimination of All Forms of Racial Discrimination

1966 International Covenant on Civil and Political Rights) and the 1966 (First) Optional Protocol to the International Covenant on Civil and Political Rights (adopted 16 December 1966, 999 UNTS 171)

1966 International Covenant on Economic, Social and Cultural Rights (adopted on 16 December 1966, 993 UNTS 3)

1969 Vienna Convention on the Law of Treaties (adopted 23 May 1969, 1155 UNTS 331)

1984 Convention against Torture and Other Cruel, Inhuman or Degrading Treatment or Punishment (adopted 10 December 1984, 1465 UNTS 85) and the 2002 Optional Protocol to the Convention against Torture and Other Cruel, Inhuman or Degrading Treatment or Punishment (adopted 18 December 2002, A/RES/57/199)

1989 United Nations Convention on the Rights of the Child (adopted on 20 November 19891577 UNTS 3)

2000 United Nations Convention against Transnational Organized Crime and 2000 Protocol against the Smuggling of Migrants by Land, Sea and Air, supplementing the United Nations Convention against Transnational Organized Crime (adopted 15 November 2000, 2225 UNTS 209)

2006 Convention on the Rights of Persons with Disabilities (adopted 24 January 2007, A/RES/61/106)

\section{United Nations}

Bhagawati, Justice P N, Regional Advisor for Asia and the Pacific of the United Nations High Commissioner for Human Rights, Mission to Australia, 24 May to 2 June 2002, Human Rights and Immigration Detention in Australia, http://www.unhchr.ch/huricane/ 
huricane.nsf/424e6fc8b8e55fa6802566b0004083d9/bc4c8230f96684c8 c1256c070032f5f1/\$FILE/Report.doc

UNICEF, Implementation Handbook for the Convention on the Rights of the Child, (3 ed), 2007

United Nations General Assembly, International Migration and Development - Report of the Secretary-General, 18 May 2006, Doc A/60/871

United Nations Population Division, Department of Economic and Social Affairs, United Nations Secretariat, Replacement migration: is it a solution to declining and ageing populations, 21 March 2000, http://www.un.org/esa/population/publications/migration/migration.htm

United Nations Principles for the Protection of all Persons under Any form of Detention or Imprisonment, Adopted by General Assembly Resolution 43/173 of 9 December 1988 http://www2.ohchr.org/english/law/bodyprinciples.htm

United Nations Rules for the Protection of Juveniles Deprived of their Liberty, 14 December 1990, A/RES/45/113, http://www.un.org/documents/ga/res/45/a45r113.htm

United Nations Standard Minimum Rules for Non-custodial Measures ("The Tokyo Rules"), G.A. Res 45/110, 14 December 1990

United Nations Standard Minimum Rules for the Administration of Juvenile Justice ("The Beijing Rules”), $29 \quad$ November $1985, \quad$ A/RES/40/33, http://www.un.org/documents/ga/res/40/a40r033.htm

United Nations Standard Minimum Rules of the Treatment of Prisoners, Adopted by the First United Nations Congress on the Prevention of Crime and the Treatment of Offenders, held at Geneva in 1955, and approved by the Economic and Social Council by its resolutions 663 C (XXIV) of 31 July 1957 and 2076 (LXII) of 13 May 1977

United Nations, A Study of Statelessness, August 1949, Lake Success, New York, E/112E/1112/Add.1 http://www.unhcr.org/3ae68c2d0.pdf

United Nations, High Commissioner for Human Rights, Special Rapporteur on the situation of human rights and fundamental freedoms of indigenous people, James Anaya, Statement of the Special Rapporteur on the situation of human rights and fundamental freedoms of indigenous people, James Anaya, as he concludes his visit to Australia, 27 August 2009, http://www.unhchr.ch/huricane/huricane.nsf/view01/313713727C084992C125761F0044 3D60?opendocument

\section{United Nations High Commissioner for Refugees}

Edwards, A, Back to Basics: The Right to Liberty and Security of Person and 'Alternatives to Detention' of Refugees, Asylum-Seekers, Stateless Persons and Other Migrants, UNHCR, April 2011, PPLA/2011/01.Rev.1

Field, O, with Edwards, A, Alternatives to Detention of Asylum Seekers and Refugees, United Nations High Commissioner for Refugees, Division of International Protection Services, April 2006, POLAS/2006/03

Mandal, R, Protection Mechanisms Outside of the 1951 Geneva Convention ("Complementary Protection”), UNHCR Legal and Protection Policy Research Series, June 2005, PPLA/2005/02 
UNHCR, Executive Committee Conclusion No. 8 (XXVIII) - Determination of Refugee Status, 1977

UNHCR, Executive Committee Conclusion No. 22 (XXXII) - Protection of Asylum Seekers in Situations of Mass Influx, 1981

UNHCR, Executive Committee Conclusion No. 44 (XXXVII) - Detention of Refugees and Asylum-Seekers, 1986

UNHCR, Executive Committee Conclusion No. 47 (XXXVIII) - Refugee Children, 1987

UNHCR, Executive Committee Conclusion No. 68 (XLIII) - General Conclusion on International Protection, 1992

UNHCR, Executive Committee Conclusion No. 78 (XLVI), Prevention and Reduction of Statelessness and Protection of Stateless Persons, 1995;

UNHCR, Executive Committee Conclusion No. 84 (XLVIII) - Conclusion on Refugee Children and Adolescents, 1997

UNHCR, Executive Committee Conclusion No. 85 (XLIX) - Conclusion on International Protection, 1998

UNHCR, Executive Committee Conclusion No. 88 (XLX) - Protection of the Refugee's Family, 1999

UNHCR, Executive Committee Conclusion No. 101 (LV) - Conclusion on Legal Safety Issues in the Context of Voluntary Repatriation of Refugees, 2004

UNHCR, Executive Committee Conclusion No. 103 (LVI), Conclusion on the Provision of International Protection Including Through Complementary Forms of Protection, 7 October 2005

UNHCR, Executive Committee Conclusion No. 106 (LVII), Identification, Prevention and Reduction of Statelessness and Protection of Stateless Persons, 2006

UNHCR, Executive Committee Conclusion No. 107 (LVIII) - Children at Risk, 2007

UNHCR, Executive Committee Conclusion No 108 (LIX) - Refugees and others of concern with disabilities, 2008

UNHCR, Executive Committee Conclusion No 110 (LXI) - Refugees with disabilities and other persons with disabilities, 2010

UNHCR Regional Office - Australia, New Zealand, Papua New Guinea and the Pacific, Resettlement, http://unhcr.org.au/unhcr/index.php?option=com_content\&view $=$ article $\&$ id $=139 \&$ Itemid $=60$

UNHCR Statement on the reception conditions of asylum-seekers under the Dublin procedure, 1 August 2011, http://www.unhcr.org/4e3801d09.pdf

UNHCR, Addendum to the Report of the United Nations High Commissioner for Refugees, 31 October 1977, A/32/12/Add.1 
UNHCR, Asylum Levels and Trends in Industrialized Countries 2011, 27 March 2012, http://www.unhcr.org/4e9beaa19.html

UNHCR, Expert Meeting - Statelessness Determination Procedures and the Status of Stateless Persons - Summary Conclusions, Expert meeting convened by the Office of the United Nations High Commissioner for Refugees and the Open Society Justice Initiative, Geneva, Switzerland, 6-7 December 2010

UNHCR, Expert Meeting - The Concept of Stateless Persons under International Law - Summary Conclusions, Expert meeting organised by the Office of the United Nations High Commissioner for Refugees, Prato, Italy, 27-28 May 2010

UNHCR, Guidelines on Statelessness No. 2: Procedures for Determining whether an Individual is a Stateless Person, HCR/GS/12/02, 5 April 2012

UNHCR, Handbook on Procedures and Criteria for Determining Refugee Status, 1979, 1992 reed

UNHCR, Massey, H, UNHCR and De Facto Statelessness, April 2010, LPPR/2010/01, http://www.unhcr.org/refworld/docid/4bbf387d2.html

UNHCR, Nationality and Statelessness. A Handbook for Parliamentarians, 20 October 2005, http://www.unhcr.org/refworld/docid/436608b24.html

UNHCR, Note on International Protection, 31 August 1993, A/AC.96/815 http://www.unhcr.org/refworld/docid/3ae68d5d10.html

UNHCR, Safeguards needed as Australia's suspension of claims by Sri Lankans and Afghans comes into force, 16 April 2010, http://unhcr.org.au/pdfs/100416_aulpress.pdf

UNHCR, The Problem of Manifestly Unfounded or Abusive Applications for Refugee Status or Asylum, 20 October 1983, no. 30 (XXXIV) http://www.unhcr.org/refworld /docid/3ae68c6118.html

UNHCR, UNHCR - About Us - About Refugees - http://unhcr.org.au/unhcr/index.php? option=com_content\&view $=$ article $\& i d=179 \&$ Itemid $=54$

UNHCR, UNHCR 2010 Statistical Yearbook - Trends in Displacement Protection and Solutions, http://www.unhcr.org/static/statistical_yearbook/2010/2011-SYB10-all-chapters.zip

UNHCR, UNHCR chief praises Australia's refugee resettlement services, 25 February 2009, http://www.unhcr.org/49a55ff32.html

UNHCR, UNHCR Comments on the European Commission's Proposal for a recast of the Directive laying down minimum standards for the reception of asylum seekers (COM(2008)815 final of 3 December 2008, March 2009, http://www.unhcr.org/4a0d6bf86.pdf

UNHCR, UNHCR Refugee Children Guidelines on Protection and Care, 1994, http://www.unhcr.org/3b84c6c67.html

UNHCR, UNHCR comments on the European Commission's Proposal for a recast of the Regulation of the European Parliament and of the Council establishing the criteria and mechanisms for determining the Member State responsible for examining an application for international protection lodged in one of the Member States by a third country national or a stateless person ("Dublin II") 
(COM(2008) 820, 3 December 2008) and the European Commission's Proposal for a recast of the Regulation of the European Parliament and of the Council concerning the establishment of 'Eurodac' for the comparison of fingerprints for the effective application of [the Dublin II Regulation] (COM(2008) 825, 3 December 2008), 18 March 2009, http://www.unhcr.org/ $4 \mathrm{a} 0 \mathrm{~d} 6 \mathrm{a} 6710 . \mathrm{pdf}$

UNHCR, UNHCR Revised Guidelines on Applicable Criteria and Standards relating to the Detention of Asylum Seekers, February 1999

\section{United Nations Human Rights Committee Views}

A v Australia, Communication No. 560/1993, UN Doc. CCPR/C/59/D/560/1993, 30 April 1997

Adolfo Drescher Caldas v Uruguay, Communication No. 43/1979, 1990

Ahani $v$ Canada, Communication No. 1051/2002, UN Doc CCPRC/C/80/D/1051/2002, 29 March 2004

Arzuaga v Uruguay, Communication 147/1983, ICCPR A/41/40 128, 1 November 1985

Baban $v$ Australia, Communication No. 1014/2001, UN Doc. CCPR/C/78/D/1014/2001, 6 August 2003

Bakhtiyari v Australia, Communication No. 1069/2002, 29 October 2003, CCPR/C/79/D/1069/2002

C v Australia, Communication No. 900/1999, CCPR/C/76/D/900/1999, 28 October 2002

Caldas v Uruguay, Communication 43/1979, ICCPR A/38/40 192, 21 July 1983

Celepli v Sweden, Communication No. 456/1991, CCPR/C/51/D/456/1991, 2 August 1994

$D$ and $E v$ Australia, 11 July 2006, Communication No. 1050/2002, UN Doc $\mathrm{CCPR} / \mathrm{C} / 87 / \mathrm{D} / 1050 / 2002$

De Romero v Uruguay, Communication 85/1981, ICCPR A/39/40 159

Jalloh $v$ The Netherlands, Communication No. 794/1998, CCPR/C/74/D/794/1988, 15 April 2002

López Burgos v Uruguay, Communication No.52/1979, CCPR/C/13/D/1979, 29 July 1981

Machado v Uruguay, Communication 83/1981, CCPR/C/20/D/1981, 4 November 1983

Madafferi $v$ Australia, Communication No. 1011/2001, UN Doc. CCPR/C/81/D/1011/2001, 26 August 2004

Marais v Madagascar, Communication 49/1979, ICCPR A/38/40 141, 24 March 1983 
Marques de Morais v Angola, Communication 1128/2002, CCPR/C/83/D/1128/2002, 29 March 2005

Muteba v Zaire, Communication 124/1982, ICCPR A/39/40 182, 24 July 1984

Pietraroia v Uruguay, Communication 44/1979, ICCPR A/36/40 153, 27 March 1981

Shafiq $v$ Australia, Communication No. 1324/2004, UN Doc. CCPR/C/88/D/1324/2004, 13 November 2006

Shams et al v Australia, Communication Nos. 1255, 1256, 1259, 1260, 1268, 1270, 1288/2004, UN Doc CCPR/C/90/D/1255, 1256, 1259, 1260, 1266, 1268, 1270 \& 1288/2004, 11 September 2007

Simones v Uruguay, Communication R 17/70, ICCPR A/37/40 174, April 1982

Torres v Finland, Communication No. 291/1988, UN Doc CCPR/C/38/D/291/1988, 5 April 1990

van Alphen $v$ The Netherlands, Communication No. 305/1988, CCPR/C/39/D/305/1988, 15 August 1990

Van Duzen v Canada, Communication No. 50, CCPR/C/15/D/1979, 7 April 1982

Vuolanne v Finland, Communication No. 265/1987, UN Doc CCPR/C?35/D/265/1987, 7 April 1989

\section{United Nations Human Rights Council}

United Nations Human Rights Council, Report of the Working Group on Arbitrary Detention, 18 January $2010, \mathrm{~A} / \mathrm{HRC} / 13 / 30$

\section{United Nations Commission on Human Rights}

United Nations Commission on Human Rights, 49 $9^{\text {th }}$ Session, Question of the Human Rights of All Persons Subjected to Any Form of Detention or Imprisonment - Report of the Working Group on Arbitrary Detention, UN Doc. E/CN.4/1993/24, 12 January 1993

United Nations Commission on Human Rights, Working Group on Arbitrary Detention, Question of the Human Rights of all Persons Subjected to Any Form of Detention or Imprisonment, Situation Regarding Immigrants and Asylum Seekers, UN Doc. E/CN.4/1998/44, 19 December 1997

United Nations Commission on Human Rights, Working Group on Arbitrary Detention, Body of Principles for the Protection of All Persons under Any Form of Detention or Imprisonment regarding the situation of immigrants and asylum seekers, Deliberation No. 5, UN Doc. E/CN.4/2000/4/Annex 2, 28 December 1999 


\section{United Nations Treaty Bodies - General Comments and Concluding Observations}

Human Rights Committee

United Nations Human Rights Committee, General Comment No. 8: Right to liberty and security of persons (Art. 9), 30 June 1982

United Nations Human Rights Committee, General Comment No. 15 - The position of aliens under the Covenant, 11 April 1986

United Nations Human Rights Committee, General Comment No. 16: The right to respect of privacy, family, home and correspondence, and protection of honour and reputation (Art, 17), 8 April 1988

United Nations Human Rights Committee, General Comment No. 17 - Rights of the child (Art. 24), 7 April 1989

United Nations, Human Rights Committee, General Comment 19 - Protection of the family, the right to marriage and equality of the spouses - Article 23, 27 July 1990

United Nations Human Rights Committee, General Comment No. 20: Replaces general comment 7 concerning prohibition of torture and cruel treatment or punishment, 10 March 1992

United Nations Human Rights Committee, General Comment No. 21: Replaces general comment 9 concerning humane treatment of persons deprived of liberty, 10 April 1992

United Nations Human Rights Committee, General Comment No. 27: Freedom of Movement (Art. 12), CCPR/C/21/Rev.1/Add.9, 2 November 1999

United Nations, Human Rights Committee, General Comment 31 - Nature of the General Legal Obligation Imposed on State Parties to the Covenant, 26 May 2004

United Nations Human Rights Committee, Concluding observations of the Human Rights Committee - Australia, 7 May 2009, CCPR/C/AUS/CO/5

Committee Against Torture

United Nations, Committee Against Torture, General Comment No. 2 - Implementation by State Parties, 24 January 2008

United Nations, Committee Against Torture, Concluding Observations of the Committee Against Torture - Australia, CAT/C/AUS/CO/3, 22 May 2008

Committee on the Elimination of Racial Discrimination

United Nations, Committee on the Elimination of Racial Discrimination, General Recommendation No. 30 - Discrimination Against Non Citizens, 1 October 2004

Committee on the Rights of the Child

United Nations, Committee on the Rights of the Child, General Comment No. 5 - General measures of implementation of the Convention on the Rights of the Child (arts. 4, 42 and 44, para 6), 27 November 2003 
United Nations, Committee on the Rights of the Child, General Comment No. 6 Treatment of Unaccompanied and Separated Children Outside their Country of Origin, 1 September 2005

United Nations, Committee on the Rights of the Child, General Comment No. 10 Children's rights in juvenile justice, 25 April 2007

United Nations, Committee on the Rights of the Child, General Comment No. 12 - The right of the child to be heard, 20 July 2009

United Nations, Committee on the Rights of the Child, General Comment No. 13 (2011) The right of the child to freedom from all forms of violence, 18 April 2011

United Nations, Committee on the Rights of the Child, Consideration of Reports Submitted by States Parties under Article 44 of the Convention - Concluding Observations: Australia, 20 October 2005, CRC/C/15/Add.268

United Nations, Committee on the Rights of the Child, UN Committee on the Rights of the Child: Concluding Observations, Benin, 20 October 2006, CRC/C/BEN/CO/2

United Nations, Committee on the Rights of the Child, UN Committee on the Rights of the Child: Concluding Observations: Canada, 27 October 2003, CRC/C/15/Add.215

United Nations, Committee on the Rights of the Child, UN Committee on the Rights of the Child: Concluding Observations, Latvia, 28 June 2006, CRC/C/LVA/CO/2

United Nations, Committee on the Rights of the Child, UN Committee on the Rights of the Child: Concluding Observations, Oman, 29 September 2006, CRC/C/OMN/CO/2

United Nations, Committee on the Rights of the Child, Concluding Observations of the Committee on the Rights of the Child: St Kitts and Nevis, 24 August 1999, CRC/C/15/Add.104

Committee on Economic, Social and Cultural Rights

United Nations, Committee on Economic, Social and Cultural Rights, General Comment No. 3 - The nature of States' parties obligations (Art 2, par. 1), 14 December 1990

United Nations, Committee on Economic, Social and Cultural Rights, General Comment No. 14 - The right to the highest attainable standard of health (article 12 of the International Covenant on Economic, Social and Cultural Rights, 11 August 2000

\section{International Court of Justice}

Nottebohm Case (Liechtenstein v Guatemala), Second Phase, Judgment of 6 April 1955: ICJ Reports 1955, P.4

Advisory Opinion on the Legal Consequences of the Construction of a Wall in the Occupied Palestinian Territory, General List No. 131 [2004] ICJ 2 


\section{Council of Europe}

Statute of the Council of Europe (London, 5 May 1949, CETS No.1)

European Convention for the Protection of Human Rights and Fundamental Freedoms (and its Protocols) (Rome, 5 November 1950, CETS No. 5)

European Convention for the Prevention of Torture, Inhuman and Degrading Treatment or Punishment (Strasbourg, 26 November 1987, CETS No. 126)

European Convention on the Exercise of Children's Rights (Strasbourg, 25 January 1996, CETS No. 160

European Convention on Nationality (Strasbourg, 6 November 1997, CETS No. 166)

Convention on the avoidance of statelessness in relation to State succession (Strasbourg, 19 May 2006, CETS No. 200)

Committee of Ministers, Council of Europe, Recommendation Rec(2003)5 of the Committee of Ministers to member states on measures of detention to asylum seekers, 16 April 2003

Committee of Ministers, Council of Europe, Twenty Guidelines on Forced Return, CM(2005)40 Addendum final, Strasbourg, 20 May 2005

Committee of Ministers, Council of Europe, Recommendation (2009)13 of the Committee of Ministers to member states on the nationality of children, 9 December 2009

Council of Europe, $A$ short history of the Council of Europe, http://portal.coe.ge/index.php?lan=en\&id= million\&sub $=1$

Council of Europe, Human Rights: protection, promotion and prevention http://portal.coe.ge/index.php?lan=en\&id= million\&sub $=7$

Council of Europe, Reform of European Court of Human Rights: Protocol 14 enters into force, 31 May 2010, https://wcd.coe.int/wcd/ViewDoc.jsp?Ref=PR437(2010)\&Language= lanEnglish $\&$ Ver $=$ original $\&$ BackColorInternet $=$ F5CA75 $\&$ BackColorIntranet $=$ F5CA $75 \& B a$ ckColorLogged $=$ A9BACE

Council of Europe, Joint talks on EU's accession to Convention on Human Rights begins, http://human-rights-convention.org/2010/07/07/joint-talks-on-eus-accession-toconvention-on-human-rights-begin/

Council of Europe, Draft Meeting Report, $5^{\text {th }}$ Working Meeting of the CDDH Informal Working Group on the Accession of the European Union to the European Convention on Human Rights (CDDH-UE) with the European Commission, 28 January 2011, Document CDDH-EU(2011)03

Council of Europe, Meeting Report, $8^{\text {th }}$ Working Meeting of the CDDH Informal Working Group on the Accession of the European Union to the European Convention on Human Rights (CDDH-UE) with the European Commission, 19 July 2011, Document CDDHEU(2011)16 
Council of Europe, Parliamentary Assembly, Lives lost in the Mediterranean Sea: who is responsible? 29 March 2012, http://assembly.coe.int/CommitteeDocs/2012 /20120329_mig_RPT.EN.pdf

European Committee for the Prevention of Torture and Inhuman or Degrading Treatment or Punishment, The CPT Standards, October 2006, Strasbourg, CPT/Inf/E (2002) 1 - Rev. 2010

European Committee for the Prevention of Torture and Inhuman or Degrading Treatment, Report to the Government of Greece carried out by the European Committee for the Prevention of Torture and Inhuman or Degrading Treatment from 17 to 29 September 2009, 17 November 2010, CPT/Inf (2010) 33, http://www.cpt.coe.int/documents/grc/2010-33inf-eng.htm

\section{Case law of the European Court of Human Rights}

A v United Kingdom, No. 25599/94, Judgment, 23 September 1998

A. A. v Greece, No. 12186/08, Judgment, 22 July 2010

Abdulaziz, Cabales and Balkandali $v$ the United Kingdom, Nos. 9214/80, 9473/81, and 9474/81, Judgment, 28 May 1985

Aerts $v$ Belgium, No, 25357/94, Judgment, 30 July 1998

Ahmut $v$ the Netherlands, No. 21702/93, Judgment, 28 November 1996

Airey v Ireland, No. 6289/73, Judgment, 9 October 1979

Aksoy v Turkey, No. 21987/93, Judgment, 18 December 1996

Al Nashif v Bulgaria, No. 50963/99, Judgment, 20 June 2002

Al-Agha v Romania, No. 40933/02, Judgment, 12 January 2010

Amuur v France, No. 19776/92, Judgment, 25 June 1996,

Ashingdane v United Kingdom, No. 8225/78, Judgment, 28 May 1985

Assenov v Bulgaria, 24760/94, Judgment, 28 October 1998

Auad v Bulgaria, No. 46390/10, Judgment, 11 October 2011

B. $v$ United Kingdom, No. 9840/82, Judgment, 8 July 1987

Bankovic et al. v Belgium et al., No. 52207/99, Decision, Grand Chamber, 12 December 2001

Baranowski v Poland, No. 28358/95, Judgment, 28 March 2000

Beldjoudi v France, No. 12083/86, Judgment, 26 March 1992

Benjamin and Wilson v United Kingdom, No. 28212/95, Judgment

Berrehab v The Netherlands, No. 10730/84, Judgment, 21 June 1988

Bezicheri v Italy, No. 11400/85, Judgment, 25 October 1989

Bizzotto v Greece, No. 22126/93, Judgment, 15 November 1996

Bosphorus Hava Yollari Turizm Ve Ticaret Anonim Sirketi v Ireland, No. 45036/98, Judgment, Grand Chamber, 30 June 2005

Boultif v Switzerland, No. 54273/00, Judgment, 2 August 2001

Chahal $v$ the United Kingdom, No. 22414/93, Judgment, Grand Chamber, 15 November 1996

Čonka v Belgium, No. 51564/99, Judgment, 5 February 2002

Costello-Roberts v United Kingdom, No. 13134/87, Judgment, 25 March 1993

Cruz Varas v Sweden, No. 15576/89, 20 March 1991, Judgment (Plenary)

Curley $v$ United Kingdom, No. 32340/96, Judgment, 28 March 2000

$D v$ the United Kingdom, No. 30240/96, Judgment, 2 May 1997

De Wilde, Ooms and Versyp v Belgium, Nos. 28322/66, 2835/66, 2899/66), Judgment, 18 June 1971

Dougoz v Greece, Application 40907/98, Judgment, 6 March 2001

Dzhurayev v Russia, No. 38124/07, Judgment, 17 December 2009 
E $v$ Norway, No. 11701/85, Judgment, 29 August 1990

Ecli v Turkey, Nos. 23145/93 and 25091/94, Judgment, 13 November 2003

Eminbeyli v Russia, No. 42443/02, Judgment, 26 February 2009

Eriksson v Sweden, No. 11373/85, Judgment, 22 June 1989,

Fox, Campbell and Hartley $v$ United Kingdom, Nos. 12446/86, 12245/86 and 12383/86, Judgment, 30 August 1990

Gebremedhin v France, No. 25389/05, Judgment, 26 April 2007

Gnahoré v France, No. 40031/98, Judgment, 19 September 2000

Goodwin v The United Kingdom, No. 28957/95, Judgment, Grand Chamber, 11 July 2002

Gül v Switzerland, No. 23218/94, Judgment, 19 February 1996

Guzzardi v Italy, No. 7367/76, Judgment, Plenary Chamber, 6 November 1980

Hirsi Jamaa and Others $v$ Italy, No. 27765/09, Judgment, Grand Chamber, 23 February

2012,

I.M. v France, No. 9152/09, Judgment, 2 February 2012

Ilaşcu et al. v Moldova and Russia, No. 48787/99, Judgment, Grand Chamber, 8 July 2004

Ireland $v$ United Kingdom, No. 5310/71, Judgment (Plenary), 18 January 1978

Jabari v Turkey, No. 40035/98, Judgment, 11 July 2000

Kaboulov v Ukraine, No. 41015/04, Judgment, 19 November 2009

Kadem v Malta, No. 55263/00, Judgment, 9 January 2003

Kamyshev v Russia, No. 3990/06, Judgment, 20 May 2010

Kanagaratnam \& Others $v$ Belgium, No. 15297/09, Judgment, 13 December 2011

Kerr v United Kingdom, No. 40451/98, Partial Decision, 7 December 1999

Khaydarov v Russia, No. 21055/09, Judgment, 20 May 2010

Khodzhayev v Russia, No. 52466/08, Judgment, 12 May 2010

Kolompar v Belgium, No.11613/85, Judgment, 24 September 1992

KRS $v$ the United Kingdom, No. 32733/08, Admissibility Decision, 2 December 2008

Kudla v Poland, No. 30210/96, Judgment Grand Chamber, 26 October 2000

Labita v Italy, No. 26772/95, Judgment, 6 April 2000

Loizidou v Turkey, No. 15318/89, Judgment, Grand Chamber, 23 March 1995

Lokpo and Touré v Hungary, No. 10816/10, Judgment, 20 September 2011

Longa Yonkeu v Latvia, No. 57229/09, Judgment, 15 November 2011

Luberti v Italy, 9019/80, Judgment, 23 February 1984

$M$ and Others $v$ Bulgaria, No. 41416/08, Judgment 26 July 2011

Mamatkulov and Askarov v Turkey, Nos. 46827/99 and 46951/99, Judgment Grand Chamber, 4 February 2005

Matthews $v$ United Kingdom, No. 24833/94, Judgment, Grand Chamber, 18 February 1999

Medvedyev and Others v France, No. 3394/03, Judgment, Grand Chamber, 29 March 2010

Mikolenko v Estonia, No. 10664/05, Judgment, 8 October 2009

Mouisel v France, No. 67263/01, Judgment, 14 November 2002

Moustaquim v Belgium, No. 12313/86, Judgment, 18 February 1991

MSS v Belgium \& Greece, No. 30696/09, Judgment, Grand Chamber, 21 January 2011

Mubilanzila Mayeka and Kaniki Mitunga v Belgium, No. 13178/03, Judgment, 12 October 2006

Murray v United Kingdom, No. 14310/88, Judgment, Grand Chamber, 28 October 1994

Muskhadzhiyeva $v$ Belgium, No. 41442/07, Judgment, 19 January 2010

$N A v$ the United Kingdom, No. 25904/07, Judgment, 17 July 2008

Neumeister v Austria, No. 1936/63, Judgment, 27 June 1968

Nevmerzhitsky $v$ Ukraine, No. 54825/00, Judgment, 5 April 2005

Öcalan v Turkey, No. 46221/99, Judgment, Grand Chamber, 12 May 2005

Olsson v Sweden (No. 1), No. 10465/83, Judgment, 24 March 1988

Peers $v$ Greece, No. 28524/95, Judgment, 19 April 2001

Popov v France, Nos. 39472 and 39474/07, Judgment, 19 January 2012

Pretty v United Kingdom, No. 2346/02, Judgment, 29 April 2002

R.U. v Greece, No. 2237/08, Judgment, 7 June 2011 
Rahimi v Greece, No. 8687/08, Judgment, 5 April 2011

Rashed v Czech Republic, No. 298/07, Judgment, 27 November 2008

Raza v Bulgaria, No. 31465/08, Judgment, 11 February 2010

Riad and Idiab v Belgium, No. 29787/03 and 29810/03, Judgment, 24 January 2008

Rodrigues da Silva and Hoogkamer $v$ The Netherlands, No. 50435/99, Judgment, 31 January 2006

Rusu v Austria, No. 34082/02, Judgment, 2 October 2008

Saadi v United Kingdom, No. 13229/03, Judgment, Grand Chamber, 29 January 2008

Sadaykov v Bulgaria, No. 75157/01, Judgment, 22 May 2008

Salah Sheekh $v$ the Netherlands, No. 1948/04, Judgment, 11 January 2007

Sanchez-Reisse v Switzerland, No. 9862/82, Judgment, 21 October 1986

SD $v$ Greece, No. 53541/07, Judgment, 11 June 2009

Selmouni v France, No. 25803/94, Judgment, 28 July 1999

Sen $v$ the Netherlands, No. 31465/96, Judgment, 21 December 2001

Sevtap Veznedaroğluv Turkey, No. 32357/96, Judgment, 11 April 2000

Shamsa v Poland, No. 45355/99 and 45357/99, 27 November 2003

Shchebet $v$ Russia, No. 16074/07, Judgment, 12 June 2008

Shchukin \& Ors v Cyprus, No. 14030/03, Judgment, 29 July 2010

Singh v Czech Republic, No. 60538/00, Judgment, 25 January 2005

Singh $v$ United Kingdom, No. 23389/94, Judgment, 21 February 1996

Soering $v$ the United Kingdom, No. 14038/88, Judgment, 7 July 1989

Soldatenko v Ukraine, 2440/07, Judgment, 23 October 2008

Sultani v France, No. 45223/05, Judgment, 20 September 2007

Tabesh v Greece, No. 8256/07, Judgment, 26 November 2009

Tekdemir $v$ the Netherlands, No. 46860/99 and 49823/99, Admissibility Decision, 1 October 2002

Tyrer $v$ United Kingdom, No. 5862/72, Judgment, 25 April 1978

Vv United Kingdom, No. 24888/94, Judgment, 16 December 1999

Vasileva v Denmark, No. 52792/99, Judgment, 25 December 2003

Weeks $v$ United Kingdom, No. 9787/82, Judgment, Plenary, 2 March 1987

Winterwerp $v$ the Netherlands, No. 6301/73, Judgment, 24 October 1979

$X v$ United Kingdom, No. 7215/75, Judgment, 5 November 1981

Yildiz v Austria, No. 37295/97, Judgment 31 October 2002

Zamir v United Kingdom, No. 9174/80, Commission Report, 11 October 1983

The Court

European Court of Human Rights, Rules of Court, April 2011, Strasbourg, http://www.echr.coe.int/NR/rdonlyres/6AC1A02E-9A3C-4E06-94EF-

E0BD377731DA/0/REGLEMENT_EN_Avril2011.pdf

European Court of Human Rights, Practice Direction, Requests for Interim Measures, http://www.echr.coe.int/NR/rdonlyres/5F40172B-450F-4107-9514-

69D6CBDECF5C/0/INSTRUCTION_PRATIQUE_Demandes_de_mesures_provisoires _juillet_2011_EN.pdf

European Court of Human Rights, Press Release, New statistics and instructions published on request to suspend expulsion of applicants before European Court of Human Rights, 28 July 2011 http:// cmiskp.echr.coe.int/tkp197/view.asp?action=open\&documentId=888948\&portal=h bkm\&source $=$ externalbydocnumber\&table $=$ F69A27FD8FB86142BF01C1166DEA398649

European Court of Human Rights, Statistics in relation to interim measures http://www.echr.coe.int/NR/rdonlyres/43F2D6A8-8034-4271-9498-

AD9EAC707FB6/0/ART_39_TABLEAU_PAR_PAYS_2011_EN.pdf 


\section{European Union Primary Law}

Treaty on the European Union, OJ C 83, 30 March 2010

Treaty on the Functioning of the European Union, OJ C 83, 30 March 2010

Treaty of Maastricht, OJ C 191, 29 July 1992

Treaty of Amsterdam, OJ C 340, 10 November 1997

Treaty of Nice, OJ C 80, 10 March 2001

Treaty Establishing a Constitution for Europe, OJ C 310, 16 December 2004

Treaty of Lisbon, OJ C 306, 17 December 2007

Charter of Fundamental Rights of the European Union, OJ C 83, 30 March 2010

Treaty Establishing the European Community, OJ C 321E, 29 December 2006

\section{European Union Agreements and Decisions}

Association Agreement between Turkey-EEC signed on12 September 1963 and Additional Protocol to the Association Agreement signed 23 November 1970, OJ C 113/1, 24 December 1973

Decisions of the Turkey-EEC Association Council 2/76, 1/80 and 3/80

Agreement on the European Economic Area, OJ L1/3, 3 January 1994

Convention determining the State responsible for examining applications for asylum lodged in one of the Member States of the European Communities - Dublin Convention OJ C 254/1, 19 August 1997

Protocol on the consequences of the Dublin Agreement coming into effect for some regulations on the Schengen Supplementary Agreement ("the Bonn Protocol"), 26 April 1994

Partnership and Cooperation Agreement between the European Communities and Russia, OJ L 327/3, 28 November 1997

Partnership and Cooperation Agreements between the EC and: Armenia, OJ L 239, 9 September 1999;

Azerbaijan, OJ L 246, 17 September 1999;

Georgia, OJ L 205, 4 August 1999;

Kazakhstan, OJ L 196, 28 July 1999;

Kyrgyz Republic, OJ L 196 of 28 July 1999;

Republic of Moldova, OJ L 181, 24 June 1998;

Ukraine, OJ L 327, 19 February 1998;

Republic of Uzbekistan, OJ L 229, 31 August 1999;

Tajikstan, OJ L 350, 29 December 2009

Lebanese Republic, OJ L 143, 30 May 2006;

People's Democratic Republic of Algeria, OJ L 265, 10 October 2005; 
Arab Republic of Egypt, OJ L 304, 30 September 2004;

Hashemite Kingdom of Jordan, OJ L 129, 15 May 2002;

State of Israel, OJ L 147, 21 June 2000;

Kingdom of Morocco, OJ L 138, 9 June 2000;

Republic of Tunisia, OJ L 97, 30 March 1998.

Cotonou Agreement signed 23 June 2000, OJ L 317/3, 15 December 2000

Agreement between the European Community and its Member States, of the one part, and the Swiss Confederation, of the other, on the free movement of persons, OJ L114/6, 30 April 2002

EC-Chile Association Agreement, OJ L 352/1, 30 December 2002

Memorandum of Understanding between the Council of Europe and the European Union (Strasbourg, 23 May 2007)

Agreement between the European Community and the Swiss Confederation concerning the criteria and mechanisms for establishing the State responsible for examining a request for asylum lodged in a Member State or in Switzerland - Final Act - Declarations [2008] OJ L 53/5 and Information relating to the entry into force of the Agreement between the European Union, the European Community and the Swiss Confederation on the Swiss Confederation's association with the implementation, application and development of the Schengen acquis, as well as of the Agreement between the European Community and the Swiss Confederation concerning the criteria and mechanisms for establishing the State responsible for examining a request for asylum lodged in a Member State in Switzerland [2008] OJ L 53/18

Stabilization and Association Agreements between the European Communities and:

Croatia, OJ L 26, 28 January 2005

Albania, OJ L 239, 1 September 2009

http://europa.eu/legislation_summaries/enlargement/western_balkans/r18003_en. htm

\section{European Union Secondary Law}

Joint Action of 4 March 1996 adopted by the Council on the basis of Article K.3 of the Treaty on the European Union on air transit arrangements, OJ L063/9 13 March 1996

Council Directive 2000/43/EC of 29 June 2000 implementing the principle of equal treatment between persons irrespective of racial or ethnic origin

Council Directive 2000/78/EC of 27 November 2000 establishing a general framework for equal treatment in employment and occupation

Council Decision 2000/596EC of 28 September 2000 establishing the European Refugee Fund

Council Regulation (EC) No 2725/2000 concerning the establishment of Eurodac for the comparison of fingerprints for the effective application of the Dublin Convention, [2006] OJ L 66/37 
Council Directive 2001/40/EC of 28 May 2001 on the mutual recognition of decisions on the expulsion of third country nationals

Council Directive 2001/51/EC of 28 June 2001 supplementing the provisions of Article 26 of the Convention Implementing the Schengen Agreement of 14 June 1985

Council Directive 2001/55/EC of 20 July 2001 on minimum standards for giving temporary protection in the event of a mass influx of displaced persons and on measures promoting a balance of efforts between Member States in receiving such persons and bearing the consequences thereof

Council Decision 2001/258/EC of 15 March 2001 concerning the conclusion of an Agreement between the European Community and the Republic of Iceland and the Kingdom of Norway concerning the criteria and mechanisms for establishing the State responsible for examining a request for asylum lodged in a Member State or Iceland or Norway [2001] OJ L 93/38

Council Regulation (EC) 539/2001 of 15 March 2001 listing the third countries whose nationals must be in possession of visas when crossing the external borders and those whose nationals are exempt from that requirement

Council Regulation 407/2002 of 28 February 2002 laying down certain rules to implement Regulation (EC) No 2725/2000 concerning the establishment of 'Eurodac' for the comparison of fingerprints for the effective application of the Dublin Convention

Council Directive 2003/9/EC of 27 January 2003 laying down minimum standards for the reception of asylum seekers

Council Directive 2003/86/EC of 22 September 2003 on the right to family reunification

Council Directive 2003/109/EC of 25 November 2003 concerning the status of third country nationals who are long-term residents

Council Regulation 343/2003 of 18 February 2003 establishing the criteria and mechanisms for determining the Member State responsible for examining an asylum application lodged in one of the Member States by a third-country national

Commission Regulation 1560/2003 of 2 September 2003 laying down detailed rules for the application of Council Regulation (EC) No 343/2003 establishing the criteria and mechanisms for determining the Member State responsible for examining an asylum application lodged in one of the Member States by a third-country national

Directive 2004/38 of the European Parliament and of the Council of 29 April 2004 on the right of citizens and the Union and their family members to move and reside freely within the territory of the Member States

Council Directive 2004/83/EC of 29 April 2004 on minimum standards for the qualification and status of third country nationals or stateless persons as refugees or as persons who otherwise need international protection and the content of the protection granted

Directive 2004/114/EC of 13 December 2004 on the conditions of admission of third country nationals for the purposes of studies, pupil exchange, unremunerated training or voluntary service 
Regulation 491/2004 of the European Parliament and of the Council of 10 March 2004 establishing a programme for financial and technical assistance to third countries in the areas of migration and asylum

Council Directive 2005/71/EC of 12 October 2005 on a specific procedure for admitting third country nationals for the purposes of scientific research

Council Directive 2005/85/EC of 1 December 2005 on minimum standards on procedures in Member States for granting and withdrawing refugee status

Council Regulation (EC) 2007/2004 of 26 October establishing a European Agency for the Management of Operation Cooperation at the External Borders of the Member States of the European Union

Council Decision 2006/188/EC of 21 February 2006 on the conclusion of the Agreement between the European Community and the Kingdom of Denmark extending to Denmark the provisions of Council Regulation (EC) No 343/2003 establishing the criteria and mechanisms for determining the Member State responsible for examining an asylum application lodged in one of the Member States by a third-country national

Regulation 562/2006 of the European Parliament and of the Council of 15 March 2006 establishing a Community Code on the rules governing the movement of persons across borders (Schengen Borders Code)

Directive 2008/115/EC of the European Parliament and of the Council of 16 December 2008 on common standards and procedures in Member States for returning illegally staying third-country nationals

Council Directive 2009/50/EC of 25 May 2009 on the conditions of entry and residence of third country nationals for the purposes of highly qualified employment

Directive 2009/52/EC of the European Parliament and the Council of 18 June 2009 providing for minimum standards on sanctions and measures against employers of illegally staying third-country nationals

Regulation (EU) No 439/2010 of the European Parliament and of the Council of 19 May 2010 establishing a European Asylum Support Office

Directive 2011/95/EU of the European Parliament and of the Council of 13 December 2011 on standards for the qualification of third-country nationals or stateless persons as beneficiaries of international protection, for a uniform status for refugees or for persons eligible for subsidiary protection, and for the content of the protection granted

Directive 2011/98/EU of the European Parliament and of the Council of 13 December 2011 on a single application procedure for a single permit for third country nationals to reside and work in the territory of a Member State and on a common set of rights for thirdcountry workers legally residing in the territory of a Member State

Regulation 493/2011 of the European Parliament and of the Council of 5 April 2011 amending Council Regulation (EC) No 377/2004 on the creation of an immigration liaison officers network 


\section{Case law of the European Court of Justice}

Case C-8/55, Fédération Charbonière de Belgique v High Authority of the European Coal and Steel Community [1956] ECR 245, Judgment, 16 July 1956

Case 25/62 Plaumann \& Co v Commission [1963] ECR 95, Judgment, 16 July 1963,

Case 11/70 Internationale Handelsgesellschaft $v$ Einfuhr- und Vorrastelle für Getreide und Futtermittel [1970] ECR 1125, Judgment, 17 December 1970

Case C-39/72 Commission v Italy ("the Slaughtered Cow case") [1973] ECR 101, Judgment, 7 February 1973

Case 4/73 Nold v Commission [1974] ECR 491, Judgment, 14 May 1974

Case C-167/73 Commission v France [1974] ECR 359, Judgment, 4 April 1974

Case C-8/74 Procurer du Roi v Benoît and Gustave Dassonville [1974] ECR 837, Judgment, 11 July 1974

Case C-41/74 Van Duyn v Home Office [1974] ECR 1337, Judgment 4 December 1974,

Case C-36/75 Roland Rutili v Ministre de l'intérieur [1975] ECR 1219, Judgment, 28 October 1975

Case C-48/75 Jean Noël Royer [1976] ECR 497, Judgment, 8 April 1975

Case C-104/75 Adriaan de Peijper, Managing Director of Centrafarm BV [1976] ECR 613, Judgment, 20 May 1976

Case C-118/75 Lynne Watson and Alessandron Belmann [1976] ECR 1185, Judgment, 7 July 1976

Case C-30/77, Régina v Pierre Bouchereau [1977] ECR 1999, Judgment, 27 October 1977

Case C-120/78 Rewe-Zentrale AG v Bundesmonoplverwaltung für Branntwein [1979] ECR 649, 20 February 1979, Judgment

C-148/78 Pubblico Ministero v Tullio Ratti [1979] ECR 1629, Judgment, 5 April 1979

Case C-44/79 Liselotte Hauer v Land Rheinland-Pfalz [1979] ECR 3727, Judgment, 13 December 1979

Case C-157/79 Regina v Stanislaus Pieck [1980] ECR 2171, Judgment, 3 July 1980

Case C-203/80, Criminal proceedings against Guerrino Casati [1981] ECR 2595, Judgment, 11 November 1981

Case C-8/81 Becker v Finanzamt Münster-Innestadt [1982] ECR 53, 19 January 1982, Judgment

Case C-77/81 Zuckerfabrik Franken GmbH v Federal Republic of Germany [1982] ECR 681, Judgment, 18 February 1982 
Case C-14/83 Von Colson and Kamann v Land Nordrhein Westfalen [1984] ECR 1891, Judgment, 10 April 1984

Case C-152/84 Marshall v Southampton and South-West Hampshire Area Health Authority (Teaching) [1986] ECR 723, Judgment, 26 February 1986

Case C-178/84 Commission of the European Communities v Federal Republic of Germany [1987] ECR 1227, Judgment, 12 March 1987

Case C-222/84 Johnston v Chief Constable of the Royal Ulster Constabulary [1986] ECR 1651, Judgment, 15 May 1986

Cases C-201 and 202/85 Klensch and others v Secrétaire d'État à l'Agirculture et à la Viticulture [1986] ECR 3477, 25 November 1986

Case 222/86 UNECTEF v Heylens [1987] ECR 4097, Judgment, 15 October 1987

Case C-382/87, R. Buet and Educational Business Services (EBS) v Ministère public [1989] ECR 1235, Judgment, 16 May 1989

Case C-68/88 Commission v Greece [1989] ECR 2965, Judgment, 21 September 1989

Case C-143/88 and C-92/89 Zuckerfabrik Süderdithmarschen AGv Hauptzollamt Itzehoe and Zuckerfabrik Soest GmbH v Hauptzollamt Paderborn [1991] ECR I-415, Judgment, 21 February 1991

Case C-265/88 Criminal proceedings against Lothar Messner [1989] ECR 4209, Judgment, 12 December 1989

Case C-331/88 The Queen v Minister of Agriculture, Fisheries and Food and Secretary of State for Health, ex parte: Fedesa and others [1990] ECR I-4023, Judgment, 13 November 1990

Case C-106/89 Marleasing SA v La Commercial Internacionale de Alimentacion SA [1990] ECR I-4135, 13 November 1990, Judgment

Case C-188/89 Foster and others v British Gas plc [1990] ECR I-3313, 12 July 1990, Judgment

Case C-192/89 Sevince v Staatsecretaris van Justitie [1990] ECR I-3461, 20 September 1990, Judgment

Case C-213/89 The Queen v Secretary of State for Transport, ex parte Factortame Ltd \& Ors, Judgment [1990] ECR I-2433, 19 June 1990, ("Factortame I")

Case C-340/89 Vlassopolou v Ministerium für Justiz, Bundes- und Europaangelenheiten BadenWürttemberg [1991] ECR I-2357, Judgment, 7 May 1991

Case C-6/90 and C-9/90 Francovich and Bonifaci v Italy [1991] ECR I-5357, Judgment, 19 November 1991

Case C-156/91 Hansa Fleisch Ernst Mundt GmbH \& Co v Landrat des Kreises SchleswigFlensburg [1992] ECR I-5567, Judgment, 10 November 1992 
Case C-237/91 Kus v Landeshauptstadt v Wiesbaden [1992] ECR I-6781, Judgment, 16 December 1992

Case C-19/92 Kraus v Land Baden-Württemberg [1993] ECR I-1663, Judgment, 31 March 1993

Case C-188/92 TWD Textilwerke Deggendorf GmbH v Germany [1994] ECR I-833, Judgment, 9 March 1994

Case C-315/92 Verband Sozialer Wettbewerb eV v Clinique Laboratories SNC and Estée Lauder Cosmetics GmbH [1994] ECR I-317, Judgment, 2 February 1994

Case C-419/92 Scholz v Opera Universitaria di Cagliari [1994] ECR I-505, Judgment, 23 February 1994

Cases C-46/93 and C-48/98 Brasserie du Pêcheur SAv Bundesrepublik Deutschland, and The Queen v Secretary of State for Transport, ex parte: Factortame Ltd and others ECR [1996] I-1029, Judgment, 5 March 1996

Case C-280/93 Federal Republic of Germany $v$ Council of the European Union [1994] I-4973, Judgment, 5 October 1994

Case C-316/93 Vaneetveld v Le Foyer SA [1994] ECR I-763, Judgment, 3 March 1994

Case C-434/93 Bozkurt v Staatsecretaris van Justitie [1995] ECR I-1475, Judgment, 6 June 1995

Case C-465/93 Atlanta Fruchtandelsgesellschaft I v Bundesamt für Ernährung und Forstwirtschaft [1995] ECR I-3761, Judgment, 9 November 1995

Case C-84/94 United Kingdom of Great Britain and Northern Ireland $v$ Council of the European Union [1996] ECR I-5755, Judgment, 12 November 1996

Case C-194/94 CIA Security International SA v Signalson SA and Securitel SPRL [1996] ECR I-2201, Judgment, 30 April 1996

Cases C-286/94, C-340/95, C-401/95, C-47/96 Garage Molenheide BVBA, Peter Schepens, Bureau Rik Decan-Business Research \& Development NV (BRD) v Belgische Staat [1997] ECR I-7281, Judgment, 18 December 1997

Case C-68/95, T. Port GmbH v Bundesanstalt für Lanwirtschaft und Ernährung [1996] ECR I6065, Judgment, 26 November 1996

Case C-70/95 Sodemare SA et al v Regione Lombardia [1997] ECR I-3395, Judgment, 17 June 1997

Case C-265/95 Commission v France [1997] ECR I-6959, Judgment, 9 December 1997 ("the Spanish Strawberries Case")

Case C-36/96 Günaydin v Freistaat Bayern [1997] ECR I-5143, Judgment, 30 September 1997

Case C-129/96 Inter-Environment Wallonie ASBL v Région Wallone [1997] ECR I-7411, Judgment, 18 December 1997 


\section{BIBLIOGRAPHY}

Case C-348/96 Criminal proceedings against Donatella Calfa [1999] ECR I-11, Judgment, 19 January 1999

Case C-77/97 Österreichische Unilever GmbbH v Smithkline Beecham Markenartikel GmbH, [1999] ECR I-431, Judgment, 28 January 1999

Case C-37/98 The Queen v Secretary of State for the Home Department, ex parte Abdulnasir Savas [2000] ECR I-2927, Judgment, 11 May 2000

Case C-254/98 Schutzverband gegen unlauteren Wettbewerb $v$ TK-Heimdienst Sass GmbH [2000] ECR I-151, Judgment, 13 January 2000

Case C-348/98 Vitor Manuel Mendes Ferreira and Maria Clara Delgado Correia Ferreira $v$ Companhia de Seguros Mundial Confiança SA [2000] ECR I-6711, Judgment, 14 September 2000

Case C-376/98 Federal Republic of Germany $v$ European Parliament and Council of the European Union [2000] ECR I-8419, Judgment, 5 October 2000 (“Tobacco Advertising”)

Case C-377/98 Kingdom of the Netherlands $v$ European Parliament and Council of the European Union [2001] ECR I-7079, Judgment, 9 October 2001

Case C-403/98 Azienda Agricola Monte Arcosu v Regione Automna della Sardegna [2001] ECR I-103, Judgment, 11 January 2001

Case C-443/98 Unilever Italia SpA v Central Food SpA [2000] ECR I-7535, Judgment, 26 September 2000

Case C-184/99 Grzelczyk v Centre public d'aide sociale d'Ottignies-Louvain-la-Neuve [2001] ECR I-6193, Judgment, 20 September 2001

Case C-313/99 Mulligan and Others v Minister for Agriculture and Food, Ireland and Attorney General [2002] ECR I-5719, Judgment, 20 June 2002

Case C-413/99 Baumbast and $R v$ Secretary of State for the Home Department [2002] ECR I7091, Judgment, 17 September 2002

Case C-459/99 Mouvement contre le racism, l'antisémitisme et la xénophobie ASBL (MRAX) v Belgian State [2002] ECR I-6591, Judgment, 25 July 2002

Case C-11/00 Commission of the European Communities v European Central Bank [2003] ECR I-7147, Judgment, 10 July 2003

Cases C-20/00 and C-64/00 Booker Aquaculture Ltd and Hydro Seafood GSP Ltd v The Scottish Ministers [2003] ECR I-7411, Judgment, 10 July 2003

Case C-50/00 P Unión de Pequeños Agricultores v Council [2002] ECR I-6677, Judgment, 25 July 2002 ("UPA")

Case C-62/00 Marks \& Spencer plc v Commisoners of Customs and Excise [2002] ECR I-6325, Judgment, 11 July 2002 


\section{BIBLIOGRAPHY}

Case C-112/00 Eugen Schmidberger, Internationale Transporte und Planzüge $v$ Republik Österreich [2003] ECR I-5659, Judgment, 12 June 2003

Cases C-480/00, C-481/00, C-482/00, C-484/00, C-489/00, C-490/00, C-491/00, C497/00, C-498/00 and C-499/00 Azienda Agricola Ettore Ribaldi v Azienda di Stato per gli interventi nel mercato agricolo (AIMA) and Ministero del Tesoro, del Bilancio e della Programmazione Economica, and Caseificio Nazionale Novarese Soc. coop. arl and joined cases [2004] ECR I-2943, Judgment, 25 March 2004

Case C-100/01 Ministre de l'Intérieur v Aitor Oteiza Olazabal [2002] ECR I-10981, Judgment, 26 November 2002

Case C-109/01 Secretary of State for the Home Department v Hacene Akrich [2003] ECR I9607, Judgment, 23 September 2003

Case C-171/01 Wählegruppe Gemeinsam [2003] ECR I-4301, Judgment, 8 May 2003

Case C-397-403/01 Pfeiffer and others $v$ Deutsches Rotes Kreuz, Kreisverband Waldshut eV [2004] ECR I-8835, Judgment Grand Chamber, 5 October 2004

Cases C-482/01 and C-493/01 Georgios Orfranopoulos and Others and Raffaele Oliveri $v$ Land Baden-Württemberg [2004] ECR I-5257, Judgment, 29 April 2004

Case C-491-01 The Queen v Secretary of State for Health, ex parte British American Tobacco (Investments) Ltd and Imperial Tobacco Ltd [2002] ECR I-11453, Judgment, 10 December 2002 ("Tobacco Labelling")

Case C-494/01 Commission v Ireland [2005] ECR I-3331, Judgment Grand Chamber, 26 April 2005

Case C-36/02 Omega Spielhalen- und Automatenaufstellungs-GmbH v Oberbürgermeistern der Bundesstadt Bonn [2004] ECR I-9609, Judgment, 14 October 2004

Case C-157/02 Rieser Internationale Transporte GmbH v Autobahnen- und SchnellstraßenFinanzierungs-AG (Asfinag) [2004] ECR I-1477, Judgment, 5 February 2004

Cases C-184/02 and C-223/02 Kingdom of Spain and Republic of Finland $v$ European Parliament and Council of the European Union [2004] ECR I-7789, Judgment, 9 September 2004

Case C-239/02 Douwe Egberts NVv Westrom Pharma NV and Cristophe Souranis, carrying on business under the commercial name of 'Establissements FICS' and Douwe Egberts NV v FICSWorld BVBA [2004] ECR I-7007, Judgment, 15 July 2004

Case C-263/02 P Commission v Jégo Quéré \& Cie. SA [2004] ECR I-3425, Judgment, 1 April 2004, ("Jégo-Quéré")

Case C-456/02 Michel Trojani v Centre public d'aide sociale de Bruxelles (CPAS) [2004] ECR I-7573, Judgment Grand Chamber, 7 September 2004

Case C-147/03 Commission v Austria [2005] ECR I-5969, Judgment, 7 July 2005

Case C-215/03 Salah Oulane v Minister voor Vreemdelingenzaken en Integratie [2005] ECR I1215, Judgment, 17 February 2005 
Case C-265/03 Simutenkov v Ministerio de Educación y Cultura and Real Federación Española de Fútbol [2005] ECR I-2579, Judgment Grand Chamber, 12 April 2005

Cases C-453/03, C-11/04, C-12/04 and C-194/04 The Queen, on the application of ABNA Ltd and Others $v$ Secretary of State for Health and Food Standards Agency, Fratelli Martini \& C. $\mathrm{SpA}$ and Cargill Srl v Ministero delle Politiche Agricole e Forestali and Others, Ferrari Mangimi Srl and Associazione nazionale tra $i$ produttori di alimenti zootecnici (Assalzoo) $v$ Ministero delle Politiche Agricole e Forestali and Others and Nederlandse Vereniging Diervoederindustrie (Nevedi) v Productschap Diervoeder [2005] ECR I-10423, Judgment Grand Chamber, 6 December 2005

Case C-540/03, European Parliament v Council of the European Union [2006] ECR I-5769, Judgment, 27 June 2006

Case C-53/04 Marrosu and Sardino v Azienda Ospedaliera San Martino di Genova e Cliniche Universitarie Convenzionate [2006] ECR I-7213, Judgment, 7 September 2006

Case C-144/04 Mangold v Rüdiger Helm [2005] ECR I-9981, Judgment Grand Chamber, 22 November 2005

Case C-180/04 Vasallo v Azienda Ospedaliera San Martino di Genova e Cliniche Universitarie Convenzionate [2006] ECR I-7251, Judgment, 7 September 2006

Case C-212/04 Adeneler \& Ors v Ellinikos Organismos Galaktos (ELOG) [2006] ECR I6057, Judgment Grand Chamber, 4 July 2006

Case C-6/05 Medipac-Kazantzidis AEv Venizelio-Pananeio (PE.S.Y. KRITIS) [2007] ECR I-4557, Judgment, 14 June 2007

Case C-97/05 Gattoussi v Stadt Rüsselsheim [2006] ECR I-11917, Judgment, 14 December 2006

Case C-291/05 Minister voor Vreemdelingenzaken en Integratie v R N G Eind [2007] ECR I10719, Judgment Grand Chamber, 11 December 2007

Cases C-402/05 and 415/05 Kadi and Al Barakaat International Foundation v Council of the European Union and Commission of the European Communities [2008] ECR I-6351, Judgment Grand Chamber, 3 September 2008 ("Kadi I")

Cases C-37/06 and C-58/06 Viamex Agrar Handels GmbH and Zuchtvieh-Kontor GmbH (ZVK) v Hauptzollamt Hamburg-Jonas [2008] ECR I-69, Judgment, 17 January 2008

Case 133/06 European Parliament v Council of the European Union [2008] ECR I-3189, Judgment Grand Chamber, 6 May 2008

Case C-242/06 Minister voor Vreemdelingenzaken en Integratie v Sahin [2009] ECR I-8465, Judgment, 17 September 2009

Case C-246/06 Navarro v Fondo de Garantía Salarial (Fogasa) [2008] ECR I-105, Judgment, 17 January 2008

Cases C-399/06 P and C-403/06 P Faraj Hassan v Council of the European Union and European Commission and Chafiq Ayadi v Council of the European Union [2009] ECR I-11393, Judgment, 3 December 2009 
Case C-226/07 Flughafen Köln/Bonn GmbH v Hauptzollamt Köln [2008] ECR I-5999, Judgment, 17 July 2008

Case C-465/07 Meki Elgafaji and Noor Elgafaji v Staatssecretaris van Justitie [2009] ECR I-921, Judgment Grand Chamber, 17 February 2009

Case C-19/08 Migrationsverket v Edgar Petrosian and Others [2009] ECR I-495, Judgment, 29 January 2009

Case C-127/08 Blaise Baheten Metock and others $v$ Minister for Justice, Equality and Law Reform, [2008] I-6241, Judgment Grand Chamber, 25 July 2008

Case C-135/08 Janko Rottman v Freistaat Bayern [2010] ECR I-1449, Judgment Grand Chamber, 2 March 2010

Cases C-175/08, C-176/08, C-178/08 and 179/08 Aydin Salahadin Abdulla \& Ors $v$ Bundesrepublik Deutschland [2010] ECR I-1493, 2 March 2010

Case C-31/09 Nawras Bolbol v Bevándorlási és Állampolgársárgi Hivatal [2010] ECR I-5539, Judgment Grand Chamber, 17 June 2010

Case C-34/09 Gerardo Ruiz Zambrano v Office national de l'emploi [2011] ECR nyr, Judgment Grand Chamber 8 March 2011

Cases C-57/09 and C101-09 Bundesrepublik Deutschland v B \& D [2010] ECR I-10979, Judgment Grand Chamber, 9 November 2010

Case C-145/09 Land Baden-Württemburg v Panagiotis Tsakouridis [2010] ECR I-11979, Judgment, 23 November 2010

Case C-279/09 DEB Deutsche Energiehandels- und Beratungsgesllschaft mbH $v$ Bundesrepublik Deutschland, Judgment, 22 December 2010

Case C-250/09 and 268/09 Georgiev v Tehnicheski universitet - Sofia, filial Plovdiv [2010] ECR I-11869, Judgment, 18 November 2010

Case C-357/09 PPU Said Shamilovich Kadzoev (Hucbarov) [2009] ECR I-11189, Judgment, 30 November 2009

Case C-434/09 Shirley McCarthy $v$ Secretary of State for the Home Department [2011] ECR nyr, Judgment, 5 May 2011

C-69/10 Brahim Samba Diouf v Ministre du Travail, de l'Emploi et de l'Immigration [2011] ECR nyr, Judgment, 28 July 2011

Cases C-411/10 and C-493/10 N.S. v Secretary of State for the Home Department and M. E. and Others $v$ Refugee Applications Commissioner and Minister for Justice, Equality and Law Reform, [2011] ECR nyr, Judgment Grand Chamber, 21 December 2011

Case C-61/11 PPU Hassen El Dridi (alias Soufi Karim) [2011] ECR nyr, Judgment, 28 April 2011 
Case C-179/11 CIMADE, Groupe d'information et de soutien des immigrés (GISTI) v Ministre de l'Intérieur, de l'Outre-Mer, des Collectivités Territoriales et de l'Immigration, Reference for Preliminary Ruling lodged 18 April 2011

Case C-256/11 Murat Dereci and Others v Bundesministerium für Inneres [2011] ECR nyr, Judgment Grand Chamber, 15 November 2011

Opinions

Case C-316/93 Vaneetveld v Le Foyer SA [1994] ECR I-763, Opinion, 27 January 1994

Case C-70/95 Sodemare SA et al v Regione Lombardia [1997] ECR I-3395, Opinion, 6 February 1997

Cases C-20/00 and C-64/00 Booker Acquaculture Ltd and Hydro Seafood GSP Ltd $v$ The Scottish Ministers [2003] ECR I-7411, Opinion, 20 September 2001

Case C-263/02 P Commission v Jégo Quéré \& Cie. SA [2004] ECR I-3425, Opinion, 10 July 2003

Cases C-402/05 and 415/05 Kadi and Al Barakaat International Foundation $v$ Council of the European Union and Commission of the European Communities [2008] ECR I-6351, Opinion, 23 January 2008

Case C-158/07, Jacqueline Förster v Hoofdirectie van de Informatie Beheer Groep [2008] ECR I8507, Opinion, 10 July 2008

Case C-34/09 Gerardo Ruiz Zambrano v Office national de l'emploi [2011] ECR nyr, Opinion, 30 September 2010

Case C-355/10 European Parliament $v$ Council of the European Union [2012] ECR nyr, Opinion, 17 April 2012

Case C-411/10 N.S. v Secretary of State for the Home Department [2011] ECR nyr, Opinion, 22 September 2011

Cases C-71/11 and C-99/11 Federal Republic of Germany $v$ Y and Z, Opinion [2012] ECR nyr, 19 April 2012

The Court

Statute of the Court of Justice of the European Union (Protocol No. 3 to the Lisbon Treaty) OJ 2004, C 310/210

Rules of Procedure of the Court of Justice of the European Union, amendments up to 24 May 2011, OJ 2011 L 162/17 (22 June 2011)

2009 Information note on references from national courts for a preliminary ruling, OJ 2009, C 297/01 


\section{Case law of the Court of First Instance/General Court of the European Union}

Case T-13/99 Pfizer Animal Heath SA v Council of the European Union [2002] ECR II-3305, Judgment, 11 September 2002

Case T-306/01 Yusuf and Al Barakaat International Foundation v Council of the European Union and Commission of the European Communities [2005] ECR II-3533, Judgment, 21 September 2005

Case T-315/01 Kadi $v$ Council of the European Union and Commission of the European Communities [2005] ECR II-3649, Judgment, 21 September 2005

Case T-318/01 Omar Mohammed Othman v Council of the European Union and Commission of the European Communities [2009] ECR II-1627, Judgment, 11 June 2009

Case T-228/02 Organisation de Mohadjedines du peuple d'Iran $v$ Council of the European Union [2006] ECR II-4665, Judgment, 12 December 2006 (“OMPI”)

Case T-47/03 Jose Maria Sison v Council of the European Union [2007] ECR II-73, Judgment, 11 July 2007

Case T-327/03 Stichting Al-Aqsa v Council of the European Union [2007] ECR II-79, Judgment, 11 July 2007

Case T-253/04 Kongra-Gel and Others v Council of the European Union [2007] ECR II-46, Judgment, 3 April 2008

Case T-135/06 - T-138/06 Al-Bashir Mohammed Al-Faqih and Others $v$ Council of the European Union [2010] ECR II-208, Judgment, 29 September 2010

Case T-256/07 People's Mohajedin Organization of Iran v Council of the European Union [2008] ECR II-3019, Judgment, 23 October 2008 (“PMOI I”)

Case T-341/07 Jose Maria Sison v Council of the European Union [2009] ECR II-3625, Judgment, 30 September 2009

Case T-341/07 Jose Maria Sison v Council of the European Union [2011] ECR 0, Judgment, 23 November 2011

Case T-348/07 Stichting Al-Aqsa v Council of the European Union [2010] ECR II-4575, Judgment, 9 September 2010

Case T-181/08 Pye Phyo Tay Za v Council of the European Union [2010] ECR II-1965, Judgment, 19 May 2010

Case T-284/08 People's Mohajedin Organization of Iran v Council of the European Union [2008] ECR II-3487, Judgment, 4 December 2008 (“PMOI II")

Case T-390/08 Bank Melli Iran v Council of the European Union [2009] ECR II-3967, Judgment, 14 October 2009

Case T-85/09 Kadi v European Commission [2010] ECR II-5177, Judgment, 30 September 2010 (“Kadi II”) 


\section{European Union Commission Proposals and other Commission documents}

European Commission, Completing the Internal Market, COM (85)310, 14 June 1985

Commission of the European Communities, Commission Staff Working Paper SEC (2000) 522

Commission Communication, Towards a common asylum procedure and a uniform status for those granted asylum valid throughout the Union $\operatorname{COM}(2000) 755$ final

Communication from the Commission to the Council and the European Parliament on a Community Immigration Policy, COM(2000)757 final, 22 November 2000

Commission of the European Communities, Proposal for a Council Regulation establishing the criteria and mechanisms for determining the Member State responsible for examining an asylum application lodged in one of the Member States by a third-country national COM(2001) 447 final

Commission of the European Communities, Commission Staff Working Paper - Evaluation of the Dublin Convention, 13 June 2001, SEC(2001) 756

European Commission, Communication from the Commission to the Council, the European Parliament, the European Economic and Social Committee and the Committee of the Regions Study on the links between legal and illegal migration, 4 June 2004, COM(2004) 412 final

Commission Communication Migration and Development: Some Concrete Orientations $\operatorname{COM}(2005) 390$ final

Commission Communication Global Approach to Migration One Year On: Towards a Comprehensive European Migration Policy COM(2006) 73 final

European Commission, 19 July 2006, Communication from the Commission on Policy priorities in the fight against illegal immigration of third-country nationals COM (2006) 402 final

European Commission (2006), The European Citizens and the Future of Europe - Qualitative Study in the 25 Member States, Eurobarometer, Optem, DG Communication

Commission Communication Circular Migration and Mobility Partnerships between the EU and third countries $\operatorname{COM}(2007) 248$ final

Commission of the European Communities, Green Paper on the Future Common European Asylum System, 6 June 2007, COM(2007) 301 final

European Commission, Proposal for a Directive of the European Parliament and of the Council laying down minimum standards for the reception of asylum seekers 3 December 2008, $\operatorname{COM}(2008) 815$ final

European Commission, Proposal for a Regulation of the European Parliament and of the Council establishing the criteria and mechanisms for determining the Member State responsible for examining an application for international protection lodged in one of the Member States by a third-country national or a stateless person, 3 December 2008, COM(2008) 820 final

European Commission, 17 June 2008, Policy Plan on Asylum - An Integrated Approach to Protection Across the EU COM (2008) 360 final 
European Commission, Proposal for a Regulation of the European Parliament and of the Council establishing a European Asylum Support Office COM (2009) 66 final

Communication from the Commission to the European Parliament and the Council, An area of freedom security and justice serving the citizen $\operatorname{COM}(2009) 262 / 4$

European Commission, Proposal for a Directive of the European Parliament and of the Council on minimum standards on procedures in Member States for granting and withdrawing international protection, 21 October 2009, COM(2009) 554 final

Communication from the Commission to the European Parliament, the Council, the European Economic and Social Committee and the Committee of the Regions, Delivering an area of freedom, security and justice for Europe's citizens - Action Plan Implementing the Stockholm Programme COM(2010) 171 final, 20 April 2010

European Commission, Southern Mediterranean: towards a new era of dialogue and partnership, 24 May 2011, Memo/11/330, http://europa.eu/rapid/pressReleasesAction.do ?reference $=\mathrm{MEMO} / 11 / 330$

European Commission, Amended proposal for a Directive of the European Parliament and of the Council laying down standards for the reception of asylum seekers, 1 June 2011, COM(2011) 320 final

European Commission, Directive of the European Parliament and of the Council on common procedures for granting and withdrawing international protection status (Recast), 1 June 2011, $\operatorname{COM}(2011) 319$ final

European Commission, Communication from the Commission to the European Parliament, the Council, The European Economic and Social Committee and the Committee of the Regions, 2 December 2011, COM(2011) 845 final

\section{European Parliament}

European Parliament, Directorate-General for Internal Policies, Policy Department C, Citizens' Rights and Constitutional Affairs, Implementation of the EU Charter of Fundamental Rights and its Impact on EU Home Affairs Agencies, 2011, http://www.europarl.europa.eu/committees/en/libe/studiesdownload.html?languageDocu ment $=\mathrm{EN} \&$ file $=48349$

European Parliament, Directorate-General for Internal Policies, Policy Department C, Citizens' Rights and Constitutional Affairs, The Implementation of Article 80 TFEU on the principle of solidarity and fair sharing of responsibility, including its financial implications, between Member States in the field of border checks, asylum and immigration, 2011, http://www.europarl.europa.eu/committees/en/studiesdownload.htmlllanguageDocument $=\mathrm{EN} \&$ file $=35591$

\section{European Union agencies}

European Union Agency for Fundamental Rights, Seminar on Fundamental rights in the EU in view of the accession of the Union to the European Convention on Human Rights (02/02/2010), http://fra.europa.eu/fraWebsite/news_and_events/infocus10_0202_en.htm 
Eurostat, Asylum applicants and first instance decisions on asylum applications in 2010, 5/2011, 21 March 2011, P.10, Table 6a http://epp.eurostat.ec.europa.eu/cache/ITY_OFFPUB/KSQA-11-005/EN/KS-QA-11-005-EN.PDF

\section{European Council and Council of the European Union}

Presidency Conclusions, Vienna European Council, 11 and 12 December 1998, http://www.consilium.europa.eu/ueDocs/cms_Data/docs/pressData/en/ec/00300R1.EN8.htm

Tampere European Council 15 and 16 October 1999, Presidency Conclusions, http://www.europarl.europa.eu/summits/tam_en.htm

Lisbon European Council 23 and 24 March 2000, Presidency Conclusions, http://www.europarl.europa.eu/summits/lis1_en.htm

Council, The Schengen Acquis as referred to in Article 1(2) of Council Decision 1999/435/EC of 20 May 1999, 22 September 2000, OJ L 176/1

Council of the European Union, Seville European Council, 21 and 22 June 2002, Presidency Conclusions, 24 October 2001, Document 13463/02, http://www.consilium.europa.eu /ueDocs/cms_Data/docs/pressData/en/ec/72638.pdf

Presidency Conclusions of the Brussels European Council. 4-5 November 2004, http://www.europol.europa.eu/jit/hague_programme_en.pdf

Council, Common Consular Instructions on Visas for the Diplomatic Missions and Consular Posts OJ C 326/01, 22 December 2005

Council of the European Union, European Pact on Immigration and Asylum, 24 September 2008, http://register.consilium.europa.eu/pdf/en/08/st13/st13440.en08.pdf

Presidency, Council of the European Union, The Stockholm Programme - An open and secure Europe serving and protecting the citizens, 17024/09, 2 December 2009

Note from the Presidency, Council of the European Union to CATS/Coreper/Council dated 8 February 2010, Document No. 6180/10

Note from the General Secretariat of the Council to Coreper/Conseil dated 21 May 2010 on the Conclusions of the seminars organised by the Spanish Presidency in the area of Justice

Council of the European Union, Note to Working Party on Integration, Migration and Expulsion/Mixed Committee, Questionnaire on defining the conditions under which an entry ban can be imposed and the means by which Member States can have rapid access to information on an entry ban, 21 June 2011, Document 11905/11

Council of the European Union, Note from the German, French and United Kingdom delegations, Joint contribution of the German, French and United Kingdom delegations regarding the proposals for a directive laying down standards for the reception of asylum seekers and for asylum procedures, 27 June 2011, Document No. 12168/11 
Council of the European Union, Outcome of Proceedings of Asylum Working Party on 23 June 2011, 18 July 2011, Document No. 12069/11

Council of the European Union, Outcome of Proceedings of the Asylum Working Party on 6 July 2011, 22 July 2011, Document No. 12580/11

Council of the European Union, High Level Working Group on Immigration and Asylum, Outcome of Proceedings, 27 July 2011, Document No. 12589/11

Council of the European Union, Note from Presidency to Asylum Working Party of 26 September 2011, 12 September 2011, Document No. 13102/11

Council of the European Union, Outcome of Proceedings of Asylum Working Party on 28 June, 5 and 20 July and 27 September 2011, 3 October 2011, Document No. 12579/11;

Council of the European Union, Note from Presidency to Strategic Committee on Immigration, Frontiers and Asylum (SCIFA) on 10 October 2011, 5 October 2011, Document No. $15055 / 11$

Council of the European Union, Outcome of Proceedings of Asylum Working Party on 5 October 2011, 19 October 2011, Document No. 15381/11

Council of the European Union, Outcome of Proceedings of Asylum Working Party on 6 December 2011, 13 December 2011, Document No. 17831/11

Council of the European Union, Outcome of Proceedings of Asylum Working Party of 6 December 2011, 13 December 2011, Document No. 17832/11

Council of the European Union, Outcome of Proceedings of Asylum Working Party on 5 January 2012, 12 January 2012, Document No. 5168/12

Council of the European Union, Outcome of Proceedings of JHA Counsellors on 23 January 2012, 27 January 2012, Document No. 5515/12

Council of the European Union, Revised Note from Presidency to Permanent Representatives Committee on 22 February 2012, 20 February 2012, Document No. 6394/1/12 Rev 1

Presidency, European Council, Proposal for a Regulation of the European Parliament and of the Council amending Regulation (EC) No 562/2006 in order to provide for common rules on the temporary introduction of border control at internal borders in exceptional circumstances, 27 March 2012, Doc No 6161/1/12 Rev 1

Council of the European Union, EU long term residents' directive extended to refugees and other beneficiaries of international protection, 11 April 2012, http://www.consilium.europa.eu /uedocs/cms_data/docs/pressdata/en/jha/121451.pdf

\section{Australian case law}

High Court of Australia Al-Kateb v Godwin [2004] HCA 37

Australian Capital Television Pty Limited v The Commonwealth ("ACTV”) (1992) 177 CLR 106 
Behrooz $v$ Secretary of the Department of Immigration and Multicultural and Indigenous Affairs (2004) 219 CLR 486

Bennett v Minister of Community Welfare (1992) 176 CLR 408

Brown v Lizars (1905) 2 CLR 837

Burnie Port Authority v General Jones Pty Ltd [1994] HCA 13

Castlemaine Tooheys Limited v South Australia (1990) 169 CLR 436

Chu Kheng Lim v Minister for Immigration Local Government and Ethnic Affairs (1992) 176 CLR 1

Church of Scientology Inc v Woodward (1982) 154 CLR 25; [1982] HCA 78

Cocov The Queen (1994) 179 CLR 427

Coleman v Power [2004] HCA 39

Commonwealth v Tasmania ("the Tasmanian Dam case") (1983) 158 CLR 1

Cunliffe v The Commonwealth (1994) 182 CLR 272

Davis v The Commonwealth (1988) 166 CLR 79

Dietrich $v R$ (1992) 177 CLR 292

Ex parte Walsh and Johnson; In re Yates (1925) 37 CLR 36

Griffith University $v$ Tang [2005] HCA 7

Howard $v$ Jarvis [1958] HCA 19

Kioa $v$ West (1985) 159 CLR 550

Kirk v Industrial Relations Commission (NSW) [2010] HCA

Kondis $v$ State Transport Authority [1984] HCA 61

Krugerv The Commonwealth (1997) 190 CLR 1

Lange v Australian Broadcasting Corporation (1997) 189 CLR 520

Leask v The Commonwealth (1996) 187 CLR 579

Lim v Minister for Immigration, Local Government and Ethnic Affairs (1992) 176 CLR 1

M168/2010 By His Litigation Guardian Sister Brigid (Marie) Arthur \& Ors $v$ Commonwealth of Australia \& Anor [2011] HCATrans 1 (19 January 2011)

M168/2010 By His Litigation Guardian Sister Brigid (Marie) Arthur \& Ors $v$ Commonwealth of Australia \& Anor [2011] HCATrans 4 (24 January 2011)

Mabo \& Others $v$ Queensland (No.2) [1992] HCA 23

Minister for Aboriginal Affairs v Peko Wallsend Ltd [1986] HCA 40

Minister for Immigration and Ethnic Affairs $v$ Teoh [1995] HCA 20

Minister for Immigration and Multicultural and Indigenous and Affairs $v$ Al Khafaji v [2004] HCA 38

Minister of State for Immigration E Ethnic Affairs $v$ Teoh (1995) 183 CLR 273

Nationwide News Limited Pty Limited $v$ Wills (1992) 177 CLR 1

NEAT Domestic Trading $v$ AWB Limited [2003] HCA 35

New South Wales v Bujdoso [2005] HCA 76

Nolan v Minister for Immigration and Ethnic Affairs (1988) 165 CLR 178

Plaintiff M168/10v The Commonwealth \& Ors [2011] HCA 25

Plaintiff M47/2012 v Director General of Security \& Ors; Plaintiff S138/2012v Australian Security and Intelligence Organisation [2012] (judgment reserved)

Plaintiff M61/2010E v Commonwealth of Australia; Plaintiff M69 of $2010 v$ Commonwealth of Australia [2010] HCA 41

Plaintiff M70/2011 v Minister for Immigration and Citizenship; Plaintiff M106 of $2011 v$ Minister for Immigration and Citizenship [2011] HCA 32

Plaintiff S157/2002 v Commonwealth [2003] HCA 2

Polyukovichv The Commonwealth (1991) 172 CLR 501

Potterv Minahan (1908) 7 CLR 277

Public Service Board v Osmond [1986] HCA 7

$R v$ Davey, ex parte Freer (1936) 56 CLR 381

$R$ v Kirby; Ex Parte Boilermakers' Society of Australia (Boilermakers' Case) (1956) 94 CLR 254

$R v$ Macfarlane; Ex parte O'Flanagan and O'Kelly (Irish Envoys' Case) (1923) 32 CLR 518

$R v$ Murray and Cormie; Ex parte Commonwealth [1916] HCA 58; (1916) 22 CLR 437 
$R v$ Wilson, Ex parte Kisch (1934) 52 CLR 234; [1934] HCA 50

Re Minister for Immigration and Multicultural Affairs; Ex parte Lam [2003] HCA 6

Re Minister for Immigration and Multicultural and Indigenous Affairs [2003] HCA 1

Re Nolan; Ex parte Young (1991) 172 CLR 460

Re Woolley; Ex parte Applicants M276/2003 [2004] HCA 49

Ruddock v Taylor [2005] HCA 48

South Australia v Tanner (1989) 166 CLR 161

SZATV v Minister for Immigration and Citizenship [2007] HCA 40

WACB v Minister for Immigration and Multicultural and Indigenous Affairs [2004] HCA 50

Wik Peoples v Queensland [1996] HCA 40

Rules of Court

High Court Rules 2004

Federal Court of Australia - Full Court

Al Raied v Minister for Immigration and Multicultural Affairs [2001] FCA 313

Applicant NADB of 2001 v Minister for Immigration and Multicultural Affairs [2002] FCAFC 326

Goldie v Commonwealth [2002] FCAFC 10

Howells v Minister for Immigration Multicultural and Indigenous Affairs [2004] FCAFC 327

Leghaei v Director General of Security [2007] FCFCA 37; (2007) 241 ALR 141

Masila v Minister for Immigration and Multicultural Affairs [2001] FCA 1611

Minister for Immigration \& Multicultural and Indigenous Affairs $v$ Godley [2005] FCAFC 10

Minister for Immigration and Citizenship v Haneef [2007] FCAFC 203

Minister for Immigration and Ethnic Affairs $v$ Baker (1997) 73 FCR 187; [1997] FCA 105

Minister for Immigration and Multicultural Affairs v Al Masri [2003]FCAFC 70

Minister for Immigration and Multicultural Affairs $v$ WAIK [2003] FCAFC 307

Minister for Immigration and Multicultural and Indigenous Affairs v VFAD of 2002 [2002]

FCAFC 390

Minister for Immigration Multicultural and Indigenous Affairs v Hicks (2004) FCAFC

Minister for Immigration, Local Government and Ethnic Affairs v Gray [1994] FCA 1052

Minister for State Resources v Dover Fisheries (1993) FCR 565

Mujedenovski v Minister for Immigration and Citizenship [2009] FCAFC 149

Nulyarimma $v$ Thompson [1999] FCA 1192

O'Sullivan v Parkin [2007] FCAFC 98

O'Sullivan v Parkin (2008) 169 FCR 283; [2008] FCAFC 134

Odhiambo v Minister for Immigration and Multicultural Affairs [2002] FCAFC 194

Ruddock v Vadarlis [2001] FCA 1329

Secretary, Department of Immigration and Multicultural and Indigenous Affairs v Mastipour [2004]

FCAFC 93

Seyfarth $v$ Minister for Immigration Multicultural and Indigenous Affairs [2005] FCAFC 105

SZKUO v Minister for Immigration and Citizenship [2009] FCAFC 167

SZQDZ v Minister for Immigration and Citizenship [2012] FCAFC 26

Tchoylak v Minister for Immigration and Multicultural Affairs [2001] FCA 872

Tennakoon v Minister for Immigration and Multicultural Affairs [2001] FCA 1685

$W u Y u$ Fang and 117 Others $v$ the Minister for Immigration and Ethnic Affairs and Commonwealth of Australia [1996] FCA 1272

Federal Court of Australia

Ahmed v Minister for Immigration and Multicultural Affairs [1999] FCA 430

Alsalih v Manager Baxter Immigration Detention Facility [2004] FCA 352

Applicant VAAN of 2001 v Minister for Immigration and Multicultural Affairs [2002] FCA 197

Applicant WAIV v Minister for Immigration Multicultural and Indigenous Affairs [2002] FCA 1186 
Applicant WAJC v Minister for Immigration Multicultural and Indigenous Affairs [2002] FCA 1631

Arkan v Minister for Immigration and Multicultural Affairs [2000] FCA 1134

Black v Minister for Immigration and Citizenship [2007] FCA 1249

Bolea v Minister for Immigration and Multicultural Affairs [2001] FCA 1129

Cabal v Secretary, Department of Justice (Victoria) [2000] FCA 949

Chen v Minister for Immigration and Multicultural Affairs [2001] FCA 285

Damanik v Minister for Immigration and Multicultural Affairs [2000] FCA 771

De Silva $v$ Minister for Immigration and Multicultural Affairs [2001] FCA 962

El Ess v Minister for Immigration, Multicultural and Indigenous Affairs [2004] FCA 1038

Godley v Minister for Immigration and Multicultural and Indigenous Affairs [2004] FCA 774

Halmi v Minister for Immigration and Multicultural Affairs [2000] FCA 113

Haneef $v$ Minister for Immigration and Citizenship [2007] FCA 1273

Huang $v$ Minister for Immigration and Multicultural Affairs [2001] FCA 284

Jaffari v Minister for Immigration \& Multicultural Affairs [2001] FCA 985

Kopiev v Minister for Immigration and Multicultural Affairs [2000] FCA 1831

Leghaei v Director General of Security [2005] FCA 1576

Masila v Minister for Immigration and Multicultural Affairs [2001] FCA 649

Mastipour v Secretary, Department of Immigration and Multicultural and Indigenous Affairs [2004]

FCA 1571

Mitrevski v Minister for Immigration and Multicultural Affairs [2001] FCA 221

Mouradian v Migration Review Tribunal [2001] FCA 1413

NADB v Minister for Immigration and Multicultural Affairs [2002] FCA 200

O'Sullivan v Parkin [2006] FCA 1654

Ozmanian v Minister for Immigration, Local Government and Ethnic Affairs \& Anor [1996] FCA 1467

P1/2003 v Minister for Immigration and Multicultural and Indigenous Affairs [2003] FCA 1029

Parkin v O'Sullivan (2009) 260 ALR 503; [2009] FCA 1096

Parkin v O'Sullivan [2006] FCA 1413

Parkin v O'Sullivan [2007] FCA 1647

QAAE of 2002 v Minister for Immigration and Multicultural and Indigenous Affairs [2002] FCA 1213

Re Masoud Azemoudeh v Minister for Immigration and Ethnic Affairs and Emil Joseph (1985) 8 ALD 281; [1985] FCA 380

Ruhl v Minister for Immigration and Multicultural Affairs [2001] FCA 648

$S v$ Secretary, Department of Immigration and Multicultural and Indigenous Affairs [2005] FCA 549

Sadiqi v Commonwealth of Australia (No 2) [2009] FCA 1117

Sadiqi v Commonwealth of Australia (No. 3) [2010] FCA 596

Sagar $v$ O'Sullivan [2011] FCA 182

Sandoval v Minister for Immigration and Multicultural Affairs [2001] FCA 1237

Smith v Minister for Immigration Multicultural and Indigenous Affairs [2002] FCA 306

SZFDZ v Minister for Immigration and Multicultural Affairs [2006] FCA 1366

SZLDG v Minister for Immigration and Citizenship [2008] FCA 11

SZLHM v Minister for Immigration and Citizenship [2008] FCA 754

Tennakoon v Minister for Immigration and Multicultural Affairs [2001] FCA 615

Victorian Council for Civil Liberties Incorporated v Minister for Immigration [2001] FCA 1297

VWEX $v$ Minister for Immigration and Multicultural and Indigenous Affairs [2004] FCA 460

Walton v Phillip Ruddock, The Minister for Immigration \& Multicultural Affairs [2001] FCA 1839

X $v$ Minister for Immigration and Multicultural Affairs [1999] FCA 995

Yusufv Minister for Immigration and Multicultural Affairs [2002] FCA 1103

Federal Magistrates Court of Australia

Singh v Minister for Immigration \& Anor [2006] FMCA 1163 
Uppu v Minister for Immigration and Anor [2012] FMCA 157

Administrative Appeals Tribunal

Re Drake and Minister for Immigration and Ethnic Affairs (No. 2) (1979) 2 ALD 634 (per Brennan J)

New South Wales - Court of Appeal

New South Wales $v$ Napier [2002] NSWCA 402

New South Wales $v$ Zerafa [2005] NSWCA 187

State of New South Wales v Macquarie Bank (1992) 30 NSWLR 307

New South Wales - Supreme Court

Oliviera $v$ New South Wales [1995] NSWSC 7

Schneidas $v$ Corrective Services Commission, NSWSC, Lee J, 8 April 1983, unreported

Shayan Badraie by his tutor Mohammed Saeed Badraie $v$ Commonwealth of Australia and Ors [2005] NSWSC 1195

New South Wales Administrative Decisions Tribunal

Law Society of New South Wales v Jayawardena [2008] NSWADT 187

Portale v Law Society of NSW (No.2) (LSD) [2003] NSWADTAP 56

Queensland Court of Appeal

JJ Richards \& Sons Ltd v Bowen Shire Council [2008] QCA 16

Northern Territory

L $v$ the Commonwealth of Australia (1976) 10 ALR 269

\section{Australian Legislation}

Commonwealth Legislation

Acts Interpretation Act 1901 (Cth)

Administrative Appeals Tribunal Act 1975 (Cth)

Administrative Decisions (Judicial Review) Act 1977 (Cth)

Australian Citizenship Act 2007 (Cth)

Australian Human Rights Commission Act 1986 (Cth)

Australian Security Intelligence Organisation Act 1979 (Cth)

Border Protection (Validation and Enforcement Powers) Act 2001 (Cth)

Border Protection Legislation Amendment Act 1999 (Cth)

Commonwealth Electoral Act 1949 (Cth)

Commonwealth Franchise Act 1902 (Cth)

Crimes Act 1914 (Cth)

Customs Act 1901 (Cth)

Disability Discrimination Act 1992 (Cth)

Fisheries Management Act 1991 (Cth)

Health Insurance Act 1973 (Cth)

Immigration (Guardianship of Children) Act 1946 (Cth)

Immigration (Unauthorised Arrivals) Act 1980 (Cth)

Immigration Restriction Act 1901 (Cth)

Judiciary Act 1903 (Cth)

Migration (Amendment Complementary Protection) Act 2011 (Cth)

Migration Act 1958 (Cth)

Migration Amendment (Excision from Migration Zone) (Consequential Provisions) Act 2001 (Cth)

Migration Amendment (Excision from Migration Zone) Act 2001 
Migration Amendment (Strengthening the Character Test and Other Provisions) Act 2011 (Cth)

Migration Amendment Act 1983 (Cth)

Migration Legislation Amendment Act (No 1) 2001 (Cth)

Migration Legislation Amendment Act (No 5) 2001 (Cth)

Migration Legislation Amendment Act (No 6) 2001 (Cth)

Migration Legislation Amendment Act (No.1) 1999 (Cth), No. 89 of 1999

Migration Reform Act 1992 (Cth)

Nationality Act 1920 (Cth)

Nationality and Citizenship Act 1948 (Cth)

Native Title Act 1993 (Cth)

Naturalisation Act 1903 (Cth)

Northern Territory Emergency Response Act 2007 (Cth)

Occupational Health and Safety Act 1991 (Cth)

Ombudsman Act 1976 (Cth)

Pacific Islanders Labourers Act 1901 (Cth)

Quarantine Act 1908 (Cth)

Racial Discrimination Act 1975 (Cth)

Commonwealth Regulations

Migration Amendment Regulations 1999 (No.12) (Cth)

Migration Amendment Regulations 1999 (No.2) 1999 (Cth) No. 58 of 1999

Migration Regulations 1994 (Cth)

Commonwealth Bills

Migration Amendment (Designated Unauthorised Arrivals) Bill 2006 (Cth)

Migration Amendment (Immigration Detention Reform) Bill 2009

New South Wales Legislation

Legal Profession Act 2004 (NSW)

Victorian Legislation

Charter of Human Rights and Responsibilities Act 2006 (Vic)

Australian Capital Territory Legislation

Human Rights Act (2004) (ACT)

\section{Australian official documents and websites}

ACT Government, ACT Health, Public Service to Medicare Ineligible Asylum Seekers Policy, 1 May 2011, http://health.act.gov.au/c/health?a=dlpubpoldoc\&document $=891$

AHRC, 2008 Immigration Detention Report - Summary of observations following the inspection of Australia's immigration detention facilities, December 2008, http://www.humanrights.gov.au/ human_rights/immigration/idc2008.pdf

AHRC, Australian Human Rights Commission Submission to the Joint Select Committee on Australia's Immigration Detention Network, August 2011, http://www.hreoc.gov.au/ legal/submissions/2011/201108_immigration.pdf

AHRC, Australian Human Rights Commission welcomes the removal of the 45-day rule for bridging visas and abolition of immigration debt, 9 September 2009, http://www.hreoc.gov.au/ about/media/media_releases/2009/84_09.html 
AHRC, Background Paper: Immigration detention and visa cancellation under section 501 of the Migration Act, March 2010, http://www.hreoc.gov.au/human_rights/ immigration/501_migration_2010.pdf

AHRC, Immigration Detention Guidelines, March 2000, http://www.hreoc.gov.au/ pdf/human_rights/asylum_seekers/idc_guidelines.pdf

AHRC, Independent Review of the Intelligence Community - Australian Human Rights Commission Submission, April 2011, Sydney, http://www.hreoc.gov.au/legal/submissions/ 2011/20110431_intelligence.pdf

AHRC, Inquiry into Australia's agreement with Malaysia in relation to asylum seekers - Australian Human Rights Commission Submission to the Senate Standing Committees on Legal and Constitutional Affairs, 14 September 2011, Sydney, http://www.hreoc.gov.au/legal/ submissions/2011/20110914_asylum_seekers.pdf

AHRC, Migration Amendment (Immigration Detention Reform) Bill 2009, Submission to the Senate Standing Committee on Legal and Constitutional Affairs, 31 July 2009, Sydney, http://www.humanrights.gov.au/legal/submissions/2009/20090731_migration.pdf

AHRC, Migration Amendment (Immigration Detention Reform) Bill 2009, Submission to the Senate Standing Committee on Legal and Constitutional Affairs, 31 July 2009, Sydney, http://www.humanrights.gov.au/legal/submissions/2009/20090731_migration.pdf

AHRC, Stronger Futures in the Northern Territory Bill 2011 and two related Bills - Australian Human Rights Commission - Submission to the Senate Community Affairs Legislation Committee, 6 February 2012, http://www.hreoc.gov.au/legal/submissions/2012/20120206 _stronger.pdf

AHRC, Suspension of processing asylum seekers raises serious concerns, 9 April 2010, http://www.hreoc.gov.au/about/media/media_releases/2010/29_10.html

ANAO, Audit Report 54 2003-2004, Performance Audit, Management of the Detention Centre Contracts - Part A, 18 June 2004, http://www.anao.gov.au/ /media/Uploads/Documents/ 2003\%2004_audit_report_54.pdf

Arrangement between the Government of Australia and the Government of Malaysia on Transfer and Resettlement, 25 July 2011 http://www.minister.immi.gov.au/media/mediareleases/_pdf/20110725-arrangement-malaysia-aust.pdf;_Annex A-Operational Guidelines to support transfers and resettlement, http://www.immi.gov.au/managing-australiasborders/border-security/_pdf/operational-guidelines-transfers-resettlement.pdf

Australian Government Media Release, Budget 2008-09 - Rudd Government scraps Temporary Protection visas http://www.minister.immi.gov.au/media/media-releases/2008/ce05-buget08.htm

Australian Government Media Release, Last Refugees leave Nauru, 8 February 2008, http://www.minister.immi.gov.au/media/media-releases/2008/ce08014.htm

Australian Government, Attorney-General's Department, Legal Aid Program, http://www.ag.gov.au/Legalaid/Pages/LegalAidProgram.aspx 
Australian Government, Attorney-General's Department, Schemes administered by the Attorney-General's Department, http://www.ag.gov.au/Legalaid/Pages/Schemesadministered bytheAttorneyGeneralsDepartment.aspx

Australian Government, Attorney-General's Department, The Commonwealth Public Interest and Test Cases Scheme Guidelines and Conditions, October 2011, http://www.ag.gov.au/Legalaid/Documents/Commonwealth\%20Public\%20Interest\%20an d\%20Test\%20Scheme\%20Guidelines\%20revised\%20October\%202011.pdf

Australian Government, Department of Defence, http://www.defence.gov.au/ woomera/about.htm

Australian Government, Department of Families, Housing, Community Services and Indigenous Affairs, Place Based Income Management in Bankstown, http://www.families.fahcsia.gov.au/sites/default/files/documents/income_mgt_bankstown. pdf

Australian Government, Department of Human Services, Medicare, Eligibility and Enrolment, http://www.medicareaustralia.gov.au/public/register/eligibility.jsp\#N1004E

Australian Government, Department of Immigration and Citizenship, 2010-2011 Humanitarian Program, http://www.immi.gov.au/media/statistics/pdf/humanitarianprogram-outcomes-2010-11.pdf

Australian Government, Department of Immigration and Citizenship, Australia's Humanitarian Program 2012-2013 and beyond, December 2011, http://www.immi.gov.au/about/contracts-tenders-submissions/_pdf/2012-13humanitarian-program-information-paper.pdf

Australian Government, Department of Immigration and Citizenship, Department of Immigration and Citizenship Annual Report 2010-2011, http://www.immi.gov.au/about /reports/annual/2010-11/pdf/report-on-performance.pdf

Australian Government, Department of Immigration and Citizenship, Form 866 Application for a Protection (Class XA) visa, http://www.immi.gov.au/allforms/pdf/866.pdf

Australian Government, Department of Immigration and Citizenship, Form 866DApplication for a Protection (Class XA) visa - Application for a member of the family unit http://www.immi.gov.au/allforms/pdf/866d.pdf

Australian Government, Department of Immigration and Citizenship, Fact Sheet 1 http://www.immi.gov.au/media/fact-sheets/01backgd.htm

Australian Government, Department of Immigration and Citizenship, Fact Sheet 17 http://www.immi.gov.au/media/fact-sheets/17nz.htm

Australian Government, Department of Immigration and Citizenship, Fact Sheet 40, http://www.immi.gov.au/media/fact-sheets/40special.htm

Australian Government, Department of Immigration and Citizenship, Fact Sheet 60, http://www.immi.gov.au/media/fact-sheets/60refugee.htm 
Australian Government, Department of Immigration and Citizenship, Fact Sheet 63 Immigration Advice and Application Assistance Scheme, http://www.immi.gov.au/media/factsheets/63advice.htm

Australian Government, Department of Immigration and Citizenship, Fact Sheet 64 Community Assistance Support Program, http://www.immi.gov.au/media/factsheets/64community-assistance.htm

Australian Government, Department of Immigration and Citizenship, Fact Sheet 65 Onshore Processing for Irregular Maritime Arrivals, http://www.immi.gov.au/media/factsheets/65onshore-processing-irregular-maritime-arrivals.htm

Australian Government, Department of Immigration and Citizenship, Fact Sheet 68 Abolition of the Temporary Protection visa (TPV) and Temporary Humanitarian visas (THVs), http://www.immi.gov.au/media/fact-sheets/68tpv_further.htm

Australian Government, Department of Immigration and Citizenship, Fact Sheet 75 Processing Irregular Maritime Arrivals, http://www.immi.gov.au/media/factsheets $/ 75$ processing-irregular-maritime-arrivals.htm

Australian Government, Department of Immigration and Citizenship, Fact Sheet 81 Australia's Excised Offshore Places, http://www.immi.gov.au/media/fact-sheets/81excisedoffshore.htm

Australian Government, Department of Immigration and Citizenship, Fact Sheet $83 a-$ Community Detention, http://www.immi.gov.au/media/fact-sheets/83acommunitydetention.htm

Australian Government, Department of Immigration and Citizenship, Bridging Visas, Form 1024i, http://www.immi.gov.au/allforms/pdf/1024i.pdf

Australian Government, Department of Immigration and Citizenship, Immigration Detention Statistics Summary, 30 April 2012, http://www.immi.gov.au/managing-australiasborders/detention/_pdf/immigration-detention-statistics-20120430.pdf

Australian Government, Department of Immigration and Citizenship, Implementation of a single process for Irregular Maritime Arrivals (Questions and Answers), http://www.immi.gov.au/visas/humanitarian/_pdf/implementation_single_process_ima.pd f

Australian Government, Department of Immigration and Citizenship, Key Immigration Detention Values, http://www.immi.gov.au/managing-australias-borders/detention/about /key-values.htm

Australian Government, Department of Immigration and Citizenship, Onshore - Protection, http://www.immi.gov.au/visas/humanitarian/onshore/

Australian Government, Department of Immigration and Citizenship, Pacific Seasonal Workers Scheme, http://www.immi.gov.au/skilled/pacific-seasonal-worker/

Australian Government, Department of Immigration and Citizenship, Pacific Seasonal Workers Scheme - What's New, http://www.immi.gov.au/skilled/pacific-seasonalworker/whats-new.htm 
Australian Government, Department of Immigration and Citizenship, Submission to the Joint Select Committee on Australia's Immigration Detention Network, September 2011, http://www.immi.gov.au/media/publications/pdf/2011/diac-jscaidn-submissionsept11.pdf

Australian Government, Department of Immigration and Citizenship, Trends in Migration: Australia 2010-2011, http://www.immi.gov.au/media/publications/statistics/trends-inmigration/trends-in-migration-2010-11.pdf

Australian Government, Department of Immigration and Citizenship, http://www.immi.gov.au/media/fact-sheets/81-excision-places-map.pdf

Australian Government, Department of Immigration and Citizenship, Managing Australia's Borders, Detention Services, Facilities, About the Facilities, About Immigration Detention Facilities, http://www.immi.gov.au/managing-australias-borders/detention/facilities/about /immigration-detention-facilities.htm

Australian Government, Department of Immigration and Citizenship, Managing Australia's Borders, Detention Services, Facilities, About the Facilities, http://www.immi.gov.au/ managing-australias-borders/detention/facilities/about/

Australian Government, Department of Immigration and Citizenship, Managing Australia's Borders, Detention, Regulations, External Scrutiny of Immigration Detention Services, http://www.immi.gov.au/managing-australias-borders/detention/regulations/externalscrutiny.htm

Australian Government, Department of Immigration and Citizenship, Managing Australia's Borders, Detention Services, Council for Immigration Services and Status Resolution (CISSR), http://www.immi.gov.au/managing-australias-borders/detention/regulations/ cissr/

Australian Government, Department of Immigration and Citizenship, Legislation and International Conventions, http://www.immi.gov.au/managing-australias-borders/detention/ regulations/legislation-conventions.htm

Australian Government, Department of Immigration and Citizenship, Standards for Design and Fitout of Immigration Detention Facilities, http://www.immi.gov.au/managing-australiasborders/detention/facilities/standards-for-design-fitout.htm

Australian Government, Department of Immigration and Citizenship, Services Provided at Immigration Detention Facilities, http://www.immi.gov.au/managing-australiasborders/detention/services/services-at-facilities.htm

Australian Government, Department of Immigration and Citizenship, Managing Australia's Borders, Detention Health Advisory Group (DeHAG), http://www.immi.gov.au/managingaustralias-borders/detention/services/dehag.htm

Australian Government, Department of Immigration and Citizenship, Families with Children, http://www.immi.gov.au/managing-australias-borders/detention/services/ families-with-children.htm

Australian Government, Department of Immigration and Citizenship, Accompanied and Unaccompanied Minors, http://www.immi.gov.au/managing-australias-borders/detention/ services/minors.htm 
Australian Government, Department of Immigration and Citizenship, Bridging Visa E Primary Processing, Judicial and Merits Review, http://www.immi.gov.au/refugee/permission /e-review.htm

Australian Government, Department of Immigration and Citizenship, Bridging Visa E Ministerial Intervention, http://www.immi.gov.au/refugee/permission/e-ministerial.htm

Australian Government, Department of Immigration and Citizenship, New Permission to Work Arrangements, http://www.immi.gov.au/refugee/permission/

Australian Government, Parliament of Australia, Department of Parliamentary Services, Parliamentary Library, Buckmaster, L, Spooner, D, and Magarey, K, Income Management and the Racial Discrimination Act, 20 March 2012, http://parlinfo.aph.gov.au/parlInfo/ download/library/prspub/1511200/upload_binary/1511200.pdf;fileType=application/pdf

Australian Government, Response of the Australian Government to the Views of the Committee in Communication No. 1324/2004 Shafiq v Australia, http://www.ag.gov.au/Documents /Human\%20Rights\%20Communications\%20-\%20Government\%20Response\%20to\% 201324\%202004\%20Shafiq\%20v\%20Australia.pdf

Australian Government, Response of the Australian Government to the Views of the Committee in Communication No. 1050/2002 DE E v Australia, http://www.ag.gov.au/Documents/Communication+No+1050-2002+-+Australian+ Government+Response-+PDF+44KB.pdf

Australian Government, Response of the Australian Government to the Views of the Committee in Communications Numbers 1255/2004, 1256/2004, 1259/2004, 1260/2004, 1268/2004, 1270/2004, 1288/2004 Saed Shams, Kooresh Atvan, Shahin Shahrooei, Payam Saadat, Behrouz Ramezani, Behzad Boostani, Meharn Behrooz, Amin Houvedar Sefed, http://www.ag.gov.au/Documents/n8Iranians\%20\%20Communications\%20_\%20Final\% 20Response.pdf

Australian Government, Response of the Australian Government to the Views of the Committee in Communication No. 1011/2001 Madafferi v Australia http://webcache.googleusercontent.com /search?q=cache:kw44cHSZ6jEJ:www.ag.gov.au/www/agd/rwpattach.nsf/VAP//CFD7369FCA E9B8F32F341DBE097801FF) 1011Madafferi\%252BResponse.pdf/\$file/1011Madafferi\%252 BResponse.pdf +australian + government's + reponse + to + the + views + of + the + committee + in + madafferi $\varepsilon h l=e n \varepsilon g l=a u$

Bowen, the Honourable Chris, Minister for Immigration and Citizenship, Australia and Papua New Guinea Sign MoU, 19 August 2011, http://www.minister.immi.gov.au/ media/cb/2011/cb170699.htm

Bowen, The Honourable Chris, Minister for Immigration and Citizenship, Bridging visas to be issue for boat arrivals, 25 November 2011, http://www.minister.immi.gov.au/media/ $\mathrm{cb} / 2011 / \mathrm{cb} 180599 . \mathrm{htm}$

Bowen, The Honourable Chris, Minister for Immigration and Citizenship, Government announces faster, fairer refugee assessment process, 7 January 2011, http://www.minister.immi.gov.au/media/cb/2011/cb157059.htm

Bowen, The Honourable Chris, Minister for Immigration and Citizenship, Government to move children and vulnerable families into community-based accommodation - Joint Media Release 
with the Prime Minister, 18 October 2010, http://www.minister.immi.gov.au/ media/cb/2010/cb155484.htm

Bowen, The Honourable Chris, Minister for Immigration and Citizenship, Joint Press Conference Canberra with Julia Gillard - Prime Minister of Australia and Chris Bowen MP Minister for Immigration and Citizenship, 13 October 2011, http://www.minister.immi.gov.au/media/cb/2011/cb179299.htm

Bowen, The Honourable Chris, Minister for Immigration and Citizenship, Media Release, Suspension of processing of Afghan asylum seeker claims to be lifted, 30 September 2010, http://www.minister.immi.gov.au/media/cb/2010/cb155332.htm

Bowen, The Honourable Chris, Minister for Immigration and Citizenship, Minister Bowen to engage with regional partners on border protection and people smuggling, 8 October 2010, http://www.minister.immi.gov.au/media/cb/2010/cb155444.htm

Bowen, The Honourable Chris, Minister for Immigration and Citizenship, Moving asylum seeker children into the community - Statement by the Minister for Immigration and Citizenship, the Hon Chris Bowen, MP, 1 March 2011, http://www.minister.immi.gov.au/ media/cb/2011/cb159599.htm

Comcare, Investigation Report on National Detention Facilities, Investigation No. EVE00205473, 21 July 2011, http://www.comcare.gov.au/_data/assets/pdf_file/ 0008/95984/A_copy_of_the_Investigation_Report_on_National_Detention_Facilities.pdf

Commonwealth Ombudsman, Department of Immigration and Multicultural Affairs - Report on referred immigration cases: $M r$ T, March 2006, Report under the Ombudsman Act 1976 by the Commonwealth Ombudsman Prof. John McMillan, Report 04/2006 http://www.ombudsman.gov.au/commonwealth/publish.nsf/AttachmentsByTitle/reports_ 2006_04.pdf/\$FILE/MrT_immigration_mar2006.pdf

Commonwealth Ombudsman, Department of Immigration and Multicultural Affairs Administration of 5501 of the Migration Act 1958 as it applies to long-term residents, February 2006, Report 01/2006, http://www.ombudsman.gov.au/files/investigation_2006_01.pdf

Commonwealth Ombudsman, Inquiry into the Circumstances of the Vivian Alvarez matter, Report under the Ombudsman Act 1976 by the Commonwealth Ombudsman Prof. John McMillan, of an inquiry undertaken by Mr Neil Comrie AO APM, 26 September 2005, Report 03/2005. http://www.immi.gov.au/media/publications/pdf/alvarez_report03.pdf

Commonwealth Ombudsman, Submission by the Commonwealth and Immigration Ombudsman - Joint Select Committee on Australia's Immigration Detention Network, September 2011, http://www.ombudsman.gov.au/files/Joint_Select_Committee_on_Australias_Immigration _Detention_Network_September_2011.pdf

Evans, Senator the Honourable Chris, Minister for Immigration and Citizenship, speech to the Australian National University in Canberra, 29 July 2008, New Directions in DetentionRestoring Integrity to Australia's Immigration System, http://www.nswbar.asn.au/ circulars/july/evans2.pdf

Evans, The Honourable Senator Chris, Minister for Immigration and Citizenship, Smith, The Honourable Stephen, Minister for Foreign Affairs, and O'Connor, The Honourable Brendan, Minister for Home Affairs, Changes to Australia's Immigration Processing System, 9 April 2010, http://www.minister.immi.gov.au/media/media-releases/2010/ce10029.htm 
Gillard, The Honourable Julia, Prime Minister, Joint Statement with the Prime Minister of Malaysia, 7 May 2011, http://www.pm.gov.au/press-office/joint-statement-primeminister-malaysia

Gillard, The Honourable Julia, Prime Minister, Transcript of joint press conference, Brisbane, 1 September 2011, http://www.pm.gov.au/press-office/transcript-joint-press-conferencebrisbane-1

Gillard, The Honourable Prime Minister Julia, Moving Australia Forward, 6 July 2010, Lowy Institute, Sydney, http://www.lowyinstitute.org/Publication.asp?pid=1328

Hanson, Pauline, Maiden Speech, 10 September 1996, Hansard, 38 th Parliament, First Session, First Period, http://www.aph.gov.au/Hansard/reps/dailys/dr100996.pdf

HREOC, A last resort? National Inquiry into Children in Immigration Detention, April 2004, Sydney

HREOC, National Inquiry into the Separation of Aboriginal and Torres Strait Islander Children from Their Families, Bringing Them Home, 1997

HREOC, Report of an inquiry into a complaint by Mr Mohammed Bedraie on behalf of his son Shayan regarding acts or practices of the Commonwealth of Australia (the Department of Immigration, Multicultural and Indigenous Affairs), HREOC Report No.25 (last updated 12 December 2002) http://www.hreoc.gov.au/legal/humanrightsreports/hrc_25.html

HREOC, Those who've come across the seas - Detention of unauthorised arrivals, 1998, Sydney

Immigration Detention Standards, http://www.aph.gov.au/Parliamentary_Business/ Committees/House_of_Representatives_Committees?url=jfadt/idcvisits/idcapph.pdf

Instrument of Declaration of Malaysia as a Declared Country under Subsection 198A(3) of the Migration Act 1958, declared 25 July 2011, Registered 18 August 2011, http://www.comlaw.gov.au/Details/F2011L01685

Memorandum of Understanding between the Government of the Independent State of Papua New Guinea and the Government of Australia, Relating to the Transfer to and Assessment of Persons in Papua New Guinea, and Related Issues, http://www.minister.immi.gov.au/media/mediareleases/_pdf/20110819-aust-png-mou.pdf

National Population Council (Australia), The National Population Council's refugee review, 1991, Australian Government Printing Service, Canberra

Northern Territory Government, Board of Inquiry into the Protection of Aboriginal Children from Sexual Abuse, Ampe Akelyernemane Meke Mekarle - Little Children are Sacred, 2007, http://www.inquirysaac.nt.gov.au/pdf/bipacsa_final_report.pdf

Palmer, M, Inquiry into the Circumstances of the Detention of Cornelia Rau, July 2005, Commonwealth of Australia, Canberra http://www.immi.gov.au/media/publications/pdf/ palmer-report.pdf 
Parliament Australia, Joint Standing Committee on Migration, Immigration Detention in Australia: A new beginning - criteria for release from detention, 2008, Canberra, http://www.aph.gov.au/house/committee/mig/detention/report/fullreport.pdf

Parliament of Australia - Senate, Senate Select Committee on Ministerial Discretion in Migration Matters, 31 April 2004 http://www.aph.gov.au/senate_minmig/index.htm

Parliament of Australia, Department of Parliamentary Services, Parliamentary Library, Background Note, Asylum seekers and refugees: what are the facts?, 14 January 2011, http://www.aph.gov.au/library/pubs/bn/sp/AsylumFacts.pdf

Parliament of Australia, House of Representatives, The Hon Ian Macphee, Minister For Immigration and Ethnic Affairs, Second Reading Speech, Immigration (Unauthorised Arrivals) Bill 1980, 1 May 1980

Parliament of Australia, House of Representatives, The Hon M. MacKellar, Minister for Immigration and Ethnic Affairs, Refugee Policy and Mechanisms, 24 May 1977

Parliament of Australia, Joint Select Committee on Australia's Immigration Detention Network, http://www.aph.gov.au/Parliamentary_Business/Committees/Senate_ Committees?url=immigration_detention_ctte/immigration_detention/index.htm

Parliament of Australia, Joint Standing Committee on Migration, Asylum Border Control and Detention, 1994, Australian Government Printing Service, Canberra

Parliament of Australia, Joint Standing Committee on Migration, Immigration Detention in Australia: Community-based alternatives to detention, 2009, Canberra, http://www.aph.gov.au/house/committee/mig/detention/report2/fullreport.pdf

Parliament of Australia, Joint Standing Committee on Migration, Immigration Detention in Australia: Facilities, services and transparency, 2009, Canberra, http://www.aph.gov.au/house/committee/mig/detention/report3/fullreport.pdf

Parliament of Australia, Migration Amendment (Immigration Detention Reform) Bill 2009, Explanatory Memorandum, http://parlinfo.aph.gov.au/parlInfo/search/display/display. w3p;query=Id\%3A\%22legislation\%2Fems\%2Fs720_ems_1284af8e-e006-4320-b4f3cbcc9d8ded $94 \% 22 ;$ rec $=0$

Parliament of Australia, Senate Community Affairs Legislations Committee, Stronger Futures in the Northern Territory Bill 2011 and two related bills, http://www.aph.gov.au/ Parliamentary_Business/Committees/Senate_Committees?url=clac_ctte/strong_future_nt_ 11/report/index.htm

Phillips, J, and Spinks, H, Boat arrivals in Australia since 1976, Parliament of Australia, Department of Parliamentary Sevices, Parliamentary Library, updated 5 January 2011, statistics updated 9 July 2012, http://parlinfo.aph.gov.au/parlInfo/download/ library/prspub/5P1X6/upload_binary/5P1X6.pdf;fileType $=$ application/pdf\#search=\%22b oat $\% 20$ arrivals $\% 20$ in $\% 20$ Australia $\% 20$ since $\% 22$

Victorian Government, Department of Health, Guide to asylum seeker access to health and community services in Victoria, May 2011, http://docs.health.vic.gov.au/docs /doc/DD261ED347439C91CA2578CA007A31FC/\$FILE/Guide\%20to\%20asylum\%20see ker\%20access\%20to\%20health\%20and\%20community\%20services\%20in\%20Victoria.pdf 


\section{Books, reports and journal articles}

Administrative Review Council, Judicial Review in Australia - Consultation Paper, April 2011, http://www.ag.gov.au/agd/WWW/rwpattach.nsf/VAP/(339383A93E59A076831A75961 C22D2A2) Consultation+Paper+-+Judicial+Review+in+Australia+_+20+April+11++ Version+2.pdf/\$file/Consultation+Paper+-+Judicial+Review+in+Australia+$+20+$ April+11+-+Version+2.pdf

Aitken, LJW, The High Court's Power to Grant Certiorari - the Unresolved Question, (1986) 16(4) Federal Law Review 370

Alexy, R, A Theory of Constitutional Rights, 2002, OUP, Oxford

Allars, M, Proportionality, Tradition and Constitutional Framework: Borrowing Foreign Legal Notions in Australian Public Law in Doeker-Mach, G, and Ziegert, K, Law and Legal Culture in Comparative Perspective, 2004, Franz Steiner Verlag, Stuttgart

Allars, M, Public Administration in Private Hands, (2005) 12(2) Australian Journal of Administrative Law 126

Amnesty International, Detention of children on Christmas Island must end, 18 June 2009, http://www.amnesty.org.au/news/comments/21194/

Amnesty International, Government response to report on immigration detention unacceptable, 19 August 2009, http://www.amnesty.org.au/news/comments/21567/

Ang, I, From White Australia to Fortress Australia: the anxious nation in the new century in Jayasuriya, L, Walker, D, and Gothard, J (eds), Legacies of White Australia: Race Culture and Nation, 2003, University of Western Australia Press, Crawley

Anthony, T, Cuneen, C, The Critical Criminology Companion, 2008, Hawkins Press, Annandale

Applelby, G J, Proportionality and Federalism: Can Australia learn from the European Community the US and Canada? (2007) 26(1) University of Tasmania Law Review 1

Arai-Takahashi, Y, The Margin of Appreciation Doctrine and the Principle of Proportionality in the Jurisprudence of the ECHR, 2002, Intersentia, Oxford

Aronson, M, Dyer, B, and Groves, M, Judicial Review of Administrative Action, 4ed, 2009, Lawbook Co, Pyrmont

Arora, N, Not So Neat: Non-Statutory Corporations and the Reach of the Administrative Decisions (Judicial Review) Act 1977 (2004) 32(1) Federal Law Review 141

Australian Red Cross, Fact Sheet - Migrant Support Programs - Asylum Seeker Assistance Scheme, http://www.redcross.org.au/files/20120203_ASAS_Fact_Sheet_.pdf

Babacan, A, and Briskman, L, (eds) Asylum Seekers: International Perspectives on Interdiction and Deterrence, 2008, Cambridge Scholars Publishing

Bagaric, M, and Edney, R, The Proportionality Thesis in Australia: Application and Analysis (2008) 4(1) IJPS 38 


\section{BIBLIOGRAPHY}

Bailey, P, The Human Rights Enterprise in Australia and Internationally, 2009, Butterworths

Baldaccini, A, Extraterritorial Border Controls in the EU: The Role of Frontex in Operations at Sea, in Ryan, B, and Mitsilegas, V, (eds) Extraterritorial Immigration Control - Legal Challenges, 2010, Brill

Baldaccini, A, Guild, E, and Toner, H, (eds) Whose Freedom Security and Justice? EU Immigration and Asylum Law and Policy, 2007, Hart Publishing, Portland, Oregon

Baldaccini, A, The EU Directive on Returns: Principles and Protests, (2010) 28(4) RSQ 114

Baldaccini, A, The Return and Removal of Irregular Migrants under EU Law: An Analysis of the Returns Directive (2009) 11 European Journal of Migration and Law 1

Balkin, R P, and Davis, J L R, Law of Torts, 4ed, 2009, LexisNexis Butterworths, Chatswood

Ball, R, Beacroft, L, and Lindley, J, Australia's pacific seasonal worker pilot scheme: managing vulnerabilities to exploitation, November 2011, Australian Institute of Criminology, Trends and Issues in Crime and Criminal Justice, No.432

Barendt, E, Dicey and Civil Liberties [1985] Public Law 596

Baringshorst, S, Policies of Backlash: Recent Shifts in Australian Migration Policy (2004) 6(2) Journal of Comparative Policy Analysis: Research and Practice 131

Barnard, C, The PPU: Is it worth the candle? An early assessment, (2009) 34 ELRev 281

Barnard, C, The Substantive Law of the EU - The Four Freedoms, 2010, 3ed, Oxford, OUP

Bashford, A, and Strange, C, Asylum-Seekers and National Histories of Detention (2002) 48(4) Australian Journal of Politics and History 509

Battjes, H, The Soering Threshold: Why Only Fundamental Values Prohibit Refoulement in ECHR Case Law (2009) 11 EJML 205

Beaton-Wells, Australian administrative law: the asylum-seeker legacy, [2005] Public Law 267

Beaton-Wells, C, Judicial Review of Migration Decisions: Life After S157, (2005) 33 Federal Law Review 141

Beatty, D. M., The Ultimate Rule of Law, 2004, OUP, Oxford

Berro-Lefevre, I, Children's Access to the European Court of Human Rights, http://www.coe.int/t/dg3/children/JusticeSpeeches/berro_en.asp

Besson, S, and Utzinger, A, Introduction, Future Challenges of European Citizenship - Facing a Wide-Open Pandora's Box (2007) 13(5) European Law Journal 573

Bierbach, J. B., European Citizens' Third Country Family Members and Community Law (2008) 4 European Constitutional Law Review 344 
Bigo, D, Criminalisation of "Migrants": The side effect of the will to control the frontiers and the sovereign illusion in Bogusz, B, Cholewinski, R, Cygnan, A, and Szyszczak, E, (eds) Irregular Migration and Human Rights: Theoretical, European and International Perspectives, 2004, Martinus Nijhoff Publishers, Leiden/Boston, Pp.61-91

Bingham, T, Widening Horizons - The Influence of Comparative Law and International Law on Domestic Law, 2010, CUP, Cambridge

Blackshield, T, and Williams, G, Australian Constitutional Law and Theory - Commentary and Materials, 2010, 5ed, Federation Press, Sydney

Bonjour, S, Between Integration Provision and Selection Mechanism. Party Politics, Judicial Constraints, and the Making of French and Dutch Policies of Civic Integration Abroad (2010) 12 European Journal of Migration and Law 299

Bourgonje, P, Education for refugee and asylum seeking children in OECD countries, Education International, March 2010, http://download.ei-ie.org/Docs/WebDepot /EIResearch_Paloma_Eng_final_med.pdf

Boyron, S, Proportionality in English Administrative Law: A Faulty Translation?” [1987] PL 368

Bunyan, T, The Story of Tampere, September 2003, Statewatch Briefing, http://www.statewatch.org/news/2003/sep/tampere.doc

Bunyan, T, Trevi, Europol and the European State, Statewatch, http://www.statewatch.org/news/handbook-trevi.pdf

Burnside, J, Watching Brief, 2007, Scribe Publications, Melbourne

Buti, A, British Child Migration to Australia: History, Senate Inquiry and Responsibilities, (2002) 9(4) E-Law - Murdoch University Electronic Journal of Law http://www.murdoch.edu.au/elaw/issues/v9n4/buti94.html

Caflisch, L, The Reform of the European Court of Human Rights: Protocol No.14 and Beyond (2006) 6(2) Human Rights Law Review 403

Cameron, K, Aboriginal People Struggle for Citizenship Rights, http://www.abc.net.au/civics/democracy/struggle.htm

Campbell, E, and Groves, M, Privative Clauses and the Australian Constitution (2004) 4 Oxford University Commonwealth Law Review Journal 51

Carrera Nuñez, S, In Search of the Perfect Citizen - the intersection between integration, immigration and nationality in the EU, 2008

Carrera, S and Guild, E, The French Presidency's European Pack on Immigration and Asylum: Intergovernmentalism vs Europeanisation? Security vs Rights? September 2008, CEPS Policy Brief, No. 170, http://www.libertysecurity.org/IMG/pdf_The_French_Presidency _s_European_Pact_on_Immigration_and_Asylum.pdf

Carrera, S and Sagrera, R. H., The externalisation of the EU's Labour Immigration Policy Towards Mobility or Insecurity Partnerships?, CEPS Working Document No. 321/October 2009, http://www.ceps.eu/system/files/book/2009/10/WD321\%20Carrera\%20and\% 20Sagrera $\% 20 \mathrm{e}-$ version $\% 20$ final.pdf 
Carrera, S, and Guild, E, Undocumented Migrants and the Stockholm Programme in Carrera, S, and Merlino, M, (eds) Assessing EU Policy on Irregular Migration under the Stockholm Programme, October 2010, Centre for European Policy Studies, at Pp.1-9

Carrera, S, and Merlino, M, State of the Art on The European Court of Justice and Enacting Citizenship, April 2009, Centre for European Policy Studies Special Report

Carrera, S, and Wiesbrock, A, Civic Integration of Third-Country Nationals - Nationalism versus Europeanisation in the Common EU Immigration Policy, October 2009, Centre for European Policy Studies, http://aei.pitt.edu/15100/1/ENACT_report_on_integrating_TCNs_eversion_final.pdf (last accessed 15 May 2012)

Carrera, S, Guild, E, Merlino, M, Parkin, J, A Race against Solidarity - The Schengen Regime and the Franco-Italian affair, Centre for European Policy Studies, April 2011

Carrera, S, The EU Border Management Strategy - FRONTEX and the Challenges of Irregular Immigration in the Canary Islands, CEPS Working Document No. 261, March 2007, http://aei.pitt.edu/7385/1/1482.pdf

Castillo de la Torre, F, Interim Measures in Community Courts: Recent Trends (2007) 44 CMLRev 273

Castles, S, and Vasta, E, New Conflicts Around Old Dilemmas in Cornelius, W.A., Tsuda, T, Martin, P.L., and Hollfield, J.F. (eds), Controlling Immigration - A Global Perspective, 2ed, 2004, Stanford University Press, Stanford, CA, Pp.141-177, via Google Books at http://books.google.com/books?id=i0d10wbGkWEC\&printsec $=$ frontcover\&source $=\mathrm{gbs} \_\mathrm{v}$ 2_summary_r $\&$ cad $=0 \# \mathrm{v}=$ onepage $\& \mathrm{q}=\& \mathrm{f}=$ false

Castles, S, The Australian Model of Immigration and Multiculturalism: Is It Applicable to Europe? (1992) 26(2) International Migration Review 549

Charlesworth, H, Human Rights: Australia versus the UN, Democratic Audit of Australia Discussion Paper 22/06, August 2006, http://democratic.audit.anu.edu.au/papers/ 20060809_charlesworth_aust_un.pdf

Cholewinksi, R, European Union Policy on Irregular Migration: Human Rights Lost? in Bogusz, B, Cholewinski, R, Cygnan, A, and Szyszczak, E, (eds) Irregular Migration and Human Rights: Theoretical, European and International Perspectives, 2004, Martinus Nijhoff Publishers, Leiden/Boston, Pp.159-192

Cholewinski, R, The Criminalisation of Migration in EU Law and Policy in Baldaccini, A, Guild, E, and Toner, H, (eds), Whose Freedom, Security and Justice - EU Immigration and Asylum Law and Policy, 2007, Hart Publishing, Oxford

Colic-Peisker, V, 'At Least You're the Right Colour': Identity and Social Inclusion of Bosnian Refugees in Australia (2005) 31(4) Journal of Ethnic and Migration Studies 615

Comte, F, A New Agency Is Born in the European Union: The European Asylum Support Office, 2010, European Journal of Migration and Law 12

Coomans, F, and Kamminga, M, (eds), Extraterritorial Application of Human Rights Treaties, 2004, Insentia, Oxford 
Corker, J, Funding Litigation: The Challenge [2007] UNSWLRS 2

Corlett, D, Following them home - the fate of the returned asylum seekers, 2005, Black Ink, Melbourne

Cornelisse, G, Immigration Detention and Human Rights - Rethinking Territorial Sovereignty, 2010, Martinus Nijhoff Leiden

Costello, C, The Bosphorus Ruling of the European Court of Human Rights: Fundamental Rights and Blurred Boundaries in Europe (2006) 6(1) Human Rights Law Review 87

Craig, P, and de Búrca, G, EU Law - Text Cases and Materials, 2011, 5ed, Oxford University Press, Oxford

Craig, P, EU Administrative Law, 2006, OUP, Oxford

Crock, M, and Berg, L, Immigration, Refugees and Forced Migration - Law, Policy and Practice in Australia, 2011, Federation Press, Leichhardt

Crock, M, Climbing Jacob's Ladder: the High Court and the Administrative Detention of Asylum Seekers in Australia, (1993) 15 Sydney Law Review 338

Crock, M, Defining Strangers: The Foundations for a Just Society (2007) 31 Melbourne University Law Review 1

Crock, M, First Term Blues: Labor, Refugees and Immigration Reform, May 2010, Sydney Law School Legal Studies Research Paper 10/43

Crock, M, In the wake of the Tampa: Conflicting Visions of International Refugee Law in the Management of Refugee Flows (2002) 12(1) Pacific Rim Law and Policy Journal 49

Crock, M, Saul, B, and Dastyari, A, Future Seekers II, 2006, Federation Press, Leichhardt

Crock, M, Seeking Asylum Alone, 2006, Themis Press, Leichhardt

Crock, $\mathrm{M}$, You have to be stronger than razor wire: Legal issues relating to the detention of Refugees and asylum seekers (2002) $10 \mathrm{AJ}$ Admin L 33

Cronin, K, A culture of control: an overview of immigration policy-making, in Jupp, J and Kabala, M, (eds), The Politics of Australian Immigration, 1993, Bureau of Immigration Research, Australian Government Printing Service, Canberra

Crowley-Cyr, L, Mental Illness \& Indefinite Detention at the Minister's Pleasure (2004) 9(1) UWSLR 53

Curtin, J, 'Never Say Never': Al-Kateb v Godwin [2005] Sydney Law Review 16

Da Lomba, S, The Right to seek Refugee Status in the European Union, 2004, Intersentia, Antwerp

de Búrca, G, Proportionality and Wednesbury Unreasonableness: The Influence of European Legal Concepts on UK Law (1997) 3(4) EPL 561 
de Búrca, G, Reflections on the EU's Path from the Constitutional Treaty to the Lisbon Treaty, June 2008, Fordham University School of Law Research Paper, http://papers.ssrn.com/sol3/Delivery.cfm/SSRN_ID1148448_code339387.pdf?abstractid= 11245868 mirid $=3$

de Búrca, G, The Principle of Subsidiarity and the Court of Justice as an Institutional Actor (1998) 36(2) JCMS 217

de Waele, H, EU Citizenship: Revisiting its Meaning, Place and Potential, (2010) 12 European Journal of Migration and Law 319

Della Cananea, G, Return to the due process of law: the European Union and the fight against terrorism (2007) 32(6) ELR 896

den Heijer, M, Whose Rights and Which Rights? The Continuing Story of Non-Refoulement under the European Convention on Human Human Rights (2008) 10 EJML 277

Doulman, J, and Lee, D, Every Assistance and Protection - A History of the Australian Passport, 2008, Federation Press, Leichhardt

Doyle, J and Wells, B, How Far Can the Common Law Go Towards Protecting Human Rights? in Allston, P (ed), Promoting Human Rights Through Bills of Rights: Comparative Perspectives, 1999, OUP, Oxford

Eckes, C, Judicial Review of European Anti-Terrorism Measures - the Yusuf and Kadi Judgments of the Court of First Instance (2008) 14(1) ELJ 74

ECRE, Comments from the European Council on Refugees and Exiles on the Proposal for a Regulation of the European Parliament and of the Council establishing a European Asylum Support Office, April 2009, http://www.ecre.org/files/ECRE_Response_to_Proposal_establishing _EASO_2009.pdf

ECRE, Comments from the European Council on Refugees and Exiles on the European Commission Proposal to recast the Dublin Regulation, April 2009, http://www.ecre.org/component/downloads/downloads/112.html

ECRE, Comments from the European Council on Refugees and Exiles on the European Commission Proposal to recast the Reception Conditions Directive, April 2009, http://www.ecre.org/component/downloads/downloads/121.html

ECRE, Comments from the European Council on Refugees and Exiles on the European Commission Proposal to recast the Asylum Procedures Directive, May 2010, http://www.ecre.org/component/downloads/downloads/145.html

ECRE, Comments from the European Council on Refugees and Exiles on the Amended Commission Proposal to Recast the Asylum Procedures Directive (COM(2011) 319 final, September 2011

ECRE, Comments from the European Council on Refugees and Exiles on the Amended Commission Proposal to recast the Reception Conditions Directive (COM(2011) 320 final), September 2011, Brussels, http://www.ecre.org/component/content/article/57-policypapers/253-ecre-comments-and-recommendations-on-the-amended-commission-proposalto-recast-the-reception-conditions-directive-com2011-320-final.html 
ECRE, Information Note on the Council Directive 2005/85/EC of 1 December 2005 on minimum standards on procedures in Member States for granting and withdrawing refugee status, October 2006, IN1/10/2006/EXT/JJ, www.ecre.org/component/downloads/ downloads/87.html

ECRE, Information Note on the Directive 2008/115/EC of the European Parliament and of the Council of 16 December 2008 on common standards and procedures in Member States for returning illegally staying third-country nationals, 7 January 2009

ECRE, Submission from the European Council on Refugees and Exiles in response to the Commission's Green Paper on the Future Common European Asylum System (COM (2007) 301), September 2007, AD5/9/2007/Ext/RW

Edney, R, Judicial Deference to the Expertise of Correctional Administrators: The Implications for Prisoners' Rights, (2001) 7(1) AJHR 91

Edwards, A, The Optional Protocol to the Convention Against Torture and the Detention of Refugees, (2008) 57 ICLQ 789

ELENA and ECRE, Research on ECHR Rule 39 Interim Measures - Executive Summary, April 2012, http://www.ecre.org/component/downloads/downloads/476.html

Emiliou, N, The Principle of Proportionality in European Law - A Comparative Study, 1996, Kluwer, London

Equal Rights Trust, Guidelines on the Detention of Stateless Persons, 2011

Equal Rights Trust, Unravelling Anomaly - Detention, Discrimination and the Protection Needs of Stateless Persons, July 2010, Equal Rights Trust, London

European Council on Refugees and Exiles, Comments from the European Council on Refugees and Exiles on the European Commission Proposal to recast the Reception Conditions Directive, April 2009, http://www.ecre.org/files/ECRE_Comments_on_Reception_Conditions_Directive _recast_2009.pdf

European Migration Network, Ad-Hoc Query on facilities for detention of a third-country national who is the subject of return procedures and asylum seekers, 1 June 2011, http://www.emn.fi/files/424/EE_EMN_Ad_Hoc_Query_on_facilities_for_detention_CO MPILATION_open_2_.pdf

Fahey, E, Going Back to Basics: Re-embracing the Fundamentals of the Free Movement of Persons in Metock (2009) 36(1) Legal Issues of Economic Integration 83

Feldman, D, Monism, Dualism and Constitutional Legitimacy (1999) 20 Australian Year Book of International Law 105

Feller, E, Türk, V, and Nicholson, F, Refugee Protection in International Law, 2003, Cambridge University Press, Cambridge

Fitzgerald, B, Proportionality and Australian Constitutionalism (1993) 12(2) University of Tasmania Law Review 263

Flynn, M, and Cannon, C, Global Detention Project, The Privatization of Immigration Detention: Towards a Global View, September 2009, 
http://www.globaldetentionproject.org/fileadmin/docs/GDP_PrivatizationPaper_Final5.p df

Flynn, M, Immigration Detention and Proportionality - Global Detention Project Working Paper No. 4, February 2011, Global Detention Project

Foster, M and Pobjoy, J, A Failed Case of Legal Exceptionalism? Refugee Status Determination in Australia's 'Excised' Territory (2011) 23(4) IJRL 583

Foster, M, An "Alien" by the barest of threads - the legality of the deportation of long-term residents from Australia, (2009) 33(2) MULR 483

Foster, M, International Refugee Law and Socio-Economic Rights, 2007, CUP, New York

Francis, A, and Caton, S, Access to Protection for 'Offshore Entry Persons' aka asylum seekers (2011) 36(3) AltLJ 172

Francis, A, Bringing Protection Home: Healing the Schism Between International Obligations and National Safeguards Created by Extraterritorial Processing (2008) 20 IJRL 273

Freckleton, I, Editorial: Madness Migration and Misfortune: The Challenge of the Bleak Tale of Cornelia Rau (2005) 12(1) Psychiatry, Pschology and Law 1

Gageler, S and Glass, A, Constitutional Law and Human Rights in Kinley, D (ed), Human Rights in Australian Law, 1998, Federation Press, Leichhardt

Gale, N, A case of double rejection: the immigration of Sephardim to Australia (1994) 20(2) Journal of Ethnic and Migration Studies 269

Gil-Bazo, M. T., The Charter of Fundamental Rights of the European Union and the Right to be Granted Asylum in the Union's Law, (2008) 27(3) Refugee Survey Quarterly 33

Gilbert + Tobin Centre of Public Law, Faculty of Law, University of New South Wales, submission to the Joint Select Committee on Immigration Detention, Annexure 1, 7 November 2011, https://senate.aph.gov.au/submissions/comittees/viewdocument. aspx?id=018ca141-39cc-4350-985f-db4dcf3b900a

Gilbert + Tobin Centre of Public Law, Faculty of Law, University of New South Wales, submission to the Joint Select Committee on Australia's Immigration Detention Network, 10 August 2011, https://senate.aph.gov.au/submissions/comittees/viewdocument.aspx?id= 4033d753-221c-4278-af91-9fceea7eb41d

Godinho, J, When Worlds Collide: Enforcing United Nations Security Council Asset Freezes in the EU Legal Order (2010) 16(1) ELJ 67

Gondek, M, The Emerging European Asylum Law: between Protection and Rejection in Schneider, H, Migration, Integration and Citizenship: A Challenge for Europe's Future, 2005, Forum Maastricht, Maastricht, Pp.187-228

Goodwin-Gill, G, and McAdam, J, The Refugee in International Law, 2007, OUP, Oxford

Gordon, R, EC Law in Judicial Review, 2007, OUP, Oxford 


\section{BIBLIOGRAPHY}

Grewcock, M, Shooting the passenger: Australia's war on illicit migrants, in Lee, M, (ed), Human Trafficking, 2007, Willan Publishing, Devon, Pp.178-209

Groves, M, Immigration Detention vs Imprisonment: Differences explored (2004) 29(5) Alternative Law Journal 228

Groves, M, International Law and Australian Prisoners [2001] UNSWLJ 11

Groves, M, Outsourcing and Non-Delegable Duties (2005) 16 Public Law Review 265

Groves, M, Outsourcing and s75(v) of the Constitution, (2011) 22 Public Law Review 3

Guild, E, Citizens Without a Constitution, Borders Without a State: EU Free Movement of Person, in Baldaccini, A, Guild, E, and Toner, H, (eds), Whose Freedom, Security and JusticeEU Immigration and Asylum Law and Policy, 2007, Oxford, Hart Publishing, Pp. 25-56

Guild, E, Legal Elements of European Identity, 2004, Kluwer Law International, The Hague

Guild, E, The Europeanisation of Europe's Asylum Policy, (2006) 18(3-4) International Journal of Refugee Law 630

Gümüs, Y. K., The EU Blue Card Scheme: The Right Step in the Right Direction, (2010) 12 European

Journal of Migration and Law 435

Habermas, J, Between Facts and Norms, 1996, MIT, Cambridge MA

Hermann, M in Hailbronner, K, (ed) EU Immigration and Asylum Law - Commentary on EU Regulations and Directives, 2010, Beck, München, Pp.1351-1488

Hailbronner, K, (ed) EU Immigration and Asylum Law - Commentary on EU Regulations and Directives, 2010, Beck, München

Hailbronner, K, Detention of Asylum Seekers (2007) 9 European Journal of Migration and Law 159

Halberstam, D, and Stein, E, The United Nations, the European Union, and the King of Sweden: Economic Sanctions and Individual Rights in a Plural World Order (2009) 46 CMLRev 13

Hammerton, C, Children in Detention: Shayan's Story [2006] HRightsDef 28

Harbo, T-I, The Function of the Proportionality Principle in EU Law (2010) 16(2) ELJ 158

Hathaway, J C, The Rights of Refugees under International Law, 2005, Cambridge University Press, Cambridge

Hathaway, J, Leveraging Asylum [2009] University of Melbourne Law School Research Series 6

Hawkins, F, Critical Years in Immigration: Canada and Australia Compared, 2ed, 1991, McGillQueens's University Press

Head, M, Detention Without Trial - A Threat to Democratic Rights, 2005, University of Western Sydney Law Review 3 
Head, M, High Court Sanctions Indefinite Detention of Asylum Seekers, [2004] University of Western Sydney Law Review 7

Hermann, M, in Hailbronner, K, (ed), EU Immigration and Asylum Law - Commentary on EU Regulations and Directives, 2010, Beck, München, Pp.1351-1488

Heckman, G, International Decisions - Ahani v Canada, (2005) 99 American Journal of International Law 669

Hettiarachi, P, The Sacred and the Profound: Judicial Review and Rights, Proportionality and Deference to Executive Conduct (2007) 29 Australian Bar Review 223

Hioureas, C. G., Behind the Scenes of Protocol No. 14: Politics in Reforming the European Court of Human Rights (2006) 24 Berkley Journal of International Law 718

Hovell, D, The sovereignty stratagem - Australia's response to UN human rights treaty bodies, (2003) 28(6) AltLJ 297

Howard-Wagner, D, Legislating away Indigenous Rights (2008) 12 Law Text Culture 45

Howard-Wagner, D, Restoring Social Order through Tackling 'Passive Welfare': The Statutory Intent of the Northern Territory and National Emergency Response Act 2007 (Cth) and Social Security and Other Legislation Amendment (Welfare Payment Reform) Act 2007 (Cth) (2007-2008) 19 Current Issues in Criminal Justice 243

Howard, J, To Deter and Deny: Australia and the Interdiction of Asylum Seekers (2003) 21(4) Refuge 35

Human Rights Watch, "By Invitation Only:” Australia's Asylum Policy, December 2002, Volume 14 , No. 10

Human Rights Watch, The Netherlands: Discrimination in the Name of Integration - Migrants Rights Under the Integration Abroad Act, May 2008, http://www.hrw.org/sites/default/files/ reports/netherlands0508.pdf

Immigration Law Practitioner's Association ("ILPA"), Immigration Law Practitioners' Association (ILPA) Analysis and Critique of Council Directive on minimum standards on procedures in Member States for granting and withdrawing refugee status (30 April 2004), July 2004, http://www.ilpa.org.uk/data/resources/13178/04.07.00-ILPA-Analysis-Critique-ECdirective-Granting-Withdrawing-Refugee-Status..pdf

Jackson, V, Being Proportional About Proportionality, (2004) 21 Constitutional Commentary 803

Jacobs, F, Effective Judicial Protection of Individuals in the European Union, Now and in the Future, in Andenas, M, and Usher, J (eds), The Treaty of Nice and Beyond, Enlargement and Constitutional Reform, 2003, Hart Publishing, Oxford, Pp.335-344 accessed via Google Books at http://books.google.nl/books?id=Oeu3ZZqpqhIC\&printsec $=$ frontcover\&hl= en\&source $=$ gbs_ge_summary_r\&cad $=0 \# \mathrm{v}=$ onepage $\& \mathrm{q} \& \mathrm{f}=$ false

Jans, J H, Proportionality Revisited (2000) 27(3) Legal Issues of Economic Integration 239 
Jesuit Refugee Service, Detention in the Context of the Dublin II Regulation, http://www.detention-in-europe.org/index.php?option=com_content\&view=article\&id= $175 \&$ Itemid $=209$

Joppke, C, Selecting by Origin: Ethnic Migration in the Liberal State, 2005, Harvard University Press, Cambridge, MA

Jupp, J, From White Australia to Woomera - The Story of Australian Immigration, 2ed, 2007, Cambridge University Press, Melbourne

Jupp, J, The Pacific Solution, (2002) 21 Dialogue 10

Kadelbach, S, Union Citizenship, Jean Monet Working Paper 9/03, Max Planck Institute for Comparative Public Law and International Law, Heidelberg, 24-27 February 2003

Kennedy, R, Duty of Care in Human Services, 2009, CUP, New York

Kiefel AC, The Honourable Justice Susan, Proportionality: A rule of reason (2012) 23 PLR 85

Kiefel, The Honourable Justice Susan, Section 92: Markets, Protectionism and Proportionality Australian and European Perspectives (2010) 36(2) Monash Law Review 1

Kinley, D, Constitutional Brokerage in Australia: Constitutions and the Doctrines of Parliamentary Supremacy and the Rule of Law (1992) 22 Federal Law Review 194

Kirk, J, Constitutional guarantees, characterisation and the concept of proportionality (1997) 21 MelbUnivLR 1

Kirk, J. K., The Concept of Jurisdictional Error, paper delivered at Continuing Professional Development seminar for the New South Wales Bar Association, 30 May 2012 (copy held on file by author)

Kneebone, S, (ed), Refugees, Asylum Seekers and the Rule of Law, 2009, CUP, Cambridge

Kneebone, S, The Australian Story: Asylum Seekers outside the Law in Kneebone, S, (ed), Refugees, Asylum Seekers and the Rule of Law, 2009, CUP, Cambridge, Pp. 171-227

Kneebone, S, (ed), The Refugee Convention 50 Years On, 2003, Ashgate, Aldershot

Kneebone, S, Ruddock and Others v Taylor [2005] Sydney Law Review 6

Kostakopoulos, D, Ideas, Norms, and European Citizenship: Explaining Institutional Change, 2005, Modern Law Review, Volume 68, No. 2, Pp.233-267

Kostakopoulou, D, European Union Citizenship: Writing the Future (2007) 13(5) European Law Journal 623

Kumin, J, Orderly Departure From Vietnam: Cold War Anomaly or Humanitarian Innovation? (2008) 27(1) RSQ 104

Lacey, W, A Prelude to the Demise of Teoh: The High Court Decision in Re Minister for Immigration and Multicultural Affairs; Ex parte Lam (2004) 26(1) Sydney Law Review 131 
Lahuerta, S. B., Race Equality and TCNs, or How to Fight Discrimination with A Discriminatory Law (2009) 15(6) European Law Journal 738

Law Council of Australia, Review of Bridging Visas - Submission by the International Law Section of the Law Council of Australia, 7 August 2006 http://www.lawcouncil.asn.au/ shadomx/apps/fms/fmsdownload.cfm?file_uuid=8C745FD0-1C23-CACD-22DC92835705A9D9\&siteName $=$ lca

Law Society of New South Wales, Pro Bono Scheme, http://www.lawsociety.com.au/community/findingalawyer/probono/

Leczykiewicz, D, "Effective Judicial Protection" of human rights after Lisbon: should national courts be empowered to review EU secondary law? (2010) 35(3) ELRev 326

Lee, H P, Proportionality in Australian Constitutional Adjudication, in Lindell, G, (ed) Future Directions in Australian Constitutional Law: Essays in Honour of Professor Leslie Zines, 1994, Federation Press, Sydney

Lee, M, (ed), Human Trafficking, 2007, Willan Publishing, Devon

Legal Aid New South Wales, http://lacextra.legalaid.nsw.gov.au/Publications ResourcesService/PublicationImprints/Files/384.pdf

Lenaerts, K and de Smijter, E, The Charter and the Role of the European Courts (2001) 8(1) Maastricht Journal of European and Comparative Law 90

Lock, T, Beyond Bosphorous: The European Court of Human Rights' Case Law on the Responsibility of Member States of International Organisations under the European Convention of Human Rights (2010) 10(3) Human Rights Law Review 529

Lusher, D, and Haslam, N (eds) Yearning to Breathe Free: seeking asylum in Australia, 2007, The Federation Press, Annandale

Maccanico, Y, The EU's self-interested response to unrest in north Africa: the meaning of treaties and readmission agreements between Italy and north African states, http://www.statewatch.org/analyses/no-165-eu-north-africa.pdf

Mackay, A, Harm suffered by children in immigration detention: Can tort law provide redress? (2006) 14 Tort Law Review 16

Magner, T, A Less than Pacific Solution for Asylum Seekers in Australia (2004) 16(1) International Journal of Refugee Law 53

Mahoney, P, The Doctrine of the Margin of Appreciation under the European Convention on Human Rights: Its Legitimacy in Theory and Application in Practice (1998) 19(1) HRLJ 1

Maley, W, Asylum-seekers in Australia's International Relations (2003) 57(1) Australian Journal of International Affairs 187

Mallia, P, Migrant Smuggling by Sea - Combatting a Current Threat to Maritime Security through the Creation of a Cooperative Framework, 2010, Martinus Nijhoff, Leiden/Boston

Markus, A, Jupp, J, and McDonald, P, Australia's Immigration Revolution, 2009, Allen \& Unwin, Crows Nest 
Marr, D, and Wilkinson, M, Dark Victory, (2ed), 2004, Allen \& Unwin, Crows Nest

Martin, M, "A radically changing political landscape in the Southern Mediterranean"? The Dialogue for Migration, Mobility and Security with the Southern Mediterranean countries, July 2011, Statewatch Analysis, http://www.statewatch.org/analyses/no-136-southern-med.pdf

Martin, M, The Arab Spring and the death toll in the Mediterranean: the true face of Fortress Europe, Statewatch, Analysis, http://www.statewatch.org/analyses/no-167-arab-springmed.pdf

Mathew, P, International Association of Refugee Law Judges Conference - Address - Legal Issues Concerning Interception, (2003) 17 Georgetown Immigration Law Journal 221

McAdam, J, Climate change, forced migration, and international law, 2012, OUP, Oxford

McAdam, J, Complementary Protection in International Refugee Law, 2007, OUP, Oxford

McAdam, J, Seeking Asylum under the Convention on the Rights of the Child: A case for Complementary Protection (2006) 15 International Journal of Children's Rights 251

McCulloch, J, National (in)security politics in Australia: fear and the federal election, http://www.statewatch.org/analyses/no-30-jude-mccullogh.pdf

McDonald, S, Involuntary Detention and the Separation of Judicial Power (2007) 35 FedLRev 25

McGlone, F, and Stickley, A, Australian Torts Law, 2ed, 2009, LexisNexis Butterworths, Chatswood

McMaster, D, Asylum Seekers - Australia's Response to Refugees, 2002, Melbourne University Press, Melbourne

McMillan AO, Professor John, Regulating Migration Litigation after Plaintiff M61 - Report to the Minister for Immigration and Citizenship, 2011, http://www.immi.gov.au/media/publications/pdf/2011/mcmillan-review-regulatingmigration-litigation.pdf

McMillan, J and Williams, Administrative Law and Human Rights in Kinley, D, Human Rights in Australian Law, 1998, Federation Press, Leichhardt, Pp.63-90

McSherry, B, and Dastyari, A, Providing Mental Health Services and Psychiatric Care to Immigration Detainees: What Tort Law Requires (2007) 14(2) Psychiatry, Psychology and the Law 260

McSherry, B, The government's duty of care to provide adequate health care to immigration detainees (2006) 13 Journal of Law and Medicine 281

Meijers Committee, Letter dated 26 March 2012 to European Parliament Civil Liberties, Justice and Home Affairs Committee, http://www.statewatch.org/news/2012/mar/ meijers-cttee-letter-EP-dublin.pdf

Menski, W, Comparative Law in a Global Context - The Legal Systems of Asia and Africa, (2ed), 2006, CUP, Cambridge 
Metcalfe, S, The Pacific Solution, 2010, Australian Scholarly Publishing, North Melbourne

Michaelsen, C, The Proportionality Principle, Counter-terrorism Laws and Human Rights: A German-Australian Comparison (2010) 2(1) City University of Hong Kong Law Review 19

Mitchell, D, Proportionality and Remedies in WTO Disputes, (2007) 17(5) EJIL 985

Morton, P, Fire Across the Desert, 1989, AGPS, Canberra

Murphy, K, The SIEV 36 Incident, recording of presentation at the College of Law, Australian National University, 5 June 2009, ABC Fora, (recording held by author having been downloaded from http://mpegmedia.abc.net.au/tv/fora/anu_siev36_full.mp4 (at 2:33) on 23 September 2009 (link no longer available - copy of recording held on file by author)

National Archives of Australia, Documenting Democracy, Immigration Restriction Act 1901 (Cth) http://www.foundingdocs.gov.au/item.asp?dID=16

National Association of Community Legal Centres, http://www.naclc.org.au/cb_pages/clcs.php

Nettesheim, M, U.N. sanctions against individuals - a challenge to the architecture of European Union governance (2007) 44 CMLRev 567

Neumann, K, Asylum seekers, Willy Wong, and the uses of history: From 2010 to 1962, and back, (2011) 42 Australian Historical Studies 126

Neumann, K, Been there, done that? in Lusher, D, and Haslam, N (eds) Yearning to Breathe Free: seeking asylum in Australia, 2007, The Federation Press, Annandale

Neumann, K. Hush-hushing the whole matter: the UNHCR, Australia, and West Papuan Refugees (2006) 23(1) Refuge 69

Neumann, K, "Our Interests Must Come First" - Australia's response to the expulsion of Asians from Uganda (2006) 3(1) History Australia 10.1

Neumann, K, Refuge Australia - Australia's Humanitarian Record, 2004, UNSW Press, Sydney

New South Wales Bar Association, Legal Assistance Referral Scheme, http://www.nswbar.asn.au/docs/legal_assist/LARS_130910.pdf

Nicholls, G, Unsettling Admissions: Asylum Seekers in Australia (1998) 11(1) Journal of Refugee Studies 61

Niessen, J, in Guild, E, The Developing Immigration and Asylum Policies of the European Union: adopted conventions, resolutions, recommendations, decisions and conclusions, 1996, Kluwer Law International, Boston, MA, accessed via Google Books http://books.google.com/books?id=_xigcFKAG4AC\&printsec $=$ frontcover\&source $=$ gbs_v 2_summary_r\&cad $=0 \# \mathrm{v}=$ onepage $\& \mathrm{q}=\& \mathrm{f}=$ false

North AM, Justice, and Decle, P., Courts and immigration detention: The Australian experience (2002) 10 AJ Admin L 5 
O’Neil, M, Blind Conscience, 2008, UNSW Press, University of New South Wales, Pp.104118

O'Neill, N, Rice, S, and Douglas, R, Retreat from Injustice - Human Rights Law in Australia, 2004, Federation Press, Leichhardt

O'Nions, H, No Right to Liberty: The Detention of Asylum Seekers for Administrative Convenience, (2008) 10 European Journal of Migration and Law 149

Occhipinti, J D, The Politics of EU Police Cooperation: Toward a European FBI?, 2003, Lynne

Rienner, Boulder, Colorado, accessed via Google Books http://books.google.com/books?id=U8TXXHD_kqEC\&printsec $=$ frontcover\&source $=\mathrm{gbs}$ _v2_summary_r\&cad $=0 \# \mathrm{v}=$ onepage $\& \mathrm{q}=\& \mathrm{f}=$ false

Open Society Justice Initiative, De Jure Statelessness in the Real World: Applying the Prato Summary Conclusions, 2011, New York, http://www.soros.org/sites/default/files/pratostatelessness-20110303.pdf

Ovey, C, and White, R.C.A., The European Convention on Human Rights, (4ed) 2006, OUP

Ozdowski, S, An Absence of Human Rights: Children in Detention, paper delivered at Human Rights Law and Policy Conference, 16-17 June 2008, Melbourne, http://www.ajustaustralia.com/resource.php?act=attache\&id=321

Palmer, D, Between a Rock and a Hard Place: the Case of Papuan Asylum-Seekers (2006) 52(4) Australian Journal of Politics and History 576

Palmer, D, The quest for 'wriggle room': Australia and the Refugees Convention, 1951-1973 (2009) 63(2) Australian Journal of International Affairs 290

Panetta, R, Wednesdbury Unreasonableness: Judicial or Merits Review (2002) 9 Australian Journal of Administrative Law 191

Paterson, J, Robertson, A, and Duke, A, Principles of Contract Law, 3ed, 2009, Lawbook Co, Pyrmont

Pearce, D, and Geddes, R, Statutory Interpretation in Australia, 6ed, 1996, Butterworths, Sydney

Peek, M, in Hailbronner, K, (ed) EU Immigration and Asylum Law - Commentary on EU Regulations and Directives, 2010, Beck, München, Pp.871-984

Peers, S, EU Justice and Home Affairs Law, 3ed, 2011, OUP, Oxford

Peers, S, Legislative Update: EC Immigration and Asylum Law Attracting and Deterring Labour Migration: The Blue Card and Employer Sanctions Directive (2009) 11 European Journal of Migration and Law 387

Peers, S, Legislative Update: EU Immigration and Asylum Competence and Decision-Making in the Treaty of Lisbon, (2008) 10 European Journal of Migration and Law 219

Peers, S, Statewatch Analysis - Changing the institutional framework for EU Justice and Home Affairs law without the Lisbon Treaty, July 2008, http://www.statewatch.org/news/2008/jul/sw-analysis-jha-transfer-july-2008.pdf 
Peers, S, Statewatch Analysis - Update - The Proposed European Investigation Order, 24 November 2010, http://www.statewatch.org/analyses/no-112-eu-eio-update.pdf

Peers, S, The EC-Switzerland Agreement on Free Movement of Persons: Overview and Analysis (2000) 2(2) European Journal of Migraion and Law 127

Peers, S, The Jurisdiction of the Court of Justice Over EC Immigration and Asylum Law: Time For a Change?, in Baldaccini, A, Guild, E, and Toner, H, (eds), Whose Freedom Security and Justice - EU Immigration and Asylum Law and Policy, 2007, Hart Publishing, Portland, Pp.85103

Peers, S, The New Regulation on Access to Documents: A Critical Analysis, 6/2002, The Queen's Papers on Europeanisation, http://www.qub.ac.uk/schools/SchoolofPolitics InternationalStudiesandPhilosophy/FileStore/EuropeanisationFiles/Filetoupload,38419, en.p df

Peers, S, The revised 'Dublin' rules on responsibility for asylum-seekers: The Council's failure to fix a broken system, April 2012, http://www.statewatch.org/analyses/no-173-dublin-III.pdf

Peers, S, The revised directive on Refugee and Subsidiary Protection status, Statewatch Analysis, July 2011, http://www.statewatch.org/analyses/no-141-qaulifications-directive.pdf

Penovic, T, and Sifris, A, Children's rights through the lens of immigration detention (2006) 20 AJFL 12

Pickering, S, The New Criminals: Refugees and Asylum Seekers, in Anthony, T, Cuneen, C, The Critical Criminology Companion, 2008, Hawkins Press, Annandale, Pp.169-179

Poynder, N, 'Mind the Gap': Seeking Alternative Protection under the Convention Against Torture and the International Covenant on Civil and Political Rights, in Kneebone, S, (ed), The Refugee Convention 50 Years On, 2003, Ashgate, Aldershot, Pp.173-192

Poynder, N, The Incommunicado Detention of Boat People: A Recent Development in Australia's Refugee Policy [1997] Australian Journal of Human Rights 2

Public Interest Law Clearing House NSW, http://www.pilchnsw.org.au/what-we-do/

Reneman, M, An EU Right to Interim Protection during Appeal Proceedings in Asylum Cases? (2010) 12 European Journal of Migration and Law 407

Robbins, J, The Howard Government and Indigenous Rights: An Imposed National Unity? (2007) 42(2) AJPS 315

Robertson, K (with Hohmann, J, and Stewart, I), Dictating to One of "Us": The Migration of Mrs Freer (2005) 5 MacqLJ 241

Robinson, W. C., The Comprehensive Plan of Action for Indochinese Refugees, 1989-1997: Sharing the Burden and Passing the Buck (2004) 17(3) Journal of Refugee Studies 319

Roche, M, Department of Immigration and Citizenship, Detention Services Contract Review, February 2006, http://www.immi.gov.au/about/department/perf-progress/dimaimprovements/_pdf/roche/Roche_Report.pdf 
Rubenstein, K, Australian Citizenship Law in Context, 2002, Lawbook Co., Pyrmont

Rubenstein, K, Citizenship And The Centenary - Inclusion And Exclusion In 20th Century Australia (2000) 24 MULR 576

Rubenstein, K, Citizenship and the Constitutional Convention Debates: A Mere Legal Inference (1997) 25 Federal Law Review 295

Rubenstein, K, Citizenship in Australia: Unscrambling its meaning (1995) 20 MULR 503

Rubenstein, K, The High Court And The Shaping of Australian Citizenship, Paper presented to Individual, Community, Nation: 50 Years of Australian Citizen Conference, University of Melbourne, 21-23 July 1999, unpublished (copy held on file by author)

Ruddle, L, and Nicholes, S, B \& B and Minister for Immigration and Multicultural and Indigenous Affairs: Can International Treaties Release Children from Immigration Detention Centres? (2004) 5(1) Melbourne Journal of International Law 256

Ryan, B and Mitsilegas, V, (eds) Extraterritorial Immigration Control, 2010, Brill, Leiden

Ryan, N, A decade of social policy under John Howard: social policy in Australia (2005) 33(3) Policy and Politics 451

Sampson, R, and Bowring, L, There are alternatives: A handbook for preventing unnecessary immigration detention, 2011, Immigration Detention Coalition, Melbourne

Saul, B, Submission to Joint Select Committee on Immigration Detention dated 31 August 2011, together with annexed Communication to the UN Human Rights Committee dated 28 August 2011

https://senate.aph.gov.au/submissions/comittees/viewdocument.aspx?id=e82994a0-5a9044c9-80f0-a96aafb95948,

https://senate.aph.gov.au/submissions/comittees/viewdocument.aspx?id=229128ab-d97b4dab-9b97-bcf31229b81c

Saul, B, The Kafka-esque case of Sheikh Mansour Leghaei: The denial of the international human right to a fair hearing in national security assessments and migration hearings in Australia, (2010) 33(3) UNSWLJ 629

Schieffer, M, Chapter V-Termination of Residence in Hailbronner, K, (ed), EU Immigration and Asylum Law - Commentary on EU Regulations and Directives, 2010, Beck, München, Pp.1489-1552

Schloenhardt, A, Australia and the Boat-People: 25 Years of Unauthorised Arrivals 2000 23(3) UNSWLJ 33

Schloenhardt, A, Migrant Smuggling: Illegal Migration and Organised Crime in Australia and the Asia Pacific Region, 2003, Brill, Leiden

Schloenhardt, A, To Deter, Detain and Deny: Protection of Onshore Asylum Seekers in Australia (2002) 14 IJRL 302

Schneider, H, Claessens, S, and Garben S, The Recognition of Diplomas, Accreditation Procedures and the Free Movement of Professionals in the European Union: Obstacles and Solutions, 
undated, part of learning materials for the Substantive European Union Law course, Maastricht University, 2011

Schokkenbroek, J, The Basis, Nature and Application of the Margin-of-Appreciation Doctrine in the Case-Law of the European Court of Human Rights, (1998) 19(1) HRLJ 30

Schwarze, J, European Administrative Law, Rev 1ed, 2006, Sweet and Maxwell, London

Scott, K, Gareth Evans, 1999, Allen \& Unwin, St Leonards

Selby, H, (ed) Tomorrow's Law, 1995, Federation Press, Leichhardt

Selway QC, B, The Rise and Rise of the Reasonable Proportionality Test in Public Law (1996) 7 PLR 212

Short, D, Reconciliation, Assimilation and the Indigenous Peoples of Australia (2003) 24(4) International Political Science Review 491

Skulan, C, Australia's Mandatory Detention of Unauthorised Asylum Seekers: History, Politics, and Analysis, under International Law, (2006) 21(1) Georgetown Immigration Law Journal 61

Smit, J H, Malcolm Fraser's response to 'commercial' refugee voyages (2010) 8(2) Journal of International Relations (Dhaka University, Bangladesh) 76 (also available at http://ro.ecu.edu.au/ecuworks/6218/

Spijkerboer, T, and Arbaoui, Y, in Hailbronner, K, (ed), EU Immigration and Asylum Law Commentary on EU Regulations and Directives, 2010, Beck, München, Pp.1227-1350

Stanton, M, Removing Voices from the Voiceless: The Migration Litigation Reform Act 2005 [2006] AltLawJ 8

Statewatch, Court decision overturns government attempt to deny foreigners' access to lawyers in transit zones, 2012, http://www.statewatch.org/news/2012/jan/03fr-anfe.htm

Statewatch, ECJ General Advocate's opinion on sea surveillance and the Schengen Borders Code: reasserting the Parliament's legislative role, reopening the Frontex debate? http://www.statewatch.org/news/2012/may/ecj-schengen-borders.pdf

Stern, M, The Educational Rights of Asylum Seeking Children - Observing Failure (2010) 5(7) Journal of Law and Social Justice 1

Stone Sweet, A, and Mathews, J, Proportionality Balancing and Global Constitutionalism, (2008) 47 Columbia Journal of Transnational Law 73

Stubbs, M, Arbitrary Detention in Australia: Detention of Unlawful Non-Citizens under the Migration Act 1958 (Cth) (2006) 25 Australian Yearbook of International Law 273

Šǔnjar, D, Proportionality, Fundamental Rights and Balance of Powers, 2010, Martinus Nijhoff, Leiden

Tavan, G, and Neumann, K (eds) Does History Matter - Making and debating citizenship, immigration and refugee policy in Australian and New Zealand, 2009, Australian National University E-Press, Canberra, http://epress.anu.edu.au/anzsog/immigration /html/frames.php 
Tavan, G, The long, slow death of White Australia, 2005, Scribe Publications, Carlton North

Taylor, J, Behind Australian Doors: Examining the Conditions of Detention of Asylum Seekers in Indonesia, 3 November 2009, http://www.law.monash.edu.au/castancentre/news/behindaustralian-doors-report.pdf

Taylor, J, Guardianship of Child Asylum Seekers (2006) 34 Federal Law Review 185

Taylor, S, and Rafferty-Brown, B, Waiting for Life to Begin: the Plight of Asylum Seekers Caught by Australia's Indonesian Solution (2010) 22(4) IJRL 558

Taylor, S, Australia's 'Safe Third Country' Provisions - Their Impact on Australia's Fulfillment of Its Non-Refoulement Obligations (1996) 15(2) University of Tasmania Law Review 196

Taylor, S, Australia's Border Control and Refugee Protection Capacity-Building Activities in the Asia-Pacific Region in Babacan, A, and Briskman, L, Asylum Seekers: International Perspectives on Interdiction and Deterrence, 2008, Cambridge Scholars Publishing, Pp.63-81

Taylor, S, Australian Funded Care and Maintenance of Asylum Seekers in Indonesia and Papua New Guinea: All Care But No Responsibility? (2010) 33(2) UNSWLJ 337

Taylor, S, Exclusion From Protection of Persons of 'Bad Character': Is Australia Fulfilling Its Treaty-based Non-refoulement Obligations?” (2002) 8(1) Australian Journal of Human Rights 83

Taylor, S, Protecting the Human Rights of Immigration Detainees in Australia: An Evaluation of Current Accountability Mechanisms (2000) 22 SydLR 50

Taylor, S, Reconciling Australia's International Protection Obligations with the War on Terrorism (2002) 14(2) Pacfica Review 121

Taylor, S, Should Unauthorised Arrivals in Australia Have Free Access to Advice and Assistance [2000] Australian Journal of Human Rights 3

Taylor, S, The Human Rights of Rejected Asylum Seekers Being Removed From Australia in Kneebone, S, (ed), The Refugee Convention 50 Years On, 2003, Ashgate, Aldershot, Pp.193232

Theele, T, Rights of Turkish Workers on the Basis of the EEC/Turkey Agreement, in Schneider, H, (ed), Migration, Integration and Citizenship - A Challenge for Europe's Future, Vol II, 2005, Forum Maastricht, Maastricht, Pp.139-165

Tomuschat, C, Human Rights - Between Idealism and Realism, 2008, (2ed), OUP, Oxford

Tridimas, T, and Guiterrez-Fons, J. A., EU law, international law, and economic sanctions against terrorism: the judiciary in distress? (2008) 32 Fordham International Law Journal 660

Tridimas, T, Terrorism and the ECJ: empowerment and democracy in the EC legal order (2009) 34(1) ELRev 103

Tridimas, T, The General Principles of EU Law, 2ed, 2006, OUP, Oxford 
Trindade, F, Cane, P and Lunney, M, The Law of Torts in Australia, 4ed, 2007, OUP, South Melbourne

Türk, A. H., Judicial Review in EU Law, 2009, Edward Elgar Publishing, Cheltenham, UK; Northampton, MA

Türküler Isikel, N, Fundamental rights in the EU after Kadi and Al Barakat (2010) 16(5) ELJ 551

Turton, D, Who is a Forced Migrant? in de Wet, C, (ed) Development-induced Displacement, 2006, Berghahn Books, New York, Pp.14-36

Tzanou, M and El Droubi, S, Case T-318/01, Omar Mohammed Othman v. Council of the European Union and Commission of the European Communities, Judgment of the Court of First Instance of 11 June 2009 (Seventh Chamber), not yet reported (2010) 47 CMLRev 1233

van de Klaauw, Irregular Migration and Asylum-seeking: Forced Marriage or Reason for Divorce in Bogusz, B, Cholewinski, R, Cygnan, A, and Szyszczak, E, (eds) Irregular Migration and Human Rights: Theoretical, European and International Perspectives, 2004, Martinus Nijhoff Publishers, Leiden/Boston, Pp.115-135

Van den Bossche, P, The Law and Policy of the World Trade Organization, 2ed, 2008, CUP, Cambridge

van der Velde, J, The protection of fundamental rights within the European Union - A historical approach, undated, part of course materials for European Human Rights course towards degree of Magister Iuris Communis, Maastricht University, 2009 (copy held on file by author)

Viviani, N, The Long Journey, 1984, Melbourne University Press, Carlton

Vohra, S, Detention of Irregular Migrants and Asylum Seekers in Cholewinski, R, Perruchoud, R, MacDonald, E, (eds), International Migration Law: Developing Paradigms and Key Challenges, 2007, TMC Asser Press, The Hague, Pp.49-69

Vrachnas, J, Dimopoulos, P, Boyd, K, Bagaric, M, Migration and Refugee Law: Principles and Practice in Australia, 2008, 2ed, Cambridge University Press, Port Melbourne

Webber, G C N, Proportionality, Balancing, and the Cult of Constitutional Rights Scholarship (2010) 23(1) Canadian Journal of Law and Jurisprudence 179

Weisbrott, D, The Human Rights of Non-Citizens, 2008, Oxford University Press, Oxford

Weiß, W, Human Rights in the EU: Rethinking the Role of the European Convention on Human Rights After Lisbon (2011) 7 European Constitutional Law Review 64

Wesley, M, The Howard Paradox - Australian Diplomacy in Asia 1996-2006, 2007, ABC Books

White, M. W. D., Australian Offshore Laws, 2009, Federation Press, Annandale

Whitlam, G, The Whitlam Government 1972-1975, 1985, Penguin Books, Ringwood 
Wiesbrock, A, and Schneider, H, Circular Migration and Mobility Partnerships, Briefing Paper, European Parliament, D-G Internal Policies of the Union, Policy Department C, Citizens' Rights and Constitutional Affairs, February 2009

Wiesbrock, A, Legal Migration to the European Union - Ten Years After Tampere, 2009, Wolf Legal Publishers, Nijmegen

Willard, M, History of the White Australia Policy to 1920, 1974, Melbourne University Press, Victoria

Willmott, L, Christensen, S, Butler, D, and Dixon, B, Contract Law, 3ed, 2009, OUP, South Melbourne

Wilsher, D, Immigration Detention and the Common European Asylum Policy, in Baldaccini, A, Guild, E, and Toner, H, Whose Freedom Security and Justice? EU Immigration and Asylum Law and Policy, 2007, Hart Publishing, Portland, Oregon

Wilsher, D, The Administrative Detention of Non-Nationals Pursuant to Immigration Control: International and Constitutional Law Perspectives, (2004) 53 ICLQ 897

Wilsher, D, The Liberty of Foreigners - A History, Law and Politics of Immigration Detention, 2008, Wolf Legal Publishers, Nijmegen

Winterton, G, The Relationship Between Commonwealth Legislative and Executive Power (2004) 25(1) Adelaide Law Review 21

Wood, T, and McAdam, J, Australian Asylum Policy All At Sea: An Analysis of Plaintiff M70/2011 v Minister for Immigration and Citizenship and the Australia-Malaysia Arrangement (2012) 61 ICLQ 274

Yarwood, A. T., The Dictation Test - Historical Survey (1958) 30(2) Australian Quarterly 19

Zagor, M, Uncertainty and Exclusion: Detention and Aliens and the High Court (2006) 34 Federal Law Review 127

Zweigert, K, and Kötz, H, An Introduction to Comparative Law, (3ed), 1998, OUP, Oxford

\section{News and newspaper articles}

ABC News Online, Detention Probe handed 200 cases, 25 May 2005, http://www.abc.net.au/news/newsitems/200505/s1376464.htm

Armitage, C, Australia a world leader in skilled migration, Sydney Morning Herald, 9 April 2012, http://www.smh.com.au/opinion/political-news/australia-a-world-leader-in-skilledmigration-20120408-1wjm0.html

Australian Broadcasting Corporation, Asylum, aired Monday, 24 October 2011, http://www.abc.net.au/4corners/stories/2011/10/20/3344543.htm

Australian Broadcasting Corporation, Detention centres branded third world jails, 27 October 2009, http://www.abc.net.au/news/stories/2009/10/27/2725761.htm 
Australian Broadcasting Corporation, Oceanic Viking leaves Indonesia after four week stalemate, 19 November 2009, http://www.abc.net.au/am/content/2009/s2747054.htm

Australian Broadcasting Corporation, Oceanic Viking stand-off ends, 17 November 2009, http://www.abc.net.au/news/stories/2009/11/17/2745239.htm

Australian Broadcasting Corporation, Sri Lankans won't set foot in Australia, 28 October 2009, http://www.abc.net.au/news/stories/2009/10/28/2726181.htm

Banham, C, and Debelle, P, Bakhtiari family deported under cover of darkness, Sydney Morning Herald, 31 December 2004, http://www.smh.com.au/news/National/Bakhtiari-familydeported-under-cover-of-darkness/2004/12/30/1104344932116.html

Beck, M, The voices of those held in indefinite detention, Sydney Morning Herald, 3 June 2012 http://www.smh.com.au/opinion/political-news/the-voices-of-those-held-in-indefinitedetention-20120602-1zoy2.html

Benzow, G, Italy protests after France blocks trains in migrant spat, Deutsche Welle, 18 April 2011, http://www.dw-world.de/dw/article/0,,14996064,00.html

Borrello, E, Media breach 'bigger threat to Serco than depression', ABC News, 10 November 2011, http://www.abc.net.au/news/2011-11-10/serco-contract-released/3656214

Connor, R, Berlusconi visits Lampedusa, promises to remove migrants, Deutsche Welle, 30 March 2011, http://www.dw-world.de/dw/article/0,,14956449,00.html

Coorey, P, Paralysis in Parliament, Sydney Morning Herald, 28 June 2012, http://www.smh.com.au/opinion/political-news/paralysis-in-parliament-20120627212ye.html

Dannenberg, N, Bolsolver, C, Connor, R, EU grants Italy emergency funds to deal with migrant influx, Deutsche Welle, 16 February 2011, http://www.dwworld.de/dw/article/0,,14843170,00.html

Deutsche Welle, European leaders agree to Czech demands over Lisbon Treaty, 29 October 2009, http://www.dw-world.de/dw/article/0,,4839060,00.html

Flitton, D, Men waited in hope as asylum bid faltered, Sydney Morning Herald, 2 June 2012, http://www.smh.com.au/national/men-waited-in-hope-as-asylum-bid-faltered-201206011znjg.html

Franklin, M, and Kelly, J, Offshore processing backdown will bring boats: Julia Gillard, The Australian, 14 October 2011, http://www.theaustralian.com.au/nationalaffairs/immigration/offshore-processing-backdown-will-bring-boats-julia-gillard/storyfn9hm1gu-1226166277194

Gordon, M, Lawyers disagree over Bowen's role, Sydney Morning Herald, 22 June 2012, http://www.smh.com.au/opinion/political-news/lawyers-disagree-over-bowens-role20120621-20qyr.html

Iggulden, T, ABC News, Report scathing of detention centre conditions, 12 August 2011, http://www.abc.net.au/news/2011-08-11/comcare-report-scathing-of-detention-centreconditions $/ 2835820$ 
Johnston, M, and Hudson, P, Julia Gillard abandons offshore processing following death of Malaysia deal, Herald Sun, 13 October 2011, http://www.heraldsun.com.au/news/morenews/nationals-mp-tony-crook-may-sink-vote-on-malaysia-swap-deal/story-fn7x8me21226165520491

Levitz, D, Italy warns of an immigration 'emergency' due to North Africa Unrest, Deutsche Welle, 11 February 2011, http://www.dw-world.de/dw/article/0,14837362,00.html

Lowenstein, A, Cordell, M, and Farrell, P, Exclusive: Our Contract with Serco, New Matilda, 9 November 2011, http://newmatilda.com/2011/11/09/exclusive-our-contract-serco

Maley, P, Pacific Solution Sinks Quietly, The Australian, 9 February 2009, http://www.theaustralian.news.com.au/story/0,25197,23183785-5013404,00.html

Mara, D, EU, Italy at odds over Tunisian asylum surge, Deutsche Welle, 14 February 2011 http://www.dw-world.de/dw/article/0,,14842235,00.html

Mara, D, Germany tells Italy to 'solve its own problems' in Tunisian refugee row, Deutsche Welle, 10 April 2011, http://www.dw-world.de/dw/article/0,,14980272,00.html

Marr, D, Cornelia Rau: the verdict, Sydney Morning Herald, 18 July 2005 http://www.smh.com.au/news/national/cornelia-rau-the-verdict/2005/07/17/ 1121538868891.html

Marr, D, Purgatory in Baxter, Sydney Morning Herald, 19 July 2005, http://www.smh.com.au/news/national/purgatory-in-baxter/2005/07/18/ 1121538922305.html

McLeod, S, Refugees challenge ASIO risk assessment, ABC News, 20 January 2011, http://www.abc.net.au/news/2011-01-20/refugees-challenge-asio-riskassessment/1912678

Metherell, M, First of Oceanic Viking's asylum seekers arrive, Sydney Morning Herald, 21 December 2009, http://www.smh.com.au/national/first-of-oceanic-vikings-asylumseekers-arrive-20091220-17iw.html

Needham, K, Boat refugees will be assessed as air arrivals, Sydney Morning Herald, 20 March 2012, http://www.smh.com.au/opinion/political-news/boat-refugees-will-be-assessed-asair-arrivals-20120319-1vfrn.html

Needham, K, Protest as teenage asylum seekers are detained with adults, Sydney Morning Herald, 16 December 2011, http://www.smh.com.au/world/protest-as-teenage-asylumseekers-are-detained-with-adults-20111215-1owyf.html

Needham, K, Without hope, without reason, Sydney Morning Herald, 14 January 2012, http://www.smh.com.au/national/without-hope-without-reason-20120113-1pzei.html

Pop, V, France and Italy acted against 'spirit' of EU border laws, EUobserver, 25 July 2011, http://euobserver.com/22/32657

Shahrigian, S, EU ministers reject Italian request for help with feared Libyan 'exodus', Deutsche Welle, 24 February 2011, http://www.dw-world.de/dw/article/0,,14872918,00.html 
Sydney Morning Herald, Mrs Bakhtiari is one of ours, say Afghan, 28 September 2005, http://www.smh.com.au/news/world/mrs-bakhtiari-is-one-of-ours-say-afghan/2005 /09/27/1127804478530.html

Sydney Morning Herald, The lies that kept Vivian Alvarez hidden for years, 20 August 2005 http://www.smh.com.au/news/national/the-lies-that-kept-vivian-alvarez-hidden-foryears/2005/08/19/1124435144969.html

Tasker, B, Push for asylum seeker Medicare cover, Sydney Morning Herald, 14 August 2011, http://www.smh.com.au/national/push-for-asylum-seeker-medicare-cover-201108141ispm.html

The Guardian, Another Project in Trouble, 30 April - 6 May 2011

Tippet, G, The missing months of Cornelia Rau, The Age, 12 February 2005, http://www.theage.com.au/news/National/The-missing-months-of-Cornelia$\mathrm{Rau} / 2005 / 02 / 11 / 1108061868901 . h t m l$

Vasek, L, Boat arrivals up more than eightfold on a year ago, The Australian, 29 June 2012, http://www.theaustralian.com.au/national-affairs/immigration/boat-arrivals-up-morethan-eightfold-on-a-year-ago/story-fn9hm1gu-1226411567024

Whitmont, D, Anna's Story, Australian Broadcasting Corporation, 4 April 2005, Transcript, http://www.abc.net.au/4corners/content/2005/s1338239.htm

\section{International Criminal Tribunal for the former Yugoslavia}

Prosecutor $v$ Stevan Todorovic (Sentencing Judgment), IT-95-9/1-S, International Criminal Tribunal for the former Yugoslavia (ICTY), 31 July 2001

\section{United Kingdom Case Law}

Associated Provincial Picture Houses Ltd v Wednesbury Corp [1948] 1 KB 223

Kirkham v Chief Constable of the Greater Manchester Police [1989] EWCA Civ 3

Malone v Metropolitan Police Commissioner [1979] Ch 344

Fornah $v$ Secretary of State for the Home Department [2006] UKHL 46

$R v$ Immigration Appeal Tribunal, Ex parte Shah [1999] 2 AC 629

$R v$ Panel on Takeovers and Mergers, Ex parte Datafin plc [1987] QB 815

$R v$ Secretary of State for the Home Department, ex parte Adam [2005] UKHL 66

$R v$ Secretary of State for the Home Department, Ex parte Adan [2001] AC 477

Reeves $v$ Commissioner of Police of the Metropolis [1999] 3 WLR 363

Secretary of State for the Home Department v Limbuela [2004] EWCA Civ 540

The Queen on the Application of "B" \& Ors $v$ Secretary of State for the Foreign \& Commonwealth Office [2004] EWCA Civ 1344

\section{South African Legislation}

Natal Act 1897, No.1

\section{New Zealand Case Law}

Powerco Ltd v Commerce Commission [2006] NZHC 662 
Regional Cooperation - Australia

http://www.baliprocess.net/ 


\section{Resumé}

Mark Provera was born on 29 August 1978 in Sydney, Australia. He graduated from the University of Technology, Sydney with a Bachelor of Laws with First Class Honours in 2002 after working as the Associate to Master McLaughlin (later the Honourable Associate Justice McLaughlin) in the Equity Division of the Supreme Court of New South Wales and later as a law clerk with a medium-sized law firm in Sydney. Having been appointed in 2002 as Research Assistant to the Dean of the Faculty of Law, Professor David Barker, AM, he researched international military justice systems, tutored in the Law of Tort and lectured in the Law of Succession at the University of Technology, Sydney. He was called to the New South Wales' Bar in 2003 where he practised predominantly in the Equity Division of the Supreme Court of New South Wales. Having relocated to The Netherlands in 2008, Mark graduated in 2010 from Maastricht University with an LL.M (cum laude) in Comparative, International and European Law, specialising in Globalisation and Human Rights. His LL.M thesis won the Hanneke Steenbergen Foundation prize for best Master thesis in the Netherlands in migration law for 2010 and which provided the scoping work for his PhD thesis of the same title. Returning to Australia, he developed a keen interest in mediation and alternative dispute resolution and worked with Amnesty International Australia as a refugee caseworker. Mark returned to the Netherlands in 2011 to take up the position of docent at Maastricht University where he taught European Migration Law and Citizenship, Substantive European Union Law and assisted with the Moot Court, later focussing on the completion of his $\mathrm{PhD}$ research and dissertation in Australia from the summer of 2011. He is a member of the New South Wales Bar Association, the Ius Commune Research School and the Maastricht Centre for European Law. 
